\title{
VIABILIDADE DA IRRIGAÇÃO, SOB RISCO CLIMÁTICO E ECONÔMICO, NAS MICRORREGIÕES DE TERESINA E LITORAL PIAUIENSE
}

\section{Aderson SOARES de ANDRADE JÚNIOR}

Engenheiro Agrônomo

Orientador: Prof. Dr. JOSÉ ANTONIO FRIZZONE

Tese apresentada à Escola Superior de Agricultura "Luiz de Queiroz", Universidade de São Paulo, para obtenção do título de Doutor em Agronomia, Área de Concentração: Irrigação e Drenagem.

P I R A C I C A B A

Estado de São Paulo - Brasil

Outubro - 2000 


\section{Dados Internacionais de Catalogação na Publicação (CIP) DIVISĀO DE BIBLIOTECA E DOCUMENTAÇĀO - Campus "Luiz de Queiroz"/USP}

Andrade Júnior, Aderson Soares de

Viabilidade da irrigação, sob risco climático e econômico, nas microrregiōes de Teresina e Litoral Piauiense / Aderson Soares de Andrade Júnior. - - Piracicaba, 2000.

566 p. : il.

Tese (doutorado) - Escola Superior de Agricultura Luiz de Queiroz, 2000. Bibliografia.

1. Balanço hídrico 2. Caupi 3. Chuva 4. Evapotranspiração 5. Melancia 6. Probabilidade 7. Simulação I. Título 
Aos meus queridos pais Aderson e Dalziza por todo apoio, confiança, amor e carinho constantes ao longo de toda minha vida. Aos meus estimados irmãos Rita de Cássia, Paulo Ney, Marcos Antônio e Eliane pelo amor, amizade e convivência harmoniosa.

Ofereço

À minha querida esposa Maria Eugênia, amiga e companheira dos momentos mais difíceis, por seu amor, carinho, compreensão e incentivo e às minhas filhas Mariana e Marcela, razão maior da minha existência e alegria de viver

D e d i c o 


\section{AGRADECIMENTOS}

À DEUS, por ter me concedido o direito de nascer e que continua dando-me forças para continuar perseverante na vida.

À Empresa Brasileira de Pesquisa Agropecuária/Embrapa Meio Norte, pela oportunidade para a realização deste curso.

Ao Conselho Nacional de Desenvolvimento Científico e Tecnológico (CNPq), pela concessão da bolsa de estudos.

Ao professor José Antonio Frizzone pela orientação eficiente, segura e prestativa durante todo curso.

Aos professores dos Departamentos de Engenharia Rural, Ciências Exatas e Economia, Administração e Sociologia, ESALQ/USP, pelos ensinamentos transmitidos durante o curso.

Aos amigos Edson Alves Bastos e Paulo César Sentelhas, pelas sugestões e críticas na redação final do trabalho.

Aos amigos Braz Henrique Nunes Rodrigues e Milton José Cardoso, pelo envio e atualização constante dos dados climáticos utilizados no estudo. 
À ISRATEC - Teresina, Centrais de Abastecimento do Piauí S.A. (CEASA-PI) e Companhia Energética do Piauí (CEPISA), pela cessão dos dados relativos aos preços dos equipamentos de irrigação, preços de venda dos produtos e tarifas de energia elétrica, respectivamente, usados no estudo.

Aos funcionários do Departamento de Engenharia Rural, ESALQ/USP, pela atenção especial e dedicação na condução das atividades relacionadas ao curso.

Aos funcionários da Seção de Pós-Graduação, Biblioteca e Xerox, pela gentileza e simpatia no atendimento prestado.

À Eliana Maria G. Sabino, pela revisão das referências bibliográficas.

Aos colegas do curso de Pós-Graduação em Irrigação e Drenagem, pelo alegre, harmonioso e descontraído convívio e troca de experiências e ensinamentos.

Enfim, a todos aqueles, que de forma direta ou indireta, contribuíram para a realização deste trabalho. 


\section{SUMÁRIO}

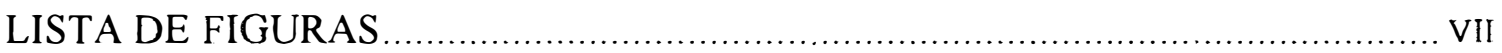

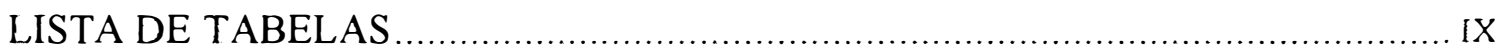

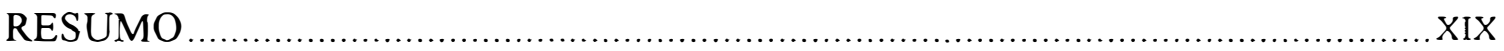

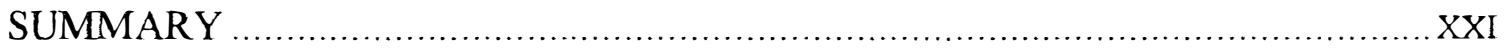

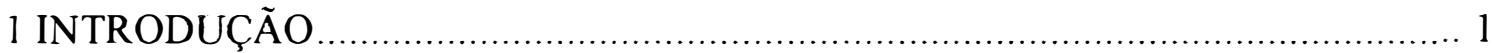

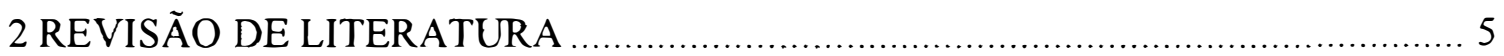

2.1 Necessidade de irrigação e efeito do déficit hídrico na cultura do feijão caupi ........ 5

2.2 Necessidade de irrigação e efeito do déficit hídrico na cultura da melancia ............12

2.3 Déficit de evapotranspiração e produção relativa........................................... 15

2.4 Funções de distribuição para previsão de precipitação e evapotranspiração ...........20

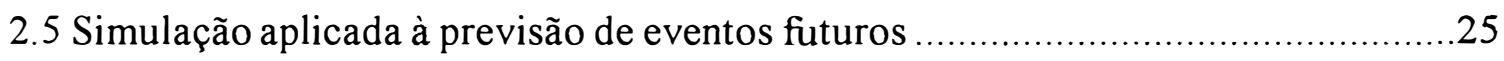

2.6 Balanço hídrico e necessidade de irrigação.....................................................28

2.7 Estimativa e previsão de custos associados à irrigação ................................... 32

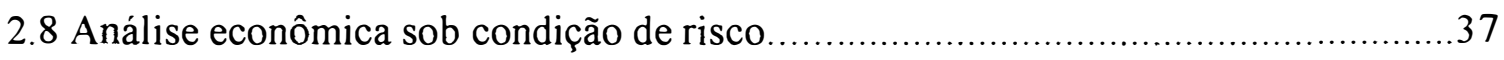

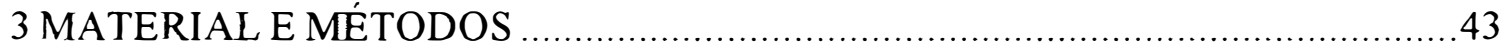

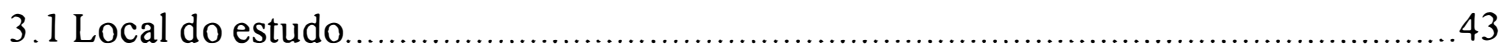

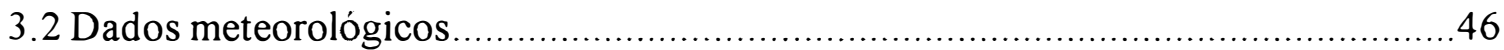

3.3 Cálculo da evapotranspiração de referência ................................................4 47

3.4 Estimativa da precipitação pluviométrica e evapotranspiração de referência ..........50

3.4.1 Estimativa dos parâmetros $\gamma$ e $\beta$ da distribuição gama ..................................51

3.4.2 Estimativa dos parâmetros $\mu$ e $\sigma$ da distribuição normal .................................52

3.4.3 Estimativa dos parâmetros $\alpha$ e $\beta^{\prime}$ da distribuição beta ..................................53

3.4.4 Estimativa dos parâmetros $\varepsilon$ e $\phi$ da distribuição triangular................................54

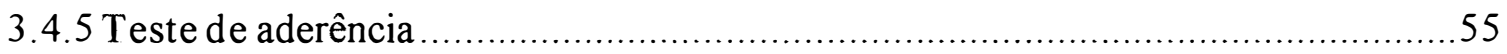

3.5 Simulação da precipitação pluviométrica e evapotranspiração de referência ...........56

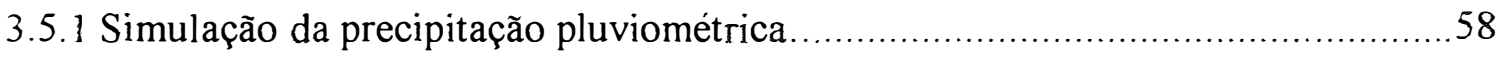

3.5.1.1 Modelagem da ocorrência da precipitação diária ........................................58

3.5.1.2 Modelagem da quantidade de precipitação diária ....................................61 


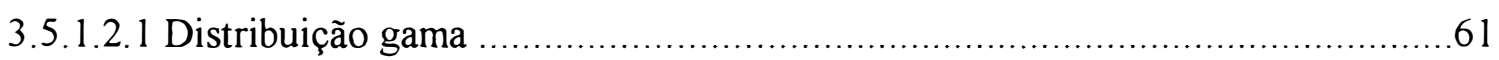

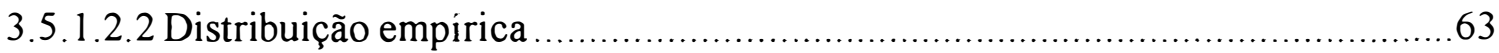

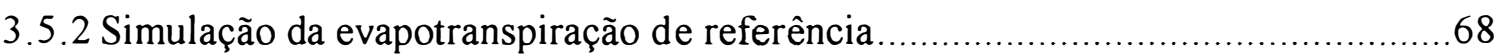

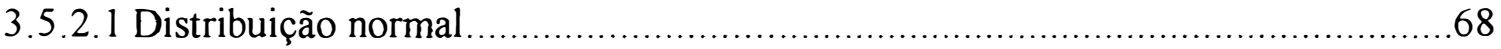

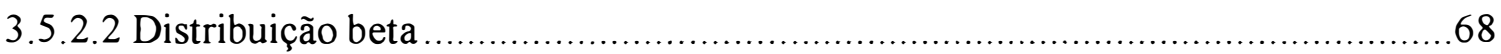

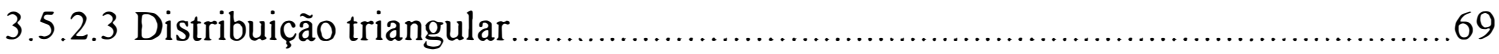

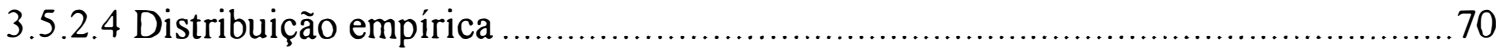

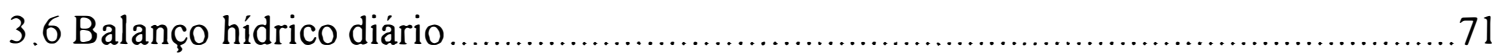

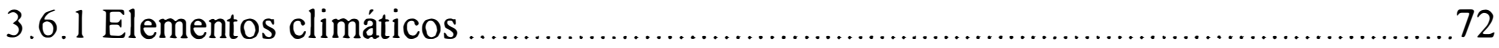

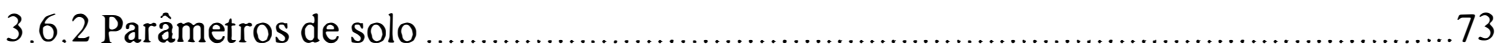

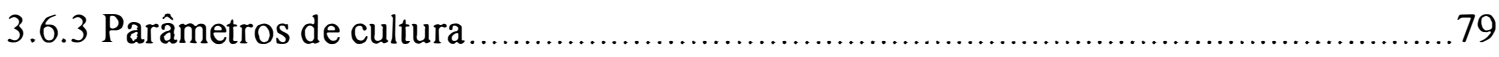

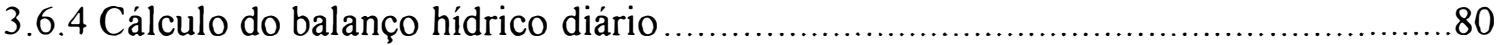

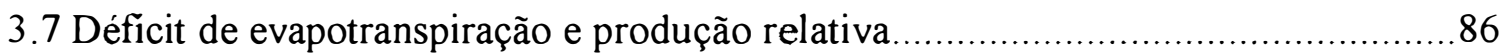

3. 8 Custo da água de irrigação e preço de venda dos produtos.................................... 88

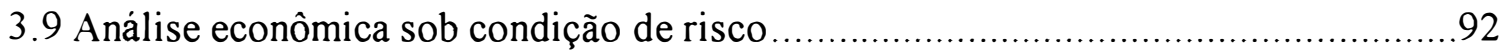

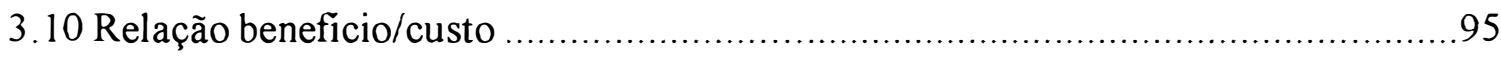

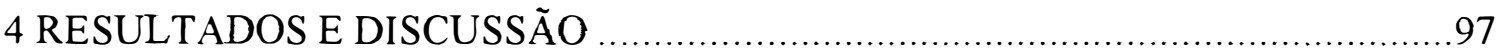

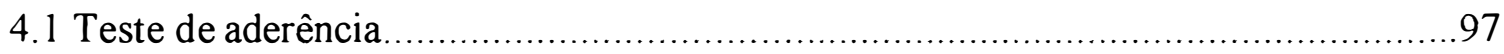

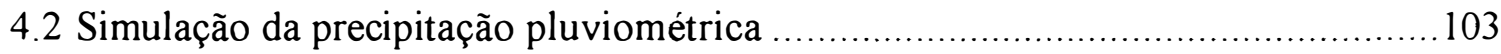

4.3 Simulação da evapotranspiração de referência ................................................114

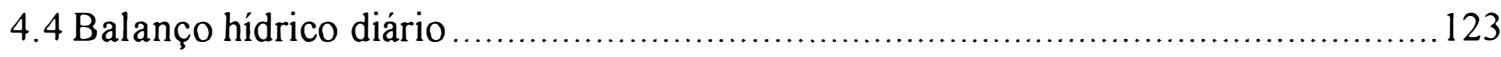

4.5 Estimativa da lâmina bruta de irrigação e produtividade das culturas....................159

4.6 Preços de venda dos produtos e das tarifas de energia elétrica ............................. 176

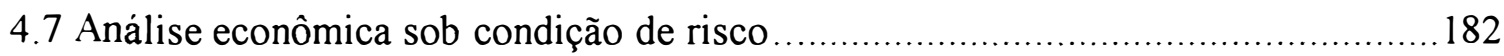

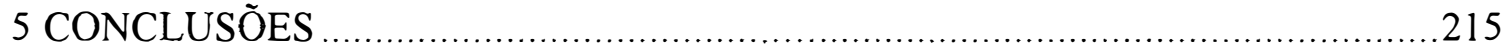

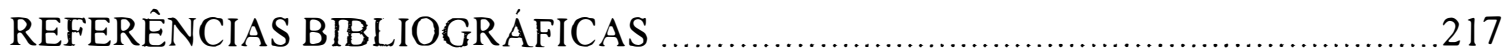

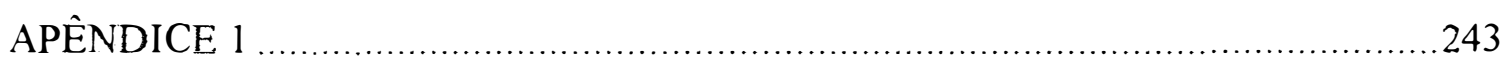

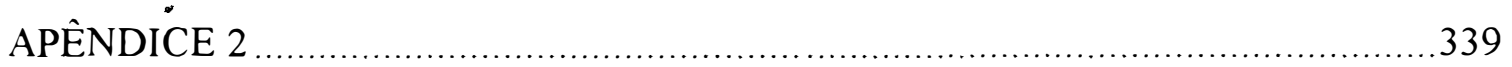




\section{LISTA DE FIGURAS}

Página

1 Área de abrangência das microrregiões do Litoral Piauiense e de Teresina,

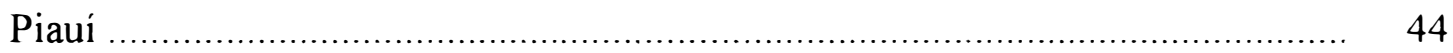

2 Balanço hídrico normal mensal para Parnaíba (a) e Teresina (b), Piauí .............. 45

3 Definição da ocorrência de dias secos e chuvosos ........................................... 60

4 Geração da quantidade de precipitação pluviométrica diária usando a função de distribuição de probabilidade gama

5 Geração da quantidade de precipitação pluviométrica diária usando a função de distribuição de probabilidade empírica

6 Curvas de retenção de água no solo e relação entre a fração p e o potencial mátrico de água no solo para Areia Quartzosa (a) e Latossolo VermelhoAmarelo (b)

7 Evolução da capacidade de água disponivel (CAD) durante o ciclo das culturas de feijão caupi e melancia, nos solos Areia Quartzosa (AQ) e Latossolo Vermelho-Amarelo (LVA)

8 Variação da evapotranspiração real em função do armazenamento de água disponivel no solo

9 Comparação entre as médias dos valores observados e simulados de número de dias secos $(\mathrm{N}(\mathrm{S}))$, número de dias chuvosos $(\mathrm{N}(\mathrm{C}))$ e precipitação pluviométrica total $(\mathrm{P})$ em épocas específicas de semeadura no município de Parnaíba, Piauí

10 Comparação entre as médias dos valores observados e simulados de número de dias secos $(\mathrm{N}(\mathrm{S}))$, número de dias chuvosos $(\mathrm{N}(\mathrm{C}))$ e precipitação pluviométrica total $(\mathrm{P})$ em épocas específicas de semeadura no município de Teresina, Piauí

11 Comparação entre as médias dos valores observados e simulados de precipitação pluviométrica diária $(\mathrm{P})$ em épocas específicas de semeadura na estação chuvosa do município de Parnaiba, Piauí

12 Comparação entre as médias dos valores observados e simulados de precipitação pluviométrica diária $(\mathrm{P})$ em épocas específicas de semeadura na estação chuvosa do município de Teresina, Piauí 
13 Comparação entre as médias dos valores observados e simulados de evapotranspiração de referência (ETo) em épocas especificas de semeadura nos municípios de Parnaíba (a) e Teresina (b), Piauí

14 Comparação entre as médias dos valores observados e simulados de evapotranspiração de referência diária (ETo) em épocas específicas de semeadura na estação chuvosa (a) e seca (b) do município de Parnaiba, Piauí

15 Comparação entre as médias dos valores observados e simulados de evapotranspiração de referência diária (ETo) em épocas específicas de semeadura na estação chuvosa (a) e seca (b) do município de Teresina, Piauí ....

16 Simulação de balanço hídrico diário na cultura de feijão caupi em Parnaíba (a) e Teresina (b)

17 Lâminas brutas de irrigação para a cultura de feijão caupi em função dos níveis de manejo de irrigação em cada época de semeadura nos municípios de Parnaiba (a) e Teresina (b)

18 Lâminas brutas de irrigação para a cultura de melancia em função dos niveis de manejo de irrigação em cada época de semeadura nos municípios de Parnaíba (a) e Teresina (b)

19 Evapotranspiração (ET) máxima e real da cultura de feijão caupi em função dos niveis de manejo de irrigação em cada época de semeadura nos municípios de Parnaiba (a) e Teresina (b)

20 Evapotranspiração máxima (ETm) e real (ETr) da cultura de melancia em função dos níveis de manejo de irrigação em cada época de semeadura nos municípios de Parnaiba (a) e Teresina (b)

21 Produtividade de grãos de feijão caupi em função dos niveis de manejo de irrigação em cada época de semeadura nos municípios de Parnaiba (a) e Teresina (b)

22 Produtividade de frutos de melancia em função dos níveis de manejo de irrigação em cada época de semeadura nos municípios de Parnaíba (a) e Teresina (b)

23 Produtividade de grãos de feijão caupi em função da precipitação efetiva em cada época de semeadura nos municípios de Parnaiba (a) e Teresina (b)

24 Produtividade de frutos de melancia em função da precipitação efetiva em cada época de semeadura nos municipios de Parnaiba (a) e Teresina (b) 


\section{LISTA DE TABELAS}

Página

1 Épocas de semeadura adotadas para as culturas de feijão caupi e melancia 57

2 Características fisico-hídricas dos solos representativos das microrregiões do Litoral Piauiense (Areia Quartzosa) (AQ) e de Teresina (Latossolo VermelhoAmarelo) (LVA)

3 Coeficiente de cultivo $(\mathrm{Kc})$ e fator de resposta ao déficit hídrico (Ky) para as feijão caupi e melancia

4 Ajuste dos dados diários de precipitação pluviométrica à função de distribuição gama, pelo teste de Kolmogorov-Smirnov, em cada época de semeadura nos municípios de Parnaiba e Teresina, Piauí .

5 Ajuste dos dados diários de evapotranspiração de referência à função de distribuição normal, pelo teste de Kolmogorov-Smirnov, em cada época de semeadura nos municípios de Parnaíba e Teresina, Piauí

6 Ajuste dos dados diários de evapotranspiração de referência à função de distribuição beta, pelo teste de Kolmogorov-Smirnov, em cada época de semeadura nos municípios de Parnaíba e Teresina, Piauí

7 Ajuste dos dados diários de evapotranspiração de referência à função de distribuição triangular, pelo teste de Kolmogorov-Smirnov, em cada época de semeadura nos municípios de Parnaíba e Teresina, Piauí

8 Resumo das funções de distribuição adotadas para a estimativa da precipitação pluviométrica diária (P) e evapotranspiração de referência diária (ETo) em cada época de semeadura nos municípios de Parnaíba e Teresina, Piauí

9 Probabilidades condicionais da cadeia de Markov $\mathrm{P}(\mathrm{C} / \mathrm{S})$ e $\mathrm{P}(\mathrm{C} / \mathrm{C})$ e parâmetros $\gamma$ e $\beta$ da distribuição gama em cada época de semeadura nos municípios de Parnaíba e Teresina, Piauí

10 Valores observados $(\mathrm{O})$ e simulados $(\mathrm{S})$ de número de dias secos $(\mathrm{N}(\mathrm{S}))$, número de dias chuvosos $(\mathrm{N}(\mathrm{C}))$ e precipitação pluviométrica total $(\mathrm{P})$ em cada época de semeadura e os correspondentes indices de desempenho estatístico nos municípios de Parnaíba e Teresina, Piauí 
11 Coeficientes de variação (\%) dos valores observados (O) e simulados (S) de número de dias secos $(\mathrm{N}(\mathrm{S}))$, número de dias chuvosos $(\mathrm{N}(\mathrm{C}))$ e precipitação pluviométrica total $(\mathrm{P})$ em cada época de semeadura para os municípios de Parnaiba e Teresina, Piauí

12 Índices de desempenho estatístico em função do número de simulações usadas na modelagem dos parâmetros relacionados à ocorrência $(\mathrm{N}(\mathrm{S})$ e $\mathrm{N}(\mathrm{C})$ ) e magnitude da precipitação pluviométrica (P) em Parnaíba e Teresina, Piauí

13 Valores observados $(\mathrm{O})$ e simulados $(\mathrm{S})$ d e evapotranspiração de referência (ETo) em cada época de semeadura e os correspondentes índices de desempenho estatístico nos municípios de Parnaíba e Teresina, Piauí

14 Coeficientes de variação (\%) dos valores observados (O) e simulados (S) de evapotranspiração de referência (ETo) em cada época de semeadura para os municípios de Parnaíba e Teresina, Piauí

15 Índices de desempenho estatístico em função do número de simulações usadas na estimativa dos valores de evapotranspiração de referência em Parnaiba e Teresina, Piauí

16 Precipitação efetiva $(\mathrm{Pe})$ e lâmina bruta de irrigação em função dos níveis de manejo em cada época de semeadura na cultura de feijão caupi, no município de Parnaíba, Piauí

17 Precipitação efetiva $(\mathrm{Pe})$ e lâmina bruta de irrigação em função dos níveis de manejo em cada época de semeadura na cultura de feijão caupi, no município de Teresina, Piauí

18 Precipitação efetiva $(\mathrm{Pe})$ e lâmina bruta de irrigação em função dos níveis de manejo em cada época de semeadura na cultura de melancia, no município de Parnaíba, Piauí

19 Precipitação efetiva $(\mathrm{Pe})$ e lâmina bruta de irrigação em função dos níveis de manejo em cada época de semeadura na cultura de melancia, no município de Teresina, Piauí

20 Evapotranspiração máxima (ETm) e real (ETr) em função dos níveis de manejo em cada época de semeadura na cultura de feijão caupi, no município de Parnaiba, Piauí

21 Evapotranspiração máxima (ETm) e real (ETr) em função dos níveis de manejo em cada época de semeadura na cultura de feijão caupi, no município de Teresina, Piauí 
22 Evapotranspiração máxima (ETm) e real (ETr) em função dos níveis de manejo em cada época de semeadura na cultura de melancia, no municipio de Parnaiba, Piauí

23 Evapotranspiração máxima (ETm) e real (ETr) em função dos niveis de manejo em cada época de semeadura na cultura de melancia, no município de Teresina, Piauí

24 Produtividade de grãos de feijão caupi em função dos niveis de manejo de irrigação em cada época de semeadura, no município de Parnaiba, Piauí

25 Produtividade de grãos de feijão caupi em função dos niveis de manejo de irrigação em cada época de semeadura, no municipio de Teresina, Piauí

26 Produtividade de frutos de melancia em função dos niveis de manejo de irrigação em cada época de semeadura, no município de Parnaíba, Piauí

27 Produtividade de frutos de melancia em função dos niveis de manejo de irrigação em cada época de semeadura, no municipio de Teresina, Piauí

28 Médias mensais de precipitação pluviométrica $(\mathrm{P})$, evapotranspiração de referência (ETo), temperatura (T), umidade relativa (UR), velocidade do vento (U) e insolação $(n)$ referentes à série histórica de observações em Parnaiba e Teresina, Piauí

29 Déficits hídricos impostos à cultura de feijão caupi em função dos níveis de manejo da irrigação adotados em cada época de semeadura no município de Parnaiba, Piauí

30 Déficits hidricos impostos à cultura de feijão caupi em função dos niveis de manejo da irrigação adotados em cada época de semeadura no município de Teresina, Piauí

31 Déficits hídricos impostos à cultura de melancia em função dos níveis de manejo da irrigação adotados em cada época de semeadura no município de Parnaiba, Piauí

32 Déficits hídricos impostos à cultura de melancia em função dos níveis de manejo da irrigação adotados em cada época de semeadura no município de Teresina, Piauí

33 Estimativa da lâmina bruta de irrigação $(\mathrm{mm})$ necessária à cultura de feijão caupi, com diferentes probabilidades de ocorrência, em cada época de semeadura e nível de manejo (p) no município de Parnaiba, Piauí 
34 Estimativa da produtividade de grãos de feijão caupi $\left(\mathrm{kg} \mathrm{ha}^{-1}\right)$, com diferentes probabilidades de ocorrência, em cada época de semeadura e nivel de manejo (p) no município de Parnaiba, Piauí

35 Estimativa dos preços mensais de venda do feijão caupi (US\$ kg ${ }^{-1}$ ), em cada época de semeadura, com diferentes probabilidades de ocorrência

36 Estimativa dos preços mensais de venda da melancia (US\$ kg ${ }^{-1}$ ), em cada época de semeadura, com diferentes probabilidades de ocorrência

37 Estimativa dos preços médios mensais da tarifa de consumo de energia elétrica (US\$ $\mathrm{kWh}^{-1}$ ), com diferentes probabilidades de ocorrência, em cada época de semeadura

38 Receitas brutas, composição de custos da irrigação, receitas líquidas e relação beneficio/custo para o feijão caupi, em cada época de semeadura, nível de manejo da irrigação e risco de $20 \%$. Parnaíba, Piauí

39 Receitas líquidas para a melancia (US\$ ha ${ }^{-1}$ ), em cada época de semeadura, nível de manejo da irrigação e nível de risco. Teresina, Piauí

40 Receitas líquidas para o feijão caupi (US\$ ha ${ }^{-1}$ ), sob regime de sequeiro, em cada época de semeadura e nível de risco. Parnaíba, Piauí

41 Receitas líquidas para o feijão caupi (US $\$ \mathrm{ha}^{-1}$ ), sob regime de sequeiro, em cada época de semeadura e nível de risco. Teresina, Piauí

42 Receitas líquidas para a melancia (US\$ ha ${ }^{-1}$ ), sob regime de sequeiro, em cada época de semeadura e nível de risco. Parnaiba, Piauí

43 Receitas líquidas para a melancia (US $\$ \mathrm{ha}^{-1}$ ), sob regime de sequeiro, em cada época de semeadura e nível de risco. Teresina, Piauí

44 Relação beneficio/custo para o feijão caupi, em cada época de semeadura, nível de manejo da irrigação e nível de risco. Parnaíba, Piauí

1 A Ajuste dos valores simulados de lâmina bruta de irrigação e produtividade de grãos de feijão caupi à função de distribuição normal, pelo teste de Kolmogorov-Smirnov, em cada nível de manejo (p) e época de semeadura no município de Parnaíba, Piauí

2A Ajuste dos valores simulados de lâmina bruta de irrigação e produtividade de grãos de feijão caupi à função de distribuição normal, pelo teste de Kolmogorov-Smirnov, em cada nível de manejo (p) e época de semeadura no município de Teresina, Piauí 
3A Ajuste dos valores simulados de lâmina bruta de irrigação e produtividade de frutos de melancia à função de distribuição normal, pelo teste de KolmogorovSmirnov, em cada nível de manejo (p) e época de semeadura no Parnaiba, Piauí

4A Ajuste dos valores simulados de lâmina bruta de irrigação e produtividade de frutos de melancia à função de distribuição normal, pelo teste de KolmogorovSmirnov, em cada nivel de manejo (p) e época de semeadura no Teresina, Piaui

5A Parâmetros da distribuição normal relativos aos valores simulados de lâmina bruta de irrigação e produtividade de grãos de feijão caupi, em cada nivel de manejo (p) e época de semeadura no município de Parnaiba, Piauí

6A Parâmetros da distribuição normal relativos aos valores simulados de lâmina bruta de irrigação e produtividade de frutos de melancia, em cada nível de manejo (p) e época de semeadura no município de Parnaiba, Piauí

7A Parâmetros da distribuição normal relativos aos valores simulados de lâmina bruta de irrigação e produtividade de grãos de feijão caupi, em cada nivel de manejo (p) e época de semeadura no município de Teresina, Piauí

8A Parâmetros da distribuição normal relativos aos valores simulados de lâmina bruta de irrigação e produtividade de frutos de melancia, em cada nivel de manejo (p) e época de semeadura no município de Teresina, Piauí

9A Parâmetros da distribuição normal relativos aos valores simulados de produtividade de grãos de feijão caupi $\left(\mathrm{kg} \mathrm{ha}^{-1}\right)$, em regime de sequeiro, em cada época de semeadura nos municípios de Parnaiba e Teresina, Piauí

10A Parâmetros da distribuição normal relativos aos valores simulados de produtividade de frutos de melancia $\left(\mathrm{kg} \mathrm{ha}^{-1}\right)$, em regime de sequeiro, em cada época de semeadura nos municípios de Parnaiba e Teresina, Piauí

11 A Estimativa da lâmina bruta de irrigação $(\mathrm{mm})$ necessária à cultura de feijão caupi, com diferentes probabilidades de ocorrência, em cada época de semeadura e nível de manejo (p) no município de Teresina, Piauí

$12 \mathrm{~A}$ Estimativa da lâmina bruta de irrigação $(\mathrm{mm})$ necessária à cultura de melancia, com diferentes probabilidades de ocorrência, em cada época de semeadura e nivel de manejo (p) no município de Parnaiba, Piauí

13A Estimativa da lâmina bruta de irrigação $(\mathrm{mm})$ necessária à cultura de melancia, com diferentes probabilidades de ocorrência, em cada época de semeadura e nível de manejo (p) no município de Teresina, Piauí 
14A Estimativa da produtividade de grãos de feijão caupi $\left(\mathrm{kg} \mathrm{ha}^{-1}\right)$, com diferentes probabilidades de ocorrência, em cada época de semeadura e nível de manejo (p) no município de Teresina, Piauí

15A Estimativa da produtividade de frutos de melancia $\left(\mathrm{kg} \mathrm{ha}^{-1}\right)$, com diferentes probabilidades de ocorrência, em cada época de semeadura e nivel de manejo (p) no município de Parnaiba, Piauí

16A Estimativa da produtividade de frutos de melancia $\left(\mathrm{kg} \mathrm{ha}^{-1}\right)$, com diferentes probabilidades de ocorrência, em cada época de semeadura e nível de manejo (p) no municipio de Teresina, Piaú

17A Estimativa da produtividade de grãos de feijão caupi $\left(\mathrm{kg} \mathrm{ha}^{-1}\right)$, em regime de sequeiro, com diferentes probabilidades de ocorrência, em cada época de semeadura no município de Parnaíba, Piauí

$18 \mathrm{~A}$ Estimativa da produtividade de grãos de feijão caupi $\left(\mathrm{kg} \mathrm{ha}^{-1}\right)$, em regime de sequeiro, com diferentes probabilidades de ocorrência, em cada época de semeadura no município de Teresina, Piauí

19A Estimativa da produtividade de frutos de melancia $\left(\mathrm{kg} \mathrm{ha}^{-1}\right)$, em regime de sequeiro, com diferentes probabilidades de ocorrência, em cada época de semeadura no município de Parnaiba, Piauí

20A Estimativa da produtividade de frutos de melancia $\left(\mathrm{kg} \mathrm{ha}^{-1}\right)$, em regime de sequeiro, com diferentes probabilidades de ocorrência, em cada época de semeadura no município de Teresina, Piauí

$21 \mathrm{~A}$ Ajuste dos preços mensais de venda dos produtos à função de distribuição triangular, pelo teste de Kolmogorov-Smirnov

22A Ajuste dos preços mensais da tarifa de consumo de energia elétrica à função de distribuição triangular, pelo teste de Kolmogorov-Smirnov

23A Parâmetros da distribuição triangular relativos aos preços mensais de venda dos produtos (US\$ kg ${ }^{-1}$ )

24A Parâmetros da distribuição triangular relativos aos preços mensais da tarifa de consumo de energia elétrica (US $\$ \mathrm{kWh}^{-1}$ )

$1 \mathrm{~B}$ Receitas brutas, composição de custos da irrigação, receitas líquidas e relação benefício/custo para o feijão caupi, em cada época de semeadura, nível de manejo da irrigação e risco de $5 \%$. Parnaíba, Piauí 
2B Receitas brutas, composição de custos da irrigação, receitas líquidas e relação beneficio/custo para o feijão caupi, em cada época de semeadura, nível de manejo da irrigação e risco de $10 \%$. Parnaíba, Piauí

3B Receitas brutas, composição de custos da irrigação, receitas líquidas e relação beneficio/custo para o feijão caupi, em cada época de semeadura, nível de manejo da irrigação e risco de $15 \%$. Parnaíba, Piauí

4B Receitas brutas, composição de custos da irrigação, receitas líquidas e relação benefício/custo para o feijão caupi, em cada época de semeadura, nível de manejo da irrigação e risco de $25 \%$. Parnaíba, Piauí

5B Receitas brutas, composição de custos da irrigação, receitas líquidas e relação benefício/custo para o feijão caupi, em cada época de semeadura, nível de manejo da irrigação e risco de 30 \%. Parnaíba, Piauí

6B Receitas brutas, composição de custos da irrigação, receitas líquidas e relação benefício/custo para o feijão caupi, em cada época de semeadura, nível de manejo da irrigação e risco de $35 \%$. Parnaíba, Piauí

7B Receitas brutas, composição de custos da irrigação, receitas líquidas e relação benefício/custo para o feijão caupi, em cada época de semeadura, nível de manejo da irrigação e risco de 40 \%. Parmaíba, Piauí

8B Receitas brutas, composição de custos da irrigação, receitas líquidas e relação beneficio/custo para a melancia, em cada época de semeadura, nível de manejo da irrigação e risco de $5 \%$. Parnaiba, Piauí

9B Receitas brutas, composição de custos da irrigação, receitas líquidas e relação benefício/custo para a melancia, em cada época de semeadura, nível de manejo da irrigação e risco de $10 \%$. Parnaíba, Piauí

10B Receitas brutas, composição de custos da irrigação, receitas líquidas e relação benefício/custo para a melancia, em cada época de semeadura, nível de manejo da irrigação e risco de $15 \%$. Parnaíba, Piauí

11B Receitas brutas, composição de custos da irrigação, receitas líquidas e relação benefício/custo para a melancia, em cada época de semeadura, nível de manejo da irrigação e risco de $20 \%$. Parnaíba, Piauí

12B Receitas brutas, composição de custos da irrigação, receitas líquidas e relação benefício/custo para a melancia, em cada época de semeadura, nível de manejo da irrigação e risco de 25 \%. Parnaíba, Piauí 
13B Receitas brutas, composição de custos da irrigação, receitas líquidas e relação benefício/custo para a melancia, em cada época de semeadura, nível de manejo da irrigação e risco de $30 \%$. Parnaiba, Piauí

14B Receitas brutas, composição de custos da irrigação, receitas líquidas e relação beneficio/custo para a melancia, em cada época de semeadura, nível de manejo da irrigação e risco de $35 \%$. Parnaíba, Piauí

15B Receitas brutas, composição de custos da irrigação, receitas líquidas e relação benefício/custo para a melancia, em cada época de semeadura, nível de manejo da irrigação e risco de $40 \%$. Parnaíba, Piauí

16B Receitas brutas, composição de custos da irrigação, receitas líquidas e relação benefício/custo para o feijão caupi, em cada época de semeadura, nível de manejo da irrigação e risco de $5 \%$. Teresina, Piauí

17B Receitas brutas, composição de custos da irrigação, receitas líquidas e relação benefício/custo para o feijão caupi, em cada época de semeadura, nível de manejo da irrigação e risco de $10 \%$. Teresina, Piauí

18B Receitas brutas, composição de custos da irrigação, receitas líquidas e relação benefício/custo para o feijão caupi, em cada época de semeadura, nível de manejo da irrigação e risco de $15 \%$. Teresina, Piauí

19B Receitas brutas, composição de custos da irrigação, receitas líquidas e relação benefício/custo para o feijão caupi, em cada época de semeadura, nível de manejo da irrigação e risco de $20 \%$. Teresina, Piauí

20B Receitas brutas, composição de custos da irrigação, receitas líquidas e relação beneficio/custo para o feijão caupi, em cada época de semeadura, nível de manejo da irrigação e risco de $25 \%$. Teresina, Piauí

21B Receitas brutas, composição de custos da irrigação, receitas líquidas e relação benefício/custo para o feijão caupi, em cada época de semeadura, nível de manejo da irrigação e risco de 30 \%. Teresina, Piauí

22B Receitas brutas, composição de custos da irrigação, receitas líquidas e relação benefício/custo para o feijão caupi, em cada época de semeadura, nível de manejo da irrigação e risco de $35 \%$. Teresina, Piauí

23B Receitas brutas, composição de custos da irrigação, receitas líquidas e relação benefício/custo para o feijão caupi, em cada época de semeadura, nível de manejo da irrigação e risco de $40 \%$. Teresina, Piauí 
24B Receitas brutas, composição de custos da irrigação, receitas líquidas e relação benefício/custo para a melancia, em cada época de semeadura, nivel de manejo da irrigação e risco de $5 \%$. Teresina, Piauí

25B Receitas brutas, composição de custos da irrigação, receitas líquidas e relação benefício/custo para a melancia, em cada época de semeadura, nível de manejo da irrigação e risco de $10 \%$. Teresina, Piauí .

26B Receitas brutas, composição de custos da irrigação, receitas líquidas e relação beneficio/custo para a melancia, em cada época de semeadura, nível de manejo da irrigação e risco de $15 \%$. Teresina, Piauí

27B Receitas brutas, composição de custos da irrigação, receitas líquidas e relação benefício/custo para a melancia, em cada época de semeadura, nível de manejo da irrigação e risco de $20 \%$. Teresina, Piauí

28B Receitas brutas, composição de custos da irrigação, receitas líquidas e relação benefício/custo para a melancia, em cada época de semeadura, nível de manejo da irrigação e risco de $25 \%$. Teresina, Piauí

29B Receitas brutas, composição de custos da irrigação, receitas líquidas e relação beneficio/custo para a melancia, em cada época de semeadura, nível de manejo da irrigação e risco de $30 \%$. Teresina, Piauí

30B Receitas brutas, composição de custos da irrigação, receitas líquidas e relação beneficio/custo para a melancia, em cada época de semeadura, nível de manejo da irrigação e risco de $35 \%$. Teresina, Piauí

31B Receitas brutas, composição de custos da irrigação, receitas líquidas e relação benefício/custo para a melancia, em cada época de semeadura, nível de manejo da irrigação e risco de $40 \%$. Teresina, Piauí

32B Receitas líquidas para o feijão caupi (US\$ ha ${ }^{-1}$ ), em cada época de semeadura, nível de manejo da irrigação e nível de risco. Parnaiba, Piauí

33B Receitas líquidas para o feijão caupi (US $\$ \mathrm{ha}^{-1}$ ), em cada época de semeadura, nível de manejo da irrigação e nível de risco. Teresina, Piauí

34B Receitas líquidas para a melancia (US\$ ha ${ }^{-1}$ ), em cada época de semeadura, nível de manejo da irrigação e nível de risco. Parnaiba, Piauí

35B Relação beneficio/custo para o feijão caupi, em cada época de semeadura, nivel de manejo da irrigação e nível de risco. Teresina, Piauí

36B Relação benefício/custo para a melancia, em cada época de semeadura, nivel de manejo da irrigação e nível de risco. Parnaíba, Piauí 
37B Relação benefício/custo para a melancia, em cada época de semeadura, nivel de manejo da irrigação e nivel de risco. Teresina, Piauí

38B Relação benefício/custo para o feijão caupi, em regime de sequeiro, em cada época de semeadura e nivel de risco. Parnaiba, Piauí

39B Relação beneficio/custo para o feijão caupi, em regime de sequeiro, em cada época de semeadura e nível de risco. Teresina, Piauí

40B Relação benefício/custo para a melancia, em regime de sequeiro, em cada época de semeadura e nivel de risco. Parnaiba, Piauí

41B Relação benefício/custo para a melancia, em regime de sequeiro, em cada época de semeadura e nivel de risco. Teresina, Piauí 


\title{
VIABILIDADE DA IRRIGAÇÃO, SOB RISCO CLIMÁTICO E ECONÔMICO, NAS MICRORREGIÕES DE TERESINA E LITORAL PIAUIENSE
}

\author{
Autor: ADERSON SOARES DE ANDR ADE JÚNIOR \\ Orientador: Prof. JOSÉ ANTONIO FRIZZONE
}

\section{RESUMO}

O objetivo deste estudo foi avaliar a viabilidade da irrigação das culturas de feijão caupi e melancia sob risco climático e econômico, nas condições edafoclimáticas das microrregiões do Litoral Piauiense e de Teresina, no Piauí, utilizando-se diferentes níveis de manejo (extração de 0,$2 ; 0,3 ; 0,4 ; 0,5 ; 0,6 ; 0,7$ e 0,8 da capacidade de água disponivel no solo), épocas de semeadura (de 1-Jan a 15-Dez com intervalo de 15 dias) e níveis de risco $(5,10,15,20,25,30,35$ e $40 \%)$. A estimativa das necessidades de irrigação e das produtividades das culturas foi baseada no déficit de evapotranspiração relativa obtido do balanço hídrico sequencial na escala diária. Os valores diários de precipitação pluviométrica, evapotranspiração de referência e as estimativas mensais dos preços de venda dos produtos e das tarifas de energia elétrica foram simuladas pelo método de Monte Carlo. Constatou-se que as funções de distribuição de probabilidade gama (precipitação pluviométrica), normal (evapotranspiração de referência) e triangular (preços dos produtos e das tarifas de energia elétrica) ajustaram-se aos valores observados para essas variáveis, segundo o teste de aderência de Kolmogorov - Smirnov ao nivel de $5 \%$ de probabilidade. O modelo de simulação da precipitação pluviométrica e evapotranspiração de referência adotado mostrou-se bastante eficiente, comprovado pelos resultados dos índices de desempenho estatístico (coeficiente de correlação de Pearson, índice de Willmott e coeficiente "c" de Camargo) avaliados. O balanço hídrico simulado possibilitou estimativas das lâminas brutas de irrigação e das produtividades das culturas dentro da faixa de valores comumente alcançados, em condições de campo, nas duas microrregiões estudadas. A irrigação das culturas de feijão caupi e melancia 
apresentou viabilidade econômica para diversas combinações entre microrregiões, épocas de semeadura, níveis de manejo e de risco avaliados. As receitas líquidas auferidas com ambas as culturas aumentaram à medida que o nível de risco variou de $5 \%$ a $40 \%$. Para os produtores propensos ao risco, é preferivel a adoção da irrigação suplementar, durante a estação chuvosa, devido à maior atratividade econômica dessa alternativa, já que esta prática proporcionou ganhos significativos de produção associada aos bons preços de venda dos produtos e incorporou baixos custos de energia elétrica ao custo total de produção, devido à necessidade de aplicação de pequenas làminas brutas de irrigação. Em face da coerência dos resultados alcançados e da simplicidade da metodologia empregada, este estudo constitui uma importante ferramenta auxiliar na definição das estratégias de manejo econômico da irrigação de feijão caupi e melancia, considerando-se a análise de risco no processo de tomada de decisão. 


\title{
IRRIGATION FEASIBILITY UNDER CLIMATIC AND ECONOMIC RISK IN TERESINA AND PIAUÍ COAST, PIAUÍ STATE, BRAZIL
}

\author{
Author: ADERSON SOARES DE ANDRADE JÚNIOR \\ Adviser: Prof. JOSÉ ANTONIO FRIZZONE
}

\section{SUMMARY}

The objective of this study was to evaluate the feasibility of cowpea and watermelon irrigation under climatic and economic risk, in the Piauí coast and Teresina, in Piauí State, Brazil. It takes in account the local soil and climatic conditions. Different irrigations threshold levels $(0,2 ; 0,3 ; 0,4 ; 0,5 ; 0,6 ; 0,7$ and 0,8$)$, planting date (from 1 -Jan to 15 -Dez with interval of 15 days) and risk levels $(5,10,15,20,25,30,35$ and 40\%) were evaluated. To estimate the irrigation requirements and crops yield was used a daily water balance model. Rainfall and reference evapotranspiration daily values, monthly estimates of commodity sale prices and energy cost were simulated using the Monte Carlo's method. It was verified that gamma (rainfall), normal (reference evapotranspiration) and triangular (commodity price and energy cost) probability distribution functions were adjusted to the observed values for all variables, according to Kolmogorov - Smirnov test at 5\% of confidence level. The rainfall and reference evapotranspiration simulation models showed good statistical performance indexes (Pearson's correlation, Willmott and Camargo's "c" coefficients). The simulate water balance estimated the irrigation depth and crops yield in a range of similar values obtained in field conditions. The cowpea and watermelon irrigation showed economic feasibility for the evaluated interactions among regions, planting date, risk levels and irrigation thresholds. For both crops, the net returns were higher as the risk level increased from $5 \%$ to $40 \%$. For producers that take risk, the best option is the seasonal irrigation, during the rain season, due to the largest economic benefits of this alternative. This practice provided the highest yield associated with a good commodity sale prices. It 
incorporated low energy costs at the total production cost because of low crop irrigation requirements. This study showed that this model is an important tool to identify and optimize cowpea and watermelon irrigation strategies. taking into account the risk assessment in the making decision process. 


\section{INTRODUÇÃO}

A agricultura é uma atividade econômica, que por estar sujeita à variabilidade do clima, dos preços agrícolas, do mercado e da política agrária, torna-se instável e de alto risco, devendo ser bem planejada para que as chances de sucesso sejam maximizadas. Entre todas as atividades econômicas, é a que apresenta maior dependência das condições climáticas. Essa dependência é responsável por 60 a $70 \%$ da variabilidade final da produção (Ortolani \& Camargo, 1987).

O Estado do Piauí apresenta duas estações bem definidas: uma chuvosa e outra seca. É caracterizado por três regimes pluviométricos bem definidos: i) região sul, de novembro a março; ii) região central, de dezembro a abril e iii) região norte, de janeiro a maio. Nesses períodos, as chuvas são superiores a $1.000 \mathrm{~mm}$ em, aproximadamente, $48 \%$ do território piauiense. Entretanto, para o restante dos meses ocorre redução significativa nas alturas pluviométricas, destacando-se agosto e setembro como os mais críticos devido aos baixos índices pluviométricos. Salienta-se que durante a estação chuvosa as precipitações não são uniformemente distribuídas.

Tradicionalmente, predomina no Estado a chamada "agricultura de sequeiro", na qual a produção agrícola é totalmente dependente das precipitações pluviométricas, as quais devido à sua irregularidade e variabilidade, tanto temporal como espacial, favorecem a ocorrência de déficits hídricos, que conferem uma extrema aleatoriedade ao rendimento das principais culturas agrícolas exploradas.

Devido à característica climática do Piauí, a irrigação torna-se uma prática fundamental e imprescindivel para viabilizar e incrementar a produção agricola do Estado, apresentando caráter suplementar durante a estação chuvosa e de irrigação total, na estação seca. 
Em função disso, faz-se necessário uma análise da viabilidade econômica da irrigação, notadamente da efetuada com caráter suplementar, visando a exploração de culturas de grãos e hortaliças. Isto porque, recentemente, os programas oficiais do governo na área de irrigação para o Nordeste têm-se caracterizado por excessivos incentivos para a implantação de projetos voltados para a fruticultura irrigada, sob a premissa de que apenas esse tipo de exploração apresenta rentabilidade econômica.

Alguns estudos têm concluído que a irrigação de determinadas culturas de grãos, tais como milho e feijão, e de hortaliças é economicamente viável. Entretanto, a análise econômica efetuada nestes estudos não foi associada à questão do risco climático e econômico, ou seja, não considerou a incerteza das precipitações pluviométricas, bem como dos preços dos produtos agrícolas e das tarifas de energia elétrica, os quais afetam decisivamente a variabilidade dos retornos líquidos advindos da introdução dessa técnica.

As culturas de feijão caupi (Vigna unguiculata (L.) Walp.), conhecido como feijão-de-corda ou feijão macassar, e melancia (Citrullus lanatus Thumb. Mansf.) desempenham importante papel na produção agrícola piauiense, verificando-se ultimamente uma expansão da área com essas culturas em cultivos comerciais sob regime de irrigação. Essas culturas foram selecionadas para estudo, devido à sua importância sócio-econômica e aos impactos negativos quando cultivadas em condição de sequeiro. Além disso, existem resultados de pesquisas consolidados, envolvendo diversos aspectos ligados ao seu processo produtivo, em determinadas condições edafoclimáticas do Estado.

O objetivo geral deste estudo foi avaliar a viabilidade da irrigação das culturas de feijão caupi e melancia sob risco climático e econômico, nas condições edafoclimáticas das microrregiões do Litoral Piauiense e de Teresina, no Piauí, utilizando-se diferentes níveis de manejo e épocas de semeadura. Os objetivos especificos foram: i) simular a precipitação pluviométrica e evapotranspiração de referência diária; ii) estabelecer níveis de manejo da irrigação para as referidas culturas de forma que tenham sustentabilidade econômica e iii) avaliar o nível de risco envolvido no manejo da irrigação suplementar e total das culturas de feijão caupi e melancia nas duas regiões edafoclimáticas. 
Espera-se que os resultados oriundos desse estudo possam ser aplicados para orientar o planejamento agrícola das culturas de feijão caupi e de melancia sob irrigação, de modo a torná-las economicamente viáveis, e dar suporte ao processo de tomada de decisão com relação à adoção econômica da irrigação. 



\section{REVISĀO DE LITERATURA}

\subsection{Necessidade de irrigação e efeito do déficit hídrico na cultura do feijão caupi}

O feijão caupi é a principal leguminosa de grãos cultivada no Estado do Piauí. Ocupa o segundo lugar em área cultivada e tem destaque sócio-econômico como fonte de proteina e fixadora de mão-de-obra (Cardoso et al., 1997).

Diversos estudos têm sido realizados a fim de viabilizar técnica $\mathrm{e}$ economicamente o cultivo do feijão em regime irrigado, pois essa leguminosa responde positivamente à irrigação e os impactos na produção de grãos advindos da ocorrência de períodos de déficit hídrico durante o seu ciclo de desenvolvimento são expressivos. Entretanto, face à sua importância regional, poucos são os trabalhos de pesquisa conduzidos com a espécie Vigna unguiculata em relação à espécie Phaseolus vulgaris, que apresenta abrangência nacional.

Silva (1978), estudando os efeitos de cinco lâminas de água $(235,285,378,466$ e $471 \mathrm{~mm})$ e quatro doses de adubação nitrogenada $\left(0,40,80\right.$ e $\left.120 \mathrm{~kg} \mathrm{ha}^{-1}\right)$ sobre a produção do feijão caupi e seus componentes, verificou que a aplicação de água repercutiu em aumento linear na produção de grãos, alcançando os maiores valores ( 1.070 e $1.376 \mathrm{~kg} \mathrm{ha}^{-1}$ ) com a aplicação de $466 \mathrm{~mm}$ com $80 \mathrm{~kg} \mathrm{ha}^{-1}$ de $\mathrm{N}$ e $471 \mathrm{~mm}$ com $120 \mathrm{~kg}$ de $\mathrm{N} \mathrm{ha}^{-1}$. Dentre os componentes de produção, o número de vagens por planta apresentou resposta linear em relação à aplicação das lâminas de irrigação.

Silva \& Millar (1981a) verificaram a influência do conteúdo de água $(6,6 ; 5,5$; 4,0; 3,5 e 3,0 \% em peso) e do potencial mátrico de água no solo $(30,50,120,220$ e 460 $\mathrm{kPa}$ ) sobre o rendimento de grãos do feijão caupi. Concluíram que o conteúdo de água no solo afetou a rendimento de grãos e que a produção máxima $\left(991,4 \mathrm{~kg} \mathrm{ha}^{-1}\right)$ foi 
alcançada com um conteúdo de água no solo de 5,5\% em peso, correspondendo a manutenção de um potencial mátrico de água no solo de $50 \mathrm{kPa}$.

Guimarães et al. (1983) verificaram que a suspensão da irrigação a partir do início do enchimento dos grãos reduziu $10 \%$ a produtividade em comparação com a irrigação constante durante todo o ciclo do feijão caupi. Quando a suspensão da irrigação ocorreu a partir do início da floração, a produtividade foi reduzida de $56 \%$, indicando a maior sensibilidade das plantas à suspensão da irrigação nesta fase de desenvolvimento.

Bezerra \& Freire Filho (1984) calcularam a evapotranspiração da cultura (ETm) de feijão caupi de ciclo precoce, médio e tardio, semeado em diferentes épocas do ano, nas condições edafoclimáticas de Teresina (PI). Concluíram que a ETm aumentou a partir do mês de abril até a máxima demanda, em setembro, com valores médios diários variando de 3,2 $\mathrm{mm} \mathrm{dia}^{-1}$ a 5,4 $\mathrm{mm} \mathrm{dia}^{-1}$ (precoce), 3,3 $\mathrm{mm} \mathrm{dia}^{-1}$ a $5,4 \mathrm{~mm} \mathrm{dia}^{-1}$ (médio) e $3,4 \mathrm{~mm} \mathrm{dia}^{-1}$ a $5,5 \mathrm{~mm} \mathrm{dia}^{-1}$ (tardio). A lâmina líquida de irrigação necessária para o cultivo de variedades precoces variou de $209,8 \mathrm{~mm}$ a $349,4 \mathrm{~mm}$ entre o período de menor e maior demanda evapotranspirativa.

Ziska et al. (1985) conduziram estudo com o objetivo de avaliar métodos para o manejo da irrigação do feijão caupi, que possibilitassem a redução do uso de água e a elevação da produtividade de sementes. Observaram que a manutenção de um estresse hídrico durante a fase vegetativa associado com os manejos da irrigação efetuados quando o solo atingia $25 \%\left(2,22 \mathrm{tha}^{-1}\right), 50 \%\left(2,17 \mathrm{tha}^{-1}\right)$ e $75 \%\left(2,22 \mathrm{tha}^{-1}\right)$ da água disponivel não reduziram significativamente $(\mathrm{P}>0,05)$ a produtividade de sementes.

Padilha Júnior (1986) procedeu a estimativa da evapotranspiração real (ETr) da cultura do feijão caupi utilizando a metodologia de balanço hídrico aplicado em um volume de controle do solo. Verificou que as taxas diárias de $\operatorname{ETr}$ foram de 5,8; 7,7 e 4,9 $\mathrm{mm}$, correspondentes aos primeiros 31 dias, aos 41 dias subsequentes e 11 dias finais, respectivamente.

Bezerra \& Saunders (1992), objetivando avaliar o efeito de dois potenciais mátricos de água no solo $(-40$ e $-70 \mathrm{kPa})$ sobre a produção de cultivares de feijão caupi, concluíram que o rendimento médio de grãos diminuiu significativamente $(P<0,05)$ 
quando o potencial mátrico de água no solo passou de $-40 \mathrm{kPa}\left(1.503,7 \mathrm{~kg} \mathrm{ha}^{-1}\right)$ para -70 $\mathrm{kPa}\left(583,2 \mathrm{~kg} \mathrm{ha}^{-1}\right)$. As evapotranspirações reais médias foram 4,3 e 3,4 $\mathrm{mm} \mathrm{dia}^{-1}$ nos potenciais de -40 e $-70 \mathrm{kPa}$, respectivamente.

Espínola et al. (1992a) visando determinar a resposta do feijão caupi a períodos de estresse hídrico durante as fases de crescimento da cultura, avaliaram os seguintes tratamentos: A - testemunha sem déficit hídrico; B - déficit hídrico na fase de formação da vagem; C - déficit hídrico na fase de maturação; $E$ - déficit hídrico nas fases de crescimento vegetativo e formação de vagem e $F$ - déficit hídrico nas fases de formação da vagem e maturação. Quando da aplicação destes tratamentos, os estádios restantes foram mantidos sem déficit hídrico. Constataram que o déficit hídrico em todos os estádios testados afetaram, em maior ou menor grau, o rendimento de grãos, o número de vagens por planta e o número de grãos por vagem. A fase mais crítica à falta de água foi a de crescimento vegetativo e formação de vagem, onde obtiveram os menores valores de produção de grãos $\left(316 \mathrm{~kg} \mathrm{ha}^{-1}\right)$, número de vagens por planta $(4,0)$ e número de grãos por vagem $(10,5)$.

Espínola et al. (1992b) conduziram experimento visando determinar o efeito da aplicação de cinco lâminas de água $(320,285,235,175$ e $125 \mathrm{~mm})$ sobre a produção e componentes de produção do feijão caupi. Observaram que a produção de grãos foi influenciada pelas lâminas de irrigação aplicadas $(\mathrm{P}<0,05)$, tendo obtido as maiores produções de grãos $\left(1.112,3\right.$ e $\left.1.026,0 \mathrm{~kg} \mathrm{ha}^{-1}\right)$ com a aplicação das lâminas de irrigação de 320 e 285 mm, respectivamente. As menores produtividades de grãos (314,6 e 194,5 $\mathrm{kg} \mathrm{ha}{ }^{-1}$ ) foram alcançadas com as lâminas de irrigação de 175 e $125 \mathrm{~mm}$, respectivamente. Quanto aos componentes de produção, as lâminas de irrigação afetaram o número de vagens por planta e o número de grãos por vagem, os quais foram superiores com a aplicação das maiores lâminas de irrigação.

Nogueira \& Nogueira (1995), nas condições de solo arenoso dos Tabuleiros Costeiros do Piauí, avaliaram o efeito da aplicação de quatro lâminas de irrigação (77,7; $154,1 ; 263,7$ e $415,7 \mathrm{~mm})$ e três doses de fósforo $\left(60 ; 120\right.$ e $\left.180 \mathrm{~kg} \mathrm{ha}^{-1}\right)$ sobre a produção de grãos de feijão caupi cv. BR 12 Canindé e obtiveram produtividades de 
grãos de $1.300 \mathrm{~kg} \mathrm{ha}^{-1}$ com a aplicação da lâmina de irrigação de $415,7 \mathrm{~mm}$ combinado com a dose de $180 \mathrm{~kg} \mathrm{hă}^{-1}$ de fósforo.

Lima (1996) estudou os mecanismos de resistência à seca em duas cultivares de feijão caupi (Pitiúba e João Paulo II), através da imposição de diferentes níveis de estresse hídrico por um sistema de aspersão em linha. Verificou que o número de vagens por planta e o peso de vagens foram reduzidos com o estresse hídrico crescente, com as melhores médias entre cultivares de 9,2 vagens por planta e $29 \mathrm{~g}$, respectivamente. Houve redução na produção de grãos nos tratamentos mais úmidos e mais secos. A maior produção de grãos $\left(1.215,5 \mathrm{~kg} \mathrm{ha}^{-1}\right)$ foi obtida com o tratamento intermediário.

Costa et al. (1997) conduziram experimento em casa-de-vegetação com o objetivo de estudar o efeito do déficit hídrico, imposto nas fases vegetativa (15 a 36 dias após a germinação) e reprodutiva (36 a 80 dias após a germinação), sobre a produção, componentes de produção e distribuição das raízes de feijão caupi cvs. Pitiúba, Setentão e Epace-10. Verificaram que todas as cultivares aprofundaram o sistema radicular em relação à testemunha (sem déficit hídrico). A deficiência hídrica na fase vegetativa determinou um adiamento do florescimento nas três cultivares. $O$ número de vagens por planta, o número de flores por planta e o peso das vagens por planta foram reduzidos igualmente $(\mathrm{P}<0,05)$ pelo déficit hídrico imposto nas duas fases.

Nas condições de solo e clima de Parnaíba (PI), Andrade Júnior et al. (1998a) analisaram a aplicação de quatro lâminas de irrigação (189,2; 273,5; 330,1 e 455,3 mm) sobre a produção de grãos de duas variedades de feijão caupi (BR 14 Mulato e BR 17 Gurguéia) e concluíram que a cultivar BR 17 Gurguéia apresentou maior produtividade de grãos $\left(2.151,2 \mathrm{~kg} \mathrm{ha}^{-1}\right)$ em relação à cultivar BR 14 Mulato $\left(1.858,1 \mathrm{~kg} \mathrm{ha}^{-1}\right)$, devido ao seu melhor desempenho quanto ao número de vagens por planta $(20,9)$, número de grãos por vagem $(13,9)$ e comprimento de vagem $(16,4 \mathrm{~cm})$. Esta cultivar mostrou-se, em valores absolutos, mais eficiente na utilização da água para a produção de grãos $(7,1$ $\mathrm{kg} \mathrm{ha}^{-1} \mathrm{~mm}^{-1}$ ). A produtividade máxima de grãos, para a cultivar BR 17 Gurguéia, foi obtida com a aplicação da lâmina de irrigação de $425 \mathrm{~mm}$ durante todo o ciclo. Ressaltase que a produtividade de grãos obtida nesse estudo foi superior à alcançada por 
Nogueira \& Nogueira (1995) devido ao maior potencial produtivo, sob condições de irrigação, das cultivares utilizadas no ensaio.

Gomes Filho \& Tahin (1998) avaliaram a resposta fisiológica de duas cultivares de feijão caupi (TVu-4552 e Pitiúba) submetidas a cinco niveis de estresse hídrico impostos por um sistema de aspersão em linha. Em ambas as cultivares observaram uma diminuição na taxa de assimilação líquida sempre que aumentava a carência hídrica no solo. A deficiência hídrica não induziu reduções acentuadas no potencial hídrico foliar. Os valores de potencial hídrico foliar, medidos ao alvorecer, permaneceram sempre acima de $-90 \mathrm{kPa}$, na cultivar Pitiúba e $-60 \mathrm{kPa}$, na TVu-4552, no tratamento mais estressado.

A produtividade do feijão caupi cv. Epace-1l sob regime de déficit hídrico em diferentes estádios fenológicos (vegetativo, floração, enchimento de grãos e diversas combinações) foi avaliada por Cordeiro et al. (1998a). O estresse aplicado em apenas um estádio fenológico (enchimento de grãos, floração ou desenvolvimento vegetativo) reduziu a produtividade em $20 \%, 21 \%$ e $26,2 \%$, respectivamente, em relação à testemunha. O estádio de enchimento de grãos foi considerado o mais crítico à deficiência hídrica. Quanto aos componentes de produção, o déficit hídrico afetou significativamente o número de vagens por planta e número de grãos por vagem, enquanto o comprimento de vagem e o peso de cem grãos não foram afetados pela deficiência hídrica.

Segundo Fancelli \& Dourado-Neto (1999) a etapa de formação de vagens é extremamente influenciada pelas condições climáticas, além de ser também considerada como uma das mais sensíveis à falta de água. Deficiências hídricas nesse estádio diminuem a produção pela redução da fotossíntese e do metabolismo da planta, pela queda de vagens jovens (abortamento) e pela retração do tamanho das vagens em fase de crescimento.

Rodrigues et al. (1999) avaliaram o efeito da aplicação de quatro lâminas de irrigação $(392,1 ; 335,9 ; 207,4$ e 113,8 mm) sobre a produção de grãos e vagens verdes de duas cultivares de feijão caupi (BR 10 Piauí e BR 14 Mulato) nas condições edafoclimáticas de Pamaíba (PI). Observaram que as cultivares apresentaram resposta 
diferenciada em relação às lâminas de irrigação apenas para número de vagens por planta. Considerando a média das cultivares, os valores máximos de produtividade de vagens $\left(6.579 \mathrm{~kg} \mathrm{ha}^{-1}\right)$ e de grãos verdes $\left(4.272 \mathrm{~kg} \mathrm{ha}^{-1}\right)$ foram obtidos com a aplicação da lâmina de irrigação de $392,1 \mathrm{~mm}$.

Nas mesmas condições de clima e solo, Andrade Júnior et al. (1999) avaliaram a aplicação de quatro lâminas de irrigação $(449,1 ; 428,6 ; 317,1$ e $194,4 \mathrm{~mm})$ sobre os componentes de produção e a produtividade de grãos secos de duas cultivares de feijão caupi (BR 14 Mulato e BR 17 Gurguéia). Verificaram que houve efeito significativo $(\mathrm{P}<0,05)$ da interação lâminas de irrigação e cultivar somente no número de vagens por planta (NVP) e na produtividade de grãos (PG). A análise de regressão revelou que o maior NVP $(25,6)$ e a máxima PG $\left(2.809 \mathrm{~kg} \mathrm{ha}^{-1}\right)$, para a cultivar BR 17 Gurguéia, foram obtidos com a lâmina de irrigação de 449,1 mm. Para a cultivar BR 14 Mulato, os valores máximos de NVP $(15,0)$ e PG $\left(2.103,4 \mathrm{~kg} \mathrm{ha}^{-1}\right)$ foram obtidos com as lâminas de irrigação de $363,5 \mathrm{~mm}$ e $389,9 \mathrm{~mm}$, respectivamente.

Andrade et al. (1999a) submeteram a cultivar de feijão caupi BR 1 Piauí a quatro diferentes níveis de estresse hídrico iniciais (A - testemunha, B - irrigação aos 30 dias após a germinação (DAG), C - irrigação aos 40 DAG e D - irrigação aos 50 DAG) nas condições edafoclimáticas do Vale do Curu (CE). A irrigação foi efetuada quando o potencial mátrico de água no solo atingia $60 \mathrm{kPa}$. Não detectaram redução significativa $(\mathrm{P}>0,05)$ na produtividade de grãos entre os tratamentos $\mathrm{B}\left(1.618 \mathrm{~kg} \mathrm{ha}^{-1}\right), \mathrm{C}(1.566 \mathrm{~kg}$ $\left.\mathrm{ha}^{-1}\right)$ e $\mathrm{D}\left(1.203 \mathrm{~kg} \mathrm{ha}^{-1}\right)$. A produtividade de grãos do tratamento $\mathrm{A}\left(2.134 \mathrm{~kg} \mathrm{ha}^{-1}\right)$ foi estatisticamente superior $(\mathrm{P}<0,05)$ aos que foram submetidos ao déficit hídrico inicial.

Lima et al. (1999) avaliaram o efeito da aplicação de cinco lâminas de irrigação $(291,8 ; 251,7 ; 219,0 ; 175,7$ e $141,2 \mathrm{~mm})$ sobre a produtividade de grãos de três variedades de feijão caupi (João Paulo II, Pitiúba e Setentão). Concluíram que os valores máximos de produtividade de grãos para as variedades estudadas $\left(1.429,0 \mathrm{~kg} \mathrm{ha}^{-1}\right.$, João Paulo II; $971,0 \mathrm{~kg} \mathrm{ha}^{-1}$, Pitiúba e $1.271,1 \mathrm{~kg} \mathrm{ha}^{-1}$, Setentão) foram obtidos com a aplicação das lâminas de $240,7 \mathrm{~mm} ; 225,9 \mathrm{~mm}$ e $250,6 \mathrm{~mm}$, respectivamente. 
Bastos (1999) adaptou e aplicou o modelo CROPGRO para simulação do crescimento e produtividade do feijão caupi em diferentes condições hídricas e épocas de semeadura em Parnaiba (Areia Quartzosa) e Teresina (Aluvial Eutrófico), visando fornecer informações quanto ao manejo econômico da cultura. Para os dois locais, concluiu que a adoção do manejo de irrigação que mantém o solo com $50 \%$ da capacidade de água disponivel foi o que maximizou a receita liquida do produtor. Verificou que a semeadura em 15 de junho foi a mais indicada em ambos os locais, podendo a mesma estender-se até o mês de setembro, em Parnaiba, e julho, em Teresina. Contudo, o estudo não contemplou épocas de semeadura durante a estação chuvosa (irrigação suplementar) e a análise do manejo econômico da irrigação não foi efetuada sob condição de risco. Quanto aos parâmetros de crescimento, ficou evidenciado que a matéria seca total, o número de folhas e o indice de área foliar foram os mais afetados pelo déficit hídrico (Bastos et al., 2000).

Constatou-se, pelos trabalhos de pesquisa consultados, que a produtividade da cultura do feijão sob regime irrigado é bastante variável em função das condições edafoclimáticas e do potencial produtivo das cultivares. Para o caso específico das regiões do estudo, o feijão caupi apresenta desempenho produtivo satisfatório (1.500 a $2.000 \mathrm{~kg} \mathrm{ha}^{-1}$ ) com a aplicação de lâminas de irrigação variando entre 300 e $450 \mathrm{~mm}$ durante todo o ciclo (Bezerra \& Freire Filho, 1984; Cardoso et al., 1987; Nogueira \& Nogueira, 1995; Cardoso et al., 1997; Andrade Júnior et al., 1998a; Andrade Júnior et al., 1999; Bastos, 1999). Ficou evidente que a ocorrência de deficiência hídrica durante as fases de floração e de enchimento de grãos reduz sensivelmente a produtividade da cultura.

Quanto à viabilidade técnica da irrigação do feijoeiro, os estudos demonstram que a cultura responde positivamente a esta prática. Contudo, o mesmo não pode-se afirmar a respeito da viabilidade econômica desta técnica, devido à carência de trabalhos com esse objetivo, especialmente, sob condição de risco climático e econômico. 


\subsection{Necessidade de irrigação e efeito do déficit hídrico na cultura da melancia}

De maneira geral, o estado do Piauí caracteriza-se por apresentar solos de textura arenosa, possuir um considerável potencial hídrico de boa qualidade e clima favorável para a produção de frutas e hortaliças sob irrigação.

Dentre as hortaliças com potencial de produção no Estado, destaca-se a cultura da melancia que vêm apresentando um acréscimo na área cultivada a cada ano. Segundo Andrade Júnior \& Duarte (1999), de um volume médio anual de 11.250 t de melancia, o Estado contribuiu com 1.795 t, o que representa cerca de $16 \%$ do mercado. Constataram que, apesar da participação do Estado ainda ser baixa em comparação a Pernambuco e Bahia, esse volume comercializado representa um acréscimo de quase $100 \%$ em relação ao do período anterior (1986-1991)(Duarte et al., 1992), comprovando a expansão que essa cultura apresentou nos últimos seis anos.

As hortaliças têm o seu desenvolvimento e rendimento influenciados pelas condições de clima e umidade do solo. O teor de água no solo exerce influência tanto pela deficiência como pelo excesso (Marouelli et al., 1996; Reichardt, 1987). Segundo Filgueira (1982) e Casali et al. (1982), é indispensável, para a cultura da melancia, o uso bem controlado da irrigação, para a obtenção de elevadas produtividades e frutos de melhor qualidade. Além disso, segundo os mesmos autores, a melancia apresenta consumo de água diferenciado ao longo do seu ciclo, sendo que a exigência aumenta do início da ramificação até a frutificação, quando a ocorrência de deficiência hídrica atrasa o crescimento e diminui o tamanho dos frutos. A fase crítica é a que vai da frutificação até o início da maturação, quando a produção é altamente afetada pelo déficit hídrico.

Alguns trabalhos constataram relação de dependência entre o nível de água no solo, o desenvolvimento e a produtividade da cultura da melancia. Em Petrolina (PE), região do Submédio São Francisco, Soares et al. (s.d.) verificaram que os níveis de irrigação $25 \%, 50 \%$ e $75 \%$ da água no solo não proporcionaram diferença significativa na produtividade da melancia. No entanto, observaram um ligeiro acréscimo no peso médio dos frutos, na segunda colheita, quando a irrigação foi efetuada com o consumo de $25 \%$ da água disponível no solo. 
Hedge (1987) analisou os efeitos da irrigação sobre a produção de matéria seca, produtividade e eficiência do uso de água (EUA) da melancia. Concluiu que os melhores resultados quanto à produção de matéria seca $\left(193\right.$ g.planta $\left.{ }^{-1}\right)$ e produtividade $(35,58$ t. ha ${ }^{-1}$ ) foram obtidos com a manutenção de elevados teores de água no solo. O mesmo autor, verificou ainda, que o estresse hídrico correspondente a um potencial mátrico de água no solo de $-75 \mathrm{kPa}$, imposto durante as fases de pré-floração, floração e desenvolvimento dos frutos, reduziu significativamente a produção de matéria seca (16$18 \%$ ) e a produtividade da melancia (19-24\%). Com relação à EUA, constatou uma variação de 84,3 a 99,5 $\mathrm{kg} \mathrm{ha}^{-1} \mathrm{~mm}^{-1}$ com a imposição de potenciais de água no solo de $25 \mathrm{a}-75 \mathrm{kPa}$ durante as fases de pré-floração, floração e desenvolvimento de frutos.

Rudich et al. (1978) observaram que a irrigação contínua da melancia durante a fase de desenvolvimento dos frutos resultou em uma produtividade de $54,4 \mathrm{t}^{-\mathrm{ha}^{-1}}$, o que representou um acréscimo de $48 \%$ na produtividade final da cultura em relação ao tratamento que não previa a irrigação nessa fase.

Dentre os vários métodos para o manejo da irrigação existentes, o do tanque Classe A tem sido amplamente utilizado em todo o mundo devido, principalmente, ao custo relativamente baixo, possibilidade de instalação próximo da cultura a ser irrigada e a sua facilidade de operação (Volpe \& Churata-Masca, 1988), além dos resultados satisfatórios para a estimativa hidrica das culturas (Klar, 1974; Sediyama, 1987; Saad \& Scaloppi, 1988; Lima \& Silva, 1988 e Bastos, 1994).

A evaporação da superficie de água do tanque Classe A fornece uma medida do efeito integrado da radiação solar, vento e umidade relativa do ar, os quais são os mesmos elementos climáticos que afetam a demanda hídrica da cultura em condições de campo (Klar, 1991a e Doorenbos \& Pruitt, 1997a). Por isso, com a finalidade de estimar com maior precisão a evapotranspiração da cultura, torna-se bastante interessante a determinação de um coeficiente denominado de fator de evaporação do tanque Classe A $(\mathrm{Kt})$, que correlacione os elementos climáticos envolvidos no processo com as reais necessidades hidricas das culturas em cada região específica.

Mangal et al. (1985) analisaram os efeitos de diferentes níveis de irrigação $(0,4$; 0,6; 0,8 e 1,0) em função da evaporação do tanque Classe A (ECA) sobre a 
produtividade e crescimento da melancia. A aplicação do nível 1,0 da ECA possibilitou a obtenção da maior produtividade da cultura $\left(8,45 \mathrm{t} \mathrm{ha}^{-1}\right)$.

Rudich et al. (1978), analisando o efeito da irrigação em diferentes fases do ciclo da melancia, observaram que a melhor produtividade $\left(54,4\right.$ t.ha $\left.{ }^{-1}\right)$ foi obtida irrigando-se as plantas durante toda a fase de desenvolvimento dos frutos. As lâminas de irrigação aplicadas foram calculadas em $70 \%(\mathrm{Kt}=0,7)$ da evaporação diária do tanque Classe $\mathrm{A}$. $\mathrm{O}$ incremento na produtividade foi devido, principalmente, ao efeito da irrigação sobre $\mathrm{o}$ peso médio do fruto.

Srinivas et al. (1989), estudando os efeitos de quatro níveis de irrigação $(0,25$; 0,$50 ; 0,75$ e 1,00) em função da evaporação do tanque Classe A (ECA) sobre uma cultura de melancia irrigada por gotejamento, verificaram que a produtividade máxima $\left(31,0\right.$ tha $\left.^{-1}\right)$ foi alcançada com a utilização de $\mathrm{Kt}=1,0$, embora não tenha sido diferente estatisticamente da produtividade obtida com a aplicação de $\mathrm{Kt}=0,75\left(29,5 \mathrm{t}_{\mathrm{ha}} \mathrm{h}^{-1}\right)$.

Nas condições edafoclimáticas da microrregião do Litoral Piauiense, Andrade Júnior et al. (1997) avaliaram o efeito de diferentes níveis de irrigação por gotejamento sobre a produção e a qualidade de frutos de melancia. Os níveis de irrigação foram baseados em frações $(0,2 ; 0,4 ; 0,6 ; 0,8$ e 1,0$)$ da evaporação do tanque Classe A. Os resultados mostraram que o peso médio de fruto comercial $(9,8 \mathrm{~kg})$ e a produtividade comercial $\left(65,4 \mathrm{t} \mathrm{ha}^{-1}\right)$ máximos foram obtidos com a aplicação do nível de irrigação equivalente a 0,7 da evaporação do tanque Classe $A$, que representou a aplicação de uma lâmina total de 410,9 mm.

Sob as mesmas condições edafoclimáticas e adotando metodologia semelhante, porém, em ensaio conduzido de setembro a novembro de 1997, Andrade Júnior et al. (1998b) verificaram que o peso médio de fruto comercial $(9,4 \mathrm{~kg})$ e a produtividade comercial $\left(62,6 \mathrm{t} \mathrm{ha}^{-1}\right)$ máximas foram obtidos com a aplicação do nível de irrigação correspondente a 0,6 da evaporação do tanque Classe A $(326,5 \mathrm{~mm})$.

Observou-se que a cultura da melancia apresenta respostas, as mais variadas possíveis, em termos de crescimento e de produção, face às condições hídricas e à demanda evapotranspirativa da atmosfera dos locais onde os estudos foram executados. Por isso, a definição quanto ao manejo da irrigação da cultura a ser adotado é 
aconselhado apenas para as referidas condições. Para o caso específico da microrregião do Litoral Piauiense, os resultados de pesquisa, visando a máxima eficiência técnica, têm apontado para a utilização de lâminas de irrigação entre 300 e $400 \mathrm{~mm}$ durante todo o ciclo (Andrade Júnior et al., 1997; Andrade Júnior et al., 1998b). A ocorrência de deficiência hídrica durante as fases de floração e enchimento dos frutos reduz sensivelmente a produtividade da cultura. De acordo com a literatura não há dúvidas quanto à viabilidade técnica da irrigação da melancia. Entretanto, o mesmo não se pode afirmar quanto à economicidade dessa prática devido a carência de trabalhos com o objetivo de analisar a viabilidade econômica da irrigação nessa cultura, notadamente, sob condição de risco climático e econômico.

\subsection{Déficit de evapotranspiração e produção relativa}

A evapotranspiração constitui a transferência de água, na forma de vapor, do sistema solo-planta para a atmosfera. Trata-se de um fluxo que depende principalmente da energia disponível para a evaporação da água. Não havendo restrição de água no solo, a evapotranspiração é controlada pela disponibilidade de energia e pelo poder evaporante do ar.

Contudo, em condições normais de cultivo, a disponibilidade de água no solo nem sempre encontra-se em níveis ótimos. Dessa forma, a evapotranspiração está sujeita à interação entre a demanda atmosférica e a umidade do solo. Denmead \& Shaw (1962) mostraram que o solo é um reservatório ativo de água que, dentro de certos limites, controla a taxa de perda de água pelas plantas.

Com o objetivo de sistematizar o uso dos métodos de determinação da evapotranspiração e padronizar os conceitos, Doorenbos \& Pruitt (1997a) apresentaram os conceitos básicos de evapotranspiração de referência (ETo), evapotranspiração máxima ou de cultura (ETm) e coeficiente de cultivo (Kc). Segundo os autores, a ETo corresponde à evapotranspiração de uma superficie extensa de gramínea verde de 8 a 15 $\mathrm{cm}$ de altura, uniforme, em ativo crescimento, sombreando completamente o solo e onde não exista limitação de água. A ETo constitui-se como um fator básico na determinação 
do total de água necessária durante o ciclo de uma cultura, quando se deseja um manejo racional da água de irrigação.

Considerando a diferença existente entre a grama em crescimento ativo e outras culturas, definiram a ETm como a perda de água por uma cultura qualquer, sem restrição hídrica em qualquer estádio de desenvolvimento. O valor de ETm é relacionado ao de ETo através de um coeficiente apropriado, denominado de coeficiente de cultura $(\mathrm{Kc})$. Esse coeficiente quantifica os efeitos das características da cultura sobre suas necessidades hídricas. Na ausência das condições fixadas para a definição da ETm, a evapotranspiração é chamada de evapotranspiração real (ETr), ou seja, refere-se à perda de água por uma comunidade vegetal qualquer, com ou sem restrição hídrica, em qualquer estádio de desenvolvimento. Dessa forma, o valor de ETr será sempre menor ou igual a ETm.

Diversos são os métodos de estimativa da evapotranspiração de referência. Contudo, o importante é conhecer-se as limitações de cada método e os detalhes de seu desenvolvimento, a fim de permitir ao usuário a decisão quanto a conveniência de sua utilização em uma determinada situação (Pereira et al., 1997a).

Segundo estes autores, de acordo com os princípios envolvidos no desenvolvimento, os métodos de estimativa da ETo podem ser agrupados em cinco categorias: a) empíricos; b) aerodinâmico; c) balanço de energia; d) combinados e e) correlação de turbilhões. Dentro da categoria dos métodos combinados, destacam-se o método de Penman e o de Penman - Monteith, os quais integram os efeitos do balanço de energia com os do poder evaporante do ar.

O método de Penman - Monteith constitui uma modificação do método de Penman original, com a inclusão dos parâmetros relativos à resistência aerodinâmica e resistência da cultura, sendo atualmente recomendado pela FAO como método padrão de estimativa, sempre que houver disponibilidade dos dados requeridos para o seu cálculo (Brito \& Amorim Neto, 1994). Segundo esses autores, cálculos comparativos entre esses dois métodos, efetuados em oito diferentes localidades, sugerem uma tendência de superestimativa da ETo pelo método de Penman em relação a Penman - Monteith. 
Para as condições climáticas de Teresina (PI), Lima \& Silva (1988) compararam os valores de ETo determinados pelos métodos de Radiação Solar, do tanque Classe A, de Thornthwaite, de Hargreaves, de Blaney \& Criddle e de Benavidez \& Lopez durante o periodo de maior demanda hídrica (outubro a dezembro). Observaram que os métodos baseados nos mesmos elementos meteorológicos, tais como: Thornthwaite, Hargreaves, Blaney \& Criddle e Benavidez \& Lopez apresentaram coeficientes de correlação similares entre si. Por exemplo, os modelos de Hargreaves e de Benavídez \& Lopez, que utilizam a temperatura média e a umidade relativa do ar, apresentaram um coeficiente de correlação igual a 0,98. Os autores recomendaram, para a estimativa da ETo na região, os modelos de Radiação Solar, tanque Classe A e Thornthwaite.

Nas mesmas condições climáticas, Nascimento et al. (1997) correlacionaram valores médios diários de ETo, medidos em evapotranspirômetros com lençol freático de nivel constante, com a evaporação do tanque Classe A (ECA), para subperíodos de cinco dias. Ajustaram uma equação de regressão linear simples entre esses dois elementos $(E T o=0,97+0,5869 \mathrm{ECA})$ com um coeficiente de determinação $\mathrm{R}^{2}=0,80^{* *}$, que permite a estimativa da ETo sem a necessidade de dados de umidade relativa do ar e velocidade do vento locais. Observaram que os coeficientes de tanque $(\mathrm{Kp})$, obtidos experimentalmente pela relação ETo/ECA, foram, em geral, inferiores aos sugeridos pela FAO.

Utilizando a evaporação do tanque Classe A para a estimativa da ETo na região de Teresina (PI), Bastos et al. (1997) efetuaram o ajuste da distribuição de freqüência da evapotranspiração de referência através do modelo de Gumbel, com a finalidade de orientar a escolha de valores representativos de ETo, para periodos acumulados de 1 a 7 dias, em diferentes níveis de probabilidade visando o dimensionamento mais criterioso dos sistemas de irrigação nessa região.

As necessidades hídricas das culturas são normalmente expressas mediante a evapotranspiração de referência, as quais estão relacionadas com a evapotranspiração máxima da cultura através dos coeficientes de cultivo $(\mathrm{Kc})$. Os valores dos coeficientes de cultivo variam com a cultura, com seu estádio de desenvolvimento e, até certo ponto, com a velocidade do vento e a umidade relativa do ar (Doorenbos \& Praitt, 1997b). 
Diversos trabalhos foram executados para determinar os coeficientes de cultivo para feijão caupi (Silva \& Millar, 1981a; Espínola Sobrinho et al., 1989; Padilha Júnior, 1986; Aguiar et al., 1992; Santos et al., 1998; Bezerra \& Oliveira, 1998b; Bezerra et al., 1999) e melancia (Bezerra \& Oliveira, 1998a; Freitas \& Bezerra, 1999a) em diferentes condições agroecológicas.

Para as condições edafoclimáticas de Parnaíba (PI), destaca-se o trabalho de Andrade et al. (1993), no qual os autores propõem equações de regressão para o cálculo diário do Kc de feijão caupi cv. BR 12 Canindé, nos seus diferentes estádios de desenvolvimento, em função dos dias após o plantio. Para as condições de Teresina (PI), Lima \& Silva (1988) determinaram o Kc do feijão caupi utilizando diferentes métodos para a estimativa da evapotranspiração potencial.

A análise do efeito do suprimento de água sobre os rendimentos das culturas é fundamental para o planejamento, projeto e operação de sistemas de irrigação. A relação entre o rendimento da cultura e o suprimento de água pode ser determinada a partir da quantificação das necessidades hídricas da cultura, dos efeitos dos déficits hídricos, do rendimento máximo e real da cultura (Downey, 1972; Howell \& Hiler, 1975; Doorenbos \& Kassam, 1994).

Segundo esses autores, os déficits hídricos nas culturas e o conseqüente estresse hídrico na planta têm certos efeitos sobre a evapotranspiração e o rendimento da cultura. $O$ estresse hídrico na planta pode ser quantificado mediante a relação entre a evapotranspiração real (ETr) e a evapotranspiração máxima (ETm), denominada de evapotranspiração relativa ( 1 - ETr/ETm). A queda de rendimento é obtida pela relação entre o rendimento real (Yr) e o rendimento máximo da cultura (Ym), chamada de rendimento relativo $(1-\mathrm{Yr} / \mathrm{Ym})$.

A resposta do suprimento hídrico de água sobre o rendimento da cultura é quantificada através do fator de resposta da cultura $(\mathrm{Ky})$, o qual relaciona a queda de rendimento relativo com o déficit de evapotranspiração relativa (Doorenbos \& Kassam, 1994).

Sousa \& Frizzone (1997) e Sousa (1999) utilizaram essa relação para quantificar o efeito do estresse hídrico, oriundo da ocorrência de veranicos de diferentes 
intensidade, sobre a queda de produção das culturas. Por outro lado, Bernardo et al. (1988) fizeram uso dessa relação para a estimativa da produtividade das culturas de feijão, milho, sorgo e alfafa em função do déficit de evapotranspiração, no desenvolvimento de um modelo de simulação visando a otimização econômica da lâmina de irrigação sob condição de disponibilidade de água limitada.

$\mathrm{O}$ valor de Ky para diferentes culturas baseia-se na avaliação de inúmeros resultados de pesquisa, abrangendo ampla faixa de condições de crescimento. No caso especifico das culturas de feijão caupi e melancia, destacam-se os trabalhos de Cordeiro et al. (1998b) e Freitas \& Bezerra (1999b), respectivamente.

O rendimento máximo de uma cultura (Ym) é aquele obtido de uma variedade altamente produtiva e bem adaptada ao respectivo ambiente de crescimento, sem limitações de fatores como água, nutrientes, pragas e doenças durante todo o ciclo. É determinado, principalmente, por suas características genéticas e grau de adaptação ao meio ambiente (Doorenbos \& Kassam, 1994).

Existem vários métodos de cálculo do rendimento máximo das culturas para diferentes condições climáticas. Entretanto, segundo Doorenbos \& Kassam (1994), devido à complexidade das inter-relações entre muitos parâmetros, a derivação desses métodos torna-se muito complicada. Por isso, uma alternativa viável para se obter uma estimativa confiável seria a utilização de valores potenciais de produtividade, a nível de campo ou experimentais, nas condições edafoclimáticas de interesse. Franke (1996) utilizou com sucesso esse procedimento para estimar a produtividade potencial das culturas de soja e milho, visando avaliar a viabilidade econômica de sua exploração sob irrigação.

A taxa real de absorção de água do solo pela cultura em relação à sua evapotranspiração máxima é regulada pela suficiente disponibilidade de água no solo e/ou pela ocorrência de déficit hídrico. A determinação da evapotranspiração real (ETr) deve considerar o nível de água disponivel no solo. Quando a disponibilidade de água no solo for suficiente para a cultura, tem-se que ETr $=E T m$. Porém, quando a disponibilidade de água no solo for limitada, ocorre que a ETr $<$ ETm. A disponibilidade 
de água no solo é definida pela fração p que pode ser deduzida da água total disponível do solo, sem que a ETr se torne menor que a ETm (Doorenbos \& Kassam, 1994).

É importante destacar que a relação entre o suprimento de água e o rendimento das culturas é afetada por outros fatores, tais como: cultivar, fertilizantes, salinidade, pragas e doenças e práticas agronômicas. Contudo, com o intuito de facilitar a análise efetuada nesse estudo, considerou-se que as relações apresentadas referem-se a cultivares altamente produtivas, bem adaptadas ao ambiente de crescimento, onde as práticas agronômicas e o manejo da irrigação são realizados sob condições ótimas, conforme ressaltado por Doorenbos \& Kassam (1994).

\subsection{Funções de distribuição para previsão de precipitação e evapotranspiração}

Os elementos climáticos, as características das plantas, as práticas culturais e o conteúdo de água no solo são muito importantes para a quantificação da lâmina de irrigação requerida pelas culturas, sendo que as principais técnicas utilizadas para sua estimativa baseiam-se em dados climáticos (Soares et al., 1998), principalmente, os relacionados à precipitação pluviométrica e evapotranspiração.

Dessa forma, o estudo da distribuição e variabilidade dessas duas varáveis climáticas são importantes, pois possibilitam determinar os seus valores prováveis de ocorrência através do uso de funções de distribuição de probabilidades adequadas. Essas informações facilitam a programação das atividades agrícolas, diminuindo os riscos conseqüentes de seca, veranicos e/ou excessos de chuvas (Andrade Júnior \& Bastos, 1997a), bem como o planejamento e o manejo racional da irrigação.

Em climatologia, a maneira mais utilizada de avaliar-se a probabilidade de um determinado evento é por meio das funções de distribuição de probabilidade, as quais são estimadas com base na experimentação ou através dos eventos passados (Sousa, 1999). Entretanto, um ponto crucial nesse processo é a definição quanto à função de distribuição a ser utilizada e o número mínimo de elementos ou anos de observações necessário para uma adequada estimativa. 
Segundo Assis et al. (1996), um erro muito comum em análise de dados climatológicos é desprezar-se as caracteristicas da distribuição de probabilidade mais adequada para os dados em estudo. O mais freqüente é adotar-se, a priori, a distribuição normal de probabilidades, o que pode resultar em conclusões erradas, caso os dados não obedeçam a essa distribuição. Por isso, é fundamental o uso prévio de procedimentos ou testes de aderência para determinar-se qual a distribuição de probabilidade mais adequada para um determinado conjunto de dados. Dentre esses testes, destaca-se o de Kolmogorov-Smirnov (Campos, 1979).

Quanto ao número de observações necessário, Assis et al. (1996) consideram como razoável, uma amostra de dados, com no minimo, 30 anos de observações. Entretanto, vários trabalhos utilizaram séries menores de dados, sem contudo afetar significativamente as previsões obtidas. De fato, Soares et al. (1998) efetuaram uma caracterização da evapotranspiração de referência e precipitação dependente no Estado de Minas Gerais, com dados de uma série de 10 anos para precipitação e 5 anos para evapotranspiração.

Por outro lado, Andrade et al. (1999b) analisando a representatividade dos dados pluviométricos totais anuais de duas estações climatológicas no Litoral (Fortaleza, com 33 anos de dados) e região Semi-árida do Ceará (Quixeramobim, com 40 anos de dados), com base na determinação do erro da média a longo prazo e da média móvel de 5 anos, verificaram que a precipitação média anual de Fortaleza e Quixeramobim podem ser estimadas pela média da amostragem com um erro de $7 \%$ e $5 \%$, respectivamente, indicando que séries com 40 anos de dados sejam usadas nessas regiões quando se deseja uma melhor representatividade. Concluíram que séries de 30 e 40 anos de dados pluviométricos para estas regiões não foram suficientes para se determinar se a variabilidade temporal da precipitação anual apresenta uma variação definida.

$\mathrm{Na}$ realidade, existem poucas estações climatológicas no Brasil com dados suficientes para ajustar-se aos modelos de distribuição, o que torna necessário a busca de alternativas para a previsão de eventos climáticos futuros, dentre as quais destaca-se a técnica de simulação (Sousa, 1999). 
Existem várias metodologias para a estimativa da precipitação pluviométrica provável, dentre as quais destaca-se a distribuição gama. Apesar de mais complexa que a distribuição normal, a distribuição gama é a que tem apresentado melhores resultados para o ajuste de totais de chuva mensais ou inferiores (Assis et al., 1996). Entretanto, as precipitações pluviométricas de pequenos intervalos de dias são limitadas inferiormente pelo valor zero e os parâmetros da distribuição gama não podem ser estimados pelo método da máxima verossimilhança, o mais geral e recomendado. Nesses casos, deve ser utilizada a função de distribuição gama mista, uma vez que permite uma maior flexibilidade da curva e melhor ajuste aos dados pluviométricos (Castro \& Leopoldo, 1996).

Diversos estudos probabilísticos utilizando a função de distribuição gama foram realizados com o intuito de analisar as precipitações pluviométricas prováveis em diferentes localidades e para diferentes intervalos de dias (Vivaldi, 1973; Frizzone, 1979; Pedro Neto \& Silveira, 1981; Frizzone et al., 1985; Massignam, 1993; Assis \& Villa Nova, 1993; Rodrigues \& Pruski, 1996; Rodrigues \& Machado, 1996; Andrade Júnior \& Bastos, 1997a; Andrade Júnior \& Bastos, 1997b; Bastos et al., 1998; Araújo et al., 1999 e Viana et al., 1999). Entretanto, a resposta dos modelos matemáticos aplicados à estimativa da precipitação provável devem ser reavaliados nas diferentes regiões (Frizzone, 1979), principalmente nas que apresentam grande potencial agrícola (Rodrigues \& Pruski, 1996).

Apesar de ser vasta a literatura quanto ao uso da distribuição gama para efetuar a estimativa da precipitação pluviométrica provável, raros são os trabalhos executados para as localidades contempladas nesse estudo. Destaca-se, unicamente, o trabalho de Silva (1997), que analisou as séries de dados mensais de precipitação pluviométrica do período de 1971 a 1992, em Parnaíba (PI), utilizando as distribuições de probabilidade empírica e gama incompleta. Apresentou estimativas das precipitações mensais esperadas, para os niveis de probabilidade de $5 \%$ a $99 \%$, durante o período chuvoso na região (janeiro a junho). Entretanto, essas informações mensais, apesar de serem úteis para o dimensionamento de sistemas de irrigação, não são adequadas para o manejo da irrigação, especialmente, das culturas de ciclo curto. 
Com relação à evapotranspiração de referência, vários trabalhos mostraram que sua estimativa pode ser efetuada com a função de distribuição normal (Nixon et al., 1972; Pruitt et al., 1972; Arruda \& Barroso, 1984; Saad \& Scaloppi, 1988; Saad, 1990; Silva et al., 1998), beta (Yao, 1969; Saad \& Scaloppi, 1988; Saad, 1990; Silva et al., 1998) e Gumbel (Bastos et al., 1997). Entretanto, para que ocorra um bom ajuste há necessidade de um grande número de dados, no mínimo, 20 anos de observações.

Considerando-se eventos extremos de evapotranspiração de referência (ETo), Bastos et al. (1997) analisaram a distribuição de freqüência da ETo utilizando o modelo de Gumbel a partir de uma série histórica de 15 anos de dados meteorológicos de Teresina (PI). Os valores diários de ETo foram acumulados em períodos de $1,2,3,4,5$, 6 e 7 dias, estabelecendo-se os valores máximos para cada período e ano. Os autores apresentaram os valores máximos de ETo para períodos de 1 a 7 dias, em níveis de probabilidade variando de $5 \%$ a $95 \%$, para os meses de maior demanda hídrica (setembro e outubro), que permitem o dimensionamento e manejo de sistemas de irrigação mais criteriosos nessa região.

Para contornar a limitação quanto ao número insuficiente de observações, Sousa (1999) propõe o uso da distribuição triangular de probabilidade associada à técnica da simulação pelo método de Monte Carlo para a estimativa de valores de evapotranspiração de referência diária. A utilização da distribuição triangular de probabilidade é bastante facilitada nessas situações, pois são necessários apenas os valores máximo, mínimo e o valor mais freqüente ou moda da distribuição.

Sousa \& Frizzone (1998b) compararam os valores do déficit de evapotranspiração na cultura do fumo em Cruz das Almas (BA) simulados com base nas funções de distribuição triangular e normal para dois períodos do ano (verão e inverno). Concluiram que os valores simulados pelas duas funções foram estatisticamente diferentes entre si pelo teste de Tukey ao nível de $5 \%$. Porém, as diferenças foram pequenas, em média inferiores a 5,0\% (período de verão) e $8,5 \%$ (período de inverno), indicando que a função triangular pode ser utilizada como uma alternativa para a simulação de valores de ETo e déficit de evapotranspiração em regiões onde os dados são insuficientes para o ajuste pela função normal. 
O uso de distribuições de probabilidade mais simples, como a distribuição triangular, é particularmente indicado em situações quando se dispõe de poucas informações ou estas constituem-se apenas em probabilidades subjetivas (Anderson et al., 1977; Biserra, 1994; Dias, 1996). Como a utilização desta função muitas vezes está associado a inferências subjetivas nos valores dos parâmetros de entrada deve-se ter atenção especial nos possiveis efeitos que as variações destes parâmetros possam proporcionar nos valores calculados com essa distribuição.

Sousa \& Frizzone (1998a) conduziram estudo com o objetivo de analisar a sensibilidade às variações impostas nos valores iniciais dos parâmetros de entrada da função triangular (valores máximo, mínimo e moda) aplicada à simulação da evapotranspiração de referência (ETo) e do conseqüente déficit de evapotranspiração. As análises de sensibilidade foram efetuadas para os meses de janeiro e julho e consideraram subestimativas e superestimativas de $10 \%, 20 \%$ e $30 \%$ em cada uma dos parâmetros da função triangular. Para os dois meses, considerando uma mesma percentagem de variação imposta, o parâmetro mais sensivel foi o correspondente ao valor máximo da ETo, seguida da moda e do valor mínimo. O valor mínimo de ETo mostrou-se pouco sensivel, pois variações de $30 \%$ neste parâmetro proporcionaram variações da ordem de $9 \%$ (janeiro) e de $6 \%$ (julho) nos valores simulados de déficit de evapotranspiração.

Utilizando a distribuição triangular de probabilidade para a estimativa de ETo diária para os meses de março e julho no município de Piracicaba (SP) em comparação com a distribuição normal de probabilidades, Sousa (1999) verificou maior dispersão nos valores de ETo simulados pela função triangular, quando comparados com os simulados pela função normal, em relação ao valor médio observado. Observou, para a função triangular, uma variação da média simulada da ETo no mês de março inferior à $6,4 \%$ em relação ao valor médio simulado pela função normal. No mês de julho, a função triangular superestimou o valor médio da ETo em $4,6 \%$ em relação à função normal. Concluiu que a função normal proporcionou melhor ajuste quando comparada com a função triangular. 
Verificou-se, portanto, que além das distribuições de probabilidade gama, normal e beta, tradicionalmente utilizadas para a estimativa da precipitação pluviométrica e evapotranspiração de referência, pode-se empregar a distribuição triangular de probabilidade, quando não se dispõe de uma longa série de dados. Em ambos os casos, o uso simultâneo da técnica de simulação constitui-se uma alternativa viável para contornar a limitação quanto ao tamanho insuficiente da série de dados disponível.

\subsection{Simulação aplicada à previsão de eventos futuros}

Simulação é a representação dinâmica de um sistema mediante um modelo, o qual é por natureza, em grande parte matemático. Por sistema entende-se um conjunto de componentes e variáveis que se interrelacionam, formando um corpo único (Frizzone \& Silveira, 2000). Para a descrição do sistema é necessário que a variação de seus elementos possam ser preditos, pelo menos, em termos de distribuição de probabilidades (Hillier \& Lieberman, 1988).

A simulação de dados permite o cálculo de diferentes combinações que probabilisticamente podem ocorrer, obtendo-se como resultado não um valor determinista, mas uma distribuição de freqüências, sendo o risco traduzido em números pela variância (Brunelli, 1990; Dias, 1996; Frizzone \& Silveira, 2000).

Segundo Sousa (1999), a técnica de simulação pode ser adotada com a finalidade de fazer a previsão de fenômenos meteorológicos, uma vez que permite a partir de dados históricos simular a ocorrência futura de possíveis valores. Essa possibilidade é muito importante, uma vez que, na maioria dos casos, as séries de dados climáticos disponíveis para efetuar-se estudos envolvendo as inter-relações clima versus sistema agrícola são muito pequenas, o que pode levar a obtenção de resultados tendenciosos para uma determinada região (Genneville \& Boock, 1983).

Alguns trabalhos foram executados com o intuito de aplicar e validar a técnica de simulação para a geração de valores de evapotranspiração de referência (Howell et al., 1975; Sousa \& Frizzone, 1998a; Sousa \& Frizzone, 1998b e Sousa, 1999), enquanto outros foram conduzidos visando a modelagem estocástica da ocorrência de precipitação 
pluviométrica através da cadeia de Markov (Howell et al., 1975; Genneville \& Boock, 1983; Azevedo \& Leitão, 1990; Almeida, 1995; Sediyama et al., 1996 e Fietz et al., 1998) e de sua magnitude associada à distribuição gama (Carey \& Haan, 1978; Assis, 1991; Assis \& Villa Nova, 1993; Peiter, 1998; Peiter et al., 1999).

A cadeia de Markov é um processo em que a probabilidade do sistema estar em um determinado dia em certo estado depende basicamente do estado do sistema no dia anterior (Marouelli \& Sediyama, 1988; Sousa, 1999). Essa técnica é comprovadamente eficiente para a descrição da ocorrência de dias secos e chuvosos em um determinado período de tempo e região. Contudo, por esse processo não é possível a determinação da magnitude ou quantidade de chuva observada, devendo ser utilizado em associação com uma função de distribuição de probabilidade de precipitação adequada.

No que diz respeito à estimativa de valores de precipitação pluviométrica através da modelagem estocástica, Genneville \& Boock (1983) desenvolveram um modelo para a geração de séries de precipitação pluviométrica diária para a região de Campo Grande (MS). O modelo foi construído usando-se basicamente duas variáveis: i) a probabilidade de ocorrência de chuva em cada dia do mês, com base na cadeia de Markov de primeira ordem e ii) a probabilidade de ocorrência dessa chuva dentro de certa magnitude, utilizando uma distribuição empírica de probabilidade em função das classes de precipitação observadas. A avaliação do modelo mostrou-se positiva tendo verificado pequenos desvios quando comparou-se as médias anuais e mensais de precipitação geradas com as da série histórica.

Nessa mesma linha de estudo, Peiter et al. (1999) efetuaram a estimativa da ocomência e quantidade de chuva diária para a cidade de Santa Maria (RS), no período compreendido entre setembro e janeiro, através da técnica da cadeia de Markov de primeira ordem e do ajuste a uma série histórica (1980-1996) utilizando a distribuição gama. Os autores obtiveram séries geradas com parâmetros estatísticos aceitáveis quando comparados aos verificados nas séries históricas, demonstrando que este método pode ser recomendado para a estimativa da precipitação pluviométrica em Santa Maria (RS). 
Uma técnica de simulação muito utilizada é o método de Monte Carlo, que baseia-se na comparação de números randômicos com uma determinada função estatística (Peres \& Mattos, 1990; Sousa, 1999), ou seja, a partir de um número aleatório e conhecendo-se a distribuição de probabilidades que descreve o evento, o método permite a geração de outros possíveis valores para o referido evento. A literatura apresenta inúmeros trabalhos nos quais essa metodologia foi empregada com resultados satisfatórios (Howell et al., 1975; Noronha, 1982; Neves, 1984; Sá, 1985; Azevedo Filho, 1988; Latapia, 1988; Brunelli, 1990; Peres \& Mattos, 1990; Biserra, 1994; Sousa e Frizzone, 1997; Sousa \& Frizzone, 1998b e Sousa, 1999).

Nos estudos desenvolvidos por Sousa \& Frizzone (1998b) e Sousa (1999) foi utilizada a técnica de simulação de Monte Carlo para a geração de valores de ETo e déficit de evapotranspiração, os quais foram obtidos com as funções de distribuição normal e triangular. Concluíram que os valores de ETo e déficit de evapotranspiração simulados pelas funções de distribuição normal e triangular apresentaram um bom ajuste quando comparados aos valores observados, apresentando índices de concordância de Willmott acima de 0,94 e coeficientes de correlação superiores a 0,97 , indicando uma elevada exatidão e precisão na estimativa do déficit de evapotranspiração com o uso destas duas funções de distribuição de probabilidade, independentemente do número de simulações utilizado. Estes resultados comprovam a viabilidade e a eficácia da aplicação dessa técnica.

A técnica de simulação de Monte Carlo também tem sido empregada em estudos de análise de risco em avaliação de investimento em projetos e de custo de produção, tais como os trabalhos de Noronha (1982), Neves (1984), Sá (1985), Azevedo Filho (1988), Latapia (1988), Brunelli (1990), Biserra (1994) e Dias (1996). Em estudos econômicos, normalmente, não dispõe-se de informações suficientes quanto às variáveis a serem analisadas. Desse modo, usualmente, adota-se a distribuição triangular de probabilidade para proceder-se a estimativa das variáveis de maior relevância (Pouliquen ${ }^{1}$ citado por Biserra, 1994).

${ }^{1}$ POULIQUEN, L. Y. Risk analysis in project appraisal. Baltimore, Johns Hapkins University Press, 1983. 79p. 


\subsection{Balanço hídrico e necessidade de irrigação}

O balanço hídrico é um sistema contábil de monitoramento da água do solo e resulta da aplicação do princípio da conservação de massa para a água em um volume de solo vegetado. A variação do armazenamento $(\Delta \mathrm{A})$ representa o balanço entre as entradas e saídas de água do volume de controle em um determinado intervalo de tempo (Pereira et al., 1997b).

A chuva, irrigação, ascensão capilar e drenagem lateral constituem os principais componentes de entrada de água no volume de solo, enquanto a evapotranșpiração, escoamento superficial, drenagem lateral e drenagem profunda correspondem às saídas. A irrigação, utilizada para manter o armazenamento em nível adequado às plantas, é função do próprio balanço hídrico, integrando os efeitos do clima, do solo e da planta.

Com relação ao componente precipitação, normalmente, os balanços hídricos são contabilizados considerando a precipitação total ocorrida. Entretanto, nem toda a água proveniente das precipitações está disponivel à cultura. Por isso, deve-se considerar somente a precipitação efetiva, ou seja, a diferença entre a precipitação total e a perda por percolação profunda e/ou escoamento superficial (Bernardo, 1989; Andrade Júnior, 1992; Sousa et al., 1997). Contudo, a estimativa da precipitação efetiva, para períodos de um dia, é dificil e trabalhosa na prática (Marouelli et al., 1996).

Dessa forma, para fins de manejo de irrigação, Marouelli et al. (1996) propõem uma metodologia para a estimativa da precipitação efetiva a partir dos valores de precipitação total e da lâmina de irrigação necessária para que o conteúdo de água no solo retorne à capacidade de campo na camada correspondente ao sistema radicular da cultura, desde que assumidas algumas condições. Outra metodologia utilizada para essa estimativa é proposta pelo U. S. Conservation Service, a qual leva em consideração o tipo de solo e as práticas de cultivo (Franke, 1996).

Os resultados de um balanço hídrico podem ser utilizados para o zoneamento agroclimático da região, demanda potencial de água das culturas irrigadas, definição de prioridades no planejamento de pesquisas ou para o conhecimento do regime hídrico (Aguilar et al., 1986). 
Ortolani \& Camargo (1987) destacam o balanço hídrico de campo como uma alternativa viável para a estimativa da disponibilidade hídrica no solo, em virtude de levar em consideração as características específicas do solo e da planta em estudo. Este método consiste na determinação dos componentes do balanço hídrico através de medições diretas, como no caso da variação do armazenamento, utilizando-se o método gravimétrico direto ou equipamentos como tensiômetros ou sonda de neutrons.

Reichardt (1990) faz uma distinção entre balanço hídrico real e balanço hídrico climatológico. Para o autor, o balanço hídrico real é a contabilidade de todas as adições e retiradas de água que realmente ocorrem em dada área utilizada na produção agrícola. Este tipo de balanço hídrico mostra a situação hídrica pela qual uma cultura realmente passa e fornece subsidios para definir quando e quanto irrigar. $O$ balanço hídrico climatológico é uma estimativa do que vai ocorrer em uma dada localidade ou região, baseado em uma série de dados climatológicos coletados durante vários anos, possibilitando sua caracterização hídrica.

Medeiros \& Pinheiro ${ }^{2}$, utilizando a metodologia de balanço hídrico climatológico proposta por Thorntwaite \& Mather, efetuaram a caracterização hídrica (quantificação e definição dos períodos de deficiência e excedentes hídricos) de alguns municípios do estado do Piaui (Luzilândia, Esperantina, Piripiri, Alto Longa, Simplício Mendes e Cristino Castro). Contudo, apesar de terem utilizado a escala mensal para calcular os balanços hídricos, apresentam os valores e periodos de déficits e excessos de umidade no solo em escala anual, informações estas não muito úteis para o planejamento e manejo da irrigação das culturas de ciclo curto exploradas nesses municípios.

De acordo com os objetivos especificos a que se destina, Rolim et al. (1998) caracterizam o balanço hídrico normal, seqüencial e de cultura. Para estes autores, o balanço hídrico normal é orientado para o planejamento agrícola e caracterização climática de uma região, servindo de subsídio para a definição da melhor época e tipo de manejo da exploração agrícola. O balanço hídrico seqüencial presta-se mais para o processo de tomada de decisão em práticas agrícolas, tais como: plantio, colheita e

\footnotetext{
' MEDEIROS, R. M. \& PINHEIRO, J. U. Balanço hídrico segundo Thorntwaite \& Mather para alguns municípios do Piaú. Teresina: Secretaria de Agricultura. Abastecimento e Irrigação.
} 
irrigação. Por fim, o balanço hídrico de cultura é importante para os mesmos itens acima destacados, porém levando em consideração as diferentes necessidades hídricas das culturas.

A metodologia de balanço hídrico têm sido aplicada com o intuito de quantificar as deficiências hídricas e as necessidades de irrigação total e suplementar, informações estas fundamentais para a planejamento da irrigação a nível de propriedade e/ou em escala regional.

Neste contexto, Bernardo (1975) desenvolveu um modelo computacional para predizer o manejo da irrigação suplementar para uma determinada combinação soloclima-cultura. Para tanto, o modelo determina a freqüência de irrigação, a lâmina líquida de irrigação e a quantidade total de água requerida por mês e ano. $\mathrm{O}$ modelo foi avaliado usando-se dados de clima e solo do vale do São Francisco. Para um melhor aprimoramento de outros modelos nessa linha, sugeriu a inclusão de um rotina para o cálculo da produtividade em função da evapotranspiração atual, bem como para possibilitar uma análise econômica da irrigação.

Oliveira (1990) procedeu à estimativa da evapotranspiração máxima e necessidade de irrigação das culturas de feijão Phaseolus e trigo através de balaņ̣os hídricos diários efetuados para seis municípios no Estado do Paraná. Apresentou os resultados de evapotranșiração máxima e lâmina de irrigação suplementar em níveis de 50,75 e $90 \%$ de probabilidade de ocorrência. Destacou a importância de estudos dessa natureza para fornecer informações básicas ao dimensionamento de projetos de irrigação e planejamento dos recursos hídricos, especialmente quando associado a estudos de viabilidade econômica

Baseado na análise pluviométrica de 49 municípios do Piauí e Estados limítrofes, Rodrigues Neto (1991) efetuou um zoneamento pluviométrico visando o cultivo de sequeiro das culturas de feijão, milho e arroz. Efetuou o estudo da distribuição pluviométrica ao longo do tempo e do espaço, ajustando os valores mensais ao modelo de distribuição gama incompleta aos níveis de 75, 50 e $25 \%$ de probabilidade. Com base na demanda de água das culturas selecionadas e nas precipitações pluviométricas mensais ocorridas no trimestre e semestre mais chuvoso, propôs uma classificação 
mensal das necessidades de irrigação em total ou suplementar. Contudo, o estudo não considerou a variabilidade dos solos no que diz respeito à sua capacidade de armazenamento e assumiu como igual, em todos os municípios, a demanda hídrica mensal das culturas.

Pires (1992) quantificou as necessidades de irrigação de culturas através da simulação de balanços hídricos diários efetuados para os meses de fevereiro e julho, em Ribeirão Preto (SP). Concluiu que a técnica utilizada associada ao uso de valores probabilísticos no cálculo da lâmina e do intervalo entre irrigações forneceu subsídios importantes para o planejamento e manejo dos sistemas de irrigação na região.

Para as condições edafoclimáticas do Planalto Médio e Missões (RS), Franke (1996) procedeu a avaliação econômica da irrigação por aspersão (pivô central) das culturas da soja e milho, a partir da determinação da evapotranspiração das culturas e de suas necessidades de irrigação, através da realização de balanços hídricos diários baseados em série histórica de dados, combinando diferentes épocas de semeadura e niveis de manejo de irrigação.

Zullo Júnior et al. (1999) efetuaram o zoneamento agrícola para a cultura do trigo de sequeiro no Estado de São Paulo, sob condição de risco climático, definindo as melhores épocas de plantio para as cultivares de ciclo precoce e normal, em três tipos principais de solo. Utilizaram a metodologia do balanço hídrico diário para a determinação do índice de satisfação das necessidades de água da cultura para cada município, o qual foi um dos critérios adotados para a definição das datas favoráveis de plantio.

Alguns trabalhos utilizando o método do balanço hídrico com o intuito de quantificar a evapotranspiração e/ou as necessidades de irrigação das culturas de feijão caupi (Silva \& Millar, 1981b; Saunders et al., 1981; Saunders et al., 1985; Padilha Júnior, 1986; Aguiar et al., 1992; Barros et al., 1998; Bezerra \& Oliveira, 1998a; Santos et al., 1998; Bezerra et al., 1999) e melancia (Bezerra \& Oliveira, 1998b; Freitas \& Bezerra, 1999a) foram encontrados na literatura. Contudo, raras são as referências a trabalhos anteriores desenvolvidos nas condições edafoclimáticas de interesse para esse estudo. 
Lima \& Silva (1988) determinaram a evapotranspiração do feijão caupi (ETc) utilizando o balanço hídrico em um volume de solo contido em evapotranspirômetros de lençol freático constante, instalados nas condições climáticas de Teresina (PI). Observaram que a ETc acumulada durante o ciclo da cultura foi de $509 \mathrm{~mm}$, com uma média geral de $6,6 \mathrm{~mm} \mathrm{dia}^{-1}$. Os valores médios de ETc nas fases fisiológicas foram 2,1 $\mathrm{mm} \mathrm{dia}^{-1}$ (inicial); 5,2 $\mathrm{mm} \mathrm{dia}^{-1}$ (vegetativa); $8,7 \mathrm{~mm} \mathrm{dia}^{-1}$ (reprodutiva) e $8,3 \mathrm{~mm} \mathrm{dia}^{-1}$ (maturação).

O único trabalho efetuado, nas condições de clima e solo de Parnaiba (PI), é o de Andrade et al. (1993), que empregando a metodologia de balanço hídrico no campo, estimou a evapotranspiração da cultura (ETc) e o coeficiente de cultivo para o feijão caupi. Obtiveram valores de ETc variando de $5 \mathrm{~mm} \mathrm{dia}^{-1}$, no início do ciclo, a $9 \mathrm{~mm}$ $\operatorname{dia}^{-1}$, aos 32 dias após o plantio, quando a cultura alcançou pleno desenvolvimento vegetativo. O consumo de água em todo o ciclo foi de $380 \mathrm{~mm}$, correspondendo a um consumo médio de $6,3 \mathrm{~mm} \mathrm{dia}^{-1}$. Entretanto, esse estudo se restringiu apenas ao período de maior demanda hídrica da região.

\subsection{Estimativa e previsão de custos associados à irrigação}

A irrigação é uma tecnologia que requer elevados investimentos e intensiva utilização de insumos. Por isso, é importante efetuar uma análise dos custos associados aos sistemas de irrigação empregados, os quais constituem-se em um dos fatores determinantes da viabilidade econômica do investimento.

Os custos variáveis associados à irrigação abrangem os dispêndios relacionados com energia, mão-de-obra, lubrificação, reparos dos equipamentos e da infra-estrutura utilizados na operação do sistema (Rocha, 1988; Frizzone, 1999). Os gastos anuais com manutenção e reparos tem a finalidade de manter o sistema em condições adequadas de uso. A manutenção ocorre de maneira preventiva, enquanto os reparos são de difícil previsão e estimativa (Franke, 1996). Por isso, a literatura recomenda que esses gastos devem ser considerados como uma percentagem do investimento com o sistema de 
irrigação. Neste sentido, existe sugestão de que esses custos sejam da ordem de $4 \%$ a.a. sobre equipamentos de irrigação e 1,25 \% a.a. sobre obras de infra-estrutura (Brasil, 1987; Frizzone, 1999).

Os componentes de custos da irrigação variam nas diferentes regiões irrigadas do País, principalmente devido as diferenças quanto às exigências hídricas de cada região. Neste contexto, Brito \& Scaloppi (1986) fizeram uma composição estimativa de custos de sistemas de irrigação por aspersão mais utilizados (convencional com linhas laterais portáteis, autopropelido e pivô central) acionados a energia elétrica e a óleo diesel, dentro de um contexto de fatores que representam as regiões Semi-árida $(E \operatorname{Tr}=6,5 \mathrm{~mm}$ $\left.\mathrm{dia}^{-1}\right)$ e Centro-Sul do Brasil $\left(\mathrm{ETr}=4,5 \mathrm{~mm} \mathrm{dia}^{-1}\right)$. Os componentes de custo envolvidos foram a depreciação do equipamento, juros e os custos de energia, mão-de-obra, reparos e manutenção do sistema. Observaram uma grande desvantagem econômica dos sistemas acionados a óleo diesel em relação à eletricidade. Considerando apenas os sistemas acionados a energia elétrica, constataram que o sistema de linhas laterais portáteis apresentou os menores custos, até um valor de uso consuntivo de $600 \mathrm{~mm}$, seguido pelo autopropelido e pivô central. A análise demostrou que, entre os custos variáveis, o mais significativo foi o de energia (55\% para energia elétrica e $80 \%$ para o óleo diesel), inviabilizando o óleo diesel como fonte de energia. O custo menos representativo foi o de mão-de-obra, o que constitui, do ponto de vista econômico, pouco estímulo à automação dos sistemas de irrigação.

Estudo semelhante, porém direcionado unicamente para as condições de Minas Gerais, foi realizado por Mello (1993). O autor verificou que, para todos os sistemas de irrigação analisados (aspersão convencional semiportátil, autopropelido e pivô central), o gasto com energia foi o item de maior participação relativa na composição dos custos variáveis.

Mattoso \& Silva (1989) desenvolveram uma planilha para estimativa do custo de produção de culturas irrigadas e que permite avaliar os efeitos econômicos de variações impostas em qualquer um dos componentes de custo. Exemplificaram a utilização da planilha com a cultura do milho irrigado por aspersão pivô central nas condições de solo e clima de Parnaiba (PI). Observaram que a cultura deve apresentar uma produtividade 
mínima de $5.816 \mathrm{~kg} \mathrm{ha}^{-1}$ (ponto de equilíbrio) para cobrir o custo total de produção e viabilizar economicamente a irrigação. Entre os componentes de custo, o item irrigação (custos fixos e variáveis do pivô central + mão-de-obra + energia elétrica) foi o que apresentou maior participação $(40,9 \%)$ do custo total de produção. O componente energia elétrica correspondeu a $17,7 \%$ do custo total de produção do milho.

Para as condições de Guaíra (SP), Pizysieznig Filho et al. (1992) concluíram que os custos variáveis pesam mais que os custos de investimento. Nos custos variáveis, o custo de energia elétrica foi responsável por $60 \%$, em média, reforçando a importância do dimensionamento e manejo adequado dos sistemas de irrigação.

Analisando diferentes fontes alternativas de energia para irrigação (diesel, gasolina e álcool) em comparação com a energia elétrica, Scaloppi (1985) observou um elevado custo dessas fontes alternativas, o qual significou acréscimos de $599 \%$ (diesel), 934 \% (gasolina) e $859 \%$ (álcool) em relação à energia elétrica. Segundo o autor, isso é devido ao elevado rendimento global dos motores elétricos associado ao reduzido custo do $\mathrm{kWh}$ utilizado no período fora de pico.

Para as condições do Brasil Central, segundo Lana ${ }^{3}$ citado por Franke (1996), os gastos anuais médios, por hectare, com energia elétrica para os sistemas de irrigação por aspersão convencional e pivô central são da ordem de US\$ 134,3 e US\$ 94,3, respectivamente.

Em estudo de viabilidade econômica da irrigação por aspersão pivô central na cultura do milho nas condições agroecológicas do Planalto Médio e Missões (RS), Franke \& Dorfman (1998) verificaram que os custos devido exclusivamente à irrigação variaram de 30 a $45 \%$ do custo total de produção. Dentre estes, destaca-se o custo de energia elétrica com uma participação de apenas 5,5 a 7,0 \% do custo total de produção da lavoura irrigada.

$r^{\circ} \quad \mathrm{O}$ custo anual de bombeamento, para bombas acionadas por motor elétrico é função dos gastos com energia elétrica durante um determinado intervalo de tempo, os quais dependem da demanda de potência (faturamento anual de demanda) e do consumo

\footnotetext{
${ }^{3}$ LANNA. A.E. Engenharia econômica dos recursos hídricos. Porto Alegre: IPH. UFRGS, 1991. 320 p.
} 
de energia elétrica (faturamento anual de consumo). A demanda de potência corresponde à média das potências solicitadas pelo consumidor, durante um intervalo de tempo, usualmente, 15 minutos, registrado por medidores de demanda. A tarifa de demanda é o valor de $1 \mathrm{kWh}$ de potência demandada, que dá o direito à sua utilização pelo período de um mês. $\mathrm{O}$ consumo efetivo de energia elétrica refere-se à quantidade de energia elétrica utilizada durante qualquer período de tempo, expressa em $\mathrm{kWh}$. A tarifa de consumo é o valor de venda de $1 \mathrm{kWh}$ de energia consumida. O preço das tarifas de demanda e consumo varia de acordo com a modalidade de tarifação em que o mesmo se enquadra diante da concessionária de energia elétrica (Dorfman et al., 1988; Frizzone, 1999).

Existem três modalidades de tarifas de energia elétrica, quais sejam: a tarifa convencional e as tarifas horo-sazonais (verde e azul), as quais apresentam custos diferenciados em função de sua utilização durante as horas do dia e durante os períodos do ano. Essa diferenciação visa reduzir os custos de fornecimento de energia elétrica entregue ao consumidor, decorrente da otimização do sistema elétrico nacional. A utilização dessas tarifas permite ao consumidor reduzir suas despesas com energia elétrica desde que consiga programar o seu uso, evitando-se o horário de ponta e/ou deslocando-se o consumo para determinados meses do ano. O horário de ponta compreende entre as 17 e $22 \mathrm{~h}$ (ou definido pela concessionária) de segunda a sextafeira, enquanto o horário fora de ponta são as horas complementares às de ponta, acrescida à totalidade das horas dos sábados e domingos. O período seco é composto de sete meses consecutivos (maio a novembro), enquanto o período úmido é composto dos cinco meses consecutivos (dezembro a abril) (Dorfman et al., 1988; Frizzone, 1999).

Entretanto, apesar das evidentes vantagens da utilização das tarifas horosazonais, a sua efetiva aplicação apenas é possivel nas propriedades rurais onde encontram-se em operação instalações e redes elétricas de alta tensão. No caso do estado do Piauí, segundo informações obtidas junto à Companhia Energética do Piaui ${ }^{4}$ (CEPISA), a sua efetiva aplicação apenas ocorre em $0,5 \%$ dos estabelecimentos rurais (63 usuários). A quase totalidade dos estabelecimentos rurais piauienses $(99,5 \%)$ (12.913 usuários) enquadram-se na chamada classe rural, que utilizam instalações e 
redes elétricas de baixa tensão. Para essa classe de consumidores de energia elétrica é efetuada a cobrança com base na tarifa de consumo denominada B2, a qual independe da potência elétrica instalada na propriedade.

Em geral, os estudos de custos de produção pressupõem que os valores dos coeficientes técnicos, preços e disponibilidade de recursos são constantes. Isto implica em adotar formas deterministas para certos componentes do custo que na realidade tem variação aleatória. Contudo, para incluir-se o risco no cálculo do custo de produção é usualmente utilizada a técnica de simulação de Monte Carlo (Brunelli, 1990; Biserra, 1994).

Para simplificar a aplicação dessa técnica, é fundamental determinar-se quais as variáveis mais significativas dentro da estrutura do custo de produção. Segundo Latapia (1988), não é necessário efetuar-se uma análise de sensibilidade para escolher as variáveis mais significativas, bastando, para isso, observar e escolher as variáveis que representam as maiores participações percentuais no custo de produção. No caso específico de custos de produção de culturas irrigadas, observou-se, nos trabalhos citados anteriormente, que o custo de energia é o item de maior participação na composição dos custos variáveis e que pode comprometer a viabilidade econômica do empreendimento.

Neste estudo, em paŕticular, além do custo de energia elétrica elegeu-se como variáveis relevantes, cuja aleatoriedade afeta a rentabilidade da atividade, a produtividade das culturas de feijão e melancia e seus respectivos preços de venda. Estas variáveis apresentam evidente e notória variabilidade em função das condições edafoclimáticas reinantes e das oscilações de mercado. Levando em consideração esses mesmos motivos, Brunelli (1990) assumiu como relevantes, no processo de simulação do custo de produção da laranja no Estado de São Paulo, as variáveis relacionadas com os coeficientes técnicos das operações, preços dos insumos e produtos, quantidade de insumos e a produtividade da cultura. Da mesma forma, Biserra (1994) considerou como variáveis aleatórias significativas a produtividade das culturas (arroz, feijão, banana,

\footnotetext{
${ }^{4}$ Informações obtidas junto à Gerência Técnica e Comercial. Situação em dezembro de 1999.
} 
milho, algodão e melancia) e os preços dos produtos, as quais conjuntamente participaram com mais de $80 \%$ da receita bruta.

Entretanto, para a aplicação da técnica de simulação é necessário atribuir-se uma função de distribuição de probabilidade a cada variável, que seja adequada para representar a variação da mesma. Em Economia, em que normalmente dispõe-se de poucas informações quanto às variáveis a serem analisadas, usualmente adota-se a distribuição triangular de probabilidades para representar a variação e proceder-se à estimativa de variáveis (Pouliquen citado por Biserra, 1994; Dias, 1996), tais como as produtividades das culturas e os preços dos produtos agricolas. De fato, Brunelli (1990), Biserra (1994) e Dias (1996) assumiram essa distribuição de probabilidade como representativa de diversas variáveis envolvidas no custo de produção das culturas de laranja, arroz, feijão, banana, milho, algodão, melancia, tomate, goiaba e manga.

\subsection{Análise econômica sob condição de risco}

A agricultura constitui-se em uma das atividades econômicas mais complexas e sujeita a aleatoriedade dos vários fenômenos climáticos e biológicos e ao grande número de variáveis envolvidas na comercialização do produto e lucro do agricultor, fazendo com que as decisões quase sempre sejam tomadas, sem que se conheçam, com exatidão, suas implicações e conseqüências (Pastore ${ }^{5}$ citado por Rodrigues, 1987).

Segundo Hiessl \& Plate $^{6}$ citado por Peiter (1998), a variabilidade final da produção agrícola é causada, principalmente, devido ao suprimento limitado de água, suprimento distribuído desfavoravelmente ao longo da estação de crescimento e distribuição temporal e quantitativa do suprimento hídrico com alta variabilidade estocástica de ano para ano (Saunders et al., 1997).

Por isso, no caso específico da cultura do feijão, Fancelli \& Dourado Neto (1997) recomendam o desenvolvimento de estratégias de manejo com enfoque sistêmico, bem

\footnotetext{
${ }^{5}$ PASTORE, J. Decisões em condições de incerteza na agricultura. São Paulo, Fac. Economia e Administração da USP, 1974. $27 \mathrm{p}$ (Trabalho para discussão, 9).

${ }^{6}$ HIESSL, H.; PLATE, E. J. A heuristic closed-loop controller for water distribution in complex irrigation systems. Water Resources Research, v. 26, n. 7, p. 1323-1333, 1990.
} 
como o emprego de sistemas de produção que visem o máximo rendimento econômico da cultura, como forma de tornar a oferta do produto mais estável em seu cenário comercial.

Em termos de planejamento, diz-se que existe risco quando há a possibilidade de que ocorram variações no retorno associado a uma determinada alternativa de decisão. Em outras palavras, o risco é a variabilidade dos futuros retornos de um investimento. $\mathrm{O}$ nível de risco que um agricultor pode estar sujeito depende muito do valor econômico da cultura explorada (Marchetti, 1995) e de seu grau de aversão a riscos (Arruda, 1982). Segundo Grassi $^{7}$ citado por Franke (1996), para a agricultura irrigada, na qual se realizam investimentos consideráveis, deve-se utilizar nas análises econômicas um nível de risco de $80 \%$ de probabilidade.

O risco é parte integrante do processo de tomada de decisão e é impossível eliminá-lo, porque não se pode coletar todas as informações relevantes necessárias (Arruda, 1982) ou porque não é possível prever o futuro. A incorporação do risco no processo de tomada de decisão pode ser realizado quando são conhecidos os possíveis estados futuros de uma certa variável e suas respectivas probabilidades de ocorrência (Dias, 1996; Frizzone \& Silveira, 2000).

Segundo Pizysieznig Filho (1992) e Franke (1996), o risco econômico da atividade agrícola pode ser decomposto em duas componentes: variabilidade de produção e variabilidade de preços. A irrigação, quando manejada de forma racional e adequada, garante niveis de produção sem flutuações significativas, independentemente das condições climáticas do período, contribuindo para a redução dos riscos do investimento para a produção agrícola (Franke, 1996; Peiter, 1998). Com relação aos riscos de preços, a redução da sazonalidade causada pela irrigação é uma grande contribuição para a estabilidade de preços. Entretanto, varia em função da água disponivel, dos coeficientes insumo - produto e da quantidade de água necessária por unidade de produto, constituindo-se em um componente decisivo na determinação do ponto ótimo econômico (Arruda, 1982; Saunders et al., 1997).

\footnotetext{
${ }^{3}$ GRASSI, C. J. Estimacion de los usos consuntivos de água y requerimientos de riego con fins de formulacion y diseno de proyectos. Merida: CIDIAT, 1968. 96p.
} 
Contudo, a implantação de um sistema de irrigação introduz riscos econômicos ao empreendimento, em função dos incrementos nos custos fixos e variáveis da produção. Por isso, a produção agrícola, sob condições irrigadas, necessita de um manejo intensivo, com o intuito de evitar que a receita do irrigante seja superada pelos custos de implantação e manutenção do sistema de irrigação (Peiter, 1998).

Segundo Dourado Neto \& Fancelli (1999), a irrigação, normalmente, é viável economicamente quando o fator limitante é água e/ou preço de venda favorável, uma vez que viabiliza a minimização de risco e estabilidade de rendimento. Quando a água é fator limitante, sugerem que a análise econômica seja realizada levando-se em consideração, principalmente, a evapotranspiração, a precipitação pluviométrica (altura, intensidade, distribuição e probabilidade de ocorrência), rendimento almejado e capacidade de água disponível na profundidade efetiva do sistema radicular. No caso de preço de venda ser favorável, deve-se considerar a época de máxima probabilidade de pico de preço, com base em uma série histórica de preços dos últimos anos.

O objetivo da análise econômica é verificar se os beneficios resultantes de um projeto justificam os investimentos. Segundo Marchetti (1995), a avaliação de investimentos produtivos pode ser efetuada sob duas abordagens: a determinística e a probabilística. A abordagem determinística baseia-se em informações tidas como certas, originando um único valor para as medidas de decisão, não incluindo a estimativa quantitativa do risco. Por outro lado, a abordagem probabilística quantifica o risco do investimento através de uma distribuição de probabilidade das medidas de mérito.

Existem diversos métodos para a avaliação dos méritos de diferentes projetos, dentre eles destaca-se a relação beneficio/custo $(B / C)$. Por este critério, a viabilidade econômica é verificada confrontando-se os beneficios versus os custos do projeto, podendo ser empregado em qualquer análise econômica e intervalo de tempo. Diz-se que uma alternativa é viável, se os benefícios são maiores que os custos, resultando em uma relação $\mathrm{B} / \mathrm{C}$ igual ou maior que a unidade. Caso os custos sejam maiores que os beneficios, a relação $\mathrm{B} / \mathrm{C}$ será inferior a unidade, sendo que a alternativa não apresenta viabilidade econômica (Dorfman et al., 1988; Frizzone \& Silveira, 2000). 
Para que um irrigante maximize seus beneficios, minimize seus custos ou maximize sua produção algum método de programação de irrigação é necessário. Entretanto, muitas pesquisas ainda são necessárias para melhorar as tomadas de decisão de quanto e quando irrigar, a fim de incrementar a eficiência do uso de água e reduzir os custos (Peiter, 1998).

Neste contexto, com o intuito de aumentar a eficiência do uso de água da cultura do feijão Phaseolus irrigado por pivô central, Saad et al. (1998) sugerem a estratégia de adotar a irrigação com déficit hídrico em determinados estádios fenológicos da cultura. Concluíram que o déficit de irrigação somente é recomendado para a fase de maturação, desde que o preço do quilo do feijão pago ao produtor seja igual ou inferior a $\mathrm{R} \$ 0,46 \mathrm{e}$ o custo unitário da água de irrigação seja igual ou superior a $R \$ 75,00$ para cada 1.000 $\mathrm{m}^{3}$ aplicado.

Calheiros et al. (1996) analisaram as relações entre produção do feijão Phaseolus, lâmina total de água e preço do produto com os aspectos econômicos da irrigação com déficit dessa cultura. Observaram que a irrigação com déficit proporcionou produção e rendas líquidas economicamente satisfatórias, constituindo-se em importante estratégia no planejamento da irrigação em situações em que a água é fator limitante. Constataram que o preço do produto foi o fator mais importante na definição dessa estratégia ótima.

Os aspectos teóricos relativos à incorporação de riscos em modelos de tomada de decisão encontram-se bem apresentados e discutidos na literatura (Cruz, 1984; Berbel, 1993; Marchetti, 1995; Bigman, 1996; Dias, 1996). Neste particular, destacam-se os modelos Motad (Hazell, 1971; Anderson et al., 1977; Tauer, 1983; Berbel, 1988; Berbel, 1993), os quais são mais indicados para a análise econômica sob condição de risco em situações específicas, como por exemplo, para o planejamento de propriedades ou otimização de perímetros irrigados (Millan, 1992; Millan \& Berbel, 1994; Dias, 1996), dada uma determinada disponibilidade específica de recursos relativos ao processo produtivo, tais como água, terra, mão-de-obra, dentre outros.

Tendo em vista um contexto mais abrangente da análise econômica do sistema agrícola irrigado, encontrou-se na literatura inúmeros trabalhos com o objetivo de verificar a viabilidade econômica da irrigação, sob condição de risco, de culturas tais 
como: o milho (Apland et al., 1980; Boggess \& Ritchie, 1988; Martin et al., 1996; Franke \& Dorfman, 1998; Peiter, 1998), o trigo (Saunders et al., 1997), o algodão (Dudley \& Hearn, 1993), a soja (Franke, 1996) e o feijão Phaseolus (Faria et al., 1997) ou de várias culturas conjuntamente em perímetros irrigados (Bernardo et al., 1988; Biserra, 1994). Nestes trabalhos, a estimativa da produtividade das culturas foi efetuada utilizando-se modelos de simulação de crescimento e produção (Apland et al., 1980; Bernardo et al., 1988; Boggess \& Ritchie, 1988; Dudley \& Hearn, 1993; Martin et al., 1996; Faria et al., 1997; Peiter, 1998) e/ou através do cálculo do déficit de evapotranspiração pelo balanço de água no solo (Pandey, 1991; Mannocchi \& Mecarelli, 1994; Martin et al., 1996; Franke, 1996; Franke \& Dorfman, 1998).

Entretanto, raros são os trabalhos com o intuito de verificar a viabilidade econômica da irrigação desenvolvidos nas condições edafoclimáticas dos locais de interesse para esse estudo. Destacam-se, apenas, os trabalhos de Mattoso \& Silva (1989), Cardoso et al. (1995) e Bastos (1999), os quais procederam a avaliação agroeconômica da produção de milho e feijão caupi nas condições de solo e clima de Parnaíba e Teresina, Piauí.

Com relação à cultura da melancia, Andrade Júnior et al. (1998c) conduziram estudo de viabilidade econômica nas condições edafoclimáticas do Litoral Piauiense. Determinaram as estratégias ótimas de irrigação com déficit, considerando diferentes combinações de valores para o preço do produto e custos da energia elétrica. Concluíram que, independentemente do custo de energia elétrica, a utilização de irrigação com déficit foi vantajosa no intervalo de variação de preços do produto de $R \$ 0,15 \mathrm{~kg}^{-1}$ a $\mathrm{R} \$$ $0,40 \mathrm{~kg}^{-1}$. Em condições de preço do produto fora dessa faixa, a cultura deve ser irrigada com uma lâmina total de $356 \mathrm{~mm}$, a qual proporciona a máxima produção de frutos.

Contudo, tanto no caso do feijão caupi como da melancia, as análises realizadas não levaram em consideração o risco climático e econômico envolvido no processo produtivo dessas culturas, ou seja, essas análises foram puramente deterministas. Além disso, não contemplaram possíveis combinações entre épocas de semeadura e níveis de manejo de irrigação, que constituam-se em estratégias econômicas alternativas para os produtores. 



\section{MATERIAL E MÉTODOS}

\subsection{Local do estudo}

O estudo foi realizado para as condições edafoclimáticas das microrregiões do Litoral Piauiense e de Teresina, situadas na mesorregião do Norte e Centro-Norte do Estado do Piauí, respectivamente (Figura 1).

O clima dessas microrregiões é influenciado pelos fatores climáticos relativos às massas de ar associados aos fatores geográficos como latitude, relevo e natureza do solo, os quais definem as condições de precipitação pluviométrica, evapotranspiração, temperatura e balanço hídrico (Figura 2). As partes mais baixas, situadas próximas ao Rio Parnaíba e litoral norte estão sujeitas às influências das Massas Equatorial Continental e Equatorial Atlântica Norte. O regime de precipitação pluviométrica é o Equatorial Marítimo, com trimestre mais chuvoso em fevereiro - março - abril e valores médios de precipitação pluviométrica anual variando de $1.000 \mathrm{~mm}$ a $1.600 \mathrm{~mm}$. Quanto a temperatura do ar, os maiores valores médios mensais $\left(27^{\circ} \mathrm{C}\right)$ ocorrem no período de julho a novembro, devido ao aumento da radiação ocasionado pela redução de nebulosidade (Empresa Brasileira de Pesquisa Agropecuária - Embrapa, 1989).

A classe de solo predominante na microrregião do Litoral Piauiense é a Areia Quartzosa, que caracteriza-se por solos profundos, arenosos, bem drenados, não pedregosos, quimicamente pobres e ácidos. Ocorre em áreas de relevo plano ou suavemente ondulado (Nogueira \& Nogueira, 1993). Ocupa a maior área (9,2 milhões de hectares), correspondendo a $36 \%$ da superficie do Estado, dos quais $20 \%$ mostram aptidão agrícola regular, desde que utilizados capital e tecnologia (Embrapa, 1989). 


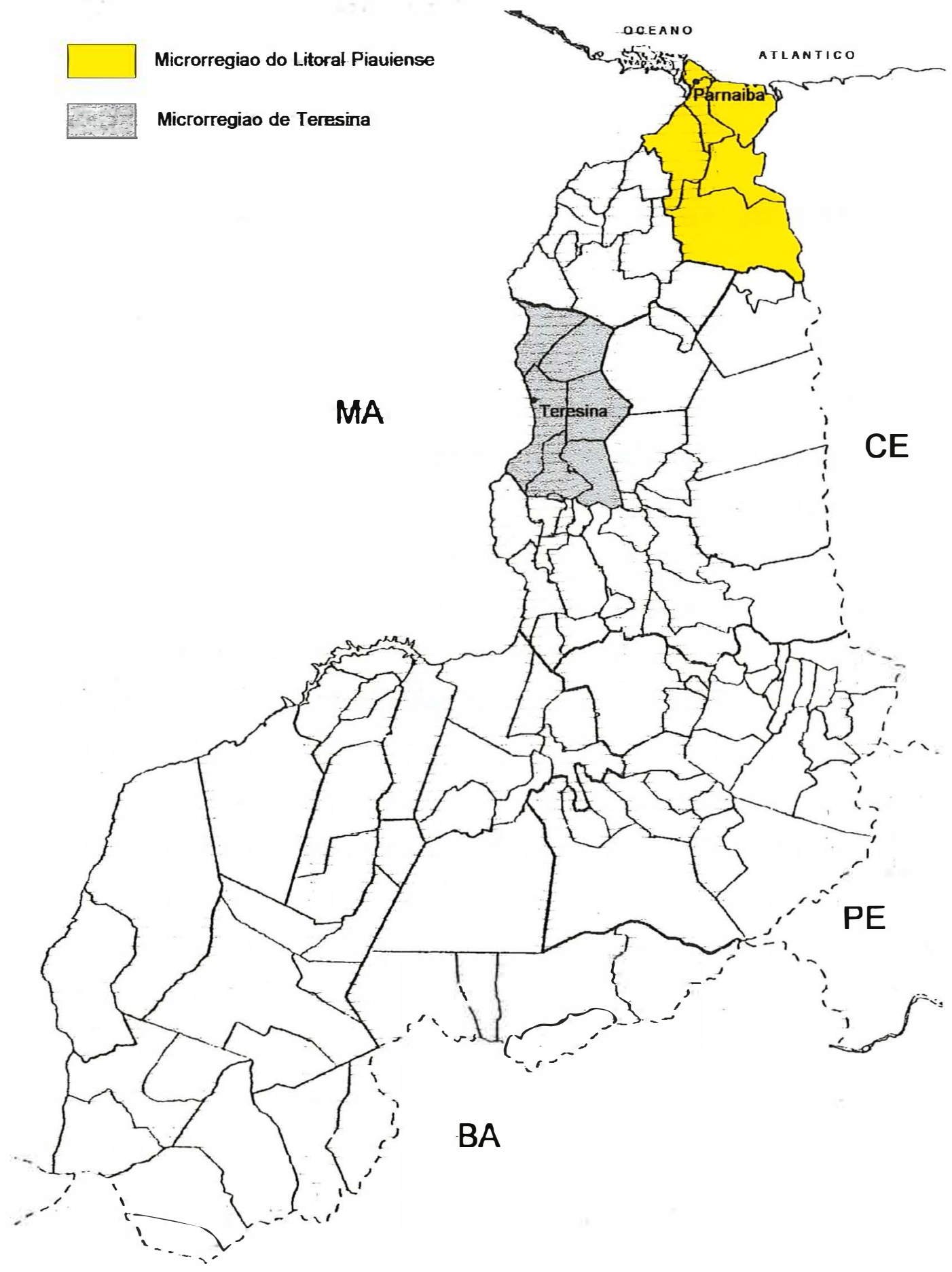

Figura 1.. Área de abrangência das miccronegiões do Litoral Piauiense e de Teresina, Piauí. 

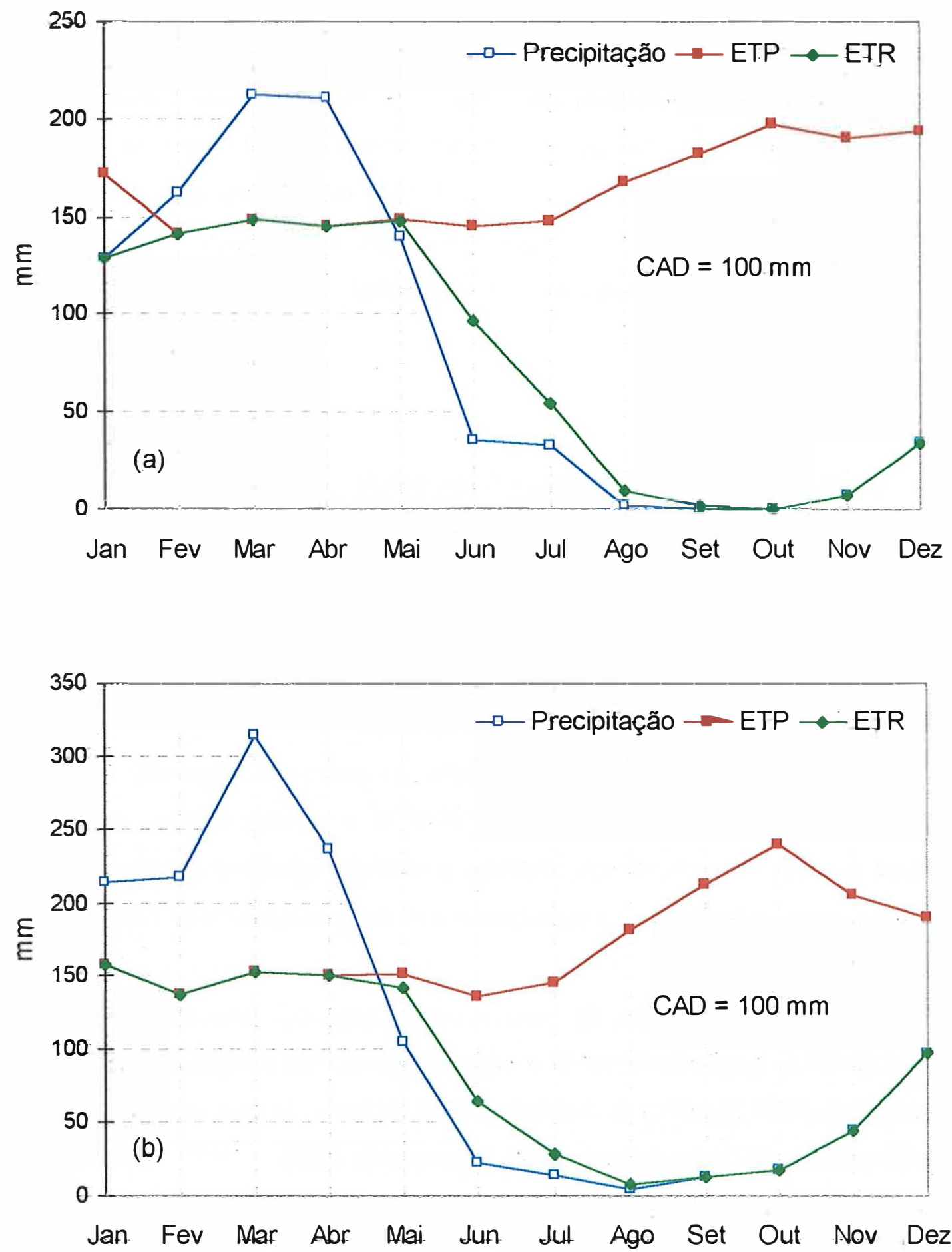

Figura 2. Balanço-hídrico normat mensal para Parnaíba-(a) e Teresina (b), Piauí. 
Na microrregião de Teresina ccorre, com mais freqüência, a classe Latossolo Vermelho-Amarelo, geralmente em associação com Areia Quartzosa. Caracteriza-se por solos de textura média, profundos e de baixa fertilidade natural (Embrapa, 1980). Esta classe de solo ocupa uma vasta superficie do Estado, compreendendo a $35 \%$ dos seus solos. Dessa área total, cerca de 77 \% prestam-se para algum tipo de utilização agrícola, predominado aquelas que exigem a aplicação de capital e tecnologia (Embrapa, 1989).

\subsection{Dados meteorológicos}

Os dados meteorológicos básicos foram obtidos junto aos registros das estações meteorológicas do Instituto Nacional de Meteorologia (INMET), instaladas nos Campos Experimentais da Embrapa Meio Norte, em Parnaiba (Embrapa, 1992) e Teresina, Piauí. Em ambas as estações, foram coletados os registros diários das seguintes variáveis meteorológicas: precipitação pluviométrica, pressão atmosférica, temperatura do ar, umidade relativa do ar, velocidade do vento e insolação.

A estação meteorológica de Parnaíba apresenta as seguintes coordenadas geográficas: latitude $03^{\circ} 05^{\prime} \mathrm{S}$, longitude $41^{\circ} 47^{\prime} \mathrm{W}$ e altitude $46,8 \mathrm{~m}$. Esta estação forneceu os dados básicos diários relativos à condição climática da microrregião do Litoral Piauiense, referente a uma série histórica de dez anos (janeiro de 1990 a fevereiro de 2000).

A estação meteorológica de Teresina tem as seguintes coordenadas geográficas: latitude $05^{\circ} 05^{\prime} \mathrm{S}$, longitude $42^{\circ} 49^{\prime} \mathrm{W}$ e altitude $74,4 \mathrm{~m}$. Esta estação forneceu os dados diários da condição climática da microrregião de Teresina, de uma série histórica de 22 anos (janeiro de 1977 a fevereiro de 2000, à exceção de 1984).

Ressalta-se que essas séries históricas de dados não são ininterruptas, uma vez que apresentam alguns dias com ausência de dados relativos às variáveis climáticas de interesse para esse estudo. $\mathrm{O}$ preenchimento dessas falhas ocorreu através da utilização dos valores mais freqüentes (moda) da série histórica de dados. No caso da temperatura média do ar, que representou a média entre os valores extremos de máxima e mínima do dia, as falhas foram inicialmente preenchidas pelos valores médios de temperatura do ar 
determinados pelas leituras das 9, 15 e 21 horas. Na ausência desses valores, utilizou-se a moda da série histórica. Contudo, devido ao tamanho das séries históricas, o processo de preenchimento das falhas, provavelmente, não comprometeu o resultado do estudo, uma vez que representou apenas 0,5\% (Parnaíba) e 2,5\% (Teresina) dos dados.

$\mathrm{Na}$ definição de estação chuvosa e seca considerou-se os valores normais mensais de precipitação pluviométrica $(\mathrm{P})$ e evapotranspiração de referência (ETo) em cada época de semeadura (Figura 2). Assumiu-se como estação chuvosa a constituída por épocas de semeadura em que os valores de $\mathrm{P} \geq \mathrm{ETo}$. Por outro lado, para os valores de $\mathrm{P}<$ ETo, a estação foi considerada como seca.

\subsection{Cálculo da evapotranspiração de referência}

A evapotranspiração de referência (ETo) diária $\left(\mathrm{mm} \mathrm{d}^{-1}\right)$ foi calculada pelo método de Penman-Monteith com a parametrização proposta pela FAO, conforme descrito por Pereira et al. (1997a). Por esse método, a estimativa da ETo é efetuada de acordo com a equação (1), seguindo-se o procedimento de cálculo abaixo (Pereira et al., 1997a):

$$
\text { ETo }=\frac{s}{s+\gamma^{*}} \cdot(R n-G) \cdot \frac{1}{\lambda}+\frac{\gamma}{\left(s+\gamma^{*}\right)} \cdot \frac{900}{(T+275)} \cdot U_{2}\left(e_{s}-e_{a}\right)
$$

em que:

$\mathrm{s}$ - declividade da curva de pressão de vapor, $\mathrm{kPa}^{\circ} \mathrm{C}^{-1}$;

$\gamma^{*}$ - constante psicrométrica modificada, $\mathrm{kPa}{ }^{\circ} \mathrm{C}^{-1}$;

$\gamma$ - constante psicrométrica, $\mathrm{kPa}{ }^{\circ} \mathrm{C}^{-1}$;

$\lambda$ - calor latente de evaporação $=2,45 \mathrm{MJ} \mathrm{kg}^{-1}$;

$\mathrm{Rn}$ - saldo de radiação ou radiação líquida efetiva, $\mathrm{MJ} \mathrm{m}^{-2} \mathrm{~d}^{-1}$;

$\mathrm{G}$ - fluxo de calor no solo, $\mathrm{MJ} \mathrm{m}^{-2} \mathrm{~d}^{-1}$;

$\mathrm{T}$ - temperatura média do ar, ${ }^{\circ} \mathrm{C}$; 
$\mathrm{U}_{2}$ - velocidade do vento a $2 \mathrm{~m}, \mathrm{~m} \mathrm{~s}^{-1}$;

$\mathrm{e}_{\mathrm{S}}$ - pressão de vapor de saturação, $\mathrm{kPa}$;

$\mathrm{e}_{\mathrm{a}}$ - pressão atual de vapor, $\mathrm{kPa}$.

a) Pressão de vapor de saturação

$$
e_{s}=0,6108 \cdot e^{\left(\frac{17,27 \cdot T}{T+237,3}\right)}
$$

em que:

e - base do logaritmo neperiano.

b) Pressão atual de vapor

$$
e_{a}=e_{s} \cdot\left(\frac{U R}{100}\right)
$$

em que:

UR - umidade relativa do ar, $\%$.

c) Declividade da curva de pressão de vapor

$$
s=\frac{4098 \cdot e_{s}}{(T+237,3)^{2}}
$$

d) Constante psicrométrica

$$
\gamma=0,0016286 \cdot\left(\frac{\mathbf{P}}{\lambda}\right)
$$

em que:

$\mathrm{P}$ - pressão atmosférica local, $\mathrm{kPa}$.

e) Constante psicrométrica modificada

$$
\gamma^{*}=\gamma \cdot\left(1+0,33 \cdot U_{2}\right)
$$




\section{f) Saldo de radiação ou radiação líquida efetiva}

$$
R n=\left[Q_{0}\left(a+b \frac{n}{N}\right)(1-r)\right]-\left[\left(0,34-0,14 \sqrt{e_{a}}\right) \sigma T^{4}\left(0,1+0,9 \frac{n}{N}\right)\right]
$$

em que:

$\mathrm{Q}_{0}$ - radiação no topo da atmosfera, $\mathrm{MJ} \mathrm{m}^{-2} \mathrm{~d}^{-1}$;

a e b - coeficientes do modelo de Ângströn (Dourado Neto \& Fancelli, 1999);

$\mathrm{n}$ - insolação, h;

$\mathrm{N}$ - horas de brilho solar, h;

$\mathrm{r}$ - albedo (grama $=0,23$ );

$\sigma$ - constante de Stefan - Boltzmann $=4,903 \times 10^{-9} \mathrm{MJ} \mathrm{m}^{-2} \mathrm{~d}^{-1} \mathrm{~K}^{-4}$;

Ta - temperatura média do ar, ${ }^{\circ} \mathrm{K}$.

Os valores de "a" e "b" são específicos para cada local e época do ano (Pereira et al., 1997a). Em Parnaíba, devido a ausência de informações locais, usou-se os valores de $\mathrm{a}=0,29 \cos \varphi=0,2897$ e $\mathrm{b}=0,52$, em que $\varphi$ é a latitude do local, em graus (Pereira et al., 1997a). Em Teresina, utilizou-se os valores de $a=0,31$ e b $=0,37$, obtidos na escala anual e apresentados em Dourado Neto \& Fancelli (1999).

\section{g) Radiação solar no topo da atmosfera}

$$
Q_{0}=37,586 \cdot d_{r} \cdot\left(\omega_{S} \cdot \operatorname{sen} \varphi^{\prime} \cdot \operatorname{sen} \delta+\cos \varphi^{\prime} \cdot \cos \delta \cdot \operatorname{sen} \omega_{\mathrm{S}}\right)
$$

em que:

$$
\begin{aligned}
& \mathrm{d}_{\mathrm{r}} \text { - distância relativa Terra - Sol; } \\
& \omega_{\mathrm{S}} \text { - ângulo horário do pôr do Sol, rad; } \\
& \varphi^{\prime} \text { - latitude do local, rad; } \\
& \delta \text { - declinação solar, rad. }
\end{aligned}
$$

sendo que:

$$
d_{r}=1+0,033 \cdot \cos \left(J \frac{2 \pi}{365}\right)
$$




$$
\begin{aligned}
& \omega_{\mathrm{S}}=\arccos \left(-\tan \varphi^{\prime} \cdot \tan \delta\right) \\
& \delta=0,4093 \cdot \operatorname{sen}\left(\mathrm{J} \frac{2 \pi}{365}-1,405\right)
\end{aligned}
$$

em que:

$\mathrm{J}$ - dia do ano pelo calendário juliano.

\section{h) Horas de brilho solar}

$$
\mathrm{N}=\frac{24}{\pi} \omega_{\mathrm{S}}
$$

\section{i) Fluxo de calor no solo}

O fluxo de calor no solo ( $G$ ) foi calculado pela equação (13) abaixo, uma vez que dispõe-se dos valores de temperatura média dos três dias anteriores, conforme recomendação de Pereira et al. (1997a):

$$
\mathrm{G}=0,38 \cdot\left(\mathrm{T}-\mathrm{T}_{-3 \mathrm{~d}}\right)
$$

em que:

$\mathrm{T}_{-3 \mathrm{~d}}$ - temperatura média dos 3 dias anteriores, ${ }^{\circ} \mathrm{C}$.

\subsection{Estimativa da precipitação pluviométrica e evapotranspiração de referência}

Os dados diários de precipitação pluviométrica foram ajustados à função de distribuição de probabilidade gama, enquanto os valores diários de evapotranspiração de referência, calculados pela equação (1), foram ajustados às funções de distribuição de probabilidades normal, beta e triangular. A estimativa dos parâmetros empíricos das distribuições gama, normal, beta e triangular $\left(\gamma, \beta, \mu, \sigma, \alpha, \beta^{\prime}, \varepsilon\right.$ e $\left.\phi\right)$ foi efetuada segundo as equações apresentadas por Assis et al. (1996) descritas a seguir: 


\subsubsection{Estimativa dos parâmetros $\gamma$ e $\beta$ da distribuição gama}

É uma distribuição de probabilidade de dois parâmetros e sua função cumulativa de distribuição de probabilidades tem a seguinte forma (Assis et al., 1996):

$$
F(x)=\frac{1}{\Gamma(\gamma) \cdot \beta^{\gamma}} \int_{0}^{x} x^{\gamma-1} e^{-\frac{x}{\beta}} d x
$$

em que:

$\mathrm{F}(\mathrm{x})$ - função de distribuição acumulada do evento, decimal;

$\mathrm{x}$ - variável aleatória (precipitação pluviométrica diária), $\mathrm{mm}$;

$\Gamma(\gamma)$ - função gama;

$\gamma$ - parâmetro de forma da distribuição $(\gamma>0)$;

$\beta$ - parâmetro de escala da distribuição $(\beta>0)$.

As estimativas dos parâmetros $\gamma$ e $\beta$ foram efetuadas pelo método da máxima verossimilhança proposto por $\mathrm{Thom}^{8}$ citado por Assis et al. (1996):

$$
\begin{aligned}
& \gamma=\frac{1}{4 \mathrm{~A}}\left(1+\sqrt{1+\frac{4 \mathrm{~A}}{3}}\right) \\
& \beta=\frac{\bar{x}}{\gamma}
\end{aligned}
$$

sendo que:

$$
\begin{aligned}
& A=\ln \bar{x}-x_{g} \\
& \bar{x}=\frac{1}{n} \sum_{i=1}^{n} x_{i} \\
& x_{g}=\frac{1}{n} \sum_{i=1}^{n} \ln \left(x_{i}\right)
\end{aligned}
$$

em que: 
$\overline{\mathrm{x}}$ - média aritmética das observações, $\mathrm{mm}$;

$\mathrm{x}_{\mathrm{g}}$ - média geométrica das observações, $\mathrm{mm}$;

$\mathrm{x}_{\mathrm{i}}$ - i-ésimo valor da precipitação pluviométrica diária, mm;

n - número de observações.

\subsubsection{Estimativa dos parâmetros $\mu$ e $\sigma$ da distribuição normal}

É a função de distribuição de probabilidade contínua mais utilizada, geralmente citada como curva normal ou curva de Gauss. É também uma distribuição de probabilidade de dois parâmetros e sua função cumulativa de distribuição tem a seguinte forma (Assis et al., 1996):

$$
F(x)=\frac{1}{\sigma \sqrt{2 \pi}} \int_{-\infty}^{x} e^{-\frac{(x-\mu)^{2}}{2 \sigma^{2}}} d x
$$

em que:

$\mu$ - média das observações na série de dados, mm;

$\sigma$ - desvio padrão das observações na série de dados, mm.

As estimativas de máxima verossimilhança dos parâmetros $\mu$ e $\sigma$ foram obtidas por:

$$
\begin{aligned}
& \mu=\frac{\sum_{i=1}^{n} x_{i}}{n} \\
& \sigma=\sqrt{\frac{\sum_{i=1}^{n}\left(x_{i}-\mu\right)^{2}}{n}}
\end{aligned}
$$

\footnotetext{
${ }^{8}$ THOM, H. C. S. Some methods of climatological analysis. Roma: FAO, 1966. 50 p. (FAO. Technical
} Notes. 81). 


\subsubsection{Estimativa dos parâmetros $\alpha$ e $\beta^{\prime}$ da distribuição beta}

É uma distribuição de probabilidade freqüentemente utilizada em estudos envolvendo evapotranspiração de referência (Saad \& Scaloppi, 1988; Saad, 1990; Silva et al., 1998). A função densidade de probabilidade da distribuição beta para o intervalo $(\mathrm{a} \leq \mathrm{x} \leq \mathrm{b})$ é definida pela seguinte expressão (Saad, 1990):

$$
f(x)=\frac{1}{(b-a) \Gamma(\alpha) \cdot \Gamma\left(\beta^{\prime}\right)} \cdot\left(\frac{x-a}{b-a}\right)^{\alpha-1}\left(1-\frac{x-a}{b-a}\right)^{\beta^{\prime}-1}
$$

em que:

a - valor mínimo das observações na série de dados, mm;

b - valor máximo das observações na série de dados, $\mathrm{mm}$;

$\alpha$ e $\beta^{\prime}$ - parâmetros de forma da distribuição beta $(\alpha>0, \beta>0)$;

$\mathrm{x}$ - valor da variável em estudo (evapotranspiração de referência), mm.

Segundo Assis et al. (1996) a função densidade de probabilidade da distribuição beta é usualmente definida no intervalo $(0,1)$. Por isso, na forma em que se encontra na equação (23) não pode ser aplicada, devendo ser transformada através da seguinte relação (Saad, 1990):

$$
x^{\prime}=\frac{x-a}{b-a}
$$

em que:

$x^{\prime}$ - evapotranspiração de referência transformada $\left(0 \leq x^{\prime} \leq 1\right)$.

Com essa transformação, a função densidade de probabilidade da distribuição beta assume a seguinte forma:

$$
f\left(x^{\prime}\right)=\frac{\Gamma\left(\alpha+\beta^{\prime}\right)}{\Gamma(\alpha) \cdot \Gamma\left(\beta^{\prime}\right)} \cdot x^{\prime \alpha-1} \cdot\left(1-x^{\prime}\right)^{\beta^{\prime}-1}
$$


A função cumulativa de probabilidade da distribuição beta é dada pela expressão (Saad, 1990):

$$
\mathrm{F}\left(\mathrm{x}^{\prime}\right)=\frac{\Gamma\left(\alpha+\beta^{\prime}\right)}{\Gamma(\alpha) \cdot \Gamma\left(\beta^{\prime}\right)} \cdot \int_{0}^{x^{\prime}} \mathrm{x}^{\prime \alpha-1}\left(1-\mathrm{x}^{\prime}\right)^{\beta^{\prime}-1} \mathrm{dx^{ \prime }}
$$

A estimativa dos parâmetros $\alpha$ e $\beta^{\prime}$ da distribuição beta foi efetuada com base nas equações apresentadas por Assis et al. (1996):

$$
\begin{aligned}
& \alpha=\bar{x}^{\prime} \theta \\
& \beta^{\prime}=\left(1-\bar{x}^{\prime}\right) \theta \\
& \theta=\frac{\bar{x}^{\prime}\left(1-\bar{x}^{\prime}\right)}{\sigma^{2}}-1 \\
& \sigma^{2}=\frac{n \sum_{i=1}^{n} x_{i}^{\prime}-\left(\sum_{i=1}^{n} x_{i}^{\prime}\right)^{2}}{n(n-1)}
\end{aligned}
$$

em que:

$\overline{\mathrm{X}}^{\prime}$ - média da evapotranspiração de referência transformada;

$\sigma^{2}$ - variância da evapotranspiração de referência transformada;

$\mathrm{x}_{\mathrm{i}}^{\prime}$ - i-ésimo valor da evapotranspiração de referência transformada.

\subsubsection{Estimativa dos parâmetros $\varepsilon$ e $\phi$ da distribuição triangular}

Uma variável aleatória contínua $\mathrm{x}$ tem distribuição triangular quando sua função densidade de probabilidade $\mathrm{f}(\mathrm{x}$ ) for definida por (Dias, 1996; Frizzone \& Silveira, 2000): 


$$
f(x)= \begin{cases}\frac{2(x-a)}{(b-a)(m-a)} & \text { para } a \leq x \leq m \\ \frac{2(b-x)}{(b-a)(b-m)} & \text { para } m \leq x \leq b \\ 0 & \text { para outros valores }\end{cases}
$$

em que:

m - moda das observações na série de dados, mm.

A função cumulativa de probabilidade da distribuição triangular $F(x)$ é:

$$
\begin{aligned}
& F(x)=\frac{(x-a)^{2}}{(b-a)(m-a)} \quad \text { se } a \leq x \leq m \\
& F(x)=\frac{(m-a) \quad(b-x)^{2}}{(b-a)(b-a)(b-m)}+\frac{(b-m)}{(b-a)} \quad \text { se } m \leq x \leq b
\end{aligned}
$$

A média $(\varepsilon)$ e o desvio padrão $(\phi)$ da distribuição triangular é dada por:

$$
\begin{aligned}
& \varepsilon=\frac{a+b+m}{3} \\
& \phi=\sqrt{\frac{(b-a)^{2}+(m-a)^{2}-(b-a)(m-a)}{18}}
\end{aligned}
$$

\subsubsection{Teste de aderência}

Para verificar o ajuste dos dados diários de precipitação pluviométrica à função de distribuição gama e dos valores diários de evapotranspiração de referência às funções de distribuição de probabilidades normal, beta e triangular foi utilizado o teste de aderência de Kolmogorov-Smirnov ao nível de 5\% de significância, conforme metodologia apresentada por Campos (1979). 


\subsection{Simulação da precipitação pluviométrica e evapotranspiração de referência}

Para a obtenção dos valores diários de precipitação pluviométrica e de evapotranspiração de referência foram realizadas 100 simulações pelo método de Monte Carlo, de modo a permitir a realização de igual número de balanços hídricos diários.

$\mathrm{Na}$ simulação da precipitação pluviométrica diária foi utilizada a função de distribuição de probabilidade gama, enquanto para os valores de evapotranspiração de referência foram usadas as funções normal, beta e triangular. Opcionalmente, em ambos os casos, utilizou-se a função de distribuição empírica nas épocas de semeadura que não apresentaram ajuste, pelo teste de aderência de Kolmogorov-Smirnov, às distribuições citadas anteriormente.

O processo de simulação foi efetuado para os 24 períodos de 70 dias em que foi dividido o ano, em função das épocas de semeadura avaliadas para as duas culturas, conforme especificadas na Tabela 1.

Em Teresina, este processo foi efetuado com os dados diários de precipitação pluviométrica e evapotranspiração de referência obtidos no período de 1985 a 1999. A etapa seguinte de avaliação do modelo de simulação foi realizada com os dados dessas variáveis referentes ao período de 1977 a 1983. Essa divisão deve-se à ausência dos dados de 1984. Em Parnaíba, devido ao reduzido número de anos de observação (19901999), efetuou-se o ajuste do modelo retirando-se sucessivamente um ano de dados de cada vez, da seguinte forma: i) inicialmente, retirou-se o ano de 1990 e procedeu-se ao ajuste com os dados do período compreendido entre 1991 a 1999; ii) em seguida, retirou-se o ano de 1991 e procedeu-se ao ajuste com os dados do ano de 1990 e do período compreendido entre 1992-1999 e assim por diante. Nesse caso, a etapa de avaliação foi realizada com os dados do ano excluído do ajuste. Os parâmetros das funções de distribuição de probabilidade, da combinação de períodos de dados com o melhor desempenho estatístico, foram utilizados para a geração dos valores de precipitação pluviométrica e evapotranspiração de referência diária. 
Tabela 1. Épocas de semeadura adotadas para as culturas de feijão caupi e melancia ${ }^{1}$

\begin{tabular}{|c|c|c|c|}
\hline \multirow{2}{*}{$\mathrm{N}^{\circ}$} & \multirow{2}{*}{ Data de semeadura } & \multicolumn{2}{|c|}{ Ciclo de cultivo ${ }^{2}$} \\
\hline & & Início & Término \\
\hline 1 & 1 - Janeiro & 5 - Janeiro & 10 - Março \\
\hline 2 & 15 - Janeiro & 19 - Janeiro & 24 - Março \\
\hline 3 & 1 - Fevereiro ${ }^{3}$ & 5 - Fevereiro & $10-$ Abril \\
\hline 4 & 15 - Fevereiro & 19 - Fevereiro & 21 - Abril \\
\hline 5 & 1 - Março & 5 - Março & 8 - Maio \\
\hline 6 & 15 - Março & 19 - Março & 22 - Maio \\
\hline 7 & 1 - Abril & 5 - Abril & 8 - Junho \\
\hline 8 & 15 - Abril & 19 - Abril & 22 - Junho \\
\hline 9 & 1 - Maio & 5 - Maio & 8 - Julho \\
\hline 10 & 15 - Maio & 19 - Maio & 22 - Julho \\
\hline 11 & 1 - Junho & 5 - Junho & 8 - Agosto \\
\hline 12 & 15 - Junho & 19 - Junho & 22 - Agosto \\
\hline 13 & 1 - Julho & 5 - Julho & 7 - Setembro \\
\hline 14 & 15 - Julho & 19 - Julho & 21 - Setembro \\
\hline 15 & 1 - Agosto & 5 - Agosto & 8 - Outubro \\
\hline 16 & 15 - Agosto & 19 - Agosto & 22 - Outubro \\
\hline 17 & 1 - Setembro & 5 - Setembro & 8 - Novembro \\
\hline 18 & 15 - Setembro & 19 - Setembro & 22 - Novembro \\
\hline 19 & 1 - Outubro & 5 - Outubro & 9 - Dezembro \\
\hline 20 & 15 - Outubro & 19 - Outubro & 22 - Dezembro \\
\hline 21 & 1 - Novembro & 5 - Novembro & 8 - Janeiro \\
\hline 22 & 15 - Novembro & 19 - Novembro & 22 - Janeiro \\
\hline 23 & 1 - Dezembro & 5 - Dezembro & 7 - Fevereiro \\
\hline 24 & 15 - Dezembro & 19 - Dezembro & 21 - Fevereiro \\
\hline
\end{tabular}

' Ciclo das culturas da semeadura à colheita $=70$ dias: ${ }^{2}$ Assumiu-se um período de 5 dias entre a semeadura e a emergência; ${ }^{3}$ Mês de fevereiro com 28 dias. 


\subsubsection{Simulação da precipitação pluviométrica}

Os modelos estocásticos de precipitação pluviométrica são geralmente divididos em duas etapas: a primeira modela a ocorrência da precipitação e a segunda a quantidade ou magnitude da precipitação, caso esta venha a ocorrer (Genneville \& Boock, 1983; Peiter, 1998).

\subsubsection{Modelagem da ocorrência da precipitação pluviométrica diária}

Para a modelagem da ocorrência da precipitação pluviométrica diária utilizou-se um processo baseado na cadeia de Markov admitindo-se a hipótese de persistência em $1^{\mathrm{a}}$ ordem, ou seja, que o evento do dia atual depende unicamente do evento do dia anterior. Optou-se por essa metodologia devido aos resultados satisfatórios alcançados em outros trabalhos (Carey \& Haan, 1978; Genneville \& Boock, 1983; Genovez, 1987; Peiter, 1998). Além disso, os modelos que se baseiam na hipótese de que a precipitação pluviométrica diária seja um processo aleatório independente não apresentam bom desempenho (Genovez, 1987).

Para a utilização desse procedimento, inicialmente definiu-se a matriz de probabilidade de transição de uma cadeia de Markov de $1^{\text {a }}$ ordem da seguinte forma:

\begin{tabular}{ccc}
\hline \multirow{2}{*}{ Dia atual } & \multicolumn{2}{c}{ Dia anterior } \\
\cline { 2 - 3 } & Seco & Chuvoso \\
\hline Seco & $\mathrm{P}(\mathrm{S} \mid \mathrm{S})$ & $\mathrm{P}(\mathrm{S} \mid \mathrm{C})$ \\
Chuvoso & $\mathrm{P}(\mathrm{C} \mid \mathrm{S})$ & $\mathrm{P}(\mathrm{C} \mid \mathrm{C})$ \\
\hline
\end{tabular}

em que:

$\mathrm{P}(\mathrm{S} \mid \mathrm{S})$ - probabilidade do dia atual ser seco dado que o dia anterior foi seco;

$\mathrm{P}(\mathrm{C} \mid \mathrm{S})$ - probabilidade do dia atual ser chuvoso dado que o dia anterior foi seco;

$\mathrm{P}(\mathrm{S} \mid \mathrm{C})$ - probabilidade do dia atual ser seco dado que o dia anterior foi chuvoso;

$\mathrm{P}(\mathrm{C} \mid \mathrm{C})$ - probabilidade do dia atual ser chuvoso dado que o dia anterior foi chuvoso. 
O cálculo das probabilidades condicionais da matriz de transição foi efetuado através das seguintes equações (Robertson, 1976; Fietz et al., 1998; Sousa, 1999):

$$
\begin{aligned}
& \mathrm{P}(\mathrm{S} \mid \mathrm{S})=\frac{\mathrm{N}(\mathrm{S} \mid \mathrm{S})}{\mathrm{N}(\mathrm{S} \mid \mathrm{S})+\mathrm{N}(\mathrm{C} \mid \mathrm{S})}=\frac{\mathrm{N}(\mathrm{S} \mid \mathrm{S})}{\mathrm{N}(\mathrm{S})} \\
& \mathrm{P}(\mathrm{C} \mid \mathrm{S})=\frac{\mathrm{N}(\mathrm{C} \mid \mathrm{S})}{\mathrm{N}(\mathrm{S} \mid \mathrm{S})+\mathrm{N}(\mathrm{C} \mid \mathrm{S})}=\frac{\mathrm{N}(\mathrm{C} \mid \mathrm{S})}{\mathrm{N}(\mathrm{S})}=1-\mathrm{P}(\mathrm{S} \mid \mathrm{S}) \\
& \mathrm{P}(\mathrm{C} \mid \mathrm{C})=\frac{\mathrm{N}(\mathrm{C} \mid \mathrm{C})}{\mathrm{N}(\mathrm{S} \mid \mathrm{C})+\mathrm{N}(\mathrm{C} \mid \mathrm{C})}=\frac{\mathrm{N}(\mathrm{C} \mid \mathrm{C})}{\mathrm{N}(\mathrm{C})} \\
& \mathrm{P}(\mathrm{S} \mid \mathrm{C})=\frac{\mathrm{N}(\mathrm{S} \mid \mathrm{C})}{\mathrm{N}(\mathrm{S} \mid \mathrm{C})+\mathrm{N}(\mathrm{C} \mid \mathrm{C})}=\frac{\mathrm{N}(\mathrm{S} \mid \mathrm{C})}{\mathrm{N}(\mathrm{C})}=1-\mathrm{P}(\mathrm{C} \mid \mathrm{C})
\end{aligned}
$$

em que:

$\mathrm{N}(\mathrm{S} \mid \mathrm{S})$ - número de dias secos dado que o dia anterior foi seco;

$\mathrm{N}(\mathrm{C} \mid \mathrm{S})$ - número de dias chuvosos dado que o dia anterior foi seco;

$\mathrm{N}(\mathrm{S} \mid \mathrm{C})$ - número de dias secos dado que o dia anterior foi chuvoso;

$\mathrm{N}(\mathrm{C} \mid \mathrm{C})$ - número de dias chuvosos dado que o dia anterior foi chuvoso;

$\mathrm{N}(\mathrm{S})$ - número total de dias secos;

$\mathrm{N}(\mathrm{C})$ - número total de dias chuvosos.

Considerou-se como dias secos aqueles em que a precipitação pluviométrica foi inferior à evapotranspiração de referência estimada pelo método de Penman - Monteith. Estratégia semelhante foi adotada por Fietz et al. (1998) e Sousa (1999).

A montagem da matriz de transição para cada local (Parnaíba e Teresina) foi realizada por época de semeadura e usando-se os dados diários de precipitação pluviométrica das séries históricas. O processo de geração das séries de dias secos e chuvosos foi efetuada utilizando-se as probabilidades condicionais $\mathrm{P}(\mathrm{C} \mid \mathrm{S})$ e $\mathrm{P}(\mathrm{C} \mid \mathrm{C})$ e uma série de números aleatórios uniformemente distribuídos entre zero e um $\left(U_{1}(0,1)\right)$. 
O processo foi inicializado no dia $1^{\circ}$ de janeiro. Dessa forma, a definição do estado inicial (seco ou chuvoso) do dia 31 de dezembro foi feita da seguinte maneira: i) gerouse um número aleatório ( $\mathrm{x}$ ) entre zero e um; ii) comparou-se esse número aleatório com as probabilidades condicionais $\mathrm{P}(\mathrm{C} \mid \mathrm{S})$ e $\mathrm{P}(\mathrm{C} \mid \mathrm{C})$ obtidas para a data de plantio de 15 de dezembro: a) se $0<\mathrm{x} \leq \mathrm{P}(\mathrm{C} \mid \mathrm{S})$, o estado inicial é chuvoso; b) se $\mathrm{P}(\mathrm{C} \mid \mathrm{S})<\mathrm{x} \leq \mathrm{P}(\mathrm{C} \mid \mathrm{C})$, o estado inicial é chuvoso e c) se $\mathrm{x}>\mathrm{P}(\mathrm{C} \mid \mathrm{C})$, o estado inicial é seco. Para os demais dias, seguiu-se o esquema apresentado na Figura 3.

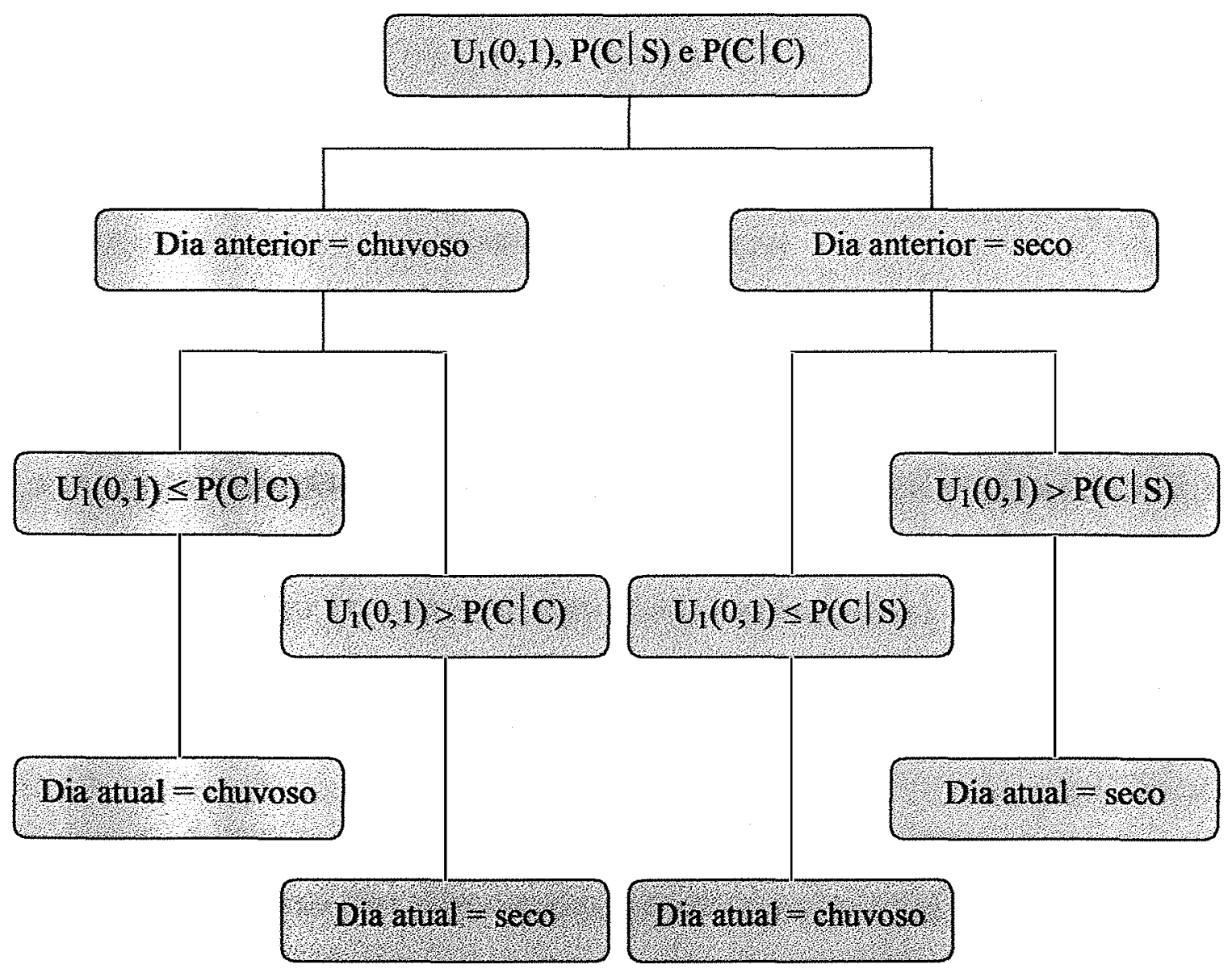

Figura 3. Definição da ocorrência de dias secos e chuvosos 
Procedimento semelhante foi adotado para as demais épocas de semeadura. Nesse caso, utilizou-se sempre para a definição do estado inicial (seco ou chuvoso) as probabilidades $\mathrm{P}(\mathrm{C} \mid \mathrm{S})$ e $\mathrm{P}(\mathrm{C} \mid \mathrm{C})$ obtidas para as épocas de semeadura imediatamente anteriores.

\subsubsection{Modelagem da quantidade de precipitação pluviométrica diária}

Após a identificação da ocorrência de chuva (dia atual = chuvoso), o processo de simulação passou à etapa seguinte de modelagem da quantidade. Caso contrário, assumiu-se o valor diário de precipitação pluviométrica igual a zero. Utilizou-se as funções de distribuição gama e empírica, cuja aplicabilidade é constatada e justificada nos trabalhos de Genneville \& Boock (1983), Genovez (1987) e Peiter (1998).

\subsection{Distribuição gama}

Utilizou-se os parâmetros $\gamma$ e $\beta$ da distribuição gama (equações 15 a 19), os quais foram calculados para cada época de semeadura j com base nos dados diários de precipitação pluviométrica e uma série de números aleatórios com distribuição uniforme entre zero e um $\left(\mathrm{U}_{2}(0,1)\right)$. Os valores diários de precipitação pluviométrica $\left(\mathrm{Pp}_{\mathrm{ij}}\right)$, correspondentes a uma dada probabilidade de ocorrência, foram obtidos através da função inversa da distribuição gama disponível em planilha eletrônica. Por esse procedimento, a inversa da função de distribuição gama é calculada por uma técnica iterativa até que seja atingida a precisão de $\pm 3 \times 10^{-7}$. A quantidade máxima de precipitação pluviométrica (Pmáx $)$ que pode ocorrer em cada época de semeadura foi limitada pelo valor máximo observado na série histórica.

Para efetivar essa rotina, os valores diários de $\mathrm{Pp}_{\mathrm{ij}}$ simulados foram acumulados em uma variável chamada de precipitação pluviométrica acumulada $\left(\mathrm{Pa}_{\mathrm{j}}\right)$. Cada dia que ocorria uma chuva $\left(\mathrm{Pp}_{\mathrm{ij}}\right)$, o valor de $\mathrm{Pa}_{\mathrm{j}}$ era comparado com o valor máximo observado $\left(\right.$ Pmáx $_{\mathrm{j}}$ ). Se o valor armazenado em $\mathrm{Pa}_{\mathrm{j}}$ fosse menor ou igual que $\mathrm{Pmáx}$, chovia a 
quantidade estipulada em $\mathrm{Pp}_{\mathrm{ij}}$. Caso contrário, o processo de geração era interrompido e nos dias restantes do período o valor de $\mathrm{Pp}_{\mathrm{ij}}$ era igual a zero. Esquematicamente, o processo é apresentado na Figura 4.

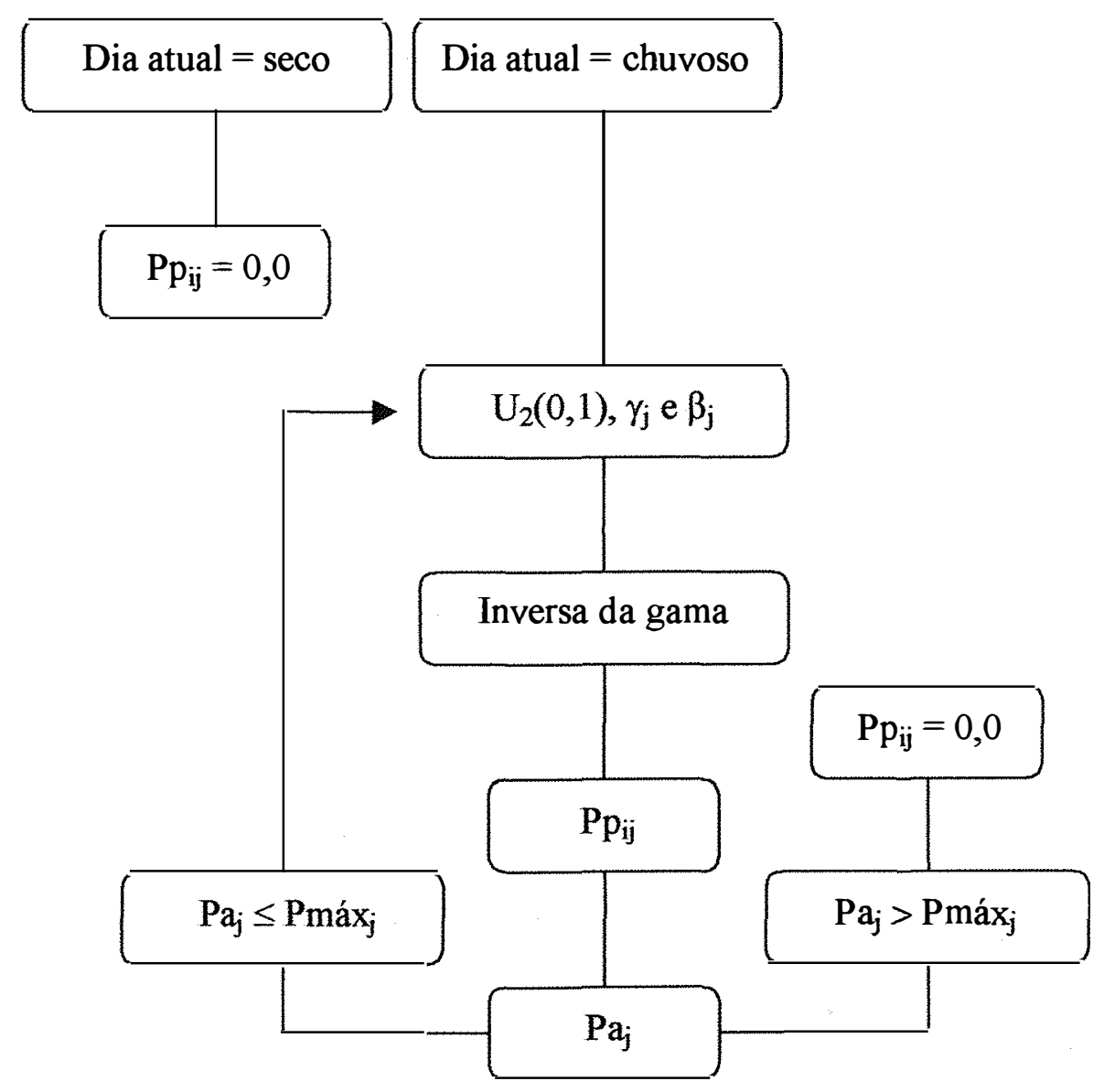

Figura 4. Geração da quantidade de precipitação pluviométrica diária usando a função de distribuição de probabilidade gama. 


\subsection{Distribuição empírica}

Esta distribuição foi determinada a partir dos valores diários de precipitação pluviométrica observados nas séries históricas, sintetizando-os com relação à freqüência com que ocorrem diferentes alturas de chuva em cada época de semeadura.

Inicialmente, elaborou-se uma rotina para a divisão em classes de precipitação pluviométrica, de acordo com o tamanho da série histórica disponível, segundo as equações apresentadas por Sampaio (1998). Neste contexto, é importante que essa classificação seja efetuada de forma adequada de modo a não causar distorções na distribuição dos dados devido ao uso de um número reduzido ou excessivo de classes. $\mathrm{O}$ número de classes que otimiza o estudo da distribuição foi obtido pela fórmula de Yule, definido em função do número de observações (Sampaio, 1998):

$$
\mathrm{NIC}_{\mathrm{j}}=2,5 \cdot \sqrt[4]{\mathrm{N}_{\mathrm{j}}}
$$

em que:

$\mathrm{NIC}_{\mathrm{j}}$ - número ideal de classes de precipitação pluviométrica na j-ésima época de semeadura $(j=1,2, \ldots, 24)$;

$\mathrm{N}_{\mathrm{j}}$ - número de observações de precipitação pluviométrica disponíveis na j-ésima época de semeadura.

$\mathrm{O} \mathrm{NIC}_{\mathrm{j}}$ foi aproximado para o número inteiro imediatamente superior, de modo a conter todas as observações dentro de todas as classes definidas (Sampaio, 1998). Em seguida, para a caracterização das classes de precipitação pluviométrica, foi necessário o cálculo do intervalo de classe (Sampaio, 1998):

$$
\mathrm{IC}_{\mathrm{j}}=\frac{\left(\operatorname{Máx}_{\mathrm{j}}-\mathrm{Min}_{\mathrm{j}}\right)}{\mathrm{NIC}_{\mathrm{j}}}
$$

em que:

ICj - intervalo de classe de precipitação pluviométrica da j-ésima época de semeadura ${ }_{2} \mathrm{~mm}$; 
Máx ${ }_{j}$ - valor máximo de precipitação pluviométrica observado na j-ésima época de semeadura, $\mathrm{mm}$;

$\operatorname{Min}_{\mathrm{j}}$ - valor mínimo de precipitação pluviométrica observado na j-ésima época de semeadura, $\mathrm{mm}$.

A definição dos limites superior e inferior de cada classe foi efetuada em função do intervalo de classe especificado anteriormente. No caso da classe número 1, o limite inferior correspondeu ao valor mínimo de precipitação pluviométrica observado na respectiva época de semeadura. Para a última classe, o limite superior foi igual ao valor máximo de precipitação pluviométrica observado na respectiva época de semeadura. Para as classes intermediárias, a definição foi efetuada da seguinte forma:

$$
\begin{aligned}
\mathrm{LI}_{\mathrm{kj}} & =\mathrm{LS}(\mathrm{k}-1) \mathrm{j} \\
\mathrm{LS}_{\mathrm{kj}} & =\mathrm{LI}_{\mathrm{kj}}+\mathrm{IC}_{\mathrm{j}}
\end{aligned}
$$

em que:

$\mathrm{LS}_{\mathrm{kj}}$ - limite superior da k-ésima classe de precipitação pluviométrica na j-ésima época de semeadura, $\mathrm{mm}(\mathrm{k}=1,2, \ldots, \infty)$;

$\mathrm{LI}_{\mathrm{kj}}$ - limite inferior da k-ésima classe de precipitação pluviométrica na j-ésima época de semeadura, $\mathrm{mm}$.

Posteriormente, fez-se a contagem do número de observações que ocorreu em cada classe de precipitação pluviométrica, de modo a permitir a determinação das freqüências relativas e acumuladas:

$$
\begin{aligned}
F_{k j} & =\frac{n_{k j}}{N_{j}} \\
F A_{k j} & =\sum_{k=1}^{N I C_{j}} F_{k j}
\end{aligned}
$$

em que: 
$\mathrm{FR}_{\mathrm{kj}}$ - freqüência relativa da $\mathrm{k}$-ésima classe de precipitação pluviométrica na jésima época de semeadura;

$\mathrm{FA}_{\mathrm{kj}}$ - freqüência acumulada da k-ésima classe de precipitação pluviométrica na j-ésima época de semeadura;

$\mathrm{n}_{\mathrm{kj}}$ - número de observações da k-ésima classe de precipitação pluviométrica na j-ésima época de semeadura.

Neste caso, o processo de simulação baseou-se no método de Hertz, o qual é semelhante ao método de Monte Carlo, porém aplicado a um conjunto de dados que se desconhece, a priori, sua função de distribuição de probabilidade, denominada de função de distribuição de probabilidade empírica. Basicamente, o processo é dividido em duas etapas: i) gerou-se um número aleatório $\mathrm{U}_{3}(0,1)$ e selecionou-se a classe de precipitação pluviométrica e ii) gerou-se um novo número aleatório $U_{4}(0,1)$ e determinou-se o valor da precipitação pluviométrica dentro de cada classe. Esses valores de precipitação pluviométrica somente são gerados se o estado do dia atual for chuvoso, definido na fase de ocorrência de precipitação pluviométrica.

Na primeira etapa, diz-se que a precipitação pluviométrica a ser gerada pertence a uma determinada classe de ordem $k$ na época de semeadura $j\left(C_{k j}\right)$ se a condição abaixo for verdadeira:

a) Para a classe de ordem $1\left(\mathrm{C}_{1 \mathrm{j}}\right) \rightarrow \mathrm{U}_{3}(0,1) \leq \mathrm{FA}_{1 \mathrm{j}}$

b) Para as demais classes de ordem $\mathrm{k}\left(\mathrm{C}_{\mathrm{kj}}\right) \rightarrow \mathrm{FA}_{(\mathrm{k}-1) \mathrm{j}}<\mathrm{U}_{3}(0,1) \leq \mathrm{FA}_{\mathrm{kj}}$

$\mathrm{Na}$ segunda etapa, a magnitude da precipitação pluviométrica no i-ésimo dia da jésima época de semeadura $\left(\mathrm{Pp}_{\mathrm{ij}}\right)$ foi obtida pela seguinte equação:

$$
\mathrm{Pp}_{\mathrm{ij}}=\mathrm{LS}_{\mathrm{kj}}-\left[\mathrm{U}_{4}(0,1) \cdot \mathrm{IC} \mathrm{j}\right]
$$

em que:

$\mathrm{Pp}_{\mathrm{ij}}$ - precipitação pluviométrica no i-ésimo dia da j-ésima época de semeadura, $\mathrm{mm}(\mathrm{i}=1,2, \ldots ., 70)$. 
Da mesma forma que na distribuição gama, a quantidade máxima de precipitação pluviométrica $\left(\operatorname{Pmáx}_{\mathrm{j}}\right)$ que pode ocorrer em cada época de semeadura foi limitada pelo valor máximo observado na série histórica. Esquematicamente, o processo é apresentado na Figura 5.

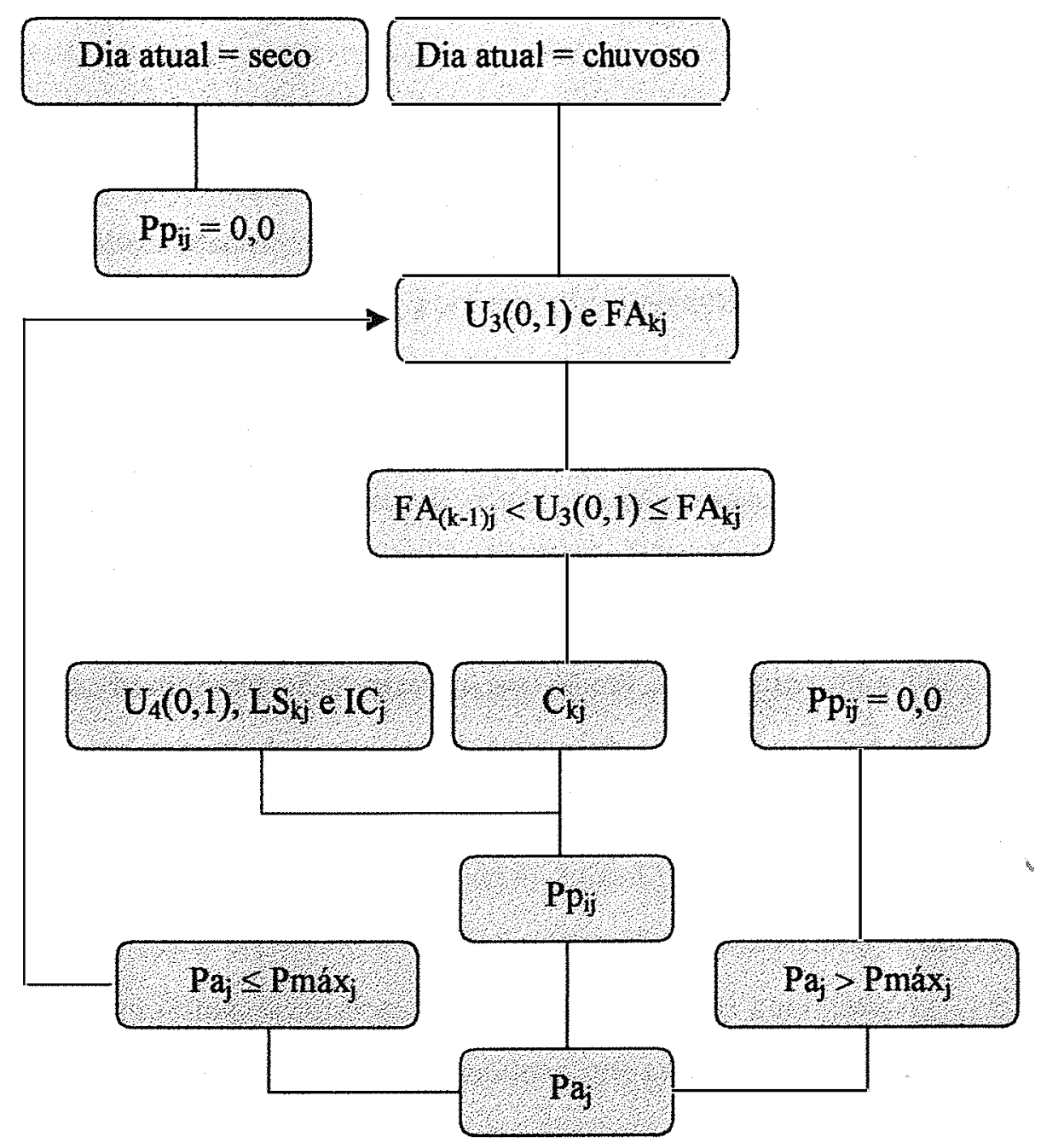

Figura 5. Geração da quantidade de precipitação pluviométrica diária usando a função de distribuição de probabilidade empírica 
Nas duas fases de modelagem da precipitação pluviométrica foram utilizadas sequeencias independentes de números aleatórios uniformemente distribuídos entre zero e um $\left(0 \leq U_{\mathrm{x}} \leq 1\right)$ identificados como $\mathrm{U}_{1}, \mathrm{U}_{2}, \mathrm{U}_{3}$ e $\mathrm{U}_{4}$.

Visando avaliar o desempenho do processo de simulação da precipitação pluviometrica, efetuou-se 100 simulações da ocorrência e quantidade de chuva e comparou-se a média dos valores simulados com a média dos valores observados de número de dias secos $(\mathrm{N}(\mathrm{S})$ ), número de dias chuvosos $(\mathrm{N}(\mathrm{C})$ ) e precipitação pluviometrica total ocorrida em cada época de semeadura. Para tanto, utilizou-se os seguintes indicadores de desempenho estatístico: i) precisão - coeficiente de correlação de Pearson (equação 47); ii) exatidão - índice de concordância de Willmott (Willmott, 1981) (equação 48) e iii) índice de confiança ou desempenho de Camargo (c) (Camargo $\&$ Sentelhas, 1997), o qual constitui-se em um produto dos dois índices anteriores. Essa estratégia permite identificar o grau de precisão e de exatidão do processo de modelagem da precipitação pluviométrica (Camargo \& Sentelhas, 1997; Pereira, 1998; Sousa, 1999).

$$
\begin{aligned}
& r=\frac{N\left(\sum_{j=1}^{N} S_{j} O_{j}\right)-\left(\sum_{j=1}^{N} S_{j}\right)\left(\sum_{j=1}^{N} O_{j}\right)}{\sqrt{\left[\left(N \sum_{j=1}^{N}\left(S_{j}\right)^{2}\right)-\left(\sum_{j=1}^{N} S_{j}\right)^{2}\right]\left[\left(N \sum_{j=1}^{N}\left(O_{j}\right)^{2}\right)-\left(\sum_{j=1}^{N} O_{j}\right)^{2}\right]}} \\
& I d=1-\frac{\sum_{j=1}^{N}\left(S_{j}-O_{j}\right)^{2}}{\sum_{j=1}^{N}\left(\left|S_{j}-\bar{O}\right|+\left|O_{j}-\bar{O}\right|\right)^{2}}
\end{aligned}
$$

em que:

$\mathrm{r}$ - coeficiente de correlação de Pearson;

Id - índice de concordância de Willmott; 
$S_{\mathrm{j}}$ - variável simulada na j-ésima época de semeadura;

$\mathrm{O}_{\mathrm{j}}$ - variável observada na série histórica na j-ésima época de semeadura;

$\overline{\mathrm{O}}$ - média da variável observada na série histórica;

$\mathrm{N}$ - número de épocas de semeadura avaliadas.

\subsubsection{Simulação da evapotranspiração de referência}

\subsubsection{Distribuição normal}

Para a simulação dos valores diários de evapotranspiração de referência utilizouse os parâmetros $\mu_{\mathrm{j}}$ e $\sigma_{\mathrm{j}}$ previamente calculados (equações 21 e 22) para cada época de semeadura j, aplicando-os na equação abaixo descrita (Hillier \& Lieberman, 1988):

$$
E \mathrm{Eo}_{\mathrm{ij}}=\sigma_{\mathrm{j}} \sum_{\mathrm{n}=1}^{12} \mathrm{U}_{5_{\mathrm{n}}}+\left(\mu_{\mathrm{j}}-6 \sigma_{\mathrm{j}}\right)
$$

em que:

$E T o_{i j}$ - evapotranspiração de referência no i-ésimo dia da j-ésima época de semeadura, $\mathrm{mm}$;

$$
\mathrm{U}_{5_{\mathrm{n}}} \text { - número aleatório gerado }\left(0 \leq \mathrm{U}_{5_{\mathrm{n}}} \leq 1\right) \text {. }
$$

\subsubsection{Distribuição beta}

Utilizou-se o procedimento de cálculo contido em planilha eletrônica para a estimativa da inversa da distribuição beta cumulativa. Por esse procedimento, a estimativa dos valores de evapotranspiração de referência diária, para cada época de semeadura, é efetuada por um processo iterativo até que seja atingida a precisão de $\pm 3 \mathrm{x}$ $10^{-7}$. Para tanto, usou-se os parâmetros $\alpha$ e $\beta^{\prime}$ previamente calculados (equações 27 a 30) e um número aleatório uniformemente distribuído entre zero e um $\left(\mathrm{U}_{6}\right)$ como o valor de probabilidade desejado. 
Nesse caso, como a estimativa dos parâmetros $\alpha$ e $\beta^{\prime}$, para cada época de semeadura, foi efetuada com os valores transformados de evapotranspiração de referência ( $x^{\prime}$ ) (equação 24), fez-se necessário a reconversão dos valores de ETo para a ordem de grandeza dos valores originais, realizada através da equação (50):

$$
E \mathrm{To}_{\mathrm{ij}}=\mathrm{a}+\mathrm{x}_{\mathrm{ij}}^{\prime}(\mathrm{b}-\mathrm{a})
$$

em que:

$\mathrm{x}_{\mathrm{ij}}^{\prime}$ - evapotranspiração de referência transformada no i-ésimo dia da j-ésima época de semeadura.

\subsubsection{Distribuição triangular}

Para a utilização dessa função foi necessário apenas conhecer-se previamente os valores mínimo, máximo e a moda ou valor mais freqüente da evapotranspiração de referência diária. $O$ processo de simulação consistiu na seguinte seqüência de equações (Frizzone \& Silveira, 2000):

$$
\mathrm{U}^{*}=\frac{(\mathrm{m}-\mathrm{a})}{(\mathrm{b}-\mathrm{a})}
$$

em que:

$\mathrm{U}^{*}$ - número aleatório ou randômico limite

Em seguida, foi gerado um número aleatório $U_{7}(0,1)$. Quando o número gerado foi menor que o número randômico limite, a evapotranspiração de referência foi simulada através da seguinte equação:

$$
E \mathrm{Eo}_{\mathrm{ij}}=\mathrm{a}+\sqrt{\mathrm{U}_{7}(\mathrm{~b}-\mathrm{a})(\mathrm{m}-\mathrm{a})}
$$


Quando o número aleatório $U_{7}$ foi maior que o número randômico limite, o valor simulado de ETo foi obtido por:

$$
\mathrm{ETo}_{\mathrm{ij}}=\mathrm{b}-\sqrt{\left(1-\mathrm{U}_{7}\right)(\mathrm{b}-\mathrm{a})(\mathrm{b}-\mathrm{m})}
$$

Finalmente, quando o número aleatório gerado $\left(\mathrm{U}_{7}\right)$ foi igual ao número randômico limite, o valor simulado de $\mathrm{ETo}_{\mathrm{ij}}$ foi igual à moda da distribuição, ou seja: $\mathrm{ETo}_{\mathrm{ij}}=\mathrm{m}$.

\subsubsection{Distribuição empírica}

Utilizou-se um procedimento semelhante ao empregado na fase de simulação da magnitude da precipitação pluviométrica diária pela distribuição empírica (item 3.5.1.2.2). Porém, usou-se seqüências diferentes de números aleatórios para a definição da classe de evapotranspiração $\left(\mathrm{U}_{8}\right)$ e da magnitude de evapotranspiração dentro de cada classe $\left(U_{9}\right)$ :

$\mathrm{Na}$ primeira etapa, diz-se que a evapotranspiração de referência diária a ser gerada pertencia a uma determinada classe de ordem $k$ na época de semeadura $\mathrm{j}\left(\mathrm{C}_{\mathrm{kj}}\right)$ se a condição abaixo fosse verdadeira:

a) Para a classe de ordem $1\left(\mathrm{C}_{1 \mathrm{j}}\right) \rightarrow \mathrm{U}_{8}(0,1) \leq \mathrm{FA}_{1 \mathrm{j}}$

b) Para as demais classes de ordem $\mathrm{k}\left(\mathrm{C}_{\mathrm{kj}}\right) \rightarrow \mathrm{FA}_{(\mathrm{k}-1) \mathrm{j}}<\mathrm{U}_{8}(0,1) \leq \mathrm{FA}_{\mathrm{kj}}$

$\mathrm{Na}$ segunda etapa, a magnitude da evapotranspiração de referência no i-ésimo dia da j-ésima época de semeadura $\left(E \mathrm{o}_{\mathrm{ij}}\right)$ foi obtida pela seguinte equação:

$$
\mathrm{ETo}_{\mathrm{ij}}=\mathrm{LS}_{\mathrm{kj}}-\left[\mathrm{U}_{9}(0,1) \mathrm{IC}_{\mathrm{j}}\right]
$$

em que:

$\mathrm{LS}_{\mathrm{kj}}$ - limite superior da k-ésima classe de evapotranspiração de referência na jésima época de semeadura, $\mathrm{mm}$; 
ICj - intervalo de classe de evapotranspiração de referência da j-ésima época de semeadura, $\mathrm{mm}$.

Da mesma forma que na simulação da precipitação pluviométrica diária, em todas as funções de distribuição de probabilidades utilizadas para a estimativa da evapotranspiração de referência (ETo) diária, a quantidade máxima de ETo de cada época de semeadura $\left(E T\right.$ máx $_{\mathrm{j}}$ ) foi limitada pelo valor máximo observado na série histórica. Na hipótese da ETo acumulada em uma determinada época de semeadura $\mathbf{j}$ $\left(\mathrm{ETo}_{\mathrm{aj}}\right)$ ultrapassar esse limite, efetuou-se uma nova simulação dos valores de $\mathrm{ETo}_{\mathrm{ij}}$.

A avaliação da simulação da ETo diária seguiu a mesma metodologia utilizada na avaliação da simulação da precipitação pluviométrica.

\subsection{Balanço hídrico diário}

O balanço hídrico sequencial diário foi efetuado de acordo com a metodologia proposta por Thornthwaite \& Mather $^{9}$ citado por Pereira et al. (1997b). Por este método, a evapotranspiração e as necessidades de irrigação para as culturas de feijão caupi e melancia foram obtidas com base nos parâmetros edafoclimáticos das microrregiões do Litoral Piauiense e de Teresina e as particularidades inerentes ao consumo hídrico das culturas definidas através dos coeficientes de cultivo. Para cada microrregião, foram simulados 100 balanços hídricos diários distintos por época de semeadura e nível de manejo de irrigação adotados. Adicionalmente, durante o período chuvoso, foram efetuados balanços hídricos diários sem a aplicação dos niveis de manejo de irrigação suplementar, com o intuito de constatar a viabilidade econômica da adoção dessa prática.

${ }^{9}$ THORNTHWAITE, C.W.; MATHER, J.R. The water balance. Publications in Climatology. New Jersey: Drexel Institute of Technology, 1955. 104p. 


\subsubsection{Elementos climáticos}

Utilizou-se no balanço hídrico os valores diários simulados de precipitação pluviométrica e evapotranspiração de referência. Normalmente os balanços hídricos são contabilizados considerando a precipitação pluviométrica total ocorrida. Entretanto, nem toda a água proveniente das precipitações pluviométricas fica disponivel à cultura. Por isso, foi considerada somente a precipitação pluviométrica efetiva, ou seja, a diferença entre a precipitação pluviométrica total e a perda por percolação profunda e/ou escoamento superficial (Bernardo, 1989; Andrade Júnior, 1992; Marouelli et al., 1996; Sousa et al., 1997).

Para a estimativa da precipitação pluviométrica efetiva usou-se a metodologia proposta pelo U. S. Conservation Service - USDA (Franke, 1996). Por este método, a precipitação pluviométrica reparte-se em perdas iniciais, devido à interceptação e enchimento das rugosidades superficiais do solo, e perdas por escoamento superficial, as quais foram computadas pelas seguintes equações adaptadas de Franke (1996):

$$
\begin{array}{ll}
\mathrm{Pi}=\frac{5080}{\mathrm{NC}}-50,8 & \\
\operatorname{Pr}=\frac{(\mathrm{P}-0,2 \cdot \mathrm{s})^{2}}{(\mathrm{P}+0,8 \cdot \mathrm{s})} & \mathrm{P}>0,2 \mathrm{~s} \\
\operatorname{Pr}=0,0 & \mathrm{P} \leq 0,2 \mathrm{~s}
\end{array}
$$

sendo que:

$$
\mathrm{s}=254 \cdot\left(\frac{100}{\mathrm{NC}}-1\right)
$$

em que:

$\mathrm{Pi}$ - perdas iniciais devido à interceptação e enchimento das rugosidades superficiais do solo, $\mathrm{mm}$;

$\mathrm{Pr}$ - perdas por escoamento superficial, $\mathrm{mm}$;

$\mathrm{P}$ - precipitação pluviométrica simulada, mm; 
$\mathrm{NC}$ - número curva;

s - parâmetro de retenção, adimensional.

O parâmetro de retenção (s) varia com o tipo de solo, uso e práticas de manejo, sendo definido em função do número curva $(0 \leq \mathrm{NC} \leq 100)$ encontrado em tabela (Lima, 1995). Nesse estudo, adotou-se o número curva 67 (Areia Quartzosa) e 78 (Latossolo Vermelho-Amarelo).

Por essa metodologia, parte das perdas iniciais é evaporada (25\%) e apenas $75 \%$ infiltra-se no solo. Dessa forma, a precipitação pluviométrica que efetivamente contribuiu para a variação do armazenamento de água no solo foi obtida pela expressão:

$$
\begin{array}{ll}
\mathrm{Pe}=\mathrm{P}-\mathrm{Pr}-0,25 \cdot \mathrm{Pi} & \mathrm{P}>\mathrm{Pi} \\
\mathrm{Pe}=0,75 \cdot \mathrm{P} & \mathrm{P} \leq \mathrm{Pi}
\end{array}
$$

em que:

Pe - precipitação pluviométrica efetiva, $\mathrm{mm}$.

\subsubsection{Parâmetros de solo}

As características fisico-hídricas de solos representativos das microrregiões do Litoral Piauiense (Areia Quartzosa) e de Teresina (Latossolo Vermelho-Amarelo) são apresentadas na Tabela 2. As curvas de retenção de água no solo (Figura 6), obtidas a partir de amostras indeformadas, foram determinadas no Laboratório de Solos da Embrapa Meio Norte e ajustadas ao modelo de Genuchten (1980), através do programa computacional Soil Water Retention Curve ${ }^{10}$, cujas equações são:

a) Areia Quartzosa:

${ }^{10}$ DOURADO NETO, D.; NIELSEN, D.R.; HOPMANS, J.W.; PARLANGE, M.B. Soil Water Retention Curve. v. 1.0. ESALQ, USP; University of California, 1995. 


$$
\begin{array}{ll}
\left|\psi_{\mathrm{m}}\right|=4,466\left[\left(\frac{0,130}{\theta-0,041}\right)^{9,1659}-1\right]^{0,1165} & (0-0,2 \mathrm{~m}) \\
\left|\psi_{\mathrm{m}}\right|=4,708\left[\left(\frac{0,152}{\theta-0,058}\right)^{8,9047}-1\right]^{0,1088} & (0,2-0,4 \mathrm{~m})
\end{array}
$$

b) Latossolo Vermelho-Amarelo:

$$
\begin{array}{ll}
\left|\psi_{\mathrm{m}}\right|=20,492\left[\left(\frac{0,145}{\theta-0,062}\right)^{1,3583}-1\right]^{0,4573} & (0-0,2 \mathrm{~m}) \\
\left|\psi_{\mathrm{m}}\right|=3,7369\left[\left(\frac{0,253}{\theta-0,058}\right)^{3,2637}-1\right]^{0,5176} & (0,2-0,4 \mathrm{~m})
\end{array}
$$

em que:

$\psi_{\mathrm{m}}$ - potencial mátrico de água no solo, $\mathrm{kPa}$;

$\theta$ - conteúdo de água no solo, $\mathrm{cm}^{3} \mathrm{~cm}^{-3}$.

\begin{tabular}{|c|c|c|c|c|c|c|c|}
\hline \multirow[t]{2}{*}{ Solo } & \multirow{2}{*}{$\begin{array}{c}\text { Camada } \\
\text { (m) }\end{array}$} & \multicolumn{3}{|c|}{ Granulometria $\left(\mathrm{g} \mathrm{kg}^{-1}\right)$} & \multirow{2}{*}{$\begin{array}{c}\mathrm{Dg} \\
\left(\mathrm{kg} \mathrm{m}^{-3}\right)\end{array}$} & \multicolumn{2}{|c|}{ Umidade $(\%$, em massa seca) } \\
\hline & & Areia & Silte & Argila & & $\mathrm{CC}$ & PM \\
\hline \multirow[t]{2}{*}{$\mathrm{AQ}$} & $0-0,2$ & 880 & 60 & 60 & 1630 & 9,78 & 2,94 \\
\hline & $0,2-0,4$ & 850 & 70 & 80 & 1630 & 12,15 & 4,03 \\
\hline \multirow[t]{2}{*}{ LVA } & $0-0,2$ & 790 & 110 & 100 & 1560 & 12,08 & 3,96 \\
\hline & $0,2-0,4$ & 800 & 100 & 100 & 1.580 & 12,20 & 4,13 \\
\hline
\end{tabular}

Tabela 2. Características físico-hídricas de solos representativos das microrregiões do Litoral Piauiense (Areia Quartzosa) (AQ) e de Teresina (Latossolo VermelhoAmarelo) (LVA).

Fonte: Laboratório de Solos da Embrapa Meio Norte. Dg - massa específica do solo 

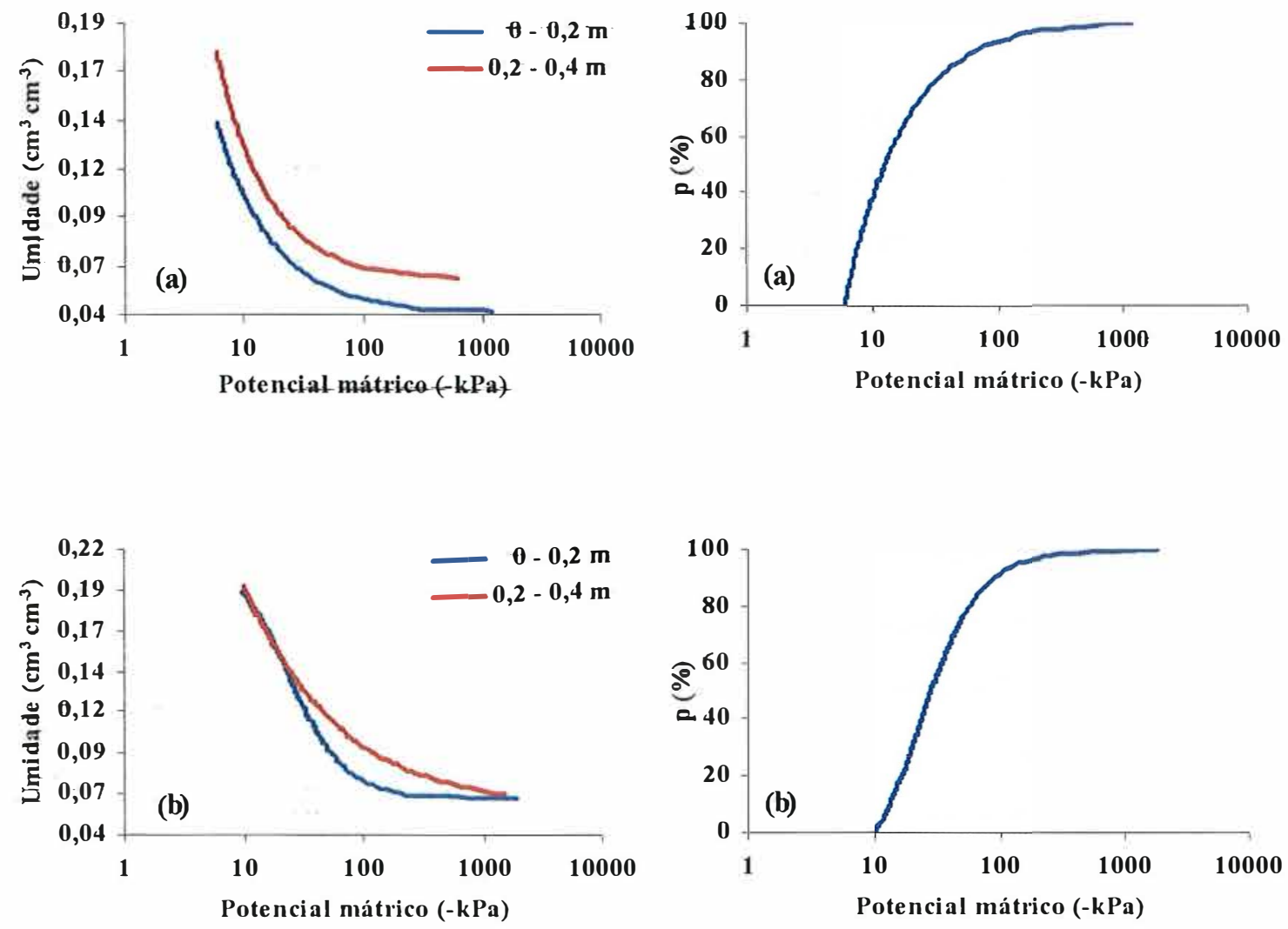

Figura 6. Curvas de retenção de água no solo e relação entre a fração p e o potencial mátrico de água no solo para Areia Quartzosa (a) e Latossolo VermelhoAmarelo (b).

A capacidade de água disponível no solo para as plantas depende basicamente da capacidade de retenção de água no solo e da profundidade efetiva do sistema radicular da cultura, sendo calculada pela expressão (Marouelli et al., 1996):

$$
\mathrm{CAD}=\frac{(\mathrm{CC}-\mathrm{PM})}{100} \mathrm{D}_{\mathrm{g}} \mathrm{Z}
$$

em que:

CAD - capacidade de água disponível no solo, $\mathrm{mm}$;

CC - capacidade de campo, $\%$ em massa seca;

PM - ponto de murcha permanente, $\%$ em massa seca;

$\mathrm{Dg}$ - massa específica do solo, $\mathrm{kg} \mathrm{m}^{-3}$;

$\mathrm{Z}$ - profundidade efetiva do sistema radicular da cultura, $\mathrm{m}$. 
Para a definição dos limites superior (CC) e inferior (PM) de disponibilidade de água no solo (Tabela 2) utilizou-se os valores clássicos de $\mathrm{CC}$, associados às tensões de água no solo de $10 \mathrm{kPa}$ para solos de textura arenosa, e de $1500 \mathrm{kPa}$ para o PM, conforme recomendação de Marouelli et al. (1996).

Em irrigação, normalmente, utiliza-se apenas a profundidade do solo onde se concentram cerca de $80 \%$ a $90 \%$ do sistema radicular da cultura. Assumiu-se uma variação linear na profundidade efetiva do sistema radicular da cultura e, portanto, na $\mathrm{CAD}$, desde um valor mínimo, na emergência, até um valor máximo na fase de maior demanda hídrica, permanecendo esta constante até a fase de maturidade fisiológica. Uma relação linear entre dias após a semeadura e crescimento em profundidade das raízes com a CAD também foi assumida por Franke (1996) com resultados satisfatórios.

A definição de $Z$ para as culturas de feijão caupi e melancia foi efetuada em função de resultados de pesquisa nos locais do estudo (Nogueira \& Nogueira, 1995), experiência de campo e na literatura (Andrade Júnior, 1992; Marouelli et al., 1996; Sousa et al., 1997). Adotou-se um valor de $Z$ de $0,05 \mathrm{~m}$, na fase da emergência da cultura, evoluindo até o valor máximo de $0,25 \mathrm{~m}$, na fase de florescimento e enchimento das vagens de feijão caupi e dos frutos de melancia.

A evolução linear da $\mathrm{CAD}$ ao longo do ciclo das culturas foi determinada através das equações (66) e (67), cujo aspecto gráfico é apresentado na Figura 7.

$$
\mathrm{CAD}=\mathrm{CAD}_{\mathrm{e}}+\left[\mathrm{b}\left(\mathrm{D}^{\prime}-\mathrm{d}\right)\right]
$$

sendo que:

em que:

$$
\mathrm{b}=\frac{\left(\mathrm{CAD}_{\mathrm{f}}-\mathrm{CAD} \mathrm{D}_{\mathrm{e}}\right)}{(\mathrm{D}-\mathrm{d})}
$$

b - coeficiente angular da equação;

$\mathrm{CAD}_{\mathrm{e}}-\mathrm{CAD}$ na fase de emergência para cada solo, $\mathrm{mm}$;

$\mathrm{CAD}_{\mathrm{f}}-\mathrm{CAD}$ na fase de florescimento para cada solo, $\mathrm{mm}$;

d - período de tempo entre a semeadura e a emergência da cultura, dias;

D - período de tempo entre a semeadura e o florescimento da cultura, dias; 
D' - período de tempo correspondente à fase atual da cultura, dias.

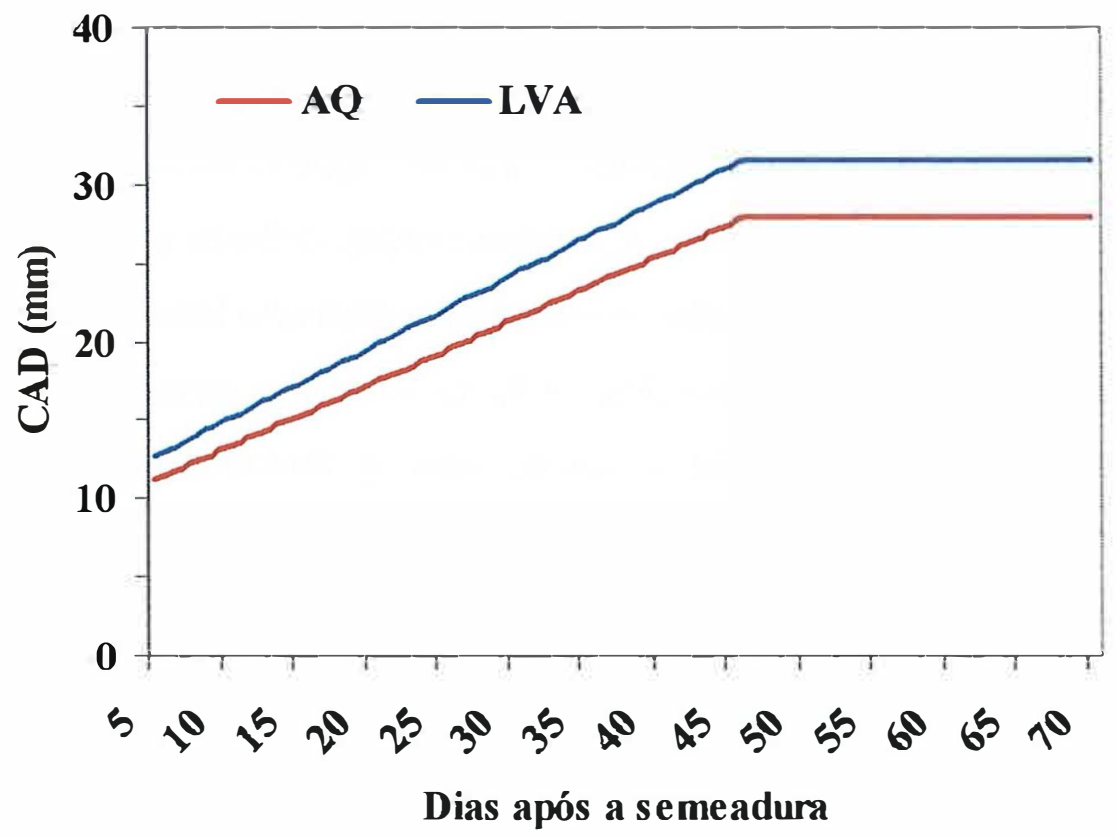

Figura 7. Evolução da capacidade de água disponivel (CAD) durante o ciclo das culturas de feijão caupi e melancia, nos solos Areia Quartzosa (AQ) e Latossolo Vermelho-Amarelo-(LVA).

A água prontamente disponivel (AD), utilizada pelas plantas- no processo de evapotranspiração, corresponde apenas a uma fração da CAD que pode ser utilizada pelas culturas sem configurar um déficit hídrico superior ao estabelecido pelos-níveis de manejo de irrigação:

$$
\mathrm{AD}=-\mathrm{p}_{\mathrm{i}} \cdot \mathrm{CAD}
$$

em que:

$\mathrm{p}_{\mathrm{r}}$ - fração de esgotamento admissível da água no solo para o nível de manejo de irrigação i $(i=1,2, \ldots ., 7)$.

Os níveis-de manejo de irrigação simulados-através da fração- $p_{i}$ foram definidos dentro da faixa estabelecida por Doorenbos \& Kassam-(1994) para as culturas de feijão e 
melancia (grupo de culturas 3), quais sejam: $\mathrm{p}_{1}=0,2 ; \mathrm{p}_{2}=0,3 ; \mathrm{p}_{3}=0,4 ; \mathrm{p}_{4}=0,5 ; \mathrm{p}_{5}=$ 0,$6 ; \mathrm{p}_{6}=0,7$ e $\mathrm{p}_{7}=0,8$

Pelo modelo de balanço hídrico diário adotado, as culturas foram irrigadas quando foi consumida a $\mathrm{AD}$ do solo. No entanto, o efeito do estresse hídrico sobre a produção das culturas manifestou-se quando o valor da fração $p_{i}$ simulada foi superior à indicada como adequada por Doorenbos \& Kassam (1994), definida em função da ETm diária da cultura. Quando essa condição ocorreu, houve limitação hídrica no solo (ETr < ETm) com reflexo direto na produção (Figura 8). O mesmo procedimento foi adotado para o balanço hídrico na estação chuvosa, com a diferença de não haver a suplementação hídrica via irrigação quando a $\mathrm{AD}$ foi consumida, a qual dependeu unicamente da ocorrência ou não de precipitações pluviométricas.

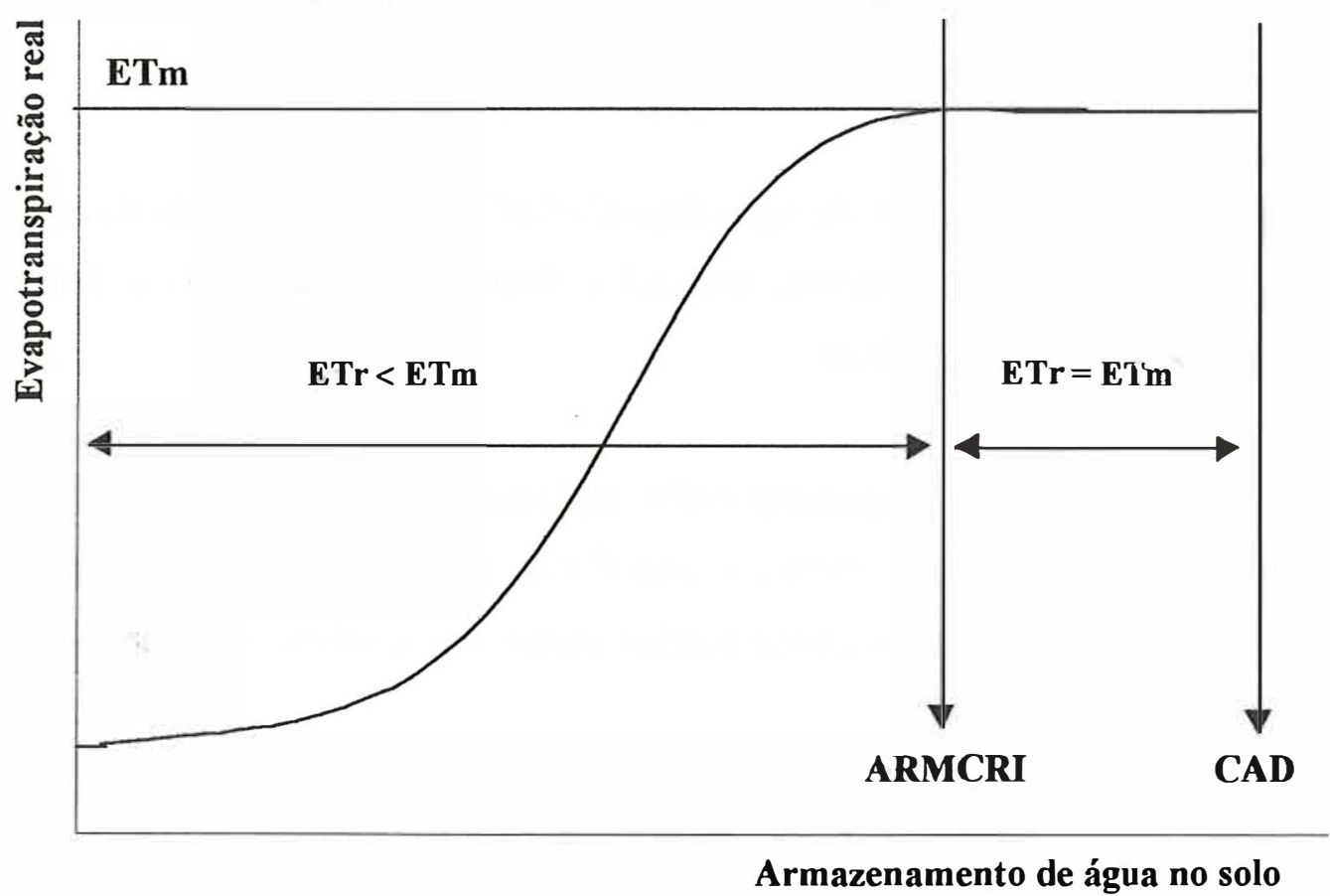

Figura 8. Variação da evapotranspiração real em função do armazenamento de água disponível no solo. 


\subsubsection{Parâmetros de cultura}

Os principais parâmetros culturais de importância para a realização do balanço hídrico dizem respeito à época de semeadura, a duração do ciclo e o coeficiente de cultivo em seus diferentes estádios de desenvolvimento.

Em termos climáticos, as culturas de feijão caupi e melancia podem ser cultivadas o ano inteiro nas duas regiões edafoclimáticas de interesse para esse estudo, pois não existe limitação climática, como por exemplo de temperaturas do ar e do solo, que venha a induzir a semeadura em determinadas épocas do ano. Tradicionalmente, são efetuados os chamados cultivos de sequeiro, os quais ocorrem na estação chuvosa e sem utilização da irrigação, e irrigado, que ocorrem em plena estação seca com o uso de irrigação total.

Dessa forma, efetuou-se a análise da viabilidade econômica da irrigação dessas culturas através da simulação de diferentes épocas de semeadura ao longo do ano (Tabela 1). Com isso, as culturas foram submetidas a períodos de maior e menor probabilidade de ocorrência de deficiência hídrica em seus subperíodos mais criticos.

Com relação à duração do ciclo das culturas, praticamente não existem variações significativas ao longo do ano, uma vez que praticamente não ocorrem grandes oscilações nos valores de temperatura do ar. Considerou-se um ciclo total de 65 dias, desde a emergência até a maturidade fisiológica, para as culturas de feijão caupi (Bezerra \& Freire Filho, 1984) e melancia (Andrade Júnior et al., 1998d).

Os valores de coeficiente de cultivo (Kc), nos diferentes estádios de desenvolvimento das culturas, foram obtidos de uma coletânea dos trabalhos de pesquisa locais (Bezerra \& Freire Filho, 1984; Lima \& Silva, 1988; Andrade et al., 1993) ou conduzidos em condições edafoclimáticas semelhantes (Silva \& Millar, 1981b; Saunders et al., 1981; Saunders et al., 1985; Padilha Júnior, 1986; Miranda et al., 1997; Barros et al., 1998; Bezerra \& Oliveira, 1998a; Santos et al., 1998; Bezerra et al., 1999; Bezerra \& Oliveira, 1998b; Freitas \& Bezerra, 1999a), tendo como orientação os valores recomendados por Doorenbos \& Kassam (1994). Um sumário destes valores de Kc são apresentados na Tabela 3 . 
Tabela 3. Coeficiente de cultivo $(\mathrm{Kc})$ e fator de resposta ao déficit hídrico $(\mathrm{Ky})$ para as culturas de feijão caupi e melancia.

\begin{tabular}{cccccccc}
\hline \multirow{2}{*}{ Fases } & DAS $^{1}$ & Z & \multicolumn{2}{c}{ Feijão caupi } & \multicolumn{2}{c}{ Melancia } \\
\cline { 5 - 8 } & (dias) & $(\mathrm{m})$ & Kc & Ky & Kc & Ky \\
\hline I & $0-20$ & 0,10 & 0,40 & 0,20 & 0,50 & 0,30 \\
II & $21-45$ & 0,15 & 0,80 & 0,35 & 0,80 & 0,70 \\
III & $46-60$ & 0,25 & 1,20 & 1,10 & 1,05 & 1,00 \\
IV & $61-70$ & 0,25 & 0,70 & 0,20 & 0,75 & 0,55 \\
\hline
\end{tabular}

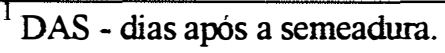

A definição da duração das fases de desenvolvimento das culturas foi efetuada conforme recomendação de Doorenbos \& Kassam (1994): I - estabelecimento (da emergência até $10 \%$ de cobertura do solo); II - desenvolvimento vegetativo (de $10 \%$ a $80 \%$ de cobertura do solo); III - floração e frutificação (de $80 \%$ de cobertura do solo até o início da maturação) e IV - maturação (início da maturação à colheita).

\subsubsection{Cálculo do balanço hídrico diário}

O cálculo do balanço hídrico sequencial diário foi efetuado, para cada época de semeadura e nivel de manejo de irrigação, em função dos elementos climáticos (ETo e $\mathrm{Pe}$ ), oriundos das simulações, características fisico-hídricas do solo (CAD e AD) e culturais $(\mathrm{Kc})$.

A sequêencia básica de cálculo foi constituída das seguintes etapas e utilizando-se as equações apresentadas por Doorenbos \& Kassam (1994) e Pereira et al. (1997b):

a) Cálculo da evapotranspiração máxima (ETm):

$$
\mathrm{ETm}=\mathrm{Kc} \cdot \mathrm{ETo}
$$

em que:

ETm - evapotranspiração máxima da cultura, $\mathrm{mm} \mathrm{dia}^{-1}$;

Kc - coeficiente de cultivo, adimensional; 
ETo - evapotranspiração de referência, $\mathrm{mm} \mathrm{dia}^{-1}$.

b) Cálculo do armazenamento crítico (ARMCRI):

$$
\text { ARMCRI }=\left(1-p_{i}\right) \cdot C A D
$$

c) Variação do armazenamento de água no solo (ARM):

No primeiro dia do balanço hídrico, assumiu-se que o armazenamento é igual à capacidade de água disponível na zona radicular da cultura, ou seja: $A R M=C A D$. Esta hipótese é sustentável, uma vez que em condições normais de campo, durante a fase de emergência das plântulas, normalmente o solo encontra-se com elevado conteúdo de água, já que a semeadura ocorre sempre após um período chuvoso ou irrigação (Oliveira, 1990).

Para os dias seguintes, os valores de CAD foram calculados diariamente utilizando-se a equação (66) até a fase de maior demanda hídrica. A partir dessa fase, a $\mathrm{CAD}$ foi assumida constante até a maturidade fisiológica.

Esquematicamente, a seqüência de cálculos pode ser resumida da seguinte forma:

\section{Dia 1}
$\mathrm{ARM}_{1}=\mathrm{CAD}$
$\mathrm{ALT}_{1}=0$
$\mathrm{EXC}_{1}=0$
$\mathrm{N}_{1}=0$
$\mathrm{DEF}_{1}=0$
$\mathrm{I}_{1}=0$

Dia 2 - Caso 1 (Pe $\geq$ ETm)
$\mathrm{ARM}_{2}=\mathrm{ARM}_{1}+\mathrm{Pe}-\mathrm{ETm}$
$\mathrm{N}_{2}=\mathrm{CAD} \cdot \operatorname{Ln}\left(\frac{\mathrm{ARM}_{2}}{\mathrm{CAD}}\right)$
$\mathrm{ALT}_{2}=\mathrm{ARM}_{2}-\mathrm{ARM}_{1}$
$\mathrm{DEF}_{2}=0$ 
Contudo, três situações podem ocorrer:

a) $\mathrm{Se} \mathrm{ARM}_{2} \leq \mathrm{ARMCRI}$ :

$$
\begin{aligned}
& \mathrm{I}_{2}=\left(\frac{\left|\mathrm{N}_{2}\right|}{\mathrm{Ef}}\right) \Rightarrow \mathrm{ARM}_{2}=\mathrm{CAD} \quad \Rightarrow \quad\left(\mathrm{Se}\left|\mathrm{N}_{2}\right| \leq \mathrm{ARMCRI}-\mathrm{N}_{2}^{\prime}=0\right. \\
& \left.\mathrm{EXC}_{2}=0\right) \\
& \mathrm{EXC}_{2}=\left|\mathrm{N}_{2}\right|-\mathrm{AD} \quad\left(\mathrm{Se}\left|\mathrm{N}_{2}\right|>\mathrm{ARMCRI}-\mathrm{ARM}_{2}\right)
\end{aligned}
$$

b) Se ARMCRI $<\mathrm{ARM}_{2}<\mathrm{CAD}$ :

$$
\mathrm{I}_{2}=0 \quad \mathrm{ARM}_{2}=\mathrm{ARM}_{2} \quad \mathrm{~N}_{2}^{\prime}=\mathrm{N}_{2} \quad \mathrm{EXC}_{2}=0
$$

c) $\mathrm{Se} \mathrm{ARM}_{2} \geq \mathrm{CAD}$ :

$$
\mathrm{I}_{2}=0 \quad \mathrm{ARM}_{2}=\mathrm{CAD} \quad \mathrm{N}_{2}^{\prime}=0 \quad \mathrm{EXC}_{2}=\mathrm{Pe}-\mathrm{ETm}-\mathrm{ALT}_{2}
$$

\section{Dia 2 - Caso 2 (Pe $<$ ETm)}

$$
\begin{array}{ll}
\mathrm{N}_{2}=\mathrm{N}_{1}+\mathrm{Pe}-\mathrm{ETm} \quad\left(\mathrm{Se} \mathrm{I}_{1}=0\right) & \mathrm{N}_{2}=\mathrm{Pe}-\mathrm{ETm} \quad\left(\mathrm{Se} \mathrm{I}_{1} \neq 0\right) \\
\mathrm{ARM}_{2}=\mathrm{CAD} \cdot \mathrm{EXP}\left(\frac{\mathrm{N}_{2}}{\mathrm{CAD}}\right) & \mathrm{ALT}_{2}=\mathrm{ARM}_{2}-\mathrm{ARM}_{1} \\
\mathrm{DEF}_{2}=\mathrm{ETm}-\mathrm{ETI}_{2} &
\end{array}
$$

Entretanto, duas situações podem ocorrer:

a) $\operatorname{Se}\left|N_{2}\right| \geq A D$

$$
\mathrm{I}_{2}=\left(\frac{\left|\mathrm{N}_{2}\right|}{\mathrm{Ef}}\right) \Rightarrow \mathrm{ARM}_{2}=\mathrm{CAD} \quad \Rightarrow \quad \mathrm{N}_{2}^{\prime}=0
$$




$$
\mathrm{EXC}_{2}=\left|\mathrm{N}_{2}\right|-\mathrm{AD} \quad\left(\mathrm{Se}\left|\mathrm{N}_{2}\right|>\mathrm{AD}\right) \quad \mathrm{EXC}_{2}=0 \quad\left(\mathrm{Se}\left|\mathrm{N}_{2}\right|=\mathrm{AD}\right)
$$

b) $\operatorname{Se}\left|N_{2}\right|<A D$ :

$$
I_{2}=0 \quad \mathrm{ARM}_{2}=\mathrm{ARM}_{2} \quad \mathrm{~N}_{2}=\mathrm{N}_{2} \quad \mathrm{EXC}_{2}=0
$$

em que:

$\mathrm{ARM}_{1}, \mathrm{ARM}_{2}$ - armazenamento de água no solo no $1^{\circ}$ e $2^{\circ}$ dia, respectivamente, $\mathrm{mm}$;

$\mathrm{N}_{1}, \mathrm{~N}_{2}$ - negativo acumulado no $1^{\circ}$ e $2^{\circ}$ dia, respectivamente, $\mathrm{mm}$;

$\mathrm{N}_{2}{ }_{2}$ - negativo acumulado no $2^{\circ}$ dia após uma chuva ou irrigação, mm;

$I_{1}, I_{2}$ - lâmina bruta de irrigação suplementar ou total necessária no $1^{\circ}$ e $2^{\circ}$ dia, respectivamente, $\mathrm{mm}$;

$\mathrm{ALT}_{1}, \mathrm{ALT}_{2}$ - alteração no armazenamento de água no solo no $1^{\circ}$ e $2^{\circ}$ dia, respectivamente, $\mathrm{mm}$;

$\mathrm{DEF}_{1}, \mathrm{DEF}_{2}$ - deficiência hídrica no $1^{\circ}$ e $2^{\circ}$ dia, respectivamente, $\mathrm{mm}$;

$\mathrm{EXC}_{1}, \mathrm{EXC}_{2}$ - excedente hídrico no $1^{\circ}$ e $2^{\circ}$ dia, respectivamente, $\mathrm{mm}$;

$\mathrm{E}_{\mathrm{f}}$ - eficiência de irrigação, decimal.

A estimativa da evapotranspiração real (ETr) foi efetuada pela variação do armazenamento de água no solo, conforme proposto por Thornthwaite \& Mather (1955) citado por Pereira et al. (1997b). Os cálculos de ETr obedeceram a seguinte ordem:

\section{Dia 1}

$$
\mathrm{ETr}_{1}=\mathrm{ETm}
$$

\section{Dia 2 - Caso 1 (Pe $\geq$ ETm)}

$$
\mathrm{ETr}_{2}=\mathrm{ETm}
$$




\section{Dia 2 - Caso $2($ Pe $<$ ETm)}

a) $\operatorname{Se}\left|\mathrm{N}_{2}\right| \geq \mathrm{AD}$ :

$$
\mathrm{ETr}_{2}=\mathrm{ETm}
$$

b) Se $\left|\mathrm{N}_{2}\right|<\mathrm{AD}$

$$
\mathrm{ETr}_{2}=\mathrm{ARM}_{2}-\mathrm{ARM}_{1}
$$

em que:

$\mathrm{ETr}_{1}, \mathrm{ETr}_{2}$ - evapotranspiração real no $1^{\circ}$ e $2^{\circ}$ dia, respectivamente, $\mathrm{mm}$.

Os cálculos para os dias posteriores obedeceram a mesma seqüência apresentada para o dia 2, substituindo-se os números índices corretamente nas variáveis indexadas. Quanto à eficiência de irrigação, utilizou-se o valor de $75 \%$ para o sistema de irrigação por aspersão convencional, conforme recomendado por Klar (1991b).

Ao final do balanço hídrico diário, obteve-se os valores de evapotranspiração máxima, evapotranspiração real e lâmina bruta de irrigação, para cada combinação de cultura, local, época de semeadura e nível de manejo de irrigação, os quais foram usados nas etapas posteriores relativas à estimativa da produtividade das culturas e análise da viabilidade econômica da irrigação.

Os valores de lâmina bruta de irrigação suplementar ou total necessária às culturas (I) foram ajustados à função de distribuição de probabilidade normal, de forma a possibilitar a sua futura estimativa em função do nível de risco desejado. Utilizou-se a inversa da função de distribuição normal, a partir da definição dos parâmetros da distribuição $(\mu$ e $\sigma)$ e dos níveis de probabilidade de ocorrência desejados $(95,90,85$, $80,75,70,65$ e $60 \%$ ). Procedimento semelhante foi utilizado por Oliveira (1990) e Franke (1996). Estes valores de I foram úteis para a estimativa do custo de energia elétrica, conforme será descrito posteriormente.

Para o processo de ajuste à distribuição normal, usou-se as equações (21 e 22), descritas na estimativa dos valores diários de evapotranspiração de referência. Antes, porém, verificou-se o ajuste dos valores de I à essa distribuição de probabilidades 
através do teste de aderência de Kolmogorov-Smirnov. Para as combinações de cultura, local, época de semeadura e nivel de manejo de irrigação em que não ocorreram ajuste dos valores de I à função de distribuição de probabilidade normal, usou-se a função de distribuição de probabilidade empírica. Nestes casos, a estimativa de I correspondeu ao ponto médio da classe cuja freqüência acumulada abrange a probabilidade de ocorrência desejada.

Com relação ao balanço hídrico sequencial diário efetuado sem a suplementação hídrica por irrigação, elaborou-se uma rotina utilizando-se a mesma metodologia apresentada anteriormente, porém procedendo-se às devidas reformulações. Contudo, não se implementou as irrigações quando estas foram necessárias conforme os critérios utilizados no balanço hídrico com irrigação. A seqüência utilizada foi a seguinte:

\section{Dia 1}
$\mathrm{ARM}_{1}=\mathrm{CAD}$
$\mathrm{ALT}_{1}=0$
$\mathrm{EXC}_{1}=0$
$\mathrm{N}_{1}=0$
$\mathrm{DEF}_{1}=0$
$\mathrm{ETr}_{1}=\mathrm{ETm}$

Dia 2 - Caso 1 (Pe $\geq$ ETm)
a) $\mathrm{ARM}_{2}=\mathrm{ARM}_{1}+\mathrm{Pe}-\mathrm{ETm}$
$\left(\right.$ Se $\left.\mathrm{ARM}_{2}<\mathrm{CAD}\right)$
b) $\mathrm{ARM}_{2}=\mathrm{CAD}$
(Se $\mathrm{ARM}_{2} \geq \mathrm{CAD}$ )
$\mathrm{N}_{2}=\mathrm{CAD} \cdot \operatorname{Ln}\left(\frac{\mathrm{ARM}_{2}}{\mathrm{CAD}}\right)$
$\mathrm{ALT}_{2}=\mathrm{ARM}_{2}-\mathrm{ARM}_{1}$
$\mathrm{DEF}_{2}=0$
$\mathrm{EXC}_{2}=\mathrm{Pe}-\mathrm{ETm}-\mathrm{ALT}_{2}$
$\left(\mathrm{Se} \quad \mathrm{ARM}_{2}=\mathrm{CAD}\right)$
$\mathrm{EXC}_{2}=0$
$\left(\mathrm{Se} \quad \mathrm{ARM}_{2}<\mathrm{CAD}\right)$
$\mathrm{ETr}_{2}=\mathrm{ETm}$ 
Dia 2 - Caso $2($ Pe $<$ ETm $)$

$$
\begin{array}{ll}
\mathrm{N}_{2}=\mathrm{N}_{1}+\mathrm{Pe}-\mathrm{ETm} & \mathrm{ARM}_{2}=\mathrm{CAD} \cdot \mathrm{EXP}\left(\frac{\mathrm{N}_{2}}{\mathrm{CAD}}\right) \\
\mathrm{ALT}_{2}=\mathrm{ARM}_{2}-\mathrm{ARM}_{1} & \mathrm{ETr}_{2}=\mathrm{ALT}_{2} \\
\mathrm{EXC}_{2}=0 & \mathrm{DEF}_{2}=\mathrm{ETm}-\mathrm{ETr}_{2}
\end{array}
$$

\subsection{Déficit de evapotranspiração e produção relativa}

O efeito do estresse hídrico sobre a produção das culturas manifestou-se quando o valor da fração $p_{i}$ simulada foi superior à indicada como adequada por Doorenbos \& Kassam (1994). Quando essa situação ocorreu, configurou-se uma condição de água limitada no solo $(\mathrm{ETr}<\mathrm{ETm})$ com reflexo direto na produção.

Um déficit hídrico de determinada magnitude pode ocorrer tanto de forma contínua durante todo o período de crescimento da cultura como durante qualquer umas das fases específicas de crescimento. Por isso, sempre que possível, para a estimativa da produtividade real da cultura, é aconselhável utilizar as equações ajustadas às diferentes fases da cultura. Uma dessas formas, é a relação multiplicativa entre a produtividade relativa e o déficit de evapotranspiração (Bernardo et al., 1988; Rao et al., 1988). Optouse por um modelo multiplicativo já que as culturas de feijão caupi e melancia apresentam hábito de crescimento indeterminado e relação de dependência entre os efeitos de déficits hídricos em estádios fenológicos distintos, conforme apresentado em Frizzone (1998).

$$
\mathrm{Yr}=\mathrm{Ym}\left\{\prod_{\mathrm{i}=1}^{4}\left[1-\mathrm{Kyi} \cdot\left(1-\frac{\mathrm{ETri}}{\mathrm{ETmi}}\right)\right]\right\}
$$

em que:

Yr - produtividade real da cultura, $\mathrm{kg} \mathrm{ha}^{-1}$;

Ym - produtividade máxima ou potencial da cultura, $\mathrm{kg} \mathrm{ha}^{-1}$; 
Kyi - coeficiente de resposta da cultura ao déficit hídrico na fase i, adimensional; ETri - evapotranspiração real da cultura na fase i, mm;

ETmi - evapotranspiração máxima da cultura na fase i, $\mathrm{mm}$.

Utilizou-se os valores de Ky (Tabela 3) com base em Doorenbos \& Kassam (1994) e em trabalhos de pesquisa conduzidos em condições edafoclimáticas semelhantes, pois não se dispõe de resultados de pesquisas locais. No caso específico das culturas de feijão caupi e melancia, destacam-se os trabalhos de Cordeiro et al. (1998b) e Freitas \& Bezerra (1999b), respectivamente.

Segundo Doorenbos \& Kassam (1994), o rendimento máximo de uma cultura $(\mathrm{Ym})$ é aquele obtido de uma variedade altamente produtiva e bem adaptada ao respectivo ambiente de crescimento, em condições tais que não hajam limitações de fatores como: água, nutrientes, pragas e doenças durante todo o ciclo. Entretanto, devido à complexidade das inter-relações entre os muitos fatores que a governam, a sua determinação torna-se muito complicada. Uma alternativa viável para se processar uma estimativa confiável seria a utilização de valores potenciais de produtividade, a nivel de campo ou experimentais, obtidos nas condições edafoclimáticas de interesse.

Em função de resultados de pesquisa obtidos nas condições edafoclimáticas de Pamaiba e Teresina, assumiu-se para as culturas de feijão caupi e melancia valores de produtividade potencial iguais a $2.500 \mathrm{~kg} \mathrm{ha}^{-1}$ e $50.000 \mathrm{~kg} \mathrm{ha}^{-1}$, respectivamente. Para garantir uma margem maior de segurança, esses valores representam apenas $80 \%$ dos níveis de produtividade alcançados nos Campos Experimentais da Embrapa Meio Norte situados nas duas microrregiões (Cardoso et al., 1987; Cardoso et al., 1991; Cardoso et al., 1997; Andrade Júnior et al., 1997; Andrade Júnior et al., 1998b; Andrade Júnior et al., 1998d; Andrade Júnior et al., 1999).

Os valores de produtividade real (Yr) obtidos pela equação (71) foram ajustados à função de distribuição de probabilidade normal, de modo a permitir a sua estimativa através do uso da função inversa dessa distribuição. Para tanto, utilizou-se os parâmetros ajustados $(\mu \mathrm{e} \sigma)$ e os niveis de probabilidade de ocorrência desejados $(95,90,85,80$, $75,70,65$ e $60 \%$ ). Nesta etapa, usou-se a mesma rotina de cálculo e equações utilizadas 
na estimativa da evapotranspiração de referência (equações 21 e 22), inclusive o procedimento referente ao teste de aderência de Kolmogorov-Smirnov. Para as combinações de cultura, local, época de semeadura e nível de manejo de irrigação em que não ocorreram ajuste dos valores de Yr à função de distribuição de probabilidade normal, usou-se a função de distribuição de probabilidade empírica. Nestes casos, a estimativa de $\mathrm{Yr}$ correspondeu ao ponto médio da classe cuja freqüência acumulada abrangia a probabilidade de ocorrência desejada.

Apesar do balanço hídrico fornecer valores diários de ETr e ETm, usou-se os valores médios por estádios de desenvolvimento das culturas, de forma a possibilitar a aplicação correta dos valores de Ky na equação (71). Como não havia, a priori, o conhecimento da magnitude dos valores de déficit hídrico a serem impostos às culturas em conseqüência dos níveis de manejo de irrigação aplicados, utilizou-se os valores de Ky considerando-se como sendo linear a relação entre o rendimento relativo e a evapotranspiração relativa para qualquer condição de déficit hídrico.

\subsection{Custo da água de irrigação e preço de venda dos produtos}

Outra fonte de variabilidade muito importante nos estudos de viabilidade econômica de culturas irrigadas diz respeito aos preços dos produtos agrícolas e do custo da água de irrigação, os quais oscilam bastante no cenário agrícola brasileiro.

Em função do estágio atual de gestão dos recursos hídricos no Piauí e no País como um todo, o custo da água de irrigação pode ser considerado zero. Entretanto, para fins de análise econômica das culturas sob regime irrigado, este foi considerado igual ao custo da energia elétrica consumida pelas eletrobombas na sucção e recalque da água nos sistemas de irrigação pressurizados. Dependendo da região, constatou-se que este componente representa até $60 \%$ dos custos variáveis de produção das culturas irrigadas. Segundo Franke (1996), a estimativa do custo de energia elétrica pode ser efetuada pela equação (72):

$$
\mathrm{CE}_{\mathrm{ijklp}}=\left(\mathrm{Eb}_{\mathrm{ijklp}} \cdot \mathrm{Tc}_{\mathrm{kp}}\right)+\left(\mathrm{Dp} \cdot \mathrm{Td}_{\mathrm{kp}}\right)+\left[\mathrm{Dp} \cdot \mathrm{Td}_{\mathrm{kp}} \cdot \mathrm{y} \cdot(12-\mathrm{x})\right]
$$


Sendo que, segundo adaptação de Frizzone (1999):

$$
\begin{aligned}
& \mathrm{Eb}_{\mathrm{ijklp}}=\frac{10 \cdot \mathrm{I}_{\mathrm{ijklp}} \cdot \mathrm{Hm} \cdot \gamma_{\mathrm{a}}}{3,6 \cdot 10^{6} \cdot \eta} \\
& \mathrm{Dp}=\frac{\mathrm{Hm} \cdot \mathrm{Q} \cdot \gamma_{\mathrm{a}}}{1000 \cdot \mathrm{A} \cdot \eta}
\end{aligned}
$$

em que:

$C E_{\mathrm{j} j k l p}$ - custo de energia elétrica na cultura $i$, na microrregião $j$, na época de semeadura $k$, com manejo de irrigação 1 e probabilidade de ocorrência $p, U S \$ h^{-1}(p=$ $95 \%, 90 \%, \ldots, 60 \%)$;

$E b_{i j k l p}$ - energia requerida pela unidade de bombeamento na cultura $i$, na microrregião $\mathrm{j}$, na época de semeadura $\mathrm{k}$, com manejo de irrigação $\mathrm{l}$ e probabilidade de ocorrência $\mathrm{p}, \mathrm{kWh} \mathrm{ha}^{-1}$;

$T c_{k p}$ - tarifa média mensal de consumo de energia elétrica referente ao período coberto pela época de semeadura $\mathrm{k}$ e com probabilidade de ocorrência $\mathrm{p}$, US $\$ \mathrm{kWh}^{-1}$;

$\mathrm{Dp}$ - demanda de potência da unidade de bombeamento, $\mathrm{kWh}^{-{ }^{-1}}$;

$\mathrm{Td}_{\mathrm{kp}}$ - tarifa média mensal de demanda de potência referente ao período coberto pela época de semeadura $\mathrm{k}$ e com probabilidade de ocorrência $\mathrm{p}, \mathrm{US} \$ \mathrm{kWh}^{-1}$;

$\mathrm{y}$ - coeficiente aplicado à demanda faturável $=0,1$ da maior demanda verificada por medição nos últimos 11 meses;

$\mathrm{x}$ - número de meses que o sistema opera pelo menos uma vez (suficiente para $\mathrm{o}$ medidor registrar $100 \%$ da potência instalada);

$I_{i j k l p}$ - lâmina bruta de irrigação suplementar ou total na cultura i, na microrregião j, na época de semeadura $k$, com manejo de irrigação $l$ e probabilidade de ocorrência $p$, $\mathrm{mm}$;

$\mathrm{Hm}$ - altura manométrica total $(60 \mathrm{~m})$;

$\gamma_{\mathrm{a}}$ - densidade da água $\left(9806,65 \mathrm{~N} \mathrm{~m}^{-3}\right)$;

$\eta$ - eficiência global do conjunto eletrobomba, decimal $(0,65)$; 
Q - vazão do sistema de irrigação $\left(0,01 \mathrm{~m}^{3} \mathrm{~s}^{-1}\right)$;

A - área irrigada pelo equipamento $(6 \mathrm{ha})$.

Contudo, cerca de $99,5 \%$ das propriedades rurais piauienses enquadram-se na classe rural de consumo de energia elétrica, sobre a qual incide apenas a tarifa de consumo denominada B2, que independe da potência elétrica instalada na propriedade. Sobre esses produtores não incide a cobrança da tarifa de demanda, bem como não aplicam-se as tarifas horo-sazonais. Por isso, o consumo de energia elétrica foi quantificado pela equação (75), que representa uma simplificação da equação (72):

$$
\mathrm{CE}_{\mathrm{ijklp}}=\mathrm{Eb}_{\mathrm{ijklp}} \cdot \mathrm{Tc}_{\mathrm{kp}}
$$

Para a estimativa do custo de energia elétrica, os preços mensais da tarifa de consumo foram obtidos na Companhia Energética do Piauí (CEPISA), contemplando um período de dez anos de registros (1990-1999), e representam os valores cobrados sem os subsídios assegurados pela Lei Estadual de Incentivo à Irrigação (Lei $\mathrm{n}^{\circ} 4.542$, de 28/12/1992, posteriormente alterada pela Lei $\mathrm{n}^{\circ} 4.995$, de 30/12/1997), devido à dificuldade de sua implementação nesse estudo, já que os subsídios concedidos variam conforme a dimensão da área irrigada. Quanto a estimativa da energia requerida pela unidade de bombeamento, considerou-se uma situação hipotética de um projeto de sistema de irrigação representativa das condições edafoclimáticas das microrregiões do Litoral Piauiense e de Teresina.

Nesse caso, foram obtidos os valores mais comuns de altura manométrica total e de vazão, normalmente, verificados nos projetos de sistemas de irrigação por aspersão convencional dimensionados para essas duas microrregiões, os quais foram conseguidos junto a empresas privadas de elaboração de projetos.

Os preços mensais de venda do feijão caupi e melancia foram coletados junto às Centrais de Abastecimento do Estado do Piauí (CEASA-PI), contemplando o período referente aos últimos seis anos de registros (1994-1999) e representando os preços de venda praticados no atacado. Para garantir uma margem maior de segurança nas análises 
econômicas, considerou-se que preços pagos ao produtor eqüivalem a apenas $50 \%$ do preço de venda dos produtos no atacado. Os preços das tarifas de energia elétrica e de venda dos produtos foram convertidos em dólar, utilizando-se a cotação do câmbio comercial médio mensal na época de sua ocorrência.

Para a inclusão do risco econômico na análise de viabilidade econômica da irrigação, os preços mensais da tarifa de consumo e de venda do feijão caupi e melancia foram ajustados à função de distribuição de probabilidades triangular, conforme comumente utilizada em estudos econômicos (Brunelli, 1990; Biserra, 1994).

Processou-se mensalmente as estimativas dos preços da tarifa de energia elétrica e de venda dos produtos utilizando-se a inversa da função de distribuição de probabilidade triangular (equações 51, 52 e 53), apresentadas pelas equações (76), (77) e (78), respectivamente.

$$
\mathrm{P}^{*}=\frac{(\mathrm{m}-\mathrm{a})}{(\mathrm{b}-\mathrm{a})}
$$

em que:

$\mathrm{P}^{*}$ - nível de probabilidade de ocorrência limite

$$
\begin{array}{lll}
P_{1}=a+\sqrt{P(b-a)(m-a)} & \text { quando } & P<P^{*} \\
P_{1}=b-\sqrt{(1-P)(b-a)(b-m)} & \text { quando } & P>P^{*}
\end{array}
$$

em que:

P - probabilidade de ocorrência desejada, decimal;

$\mathrm{P}_{\mathrm{i}}$ - preço mensal de venda da cultura $\mathbf{i}\left(\mathrm{US} \$ \mathrm{~kg}^{-1}\right.$ ) ou o preço mensal da tarifa de consumo de energia elétrica (US\$ $\mathrm{kWh}^{-1}$ ), conforme o caso. Quando $\mathrm{P}=\mathrm{P}^{*}$, o valor de $\mathrm{P}_{\mathrm{i}}=\mathrm{m}$

Para a simulação desses preços foram fornecidos os parâmetros da distribuição (valor máximo, valor mínimo e moda) e o nível de probabilidade de ocorrência desejado 
$(95,90,85,80,75,70,65$ e $60 \%)$. Quando não foi possível a determinação da moda, efetuou-se as simulações usando-se a média.

Previamente, utilizou-se o teste de aderência de Kolmogorov-Smirnov para verificar o ajuste desses dados à função de distribuição de probabilidades triangular. Considerou-se na análise os preços mensais de venda praticados por ocasião da colheita do feijão caupi e melancia, pois foram simuladas diferentes épocas de semeadura ao longo do ano. Na estimativa do custo da energia elétrica com irrigação, quando necessário, simulou-se ao longo do ciclo, o preço médio mensal da tarifa de consumo no período coberto pelas diversas épocas de semeadura.

\subsection{Análise econômica sob condição de risco}

Para a análise da viabilidade econômica das culturas de feijão caupi e melancia sob irrigação, considerou-se o risco climático e econômico. Estes riscos foram incluídos em função das estimativas probabilísticas dos valores de lâmina bruta de irrigação (suplementar ou total), produtividade real da cultura, preço de venda dos produtos e custo da energia elétrica.

Com as estimativas de produtividade real, obtidas durante o período chuvoso sem o uso de irrigação, e do preço de venda dos produtos, estimou-se a rentabilidade econômica das culturas sob condição de sequeiro, de forma a constatar-se a viabilidade econômica da irrigação suplementar dessas culturas. No caso de ser viável, definiu-se ainda o nível de manejo de irrigação suplementar mais econômico em função da época de semeadura adotada nas duas microrregiões.

Neste estudo, os niveis de riscos analisados $(5,10,15,20,25,30,35$ e $40 \%)$ constituíram o complemento percentual para se atingir uma condição de certeza (100 \%) em relação aos valores de probabilidade de ocorrência $(95,90,85,80,75,70,65$ e 60 \%) utilizados na estimativa das variáveis acima citadas. Para tanto, utilizou-se a inversa das funções de distribuição de probabilidade normal e triangular (Frizzone \& Silveira, 2000). 
Tendo em vista as diferentes combinações entre culturas, microrregiões, épocas de semeadura e nível de manejo de irrigação associados a uma determinada probabilidade ou nível de risco, os possíveis valores de receita líquida foram quantificados através da seguinte equação adaptada de Franke (1996):

$$
\begin{array}{ll}
\mathrm{RL}_{\mathrm{ijklr}}=\mathrm{RB}_{\mathrm{ijklr}}-\mathrm{CF}_{\mathrm{i}}-\mathrm{CE}_{\mathrm{ijklr}}-\mathrm{CAE} & \text { (com irrigação) } \\
\mathrm{RL}_{\mathrm{ijkr}}=\mathrm{RB}_{\mathrm{ijkr}}-\mathrm{CF}_{\mathrm{i}} & \text { (sem irrigação) }
\end{array}
$$

sendo que:

$$
\begin{array}{ll}
\mathrm{RB}_{\mathrm{ijklr}}=\mathrm{Yr}_{\mathrm{ijklr}} \cdot \mathrm{P}_{1 \mathrm{r}} & \text { (com irrigação) } \\
\mathrm{RB}_{\mathrm{ijkr}}=\mathrm{Yr}_{\mathrm{ijkr}} \cdot \mathrm{P}_{\mathrm{ir}} & \text { (sem irrigação) } \\
\mathrm{CAE}=\mathrm{C} \cdot \mathrm{J} & \\
\mathrm{J}=\frac{\mathrm{j}(1+\mathrm{j})^{\mathrm{n}}}{(1+\mathrm{j})^{\mathrm{n}}-1} &
\end{array}
$$

em que:

$R L_{\mathrm{ijkl}}$ - receita líquida auferida pela cultura $i$, na microrregião $j$, na época de semeadura $k$, com manejo de irrigação l e nível de risco $r$, US $\$ h^{-1}(r=5 \%, 10 \%, \ldots$, $40 \%$;

$R L_{i j k r}$ - receita líquida auferida pela cultura $i$, na microrregião $j$, na época de semeadura $\mathrm{k}$ e com nível de risco $\mathrm{r}$, US $\$ \mathrm{ha}^{-1}$;

$R B_{i j k l r}$ - receita bruta auferida pela cultura $i$, na microrregião $j$, na época de semeadura $k$, com manejo de irrigação le nível de risco r, US\$ ha ${ }^{-1}$;

$\mathrm{RB}_{\mathrm{ijkr}}$ - receita bruta auferida pela cultura $\mathrm{i}$, na microrregião $\mathrm{j}$, na época de semeadura $\mathrm{k}$ e com nível de risco $r$, US $\$ \mathrm{ha}^{-1}$;

$\mathrm{P}_{\text {ir }}$ - preço mensal de venda da cultura i com o nível de risco $\mathrm{r}\left(\mathrm{US} \$ \mathrm{~kg}^{-1}\right.$ );

$\mathrm{CF}_{\mathrm{i}}$ - custo de formação da lavoura para a cultura i, US\$ $\mathrm{ha}^{-1}$; 
$\mathrm{CE}_{\mathrm{ijklr}}$ - custo de energia elétrica na cultura $i$, na microrregião $j$, na época de semeadura $\mathrm{k}$, com manejo de irrigação le nível de risco r, US $\$ \mathrm{ha}^{-1}$;

$\mathrm{Yr}_{\mathrm{ijk} k \mathrm{r}}$ - produtividade real da cultura $\mathrm{i}$, na microrregião $\mathrm{j}$, na época de semeadura $\mathrm{k}$, com manejo de irrigação $\mathrm{l}$ e nível de risco $\mathrm{r}, \mathrm{kg} \mathrm{ha}^{-1}$;

$\mathrm{Yr}_{\mathrm{ijkr}}$ - produtividade real da cultura $\mathrm{i}$, na microrregião $\mathrm{j}$, na época de semeadura $\mathrm{k}$ e com nivel de risco $\mathrm{r}, \mathrm{kg} \mathrm{ha}^{-1}$;

CAE - custo anual de amortização do equipamento, US\$ ha ${ }^{-1}$;

C - valor de aquisição do equipamento (2230,0 US\$ ha $\left.{ }^{-1}\right)$;

$\mathrm{J}$ - fator de recuperação de capital, adimensional;

$\mathrm{j}$ - taxa anual de juros, decimal $(0,12)$;

$\mathrm{n}$ - período ou número de anos do empréstimo (10 anos);

Os custos de produção ${ }^{11}$ ou de formação da lavoura das culturas de feijão caupi e melancia, sem considerar os custos da aplicação da lâmina de irrigação, foram de US\$ 322,91 ha ${ }^{-1}$ (Cardoso et al., 1995) e US\$672,43 ha ${ }^{-1}$ (Andrade Júnior et al., 1998c), respectivamente. Estes custos foram obtidos em condições normais de cultivo nas duas microrregiões e empregando-se as cultivares, densidade de plantio, correção e adubação do solo, controle fitossanitário e demais tratos culturais recomendados por trabalhos de pesquisa locais (Cardoso et al., 1991; Cardoso et al., 1995; Andrade Júnior et al., 1998d).

Não considerou-se os custos de mão-de-obra, comercialização, conservação, reparos e manutenção, pois estes geralmente apresentam pequena participação no custo total da lavoura irrigada. No caso da cultura do milho irrigado por aspersão com pivô central, considerando-se todas as combinações entre épocas de semeadura, nível de manejo da irrigação e nível de risco avaliadas, representaram apenas de 2,5 a 3,5 \%, 5,5 a $8,8 \%$ e 0,5 a $0,7 \%$ do custo total da lavoura irrigada, respectivamente (Franke, 1996).

\footnotetext{
${ }^{11}$ Valores convertidos pela taxa de 1 US $\$=R \$ 1,85$
} 


\subsection{Relação benefício/custo}

Para avaliar a viabilidade econômica da irrigação das culturas de feijão caupi e melancia com base nos benefícios de sua adoção e nos investimentos e custos de sua implementação, utilizou-se o critério da relação beneficio/custo $(B / C)$. Este critério foi quantificado utilizando-se as equações (85) e (86) e considerando as combinações entre cultura, microrregião, época de semeadura, nível de manejo da irrigação e nível de risco associado à tomada de decisão:

$$
\begin{array}{ll}
\mathrm{B} / \mathrm{C}_{\mathrm{ijklr}}=\frac{\mathrm{RB}_{\mathrm{ijk} k \mathrm{l}}}{\mathrm{CF}_{\mathrm{i}}+\mathrm{CE}_{\mathrm{ijklr}}+\mathrm{CAE}} & \text { (com irrigação) } \\
\mathrm{B} / \mathrm{C}_{\mathrm{ijk} k \mathrm{r}}=\frac{\mathrm{RB}_{\mathrm{ijkr}}}{\mathrm{CF}_{\mathrm{i}}} & \text { (sem irrigação) }
\end{array}
$$

em que:

$\mathrm{B} / \mathrm{C}_{\mathrm{ijklr}}$ - relação benefício/custo da cultura $\mathrm{i}$, na microrregião $\mathrm{j}$, na época de semeadura $k$, com manejo de irrigação l e nível de risco $r$;

$\mathrm{B} / \mathrm{C}_{\mathrm{ijkr}}$ - relação beneficio/custo da cultura $\mathrm{i}$, na microrregião $\mathrm{j}$, na época de semeadura $\mathrm{k}$ e com nível de risco $\mathrm{r}$.

Todos os procedimentos de cálculo da evapotranspiração de referência, estimativa dos parâmetros das funções de distribuição de probabilidades, teste de aderência, simulação da precipitação pluviométrica e evapotranspiração de referência, balanço hídrico diário e análise econômica sob risco foram processados em planilha eletrônica.

Deve-se destacar que todas as considerações quanto à viabilidade econômica da irrigação das culturas de feijão caupi e melancia nas condições edafoclimáticas das microrregiões do Litoral Piauiense e de Teresina, foram efetuadas com base nas estimativas de produtividade, lâmina bruta de irrigação, preços de venda dos produtos e das tarifas de energia elétrica, cuja interação culminou com a indicação de estratégias de 
manejo econômico da irrigação em função do nivel de risco assumido. Portanto, dada a sua complexidade e para que isso fosse possivel, admitiu-se que os fatores agronômicos, econômicos e financeiros envolvidos no processo estavam em níveis ótimos.

Além disso, por se tratar de um estudo na área de planejamento de irrigação, é óbvio que as estratégias de viabilidade econômica da irrigação das culturas representam estimativas aproximadas e estão sujeitas às oscilações, principalmente, climáticas, econômicas e de mercado, devendo constituir-se em uma ferramenta auxiliar no processo de.tomada de decisão. 


\section{RESULTADOS E DISCUSSÃO}

\subsection{Teste de aderência}

As Tabelas 4 a 7 apresentam os resultados relativos ao ajuste dos dados diários de precipitação pluviométrica à função de distribuição gama e dos valores diários de evapotranspiração de referência às funções de distribuição de probabilidades normal, beta e triangular utilizando o teste de aderência de Kolmogorov-Smirnov ao nível de 5\% de significância, conforme metodologia apresentada por Campos (1979).

Quanto à precipitação pluviométrica, observou-se um melhor grau de ajuste dos dados à função de distribuição gama em Parnaíba do que em Teresina, devido ter apresentado uma melhor homogeneidade dos valores diários de precipitação pluviométrica. Em Parnaiba, não foi possivel a determinação do ajuste para as épocas de semeadura de 1-Ago, 15-Ago e 1-Set, na estação seca, uma vez que os conjuntos de dados apresentaram somente valores de precipitação pluviométrica igual a zero, não possibilitando o cálculo dos parâmetros $\gamma$ e $\beta$. Em Teresina, contrariamente ao que era esperado, não ocorreu ajuste dos dados à função de distribuição gama no período compreendido pela estação chuvosa (dezembro a março) (Tabela 4), provavelmente, devido a uma maior dispersão dos valores de precipitação pluviométrica nessa época do ano, aliado ao rigor estatístico do teste de Kolmogorov-Smirnov, que rejeita a hipótese dos dados seguirem uma determinada função de distribuição, quando pelo menos um dos valores de precipitação apresentar desvio superior ao tabelado. 
Tabela 4. Ajuste dos dados diários de precipitação pluviométrica à função de distribuição gama, pelo teste de Kolmogorov-Smirnov, em cada época de semeadura nos municípios de Parnaiba e Teresina, Piauí.

\begin{tabular}{|c|c|c|c|c|c|c|}
\hline \multirow{2}{*}{$\begin{array}{l}\text { Época de } \\
\text { Semeadura }\end{array}$} & \multicolumn{3}{|c|}{ Parnaiba } & \multicolumn{3}{|c|}{ Teresina } \\
\hline & $\operatorname{Dmax}^{1}$ & Dtab & Ajuste & Dmax & Dtab & Ajuste \\
\hline $1-\operatorname{Jan}$ & 0,0958 & 0,1039 & Sim & 0,0743 & 0,0598 & Não \\
\hline $15-$ Jan & 0,0952 & 0,0955 & Sim & 0,0829 & 0,0570 & Não \\
\hline $1-\mathrm{Fev}$ & 0,0851 & 0,0905 & Sim & 0,0764 & 0,0540 & Não \\
\hline $15-\mathrm{Fev}$ & 0,0797 & 0,0856 & Sim & 0,0810 & 0,0544 & Não \\
\hline 1 - Mar & 0,0637 & $0,087.5$ & Sim & 0,0830 & 0,0550 & Não \\
\hline 15 - Mar & 0,0783 & 0,0903 & Sim & 0,0748 & 0,0587 & Não \\
\hline $1-\mathrm{Abr}$ & 0,0821 & 0,1030 & Sim & 0,0810 & 0,0682 & Não \\
\hline $15-\mathrm{Abr}$ & 0,0792 & 0,1138 & Sim & 0,0889 & 0,0807 & Não \\
\hline 1 - Mai & 0,1212 & 0,1370 & Sim & 0,0821 & 0,0994 & Sim \\
\hline 15 - Mai & 0,1170 & 0,1590 & Sim & 0,1010 & 0,1312 & Sim \\
\hline 1 - Jun & 0,1291 & 0,1940 & Sim & $0,11.56$ & 0,1700 & Sim \\
\hline 15 - Jun & 0,1663 & 0,2240 & Sim & 0,1022 & 0,2210 & Sim \\
\hline 1 - Jul & 0,1553 & 0,2610 & Sim & 0,1216 & 0,2690 & Sim \\
\hline 15 - Jul & 0,1128 & 0,3610 & Sim & 0,2822 & 0,3610 & Sim \\
\hline 1 - Ago & - & - & - & 0,1935 & 0,3010 & Sim \\
\hline 15 - Ago & - & - & - & 0,1823 & 0,2540 & Sim \\
\hline 1 - Set & - & - & - & 0,1358 & 0,2030 & Sim \\
\hline $15-$ Set & 0,2596 & 0,5630 & Sim & 0,1111 & 0,1850 & Sim \\
\hline 1 - Out & 0,2848 & 0,5190 & Sim & 0,1204 & 0,1660 & Sim \\
\hline 15 - Out & 0,2014 & 0,4300 & Sim & 0,1060 & 0,1370 & Sim \\
\hline 1 - Nov & 0,2145 & 0,2210 & Sim & 0,1222 & 0,1018 & Não \\
\hline 15 - Nov & 0,1659 & 0,1660 & Sim & 0,1081 & 0,0838 & Não \\
\hline $1-$ Dez & 0,1380 & 0,1390 & Sim & 0,1143 & 0,0738 & Não \\
\hline 15 - Dez & 0,1138 & 0,1166 & Sim & 0,0850 & 0,0652 & Não \\
\hline
\end{tabular}

${ }^{1}$ Dmax - desvio máximo e Dtab - desvio tabelado (nível de $5 \%$ de probabilidade). 
Tabela 5. Ajuste dos dados de evapotranspiração de referência à função de distribuição normal, pelo teste de Kolmogorov-Smirnov, em cada época de semeadura nos municipios de Parnaiba e Teresina, Piaui.

\begin{tabular}{|c|c|c|c|c|c|c|}
\hline \multirow{2}{*}{$\begin{array}{l}\text { Época de } \\
\text { Semeadura }\end{array}$} & \multicolumn{3}{|c|}{ Parnaiba $^{1}$} & \multicolumn{3}{|c|}{ Teresina $^{\mathrm{I}}$} \\
\hline & $\operatorname{Dmax}^{2}$ & Dtab & Ajuste & Dmax & Dtab & Ajuste \\
\hline $1-$ Jan & 0,0563 & 0,1220 & Sim & 0,0459 & 0,0945 & Sim \\
\hline 15 - Jan & 0,0571 & 0,1220 & Sim & 0,0614 & 0,0945 & Sim \\
\hline $1-\mathrm{Fev}$ & 0,0662 & 0,1220 & Sim & 0,0707 & 0,0945 & Sim \\
\hline $15-\mathrm{Fev}$ & 0,0837 & 0,1220 & Sim & 0,0440 & 0,0945 & Sim \\
\hline 1 - Mar & 0,0689 & 0,1220 & Sim & 0,0602 & 0,0945 & Sim \\
\hline 15 - Mar & 0,0820 & 0,1220 & Sim & 0,0495 & 0,0945 & Sim \\
\hline $1-\mathrm{Abr}$ & 0,0532 & 0,1220 & Sim & 0,0388 & 0,0945 & Sim \\
\hline $15-\mathrm{Abr}$ & 0,0550 & 0,1220 & Sim & 0,0481 & 0,0945 & Sim \\
\hline 1 - Mai & 0,0501 & 0,1220 & Sim & 0,0494 & 0,0945 & Sim \\
\hline 15 - Mai & 0,0536 & 0,1220 & Sim & 0,0793 & 0,0945 & Sim \\
\hline 1 - Jun & 0,0317 & 0,1220 & Sim & 0,0550 & 0,0945 & Sim \\
\hline 15 - Jun & 0,0561 & 0,1220 & Sim & 0,0694 & 0,0945 & Sim \\
\hline $1-\mathrm{Jul}$ & 0,0505 & 0,1220 & Sim & 0,0503 & 0,0945 & Sim \\
\hline $15-\mathrm{Jul}$ & 0,0373 & 0,1220 & Sim & 0,0399 & 0,0945 & Sim \\
\hline 1 - Ago & 0,0412 & 0,1220 & Sim & 0,0457 & 0,0945 & Sim \\
\hline 15 - Ago & 0,0462 & 0,1220 & Sim & 0,0453 & 0,0945 & Sim \\
\hline $1-$ Set & 0,0478 & 0,1220 & Sim & 0,0582 & 0,0945 & Sim \\
\hline $15-$ Set & 0,0479 & 0,1220 & Sim & 0,0573 & 0,0945 & Sim \\
\hline 1 - Out & 0,0407 & 0,1220 & Sim & 0,0465 & 0,0945 & Sim \\
\hline 15 - Out & 0,0682 & 0,1220 & Sim & 0,0599 & 0,0945 & Sim \\
\hline 1 - Nov & 0,1169 & 0,1220 & Sim & 0,0648 & 0,0945 & Sim \\
\hline 15 - Nov & 0,0953 & 0,1220 & Sim & 0,0612 & 0,0945 & Sim \\
\hline $1-$ Dez & 0,0590 & 0,1220 & Sim & 0,0736 & 0,0945 & Sim \\
\hline $15-$ Dez & 0,0778 & 0,1220 & Sim & 0,0573 & 0,0945 & Sim \\
\hline
\end{tabular}

${ }^{1}$ Valores de ETo acumulados em períodos de cinco dias; ${ }^{2}$ Dmax - desvio máximo e Dtab desvio tabelado (nível de $5 \%$ de probabilidade). 
Tabela 6. Ajuste dos dados de evapotranspiração de referência à função de distribuição beta, pelo teste de Kolmogorov-Smirnov, em cada época de semeadura nos municípios de Parnaiba e Teresina, Piauí.

\begin{tabular}{|c|c|c|c|c|c|c|}
\hline \multirow{2}{*}{$\begin{array}{l}\text { Época de } \\
\text { Semeadura }\end{array}$} & \multicolumn{3}{|c|}{ Pamaiba ${ }^{1}$} & \multicolumn{3}{|c|}{ Teresina $^{1}$} \\
\hline & $\operatorname{Dmax}^{2}$ & Dtab & Ajuste & Dmax & Dtab & Ajuste \\
\hline $1-$ Jan & 0,0391 & 0,1220 & Sim & 0,0411 & 0,0945 & Sim \\
\hline $15-\mathrm{Jan}$ & 0,0427 & 0,1220 & Sim & 0,0419 & 0,0945 & Sim \\
\hline $1-\mathrm{Fev}$ & 0,0332 & 0,1220 & Sim & 0,0491 & 0,0945 & Sim \\
\hline $15-\mathrm{Fev}$ & 0,0377 & 0,1220 & Sim & 0,0401 & 0,0945 & Sim \\
\hline 1 - Mar & 0,0369 & 0,1220 & Sim & 0,0427 & 0,0945 & Sim \\
\hline $15-\mathrm{Mar}$ & 0,0421 & 0,1220 & Sim & 0,0591 & 0,0945 & Sim \\
\hline $1-\mathrm{Abr}$ & 0,0617 & 0,1220 & Sim & 0,0575 & 0,0945 & Sim \\
\hline $15-\mathrm{Abr}$ & 0,0670 & 0,1220 & Sim & 0,0605 & 0,0945 & Sim \\
\hline 1 - Mai & 0,0583 & 0,1220 & Sim & 0,0654 & 0,0945 & Sim \\
\hline 15 - Mai & 0,0656 & 0,1220 & Sim & 0,0746 & 0,0945 & Sim \\
\hline 1 - Jun & 0,0500 & 0,1220 & Sim & 0,0370 & 0,0945 & Sim \\
\hline 15 - Jun & 0,0510 & 0,1220 & Sim & 0,0575 & 0,0945 & Sim \\
\hline 1 - Jul & 0,0528 & 0,1220 & Sim & 0,0404 & 0,0945 & Sim \\
\hline 15 - Jul & 0,0447 & 0,1220 & Sim & 0,0324 & 0,0945 & Sim \\
\hline 1 - Ago & 0,0601 & 0,1220 & Sim & 0,0554 & 0,0945 & Sim \\
\hline $15-$ Ago & 0,0721 & 0,1220 & Sim & 0,0627 & 0,0945 & Sim \\
\hline $1-$ Set & 0,0693 & 0,1220 & Sim & 0,0631 & 0,0945 & Sim \\
\hline $15-$ Set & 0,0804 & 0,1220 & Sim & 0,0736 & 0,0945 & Sim \\
\hline $1-$ Out & 0,0603 & 0,1220 & Sim & 0,0521 & 0,0945 & Sim \\
\hline 15 - Out & 0,0509 & 0,1220 & Sim & 0,0763 & 0,0945 & Sim \\
\hline 1 - Nov & 0,0936 & 0,1220 & Sim & 0,0591 & 0,0945 & Sim \\
\hline 15 - Nov & 0,0894 & 0,1220 & Sim & 0,0444 & 0,0945 & Sim \\
\hline $1-$ Dez & 0,0491 & 0,1220 & Sim & 0,0536 & 0,0945 & Sim \\
\hline $15-\mathrm{Dez}$ & 0,0516 & 0,1220 & Sim & 0,0477 & 0,0945 & Sim \\
\hline
\end{tabular}

${ }^{1}$ Valores de ETo acumulados em períodos de cinco dias; ${ }^{2}$ Dmax - desvio máximo e Dtab desvio tabelado (nível de $5 \%$ de probabilidade). 
Tabela 7. Ajuste dos dados de evapotranspiração de referência à função de distribuição triangular, pelo teste de Kolmogorov-Smirnov, em cada época de semeadura nos municípios de Parnaiba e Teresina, Piauí.

\begin{tabular}{|c|c|c|c|c|c|c|}
\hline \multirow{2}{*}{$\begin{array}{l}\text { Época de } \\
\text { Semeadura }\end{array}$} & \multicolumn{3}{|c|}{ Parnaibal } & \multicolumn{3}{|c|}{ Teresina $^{1}$} \\
\hline & $\operatorname{Dmax}^{2}$ & Dtab & Ajuste & Dmax & Dtab & Ajuste \\
\hline $1-\operatorname{Jan}$ & 0,1909 & 0,1220 & Não & 0,0949 & 0,0945 & Não \\
\hline 15 - Jan & 0,2224 & 0,1220 & Não & 0,1694 & 0,0945 & Não \\
\hline $1-\mathrm{Fev}$ & 0,1257 & 0,1220 & Não & 0,0914 & 0,0945 & Sim \\
\hline $15-\mathrm{Fev}$ & 0,1648 & 0,1220 & Não & 0,1328 & 0,0945 & Não \\
\hline 1 - Mar & 0,0562 & 0,1220 & Sim & 0,2721 & 0,0945 & Não \\
\hline 15 - Mar & 0,1177 & 0,1220 & Sim & 0,0917 & 0,0945 & Sim \\
\hline $1-\mathrm{Abr}$ & 0,3414 & 0,1220 & Não & 0,2093 & 0,0945 & Não \\
\hline $15-\mathrm{Abr}$ & 0,1953 & 0,1220 & Não & 0,1283 & 0,0945 & Não \\
\hline 1 - Mai & 0,1866 & 0,1220 & Não & 0,2525 & 0,0945 & Não \\
\hline 15 - Mai & 0,0676 & 0,1220 & Sim & 0,2063 & 0,0945 & Não \\
\hline $1-$ Jun & 0,1220 & 0,1220 & Sim & 0,1529 & 0,0945 & Não \\
\hline 15 - Jun & 0,2407 & 0,1220 & Não & 0,0704 & 0,0945 & Sim \\
\hline $1-\mathrm{Jul}$ & 0,1143 & 0,1220 & Sim & 0,1127 & 0,0945 & Não \\
\hline $15-\mathrm{Jul}$ & 0,1069 & 0,1220 & Sim & 0,0576 & 0,0945 & Sim \\
\hline 1 - Ago & 0,2095 & 0,1220 & Não & 0,1580 & 0,0945 & Não \\
\hline $15-$ Ago & 0,1017 & 0,1220 & Sim & 0,1782 & 0,0945 & Não \\
\hline 1 - Set & 0,0744 & 0,1220 & $\operatorname{Sim}$ & 0,2058 & 0,0945 & Não \\
\hline $15-$ Set & 0,1218 & 0,1220 & Sim & 0,2060 & 0,0945 & Não \\
\hline $1-$ Out & 0,1673 & 0,1220 & Não & 0,0827 & 0,0945 & Sim \\
\hline 15 - Out & 0,2648 & 0,1220 & Não & 0,2169 & 0,0945 & Não \\
\hline $1-$ Nov & 0,1303 & 0,1220 & Não & 0,1545 & 0,0945 & Não \\
\hline 15 - Nov & 0,1161 & 0,1220 & Sim & 0,1800 & 0,0945 & Não \\
\hline 1 - Dez & 0,1805 & 0,1220 & Não & 0,0912 & 0,0945 & Sim \\
\hline $15-$ Dez & 0,1258 & 0,1220 & Não & 0,1317 & 0,0945 & Não \\
\hline
\end{tabular}

${ }^{1}$ Valores de ETo acumulados em períodos de cinco dias; ${ }^{2}$ Dmax - desvio máximo e Dtab desvio tabelado (nível de $5 \%$ de probabilidade). 
Os resultados indicam que, em Parnaiba, à exceção das épocas de semeadura de 1-Ago, 15-Ago e 1-Set, a função de distribuição gama é adequada para representar os valores de precipitação pluviométrica diária ocorridos nos períodos analisados. Em Teresina, essa adequação ocorreu apenas no periodo compreendido pelas épocas de semeadura de 1-Mai a 15-Out. Resultado semelhante foi observado por Vivaldi (1973) e Assis (1991), os quais assumiram que a função de distribuição de probabilidade gama é adequada para modelar a precipitação pluviométrica em base diária em diversos períodos do ano nos municípios de Itaguaí (RJ), Pelotas (RS) e Piracicaba (SP).

No que diz respeito à evapotranspiração de referência, as Tabelas 5 a 7 mostram que as funções de distribuição normal e beta apresentaram ajuste aos dados observados em um maior número de épocas de semeadura do que a função de distribuição triangular. Em Parnaiba, na escala diária, ocorreu ajuste dos valores de evapotranspiração de referência à função de distribuição normal em poucas épocas de semeadura. Não houve ajuste dos dados diários de evapotranspiração de referência às funções de distribuição beta e triangular.

Da mesma forma, em Teresina, não foi observado ajuste da evapotranspiração de referência na escala diária a nenhuma das três funções de distribuição avaliadas. Por essa razão, nos dois locais, procedeu-se à verificação do ajuste utilizando-se os valores de evapotranspiração de referência em períodos acumulados de cinco dias, conforme especificado nas Tabelas 5 a 7 .

Com essa modificação, verificou-se o ajuste dos dados de evapotranspiração de referência às funções de distribuição normal e beta, para todas as épocas de semeadura, concordando com os resultados obtidos por Saad (1990) e Silva et al., (1998), que consideraram essas funções de distribuição aptas para representar a evapotranspiração de referência para períodos acumulados de diferentes durações (5 a 30 dias) em Piracicaba (SP) e Cruz das Almas (BA), respectivamente

É importante destacar que, em Parnaiba, houve ajuste até mesmo na escala diária, porém, somente em algumas épocas de semeadura. Apesar de ter-se observado ajuste dos valores de evapotranspiração às funções de distribuição de probabilidade normal e beta, optou-se por utilizar-se a função de distribuição normal, devido à sua maior 
facilidade de uso e aplicabilidade (Silva et al., 1998). Estratégia semelhante foi adotada por Saad (1990), que sugere o uso da função de distribuição beta apenas quando não houver ajuste da função de distribuição normal.

Nos dois locais, não foi constatado ajuste dos valores de evapotranspiração de referência na escala diária à função de distribuição de probabilidade triangular. Contudo, ao acumular-se os valores de evapotranspiração de referência em períodos de cinco dias, verificou-se ajuste a essa função de distribuição em algumas épocas de semeadura. Esse comportamento concorda, em parte, com os resultados alcançados por Sousa \& Frizzone (1998b) e Sousa (1999), que recomendam o uso da função de distribuição triangular como uma alternativa para a simulação de valores de evapotranspiração de referência na escala mensal. Provavelmente, há uma melhor aderência dos dados de evapotranspiração de referência a função de distribuição triangular à medida que os valores são acumulados em escalas maiores de tempo, como a mensal, por exemplo.

Tanto no caso da estimativa da precipitação pluviométrica como da evapotranspiração de referência diárias, utilizou-se a função de distribuição empirica nas épocas de semeadura que não apresentaram ajuste a nenhuma das funções de distribuição teóricas. Considerando-se esse fato, é apresentado um resumo das funções de distribuição adotadas em cada época de semeadura (Tabela 8).

\subsection{Simulação da precipitação pluviométrica}

$\mathrm{Na}$ modelagem da ocorrência da precipitação pluviométrica, as probabilidades condicionais da matriz de transição $\mathrm{P}(\mathrm{C} \mid \mathrm{S})$ e $\mathrm{P}(\mathrm{C} \mid \mathrm{C})$ variaram em função do periodo analisado desde 0,143 a 0,487 (estação chuvosa) e em torno de 0,000 a 0,066 (estação seca) (Parnaiba) e de 0,235 a 0,549 (estação chuvosa) e em torno de 0,006 a 0,101 (estação seca) (Teresina), respectivamente (Tabela 9). Esses valores evidenciam a tendência natural de maiores probabilidades de ocorrência de dias chuvosos durante a estação chuvosa e dias secos na estação seca. 
Tabela 8. Resumo das funções de distribuição adotadas para a estimativa da precipitação pluviométrica diária (P) e evapotranspiração de referência diária (ETo) em cada época de semeadura nos municípios de Parnaiba e Teresina, Piauí.

\begin{tabular}{|c|c|c|c|c|}
\hline \multirow{2}{*}{$\begin{array}{l}\text { Época de } \\
\text { Semeadura }\end{array}$} & \multicolumn{2}{|c|}{ Parnaíba } & \multicolumn{2}{|c|}{ Teresina } \\
\hline & $\mathrm{P}$ & ETo $^{1}$ & $\mathrm{P}$ & ETo $^{1}$ \\
\hline $1-\operatorname{Jan}$ & Gama & Normal & Empírica & Normal \\
\hline $15-$ Jan & Gama & Normal & Empírica & Normal \\
\hline $1-\mathrm{Fev}$ & Gama & Normal & Empírica & Normal \\
\hline $15-\mathrm{Fev}$ & Gama & Normal & Empírica & Normal \\
\hline 1-Mar & Gama & Normal & Empírica & Normal \\
\hline $15-\mathrm{Mar}$ & Gama & Normal & Empírica & Normal \\
\hline $1-\mathrm{Abr}$ & Gama & Normal & Empírica & Normal \\
\hline $15-\mathrm{Abr}$ & Gama & Normal & Empírica & Normal \\
\hline 1 - Mai & Gama & Normal & Gama & Normal \\
\hline 15 - Mai & Gama & Normal & Gama & Normal \\
\hline $1-$ Jun & Gama & Normal & Gama & Normal \\
\hline 15 - Jun & Gama & Normal & Gama & Normal \\
\hline $1-\mathrm{Jul}$ & Gama & Normal & Gama & Normal \\
\hline $15-\mathrm{Jul}$ & Gama & Normal & Gama & Normal \\
\hline $1-$ Ago & Empírica & Normal & Gama & Normal \\
\hline 15 - Ago & Empírica & Normal & Gama & Normal \\
\hline $1-$ Set & Empírica & Normal & Gama & Normal \\
\hline $15-$ Set & Gama & Normal & Gama & Normal \\
\hline 1 - Out & Gama & Normal & Gama & Normal \\
\hline 15 - Out & Gama & Normal & Gama & Normal \\
\hline 1 - Nov & Gama & Normal & Empírica & Normal \\
\hline 15 - Nov & Gama & Normal & Empírica & Normal \\
\hline $1-$ Dez & Gama & Normal & Empírica & Normal \\
\hline $15-\mathrm{Dez}$ & Gama & Normal & Empírica & Normal \\
\hline
\end{tabular}

\footnotetext{
${ }^{1}$ Valores de ETo acumulados em períodos de cinco dias.
} 
Tabela 9. Probabilidades condicionais da cadeia de Markov $\mathrm{P}(\mathrm{C} \mid \mathrm{S})$ e $\mathrm{P}(\mathrm{C} \mid \mathrm{C})$ e parâmetros $\gamma$ e $\beta$ da distribuição gama em cada época de semeadura nos municípios de Parnaiba e Teresina, Piauí.

\begin{tabular}{|c|c|c|c|c|c|c|c|c|}
\hline \multirow{3}{*}{$\begin{array}{c}\text { Época } \\
\text { de } \\
\text { Semeadura }\end{array}$} & \multicolumn{4}{|c|}{ Pamaíba } & \multicolumn{4}{|c|}{ Teresina } \\
\hline & \multicolumn{2}{|c|}{ Markov } & \multicolumn{2}{|c|}{ Gama } & \multicolumn{2}{|c|}{ Markov } & \multicolumn{2}{|c|}{ Gama } \\
\hline & $\mathrm{P}(\mathrm{C} \mid \mathrm{S})$ & $\mathrm{P}(\mathrm{C} \mid \mathrm{C})$ & $\gamma$ & $\beta$ & $\mathrm{P}(\mathrm{C} \mid \mathrm{S})$ & $\mathrm{P}(\mathrm{C} \mid \mathrm{C})$ & $\gamma$ & $\beta$ \\
\hline $1-$ Jan & 0,190 & 0,436 & 1,768 & 10,539 & 0,281 & 0,469 & - & - \\
\hline $15-$ Jan & 0,223 & 0,467 & 1,744 & 10,892 & 0,315 & 0,502 & - & - \\
\hline $1-\mathrm{Fev}$ & 0,245 & 0,480 & 1,906 & 9,129 & 0,365 & 0,545 & - & - \\
\hline $15-\mathrm{Fev}$ & 0,292 & 0,487 & 1,808 & 10,131 & 0,377 & 0,549 & - & - \\
\hline 1 - Mar & 0,276 & 0,471 & 1,828 & 10,092 & 0,387 & 0,536 & - & - \\
\hline 15 - Mar & 0,255 & 0,450 & 1,772 & 10,543 & 0,315 & 0,521 & - & - \\
\hline $1-A b r$ & 0,194 & 0,394 & 1,809 & 10,877 & 0,214 & 0,484 & - & - \\
\hline $15-\mathrm{Abr}$ & 0,161 & 0,346 & 1,927 & 10,500 & 0,158 & 0,427 & $=$ & - \\
\hline 1 - Mai & 0,105 & 0,238 & 2,206 & 8,348 & 0,105 & 0,344 & 2,186 & 7,051 \\
\hline 15 - Mai & 0,089 & 0,136 & 2,422 & 6,578 & 0,066 & 0,229 & 2,333 & 5,874 \\
\hline 1 - Jun & 0,065 & 0,093 & 3,076 & 4,122 & 0,039 & 0,152 & 2,808 & 4,032 \\
\hline 15 - Jun & 0,047 & 0,097 & 2,963 & 3,979 & 0,024 & 0,103 & 2,679 & 4,690 \\
\hline $1-\mathrm{Jul}$ & 0,028 & 0,105 & 2,245 & 5,754 & 0,014 & 0,125 & 1,764 & 9,046 \\
\hline $15-\mathrm{Jul}$ & 0,018 & 0,154 & 4,569 & 1,928 & 0,006 & 0,125 & 1,251 & 14,433 \\
\hline 1 - Ago & 0,003 & 0,000 & - & - & 0,011 & 0,214 & 1,661 & 10,783 \\
\hline 15 - Ago & 0,002 & 0,000 & - & - & 0,017 & 0,150 & 1,670 & 10,541 \\
\hline 1 - Set & 0,002 & 0,000 & - & - & 0,031 & 0,114 & 1,694 & 12,273 \\
\hline 15 - Set & 0,006 & 0,200 & 3,363 & 3,236 & 0,035 & 0,103 & 2,060 & 9,833 \\
\hline 1 - Out & 0,008 & 0,167 & 1,813 & 8,954 & 0,040 & 0,152 & 1,588 & 14,952 \\
\hline 15 - Out & 0,011 & 0,125 & 2,293 & 7,468 & 0,055 & 0,200 & 1,572 & 16,913 \\
\hline 1 - Nov & 0,035 & 0,310 & 1,676 & 11,277 & 0,101 & 0,212 & - & - \\
\hline 15 - Nov & 0,066 & 0,346 & 1,474 & 14,204 & 0,139 & 0,288 & - & - \\
\hline $1-$ Dez & 0,097 & 0,354 & 1,449 & 14,380 & 0,184 & 0,292 & - & - \\
\hline 15 - Dez & 0,143 & 0,398 & 1,550 & 12,293 & 0,235 & 0,352 & - & - \\
\hline
\end{tabular}


Os parâmetros $\gamma$ e $\beta$ da distribuição gama também apresentaram variação em função do periodo analisado. Conforme ressaltado anteriormente, não foi possivel a determinação desses parâmetros nas épocas de semeadura iniciadas em 1-Ago, 15-Ago e 1-Set (Parnaiba). Contudo, sem comprometer a simulação da magnitude dos valores de precipitação pluviométrica, pois esses períodos são comprovadamente secos, com valores de $\mathrm{P}(\mathrm{C} \mid \mathrm{S})$ e $\mathrm{P}(\mathrm{C} \mid \mathrm{C})$ da ordem de 0,003 e 0,000, respectivamente (Tabela 9). Em Teresina, nas épocas de semeadura onde não houve ajuste dos dados à função de distribuição gama, obviamente não constam os valores dos parâmetros $\gamma$ e $\beta$.

A Tabela 10 apresenta os valores observados e simulados de número de dias secos $(\mathrm{N}(\mathrm{S}))$, número de dias chuvosos $(\mathrm{N}(\mathrm{C})$ ) e precipitação pluviométrica total $(\mathrm{P})$ em cada época de semeadura e os correspondentes índices de desempenho estatístico obtidos para Parnaiba e Teresina, Piauí.

Em termos médios, em ambos os locais, os valores simulados de $\mathrm{N}(\mathrm{S})$ e $\mathrm{N}(\mathrm{C})$ foram praticamente iguais aos valores observados Em Parnaiba, os valores de $\mathrm{P}$ foram menores nas séries de dados simulados em comparação com os valores observados. Contudo, em Teresina, a tendência média do modelo foi superestimar os valores de $\mathrm{P}$. No que diz respeito a N(C), Peiter et al. (1999) e Genneville \& Boock (1983) observaram uma boa concordância entre os yalores das séries de dados simulados e observados. Os valores totais de precipitação pluviométrica por época de semeadura em Teresina concordam plenamente com os resultados alcançados por Genneville \& Boock (1983) e Peiter et al. (1999), os quais obtiveram valores simulados superiores aos observados na série histórica.

Observou-se, em Teresina, que os coeficientes de variação (CV) de todas as variáveis analisadas tenderam a ser menores nas séries de dados simulados em comparação com os valores médios das séries históricas (Tabela 11), demonstrando que o modelo gerou séries de dados mais homogêneas. Comportamento semelhante foi constatado por Genneville \& Boock (1983) que também obtiveram menores valores de 
Tabela 10. Valores observados (O) e simulados (S) de número de dias secos $(\mathrm{N}(\mathrm{S})$ ), número de dias chuvosos $(\mathrm{N}(\mathrm{C}))$ e precipitação pluviométrica total $(\mathrm{P})$ em cada época de semeadura e os correspondentes índices de desempenho estatístico nos municípios de Parnaiba e Teresina, Piaui.

\begin{tabular}{|c|c|c|c|c|c|c|c|c|c|c|c|c|}
\hline \multirow{3}{*}{$\begin{array}{c}\text { Época } \\
\text { de } \\
\text { Semeadura }\end{array}$} & \multicolumn{6}{|c|}{ Parnaiba } & \multicolumn{6}{|c|}{ Teresina } \\
\hline & \multicolumn{2}{|c|}{$\mathrm{N}(\mathrm{S})$} & \multicolumn{2}{|c|}{$\mathrm{N}(\mathrm{C})$} & \multicolumn{2}{|c|}{$P(\mathrm{~mm})$} & \multicolumn{2}{|c|}{$\mathrm{N}(\mathrm{S})$} & \multicolumn{2}{|c|}{$\mathrm{N}(\mathrm{C})$} & \multicolumn{2}{|c|}{$P(\mathrm{~mm})$} \\
\hline & $\mathrm{O}$ & $\mathrm{S}$ & $\mathrm{O}$ & $\mathrm{S}$ & $\mathrm{O}$ & $S$ & $\mathrm{O}$ & $\mathrm{S}$ & $\mathrm{O}$ & $\mathrm{S}$ & $\mathrm{O}$ & $S$ \\
\hline $1-$ Jan & 54 & 52 & 16 & 18 & 279,1 & 323,7 & 47 & 47 & 23 & 24 & 533,9 & 481,3 \\
\hline $15-\mathrm{Jan}$ & 49 & 49 & 21 & 22 & 355,2 & 390,6 & 45 & 43 & 25 & 27 & 567,1 & 553,4 \\
\hline $1-\mathrm{Fev}$ & 43 & 48 & 27 & 22 & 427,0 & 376,1 & 45 & 38 & 25 & 32 & 543,4 & 642,3 \\
\hline $15-\mathrm{Fev}$ & 42 & 44 & 28 & 26 & 424,5 & 459,3 & 48 & 38 & 22 & 32 & 472,3 & 653,8 \\
\hline 1 - Mar & 42 & 46 & 28 & 24 & 419,0 & 440,0 & 49 & 39 & 21 & 31 & 406,9 & 643,8 \\
\hline 15 - Mar & 40 & 48 & 30 & 22 & 483,5 & 415,9 & 52 & 42 & 18 & 28 & 332,6 & 558,8 \\
\hline $1-\mathrm{Abr}$ & 46 & 53 & 24 & 17 & 396,4 & 337,2 & 57 & 49 & 13 & 21 & 212,4 & 391,4 \\
\hline $15-\mathrm{Abr}$ & 50 & 56 & 20 & 14 & 356,1 & 279,0 & 61 & 55 & 9 & 15 & 110,8 & 282,1 \\
\hline 1 - Mai & 52 & 62 & 18 & 8 & 298,7 & 149,2 & 64 & 60 & 6 & 10 & 66,2 & 152,8 \\
\hline 15 - Mai & 58 & 63 & 12 & 7 & 203,6 & 105,0 & 66 & 65 & 4 & 5 & 41,0 & 71,0 \\
\hline 1 - Jun & 65 & 66 & 5 & 4 & 77,4 & 57,4 & 68 & 67 & 2 & 3 & 23,4 & 33,4 \\
\hline 15 - Jun & 66 & 67 & 4 & 3 & 72,7 & 38,0 & 69 & 68 & 1 & 2 & 19,4 & 22,5 \\
\hline $1-\mathrm{Jul}$ & 67 & 68 & 3 & 2 & 68,0 & 27,3 & 69 & 69 & 1 & 1 & 19,3 & 18,5 \\
\hline 15 - Jul & 70 & 68 & 0 & 2 & 0,0 & 12,5 & 69 & 70 & 1 & 0 & 17,7 & 8,1 \\
\hline 1 - Ago & 70 & 70 & 0 & 0 & 0,0 & 0,0 & 69 & 69 & 1 & 1 & 11,0 & 14,3 \\
\hline 15 - Ago & 70 & 70 & 0 & 0 & 0,0 & 0,0 & 69 & 69 & 1 & 1 & 14,6 & 22,3 \\
\hline 1 - Set & 70 & 70 & 0 & 0 & 0,0 & 0,0 & 69 & 68 & 1 & 2 & 13,4 & 47,4 \\
\hline $15-$ Set & 70 & 69 & 0 & 1 & 0,0 & 3,6 & 68 & 67 & 2 & 3 & 23,0 & 53,9 \\
\hline $1-$ Out & 70 & 69 & 0 & 1 & 0,0 & 7,1 & 67 & 67 & 3 & 3 & 48,4 & 77,0 \\
\hline 15 - Out & 69 & 69 & 1 & 1 & 6,5 & 11,7 & 65 & 65 & 5 & 5 & 93,7 & 123,1 \\
\hline 1 - Nov & 64 & 67 & 6 & 3 & 90,3 & 66,0 & 61 & 62 & 9 & 8 & 171,5 & 215,4 \\
\hline 15 - Nov & 61 & 64 & 9 & 6 & 160,2 & 131,3 & 56 & 59 & 14 & 11 & 301,9 & 280,0 \\
\hline 1 - Dez & 59 & 61 & 11 & 9 & 170,4 & 177,5 & 52 & 55 & 18 & 15 & 403,9 & 352,7 \\
\hline $15-\mathrm{Dez}$ & 52 & 57 & 18 & 13 & 297,8 & 238,7 & 47 & 52 & 23 & 18 & 518,5 & 439,4 \\
\hline Média & 58 & 61 & 12 & 9 & 191,1 & 168,6 & 60 & 58 & 10 & 12 & 206,9 & 255,8 \\
\hline $\mathrm{r}$ & 0,9 & & & 648 & 0,9 & 627 & & & & 392 & & 9266 \\
\hline Id & 0,9 & & & 582 & 0,9 & 763 & & & & 479 & & 9465 \\
\hline $\mathrm{c}$ & 0,9 & & & 245 & 0,9 & 399 & & & & 006 & & 8777 \\
\hline
\end{tabular}


Tabela 11. Coeficientes de variação (\%) dos valores observados $(\mathrm{O})$ e simulados $(\mathrm{S})$ de número de dias secos $(\mathrm{N}(\mathrm{S}))$, número de dias cbuyosos $(\mathrm{N}(\mathrm{C}))$ e precipitação pluviométrica total $(\mathrm{P})$ em cada época de semeadura para os municípios de Parnaíba e Teresina, Piauí.

\begin{tabular}{|c|c|c|c|c|c|c|c|c|c|c|c|c|}
\hline \multirow{3}{*}{$\begin{array}{c}\text { Época } \\
\text { de } \\
\text { Semeadura }\end{array}$} & \multicolumn{6}{|c|}{ Pamaíba } & \multicolumn{6}{|c|}{ Teresina } \\
\hline & \multicolumn{2}{|c|}{$\mathrm{N}(\mathrm{S})$} & \multicolumn{2}{|c|}{$\mathrm{N}(\mathrm{C})$} & \multicolumn{2}{|c|}{$\mathrm{P}(\mathrm{mm})$} & \multicolumn{2}{|c|}{$\mathrm{N}(\mathrm{S})$} & \multicolumn{2}{|c|}{$\mathrm{N}(\mathrm{C})$} & \multicolumn{2}{|c|}{$\mathrm{P}(\mathrm{mm})$} \\
\hline & $\mathrm{O}$ & $\mathrm{S}$ & $\mathrm{O}$ & $\mathrm{S}$ & $\mathrm{O}$ & $\mathrm{S}$ & $\mathrm{O}$ & $\mathrm{S}$ & $\mathrm{O}$ & $\mathrm{S}$ & $\mathrm{O}$ & $\mathrm{S}$ \\
\hline 1 - Jan & - & 10 & - & 29 & - & 31 & 17 & 9 & 35 & 18 & 26 & 23 \\
\hline 15 - Jan & - & 11 & - & 24 & - & 27 & 14 & 11 & 26 & 18 & 16 & 24 \\
\hline $1-\mathrm{Fev}$ & - & 11 & - & 23 & - & 27 & 18 & 13 & 32 & 15 & 24 & 22 \\
\hline $15-\mathrm{Fev}$ & - & 11 & - & 19 & - & 23 & 16 & 14 & 34 & 17 & 29 & 21 \\
\hline 1 - Mar & - & 11 & - & 21 & - & 25 & 15 & 11 & 36 & 14 & 31 & 21 \\
\hline $15-\mathrm{Mar}$ & - & 11 & - & 23 & - & 27 & 14 & 12 & 41 & 18 & 40 & 24 \\
\hline $1-A b r$ & - & 8 & - & 26 & - & 32 & 15 & 11 & 65 & 24 & 71 & 29 \\
\hline $15-\mathrm{Abr}$ & - & 6 & - & 25 & - & 31 & 13 & 8 & 96 & 27 & 93 & 31 \\
\hline 1 - Mai & - & 5 & - & 40 & - & 46 & 11 & 7 & 117 & 42 & 115 & 47 \\
\hline 15 - Mai & - & 4 & $=$ & 38 & - & 48 & 7 & 4 & 133 & 52 & 126 & 58 \\
\hline 1 - Jun & - & 3 & - & 45 & - & 50 & 6 & 3 & 169 & 63 & 164 & 66 \\
\hline 15 - Jun & - & 3 & - & 55 & - & 59 & 3 & 2 & 155 & 74 & 162 & 78 \\
\hline 1 - Jul & - & 2 & - & 65 & - & 67 & 3 & 2 & 163 & 112 & 169 & 116 \\
\hline 15 - Jul & - & 2 & - & 98 & - & 97 & 2 & 1 & 142 & 174 & 165 & 218 \\
\hline 1 - Ago & - & 0 & - & - & - & - & 1 & 2 & 106 & 118 & 164 & 138 \\
\hline 15 - Ago & - & 0 & $=$ & - & - & - & 1 & 2 & 82 & 108 & 116 & 98 \\
\hline 1 - Set & - & 0 & - & - & - & - & 2 & 2 & 94 & 66 & 84 & 83 \\
\hline $15-$ Set & - & 1 & - & 183 & - & 185 & 2 & 3 & 85 & 67 & 99 & 71 \\
\hline 1 - Out & - & 1 & - & 138 & - & 155 & 4 & 3 & 97 & 63 & 85 & 68 \\
\hline 15 - Out & - & 1 & - & 126 & - & 135 & 5 & 3 & 67 & 49 & 79 & 65 \\
\hline 1 - Nov & - & 4 & - & 68 & - & 75 & 5 & 5 & 32 & 36 & 37 & 45 \\
\hline $15-\mathrm{Nov}$ & - & 5 & - & 49 & - & 54 & 9 & 6 & 38 & 32 & 49 & 34 \\
\hline $1-$ Dez & - & 6 & - & 41 & - & 43 & 12 & 7 & 34 & 27 & 39 & 32 \\
\hline $15-\mathrm{Dez}$ & - & 7 & - & 31 & - & 38 & 18 & 8 & 36 & 23 & 33 & 29 \\
\hline Média & - & 5 & - & 55 & - & 61 & 9 & 6 & 80 & 52 & 84 & 60 \\
\hline
\end{tabular}


$\mathrm{CV}$ nas médias mensais de precipitação simuladas em comparação com os valores médios observados na região de Campo Grande (MS). Obviamente, não foi possivel o cálculo do $\mathrm{CV}$ em Parnaiba, pois na fase de validação do modelo utilizou-se apenas os dados de precipitação de um ano (1990).

A amplitude de variação dos valores de CV para os valores observados de precipitação pluviométrica foi de $16 \%$ a $169 \%$, com os menores valores ocorrendo na estação chuvosa ( $16 \%$ a $93 \%$ ) e os maiores durante a estação seca (33\% a $169 \%$ ). Constatou-se tendência de aumento nos valores de CV nas épocas de semeadura na fase de transição entre a estação chuvosa e a seca. Saad (1990) analisando os totais mensais de chuva nos meses de março e setembro, em Piracicaba (SP), também observaram essa mesma tendência de variação de valores de $\mathrm{CV}$ entre os meses chuvosos (54\%) e secos (94\%). Os elevados valores de CV denotam um caráter de grande variabilidade e dispersão dos dados de precipitação pluviométrica, justificando a realização de estudos da freqüência de distribuição (Saad, 1990).

Apesar das variações ocorridas no $\mathrm{N}(\mathrm{S}), \mathrm{N}(\mathrm{C})$ e $\mathrm{P}$, isoladamente em cada período estudado, os valores médios simulados aproximaram-se bastante dos observados, evidenciando que o modelo proporcionou estimativas com razoável precisão e exatidão das variáveis relacionadas à ocorrência e magnitude da precipitação. Esse fato foi comprovado pelos bons resultados da análise de correlação (r) e índice de concordância de Willmott (Id) verificado para todas as variáveis geradas (Tabela 12). Segundo Genneville \& Boock (1983) este resultado é, em parte, próprio de modelos baseados em probabilidades.

Conforme o critério de interpretação do desempenho pelo índice "c" proposto por Camargo \& Sentelhas (1997), todas as variáveis avaliadas foram enquadradas na categoria de desempenho estatístico "ótimo" (c > 0,85). O modelo apresentou desempenho ligeiramente melhor no processo de geração da ocorrência e da magnitude da precipitação pluviométrica em Parnaiba $(c=0,9245$ e c $=0,9399)$ do que em Teresina $(\mathrm{c}=0,9006$ e $\mathrm{c}=0,8777)$. Esse resultado foi contrário ao que se pensava em termos de desempenho estatístico, uma vez que para Teresina utilizou-se uma maior série histórica de dados na estimativa dos parâmetros necessários ao modelo. Provavelmente, esse fato 
deve estar relacionado à menor variabilidade e ao melhor grau de ajuste dos dados diários de precipitação pluviométrica de Parnaiba à distribuição gama.

Constatou-se ainda, em ambos os municípios, que o número de simulações não afetou significativamente $(\mathrm{P}>0,05)$ os índices de desempenho estatistico relacionados às variáveis envolvidas nas fases de modelagem da ocorrência ( $\mathrm{N}(\mathrm{S})$ e $\mathrm{N}(\mathrm{C})$ ) e magnitude da precipitação pluviométrica diária (P). Para todas as variáveis simuladas, os índices de desempenho estatístico para o intervalo de 10 a 100 simulações não diferiram $(P<0,05)$ pelo teste de Tukey (Tabela 12). Segundo Sousa (1999), a não significância do número de simulações mostra a precisão do modelo utilizado, pois as simulações tendem a fornecer resultados semelhantes. Contudo, utilizou-se 100 simulações para a geração dos valores diários de precipitação pluviométrica em cada época de semeadura, de forma a permitir efetuar igual número de balanços hídricos diários.

Para ilustrar a boa performance do modelo de simulação, confeccionou-se as Figuras 9 e 10, as quais mostram a comparação entre as médias dos valores observados e simulados de precipitação pluviométrica total em épocas de semeadura específicas nas estações chuvosa e seca nos municípios de Parnaiba e Teresina Selecionou-se as épocas de semeadura de 15-Fev (chuvosa) e 15-Ago (seca), em Parnaiba e de 15-Jan (chuvosa) e l-Ago (seca), em Teresina.

$\mathrm{Na}$ estação seca, em ambos os municípios, não ocorreu variação muito significativa entre os valores observados e simulados de $\mathrm{N}(\mathrm{S}), \mathrm{N}(\mathrm{C})$ e $\mathrm{P}$. Contudo, na estação chuvosa, como era esperado, observou-se uma maior dispersão dos valores simulados em relação à média dos observados. A média dos valores simulados aproximou-se bastante à dos valores observados, notadamente, em Parnaiba.

Aprofundando a análise na estação chuvosa, elaborou-se as Figuras 11 e 12, onde são comparadas as médias dos valores diários observados e simulados de precipitação pluviométrica em épocas específicas de semeadura nos inunicípios de Parnaiba e Teresina, respectivamente. Nesse caso, foram selecionadas as épocas de semeadura de 
Tabela 12. Índices de desempenho estatístico em função do número de simulações usadas na modelagem dos parâmetros relacionados à ocorência (N(S) e $\mathrm{N}(\mathrm{C})$ ) e magnitude da precipitação pluviométrica (P) em Parnaíba e Teresina, Piauí.

\begin{tabular}{|c|c|c|c|c|c|c|c|c|c|}
\hline \multirow{2}{*}{$\begin{array}{c}\mathrm{N}^{\circ} \text { de } \\
\text { Simulações }\end{array}$} & \multicolumn{3}{|c|}{$r^{1}$} & \multicolumn{3}{|c|}{$\mathrm{Id}^{2}$} & \multicolumn{3}{|c|}{$c^{3}$} \\
\hline & $\mathrm{N}(\mathrm{S})$ & $\mathrm{N}(\mathrm{C})$ & $\mathrm{P}$ & $\mathrm{N}(\mathrm{S})$ & $\mathrm{N}(\mathrm{C})$ & $\mathrm{P}$ & $\mathrm{N}(\mathrm{S})$ & $\mathrm{N}(\mathrm{C})$ & $\mathrm{P}$ \\
\hline \multicolumn{10}{|c|}{ Parnaíba } \\
\hline 10 & 0,9594 & 0,9594 & 0,9576 & 0,9594 & 0,9594 & 0,9738 & 0,9204 & 0,9204 & 0,9325 \\
\hline 20 & 0,9673 & 0,9673 & 0,9640 & 0,9593 & 0,9593 & 0,9752 & 0,9279 & 0,9279 & 0,9401 \\
\hline 30 & 0,9681 & 0,9681 & 0,9646 & 0,9604 & 0,9604 & 0,9770 & 0,9298 & 0,9298 & 0,9424 \\
\hline 40 & 0,9663 & 0,9663 & 0,9653 & 0,9593 & 0,9593 & 0,9773 & 0,9270 & 0,9270 & 0,9434 \\
\hline 50 & 0,9663 & 0,9663 & 0,9657 & 0,9589 & 0,9589 & 0,9775 & 0,9266 & 0,9266 & 0,9440 \\
\hline 60 & 0,9643 & 0,9643 & 0,9634 & 0,9572 & 0,9572 & 0,9759 & 0,9230 & 0,9230 & 0,9402 \\
\hline 70 & 0,9646 & 0,9646 & 0,9639 & 0,9579 & 0,9579 & 0,9767 & $0,9.240$ & 0,9240 & 0,9414 \\
\hline 80 & 0,9643 & 0,9643 & 0,9633 & 0,9581 & 0,9581 & 0,9766 & 0,9239 & 0,9239 & 0,9408 \\
\hline 90 & 0,9657 & 0,9657 & 0,9644 & 0,9586 & 0,9586 & 0,9772 & 0,9257 & 0,9257 & 0,9424 \\
\hline 100 & 0,9648 & 0,9648 & 0,9627 & 0,9582 & 0,9582 & 0,9763 & 0,9245 & 0,9245 & 0,9399 \\
\hline \multicolumn{10}{|c|}{ Teresina } \\
\hline 10 & 0,9572 & 0,9572 & 0,9568 & 0,9562 & 0,9562 & 0,9550 & 0,9153 & 0,9153 & 0,9137 \\
\hline 20 & 0,9495 & 0,9495 & 0,9394 & 0,9520 & 0,9520 & 0,9453 & 0,9039 & 0,9039 & 0,8880 \\
\hline 30 & 0,9467 & 0,9467 & 0,9331 & 0,9522 & 0,9522 & 0,9439 & 0,9014 & 0,9014 & 0,8808 \\
\hline 40 & 0,9470 & 0,9470 & 0,9346 & 0,9531 & 0,9531 & 0,9452 & 0,9026 & 0,9026 & 0,8834 \\
\hline 50 & 0,9469 & 0,9469 & 0,9350 & 0,9530 & 0,9530 & 0,9448 & 0,9024 & 0,9024 & 0,8834 \\
\hline 60 & 0,9484 & 0,9484 & 0,9347 & 0,9537 & 0,9537 & 0,9449 & 0,9045 & 0,9045 & 0,8832 \\
\hline 70 & 0,9468 & 0,9468 & 0,9332 & 0,9335 & 0,9335 & 0,9458 & 0,8838 & 0,8838 & 0,8826 \\
\hline 80 & 0,9448 & 0,9448 & 0,9302 & 0,9535 & 0,9535 & 0,9456 & 0,9009 & 0,9009 & 0,8796 \\
\hline 90 & 0,9434 & 0,9434 & 0,9280 & 0,9530 & 0,9530 & 0,9449 & 0,8991 & 0,8991 & 0,8769 \\
\hline 100 & 0,9445 & 0,9445 & 0,9286 & 0,9535 & 0,9535 & 0,9452 & 0,9006 & 0,9006 & 0,8777 \\
\hline
\end{tabular}

1 - Coeficiente de correlação de Pearson; Id - Índice de concordância de Willmott; c - Coeficiente "c" de Camargo \& Sentelhas. 

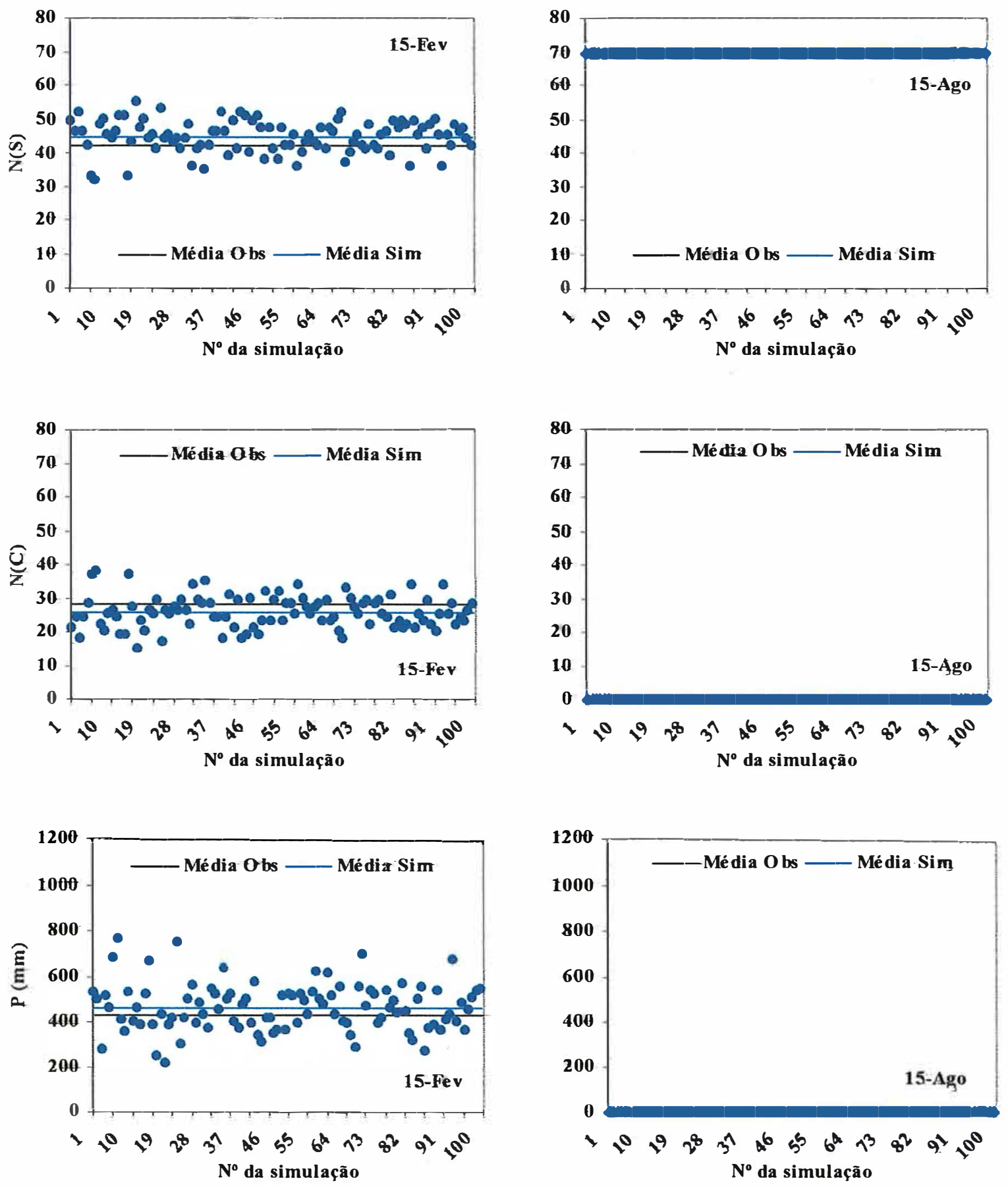

Figura 9. Comparação entre as médias dos valores observadose simulados de número de dias secos $(\mathrm{N}(\mathrm{S}))$, número de dias chuvosos $(\mathrm{N}(\mathrm{C}))$ e precipitação pluviométrica total $(\mathrm{P})$ em épocas específicas de semeadura no município de Parnaíba, Piauí. 

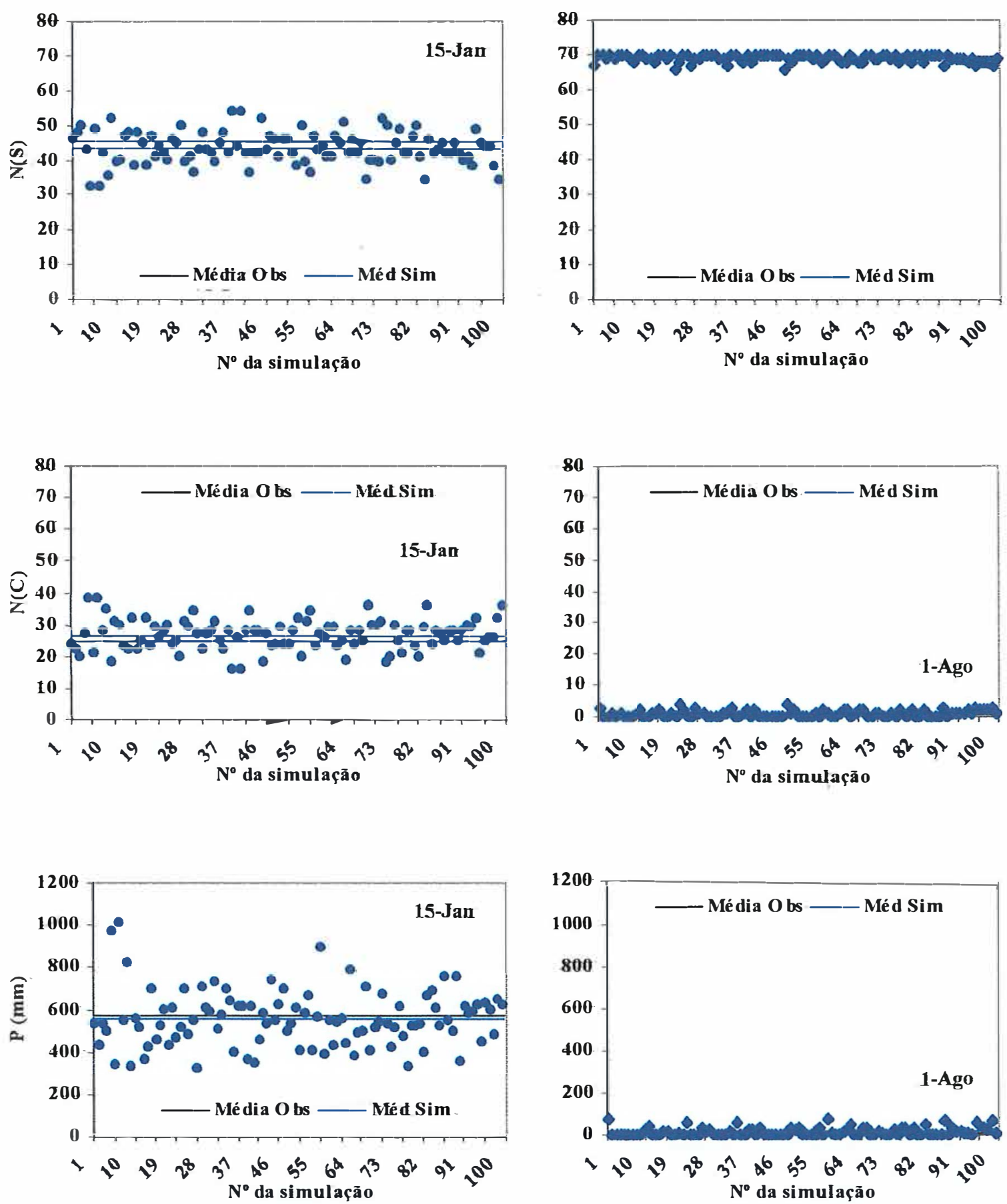

Figura 10. Comparação entre as médias dos valores observados e simulados de número de dias secos $(\mathrm{N}(\mathrm{S}))$ ), número de dias chuvosos $(\mathrm{N}(\mathrm{C}))$ ) e precipitação pluviométrica total $(\mathrm{P})$, em épocas específicas de semeadura no município de Teresina; Piaú. 
1-Jan a 15-Mar, em Parnaíba e de 1-Dez a 15-Fev, em Teresina. Percebeu-se, no início da estação chuvosa (1-Dez e 15-Dez), mais notadamente em Teresina, uma maior dispersão dos valores simulados em torno da média dos valores observados.

Essa maior variabilidade dos dados é devido ao fato desse período se constituir em uma fase de transição entre a estação seca e a chuvosa. Essa dispersão tendeu a diminuir à medida que a estação chuvosa se configurou plenamente nos dois municípios. A diferença entre as médias dos valores diários observados e simulados de precipitação pluviométrica variou apenas de -6,3\% (15-Fev) a 7,9\% (1-Dez), em Teresina, e de 5,7\% (1-Fev) a 8,1\% (15-Jan), em Parnaíba. Essas pequenas variações dos valores simulados de precipitação em relação aos valores observados demonstram a boa performance do modelo de simulação, conforme já discutido anteriormente. As diferenças observadas são inerentes à aleatoriedade do método de simulação de Monte Carlo (Sousa, 1999). Além disso, devido a sua ordem de grandeza tendem a não comprometer a análise de viabilidade econômica da irrigação, já que trata-se de uma época do ano onde, quando necessário, são efetuadas apenas irrigações de caráter suplementar.

\subsection{Simulação da evapotranspiração de referência}

A Tabela 13 apresenta uma comparação entre os valores observados e simulados de evapotranspiração de referência (ETo) em cada época de semeadura e os respectivos índices de desempenho estatístico obtidos nos municípios de Parnaíba e Teresina, Piauí. Em termos médios, nos dois municípios os valores observados e simulados de ETo apresentaram boa aproximação. Os valores de ETo tenderam a serem menores nas séries de dados simulados em comparação com os valores observados, notadamente, nas séries geradas em Teresina. Sousa (1999) verificou tendência de subestimativa de valores de déficit de evapotranspiração quando simulou ocorrência de veranicos de duração de 7 , 15 e 30 dias, no mês de março em Piracicaba (SP). 

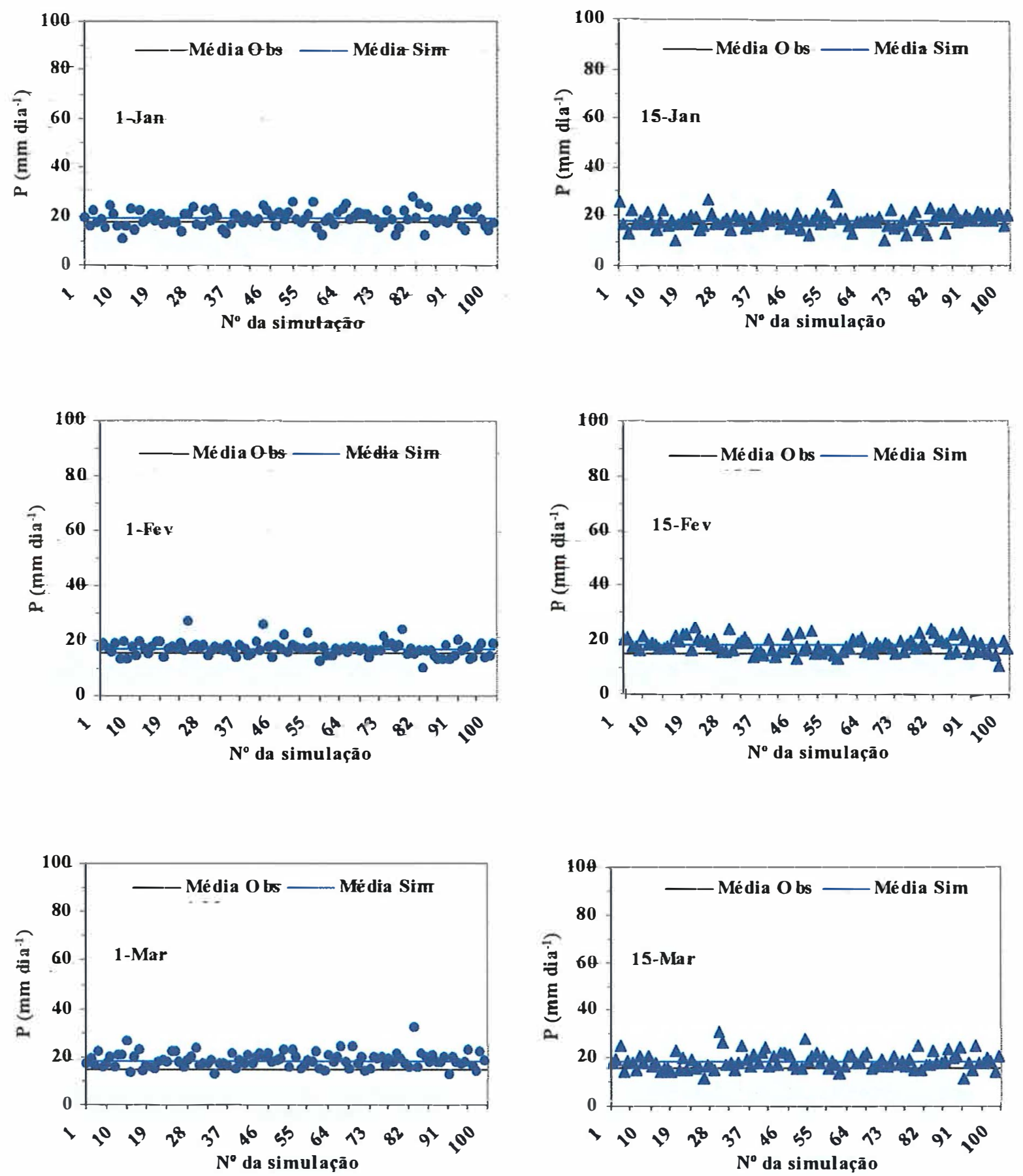

Figura 11. Comparação entre as médias dos valores observados e simulados de precipitação pluviométrica diária (P) em épocas específicas de semeadura na estação chuvosa do município-de Parnaiba, Piauí. 

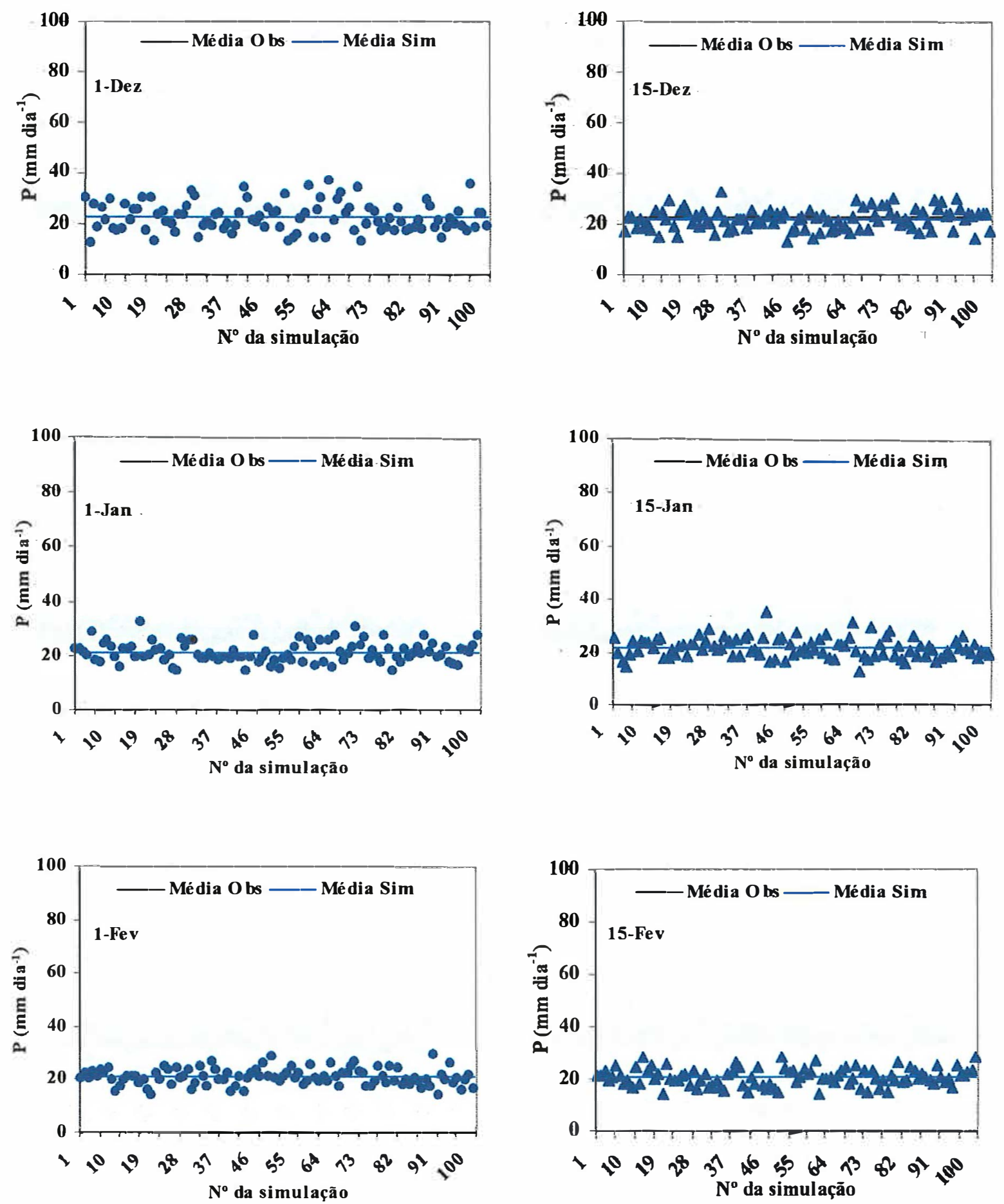

Figura 12. Comparação entre as médias dos valores observados e simulados de precipitação pluviométrica diária $(\mathrm{P})$ em épocas específicas de semeadura na estação chuvosa do município de Teresina, Piauí. 
Tabela 13. Valores observados (O) e simulados (S) de evapotranspiração de referência (ETo) em cada época de semeadura e os correspondentes indices de desempenho estatístico nos municipios de Pamaiba e Teresina, Piaui.

\begin{tabular}{|c|c|c|c|c|}
\hline \multirow{2}{*}{$\begin{array}{l}\text { Época de } \\
\text { Semeadura }\end{array}$} & \multicolumn{2}{|c|}{ Parnaiba } & \multicolumn{2}{|c|}{ Teresina } \\
\hline & $\mathrm{O}$ & S & $\mathrm{O}$ & $\mathrm{S}$ \\
\hline $1-$ Jan & 355,4 & 345,3 & 277,9 & 287,4 \\
\hline $15-\mathrm{Jan}$ & 347,5 & 334,3 & 276,6 & 285,0 \\
\hline $1-\mathrm{Fev}$ & 323,1 & 322,2 & 276,8 & 281,4 \\
\hline $15-\mathrm{Fev}$ & 316,5 & 309,5 & 280,4 & 277,8 \\
\hline $1-\mathrm{Mar}$ & 327,9 & 303,4 & 279,2 & 271,8 \\
\hline $15-\mathrm{Mar}$ & 329,2 & 297,6 & 276,0 & 267,4 \\
\hline $1-\mathrm{Abr}$ & 326,5 & 305,1 & 275,4 & 267,4 \\
\hline $15-\mathrm{Abr}$ & 328,5 & 310,0 & 277,1 & 268,5 \\
\hline 1 - Mai & 329,4 & 319,6 & 281,6 & 272,1 \\
\hline 15 - Mai & 336,3 & 325,9 & 288,3 & 280,6 \\
\hline 1 - Jun & 345,8 & 341,8 & 306,0 & 294,8 \\
\hline 15 - Jun & 369,1 & 361,6 & 324,8 & 309,8 \\
\hline 1 - Jul & 395,2 & 385,8 & 347,3 & 329,7 \\
\hline $15-\mathrm{Jul}$ & 428,1 & 413,4 & 372,2 & 351,7 \\
\hline 1 - Ago & 463,7 & 446,5 & 401,3 & 369,1 \\
\hline $15-A g o$ & 481,9 & 467,7 & 413,7 & 381,7 \\
\hline 1 - Set & 492,4 & 483,5 & 420,1 & 384,2 \\
\hline 15 - Set & 485,5 & 483,2 & 417,0 & 380,2 \\
\hline 1 - Out & 481,3 & 480,7 & 402,7 & 370,7 \\
\hline 15 - Out & 464,7 & 470,4 & 385,9 & 355,5 \\
\hline 1 - Nov & 441,0 & 439,7 & 354,4 & 332,8 \\
\hline $15-$ Nov & 401,1 & 413,2 & 330,6 & 314,5 \\
\hline 1 - Dez & 370,1 & 390,7 & 305,7 & 301,4 \\
\hline $15-$ Dez & 352,6 & 363,0 & 284,0 & 291,5 \\
\hline Média & 387,2 & 379,8 & 327,3 & 313,6 \\
\hline$r$ & & & & \\
\hline Id & & & & \\
\hline c & & & & \\
\hline
\end{tabular}


Em cada época de semeadura avaliada, os valores médios simulados aproximaramse bem dos valores observados, mostrando que o modelo efetuou estimativas de ETo com boa precisão e exatidão. Os resultados da análise de correlação (r), indice de concordância de Willmott (Id) e coeficiente "c" de Camargo (c) comprovam esse fato. Comportamento semelhante foi verificado por Sousa (1999) que também obteve elevados índices de desempenho estatístico ao utilizar o método de simulação de Monte Carlo para a geração de valores de ETo e, posteriormente, de déficit de evapotranspiração.

Com base no critério de interpretação do desempenho pelo índice "c" proposto por Camargo \& Sentelhas (1997), o modelo de simulação utilizado para a geração dos valores de ETo teve desempenho estatístico "ótimo" (c > 0,85). O modelo apresentou um desempenho pouco melhor no processo de geração daETo em_Parnaíba $(c=0,9726)$ do que em Teresina $(c=0,9496)$, devido à menor diferença dos valores simulados em relação aos observados (> Id), ou seja, uma maior exatidão do modelo. Por outro lado, em Teresina, observou-se uma menor dispersão dos valores em relação à média (>r), que reflete uma maior precisão do modelo. Porém, o grau de afastamento dos valores simulados em relação aos observados foi superior ao de Parnaíba (<Id).

Os valores do coeficiente de desempenho estatístico "c" obtidos com a simulação dos valores de precipitação pluviométrica foram inferiores aos obtidos com a simulação dos valores de ETo, indicando uma maior precisão e exatidão na estimativa dos valores de ETo pelo modelo de simulação. Provavelmente, este fato está relacionado à menor variabilidade da variável climática ETo, facilitando a sua previsão com um maior grau de precisão e exatidão.

De fato, analisando-se a Tabela 14, verificou-se que os valores de CV das séries de dados observados e simulados de ETo são bem inferiores aos obtidos com as séries de dados de precipitação pluviométrica (Tabela 11). Saad (1990) verificou esse mesmo comportamento ao confrontar os valores de CV oriundos de séries de dados de ETo e precipitação pluviométrica ocorridas em períodos de diferentes durações nos meses de março e setembro em Piracicaba (SP). 
Tabela 14. Coeficientes de variação (\%) dos valores observados (O) e simulados (S) de evapotranspiração de referência (ETo) em cada época de semeadura para os municipios de Parnaiba e Teresina, Piaui.

\begin{tabular}{|c|c|c|c|c|}
\hline \multirow{2}{*}{$\begin{array}{l}\text { Época de } \\
\text { Semeadura }\end{array}$} & \multicolumn{2}{|c|}{ Parnaiba } & \multicolumn{2}{|c|}{ Teresina } \\
\hline & $\mathrm{O}$ & $\mathrm{S}$ & $\mathrm{O}$ & $\mathrm{S}$ \\
\hline 1 - Jan & - & 1,9 & 8,2 & 1,3 \\
\hline $15-$ Jan & - & 2,0 & 5,8 & 1,3 \\
\hline $1-\mathrm{Fev}$ & - & 1,8 & 5,0 & 1,1 \\
\hline $15-\mathrm{Fev}$ & - & 1,7 & 6,4 & 1,2 \\
\hline 1 - Mar & - & 2,0 & 6,1 & 1,1 \\
\hline 15 - Mar & - & 1,8 & 5,9 & 1,2 \\
\hline $1-\mathrm{Abr}$ & - & 1,4 & 6,4 & 1,0 \\
\hline $15-A b r$ & - & 1,5 & 6,2 & 1,0 \\
\hline 1 - Mai & - & 1,5 & 6,7 & 0,9 \\
\hline 15 - Mai & - & 1,2 & 7,1 & 1,3 \\
\hline 1 - Jun & - & 1,6 & 8,5 & 1,2 \\
\hline 15 - Jun & - & 1,3 & 8,8 & 1,5 \\
\hline 1 - Jul & - & 1,6 & 10,5 & 1,4 \\
\hline 15 - Jul & - & 1,7 & 11,4 & 1,2 \\
\hline 1 - Ago & - & 1,4 & 11,5 & 1,1 \\
\hline 15 - Ago & - & 1,2 & 12,0 & 0,9 \\
\hline 1 - Set & - & 0,8 & 10,9 & 0,9 \\
\hline 15 - Set & - & 0,9 & 9,3 & 1,2 \\
\hline 1 - Out & - & 0,9 & 8,2 & 1,4 \\
\hline 15 - Out & - & 1,2 & 9,9 & 1,8 \\
\hline 1 - Nov & - & 1,7 & 8,9 & 1,7 \\
\hline $15-$ Nov & - & 2,1 & 10,3 & 1,7 \\
\hline 1 - Dez & - & 2,3 & 8,7 & 1,8 \\
\hline 15-Dez & - & 2,3 & 7,0 & 1,3 \\
\hline Média & - & 1,6 & 8,3 & 1,3 \\
\hline
\end{tabular}


Observou-se, em Teresina, que os coeficientes de variação (CV) tenderam a ser menores nas séries de dados simulados em comparação com os valores médios das séries históricas (Tabela 14), indicando que o modelo de simulação proporcionou a geração de séries de dados de ETo mais homogêneas. Não foi possível o cálculo dos valores de CV envolvendo os valores observados de ETo em Parnaíba, pois na fase de validação do modelo utilizou-se os dados de.ETo de apenas um ano (1990).

A amplitude de variação dos valores de $\mathrm{CV}$ dos dados observados de ETo foi de $12,0 \%$ a 5,0 \%, com os menores valores ocorrendo durante a estação chuvosa ( $5,0 \%$ a $8,2 \%)$ e os maiores durante a estação seca (7,0 \% a 12,0\%). Saad (1990) analisando os totais mensais de ETo nos meses de março (chuvoso) e setembro (seco), em Piracicaba (SP), encontrou valores de $\mathrm{CV}$ de $9,6 \%$ e $8,9 \%$, respectivamente, reforçando a menor variabilidade da variável climática ETo.

Da mesma forma que a precipitação pluviométrica, não constatou-se efeito significativo. $(\mathrm{P}>0,05)$ do número de simulações sobre os índices de desempenho estatístico estimados a partir dos valores de ETo (Tabela 15). Considerando-se os níveis mais elevados dos valores dos índices estatísticos, pode-se inferir com maior grau de confiabilidade que as simulações tendem a fornecer resultados semelhantes de ETo (Sousa, 1999). Apesar disso, utilizou-se 100 simulações para a geração dos valores diários de ETo em cada época de semeadura, de forma a permitir efetuarmos igual número de balanços hídricos diários.

A Figura 13 ilustra a comparação entre as médias dos valores observados e simulados deETo em épocas de semeadura específicas nas estações chuvosa e seca nos municípios de Parnaíba e Teresina. Selecionou-se as épocas de semeadura que apresentaram os menores e os maiores valores totais de ETo segundo as médias da série histórica de dados, as quais corresponderam a 15-Fev (estação chuvosa) e 1-Set (estação seca), em Parnaíba e 1-Abr (estação chuvosa) e 1-Set (estação.seca), em Teresina. 
Tabela 15. Índices de desempenho estatístico em função do número de simulações usadas na estimativa dos valores de evapotranspiração de referência em Parnaiba e Teresina, Piauí.

\begin{tabular}{ccccccc}
\hline $\mathbf{N}^{\circ}$ de & \multicolumn{3}{c}{ Parnaiba } & \multicolumn{3}{c}{ Teresina } \\
\cline { 2 - 7 } Simulações & $\mathrm{r}^{1}$ & $\mathrm{Id}^{2}$ & $\mathrm{c}^{3}$ & $\mathrm{r}$ & $\mathrm{Id}$ & $\mathrm{c}$ \\
\hline 10 & 0,9853 & 0,9884 & 0,9739 & 0,9920 & 0,9595 & 0,9518 \\
20 & 0,9850 & 0,9884 & 0,9736 & 0,9914 & 0,9589 & 0,9507 \\
30 & 0,9853 & 0,9882 & 0,9737 & 0,9917 & 0,9590 & 0,9510 \\
40 & 0,9850 & 0,9880 & 0,9732 & 0,9918 & 0,9590 & 0,9511 \\
50 & 0,9847 & 0,9879 & 0,9728 & 0,9917 & 0,9587 & 0,9507 \\
60 & 0,9849 & 0,9881 & 0,9732 & 0,9916 & 0,9585 & 0,9504 \\
70 & 0,9850 & 0,9881 & 0,9733 & 0,9915 & 0,9583 & 0,9502 \\
80 & 0,9848 & 0,9880 & 0,9730 & 0,9915 & 0,9579 & 0,9498 \\
90 & 0,9846 & 0,9880 & 0,9728 & 0,9914 & 0,9579 & 0,9497 \\
100 & 0,9845 & 0,9879 & 0,9726 & 0,9915 & 0,9577 & 0,9496 \\
\hline
\end{tabular}

1 - Coeficiente de correlação de Pearson; Id - Índice de concordância de Willmott; c - Coeficiente "c" de Camargo \& Sentelhas.

Em ambos os municípios, apesar da pequena dispersão dos valores simulados em relação à média dos valores observados, houve tendência de subestimativa dos valores de ETo nas épocas de semeaduras analisadas, independentemente da estação do ano. Contudo, observou-se uma inversão quanto à magnitude dessa subestimativa em função da estação do ano em cada município. Em Parnaíba, as maiores subestimativas de ETo ocorreram em 15-Fev (-2,2 \%) em plena estação chuvosa, enquanto em Teresina, estas foram detectadas em 1-Set $(-8,5 \%)$ durante a estação seca. Por outro lado, as menores subestimativas ocorreram justamente nas épocas de semeadura inversas, ou seja, 1-Set (-1,8\%), em Parnaíba e em 1-Abr (-2,9\%), em Teresina.

As subestimativas observadas nos valores de ETo não comprometem o desempenho do modelo de simulação e a conseqüente análise econômica da irrigação a ser implementada, uma vez que estas diferenças são normalmente atribuídas aos erros inerentes ao procedimento de estimativa da evapotranspiração, as quais dependem do método de estimativa, da qualidade e confiabilidade dos dados disponíveis (Saad, 1990). 


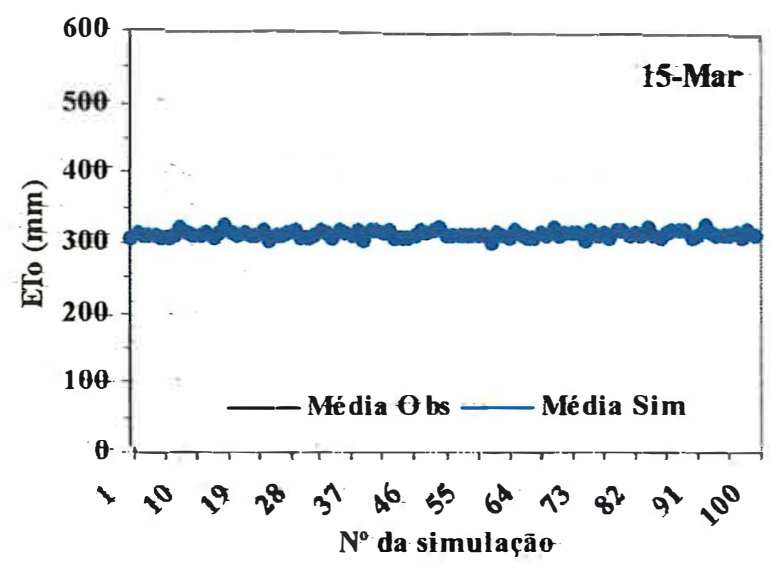

(a)

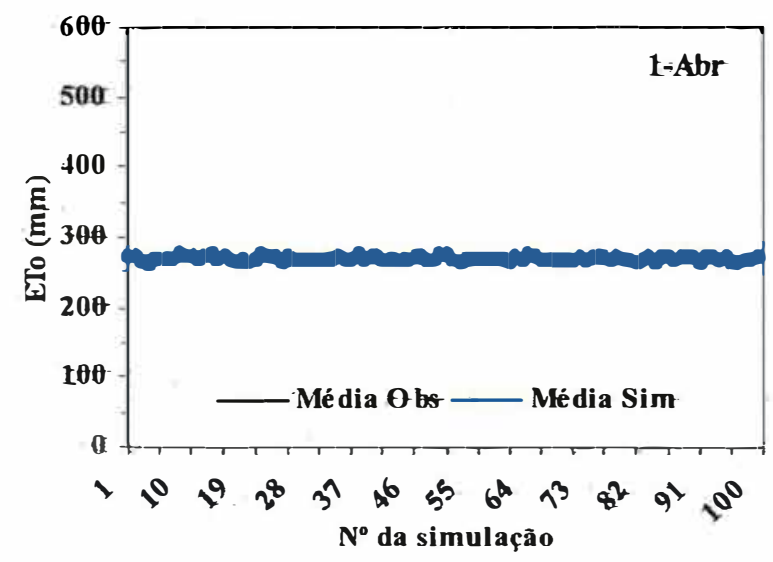

(b)

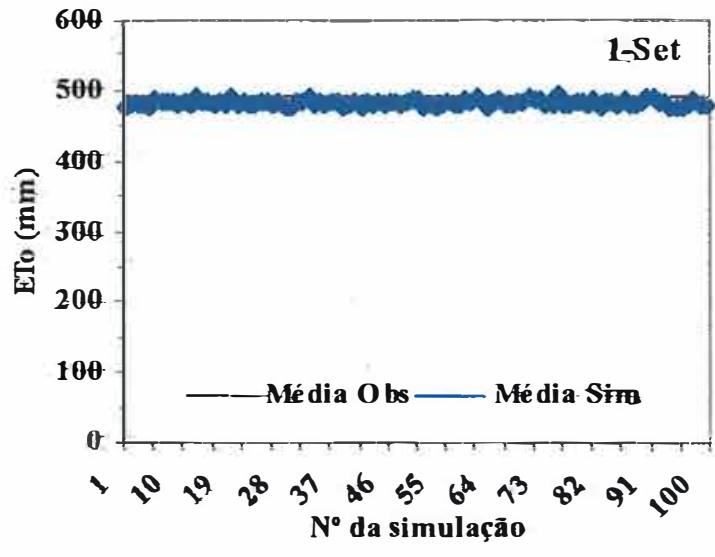

(a)

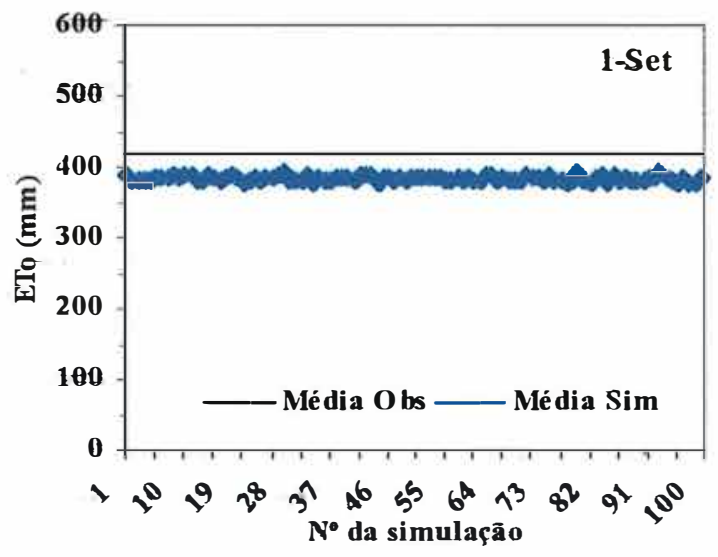

(b)

Figura 13. Comparação entre as médias dos valores observados e simulados de evapotranspiração de referênєia (ET⿱日) em épocas específicas de semeadura nos-municípios de Parnaíba (a)-e Teresina (b), Piaú. 
A título de comparação, o referido autor encontrou diferenças nos valores estimados de ETo em função da época do ano e do tamanho do período analisado de $8,3 \%$ a $11,4 \%$.

Com o intuito de aprofundar a análise do modelo de simulação na escala diária, confeccionou-se as Figuras 14 e 15, onde são comparadas as médias dos valores diários observados e simulados de ETo em épocas específicas de semeadura nos municípios de Parnaiba e Teresina, respectivamente. Selecionou-se épocas de semeadura na estação chuvosa e seca: i) Parnaíba: 1-Fev, 1-Mar e 1-Abr (estação chuvosa) e 1-Ago, 1-Set e 1Out (estação seca); ii) Teresina: 1-Mar, 1-Abr e 1-Mai (estação chuvosa) e 1-Ago, 1-Set e 1-Out (estação seca). De uma maneira geral, houve a tendência de manutenção da subestimativa dos valores simulados de ETo em relação à média dos valores observados, porém em níveis um pouco menores, indicando que os valores simulados de ETo na escala diária tendem a externar melhor as características de precisão e exatidão do modelo.

As diferenças entre as médias dos valores diários observados e simulados de ETo variaram apenas de $-0,1 \%$ (1-Out) a -9,5\% (15-Mar), em Parnaíba, e de -2,7\% (1-Mar) a $-8,8 \%$ (15-Set), em Teresina. As menores subestimativas ocorreram em 15-Set (-0,6 \%) e 1-Out (-0,1\%), em Parnaiba e em 1-Mar (-2,7\%) e 15-Mai (-2,8 \%), em Teresina. Segundo Sousa (1999), as diferenças observadas são inerentes à aleatoriedade do método de simulação de Monte Carlo e refletem a boa performance do modelo de simulação utilizado.

\subsection{Balanço hídrico diário}

Os valores de precipitação efetiva, evapotranspiração máxima, evapotranspiração real, lâmina bruta de irrigação e produtividade das culturas de feijão caupi e melancia obtidos nas diferentes épocas de semeadura, em função dos níveis de manejo de irrigação, nas condições edafoclimáticas de Parnaíba e Teresina são apresentados nas Tabelas 16 a 27. Esses valores correspondem às médias dessas variáveis resultantes da simulação de 100 balanços hídricos diários efetuados com e sem o uso de irrigação. 


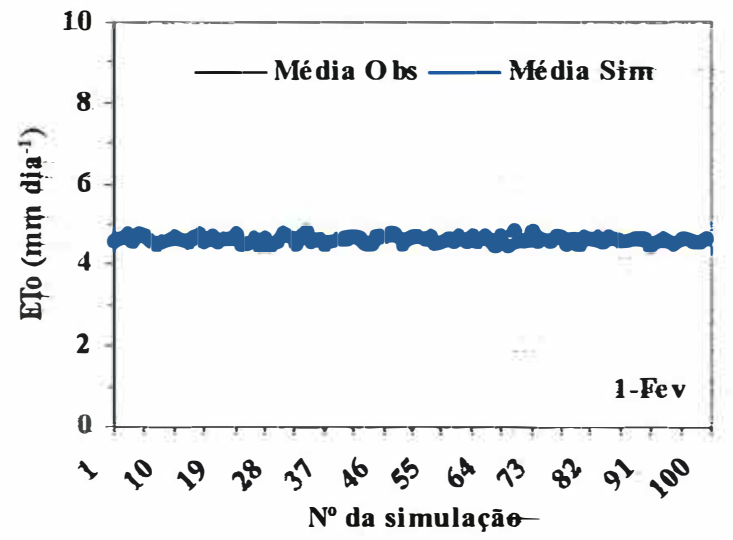

(a)

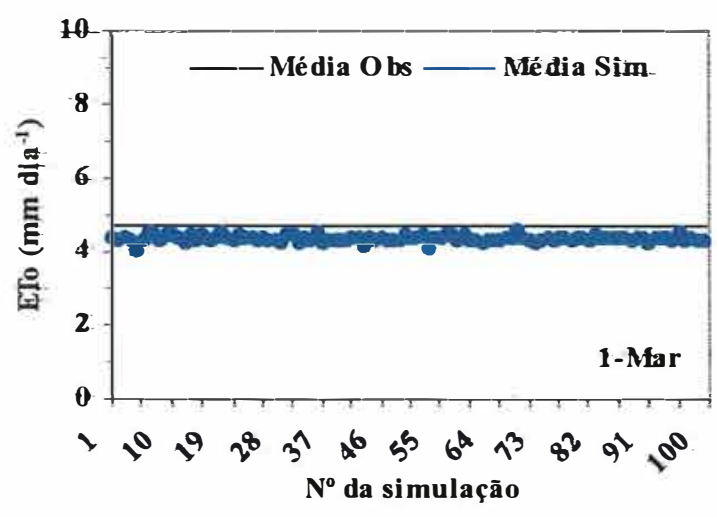

(a)

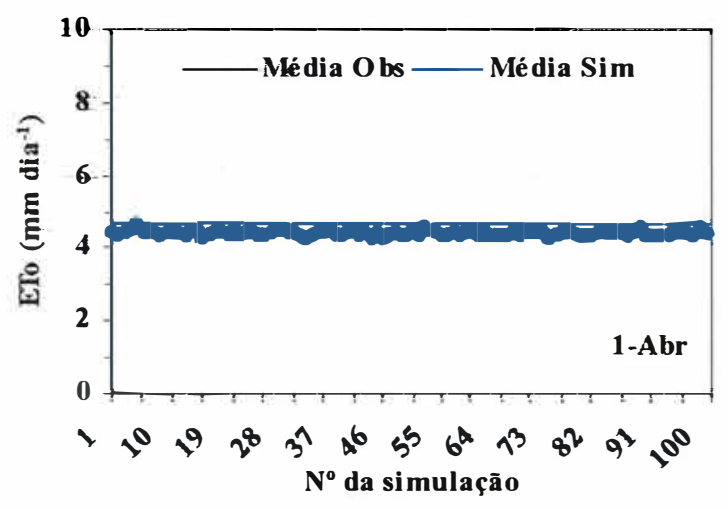

(a)

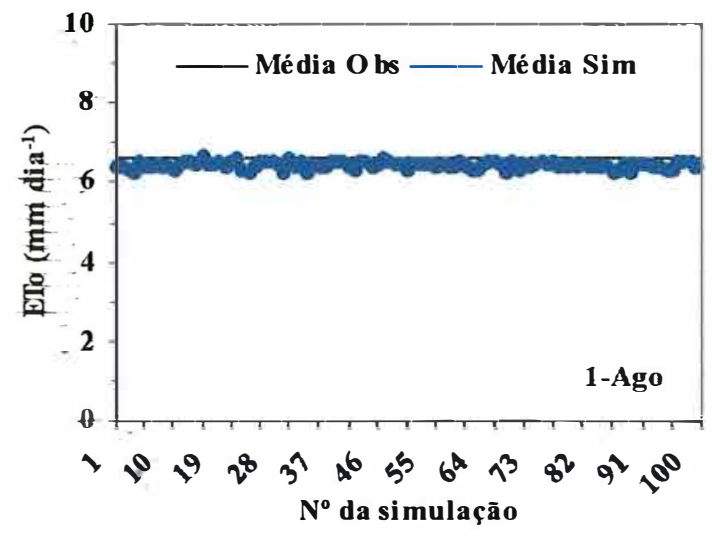

(b)

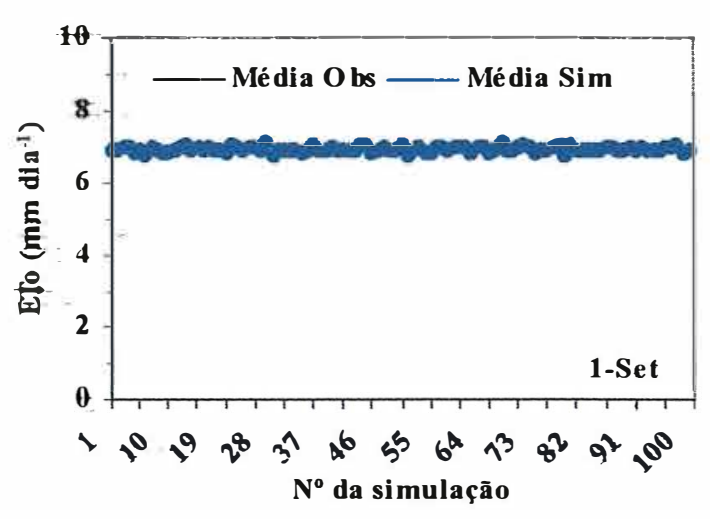

(b)

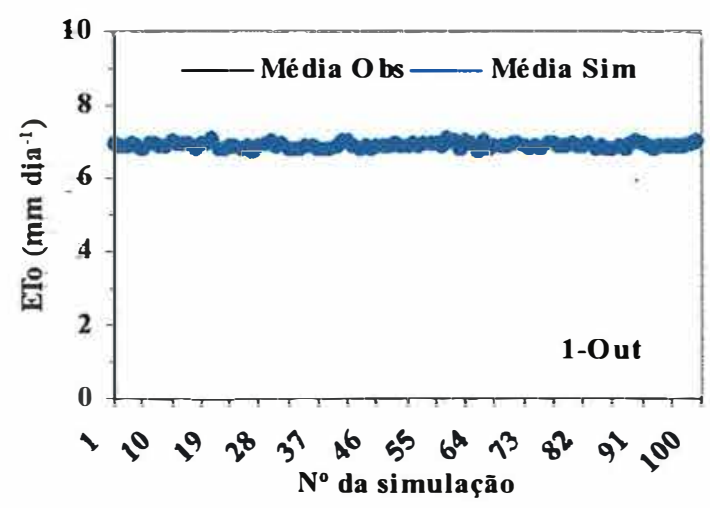

(b)

Figura 14. Comparação entre as médias dos valores observados e simulados de evapotranspiração de referência diária (ETo) em épocas específicas de semeadura na estação ehtresa-(a) e-seca (b) do município de Parnaíba, Piauí. 


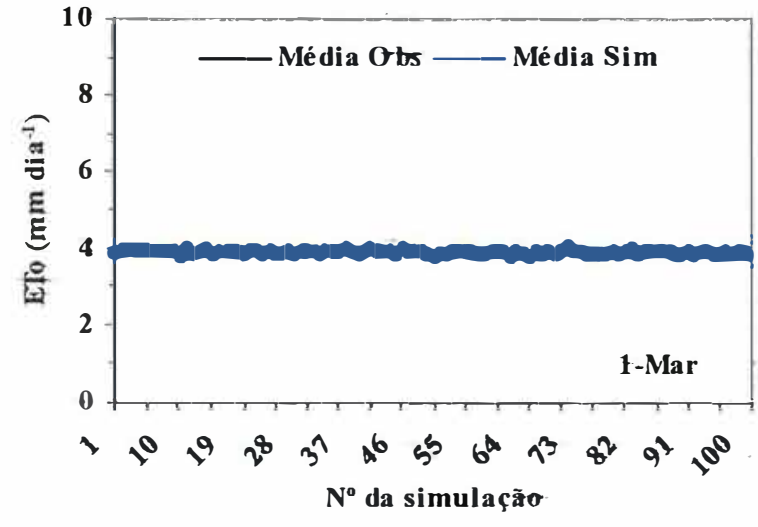

(a)

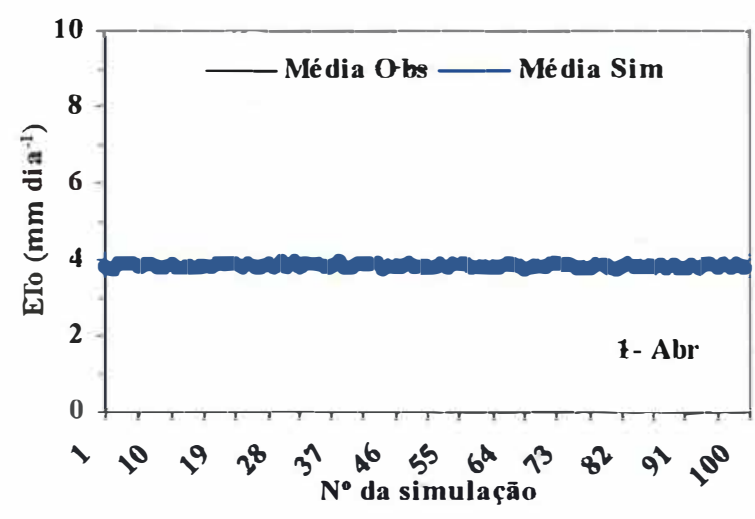

(a)

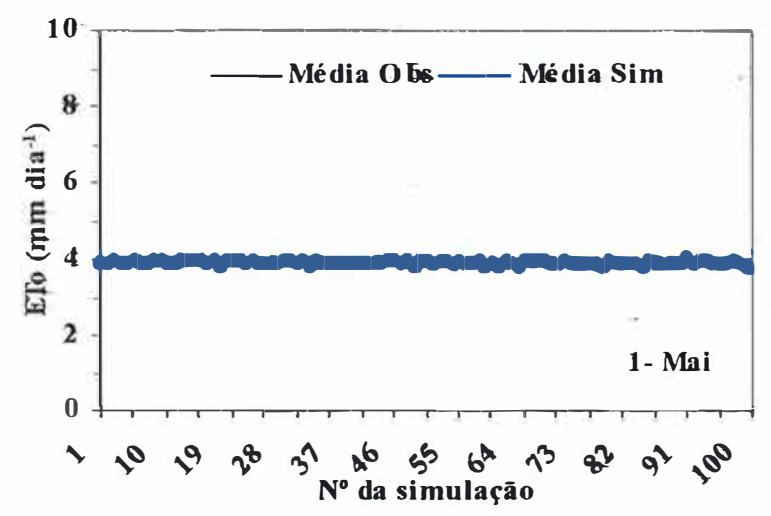

(a)

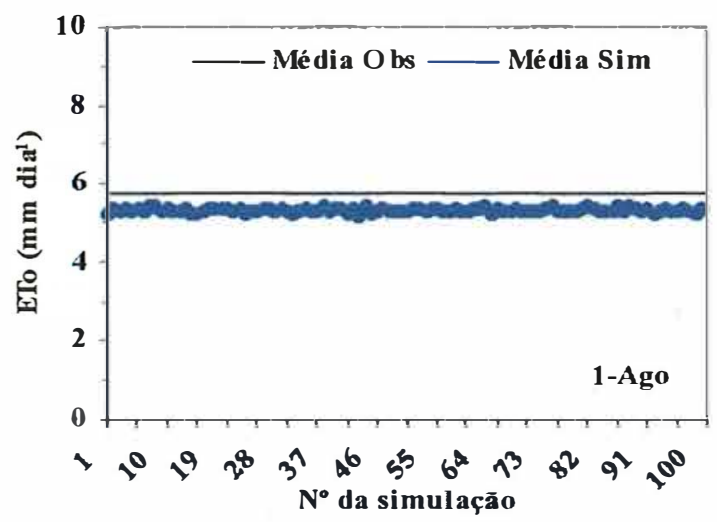

(b)

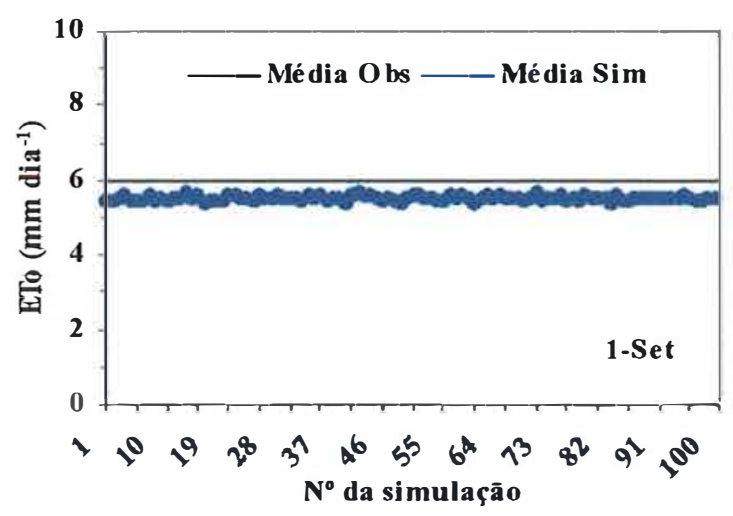

(b)

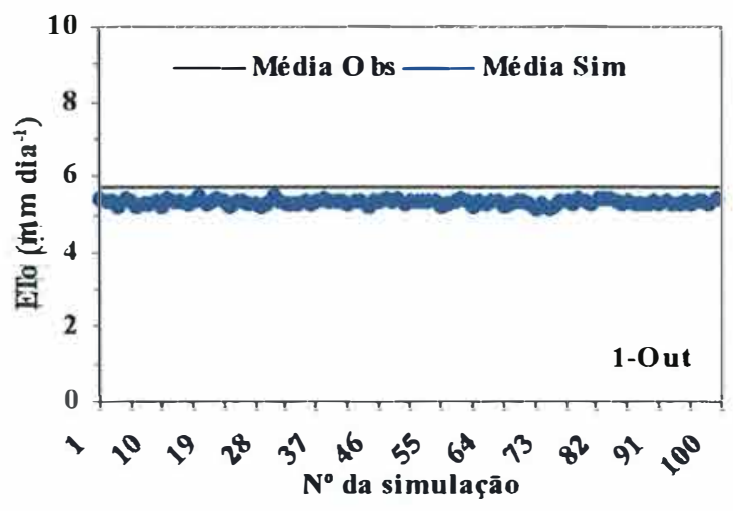

(b)

Figura 15. Comparação entre as médias dos valores observados e simulados de evapotranspiração de referência diária (ETo) em épocas específicas de semeadura na estação chuvosa (a) e seca (b) do município de Teresina, Piauí. 
Tabela 16. Precipitação efetiva $(\mathrm{Pe})$ e lâmina bruta de irrigação em função dos níveis de manejo em cada época de semeadura na cultura de feijão caupi, no município de Parnaíba, Piauí.

\begin{tabular}{|c|c|c|c|c|c|c|c|c|c|}
\hline \multirow{2}{*}{$\begin{array}{l}\text { Época de } \\
\text { Semeadura }\end{array}$} & \multirow{2}{*}{$\begin{array}{c}\mathrm{Pe} \\
(\mathrm{mm})\end{array}$} & \multicolumn{8}{|c|}{ Lâmina bruta (mm) } \\
\hline & & 0,2 & 0,3 & 0,4 & 0,5 & 0,6 & 0,7 & 0,8 & Média \\
\hline $1-\operatorname{Jan}$ & 242,0 & 236,7 & 224,2 & 211,9 & 200,5 & 188,5 & 178,4 & 168,9 & 201,3 \\
\hline $15-\mathrm{Jan}$ & 287,9 & 213,9 & 200,0 & 187,0 & 173,4 & 160,3 & 149,8 & 143,1 & 175,3 \\
\hline $1-\mathrm{Fev}$ & 285,6 & 193,1 & 177,5 & 161,4 & 150,3 & 138,9 & 128,8 & 116,8 & 152,4 \\
\hline $15-\mathrm{Fev}$ & 330,5 & 174,8 & 161,5 & 143,4 & 130,3 & 115,3 & 108,6 & 99,1 & 133,3 \\
\hline 1 - Mar & 331,9 & 167,6 & 152,9 & 136,9 & 122,4 & 111,2 & 97,6 & 85,1 & 124,8 \\
\hline 15 - Mar & 305,3 & 175,8 & 161,2 & 145,6 & 131,1 & 120,2 & 107,5 & 96,2 & 133,9 \\
\hline $1-A b r$ & 248,2 & 203,4 & 191,3 & 179,5 & 167,5 & 153,8 & 145,6 & 134,0 & 167,9 \\
\hline $15-\mathrm{Abr}$ & 195,7 & 228,4 & 216,3 & 205,9 & 195,0 & 183,3 & 170,7 & 166,5 & 195,2 \\
\hline 1 - Mai & 110,2 & 263,4 & 254,9 & 244,3 & 238,7 & 234,0 & 222,4 & 219,1 & 239,6 \\
\hline 15 - Mai & 36,5 & 277,3 & 269,6 & 264,2 & 256,2 & 249,3 & 246,7 & 240,0 & 257,6 \\
\hline 1 - Jun & 41,2 & 301,8 & 296,6 & 292,5 & 286,7 & 283,1 & 276,8 & 273,2 & 287,2 \\
\hline 15 - Jun & 29,0 & 331,2 & 327,3 & 322,1 & 319,1 & 315,9 & 311,2 & 308,9 & 319,4 \\
\hline 1 - Jul & 17,9 & 363,4 & 358,8 & 355,8 & 353,4 & 350,0 & 346,5 & 343,8 & 353,1 \\
\hline 15 - Jul & 3,3 & 394,4 & 390,3 & 389,3 & 387,2 & 385,2 & 382,9 & 381,8 & 387,3 \\
\hline 1 - Ago & 0,0 & 434,0 & 430,7 & 429,6 & 428,1 & 425,7 & 424,4 & 421,5 & 427,7 \\
\hline 15 - Ago & 0,0 & 454,1 & 451,9 & 450,3 & 446,6 & 445,5 & 441,3 & 442,8 & 447,5 \\
\hline 1 - Set & 0,0 & 469,1 & 467,1 & 465,1 & 462,1 & 462,9 & 457,7 & 456,3 & 462,9 \\
\hline 15 - Set & 2,6 & 465,2 & 463,9 & 461,3 & 458,7 & 459,5 & 455,4 & 452,1 & 459,4 \\
\hline 1 - Out & 6,9 & 461,6 & 459,6 & 456,8 & 454,1 & 453,6 & 451,4 & 447,1 & 454,9 \\
\hline 15 - Out & 9,5 & 450,1 & 446,3 & 446,1 & 441,9 & 440,5 & 435,1 & 435,5 & 442,2 \\
\hline 1 - Nov & 46,0 & 403,8 & 399,5 & 394,1 & 389,8 & 387,5 & 382,6 & 378,6 & 390,8 \\
\hline 15 - Nov & 102,7 & 357,6 & 350,6 & 345,5 & 338,8 & 331,8 & 325,8 & 319,4 & 338,5 \\
\hline 1 - Dez & 133,9 & 325,4 & 316,3 & 310,1 & 300,2 & 295,0 & 287,6 & 283,2 & 302,6 \\
\hline $15-\mathrm{Dez}$ & 183,9 & 278,8 & 265,8 & 256,8 & 246,9 & 239,7 & 229,0 & 222,4 & 248,5 \\
\hline Média & 124,8 & 317,7 & 309,8 & 302,3 & 295,0 & 288,8 & 281,8 & 276,5 & \\
\hline
\end{tabular}


Tabela 17. Precipitação efetiva $(\mathrm{Pe})$ e làmina bruta de irrigação em função dos níveis de manejo em cada época de semeadura na cultura de feijão caupi, no município de Teresina, Piauí.

\begin{tabular}{lrrrrrrrrr}
\hline Época de & Pe & \multicolumn{7}{c}{ Lâmina bruta $(\mathrm{mm})$} \\
\cline { 3 - 9 } Semeadura & $(\mathrm{mm})$ & 0,2 & 0,3 & 0,4 & 0,5 & 0,6 & 0,7 & 0,8 & Média \\
\hline 1 - Jan & 356,0 & 148,7 & 134,8 & 118,6 & 102,4 & 86,9 & 75,6 & 68,1 & 105,0 \\
15 - Jan & 406,1 & 133,4 & 117,5 & 101,5 & 86,1 & 73,0 & 59,9 & 52,6 & 89,1 \\
1 - Fev & 465,6 & 114,1 & 95,1 & 77,2 & 63,0 & 53,7 & 41,3 & 34,0 & 68,3 \\
15 - Fev & 466,1 & 106,6 & 89,7 & 73,5 & 56,7 & 48,0 & 38,3 & 31,5 & 63,4 \\
1 - Mar & 451,6 & 107,5 & 89,6 & 68,6 & 58,5 & 49,7 & 38,7 & 28,8 & 63,0 \\
15 - Mar & 382,2 & 128,5 & 109,7 & 94,2 & 80,6 & 70,6 & 56,8 & 48,3 & 84,1 \\
1 - Abr & 278,9 & 155,0 & 141,1 & 128,1 & 115,7 & 104,8 & 95,5 & 83,6 & 117,7 \\
15 - Abr & 182,2 & 188,1 & 177,4 & 163,6 & 151,4 & 144,5 & 136,0 & 126,9 & 155,4 \\
1 - Mai & 111,4 & 212,6 & 202,0 & 193,1 & 185,2 & 178,8 & 172,5 & 161,8 & 186,6 \\
15 - Mai & 53,6 & 241,8 & 235,0 & 229,0 & 223,6 & 218,7 & 211,0 & 208,0 & 223,9 \\
1 - Jun & 24,4 & 266,6 & 261,5 & 258,6 & 255,2 & 249,8 & 248,5 & 244,7 & 255,0 \\
15 - Jun & 17,8 & 288,3 & 284,2 & 280,6 & 276,9 & 273,6 & 271,3 & 266,7 & 277,4 \\
1 - Jul & 10,6 & 314,7 & 312,4 & 310,0 & 306,3 & 305,0 & 299,0 & 300,6 & 306,9 \\
15 - Jul & 4,6 & 337,2 & 334,8 & 332,0 & 329,8 & 328,8 & 323,5 & 321,0 & 329,6 \\
1 - Ago & 12,5 & 351,5 & 348,4 & 347,1 & 340,5 & 338,3 & 335,0 & 334,3 & 342,2 \\
15 - Ago & 17,0 & 360,8 & 357,8 & 356,0 & 350,3 & 349,4 & 345,0 & 341,3 & 351,5 \\
1 - Set & 34,0 & 358,3 & 353,7 & 349,5 & 344,1 & 338,8 & 337,1 & 332,4 & 344,8 \\
15 - Set & 39,1 & 349,3 & 344,9 & 338,7 & 333,8 & 331,4 & 325,4 & 323,7 & 335,3 \\
1 - Out & 50,7 & 336,7 & 332,9 & 326,8 & 321,5 & 315,4 & 311,1 & 308,2 & 321,8 \\
15 - Out & 76,8 & 317,3 & 311,5 & 304,3 & 295,3 & 291,7 & 286,9 & 282,1 & 298,4 \\
1 - Nov & 124,6 & 273,2 & 264,8 & 253,6 & 248,5 & 239,9 & 231,9 & 223,6 & 247,9 \\
15 - Nov & 179,7 & 236,4 & 225,0 & 210,5 & 199,7 & 189,8 & 180,3 & 172,9 & 202,1 \\
1 - Dez & 219,2 & 208,1 & 194,8 & 180,7 & 166,9 & 161,2 & 145,8 & 133,7 & 170,2 \\
15 - Dez & 265,7 & 178,8 & 165,2 & 148,7 & 134,2 & 122,6 & 110,0 & 97,4 & 136,7 \\
\hline Média & 176,3 & 238,1 & 228,5 & 218,5 & 209,4 & 202,7 & 194,9 & 188,6 & \\
\hline & & & & & & & & &
\end{tabular}


Tabela 18. Precipitação efetiva $(\mathrm{Pe})$ e lâmina bruta de irrigação em função dos niveis de manejo em cada época de semeadura na cultura de melancia, no município de Pamaiba, Piauí.

\begin{tabular}{lrrrrrrrrr}
\hline Época de & $\mathrm{Pe}$ & \multicolumn{7}{c}{ Lâmina bruta $(\mathrm{mm})$} \\
\cline { 3 - 9 } Semeadura & $(\mathrm{mm})$ & 0,2 & 0,3 & 0,4 & 0,5 & 0,6 & 0,7 & 0,8 & Média \\
\hline 1 - Jan & 242,0 & 233,6 & 224,6 & 211,2 & 202,1 & 188,6 & 178,3 & 165,4 & 200,5 \\
15 - Jan & 287,9 & 211,5 & 198,7 & 182,7 & 172,0 & 157,3 & 148,9 & 139,7 & 173,0 \\
1 - Fev & 285,6 & 190,2 & 176,3 & 157,0 & 147,0 & 137,4 & 124,9 & 115,3 & 149,7 \\
15 - Fev & 330,5 & 172,5 & 158,1 & 143,0 & 127,8 & 115,4 & 104,3 & 93,8 & 130,7 \\
1 - Mar & 331,9 & 166,0 & 150,3 & 133,3 & 120,8 & 105,7 & 93,9 & 82,6 & 121,8 \\
15- Mar & 305,3 & 174,3 & 159,5 & 142,4 & 131,4 & 116,7 & 105,9 & 89,4 & 131,4 \\
1 - Abr & 248,2 & 202,1 & 191,8 & 176,2 & 164,7 & 154,8 & 141,1 & 133,9 & 166,4 \\
15 - Abr & 195,3 & 225,2 & 215,9 & 202,3 & 193,3 & 180,2 & 170,1 & 162,2 & 192,7 \\
1 - Mai & 110,2 & 261,2 & 254,4 & 243,1 & 236,8 & 228,5 & 222,5 & 215,5 & 237,4 \\
15 - Mai & 76,5 & 273,8 & 267,6 & 260,5 & 255,6 & 247,8 & 243,9 & 236,2 & 255,0 \\
1 - Jun & 41,2 & 299,9 & 294,9 & 290,3 & 284,7 & 278,4 & 276,7 & 272,0 & 285,3 \\
15 - Jun & 29,0 & 328,3 & 325,0 & 319,1 & 315,9 & 311,8 & 312,3 & 305,9 & 316,9 \\
1 - Jul & 17,9 & 360,3 & 356,3 & 353,6 & 349,9 & 348,1 & 344,0 & 343,9 & 350,9 \\
15 - Jul & 7,3 & 391,5 & 388,1 & 385,7 & 384,7 & 380,3 & 379,5 & 376,1 & 383,7 \\
1 - Ago & 0,0 & 430,6 & 428,3 & 426,9 & 424,8 & 421,6 & 420,5 & 420,4 & 424,7 \\
15 - Ago & 0,0 & 450,2 & 448,8 & 446,5 & 445,0 & 442,8 & 439,9 & 440,9 & 444,9 \\
1 - Set & 0,0 & 464,8 & 464,3 & 461,3 & 458,0 & 457,5 & 455,0 & 453,9 & 459,2 \\
15 - Set & 2,6 & 461,4 & 460,4 & 457,9 & 455,0 & 454,3 & 451,5 & 447,5 & 455,4 \\
1 - Out & 6,9 & 458,2 & 456,2 & 453,6 & 450,5 & 448,7 & 447,4 & 445,1 & 451,4 \\
15 - Out & 9,5 & 446,7 & 444,3 & 442,6 & 438,9 & 436,9 & 432,9 & 431,9 & 439,2 \\
1 - Nov & 46,0 & 401,0 & 397,2 & 391,0 & 388,7 & 383,6 & 379,7 & 375,5 & 388,1 \\
15 - Nov & 102,7 & 354,9 & 348,2 & 343,0 & 336,1 & 326,9 & 323,6 & 317,1 & 335,7 \\
1 - Dez & 133,9 & 322,6 & 314,8 & 308,8 & 298,0 & 291,1 & 284,1 & 279,2 & 299,8 \\
15 - Dez & 183,9 & 275,4 & 264,7 & 253,4 & 244,5 & 235,9 & 226,1 & 218,4 & 245,5 \\
\hline Média & 124,8 & 314,8 & 307,9 & 299,4 & 292,8 & 285,4 & 279,5 & 273,4 & \\
\hline & & & & & & & & &
\end{tabular}


Tabela 19. Precipitação efetiva $(\mathrm{Pe})$ e lâmina bruta de irrigação em função dos níveis de manejo em cada época de semeadura na cultura de melancia, no município de Teresina, Piauí.

\begin{tabular}{lrrrrrrrrr}
\hline Época de & Pe & \multicolumn{7}{c}{ Lâmina bruta $(\mathrm{mm})$} \\
\cline { 3 - 9 } Semeadura & $(\mathrm{mm})$ & 0,2 & 0,3 & 0,4 & 0,5 & 0,6 & 0,7 & 0,8 & Média \\
\hline 1 - Jan & 356,0 & 149,3 & 132,1 & 115,2 & 97,9 & 83,9 & 73,8 & 65,7 & 102,6 \\
15 - Jan & 406,1 & 134,0 & 112,4 & 96,8 & 82,3 & 69,6 & 58,5 & 50,6 & 86,3 \\
1 - Fev & 465,6 & 113,3 & 91,4 & 76,2 & 60,9 & 50,3 & 36,7 & 31,8 & 65,8 \\
15 - Fev & 466,1 & 107,6 & 85,6 & 72,1 & 55,1 & 44,5 & 36,5 & 30,5 & 61,7 \\
1 - Mar & 451,6 & 107,5 & 85,9 & 66,3 & 55,8 & 45,6 & 34,2 & 24,3 & 59,9 \\
15 - Mar & 382,2 & 127,3 & 106,6 & 91,4 & 80,0 & 65,6 & 54,3 & 45,6 & 81,5 \\
1 - Abr & 278,9 & 154,5 & 139,3 & 125,5 & 114,1 & 102,5 & 92,4 & 81,3 & 115,6 \\
15 - Abr & 182,2 & 187,5 & 175,3 & 159,8 & 150,8 & 140,4 & 134,0 & 125,6 & 153,3 \\
1 - Mai & 111,4 & 212,3 & 199,8 & 189,9 & 183,7 & 176,5 & 166,5 & 160,7 & 184,2 \\
15 - Mai & 53,6 & 240,3 & 230,6 & 227,8 & 220,4 & 214,6 & 208,3 & 207,3 & 221,3 \\
1 - Jun & 24,4 & 264,2 & 260,2 & 256,4 & 253,8 & 247,8 & 246,9 & 242,7 & 253,2 \\
15 - Jun & 17,8 & 286,6 & 281,8 & 277,6 & 277,0 & 270,7 & 271,1 & 266,4 & 275,9 \\
1 - Jul & 10,6 & 313,1 & 311,0 & 306,6 & 304,8 & 302,3 & 297,2 & 296,9 & 304,6 \\
15 - Jul & 4,6 & 335,3 & 331,9 & 330,7 & 327,1 & 324,4 & 322,7 & 323,4 & 327,9 \\
1 - Ago & 12,5 & 348,9 & 346,2 & 343,9 & 339,2 & 337,2 & 333,3 & 330,8 & 339,9 \\
15 - Ago & 17,0 & 357,9 & 355,5 & 352,0 & 348,3 & 346,9 & 344,2 & 337,9 & 348,9 \\
1 - Set & 34,0 & 354,4 & 350,3 & 346,1 & 341,4 & 337,0 & 333,8 & 328,8 & 341,7 \\
15 - Set & 39,1 & 346,9 & 341,8 & 336,8 & 332,3 & 327,7 & 325,8 & 320,9 & 333,2 \\
1 - Out & 50,7 & 334,6 & 330,2 & 323,7 & 320,1 & 315,3 & 310,8 & 305,4 & 320,0 \\
15 - Out & 76,8 & 314,8 & 309,0 & 304,2 & 296,0 & 290,0 & 281,7 & 278,6 & 296,3 \\
1 - Nov & 124,6 & 271,8 & 263,4 & 255,0 & 244,6 & 236,7 & 228,3 & 220,1 & 245,7 \\
15 - Nov & 179,7 & 235,5 & 224,0 & 209,8 & 201,3 & 189,4 & 180,0 & 170,9 & 201,6 \\
1 - Dez & 219,2 & 207,5 & 193,5 & 177,7 & 166,2 & 156,1 & 146,3 & 129,5 & 168,1 \\
15 - Dez & 265,7 & 179,3 & 160,4 & 149,0 & 132,9 & 117,8 & 107,3 & 96,2 & 134,7 \\
\hline Média & 176,3 & 236,8 & 225,8 & 216,3 & 207,7 & 199,7 & 192,7 & 186,3 & \\
\hline & & & & & & & & &
\end{tabular}


Tabela 20. Evapotranspiração máxima (ETm) e real (ETr) em função dos niveis de manejo em cada época de semeadura na cultura de feijão caupi, no município de Parnaiba, Piauí.

\begin{tabular}{lccccccccc}
\hline Época de & ETm & \multicolumn{7}{c}{ ETr $(\mathrm{mm})$} \\
\cline { 3 - 9 } Semeadura & $(\mathrm{mm})$ & 0,2 & 0,3 & 0,4 & 0,5 & 0,6 & 0,7 & 0,8 & Média \\
\hline 1 - Jan & 254,3 & 240,7 & 232,7 & 225,3 & 216,9 & 210,6 & 203,9 & 198,1 & 218,3 \\
15 - Jan & 245,6 & 233,8 & 226,7 & 219,3 & 212,2 & 206,0 & 200,2 & 195,6 & 213,4 \\
1 - Fev & 235,8 & 224,1 & 217,5 & 210,4 & 204,6 & 199,0 & 194,1 & 189,4 & 205,6 \\
15 - Fev & 227,7 & 215,9 & 210,1 & 202,9 & 197,6 & 192,4 & 188,5 & 184,0 & 198,8 \\
1 - Mar & 222,5 & 210,7 & 205,1 & 198,3 & 193,2 & 188,1 & 183,9 & 180,0 & 194,2 \\
15- Mar & 218,7 & 206,2 & 200,6 & 193,4 & 188,1 & 182,6 & 178,4 & 174,3 & 189,1 \\
1 - Abr & 223,9 & 210,9 & 204,4 & 196,5 & 190,4 & 183,9 & 179,0 & 173,7 & 191,3 \\
15 - Abr & 227,8 & 214,4 & 207,3 & 198,9 & 192,0 & 184,7 & 179,2 & 173,1 & 192,8 \\
1 - Mai & 233,8 & 219,6 & 212,0 & 202,6 & 194,6 & 186,8 & 179,9 & 173,0 & 195,5 \\
15 - Mai & 239,6 & 225,4 & 217,4 & 207,9 & 199,2 & 191,3 & 183,9 & 176,8 & 200,3 \\
1 - Jun & 250,3 & 236,4 & 227,5 & 218,0 & 207,7 & 200,4 & 191,1 & 183,5 & 209,2 \\
15 - Jun & 265,6 & 252,3 & 242,1 & 233,3 & 221,4 & 213,7 & 203,7 & 195,9 & 223,2 \\
1 - Jul & 283,9 & 271,9 & 259,7 & 251,3 & 238,8 & 229,4 & 219,7 & 209,9 & 240,1 \\
15 - Jul & 303,9 & 293,0 & 279,2 & 271,0 & 258,8 & 246,5 & 238,3 & 226,6 & 259,0 \\
1 - Ago & 328,4 & 319,2 & 303,4 & 294,6 & 283,4 & 268,4 & 259,0 & 248,0 & 282,3 \\
15 - Ago & 343,7 & 336,0 & 319,0 & 309,6 & 298,8 & 283,1 & 271,3 & 262,6 & 297,2 \\
1 - Set & 355,0 & 348,2 & 330,8 & 320,4 & 310,6 & 294,5 & 280,6 & 273,6 & 308,4 \\
15 - Set & 354,6 & 347,9 & 330,1 & 320,2 & 310,2 & 294,3 & 281,1 & 273,3 & 308,1 \\
1 - Out & 352,8 & 345,9 & 328,6 & 318,5 & 308,3 & 292,5 & 279,7 & 272,0 & 306,5 \\
15 - Out & 344,8 & 337,2 & 320,4 & 310,9 & 300,5 & 284,8 & 273,5 & 264,9 & 298,9 \\
1 - Nov & 322,8 & 313,4 & 299,0 & 289,9 & 278,9 & 265,9 & 256,3 & 246,2 & 278,5 \\
15 - Nov & $303,3-$ & 292,7 & 280,3 & 271,8 & 261,2 & 249,9 & 241,9 & 232,0 & 261,4 \\
1 - Dez & 287,3 & 276,0 & 265,0 & 256,9 & 246,1 & 237,0 & 229,0 & 220,2 & 247,2 \\
15 - Dez & 266,7 & 254,9 & 245,3 & 237,7 & 228,3 & 220,9 & 213,3 & 206,3 & 229,5 \\
\hline Média & 278,9 & 267,8 & 256,8 & 248,3 & 239,2 & 229,4 & 221,2 & 213,9 & \\
\hline & & & & & & & & &
\end{tabular}


Tabela 21. Evapotranspiração máxima (ETm) e real (ETr) em função dos niveis de manejo em cada época de semeadura na cultura de feijão caupi, no municipio de Teresina, Piaui.

\begin{tabular}{lccccccccc}
\hline Época de & ETm & \multicolumn{7}{c}{ ETr $(\mathrm{mm})$} \\
\cline { 3 - 9 } Semeadura & $(\mathrm{mm})$ & 0,2 & 0,3 & 0,4 & 0,5 & 0,6 & 0,7 & 0,8 & Média \\
\hline 1 - Jan & 211,2 & 196,0 & 190,1 & 184,1 & 178,7 & 174,9 & 171,3 & 168,3 & 180,5 \\
15 - Jan & 209,9 & 196,7 & 191,0 & 185,8 & 181,1 & 177,8 & 174,6 & 172,1 & 182,7 \\
1 - Fev & 206,6 & 194,6 & 189,2 & 184,9 & 180,8 & 178,3 & 175,8 & 174,0 & 182,5 \\
15 - Fev & 203,9 & 192,1 & 187,0 & 182,9 & 179,0 & 176,7 & 174,5 & 172,8 & 180,7 \\
1 - Mar & 199,4 & 187,5 & 182,2 & 178,0 & 174,7 & 172,2 & 169,8 & 167,8 & 176,0 \\
15 - Mar & 196,5 & 183,7 & 177,4 & 173,1 & 168,6 & 165,1 & 162,3 & 159,8 & 170,0 \\
1 - Abr & 196,5 & 182,5 & 175,4 & 170,1 & 164,6 & 160,1 & 156,4 & 152,9 & 166,0 \\
15 - Abr & 197,2 & 181,7 & 173,7 & 167,5 & 160,8 & 155,4 & 150,6 & 145,7 & 162,2 \\
1 - Mai & 199,4 & 182,9 & 174,0 & 167,4 & 160,0 & 153,6 & 148,3 & 142,7 & 161,3 \\
15 - Mai & 205,9 & 188,5 & 179,7 & 171,5 & 163,0 & 156,4 & 149,7 & 143,6 & 164,6 \\
1 - Jun & 216,3 & 198,3 & 189,7 & 180,2 & 171,4 & 164,0 & 156,6 & 149,9 & 172,9 \\
15 - Jun & 227,8 & 209,6 & 201,1 & 190,3 & 182,1 & 173,4 & 165,2 & 158,7 & 182,9 \\
1 - Jul & 243,7 & 225,7 & 217,0 & 205,2 & 196,8 & 187,0 & 178,7 & 170,5 & 197,3 \\
15 - Jul & 258,0 & 240,3 & 231,5 & 219,0 & 209,9 & 199,0 & 191,0 & 181,2 & 210,3 \\
1 - Ago & 271,4 & 254,2 & 245,0 & 233,1 & 222,2 & 211,9 & 203,0 & 194,1 & 223,4 \\
15 - Ago & 280,4 & 263,7 & 254,1 & 242,5 & 230,5 & 221,5 & 211,0 & 202,5 & 232,3 \\
1 - Set & 282,6 & 266,2 & 256,4 & 245,2 & 232,7 & 223,7 & 213,5 & 205,4 & 234,7 \\
15 - Set & 279,0 & 262,4 & 252,9 & 241,2 & 229,9 & 220,9 & 210,9 & 202,4 & 231,5 \\
1 - Out & 271,6 & 254,8 & 245,6 & 234,0 & 223,6 & 213,9 & 204,8 & 196,5 & 224,7 \\
15 - Out & 261,8 & 244,9 & 236,2 & 224,5 & 215,3 & 205,9 & 197,7 & 189,6 & 216,3 \\
1 - Nov & 244,4 & 227,7 & 219,6 & 208,9 & 201,5 & 192,8 & 185,8 & 178,6 & 202,1 \\
15 - Nov & 231,4 & 215,2 & 207,4 & 198,2 & 191,1 & 184,0 & 177,4 & 171,9 & 192,2 \\
1 - Dez & 221,8 & 206,0 & 198,7 & 190,4 & 183,9 & 177,9 & 172,1 & 166,9 & 185,1 \\
15 - Dez & 213,4 & 198,3 & 191,5 & 184,4 & 178,1 & 173,3 & 168,8 & 164,4 & 179,8 \\
\hline Média & 230,4 & 214,7 & 206,9 & 198,4 & 190,8 & 184,2 & 177,9 & 172,2 & \\
\hline & & & & & & & & &
\end{tabular}


Tabela 22. Evapotranspiração máxima (ETm) e real (ETr) em função dos niveis de manejo em cada época de semeadura na cultura de melancia, no município de Parnaiba, Piauí.

\begin{tabular}{lccccccccc}
\hline Época de & ETm & \multicolumn{7}{c}{ ETr $(\mathrm{mm})$} \\
\cline { 3 - 9 } Semeadura & $(\mathrm{mm})$ & 0,2 & 0,3 & 0,4 & 0,5 & 0,6 & 0,7 & 0,8 & Média \\
\hline 1 - Jan & 253,5 & 239,1 & 232,3 & 223,6 & 216,1 & 208,9 & 202,7 & 196,6 & 217,0 \\
15 - Jan & 244,8 & 232,8 & 226,5 & 218,0 & 211,8 & 204,6 & 199,8 & 194,7 & 212,6 \\
1 - Fev & 235,2 & 223,2 & 217,5 & 209,3 & 204,2 & 198,2 & 193,4 & 188,5 & 204,9 \\
15 - Fev & 227,0 & 215,0 & 209,5 & 202,4 & 196,9 & 191,9 & 187,4 & 183,4 & 198,1 \\
1 - Mar & 222,0 & 210,2 & 204,8 & 197,8 & 192,7 & 187,5 & 183,3 & 179,7 & 193,7 \\
15 - Mar & 218,0 & 205,6 & 200,0 & 192,8 & 187,5 & 181,8 & 177,6 & 173,8 & 188,4 \\
1 - Abr & 223,3 & 210,1 & 204,3 & 195,9 & 189,6 & 183,4 & 178,1 & 173,4 & 190,7 \\
15 - Abr & 227,1 & 213,3 & 207,0 & 198,0 & 191,2 & 184,2 & 178,0 & 172,9 & 192,1 \\
1 - Mai & 233,2 & 218,5 & 212,0 & 201,6 & 194,1 & 186,0 & 179,2 & 172,6 & 194,8 \\
15 - Mai & 238,9 & 223,9 & 217,5 & 206,5 & 198,9 & 190,0 & 183,2 & 176,0 & 199,4 \\
1 - Jun & 249,7 & 234,9 & 227,9 & 216,2 & 208,2 & 198,1 & 191,0 & 182,7 & 208,4 \\
15 - Jun & 264,8 & 250,9 & 242,8 & 231,3 & 221,7 & 211,8 & 203,4 & 194,8 & 222,4 \\
1 - Jul & 283,2 & 270,8 & 260,3 & 250,2 & 238,0 & 228,6 & 218,3 & 210,1 & 239,5 \\
15 - Jul & 303,0 & 292,3 & 279,4 & 270,6 & 256,7 & 247,2 & 235,6 & 226,1 & 258,3 \\
1 - Ago & 327,4 & 319,7 & 302,5 & 294,8 & 280,1 & 268,0 & 258,6 & 245,9 & 281,4 \\
15- Ago & 342,7 & 336,8 & 316,9 & 310,3 & 296,2 & 281,7 & 273,1 & 258,6 & 296,2 \\
1 - Set & 353,9 & 349,5 & 327,3 & 321,7 & 308,5 & 291,3 & 283,5 & 269,5 & 307,3 \\
15- Set & 353,6 & 349,1 & 327,2 & 321,4 & 308,5 & 292,1 & 283,3 & 269,4 & 307,3 \\
1 - Out & 351,7 & 347,0 & 325,4 & 319,6 & 306,7 & 289,7 & 281,9 & 267,8 & 305,4 \\
15- Out & 343,8 & 338,0 & 318,3 & 311,6 & 297,8 & 283,3 & 274,8 & 260,5 & 297,7 \\
1 - Nov & 322,0 & 313,3 & 298,3 & 290,0 & 276,8 & 265,7 & 255,2 & 244,6 & 277,7 \\
15- Nov & 302,4 & 292,3 & 280,0 & 271,4 & 259,2 & 249,7 & 240,1 & 230,8 & 260,5 \\
1 - Dez & 286,5 & 275,4 & 265,0 & 256,0 & 245,1 & 236,3 & 227,6 & 219,1 & 246,4 \\
15- Dez & 265,9 & 253,9 & 245,5 & 236,4 & 227,8 & 219,6 & 212,2 & 205,1 & 228,6 \\
\hline Média & 278,1 & 267,3 & 256,2 & 247,8 & 238,1 & 228,3 & 220,9 & 212,3 & \\
\hline & & & & & & & & &
\end{tabular}


Tabela 23. Evapotranspiração máxima (ETm) e real (ETr) em função dos niveis de manejo em cada época de semeadura na cultura de melancia, no município de Teresina, Piaui.

\begin{tabular}{|c|c|c|c|c|c|c|c|c|c|}
\hline \multirow{2}{*}{$\begin{array}{l}\text { Época de } \\
\text { Semeadura }\end{array}$} & \multirow{2}{*}{$\begin{array}{l}\text { ETm } \\
(\mathrm{mm})\end{array}$} & \multicolumn{8}{|c|}{$\mathrm{ETr}(\mathrm{mm})$} \\
\hline & & 0,2 & 0,3 & 0,4 & 0,5 & 0,6 & 0,7 & 0,8 & Média \\
\hline 1 - Jan & 210,6 & 195,8 & 188,6 & 183,3 & 177,9 & 173,7 & 170,4 & 167,3 & 179,6 \\
\hline $15-$ Jan & 209,2 & 196,9 & 190,1 & 185,2 & 180,7 & 177,1 & 174,2 & 171,7 & 182,3 \\
\hline $1-\mathrm{Fev}$ & 206,0 & 194,6 & 188,3 & 184,3 & 180,7 & 177,5 & 175,2 & 173,5 & 182,0 \\
\hline $15-\mathrm{Fev}$ & 203,4 & 192,3 & 186,3 & 182,4 & 178,8 & 176,1 & 174,1 & 172,6 & 180,4 \\
\hline 1 - Mar & 198,8 & 187,6 & 181,5 & 177,4 & 174,3 & 171,7 & 169,3 & 167,6 & 175,6 \\
\hline 15 - Mar & 195,9 & 183,8 & 177,0 & 172,0 & 168,5 & 164,9 & 161,9 & 159,3 & 169,6 \\
\hline $1-\mathrm{Abr}$ & 195,9 & 182,6 & 174,8 & 169,1 & 164,4 & 159,8 & 155,8 & 152,4 & 165,6 \\
\hline $15-\mathrm{Abr}$ & 196,7 & 182,1 & 173,3 & 166,2 & 160,7 & 155,4 & 150,1 & 145,2 & 161,9 \\
\hline 1 - Mai & 198,9 & 183,3 & 173,4 & 166,1 & 160,0 & 153,4 & 147,4 & 142,0 & 160,8 \\
\hline 15 - Mai & 205,3 & 189,0 & 178,3 & 170,6 & 163,0 & 155,5 & 148,9 & 143,0 & 164,1 \\
\hline 1 - Jun & 215,6 & 198,8 & 188,3 & 180,2 & 171,3 & 163,0 & 156,2 & 149,1 & 172,4 \\
\hline 15 - Jun & 227,1 & 209,9 & 199,8 & 190,8 & 181,1 & 172,7 & 165,1 & 157,5 & 182,4 \\
\hline $1-\mathrm{Jul}$ & 243,1 & 225,4 & 216,5 & 205,4 & 195,1 & 187,0 & 177,7 & 170,0 & 196,7 \\
\hline $15-\mathrm{Jul}$ & 257,2 & 239,0 & 231,2 & 218,4 & 208,9 & 199,3 & 189,5 & 181,8 & 209,7 \\
\hline 1 - Ago & 270,6 & 252,2 & 245,3 & 231,2 & 222,5 & 211,0 & 202,3 & 193,4 & 222,5 \\
\hline 15 - Ago & 279,5 & 261,4 & 254,5 & 239,9 & 231,3 & 219,0 & 211,1 & 200,1 & 231,0 \\
\hline 1 - Set & 281,7 & 264,0 & 256,7 & 242,4 & 233,8 & 221,8 & 213,5 & 203,1 & 233,6 \\
\hline 15 - Set & 278,1 & 260,3 & 253,1 & 239,2 & 230,9 & 219,1 & 210,9 & 200,8 & 230,6 \\
\hline 1 - Out & 270,8 & 253,2 & 245,8 & 232,2 & 223,8 & 212,6 & 204,3 & 195,4 & 223,9 \\
\hline 15 - Out & 261,1 & 243,9 & 236,0 & 223,6 & 214,9 & 205,2 & 196,7 & 189,1 & 215,6 \\
\hline 1 - Nov & 243,8 & 227,3 & 219,1 & 209,0 & 200,4 & 192,3 & 184,9 & 178,0 & 201,6 \\
\hline 15 - Nov & 230,8 & 215,2 & 206,8 & 198,3 & 190,6 & 183,6 & 176,9 & 171,3 & 191,8 \\
\hline $1-$ Dez & 221,2 & 206,1 & 197,7 & 190,3 & 183,3 & 177,1 & 172,0 & 166,4 & 184,7 \\
\hline $15-\mathrm{Dez}$ & 212,8 & 198,6 & 190,3 & 184,3 & 177,9 & 172,5 & 168,0 & 163,9 & 179,3 \\
\hline Média & 229,8 & 214,3 & 206,4 & 197,6 & 190,6 & 183,4 & 177,3 & 171,4 & \\
\hline
\end{tabular}


Tabela 24. Produtividade de grãos de feijão caupi em função dos níveis de manejo de irrigação em cada época de semeadura, no município de Parnaíba, Piauí.

\begin{tabular}{lcccccccc}
\hline Época de & \multicolumn{7}{c}{ Produtividade $\left(\mathrm{kg} \mathrm{ha}^{-1}\right)$} \\
\cline { 2 - 8 } Semeadura & 0,2 & 0,3 & 0,4 & 0,5 & 0,6 & 0,7 & 0,8 & Média \\
\hline 1 - Jan & 2287,1 & 2162,0 & 2057,2 & 1934,0 & 1840,2 & 1742,2 & 1662,9 & 1955,1 \\
15 - Jan & 2309,6 & 2195,8 & 2078,9 & 1966,8 & 1868,5 & 1776,7 & 1707,1 & 1986,2 \\
1 - Fev & 2302,9 & 2196,1 & 2074,6 & 1978,5 & 1885,9 & 1806,1 & 1731,0 & 1996,5 \\
15 - Fev & 2293,8 & 2197,6 & 2068,8 & 1981,2 & 1891,0 & 1829,9 & 1749,8 & 2001,7 \\
1 - Mar & 2291,5 & 2199,1 & 2067,9 & 1987,6 & 1894,6 & 1824,0 & 1755,0 & 2002,8 \\
15 - Mar & 2272,6 & 2182,8 & 2040,2 & 1952,2 & 1851,3 & 1778,0 & 1702,0 & 1968,4 \\
1 - Abr & 2273,3 & 2168,0 & 2019,0 & 1924,5 & 1803,6 & 1728,9 & 1640,7 & 1936,9 \\
15 - Abr & 2265,4 & 2151,7 & 1997,2 & 1888,9 & 1763,1 & 1676,1 & 1578,1 & 1902,9 \\
1 - Mai & 2261,6 & 2140,7 & 1977,7 & 1853,6 & 1732,0 & 1625,9 & 1517,6 & 1872,7 \\
15 - Mai & 2268,2 & 2139,4 & 1989,4 & 1849,1 & 1728,7 & 1618,6 & 1510,2 & 1872,0 \\
1 - Jun & 2283,3 & 2144,8 & 2005,7 & 1843,8 & 1742,4 & 1600,5 & 1510,6 & 1875,9 \\
15 - Jun & 2309,4 & 2148,5 & 2036,2 & 1846,2 & 1762,2 & 1615,3 & 1520,7 & 1891,2 \\
1 - Jul & 2335,3 & 2154,6 & 2059,1 & 1874,7 & 1763,1 & 1639,5 & 1522,5 & 1907,0 \\
15 - Jul & 2361,9 & 2166,7 & 2076,4 & 1924,5 & 1767,4 & 1677,3 & 1529,0 & 1929,0 \\
1 - Ago & 2391,8 & 2185,4 & 2088,7 & 1978,5 & 1775,1 & 1694,1 & 1577,5 & 1955,9 \\
15 - Ago & 2411,5 & 2206,4 & 2098,0 & 2005,2 & 1800,5 & 1691,4 & 1613,2 & 1975,2 \\
1 - Set & 2420,8 & 2223,5 & 2098,9 & 2020,7 & 1826,5 & 1689,9 & 1642,9 & 1989,0 \\
15 - Set & 2423,4 & 2219,6 & 2101,4 & 2023,0 & 1828,7 & 1697,9 & 1642,7 & 1991,0 \\
1 - Out & 2417,6 & 2223,4 & 2101,2 & 2018,2 & 1821,2 & 1695,4 & 1641,5 & 1988,3 \\
15 - Out & 2412,4 & 2206,6 & 2300,8 & 2013,5 & 1809,2 & 1699,7 & 1629,2 & 1981,6 \\
1 - Nov & 2382,2 & 2196,2 & 2095,5 & 1967,4 & 1801,9 & 1706,4 & 1589,7 & 1962,7 \\
15 - Nov & 2358,4 & 2188,5 & 2091,0 & 1948,5 & 1808,2 & 1717,3 & 1595,1 & 1958,1 \\
1 - Dez & 2338,1 & 2180,7 & 2078,5 & 1929,9 & 1811,6 & 1708,2 & 1599,3 & 1949,5 \\
15 - Dez & 2322,5 & 2176,4 & 2075,1 & 1928,4 & 1826,6 & 1716,1 & 1627,6 & 1953,2 \\
\hline Média & 2333,1 & 2181,4 & 2061,5 & 1943,3 & 1808,5 & 1706,5 & 1616,5 & \\
\hline & & & & & & & & \\
\hline
\end{tabular}


Tabela 25. Produtividade de grãos de feijão caupi em função dos niveis de manejo de irrigação em cada época de semeadura, no município de Teresina, Piauí.

\begin{tabular}{lcccccccc}
\hline Época de & \multicolumn{7}{c}{ Produtividade $\left(\mathrm{kg} \mathrm{ha}^{-1}\right)$} \\
\cline { 2 - 8 } Semeadura & 0,2 & 0,3 & 0,4 & 0,5 & 0,6 & 0,7 & 0,8 & Média \\
\hline 1 - Jan & 2220,1 & 2120,8 & 2007,7 & 1900,3 & 1836,8 & 1766,0 & 1709,0 & 1937,2 \\
15 - Jan & 2257,7 & 2160,8 & 2061,4 & 1970,7 & 1906,5 & 1844,2 & 1795,4 & 1999,5 \\
1 - Fev & 2276,1 & 2182,8 & 2095,8 & 2015,4 & 1971,3 & 1918,3 & 1881,3 & 2048,7 \\
15 - Fev & 2275,0 & 2181,2 & 2100,8 & 2024,1 & 1983,2 & 1939,5 & 1903,9 & 2058,2 \\
1 - Mar & 2270,2 & 2171,0 & 2088,5 & 2016,7 & 1966,8 & 1915,4 & 1875,0 & 2043,4 \\
15 - Mar & 2251,5 & 2125,6 & 2046,8 & 1942,1 & 1872,7 & 1818,6 & 1763,0 & 1974,3 \\
1 - Abr & 2228,8 & 2091,4 & 1999,8 & 1882,6 & 1798,8 & 1729,9 & 1661,9 & 1913,3 \\
15 - Abr & 2204,3 & 2048,0 & 1939,8 & 1808,9 & 1701,7 & 1614,3 & 1535,0 & 1836,0 \\
1 - Mai & 2187,2 & 2019,5 & 1905,0 & 1759,8 & 1647,0 & 1564,4 & 1455,8 & 1791,3 \\
15 - Mai & 2177,7 & 2025,5 & 1881,5 & 1724,1 & 1621,2 & 1505,1 & 1407,5 & 1763,2 \\
1 - Jun & 2180,3 & 2042,9 & 1874,2 & 1721,6 & 1618,9 & 1494,6 & 1386,8 & 1759,9 \\
15 - Jun & 2190,8 & 2066,0 & 1875,1 & 1743,3 & 1612,4 & 1490,9 & 1394,5 & 1767,6 \\
1 - Jul & 2211,5 & 2091,2 & 1889,8 & 1777,5 & 1634,9 & 1523,5 & 1410,9 & 1791,3 \\
15 - Jul & 2233,2 & 2110,9 & 1915,1 & 1804,4 & 1636,3 & 1543,1 & 1412,7 & 1807,9 \\
1 - Ago & 2259,3 & 2128,3 & 1960,0 & 1813,0 & 1674,1 & 1556,1 & 1446,9 & 1834,0 \\
15 - Ago & 2275,2 & 2136,2 & 1994,5 & 1820,3 & 1717,5 & 1576,7 & 1488,2 & 1858,4 \\
1 - Set & 2280,6 & 2137,5 & 1999,5 & 1823,2 & 1717,6 & 1577,1 & 1500,9 & 1862,3 \\
15 - Set & 2273,4 & 2135,2 & 1984,8 & 1825,0 & 1716,8 & 1583,1 & 1491,7 & 1858,6 \\
1 - Out & 2257,6 & 2128,5 & 1967,3 & 1826,4 & 1698,7 & 1574,6 & 1472,1 & 1846,5 \\
15 - Out & 2245,1 & 2127,7 & 1944,1 & 1827,7 & 1685,8 & 1583,2 & 1473,0 & 1840,9 \\
1 - Nov & 2231,1 & 2116,2 & 1937,2 & 1830,6 & 1694,5 & 1599,2 & 1495,2 & 1843,4 \\
15 - Nov & 2225,2 & 2109,2 & 1950,0 & 1842,0 & 1728,6 & 1627,9 & 1548,3 & 1861,6 \\
1 - Dez & 2221,8 & 2106,0 & 1957,8 & 1841,6 & 1744,0 & 1645,3 & 1564,4 & 1868,7 \\
15 - Dez & 2227,0 & 2112,3 & 1975,8 & 1864,6 & 1786,0 & 1697,1 & 1622,4 & 1897,9 \\
\hline Média & 2235,9 & 2111,4 & 1973,0 & 1850,2 & 1748,8 & 1653,7 & 1570,7 & \\
\hline & & & & & & & & \\
\hline
\end{tabular}


Tabela 26. Produtividade de frutos de melancia em função dos níveis de manejo de irrigação em cada época de semeadura, no município de Parnaíba, Piauí.

\begin{tabular}{|c|c|c|c|c|c|c|c|c|}
\hline \multirow{2}{*}{$\begin{array}{l}\text { Época de } \\
\text { Semeadura }\end{array}$} & \multicolumn{8}{|c|}{ Produtividade $\left(\mathrm{kg} \mathrm{ha}^{-1}\right)$} \\
\hline & 0,2 & 0,3 & 0,4 & 0,5 & 0,6 & 0,7 & 0,8 & Média \\
\hline $1-\operatorname{Jan}$ & 43552,7 & 40743,4 & 37257,3 & 34515,7 & 31812,6 & 29701,0 & 27604,2 & 35026,7 \\
\hline $15-\mathrm{Jan}$ & 44329,4 & 41579,9 & 37886,8 & 35407,5 & 32773,1 & 30958,0 & 29087,7 & 36003,2 \\
\hline $1-\mathrm{Fev}$ & 44203,8 & 41562,0 & 37977,0 & 35778,8 & 33420,2 & 31472,3 & 29683,5 & 36299,7 \\
\hline $15-\mathrm{Fev}$ & 44061,5 & 41385,8 & 38140,9 & 35674,9 & 33719,1 & 31784,2 & 30174,4 & 36420,1 \\
\hline 1 - Mar & 44108,6 & 41399,6 & 38124,5 & 35784,5 & 33652,7 & 31787,0 & 30395,1 & 36464,6 \\
\hline $15-\mathrm{Mar}$ & 43745,8 & 40897,4 & 37528,4 & 35123,5 & 32737,4 & 30918,4 & 29310,1 & 35751,6 \\
\hline $1-\mathrm{Abr}$ & 43513,0 & 40633,5 & 36795,5 & 33989,4 & 31534,7 & 29309,5 & 27577,9 & 34764,8 \\
\hline $15-\mathrm{Abr}$ & 43262,9 & 40248,7 & 36174,0 & 33306,1 & 30578,6 & 28080,6 & 26297,2 & 33992,6 \\
\hline 1- Mai & 43041,7 & 40050,6 & 35478,3 & 32442,5 & 29482,1 & 26873,8 & 24741,9 & 33158,7 \\
\hline 15 - Mai & 43039,6 & 40120,3 & 35468,1 & 32526,2 & $.29197,6$ & 26870,5 & 24445,6 & 33095,4 \\
\hline 1 - Jun & 43297,0 & 40375,4 & 35541,8 & 32661,0 & 28967,3 & 26795,2 & 24020,2 & 33094,0 \\
\hline 15 - Jun & 43891,0 & 40720,6 & 36197,6 & 32907,4 & 29517,8 & 26888,7 & 24244,1 & 33481,0 \\
\hline $1-\mathrm{Jul}$ & 44668,3 & 40988,6 & 37154,9 & 33022,9 & 30100,4 & 26961,0 & 24684,3 & 33940,1 \\
\hline $15-\mathrm{Jul}$ & 45546,1 & 41298,2 & 38118,3 & 33490,3 & 30876,8 & 27384,8 & 25029,8 & 34534,9 \\
\hline 1 - Ago & 46923,8 & 41471,5 & 38868,6 & 34315,3 & 31030,0 & 28523,1 & 25205,2 & 35191,1 \\
\hline 15 - Ago & 47644,4 & 41537,5 & 39354,6 & 35144,5 & 31290,4 & 29152,6 & 25396,6 & 35645,8 \\
\hline 1 - Set & 48167,5 & 41506,9 & 39597,4 & 36089,0 & 31382,5 & 29614,6 & 25906,1 & 36037,7 \\
\hline 15 - Set & 48172,6 & 41600,5 & 39619,4 & 36054,6 & 31582,7 & 29572,2 & 25989,7 & 36084,5 \\
\hline 1 - Out & 48014,4 & 41577,2 & 39585,1 & 36034,9 & 31419,7 & 29570,2 & 25904,3 & 36015,1 \\
\hline 15 - Out & 47687,7 & 41623,1 & 39445,9 & 35333,2 & 31419,0 & 29323,9 & 25667,3 & 35785,7 \\
\hline $1-\mathrm{Nov}$ & 46332,0 & 41701,1 & 38761,8 & 34612,4 & 31501,7 & 28608,9 & 25834,6 & 35336,1 \\
\hline 15 - Nov & 45622,7 & 41580,7 & 38456,4 & 34363,6 & $3.1563,0$ & 28638,6 & 26166,3 & 35198,8 \\
\hline $1-$ Dez & 45034,4 & 41440,0 & 37981,1 & 34227,6 & 31434,1 & 28770,7 & 26322,5 & 35030,1 \\
\hline $15-\mathrm{Dez}$ & 44518,3 & 41333,0 & 37650,9 & 34489,4 & 31679,7 & 29192,5 & 27023,4 & 35126,7 \\
\hline Média & 45099,1 & 41140,6 & 37798,5 & 34470,6 & 31361,4 & 29031,4 & 26529,7 & \\
\hline
\end{tabular}


Tabela 27. Produtividade de frutos de melancia em função dos niveis de manejo de irrigação em cada época de semeadura, no municipio de Teresina, Piaui.

\begin{tabular}{|c|c|c|c|c|c|c|c|c|}
\hline \multirow{2}{*}{$\begin{array}{c}\text { Época de } \\
\text { Semeadura }\end{array}$} & \multicolumn{8}{|c|}{ Produtividade $\left(\mathrm{kg} \mathrm{ha}^{-1}\right)$} \\
\hline & 0,2 & 0,3 & 0,4 & 0,5 & 0,6 & 0,7 & 0,8 & Média \\
\hline 1 - Jan & 42532,8 & 38892,6 & 36433,1 & 33971,2 & 32088,6 & 30692,1 & 29416,6 & 34861,0 \\
\hline $15-\mathrm{Jan}$ & 43583,8 & 40054,5 & 37802,7 & 35707,9 & 33985,0 & 32622,0 & 31569,4 & 36475,0 \\
\hline 1 - Fev & 43947,5 & 40656,0 & 38709,3 & 36912,3 & 35428,6 & 34346,4 & 33524,4 & 37646,4 \\
\hline $15-\mathrm{Fev}$ & 44059,8 & 40900,6 & 38908,0 & 37154,7 & 35865,2 & 34941,0 & 34271,8 & 38014,5 \\
\hline 1 - Mar & 43848,5 & 40634,1 & 38455,3 & 36958,4 & 35623,2 & 34402,6 & 33615,9 & 37648,3 \\
\hline $15-\mathrm{Mar}$ & 43303,1 & 39654,3 & 37079,7 & 35312,7 & 33533,4 & 32097,3 & 30883,3 & 35980,5 \\
\hline $1-A b r$ & 42677,8 & 38585,8 & 35694,1 & 33421,2 & 31280,1 & 29482,4 & 27999,6 & 34163,0 \\
\hline $15-\mathrm{Abr}$ & 42115,9 & 37479,5 & 34008,8 & 31497,0 & 29157,0 & 26913,0 & 24965,3 & 32305,2 \\
\hline 1 - Mai & 41613,6 & 36619,7 & 33037,6 & 30385,9 & 27644,0 & 25204,5 & 23094,6 & 3108 \\
\hline $15-\mathrm{Mai}$ & & 36182,4 & 32655,2 & 29531,7 & 26440,7 & 23954,7 & & \\
\hline 1 - Jun & 41556,6 & 36562,9 & 33014,4 & 29415,3 & 26194,8 & 23815,9 & 21517,4 & 30296,8 \\
\hline 15 - Jun & 41878,7 & 37175,5 & 33459,1 & 29552,3 & 26590,0 & 23939,9 & & \\
\hline 1 - Jul & 42132,1 & 38244,1 & 33818,9 & 29878,4 & 27202,5 & 24121,2 & 21793,7 & 31027,3 \\
\hline $15-J u l$ & 42276,6 & 39070,9 & 34106,5 & 30740,5 & 27303,0 & 24497,1 & 22499,5 & 31556,3 \\
\hline 1 - Ago & & 39813,0 & 34523,3 & & & & & \\
\hline $15-$ Ago & 42803,0 & 40180,0 & 34835,1 & 32186,0 & 28185,5 & 25962,0 & 22874,0 & 32432,2 \\
\hline 1 - Set & 42956,5 & 40249,5 & 35037,9 & 32353,1 & 28453,0 & 26120,5 & 23244,6 & 32630,7 \\
\hline $15-$ Set & 42878,6 & 40091,5 & 35012,8 & 32356,7 & $285.12,2$ & 26248,2 & & 32639,4 \\
\hline 1 - Out & 42778,4 & 39892,6 & 34823,6 & 31983,0 & 28363,1 & 25876,8 & 23303,3 & 32431,5 \\
\hline $15-$ Out & 42706,2 & 39487,7 & 34798,1 & 31650,0 & 28452,2 & 25741,7 & 23633,8 & 32352,8 \\
\hline 1 - Nov & 42568,9 & 38952,0 & 34902,3 & 31521,1 & 28697,0 & 26138,6 & 23977,4 & 32393,9 \\
\hline $15-$ Nov & 42634,4 & 38697,3 & 35206,3 & 32031,2 & 29367,8 & 26992,3 & 25121,7 & 32864,4 \\
\hline 1 - Dez & 42575,2 & 38515,1 & 35316,7 & 32273,0 & 29750,4 & 27761,7 & 25681,4 & 33124,8 \\
\hline $15-\mathrm{Dez}$ & 42802,7 & 38619,7 & 35879,1 & 33022,9 & 30700,9 & 28870,2 & 27246,5 & 33877,4 \\
\hline Média & 42678,6 & 38967,1 & 35313,3 & 32561,1 & 29879,9 & 27756,7 & 25836,8 & \\
\hline
\end{tabular}


Em termos de precipitação efetiva $(\mathrm{Pe})$, constatou-se que os valores observados em Teresina (Tabela 17), à exceção do período referente as épocas de semeadura de 15Mai a 15-Jul, foram superiores aos obtidos em Parnaiba (Tabela 16), indicando que em Teresina houve uma melhor contribuição da variável precipitação pluviométrica nos balanços hídricos efetuados, notadamente durante a estação chuvosa. Essa contribuição tornou-se mais relevante na expressão final da produtividade das culturas quando da realização dos balanços hídricos sem o uso da irrigação.

A superioridade dos valores de $\mathrm{Pe}$ em Teresina em relação à Pamaíba pode ser justificada pelos maiores valores de precipitação pluviométrica total observados neste município (Tabela 28), uma vez que o escoamento superficial, definido pelo número curva de escoamento selecionado, não diferiu substancialmente nos dois locais, devido os solos estudados apresentarem composição granulométrica e textura semelhantes (Tabela 2).

Historicamente, a precipitação pluviométrica média anual de Teresina é superior à de Parnaiba (1.300 mm, em Teresina e $1.000 \mathrm{~mm}$, em Parnaíba) (Tabela 28). Além disso, o regime de precipitações pluviométricas em Teresina abrange o período compreendido entre os meses de dezembro a março (Medeiros, 1996), justificando a superioridade dos valores de Pe nessa época do ano. Por outro lado, o regime de precipitações pluviométricas em Parnaiba inicia-se mais tardiamente (janeiro) e prolonga-se até os meses de maio a junho (Medeiros, 1996), proporcionando a ocorrência de maiores valores de Pe em relação à Teresina, no período compreendido pelas épocas de semeadura de 15-Mai a 15-Jul.

Quanto à evapotranspiração máxima (ETm) das culturas de feijão caupi e melancia, a variação ocorrida nos dois municípios foi contrária a apresentada pela precipitação pluviométrica. Em ambas as culturas, es valores de ETm em Parnaíba foram maiores que os estimados para Teresina. Esse comportamento é reflexo da variação ocorrida na estimativa dos valores de evapotranspiração de referência (ETo), pois usou-se os mesmos valores de Kc para as culturas de feijão caupi e melancia nos dois locais. 
Tabela 28. Médias mensais de precipitação pluviométrica (P), evapotranspiração de referência (ETo), temperatura $(\mathrm{T})$, umidade relativa (UR), velocidade do vento (U) e insolação (n) referentes à série histórica de observações em Parnaiba e Teresina, Piauí.

\begin{tabular}{|c|c|c|c|c|c|c|}
\hline Mês & $\begin{array}{c}\mathrm{P} \\
(\mathrm{mm})\end{array}$ & $\begin{array}{l}\text { ETo } \\
(\mathrm{mm})\end{array}$ & $\begin{array}{c}\mathrm{T} \\
\left({ }^{\circ} \mathrm{C}\right) \\
\end{array}$ & $\begin{array}{l}\text { UR } \\
(\%) \\
\end{array}$ & $\begin{array}{c}\mathrm{U} \\
\left(\mathrm{m} \mathrm{s}^{-1}\right)\end{array}$ & $\begin{array}{c}\mathrm{n} \\
(\mathrm{h}) \\
\end{array}$ \\
\hline \multicolumn{7}{|c|}{ Parnaíba } \\
\hline Janeiro & 128,8 & 157,4 & 28,0 & 76 & 2,9 & 6,3 \\
\hline Fevereiro & 162,4 & 136,2 & 27,4 & 80 & 2,3 & 6,5 \\
\hline Março & 212,3 & 137,1 & 27,1 & 83 & 1,9 & 5,6 \\
\hline Abril & 211,0 & 130,0 & 27,2 & 85 & 1,9 & 6,4 \\
\hline Maio & 140,0 & 137,7 & 27,2 & 82 & 1,9 & 7,6 \\
\hline Junho & 36,0 & 139,3 & 27,3 & 77 & 2,1 & 8,3 \\
\hline Julho & 33,5 & 152,8 & 27,2 & 74 & 2,3 & 8,8 \\
\hline Agosto & 2,1 & 182,7 & 28,0 & 70 & 3,3 & 9,7 \\
\hline Setembro & 0,1 & 202,9 & 28,7 & 67 & 4,3 & 9,7 \\
\hline Outubro & 0,0 & 218,7 & 29,0 & 67 & 4,6 & 9,7 \\
\hline Novembro & 7,0 & 199,7 & 28,9 & 68 & 4,5 & 8,8 \\
\hline Dezembro & 34,1 & 194,8 & 28,8 & 69 & 4,1 & 8,3 \\
\hline & 967,3 & 1989,3 & 27,9 & 75 & 3,0 & 8,0 \\
\hline \multicolumn{7}{|c|}{ Teresina } \\
\hline Janeiro & 214,2 & 125,6 & 27,4 & 78 & 1,3 & 5,9 \\
\hline Fevereiro & 217,9 & 113,1 & 27,2 & 80 & 1,3 & 5,8 \\
\hline Março & 314,2 & 123,9 & 27,3 & 82 & 1,3 & 5,8 \\
\hline Abril & 236,5 & 116,5 & 27,5 & 82 & 1,3 & 6,5 \\
\hline Maio & 104,8 & 118,5 & 27,4 & 79 & 1,3 & 7,6 \\
\hline Junho & 22,1 & 119,4 & 27,0 & 72 & 1,6 & 8,9 \\
\hline Julho & 14,2 & 134,7 & 27,2 & 65 & 1,8 & 9,3 \\
\hline Agosto & 4,2 & 157,9 & 28,6 & 58 & 1,9 & 9,7 \\
\hline Setembro & 12,7 & 169,5 & 29,8 & 54 & 1,9 & 9,4 \\
\hline Outubro & 18,4 & 176,7 & 30,3 & 55 & 1,9 & 8,5 \\
\hline Novembro & 44,3 & 157,9 & 29,4 & 60 & 1,7 & 7,8 \\
\hline \multirow[t]{2}{*}{ Dezembro } & 97,7 & 144,4 & 28,6 & 67 & 1,6 & 6,6 \\
\hline & 1301,2 & 1658,1 & 28,1 & 69 & 1,6 & 7,7 \\
\hline
\end{tabular}


A Tabela 28 mostra que as médias mensais de ETo da série histórica de Parnaíba são superiores às de Teresina, devido, principalmente, às maiores médias mensais de velocidade do vento, que aumentam sobremaneira a contribuição do termo aerodinâmico da equação de Penman - Monteith e, por conseguinte, a demanda evapotranspirativa.

É importante ressaltar que a variação dos valores simulados de Pe e ETo por época de semeadura nos dois municípios mantém uma estreita relação de concordância com os dados históricos observados, reforçando os resultados relativos a boa estimativa desses elementos climáticos durante a fase de simulação.

Como conseqüência da maior demanda evapotranspirativa observada em Parnaiba, os valores de evapotranspiração real e lâmina bruta de irrigação necessária ao suprimento hídrico das culturas foram superiores aos obtidos em Teresina em todos os níveis de manejo da irrigação avaliados (Tabelas 20 a 23). Considerando-se, por exemplo, a cultura do feijão caupi e adotando-se o nível de manejo de irrigação de 50 \% da capacidade de água disponível $(\mathrm{CAD})(\mathrm{p}=0,5)$, a evapotranspiração real e as lâminas brutas de irrigação em Parnaíba foram, em média, 25,4 \% e 40,9\% superiores às obtidas em Teresina, respectivamente.

Esse comportamento é também justificado pelo fato do solo Areia Quartzosa (Parnaíba) apresentar menor CAD do que o Latossolo Amarelo (Teresina) (Figura 6), que resulta na necessidade de um maior número de irrigações em Parnaíba. A fim de ilustrar essa situação, confeccionou-se a Figura 16, que exemplifica a simulação de um balanço hídrico diário na cultura do feijão caupi semeado em plena estação seca (15-Set, em Parnaíba e 15-Ago, em Teresina), com um nível de manejo da irrigação correspondente a $50 \%$ da $\mathrm{CAD}(\mathrm{p}=0,5)$. Constatou-se nessas épocas de semeadura a necessidade da aplicação de uma lâmina bruta de irrigação de 460,4 mm (Parnaíba) e 344,9 mm (Teresina), efetuada com 25 irrigações (Parnaíba) e 16 irrigações (Teresina).

Constatou-se que as lâminas brutas de irrigação aplicadas nas culturas de feijão caupi e melancia nas épocas de semeadura compreendidas na estação chuvosa foram inferiores às aplicadas nas épocas de semeadura que abrangem a estação seca, notadamente, em Teresina (Figuras 17 e 18). Essa tendência é natural haja visto a contribuição da precipitação efetiva $(\mathrm{Pe})$ para o atendimento das exigências hídricas das 

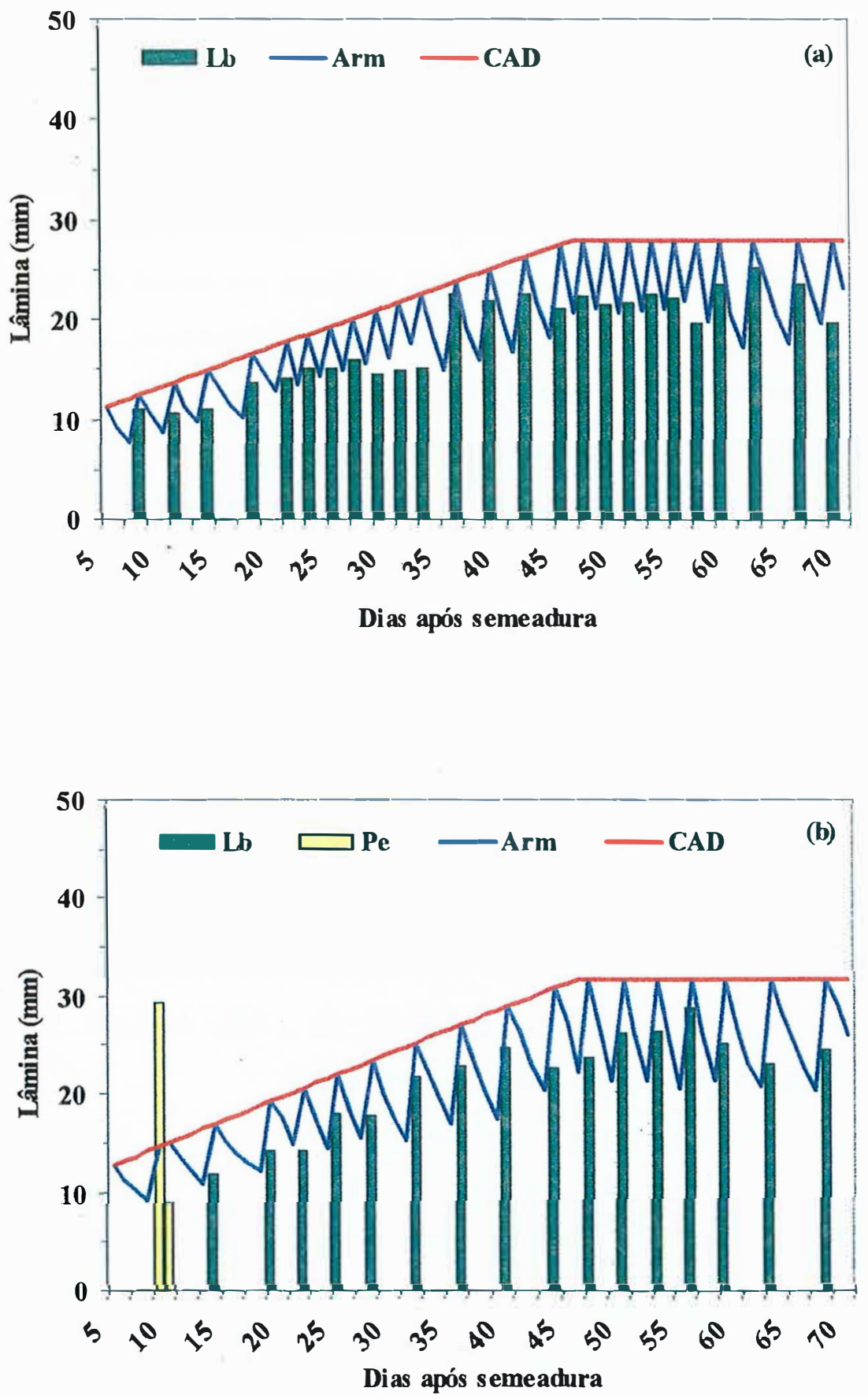

Figura 16. Simulação de balanço hídrico diário na cultura de feijão caupi em Pamaíba (a) e Teresina (b). 
culturas durante a estação chuvosa.

Ressalta-se, porém, que este fato contribuiu para uma maior dispersão entre os valores de lâminas brutas de irrigação aplicadas em função dos niveis de manejo adotados durante a estação chuvosa em comparação com a estação seca. Por outro lado, a grande proximidade entre as curvas de lâmina bruta de irrigação durante a estação seca evidencia uma baixa sensibilidade das lâminas em resposta aos níveis de manejo de irrigação adotados, como conseqüência da reduzida capacidade de retenção de água dos dois solos estudados. Por exemplo, a cultura do feijão caupi semeada em 15-Set, em Parnaiba, e com um manejo de irrigação correspondente à fração de $20 \%$ da $\mathrm{CAD}$ ( $\mathrm{p}=$ 0,2 ) consumiu uma lâmina bruta de irrigação de $465,2 \mathrm{~mm}$. Nessa mesma condição edafoclimática e época de semeadura, porém com a utilização de um manejo de irrigação referente à $80 \%$ da $\mathrm{CAD}(\mathrm{p}=0,8)$ necessitou de $452,1 \mathrm{~mm}$. Ou seja, a aplicação de 13,1 $\mathrm{mm}$ a menos durante o ciclo da cultura foi responsável pela variação de $60 \%$ na $\mathrm{CAD}$.

Em Parnaíba, os valores de lâmina bruta de irrigação simulados para a cultura do feijão caupi variaram desde $85,1 \mathrm{~mm}$, utilizando-se o nível de manejo de irrigação equivalente a $80 \%$ da $\operatorname{CAD}(p=0,8)$ associado à época de semeadura de 1-Mar, a 469,1 $\mathrm{mm}$, correspondente à utilização do nível de manejo da irrigação de $20 \%$ da CAD ( $\mathrm{p}=$ $0,2)$ na época de semeadura de 1-Set (Tabela 16). Os menores valores de lâmina bruta de irrigação foram registrados na época de semeadura de 1-Mar (estação chuvosa), enquanto os mais elevados ocorreram em 1-Set (estação seca).

Em Teresina, o intervalo de variação da lâmina bruta de irrigação foi de $28,8 \mathrm{~mm}$ $(1-\mathrm{Mar}+80 \%$ da CAD) a $360,8 \mathrm{~mm}(15-$ Ago $+20 \%$ da CAD). A ocorrência dos menores valores de lâmina bruta de irrigação foi em 1-Mar (estação chuvosa) e os maiores em 15-Ago (estação seca) (Tabela 17). Em termos médios, notadamente durante a estação seca, os valores simulados de lâmina bruta de irrigação estão próximos da faixa recomendada para a cultura (300 - $450 \mathrm{~mm}$ ), conforme apresentado nos trabalhos de Bezerra \& Freire Filho (1984), Espínola et al. (1992b), Nogueira \& Nogueira (1995), Andrade Júnior et al. (1998a), Andrade Júnior et al. (1999), Lima et al. (1999) e Bastos (1999). 

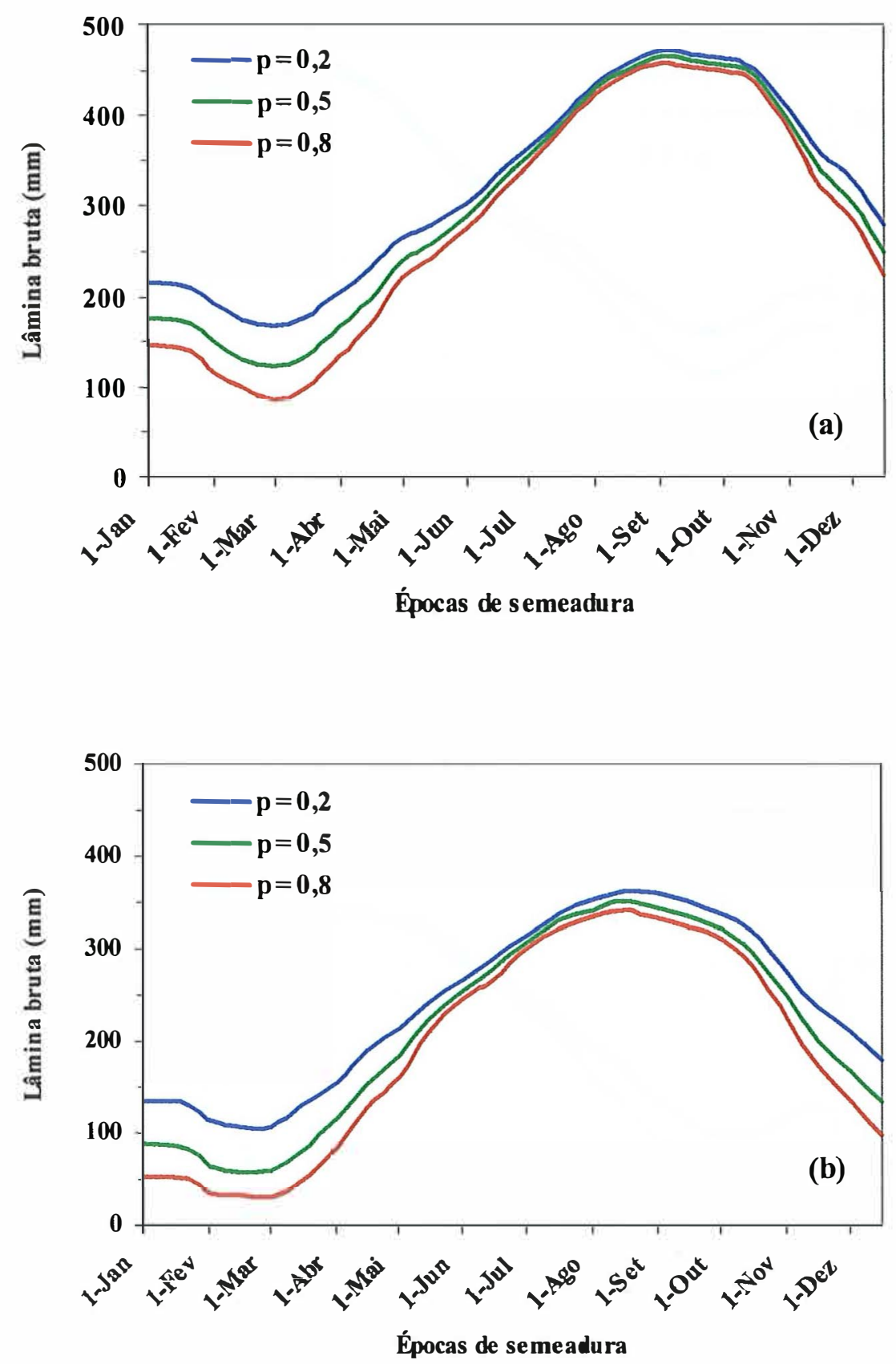

Figura 17. Lâminas brutas de irrigação para a cultura de feijão caupi em função dos níveis de manejo de irrigação em cada época de semeadura nos municípios de Parnaíba (a) e Teresina (b). 

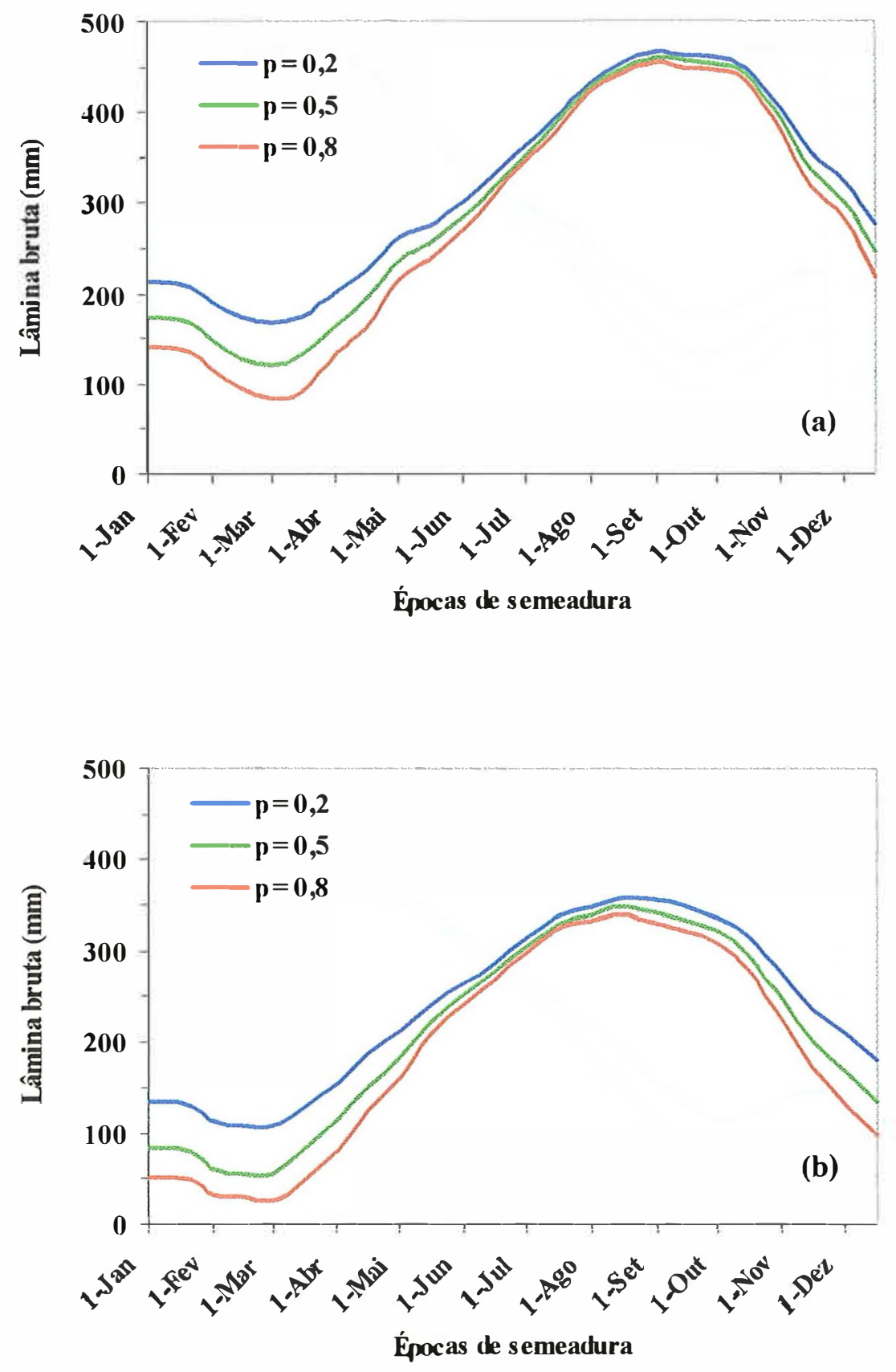

Figura 18. Lâminas brutas de irrigação para a cultura de melancia em função dos níveis de manejo de irrigação em cada época de semeadura nos municípios de Parnaíba (a) e Teresina (b). 
Com relação à cultura da melancia, em Teresina, os valores de lâminas brutas de irrigação simuladas oscilaram de 24,3 mm (1-Mar + $80 \%)$ a 357,9 mm (15-Ago + $20 \%$ da CAD) (Tabela 19). Os menores valores de lâmina bruta de irrigação ocorreram em 1Mar (estação chuvosa), enquanto os mais elevados foram registrados em 15-Ago (estação seca). Em Parnaíba, o intervalo de variação da lâmina bruta de irrigação foi de $82,6 \mathrm{~mm}(1-\mathrm{Mar}+80 \%$ da CAD) a 464,8 mm (1-Set $+20 \%$ da CAD). As menores lâminas brutas de irrigação ocorreram em 1-Mar (estação chuvosa) e os maiores em 1Set (estação seca) (Tabela 18). Durante a estação seca, onde o uso da irrigação constitui a única forma de suprimento hídrico da cultura, os valores simulados de lâmina bruta de irrigação oscilaram em torno de 350 - $450 \mathrm{~mm}$, bastante próximos dos valores considerados ideais para a cultura (Andrade Júnior et al., 1997; Andrade Júnior et al, 1998b).

A variação dos valores de evapotranspiração real (ETr) devido ao balanço de água no solo em função dos níveis de manejo de irrigação (Figuras 19 e 20) conduziu a uma condição de relativa dispersão dos valores de produtividade das culturas de feijão caupi e melancia (Tabelas 24 a 27). Esse comportamento foi reflexo da magnitude do déficit hídrico, expresso na forma do déficit de evapotranspiração relativa (Doorenbos \& Kassam, 1994), imposto às culturas durante o seu ciclo de desenvolvimento (Tabelas 29 a 32).

Ressalta-se, porém, que apesar da estimativa do déficit de evapotranspiração relativa ter sido efetuada por fase de desenvolvimento das culturas, os valores de déficit hídricos apresentados nestas tabelas representam o déficit hídrico ocorrido durante todo o ciclo, o qual proporcionou quedas de produtividade de diferentes intensidades, dependendo da fase da cultura durante a qual tenha sido verificado a sua ocorrência. Excluindo-se a condição de não uso da irrigação, constatou-se que os valores de déficit hídrico impostos não foram superiores a $50 \%$ em nenhuma das condições edafoclimáticas estudadas, o que é primordial para a adequada utilização dos valores de Ky na estimativa do rendimento das culturas. 

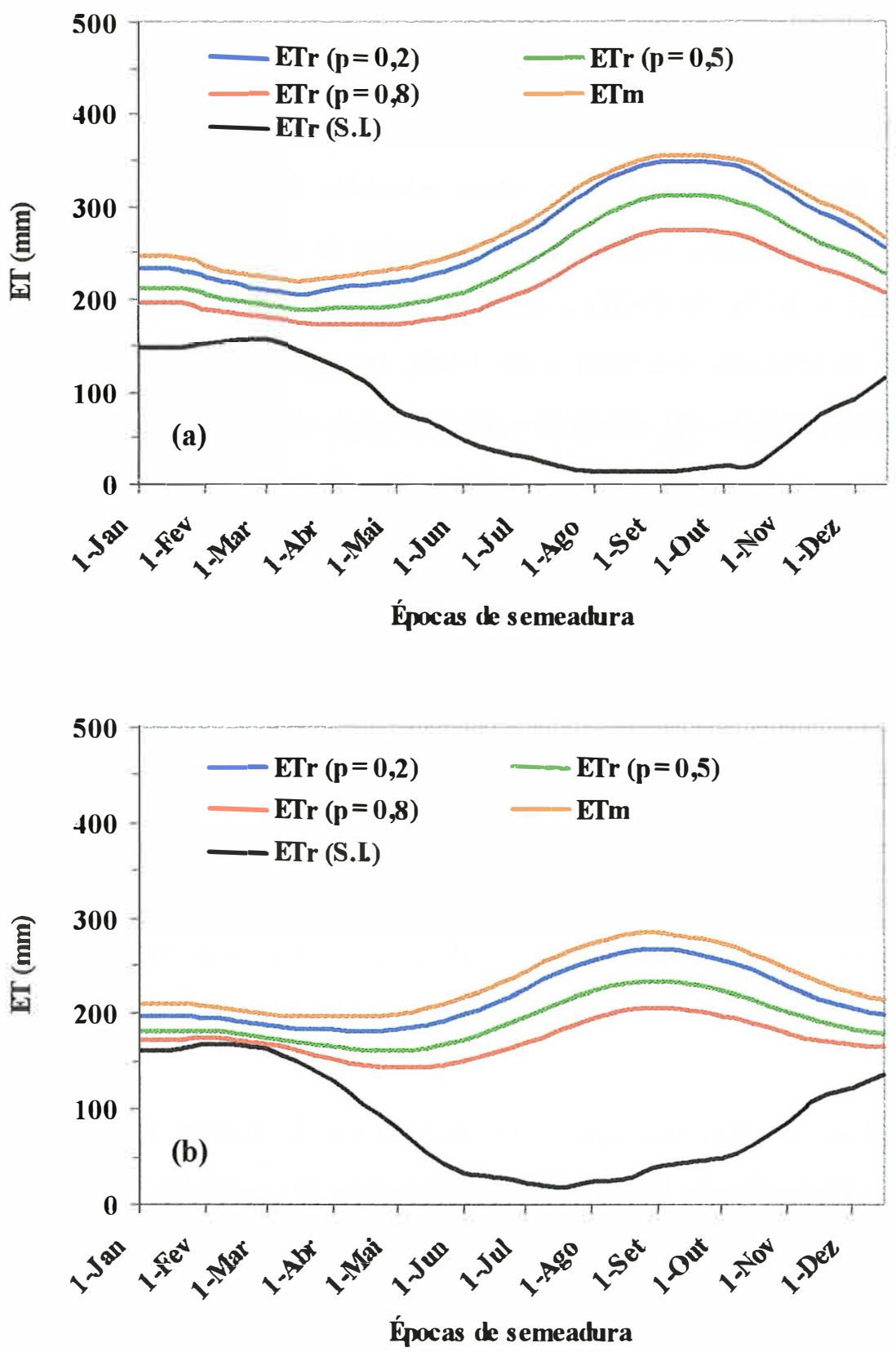

Figura 19. Evapotranspiração (ET) máxima e real da cultura de feijão caupi em função dos níveis de manejo de irrigação em cada época de semeadura nos municípios de Parnaíba (a) e Teresina (b). 

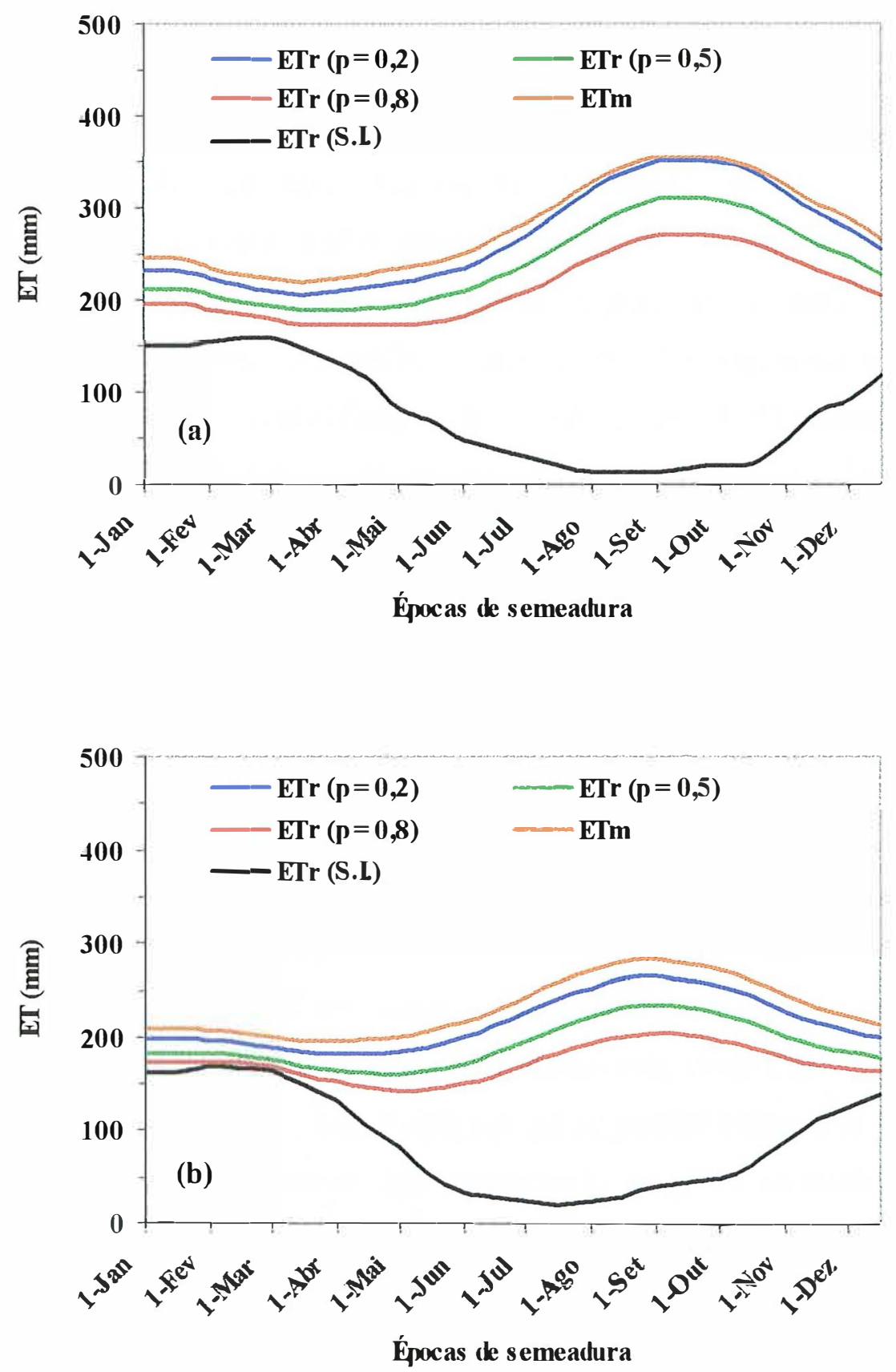

Figura 20. Evapotranspiração máxima (ETm) e real (ETr) da cultura de melancia em função dos níveis de manejo de irrigação em cada época de semeadura nos municípios de Parnaíba (a) e Teresina (b). 
A simulação dos balanços hídricos sem o uso da irrigação conduziu a elevados déficits hídricos, inclusive superiores ao limite de $50 \%$ estabelecido por Doorenbos \& Kassam (1994) para a adequada utilização dos valores de Ky na estimativa do rendimento das culturas. Entretanto, observou-se que os valores simulados de produtividade das culturas em conseqüência desses déficits hídricos aproximaram-se dos alcançados em ensaios de campo executados nessas condições edafoclimáticas, indicando que a estratégia utilizada de não obediência à recomendação efetuada por Doorenbos \& Kassam (1994) não comprometeu a qualidade dos resultados.

Em relação ao feijão caupi, os valores de produtividade da cultura foram melhores nas condições edafoclimáticas de Parnaíba do que em Teresina, em todos os níveis de manejo da irrigação (Tabelas 24 e 25), devido à cultura ter sofrido déficits hídricos de menores intensidades (Tabelas 29 e 30). Considerando-se, por exemplo, o nível de manejo de irrigação relativo a $20 \%$ da $\operatorname{CAD}(p=0,2)$, obteve-se uma produtividade média de grãos de $2.333,1 \mathrm{~kg} \mathrm{ha}^{-1}$ (Parnaíba) (Tabela 24) e de $2.235,9 \mathrm{~kg}$ $\mathrm{ha}^{-1}$ (Teresina) (Tabela 25), ou seja, um acréscimo de apenas $4,4 \%$. Para esse mesmo nível de manejo, a cultura apresentou uma ETr de 267,8 mm (Parnaíba) e de 214,7 mm (Teresina), ao passo que a ETm foi de 278,9 mm (Parnaíba) e de 230,4 mm (Teresina), ou seja, a cultura sofreu um déficit hídrico maior em Teresina $(6,8 \%)$ do que em Parnaíba (4,0\%), justificando plenamente os valores de produtividade alcançados, uma vez que usou-se os mesmos valores de Ky nos dois locais.

Para a cultura da melancia, observou-se essa mesma tendência de superioridade de produção quando semeada nas condições edafoclimáticas de Parnaíba, independentemente dos níveis de manejo da irrigação e época de semeadura. A produtividade média de frutos foi de 45:099,1 $\mathrm{kg} \mathrm{ha}^{-1}$ (Parnaíba) (Tabela 26) e de $42.678,6 \mathrm{~kg} \mathrm{ha}^{-1}$ (Teresina) (Tabela 27), quando adotou-se o nível de manejo da irrigação de $20 \%$ da $\operatorname{CAD}(p=0,2)$, representando um acréscimo de 5,7\%. Com esse nível de manejo de irrigação, a ETr da cultura foi de 267,3 mm (Parnaíba) e de 214,3 $\mathrm{mm}$ (Teresina), enquanto a ETm foi de 278,1 mm (Parnaíba) e de 229,8 mm (Teresina), induzindo a uma condição de déficit hídrico de 3,9 \% (Parnaíba) e de 6,7 \% (Teresina). 
Tabela 29. Déficits hídricos impostos à cultura de feijão caupi em função dos niveis de manejo da irrigação adotados em cada época de semeadura no município de Parnaiba, Piauí.

\begin{tabular}{|c|c|c|c|c|c|c|c|c|}
\hline \multirow{2}{*}{$\begin{array}{l}\text { Época de } \\
\text { Semeadura }\end{array}$} & \multicolumn{8}{|c|}{ Déficit hidrico (\%) } \\
\hline & 0,2 & 0,3 & 0,4 & 0,5 & 0,6 & 0,7 & 0,8 & S. I $I^{1}$ \\
\hline $1-\operatorname{Jan}$ & 5,3 & 8,5 & 11,4 & 14,7 & 17,2 & 19,8 & 22,1 & 44,5 \\
\hline $15-J a n$ & 4,8 & 7,7 & 10,7 & 13,6 & 16,1 & 18,5 & 20,4 & 39,6 \\
\hline $1-\mathrm{Fev}$ & 5,0 & 7,8 & 10,8 & 13,2 & 15,6 & 17,7 & 19,7 & 35,0 \\
\hline $15-\mathrm{Fev}$ & 5,2 & 7,7 & 10,9 & 13,2 & 15,5 & 17,2 & 19,2 & 30,8 \\
\hline 1 - Mar & 5,3 & 7,8 & 10,9 & 13,2 & 15,5 & 17,3 & 19,1 & 29,5 \\
\hline 15 - Mar & 5,7 & 8,3 & 11,5 & 14,0 & 16,5 & 18,4 & 20,3 & 33,2 \\
\hline $1-\mathrm{Abr}$ & 5,8 & 8,7 & 12,2 & 15,0 & 17,9 & 20,0 & 22,4 & 41,9 \\
\hline $15-\mathrm{Abr}$ & 5,9 & 9,0 & 12,7 & 15,7 & 18,9 & 21,4 & 24,0 & 50,1 \\
\hline 1 - Mai & 6,1 & 9,3 & 13,4 & 16,8 & 20,1 & 23,1 & 26,0 & 65,6 \\
\hline 15 - Mai & 6,0 & 9,3 & 13,2 & 16,9 & 20,1 & 23,3 & 26,2 & 71,5 \\
\hline $1-$ Jun & 5,6 & 9,1 & 12,9 & 17,0 & 20,0 & 23,6 & 26,7 & 81,0 \\
\hline 15 - Jun & 5,0 & 8,9 & 12,2 & 16,6 & 19,5 & 23,3 & 26,3 & 86,1 \\
\hline $1-\mathrm{Jul}$ & 4,3 & 8,5 & 11,5 & 15,9 & 19,2 & 22,6 & 26,1 & 89,8 \\
\hline $15-\mathrm{Jul}$ & 3,6 & 8,1 & 10,8 & 14,8 & 18,9 & 21,6 & 25,4 & 93,3 \\
\hline 1 - Ago & 2,8 & 7,6 & 10,3 & 13,7 & 18,2 & 21,1 & 24,5 & 95,8 \\
\hline 15 - Ago & 2,2 & 7,2 & 9,9 & 13,1 & 17,6 & 21,1 & 23,6 & 96,0 \\
\hline 1 - Set & 1,9 & 6,8 & 9,7 & 12,5 & 17,0 & 21,0 & 22,9 & 96,1 \\
\hline 15 - Set & 1,9 & 6,9 & 9,7 & 12,5 & 17,0 & 20,7 & 22,9 & 95,4 \\
\hline 1 - Out & 2,0 & 6,9 & 9,7 & 12,6 & 17,1 & 20,7 & 22,9 & 94,4 \\
\hline 15 - Out & 2,2 & 7,1 & 9,8 & 12,9 & 17,4 & 20,7 & 23,2 & 93,7 \\
\hline $1-\mathrm{Nov}$ & 2,9 & 7,4 & 10,2 & 13,6 & 17,6 & 20,6 & 23,7 & 85,0 \\
\hline 15 - Nov & 3,5 & 7,6 & 10,4 & 13,9 & 17,6 & 20,2 & 23,5 & 74,5 \\
\hline $1-$ Dez & 3,9 & 7,8 & 10,6 & 14,4 & 17,5 & 20,3 & 23,4 & 68,1 \\
\hline $15-\mathrm{Dez}$ & 4,4 & 8,0 & 10,9 & 14,4 & 17,2 & 20,0 & 22,7 & 56,8 \\
\hline Média & 4,2 & 8,0 & 11,1 & 14,3 & 17,7 & 20,6 & 23,2 & 68,7 \\
\hline
\end{tabular}

${ }^{1}$ S. I = sem irrigação 
Tabela 30. Déficits hídricos impostos à cultura de feijão caupi em função dos níveis de manejo da irrigação adotados em cada época de semeadura no município de Teresina, Piauí.

\begin{tabular}{|c|c|c|c|c|c|c|c|c|}
\hline \multirow{2}{*}{$\begin{array}{l}\text { Época de } \\
\text { Semeadura }\end{array}$} & \multicolumn{8}{|c|}{ Déficit hídrico $(\%)$} \\
\hline & 0,2 & 0,3 & 0,4 & 0,5 & 0,6 & 0,7 & 0,8 & S.I \\
\hline 1 - Jan & 7,2 & 10,0 & 12,8 & 15,4 & 17,2 & 18,9 & 20,3 & 27,5 \\
\hline 15 - Jan & 6,3 & 9,0 & 11,5 & 13,7 & 15,3 & 16,8 & 18,0 & 23,7 \\
\hline $1-\mathrm{Fev}$ & 5,8 & 8,4 & 10,5 & 12,5 & 13,7 & 14,9 & 15,8 & 19,1 \\
\hline $15-\mathrm{Fev}$ & 5,8 & 8,3 & 10,3 & 12,2 & 13,3 & 14,4 & 15,3 & 18,4 \\
\hline 1 - Mar & 6,0 & 8,6 & 10,7 & 12,4 & 13,7 & 14,9 & 15,8 & 18,7 \\
\hline $15-\mathrm{Mar}$ & 6,5 & 9,7 & 11,9 & 14,2 & 15,9 & 17,4 & 18,6 & 24,3 \\
\hline $1-\mathrm{Abr}$ & 7,1 & 10,8 & 13,5 & 16,3 & 18,5 & 20,4 & 22,2 & 33,7 \\
\hline $15-\mathrm{Abr}$ & 7.9 & 11,9 & 15,1 & 18,5 & 21,2 & 23,6 & 26,1 & 47,3 \\
\hline 1 - Mai & 8,3 & 12,8 & 16,1 & 19,8 & 23,0 & 25,6 & 28,4 & 59,5 \\
\hline 15 - Mai & 8,5 & 12,7 & 16,7 & 20,9 & 24,0 & 27,3 & 30,3 & 74,1 \\
\hline $1-$ Jun & 8,3 & 12,3 & 16,7 & 20,8 & 24,2 & 27,6 & 30,7 & 84,3 \\
\hline 15 - Jun & 8,0 & 11,7 & 16,5 & 20,1 & 23,9 & 27,5 & 30,3 & 87,1 \\
\hline $1-\mathrm{Jul}$ & 7,4 & 11,0 & 15,8 & 19,2 & 23,3 & 26,7 & 30,1 & 90,6 \\
\hline $15-\mathrm{Jul}$ & 6,9 & 10,3 & 15,1 & 18,7 & 22,9 & 26,0 & 29,8 & 92,8 \\
\hline 1 - Ago & 6,3 & 9,7 & 14,1 & 18,1 & 21,9 & 25,2 & 28,5 & 91,2 \\
\hline 15 - Ago & 5,9 & 9,4 & 13,5 & 17,8 & 21.0 & 24,8 & 27,8 & 90,3 \\
\hline 1 - Set & 5,8 & 9,3 & 13,2 & 17,6 & 20,8 & 24,4 & 27,3 & 86,1 \\
\hline 15 - Set & 5,9 & 9,3 & 13,5 & 17,6 & 20,8 & 24,4 & 27,4 & 84,3 \\
\hline 1 - Out & 6,2 & 9,6 & 13,8 & 17,7 & 21,2 & 24,6 & 27,6 & 82,0 \\
\hline 15 - Out & 6,4 & 9,8 & 14,3 & 17,7 & 21,3 & 24,5 & 27,6 & 76,3 \\
\hline 1 - Nov & 6,9 & 10,2 & 14,5 & 17,6 & 21,1 & 24,0 & 26,9 & 64,0 \\
\hline $15-\mathrm{Nov}$ & 7,0 & 10,4 & 14,4 & 17,4 & 20,5 & 23,3 & 25,7 & 52,2 \\
\hline $1-$ Dez & 7,1 & 10,4 & 14,2 & 17,1 & 19,8 & 22,4 & 24,8 & 44,8 \\
\hline $15-\mathrm{Dez}$ & 7,1 & 10,3 & 13,6 & 16,6 & 18,8 & 20,9 & 23,0 & 36,0 \\
\hline Média & 6,9 & 10,2 & 13,8 & 17,1 & 19,9 & 22,5 & 24,9 & 58,7 \\
\hline
\end{tabular}

${ }^{1}$ S. I = sem irrigação 
Tabela 31. Déficits hídricos impostos à cultura de melancia em função dos niveis de manejo da irrigação adotados em cada época de semeadura no município de Parnaiba, Piauí.

\begin{tabular}{lcccccccc}
\hline Época de & \multicolumn{7}{c}{ Déficit hídrico (\%) } \\
\cline { 2 - 8 } Semeadura & 0,2 & 0,3 & 0,4 & 0,5 & 0,6 & 0,7 & 0,8 & S. I $^{1}$ \\
\hline 1 - Jan & 4,9 & 7,5 & 11,0 & 13,5 & 16,4 & 18,4 & 20,5 & 43,8 \\
15 - Jan & 5,1 & 7,5 & 11,0 & 13,2 & 15,7 & 17,8 & 19,8 & 38,5 \\
1 - Fev & 5,3 & 7,7 & 10,9 & 13,3 & 15,5 & 17,5 & 19,2 & 33,9 \\
15 - Fev & 5,3 & 7,7 & 10,9 & 13,2 & 15,5 & 17,4 & 19,0 & 30,0 \\
1 - Mar & 5,7 & 8,2 & 11,5 & 14,0 & 16,6 & 18,5 & 20,3 & 28,5 \\
15 - Mar & 5,9 & 8,5 & 12,2 & 15,1 & 17,9 & 20,2 & 22,3 & 32,2 \\
1 - Abr & 6,1 & 8,9 & 12,8 & 15,8 & 18,9 & 21,6 & 23,9 & 41,0 \\
15 - Abr & 6,3 & 9,1 & 13,5 & 16,8 & 20,2 & 23,2 & 26,0 & 49,0 \\
1 - Mai & 6,2 & 9,0 & 13,5 & 16,7 & 20,5 & 23,3 & 26,3 & 64,7 \\
15 - Mai & 5,9 & 8,7 & 13,4 & 16,6 & 20,7 & 23,5 & 26,8 & 70,7 \\
1 - Jun & 5,3 & 8,3 & 12,7 & 16,3 & 20,0 & 23,2 & 26,4 & 80,5 \\
15 - Jun & 4,4 & 8,1 & 11,6 & 15,9 & 19,3 & 22,9 & 25,8 & 85,7 \\
1 - Jul & 3,5 & 7,8 & 10,7 & 15,3 & 18,4 & 22,3 & 25,4 & 89,5 \\
15 - Jul & 2,3 & 7,6 & 10,0 & 14,4 & 18,1 & 21,0 & 24,9 & 93,0 \\
1 - Ago & 1,7 & 7,5 & 9,4 & 13,6 & 17,8 & 20,3 & 24,5 & 95,6 \\
15 - Ago & 1,2 & 7,5 & 9,1 & 12,8 & 17,7 & 19,9 & 23,9 & 95,8 \\
1 - Set & 1,3 & 7,5 & 9,1 & 12,8 & 17,4 & 19,9 & 23,8 & 95,9 \\
15 - Set & 1,4 & 7,5 & 9,1 & 12,8 & 17,6 & 19,8 & 23,9 & 95,1 \\
1 - Out & 1,7 & 7,4 & 9,4 & 13,4 & 17,6 & 20,1 & 24,2 & 94,2 \\
15 - Out & 2,7 & 7,4 & 10,0 & 14,0 & 17,5 & 20,7 & 24,1 & 93,5 \\
1 - Nov & 3,3 & 7,4 & 10,2 & 14,3 & 17,4 & 20,6 & 23,7 & 84,6 \\
15 - Nov & 3,9 & 7,5 & 10,6 & 14,4 & 17,5 & 20,6 & 23,5 & 73,9 \\
1 - Dez & 4,5 & 7,7 & 11,1 & 14,4 & 17,4 & 20,2 & 22,9 & 67,3 \\
15 - Dez & 3,9 & 7,9 & 10,9 & 14,4 & 17,9 & 20,6 & 23,6 & 55,9 \\
\hline Média & 4,1 & 7,9 & 11,0 & 14,5 & 17,9 & 20,6 & 23,5 & 68,0 \\
\hline 1 S. I = sem irrigação & & & & & & & \\
\hline
\end{tabular}


Tabela 32. Déficits hídricos impostos à cultura de melancia em função dos níveis de manejo da irrigação adotados em cada época de semeadura no município de Teresina, Piauí.

\begin{tabular}{lrrrrrrrr}
\hline Época de & \multicolumn{7}{c}{ Déficit hídrico (\%) } \\
\cline { 2 - 7 } Semeadura & 0,2 & 0,3 & 0,4 & 0,5 & 0,6 & 0,7 & 0,8 & S. I \\
\hline 1 - Jan & 7,0 & 10,4 & 13,0 & 15,5 & 17,5 & 19,1 & 20,5 & 26,7 \\
15 - Jan & 5,9 & 9,2 & 11,5 & 13,6 & 15,3 & 16,7 & 17,9 & 23,0 \\
1 - Fev & 5,6 & 8,6 & 10,5 & 12,3 & 13,8 & 14,9 & 15,8 & 18,5 \\
15 - Fev & 5,5 & 8,4 & 10,3 & 12,1 & 13,4 & 14,4 & 15,1 & 17,9 \\
1 - Mar & 5,7 & 8,7 & 10,8 & 12,3 & 13,7 & 14,9 & 15,7 & 18,1 \\
15 - Mar & 6,2 & 9,7 & 12,2 & 14,0 & 15,8 & 17,4 & 18,7 & 23,5 \\
1 - Abr & 6,8 & 10,8 & 13,7 & 16,1 & 18,4 & 20,5 & 22,2 & 32,9 \\
15 - Abr & 7,4 & 11,9 & 15,5 & 18,3 & 21,0 & 23,7 & 26,2 & 46,1 \\
1 - Mai & 7,8 & 12,8 & 16,5 & 19,6 & 22,8 & 25,9 & 28,6 & 58,6 \\
15 - Mai & 7,9 & 13,1 & 16,9 & 20,6 & 24,3 & 27,5 & 30,3 & 73,5 \\
1 - Jun & 7,8 & 12,7 & 16,5 & 20,6 & 24,4 & 27,5 & 30,9 & 83,9 \\
15 - Jun & 7,6 & 12,0 & 16,0 & 20,2 & 23,9 & 27,3 & 30,6 & 86,8 \\
1 - Jul & 7,3 & 10,9 & 15,5 & 19,7 & 23,1 & 26,9 & 30,1 & 90,3 \\
15 - Jul & 7,1 & 10,1 & 15,1 & 18,8 & 22,5 & 26,3 & 29,3 & 92,6 \\
1 - Ago & 6,8 & 9,4 & 14,6 & 17,8 & 22,0 & 25,2 & 28,5 & 90,9 \\
15 - Ago & 6,5 & 9,0 & 14,2 & 17,2 & 21,6 & 24,5 & 28,4 & 89,9 \\
1 - Set & 6,3 & 8,9 & 14,0 & 17,0 & 21,3 & 24,2 & 27,9 & 85,6 \\
15 - Set & 6,4 & 9,0 & 14,0 & 17,0 & 21,2 & 24,2 & 27,8 & 83,9 \\
1 - Out & 6,5 & 9,2 & 14,2 & 17,4 & 21,5 & 24,5 & 27,8 & 81,5 \\
15 - Out & 6,6 & 9,6 & 14,3 & 17,7 & 21,4 & 24,7 & 27,6 & 75,7 \\
1 - Nov & 6,8 & 10,1 & 14,3 & 17,8 & 21,1 & 24,2 & 27,0 & 63,1 \\
15 - Nov & 6,8 & 10,4 & 14,1 & 17,4 & 20,5 & 23,4 & 25,8 & 51,5 \\
1 - Dez & 6,8 & 10,6 & 14,0 & 17,1 & 19,9 & 22,2 & 24,8 & 43,6 \\
15 - Dez & 6,7 & 10,6 & 13,4 & 16,4 & 18,9 & 21,0 & 23,0 & 35,0 \\
\hline Média & 6,7 & 10,3 & 14,0 & 16,9 & 20,0 & 22,5 & 25,0 & 58,0 \\
\hline 1 S. I = sem irrigação & & & & & & & \\
& & & & & & & &
\end{tabular}


Para a mesma condição edafoclimática e sob irrigação, os níveis de déficit hídrico impostos foram superiores aos do feijão caupi (Tabelas 31 e 32), devido a melancia apresentar uma maior sensibilidade ao déficit hídrico, constatada pelos maiores valores de $\mathrm{Ky}$, especialmente durante as fases de estabelecimento, desenvolvimento vegetativo e maturação dos frutos (Tabela 3).

Vale ressaltar que a produtividade de grãos de feijão caupi e de frutos de melancia simulados nas condições edafoclimáticas de Parnaíba e Teresina enquadram-se dentro da faixa de valores obtidos em ensaios de campo efetuados nessas condições, conforme apresentado nos trabalhos de Cardoso et al (1987), Nogueira \& Nogueira (1995), Cardoso et al. (1997), Andrade Júnior et al. (1997), Andrade Júnior et al. (1998a), Andrade Júnior et al. (1998b), Andrade Júnior et al. (1999).

As Figuras 21 e 22 mostram a variação das produtividades das culturas de feijão caupi e melancia em função dos níveis de manejo da irrigação referentes a $20 \%$ (p = $0,2), 50 \%(p=0,5)$ e $80 \%(p=0,8)$ da CAD e utilizando apenas a Pe, ou seja, sem o uso da irrigação. Comparando-se os valores de produtividade obtidos com a fração $p=$ 0,2 com os alcançados com o uso exclusivo da Pe, constatou-se acréscimos de produtividade de grãos de feijão caupi da ordem de $952,2 \mathrm{~kg} \mathrm{ha}^{-1}$ (1-Mar) (estação chuvosa) e de $2.422,7 \mathrm{~kg} \mathrm{ha}^{-1}$ (15-Set) (estação seca), em Parnaíba, e de 500,6 kg ha ${ }^{-1}$ (15-Fev) (estação chuvosa) e de 2211,9 kg ha ${ }^{-1}$ (1-Set) (estação seca), em Teresina. Para a cultura da melancia, os acréscimos na produtividade de frutos foram de $21.540,2 \mathrm{~kg}$ ha 1 (1-Mar) (estação chuvosa) e de 48.166,0 kg ha ${ }^{-1}$ (1-Set) (estação seca), em Parnaíba, e de $12.390,7 \mathrm{~kg} \mathrm{ha}^{-1}$ (15-Fev) (estação chuvosa) e de 42.135,3 $\mathrm{kg} \mathrm{ha}^{-1}$ (1-Set) (estação seca), em Teresina.

Evidenciou-se, também, embora em menor proporção, que até mesmo a adoção da irrigação com o uso da fração $p=0,8$, que proporcionou os maiores déficits hídricos sob condição irrigada, permitiu a obtenção de produtividades de grãos e de frutos superiores às obtidas com o uso exclusivo da Pe. Estes resultados comprovam a viabilidade técnica da irrigação, tanto com caráter suplementar como total. 

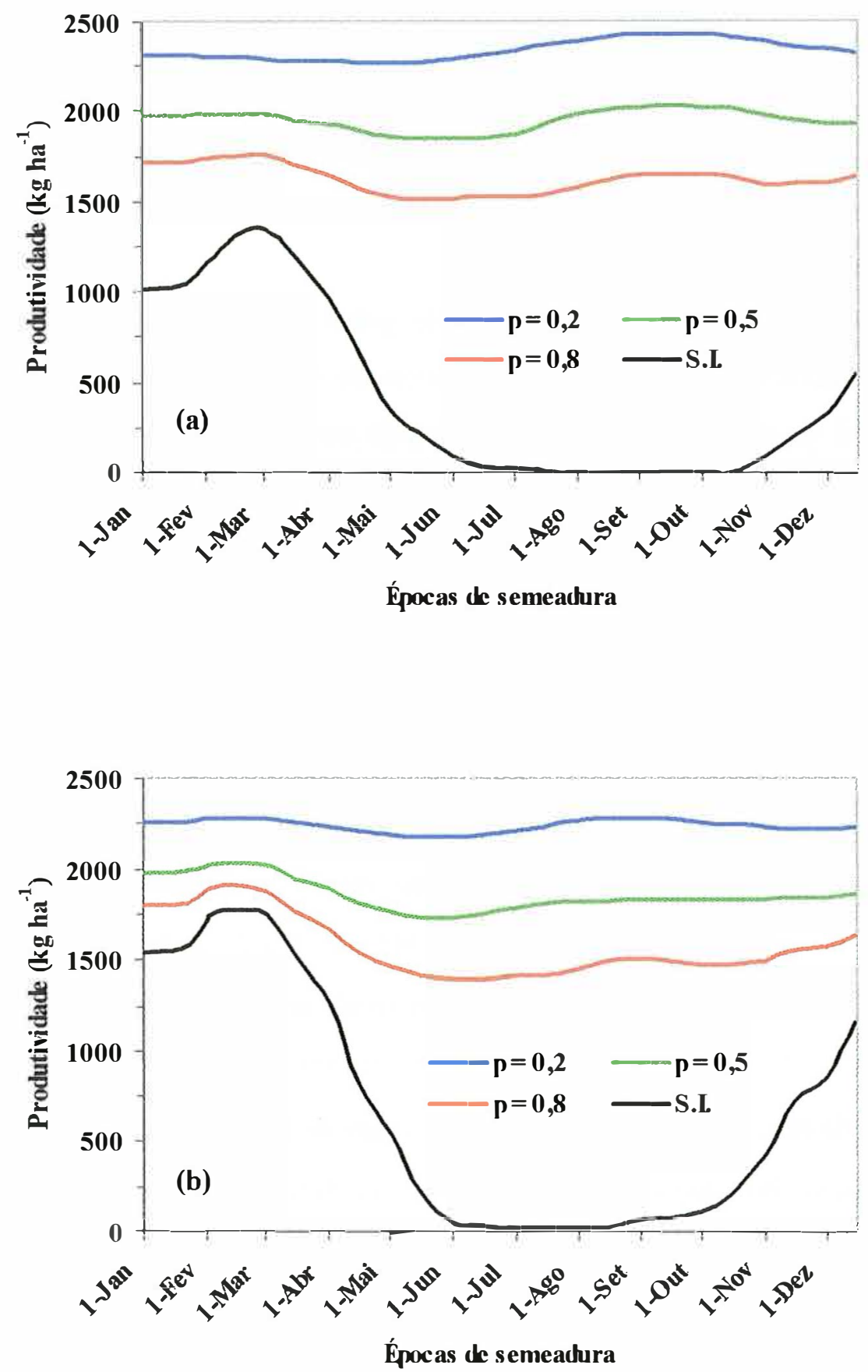

Figura 21. Produtividade de grãos de feijão caupi em função dos níveis de manejo de irrigação em cada época de semeadura nos municípios de Parnaíba (a) e Teresina (b). 

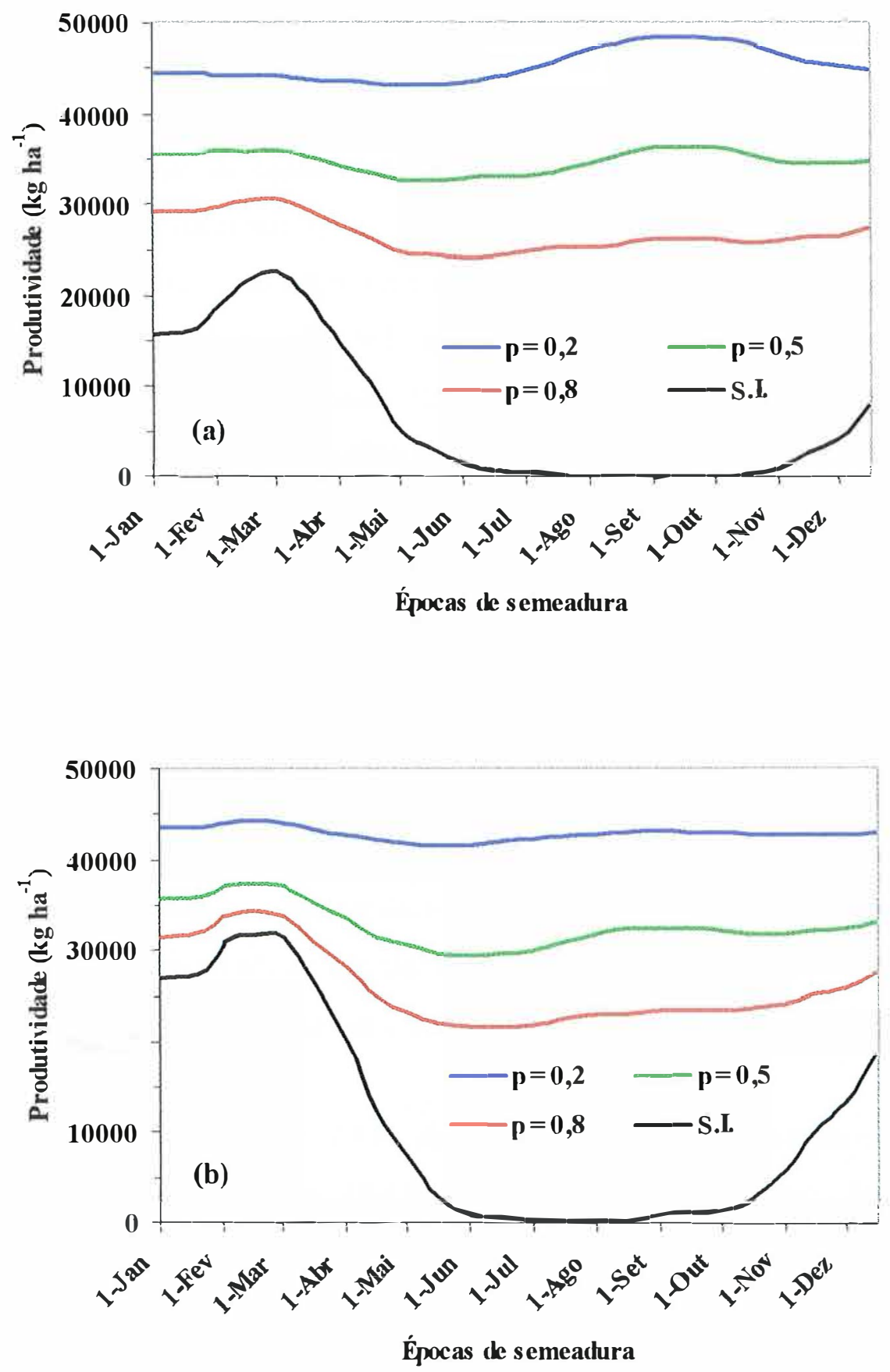

Figura 22. Produtividade de frutos de melancia em função dos níveis de manejo de irrigação em cada época de semeadura nos municípios de Parnaiba (a) e Teresina (b). 
Além disso, observou-se uma maior dispersão dos valores de produtividade de grãos de feijão caupi e de frutos de melancia nas épocas de semeadura de 1-Jan a 1-Mai (estação chuvosa), notadamente, com os níveis de manejo de irrigação relativos às frações $p=0,5$ e $p=0,8$ (Figuras 21 e 22). Esse comportamento é conseqüência dos resultados relativos ao balanço de água no solo em função da contribuição da Pe nessa época do ano, conforme discutido anteriormente. Em todas as épocas de semeadura, o uso da fração $\mathrm{p}=0,2$ possibilitou a obtenção das maiores produtividades de grãos e de frutos sem contudo proporcionar variações significativas ao longo do ano, ou seja, este nível de manejo de irrigação permitiu a maior estabilidade de produção das culturas.

A análise conjunta das Figuras 17, 18, 21 e 22 permitiu verificar que a aplicação das maiores lâminas de irrigação não necessariamente implicou na obtenção das melhores produtividades, especialmente na estação chuvosa Por exemplo, em Teresina, na época de semeadura de 1-Set e utilizando-se uma fração $p=0,2$ aplicou-se uma lâmina de irrigação de $358,3 \mathrm{~mm}$, a qual proporcionou produtividade de grãos de $2.280,6$ $\mathrm{kg} \mathrm{ha}^{-1}$. Essa produtividade foi praticamente igual à obtida em 1-Fev $\left(2.276,1 \mathrm{~kg} \mathrm{ha}^{-1}\right)$ com a utilização de uma lâmina de irrigação suplementar de apenas 114,1 mm. Vale ressaltar que, nesta época de semeadura, a contribuição da Pe foi de $465,6 \mathrm{~mm}$, a qual devido a sua má distribuição não foi suficiente para atender a exigência hídrica da cultura.

Considerando-se apenas a contribuição da Pe na expressão da produtividade das culturas de feijão caupi e melancia, constatou-se uma estreita relação de dependência entre ambas, com a obtenção das maiores produtividades de grãos e de frutos associado à ocorrência dos valores mais elevados de Pe (Figuras 23 e 24). Os reduzidos valores de produtividade, especialmente de feijão caupi simulados nas épocas de semeadura da estação seca, refletem a magnitude de valores obtidos em condições reais de campo, sem a adoção da prática da irrigação. 


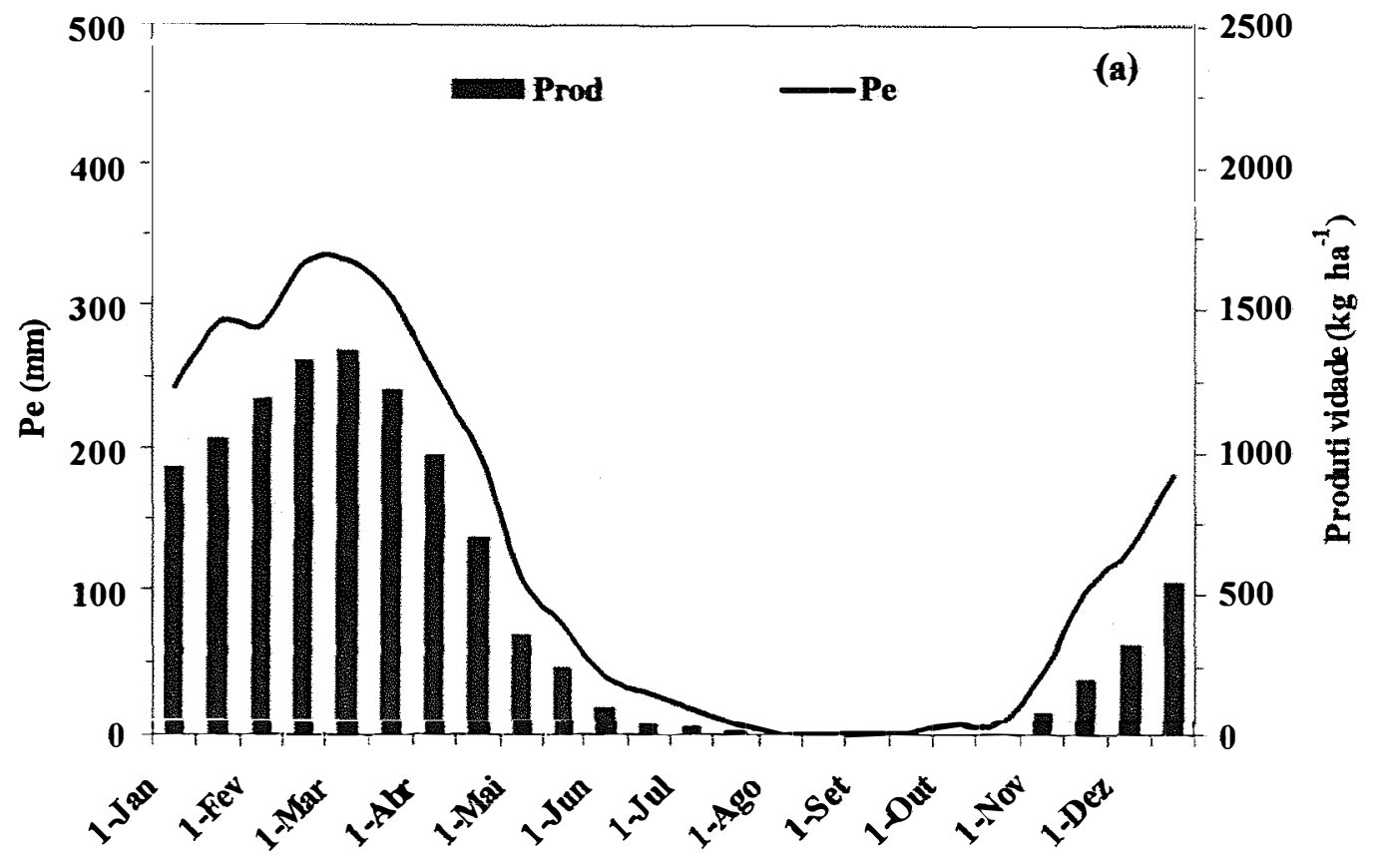

Épocas de semeadura

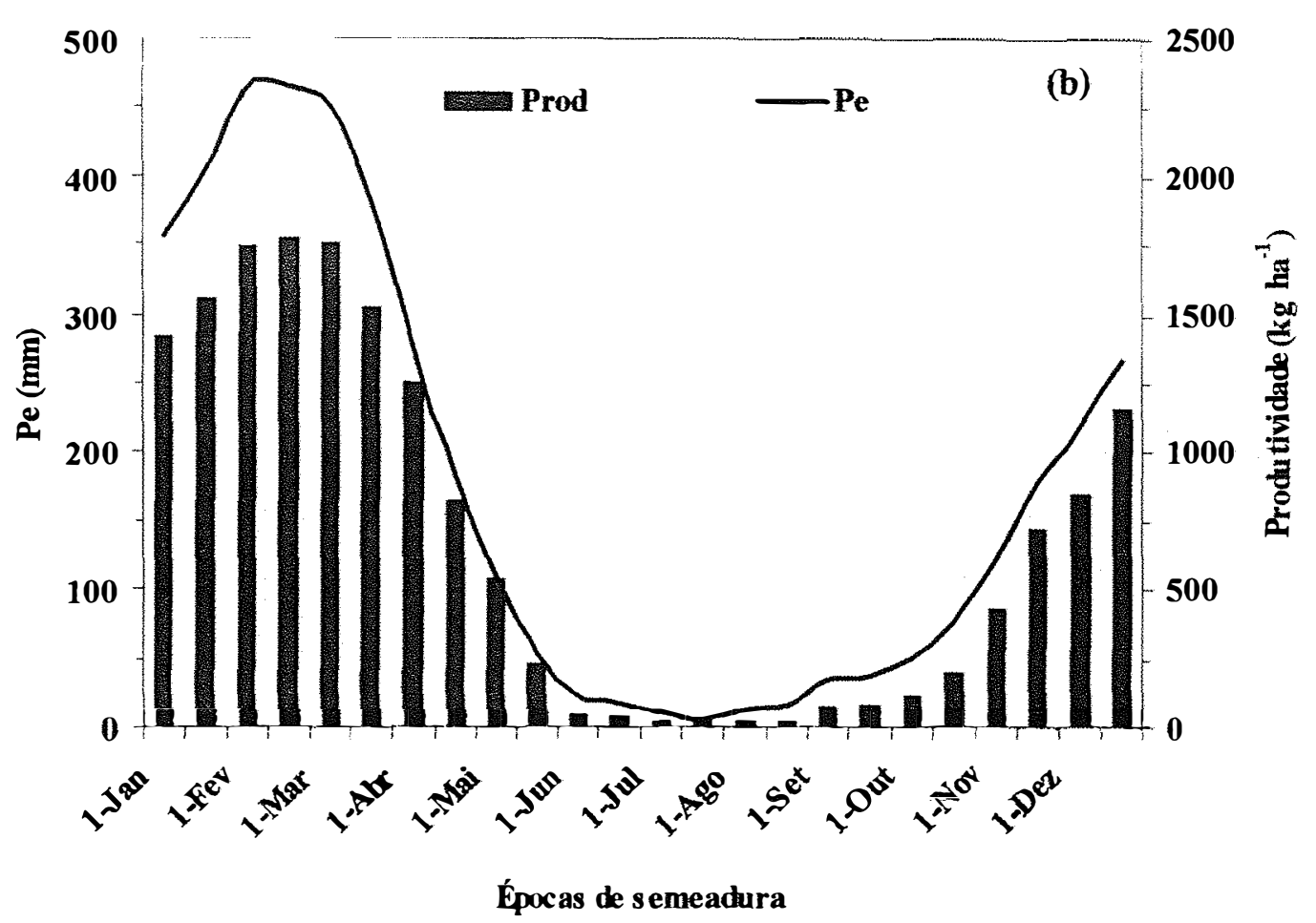

Figura 23. Produtividade de grãos de feijão caupi em função da precipitação efetiva em cada época de semeadura nos municípios de Parnaíba (a) e Teresina (b). 
158

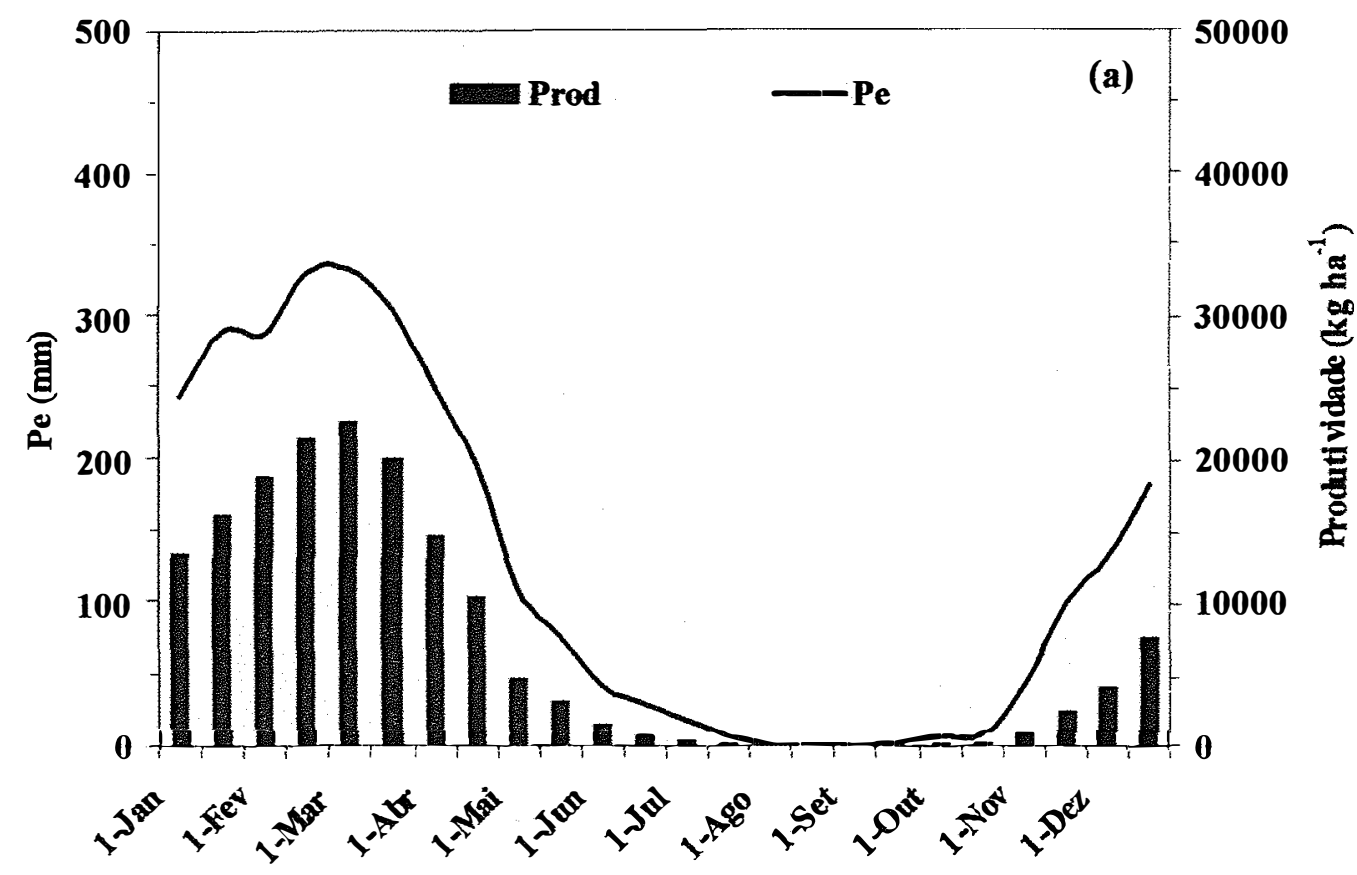

Épocas de semeadura

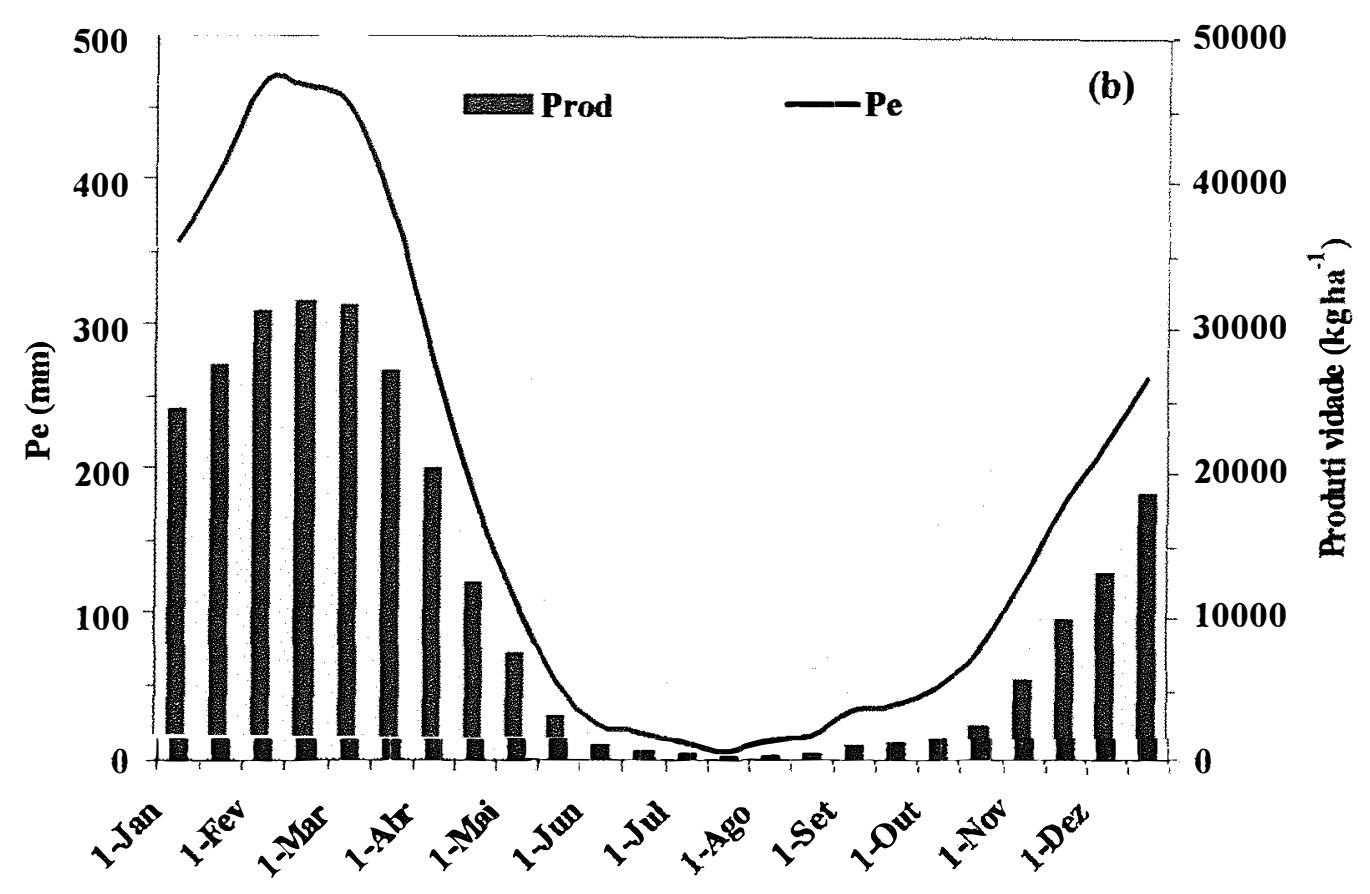

Épocas de semeadura

Figura 24. Produtividade de frutos de melancia em função da precipitação efetiva em cada época de semeadura nos municípios de Parnaíba (a) e Teresina (b). 
Uma análise preliminar, sem considerar o aspecto econômico e o risco envolvidos no processo de tomada de decisão, permite recomendar as épocas de semeaduras de 1-Set (feijão caupi) e 15-Set (melancia) como as mais indicadas para o cultivo irrigado nos dois municípios, independente do nível de manejo de irrigação. Para o cultivo de sequeiro ou com a adoção de irrigação suplementar, sugere-se a época de semeadura de 15-Fev, para ambas as culturas, nas duas condições edafoclimáticas.

\subsection{Estimativa da lâmina bruta de irrigação e produtividade das culturas}

As Tabelas 1A a 4A (Apêndice 1) apresentam os resultados do ajuste dos valores simulados de lâmina bruta de irrigação e produtividade real das culturas de feijão caupi e melancia, em cada local, nível de manejo e época de semeadura, à função de distribuição normal utilizando o teste de aderência de Kolmogorov-Smirnov ao nível de $5 \%$ de significância, conforme metodologia apresentada por Campos (1979).

Quanto aos valores simulados de lâmina bruta de irrigação (I), observou-se que apenas para o feijão caupi, em Parnaíba, ocorreu ajuste dos valores simulados de I à distribuição normal em todas as épocas de semeadura e níveis de manejo de irrigação. Para o feijão caupi, em Teresina, não detectou-se ajuste dos valores simulados de I à distribuição normal para as seguintes épocas de semeadura e niveis de irngação (p): 15$\operatorname{Jan}(p=0,8), 1-\operatorname{Fev}(p=0,7 ; p=0,8), 15-\operatorname{Fev}(p=0,7 ; p=0,8), 1-\operatorname{Mar}(p=0,8), 15-\operatorname{Mar}$ $(p=0,8), 1-J u n(p=0,8), 1-J u l(p=0,6 ; p=0,8), 15-J u l(p=0,7 ; p=0,8)$ e 1-Ago $(p=0,5 ;$ $\mathrm{p}=0,6)$. Para a melancia em Parnaíba, as épocas de semeadura e níveis de manejo que não apresentaram ajuste foram: 15 -Ago $(p=0,6), 1$-Set $(p=0,6)$ e 1-Out $(p=0,6)$. Para essa mesma cultura em Teresina, não foi verificado ajuste de I em 15-Jan ( $\mathrm{p}=0,8), 1-\mathrm{Fev}$ $(\mathrm{p}=0,8), 15-\mathrm{Fev}(\mathrm{p}=0,8), 15-\mathrm{Mar}(\mathrm{p}=0,8), 15-J u n(\mathrm{p}=0,8), 1-J u l(\mathrm{p}=0,8), 15-J u l(p=0,7$; $\mathrm{p}=0,8), 1$-Ago $(\mathrm{p}=0,8), 15$-Ago $(\mathrm{p}=0,8)$ e 15-Set $(\mathrm{p}=0,8)$.

Esses resultados concordam com os obtidos por Oliveira (1990) e Franke (1996) que também verificaram ajuste dos valores totais de lâmina de irrigação suplementar à distribuição normal apenas para determinadas combinações de cultura, local e época de semeadura avaliadas. Franke (1996) argumentou que o não ajuste dos valores de I à 
distribuição normal em algumas combinações entre local, cultura e época de semeadura pode ser atribuído ao pequeno número de anos da série histórica de dados meteorológicos usados no trabalho. No caso deste estudo, essa argumentação não se aplica, pois para execução dos balanços hídricos utilizaram-se valores diários de precipitação pluviométrica e evapotranspiração de referência relativos à simulação de 100 anos de observações.

Independentemente da época de semeadura, o não ajuste dos valores simulados de I à distribuição normal deveu-se, provavelmente, à maior variabilidade dos valores de I, pois não houve ajuste, principalmente, nos níveis de manejo de irrigação $p=0,7$ e $p=$ 0,8. De fato, analisando-se as Tabelas 7A a 10A, observou-se tendência de redução da média e aumento do desvio padrão dos valores de I à medida que variaram os níveis de manejo de irrigação de $p=0,2$ a $p=0,8$.

Quanto aos valores simulados de produtividade das culturas (Yr), observou-se um melhor ajuste à função de distribuição normal do que os valores simulados de I, para ambas as culturas, notadamente em Teresina. Para o feijão caupi, em Parnaíba, não detectou-se ajuste dos valores simulados de Yr à distribuição normal para as seguintes épocas de semeadura e níveis de irrigação $(p)$ : 15 -Set $(p=0,4)$ e 1-Out $(0,2)$. Para essa mesma cultura, em Teresina, apenas não detectou-se ajuste para a época de semeadura de 15-Ago e nível de manejo de irrigação $\mathrm{p}=0,3$. Para a melancia, em Parnaiba, as épocas de semeadura e níveis de manejo que não apresentaram ajuste foram: 15-Abr $(p=0,7)$ e 15-Ago $(p=0,8)$. Em Teresina, o ajuste dos valores de $Y r$ à função de distribuição normal foi observado apenas em 1-Ago $\operatorname{com} p=0,8$.

É importante ressaltar que o não ajuste de Yr à distribuição normal foi devido às pequenas diferenças entre os valores de desvio máximo e desvio tabelado ao nível de $5 \%$ de probabilidade, indicando que a variável produtividade foi mais estável que a lâmina bruta de irrigação. Essa afirmativa pode ser comprovada pela análise dos valores médios e de desvio padrão relativos a Yr apresentados nas Tabelas 5A a 10A. Nestas Tabelas é possivel verificar que os valores de desvio padrão em relação à média de $\mathrm{Yr}$ são, proporcionalmente, menores que os valores de desvio padrão relacionados às médias de lâmina bruta de irrigação. 
A lâmina bruta de irrigação e a produtividade das culturas, nas combinações entre local, cultura, época de semeadura e nivel de manejo de irrigação que não apresentaram ajuste à distribuição normal, foram estimadas pela função de distribuição empírica nas probabilidades de ocorrência desejadas.

As Tabelas 33 e 34 apresentam os valores estimados de lâmina bruta de irrigação e produtividade de grãos de feijão caupi, com diferentes niveis de probabilidade de ocorrência, em cada época de semeadura e nível de manejo no município de Parnaíba. Essas estimativas foram obtidas a partir do ajustamento dos valores de lâmina bruta de irrigação e produtividade das culturas, oriundos dos balanços hídricos simulados, à função de distribuição normal.

Constatou-se que os valores de lâmina bruta de irrigação mostraram tendência de redução à medida que decrescem as probabilidades de ocorrência. Essa é uma tendência natural devido as estimativas serem baseadas em probabilidades de não excedência, ou seja, dos valores de lâmina bruta de irrigação não serem excedidos nos referidos níveis de probabilidade.

Conforme salientou Franke (1996), essa forma de análise e apresentação é condizente com os projetos de irrigação, os quais são geralmente dimensionados com base nos valores máximos possíveis de serem atingidos em determinada situação. Por exemplo, considerando-se a época de semeadura de 1-Set, o nível de manejo $p=0,4$ e a probabilidade de ocorrência de $90 \%$, a lâmina bruta de irrigação necessária para o feijão caupi foi de $473,0 \mathrm{~mm}$. Isto significa que em $90 \%$ dos casos (9 em cada 10 anos) os valores de lâmina bruta de irrigação serão no máximo iguais a $473,0 \mathrm{~mm}$, ou seja, este valor somente será superado uma vez a cada 10 anos, o que representa um risco de falha de $10 \%$. Interpretação semelhante pode ser efetuada com as demais probabilidades de ocorrência nas outras épocas de semeadura e niveis de manejo.

Verificou-se que os valores de lâmina bruta de irrigação variaram desde 95,2 mm (1-Mar, nivel de manejo $p=0,8$ e $60 \%$ de probabilidade de ocorrência) a 477,7 mm (1Set, nivel de manejo $\mathrm{p}=0,2$ e $95 \%$ de probabilidade de ocorrência). Essa ampla variação ocorreu em função da época de semeadura e do nível de manejo de irrigação, obtendo-se os maiores valores à medida que coincidem os períodos de maior exigência 
Tabela 33. Estimativa da lâmina bruta de irrigação $(\mathrm{mm})$ necessária à cultura do feijão caupi, com diferentes probabilidades de ocorrência, em cada época de semeadura e nivel de manejo (p) no município de Parnaiba, Piaui.

\begin{tabular}{|c|c|c|c|c|c|c|c|c|c|}
\hline \multirow{2}{*}{$\begin{array}{l}\text { Época de } \\
\text { Semeadura }\end{array}$} & \multirow[t]{2}{*}{$\mathrm{p}$} & \multicolumn{8}{|c|}{ Probabilidade de ocorrência (\%) } \\
\hline & & 95 & 90 & 85 & 80 & 75 & 70 & 65 & 60 \\
\hline \multirow{7}{*}{ 1-Jan } & 0,2 & 280,7 & 271,0 & 264,4 & 259,2 & 254,7 & 250,7 & 247,0 & 243,5 \\
\hline & 0,3 & 273,8 & 262,9 & 255,5 & 249,6 & 244,6 & 240,0 & 235,8 & 231,9 \\
\hline & 0,4 & 267,0 & 254,9 & 246,7 & 240,1 & 234,5 & 229,5 & 224,8 & 220,4 \\
\hline & 0,5 & 258,3 & 245,6 & 236,9 & 230,1 & 224,2 & 218,9 & 214,0 & 209,4 \\
\hline & 0,6 & 249,0 & 235,6 & 226,6 & 219,4 & 213,3 & 207,8 & 202,7 & 197,8 \\
\hline & 0,7 & 243,5 & 229,1 & 219,4 & 211,7 & 205,1 & 199,2 & 193,7 & 188,4 \\
\hline & 0,8 & 236,0 & 221,2 & 211,2 & 203,2 & 196,4 & 190,3 & 184,6 & 179,2 \\
\hline \multirow{7}{*}{ 15-Jan } & 0,2 & 255,1 & 246,0 & 239,9 & 235,0 & 230,8 & 227,0 & 223,6 & 220,3 \\
\hline & 0,3 & 247,1 & 236,7 & 229,7 & 224,1 & 219,3 & 215,0 & 211,0 & 207,3 \\
\hline & 0,4 & 240,7 & 228,8 & 220,8 & 214,5 & 209,0 & 204,1 & 199,6 & 195,3 \\
\hline & 0,5 & 231,9 & 219,0 & 210,3 & 203,3 & 191,4 & 192,0 & 187,1 & 182,4 \\
\hline & 0,6 & 218,8 & 205,9 & 197,2 & 190,2 & 184,3 & 179,0 & 174,0 & 169,3 \\
\hline & 0,7 & 216,5 & 201,8 & 191,8 & 183,9 & 177,1 & 171,0 & 165,4 & 160,0 \\
\hline & 0,8 & 209,0 & 194,5 & 184,6 & 176,8 & 170,1 & 164,1 & 158,5 & 153,2 \\
\hline \multirow{7}{*}{$1-\mathrm{Fev}$} & 0,2 & 237,5 & 227,7 & 221,1 & 215,8 & 211,3 & 207,2 & 203,5 & 199,9 \\
\hline & 0,3 & 228,4 & 217,2 & 209,6 & 203,6 & 198,4 & 193,7 & 189,4 & 185,3 \\
\hline & 0,4 & 218,4 & 205,8 & 197,3 & 190,5 & 184,7 & 179,5 & 174,7 & 170,2 \\
\hline & 0,5 & 205,4 & 193,2 & 185,0 & 178,5 & 172,9 & 167,9 & 163,2 & 158,8 \\
\hline & 0,6 & 200,1 & 186,6 & 177,5 & 170,2 & 164,0 & 158,4 & 153,3 & 148,3 \\
\hline & 0,7 & 191,3 & 177,5 & 168,2 & 160,8 & 154,4 & 148,7 & 143,4 & 138,4 \\
\hline & 0,8 & 180,5 & 166,4 & 156,9 & 149,4 & 142,9 & 137,1 & 131,7 & 126,6 \\
\hline \multirow{7}{*}{$15-\mathrm{Fev}$} & 0,2 & 216,1 & 206,9 & 200,8 & 195,9 & 191,7 & 187,9 & 184,4 & 181,1 \\
\hline & 0,3 & 206,4 & 196,5 & 189,8 & 184,5 & 179,9 & 175,8 & 172,0 & 168,4 \\
\hline & 0,4 & 194,5 & 183,2 & 175,6 & 169,5 & 164,3 & 159,7 & 155,3 & 151,2 \\
\hline & 0,5 & 183,5 & 171,8 & 163,8 & 157,5 & 152,1 & 147,2 & 142,7 & 138,5 \\
\hline & 0,6 & 165,0 & 154,1 & 146,6 & 140,7 & 135,7 & 131,1 & 126,9 & 122,9 \\
\hline & 0,7 & 162,8 & 150,8 & 142,7 & 136,3 & 130,8 & 125,9 & 121,3 & 116,9 \\
\hline & 0,8 & 155,4 & 142,9 & 134,5 & 127,9 & 122,2 & 117,0 & 112,3 & 107,7 \\
\hline
\end{tabular}


Tabela 33. Estimativa da lâmina bruta de irrigação $(\mathrm{mm})$ necessária à cultura do feijão caupi, com diferentes probabilidades de ocorrência, em cada época de semeadura e nível de manejo (p) no município de Parnaiba, Piauí.

\begin{tabular}{|c|c|c|c|c|c|c|c|c|c|}
\hline \multirow{2}{*}{$\begin{array}{l}\text { Época de } \\
\text { Semeadura }\end{array}$} & \multirow[t]{2}{*}{$\mathrm{p}$} & \multicolumn{8}{|c|}{ Probabilidade de ocorrência (\%) } \\
\hline & & 95 & 90 & 85 & 80 & 75 & 70 & 65 & 60 \\
\hline \multirow{7}{*}{ 1-Mar } & 0,2 & 211,2 & 201,6 & 195,1 & 189,9 & 185,5 & 181,5 & 177,8 & 174,3 \\
\hline & 0,3 & 203,8 & 192,5 & 185,0 & 178,9 & 173,8 & 169,1 & 164,8 & 160,8 \\
\hline & 0,4 & 191,7 & 179,6 & 171,4 & 164,9 & 159,4 & 154,4 & 149,7 & 145,3 \\
\hline & 0,5 & 176,3 & 164,4 & 156,3 & 150,0 & 144,5 & 139,6 & 135,0 & 130,7 \\
\hline & 0,6 & 170,3 & 157,3 & 148,4 & 141,5 & 135,5 & 130,1 & 125,1 & 120,3 \\
\hline & 0,7 & 160,1 & 146,3 & 137,0 & 129,6 & 123,2 & 117,5 & 112,3 & 107,3 \\
\hline & 0,8 & 150,6 & 136,1 & 126,4 & 118,6 & 111,9 & 106,0 & 100,4 & 95,2 \\
\hline \multirow{7}{*}{ 15-Mar } & 0,2 & 218,2 & 208,8 & 202,5 & 197,5 & 193,2 & 189,3 & 185,7 & 182,3 \\
\hline & 0,3 & 206,8 & 196,8 & 190,0 & 184,5 & 179,9 & 175,7 & 171,9 & 168,2 \\
\hline & 0,4 & 195,9 & 184,8 & 177,3 & 171,3 & 166,2 & 161,6 & 157,4 & 153,3 \\
\hline & 0,5 & 186,7 & 174,4 & 166,1 & 159,5 & 153,9 & 148,8 & 144,1 & 139,7 \\
\hline & 0,6 & 180,9 & 167,5 & 158,4 & 151,2 & 145,1 & 139,5 & 134,4 & 129,5 \\
\hline & 0,7 & 166,9 & 153,8 & 145,0 & 137,9 & 131,9 & 126,5 & 121,4 & 116,7 \\
\hline & 0,8 & 156,4 & 143,1 & 134,1 & 127,0 & 120,9 & 115,4 & 110,3 & 105,5 \\
\hline \multirow{7}{*}{ 1-Abr } & 0,2 & 243,6 & 234,7 & 228,7 & 224,0 & 219,9 & 216,2 & 212,8 & 209,6 \\
\hline & 0,3 & 235,6 & 225,8 & 219,2 & 214,0 & 209,5 & 205,4 & 201,7 & 198,1 \\
\hline & 0,4 & 228,8 & 217,9 & 210,5 & 204,7 & 199,7 & 195,2 & 191,0 & 187,1 \\
\hline & 0,5 & 216,8 & 206,0 & 198,6 & 192,8 & 187,8 & 183,3 & 179,1 & 175,1 \\
\hline & 0,6 & 209,5 & 197,2 & 188,9 & 182,3 & 176,7 & 171,6 & 166,9 & 162,4 \\
\hline & 0,7 & 205,6 & 192,3 & 183,4 & 176,3 & 170,2 & 164,7 & 159,7 & 154,9 \\
\hline & 0,8 & 197,7 & 183,6 & 174,1 & 166,6 & 160,1 & 154,3 & 148,9 & 143,8 \\
\hline \multirow{7}{*}{ 15-Abr } & 0,2 & 265,9 & 257,6 & 252,0 & 247,6 & 243,8 & 240,4 & 237,2 & 234,2 \\
\hline & 0,3 & 260,8 & 251,0 & 244,3 & 239,1 & 234,5 & 230,5 & 226,7 & 223,1 \\
\hline & 0,4 & 250,6 & 240,7 & 234,1 & 228,8 & 224,2 & 220,2 & 216,4 & 212,8 \\
\hline & 0,5 & 245,0 & 234,0 & 226,5 & 220,6 & 215,5 & 210,9 & 206,7 & 202,7 \\
\hline & 0,6 & 240,3 & 227,7 & 219,2 & 212,4 & 206,6 & 201,4 & 196,6 & 192,0 \\
\hline & 0,7 & 232,3 & 218,7 & 209,5 & 202,2 & 196,0 & 190,4 & 185,1 & 180,2 \\
\hline & 0,8 & 232,7 & 218,1 & 208,2 & 200,4 & 193,6 & 187,6 & 182,0 & 176,7 \\
\hline
\end{tabular}


164

Tabela 33. Estimativa da lâmina bruta de irrigação $(\mathrm{mm})$ necessária à cultura do feijão caupi, com diferentes probabilidades de ocorrêncią,.. em cada época de semeadura e nível de manejo (p) no município de Parnaíba, Piauí.

\begin{tabular}{|c|c|c|c|c|c|c|c|c|c|}
\hline \multirow{2}{*}{$\begin{array}{c}\text { Época de } \\
\text { Semeadura }\end{array}$} & \multirow[t]{2}{*}{$\mathrm{p}$} & \multicolumn{8}{|c|}{ Probabilidade de ocorrência $(\%)$} \\
\hline & & 95 & 90 & 85 & 80 & 75 & 70 & 65 & 60 \\
\hline \multirow{7}{*}{ 1-Mai } & 0,2 & 295,6 & 288,5 & 283,7 & 279,9 & 276,6 & 273,7 & 271,0 & 268,4 \\
\hline & 0,3 & 289,0 & 281,5 & 276,4 & 272,4 & 268,9 & 265,8 & 262,9 & 260,2 \\
\hline & 0,4 & 283,7 & 275,0 & 269,2 & 264,5 & 260,5 & 256,9 & 253,6 & 250,4 \\
\hline & 0,5 & 281,7 & 272,2 & 265,8 & 260,7 & 256,3 & 252,4 & 248,8 & 245,3 \\
\hline & 0,6 & 283,6 & 272,6 & 265,2 & 259,4 & 254,3 & 249,8 & 245,6 & 241,6 \\
\hline & 0,7 & 280,1 & 267,4 & 258,8 & 252,0 & 246,1 & 240,8 & 235,9 & 231,3 \\
\hline & 0,8 & 282,3 & 268,4 & 258,9 & 251,5 & 245,0 & 239,3 & 233,9 & 228,9 \\
\hline \multirow{7}{*}{ 15-Mai } & 0,2 & 308,4 & 301,5 & 296,9 & 293,2 & 290,1 & 287,2 & 284,6 & 282,1 \\
\hline & 0,3 & 306,3 & 298,2 & 292,7 & 288,4 & 284,6 & 281,3 & 278,2 & 275,2 \\
\hline & 0,4 & 302,8 & 294,3 & 288,5 & 284,0 & 280,0 & 276,5 & 273,2 & 270,1 \\
\hline & 0,5 & 299,6 & 290,0 & 283,6 & 278,4 & 274,0 & 270,1 & 266,4 & 262,9 \\
\hline & 0,6 & 294,8 & 284,8 & 278,0 & 272,6 & 268,0 & 263,8 & 260,0 & 256,3 \\
\hline & 0,7 & 296,9 & 285,8 & 278,3 & 272,4 & 267,3 & 262,7 & 258,4 & 254,4 \\
\hline & 0,8 & 291,2 & 279,9 & 272,2 & 266,2 & 261,0 & 256,3 & 252,0 & 247,9 \\
\hline \multirow{7}{*}{ 1-Jun } & 0,2 & 325,6 & 320,3 & 316,8 & 314,0 & 311,6 & 309,4 & 307,4 & 305,5 \\
\hline & 0,3 & 322,1 & 316,5 & 312,7 & ],309 & 301,1 & 304,7 & 302,6 & 300,5 \\
\hline & 0,4 & 322,4 & 315,8 & 311,3 & 307,8 & 304,7 & 302,0 & 299,5 & 297,1 \\
\hline & 0,5 & 319,3 & 312,1 & 307,3 & 303,4 & 300,1 & 297,1 & 294,3 & 291,7 \\
\hline & 0,6 & 317,2 & 309,6 & 304,6 & 300,5 & 297,1 & 294,0 & 291,1 & 288,4 \\
\hline & 0,7 & 314,6 & 306,3 & 300,7 & 296,2 & 292,3 & 288,9 & 285,7 & 282,7 \\
\hline & 0,8 & 315,4 & 306,1 & 299,8 & 294,8 & 290,5 & 286,7 & 283,1 & 279,7 \\
\hline \multirow{7}{*}{ 15-Jun } & 0,2 & 353,2 & 348,3 & 345,0 & 342,4 & 340,2 & 338,2 & 336,3 & 334,5 \\
\hline & 0,3 & 350,3 & 345,3 & 341,8 & 339,1 & 336,8 & 334,7 & 332,7 & 330,9 \\
\hline & 0,4 & 349,0 & 343,1 & 339,1 & 335,9 & 333,1 & 330,7 & 328,4 & 326,2 \\
\hline & 0,5 & 345,0 & 339,3 & 335,4 & 332,4 & 329,7 & 327,4 & 325,2 & 323,1 \\
\hline & 0,6 & 347,4 & 340,5 & 335,8 & 332,0 & 328,8 & 325,9 & 323,3 & 320,7 \\
\hline & 0,7 & 345,7 & 338,1 & 332,9 & 328,9 & 325,4 & 322,2 & 319,3 & 316,5 \\
\hline & 0,8 & 344,2 & 336,4 & 331,1 & 327,0 & 323,4 & 320,2 & 317,2 & 314,3 \\
\hline
\end{tabular}


Tabela 33. Estimativa da lâmina bruta de irrigação $(\mathrm{mm})$ necessária à cultura do feijão caupi, com diferentes probabilidades de ocorrência, em cada época de semeadura e nível de manejo (p) no município de Parnaiba, Piauí

\begin{tabular}{|c|c|c|c|c|c|c|c|c|c|}
\hline \multirow{2}{*}{$\begin{array}{l}\text { Época de } \\
\text { Semeadura }\end{array}$} & \multirow[t]{2}{*}{$\mathrm{p}$} & \multicolumn{8}{|c|}{ Probabilidade de ocorrência $(\%)$} \\
\hline & & 95 & 90 & 85 & 80 & 75 & 70 & 65 & 60 \\
\hline \multirow{7}{*}{$1-J u l$} & 0,2 & 381,4 & 377,5 & 374,8 & 372,6 & 370,8 & 369,2 & 367,7 & 366,2 \\
\hline & 0,3 & 379,3 & 374,8 & 371,7 & 369,3 & 367,2 & 365,3 & 363,6 & 362,0 \\
\hline & 0,4 & 377,5 & 372,7 & 369,4 & 366,9 & 364,7 & 362,7 & 360,8 & 359,1 \\
\hline & 0,5 & 381,2 & 375,1 & 370,9 & 367,6 & 364,8 & 362,2 & 359,9 & 357,7 \\
\hline & 0,6 & 376,6 & 370,7 & 366,7 & 363,6 & 360,9 & 358,4 & 356,2 & 354,1 \\
\hline & 0,7 & 376,2 & 369,6 & 365.2 & 361,7 & 358,7 & 356,0 & 353,5 & 351,1 \\
\hline & 0,8 & 374,9 & 368,0 & 363,4 & 359,7 & 356,5 & 353,7 & 351,1 & 348,6 \\
\hline \multirow{7}{*}{ 15-Jul } & 0,2 & 412,7 & 408,7 & 406,0 & 403,8 & 401,9 & 400,3 & 398,7 & 397,3 \\
\hline & 0,3 & 408,6 & 404,5 & 401,8 & 399,7 & 397,8 & 396,1 & 394,6 & 393,1 \\
\hline & 0,4 & 410,5 & 405,8 & 402,7 & 400,2 & 398,0 & 396,1 & 394,3 & 392,6 \\
\hline & 0,5 & 410,2 & 405,1 & 401,7 & 399,0 & 396,6 & 394,5 & 392,6 & 390,7 \\
\hline & 0,6 & 409,9 & 404,4 & 400,7 & 397,8 & 395,3 & 393,1 & 391,0 & 389,0 \\
\hline & 0,7 & 407,7 & 402,2 & 398,5 & 395,5 & 393,0 & 390,8 & 388,7 & 386,7 \\
\hline & 0,8 & 407,4 & 401,7 & 397,9 & 394,9 & 392,3 & 390,0 & 387,8 & 385,8 \\
\hline \multirow{7}{*}{ 1-Ago } & 0,2 & 443,7 & 441,5 & 440,1 & 438,9 & 438,0 & 437,1 & 436,3 & 435,5 \\
\hline & 0,3 & 442,4 & 439,8 & 438,1 & 436,7 & 435,5 & 434,4 & 433,4 & 432,5 \\
\hline & 0,4 & 440,3 & 438,0 & 436,4 & 435,1 & 434,0 & 433,0 & 432,1 & 431,3 \\
\hline & 0,5 & 441,8 & 438,8 & 436,7 & 435,1 & 433,7 & 432,5 & 431,3 & 430,2 \\
\hline & 0,6 & 438,4 & 435,6 & 433,7 & 432,2 & 430,9 & 429,7 & 428,7 & 427,6 \\
\hline & 0,7 & 436,1 & 433,5 & 431,8 & 430,4 & 429,2 & 428,2 & 427,2 & 426,2 \\
\hline & 0,8 & 439,3 & 435,4 & 432,7 & 430,6 & 428,8 & 427,2 & 425,7 & 424,3 \\
\hline \multirow{7}{*}{ 15-Ago } & 0,2 & 463,5 & 461,4 & 460,0 & 458,9 & 457,9 & 457,1 & 456,3 & 455,5 \\
\hline & 0,3 & 463,7 & 461,1 & 459,3 & 457,9 & 456,7 & 455,6 & 454,6 & 453,7 \\
\hline & 0,4 & 460,2 & 458,0 & 456,5 & 455,4 & 454,4 & 453,5 & 452,6 & 451,8 \\
\hline & 0,5 & 458,6 & 456,0 & 454,2 & 452,7 & 451,5 & 450,4 & 449,4 & 448,4 \\
\hline & 0,6 & 460,2 & 457,0 & 454,8 & 453,0 & 451,5 & 450,2 & 449,0 & 447,8 \\
\hline & 0,7 & 460,9 & 456,5 & 453,6 & 451,3 & 449,3 & 447,6 & 445,9 & 444,3 \\
\hline & 0,8 & 460,9 & 456,9 & 454,2 & 452,1 & 450,2 & 448,6 & 447,0 & 445,6 \\
\hline
\end{tabular}


Tabela 33. Estimativa da lâmina bruta de irrigação $(\mathrm{mm})$ necessária à cultura do feijão caupi, com diferentes probabilidades de ocorrência, em cada época de semeadura e nível de manejo (p) no município de Parnaíba, Piauí.

\begin{tabular}{|c|c|c|c|c|c|c|c|c|c|}
\hline \multirow{2}{*}{$\begin{array}{c}\text { Época de } \\
\text { Semeadura }\end{array}$} & \multirow[t]{2}{*}{$\mathrm{p}$} & \multicolumn{8}{|c|}{ Probabilidade de ocorrência (\%) } \\
\hline & & 95 & 90 & 85 & 80 & 75 & 70 & 65 & 60 \\
\hline \multirow{7}{*}{ 1-Set } & 0,2 & 477,7 & 475,8 & 474,5 & 473,5 & 472,6 & 471,8 & 471,1 & 470,4 \\
\hline & 0,3 & 477,4 & 475,1 & 473,6 & 472,3 & 471,3 & 470,4 & 469,5 & 468,7 \\
\hline & 0,4 & 475,2 & 473,0 & 471,5 & 470,3 & 469,2 & 468,3 & 467,5 & 466,7 \\
\hline & 0,5 & 473,7 & 471,1 & 469,4 & 468,0 & 466,8 & 465,8 & 464,8 & 463,9 \\
\hline & 0,6 & 475,9 & 473,1 & 471,1 & 469,6 & 468,2 & 467,0 & 465,9 & 464,9 \\
\hline & 0,7 & 476,2 & 472,1 & 469,4 & 467,2 & 465,3 & 463,6 & 462,1 & 460,6 \\
\hline & 0,8 & 475,2 & 471,1 & 468,2 & 466,0 & 464,1 & 462,4 & 460,8 & 459,3 \\
\hline \multirow{7}{*}{$15-$ Set } & 0,2 & 476,8 & 474,3 & 472,5 & 471,1 & 469,9 & 468,9 & 467,9 & 467,0 \\
\hline & 0,3 & 475,7 & 473,1 & 471,4 & 470,0 & 468,8 & 467,7 & 466,7 & 465,8 \\
\hline & 0,4 & 473,2 & 470,6 & 468,8 & 467,4 & 466,2 & 465,1 & 464,1 & 463,1 \\
\hline & 0,5 & 473,5 & 470,3 & 468,0 & 466,3 & 464,8 & 463,4 & 462,2 & 461,0 \\
\hline & 0,6 & 474,4 & 471,1 & 468,9 & 467,1 & 465,6 & 464,2 & 463,0 & 461,8 \\
\hline & 0,7 & 476,0 & 471,4 & 468,4 & 465,9 & 463,9 & 462,0 & 460,2 & 458,6 \\
\hline & 0,8 & 470,2 & 466,2 & 463,5 & 461,3 & 459,5 & 457,8 & 456,3 & 454,9 \\
\hline \multirow{7}{*}{ 1-Out } & 0,2 & 476,0 & 472,8 & 470,7 & 469,0 & 467,5 & 466,2 & 465,0 & 463,8 \\
\hline & 0,3 & 476,4 & 472,7 & 470,2 & 468,2 & 466,5 & 465,0 & 463,6 & 462,2 \\
\hline & 0,4 & 474,3 & 470,5 & 467,9 & 465,8 & 464,0 & 462,4 & 460,9 & 459,5 \\
\hline & 0,5 & 473,5 & 469,2 & 466,3 & 464,0 & 462,1 & 460,3 & 458,7 & 457,1 \\
\hline & 0,6 & 474,8 & 470,1 & 467,0 & 464,5 & 462,3 & 460,4 & 458,6 & 456,9 \\
\hline & 0,7 & 472,7 & 468,0 & 464,8 & 462,3 & 460,1 & 458,2 & 456,4 & 454,7 \\
\hline & 0,8 & 469,2 & 464,3 & 461,0 & 458,4 & 456,2 & 454,1 & 452,3 & 450,5 \\
\hline \multirow{7}{*}{ 15-Out } & 0,2 & 466,9 & 463,2 & 460,7 & 458,7 & 457,0 & 455,5 & 454,0 & 452,7 \\
\hline & 0,3 & 464,6 & 460,6 & 457,8 & 455,7 & 453,8 & 452,2 & 450,6 & 449,1 \\
\hline & 0,4 & 463,8 & 459,9 & 457,3 & 455,2 & 453,4 & 451,8 & 450,3 & 448,9 \\
\hline & 0,5 & 461,4 & 457,1 & 454,2 & 451,9 & 449,9 & 448,1 & 446,5 & 444,9 \\
\hline & 0,6 & 462,7 & 457,8 & 454,5 & 451,8 & 449,6 & 447,6 & 445,7 & 443,9 \\
\hline & 0,7 & 460,8 & 455,1 & 451,3 & 448,3 & 445,6 & 443,3 & 441,1 & 439,1 \\
\hline & 0,8 & 460,7 & 455,1 & 451,4 & 448,4 & 445,8 & 443,5 & 441,4 & 439,4 \\
\hline
\end{tabular}


Tabela 33. Estimativa da lâmina bruta de irrigação $(\mathrm{mm})$ necessária à cuitura do feijão caupi, com diferentes probabilidades de ocorrência, em cada época de semeadura e nivel de manejo (p) no municipio de Parnaiba, Piauí.

\begin{tabular}{|c|c|c|c|c|c|c|c|c|c|}
\hline \multirow{2}{*}{$\begin{array}{l}\text { Época de } \\
\text { Semeadura }\end{array}$} & \multirow[t]{2}{*}{$\mathrm{p}$} & \multicolumn{8}{|c|}{ Probabilidade de ocorrência (\%) } \\
\hline & & 95 & 90 & 85 & 80 & 75 & 70 & 65 & 60 \\
\hline \multirow{7}{*}{$1-\mathrm{Nov}$} & 0,2 & 432,3 & 426,0 & 421,7 & 418,3 & 415,4 & 412,8 & 410,4 & 408,1 \\
\hline & 0,3 & 432,3 & 425,1 & 420,2 & 416,3 & 413,0 & 410,0 & 407,2 & 404,6 \\
\hline & 0,4 & 428,3 & 420,7 & 415,6 & 411,6 & 408,1 & 405,0 & 402,1 & 399,4 \\
\hline & 0,5 & 424,3 & 416,7 & 411,5 & 407,4 & 403,9 & 400,8 & 397,9 & 395,1 \\
\hline & 0,6 & 427,5 & 418,6 & 412,7 & 408,0 & 403,9 & 400,3 & 396,9 & 393,7 \\
\hline & 0,7 & 425,9 & 416,4 & 409,9 & 404,8 & 400,4 & 396,4 & 392,7 & 389,2 \\
\hline & 0,8 & 425,2 & 414,9 & 408,0 & 402,5 & 397,7 & 393,5 & 389,6 & 385,8 \\
\hline \multirow{7}{*}{$15-\mathrm{Nov}$} & 0,2 & 391,3 & 383,9 & 378,9 & 374,9 & 371,4 & 368,4 & 365,5 & 362,8 \\
\hline & 0,3 & 387,5 & 379,4 & 373,8 & 369,5 & 365,7 & 362,3 & 359,2 & 356,3 \\
\hline & 0,4 & 386,4 & 377,3 & 371,2 & 366,4 & 362,2 & 358,5 & 355,1 & 351,8 \\
\hline & 0,5 & 385,1 & 374,9 & 368,0 & 362,5 & 357,8 & 353,6 & 349,7 & 346,0 \\
\hline & 0,6 & 379,6 & 369,0 & 361,9 & 356,3 & 351,4 & 347,0 & 343,0 & 339,2 \\
\hline & 0,7 & 380,9 & 368,7 & 360,5 & 354,0 & 348,4 & 343,3 & 338,7 & 334,3 \\
\hline & 0,8 & 377,3 & 364,5 & 355,9 & 349,0 & 343,1 & 337,9 & 333,0 & 328,3 \\
\hline \multirow{7}{*}{ 1-Dez } & 0,2 & 359,2 & 351,7 & 346,7 & 342,7 & 339,2 & 336,1 & 333,3 & 330,6 \\
\hline & 0,3 & 354,8 & 346,3 & 340,6 & 336,0 & 332,1 & 328,6 & 325,3 & 322,2 \\
\hline & 0,4 & 350,8 & 341,8 & 335,7 & 330,9 & 326,8 & 323,0 & 319,6 & 316,3 \\
\hline & 0,5 & 346,4 & 336,2 & 329,3 & 323,9 & 319,2 & 315,0 & 311,1 & 307,4 \\
\hline & 0,6 & 339,5 & 329,6 & 323,0 & 317,8 & 313,2 & 309,2 & 305,4 & 301,9 \\
\hline & 0,7 & 340,0 & 328,4 & 320,6 & 314,4 & 309,1 & 304,3 & 299,9 & 295,7 \\
\hline & 0,8 & 338,7 & 326,4 & 318,2 & 311,6 & 306,0 & 300,9 & 296,2 & 291,8 \\
\hline \multirow{7}{*}{ 15-Dez } & 0,2 & 321,8 & 312,3 & 305,9 & 300,8 & 296,4 & 292,5 & 288,9 & 285,5 \\
\hline & 0,3 & 314,1 & 303,4 & 296,2 & 290,5 & 285,6 & 281,2 & 277,1 & 273,2 \\
\hline & 0,4 & 309,8 & 298,1 & 290,2 & 283,9 & 278,6 & 273,7 & 269,2 & 265,0 \\
\hline & 0,5 & 303,2 & 290,8 & 282,4 & 275,7 & 270,0 & 264,9 & 260,1 & 255,6 \\
\hline & 0,6 & 297,9 & 285,1 & 276,4 & 269,5 & 263,6 & 258,3 & 253,4 & 248,7 \\
\hline & 0,7 & 293,2 & 279,0 & 269,4 & 261,8 & 255,3 & 249,5 & 244,1 & 238,9 \\
\hline & 0,8 & 291,9 & 276,5 & 266,2 & 257,9 & 250,9 & 244,5 & 238,7 & 233,1 \\
\hline
\end{tabular}


Tabela 34. Estimativa da produtividade de grãos de feijão caupi $\left(\mathrm{kg} \mathrm{ha}^{-1}\right)$, com diferentes probabilidades de ocorrência, em cada época de semeadura e nível de manejo (p) no município de Parnaíba, Piauí.

\begin{tabular}{|c|c|c|c|c|c|c|c|c|c|}
\hline \multirow{2}{*}{$\begin{array}{l}\text { Época de } \\
\text { Semeadura }\end{array}$} & \multirow[t]{2}{*}{$\mathrm{p}$} & \multicolumn{8}{|c|}{ Probabilidade de ocorrência (\%) } \\
\hline & & 5 & 10 & 15 & 20 & 25 & 30 & 35 & 40 \\
\hline \multirow{7}{*}{$1-J a n$} & 0,2 & 2245,1 & 2254,4 & 2260,7 & 2265,6 & 2269,9 & 2273,7 & 2277,3 & 2280,7 \\
\hline & 0,3 & 2112,4 & 2123,3 & 2130,7 & 2136,6 & 2141,7 & 2146,2 & 2150,4 & 2154,4 \\
\hline & 0,4 & 1978,4 & 1995,8 & 2007,5 & 2016,9 & 2024,9 & 2032,1 & 2038,7 & 2045,1 \\
\hline & 0,5 & 1845,3 & 1864,9 & 1878,1 & 1888,6 & 1897,6 & 1905,7 & 1913,2 & 1920,3 \\
\hline & 0,6 & 1732,3 & 1756,1 & 1772,2 & 1785,0 & 1796,0 & 1805,8 & 1814,9 & 1823,6 \\
\hline & 0,7 & 1611,5 & 1640,4 & 1659,8 & 1675,3 & 1688,6 & 1700,5 & 1711,5 & 1722,0 \\
\hline & 0,8 & 1520,4 & 1551,9 & 1573,1 & 1590,0 & 1604,5 & 1617,5 & 1629,6 & 1641,0 \\
\hline \multirow{7}{*}{$15-J a n$} & 0,2 & 2268,3 & 2277,4 & 2283,6 & 2288,5 & 2292,7 & 2296,4 & 2299,9 & 2303,2 \\
\hline & 0,3 & 2147,6 & 2158,3 & 2165,5 & 2171,2 & 2176,1 & 2180,5 & 2184,5 & 2188,4 \\
\hline & 0,4 & 2005,4 & 2021,7 & 2032,6 & 2041,3 & 2048,8 & 2055,5 & 2061,7 & 2067,6 \\
\hline & 0,5 & 1878,1 & 1897,7 & 1910,9 & 1921,4 & 1930,4 & 1938,5 & 1946,0 & 1953,1 \\
\hline & 0,6 & 1749,0 & 1775,4 & 1793,2 & 1807,3 & 1819,5 & 1830,4 & 1840,5 & 1850,1 \\
\hline & 0,7 & 1652,8 & 1680,2 & 1698,6 & 1713,3 & 1725,9 & 1737,2 & 1747,7 & 1757,6 \\
\hline & 0,8 & 1564,1 & 1595,7 & 1617,0 & 1633,9 & 1648,5 & 1661,5 & 1673,6 & 1685,1 \\
\hline \multirow{7}{*}{$1-\mathrm{Fev}$} & 0,2 & 2261,8 & 2270,9 & 2277,0 & 2281,9 & 2286,1 & 2289,8 & 2293,3 & 2296,6 \\
\hline & 0,3 & 2148,6 & $2159 ., 1$ & 2166,2 & 2171,8 & 2176,6 & 2181,0 & 2185,0 & 2188,8 \\
\hline & 0,4 & 1989,2 & 2008,1 & 2020,8 & 2030,9 & 2039,6 & 2047,4 & 2054,6 & 2061,5 \\
\hline & 0,5 & 1886,1 & 1906,5 & 1920,2 & 1931,2 & 1940,6 & 1949,0 & 1956,8 & 1964,2 \\
\hline & 0,6 & 1764,8 & 1791,6 & 1809,6 & 1824,0 & 1836,3 & 1847,3 & 1857,6 & 1867,3 \\
\hline & 0,7 & 1664,9 & 1696,1 & 1717,2 & 1733,9 & 1748,2 & 1761,1 & 1773,0 & 1784,4 \\
\hline & 0,8 & 1559,9 & 1597,7 & 1623,2 & 1643,4 & 1660,8 & 1676,4 & 1690,9 & 1704,6 \\
\hline \multirow{7}{*}{$15-\mathrm{Fev}$} & 0,2 & 2251,1 & 2260,5 & 2266,9 & 2271,9 & 2276,3 & 2280,2 & 2283,8 & 2287,2 \\
\hline & 0,3 & 2147,3 & 2158,4 & 2165,9 & 2171,9 & 2177,0 & 2181,6 & 2185,8 & 2189,9 \\
\hline & 0,4 & 1980,1 & 1999,6 & 2012,9 & 2023,4 & 2032,4 & 2040,5 & 2048,0 & 2055,1 \\
\hline & 0,5 & 1881,7 & 1903,7 & 1918,5 & 1930,3 & 1940,4 & 1949,5 & 1957,9 & 1965,9 \\
\hline & 0,6 & 1756,3 & 1786,0 & 1806,1 & 1822,0 & 1835,7 & 1848,0 & 1859,4 & 1870,2 \\
\hline & 0,7 & 1691,1 & 1721,8 & 1742,5 & 1758,9 & 1773,0 & 1785,7 & 1797,4 & 1808,6 \\
\hline & 0,8 & 1583,7 & 1620,4 & 1645,1 & 1664,8 & 1681,7 & 1696,8 & 1710,9 & 1724,2 \\
\hline
\end{tabular}


Tabela 34. Estimativa da produtividade de grãos de feijão caupi ( $\left.\mathrm{kg} \mathrm{ha}^{-\mathrm{I}}\right)$, com diferentes probabilidades de ocorrência, em cada época de semeadura e nivel de manejo (p) no municipio de Parnaiba, Piaui.

\begin{tabular}{|c|c|c|c|c|c|c|c|c|c|}
\hline \multirow{2}{*}{$\begin{array}{l}\text { Época de } \\
\text { Semeadura }\end{array}$} & \multirow[t]{2}{*}{$\mathrm{p}$} & \multicolumn{8}{|c|}{ Probabilidade de ocorrência (\%) } \\
\hline & & 5 & 10 & 15 & 20 & 25 & 30 & 35 & 40 \\
\hline \multirow{7}{*}{ 1-Mar } & 0,2 & 2247,2 & 2257,0 & 2263,6 & 2268,8 & 2273,3 & 2277,4 & 2281,1 & 2284,7 \\
\hline & 0,3 & 2143,0 & 2155,4 & 2163,7 & 2170,4 & 2176,1 & 2181,2 & 2186,0 & 2190,5 \\
\hline & 0,4 & 1977,2 & 1997,2 & 2010,7 & 2021,5 & 2030,7 & 2039,0 & 2046,6 & 2053,9 \\
\hline & 0,5 & 1874,4 & 1899,4 & 1916,2 & 1929,7 & 1941,2 & 1951,5 & 1961,1 & 1970,2 \\
\hline & 0,6 & 1758,3 & 1788,5 & 1808,8 & 1824,9 & 1838,8 & 1851,2 & 1862,7 & 1873,7 \\
\hline & 0,7 & 1661,4 & 1697,3 & 1721,6 & 1740,8 & 1757,3 & 1772,2 & 1785,9 & 1799,0 \\
\hline & 0,8 & 1573,5 & 1613,6 & 1640,7 & 1662,2 & 1680,6 & 1697,2 & 1712,5 & 1727,1 \\
\hline \multirow{7}{*}{ 15-Mar } & 0,2 & 2230,5 & 2239,8 & 2246,1 & 2251,1 & 2255,3 & 2259,2 & 2262,7 & 2266,1 \\
\hline & 0,3 & 2127,2 & 2139,5 & 2147,8 & 2154,4 & 2160,0 & 2165,1 & 2169,8 & 2174,2 \\
\hline & 0,4 & 1959,3 & 1977,2 & 1989,2 & 1998,8 & 2007,0 & 2014,4 & 2021,3 & 2027,7 \\
\hline & 0,5 & 1856,5 & 1877,6 & 1891,9 & 1903,2 & 1913,0 & 1921,7 & 1929,8 & 1937,5 \\
\hline & 0,6 & 1732,5 & 1758,7 & 1776,4 & 1790,5 & 1802,6 & 1813,4 & 1823,5 & 1833,0 \\
\hline & 0,7 & 1638,0 & 1668,9 & 1689,8 & 1706,4 & 1720,6 & 1733,4 & 1745,2 & 1756,4 \\
\hline & 0,8 & 1528,9 & 1567,1 & 1592,9 & 1613,4 & 1631,0 & 1646,8 & 1661,4 & 1675,3 \\
\hline \multirow{7}{*}{$1-\mathrm{Abr}$} & 0,2 & 2235,4 & 2243,8 & 2249,4 & 2253,9 & 2257,8 & 2261,2 & 2264,5 & 2267,5 \\
\hline & 0,3 & 2119,8 & 2130,5 & 2137,7 & 2143,4 & 2148,3 & 2152,6 & 2156,7 & 2160,6 \\
\hline & 0,4 & 1941,6 & 1958,7 & 1970,3 & 1979,4 & 1987,3 & 1994,3 & 2000,9 & 2007,1 \\
\hline & 0,5 & 1830,1 & 1851,0 & 1865,0 & 1876,2 & 1885,8 & 1894,4 & 1902,4 & 1910,0 \\
\hline & 0,6 & 1687,0 & 1712,8 & 1730,1 & 1743,9 & 1755,8 & 1766,4 & 1776,3 & 1785,6 \\
\hline & 0,7 & 1595,0 & 1624,6 & 1644,6 & 1660,4 & 1674,0 & 1686,2 & 1697,6 & 1708,3 \\
\hline & 0,8 & 1486,4 & 1520,4 & 1543,4 & 1561,7 & 1577,4 & 1591,5 & 1604,5 & 1616,9 \\
\hline \multirow{7}{*}{$15-\mathrm{Abr}$} & 0,2 & 2231,2 & 2238,8 & 2243,9 & 2247,9 & 2251,4 & 2254,5 & 2257,4 & 2260,1 \\
\hline & 0,3 & 2108,8 & 2118,2 & 2124,6 & 2129,7 & 2134,1 & 2138,0 & 2141,7 & 2145,1 \\
\hline & 0,4 & 1927,7 & 1943,1 & 1953,4 & 1961,6 & 1968,7 & 1975,0 & 1980,9 & 1986,5 \\
\hline & 0,5 & 1801,2 & 1820,5 & 1833,6 & 1844,0 & 1852,9 & 1861,0 & 1868,4 & 1875,4 \\
\hline & 0,6 & 1652,8 & 1677,2 & 1693,6 & 1706,7 & 1717,9 & 1728,0 & 1737,3 & 1746,1 \\
\hline & 0,7 & 1558,7 & 1584,6 & 1602,1 & 1616,0 & 1628,0 & 1638,7 & 1648,6 & 1658,0 \\
\hline & 0,8 & 1443,4 & 1473,2 & 1493,3 & 1509,2 & 1522,9 & 1535,2 & 1546,6 & 1557,4 \\
\hline
\end{tabular}


Tabela 34. Estimativa da produtividade de grãos de feijão caupi ( $\left.\mathrm{kg} \mathrm{ha}^{-1}\right)$, com diferentes probabilidades de ocorrência, em cada época de semeadura e nível de manejo (p) no município de Parnaíba, Piauí.

\begin{tabular}{|c|c|c|c|c|c|c|c|c|c|}
\hline \multirow{2}{*}{$\begin{array}{l}\text { Época de } \\
\text { Semeadura }\end{array}$} & \multirow[t]{2}{*}{$\mathrm{p}$} & \multicolumn{8}{|c|}{ Probabilidade de ocorrência (\%) } \\
\hline & & 5 & 10 & 15 & 20 & 25 & 30 & 35 & 40 \\
\hline \multirow{7}{*}{ 1-Mai } & 0,2 & 2228,0 & 2235,4 & 2240,4 & 2244,4 & 2247,8 & 2250,9 & 2253,7 & 2256,4 \\
\hline & 0,3 & 2101,0 & 2109,8 & 2115,7 & 2120,4 & 2124,4 & 2128,0 & 2131,4 & 2134,5 \\
\hline & 0,4 & 1915,7 & 1929,4 & 1938,6 & 1945,9 & 1952,2 & 1957,9 & 1963,1 & 1968,1 \\
\hline & 0,5 & 1788,3 & 1802,8 & 1812,5 & 1820,2 & 1826,8 & 1832,8 & 1838,3 & 1843,5 \\
\hline & 0,6 & 1655,2 & 1672,2 & 1683,6 & 1692,7 & 1700,5 & 1707,5 & 1714,0 & 1720,2 \\
\hline & 0,7 & 1538,0 & 1557,4 & 1570,5 & 1580,9 & 1589,9 & 1597,9 & 1605,3 & 1612,4 \\
\hline & 0,8 & 1431,1 & 1450,2 & 1463,1 & 1473,4 & 1482,1 & 1490,0 & 1497,3 & 1504,3 \\
\hline \multirow{7}{*}{ 15-Mai } & 0,2 & 2231,2 & 2239,3 & 2244,9 & 2249,3 & 2253,0 & 2256,4 & 2259,5 & 2262,5 \\
\hline & 0,3 & 2105,3 & 2112,9 & 2117,9 & 2122,0 & 2125,4 & 2128,6 & 2131,4 & 2134,2 \\
\hline & 0,4 & 1921,8 & 1936,8 & 1946,8 & 1954,8 & 1961,7 & 1967,9 & 1973,6 & 1979,0 \\
\hline & 0,5 & 1786,8 & 1800,5 & 1809,8 & 1817,2 & 1823,5 & 1829,2 & 1834,5 & 1839,5 \\
\hline & 0,6 & 1655,2 & 1671,4 & 1682,4 & 1691,1 & 1698,6 & 1705,3 & 1711,5 & 1717,4 \\
\hline & 0,7 & 1540,5 & 1557,8 & 1569,4 & 1578,7 & 1586,6 & 1593,7 & 1600,3 & 1606,6 \\
\hline & 0,8 & 1430,5 & 1448,1 & 1460,0 & 1469,4 & 1477,5 & 1484,8 & 1491,5 & 1497,9 \\
\hline \multirow{7}{*}{ 1-Jun } & 0,2 & 2248,0 & 2255,8 & 2261,1 & 2265,2 & 2268,8 & 2272,1 & 2275,1 & 2277,9 \\
\hline & 0,3 & 2117,3 & 2123,4 & 2127,5 & 2130,7 & 2133,5 & $2] 36,0$ & 2138,4 & 2140,6 \\
\hline & 0,4 & 1943,6 & 1957,3 & 1966,6 & 1973,9 & 1980,3 & 1985,9 & 1991,2 & 1996,1 \\
\hline & 0,5 & 1797,9 & 1808,1 & 1814,9 & 1820,3 & 1825,0 & 1829,1 & 1833,0 & 1836,7 \\
\hline & 0,6 & 1669,0 & 1685,2 & 1696,2 & 1704,9 & 1712,3 & 1719,0 & 1725,2 & 1731,1 \\
\hline & 0,7 & 1534,6 & 1549,2 & 1559,0 & 1566,8 & 1573,5 & 1579,5 & 1585,0 & 1590,3 \\
\hline & 0,8 & 1430,7 & 1448,3 & 1460,2 & 1469,7 & 1477,8 & 1485,1 & 1491,8 & 1498,3 \\
\hline \multirow{7}{*}{ 15-Jun } & 0,2 & 2272,9 & 2281,0 & 2286,4 & 2290,7 & 2294,4 & 2297,7 & 2300,8 & 2303,7 \\
\hline & 0,3 & 2118,8 & 2125,4 & 2129,8 & 2133,3 & 2136,3 & 2139,1 & 2141,6 & 2143,9 \\
\hline & 0,4 & 1981,9 & 1993,9 & 2002,0 & 2008,4 & 2013,9 & 2018,9 & 2023,5 & 2027,8 \\
\hline & 0,5 & 1800,0 & 1810,2 & 1817,1 & 1822,6 & 1827,3 & 1831,5 & 1835,4 & 1839,1 \\
\hline & 0,6 & 1706,1 & 1718,5 & 1726,8 & 1733,5 & 1739,2 & 1744,3 & 1749,0 & 1753,5 \\
\hline & 0,7 & 1541,3 & $1.557,7$ & 1568,7 & 1577,4 & 1585,0 & 1591,7 & 1598,0 & 1603,9 \\
\hline & 0,8 & 1454,0 & 1468,7 & 1478,7 & 1486,6 & 1493,4 & 1499,5 & 1505,1 & 1510,4 \\
\hline
\end{tabular}


Tabela 34. Estimativa da produtividade de grãos de feijão caupi $\left(\mathrm{kg} \mathrm{ha}^{-1}\right)$, com diferentes probabilidades de ocorrência, em cada época de semeadura e nível de manejo (p) no município de Parnaiba, Piauí.

\begin{tabular}{cccccccccc}
\hline Época de & $p$ & \multicolumn{7}{c}{ Probabilidade de ocorrência (\%) } \\
\cline { 2 - 9 } Semeadura & & 5 & 10 & 15 & 20 & 25 & 30 & 35 & 40 \\
\hline \multirow{6}{*}{ 1-Jul } & 0,2 & 2301,1 & 2308,7 & 2313,8 & 2317,8 & 2321,3 & 2324,4 & 2327,3 & 2330,0 \\
& 0,3 & 2126,0 & 2132,3 & 2136,6 & 2140,0 & 2142,9 & 2145,5 & 2147,9 & 2150,2 \\
& 0,4 & 2010,9 & 2021,6 & 2028,7 & 2034,4 & 2039,3 & 2043,7 & 2047,8 & 2051,7 \\
& 0,5 & 1818,1 & 1830,6 & 1839,0 & 1845,7 & 1851,5 & 1856,6 & 1861,4 & 1866,0 \\
& 0,6 & 1720,8 & 1730,1 & 1736,4 & 1741,5 & 1745,8 & 1749,6 & 1753,2 & 1756,6 \\
& 0,7 & 1573,2 & 1587,9 & 1597,8 & 1605,6 & 1612,3 & 1618,4 & 1624,0 & 1629,3 \\
& 0,8 & 1464,9 & 1477,6 & 1486,2 & 1493,0 & 1498,9 & 1504,1 & 1509,0 & 1513,6 \\
\hline \multirow{4}{*}{ 15-Jul } & 0,2 & 2328,4 & 2335,8 & 2340,8 & 2344,8 & 2348,2 & 2351,2 & 2354,1 & 2356,7 \\
& 0,3 & 2136,2 & 2143,0 & 2147,5 & 2151,1 & 2154,2 & 2157,0 & 2159,6 & 2162,0 \\
& 0,4 & 2042,6 & 2050,1 & 2055,1 & 2059,1 & 2062,5 & 2065,6 & 2068,5 & 2071,2 \\
& 0,5 & 1856,5 & 1871,5 & 1881,7 & 1889,7 & 1896,6 & 1902,8 & 1908,6 & 1914,1 \\
& 0,6 & 1726,0 & 1735,1 & 1741,3 & 1746,2 & 1750,4 & 1754,2 & 1757,7 & 1761,0 \\
& 0,7 & 1617,4 & 1630,6 & 1639,5 & 1646,6 & 1652,7 & 1658,2 & 1663,2 & 1668,0 \\
& 0,8 & 1462,0 & 1476,8 & 1486,8 & 1494,7 & 1501,5 & 1507,6 & 1513,3 & 1518,6 \\
\hline \multirow{4}{*}{ 15-Ago } & 0,2 & 2362,3 & 2368,8 & 2373,2 & 2376,7 & 2379,7 & 2382,4 & 2384,9 & 2387,2 \\
& 0,3 & 2156,5 & 2162,9 & 2167,2 & 2170,6 & 2173,5 & 2176,2 & 2178,6 & 2181,0 \\
& 0,5 & 1961,0 & 1970,8 & 1977,4 & 1982,6 & 1987,1 & 1991,1 & 1994,9 & 1998,4 \\
& 0,6 & 1746,7 & 1758,6 & 1766,6 & 1773,0 & 1778,4 & 1783,3 & 1787,9 & 1792,2 \\
& 0,4 & 2058,7 & 2065,4 & 2069,8 & 2073,4 & 2076,4 & 2079,1 & 2081,7 & 2084,1 \\
& 0,7 & 1659,9 & 1666,9 & 1671,6 & 1675,3 & 1678,5 & 1681,4 & 1684,1 & 1686,6 \\
& 0,8 & 1555,4 & 1568,2 & 1576,8 & 1583,7 & 1589,5 & 1594,8 & 1599,7 & 1604,3
\end{tabular}


Tabela 34. Estimativa da produtividade de grãos de feijão caupi $\left(\mathrm{kg} \mathrm{ha}^{-1}\right)$, com diferentes probabilidades de ocorrência, em cada época de semeadura e nível de manejo (p) no município de Pamaíba, Piauí.

\begin{tabular}{|c|c|c|c|c|c|c|c|c|c|}
\hline \multirow{2}{*}{$\begin{array}{l}\text { Época de } \\
\text { Semeadura }\end{array}$} & \multirow[t]{2}{*}{$\mathrm{p}$} & \multicolumn{8}{|c|}{ Probabilidade de ocorrência (\%) } \\
\hline & & 5 & 10 & 15 & 20. & 25 & 30 & 35 & 40 \\
\hline \multirow{7}{*}{ 1-Set } & 0,2 & 2395,7 & 2401,2 & 2405,0 & 2408,0 & 2410,5 & 2412,8 & 2414,9 & 2417,0 \\
\hline & 0,3 & 2182,5 & 2191,6 & 2197,7 & 2202,5 & 2206,7 & 2210,4 & 2213,9 & 2217,2 \\
\hline & 0,4 & 2071,1 & 2077,3 & 2081,4 & 2084,7 & 2087,5 & 2090,0 & 2092,4 & 2094,6 \\
\hline & 0,5 & 1986,4 & 1993,9 & 1999,1 & 2003,1 . & 2006,6 & 2009,7 & 2012,6 & 2015,4 \\
\hline & 0,6 & 1757,3 & 1772,5 & 1782,9 & 1791,1 & 1798,1 & 1804,4 & 1810,2 & 1815,8 \\
\hline & 0,7 & 1658,9 & 1665,8 & 1670,4 & 1674,0 & 1677,2 & 1680,0 & 1682,6 & 1685,1 \\
\hline & 0,8 & 1609,1 & 1616,6 & 1621,6 & 1625,6 & 1629,1 & 1632,1 & 1635,0 & 1637,7 \\
\hline \multirow{7}{*}{ 15-Set } & 0,2 & 2398,9 & 2404,3 & 2408,0 & 2410,9 & 2413,4 & 2415,6 & 2417,7 & 2419,6 \\
\hline & 0,3 & 2182,0 & 2190,3 & 2195,9 & 2200,4 & 2204,2 & 2207,6 & 2210,8 & 2213,8 \\
\hline & 0,4 & 2073,6 & 2073,6 & 2083,0 & 2083,0 & 2092,4 & 2092,4 & 2101,8 & 2101,8 \\
\hline & 0,5 & 1985,1 & 1993,4 & 19991 & 2003,6 & 2007,4 & 2010,9 & 2014,1 & 2017,1 \\
\hline & 0,6 & 1760,4 & 1775,5 & 1785,7 & 1793,8 & 1800,7 & 1806,9 & 1812,7 & 1818,2 \\
\hline & 0,7 & 1659,5 & 1668,0 & 1673,7 & 1678,2 & 1682,1 & 1685,6 & 1688,9 & 1692,0 \\
\hline & 0,8 & 1599,6 & 1609,1 & 1615,6 & 1620,7 & 1625,1 & 1629,0 & 1632,6 & 1636,1 \\
\hline \multirow{7}{*}{ 1-Out } & 0,2 & 2387,1 & 2395,0 & 2395,0 & 2395,0 & 2403,0 & 2403,0 & 2410,9 & 2410,9 \\
\hline & 0,3 & 2186,1 & 2194,3 & 2199,9 & 2204,3 & 2208,1 & 2211,5 & 2214,6 & 2217,6 \\
\hline & 0,4 & 2072,4 & 2078,8 & 2083,1 & 2086,5 & 2089,4 & 2092,0 & 2094,4 & 2096,7 \\
\hline & 0,5 & 1980,8 & 1989,0 & 1994,6 & 19991999 & 2002,9 & 2006,3 & 2009,5 & 2012,5 \\
\hline & 0,6 & 1757,2 & 1771,3 & 1780,9 & 1788,5 & 1795,0 & 1800,8 & 1806,2 & 1811,3 \\
\hline & 0,7 & 1654,4 & 1663,4 & 1669,6 & 1674,4 & 1678,6 & 1682,3 & 1685,8 & 1689,1 \\
\hline & 0,8 & 1602,2 & 1610,8 & 1616,7 & 1621,3 & 1625,3 & 1628,9 & 1632,3 & 1635,4 \\
\hline \multirow{7}{*}{ 15-Out } & 0,2 & 2385,3 & 2391,3 & 2395,3 & 2398,5 & 2401,3 & 2403,8 & 2406,1 & 2408,2 \\
\hline & 0,3 & 2171,8 & 2179,5 & 2184,7 & 2188,8 & 2192,3 & 2195,5 & 2198,5 & 2201,3 \\
\hline & 0,4 & 2069,6 & 2076,5 & 2081,1 & 2084,8 & 2088,0 & 2090,8 & 2093,5 & 2096,0 \\
\hline & 0,5 & 1973,4 & 1982,3 & 1988,3 & 1993,0 & 1997,1 & 2000,7 & 2004,1 & 2007,3 \\
\hline & 0,6 & 1746,3 & 1760,2 & 1769,6 & 1777,0 & 1783,4 & 1789,1 & 1794,4 & 1799,5 \\
\hline & 0,7 & 1659,7 & 1668,5 & 1674,5 & 1679,2 & 1683,3 & 1686,9 & 1690,3 & 1693,5 \\
\hline & 0,8 & 1569,7 & 1582,9 & 1591,7 & 1598,8 & 1604,8 & 1610,2 & 1615,3 & 1620,1 \\
\hline
\end{tabular}


Tabela 34. Estimativa da produtividade de grãos de feijão caupi $\left(\mathrm{kg} \mathrm{ha}^{-1}\right)$, com diferentes probabilidades de ocorrência, em cada época de semeadura e nível de manejo (p) no municipio de Parnaiba, Piaui.

\begin{tabular}{|c|c|c|c|c|c|c|c|c|c|}
\hline \multirow{2}{*}{$\begin{array}{l}\text { Época de } \\
\text { Semeadura }\end{array}$} & \multirow[t]{2}{*}{$\mathrm{p}$} & \multicolumn{8}{|c|}{ Probabilidade de ocorrência (\%) } \\
\hline & & 5 & 10 & 15 & 20 & 25 & 30 & 35 & 40 \\
\hline \multirow{7}{*}{$1-\mathrm{Nov}$} & 0,2 & 2348,7 & 2356,1 & 2361,1 & 2365,1 & 2368,5 & 2371,5 & 2374,3 & 2377,0 \\
\hline & 0,3 & 2163,3 & 2170,6 & 2175,5 & 2179,4 & 2182,7 & 2185,7 & 2188,5 & 2191,2 \\
\hline & 0,4 & 2057,9 & 2066,2 & 2071,8 & 2076,3 & 2080,1 & 2083,5 & 2086,7 & 2089,7 \\
\hline & 0,5 & 1907,0 & 1920,3 & 1929,3 & 1936,5 & 1942,6 & 1948,1 & 1953,2 & 1958,1 \\
\hline & 0,6 & 1740,7 & 1754,2 & 1763,4 & 1770,6 & 1776,8 & 1782,4 & 1787,5 & 1792,5 \\
\hline & 0,7 & 1647,0 & 1660,1 & 1669,0 & 1676,0 & 1682,0 & 1687,4 & 1692,5 & 1697,2 \\
\hline & 0,8 & 1507,8 & 1525,9 & 1538,1 & 1547,8 & 1556,1 & 1563,6 & 1570,5 & 1577,1 \\
\hline \multirow{7}{*}{ 15-Nov } & 0,2 & 2323,8 & 2331,4 & 2336,6 & 2340,7 & 2344,2 & 2347,4 & 2350,3 & 2353,1 \\
\hline & 0,3 & 2146,5 & 2155,8 & 2162,0 & 2167,0 & 2171,3 & 2175,1 & 2178,7 & 2182,0 \\
\hline & 0,4 & 2043,4 & 2053,9 & 2061,0 & 2066,6 & 2071,5 & 2075,8 & 2079,8 & 2083,7 \\
\hline & 0,5 & 1871,3 & 1888,3 & 1899,8 & 1909,0 & 1916,8 & 1923,9 & 1930,4 & 1936,6 \\
\hline & 0,6 & 1738,8 & 1754,1 & 1764,4 & 1772,7 & 1779,7 & 1786,0 & 1791,9 & 1797,5 \\
\hline & 0,7 & 1638,3 & 1655,7 & 1667,5 & 1676,9 & 1684,9 & 1692,1 & 1698,8 & 1705,2 \\
\hline & 0,8 & 1499,4 & 1520,6 & 1534,8 & 1546,1 & 1555,9 & 1564,6 & 1572,7 & 1580,4 \\
\hline \multirow{7}{*}{ 1-Dez } & 0,2 & 2294,1 & 2303,8 & 2310,4 & 2315,6 & 2320,1 & 2324,1 & 2327,8 & 2331,3 \\
\hline & 0,3 & 2140,6 & 2149,5 & 2155,4 & 2160,2 & 2164,2 & 2167,9 & 2171,3 & 2174,5 \\
\hline & 0,4 & 2020,5 & 2033,3 & 2042,0 & 2048,8 & 2054,7 & 2060,0 & 2064,9 & 2069,6 \\
\hline & 0,5 & 1854,2 & 1870,9 & 1882,2 & 1891,2 & 1898,9 & 1905,8 & 1912,2 & 1918,2 \\
\hline & 0,6 & 1726,1 & 1745,0 & 1757,7 & 1767,8 & 1776,5 & 1784,3 & 1791,5 & 1798,4 \\
\hline & 0,7 & 1613,9 & 1634,8 & 1648,8 & 1660,0 & 1669,6 & 1678,2 & 1686,1 & 1693,7 \\
\hline & 0,8 & 1500,1 & 1522,0 & 1536,8 & 1548,5 & 1558,6 & 1567,7 & 1576,0 & 1584,0 \\
\hline \multirow{7}{*}{ 15-Dez } & 0,2 & 2282,3 & 2291,1 & 2297,1 & 2301,9 & 2306,0 & 2309,7 & 2313,1 & 2316,3 \\
\hline & 0,3 & 2133,6 & 2143,1 & 2149,5 & 2154,5 & 2158,9 & 2162,8 & 2166,4 & 2169,8 \\
\hline & 0,4 & 2010,4 & 2024,7 & 2034,3 & 2042,0 & 2048,6 & 2054,5 & 2059,9 & 2065,1 \\
\hline & 0,5 & 1839,5 & 1859,1 & 1872,4 & 1882,9 & 1892,0 & 1900,1 & 1907,6 & 1914,7 \\
\hline & 0,6 & 1728,5 & 1750,2 & 1764,8 & 1776,4 & 1786,4 & 1795,3 & 1803,6 & 1811,5 \\
\hline & 0,7 & 1604,5 & 1629,1 & 1645,8 & 1659,0 & 1670,3 & 1680,5 & 1690,0 & 1698,9 \\
\hline & 0,8 & 1498,5 & 1527,0 & 1546,2 & 1561,5 & 1574,6 & 1586,4 & 1597,3 & 1607,7 \\
\hline
\end{tabular}


hídrica da cultura com os de máxima demanda evapotranspirativa (Franke, 1996). O nível de manejo de irrigação influiu nessa variação, pois quanto menores foram os níveis de extração da CAD simulados, as irrigações tornaram-se mais freqüentes, elevando os requerimentos de lâmina bruta para a suplementação hídrica da cultura

Quanto à produtividade da cultura, verificou-se tendência de aumento dos valores da mesma à medida que elevaram-se as probabilidades de ocorrência. Essa variação probabilística é a oposta da ocorrida com a lâmina bruta de irrigação. Isso porque, enquanto as estimativas de lâmina bruta de irrigação são baseadas nos valores máximos de ocorrência, as da produtividade de grãos baseiam-se nos valores mínimos, pois é fundamental garantir valores mínimos de produtividade possíveis de serem alcançados nos referidos níveis de probabilidade.

Por exemplo, considerando-se a época de semeadura de 1-Set, o nível de manejo $\mathrm{p}=0,4$ e a probabilidade de ocorrência de $10 \%$, a produtividade de grãos do feijão caupi foi de $2077,3 \mathrm{~kg} \mathrm{ha}^{-1}$. Isto significa que em $10 \%$ dos casos ( 1 em cada 10 anos) os valores de produtividade de grãos serão, no mínimo, iguais a $2077,3 \mathrm{~kg} \mathrm{ha}^{-1}$, ou seja, a possibilidade de ocorrer um valor de produtividade superior a este é de nove vezes a cada 10 anos, o que representa uma garantia de níveis mínimos de produtividade de $90 \%$, ou seja, um risco de apenas $10 \%$. Em se tratando de produtividade de grãos, sob risco climático, isso é extremamente desejável. Da mesma forma que a lâmina bruta de irrigação, pode-se efetuar interpretações semelhantes com as demais probabilidades de ocorrência nas outras épocas de semeadura e níveis de manejo.

Constatou-se uma ampla variação nos valores de produtividade de grãos de feijão caupi em função da época de semeadura e do nível de manejo de irrigação. A maior estimativa de produtividade $\left(2419,6 \mathrm{~kg} \mathrm{ha}^{-1}\right)$ foi obtida em 15-Set, com nível de manejo $\mathrm{p}=0,2$ e probabilidade de ocorrência de $5 \%$, enquanto a menor $\left(1430,5 \mathrm{~kg} \mathrm{ha}^{-1}\right)$ ocorreu em 15-Mai, com nível de manejo $\mathrm{p}=0,8$ e probabilidade de ocorrência de $40 \%$. Nas épocas de semeadura compreendidas na estação seca, observou-se uma estreita relação entre os valores de produtividade de grãos e lâmina bruta de irrigação, obtendo-se os maiores valores de produtividade nos períodos em que foram aplicadas as maiores lâminas brutas de irrigação. O mesmo não se observou durante a estação chuvosa, 
devido a contribuição da precipitação efetiva no atendimento da demanda hídrica da cultura. O nivel de manejo de irrigação influiu nessa variação, pois quanto maiores foram os niveis de extração da CAD simulados, menos freqüentes foram as irrigações, contribuindo para imposição de elevados déficits hídricos à cultura.

No caso da adoção da irrigação suplementar na estação chuvosa. a análise probabilística dos valores de lâmina bruta direciona a escolha para épocas de semeadura que proporcionem os menores requerimentos de água, o que pode ser interessante em situações onde há escassez de água (Franke, 1996). Contudo, o nível de manejo de irrigação a ser adotado depende da análise econômica a ser efetuada posteriormente.

As estimativas das lâminas brutas de irrigação necessárias às culturas de feijão caupi, para as condições edafoclimáticas de Teresina, e melancia, para as condições edafoclimáticas de Pamaiba e Teresina, são apresentadas nas Tabelas 11A a 13A (Apêndice 1). Da mesma forma, as estimativas de produtividade das culturas de feijão caupi e melancia sob regime de irrigação e de sequeiro, em ambas condições edafoclimáticas, são mostradas nas Tabelas 14A a 20A (Apêndice 1).

As variações observadas em termos de lâmina bruta de irrigação (I) e produtividade das culturas (Yr) em função das épocas de semeadura, niveis de manejo de irrigação e probabilidade de ocorrência, bem como as mostradas nas Tabelas $11 \mathrm{~A}$ a 20A, evidenciam e comprovam as mesmas tendências já discutidas anteriormente no item 4.4 relativas ao balanço hídrico diário. Isto não poderia deixar de ser diferente, uma vez que as estimativas de I e Yr foram baseadas nos parâmetros da distribuição normal determinados dos valores de I e Yr oriundos dos balanços hídricos simulados.

Salienta-se que as estimativas de I e $\mathrm{Yr}$ apenas oferecem aproximações das necessidades de irrigação e do potencial produtivo das culturas nas condições edafoclimáticas avaliadas. A recomendação quanto a adoção da prática da irrigação, bem como do nivel de manejo a ser utilizado somente deverá ser efetuada após estudo de viabilidade econômica, conforme sugerem Oliveira (1990), Dorfman (1992) e Franke (1996). 


\subsection{Preços de venda dos produtos e das tarifas de energia elétrica}

As Tabelas 21A e 22A (Apêndice 1) apresentam os resultados relativos ao ajuste dos preços mensais de venda dos produtos e das tarifas de consumo de energia elétrica à função de distribuição triangular utilizando o teste de aderência de KolmogorovSmirnov ao nível de $5 \%$ de significância, conforme metodologia apresentada por Campos (1979).

Quanto aos preços mensais de venda dos produtos, observou-se que apenas os preços do feijão caupi, em maio e junho, não apresentaram ajuste à distribuição triangular. Esse fato indica que essa função de distribuição pode ser utilizada de forma satisfatória para a estimativa dos preços de venda dos produtos, conforme sugerem Brunelli (1990), Biserra (1994) e Dias (1996). Apesar de não haver ajuste em maio e junho, usou-se a função de distribuição de probabilidade triangular na estimativa dos preços mensais de venda do feijão caupi, dado a pequena diferença entre os valores dos desvios máximo e tabelado (Tabela 21A).

Da mesma forma, os preços mensais das tarifas de consumo de energia elétrica ajustaram-șe à distribuição triangular em todos os períodos analisados, comprovando a boa performance dessa função de distribuição em estudos de variação de preços e/ou custos de produção (Brunelli, 1990; Biserra, 1994 e Dias, 1996).

Para se ter idéia da magnitude dos valores empregados na estimativa probabilística dos preços de venda dos produtos e das tarifas de consumo de energia elétrica são apresentados os parâmetros da função de distribuição triangular (máximo, mínimo e moda) nas Tabelas 23A e 24A (Apêndice 1).

As Tabelas 35 e 36 apresentam os valores estimados dos preços mensais de venda das culturas de feijão caupi e melancia em cada época de semeadura, com diferentes níveis de probabilidade de ocorrência. Essas estimativas foram obtidas a partir do ajustamento dos preços mensais à função de distribuição triangular.

Constatou-se que os preços mensais de venda do feijão caupi mostraram-se superiores aos da melancia, independente da época de semeadura e da probabilidade de ocorrência, indicando que esta cultura apresenta maior valorização comercial no 
mercado atacadista de Teresina. Embora o preço do produto seja um forte indicador econômico, não implica em dizer, entretanto, que a produção de feijão caupi seja economicamente mais viável, haja visto as diferenças quanto potencial produtivo, nas diferentes combinações entre local, época de semeadura e nível de manejo de irrigação. Franke (1996) concluiu que a cultura da soja não apresentou viabilidade econômica em nenhuma das combinações estudadas, apesar de possuir maior valorização econômica que a cultura do milho.

Houve tendência de aumento dos preços mensais de venda dos produtos à medida que elevaram-se as probabilidades de ocorrência Essa tendência probabilística coincide com a apresentada pelos valores de produtividade das culturas, pois tratam-se de variáveis cuja necessidade de garantia de valores mínimos é de fundamental importância nas análises econômicas.

Por exemplo, considerando-se a cultura de feijão caupi, época de semeadura de l-Fev e probabilidade de ocorrência de $20 \%$, o preço mensal de venda do quilograma de grãos foi de US\$ $0,479 \mathrm{~kg}^{-1}$. Isto significa que em $20 \%$ dos casos ( 2 em cada 10 anos) o preço mensal do quilograma de grãos de feijão caupi será, no mínimo, igual a US\$ 0,479 $\mathrm{kg}^{-1}$. Em outras palavras, este valor tem possibilidade de ser superado 8 vezes a cada 10 anos, representando uma garantia de preços mínimos de $80 \%$, ou seja, um risco de falha de $20 \%$. Conforme mencionado anteriormente, essa característica é bastante desejável quando se objetiva analisar possíveis alternativas de preços sob risco econômico. Interpretações semelhantes podem ser efetuadas para as demais épocas de semeadura.

A variação nos valores dos preços mensais do feijão caupi, em função da época de semeadura foi bastante representativa. A maior estimativa de preços (US\$ $0,550 \mathrm{~kg}^{-1}$ ) foi obtida para as épocas de semeadura de 1-Jan e 15-Jan, as quais culminam com a colheita no mês de março, com probabilidade de ocorrência de $40 \%$, enquanto a menor (US\$ 0,359 $\mathrm{kg}^{-1}$ ) ocorreu em 1-Mai e 15-Mai, com colheita em julho e probabilidade de ocorrência de $5 \%$. A diferença entre essas estimativas foi responsável por uma variação de 53,2 \% em relação ao menor preço mensal praticado, indicando que a variável preço do produto tem participação importante na definição das combinações entre local, época de semeadura e nível de manejo de irrigação de maior rentabilidade econômica. 
Tabela 35. Estimativa dos preços mensais de venda do feijão caupi (US\$ $\mathrm{kg}^{-1}$ ), em cada época de semeadura, com diferentes probabilidades de ocorrência.

\begin{tabular}{|c|c|c|c|c|c|c|c|c|c|}
\hline \multirow{2}{*}{$\begin{array}{c}\text { Época de } \\
\text { Semeadura }\end{array}$} & \multirow{2}{*}{$C^{1}$} & \multicolumn{8}{|c|}{ Probabilidade de ocorrência (\%) } \\
\hline & & 5 & 10 & 15 & 20 & 25 & 30 & 35 & 40 \\
\hline 1-Jan & Mar & 0,464 & 0,475 & 0,487 & 0,498 & 0,511 & 0,523 & 0,536 & 0,550 \\
\hline 15-Jan & Mar & 0,464 & 0,475 & 0,487 & 0,498 & 0,511 & 0,523 & 0,536 & 0,550 \\
\hline $1-\mathrm{Fev}$ & Abr & 0,444 & 0,455 & 0,467 & 0,479 & 0,492 & 0,505 & 0,519 & 0,533 \\
\hline $15-\mathrm{Fev}$ & $\mathrm{Abr}$ & 0,444 & 0,455 & 0,467 & 0,479 & 0,492 & 0,505 & 0,519 & 0,533 \\
\hline 1-Mar & Mai & 0,455 & 0,467 & 0,480 & 0,493 & 0,506 & 0,520 & 0,534 & 0,549 \\
\hline 15-Mar & Mai & 0,455 & 0,467 & 0,480 & 0,493 & 0,506 & 0,520 & 0,534 & 0,549 \\
\hline $1-\mathrm{Abr}$ & Jun & 0,452 & 0,464 & 0,476 & 0,489 & 0,503 & 0,516 & 0,531 & 0,546 \\
\hline $15-\mathrm{Abr}$ & Jun & 0,452 & 0,464 & 0,476 & 0,489 & 0,503 & 0,516 & 0,531 & 0,546 \\
\hline 1-Mai & Jul & 0,359 & 0,374 & 0,389 & 0,404 & 0,420 & 0,436 & 0,453 & 0,471 \\
\hline 15-Mai & Jul & 0,359 & 0,374 & 0,389 & 0,404 & 0,420 & 0,436 & 0,453 & 0,471 \\
\hline 1-Jun & Ago & 0,402 & 0,415 & 0,429 & 0,443 & 0,457 & 0,472 & 0,487 & 0,503 \\
\hline 15-Jun & Ago & 0,402 & 0,415 & 0,429 & 0,443 & 0,457 & 0,472 & 0,487 & 0,503 \\
\hline 1-Jul & Set & 0,406 & 0,418 & 0,430 & 0,442 & 0,455 & 0,469 & 0,482 & 0,497 \\
\hline $15-\mathrm{Jul}$ & Set & 0,406 & 0,418 & 0,430 & 0,442 & 0,455 & 0,469 & 0,482 & 0,497 \\
\hline 1-Ago & Out & 0,382 & 0,394 & 0,406 & 0,419 & 0,433 & 0,447 & 0,461 & 0,476 \\
\hline 15-Ago & Out & 0,382 & 0,394 & 0,406 & 0,419 & 0,433 & 0,447 & 0,461 & 0,476 \\
\hline $1-$ Set & Nov & 0,387 & 0,399 & 0,412 & 0,424 & 0,438 & 0,451 & 0,465 & 0,480 \\
\hline $15-$ Set & Nov & 0,387 & 0,399 & 0,412 & 0,424 & 0,438 & 0,451 & 0,465 & 0,480 \\
\hline 1-Out & Dez & 0,402 & 0,412 & 0,423 & 0,434 & 0,445 & 0,457 & 0,469 & 0,481 \\
\hline 15-Out & Dez & 0,402 & 0,412 & 0,423 & 0,434 & 0,445 & 0,457 & 0,469 & 0,481 \\
\hline 1-Nov & Jan & 0,473 & 0,485 & 0,496 & 0,508 & 0,520 & 0,533 & 0,546 & 0,560 \\
\hline 15-Nov & Jan & 0,473 & 0,485 & 0,496 & 0,508 & 0,520 & 0,533 & 0,546 & 0,560 \\
\hline 1-Dez & Fev & 0,492 & 0,502 & 0,513 & 0,524 & 0,536 & 0,548 & 0,560 & 0,573 \\
\hline 15-Dez & Fev & 0,492 & 0,502 & 0,513 & 0,524 & 0,536 & 0,548 & 0,560 & 0,573 \\
\hline
\end{tabular}

${ }^{1} \mathrm{C}$ - Mês da colheita definido em função do ciclo da cultura. 
Tabela 36. Estimativa dos preços mensais de venda da melancia (US\$ $\mathrm{kg}^{-1}$ ), em cada época de semeadura, com diferentes probabilidades de ocorrência.

\begin{tabular}{|c|c|c|c|c|c|c|c|c|c|}
\hline \multirow{2}{*}{$\begin{array}{l}\text { Época de } \\
\text { Semeadura }\end{array}$} & \multirow{2}{*}{$\mathrm{C}^{1}$} & \multicolumn{8}{|c|}{ Probabilidade de ocorrência (\%) } \\
\hline & & 5 & 10 & 15 & 20 & 25 & 30 & 35 & 40 \\
\hline 1-Jan & Mar & 0,107 & 0,108 & 0,108 & 0,109 & 0,110 & 0,111 & 0,112 & 0,113 \\
\hline 15-Jan & Mar & 0,107 & 0,108 & 0,108 & 0,109 & 0,110 & 0,111 & 0,112 & 0,113 \\
\hline 1-Fev & $\mathrm{Abr}$ & 0,113 & 0,113 & 0,113 & 0,114 & 0,114 & 0,115 & 0,115 & 0,116 \\
\hline $15-\mathrm{Fev}$ & $\mathrm{Abr}$ & 0,113 & 0,113 & 0,113 & 0,114 & 0,114 & 0,115 & 0,115 & 0,116 \\
\hline 1-Mar & Mai & 0,112 & 0,113 & 0,114 & 0,114 & 0,115 & 0,116 & 0,117 & 0,118 \\
\hline 15-Mar & Mai & 0,112 & 0,113 & 0,114 & 0,114 & 0,115 & 0,116 & 0,117 & 0,118 \\
\hline $1-\mathrm{Abr}$ & Jun & 0,109 & 0,110 & 0,111 & 0,112 & 0,113 & 0,114 & 0,115 & 0,116 \\
\hline $15-\mathrm{Abr}$ & Jun & 0,109 & 0,110 & 0,111 & 0,112 & 0,113 & 0,114 & 0,115 & 0,116 \\
\hline 1-Mai & Jul & 0,088 & 0,089 & 0,089 & 0,090 & 0,090 & 0,091 & 0,092 & 0,092 \\
\hline 15-Mai & Jul & 0,088 & 0,089 & 0,089 & 0,090 & 0,090 & 0,091 & 0,092 & 0,092 \\
\hline 1-Jun & Ago & 0,091 & 0,092 & 0,093 & 0,094 & 0,095 & 0,096 & 0,097 & 0,098 \\
\hline 15-Jun & Ago & 0,091 & 0,092 & 0,093 & 0,094 & 0,095 & 0,096 & 0,097 & 0,098 \\
\hline 1-Jul & Set & 0,074 & 0,076 & 0,077 & 0,078 & 0,079 & 0,080 & 0,081 & 0,082 \\
\hline 15-Jul & Set & 0,074 & 0,076 & 0,077 & 0,078 & 0,079 & 0,080 & 0,081 & 0,082 \\
\hline 1-Ago & Out & 0,089 & 0,090 & 0,091 & 0,092 & 0,093 & 0,093 & 0,094 & 0,095 \\
\hline 15-Ago & Out & 0,089 & 0,090 & 0,091 & 0,092 & 0,093 & 0,093 & 0,094 & 0,095 \\
\hline 1-Set & Nov & 0,085 & 0,086 & 0,086 & 0,087 & 0,087 & 0,088 & 0,088 & 0,089 \\
\hline 15 -Set & Nov & 0,085 & 0,086 & 0,086 & 0,087 & 0,087 & 0,088 & 0,088 & 0,089 \\
\hline 1-Out & Dez & 0,087 & 0,088 & 0,088 & 0,089 & 0,089 & 0,090 & 0,090 & 0,091 \\
\hline 15-Out & Dez & 0,087 & 0,088 & 0,088 & 0,089 & 0,089 & 0,090 & 0,090 & 0,091 \\
\hline $1-\mathrm{Nov}$ & Jan & 0,097 & 0,097 & 0,098 & 0,099 & 0,099 & 0,100 & 0,100 & 0,101 \\
\hline $15-\mathrm{Nov}$ & Jan & 0,097 & 0,097 & 0,098 & 0,099 & 0,099 & 0,100 & 0,100 & 0,101 \\
\hline 1-Dez & Fev & 0,096 & 0,098 & 0,100 & 0,102 & 0,104 & 0,106 & 0,108 & 0,110 \\
\hline 15-Dez & Fev & 0,096 & 0,098 & 0,100 & 0,102 & 0,104 & 0,106 & 0,108 & 0,110 \\
\hline
\end{tabular}

${ }^{1} \mathrm{C}$ - Mês da colheita definido em função do ciclo da cultura. 
Com relação à cultura da melancia, a maior estimativa de preços (US\$ 0,118 $\mathrm{kg}^{-1}$ ) foi obtida para as épocas de semeadura de 1-Mar e 15-Mar, com colheita no mês de maio, com probabilidade de ocorrência de $40 \%$, enquanto a menor (US\$ $0,074 \mathrm{~kg}^{-1}$ ) ocorreu em 1-Jul e 15-Jul, com colheita em setembro, com probabilidade de ocorrência de $5 \%$. Essas estimativas proporcionaram uma variação de 59,5\% em relação ao menor preço mensal praticado.

A variação obtida para a melancia foi um pouco superior à do feijão caupi, apesar dos preços mensais de venda da melancia, em termos absolutos, serem inferiores aos do feijão caupi. Entretanto, face à pequena diferença entre esses percentuais de variação, pode-se admitir que os preços mensais de venda das duas culturas contribuem igualmente na definição das combinações entre local, época de semeadura e nível de manejo de irrigação de maior rentabilidade econômica.

Para os preços mensais das tarifas de consumo de energia elétrica (Tabela 37), a variação entre as estimativas máxima (US\$ $0,067 \mathrm{kWh}^{-1}$ ) e mínima (US\$ 0,052 $\mathrm{kWh}^{-1}$ ) foi de $28,8 \%$, indicando que estes têm menor contribuição no custo de energia elétrica que os preços mensais de venda dos produtos têm na composição da receita bruta. Desconsiderando-se, a priori, a magnitude das estimativas de lâmina bruta de irrigação e produtividade das culturas, esse aspecto tem importância fundamental na definição da viabilidade econômica das combinações entre local, cultura, época de semeadura (cultivo de sequeiro e irrigado) e.nível de manejo de irrigação (cultivo irrigado). 
Tabela 37. Estimativa dos preços médios mensais da tarifa de consumo de energia elétrica (US\$ $\mathrm{kWh}^{-1}$ ), com diferentes probabilidades de ocorrência, em cada época de semeadura.

\begin{tabular}{|c|c|c|c|c|c|c|c|c|c|}
\hline \multirow{2}{*}{$\begin{array}{l}\text { Época de } \\
\text { Semeadura }\end{array}$} & \multirow{2}{*}{$\mathrm{P}^{1}$} & \multicolumn{8}{|c|}{ Probabilidade de ocorrência (\%) } \\
\hline & & 95 & 90 & 85 & 80 & 75 & 70 & 65 & 60 \\
\hline $1-\mathrm{Jan}$ & J-F-M & 0,065 & 0,063 & 0,062 & 0,060 & 0,059 & 0,058 & 0,057 & 0,057 \\
\hline 15-Jan & $\mathrm{J}-\mathrm{F}-\mathrm{M}$ & 0,065 & 0,063 & 0,062 & 0,060 & 0,059 & 0,058 & 0,057 & 0,057 \\
\hline $1-\mathrm{Fev}$ & F-M-A & 0,067 & 0,065 & 0,063 & 0,061 & 0,059 & 0,058 & 0,057 & 0,056 \\
\hline $15-\mathrm{Fev}$ & F-M-A & 0,067 & 0,065 & 0,063 & 0,061 & 0,059 & 0,058 & 0,057 & 0,056 \\
\hline 1-Mar & M-A-M & 0,067 & 0,064 & 0,062 & 0,061 & 0,059 & 0,057 & 0,056 & 0,055 \\
\hline 15-Mar & M-A-M & 0,067 & 0,064 & 0,062 & 0,061 & 0,059 & 0,057 & 0,056 & 0,055 \\
\hline $1-\mathrm{Abr}$ & A-M-J & 0,063 & 0,061 & 0,059 & 0,058 & 0,056 & 0,055 & 0,053 & 0,052 \\
\hline $15-\mathrm{Abr}$ & A-M-J & 0,063 & 0,061 & 0,059 & 0,058 & 0,056 & 0,055 & 0,053 & 0,052 \\
\hline 1-Mai & M-J-J & 0,060 & 0,059 & 0,058 & 0,056 & 0,055 & 0,054 & 0,053 & 0,052 \\
\hline 15-Mai & M-J-J & 0,060 & 0,059 & 0,058 & 0,056 & 0,055 & 0,054 & 0,053 & 0,052 \\
\hline 1-Jun & $\mathrm{J}-\mathrm{J}-\mathrm{A}$ & 0,064 & 0,063 & 0,061 & 0,060 & 0,059 & 0,057 & 0,056 & 0,055 \\
\hline 15-Jun & $\mathrm{J}-\mathrm{J}-\mathrm{A}$ & 0,064 & 0,063 & 0,061 & 0,060 & 0,059 & 0,057 & 0,056 & 0,055 \\
\hline 1-Jul & J-A-S & 0,065 & 0,064 & 0,063 & 0,061 & 0,061 & 0,060 & 0,059 & 0,058 \\
\hline 15-Jul & $J-A-S$ & 0,065 & 0,064 & 0,063 & 0,061 & 0,061 & 0,060 & 0,059 & 0,058 \\
\hline 1-Ago & A-S-O & 0,065 & 0,064 & 0,063 & 0,062 & 0,061 & 0,060 & 0,059 & 0,059 \\
\hline 15-Ago & A-S-O & 0,065 & 0,064 & 0,063 & 0,062 & 0,061 & 0,060 & 0,059 & 0,059 \\
\hline 1-Set & S-O-N & 0,061 & 0,061 & 0,060 & 0,060 & 0,059 & 0,059 & 0,058 & 0,057 \\
\hline 15-Set & $\mathrm{S}-\mathrm{O}-\mathrm{N}$ & 0,061 & 0,061 & 0,060 & 0,060 & 0,059 & 0,059 & 0,058 & 0,057 \\
\hline 1-Out & O-N-D & 0,063 & 0,062 & 0,062 & 0,061 & 0,060 & 0,059 & 0,059 & 0,058 \\
\hline 15-Out & O-N-D & 0,063 & 0,062 & 0,062 & 0,061 & 0,060 & 0,059 & 0,059 & 0,058 \\
\hline $1-\mathrm{Nov}$ & N-D-J & 0,064 & 0,063 & 0,062 & 0,061 & 0,060 & 0,060 & 0,059 & 0,058 \\
\hline $15-\mathrm{Nov}$ & N-D-J & 0,064 & 0,063 & 0,062 & 0,061 & 0,060 & 0,060 & 0,059 & 0,058 \\
\hline 1-Dez & D-J-F & 0,064 & 0,062 & 0,061 & 0,060 & 0,059 & 0,059 & 0,058 & 0,057 \\
\hline 15-Dez & D-J-F & 0,064 & 0,062 & 0,061 & 0,060 & 0,059 & 0,059 & 0,058 & 0,057 \\
\hline
\end{tabular}

\footnotetext{
${ }^{1} \mathrm{P}$ - Periodo mensal relativo ao cálculo do preço médio da tarifa de energia elétrica.
} 


\subsection{Análise econômica sob condição de risco}

A Tabela 38 apresenta as estimativas das receitas brutas (RB), composição dos custos da irrigação [energia requerida para bombeamento $(\mathrm{Eb})$ e custo de energia elétrica (CE)], custo total de produção (CT), receitas líquidas (RL) e relação beneficio/custo (B/C) para a cultura de feijão caupi irrigado nas condições edafoclimáticas de Parnaíba, nas diferentes combinações entre épocas de semeadura, nível de manejo da irrigação e nível de risco de $20 \%$. As demais estimativas para as combinações entre locais, culturas, épocas de semeadura, níveis de manejo de irrigação e de risco são mostradas nas Tabelas 1B a 3 1B (Apêndice 2).

O custo total de produção consistiu no somatório dos custos da irrigação com o custo de formação da lavoura. O custo de formação da lavoura foi de US\$322,91 ha ${ }^{-1}$ e US\$ 672,43 $\mathrm{ha}^{-1}$ para a cultura do feijão caupi (Cardoso et al., 1995) e melancia (Andrade Júnior et al., 1998c), respectivamente. Os custos da irrigação foram representados pelo custo da energia elétrica e custo anual de amortização do equipamento.

Segundo informações das empresas que comercializam equipamentos de irrigação em Teresina, para as condições normais de projetos de aspersão convencional nas duas microrregiões estudadas, o custo de aquisição de um sistema novo é de US\$ $2230,0 \mathrm{ha}^{-1}$. Com este custo de aquisição, a uma taxa de juros de $12 \%$ ao ano e um prazo de financiamento de 10 anos, o custo anual de amortização foi de U $\$ \$ 394,67 \mathrm{ha}^{-1}$.

Para a cultura do feijão caupi, independente da época de semeadura e nível de manejo da irrigação, o custo da energia elétrica e o custo anual de amortização do equipamento variaram, em média, de 4,6\% (Teresina) a 6,2\% (Parnaíba) e de 52,5\% (Teresina) a 51,6\% (Parnaíba) do custo total de produção, respectivamente (Tabelas 38 e 19B). No caso do custo de energia elétrica, esses percentuais aproximaram-se bastante da faixa de variação de $5,5 \%$ a $7,0 \%$ do custo total de produção da cultura de milho irrigada por pivô central obtida por Franke (1996). 
Tabela 38. Receitas brutas, composição de custos da irrigação, receitas liquidas e relação beneficio/custo para o feijão caupi, em cada época de semeadura, nível de manejo da irrigação e risco de $20 \%$. Parnaiba, Piauí.

\begin{tabular}{|c|c|c|c|c|c|c|c|}
\hline $\begin{array}{l}\text { Época de } \\
\text { Semeadura }\end{array}$ & $\mathrm{p}$ & $\begin{array}{c}\mathrm{RB} \\
\left(\mathrm{US} \$ \mathrm{ha}^{-1}\right)\end{array}$ & $\begin{array}{c}E b \\
\left(\mathrm{kWh} \mathrm{ha}^{-1}\right)\end{array}$ & $\begin{array}{c}\text { CE } \\
\left(\mathrm{US} \$ \mathrm{ha}^{-1}\right)\end{array}$ & $\begin{array}{c}\mathrm{CT} \\
\left(\mathrm{US} \$ \mathrm{ha}^{-1}\right)\end{array}$ & $\begin{array}{c}\mathrm{RL} \\
\left(\mathrm{US} \$ \mathrm{ha}^{-1}\right)\end{array}$ & $\mathrm{B} / \mathrm{C}$ \\
\hline \multirow{7}{*}{ 1-Jan } & 0,2 & 1129,25 & 651,82 & 39,41 & 756,99 & 372,25 & 1,49 \\
\hline & 0,3 & 1064,94 & 627,62 & 37,94 & 755,53 & 309,41 & 1,41 \\
\hline & 0,4 & 1005,25 & 603,81 & 36,51 & 754,09 & 251,16 & 1,33 \\
\hline & 0,5 & 941,34 & 578,56 & 34,98 & 752,56 & 188,77 & 1,25 \\
\hline & 0,6 & 889,68 & 551,79 & 33,36 & 750,94 & 138,73 & 1,18 \\
\hline & 0,7 & 835,01 & 532,34 & 32,18 & 749,77 & 85,24 & 1,11 \\
\hline & 0,8 & 792,49 & 511,03 & 30,90 & 748,48 & 44,01 & 1,06 \\
\hline \multirow{7}{*}{ 15-Jan } & 0,2 & 1140,62 & 590,87 & 35,72 & 753,31 & 387,31 & 1,51 \\
\hline & 0,3 & 1082,16 & 563,49 & 34,07 & 751,65 & 330,50 & 1,44 \\
\hline & 0,4 & 1017,44 & 539,30 & 32,61 & 750,19 & 267,25 & 1,36 \\
\hline & 0,5 & 957,66 & 511,28 & 30,91 & 748,50 & 209,16 & 1,28 \\
\hline & 0,6 & 900,81 & 478,35 & 28,92 & 746,50 & 154,31 & 1,21 \\
\hline & 0,7 & 853,95 & 462,47 & 27,96 & 745,54 & 108,40 & 1,15 \\
\hline & 0,8 & 814,39 & 444,61 & 26,88 & 744,46 & 69,92 & 1,09 \\
\hline \multirow{7}{*}{ 1-Fev } & 0,2 & 1093,87 & 542,65 & 33,05 & 750,63 & 343,24 & 1,46 \\
\hline & 0,3 & 1041,10 & 511,84 & 31,17 & 748,76 & 292,35 & 1,39 \\
\hline & 0,4 & 973,57 & 479,11 & 29,18 & 746,76 & 226,81 & 1,30 \\
\hline & 0,5 & 925,75 & 448,82 & 27,33 & 744,92 & 180,84 & 1,24 \\
\hline & 0,6 & 874,36 & 428,04 & 26,07 & 743,65 & 130,71 & 1,18 \\
\hline & 0,7 & 831,17 & 404,24 & 24,62 & 742,20 & 88,97 & 1,12 \\
\hline & 0,8 & 787,82 & 375,65 & 22,88 & 740,46 & 47,35 & 1,06 \\
\hline \multirow{7}{*}{ 15-Fev } & 0,2 & 1089,10 & 492,58 & 30,00 & 747,58 & 341,52 & 1,46 \\
\hline & 0,3 & 1041,13 & 463,84 & 28,25 & 745,83 & 295,29 & 1,40 \\
\hline & 0,4 & 969,95 & 426,28 & 25,96 & 743,55 & 226,41 & 1,30 \\
\hline & 0,5 & 925,34 & 396,09 & 24,12 & 741,71 & 183,64 & 1,25 \\
\hline & 0,6 & 873,44 & 353,90 & 21,55 & 739,14 & 134,30 & 1,18 \\
\hline & 0,7 & 843,17 & 342,77 & 20,88 & 738,46 & 104,71 & 1,14 \\
\hline & 0,8 & 798,06 & 321,55 & 19,58 & 737,17 & 60,90 & 1,08 \\
\hline
\end{tabular}


Tabela 38. Receitas brutas, composição de custos da irrigação, receitas líquidas e relação benefício/custo para o feijão caupi, em cada época de semeadura, nivel de manejo da irrigação e risco de 20 \%. Parnaíba, Piauí

\begin{tabular}{|c|c|c|c|c|c|c|c|}
\hline $\begin{array}{l}\text { Época de } \\
\text { Semeadura }\end{array}$ & $\mathrm{p}$ & $\begin{array}{c}\mathrm{RB} \\
\left(\mathrm{US} \$ \mathrm{ha}^{-1}\right)\end{array}$ & $\begin{array}{c}E b \\
\left(k W h h a^{-1}\right)\end{array}$ & $\begin{array}{c}\text { CE } \\
\left(\mathrm{US} \$ \mathrm{ha}^{-1}\right)\end{array}$ & $\begin{array}{c}\text { CT } \\
\left(\mathrm{US} \$ \mathrm{ha}^{-1}\right)\end{array}$ & $\begin{array}{c}\mathrm{RL} \\
\left(\mathrm{US} \$ \mathrm{ha}^{-1}\right)\end{array}$ & $\mathrm{B} / \mathrm{C}$ \\
\hline \multirow{7}{*}{ 1-Mar } & 0,2 & 1118,15 & 477,54 & 28,91 & 746,49 & 371,66 & 1,50 \\
\hline & 0,3 & 1069,64 & 449,95 & 27,24 & 744,82 & 324,81 & 1,44 \\
\hline & 0,4 & 996,25 & 414,71 & 25,11 & 742,69 & 253,56 & 1,34 \\
\hline & 0,5 & 951,00 & 377,08 & 22,83 & 740,41 & 210,58 & 1,28 \\
\hline & 0,6 & 899,37 & 355,69 & 21,53 & 739,12 & 160,25 & 1,22 \\
\hline & 0,7 & 857,93 & 325,84 & 19,73 & 737,31 & 120,62 & 1,16 \\
\hline & 0,8 & 819,16 & 298,23 & 18,05 & 735,64 & 83,52 & 1,11 \\
\hline \multirow{7}{*}{ 15-Mar } & 0,2 & 1109,39 & 496,52 & 30,06 & 747,64 & 361,75 & 1,48 \\
\hline & 0,3 & 1061,73 & 464,05 & 28,09 & 745,68 & 316,06 & 1,42 \\
\hline & 0,4 & 985,07 & 430,79 & 26,08 & 743,66 & 241,41 & 1,32 \\
\hline & 0,5 & 937,98 & 401,17 & 24,29 & 741,87 & 196,11 & 1,26 \\
\hline & 0,6 & 882,42 & 380,26 & 23,02 & 740,61 & 141,81 & 1,19 \\
\hline & 0,7 & 840,95 & 346,81 & 21,00 & 738,58 & 102,37 & 1,14 \\
\hline & 0,8 & 795,14 & 319,33 & 19,33 & 736,92 & 58,23 & 1,08 \\
\hline \multirow{7}{*}{ 1-Abr } & 0,2 & 1102,84 & 563,16 & 32,43 & 750,02 & 352,82 & 1,47 \\
\hline & 0,3 & 1048,74 & 537,99 & 30,98 & 748,57 & 300,17 & 1,40 \\
\hline & 0,4 & 968,52 & 514,74 & 29,64 & 747,23 & 221,29 & 1,30 \\
\hline & 0,5 & 918,02 & 484,72 & 27,91 & 745,50 & 172,52 & 1,23 \\
\hline & 0,6 & 853,30 & 458,43 & 26,40 & 743,99 & 109,32 & 1,15 \\
\hline & 0,7 & 812,43 & 443,31 & 25,53 & 743,11 & 69,32 & 1,09 \\
\hline & 0,8 & 764,14 & 418,83 & 24,12 & 741,71 & 22,43 & 1,03 \\
\hline \multirow{7}{*}{$15-\mathrm{Abr}$} & 0,2 & 1099,90 & 622,56 & 35,85 & 753,44 & 346,46 & 1,46 \\
\hline & 0,3 & 1042,07 & 601,12 & 34,62 & 752,20 & 289,87 & 1,39 \\
\hline & 0,4 & 959,82 & 575,29 & 33,13 & 750,72 & 209,10 & 1,28 \\
\hline & 0,5 & 902,27 & 554,70 & 31,94 & 749,53 & 152,74 & 1,20 \\
\hline & 0,6 & 835,08 & 534,16 & 30,76 & 748,35 & 86,73 & 1,12 \\
\hline & 0,7 & 790,72 & 508,48 & 29,28 & 746,87 & 43,85 & 1,06 \\
\hline & 0,8 & 738,46 & 503,85 & 29,02 & 746,60 & $-8,14$ & 0,99 \\
\hline
\end{tabular}


Tabela 38. Receitas brutas, composição de custos da irrigação, receitas liquidas e relação benefício/custo para o feijão caupi, em cada época de semeadura, nivel de manejo da irnigação e risco de 20 \%. Parnaiba, Piauí.

\begin{tabular}{|c|c|c|c|c|c|c|c|}
\hline $\begin{array}{c}\text { Época de } \\
\text { Semeadura }\end{array}$ & $\mathrm{p}$ & $\begin{array}{c}\mathrm{RB} \\
\left(\mathrm{US} \$ \mathrm{ha}^{-1}\right)\end{array}$ & $\begin{array}{c}\mathrm{Eb} \\
\left(\mathrm{kWh} \mathrm{ha} \mathrm{h}^{-1}\right)\end{array}$ & $\begin{array}{c}\mathrm{CE} \\
\left(\mathrm{US} \$ \mathrm{ha}^{-1}\right)\end{array}$ & $\begin{array}{c}\text { CT } \\
\left(\mathrm{US} \$ \mathrm{ha}^{-1}\right)\end{array}$ & $\begin{array}{c}\mathrm{RL} \\
\left(\mathrm{US} \$ \mathrm{ha}^{-1}\right)\end{array}$ & $\mathrm{B} / \mathrm{C}$ \\
\hline \multirow{7}{*}{ 1-Mai } & 0,2 & 906,74 & 703,77 & 39,70 & 757,29 & 149,45 & 1,20 \\
\hline & 0,3 & 856,63 & 684,89 & 38,64 & 756,22 & 100,41 & 1,13 \\
\hline & 0,4 & 786,15 & 665,08 & 37,52 & 755,10 & 31,05 & 1,04 \\
\hline & 0,5 & 735,36 & 655,52 & 36,98 & 754,56 & $-19,20$ & 0,97 \\
\hline & 0,6 & 683,85 & 652,15 & 36,79 & 754,37 & $-70,52$ & 0,91 \\
\hline & 0,7 & 638,69 & 633,55 & 35,74 & 753,32 & $-114,63$ & 0,85 \\
\hline & 0,8 & 595,23 & 632,30 & 35,67 & 753,25 & $-158,02$ & 0,79 \\
\hline \multirow{7}{*}{ 15-Mai } & 0,2 & 908,70 & 737,31 & 41,59 & 759,18 & 149,52 & 1,20 \\
\hline & 0,3 & 857,28 & 725,07 & 40,90 & 758,49 & 98,79 & 1,13 \\
\hline & 0,4 & 789,75 & 714,02 & 40,28 & 757,86 & 31,89 & 1,04 \\
\hline & 0,5 & 734,15 & 700,12 & 39,50 & 757,08 & $-22,93$ & 0,97 \\
\hline & 0,6 & 683,20 & 685,43 & 38,67 & 756,25 & $-73,06$ & 0,90 \\
\hline & 0,7 & 637,78 & 684,88 & 38,63 & 756,22 & $-118,44$ & 0,84 \\
\hline & 0,8 & 593,63 & 669,29 & 37,76 & 755,34 & $-161,71$ & 0,79 \\
\hline \multirow{7}{*}{ 1-Jun } & 0,2 & 1002,50 & 789,48 & 47,19 & 764,77 & 237,73 & 1,31 \\
\hline & 0,3 & 942,97 & 778,67 & 46,54 & 764,12 & 178,84 & 1,23 \\
\hline & 0,4 & 873,58 & 773,95 & 46,26 & 763,84 & 109,74 & 1,14 \\
\hline & 0,5 & 805,59 & 762,87 & 45,60 & 763,18 & 42,41 & 1,06 \\
\hline & 0,6 & 754,50 & 755,71 & 45,17 & 762,75 & $-8,25$ & 0,99 \\
\hline & 0,7 & 693,39 & 744,77 & 44,51 & 762,10 & $-68,71$ & 0,91 \\
\hline & 0,8 & 650,41 & 741,27 & 44,30 & 761,89 & $-111,47$ & 0,85 \\
\hline \multirow{7}{*}{ 15-Jun } & 0,2 & 1013,77 & 861,02 & 51,46 & 769,05 & 244,73 & 1,32 \\
\hline & 0,3 & 944,12 & 852,66 & 50,96 & 768,55 & 175,57 & 1,23 \\
\hline & 0,4 & 888,83 & 844,60 & 50,48 & 768,06 & 120,77 & 1,16 \\
\hline & 0,5 & 806,59 & $835,7.5$ & 49,95 & 767,54 & 39,05 & 1,05 \\
\hline & 0,6 & 767,16 & 834,90 & 49,90 & 767,49 & $-0,32$ & 1,00 \\
\hline & 0,7 & 698,11 & 826,93 & 49,42 & 767,01 & $-68,90$ & 0,91 \\
\hline & 0,8 & 657,90 & 822,16 & 49,14 & 766,72 & $-108,83$ & 0,86 \\
\hline
\end{tabular}


186

Tabela 38. Receitas brutas, composição de custos da irrigação, receitas líquidas e relação beneficio/custo para o feijão caupi, em cada época de semeadura, nível de manejo da irrigação e risco de 20 \%. Parnaiba, Piauí.

\begin{tabular}{|c|c|c|c|c|c|c|c|}
\hline $\begin{array}{l}\text { Época de } \\
\text { Semeadura }\end{array}$ & $\mathrm{p}$ & $\begin{array}{c}\mathrm{RB} \\
\left(\mathrm{US} \$ \mathrm{ha}^{-1}\right)\end{array}$ & $\begin{array}{c}\mathrm{Eb} \\
\left(\mathrm{kWh} \mathrm{ha} \mathrm{h}^{-1}\right)\end{array}$ & $\begin{array}{c}\mathrm{CE} \\
\left(\mathrm{US} \$ \mathrm{ha}^{-1}\right)\end{array}$ & $\begin{array}{c}\mathrm{CT} \\
\left(\mathrm{US} \$ \mathrm{ha}^{-1}\right)\end{array}$ & $\begin{array}{c}\mathrm{RL} \\
\left(\mathrm{US} \$ \mathrm{ha}^{-1}\right)\end{array}$ & $\mathrm{B} / \mathrm{C}$ \\
\hline \multirow{7}{*}{ 1-Jul } & 0,2 & 1025,62 & 937,04 & 57,62 & 775,21 & 250,41 & 1,32 \\
\hline & 0,3 & 946,92 & 928,58 & 57,10 & 774,69 & 172,23 & 1,22 \\
\hline & 0,4 & 900,23 & 922,51 & 56,73 & 774,31 & 125,91 & 1,16 \\
\hline & 0,5 & 816,73 & 924,39 & 56,84 & 774,43 & 42,30 & 1,05 \\
\hline & 0,6 & 770,59 & 914,23 & 56,22 & 773,81 & $-3,22$ & 1,00 \\
\hline & 0,7 & 710,47 & 909,52 & 55,93 & 773,52 & $-63,04$ & 0,92 \\
\hline & 0,8 & 660,66 & 904,50 & 55,62 & 773,21 & $-112,55$ & 0,85 \\
\hline \multirow{7}{*}{ 15-Jul } & 0,2 & 1037,54 & 1015,38 & 62,44 & 780,03 & 257,52 & 1,33 \\
\hline & 0,3 & 951,86 & 1004,94 & 61,80 & 779,38 & 172,48 & 1,22 \\
\hline & 0,4 & 911,14 & 1006,24 & 61,88 & 779,46 & 131,67 & 1,17 \\
\hline & 0,5 & 836,19 & 1003,21 & 61,69 & 779,28 & 56,92 & 1,07 \\
\hline & 0,6 & 772,69 & 1000,35 & 61,52 & 779,10 & $-6,41$ & 0,99 \\
\hline & 0,7 & 728,62 & 994,61 & 61,16 & 778,75 & $-50,13$ & 0,94 \\
\hline & 0,8 & 661,40 & 992,97 & 61,06 & 778,65 & $-117,24$ & 0,85 \\
\hline \multirow{7}{*}{ 1-Ago } & 0,2 & 996,73 & 1103,74 & 68,29 & 785,88 & 210,85 & 1,27 \\
\hline & 0,3 & 910,30 & 1098,06 & 67,94 & 785,53 & 124,77 & 1,16 \\
\hline & 0,4 & 869,52 & 1094,08 & 67,69 & 785,28 & 84,24 & 1,11 \\
\hline & 0,5 & 817,96 & 1094,09 & 67,70 & 785,28 & 32,68 & 1,04 \\
\hline & 0,6 & 735,53 & 1086,79 & 67,24 & 784,83 & $-49,30$ & 0,94 \\
\hline & 0,7 & 702,80 & 1082,28 & 66,96 & 784,55 & $-81,75$ & 0,90 \\
\hline & 0,8 & 646,21 & 1082,84 & 67,00 & 784,58 & $-138,37$ & 0,82 \\
\hline \multirow{7}{*}{ 15-Ago } & 0,2 & 1005,26 & 1153,91 & 71,40 & 788,98 & 216,28 & 1,27 \\
\hline & 0,3 & 918,09 & 1151,44 & 71,24 & 788,83 & 129,26 & 1,16 \\
\hline & 0,4 & 873,59 & 1145,04 & 70,85 & 788,43 & 85,16 & 1,11 \\
\hline & 0,5 & 831,46 & 1138,40 & 70,44 & 788,02 & 43,44 & 1,06 \\
\hline & 0,6 & 743,54 & 1139,16 & 70,48 & 788,07 & $-44,53$ & 0,94 \\
\hline & 0,7 & 702,58 & 1134,86 & 70,22 & 787,80 & $-85,22$ & 0,89 \\
\hline & 0,8 & 664,14 & 1136,71 & 70,33 & 787,92 & $-123,77$ & 0,84 \\
\hline
\end{tabular}


Tabela 38. Receitas brutas, composição de custos da irrigação, receitas líquidas e relação beneficio/custo para o feijão caupi, em cada época de semeadura, nivel de manejo da irrigação e risco de $20 \%$. Parnaíba, Piauí.

\begin{tabular}{|c|c|c|c|c|c|c|c|}
\hline $\begin{array}{c}\text { Época de } \\
\text { Semeadura }\end{array}$ & $\mathrm{p}$ & $\begin{array}{c}\mathrm{RB} \\
\left(\mathrm{US} \$ \mathrm{ha}^{-1}\right)\end{array}$ & $\begin{array}{c}\mathrm{Eb} \\
\left(\mathrm{kWh} \mathrm{ha}^{-1}\right)\end{array}$ & $\begin{array}{c}\text { CE } \\
\left(\mathrm{US} \$ \mathrm{ha}^{-1}\right)\end{array}$ & $\begin{array}{c}\mathrm{CT} \\
\left(\mathrm{US} \$ \mathrm{ha}^{-1}\right)\end{array}$ & $\begin{array}{c}\mathrm{RL} \\
\left(\mathrm{US} \$ \mathrm{ha}^{-1}\right)\end{array}$ & $\mathrm{B} / \mathrm{C}$ \\
\hline \multirow{7}{*}{ 1-Set } & 0,2 & 1022,03 & 1190,56 & 71,13 & 788,72 & 233,31 & 1,30 \\
\hline & 0,3 & 934,84 & 1187,73 & 70,96 & 788,55 & 146,29 & 1,19 \\
\hline & 0,4 & 884,82 & 1182,47 & 70,65 & 788,23 & 96,58 & 1,12 \\
\hline & 0,5 & 850,20 & 1176,85 & 70,31 & 787,90 & 62,30 & 1,08 \\
\hline & 0,6 & 760,19 & 1180,70 & 70,54 & 788,13 & $-27,94$ & 0,96 \\
\hline & 0,7 & 710,52 & 1174,75 & 70,19 & 787,77 & $-77,25$ & 0,90 \\
\hline & 0,8 & 689,98 & 1171,79 & 70,01 & 787,59 & $-97,62$ & 0,88 \\
\hline \multirow{7}{*}{$15-$ Set } & 0,2 & 1023,26 & 1184,67 & 70,78 & 788,36 & 234,90 & 1,30 \\
\hline & 0,3 & 933.,91 & 1181,78 & 70,61 & 788,19 & 145,72 & 1,18 \\
\hline & 0,4 & 884,09 & 1175,27 & 70,22 & 787,80 & 96,29 & 1,12 \\
\hline & 0,5 & 850,39 & 1172,50 & 70,05 & 787,64 & 62,75 & 1,08 \\
\hline & 0,6 & 761,35 & 1174,53 & 70,17 & 787,76 & $-26,41$ & 0,97 \\
\hline & 0,7 & 712,30 & 1171,63 & 70,00 & 787,58 & $-75,28$ & 0,90 \\
\hline & 0,8 & 687,87 & 1160,05 & 69,31 & 786,89 & $-99,02$ & 0,87 \\
\hline \multirow{7}{*}{ 1-Out } & 0,2 & 1038,65 & 1179,23 & 71,75 & 789,33 & 249,32 & 1,32 \\
\hline & 0,3 & 955,94 & 1177,34 & 71,63 & 789,22 & 166,72 & 1,21 \\
\hline & 0,4 & 904,84 & 1171,22 & 71,26 & 788,85 & 115,99 & 1,15 \\
\hline & 0,5 & 866,93 & 1166,81 & 70,99 & 788,58 & 78,35 & 1,10 \\
\hline & 0,6 & 775,60 & 1167,93 & 71,06 & 788,65 & $-13,05$ & 0,98 \\
\hline & 0,7 & 726,14 & 1162,48 & 70,73 & 788,31 & $-62,18$ & 0,92 \\
\hline & 0,8 & 703,13 & 1152,64 & 70,13 & 787,71 & $-84,59$ & 0,89 \\
\hline \multirow{7}{*}{ 15-Out } & 0,2 & 1040,17 & 1153,39 & 70,18 & 787,76 & 252,40 & 1,32 \\
\hline & 0,3 & 949,21 & 1145,81 & 69,72 & 787,30 & 161,91 & 1,21 \\
\hline & 0,4 & 904,12 & 1144,55 & 69,64 & 787,22 & 116,89 & 1,15 \\
\hline & 0,5 & 864,30 & 1136,25 & 69,13 & 786,72 & 77,58 & 1,10 \\
\hline & 0,6 & 770,63 & 1136,16 & 69,13 & 786,71 & $-16,08$ & 0,98 \\
\hline & 0,7 & 728,22 & 1127,14 & 68,58 & 786,16 & $-57,94$ & 0,93 \\
\hline & 0,8 & 693,34 & 1127,48 & 68,60 & 786,18 & $-92,85$ & 0,88 \\
\hline
\end{tabular}


Tabela 38. Receitas brutas, composição de custos da irrigação, receitas líquidas e relação beneficio/custo para o feijão caupi, em cada época de semeadura, nível de manejo da irrigação e risco de $20 \%$. Parnaíba, Piauí.

\begin{tabular}{|c|c|c|c|c|c|c|c|}
\hline $\begin{array}{l}\text { Época de } \\
\text { Semeadura }\end{array}$ & $\mathrm{p}$ & $\begin{array}{c}\mathrm{RB} \\
\left(\mathrm{US} \$ h \mathrm{a}^{-1}\right)\end{array}$ & $\begin{array}{c}E b \\
\left(\mathrm{kWh} h \mathrm{a}^{-1}\right)\end{array}$ & $\begin{array}{c}C E \\
\left(U S \$ h a^{-1}\right)\end{array}$ & $\begin{array}{c}\text { CT } \\
\left(\mathrm{US} \$ h \mathrm{a}^{-1}\right)\end{array}$ & $\begin{array}{c}\mathrm{RL} \\
\left(\mathrm{US} \$ \mathrm{ha}^{-1}\right)\end{array}$ & $\mathrm{B} / \mathrm{C}$ \\
\hline \multirow{7}{*}{ 1-Nov } & 0,2 & 1201,47 & 1051,94 & 64,38 & 781,96 & 419,50 & 1,54 \\
\hline & 0,3 & 1107,13 & 1046,80 & 64,06 & 781,65 & 325,48 & 1,42 \\
\hline & 0,4 & 1054,75 & 1034,98 & 63,34 & 780,92 & 273,82 & 1,35 \\
\hline & 0,5 & 983,74 & 1024,53 & 62,70 & 780,28 & 203,46 & 1,26 \\
\hline & 0,6 & 899,47 & 1025,83 & 62,78 & 780,36 & 119,10 & 1,15 \\
\hline & 0,7 & 851,41 & 1017,78 & 62,29 & 779,87 & 71,54 & 1,09 \\
\hline & 0,8 & 786,28 & 1012,04 & 61,94 & 779,52 & 6,76 & 1,01 \\
\hline \multirow{7}{*}{$15-\mathrm{Nov}$} & 0,2 & 1189,08 & 942,59 & 57,69 & 775,27 & 413,81 & 1,53 \\
\hline & 0,3 & 1100,86 & 929,04 & 56,86 & 774,44 & 326,42 & 1,42 \\
\hline & 0,4 & 1049,86 & 921,32 & 56,38 & 773,97 & 275,89 & 1,36 \\
\hline & 0,5 & 969,77 & 911,54 & 55,78 & 773,37 & 196,40 & 1,25 \\
\hline & 0,6 & 900,52 & 895,80 & 54,82 & 772,41 & 128,12 & 1,17 \\
\hline & 0,7 & 851,87 & 890,03 & 54,47 & 772,05 & 79,82 & 1,10 \\
\hline & 0,8 & 785,45 & 877,63 & 53,71 & 771,29 & 14,15 & 1,02 \\
\hline \multirow{7}{*}{ 1-Dez } & 0,2 & 1213,65 & 861,65 & 51,99 & 769,57 & 444,08 & 1,58 \\
\hline & 0,3 & 1132,20 & 844,88 & 50,97 & 768,56 & 363,64 & 1,47 \\
\hline & 0,4 & 1073,84 & 832,04 & 50,20 & 767,78 & 306,06 & 1,40 \\
\hline & 0,5 & 991,21 & 814,38 & 49,13 & 766,72 & 224,49 & 1,29 \\
\hline & 0,6 & 926,56 & 799,02 & 48,21 & 765,79 & 160,77 & 1,21 \\
\hline & 0,7 & 870,03 & 790,65 & 47,70 & 765,29 & 104,75 & 1,14 \\
\hline & 0,8 & 811,63 & 783,52 & 47,27 & 764,86 & 46,77 & 1,06 \\
\hline \multirow{7}{*}{ 15-Dez } & 0,2 & 1206,48 & 756,39 & 45,64 & 763,22 & 443,26 & 1,58 \\
\hline & 0,3 & 1129,24 & 730,43 & 44,07 & 761,65 & 367,58 & 1,48 \\
\hline & 0,4 & 1070,26 & 713,95 & 43,07 & 760,66 & 309,60 & 1,41 \\
\hline & 0,5 & 986,89 & 693,32 & 41,83 & 759,41 & 227,47 & 1,30 \\
\hline & 0,6 & 931,05 & 677,70 & 40,89 & 758,47 & 172,58 & 1,23 \\
\hline & 0,7 & 869,52 & 658,42 & 39,72 & 757,31 & 112,21 & 1,15 \\
\hline & 0,8 & 818,43 & 648,57 & 39,13 & 756,71 & 61,72 & 1,08 \\
\hline
\end{tabular}


Entretanto, quanto ao custo anual de amortização do equipamento, a variação observada é superior à obtida por Franke (1996) (15\% a $24 \%$ ), provavelmente, pelas diferenças metodológicas de cálculo, uma vez que Franke (1996) admitiu que este custo é uma proporção da amortização anual clássica em função da lâmina bruta de irrigação aplicada. Essa pressuposição deve ter induzido a subestimativas no referido custo.

$\mathrm{O}$ custo de energia elétrica aumentou à medida que o nível de manejo da irrigação (p) variou de 0,2 a 0,8 , já que o mesmo é diretamente proporcional à energia requerida no bombeamento, que por sua vez depende diretamente da lâmina bruta de irrigação aplicada. De fato, em todos os níveis de manejo de irrigação avaliados, as lâminas brutas de irrigação aplicadas no feijão caupi nas condições de Parnaíba foram superiores às simuladas para Teresina, o que proporcionou maiores estimativas do custo de energia elétrica para a primeira condição.

Quanto à cultura de melancia, a composição relativa do custo total de produção foi diferente da apresentada pela cultura de feijão caupi. O custo de energia elétrica e o custo anual de amortização do equipamento variaram, em média, de 3,1\% (Teresina) a 4,2 \% (Parnaíba) e de 35,8 \% (Teresina) a 35,4\% (Parnaíba) do custo total de produção, respectivamente (Tabelas 11B e 27B, Apêndice 2), independente da época de semeadura e nível de manejo da irrigação.

A menor participação percentual do custo de energia elétrica sobre o custo total de produção foi devido à necessidade da aplicação de menores lâminas brutas de irrigação na cultura da melancia, reduzindo sobremaneira a energia requerida para efetuar o bombeamento e, portanto, o consumo de energia elétrica. Além disso, em termos médios, o custo total de produção da melancia (US\$ $1108,16 \mathrm{ha}^{-1}$ ) é superior ao do feijão caupi (US\$759,01 ha ${ }^{-1}$ ), por apresentar maior custo de formação da lavoura (US\$ 672,43 ha ${ }^{-1}$ ). Esse maior custo de produção da melancia justifica também a menor participação percentual do custo anual de amortização do equipamento na composição total dos custos da cultura.

Da mesma forma que para o feijão caupi, o custo de energia elétrica aumentou à medida que o nível de manejo de irrigação (p) variou de 0,2 a 0,8 . Conforme já destacado, isso deveu-se ao fato do mesmo ser diretamente proporcional à energia 
requerida no bombeamento, dependendo diretamente da lâmina bruta de irrigação aplicada. Embora em menores quantidades, as lâminas brutas de irrigação aplicadas na cultura da melancia em Parnaiba foram superiores às simuladas para Teresina. em todos os niveis de manejo de irrigação avaliados, proporcionando maiores estimativas do custo de energia elétrica.

É importante ressaltar que todas essas considerações foram feitas assumindo-se uma condição de risco de $20 \%$ (Tabelas 38, 11B, 19B e 27B). A composição relativa de custos varia em função do nível de risco que o produtor está disposto a assumir. Portanto, para outros niveis de risco, é necessário consultar as Tabelas 1B a 31B (Apêndice 2).

As receitas líquidas auferidas com a cultura da melancia foram superiores às proporcionadas pela cultura do feijão caupi em todas as combinações entre época de semeadura, nivel de manejo de irrigação e nível de risco, notadamente, nas condições edafoclimáticas do Litoral Piauiense (Tabelas 39 e 32B a 34B) (Apêndice 2). Isto deveuse à superioridade do volume de produção da melancia em relação ao feijão caupi, apesar do maior custo total de produção e dos preços unitários de venda serem inferiores aos do feijão caupi.

Em ambas as culturas, locais e todas as épocas de semeadura e níveis de manejo de irrigação, constatou-se que as receitas Jíquidas aumentaram à medida que o nivel de risco variou de $5 \%$ a $40 \%$. Em termos econômicos, a expectativa é que os retornos líquidos advindos de uma decisão tomada com um maior nível de risco sejam mais atrativos. Entretanto, a definição de qual nível de manejo deve ser adotado, em uma determinada época de semeadura e local, depende do grau de aversão a riscos do produtor e, _consequentemente da expectativa de rentabilidade líquida desejada da atividade.

Por exemplo, considerando-se a cultura da melancia, em Teresina, semeada em 1-Jan, com manejo de irrigação $\mathrm{p}=0,5$ e nível de risco de $5 \%$, a expectativa é que proporcione uma receita líquida de US $\$ 2262,10 \mathrm{ha}^{-1}$ (Tabela 39). Isso significa que, apenas em $5 \%$ dos casos, as receitas líquidas esperadas serão inferiores a esse valor, desde que os outros fatores não sejam alterados. Caso o produtor tenha um grau menor 
Tabela 39. Receitas liquidas para a melancia (US\$ ha ${ }^{-1}$ ), em cada época de semeadura, nível de manejo da irrigação e nível de risco. Teresina, Piauí.

\begin{tabular}{|c|c|c|c|c|c|c|c|c|c|}
\hline \multirow{2}{*}{$\begin{array}{l}\text { Época de } \\
\text { Semeadura }\end{array}$} & \multirow[t]{2}{*}{$p$} & \multicolumn{8}{|c|}{ Nivel de risco (\%) } \\
\hline & & 5 & 10 & 15 & 20 & 25 & 30 & 35 & 40 \\
\hline \multirow{7}{*}{ 1-Jan } & 0,2 & 3348,45 & 3403,92 & 3452,53 & 3498,84 & 3544,45 & 3590,17 & 3636,53 & 3683,95 \\
\hline & 0,3 & 2891,99 & 2959,81 & 3015,80 & 3067,37 & 3117,05 & 3166,08 & 3215,25 & 3265,14 \\
\hline & 0,4 & 2568,41 & 2648,01 & 2711,31 & 2768,28 & 2822,30 & 2875,03 & 2927,46 & 2980,32 \\
\hline & 0,5 & 2262,10 & 2349,71 & 2417,76 & 2478,10 & 2534,71 & 2589,53 & 2643,73 & 2698,12 \\
\hline & 0,6 & 2011,82 & 2109,04 & 2183,09 & 2247,88 & 2308,09 & 2365,99 & 2422,92 & 2479,81 \\
\hline & 0,7 & 1792,73 & 1904,27 & 1987,61 & 2059,58 & 2125,83 & 2189,07 & 2250,89 & 2312,40 \\
\hline & 0,8 & 1605,22 & 1727,10 & 1817,09 & 1894,14 & 1964,62 & 2031,57 & 2096,76 & 2161,43 \\
\hline \multirow{7}{*}{$15-J a n$} & 0,2 & 3450,09 & 3509,12 & 3560,40 & 3609,03 & 3656,78 & 3704,54 & 3752,92 & 3802,34 \\
\hline & 0,3 & 3021,33 & 3089,52 & 3146,05 & 3198,25 & 3248,62 & 3298,40 & 3348,37 & 3399,10 \\
\hline & 0,4 & 2730,71 & 2808,45 & 2870,85 & 2927,33 & 2981,12 & 3033,77 & 3086,25 & 3139,24 \\
\hline & 0,5 & 2456,77 & 2544,22 & 2612,60 & 2673,50 & 2730,83 & 2786,47 & 2841,58 & 2896,96 \\
\hline & 0,6 & 2205,93 & 2306,86 & 2383,90 & 2451,41 & 2514,22 & 2574,67 & 2634,15 & 2693,62 \\
\hline & 0,7 & 1959,33 & 2081,31 & 2172,21 & 2250,56 & 2322,58 & 2391,25 & 2458,34 & 2525,04 \\
\hline & 0,8 & 1805,78 & 1937,17 & 2031,98 & 2116,40 & 2190,85 & 2261,67 & 2330,70 & 2402,12 \\
\hline \multirow{7}{*}{$1-\mathrm{Fev}$} & 0,2 & 3725,93 & 3774,01 & 3812,09 & 3846,22 & 3878,46 & 3909,80 & 3940,85 & 3972,04 \\
\hline & 0,3 & 3305,97 & 3364,23 & 3408,73 & 3447,69 & 3483,85 & 3518,57 & 3552,62 & 3586,56 \\
\hline & 0,4 & 3001,95 & 3078,42 & 3134,97 & 3183,34 & 3227,50 & 3269,32 & 3309,92 & 3350,04 \\
\hline & 0,5 & 2750,08 & 2837,12 & 2900,57 & 2954,28 & 3002,91 & 3048,69 & 3092,89 & 3136,38 \\
\hline & 0,6 & 2507,57 & 2610,83 & 2685,03 & 2747,17 & 2802,97 & 2855,13 & 2905,22 & 2954,30 \\
\hline & 0,7 & 2335,31 & 2449,56 & 2531,02 & 2598,87 & 2659,51 & 2715,98 & 2770,04 & 2822,88 \\
\hline & 0,8 & 2201,86 & 2325,16 & 2411,29 & 2484,73 & 2550,34 & 2609,58 & 2667,98 & 2723,23 \\
\hline \multirow{7}{*}{$15-\mathrm{Fev}$} & 0,2 & 3730,21 & $3780 ; 40$ & 3819,90 & 3855,16 & 3888,36 & 3920,57 & 3952,43 & 3984,39 \\
\hline & 0,3 & 3285,17 & 3354,29 & 3406,14 & 3450,97 & 3492,20 & 3531,50 & 3569,84 & 3607,87 \\
\hline & 0,4 & 2989,64 & 3073,96 & 3135,80 & 3188,41 & 3236,21 & 3281,32 & 3324,99 & 3368,04 \\
\hline & 0,5 & 2731,54 & 2828,90 & 2899,33 & 2958,62 & 3012,07 & 3062,20 & 3110,46 & 3157,84 \\
\hline & 0,6 & 2510,13 & 2623,97 & 2705,34 & 2773,24 & 2834,01 & 2890,67 & 2944,98 & 2998,08 \\
\hline & 0,7 & 2323,03 & 2454,87 & 2548,28 & 2625,68 & 2694,58 & 2758,54 & 2819,60 & 2879,13 \\
\hline & 0,8 & 2196,14 & 2337,69 & 2440,07 & 2522,64 & 2598,28 & 2666,20 & 2730,95 & 2794,03 \\
\hline
\end{tabular}


Tabela 39. Receitas líquidas para a melancia (US\$ ha ${ }^{-1}$ ), em cada época de semeadura, nivel de manejo da irrigação e nivel de risco. Teresina, Piauí.

\begin{tabular}{|c|c|c|c|c|c|c|c|c|c|}
\hline \multirow{2}{*}{$\begin{array}{l}\text { Época de } \\
\text { Semeadura }\end{array}$} & \multirow[t]{2}{*}{$\mathrm{p}$} & \multicolumn{8}{|c|}{ Nível de risco (\%) } \\
\hline & & 5 & 10 & 15 & 20 & 25 & 30 & 35 & 40 \\
\hline \multirow{7}{*}{ 1-Mar } & 0,2 & 3673,75 & 3740,68 & 3797,79 & 3851,40 & 3903,70 & 3955,79 & 4008,37 & 4061,95 \\
\hline & 0,3 & 3225,39 & 3309,59 & 3377,47 & 3439,10 & 3497,90 & 3555,54 & 3613,04 & 3671,15 \\
\hline & 0,4 & 2926,44 & 3021,42 & 3095,98 & 3162,54 & 3225,30 & 3286,31 & 3346,79 & 3407,60 \\
\hline & 0,5 & 2707,16 & 2812,47 & 2893,59 & 2965,11 & 3031,97 & 3096,52 & 3160,19 & 3223,98 \\
\hline & 0,6 & 2473,34 & 2596,10 & 2688,64 & 2769,05 & 2843,41 & 2914,63 & 2984,45 & 3054,06 \\
\hline & 0,7 & 2238,13 & 2381,52 & 2487,67 & 2578,72 & 2662,13 & 2741,43 & 2818,73 & 2895,46 \\
\hline & 0,8 & 2085,97 & 2243,30 & 2361,35 & 2458,42 & 2546,95 & 2630,87 & 2712,46 & 2793,30 \\
\hline \multirow{7}{*}{ 15-Mar } & 0,2 & 3623,65 & 3687,21 & 3741,91 & 3793,51 & 3844,00 & 3894,38 & 3945,31 & 3997,28 \\
\hline & 0,3 & 3158,87 & 3232,42 & 3292,86 & 3348,36 & 3401,73 & 3454,33 & 3507,03 & 3560,44 \\
\hline & 0,4 & 2793,09 & 2881,87 & 2951,88 & 3014,55 & 3073,76 & 3131,39 & 3188,58 & 3246,13 \\
\hline & 0,5 & 2526,45 & 2629,03 & 2707,88 & 2777,30 & 2842,11 & 2904,63 & 2966,26 & 3027,96 \\
\hline & 0,6 & 2253,92 & 2371,38 & 2459,79 & 2536,52 & 2607,40 & 2675,25 & 2741,72 & 2807,96 \\
\hline & 0,7 & 2023,43 & 2155,15 & 2252,79 & 2336,63 & 2413,47 & 2486,58 & 2557,86 & 2628,63 \\
\hline & 0,8 & 1831,61 & 1974,72 & 2079,72 & 2169,22 & 2250,79 & 2328,05 & 2403,13 & 2477,47 \\
\hline \multirow{7}{*}{$1-\mathrm{Abr}$} & 0,2 & 3433,62 & 3498,69 & 3555,07 & 3608,46 & 3660,85 & 3713,23 & 3766,26 & 3820,44 \\
\hline & 0,3 & 2923,68 & 2999,42 & 3061,81 & 3119,21 & 3174,47 & 3229,00 & 3283,67 & 3339,13 \\
\hline & 0,4 & 2535,57 & 2624,92 & 2695,65 & 2759,15 & 2819,27 & 2877,89 & 2936,13 & 2994,82 \\
\hline & 0,5 & 2253,13 & 2348,34 & 2422,36 & $.2488,04$ & 2549,72 & 2609,48 & 2668,59 & 2727,94 \\
\hline & 0,6 & 1976,16 & 2079,24 & 2157,95 & 2226,96 & 2291,20 & 2353,06 & 2413,93 & 2474,82 \\
\hline & 0,7 & 1727,12 & $1840,3.8$ & 1925,45 & 1999,18 & 2067,24 & 2132,35 & 2196,13 & 2259,67 \\
\hline & 0,8 & 1498,30 & 1625,05 & 1718,80 & 1799,17 & 1872,77 & 1942,75 & 2010,95 & 2078,66 \\
\hline \multirow{7}{*}{$15-\mathrm{Abr}$} & 0,2 & 3386,48 & 3447,05 & 3500,27 & 3551,04 & 3601,10 & 3651,31 & 3702,26 & 3754,40 \\
\hline & 0,3 & 2825,67 & 2894,54 & 2952,01 & 3005,29 & 3056,83 & 3107,87 & 3159,18 & 3211,31 \\
\hline & 0,4 & 2398,48 & 2475,34 & 2537,19 & 2593,28 & 2646,76 & 2699,16 & 2751,42 & 2804,23 \\
\hline & 0,5 & 2077,21 & 2162,40 & 2229,15 & 2288,66 & 2344,72 & 2399,19 & 2453,16 & 2507,43 \\
\hline & 0,6 & 1762,78 & 1859,02 & 1932,54 & 1997,02 & 2057,04 & 2114,84 & 2171,73 & 2228,64 \\
\hline & 0,7 & 1484,25 & 1586,05 & 1662,67 & 1729,18 & 1790,65 & 1849,50 & 1907,18 & 1964,67 \\
\hline & 0,8 & 1242,58 & 1349,28 & 1428,65 & 1496,96 & 1559,71 & 1619,50 & 1677,87 & 1735,90 \\
\hline
\end{tabular}


Tabela 39. Receitas líquidas para a melancia (US\$ ha ${ }^{-1}$ ), em cada época de semeadura, nível de manejo da irrigação e nível de risco. Teresina. Piauí.

\begin{tabular}{|c|c|c|c|c|c|c|c|c|c|}
\hline \multirow{2}{*}{$\begin{array}{l}\text { Época de } \\
\text { Semeadura }\end{array}$} & \multirow[t]{2}{*}{$\mathrm{p}$} & \multicolumn{8}{|c|}{ Nível de risco (\%) } \\
\hline & & 5 & 10 & 15 & 20 & 25 & 30 & 35 & 40 \\
\hline \multirow{7}{*}{ 1-Mai } & 0,2 & 2494,47 & 2534,14 & 2568,73 & 2601,59 & 2633,89 & 2666,21 & 2698,95 & 2732,41 \\
\hline & 0,3 & 2013,70 & 2059,80 & 2097,81 & 2132,77 & 2166,41 & 2199,59 & 2232,84 & 2266,53 \\
\hline & 0,4 & 1660,43 & 1713,00 & 1754,70 & 1792,16 & 1827,63 & 1862,20 & 1896,54 & 1931,10 \\
\hline & 0,5 & 1425,39 & 1476,99 & 1517,56 & 1553,77 & 1587,92 & 1621,08 & 1653,94 & 1686,95 \\
\hline & 0,6 & 1133,83 & 1194,94 & 1241,41 & 1282,01 & 1319,68 & 1355,84 & 1391,33 & 1426,75 \\
\hline & 0,7 & 878,03 & $946,9.2$ & 998,19 & 1042,30 & 1082,79 & 1121,32 & 1158,90 & 1196,19 \\
\hline & 0,8 & 678,50 & 749,37 & 801,58 & 846,18 & 886,88 & 925,46 & 962,93 & 1000,02 \\
\hline \multirow{7}{*}{ 15-Mai } & 0,2 & 2506,48 & 2540,62 & 2571,48 & 2601,37 & 2631,10 & 2661,11 & 2691,69 & 2723,08 \\
\hline & 0,3 & 2007,87 & 2045,72 & 2078,10 & 2108,53 & 2138,24 & 2167,84 & 2197,71 & 2228,15 \\
\hline & 0,4 & 1672,07 & 1713,46 & 1747,58 & 1778,97 & 1809,18 & 1838,96 & 1868,81 & 1899,05 \\
\hline & 0,5 & 1385,55 & 1427,88 & 1462,06 & 1493,10 & 1522,72 & 1551,74 & 1580,67 & 1609,90 \\
\hline & 0,6 & 1090,01 & 1135,82 & 1171,77 & 1203,84 & 1234,06 & 1263,40 & 1292,46 & 1321,65 \\
\hline & 0,7 & 854,04 & 902,33 & 939,50 & 972,23 & 1002,78 & 1032,24 & 1061,26 & 1090,29 \\
\hline & 0,8 & 669,26 & 717,83 & 754,81 & 787,14 & 817,15 & 845,98 & 874,29 & 902,54 \\
\hline \multirow{7}{*}{ 1-Jun } & 0,2 & 2618,69 & 2667,76 & 2713,24 & 2757,87 & 2802,63 & 2848,06 & 2894,55 & 2942,41 \\
\hline & 0,3 & 2139,29 & 2189,44 & 2234,20 & 2277,27 & 2319,95 & 2362,93 & 2406,66 & 2451,50 \\
\hline & 0,4 & 1798,46 & 1849,45 & 1893,73 & 1935,72 & 1976,96 & 2018,22 & 2060,02 & 2102,74 \\
\hline & 0,5 & 1479,37 & 1525,49 & 1565,43 & 1603,23 & 1640,31 & 1677,38 & 1714,91 & 1753,25 \\
\hline & 0,6 & 1162,87 & 1211,39 & 1251,99 & 1289,68 & 1326,20 & 1362,40 & 1398,82 & 1435,86 \\
\hline & 0,7 & 932,26 & 981,74 & 1022,30 & 1059,49 & 1095,23 & 1130,46 & 1165,74 & 1201,52 \\
\hline & 0,8 & 731,37 & 777,21 & 814,62 & 848,85 & 881,68 & 914,00 & 946,33 & 979,10 \\
\hline \multirow{7}{*}{ 15-Jun } & 0,2 & 2659,35 & 2705,57 & 2749,25 & 2792,51 & 2836,13 & 2880,57 & 2926,15 & 2973,17 \\
\hline & 0,3 & 2196,54 & 2246,25 & 2290,90 & 2334,01 & 2376,82 & 2419,99 & 2463,96 & 2509,09 \\
\hline & 0,4 & 1846,88 & 1895,91 & 1939,01 & 1980,15 & 2020,72 & 2061,43 & 2102,75 & 2145,05 \\
\hline & 0,5 & 1495,80 & 1540,48 & 1579,50 & 1616,61 & 1653,11 & 1689,68 & 1726,74 & 1764,66 \\
\hline & 0,6 & 1208,94 & 1254,93 & 1293,96 & 1330,49 & 1366,06 & 1401,44 & 1437,13 & 1473,50 \\
\hline & 0,7 & 983,04 & 1023,46 & 1057,94 & 1090,30 & 1121,88 & 1153,32 & 1185,06 & 1217,41 \\
\hline & 0,8 & 753,61 & 797,89 & 831,75 & 863,19 & 893,64 & 923,83 & 954,19 & 986,71 \\
\hline
\end{tabular}


Tabela 39. Receitas líquidas para a melancia (US $\$ \mathrm{ha}^{-1}$ ), em cada época de semeadura, nivel de manejo da irrigação e nivel de risco. Teresina, Piauí.

\begin{tabular}{|c|c|c|c|c|c|c|c|c|c|}
\hline \multirow{2}{*}{$\begin{array}{l}\text { Época de } \\
\text { Semeadura }\end{array}$} & \multirow[t]{2}{*}{$\mathrm{p}$} & \multicolumn{8}{|c|}{ Nível de risco (\%) } \\
\hline & & 5 & 10 & 15 & 20 & 25 & 30 & 35 & 40 \\
\hline \multirow{7}{*}{ 1-Jul } & 0,2 & 1962,65 & 2049,46 & 2115,64 & 2171,34 & 2220,43 & 2264,88 & 2305,85 & 2344,11 \\
\hline & 0,3 & 1638,82 & 1725,75 & $179], 51$ & 1846,74 & 1895,42 & 1939,57 & 1980,38 & 2018,61 \\
\hline & 0,4 & 1318,94 & 1396,28 & 1454,76 & 1503,87 & 1547,16 & 1586,42 & 1622,70 & 1656,70 \\
\hline & 0,5 & 1024,50 & 1095,17 & 1148,48 & 1193,22 & 1232,65 & 1268,43 & 1301,51 & 1332,55 \\
\hline & 0,6 & 814,24 & 882,49 & 933,75 & 976,73 & 1014,61 & 1049,00 & 1080,86 & 1110,79 \\
\hline & 0,7 & 592,49 & 653,93 & 700,04 & 738,67 & 772,73 & 803,65 & 832,29 & 859,22 \\
\hline & 0,8 & 425,57 & 481,03 & 522,71 & 558,93 & 589,75 & 617,75 & 643,70 & 668,11 \\
\hline \multirow{7}{*}{ 15-Jul } & 0,2 & 1973,73 & 2060,08 & 2125,96 & 2181,43 & 2230,31 & 2274,57 & 2315,36 & 2353,44 \\
\hline & 0,3 & 1696,02 & 1784,68 & 1851,76 & 1908,10 & 1957,77 & 2002,81 & 2044,43 & 2083,42 \\
\hline & 0,4 & 1340,42 & 1417,54 & 1475,92 & 1524,96 & 1568,19 & 1607,38 & 1643,60 & 1677,52 \\
\hline & 0,5 & 1073,00 & 1147,69 & 1203,93 & 1251,10 & 1292,68 & 1330,43 & 1365,36 & 1398,15 \\
\hline & 0,6 & 873,75 & 937,76 & 986,13 & 1026,75 & 1062,56 & 1095,03 & 1125,04 & 1153,17 \\
\hline & 0,7 & 613,37 & 677,12 & 723,73 & 762,83 & 797,32 & 828,66 & 857,70 & 886,54 \\
\hline & 0,8 & 458,18 & 518,74 & 564,03 & 601,94 & 635,36 & 665,73 & 693,89 & 720,39 \\
\hline \multirow{7}{*}{ 1-Ago } & 0,2 & 2638,30 & 2680,30 & 2720,41 & 2760,33 & 2800,72 & 2841,95 & 2884,29 & 2928,01 \\
\hline & 0,3 & 2369,99 & 2415,11 & 2456,58 & 2497,10 & 2537,64 & 2578,71 & 2620,68 & 2663,86 \\
\hline & 0,4 & 1901,68 & 1941,92 & 1978,65 & 2014,42 & 2050,11 & 2086,23 & 2123,10 & 2161,00 \\
\hline & 0,5 & 1621,53 & 1664,76 & 1702,73 & 1738,96 & 1774,68 & 1810,51 & 1846,87 & 1884,08 \\
\hline & 0,6 & 1291,49 & 1330,86 & 1365,20 & 1397,84 & 1429,93 & 1462,07 & 1494,64 & 1527,94 \\
\hline & 0,7 & 1051,07 & 1092,68 & 1127,86 & 1160,71 & 1192,66 & 1224,42 & 1256,42 & 1289,01 \\
\hline & 0,8 & 844,52 & 897,68 & 916,33 & 936,51 & 956,13 & 976,36 & 1034,06 & 1056,13 \\
\hline \multirow{7}{*}{ 15-Ago } & 0,2 & 2653,61 & 2697,11 & 2738,30 & 2779,15 & 2820,37 & 2862,38 & 2905,48 & 2949,95 \\
\hline & 0,3 & 2406,62 & 2450,90 & 2491,91 & 2532,13 & 2572,46 & 2613,38 & 2655,23 & 2698,33 \\
\hline & 0,4 & 1924,57 & 1965,85 & 2003,38 & 2039,84 & 2076,19 & 2112,92 & 2150,40 & 2188,91 \\
\hline & 0,5 & 1672,38 & 1715,09 & 1752,86 & 1789,03 & 1824,76 & 1860,67 & 1897,14 & 1934,50 \\
\hline & 0,6 & 1310,39 & 1351,07 & 1386,38 & 1419,85 & 1452,70 & 1485,57 & 1518,86 & 1552,87 \\
\hline & 0,7 & 1088,56 & 1132,60 & 1169,57 & 1203,96 & 1237,32 & 1270,41 & 1303,72 & 1337,60 \\
\hline & 0,8 & 813,95 & 856,26 & 891,71 & 923,09 & 953,43 & 983,48 & 1013,67 & 1044,36 \\
\hline
\end{tabular}


Tabela 39. Receitas líquidas para a melancia (US\$ ha ${ }^{-1}$ ), em cada época de semeadura, nível de manejo da irrigação e nível de risco. Teresina, Piauí.

\begin{tabular}{|c|c|c|c|c|c|c|c|c|c|}
\hline \multirow{2}{*}{$\begin{array}{l}\text { Época de } \\
\text { Semeadura }\end{array}$} & \multirow[t]{2}{*}{$\mathrm{p}$} & \multicolumn{8}{|c|}{ Nível de risco (\%) } \\
\hline & & 5 & 10 & 15 & 20 & 25 & 30 & 35 & 40 \\
\hline \multirow{7}{*}{ 1-Set } & 0,2 & 2483,22 & 2515,53 & 2545,12 & 2573,99 & 2602,84 & 2632,05 & 2661,89 & 2692,57 \\
\hline & 0,3 & 2245,92 & $2278,5.5$ & $2307,8.8$ & 2336,21 & 2364,35 & 2392,73 & 2421,64 & 2451,30 \\
\hline & 0,4 & 1792,39 & 1824,80 & 1853,06 & 1879,90 & 1906,30 & 1932,73 & 1959,51 & 1986,89 \\
\hline & 0,5 & 1552,28 & 1586,06 & 1614,76 & 1641,64 & 1667,83 & 1693,88 & 1720,15 & 1746,92 \\
\hline & 0,6 & 1218,64 & 1251,05 & 1278,13 & 1303,25 & 1327,57 & 1351,65 & 1375,85 & 1400,45 \\
\hline & 0,7 & 996,40 & 1032,91 & 1062,36 & 1089,08 & 1114,58 & 1139,56 & 1164,48 & 1189,65 \\
\hline & 0,8 & 752,13 & 787,31 & 815,35 & 840,61 & 864,57 & 887,97 & 911,23 & 934,68 \\
\hline \multirow{7}{*}{ 15-Set } & 0,2 & 2477,23 & 2509,61 & 2539,24 & 2568,11 & 2596,96 & 2626,17 & 2655,99 & 2686,65 \\
\hline & 0,3 & 2228,45 & 2262,16 & 2292,18 & 2321,04 & 2349,62 & 2378,39 & 2407,65 & 2437,63 \\
\hline & 0,4 & 1782,24 & 1816,67 & 1846,28 & 1874,21 & 1901,53 & 1928,80 & 1956,36 & 1984,49 \\
\hline & 0,5 & 1541,79 & 1578,20 & 1608,68 & 1636,98 & 1664,38 & 1691,53 & 1718,84 & 1746,58 \\
\hline & 0,6 & 1215,85 & 1250,29 & 1278,75 & 1304,98 & 1330,25 & 1355,20 & 1380,21 & 1405,58 \\
\hline & 0,7 & 996,47 & 1035,65 & 1066,91 & 1095,10 & 1121,86 & 1148,01 & 1174,02 & 1200,24 \\
\hline & 0,8 & 756,55 & 792,49 & 821,07 & 848,99 & 873,36 & 897,15 & 920,81 & 944,65 \\
\hline \multirow{7}{*}{ 1-Out } & 0,2 & 2553,36 & 2586,99 & 2617,35 & 2646,73 & 2675,95 & 2705,42 & 2735,45 & 2766,26 \\
\hline & 0,3 & 2283,83 & 2320,10 & 2351,73 & $23.81,7.8$ & 2411,31 & 2440,88 & 2470,82 & 2501,42 \\
\hline & 0,4 & 1842,54 & 1876,43 & 1905,57 & 1933,03 & 1959,87 & 1986,64 & 2013,68 & 2041,25 \\
\hline & 0,5 & 1566,66 & 1605,41 & 1637,33 & 1666,67 & 1694,89 & 1722,70 & 1750,56 & 1778,78 \\
\hline & 0,6 & 1252,77 & 1289,56 & 1319,52 & 1346,86 & 1373,03 & 1398,74 & 1424,42 & 1450,38 \\
\hline & 0,7 & 1029,77 & 1066,86 & 1096,57 & 1123,42 & 1148,95 & 1173,90 & 1198,73 & 1223,77 \\
\hline & 0,8 & 778,95 & 820,70 & 853,10 & 881,80 & 908,70 & 934,70 & 960,37 & 986,09 \\
\hline \multirow{7}{*}{ 15-Out } & 0,2 & 2549,57 & 2583,27 & 2613,65 & 2643,04 & 2672,25 & 2701,71 & 2731,71 & 2762,49 \\
\hline & 0,3 & 2246,90 & 2284,01 & 2316,13 & 2346,51 & 2376,30 & 2406,06 & 2436,16 & 2466,89 \\
\hline & 0,4 & 1816,38 & 1856,08 & 1889,12 & 1919,68 & 1949,20 & 1978,40 & 2007,70 & 2037,44 \\
\hline & 0,5 & 1523,01 & 1565,54 & 1599,94 & 1631,22 & 1661,07 & 1690,35 & 1719,55 & 1749,04 \\
\hline & 0,6 & 1243,81 & 1285,09 & 1318,08 & 1347,85 & 1376,12 & 1403,72 & 1431,18 & 1458,85 \\
\hline & 0,7 & 1008,87 & 1048,82 & 1080,44 & 1108,78 & 1135,57 & 1161,65 & 1187,52 & 1213,55 \\
\hline & 0,8 & 812,53 & 854,29 & 886,76 & 915,52 & 942,50 & 968,59 & 994,35 & 1020,17 \\
\hline
\end{tabular}


Tabela 39. Receitas líquidas para a melancia (US\$ ha ${ }^{-1}$ ), em cada época de semeadura, nível de manejo da irrigação e nível de risco. Teresina, Piauí.

\begin{tabular}{|c|c|c|c|c|c|c|c|c|c|}
\hline \multirow{2}{*}{$\begin{array}{l}\text { Época de } \\
\text { Semeadura }\end{array}$} & \multirow[t]{2}{*}{$\mathrm{p}$} & \multicolumn{8}{|c|}{ Nível de risco (\%) } \\
\hline & & 5 & 10 & 15 & 20 & 25 & 30 & 35 & 40 \\
\hline \multirow{7}{*}{ 1-Nov } & 0,2 & 2942,91 & 2982,43 & 3017,78 & 3051,84 & 3085,59 & 3119,58 & 3154,15 & 3189,58 \\
\hline & 0,3 & 2536,06 & 2586,07 & 2627,78 & 2666,41 & 2703,76 & 2740,71 & 2777,82 & 2815,50 \\
\hline & 0,4 & 2145,51 & 2193,20 & 2232,51 & 2268,68 & 2303,48 & 2337,79 & 2372,17 & 2407,01 \\
\hline & 0,5 & 1798,38 & 1848,78 & 1889,24 & 1925,86 & 1960,70 & 1994,79 & 2028,73 & 2062,97 \\
\hline & 0,6 & 1485,10 & 1542,80 & 1587,61 & 1627,32 & 1664,54 & 1700,55 & 1736,12 & 1771,76 \\
\hline & 0,7 & 1233,66 & 1291,00 & 1335,05 & 1373,79 & 1409,93 & 1444,74 & 1479,02 & 1513,30 \\
\hline & 0,8 & 971,95 & 1039,69 & 1090,34 & 1134,04 & 1174,24 & 1212,57 & 1250,00 & 1287,18 \\
\hline \multirow{7}{*}{$15-\mathrm{Nov}$} & 0,2 & 2935,73 & 2979,39 & 3017,53 & 3053,81 & 3089,50 & 3125,23 & 3161,43 & 3198,44 \\
\hline & 0,3 & 2498,08 & 2552,10 & 2596,45 & 2637,14 & 2676,24 & 2714,75 & 2753,31 & 2792,36 \\
\hline & 0,4 & 2141,44 & 2197,99 & 2243,34 & 2284,35 & 2323,37 & 2361,53 & 2399,52 & 2437,85 \\
\hline & 0,5 & 1811,87 & 1871,72 & 1918,64 & 1960,48 & 1999,89 & 2038,14 & 2076,01 & 2114,06 \\
\hline & 0,6 & 1509,39 & 1577,78 & 1629,94 & 1675,59 & 1718,00 & 1758,78 & 1798,83 & 1838,83 \\
\hline & 0,7 & 1242,39 & 1317,75 & 1374,13 & 1422,82 & 1467,63 & 1510,38 & 1552,14 & 1593,64 \\
\hline & 0,8 & 1055,15 & 1131,11 & 1187,50 & 1235,95 & 1280,35 & 1322,57 & 1363,71 & 1404,52 \\
\hline \multirow{7}{*}{ 1-Dez } & 0,2 & 2916,25 & 3008,54 & 3096,70 & 3184,57 & 3273,57 & 3364,53 & 3458,08 & 3554,81 \\
\hline & 0,3 & 2488,58 & 2581,86 & 2668,23 & 2753,05 & 2838,23 & 2924,81 & 3013,55 & 3105,08 \\
\hline & 0,4 & 2153,00 & 2246,89 & 2331,75 & 2414,08 & 2496,19 & 2579,27 & 2664,16 & 2751,55 \\
\hline & & 1818,07 & 1915,69 & 2001,23 & 2082,91 & 2163,59 & 2244,72 & 2327,27 & 2412,01 \\
\hline & 0,6 & 1540,73 & 1641,41 & 1727,50 & 1808,62 & 1888,09 & 1967,59 & 2048,18 & 2130,71 \\
\hline & 0,7 & 1334,63 & 1435,20 & 1520,00 & 1599,30 & 1676,61 & 1753,69 & 1831,67 & 1911,38 \\
\hline & 0,8 & 1104,10 & 1207,82 & 1293,50 & 1372,68 & 1449,30 & 1525,31 & 1601,93 & 1680,08 \\
\hline \multirow{7}{*}{ 15-Dez } & 0,2 & 2940,63 & 3033,65 & 3122,43 & 3210,88 & 3300,46 & 3391,99 & 3486,13 & 3583,46 \\
\hline & 0,3 & 2472,64 & 2572,46 & 2663,31 & 2751,78 & 2840,20 & 2929,80 & 3021,43 & 3115,82 \\
\hline & 0,4 & 2171,27 & 2274,43 & 2365,89 & 2453,76 & 2540,89 & 2628,72 & 2718,25 & 2810,25 \\
\hline & 0,5 & 1864,85 & 1970,01 & 2061,11 & 2147,56 & 2232,63 & 2317,97 & 2404,68 & 2493,58 \\
\hline & 0,6 & 1571,27 & 1687,36 & 1784,44 & 1874,80 & 1962,64 & 2050,07 & 2138,40 & 2228,64 \\
\hline & 0,7 & 1362,83 & 1482,69 & 1581,22 & 1672,03 & 1759,76 & 1846,69 & 1934,28 & 2023,57 \\
\hline & 0,8 & 1175,96 & 1299,70 & 1399,86 & 1491,33 & 1579,18 & 1665,89 & 1753,00 & 1841,63 \\
\hline
\end{tabular}


de aversão a riscos, a rentabilidade líquida esperada, nessas mesmas condições. é de US\$2698,12 $\mathrm{ha}^{-1}$ (US\$ 436,02 $\mathrm{ha}^{-1}$ a mais), porém, com possibilidade de insucesso em $40 \%$ dos casos.

Para um dado nível de manejo de irrigação, o aumento das receitas líquidas com o incremento no nível de risco ocorreu devido à combinação favorável entre os fatores lâmina bruta de irrigação, produtividade das culturas, preços de venda dos produtos e preços das tarifas de energia elétrica. Analisando-se as Tabelas 35 a 37 e $11 \mathrm{~A}$ a $16 \mathrm{~A}$ (Apêndice 1), verificou-se que existe tendência das estimativas das lâminas brutas de irrigação e dos preços das tarifas de consumo de energia elétrica serem menores à medida que aumentam as probabilidades de ocorrência, ao passo que as estimativas de produtividade das culturas e dos preços de venda dos produtos tendem a ser maiores. O grau de aumento ou redução conjunta desses fatores definiu a receita bruta, o custo total de produção e, como conseqüência, a receita líquida em cada combinação.

Nas duas condições edafoclimáticas, as receitas líquidas auferidas com a cultura da melancia foram sempre positivas, indicando que a adoção da irrigação na cultura é viável economicamente para todas as combinações entre época de semeadura, nível de manejo de irrigação e nível de risco (Tabelas 39 e 34B). A irrigação suplementar, durante a estação chuvosa, mostrou-se mais viável economicamente que a irrigação total efetuada durante a estação seca. A aplicação das menores lâminas brutas de irrigação suplementar associada aos melhores preços de venda do produto foram os fatores decisivos na definição dessa viabilidade econômica

Nas condições edafoclimáticas de Parnaíba, independente do nível de manejo de irrigação adotado, o cultivo da melancia com irrigação suplementar é mais indicado nas épocas de semeadura de $15-\mathrm{Fev}$, para níveis de risco de $5 \%$ a $15 \%$, e 1-Mar, para niveis de risco de $20 \%$ a $40 \%$. Em Teresina, é mais recomendável o cultivo em 1-Fev, para um nível risco de $5 \%, 15-\mathrm{Fev}$, para níveis de risco entre $10 \%$ a $25 \%$ e 1-Mar, para níveis de risco de $30 \%$ a $40 \%$. Por outro lado, é aconselhável que sejam evitadas as épocas de semeadura de 1-Mai e 15-Mai, em ambas as condições edafoclimáticas, pelo fato das menores receitas líquidas terem sido observadas nessas épocas, em todos os 
níveis de risco. A viabilidade econômica foi inferior em decorrência das menores estimativas do preço de venda e da produtividade da cultura.

Para cultivos na estação seca, a prática da irrigação total da cultura da melancia é mais viável economicamente em 15-Ago, em todos os níveis de risco. Ressalta-se, porém, que as receitas líquidas médias auferidas em 1-Nov e 15-Nov foram superiores às obtidas em 1-Ago. Entretanto, apesar dessas épocas de semeadura terem início na estação seca, há uma contribuição da precipitação pluviométrica efetiva para o suprimento hídrico da cultura no final do ciclo, promovendo a redução das lâminas brutas de irrigação e descaracterizando essas épocas como sendo típicas da prática de irrigação total. Outro fato que influiu decisivamente foi as melhores estimativas dos preços de venda do produto nessas épocas (Tabela 36).

Em ambas condições edafoclimáticas, para uma mesma época de semeadura, as receitas líquidas diminuíram, chegando até mesmo a valores negativos no caso do feijão caupi (Tabelas 32B e 33B) (Apêndice 2), à medida que o nível de manejo de irrigação utilizado variou de 0,2 a 0,8 . No caso da cultura da melancia, essa redução de receita líquida não inviabilizou economicamente nenhum dos níveis de manejo de irrigação avaliados. Por isso, em condições de suprimento hídrico reduzido é aconselhável que sejam usados_niveis_de manejo mais elevados, proporcionando a aplicação de menores lâminas brutas de irrigação, notadamente durante a estação chuvosa.

Para a culțura do feijão caupi, a irrigação mostrou-se ser viável economicamente apenas em determinadas combinações entre épocas de semeadura, níveis de manejo da irrigação e níveis de risco, em ambas condições edafoclimáticas (Tabelas 32B e 33B) (Apêndice 2). Por exemplo, em Parnaíba, para a época de semeadura de 1-Mai e nível de risco de $25 \%$, a irrigação apenas foi viável economicamente para níveis de manejo de irrigação $p=0,2$ a $p=0,5$.

Da mesma forma que a melancia, a irrigação suplementar, na estação chuvosa, mostrou-se mais viável economicamente que a irrigação total na estação seca, proporcionando uma maior flexibilidade nos níveis de manejo de irrigação a serem adotados. A ação conjunta dos fatores lâmina bruta de irrigação suplementar e preço de venda do produto determinaram essa viabilidade econômica. 
Nas condições edafoclimáticas de Parnaíba, independente do nível de manejo de irrigação adotado, o cultivo de feijão caupi com irrigação suplementar foi mais indicado nas épocas de semeadura de 15-Jan, para níveis de risco de $5 \%$ a $20 \%$, e 1-Mar, para níveis de risco de $25 \%$ a $40 \%$. Em Teresina, é mais recomendável o cultivo em 15-Jan, para um nível risco de $5 \%$ e 1-Mar, para níveis de rísco de $10 \%$ a $40 \%$. Por outro lado, devem ser evitadas as épocas de semeadura de 1-Mai e 15-Mai, em ambas as condições edafoclimáticas, devido às menores receitas líquidas auferidas nessas épocas, em todos os níveis de risco, resultantes da ação combinada entre os menores valores para os preços de venda (Tabela 35) e produtividade da cultura (Tabelas 24 e 25).

Para cultivos durante a estação seca, em ambas condições edafoclimáticas, constatou-se menor flexibilidade nos niveis de manejo de irrigação. De fato apenas a adoção do nível de manejo de irrigação $\mathrm{p}=0,2$ proporcionou receitas líquidas positivas em todos os níveis de risco, já que possibilitou maior estabilidade de produção, conforme discutido no item 4.4 (balanço hídrico diário) (Figuras 21 e 22).

Dependendo da época de semeadura, o uso dos niveis de manejo de irrigação de $\mathrm{p}=0,3 \mathrm{a} \mathrm{p}=0,8$ somente apresentou viabilidade econômica para níveis de riscos cada vez maiores. Por exemplo, o cultivo de feijão caupi em 15-Ago, nas condições de solo e clima de Parnaíba (Tabela 32B) (Apêndice 2), apenas apresentou viabilidade econômica para os níveis de risco de $15 \%$ (US\$14,27 ha ${ }^{-1}$ ) a $40 \%$ (US\$167,53 ha ${ }^{-1}$ ). Segundo Franke (1996), este fato é explicado pela diminuição desproporcional entre a receita bruta e o custo total de produção da cultura Contudo, durante essa época do ano, as culturas estão menos sujeitas à ocorrência de problemas fitossanitários e as condições climáticas, principalmente quanto à umidade relativa do ar e insolação, possibilitam uma produção de melhor qualidade.

As maiores receitas líquidas foram auferidas em 1-Dez e 15-Dez coincidindo com as épocas de semeadura que proporcionaram as melhores estimativas nos preços de venda do feijão caupi. Além disso, ao efetuar-se a semeadura nessas épocas, o suprimento hídrico da cultura, especialmente no final do ciclo, é fornecido, em parte, pela precipitação pluviométrica efetiva, reduzindo a lâmina bruta de irrigação e, como conseqüência,-o custo total de produção. 
As receitas liquidas auferidas com o feijão caupi, bem como a indicação das épocas mais propícias de cultivo não confirmam os resultados obtidos por Bastos (1999). Este autor avaliou apenas as épocas de semeadura de 15-Jun, 15-Jul, 15-Ago e 15-Set, não possibilitando a análise das receitas líquidas com o uso da irrigação suplementar, as quais foram economicamente mais viáveis no presente estudo. Além disso, Bastos (1999) concluiu que não é recomendável economicamente o cultivo irrigado de feijão caupi nas épocas de 15-Ago e 15-Set em Teresina. Contudo, verificou-se, nessas mesmas épocas de semeadura e sem considerar os níveis de risco, que o cultivo foi viável para níveis de manejo com uma extração de até $30 \%$ da água disponivel do solo. A comparação entre as receitas liquidas auferidas nos dois trabalhos ficou prejudicada, uma vez que Bastos (1999) não apresentou valores em dólar.

Ao contrário dos resultados obtidos por Franke (1996), as receitas líquidas obtidas para as duas culturas indicaram que o ponto de máxima eficiência técnica não coincidiu necessariamente com o de máxima eficiência econômica. Ou seja, as receitas líquidas máximas foram obtidas com combinações entre época de semeadura e nível de manejo de irrigação diferentes daquelas que proporcionaram as produtividades máximas. Um dos prováveis motivos para isso foi a incorporação do risco econômico, através da análise probabilística dos preços de venda dos produtos e das tarifas de consumo de energia elétrica, na estimativa das receitas brutas e do custo total de produção das culturas. Ao fixar os preços de venda das culturas de milho e soja, bem como das tarifas de energia elétrica, Franke (1996) condicionou a variação da receita líquida unicamente à variação da estimativa da lâmina bruta de irrigação suplementar.

No item 4.4 (balanço hídrico diário) foram recomendadas as épocas de semeadura de 1-Set e 15 -Set como as mais propícias para o cultivo irrigado de feijão caupi e melancia, respectivamente, bem como 15-Fev para o cultivo de sequeiro ou com o uso de irrigação suplementar. Conforme apresentado acima, ao se incorporar o risco climático e econômico no processo de tomada de decisão, ocorreram mudanças na indicação das épocas mais propícias para o cultivo irrigado (irrigação total ou suplementar), as quais variaram com os níveis de riscos assumidos. 
Nas Tabelas 40 a 43 são apresentadas as receitas líquidas auferidas pelas culturas de feijão caupi e melancia, sob cultivo de sequeiro, em função da época de semeadura e nível de risco nas condições edafoclimáticas de Parnaíba e Teresina. Em todos os níveis de risco, o cultivo de feijão caupi foi inviável economicamente nas épocas de semeadura de 15-Abr a 15-Dez (Parnaíba) (Tabela 40) e de 1-Mai a 15-Nov (Teresina) (Tabela 41). Quanto à cultura da melancia, a inviabilidade econômica foi verificada nas épocas de semeadura de 1-Mai a 15-Dez (Parnaíba) (Tabela 42) e de 1-Mai a 1-Nov (Teresina) (Tabela 43). Esses períodos correspondem justamente à estação seca do ano, onde as precipitações pluviométricas efetivas são insuficientes para o suprimento hídrico necessário ao cultivo de sequeiro dessas culturas (Figuras 23 e 24).

Restringindo-se à estação chuvosa e comparando-se as receitas líquidas auferidas com o mesmo nível de risco, constatou-se em Parnaíba que o desempenho econômico da melancia cultivada sob irrigação foi superior à de sequeiro em todas as épocas de semeadura, indicando ser viável economicamente a prática da irrigação suplementar para qualquer nivel de manejo adotado. Entretanto, esse fato não se confirmou para o feijão caupi quando semeado de 1-Fev a 1-Abr. Para essas épocas de semeadura, a irrigação suplementar apenas apresentou viabilidade econômica quando foram adotados, no mínimo, os seguintes manejos de irrigação: 1-Fev $(p=0,6) ; 15-\mathrm{Fev}(\mathrm{p}=0,4) ; 1-\mathrm{Mar}$ $(p=0,4) ; 15-\operatorname{Mar}(p=0,5)$ e $1-\operatorname{Abr}(p=0,6)$. A utilização de manejos de irrigação até os níveis recomendados viabilizou essa prática, devido aos incrementos de produtividade compensarem economicamente os custos associados à sua adoção.

Análise semelhante para as condições edafoclimáticas de Teresina revelou que o desempenho econômico do feijão caupi em regime de sequeiro foi superior ao irrigado quando semeado de 1-Fev a 1-Mar, indicando ser inviável economicamente a prática da irrigação suplementar nas referidas épocas de semeadura. Contudo, para as demais épocas de semeadura na estação chuvosa, a prática foi viável desde que utilizados, no mínimo, os seguintes manejos de irrigação: 1-Jan $(p=0,3)$; 15-Jan $(p=0,2)$; 15-Mar ( $p$ $=0,2) ; 1-\operatorname{Abr}(p=0,4) ; 15-\operatorname{Abr}(p=0,8)$ e 15-Dez $(p=0,5)$. Para a melancia, o cultivo de sequeiro superou economicamente o irrigado apenas nas seguintes épocas de semeadura e niveis de manejo: 1-Fev $(p=0,7) ; 15-F e v(p=0,6)$ e 1-Mar $(p=0,7)$. A 
Tabela 40. Receitas líquidas para o feijão caupi (US\$ ha ${ }^{-1}$ ), sob regime de sequeiro, em cada época de semeadura e nível de risco. Pamaíba, Piauí.

\begin{tabular}{|c|c|c|c|c|c|c|c|c|}
\hline \multirow{2}{*}{$\begin{array}{l}\text { Época de } \\
\text { Semeadura }\end{array}$} & \multicolumn{8}{|c|}{ Nível de risco (\%) } \\
\hline & 5 & 10 & 15 & 20 & 25 & 30 & 35 & 40 \\
\hline 1-Jan & $-182,00$ & $-113,80$ & $-63,96$ & $-21,22$ & 18,20 & 56,10 & 93,56 & 131,34 \\
\hline 15-Jan & $-118,89$ & $-52,81$ & $-4,02$ & 38,13 & 77,20 & 114,91 & 152,26 & 190,00 \\
\hline l-Fev & $-87,26$ & $-17,68$ & 34,19 & 79,35 & 121,47 & 162,32 & 202,96 & 244,16 \\
\hline $15-\mathrm{Fev}$ & $-4,38$ & 62,68 & 113,42 & 158,02 & 199,89 & 240,68 & 281,38 & 322,72 \\
\hline 1-Mar & 26,48 & 94,86 & 146,99 & 193,05 & 236,46 & 278,87 & 321,29 & 364,45 \\
\hline 15-Mar & $-70,51$ & 3,30 & 58,53 & 106,74 & 151,82 & 195,61 & 239,26 & 283,57 \\
\hline $1-\mathrm{Abr}$ & $-171,51$ & $-102,06$ & $-50,79$ & $-6,44$ & 34,78 & 74,66 & 114,29 & 154,46 \\
\hline $15-\mathrm{Abr}$ & $-317,81$ & $-248,37$ & $-198,33$ & $-155,7.7$ & $-116,65$ & $-79,11$ & $-42,01$ & $-4,53$ \\
\hline 1-Mai & $-322,91$ & $-317,48$ & $-292,36$ & $-270,57$ & $-250,16$ & $-230,20$ & $-210,10$ & $-189,45$ \\
\hline 15-Mai & $-303,19$ & $-302,39$ & $-301,57$ & $-300,73$ & $=299,85$ & $-298,95$ & $-298,02$ & $-297,05$ \\
\hline 1-Jun & $-311,57$ & $-311,20$ & $-310,82$ & $-310,42$ & $-310,01$ & $-309,59$ & $-309,16$ & $-308,71$ \\
\hline 15-Jun & $-315,15$ & $-314,90$ & $-314,64$ & $-314,37$ & $-314,09$ & $-313,80$ & $-313,50$ & $-313,19$ \\
\hline 1-Jul & $-314,12$ & $-313,87$ & $-313,61$ & $-313,34$ & $-313,06$ & $-312,77$ & $-312,48$ & $-312,17$ \\
\hline 15-Jul & $-316,93$ & $-316,76$ & $-316,58$ & $-316,40$ & $-3.16,21$ & $-316,02$ & $-315,81$ & $-315,60$ \\
\hline 1-Ago & $-322,91$ & $-322,91$ & $-322,91$ & $-322,91$ & $-322,91$ & $-322,91$ & $-322,91$ & $-322,91$ \\
\hline 15-Ago & $-322,91$ & $-322,91$ & $-322,91$ & $-322,91$ & $-322,91$ & $-322,91$ & $-322,91$ & $-322,91$ \\
\hline 1-Set & $-322,91$ & $-322,91$ & $-322,91$ & $-322,91$ & $-322,91$ & $-322,91$ & $-322,91$ & $-322,91$ \\
\hline $15-$ Set & $-321,61$ & $-321,57$ & $-321,52$ & $-321,48$ & $-321,44$ & $-321,39$ & $-321,34$ & $-321,29$ \\
\hline 1-Out & $-319,70$ & $-319,62$ & $-319,53$ & $-319,45$ & $-319,36$ & $-319,26$ & $-319,17$ & $-319,07$ \\
\hline 15-Out & $-319,93$ & $-319,85$ & $-319,77$ & $-319,69$ & $-319,61$ & $-319,52$ & $-319,43$ & $-319,34$ \\
\hline $1-$ Nov & $-302,98$ & $-302,50$ & $-302,02$ & $-301,52$ & $-301,01$ & $-300,48$ & $-299,92$ & $-299,35$ \\
\hline 15-Nov & $-293,82$ & $-293,13$ & $-292,42$ & $-291,70$ & $-290,94$ & $-290,17$ & $-289,36$ & $-288,53$ \\
\hline 1-Dez & $-322,91$ & $-322,91$ & $-297,72$ & $-270,04$ & $-245,09$ & $-221,52$ & $-198,54$ & $-175,61$ \\
\hline 15-Dez & $-322,91$ & $-286,81$ & $-239,69$ & $-200,24$ & $-164,55$ & $-130,73$ & $-97,69$ & $-64,67$ \\
\hline
\end{tabular}


Tabela 41. Receitas líquidas para o feijão caupi (US\$ ha ${ }^{-1}$ ), sob regime de sequeiro, em cada época de semeadura e nível de risco. Teresina, Piauí.

\begin{tabular}{|c|c|c|c|c|c|c|c|c|}
\hline \multirow{2}{*}{$\begin{array}{l}\text { Época de } \\
\text { Semeadura }\end{array}$} & \multicolumn{8}{|c|}{ Nível de risco (\%) } \\
\hline & 5 & 10 & 15 & 20 & 25 & 30 & 35 & 40 \\
\hline 1-Jan & 86,77 & 152,55 & 202,68 & 246,90 & 288,48 & 329,02 & 369,45 & 410,48 \\
\hline 15-Jan & 144,13 & 212,32 & 264,59 & 310,88 & 354,53 & 397,15 & 439,72 & 482,96 \\
\hline 1-Fev & 257,14 & 315,65 & 362,35 & 404,79 & 445,51 & 485,77 & 526,34 & 567,78 \\
\hline $15-\mathrm{Fev}$ & 247,62 & 311,60 & $3.62,16$ & 407,82 & 451,47 & 494,51 & 537,81 & 582,00 \\
\hline 1-Mar & 259,41 & 323,76 & 374,93 & 421,33 & 465,81 & 509,76 & 554,05 & 599,31 \\
\hline 15-Mar & 133,13 & 199,10 & 250,39 & 296,26 & 339,85 & 382,67 & 425,64 & 469,46 \\
\hline $1-\mathrm{Abr}$ & $-44,21$ & 28,27 & 82,77 & 130,52 & 175,26 & 218,80 & 262,24 & 306,37 \\
\hline 15-Abr & $-253,83$ & $-183,65$ & $-132,54$ & $-88,73$ & $-48,29$ & $-9,33$ & 29,27 & 68,32 \\
\hline 1-Mai & $-322,91$ & $-306,02$ & $-268,94$ & $-236,72$ & $-206,51$ & $-176,93$ & $-147,14$ & $-116,52$ \\
\hline 15-Mai & $-303,45$ & $-302,66$ & $-301,85$ & $-301,02$ & $-300,16$ & $-299,27$ & $-298,35$ & $-297,39$ \\
\hline 1-Jun & $-311,28$ & $-310,90$ & $-310,51$ & $-310,11$ & $-309,69$ & $-309,26$ & $-308,81$ & $-308,35$ \\
\hline 15-Jun & $-312,44$ & $-312,09$ & $-311,74$ & $-311,38$ & $-311,00$ & $-310,61$ & $-310,21$ & $-309,79$ \\
\hline 1-Jul & $-316,80$ & $-316,63$ & $-316,44$ & $-316,26$ & $-316,06$ & $-315,86$ & $-315,66$ & $-315,44$ \\
\hline 15-Jul & $-313,58$ & $-313,31$ & $-313,03$ & $-312,75$ & $-312,45$ & $-312,15$ & $-311,83$ & $-311,50$ \\
\hline 1-Ago & $-312,59$ & $-312,26$ & $-311,92$ & $-311,56$ & $-311,20$ & $-310,83$ & $-310,44$ & $-310,03$ \\
\hline 15-Ago & $-311,08$ & $-310,69$ & $-310,30$ & $-309,90$ & $-309,48$ & $-309,05$ & $-308,61$ & $-308,15$ \\
\hline 1-Set & $-308,96$ & $-308,53$ & $-308,08$ & $-307,63$ & $-307,15$ & $-306,67$ & $-306,16$ & $-305,63$ \\
\hline $15-$ Set & $-303,20$ & $-302,58$ & $-301,96$ & $-301,31$ & $-300,64$ & $-299,95$ & $-299,23$ & $-298,49$ \\
\hline 1-Out & $-305,46$ & $-305,01$ & $-304,55$ & $-304,08$ & $-303,59$ & $-303,09$ & $-302,56$ & $-302,02$ \\
\hline 15-Out & $-300,90$ & $-300,33$ & $-299,75$ & $-299,15$ & $-298,54$ & $-297,90$ & $-297,24$ & $-296,55$ \\
\hline 1-Nov & $-322,91$ & $-322,91$ & $-286,24$ & $-251,25$ & $-219,56$ & $-189,48$ & $-160,03$ & $-130,52$ \\
\hline $15-\mathrm{Nov}$ & $-280,01$ & $-211,87$ & $-162,87$ & $-121,33$ & $-83,33$ & $-47,03$ & $-11,30$ & 24,62 \\
\hline 1-Dez & $-213,66$ & $-141,44$ & $-89,36$ & $-45,17$ & $-4,77$ & 33,79 & 71,66 & 109,66 \\
\hline 15-Dez & $-46,19$ & 25,39 & 78,16 & 123,64 & 165,67 & 206,12 & 246,08 & 286,32 \\
\hline
\end{tabular}


Tabela 42. Receitas liquidas para a melancia (US\$ ha ${ }^{-1}$ ), sob regime de sequeiro, em cada época de semeadura e nível de risco. Parnaíba, Piauí.

\begin{tabular}{|c|c|c|c|c|c|c|c|c|}
\hline \multirow{2}{*}{$\begin{array}{l}\text { Época de } \\
\text { Semeadura }\end{array}$} & \multicolumn{8}{|c|}{ Nível de risco (\%) } \\
\hline & 5 & 10 & 15 & 20 & 25 & 30 & 35 & 40 \\
\hline 1-Jan & $-209,85$ & 5,72 & 154,80 & 276,30 & 383,16 & 481,52 & 574,91 & 665,67 \\
\hline 15-Jan & 11,08 & 244,85 & 406,96 & 539,35 & 656,00 & 763,53 & 865,75 & 965,19 \\
\hline $1-\mathrm{Fev}$ & 291,57 & 551,71 & 729,73 & 873,21 & 998,01 & 1111,62 & 1218,32 & 1320,90 \\
\hline $15-\mathrm{Fev}$ & 639,78 & 891,01 & 1063,35 & 1202,54 & 1323,82 & 1434,39 & 1538,37 & 1638,45 \\
\hline 1-Mar & 701,08 & 966,96 & 1152,67 & 1305,19 & 1440,21 & 1565,15 & 1684,29 & 1800,49 \\
\hline 15-Mar & 363,18 & 638,68 & 830,21 & 986,92 & 1125,21 & 1252,86 & 1374,32 & 1492,58 \\
\hline $1-\mathrm{Abr}$ & $-129,60$ & 108,73 & 273,95 & 408,90 & 527,85 & 637,56 & 741,92 & 843,52 \\
\hline $15-\mathrm{Abr}$ & $-573,40$ & $-340,37$ & $-179,92$ & $-49,59$ & 64,76 & 169,84 & 269,47 & 366,22 \\
\hline 1-Mai & $-672,43$ & $-606,95$ & $-536,73$ & $-480,05$ & $-430,63$ & $-385,49$ & $-342,93$ & $-301,82$ \\
\hline 15-Mai & $-672,43$ & $-672,43$ & $-634,08$ & $-587,43$ & $-546,81$ & $-509,77$ & $-474,90$ & $-441,25$ \\
\hline 1-Jun & $-643,85$ & $-643,59$ & $-643,33$ & $-643,05$ & $-642,77$ & $-585,57$ & $-584,69$ & $-583,77$ \\
\hline 15-Jun & $-656,51$ & $-656,37$ & $-656,22$ & $-656,06$ & $-655,91$ & $-655,74$ & $-655,57$ & $-655,40$ \\
\hline 1-Jul & $-659,36$ & $-659,03$ & $-658,77$ & $-658,56$ & $-658,37$ & $-658,20$ & $-658,04$ & $-657,89$ \\
\hline $15-J u l$ & $-663,58$ & $-663,35$ & $-663,18$ & $-663,03$ & $-662,90$ & $-662,79$ & $-662,68$ & $-662,58$ \\
\hline 1-Ago & $-672,24$ & $-672,23$ & $-672,22$ & $-672,21$ & $-672,20$ & $-672,20$ & $-672,19$ & $-672,18$ \\
\hline 15-Ago & $-672,29$ & $-672,28$ & $-672,28$ & $-672,27$ & $-672,27$ & $-672,26$ & $-672,26$ & $-672,26$ \\
\hline 1-Set & $-672,32$ & $-672,32$ & $-672,32$ & $-672,31$ & $-672,31$ & $-672,31$ & $-672,30$ & $-672,30$ \\
\hline 15-Set & $-668,26$ & $-668,24$ & $-668,21$ & $-668,18$ & $-668,16$ & $-668,13$ & $-668,10$ & $-668,07$ \\
\hline 1-Out & $-665,61$ & $-665,57$ & $-665,53$ & $-665,49$ & $-665,44$ & $-665,40$ & $-665,35$ & $-665,31$ \\
\hline 15-Out & $-665,85$ & $-665,81$ & $-665,77$ & $-665,73$ & $-665,69$ & $-665,65$ & $-665,61$ & $-665,56$ \\
\hline $1-N o v$ & $-639,03$ & $-638,84$ & $-638,63$ & $-638,42$ & $-638,21$ & $-637,99$ & $-637,76$ & $-637,52$ \\
\hline 15-Nov & $-672,43$ & $-672,43$ & $-648,55$ & $-605,62$ & $-568,26$ & $-534,19$ & $-502,11$ & $-471,18$ \\
\hline 1-Dez & $-672,43$ & $-624,57$ & $-554,39$ & $-496,14$ & $-443,88$ & $-394,77$ & $-347,14$ & $-299,87$ \\
\hline 15-Dez & $-672,43$ & $-530,98$ & $-409,75$ & $-308,93$ & $-218,31$ & $-133,05$ & $-50,30$ & 31,89 \\
\hline
\end{tabular}


Tabela 43. Receitas liquidas para a melancia (US\$ ha ${ }^{-1}$ ), sob regime de sequeiro, em cada época de semeadura e nível de risco. Teresina, Piauí.

\begin{tabular}{|c|c|c|c|c|c|c|c|c|}
\hline \multirow{2}{*}{$\begin{array}{l}\text { Época de } \\
\text { Semeadura }\end{array}$} & \multicolumn{8}{|c|}{ Nível de risco (\%) } \\
\hline & 5 & 10 & 15 & 20 & 25 & 30 & 35 & 40 \\
\hline 1-Jan & 874,54 & 1113,74 & 1281,62 & 1420,03 & 1542,95 & 1656,99 & 1765,98 & 1872,48 \\
\hline 15-Jan & 1201,03 & 1441,35 & 1610,78 & 1750,96 & 1875,80 & 1991,89 & 2103,05 & 2211,84 \\
\hline $1-\mathrm{Fev}$ & 1934,16 & 2136,64 & 2277,27 & 2391,99 & 2492,81 & 2585,40 & 2673,02 & 2757,80 \\
\hline $15-\mathrm{Fev}$ & 1861,04 & 2099,02 & 2263,71 & 2397,68 & 2515,12 & 2622,75 & 2724,42 & 2822,66 \\
\hline 1-Mar & 1834,24 & 2074,48 & 2245,24 & 2387,41 & 2514,65 & 2633,46 & 2747,60 & 2859,59 \\
\hline 15-Mar & 1212,54 & 1470,14 & 1651,36 & 1801,04 & 1934,14 & 2057,78 & 2176,05 & 2291,70 \\
\hline $1-\mathrm{Abr}$ & 329,98 & 598,67 & 785,95 & 939,56 & 1075,43 & 1201,11 & 1320,94 & 1437,85 \\
\hline $15-\mathrm{Abr}$ & $-409,40$ & $-168,90$ & $-2,90$ & 132,22 & 250,97 & 360,23 & 463,96 & 564,78 \\
\hline 1-Mai & $-672,43$ & $-612,97$ & $-499,83$ & $-408,57$ & $-329,04$ & $-256,43$ & $-187,99$ & $-121,92$ \\
\hline 15-Mai & $-600,79$ & $-600,37$ & $-599,94$ & $-599,49$ & $-599,03$ & $-598,55$ & $-598,06$ & $-597,55$ \\
\hline 1-Jun & $-638,13$ & $-637,82$ & $-637,50$ & $-637,17$ & $-636,83$ & $-636,47$ & $-636,11$ & $-635,73$ \\
\hline 15-Jun & $-650,24$ & $-650,04$ & $-649,83$ & $-649,62$ & $-649,40$ & $-649,17$ & $-648,94$ & $-648,69$ \\
\hline 1-Jul & $-661,49$ & $-661,21$ & $-661,00$ & $-660,82$ & $-660,66$ & $-660,51$ & $-660,38$ & $-660,26$ \\
\hline 15-Jul & $-659,31$ & $-658,98$ & $-658,72$ & $-658,51$ & $-658,32$ & $-658,15$ & $-657,99$ & $-657,84$ \\
\hline 1-Ago & $-655,24$ & $-655,10$ & $-654,94$ & $-654,79$ & $-654,62$ & $-654,46$ & $-654,28$ & $-654,10$ \\
\hline 15-Ago & $-653,42$ & $-653,26$ & $-653,09$ & $-652,92$ & $-652,74$ & $-652,55$ & $-652,36$ & $-652,16$ \\
\hline 1-Set & $-645,43$ & $-645,27$ & $-645,11$ & $-644,94$ & $-644,77$ & $-644,59$ & $-644,40$ & $-644,21$ \\
\hline $15-$ Set & $-638,65$ & $-638,45$ & $-638,25$ & $-638,04$ & $-637,82$ & $-637,59$ & $-637,36$ & $-637,12$ \\
\hline 1-Out & $-636,91$ & $-636,70$ & $-636,50$ & $-636,28$ & $-636,06$ & $-635,83$ & $-635,59$ & $-635,35$ \\
\hline 15-Out & $-617,53$ & $-617,21$ & $-616,89$ & $-616,56$ & $-616,22$ & $-615,86$ & $-615,50$ & $-615,12$ \\
\hline $1-\mathrm{Nov}$ & $-672,43$ & $-662,91$ & $-558,00$ & $-473,45$ & $-399,80$ & $-332,60$ & $-269,28$ & $-208,18$ \\
\hline $15-\mathrm{Nov}$ & $-519,05$ & $-340,19$ & $-217,40$ & $-118,00$ & $-31,10$ & 48,45 & 123,59 & 196,28 \\
\hline 1-Dez & $-324,65$ & $-111,37$ & 40,94 & 169,00 & 285,06 & 394,96 & 502,13 & 608,95 \\
\hline 15-Dez & 146,44 & 377,25 & 544,63 & 686,94 & 816,99 & 940,90 & 1062,31 & 1183,71 \\
\hline
\end{tabular}


viabilidade econômica da irrigação suplementar justificou-se plenamente pelas mesmas razões de Parnaíba.

Nas Tabelas 44 e 35B a 41B (Apêndice 2) são apresentados os resultados da relação benefício/custo $(B / C)$ para todas combinações entre local, cultura, época de semeadura, manejo de irrigação e nível de risco, em regime irrigado e de sequeiro. Por tratar-se de uma relação entre as receitas brutas auferidas e os respectivos custos totais de produção, refletem uma concordância com os valores das receitas líquidas já apresentados anteriormente. Isto porque quando as combinações avaliadas apresentaram viabilidade econômica (receitas líquidas positivas), as respectivas receitas brutas foram maiores que os custos totais de produção. Por outro lado, quando as combinações foram inviáveis economicamente (receitas líquidas negativas), as correspondentes receitas brutas foram menores que os custos totais de produção.

Dessa forma, para as combinações entre local, cultura, época de semeadura, manejo de irrigação e nível de risco que apresentaram viabilidade econômica, os valores da relação $\mathrm{B} / \mathrm{C}$ foram superiores à unidade. Por outro lado, para as combinações que mostraram-se inviáveis economicamente, os valores da relação $B / C$ foram inferiores à unidade.

Por exemplo, para o feijão caupi cultivado sob irrigação nas condições edafoclimáticas de Parnaíba, a relação $B / C$ variou de 0,67 (15-Mai; $p=0,8$ e nível de risco igual a $5 \%$ ) a 1,75 (1-Dez e 15-Dez; $\mathrm{p}=0,2$ e nível de risco de $40 \%$ ) (Tabela 44). A relação $\mathrm{B} / \mathrm{C}$ igual a 0,67 significa que, caso o produtor estivesse propenso a um risco de $5 \%$, poderia ter um prejuízo de $33 \%$. Da mesma forma, a relação $\mathrm{B} / \mathrm{C}$ igual a 1,75 significa que, a um nível de risco de $40 \%$, o produtor teria uma lucratividade de $75 \%$ pela sua decisão em irrigar feijão caupi na referida época de semeadura e no nível de manejo da irrigação especificado. Essa lucratividade pode ser considerada elevada em se tratando de atividade agrícola. Entretanto, é importante ressaltar que a mesma somente tem possibilidade de ocorrer em $60 \%$ dos casos (Franke, 1996). 
Tabela 44. Relação benefício/custo para o feijão caupi, em cada época de semeadura, nivel de manejo da irrigação e nivel de risco. Parnaiba, Piauí.

\begin{tabular}{|c|c|c|c|c|c|c|c|c|c|}
\hline \multirow{2}{*}{$\begin{array}{l}\text { Época de } \\
\text { Semeadura }\end{array}$} & \multirow[t]{2}{*}{$\mathrm{p}$} & \multicolumn{8}{|c|}{ Nivel de risco (\%) } \\
\hline & & 5 & 10 & 15 & 20 & 25 & 30 & 35 & 40 \\
\hline \multirow{7}{*}{ 1-Jan } & 0,2 & 1,36 & 1,41 & 1,45 & 1,49 & 1,53 & 1,58 & 1,62 & 1,67 \\
\hline & 0,3 & 1,29 & 1,33 & 1,37 & 1,41 & 1,45 & 1,49 & 1,53 & 1,58 \\
\hline & 0,4 & 1,21 & 1,25 & 1,29 & 1,33 & 1,37 & 1,42 & 1,46 & 1,50 \\
\hline & 0,5 & 1,13 & 1,17 & 1,21 & 1,25 & 1,29 & 1,33 & 1,37 & 1,41 \\
\hline & 0,6 & 1,06 & 1,11 & 1,15 & 1,18 & 1,22 & 1,26 & 1,30 & 1,34 \\
\hline & 0,7 & 0,99 & 1,03 & 1,07 & 1,11 & 1,15 & 1,19 & 1,23 & 1,27 \\
\hline & 0,8 & 0,93 & 0,98 & 1,02 & 1,06 & 1,10 & 1,14 & 1,17 & 1,21 \\
\hline \multirow{7}{*}{$15-J a n$} & 0,2 & 1,39 & 1,43 & 1,47 & 1,51 & 1,56 & 1,60 & 1,64 & 1,69 \\
\hline & 0,3 & 1,31 & 1,36 & 1,40 & 1,44 & 1,48 & 1,52 & 1,57 & 1,61 \\
\hline & 0,4 & 1,23 & 1,27 & 1,32 & 1,36 & 1,40 & 1,44 & 1,48 & 1,53 \\
\hline & 0,5 & 1,15 & 1,20 & 1,24 & 1,28 & 1,32 & 1,36 & 1,40 & 1,44 \\
\hline & 0,6 & 1,08 & 1,12 & 1,17 & 1,21 & 1,25 & 1,29 & 1,33 & 1,37 \\
\hline & 0,7 & 1,02 & 1,06 & 1,11 & 1,15 & $1,1.8$ & 1,22 & 1,26 & 1,31 \\
\hline & 0,8 & 0,97 & 1,01 & 1,05 & 1,09 & 1,13 & 1,17 & 1,21 & 1,25 \\
\hline \multirow{7}{*}{ l-Fev } & 0,2 & 1,32 & 1,37 & 1,41 & 1,46 & 1,50 & 1,55 & 1,59 & 1,64 \\
\hline & 0,3 & 1,26 & 1,31 & 1,35 & 1,39 & 1,43 & 1,48 & 1,52 & 1,57 \\
\hline & 0,4 & 1,17 & 1,22 & 1,26 & 1,30 & 1,35 & 1,39 & 1,43 & 1,48 \\
\hline & 0,5 & 1,11 & 1,16 & 1,20 & 1,24 & 1,28 & 1,33 & 1,37 & 1,41 \\
\hline & 0,6 & 1,04 & 1,09 & 1,13 & 1,18 & 1,22 & 1,26 & 1,30 & 1,35 \\
\hline & 0,7 & 0,99 & 1,03 & 1,08 & 1,12 & 1,16 & 1,20 & 1,25 & 1,29 \\
\hline & 0,8 & 0,93 & 0,98 & 1,02 & 1,06 & 1,11 & 1,15 & 1,19 & 1,23 \\
\hline \multirow{7}{*}{$15-\mathrm{Fev}$} & 0,2 & 1,32 & 1,37 & 1,41 & 1,46 & 1,50 & 1,55 & 1,59 & 1,64 \\
\hline & 0,3 & 1,27 & $1,3]$ & 1,35 & 1,40 & 1,44 & 1,48 & 1,53 & 1,57 \\
\hline & 0,4 & 1,17 & 1,22 & 1,26 & 1,30 & 1,35 & 1,39 & 1,44 & 1,48 \\
\hline & 0,5 & 1,12 & 1,16 & 1,21 & 1,25 & 1,29 & 1,33 & 1,38 & 1,42 \\
\hline & 0,6 & 1,05 & 1,09 & 1,14 & 1,18 & 1,22 & 1,27 & 1,31 & 1,36 \\
\hline & 0,7 & 1,01 & 1,06 & 1,10 & 1,14 & 1,18 & 1,23 & 1,27 & 1,31 \\
\hline & 0,8 & 0,94 & 1,00 & 1,04 & 1,08 & 1,12 & 1,17 & 1,21 & 1,25 \\
\hline
\end{tabular}


Tabela 44. Relação benefício/custo para o feijão caupi, em cada época de semeadura, nivel de manejo da irrigação e nível de risco. Parnaíba, Piauí.

\begin{tabular}{|c|c|c|c|c|c|c|c|c|c|}
\hline \multirow{2}{*}{$\begin{array}{l}\text { Época de } \\
\text { Semeadura }\end{array}$} & \multirow[t]{2}{*}{$\mathrm{p}$} & \multicolumn{8}{|c|}{ Nivel de risco (\%) } \\
\hline & & 5 & 10 & 15 & 20 & 25 & 30 & 35 & 40 \\
\hline \multirow{7}{*}{ 1-Mar } & 0,2 & 1,36 & 1,41 & 1,45 & 1,50 & 1,54 & 1,59 & 1,64 & 1,69 \\
\hline & 0,3 & 1,30 & 1,35 & 1,39 & 1,44 & 1,48 & 1,53 & 1,58 & 1,63 \\
\hline & 0,4 & 1,20 & 1,25 & 1,30 & 1,34 & 1,39 & 1,43 & 1,48 & 1,53 \\
\hline & 0,5 & 1,14 & 1,19 & 1,24 & 1,28 & 1,33 & 1,38 & 1,42 & 1,47 \\
\hline & 0,6 & 1,07 & 1,12 & 1,17 & 1,22 & 1,26 & 1,31 & 1,35 & 1,40 \\
\hline & 0,7 & 1,02 & 1,07 & 1,12 & 1,16 & 1,21 & 1,25 & 1,30 & 1,35 \\
\hline & 0,8 & 0,96 & 1,02 & 1,07 & 1,11 & 1,16 & 1,20 & 1,25 & 1,30 \\
\hline \multirow{7}{*}{ 15-Mar } & 0,2 & 1,35 & 1,39 & 1,44 & 1,48 & 1,53 & 1,58 & 1,63 & 1,68 \\
\hline & 0,3 & 1,29 & 1,33 & 1,38 & 1,42 & 1,47 & 1,52 & 1,56 & 1,61 \\
\hline & 0,4 & 1,19 & 1,24 & 1,28 & 1,32 & 1,37 & 1,41 & 1,46 & 1,51 \\
\hline & 0,5 & 1,13 & 1,18 & 1,22 & 1,26 & 1,31 & 1,35 & 1,40 & 1,44 \\
\hline & 0,6 & 1,05 & 1,10 & 1,15 & 1,19 & 1,23 & 1,28 & 1,32 & 1,37 \\
\hline & 0,7 & 1,00 & 1,05 & 1,10 & 1,14 & 1,18 & 1,23 & 1,27 & 1,32 \\
\hline & 0,8 & 0,94 & 0,99 & 1,03 & 1,08 & 1,12 & 1,17 & 1,21 & 1,26 \\
\hline \multirow{7}{*}{$1-\mathrm{Abr}$} & 0,2 & 1,34 & 1,38 & 1,43 & 1,47 & 1,52 & 1,56 & 1,61 & 1,66 \\
\hline & 0,3 & 1,27 & 1,31 & 1,36 & 1,40 & 1,45 & 1,49 & 1,54 & 1,59 \\
\hline & 0,4 & 1,16 & 1,21 & 1,25 & 1,30 & 1,34 & 1,38 & 1,43 & 1,48 \\
\hline & 0,5 & 1,10 & 1,15 & 1,19 & 1,23 & 1,27 & 1,32 & 1,36 & 1,41 \\
\hline & 0,6 & 1,01 & 1,06 & 1,11 & 1,15 & 1,19 & 1,23 & 1,27 & 1,32 \\
\hline & 0,7 & 0,96 & 1,01 & 1,05 & 1,09 & 1,13 & 1,18 & 1,22 & 1,26 \\
\hline & 0,8 & 0,90 & 0,95 & 0,99 & 1,03 & 1,07 & 1,11 & 1,15 & 1,20 \\
\hline \multirow{7}{*}{$15-\mathrm{Abr}$} & 0,2 & 1,33 & 1,37 & 1,42 & 1,46 & 1,50 & 1,55 & 1,60 & 1,65 \\
\hline & 0,3 & 1,26 & 1,30 & 1,34 & 1,39 & 1,43 & 1,47 & 1,52 & 1,57 \\
\hline & 0,4 & 1,15 & 1,19 & 1,24 & 1,28 & 1,32 & 1,36 & 1,41 & 1,45 \\
\hline & 0,5 & 1,08 & 1,12 & 1,16 & 1,20 & 1,25 & 1,29 & 1,33 & 1,38 \\
\hline & 0,6 & 0,99 & 1,03 & 1,08 & 1,12 & 1,16 & 1,20 & 1,24 & 1,28 \\
\hline & 0,7 & 0,93 & 0,98 & 1,02 & 1,06 & 1,10 & 1,14 & 1,18 & 1,22 \\
\hline & 0,8 & 0,86 & 0,91 & 0,95 & 0,99 & 1,03 & 1,07 & 1,11 & 1,15 \\
\hline
\end{tabular}


Tabela 44. Relação benefício/custo para o feijão caupi, em cada época de semeadura, nivel de manejo da irrigação e nivel de risco. Parnaiba, Piaui.

\begin{tabular}{|c|c|c|c|c|c|c|c|c|c|}
\hline \multirow{2}{*}{$\begin{array}{l}\text { Época de } \\
\text { Semeadura }\end{array}$} & \multirow[t]{2}{*}{$\mathrm{p}$} & \multicolumn{8}{|c|}{ Nível de risco $(\%)$} \\
\hline & & 5 & 10 & 15 & 20 & 25 & 30 & 35 & 40 \\
\hline \multirow{7}{*}{ 1-Mai } & 0,2 & 1,05 & 1,10 & 1,15 & 1,20 & 1,25 & 1,30 & 1,36 & 1,41 \\
\hline & 0,3 & 0,99 & 1,04 & 1,09 & 1,13 & 1,18 & 1,23 & 1,28 & 1,34 \\
\hline & 0,4 & 0,90 & 0,95 & 1,00 & 1,04 & 1,09 & 1,14 & 1,18 & 1,24 \\
\hline & 0,5 & 0,84 & 0,89 & 0,93 & 0,97 & 1,02 & 1,06 & 1,11 & 1,16 \\
\hline & 0,6 & 0,78 & 0,82 & 0,87 & 0,91 & 0,95 & 0,99 & 1,04 & 1,08 \\
\hline & 0,7 & 0,73 & 0,77 & 0,81 & 0,85 & 0,89 & 0,93 & 0,97 & 1,02 \\
\hline & 0,8 & 0,68 & 0,72 & 0,75 & 0,79 & 0,83 & 0,87 & 0,91 & 0,95 \\
\hline \multirow{7}{*}{ 15-Mai } & 0,2 & 1,05 & 1,10 & 1,15 & 1,20 & 1,25 & 1,30 & 1,36 & 1,41 \\
\hline & 0,3 & 0,99 & 1,04 & 1,08 & 1,13 & 1,18 & 1,23 & 1,28 & 1,33 \\
\hline & 0,4 & 0,90 & 0,95 & 1,00 & 1,04 & 1,09 & 1,14 & 1,19 & 1,24 \\
\hline & 0,5 & 0,84 & 0,88 & 0,93 & 0,97 & 1,01 & 1,06 & 1,10 & 1,15 \\
\hline & 0,6 & 0,78 & 0,82 & 0,86 & 0,90 & 0,94 & 0,99 & 1,03 & 1,08 \\
\hline & 0,7 & 0,73 & 0,77 & 0,80 & 0,84 & 0,88 & 0,92 & 0,96 & 1,01 \\
\hline & 0,8 & 0,67 & 0,71 & 0,75 & 0,79 & 0,82 & 0,86 & 0,90 & 0,94 \\
\hline \multirow{7}{*}{ 1-Jun } & 0,2 & 1,17 & 1,22 & 1,26 & 1,31 & 1,36 & 1,41 & 1,46 & 1,51 \\
\hline & 0,3 & 1,11 & 1,15 & 1,19 & 1,23 & 1,28 & 1,32 & 1,37 & 1,42 \\
\hline & 0,4 & 1,01 & 1,06 & 1,10 & 1,14 & 1,19 & 1,23 & 1,28 & 1,32 \\
\hline & 0,5 & 0,94 & 0,98 & 1,02 & 1,06 & 1,09 & 1,13 & 1,18 & 1,22 \\
\hline & 0,6 & 0,87 & 0,91 & 0,95 & 0,99 & 1,03 & 1,07 & 1,11 & 1,15 \\
\hline & 0,7 & 0,80 & 0,84 & 0,87 & 0,91 & 0,95 & 0,98 & 1,02 & 1,06 \\
\hline & 0,8 & 0,75 & 0,79 & 0,82 & 0,85 & 0,89 & 0,92 & 0,96 & 1,00 \\
\hline \multirow{7}{*}{ 15-Jun } & 0,2 & 1,18 & 1,23 & 1,27 & 1,32 & 1,37 & 1,41 & 1,47 & 1,52 \\
\hline & 0,3 & 1,10 & 1,14 & 1,19 & 1,23 & 1,27 & 1,32 & 1,36 & 1,41 \\
\hline & 0,4 & 1,03 & 1,07 & 1,11 & 1,16 & 1,20 & 1,24 & 1,29 & 1,34 \\
\hline & 0,5 & 0,94 & 0,97 & 1,01 & 1,05 & 1,09 & 1,13 & 1,17 & 1,21 \\
\hline & 0,6 & 0,89 & 0,92 & 0,96 & 1,00 & 1,04 & 1,08 & 1,12 & 1,16 \\
\hline & 0,7 & 0,80 & 0,84 & 0,87 & 0,91 & 0,95 & 0,98 & 1,02 & 1,06 \\
\hline & 0,8 & 0,76 & 0,79 & 0,82 & 0,86 & 0,89 & 0,93 & 0,96 & 1,00 \\
\hline
\end{tabular}


Tabela 44. Relação benefício/custo para o feijão caupi, em cada época de semeadura, nível de manejo da irrigação e nível de risco. Parnaíba, Piauí.

\begin{tabular}{|c|c|c|c|c|c|c|c|c|c|}
\hline \multirow{2}{*}{$\begin{array}{l}\text { Época de } \\
\text { Semeadura }\end{array}$} & \multirow[t]{2}{*}{$\mathrm{p}$} & \multicolumn{8}{|c|}{ Nivel de risco (\%) } \\
\hline & & 5 & 10 & 15 & 20 & 25 & 30 & 35 & 40 \\
\hline \multirow{7}{*}{ 1-Jul } & 0,2 & 1,20 & 1,24 & 1,28 & 1,32 & 1,37 & 1,41 & 1,45 & 1,50 \\
\hline & 0,3 & 1,11 & 1,15 & 1,18 & 1,22 & 1,26 & 1,30 & 1,34 & 1,39 \\
\hline & 0,4 & 1,05 & 1,09 & 1,12 & 1,16 & 1,20 & 1,24 & 1,28 & 1,32 \\
\hline & 0,5 & 0,95 & 0,98 & 1,02 & 1,05 & 1,09 & 1,13 & 1,16 & 1,20 \\
\hline & 0,6 & 0,90 & 0,93 & 0,96 & 1,00 & 1,03 & 1,06 & 1,10 & 1,13 \\
\hline & 0,7 & 0,82 & 0,85 & 0,89 & 0,92 & 0,95 & 0,98 & 1,02 & 1,05 \\
\hline & 0,8 & 0,76 & 0,80 & 0,82 & 0,85 & 0,88 & 0,91 & 0,95 & 0,98 \\
\hline \multirow{7}{*}{ 15-Jul } & 0,2 & 1,20 & 1,25 & 1,29 & 1,33 & 1,37 & 1,42 & 1,46 & 1,51 \\
\hline & 0,3 & 1,11 & 1,14 & 1,18 & 1,22 & 1,26 & 1,30 & 1,34 & 1,39 \\
\hline & 0,4 & 1,06 & 1,09 & 1,13 & 1,17 & 1,21 & 1,25 & 1,29 & 1,33 \\
\hline & 0,5 & 0,96 & 1,00 & 1,04 & 1,07 & 1,11 & 1,15 & 1,19 & 1,23 \\
\hline & 0,6 & 0,89 & 0,93 & 0,96 & 0,99 & 1,02 & 1,06 & 1,09 & 1,13 \\
\hline & 0,7 & 0,84 & 0,87 & 0,90 & 0,94 & 0,97 & 1,00 & 1,04 & 1,07 \\
\hline & 0,8 & 0,76 & 0,79 & 0,82 & 0,85 & 0,88 & 0,91 & 0,94 & 0,97 \\
\hline \multirow{7}{*}{ 1-Ago } & 0,2 & 1,14 & 1,18 & 1,23 & 1,27 & 1,31 & 1,36 & 1,40 & 1,45 \\
\hline & 0,3 & 1,04 & 1,08 & 1,12 & 1,16 & 1,20 & 1,24 & 1,28 & 1,33 \\
\hline & 0,4 & 0,99 & 1,03 & 1,07 & 1,11 & 1,15 & 1,19 & 1,23 & 1,27 \\
\hline & 0,5 & 0,93 & 0,97 & 1,00 & 1,04 & 1,08 & 1,12 & 1,16 & 1,20 \\
\hline & 0,6 & 0,84 & 0,87 & 0,90 & 0,94 & 0,97 & 1,01 & 1,04 & 1,08 \\
\hline & 0,7 & 0,80 & 0,83 & 0,86 & 0,90 & 0,93 & 0,96 & 0,99 & 1,03 \\
\hline & 0,8 & 0,73 & 0,76 & 0,79 & 0,82 & 0,86 & 0,89 & 0,92 & 0,96 \\
\hline \multirow{7}{*}{ 15-Ago } & 0,2 & 1,15 & 1,19 & 1,23 & 1,27 & 1,32 & 1,36 & 1,41 & 1,46 \\
\hline & 0,3 & 1,04 & 1,08 & 1,12 & 1,16 & 1,20 & 1,25 & 1,29 & 1,34 \\
\hline & 0,4 & 1,00 & 1,03 & 1,07 & 1,11 & 1,15 & 1,19 & 1,23 & 1,27 \\
\hline & 0,5 & 0,94 & 0,98 & 1,02 & 1,06 & 1,09 & 1,13 & 1,17 & 1,21 \\
\hline & 0,6 & 0,84 & 0,88 & 0,91 & 0,94 & 0,98 & 1,01 & 1,05 & 1,09 \\
\hline & 0,7 & 0,80 & 0,83 & 0,86 & 0,89 & 0,92 & 0,96 & 0,99 & 1,03 \\
\hline & 0,8 & 0,75 & 0,78 & 0,81 & 0,84 & 0,87 & 0,91 & 0,94 & 0,97 \\
\hline
\end{tabular}


Tabela 44. Relação benefício/custo para o feijão caupi, em cada época de semeadura, nivel de manejo da irrigação e nivel de risco. Parnaiba, Piauí.

\begin{tabular}{|c|c|c|c|c|c|c|c|c|c|}
\hline \multirow{2}{*}{$\begin{array}{l}\text { Época de } \\
\text { Semeadura }\end{array}$} & \multirow[t]{2}{*}{$\mathrm{p}$} & \multicolumn{8}{|c|}{ Nivel de risco (\%) } \\
\hline & & 5 & 10 & 15 & 20 & 25 & 30 & 35 & 40 \\
\hline \multirow{7}{*}{ 1-Set } & 0,2 & 1,17 & 1,21 & 1,25 & 1,30 & 1,34 & 1,38 & 1,43 & 1,48 \\
\hline & 0,3 & 1,07 & 1,11 & 1,15 & 1,19 & 1,23 & 1,27 & 1,31 & 1,36 \\
\hline & 0,4 & 1,01 & 1,05 & 1,09 & 1,12 & 1,16 & 1,20 & 1,24 & 1,28 \\
\hline & 0,5 & 0,97 & 1,01 & 1,04 & 1,08 & 1,12 & 1,15 & 1,19 & 1,23 \\
\hline & 0,6 & 0,86 & 0,90 & 0,93 & 0,96 & 1,00 & 1,04 & 1,07 & 1,11 \\
\hline & 0,7 & 0,81 & 0,84 & 0,87 & 0,90 & 0,93 & 0,96 & 1,00 & 1,03 \\
\hline & 0,8 & 0,79 & 0,82 & 0,85 & 0,88 & 0,91 & 0,94 & 0,97 & 1,00 \\
\hline \multirow{7}{*}{$15-$ Set } & 0,2 & 1,17 & 1,22 & 1,26 & 1,30 & 1,34 & 1,39 & 1,43 & 1,48 \\
\hline & 0,3 & 1,07 & 1,11 & 1,15 & 1,18 & 1,22 & 1,27 & 1,31 & 1,35 \\
\hline & 0,4 & 1,02 & 1,05 & 1,09 & 1,12 & 1,16 & 1,20 & 1,25 & 1,29 \\
\hline & 0,5 & 0,97 & 1,01 & 1,04 & 1,08 & 1,12 & 1,15 & 1,19 & 1,23 \\
\hline & 0,6 & 0,86 & 0,90 & 0,93 & 0,97 & 1,00 & 1,04 & 1,07 & 1,11 \\
\hline & 0,7 & 0,81 & 0,84 & 0,87 & 0,90 & 0,94 & 0,97 & 1,00 & 1,04 \\
\hline & 0,8 & 0,78 & 0,81 & 0,84 & 0,87 & 0,90 & 0,94 & 0,97 & 1,00 \\
\hline \multirow{7}{*}{ 1-Out } & 0,2 & 1,21 & 1,25 & 1,28 & 1,32 & 1,36 & 1,39 & 1,44 & 1,48 \\
\hline & 0,3 & 1,11 & 1,14 & 1,18 & 1,21 & 1,25 & 1,28 & 1,32 & 1,36 \\
\hline & 0,4 & 1,05 & 1,08 & 1,11 & 1,15 & 1,18 & 1,21 & 1,25 & 1,29 \\
\hline & 0,5 & 1,00 & 1,04 & 1,07 & 1,10 & 1,13 & 1,16 & 1,20 & 1,23 \\
\hline & 0,6 & 0,89 & 0,92 & 0,95 & 0,98 & 1,01 & 1,05 & 1,08 & 1,11 \\
\hline & 0,7 & 0,84 & 0,87 & 0,89 & 0,92 & 0,95 & 0,98 & 1,01 & 1,04 \\
\hline & 0,8 & 0,81 & 0,84 & 0,87 & 0,89 & 0,92 & 0,95 & 0,98 & 1,00 \\
\hline \multirow{7}{*}{ 15-Out } & 0,2 & 1,21 & 1,25 & 1,28 & 1,32 & 1,36 & 1,40 & 1,44 & 1,48 \\
\hline & 0,3 & 1,10 & 1,14 & 1,17 & 1,21 & 1,24 & 1,28 & 1,31 & 1,35 \\
\hline & 0,4 & 1,05 & 1,08 & 1,12 & 1,15 & 1,18 & 1,22 & 1,25 & 1,29 \\
\hline & 0,5 & 1,00 & 1,04 & 1,07 & 1,10 & 1,13 & 1,16 & 1,20 & 1,23 \\
\hline & 0,6 & 0,89 & 0,92 & 0,95 & 0,98 & 1,01 & 1,04 & 1,07 & 1,11 \\
\hline & 0,7 & 0,84 & 0,87 & 0,90 & 0,93 & 0,95 & 0,98 & 1,01 & 1,04 \\
\hline & 0,8 & 0,80 & 0,83 & 0,85 & 0,88 & 0,91 & 0,94 & 0,97 & 1,00 \\
\hline
\end{tabular}


Tabela 44. Relação beneficio/custo para o feijão caupi, em cada época de semeadura, nivel de manejo da irrigação e nivel de risco. Parnaiba, Piauí.

\begin{tabular}{|c|c|c|c|c|c|c|c|c|c|}
\hline \multirow{2}{*}{$\begin{array}{l}\text { Época de } \\
\text { Semeadura }\end{array}$} & \multirow[t]{2}{*}{$\mathrm{p}$} & \multicolumn{8}{|c|}{ Nível de risco (\%) } \\
\hline & & 5 & 10 & 15 & 20 & 25 & 30 & 35 & 40 \\
\hline \multirow{7}{*}{$1-\mathrm{Nov}$} & 0,2 & 1,41 & 1,45 & 1,50 & 1,54 & 1,58 & 1,62 & 1,66 & 1,71 \\
\hline & 0,3 & 1,30 & 1,34 & 1,38 & 1,42 & 1,46 & 1,49 & 1,54 & 1,58 \\
\hline & 0,4 & 1,24 & 1,28 & 1,31 & 1,35 & 1,39 & 1,43 & 1,47 & 1,51 \\
\hline & 0,5 & 1,15 & 1,19 & 1,22 & 1,26 & 1,30 & 1,33 & 1,37 & 1,41 \\
\hline & 0,6 & 1,05 & 1,08 & 1,12 & 1,15 & 1,19 & 1,22 & 1,26 & 1,29 \\
\hline & 0,7 & 0,99 & 1,03 & 1,06 & 1,09 & 1,12 & 1,16 & 1,19 & 1,23 \\
\hline & 0,8 & 0,91 & 0,94 & 0,98 & 1,01 & 1,04 & 1,07 & 1,11 & 1,14 \\
\hline \multirow{7}{*}{$15-\mathrm{Nov}$} & 0,2 & 1,41 & 1,45 & 1,49 & 1,53 & 1,58 & 1,62 & 1,66 & 1,71 \\
\hline & 0,3 & 1,30 & 1,34 & 1,38 & 1,42 & 1,46 & 1,50 & 1,54 & 1,59 \\
\hline & 0,4 & 1,24 & 1,28 & 1,32 & 1,36 & 1,39 & 1,43 & 1,47 & 1,52 \\
\hline & 0,5 & 1,14 & 1,18 & 1,22 & 1,25 & 1,29 & 1,33 & 1,37 & 1,41 \\
\hline & 0,6 & 1,06 & 1,10 & 1,13 & 1,17 & 1,20 & 1,24 & 1,27 & 1,31 \\
\hline & 0,7 & 1,00 & 1,03 & 1,07 & 1,10 & 1,14 & 1,17 & 1,21 & 1,24 \\
\hline & 0,8 & 0,91 & 0,95 & 0,99 & 1,02 & 1,05 & 1,09 & 1,12 & 1,15 \\
\hline \multirow{7}{*}{ 1-Dez } & 0,2 & 1,45 & 1,50 & 1,54 & 1,58 & 1,62 & 1,66 & 1,70 & 1,75 \\
\hline & 0,3 & 1,36 & 1,40 & 1,44 & 1,47 & 1,51 & 1,55 & 1,59 & 1,63 \\
\hline & 0,4 & 1,28 & 1,32 & 1,36 & 1,40 & 1,44 & 1,47 & 1,51 & 1,55 \\
\hline & 0,5 & 1,18 & 1,22 & 1,26 & 1,29 & 1,33 & 1,37 & 1,40 & 1,44 \\
\hline & 0,6 & 1,10 & 1,14 & 1,17 & 1,21 & 1,24 & 1,28 & 1,32 & 1,35 \\
\hline & 0,7 & 1,03 & 1,07 & 1,10 & 1,14 & 1,17 & 1,21 & 1,24 & 1,28 \\
\hline & 0,8 & 0,96 & 0,99 & 1,03 & 1,06 & 1,09 & 1,13 & 1,16 & 1,19 \\
\hline \multirow{7}{*}{ 15-Dez } & 0,2 & 1,46 & 1,50 & 1,54 & 1,58 & 1,62 & 1,66 & 1,70 & 1,75 \\
\hline & 0,3 & 1,37 & 1,41 & 1,44 & 1,48 & 1,52 & 1,56 & 1,60 & 1,64 \\
\hline & 0,4 & 1,29 & 1,33 & 1,37 & 1,41 & 1,45 & 1,48 & 1,52 & 1,57 \\
\hline & 0,5 & 1,18 & 1,22 & 1,26 & 1,30 & 1,34 & 1,38 & 1,41 & 1,45 \\
\hline & 0,6 & 1,11 & 1,15 & 1,19 & 1,23 & 1,26 & 1,30 & 1,34 & 1,38 \\
\hline & 0,7 & 1,03 & 1,07 & 1,11 & 1,15 & 1,18 & 1,22 & 1,26 & 1,29 \\
\hline & 0,8 & 0,96 & 1,01 & 1,05 & 1,08 & 1,12 & 1,15 & 1,19 & 1,23 \\
\hline
\end{tabular}


A relação $B / C$ pode ser utilizada para medir o grau de atratividade econòmica das diferentes combinações entre local, cultura, época de semeadura e nível de manejo da irrigação. Para combinações em que o incremento no nivel de risco é superior à variação da relação $B / C$, configura-se uma situação de não atratividade econômica, uma vez que o acréscimo na rentabilidade da irrigação é inferior ao incremento no nivel de risco que o produtor dispõe-se a assumir. Por exemplo, considerando-se o cultivo de feijão caupi em Parnaiba, na época de semeadura de 1-Jan e com nivel de manejo de irrigação $p=0,2$, obteve-se a um nivel de risco de $5 \%$ uma relação $B / C$ igual a 1,36 ao passo que a um nivel de risco de $40 \%$ a relação B/C foi igual a 1,67 (Tabela 44). Para essa combinação, o produtor sem aversão ao risco não têm nenhuma expectativa de vantagem econômica, pois enquanto o incremento no nivel de risco a que submeteu-se foi de 35 \% o aumento na rentabilidade econômica da atividade foi de apenas $31 \%$.

Essa condição foi observada em diversas combinações entre cultura, época de semeadura e nivel de manejo de irrigação, nas condições edafoclimáticas de Parnaíba e Teresina, especialmente para as que ocorrem durante a estação seca, onde predominam a prática da irrigação total. Franke (1996) constatou fato semelhante com as culturas de soja e milho, irrigadas por pivô central, nas regiões do Planalto Médio e Missões, RS. Provavelmente, a estabilidade de produção proporcionada pela irrigação combinada com os preços de venda pouco atrativos conduz a um cenário de maior estabilidade e previsibilidade econômica, características essas que não estimulam o produtor à tomada de decisão assumindo riscos desnecessários.

Por outro lado, para as combinações que ocorrem durante a estação chuvosa, observou-se a tendência de maior atratividade econômica, notadamente da melancia, em ambas as condições edafoclimáticas. Essa tendência é explicada pelos significativos ganhos de produção com a adoção da irrigação suplementar associada aos bons preços de venda dos produtos. Destaca-se que o uso da irrigação suplementar incorpora baixos custos de energia elétrica ao custo total de produção devido à necessidade de aplicação de pequenas lâminas brutas de irrigação. Contudo, durante a estação chuvosa, as condições climáticas predominantes, principalmente quanto à umidade relativa do ar, 
predispõem as culturas de feijão caupi e melancia a problemas fitossanitários com maior freqüência, além de comprometerem a qualidade da produção. 


\section{CONCLUSÕES}

a) O modelo de simulação utilizado efetuou as estimativas de precipitação pluviométrica e evapotranspiração de referência diárias com precisão e exatidão;

b) A irrigação das culturas de feijão caupi e melancia apresentou viabilidade econômica para diversas combinações entre épocas de semeadura, níveis de manejo de irrigação e níveis de risco nas condições edafoclimáticas das microrregiões do Litoral Piauiense e de Teresina, Piauí;

c) O desempenho econômico da cultura da melancia foi superior ao da cultura do feijão caupi, em regime irrigado e de sequeiro, em ambas condições edafoclimáticas;

d) O cultivo irrigado de feijão caupi e melancia nas condições edafoclimáticas de Teresina foi mais viável economicamente que no Litoral Piauiense, independentemente da época de semeadura, níveis de manejo da irrigação e de risco avaliados;

e) Os preços de venda dos produtos exerceram uma influência maior que os preços das tarifas de energia elétrica na definição da viabilidade econômica da irrigação;

f) Para os produtores propensos ao risco, é preferivel a adoção da irrigação suplementar, notadamente na cultura de melancia, devido à maior atratividade econômica dessa alternativa. 



\section{REFERÊNCIAS BIBLIOGRÁFICAS}

AGUIAR, J.V.; LEÃO, M.C.S.; SAUNDERS, L.C.U. Determinação do consumo de água pelo caupi (Vigna unguiculata (L.) Walp.) irrigado em Bragança - Pará. Ciência Agronômica, v.23, n.1/2, p.33-37, 1992.

AGUILAR, D.J.; KRUKER, R.J.M.; CALHEIROS, R.O. et al. Determinação da evapotranspiração potencial e balanço hídrico de região da Grande Dourados. Dourados: Embrapa, UEPAE de Dourados, 1986. 150p.

ALMEIDA, R.M.B. Características climatológicas do regime de chuvas em Minas Gerais. Viçosa, 1995. 64p. Dissertação (Mestrado) - Universidade Federal de Viçosa.

ANDERSON, J.R.; DILLON, J.L.; HARDAKER, J.B. Agricultural decisions analysis. Ames: The Iowa State University Press, 1977. 344p.

ANDRADE JÚNIOR, A.S. Manejo de água em agricultura irrigada. Teresina: Embrapa, UEPAE de Teresina, 1992. 37p. (Embrapa. UEPAE de Teresina. Circular Técnica, 10).

ANDRADE JÚNIOR, A.S.; BASTOS, E.A. Precipitação pluviométrica provável em municípios do Cerrado Piauiense. Teresina: Embrapa, CPAMN, 1997a. 22p. (Embrapa. CPAMN. Documentos, 25). 
ANDRADE JÚNIOR, A.S.; BASTOS, E.A. Precipitação provável para o município de Uruçuí, no Cerrado Piauiense, utilizando a função de distribuição gama. In: CONGRESSO BRASILEIRO DE AGROMETEOROLOGIA, 10., Piracicaba, 1997b. Resumos. Piracicaba: ESALQ 1997. p.110.

ANDRADE JÚNIOR, A.S.; DUARTE, R.L.R. Oferta e comercialização de melancia na CEASA-PI (1991-1996). Horticultura Brasileira, v. 17, n.1, p.72-75, 1999.

ANDRADE JÚNIOR, A.S.; FRIZZONE, J.A.; BASTOS, E.A.; CARDOSO, M.J.; RODRIGUES, B.H.N. Estratégias ótimas de irrigação para a cultura da melancia (Citrullus lanatus). In: BALBUENA, R.H.; BENEZ, S.H.; JORAJURIA, D. Avances en el manejo del suelo y agua en la ingeniería rural latinoamericana. La Palta: UNLP, 1998c. p.259-264.

ANDRADE JÚNIOR, A.S.; RODRIGUES, B.H.N.; CARDOSO, M.J.; ATHAYDE SOBRINHO, C.; MELO, F.B. Níveis de irrigação e produtividade de grãos secos de feijão caupi. In: REUNIÃO BRASILEIRA DE MANEJO E CONSERVAÇÃO DO SOLO E DA ÁGUA, 12., Fortaleza, 1998. Resumos expandidos. Fortaleza: SBCC; UFC, 1998a. p.83-84.

ANDRADE JÚNIOR, A.S.; RODRIGUES, B.H.N.; ATHAYDE SOBRINHO, C.; MELO, F.B.; CARDOSO, M.J.; FRIZZONE, J.A. Niveis de irrigação por gotejamento em melancia. In: CONGRESSO BRASILEIRO DE ENGENHARIA AGRÍCOLA, 27., Poços de Caldas, 1998. Anais. Poços de Caldas: SBEA; UFLA, 1998b. v.1, p.1-3.

ANDRADE JÚNIOR, A.S.; RODRIGUES, B.H.N.; FRIZZONE, J.A.; CARDOSO, M. J.; BASTOS, E.A.; MELO, F.B. Niveis de irrigação na cultura do feijão caupi (compact disc). In: CONGRESSO BRASILEIRO DE ENGENHARIA AGRÍCOLA, 28., Pelotas, 1999. Anais. Pelotas: SBEA; UFPel, 1999. 
ANDRADE JÚNIOR, A.S.; RODRIGUES, B.H.N.; ATHAYDE SOBRINHO, C.; MELO, F.B.; BASTOS, EA; CARDOSO, M.J.; RIBEIRO, V.Q. Produtividade e qualidade de frutos de melancia em função de diferentes níveis de irrigação. Horticultura Brasileira, v. 15, n. 1, p.43-46, 1997.

ANDRADE JÚNIOR, A.S.; RODRIGUES, B.H.N.; ATHAYDE SOBRINHO, C.; MELO, F.B.; CARDOSO, M.J; SILVA, P.H.S.; DUARTE, R.L.R. A cultura da melancia. Brasília: Embrapa, SPI, 1998d. 86p. (Embrapa. SPI. Coleção Plantar, $34)$.

ANDRADE, C.L.T.; SILVA, A.A.G.; SOUZA, I.R.P.; CONCEIÇÃO, M.A.F. Coeficientes de cultivo e de irrigação para o caupi. Teresina: Embrapa, CNPAI, 1993. 6p. (Embrapa. CNPAI. Comunicado Técnico, 9).

ANDRADE, E.M.; PEREIRA, O.J.; CRUZ, M.G.M. Resposta do cultivar BR-1 de caupi (Vigna unguiculata L. Walp.), submetido a diferentes deficiências hídricas (compact disc). In: CONGRESSO BRASILEIRO DE ENGENHARIA AGRÍCOLA, 28., Pelotas, 1999. Anais. Pelotas: SBEA; UFPel, 1999a.

ANDRADE, E.M.; SILVEIRA, S.S.; AGUIAR, O.S. Representatividade dos dados pluviométricos em regiões semi-áridas (compact disc). In: CONGRESSO BRASILEIRO DE ENGENHARIA AGRÍCOLA, 28., Pelotas, 1999. Anais. Pelotas: SBEA; UFPel, 1999b.

APLAND, J.; McCARL, B.A.; MILLER, W.L. Risk and the demand for supplemental irrigation: a case study in the Corn Belt. American Journal of Agricultural Economics, v.62, n.1, p.142-145, 1980.

ARAÚJO, W.F.; ANDRADE JÚNIOR, A.S.; MEDEIROS, R.D.; BASTOS, E.A. Precipitação pluviométrica provável em Boa Vista - RR usando a distribuição Gama (compact disc). In: CONGRESSO BRASILEIRO DE ENGENHARIA AGRÍCOLA, 28., Pelotas, 1999. Anais. Pelotas: SBEA; UFPel, 1999 
ARRUDA, F.B.; BARROSO, L.F.S. Estimativa do uso de água para fins de projetos de irrigação em função da evaporação do tanque, em Ribeirão Preto. Bragantia, v.43, p.677-682, 1984.

ARRUDA, Z.J. Eficiência econômica na alocação de recursos na agricultura: uma avaliação de dois métodos de estimação do ponto ótimo, visando sua aplicação prática. Campo Grande: Embrapa; CNPGC, 1982. 24p. (Embrapa. CNPGC. Circular Técnica, 7).

ASSIS, F.N. Modelagem da ocorrência e da quantidade de chuva e de dias secos em Piracicaba - SP e Pelotas - RS. Piracicaba, 1991. 134p. Tese (Doutorado) - Escola Superior de Agricultura "Luiz de Queiroz", Universidade de São Paulo.

ASSIS, F.N.; VILLA NOVA, N.A. Análise da ocorrência e da quantidade de chuva em Piracicaba - SP. In: CONGRESSO BRASILEIRO DE AGROMETEOROLOGIA, 8., Santa Maria, 1993. Resumos. Santa Maria: UFSM, 1993. p.139.

ASSIS, F.N.; ARRUDA, H.V.; PEREIRA, A.R. Aplicações de estatística à climatologia: teoria e prática. Pelotas: UFPel, Editora Universitária, 1996. 161p.

AZEVEDO FILHO, A.J.B.V. Análise econômica de projetos: "software" para situações determinística e de risco envolvendo simulação. Piracicaba, 1988, 127p.. Dissertação (Mestrado) - Escola Superior de Agricultura "Luiz de Queiroz", Universidade de São Paulo.

AZEVEDO, P.V.; LEITÃO, M.M.V.B.R. Aplicação de processos em cadeia de Markov às precipitações diárias no estado da Paraíba. Revista Brasileira de Meteorologia, v.5, p.389-402, 1990. 
BARROS, V.S.; COSTA, RNT; MEDEIROS, A.T.; OLIVEIRA, V.R. Análise de componentes do balanço hídrico em cultura de feijão-de-corda sob condições de recarga natural. In: CONGRESSO BRASILEIRO DE ENGENHARIA AGRÍCOLA, 27., Poços de Caldas, 1998. Anais. Poços de Caldas: SBEA; UFLA, 1998. v.1, p. 247-249.

BASTOS, E.A. Determinação dos coeficientes de cultura da alface (Lactuca sativa L.). Botucatu, 1994. 101p.Dissertação (Mestrado) - Faculdade de Ciências Agronômicas, Universidade Estadual Paulista "Júlio de Mesquita Filho".

BASTOS, E.A. Adaptação do modelo CROPGRO para simulação do crescimento e desenvolvimento do feijão caupi (Iigna unguiculata (L.) Walp.) sob diferentes condições hídricas, no Estado do Piauí. Piracicaba, 1999. 91p.Tese (Doutorado) Escola Superior de Agricultura "Luiz de Queiroz", Universidade de São Paulo.

BASTOS, E.A.; AGUIAR NETO, A.O; ANDRADE JÚNIOR, A.S.; OLIVEIRA, C.M. M. Distribuição de freqüência da evapotranspiração de referência para fins de dimensionamento de sistemas de irrigação na região de Teresina, PI. In: SEMINÁRIO DE PESQUISA AGROPECUÁRIA DO PIAUÍ, 8., Teresina, 1994. Teresina. Anais. Teresina: Embrapa, CPAMN, 1997. p.13-18. (Embrapa. CPAMN. Documentos, 16).

BASTOS, E.A.; RODRIGUES, B.H.N; ANDRADE JÚNIOR, A.S.; CARDOSO, M.J. Crescimento e desenvolvimento do feijão caupi sob diferentes regimes hídricos (compact disc). In: CONGRESSO BRASILEIRO DE ENGENHARIA AGRÍCOLA, 29., Fortaleza, 2000. Anais. Fortaleza: SBEA; UFC, 2000.

BASTOS, E.A.; VIANA, T.V.A.; FOLEGATTI, M.V.; ANDRADE JÚNIOR, A.S.; CRISÓSTOMO JÚNIOR, RR. Precipitação provável em Fortaleza através da distribuição gama. In: CONGRESSO BRASILEIRO DE ENGENHARIA AGrícOla, 27., Poços de Caldas, 1998. Anais. Poços de Caldas: SBEA; UFLA, 1998. v.2, p.88-90. 
BERBEL, J. Target returns within risk programming models: a multi-objective approach. Journal of Agricultural Economics, v.39, n.2, p.263-270, 1988.

BERBEL, J. Risk programming in agricultural systems: a multiple criteria analysis. Agricultural Systems, v.41, n.3, p.275-288, 1993.

BERNARDO, D.J.; WHITTLESEY, N.K.; SAXTON, K.E.; BASSET, D.L. Irrigation optimization under limited water supply. Transactions of the ASAE, v.31, n.3, p.712-719, 1988.

BERNARDO, S. A computerized model to predict supplemental irrigation in tropical and subtropical climate. Logan, 1975, 140p. Thesis (PhD) - Utah State University.

BERNARDO, S. Manual de irrigação. 5. ed. Viçosa: Imprensa Universitária, 1989. cap.2., p.31-87: Relação solo-água-planta-atmosfera.

BEZERRA, J.R.C.; FREIRE FILHO, F.R. Evapotranspiração da cultura do feijão macassar (Vigna unguiculata. L. Walp.) no município de Teresina - Piauí. In: SEMINÁRIO DE PESQUISA AGROPECUÁRIA DO PIAUÍ, 3., Teresina, 1982a. Anais. Teresina: Embrapa, UEPAE_de Teresina, 1984. p.304-324.

BEZERRA, F.M.L.; OLIVEIRA, C.H.C. Evapotranspiração máxima e coeficientes de cultura nos estádios fenológicos da melancia (Citrullus vulgaris L.) irrigada através de três métodos. In: CONGRESSO BRASILEIRO DE ENGENHARIA AGRÍCOLA, 27., Poços de Caldas, 1998. Anais. Poços de Caldas: SBEA; UFLA, 1998a. v.2, p.242-244.

BEZERRA, F.M.L.; OLIVEIRA, C.H.C. Evapotranspiração real do caupi (Vigna unguiculata $\mathrm{L}$. Walp.) no período chuvoso em Fortaleza - CE. In: CONGRESSO BRASILEIRO DE ENGENHARIA AGRÍCOLA, 27., Poços de Caldas, 1998. Anais. Poços de Caldas: SBEA; UFLA, 1998b. v.2, p.85-87. 
BEZERRA, F.M.L.; SAUNDERS, L.C.U. Irrigação de dois cultivares de feijão-decorda (Vigna unguiculata (L.) Walp.) em três épocas de plantio sob dois niveis de irrigação no Vale do Curu. Ciência Agronômica, v.23, n.1/2, p.39-44, 1992.

BEZERRA, F.M.L.; ARARIPE, M.A.E.; OLIVEIRA, C.H.C. Coeficientes de cultura de três cultivares de caupi em Fortaleza, CE (compact disc). In: CONGRESSO BRASILEIRO DE ENGENHARIA AGRÍCOLA, 28., Pelotas, 1999. Anais. Pelotas: SBEA; UFPel, 1999.

BIGMAN, D. Safety-first criteria and their measures of risk. American Journal Agricultural Economics, v.78, n. 1, p.225-235, 1996.

BISERRA, J.V. Rentabilidade da irrigação pública do Nordeste, sob condições de risco o caso do perímetro Morada Nova. Revista de Economia e Sociologia Rural, v.32, n.3, p.289-303, 1994.

BOGGESS, W.G.; RITCHIE, J.T. Economic and risk analysis of irrigation decisions in humid regions. Journal of Production Agriculture, v. 1, n. 2, p. 116-122, 1988.

BRASI. Ministério da Irrigação. Tempo de irrigar: manual do irrigante. São Paulo: Mater, 1987. 64p.

BRITO, R.A.L.; AMORIM NETO, M.S. Resultados comparativos dos métodos de Penman e Penman - Monteith da FAO no cálculo da evapotranspiração de referência. Engenharia na Agricultura - Série Irrigação e Drenagem, v.3, n.32, p.1-11, 1994.

BRITO, R.A.L.; SCALOPPI, E.J. Estimativa de custos da irrigação por aspersão no Brasil. In: CONGRESSO NACIONAL DE IRRIGAÇÃO E DRENAGEM, 7., Brasília, 1986. Anais. Brasília: ABID, 1986. v.3, p.879-898. 
BRUNELLI, G.M. Simulação do custo de produção de laranja no Estado de São Paulo. Piracicaba, 1990. 99p.Dissertação (Mestrado) - Escola Superior de Agricultura "Luiz de Queiroz", Universidade de São Paulo.

CALHEIROS, C.B.M.; QUEIROZ, J.E.; FRIZZONE,J.A.; PESSOA, P.C.S. Estratégias ótimas de irrigação do feijoeiro: água como fator limitante da produção. Pesquisa Agropecuária Brasileira, v.31, n.7, p.509-515, 1996.

CAMARGO, A.P.; SENTELHAS, P.C. Avaliação do desempenho de diferentes métodos de estimativa da evapotranspiração potencial no estado de São Paulo, Brasil. Revista Brasileira de Agrometeorologia, v. 5, n. 1, p.89-97, 1997.

CAMPOS, H. Estatística experimental não - paramétrica. 3. ed. Piracicaba: ESALQ, 1979. cap.2, p.21-62: Testes aplicáveis a uma amostra.

CARDOSO, M.J.; FREIRE FILHO, FR; ATHAYDE SOBRINHO, C. Cultura do feijão macassar (Vigna unguiculata (L.) Walp.) no Piauí: aspectos técnicos. Teresina: EMBRAPA, UEPAE de Teresina, 1991. 43p. (EMBRAPA. UEPAE de Teresina. Circular Técnica, 9).

CARDOSO, M.J.; FREIRE FILHO, F.R.; BEZERRA, J.R.C. Comportamento produtivo de genótipos de feijão macassar sob regime de irrigação. Ciência Agronômica, v. 18, p.63-66, 1987.

CARDOSO, M.J.; MELO, F.B.; ANDRADE JÚNIOR, A.S. Densidade de plantas de caupi em regime irrigado. Pesquisa Agropecuária Brasileira, v.32, n.4, p.399-405, 1997.

CARDOSO, M.J.; ANDRADE JÚNIOR, A.S.; MELO, F.B.; FROTA, A.B. Avaliação agroeconômica da produção de sementes de caupi sob irrigação. Teresina: Embrapa, CPAMN, 1995. 6p. (Embrapa. CPAMN. Comunicado Técnico, 62). 
CAREY, D.I.; HAAN C.T. Markov process for simulating daily point rainfall. Journal of Irrigation and Drainage Division, v.104, n.IR1, p.111-125, 1978.

CASALI, V.W.D.; SONNENBERG, PE; PEDROSA, J.F. Melancia: cultivares e métodos culturais. Informe Agropecuário, v. 8, n.85, p.29-32, 1982.

CASTRO, R.; LEOPOLDO, P.R. A estimativa da precipitação pluviométrica provável para o período de 10 dias da cidade de Botucatu, SP (compact Disc). In: CONGRESSO BRASILEIRO DE ENGENHARIA AGRÍCOLA, 25., Bauru, 1996. Anais. Bauru: SBEA, 1996.

CORDEIRO, L.G.; BEZERRA, F.M.L.; SANTOS, J.J.A.; MIRANDA, E.P. Avaliação da produtividade do fejjão caupi (Vigna unguiculata L. Walp.) irrigado sobre regime de déficit hídrico em suas fases fenológicas. In: CONGRESSO BRASILEIRO DE ENGENHARIA AGRÍCOLA, 27., Poços de Caldas, 1998. Anais. Poços de Caldas: SBEA; UFLA, 1998a. v.2, p.181-183.

CORDEIRO, L.G.; BEZERRA, F.M.L.; SANTOS, J.J.A.; MIRANDA, E.P. Fator de sensibilidade a déficit hídrico (Ky) da cultura do feijão caupi (Vigna unguiculata $\mathrm{L}$. Walp.). In: CONGRESSO BRASILEIRO DE ENGENHARIA AGRÍCOLA, 27., Poços de Caldas, 1998. Anais. Poços de Caldas: SBEA; UFLA, 1998b. v.2, p.178180.

COSTA, M.M.M.N.; TÁVORA, J.A.F.; PINHO, J.L.N.; MELO, F.I.O. Produção, componentes de produção, crescimento e distribuição das raizes de caupi submetido à deficiência hídrica. Pesquisa Agropecuária Brasileira, v.32, n.1, p.43-50, 1997.

CRUZ, E.R. Aspectos teóricos sobre incorporação de riscos em modelos de decisão. In: CONTINI, E.; ARAÚJO, J.D.; OLIVEIRA, A.J.; GARRIDO, W.E. Planejamento da propriedade agrícola: modelos de decisão. Brasília: Embrapa, DDT, 1984. p.237-260 (Embrapa. DEP. Documentos, 7). 
DENMEAD, O.T.; SHAW, R.H. Availability of soil water to plants as affected by soil moisture content and meteorological conditions. Agronomy Journal, v.45, p.385$390,1962$.

DIAS, C.T.S. Planejamento de uma fazenda em condições de risco: programação linear e simulação multidimensional. Piracicaba, 1996. 100p.Tese (Doutorado) - Escola Superior de Agricultura "Luiz de Queiroz", Universidade de São Paulo.

DOORENBOS, J.; KASSAM, A.H. Efeito da água no rendimento das culturas. Trad. de H.R. Gheyi, A.A. de Sousa, F.A.V. Damasceno, J.F. de Medeiros. Campina Grande: UFPB, 1994. p.3-101: Rendimento e água. (Estudos FAO: Irrigação e Drenagem, 33).

DOOREMBOS, J.; PRUITT, W.O. Necessidades hídrica das culturas. Trad. de H.R. Gheyi, J.E.C. Metri, F.A.V. Damasceno. Campina Grande: UFPB, 1997b. p.47-72: Escolha do coeficiente de cultivo: Kc. (Estudos FAO: Irrigação e Drenagem, 24).

DOOREMBOS, J.; PRUITT, W.O. Necessidades hídrica das culturas. Trad. de H.R. Gheyi, J.E.C. Metri, F.A.V. Damasceno. Campina Grande: UFPB, 1997a. p.5-46: Cálculo da evapotranspiração da cultura de referência. (Estudos FAO: Irrigação e Drenagem, 24).

DORFMAN, R. Irrigar ou não: eis a questão !. In: CONGRESSO NACIONAL DE IRRIGAÇÃO E DRENAGEM, 9., Natal, 1991. Anais. Fortaleza: ABID, 1992. v.2, p.1791-1812.

DORFMAN, R.; LANNA, A.E.; ROCHA, V. Análise econômica de projetos de irrigação e drenagem. In: CONGRESSO NACIONAL DE IRRIGAÇÃO E DRENAGEM, 8., Florianópolis, 1988. Anais. Florianópolis: ABID, 1988. v.3, p.219-302. 
DOURADO NETO, D.; FANCELLI, A.L. Irrigação do feijoeiro. In: FANCELLI, A. L.; DOURADO NETO, D. Feijão irrigado: estratégias básicas de manejo. Piracicaba: Publique, 1999. p. 170-192.

DOWNEY, L.A. Water - yield relations for nonforage crops. Journal of the Irrigation and Drainge Division, v.98, IR1, p. 107-117, 1972.

DUARTE, R.L.R.; ANDRADE JÚNIOR, A.S.; RIBEIRO, V.Q. Oferta de cucurbitáceas na CEASA-PI (1986-1991). Teresina: EMBRAPA, UEPAE de Teresina, 1992. 7p. (EMBRAPA. UEPAE de Teresina. Comunicado Técnico, 56).

DUDLEY, N.J.; HEARN, A.B. Systems modeling to integrate River Valley water supply and irrigation decision making under uncertainty. Agricultural Systems, v.42, n. 1/2, p.3-23, 1993.

EMPRESA BRASILEIRA DE PESQUISA AGROPECUÁRIA. Centro Nacional de Pesquisa de Agricultura Irrigada. Boletim agrometeorológico: 1990-1991. Parnaiba: Embrapa, CNPAI, 1992. 44p. (Embrapa. CNPAI. Boletim Agrometeorológico, 1).

EMPRESA BRASILEIRA DE PESQUISA AGROPECUÁRIA. Departamento de Estudos e Pesquisas. Diagnóstico e prioridades de pesquisa em agricultura irrigada. Região Nordeste. Brasília, 1989. p.85-162. (Embrapa. DPL. Documentos, 9).

EMPRESA BRASILEIRA DE PESQUISA AGROPECUÁRIA. Serviço Nacional de Levantamento e Conservação de Solos. Levantamento detalhado dos solos da área da UEPAE de Teresina, PI. Rio de Janeiro, 1980. 154p. (Embrapa. SNLCS. Boletim Técnico, 69) 
ESPÍNOLA, F.C.S.; MEDINA, B.F.; MAIA NETO, J.M.; NOGUEIRA, F.C.; AMARO FILHO, J.; MEDEIROS FILHO, J.C. Resposta do feijão caupi (Vigna unguiculata L. Walp.) a diferentes níveis de irrigação. In: CONGRESSO NACIONAL DE IRRIGAÇÃO E DRENAGEM, 9., Natal, 1992. Anais. Fortaleza: ABID, 1992b. p.971-995.

ESPÍNOLA, F.C.S.; NOGUEIRA, F.C.; MEDINA, B.F.; MAIA NETO, J.M. Efeitos de déficits hídricos em diferentes estádios do caupi (Vigna unguiculata L. Walp.) sobre a produção e componentes da produção. In: CONGRESSO NACIONAL DE IRRIGAÇÃO E DRENAGEM, 9., Natal, 1992. Anais. Fortaleza: ABID, 1992a. p.947-970.

ESPÍNOLA SOBRINHO, J.; MEDINA, B.F.; MAIA NETO, J.M. Determinações de campo da evapotranspiração e dos coeficientes de cultivo para caupi e milho. In: CONGRESSO BRASILEIRO DE AGROMETEOROLOGIA, 6., Maceió, 1989. Anais. Campinas: Fundação Cargill, 1989. p.292-312.

FANCELLI, A.L.; DOURADO NETO, D. Ecofisiologia e fenologia do feijoeiro. In: FANCELLI, A.L.; DOURADO NETO, D. Tecnologia da produção do feijão irrigado. 2. ed. Piracicaba: Publique, 1997. p.100-120.

FANCELLI, A.L.; DOURADO NETO, D. Estresse de água e temperatura na cultura de feijão. In: FANCELLI, A. L.; DOURADO NETO, D. Feijão irrigado: estratégias básicas de manejo. Piracicaba: Publique, 1999. p.155-169.

FARIA, R.T.; FOLEGATTI, M.V.; FRIZZONE, J.A.; SAAD, A.M. Determination of a long-term optimal irrigation strategy for dry beans in Paraná State, Brazil. Scientia Agrícola, v.54, n. especial, p.155-164, 1997.

FIETZ, C.R.; URCHEI, M.A.; FRIZZONE, J.A.; FOLEGATTI, M.V. Probabilidade de ocorrência de períodos secos e chuvosos na região de Dourados, MS. Irriga, v.3, n. 1, p.16-22, 1998. 
FILGUEIRA, F.A.R. Manual de olericultura: cultura e comercialização de hortaliças. 2. ed. São Paulo: Agronômica Ceres, 1982. p.214-222.

FRANKE, A.E. Avaliação econômica da irrigação, sob condições de risco, nas condições edafoclimáticas do Planalto Médio e Missões, RS. Porto Alegre, 1996. 116p. Tese (Doutorado) - Instituto de Pesquisas Hidráulicas, Universidade Federal do Rio Grande do Sul.

FRANKE, A.E.; DORFMAN, R. Viabilidade econômica da irrigação, sob condições de risco, em regiões de clima subtropical - I. Cultura do milho. Pesquisa Agropecuária Brasileira, v.33, n. 12, p.2003-2013, 1998.

FREITAS, A.A.; BEZERRA, F.ML. Determinação da evapotranspiração máxima e real da melancia (Citrullus lanatus) var. "Crimson Sweet" (compact disc). In: CONGRESSO BRASILEIRO DE ENGENHARIA AGRÍCOLA, 28., Pelotas, 1999. Anais. Pelotas: SBEA; UFPel, 1999a.

FREITAS, A.A.; BEZERRA, F.M.L. Fator de sensibilidade ao déficit hídrico da melancia (Citnullus lanatus) (compact disc). In: CONGRESSO BRASILEIRO DE ENGENHARIA AGRícola, 28., Pelotas, 1999. Anais. Pelotas: SBEA; UFPel, 1999b.

FRIZZONE, J.A. Análise de cinco modelos para cálculo da distribuição e freqüência de precipitações na região de Viçosa, MG. Viçosa, 1979. 100p. Dissertação (Mestrado) - Universidade Federal de Viçosa.

FRIZZONE, J.A. Função de produção. In: FARIA, M.A. (Coord.) Manejo de irrigação. Lavras: UFLA; SBEA, 1998. p.86-116.

FRIZZONE, J.A. Planejamento da irrigação: uma abordagem às decisões de investimento. Piracicaba: ESALQ, DER, 1999. p.95-102: Análise de custos de sistemas de recalque de água. (Apostila). 
FRIZZONE, J.A; SILVEIRA, S.F.R. Análise econômica de projetos hidroagrícolas. In: SILVA, D.D.; PRUSKI, F.F. (Ed.) Gestão de recursos hídricos: aspectos legais, econômicos, administrativos e sociais. Brasília: SRH; Viçosa: UFV; Porto Alegre: ABRH, 2000. cap.5, p.449-617.

FRIZZONE, J.A.; RETTORE, G.T.; PEREIRA, G.T. Análise da distribuição e freqüência das precipitações em periodos de 5 e 10 dias, na região de Pereira Barreto, SP, utilizando a distribuição acumulada gama incompleta. Item, n.22, p.2$4,1985$.

GENNEVILLE, M.S.; BOOCK, A. Modelo estocástico para simulação da precipitação pluviométrica diária de uma região. Pesquisa Agropecuária Brasileira, v. 18, n.9, p.959-966, 1983

GENOVEZ, A.M. Avaliação da regularização de vazões em pequenas bacias com dados esparsos. São Carlos, 1987. 168p. Tese (Doutorado) - Escola de Engenharia de São Carlos, Universidade de São Paulo.

GENUCHTEN, M.T. van. A closed-form equation for predicting the hydraulic conductivity of unsaturated soils. Soil Science Society of America Journal, v.41, p.892-898, 1980 .

GOMES FILHO, R.R.; TAHIN, J.F. Respostas fisiológicas de cultivares de caupi (Vigna unguiculata L.) eretas e decumbentes submetidas a diferentes níveis de irrigação. In: CONGRESSO BRASILEIRO DE ENGENHARIA AGRÍCOLA, 27., Poços de Caldas, 1998. Anais. Poços de Caldas: SBEA; UFLA, 1998. v.1, p.250252.

GUIMARÃES, C.M.; WATT, E.E.; ARAÚJO, J.P.P. Irrigação do caupi em diferentes estádios de desenvolvimento e densidades de plantio. Goiânia: EMBRAPA, CNPAF, 1983. 3p. (EMBRAPA. CNPAF. Pesquisa em Andamento, 42). 
HAZELL, P.B.R. A linear alternative to quadratic and semivariance programming for farm planning under uncertainty. American Journal of Agricultural Economics, v.53, n. 1, p.53-62, 1971.

HEDGE, D.M. Effect of irrigation and $\mathrm{N}$ fertilization on dry matter production, fruit yield, mineral uptake and field water use efficiency of watermelon. International Journal of Tropical Agriculture, v.5, n.3/4, p.166-174, 1987.

HILLIER, F.S.; LIEBERMAN, G.J. Introdução à pesquisa operacional. São Paulo: EDUSP, 1988. cap. 16, p.625-659.

HOWELL, T.A; HILER, E.A. Optimization of water use efficiency under high frequency irrigation - I. Evapotranspiration and yield relationship. Transactions of the ASAE, v. 18, n.5, p.873-878, 1975.

HOWELL, T.A.; HILER, E.A; REDDELL, D.L. Optimization of water use efficiency under high frequency irrigation - II. System simulation and dynamic programming. Transactions of the ASAE, v, 18, n.5, p 879-887, 1975.

KLAR, A.E. A influência do solo e do clima nas necessidades hídricas da cultura da cebola. Botucatu, 1974. 171p.Tese (Livre Docência) - Faculdade de Ciências Agrárias, Médicas e Biológicas de Botucatu, Universidade Estadual Paulista "Júlio de Mesquita Filho".

KLAR, A.E. Irrigação: freqüência e quantidade de aplicação. São Paulo: Nobel, 1991a. cap.4, p.95-127: Uso de tanques e fórmulas climáticas em irrigação.

KLAR, A.E. Irrigação: freqüência e quantidade de aplicação. São Paulo: Nobel, 1991b. cap.5, p.129-151: Quantidade de água a aplicar na irrigação.

LATAPIA, M.X.I.C. Custo de produção agrícola sob condições de risco no Estado de São Paulo. Piracicaba, 1988, 93p. Dissertação (Mestrado) - Escola Superior de Agricultura "Luiz de Queiroz", Universidade de São Paulo. 
LIMA, G.P.B. Crescimento e produtividade do caupi (Vigna unguiculata (L.) Walp.) sob diferentes niveis de disponibilidade hídrica no solo. In: REUNIÃO NACIONAL DE PESQUISA DE CAUPI, 4., Teresina, 1996. Resumos. Teresina: EMBRAPA, CPAMN, 1996. p.41-43. ( EMBRAPA. CPAMN. Documentos, 18 ).

LIMA, G.P.B.; AGUIAR, J.V.; COSTA, R.N.; PAZ, V.P.S. Rendimento de cultivares de caupi (Vigna unguiculata (L.) Walp.) submetidas a diferentes lâminas de irrigação. Irriga, v.4, n.3, p.205-212, 1999.

LIMA, M.G. Calibração e validação do modelo Ceres-Maize em condições tropicais do Brasil. Piracicaba, 1995. 119p.Tese (Doutorado) - Escola Superior de Agricultura "Luiz de Queiroz", Universidade de São Paulo.

LIMA, M.G.; SLVA, F.A.M. Evapotranspiração máxima (ETm) da cultura do feijão macassar (Vigna unguiculata (L.) Walp.). In: SEMINÁRIO DE PESQUISA AGROPECUÁRIA DO PIAUÍ, 5., Teresina, 1988. Anais. Teresina: Embrapa, UEPAE de Teresina, 1988. p.9-20.

MANGAL, J.L.; BATRA, B.R.; SINGH, G.R Studies on nitrogen fertilization under various soil moisture regimes on growth and productivity of round melon (Citrullus lanatus). Haryana Journal of Horticultural Sciences, v.14, n.3/4, p.232-236, 1985.

MANNOCCHI, F.; MECARELLI, P. Optimization analysis of deficit irrigation systems. Journal of Irrigation and Drainage Engineering, v. 120, n.3, p.484-503, 1994.

MARCHETTI, V. Risco e decisão em investimento produtivo. Porto Alegre: Editora Universidade UFRGS, 1995. 95p.

MAROUELLI, W.A.; SEDIYAMA, G.C. Balanço hidrico visando ao máximo a precipitação natural. In: SEDIYAMA, G. C. (Ed.) Curso de engenharia de irrigação. Módulo 4. Necessidade de água para os cultivos. Brasilia: ABEAS, 1988. cap.6, p.86-101. 
MAROUELLI, W.A; SILVA, H.R.; SILVA, W.L.C. Manejo da irrigação em hortaliças. 5. ed. Brasília: Embrapa, SPI, 1996. 72p.

MARTIN, E.C.; RITCHIE, J.T.; BAER, B.D. Assessing investment risk of irrigation in humid climates. Journal of Production Agriculture, v.9, n.2, p.228-233, 1996.

MASSIGNAM, A.M. Precipitação provável para Chapecó - SC, baseada na função de distribuição de probabilidade gama. In: CONGRESSO BRASILEIRO DE AGROMETEOROLOGIA, 8, Santa Maria, 1993. Resumos. Santa Maria: UFSM, 1993. p. 155 .

MATTOSO, M.J.; SILVA, W.L.C. Modelo para estimativa de custos de produção de culturas irrigadas: caso do milho irrigado por pivô central. Parnaiba: Embrapa, CNPAI, 1989. 22p. (Embrapa. CNPAI. Circular Técnica, 1).

MEDEIROS, RM. Isoietas médias mensais e anuais do Estado do Piauí. Teresina: Secretaria de Agricultura, Abastecimento e Irrigação, Departamento de Hidrometeorologia, 1996. 24 p.

MELLO, J.F. Custos da irrigação por aspersão em Minas Gerais. Viçosa, 1993. 147p. Dissertação (Mestrado) - Universidade Federal de Viçosa.

MILLAN, J.S. Planificacion de cultivos en funcion de la disponibilidad de agua de riego y en contexto de riesgo. Investigacion Agraria Economia, v.7, n. 1, p.47-59, 1992.

MILLAN, J.S.; BERBEL, J. A multicriteria model for irrigated agricultural planning under economic and technical risk. Agricultural Systems, v.44, n.1, p.105-117, 1994.

MIRANDA, F.R.; RODRIGUES, A.G.; SILVA, H.R.; SILVA, W.L.C.; SATURNINO, H.M.; FARIA, F.H.S. Instrucões técnicas sobre a cultura da melancia. Belo Horizonte: EPAMIG, 1997. 28 p. (EPAMIG. Boletim Técnico, 51). 
NASCLMENTO, E.A.; SILVA, A.A.G.; LIMA, M.G. Correlação entre a evapotranspiração de referência e a evaporação do tanque Classe A para o municipio de Teresina, PI. In: SEMINÁRIO DE PESQUISA AGROPECUÁRIA DO PIAUÍ, 7., Teresina, 1992. Anais. Teresina: Embrapa, CPAMN, 1997. p.18-22. (Embrapa. CPAMN. Documentos, 12).

NEVES, E.M. Análise econômica de projetos em condições de risco na cultura da borracha. Piracicaba, 1984. 171p. Tese (Livre Docência) - Escola Superior de Agricultura "Luiz de Queiroz", Universidade de São Paulo.

NIXON, P.R.; LAWLESS, G.P.; RICHARDSON, G.V. Coastal California evapotranspiration frequencies. Journal of the Irrigation and Drainage Division, v.98, n. IR2, p.185-191, 1972.

NOGUEIRA, L.C.; NOGUEIRA, L.R.Q. Distribuição do sistema radicular de caupi em solo arenoso sob diferentes lâminas de água e doses de adubação fosfatada. Teresina: Embrapa, CPAMN, 1995. 4p. (Embrapa. CPAMN. Pesquisa em Andamento, 62).

NOGUEIRA, L.R.Q.; NOGUEIRA, L.C. Solos do campo experimental do CPAMNUEP de Parnaíba. Parnaiba: Embrapa, CPAMN, 1993. 161p. (Embrapa. CPAMN. Documentos, 1).

NORONHA, J.F. O sistema de avaliação econômica de projetos agropecuários na política brasileira de crédito rural. Piracicaba, 1982. 120p. Tese (Livre Docência) Escola Superior de Agricultura "Luiz de Queiroz", Universidade de São Paulo.

OLIVEIRA, D. Evapotranspiração máxima e necessidade de água para irrigação de feijão (Phaseolus vulgaris L.) e trigo (Triticum aestivum L.) determinadas por balanço hídrico para seis locais do Paraná. Piracicaba, 1990. 155p. Dissertação (Mestrado) - Escola Superior de Agricultura "Luiz de Queiroz", Universidade de São Paulo. 
ORTOLANI, A.A.; CAMARGO, M.B.P. Influência dos fatores climáticos na produção. In: CASTRO, P.R.C.; FERREIRA, S.O.; YAMADA, T. Ecofisiologia da produção agrícola. Piracicaba: Associação Brasileira para Pesquisa da Potassa e do Fosfato, 1987. p.71-81.

PADILHA JÚNIOR, I.C. Evapotranspiração - utilização de modelos. In: CONGRESSO NACIONAL DE IRRIGAÇÃO E DRENAGEM, 7., Brasilia, 1986. Anais. Brasília: ABID, 1986. v.2, p.391-436.

PANDEY, S. The economics of water harvesting and supplementary irrigation in the semi-arid tropics of India. Agricultural Systems, v.36, n.2, p.207-220, 1991.

PEDRO NETO, C.; SILVEIRA, J.V. Precipitação provável para Lavras, região sul de Minas Gerais, baseada na função de distribuição de probabilidade gama. I - Períodos mensais. Ciência \& Prática, v.5, n.2, p.144-151, 1981.

PEITER, M.X. Estudo do manejo da irrigação via modelo de simulação. São Carlos, 1998. 183p. Tese (Doutorado) - Escola de Engenharia de São Carlos, Universidade de São Paulo.

PEITER, M.X.; CHAUDHRY, F.H.; CARLESSO, R.; RUVIARO, C. Modelagem estocástica da precipitação diária para Santa Maria, RS (compact disc). In: CONGRESSO BRASILEIRO DE ENGENHARIA AGRÍCOLA, 28., Pelotas, 1999. Anais. Pelotas: SBEA; UFPel, 1999.

PERERA, A.R.; VILLA NOVA, N.A.; SEDIYAMA, G.C. Evapo(transpi)ração. Piracicaba: FEALQ, 1997b. cap.7, p.143-164: Balanço hídrico.

PEREIRA, A.R.; VILLA NOVA, N.A.; SEDIYAMA, G.C. Evapo(transpi)ração. Piracicaba: FEALQ, 1997a..cap.3, p.41-99: Estimativa da evapotranspiração. 
PEREIRA, F.A.C. Desempenho do modelo de Penman - Monteith e de dois evaporimetros na estimativa da evapotranspiração de referência (ETo) em relação a um lisímetro de pesagem. Piracicaba, 1998. 87p. Tese (Doutorado) - Escola Superior de Agricultura "Luiz de Queiroz", Universidade de São Paulo.

PERES, F.C.; MATTOS, Z.P.B. Simulação como auxilio à decisão de confinar bovinos de corte. In: SOCIEDADE BRASILEIRA DE ZOOTECNIA. Bovinocultura de Corte. Piracicaba: FEALQ, 1990. p.97-108.

PIRES, R.C.M. Simulação da irrigação suplementar de culturas em Ribeirão Preto, São Paulo. Piracicaba, 1992. 115p. Dissertação (Mestrado) - Escola Superior de Agricultura "Luiz de Queiroz", Universidade de São Paulo.

PIZYSIEZNIG FILHO, J.; GONZAGA, M.L.; SAAD, A.M. Rentabilidade e custos da agricultura irrigada na região de Guaira, SP. In: CONGRESSO NACIONAL DE IRRIGAÇÃO E DRENAGEM, 9., Natal, 1992. Anais. Fortaleza: ABID, 1992. v.2, p. $1875-1940$.

PRUITT, W.O.; OETTINGEN, S.V.; MORGAN, D.L. Central California evapotranspiration frequencies. Journal of the Irrigation and Drainage Division, v.98, n. IR2, p.177-184, 1972.

RAO, N.H.; SARMA, P.B.S.; CHANDER, S. A simple dated water-production function for use in irrigated agriculture. Agricultural Water Management, v.13, p.25-32, 1988.

REICHARDT, K. Paràmetros do solo que influenciam o manejo de água. In: SIMPÓSIO SOBRE O MANEJO DE ÁGUA NA AGRICULTURA, Campinas, 1987. Anais. Campinas: IAC; Fundação Cargill, 1987. p.3-13.

REICHARDT, K. A água em sistemas agrícolas. São Paulo: Editora Manole, 1990. cap.9, p.113-126: Balanço hídrico. 
ROBERTSON, G.W. Dry and wet spells. Pahang, Tun Razak Agriculture Research Center, 1976. 30p. (Project Field Report: Agrometeorology, A-6).

ROCHA, V. Quantificação dos custos e beneficios de projetos de irrigação. In: LANNA, A.E.; ROCHA, V. Análise econômica e financeira de projetos de irrigação. Brasília: ABEAS, 1988. p.57-104.

RODRIGUES, B.H.N.; ANDRADE JÚNIOR, A.S.; CARDOSO, M.J.; MELO, F.B.; BASTOS, E.A. Níveis de irrigação sobre a produção de vagens e grãos verdes de feijão caupi (compact disc). In: CONGRESSO BRASILEIRO DE ENGENHARIA AGRÍCOLA, 28., Pelotas, 1999. Anais. Pelotas: SBEA; UFPel, 1999.

RODRIGUES, L.C.E. Planejamento agropecuário através de um modelo de programação linear não determinista. Piracicaba, 1987. 83p. Dissertação (Mestrado) - Escola Superior de Agricultura "Luizde Queiroz", Universidade de São Paulo.

RODRIGUES, L.N.; MACHADO, M.A.M. Precipitação provável para localidades do Estado do Tocantins, baseada na função de distribuição de probabilidade gama (compact disc). In: CONGRESSO BRASILEIRO DE ENGENHARIA AGRÍCOLA, 25., Bauru, 1996. Anais. Baunl SBEA, 1996.

RODRIGUES, L.N.; PRUSKI, F.F. Precipitação provável para João Pinheiro, Minas Gerais, utilizando funções de probabilidade gama e log-normal (compact disc). In: CONGRESSO BRASILEIRO DE ENGENHARIA AGRÍCOLA, 25., Bauru, 1996. Anais. Bauru: SBEA, 1996

RODRIGUES NETO, F.R. Orientação de culturas aptas às condições de estado do Piauí, segundo as distribuições espacial e temporal. Viçosa, 1991. 49p. Dissertação (Mestrado) - Universidade Federal de Viçosa. 
ROLIM, G.S.; SENTELHAS, P.C.; BARBIERI, V. Planilhas no ambiente Excel para os cálculos de balanços hídricos: normal, sequencial, de cultura e de produtividade real e potencial. Revista Brasileira de Agrometeorologia, v.6, n. 1, p. 133-137, 1998.

RUDICH, J.; ELASSAR, G.; SHEFI, Y. Optimal growth stages for the application of drip irrigation to muskmelon and watermelon. Horticultural Science, v.53, n.1, p.11-15, 1978.

SÁ, J.M. Análise econômica de engorda de bovino de corte sob confinamento em Goiás. Piracicaba, 1985. 111p. Dissertação (Mestrado) - Escola Superior de Agricultura "Luiz de Queiroz", Universidade de São Paulo.

SAAD, A.M.; FRIZZONE, J.A.; LIBARDI, P.L. Custo do déficit de irrigação em feijoeiro (Phaseolus vulgaris $\quad$ L.). In: CONGRESSO BRASILEIRO DE ENGENHARIA AGRÍCOLA, 27., Poços de Caldas, 1998. Anais. Poços de Caldas: SBEA; UFLA, 1998. v.1, p.229-231.

SAAD, J.C.C. Estudo das distribuições de freqüência da evapotranspiração potencial e da precipitação pluvial para fins de dimensionamento de sistemas de irrigação. Piracicaba, 1990. 124p. Dissertação (Mestrado) - Escola Superior de Agricultura "Luiz de Queiroz", Universidade de São Paulo.

SAAD, J.C.C.; SCALOPPI, E.J. Análise dos principais métodos climatológicos para estimativa da evapotranspiração potencial. In: CONGRESSO NACIONAL DE IRRIGAÇÃO E DRENAGEM, 8., Florianópolis, 1988. Anais. Florianópolis: ABID, 1988. v.2, p.999-1021.

SAMPAIO, I.B.M. Estatística aplicada à experimentação animal. Belo Horizonte: Fundação de Ensino e Pesquisa em Medicina Veterinária e Zootecnia, 1998. cap.3, p.14-23: Estatísticas descritivas básicas. 
SANTOS, J.J.A.; BEZERRA, F.M.L.; MIRANDA, E.P.; CORDEIRO, L.G. Determinação da evapotranspiração de referência (ETo) e evapotranspiração máxima (ETm) em diferentes fases fenológicas do feijão caupi (Vigna unguiculata L. Walp.). In: CONGRESSO BRASILEIRO DE ENGENHARIA AGRíCOLA, 27., Poços de Caldas, 1998. Anais. Poços de Caldas: SBEA; UFLA, 1998. v.2, p.184-186.

SAUNDERS, L.C.U.; CASTRO, P.T.; BARBOSA, C.E..; MATIAS FILHO, J. Dinâmica da água no solo com a cultura do feijão-de-corda (Vigna sinensis (L) Savi), em aluvião eutrófico. Ciência Agronômica, v. 12, n. 1/2, p. 141-148, 1981.

SAUNDERS, L.C.U.; CASTRO, P.T.; BEZERRA, F.M.L.; PEREIRA, A.L.C. Evapotranspiração atual da cultura do feijão-de-corda, Vigna unguiculata (L) Walp., na microrregião homogênea de Quixeramobim, Ceará. Ciência Agronômica, v.16, n.1, p.75-81, 1985.

SAUNDERS, L.S.; WEBB, T.H.; BARRINGER, J.R.F. Integrating economic data with spatial biophysical data to analyze profitability and risks of wheat production on a regional basis. Agricultural systems, v.55, n.4, p.583-599, 1997.

SCALOPPI, E.J. Exigências de energia para irrigação. Item, n.21, p. 13-17, 1985.

SEDIYAMA, G.C. Curso de engenharia de irrigação. Brasilia: ABEAS, 1987. 413p. (Curso de Especialização por Tutoria à Distância. Módulo 4).

SEDIYAMA, G.C.; MELO, J.S.P.; ALVES, A.R.; COELHO, D.T. Dependência temporal e espacial das probabilidades de ocorrência de dias secos e/ou chuvosos em dias consecutivos, para intervalos mensais. Revista Ceres, v.43, n.247, p.267-286, 1996. 
SILVA, A.A.G. Probabilidade de ocorrência das chuvas mensais registradas no municipio de Parnaiba, PI. In : SEMINÁRIO DE PESQUISA AGROPECUÁRIA DO PIAUÍ, 8., Teresina, 1994. Anais. Teresina: Embrapa, CPAMN, 1997. p.25-31 (Embrapa. CPAMN. Documentos, 16).

SILVA, F.C.; CUNHA, M.S.; FOLEGATTI, M.V.; PEREIRA, F.A.C. Estudo da distribuição e frequeência da precipitação pluviométrica anual, média mensal, máxima e mínima mensal da região de Cruz das Almas, BA. In: CONGRESSO BRASILEIRO DE ENGENHARIA AGRÍCOLA, 27., Poços de Caldas, 1998. Anais. Poços de Caldas: SBEA; UfLA, 1998. v.2, p.269-271.

SILVA, M.A. Efeito da lâmina de água e da adubação nitrogenada sobre a produção de feijão-de-corda ( Vigna sinensis L. Savi ), utilizando o sistema de irrigação por "aspersão em linha". Viçosa, 1978. 53p. Dissertação (Mestrado) - Universidade Federal de Viçosa.

SILVA, M.A.; MILLAR, A.A. Pesquisa em irrigação no trópico Semi - Árido: solo, água, planta. Petrolina: EMBRAPA, CPATSA, 1981a. p.15-24: Evapotranspiração do feijão-de-corda. (EMBRAPA. CPATSA. Boletim de Pesquisa, 4).

SILVA, M.A.; MILlAR, A.A. Pesquisa em irrigação no trópico Semi - Árido: solo, água, planta. Petrolina: EMBRAPA, CPATSA, 1981b. p.70-85: Influência do teor de umidade no solo e da adubação nitrogenada no rendimento de grãos do feijão. (EMBRAPA. CPATSA. Boletim de Pesquisa, 4).

SOARES, A.A.; FARIA, R.A.; SEDIYAMA, G.C.; RIBEIRO, C.A A.S. Caracterização da evapotranspiração de referência e precipitação dependente no Estado de Minas Gerais. In: CONGRESSO BRASILEIRO DE ENGENHARIA AGRÍCOLA, 27., Poços de Caldas, 1998. Anais. Poços de Caldas: SBEA; UFLA, 1998. v.1, p.316318. 
SOARES, J.M.; POSSÍDIO, E.L.; PEREIRA, J.R. Interação entre níveis de irrigação, densidade de plantio e níveis de nitrogênio na cultura da melancia (Citrullus vulgaris Schard). Petrolina: Embrapa, CPATSA, s.d. 5p.

SOUSA, S.A.V. Programa computacional para simulação da ocorrência de veranicos e queda de produção. Piracicaba, 1999. 124p. Tese (Doutorado) - Escola Superior de Agricultura "Luiz de Queiroz", Universidade de São Paulo.

SOUSA, S.A.V.; FRIZZONE, J.A. Uso da distribuição triangular na simulação do déficit de evapotranspiração: análise de sensibilidade. In: CONGRESSO BRASILEIRO DE ENGENHARIA AGRÍCOLA, 27., Poços de Caldas, 1998. Anais. Poços de Caldas: SBEA; UFLA, 1998a. v.2, p.1-3.

SOUSA, S.A.V.; FRIZZONE, J.A. Uso da função triangular na simulação do déficit de evapotranspiração na cultura do fumo em Cruz das Almas, Bahia. In: CONGRESSO BRASILEIRO DE ENGENHARIA AGRÍCOLA, 27., Poços de Caldas, 1998. Anais. Poços de Caldas: SBEA; UFLA, 1998b. v.l, p.325-327.

SOUSA, S.A.V.; FRIZZONE, J.A. Veranico (v.1.00) - Programa computacional para simulação da ocorrência de seqüência de dias secos e queda de produção (compact disc). In: CONGRESSO BRASILEIRO DE ENGENHARIA AGRÍCOLA, 26., Campina Grande, 1997. Anais. Campina Grande: SBEA; UFPB, 1997.

SOUSA, V.F.; AGUIAR NETO, A.O.; ANDRADE JÚNIOR, A.S.; BASTOS, E.A.; SOUSA, A.P.; DANTAS NETO, J. Manejo da irrigação através do balanço de água no solo. Teresina: Embrapa, CPAMN, 1997. 36p. (Embrapa. CPAMN. Documentos, 23).

SRINIVAS, K.; HEDGE, D.M.; HAVANAGI, G.V. Plant water relations, canopy temperature, yield and water-use efficiency of watermelon [Citrullus lanatus (Thumb) Matsum et Nakai] under drip and furrow irrigation. Journal of Horticultural Science, v.64, n.1, p.115-124, 1989. 
TAUER, L.W. Target Motad. American Journal of Agricultural Economics, v.65, n.3, p.606-610, 1983.

VIANA, T.V.A.; ARAÚJO, W.F.; ANDRADE JÚNIOR, A.S.; AZEVEDO, B.M.; CRISÓSTOMO JÚNIOR, R.R. Precipitação decendial provável para Pentecoste CE através da distribuição gama (compact disc). In: CONGRESSO BRASILEIRO DE AGROMETEOROLOGIA, 11., Florianópolis, 1999. Anais. Florianópolis: UFSC; SBA, 1999.

VTVALDI, L.J. Utilização da distribuição gama em dados pluviométricos. Piracicaba, 1973. 77p. Dissertação (Mestrado) - Escola Superior de Agricultura "Luiz de Queiroz", Universidade de São Paulo.

VOLPE, C.A; CHURATA-MASCA, M.G.C. Manejo da irrigação em hortaliças: método do Tanque Classe A. Jaboticabal: FUNEP, 1988. 19p.

WILlMOTT, C.J. On the validation of models. Physical Geography, v.2, p. 184-194, 1981 .

YAO, A.Y.M. The R index for plant water requirement. Agricultural Meteorology, v.6, p.259-273, 1969.

ZISKA, L.H.; HALL, A.E.; HOOVER, R.M. Irrigation management methods for reducing water use of cowpea (Vigna unguiculata L. Walp.) and lima bean (Phaseolus vulgaris L.) while maintaining seed yield at maximum levels. Irrigation Science, v.6, p.223-239, 1985.

ZULLO JÚNIOR, J.; PINTO, H.S.; BRUNINI, O.; ASSAD, E. Zoneamento de riscos climáticos para a cultura do trigo (Triticum aestivum L.) de sequeiro no Estado de São Paulo (compact disc). In: CONGRESSO BRASILEIRO DE AGROMETEOROLOGIA, 11., Florianópolis, 1999. Anais. Florianópolis: UFSC; SBA, 1999. 
APÊNDICE 1 

Tabela 1A. Ajuste dos valores simulados de lâmina bruta de irrigação e produtividade de grãos de feijão caupi à função de distribuição normal, pelo teste de Kolmogorov-Smirnov, em cada nível de manejo (p) e época de semeadura no município de Parnaiba, Piauí.

\begin{tabular}{|c|c|c|c|c|c|c|c|}
\hline \multirow{2}{*}{$\begin{array}{c}\text { Época de } \\
\text { Semeadura }\end{array}$} & \multirow[t]{2}{*}{$\mathrm{p}$} & \multicolumn{3}{|c|}{ Lâmina bruta } & \multicolumn{3}{|c|}{ Produtividade } \\
\hline & & $D \max$ & Dtab & Ajuste & $D \max$ & Dtab & Ajuste \\
\hline \multirow{7}{*}{ 1-Jan } & 0,2 & 0,0449 & 0,1370 & $\operatorname{Sim}$ & 0,0480 & 0,1370 & Sim \\
\hline & 0,3 & 0,0495 & 0,1370 & $\operatorname{Sim}$ & 0,0481 & 0,1370 & $\operatorname{Sim}$ \\
\hline & 0,4 & 0,0478 & 0,1370 & $\operatorname{Sim}$ & 0,0718 & 0,1370 & $\operatorname{Sim}$ \\
\hline & 0,5 & 0,0562 & 0,1370 & Sim & 0,0566 & 0,1370 & Sim \\
\hline & 0,6 & 0,0656 & 0,1370 & $\operatorname{Sim}$ & 0,0793 & 0,1370 & $\operatorname{Sim}$ \\
\hline & 0,7 & 0,0663 & 0,1370 & $\operatorname{Sim}$ & 0,0682 & 0,1370 & $\operatorname{Sim}$ \\
\hline & 0,8 & 0,0429 & 0,1370 & $\operatorname{Sim}$ & 0,0885 & 0,1370 & $\operatorname{Sim}$ \\
\hline \multirow{7}{*}{ 15-Jan } & 0,2 & 0,0507 & 0,1370 & Sim & 0,0823 & 0,1370 & $\operatorname{Sim}$ \\
\hline & 0,3 & 0,0377 & 0,1370 & Sim & 0,0481 & 0,1370 & Sim \\
\hline & 0,4 & 0,0502 & 0,1370 & Sim & 0,0486 & 0,1370 & Sim \\
\hline & 0,5 & 0,0313 & 0,1370 & Sim & 0,0708 & 0,1370 & Sim \\
\hline & 0,6 & 0,0601 & 0,1370 & Sim & 0,0508 & 0,1370 & Sim \\
\hline & 0,7 & 0,0382 & 0,1370 & Sim & 0,0610 & 0,1370 & Sim \\
\hline & 0,8 & 0,0565 & 0,1370 & Sim & 0,0440 & 0,1370 & Sim \\
\hline \multirow{7}{*}{$1-F e v$} & 0,2 & 0,0463 & 0,1370 & Sim & 0,0629 & 0,1370 & Sim \\
\hline & 0,3 & 0,0652 & 0,1370 & Sim & 0,0453 & 0,1370 & Sim \\
\hline & 0,4 & 0,0486 & 0,1370 & Sim & 0,0624 & 0,1370 & Sim \\
\hline & 0,5 & 0,0424 & 0,1370 & Sim & 0,0659 & 0,1370 & Sim \\
\hline & 0,6 & 0,0782 & 0,1370 & Sim & 0,0498 & 0,1370 & Sim \\
\hline & 0,7 & 0,0795 & 0,1370 & Sim & 0,0531 & 0,1370 & Sim \\
\hline & 0,8 & 0,0594 & 0,1370 & Sim & 0,0658 & 0,1370 & Sim \\
\hline \multirow{7}{*}{$15-F e v$} & 0,2 & 0,0688 & 0,1370 & Sim & 0,0627 & 0,1370 & Sim \\
\hline & 0,3 & 0,0649 & 0,1370 & Sim & 0,0480 & 0,1370 & Sim \\
\hline & 0,4 & 0,0481 & 0,1370 & Sim & 0,0715 & 0,1370 & Sim \\
\hline & 0,5 & 0,0636 & 0,1370 & Sim & 0,0499 & 0,1370 & Sim \\
\hline & 0,6 & 0,0683 & 0,1370 & Sim & 0,0577 & 0,1370 & Sim \\
\hline & 0,7 & 0,0932 & 0,1370 & Sim & 0,0550 & 0,1370 & Sim \\
\hline & 0,8 & 0,0714 & 0,1370 & $\operatorname{Sim}$ & 0,0455 & 0,1370 & Sim \\
\hline
\end{tabular}


Tabela $1 \mathrm{~A}$. Ajuste dos valores simulados de lâmina bruta de irrigação e produtividade de grãos de feijão caupi à função de distribuição normal, pelo teste de Kolmogorov-Smirnov, em cada nivel de manejo (p) e época de semeadura no municipio de Parnaiba, Piaui.

\begin{tabular}{|c|c|c|c|c|c|c|c|}
\hline \multirow{2}{*}{$\begin{array}{l}\text { Época de } \\
\text { Semeadura }\end{array}$} & \multirow[t]{2}{*}{$\mathrm{p}$} & \multicolumn{3}{|c|}{ Lâmina bruta } & \multicolumn{3}{|c|}{ Produtividade } \\
\hline & & $D \max$ & Dtab & Ajuste & $D \max$ & Dtab & Ajuste \\
\hline \multirow{7}{*}{ 1-Mar } & 0,2 & 0,0578 & 0,1370 & $\mathrm{Sim}$ & 0,0729 & 0,1370 & Sim \\
\hline & 0,3 & 0,0771 & 0,1370 & Sim & 0,0499 & 0,1370 & Sim \\
\hline & 0,4 & 0,0409 & 0,1370 & Sim & 0,0650 & 0,1370 & Sim \\
\hline & 0,5 & 0,0461 & 0,1370 & Sim & 0,0778 & 0,1370 & Sim \\
\hline & 0,6 & 0,0439 & 0,1370 & Sim & 0,0563 & 0,1370 & Sim \\
\hline & 0,7 & 0,0540 & 0,1370 & Sim & 0,0455 & 0,1370 & Sim \\
\hline & 0,8 & 0,0863 & 0,1370 & Sim & 0,0694 & 0,1370 & Sim \\
\hline \multirow{7}{*}{ 15-Mar } & 0,2 & 0,0878 & 0,1370 & Sim & 0,0553 & 0,1370 & Sim \\
\hline & 0,3 & 0,0450 & 0,1370 & Sim & 0,0399 & 0,1370 & Sim \\
\hline & 0,4 & 0,0581 & 0,1370 & Sim & 0,0453 & 0,1370 & Sim \\
\hline & 0,5 & 0,0424 & 0,1370 & Sim & 0,0783 & 0,1370 & Sim \\
\hline & 0,6 & 0,0520 & 0,1370 & Sim & 0,0856 & 0,1370 & Sim \\
\hline & 0,7 & 0,0774 & 0,1370 & Sim & 0,0641 & 0,1370 & Sim \\
\hline & 0,8 & 0,0543 & 0,1370 & Sim & 0,0692 & 0,1370 & Sim \\
\hline \multirow{7}{*}{$1-\mathrm{Abr}$} & 0,2 & 0,0449 & 0,1370 & Sim & 0,0708 & 0,1370 & Sim \\
\hline & 0,3 & 0,0587 & 0,1370 & Sim & 0,0467 & 0,1370 & Sim \\
\hline & 0,4 & 0,0588 & 0,1370 & Sim & 0,0725 & 0,1370 & Sim \\
\hline & 0,5 & 0,0521 & 0,1370 & Sim & 0,0586 & 0,1370 & Sim \\
\hline & 0,6 & 0,0578 & 0,1370 & Sim & 0,0866 & 0,1370 & Sim \\
\hline & 0,7 & 0,0570 & 0,1370 & Sim & 0,0685 & 0,1370 & Sim \\
\hline & 0,8 & 0,0760 & 0,1370 & Sim & 0,0604 & 0,1370 & Sim \\
\hline \multirow{7}{*}{$15-\mathrm{Abr}$} & 0,2 & 0,0685 & 0,1370 & Sim & 0,0634 & 0,1370 & Sim \\
\hline & 0,3 & 0,0944 & 0,1370 & Sim & 0,0430 & 0,1370 & Sim \\
\hline & 0,4 & 0,0623 & 0,1370 & Sim & 0,1008 & 0,1370 & Sim \\
\hline & 0,5 & 0,0395 & 0,1370 & Sim & 0,0965 & 0,1370 & Sim \\
\hline & 0,6 & 0,0564 & 0,1370 & Sim & 0,0924 & 0,1370 & Sim \\
\hline & 0,7 & 0,0805 & 0,1370 & Sim & 0,0731 & 0,1370 & Sim \\
\hline & 0,8 & 0,0692 & 0,1370 & Sim & 0,0997 & 0,1370 & Sim \\
\hline
\end{tabular}


Tabela $1 \mathrm{~A}$. Ajuste dos valores simulados de lâmina bruta de irrigação e produtividade de grãos de feijão caupi à função de distribuição normal, pelo teste de Kolmogorov-Smirnov, em cada nível de manejo (p) e época de semeadura no municipio de Parnaiba, Piauí.

\begin{tabular}{|c|c|c|c|c|c|c|c|}
\hline \multirow{2}{*}{$\begin{array}{l}\text { Época de } \\
\text { Semeadura }\end{array}$} & \multirow[t]{2}{*}{$\mathrm{p}$} & \multicolumn{3}{|c|}{ Lâmina bruta } & \multicolumn{3}{|c|}{ Produtividade } \\
\hline & & $D \max$ & Dtab & Ajuste & $D \max$ & Dtab & Ajuste \\
\hline \multirow{7}{*}{ 1-Mai } & 0,2 & 0,0465 & 0,1370 & $\mathrm{Sim}$ & 0,1046 & 0,1370 & $\mathrm{Sim}$ \\
\hline & 0,3 & 0,0660 & 0,1370 & Sim & 0,0384 & 0,1370 & Sim \\
\hline & 0,4 & 0,0387 & 0,1370 & Sim & 0,0421 & 0,1370 & Sim \\
\hline & 0,5 & 0,0467 & 0,1370 & Sim & 0,0558 & 0,1370 & Sim \\
\hline & 0,6 & 0,0387 & 0,1370 & Sim & 0,0607 & 0,1370 & Sim \\
\hline & 0,7 & 0,0366 & 0,1370 & Sim & 0,0487 & 0,1370 & Sim \\
\hline & 0,8 & 0,0664 & 0,1370 & Sim & 0,0517 & 0,1370 & Sim \\
\hline \multirow{7}{*}{ 15-Mai } & 0,2 & 0,0944 & 0,1370 & Sim & 0,0635 & 0,1370 & Sim \\
\hline & 0,3 & 0,0787 & 0,1370 & Sim & 0,0414 & 0,1370 & Sim \\
\hline & 0,4 & 0,0786 & 0,1370 & Sim & 0,0508 & 0,1370 & Sim \\
\hline & 0,5 & 0,0524 & 0,1370 & Sim & 0,0544 & 0,1370 & Sim \\
\hline & 0,6 & 0,0717 & 0,1370 & Sim & 0,0527 & 0,1370 & Sim \\
\hline & 0,7 & 0,0573 & 0,1370 & Sim & 0,0807 & 0,1370 & Sim \\
\hline & 0,8 & 0,0604 & 0,1370 & Sim & 0,0493 & 0,1370 & Sim \\
\hline \multirow{7}{*}{ 1-Jun } & 0,2 & 0,0774 & 0,1370 & Sim & 0,0293 & 0,1370 & Sim \\
\hline & 0,3 & 0,0642 & 0,1370 & Sim & 0,0639 & 0,1370 & Sim \\
\hline & 0,4 & 0,0696 & 0,1370 & Sim & 0,0826 & 0,1370 & Sim \\
\hline & 0,5 & 0,0476 & 0,1370 & Sim & 0,0529 & 0,1370 & Sim \\
\hline & 0,6 & 0,0569 & 0,1370 & Sim & 0,0407 & 0,1370 & Sim \\
\hline & 0,7 & 0,0586 & 0,1370 & Sim & 0,0861 & 0,1370 & Sim \\
\hline & 0,8 & 0,0435 & 0,1370 & Sim & 0,0921 & 0,1370 & Sim \\
\hline \multirow{7}{*}{ 15-Jun } & 0,2 & 0,0344 & 0,1370 & Sim & 0,0738 & 0,1370 & Sim \\
\hline & 0,3 & 0,0334 & 0,1370 & Sim & 0,0881 & 0,1370 & Sim \\
\hline & 0,4 & 0,0329 & 0,1370 & Sim & 0,0462 & 0,1370 & Sim \\
\hline & 0,5 & 0,0511 & 0,1370 & Sim & 0,0456 & 0,1370 & Sim \\
\hline & 0,6 & 0,0463 & 0,1370 & Sim & 0,0448 & 0,1370 & Sim \\
\hline & 0,7 & 0,0827 & 0,1370 & Sim & 0,0612 & 0,1370 & Sim \\
\hline & 0,8 & 0,0535 & 0,1370 & Sim & 0,0830 & 0,1370 & Sim \\
\hline
\end{tabular}


Tabela 1 A. Ajuste dos valores simulados de lâmina bruta de irrigação e produtividade de grãos de feijão caupi à função de distribuição normal, pelo teste de Kolmogorov-Smirnov, em cada nivel de manejo (p) e época de semeadura no municipio de Parnaiba, Piauí.

\begin{tabular}{|c|c|c|c|c|c|c|c|}
\hline \multirow{2}{*}{$\begin{array}{l}\text { Época de } \\
\text { Semeadura }\end{array}$} & \multirow[t]{2}{*}{$\mathrm{p}$} & \multicolumn{3}{|c|}{ Lâmina bruta } & \multicolumn{3}{|c|}{ Produtividade } \\
\hline & & $D \max$ & Dtab & Ajuste & Dmax & Dtab & Ajuste \\
\hline \multirow{7}{*}{ 1-Jul } & 0,2 & 0,0640 & 0,1370 & Sim & 0,0502 & 0,1370 & Sim \\
\hline & 0,3 & 0,0723 & 0,1370 & Sim & 0,0602 & 0,1370 & Sim \\
\hline & 0,4 & 0,0772 & 0,1370 & Sim & 0,0618 & 0,1370 & Sim \\
\hline & 0,5 & 0,0954 & 0,1370 & Sim & 0,0718 & 0,1370 & Sim \\
\hline & 0,6 & 0,0750 & 0,1370 & Sim & 0,0435 & 0,1370 & Sim \\
\hline & 0,7 & 0,0683 & 0,1370 & Sim & 0,0470 & 0,1370 & Sim \\
\hline & 0,8 & 0,0878 & 0,1370 & Sim & 0,0653 & 0,1370 & Sim \\
\hline \multirow{7}{*}{ 15-Jul } & 0,2 & 0,0872 & 0,1370 & Sim & 0,0577 & 0,1370 & Sim \\
\hline & 0,3 & 0,0620 & 0,1370 & Sim & 0,0743 & 0,1370 & Sim \\
\hline & 0,4 & 0,0995 & 0,1370 & Sim & 0,0504 & 0,1370 & Sim \\
\hline & 0,5 & 0,0614 & 0,1370 & Sim & 0,0789 & 0,1370 & Sim \\
\hline & 0,6 & 0,1167 & 0,1370 & Sim & 0,0675 & 0,1370 & Sim \\
\hline & 0,7 & 0,0673 & 0,1370 & Sim & 0,0620 & 0,1370 & Sim \\
\hline & 0,8 & 0,0559 & 0,1370 & Sim & 0,0558 & 0,1370 & Sim \\
\hline \multirow{7}{*}{ 1-Ago } & 0,2 & 0,0635 & 0,1370 & Sim & 0,0865 & 0,1370 & Sim \\
\hline & 0,3 & 0,0586 & 0,1370 & Sim & 0,0803 & 0,1370 & Sim \\
\hline & 0,4 & 0,0583 & 0,1370 & Sim & 0,0516 & 0,1370 & Sim \\
\hline & 0,5 & 0,0669 & 0,1370 & Sim & 0,0697 & 0,1370 & Sim \\
\hline & 0,6 & 0,0601 & 0,1370 & Sim & 0,0526 & 0,1370 & Sim \\
\hline & 0,7 & 0,0799 & 0,1370 & Sim & 0,0438 & 0,1370 & Sim \\
\hline & 0,8 & 0,0858 & 0,1370 & Sim & 0,0977 & 0,1370 & Sim \\
\hline \multirow{7}{*}{ 15-Ago } & 0,2 & 0,0413 & 0,1370 & Sim & 0,1197 & 0,1370 & Sim \\
\hline & 0,3 & 0,0568 & 0,1370 & Sim & 0,0454 & 0,1370 & Sim \\
\hline & 0,4 & 0,0599 & 0,1370 & Sim & 0,0845 & 0,1370 & Sim \\
\hline & 0,5 & 0,0475 & 0,1370 & Sim & 0,0720 & 0,1370 & Sim \\
\hline & 0,6 & 0,0588 & 0,1370 & Sim & 0,0702 & 0,1370 & Sim \\
\hline & 0,7 & 0,1003 & 0,1370 & Sim & 0,0857 & 0,1370 & Sim \\
\hline & 0,8 & 0,0552 & 0,1370 & Sim & 0,0905 & 0,1370 & Sim \\
\hline
\end{tabular}


Tabela 1A. Ajuste dos valores simulados de lâmina bruta de irrigação e produtividade de grãos de feijão caupi à função de distribuição normal, pelo teste de Kolmogorov-Smirnov, em cada nível de manejo (p) e época de semeadura no municipio de Parnaiba, Piauí.

\begin{tabular}{|c|c|c|c|c|c|c|c|}
\hline \multirow{2}{*}{$\begin{array}{c}\text { Época de } \\
\text { Semeadura }\end{array}$} & \multirow[t]{2}{*}{$\mathrm{p}$} & \multicolumn{3}{|c|}{ Lâmina bruta } & \multicolumn{3}{|c|}{ Produtividade } \\
\hline & & $D \max$ & Dtab & Ajuste & Dmax & Dtab & Ajuste \\
\hline \multirow{7}{*}{$1-$ Set } & 0,2 & 0,0913 & 0,1370 & Sim & 0,1035 & 0,1370 & Sim \\
\hline & 0,3 & 0,0589 & 0,1370 & Sim & 0,0601 & 0,1370 & Sim \\
\hline & 0,4 & 0,0633 & 0,1370 & Sim & 0,1162 & 0,1370 & Sim \\
\hline & 0,5 & 0,0650 & 0,1370 & Sim & 0,0753 & 0,1370 & $\operatorname{Sim}$ \\
\hline & 0,6 & 0,0625 & 0,1370 & Sim & 0,0687 & 0,1370 & Sim \\
\hline & 0,7 & 0,0919 & 0,1370 & $\operatorname{Sim}$ & 0,0647 & 0,1370 & Sim \\
\hline & 0,8 & 0,1286 & 0,1370 & Sim & 0,0629 & 0,1370 & $\operatorname{Sim}$ \\
\hline \multirow{7}{*}{ 15-Set } & 0,2 & 0,1016 & 0,1370 & Sim & 0,1137 & 0,1370 & Sim \\
\hline & 0,3 & 0,0429 & 0,1370 & Sim & 0,0823 & 0,1370 & Sim \\
\hline & 0,4 & 0,0875 & 0,1370 & Sim & 0,1383 & 0,1370 & Não \\
\hline & 0,5 & 0,0766 & 0,1370 & Sim & 0,0925 & 0,1370 & Sim \\
\hline & 0,6 & 0,0762 & 0,1370 & Sim & 0,0653 & 0,1370 & Sim \\
\hline & 0,7 & 0,1044 & 0,1370 & Sim & 0,0810 & 0,1370 & Sim \\
\hline & 0,8 & 0,1187 & 0,1370 & Sim & 0,0786 & 0,1370 & $\operatorname{Sim}$ \\
\hline \multirow{7}{*}{ 1-Out } & 0,2 & 0,1029 & 0,1370 & Sim & 0,1403 & 0,1370 & Não \\
\hline & 0,3 & 0,0691 & 0,1370 & Sim & 0,0486 & 0,1370 & Sim \\
\hline & 0,4 & 0,1160 & 0,1370 & Sim & 0,1331 & 0,1370 & Sim \\
\hline & 0,5 & 0,0390 & 0,1370 & Sim & 0,0879 & 0,1370 & Sim \\
\hline & 0,6 & 0,0669 & 0,1370 & Sim & 0,0745 & 0,1370 & Sim \\
\hline & 0,7 & 0,0799 & 0,1370 & Sim & 0,0828 & 0,1370 & Sim \\
\hline & 0,8 & 0,1266 & 0,1370 & Sim & 0,0500 & 0,1370 & $\operatorname{Sim}$ \\
\hline \multirow{7}{*}{ 15-Out } & 0,2 & 0,0598 & 0,1370 & Sim & 0,0922 & 0,1370 & Sim \\
\hline & 0,3 & 0,0572 & 0,1370 & Sim & 0,0600 & 0,1370 & $\operatorname{Sim}$ \\
\hline & 0,4 & 0,0705 & 0,1370 & Sim & 0,0751 & 0,1370 & Sim \\
\hline & 0,5 & 0,0738 & 0,1370 & Sim & 0,0777 & 0,1370 & Sim \\
\hline & 0,6 & 0,0879 & 0,1370 & Sim & 0,0668 & 0,1370 & Sim \\
\hline & 0,7 & 0,0796 & 0,1370 & Sim & 0,0758 & 0,1370 & Sim \\
\hline & 0,8 & 0,0704 & 0,1370 & $\operatorname{Sim}$ & 0,0816 & 0,1370 & Sim \\
\hline
\end{tabular}


Tabela 1A. Ajuste dos valores simulados de lâmina bruta de irrigação e produtividade de grãos de feijão caupi à função de distribuição normal, pelo teste de Kolmogorov-Smirnov, em cada nível de manejo (p) e época de semeadura no município de Parnaíba, Piauí.

\begin{tabular}{|c|c|c|c|c|c|c|c|}
\hline \multirow{2}{*}{$\begin{array}{l}\text { Época de } \\
\text { Semeadura }\end{array}$} & \multirow[t]{2}{*}{$\mathrm{p}$} & \multicolumn{3}{|c|}{ Lâmina bruta } & \multicolumn{3}{|c|}{ Produtividade } \\
\hline & & $D \max$ & Dtab & Ajuste & $D \max$ & Dtab & Ajuste \\
\hline \multirow{7}{*}{$1-\mathrm{Nov}$} & 0,2 & 0,0416 & 0,1370 & Sim & 0,0503 & 0,1370 & Sim \\
\hline & 0,3 & 0,0485 & 0,1370 & Sim & 0,0431 & 0,1370 & Sim \\
\hline & 0,4 & 0,0693 & 0,1370 & Sim & 0,0777 & 0,1370 & Sim \\
\hline & 0,5 & 0,0617 & 0,1370 & Sim & 0,0737 & 0,1370 & Sim \\
\hline & 0,6 & 0,0627 & 0,1370 & Sim & 0,0710 & 0,1370 & Sim \\
\hline & 0,7 & 0,0469 & 0,1370 & Sim & 0,0576 & 0,1370 & Sim \\
\hline & 0,8 & 0,0899 & 0,1370 & Sim & 0,0566 & 0,1370 & Sim \\
\hline \multirow{7}{*}{ 15-Nov } & 0,2 & 0,0404 & 0,1370 & Sim & 0,0541 & 0,1370 & Sim \\
\hline & 0,3 & 0,0650 & 0,1370 & Sim & 0,0765 & 0,1370 & Sim \\
\hline & 0,4 & 0,0766 & 0,1370 & Sim & 0,0451 & 0,1370 & Sim \\
\hline & 0,5 & 0,0527 & 0,1370 & Sim & 0,0477 & 0,1370 & Sim \\
\hline & 0,6 & 0,0548 & 0,1370 & Sim & 0,0579 & 0,1370 & Sim \\
\hline & 0,7 & 0,0580 & 0,1370 & Sim & 0,0482 & 0,1370 & Sim \\
\hline & 0,8 & 0,0653 & 0,1370 & Sim & 0,0538 & 0,1370 & Sim \\
\hline \multirow{7}{*}{ 1-Dez } & 0,2 & 0,0535 & 0,1370 & Sim & 0,0645 & 0,1370 & Sim \\
\hline & 0,3 & 0,0782 & 0,1370 & Sim & 0,0528 & 0,1370 & Sim \\
\hline & 0,4 & 0,0667 & 0,1370 & Sim & 0,0594 & 0,1370 & Sim \\
\hline & 0,5 & 0,0591 & 0,1370 & Sim & 0,0725 & 0,1370 & Sim \\
\hline & 0,6 & 0,0450 & 0,1370 & Sim & 0,0684 & 0,1370 & Sim \\
\hline & 0,7 & 0,0290 & 0,1370 & Sim & 0,0462 & 0,1370 & Sim \\
\hline & 0,8 & 0,0596 & 0,1370 & Sim & 0,0368 & 0,1370 & Sim \\
\hline \multirow{7}{*}{ 15-Dez } & 0,2 & 0,0629 & 0,1370 & Sim & 0,0737 & 0,1370 & Sim \\
\hline & 0,3 & 0,0477 & 0,1370 & Sim & 0,0511 & 0,1370 & Sim \\
\hline & 0,4 & 0,0615 & 0,1370 & Sim & 0,0364 & 0,1370 & Sim \\
\hline & 0,5 & 0,0665 & 0,1370 & Sim & 0,0738 & 0,1370 & Sim \\
\hline & 0,6 & 0,0636 & 0,1370 & Sim & 0,0519 & 0,1370 & Sim \\
\hline & 0,7 & 0,0700 & 0,1370 & Sim & 0,0811 & 0,1370 & Sim \\
\hline & 0,8 & 0,0880 & 0,1370 & Sim & 0,0925 & 0,1370 & Sim \\
\hline
\end{tabular}


Tabela 2A. Ajuste dos valores simulados de lâmina bruta de irrigação e produtividade de grãos de feijão caupi à função de distribuição normal, pelo teste de Kolmogorov-Smirnov, em cada nivel de manejo (p) e época de semeadura no municipio de Teresina, Piauí.

\begin{tabular}{|c|c|c|c|c|c|c|c|}
\hline \multirow{2}{*}{$\begin{array}{l}\text { Época de } \\
\text { Semeadura }\end{array}$} & \multirow[t]{2}{*}{$\mathrm{p}$} & \multicolumn{3}{|c|}{ Lâmina bruta } & \multicolumn{3}{|c|}{ Produtividade } \\
\hline & & $D \max$ & Dtab & Ajuste & $D \max$ & Dtab & Ajuste \\
\hline \multirow{7}{*}{ 1-Jan } & 0,2 & 0,0633 & 0,1370 & Sim & 0,0524 & 0,1370 & Sim \\
\hline & 0,3 & 0,0475 & 0,1370 & Sim & 0,0504 & 0,1370 & Sim \\
\hline & 0,4 & 0,0569 & 0,1370 & Sim & 0,0734 & 0,1370 & Sim \\
\hline & 0,5 & 0,0450 & 0,1370 & Sim & 0,0918 & 0,1370 & Sim \\
\hline & 0,6 & 0,0783 & 0,1370 & Sim & 0,0571 & 0,1370 & Sim \\
\hline & 0,7 & 0,0648 & 0,1370 & Sim & 0,0447 & 0,1370 & Sim \\
\hline & 0,8 & 0,0977 & 0,1370 & Sim & 0,0471 & 0,1370 & Sim \\
\hline \multirow{7}{*}{ 15-Jan } & 0,2 & 0,0675 & 0,1370 & Sim & 0,0733 & 0,1370 & Sim \\
\hline & 0,3 & 0,0609 & 0,1370 & Sim & 0,0688 & 0,1370 & Sim \\
\hline & 0,4 & 0,0481 & 0,1370 & Sim & 0,0424 & 0,1370 & Sim \\
\hline & 0,5 & 0,0715 & 0,1370 & Sim & 0,0739 & 0,1370 & Sim \\
\hline & 0,6 & 0,0625 & 0,1370 & Sim & 0,0617 & 0,1370 & Sim \\
\hline & 0,7 & 0,0761 & 0,1370 & Sim & 0,0547 & 0,1370 & Sim \\
\hline & 0,8 & 0,1526 & 0,1370 & Não & 0,0796 & 0,1370 & Sim \\
\hline \multirow{7}{*}{$1-\mathrm{Fev}$} & 0,2 & 0,0531 & 0,1370 & Sim & 0,0664 & 0,1370 & Sim \\
\hline & 0,3 & 0,0293 & 0,1370 & Sim & 0,0554 & 0,1370 & Sim \\
\hline & 0,4 & 0,0436 & 0,1370 & Sim & 0,0505 & 0,1370 & Sim \\
\hline & 0,5 & 0,0446 & 0,1370 & Sim & 0,0384 & 0,1370 & Sim \\
\hline & 0,6 & 0,0970 & 0,1370 & Sim & 0,0586 & 0,1370 & Sim \\
\hline & 0,7 & 0,1599 & 0,1370 & Não & 0,0458 & 0,1370 & Sim \\
\hline & 0,8 & 0,1739 & 0,1370 & Não & 0,0452 & 0,1370 & Sim \\
\hline \multirow{7}{*}{$15-\mathrm{Fev}$} & 0,2 & 0,0709 & 0,1370 & Sim & 0,0708 & 0,1370 & Sim \\
\hline & 0,3 & 0,0620 & 0,1370 & Sim & 0,0769 & 0,1370 & Sim \\
\hline & 0,4 & 0,0883 & 0,1370 & Sim & 0,0494 & 0,1370 & Sim \\
\hline & 0,5 & 0,0693 & 0,1370 & Sim & 0,0328 & 0,1370 & Sim \\
\hline & 0,6 & 0,0927 & 0,1370 & Sim & 0,0299 & 0,1370 & Sim \\
\hline & 0,7 & 0,1479 & 0,1370 & Não & 0,0650 & 0,1370 & Sim \\
\hline & 0,8 & 0,1990 & 0,1370 & Não & 0,0423 & 0,1370 & Sim \\
\hline
\end{tabular}


Tabela 2A. Ajuste dos valores simulados de lâmina bruta de irrigação e produtividade de grãos de feijão caupi à função de distribuição normal, pelo teste de Kolmogorov-Smirnov, em cada nivel de manejo (p) e época de semeadura no município de Teresina, Piauí.

\begin{tabular}{cccccccc}
\hline Época de & $\mathrm{p}$ & \multicolumn{3}{c}{ Lâmina bruta } & \multicolumn{3}{c}{ Produtividade } \\
\cline { 3 - 8 } Semeadura & & Dmax & Dtab & Ajuste & Dmax & Dtab & Ajuste \\
\hline \multirow{4}{*}{ 1-Mar } & 0,2 & 0,0444 & 0,1370 & Sim & 0,0600 & 0,1370 & Sim \\
& 0,3 & 0,0476 & 0,1370 & Sim & 0,0574 & 0,1370 & Sim \\
& 0,4 & 0,0538 & 0,1370 & Sim & 0,0486 & 0,1370 & Sim \\
& 0,5 & 0,0770 & 0,1370 & Sim & 0,0994 & 0,1370 & Sim \\
& 0,6 & 0,0826 & 0,1370 & Sim & 0,0688 & 0,1370 & Sim \\
& 0,7 & 0,1174 & 0,1370 & Sim & 0,0794 & 0,1370 & Sim \\
& 0,8 & 0,2210 & 0,1370 & Não & 0,0642 & 0,1370 & Sim \\
\hline \multirow{4}{*}{ 15-Mar } & 0,2 & 0,0453 & 0,1370 & Sim & 0,0768 & 0,1370 & Sim \\
& 0,3 & 0,0629 & 0,1370 & Sim & 0,0499 & 0,1370 & Sim \\
& 0,4 & 0,0483 & 0,1370 & Sim & 0,0821 & 0,1370 & Sim \\
& 0,5 & 0,0765 & 0,1370 & Sim & 0,0655 & 0,1370 & Sim \\
& 0,6 & 0,0771 & 0,1370 & Sim & 0,0431 & 0,1370 & Sim \\
& 0,7 & 0,1162 & 0,1370 & Sim & 0,0696 & 0,1370 & Sim \\
& 0,8 & 0,1534 & 0,1370 & Não & 0,0689 & 0,1370 & Sim \\
\hline \multirow{4}{*}{ 15-Abr } & 0,2 & 0,0375 & 0,1370 & Sim & 0,0529 & 0,1370 & Sim \\
& 0,3 & 0,0335 & 0,1370 & Sim & 0,0660 & 0,1370 & Sim \\
& 0,5 & 0,0368 & 0,1370 & Sim & 0,0504 & 0,1370 & Sim \\
& 0,6 & 0,0373 & 0,1370 & Sim & 0,0772 & 0,1370 & Sim \\
& 0,7 & 0,0742 & 0,1370 & Sim & 0,0745 & 0,1370 & Sim \\
& 0,8 & 0,0532 & 0,1370 & Sim & 0,1076 & 0,1370 & Sim \\
& 0,5 & 0,0719 & 0,1370 & Sim & 0,0726 & 0,1370 & Sim \\
& 0,6 & 0,0338 & 0,1370 & Sim & 0,0451 & 0,1370 & Sim \\
& 0,7 & 0,1034 & 0,1370 & Sim & 0,0623 & 0,1370 & Sim \\
& 0,8 & 0,1011 & 0,1370 & Sim & 0,0712 & 0,1370 & Sim \\
\hline \multirow{4}{*}{ 1-Abry } & 0,2 & 0,0774 & 0,1370 & Sim & 0,0858 & 0,1370 & Sim \\
& 0,0585 & 0,1370 & Sim & 0,0755 & 0,1370 & Sim \\
& 0,0498 & 0,1370 & Sim & 0,0670 & 0,1370 & Sim \\
& 0,0460 & 0,1370 & Sim & 0,0636 & 0,1370 & Sim \\
& 0,4 & & & & & & \\
& 0,5 & & & &
\end{tabular}


Tabela 2A. Ajuste dos valores simulados de lâmina bruta de irrigação e produtividade de grãos de feijão caupi à função de distribuição normal, pelo teste de Kolmogorov-Smirnov, em cada nível de manejo (p) e época de semeadura no município de Teresina, Piauí.

\begin{tabular}{|c|c|c|c|c|c|c|c|}
\hline \multirow{2}{*}{$\begin{array}{l}\text { Época de } \\
\text { Semeadura }\end{array}$} & \multirow[t]{2}{*}{$\mathrm{p}$} & \multicolumn{3}{|c|}{ Lâmina bruta } & \multicolumn{3}{|c|}{ Produtividade } \\
\hline & & $D \max$ & Dtab & Ajuste & Dmax & Dtab & Ajuste \\
\hline \multirow{7}{*}{ 1-Mai } & 0,2 & 0,0837 & 0,1370 & Sim & 0,0724 & 0,1370 & Sim \\
\hline & 0,3 & 0,0513 & 0,1370 & $\operatorname{Sim}$ & 0,0495 & 0,1370 & $\operatorname{Sim}$ \\
\hline & 0,4 & 0,0647 & 0,1370 & $\operatorname{Sim}$ & 0,0626 & 0,1370 & Sim \\
\hline & 0,5 & 0,0447 & 0,1370 & $\operatorname{Sim}$ & 0,0553 & 0,1370 & Sim \\
\hline & 0,6 & 0,0672 & 0,1370 & Sim & 0,1144 & 0,1370 & Sim \\
\hline & 0,7 & 0,0678 & 0,1370 & Sim & 0,0999 & 0,1370 & $\operatorname{Sim}$ \\
\hline & 0,8 & 0,0531 & 0,1370 & Sim & 0,0729 & 0,1370 & Sim \\
\hline \multirow{7}{*}{ 15-Mai } & 0,2 & 0,0656 & 0,1370 & Sim & 0,0571 & 0,1370 & Sim \\
\hline & 0,3 & 0,0742 & 0,1370 & Sim & 0,0688 & 0,1370 & Sim \\
\hline & 0,4 & 0,0498 & 0,1370 & Sim & 0,0979 & 0,1370 & Sim \\
\hline & 0,5 & 0,0773 & 0,1370 & Sim & 0,0540 & 0,1370 & Sim \\
\hline & 0,6 & 0,0758 & 0,1370 & Sim & 0,0725 & 0,1370 & $\operatorname{Sim}$ \\
\hline & 0,7 & 0,1092 & 0,1370 & Sim & 0,1026 & 0,1370 & Sim \\
\hline & 0,8 & 0,0639 & 0,1370 & Sim & 0,1015 & 0,1370 & Sim \\
\hline \multirow{7}{*}{ 1-Jun } & 0,2 & 0,1276 & 0,1370 & Sim & 0,0618 & 0,1370 & Sim \\
\hline & 0,3 & 0,0775 & 0,1370 & Sim & 0,0573 & 0,1370 & Sim \\
\hline & 0,4 & 0,0522 & 0,1370 & Sim & 0,0602 & 0,1370 & Sim \\
\hline & 0,5 & 0,0955 & 0,1370 & Sim & 0,0723 & 0,1370 & Sim \\
\hline & 0,6 & 0,1215 & 0,1370 & Sim & 0,0535 & 0,1370 & Sim \\
\hline & 0,7 & 0,1033 & 0,1370 & Sim & 0,1003 & 0,1370 & Sim \\
\hline & 0,8 & 0,1694 & 0,1370 & Não & 0,0609 & 0,1370 & Sim \\
\hline \multirow{7}{*}{ 15-Jun } & 0,2 & 0,0525 & 0,1370 & Sim & 0,0744 & 0,1370 & Sim \\
\hline & 0,3 & 0,0866 & 0,1370 & Sim & 0,0723 & 0,1370 & Sim \\
\hline & 0,4 & 0,0781 & 0,1370 & Sim & 0,0676 & 0,1370 & Sim \\
\hline & 0,5 & 0,0650 & 0,1370 & Sim & 0,0800 & 0,1370 & Sim \\
\hline & 0,6 & 0,1235 & 0,1370 & Sim & 0,0643 & 0,1370 & Sim \\
\hline & 0,7 & 0,0939 & 0,1370 & Sim & 0,1184 & 0,1370 & Sim \\
\hline & 0,8 & 0,1270 & 0,1370 & Sim & 0,0626 & 0,1370 & Sim \\
\hline
\end{tabular}


Tabela 2A. Ajuste dos valores simulados de lâmina bruta de irrigação e produtividade de grãos de feijão caupi à função de distribuição normal, pelo teste de Kolmogorov-Smirnov, em cada nível de manejo (p) e época de semeadura no município de Teresina, Piauí.

\begin{tabular}{cccccccc}
\hline Época de & $\mathrm{p}$ & \multicolumn{3}{c}{ Lâmina bruta } & \multicolumn{3}{c}{ Produtividade } \\
\cline { 3 - 8 } Semeadura & & Dmax & Dtab & Ajuste & Dmax & Dtab & Ajuste \\
\hline \multirow{4}{*}{ 1-Jul } & 0,2 & 0,0445 & 0,1370 & Sim & 0,0522 & 0,1370 & Sim \\
& 0,3 & 0,0629 & 0,1370 & Sim & 0,0760 & 0,1370 & Sim \\
& 0,4 & 0,0749 & 0,1370 & Sim & 0,0638 & 0,1370 & Sim \\
& 0,5 & 0,0659 & 0,1370 & Sim & 0,0442 & 0,1370 & Sim \\
& 0,6 & 0,1479 & 0,1370 & Não & 0,0475 & 0,1370 & Sim \\
& 0,7 & 0,1171 & 0,1370 & Sim & 0,0582 & 0,1370 & Sim \\
& 0,8 & 0,1859 & 0,1370 & Não & 0,0917 & 0,1370 & Sim \\
\hline \multirow{4}{*}{ 15-Jul } & 0,2 & 0,0953 & 0,1370 & Sim & 0,0740 & 0,1370 & Sim \\
& 0,3 & 0,1041 & 0,1370 & Sim & 0,0539 & 0,1370 & Sim \\
& 0,4 & 0,1086 & 0,1370 & Sim & 0,0517 & 0,1370 & Sim \\
& 0,5 & 0,0679 & 0,1370 & Sim & 0,0597 & 0,1370 & Sim \\
& 0,6 & 0,0682 & 0,1370 & Sim & 0,0623 & 0,1370 & Sim \\
& 0,7 & 0,1750 & 0,1370 & Não & 0,0926 & 0,1370 & Sim \\
& 0,8 & 0,1869 & 0,1370 & Não & 0,1132 & 0,1370 & Sim \\
\hline \multirow{4}{*}{ 15-Ago } & 0,2 & 0,0898 & 0,1370 & Sim & 0,0740 & 0,1370 & Sim \\
& 0,3 & 0,0992 & 0,1370 & Sim & 0,0383 & 0,1370 & Sim \\
& 0,4 & 0,0978 & 0,1370 & Sim & 0,0556 & 0,1370 & Sim \\
& 0,5 & 0,1771 & 0,1370 & Não & 0,0748 & 0,1370 & Sim \\
& 0,6 & 0,0665 & 0,1370 & Sim & 0,0829 & 0,1370 & Sim \\
& 0,7 & 0,1348 & 0,1370 & Sim & 0,0742 & 0,1370 & Sim \\
& 0,8 & 0,0731 & 0,1370 & Sim & 0,0559 & 0,1370 & Sim \\
& 0,6 & 0,1530 & 0,1370 & Não & 0,1243 & 0,1370 & Sim \\
& 0,7 & 0,1339 & 0,1370 & Sim & 0,0552 & 0,1370 & Sim \\
& 0,8 & 0,1353 & 0,1370 & Sim & 0,1196 & 0,1370 & Sim \\
\hline \multirow{4}{*}{ 1-Ago } & 0,2 & 0,0541 & 0,1370 & Sim & 0,0665 & 0,1370 & Sim \\
& 0,0662 & 0,1370 & Sim & 0,1384 & 0,1370 & Não \\
& 0,0575 & 0,1370 & Sim & 0,0518 & 0,1370 & Sim \\
& 0,0759 & 0,1370 & Sim & 0,0707 & 0,1370 & Sim \\
& 0,3 & & & & & &
\end{tabular}


Tabela 2A. Ajuste dos valores simulados de lâmina bruta de irrigação e produtividade de grãos de feijão caupi à função de distribuição normal, pelo teste de Kolmogorov-Smirnov, em cada nível de manejo (p) e época de semeadura no município de Teresina, Piauí.

\begin{tabular}{|c|c|c|c|c|c|c|c|}
\hline \multirow{2}{*}{$\begin{array}{c}\text { Época de } \\
\text { Semeadura }\end{array}$} & \multirow[t]{2}{*}{$\mathrm{p}$} & \multicolumn{3}{|c|}{ Lâmina bruta } & \multicolumn{3}{|c|}{ Produtividade } \\
\hline & & Dmax & Dtab & Ajuste & Dmax & Dtab & Ajuste \\
\hline \multirow{7}{*}{$1-$ Set } & 0,2 & 0,0983 & 0,1370 & $\operatorname{Sim}$ & 0,0715 & 0,1370 & Sim \\
\hline & 0,3 & 0,0686 & 0,1370 & $\operatorname{Sim}$ & 0,0837 & 0,1370 & $\operatorname{Sim}$ \\
\hline & 0,4 & 0,0714 & 0,1370 & Sim & 0,0515 & 0,1370 & $\operatorname{Sim}$ \\
\hline & 0,5 & 0,0921 & 0,1370 & Sim & 0,0942 & 0,1370 & $\operatorname{Sim}$ \\
\hline & 0,6 & 0,0734 & 0,1370 & Sim & 0,0737 & 0,1370 & $\operatorname{Sim}$ \\
\hline & 0,7 & 0,0920 & 0,1370 & $\operatorname{Sim}$ & 0,0518 & 0,1370 & Sim \\
\hline & 0,8 & 0,1211 & 0,1370 & Sim & 0,0491 & 0,1370 & Sim \\
\hline \multirow{7}{*}{$15-$ Set } & 0,2 & 0,0502 & 0,1370 & $\operatorname{Sim}$ & 0,0446 & 0,1370 & Sim \\
\hline & 0,3 & 0,0560 & 0,1370 & Sim & 0,0389 & 0,1370 & Sim \\
\hline & 0,4 & 0,0889 & 0,1370 & Sim & 0,0754 & 0,1370 & Sim \\
\hline & 0,5 & 0,0556 & 0,1370 & $\operatorname{Sim}$ & 0,0732 & 0,1370 & Sim \\
\hline & 0,6 & 0,0735 & 0,1370 & Sim & 0,0851 & 0,1370 & Sim \\
\hline & 0,7 & 0,0853 & 0,1370 & Sim & 0,0818 & 0,1370 & $\operatorname{Sim}$ \\
\hline & 0,8 & 0,1202 & 0,1370 & $\operatorname{Sim}$ & 0,0682 & 0,1370 & $\operatorname{Sim}$ \\
\hline \multirow{7}{*}{ 1-Out } & 0,2 & 0,0693 & 0,1370 & $\operatorname{Sim}$ & 0,0530 & 0,1370 & $\mathrm{Sim}$ \\
\hline & 0,3 & 0,0664 & 0,1370 & Sim & 0,0448 & 0,1370 & Sim \\
\hline & 0,4 & 0,0740 & 0,1370 & Sim & 0,0553 & 0,1370 & Sim \\
\hline & 0,5 & 0,0488 & 0,1370 & Sim & 0,0729 & 0,1370 & Sim \\
\hline & 0,6 & 0,0898 & 0,1370 & Sim & 0,0653 & 0,1370 & $\operatorname{Sim}$ \\
\hline & 0,7 & 0,0741 & 0,1370 & Sim & 0,0776 & 0,1370 & $\operatorname{Sim}$ \\
\hline & 0,8 & 0,0515 & 0,1370 & Sim & 0,0836 & 0,1370 & Sim \\
\hline \multirow{7}{*}{ 15-Out } & 0,2 & 0,0557 & 0,1370 & Sim & 0,0910 & 0,1370 & $\operatorname{Sim}$ \\
\hline & 0,3 & 0,0709 & 0,1370 & Sim & 0,0436 & 0,1370 & $\operatorname{Sim}$ \\
\hline & 0,4 & 0,0551 & 0,1370 & Sim & 0,0653 & 0,1370 & $\operatorname{Sim}$ \\
\hline & 0,5 & 0,0758 & 0,1370 & Sim & 0,0694 & 0,1370 & $\operatorname{Sim}$ \\
\hline & 0,6 & 0,0600 & 0,1370 & Sim & 0,0722 & 0,1370 & Sim \\
\hline & 0,7 & 0,0819 & 0,1370 & Sim & 0,0474 & 0,1370 & $\operatorname{Sim}$ \\
\hline & 0,8 & 0,0595 & 0,1370 & Sim & 0,0738 & 0,1370 & Sim \\
\hline
\end{tabular}


Tabela 2A. Ajuste dos valores simulados de lâmina bruta de irrigação e produtividade de grãos de feijão caupi à função de distribuição normal, pelo teste de Kolmogorov-Smirnov, em cada nível de manejo (p) e época de semeadura no município de Teresina, Piauí.

\begin{tabular}{|c|c|c|c|c|c|c|c|}
\hline \multirow{2}{*}{$\begin{array}{l}\text { Epoca de } \\
\text { Semeadura }\end{array}$} & \multirow[t]{2}{*}{$\mathrm{p}$} & \multicolumn{3}{|c|}{ Lâmina bruta } & \multicolumn{3}{|c|}{ Produtividade } \\
\hline & & $D \max$ & Dtab & Ajuste & Dmax & Dtab & Ajuste \\
\hline \multirow{7}{*}{ 1-Nov } & 0,2 & 0,0660 & 0,1370 & $\operatorname{Sim}$ & 0,0695 & 0,1370 & Sim \\
\hline & 0,3 & 0,1163 & 0,1370 & Sim & 0,0536 & 0,1370 & Sim \\
\hline & 0,4 & 0,0921 & 0,1370 & Sim & 0,0577 & 0,1370 & Sim \\
\hline & 0,5 & 0,1100 & 0,1370 & Sim & 0,0361 & 0,1370 & Sim \\
\hline & 0,6 & 0,0837 & 0,1370 & Sim & 0,0755 & 0,1370 & Sim \\
\hline & 0,7 & 0,0835 & 0,1370 & Sim & 0,0599 & 0,1370 & Sim \\
\hline & 0,8 & 0,0833 & 0,1370 & Sim & 0,0721 & 0,1370 & Sim \\
\hline \multirow{7}{*}{$15-\mathrm{Nov}$} & 0,2 & 0,0505 & 0,1370 & Sim & 0,0361 & 0,1370 & Sim \\
\hline & 0,3 & 0,0568 & 0,1370 & Sim & 0,0405 & 0,1370 & Sim \\
\hline & 0,4 & 0,0724 & 0,1370 & Sim & 0,0736 & 0,1370 & Sim \\
\hline & 0,5 & 0,0583 & 0,1370 & Sim & 0,0684 & 0,1370 & Sim \\
\hline & 0,6 & 0,0448 & 0,1370 & Sim & 0,0419 & 0,1370 & Sim \\
\hline & 0,7 & 0,0463 & 0,1370 & Sim & 0,0640 & 0,1370 & Sim \\
\hline & 0,8 & 0,0790 & 0,1370 & Sim & 0,0775 & 0,1370 & Sim \\
\hline \multirow{7}{*}{ 1-Dez } & 0,2 & 0,0428 & 0,1370 & Sim & 0,0710 & 0,1370 & Sim \\
\hline & 0,3 & 0,0375 & 0,1370 & Sim & 0,0600 & 0,1370 & Sim \\
\hline & 0,4 & 0,0461 & 0,1370 & Sim & 0,0634 & 0,1370 & Sim \\
\hline & 0,5 & 0,0826 & 0,1370 & Sim & 0,0408 & 0,1370 & Sim \\
\hline & 0,6 & 0,0741 & 0,1370 & Sim & 0,0329 & 0,1370 & Sim \\
\hline & 0,7 & 0,0757 & 0,1370 & Sim & 0,0494 & 0,1370 & Sim \\
\hline & 0,8 & 0,0588 & 0,1370 & Sim & 0,0675 & 0,1370 & Sim \\
\hline \multirow{7}{*}{ 15-Dez } & 0,2 & 0,0472 & 0,1370 & Sim & 0,0563 & 0,1370 & Sim \\
\hline & 0,3 & 0,0464 & 0,1370 & Sim & 0,0646 & 0,1370 & Sim \\
\hline & 0,4 & 0,0759 & 0,1370 & Sim & 0,0973 & 0,1370 & Sim \\
\hline & 0,5 & 0,0451 & 0,1370 & Sim & 0,0483 & 0,1370 & Sim \\
\hline & 0,6 & 0,0689 & 0,1370 & Sim & 0,0561 & 0,1370 & Sim \\
\hline & 0,7 & 0,0602 & 0,1370 & Sim & 0,0564 & 0,1370 & Sim \\
\hline & 0,8 & 0,0877 & 0,1370 & Sim & 0,0743 & 0,1370 & Sim \\
\hline
\end{tabular}


Tabela $3 \mathrm{~A}$. Ajuste dos valores simulados de lâmina bruta de irrigação e produtividade de frutos de melancia à função de distribuição normal, pelo teste de Kolmogorov-Smirnov, em cada nível de manejo (p) e época de semeadura no município de Parnaiba, Piauí.

\begin{tabular}{lccccccc}
\hline Época de & $\mathrm{p}$ & \multicolumn{3}{c}{ Lâmina bruta } & \multicolumn{3}{c}{ Produtividade } \\
\cline { 3 - 8 } Semeadura & & Dmax & Dtab & Ajuste & Dmax & Dtab & Ajuste \\
\hline \multirow{4}{*}{ 1-Jan } & 0,2 & 0,0541 & 0,1370 & Sim & 0,0538 & 0,1370 & Sim \\
& 0,3 & 0,0440 & 0,1370 & Sim & 0,0820 & 0,1370 & Sim \\
& 0,4 & 0,0516 & 0,1370 & Sim & 0,0693 & 0,1370 & Sim \\
& 0,5 & 0,0801 & 0,1370 & Sim & 0,0730 & 0,1370 & Sim \\
& 0,6 & 0,0663 & 0,1370 & Sim & 0,0441 & 0,1370 & Sim \\
& 0,7 & 0,0610 & 0,1370 & Sim & 0,0902 & 0,1370 & Sim \\
& 0,8 & 0,0747 & 0,1370 & Sim & 0,0559 & 0,1370 & Sim \\
\hline \multirow{4}{*}{ 15-Jan } & 0,2 & 0,0314 & 0,1370 & Sim & 0,0632 & 0,1370 & Sim \\
& 0,3 & 0,0382 & 0,1370 & Sim & 0,0666 & 0,1370 & Sim \\
& 0,4 & 0,0740 & 0,1370 & Sim & 0,0518 & 0,1370 & Sim \\
& 0,5 & 0,0423 & 0,1370 & Sim & 0,0489 & 0,1370 & Sim \\
& 0,6 & 0,0673 & 0,1370 & Sim & 0,0499 & 0,1370 & Sim \\
& 0,7 & 0,0677 & 0,1370 & Sim & 0,0691 & 0,1370 & Sim \\
& 0,8 & 0,0554 & 0,1370 & Sim & 0,0452 & 0,1370 & Sim \\
\hline \multirow{4}{*}{ 15-Fev } & 0,2 & 0,0613 & 0,1370 & Sim & 0,0563 & 0,1370 & Sim \\
& 0,3 & 0,0593 & 0,1370 & Sim & 0,0658 & 0,1370 & Sim \\
& 0,4 & 0,0324 & 0,1370 & Sim & 0,0517 & 0,1370 & Sim \\
& 0,5 & 0,0594 & 0,1370 & Sim & 0,0884 & 0,1370 & Sim \\
& 0,6 & 0,0715 & 0,1370 & Sim & 0,0376 & 0,1370 & Sim \\
& 0,7 & 0,0662 & 0,1370 & Sim & 0,0432 & 0,1370 & Sim \\
& 0,8 & 0,0475 & 0,1370 & Sim & 0,0542 & 0,1370 & Sim
\end{tabular}


Tabela 3A. Ajuste dos valores simulados de lâmina bruta de irrigação e produtividade de frutos de melancia à função de distribuição normal, pelo teste de Kolmogorov-Smirnov, em cada nivel de manejo (p) e época de semeadura no município de Parnaíba, Piauí.

\begin{tabular}{|c|c|c|c|c|c|c|c|}
\hline \multirow{2}{*}{$\begin{array}{l}\text { Época de } \\
\text { Semeadura }\end{array}$} & \multirow[t]{2}{*}{$\mathrm{p}$} & \multicolumn{3}{|c|}{ Lâmina bruta } & \multicolumn{3}{|c|}{ Produtividade } \\
\hline & & Dmax & Dtab & Ajuste & Dmax & Dtab & Ajuste \\
\hline \multirow{7}{*}{ 1-Mar } & 0,2 & 0,0490 & 0,1370 & Sim & 0,0760 & 0,1370 & Sim \\
\hline & 0,3 & 0,0901 & 0,1370 & Sim & 0,0643 & 0,1370 & Sim \\
\hline & 0,4 & 0,0419 & 0,1370 & Sim & 0,0908 & 0,1370 & Sim \\
\hline & 0,5 & 0,0406 & 0,1370 & Sim & 0,0669 & 0,1370 & Sim \\
\hline & 0,6 & 0,0558 & 0,1370 & Sim & 0,0792 & 0,1370 & Sim \\
\hline & 0,7 & 0,0517 & 0,1370 & Sim & 0,0914 & 0,1370 & Sim \\
\hline & 0,8 & 0,0792 & 0,1370 & Sim & 0,0584 & 0,1370 & Sim \\
\hline \multirow{7}{*}{ 15-Mar } & 0,2 & 0,0888 & 0,1370 & Sim & 0,0501 & 0,1370 & Sim \\
\hline & 0,3 & 0,0642 & 0,1370 & Sim & 0,0439 & 0,1370 & Sim \\
\hline & 0,4 & 0,0804 & 0,1370 & Sim & 0,0565 & 0,1370 & Sim \\
\hline & 0,5 & 0,0476 & 0,1370 & Sim & 0,0528 & 0,1370 & Sim \\
\hline & 0,6 & 0,0537 & 0,1370 & Sim & 0,0547 & 0,1370 & Sim \\
\hline & 0,7 & 0,0482 & 0,1370 & Sim & 0,0660 & 0,1370 & Sim \\
\hline & 0,8 & 0,0568 & 0,1370 & Sim & 0,0582 & 0,1370 & Sim \\
\hline \multirow{7}{*}{$1-\mathrm{Abr}$} & 0,2 & 0,0542 & 0,1370 & Sim & 0,0777 & 0,1370 & Sim \\
\hline & 0,3 & 0,0601 & 0,1370 & Sim & 0,0675 & 0,1370 & Sim \\
\hline & 0,4 & 0,0831 & 0,1370 & Sim & 0,0561 & 0,1370 & Sim \\
\hline & 0,5 & 0,0446 & 0,1370 & Sim & 0,0489 & 0,1370 & Sim \\
\hline & 0,6 & 0,0415 & 0,1370 & Sim & 0,0677 & 0,1370 & Sim \\
\hline & 0,7 & 0,0513 & 0,1370 & Sim & 0,0619 & 0,1370 & Sim \\
\hline & 0,8 & 0,0595 & 0,1370 & Sim & 0,0573 & 0,1370 & Sim \\
\hline \multirow{7}{*}{$15-\mathrm{Abr}$} & 0,2 & 0,0683 & 0,1370 & Sim & 0,0482 & 0,1370 & Sim \\
\hline & 0,3 & 0,0770 & 0,1370 & Sim & 0,0462 & 0,1370 & Sim \\
\hline & 0,4 & 0,0467 & 0,1370 & Sim & 0,0720 & 0,1370 & Sim \\
\hline & 0,5 & 0,0733 & 0,1370 & Sim & 0,0688 & 0,1370 & Sim \\
\hline & 0,6 & 0,0668 & 0,1370 & Sim & 0,0745 & 0,1370 & Sim \\
\hline & 0,7 & 0,0538 & 0,1370 & Sim & 0,1433 & 0,1370 & Não \\
\hline & 0,8 & 0,0735 & 0,1370 & Sim & 0,0803 & 0,1370 & Sim \\
\hline
\end{tabular}


Tabela 3A. Ajuste dos valores simulados de lâmina bruta de irrigação e produtividade de frutos de melancia à função de distribuição normal, pelo teste de Kolmogorov-Smirnov, em cada nível de manejo (p) e época de semeadura no município de Parnaiba, Piaui.

\begin{tabular}{|c|c|c|c|c|c|c|c|}
\hline \multirow{2}{*}{$\begin{array}{l}\text { Época de } \\
\text { Semeadura }\end{array}$} & \multirow[t]{2}{*}{$\mathrm{p}$} & \multicolumn{3}{|c|}{ Lâmina bruta } & \multicolumn{3}{|c|}{ Produtividade } \\
\hline & & $D \max$ & Dtab & Ajuste & Dmax & Dtab & Ajuste \\
\hline \multirow{7}{*}{ 1-Mai } & 0,2 & 0,0561 & 0,1370 & Sim & 0,0843 & 0,1370 & Sim \\
\hline & 0,3 & 0,0414 & 0,1370 & Sim & 0,0500 & 0,1370 & Sim \\
\hline & 0,4 & 0,0396 & 0,1370 & Sim & 0,0502 & 0,1370 & Sim \\
\hline & 0,5 & 0,0560 & 0,1370 & Sim & 0,0570 & 0,1370 & Sim \\
\hline & 0,6 & 0,0495 & 0,1370 & Sim & 0,0464 & 0,1370 & Sim \\
\hline & 0,7 & 0,0593 & 0,1370 & Sim & 0,0925 & 0,1370 & Sim \\
\hline & 0,8 & 0,0658 & 0,1370 & Sim & 0,0565 & 0,1370 & Sim \\
\hline \multirow{7}{*}{ 15-Mai } & 0,2 & 0,0733 & 0,1370 & Sim & 0,0930 & 0,1370 & $\operatorname{Sim}$ \\
\hline & 0,3 & 0,0722 & 0,1370 & Sim & 0,0475 & 0,1370 & Sim \\
\hline & 0,4 & 0,0364 & 0,1370 & Sim & 0,0456 & 0,1370 & Sim \\
\hline & 0,5 & 0,0880 & 0,1370 & Sim & 0,0737 & 0,1370 & Sim \\
\hline & 0,6 & 0,0402 & 0,1370 & Sim & 0,0505 & 0,1370 & Sim \\
\hline & 0,7 & 0,0560 & 0,1370 & Sim & 0,0731 & 0,1370 & Sim \\
\hline & 0,8 & 0,0811 & 0,1370 & Sim & 0,0618 & 0,1370 & Sim \\
\hline \multirow{7}{*}{ 1-Jun } & 0,2 & 0,0723 & 0,1370 & Sim & 0,0609 & 0,1370 & Sim \\
\hline & 0,3 & 0,0822 & 0,1370 & Sim & 0,0459 & 0,1370 & Sim \\
\hline & 0,4 & 0,0510 & 0,1370 & Sim & 0,0558 & 0,1370 & Sim \\
\hline & 0,5 & 0,0523 & 0,1370 & Sim & 0,0481 & 0,1370 & Sim \\
\hline & 0,6 & 0,0821 & 0,1370 & Sim & 0,0542 & 0,1370 & Sim \\
\hline & 0,7 & 0,0879 & 0,1370 & Sim & 0,0662 & 0,1370 & Sim \\
\hline & 0,8 & 0,0576 & 0,1370 & Sim & 0,0651 & 0,1370 & Sim \\
\hline \multirow{7}{*}{ 15-Jun } & 0,2 & 0,0475 & 0,1370 & Sim & 0,0333 & 0,1370 & Sim \\
\hline & 0,3 & 0,0507 & 0,1370 & Sim & 0,0571 & 0,1370 & Sim \\
\hline & 0,4 & 0,0654 & 0,1370 & Sim & 0,0549 & 0,1370 & Sim \\
\hline & 0,5 & 0,0631 & 0,1370 & Sim & 0,0637 & 0,1370 & Sim \\
\hline & 0,6 & 0,0607 & 0,1370 & Sim & 0,0343 & 0,1370 & Sim \\
\hline & 0,7 & 0,0678 & 0,1370 & Sim & 0,0579 & 0,1370 & Sim \\
\hline & 0,8 & 0,0728 & 0,1370 & Sim & 0,0432 & 0,1370 & Sim \\
\hline
\end{tabular}


Tabela $3 \mathrm{~A}$. Ajuste dos valores simulados de lâmina bruta de irrigação e produtividade de frutos de melancia à função de distribuição normal, pelo teste de Kolmogorov-Smirnov, em cada nível de manejo (p) e época de semeadura no município de Parnaíba, Piauí.

\begin{tabular}{lccccccc}
\hline Época de & $\mathrm{p}$ & \multicolumn{3}{c}{ Lâmina bruta } & \multicolumn{3}{c}{ Produtividade } \\
\cline { 3 - 8 } Semeadura & & Dmax & Dtab & Ajuste & Dmax & Dtab & Ajuste \\
\hline \multirow{4}{*}{ 1-Jul } & 0,2 & 0,0580 & 0,1370 & Sim & 0,0447 & 0,1370 & Sim \\
& 0,3 & 0,0494 & 0,1370 & Sim & 0,0574 & 0,1370 & Sim \\
& 0,4 & 0,0685 & 0,1370 & Sim & 0,0495 & 0,1370 & Sim \\
& 0,5 & 0,0785 & 0,1370 & Sim & 0,0579 & 0,1370 & Sim \\
& 0,6 & 0,0919 & 0,1370 & Sim & 0,0401 & 0,1370 & Sim \\
& 0,7 & 0,0655 & 0,1370 & Sim & 0,0617 & 0,1370 & Sim \\
& 0,8 & 0,1022 & 0,1370 & Sim & 0,0848 & 0,1370 & Sim \\
\hline \multirow{4}{*}{ 15-Jul } & 0,2 & 0,0897 & 0,1370 & Sim & 0,0745 & 0,1370 & Sim \\
& 0,3 & 0,0412 & 0,1370 & Sim & 0,0676 & 0,1370 & Sim \\
& 0,4 & 0,0586 & 0,1370 & Sim & 0,0449 & 0,1370 & Sim \\
& 0,5 & 0,0837 & 0,1370 & Sim & 0,0657 & 0,1370 & Sim \\
& 0,6 & 0,0738 & 0,1370 & Sim & 0,0777 & 0,1370 & Sim \\
& 0,7 & 0,0568 & 0,1370 & Sim & 0,0877 & 0,1370 & Sim \\
& 0,8 & 0,1243 & 0,1370 & Sim & 0,0754 & 0,1370 & Sim \\
\hline \multirow{4}{*}{ 15-Ago } & 0,2 & 0,0474 & 0,1370 & Sim & 0,0488 & 0,1370 & Sim \\
& 0,3 & 0,0637 & 0,1370 & Sim & 0,0526 & 0,1370 & Sim \\
& 0,5 & 0,0514 & 0,1370 & Sim & 0,0427 & 0,1370 & Sim \\
& 0,6 & 0,1582 & 0,1370 & Não & 0,0933 & 0,1370 & Sim \\
& 0,4 & 0,0492 & 0,1370 & Sim & 0,0859 & 0,1370 & Sim \\
& 0,5 & 0,0588 & 0,1370 & Sim & 0,0604 & 0,1370 & Sim \\
& 0,1 1-Ago & 0,1142 & 0,1370 & Sim & 0,1303 & 0,1370 & Sim \\
& 0,6 & 0,1152 & 0,1370 & Sim & 0,0616 & 0,1370 & Sim \\
& 0,7 & 0,0690 & 0,1370 & Sim & 0,0495 & 0,1370 & Sim \\
& 0,8 & 0,0742 & 0,1370 & Sim & 0,0983 & 0,1370 & Sim \\
\hline \multirow{6}{*}{} & 0,0978 & 0,1370 & Sim & 0,1398 & 0,1370 & Não
\end{tabular}


Tabela 3A. Ajuste dos valores simulados de lâmina bruta de irrigação e produtividade de grãos de feijão caupi à função de distribuição normal, pelo teste de Kolmogorov-Smirnov, em cada nível de manejo (p) e época de semeadura no município de Parnaiba, Piauí.

\begin{tabular}{|c|c|c|c|c|c|c|c|}
\hline \multirow{2}{*}{$\begin{array}{c}\text { Época de } \\
\text { Semeadura }\end{array}$} & \multirow[t]{2}{*}{$\mathrm{p}$} & \multicolumn{3}{|c|}{ Lâmina bruta } & \multicolumn{3}{|c|}{ Produtividade } \\
\hline & & Dmax & Dtab & Ajuste & $D \max$ & Dtab & Ajuste \\
\hline \multirow{7}{*}{$1-$ Set } & 0,2 & 0,0669 & 0,1370 & Sim & 0,0620 & 0,1370 & $\operatorname{Sim}$ \\
\hline & 0,3 & 0,0577 & 0,1370 & Sim & 0,0880 & 0,1370 & $\operatorname{Sim}$ \\
\hline & 0,4 & 0,0846 & 0,1370 & Sim & 0,0890 & 0,1370 & Sim \\
\hline & 0,5 & 0,0833 & 0,1370 & Sim & 0,1102 & 0,1370 & Sim \\
\hline & 0,6 & 0,1583 & 0,1370 & Não & 0,0453 & 0,1370 & Sim \\
\hline & 0,7 & 0,0709 & 0,1370 & Sim & 0,1169 & 0,1370 & Sim \\
\hline & 0,8 & 0,0935 & 0,1370 & Sim & 0,1204 & 0,1370 & Sim \\
\hline \multirow{7}{*}{ 15-Set } & 0,2 & 0,0854 & 0,1370 & Sim & 0,0731 & 0,1370 & Sim \\
\hline & 0,3 & 0,0490 & 0,1370 & Sim & 0,0893 & 0,1370 & Sim \\
\hline & 0,4 & 0,0420 & 0,1370 & Sim & 0,0746 & 0,1370 & Sim \\
\hline & 0,5 & 0,0574 & 0,1370 & Sim & 0,0821 & 0,1370 & Sim \\
\hline & 0,6 & 0,1113 & 0,1370 & Sim & 0,0414 & 0,1370 & Sim \\
\hline & 0,7 & 0,0497 & 0,1370 & $\operatorname{Sim}$ & 0,0720 & 0,1370 & Sim \\
\hline & 0,8 & 0,1082 & 0,1370 & Sim & 0,1270 & 0,1370 & $\operatorname{Sim}$ \\
\hline \multirow{7}{*}{ 1-Out } & 0,2 & 0,0619 & 0,1370 & Sim & 0,0518 & 0,1370 & $\operatorname{Sim}$ \\
\hline & 0,3 & 0,0824 & 0,1370 & Sim & 0,0558 & 0,1370 & Sim \\
\hline & 0,4 & 0,0641 & 0,1370 & Sim & 0,0885 & 0,1370 & Sim \\
\hline & 0,5 & 0,0710 & 0,1370 & Sim & 0,0594 & 0,1370 & Sim \\
\hline & 0,6 & 0,1443 & 0,1370 & Não & 0,0739 & 0,1370 & Sim \\
\hline & 0,7 & 0,0555 & 0,1370 & Sim & 0,1004 & 0,1370 & Sim \\
\hline & 0,8 & 0,0859 & 0,1370 & Sim & 0,0676 & 0,1370 & Sim \\
\hline \multirow{7}{*}{ 15-Out } & 0,2 & 0,0674 & 0,1370 & Sim & 0,0532 & 0,1370 & Sim \\
\hline & 0,3 & 0,0658 & 0,1370 & Sim & 0,0408 & 0,1370 & $\operatorname{Sim}$ \\
\hline & 0,4 & 0,0529 & 0,1370 & Sim & 0,0768 & 0,1370 & Sim \\
\hline & 0,5 & 0,0761 & 0,1370 & Sim & 0,0680 & 0,1370 & Sim \\
\hline & 0,6 & 0,1240 & 0,1370 & Sim & 0,0773 & 0,1370 & Sim \\
\hline & 0,7 & 0,0649 & 0,1370 & Sim & 0,0608 & 0,1370 & Sim \\
\hline & 0,8 & 0,0551 & 0,1370 & $\operatorname{Sim}$ & 0,0589 & 0,1370 & Sim \\
\hline
\end{tabular}


Tabela $3 \mathrm{~A}$. Ajuste dos valores simulados de lâmina bruta de irrigação e produtividade de frutos de melancia à função de distribuição normal, pelo teste de Kolmogorov-Smirnov, em cada nível de manejo (p) e época de semeadura no município de Parnaíba, Piauí.

\begin{tabular}{|c|c|c|c|c|c|c|c|}
\hline \multirow{2}{*}{$\begin{array}{l}\text { Época de } \\
\text { Semeadura }\end{array}$} & \multirow[t]{2}{*}{$\mathrm{p}$} & \multicolumn{3}{|c|}{ Lâmina bruta } & \multicolumn{3}{|c|}{ Produtividade } \\
\hline & & Dmax & Dtab & Ajuste & Dmax & Dtab & Ajuste \\
\hline \multirow{7}{*}{$1-\mathrm{Nov}$} & 0,2 & 0,0557 & 0,1370 & Sim & 0,0429 & 0,1370 & $\operatorname{Sim}$ \\
\hline & 0,3 & 0,0547 & 0,1370 & Sim & 0,0488 & 0,1370 & Sim \\
\hline & 0,4 & 0,0398 & 0,1370 & Sim & 0,0508 & 0,1370 & Sim \\
\hline & 0,5 & 0,0743 & 0,1370 & Sim & 0,0477 & 0,1370 & Sim \\
\hline & 0,6 & 0,0728 & 0,1370 & Sim & 0,0670 & 0,1370 & Sim \\
\hline & 0,7 & 0,0390 & 0,1370 & Sim & 0,0647 & 0,1370 & Sim \\
\hline & 0,8 & 0,0578 & 0,1370 & Sim & 0,0578 & 0,1370 & Sim \\
\hline \multirow{7}{*}{ 15-Nov } & 0,2 & 0,0505 & 0,1370 & Sim & 0,0969 & 0,1370 & Sim \\
\hline & 0,3 & 0,0536 & 0,1370 & Sim & 0,0529 & 0,1370 & Sim \\
\hline & 0,4 & 0,0834 & 0,1370 & Sim & 0,0426 & 0,1370 & Sim \\
\hline & 0,5 & 0,0678 & 0,1370 & Sim & 0,0586 & 0,1370 & Sim \\
\hline & 0,6 & 0,0636 & 0,1370 & Sim & 0,0725 & 0,1370 & Sim \\
\hline & 0,7 & 0,0778 & 0,1370 & Sim & 0,0982 & 0,1370 & Sim \\
\hline & 0,8 & 0,0637 & 0,1370 & Sim & 0,0477 & 0,1370 & Sim \\
\hline \multirow{7}{*}{ 1-Dez } & 0,2 & 0,0455 & 0,1370 & Sim & 0,0534 & 0,1370 & Sim \\
\hline & 0,3 & 0,0834 & 0,1370 & Sim & 0,0557 & 0,1370 & Sim \\
\hline & 0,4 & 0,0660 & 0,1370 & Sim & 0,0422 & 0,1370 & Sim \\
\hline & 0,5 & 0,0701 & 0,1370 & Sim & 0,0525 & 0,1370 & Sim \\
\hline & 0,6 & 0,0736 & 0,1370 & Sim & 0,0626 & 0,1370 & Sim \\
\hline & 0,7 & 0,0399 & 0,1370 & Sim & 0,0412 & 0,1370 & Sim \\
\hline & 0,8 & 0,0508 & 0,1370 & Sim & 0,0908 & 0,1370 & Sim \\
\hline \multirow{7}{*}{ 15-Dez } & 0,2 & 0,0499 & 0,1370 & Sim & 0,0592 & 0,1370 & Sim \\
\hline & 0,3 & 0,0567 & 0,1370 & Sim & 0,0670 & 0,1370 & Sim \\
\hline & 0,4 & 0,0626 & 0,1370 & Sim & 0,0479 & 0,1370 & Sim \\
\hline & 0,5 & 0,0647 & 0,1370 & Sim & 0,0642 & 0,1370 & Sim \\
\hline & 0,6 & 0,0454 & 0,1370 & Sim & 0,0619 & 0,1370 & Sim \\
\hline & 0,7 & 0,0453 & 0,1370 & Sim & 0,0620 & 0,1370 & Sim \\
\hline & 0,8 & 0,0660 & 0,1370 & Sim & 0,0691 & 0,1370 & Sim \\
\hline
\end{tabular}


Tabela 4A. Ajuste dos valores simulados de lâmina bruta de irrigação e produtividade de frutos de melancia à função de distribuição normal, pelo teste de Kolmogorov-Smirnov, em cada nível de manejo (p) e época de semeadura no município de Teresina, Piauí.

\begin{tabular}{|c|c|c|c|c|c|c|c|}
\hline \multirow{2}{*}{$\begin{array}{l}\text { Época de } \\
\text { Semeadura }\end{array}$} & \multirow[t]{2}{*}{$\mathrm{p}$} & \multicolumn{3}{|c|}{ Lâmina bruta } & \multicolumn{3}{|c|}{ Produtividade } \\
\hline & & Dmax & Dtab & Ajuste & $D \max$ & Dtab & Ajuste \\
\hline \multirow{7}{*}{ 1-Jan } & 0,2 & 0,0482 & 0,1370 & $\operatorname{Sim}$ & 0,0557 & 0,1370 & Sim \\
\hline & 0,3 & 0,0471 & 0,1370 & Sim & 0,0610 & 0,1370 & Sim \\
\hline & 0,4 & 0,0535 & 0,1370 & Sim & 0,0478 & 0,1370 & Sim \\
\hline & 0,5 & 0,0460 & 0,1370 & Sim & 0,0717 & 0,1370 & Sim \\
\hline & 0,6 & 0,0559 & 0,1370 & Sim & 0,0677 & 0,1370 & Sim \\
\hline & 0,7 & 0,0981 & 0,1370 & Sim & 0,0967 & 0,1370 & Sim \\
\hline & 0,8 & 0,1141 & 0,1370 & Sim & 0,0642 & 0,1370 & Sim \\
\hline \multirow{7}{*}{ 15-Jan } & 0,2 & 0,0905 & 0,1370 & Sim & 0,0724 & 0,1370 & Sim \\
\hline & 0,3 & 0,0792 & 0,1370 & Sim & 0,0626 & 0,1370 & Sim \\
\hline & 0,4 & 0,0693 & 0,1370 & Sim & 0,0542 & 0,1370 & Sim \\
\hline & 0,5 & 0,0533 & 0,1370 & Sim & 0,0470 & 0,1370 & Sim \\
\hline & 0,6 & 0,0543 & 0,1370 & Sim & 0,0740 & 0,1370 & Sim \\
\hline & 0,7 & 0,0954 & 0,1370 & Sim & 0,0623 & 0,1370 & Sim \\
\hline & 0,8 & 0,1427 & 0,1370 & Não & 0,0554 & 0,1370 & Sim \\
\hline \multirow{7}{*}{$1-\mathrm{Fev}$} & 0,2 & 0,0450 & 0,1370 & Sim & 0,0594 & 0,1370 & Sim \\
\hline & 0,3 & 0,0425 & 0,1370 & Sim & 0,0733 & 0,1370 & Sim \\
\hline & 0,4 & 0,0353 & 0,1370 & Sim & 0,0431 & 0,1370 & Sim \\
\hline & 0,5 & 0,0600 & 0,1370 & Sim & 0,0730 & 0,1370 & Sim \\
\hline & 0,6 & 0,0828 & 0,1370 & Sim & 0,0542 & 0,1370 & Sim \\
\hline & 0,7 & 0,1194 & 0,1370 & Sim & 0,0361 & 0,1370 & Sim \\
\hline & 0,8 & 0,1440 & 0,1370 & Não & 0,0506 & 0,1370 & Sim \\
\hline \multirow{7}{*}{$15-\mathrm{Fev}$} & 0,2 & 0,0763 & 0,1370 & Sim & 0,0382 & 0,1370 & Sim \\
\hline & 0,3 & 0,0639 & 0,1370 & Sim & 0,0512 & 0,1370 & Sim \\
\hline & 0,4 & 0,0740 & 0,1370 & Sim & 0,0590 & 0,1370 & Sim \\
\hline & 0,5 & 0,0939 & 0,1370 & Sim & 0,0569 & 0,1370 & Sim \\
\hline & 0,6 & 0,0895 & 0,1370 & Sim & 0,0341 & 0,1370 & Sim \\
\hline & 0,7 & 0,1174 & 0,1370 & Sim & 0,0422 & 0,1370 & Sim \\
\hline & 0,8 & 0,1993 & 0,1370 & Não & 0,0393 & 0,1370 & Sim \\
\hline
\end{tabular}


Tabela 4A. Ajuste dos valores simulados de lâmina bruta de irrigação e produtividade de frutos de melancia à função de distribuição normal, pelo teste de Kolmogorov-Smirnov, em cada nível de manejo (p) e época de semeadura no municipio de Teresina, Piauí.

\begin{tabular}{|c|c|c|c|c|c|c|c|}
\hline \multirow{2}{*}{$\begin{array}{l}\text { Época de } \\
\text { Semeadura }\end{array}$} & \multirow[t]{2}{*}{$\mathrm{p}$} & \multicolumn{3}{|c|}{ Lâmina bruta } & \multicolumn{3}{|c|}{ Produtividade } \\
\hline & & $D \max$ & Dtab & Ajuste & $D \max$ & Dtab & Ajuste \\
\hline \multirow{7}{*}{ 1-Mar } & 0,2 & 0,0486 & 0,1370 & $\operatorname{Sim}$ & 0,0454 & 0,1370 & Sim \\
\hline & 0,3 & 0,0790 & 0,1370 & Sim & 0,0473 & 0,1370 & Sim \\
\hline & 0,4 & 0,0639 & 0,1370 & Sim & 0,0508 & 0,1370 & Sim \\
\hline & 0,5 & 0,0937 & 0,1370 & Sim & 0,0695 & 0,1370 & Sim \\
\hline & 0,6 & 0,0828 & 0,1370 & Sim & 0,0638 & 0,1370 & Sim \\
\hline & 0,7 & 0,1294 & 0,1370 & Sim & 0,0542 & 0,1370 & Sim \\
\hline & 0,8 & 0,2228 & 0,1370 & Não & 0,0436 & 0,1370 & Sim \\
\hline \multirow{7}{*}{ 15-Mar } & 0,2 & 0,0359 & 0,1370 & Sim & 0,0567 & 0,1370 & Sim \\
\hline & 0,3 & 0,0451 & 0,1370 & Sim & 0,0403 & 0,1370 & Sim \\
\hline & 0,4 & 0,0616 & 0,1370 & Sim & 0,0530 & 0,1370 & Sim \\
\hline & 0,5 & 0,0691 & 0,1370 & Sim & 0,0613 & 0,1370 & Sim \\
\hline & 0,6 & 0,0542 & 0,1370 & Sim & 0,0449 & 0,1370 & Sim \\
\hline & 0,7 & 0,1143 & 0,1370 & Sim & 0,0597 & 0,1370 & Sim \\
\hline & 0,8 & 0,1328 & 0,1370 & Sim & 0,0576 & 0,1370 & Sim \\
\hline \multirow{7}{*}{$1-\mathrm{Abr}$} & 0,2 & 0,0389 & 0,1370 & Sim & 0,0624 & 0,1370 & Sim \\
\hline & 0,3 & 0,0526 & 0,1370 & Sim & 0,0526 & 0,1370 & Sim \\
\hline & 0,4 & 0,0391 & 0,1370 & Sim & 0,0946 & 0,1370 & Sim \\
\hline & 0,5 & 0,0776 & 0,1370 & Sim & 0,0851 & 0,1370 & Sim \\
\hline & 0,6 & 0,0468 & 0,1370 & Sim & 0,0612 & 0,1370 & Sim \\
\hline & 0,7 & 0,0699 & 0,1370 & Sim & 0,0776 & 0,1370 & Sim \\
\hline & 0,8 & 0,0766 & 0,1370 & Sim & 0,0621 & 0,1370 & Sim \\
\hline \multirow{7}{*}{$15-\mathrm{Abr}$} & 0,2 & 0,0531 & 0,1370 & Sim & 0,0483 & 0,1370 & Sim \\
\hline & 0,3 & 0,0466 & 0,1370 & Sim & 0,0627 & 0,1370 & Sim \\
\hline & 0,4 & 0,0460 & 0,1370 & Sim & 0,0375 & 0,1370 & Sim \\
\hline & 0,5 & 0,0600 & 0,1370 & Sim & 0,0781 & 0,1370 & Sim \\
\hline & 0,6 & 0,0656 & 0,1370 & Sim & 0,0636 & 0,1370 & Sim \\
\hline & 0,7 & 0,0508 & 0,1370 & Sim & 0,0774 & 0,1370 & Sim \\
\hline & 0,8 & 0,0407 & 0,1370 & Sim & 0,0772 & 0,1370 & Sim \\
\hline
\end{tabular}


Tabela 4A. Ajuste dos valores simulados de lâmina bruta de irrigação e produtividade de frutos de melancia à função de distribuição normal, pelo teste de Kolmogorov-Smirnov, em cada nível de manejo (p) e época de semeadura no município de Teresina, Piauí.

\begin{tabular}{cccccccc}
\hline Época de & $\mathrm{p}$ & \multicolumn{3}{c}{ Lâmina bruta } & \multicolumn{3}{c}{ Produtividade } \\
\cline { 3 - 7 } Semeadura & & Dmax & Dtab & Ajuste & Dmax & Dtab & Ajuste \\
\hline \multirow{4}{*}{ 1-Mai } & 0,2 & 0,0888 & 0,1370 & Sim & 0,0804 & 0,1370 & Sim \\
& 0,3 & 0,0609 & 0,1370 & Sim & 0,0656 & 0,1370 & Sim \\
& 0,4 & 0,0763 & 0,1370 & Sim & 0,0450 & 0,1370 & Sim \\
& 0,5 & 0,0584 & 0,1370 & Sim & 0,0856 & 0,1370 & Sim \\
& 0,6 & 0,0687 & 0,1370 & Sim & 0,0710 & 0,1370 & Sim \\
& 0,7 & 0,0566 & 0,1370 & Sim & 0,0889 & 0,1370 & Sim \\
& 0,8 & 0,0968 & 0,1370 & Sim & 0,0893 & 0,1370 & Sim \\
\hline \multirow{4}{*}{ 15-Mai } & 0,2 & 0,0589 & 0,1370 & Sim & 0,0850 & 0,1370 & Sim \\
& 0,3 & 0,0647 & 0,1370 & Sim & 0,0512 & 0,1370 & Sim \\
& 0,4 & 0,0455 & 0,1370 & Sim & 0,0544 & 0,1370 & Sim \\
& 0,5 & 0,0531 & 0,1370 & Sim & 0,0751 & 0,1370 & Sim \\
& 0,6 & 0,0643 & 0,1370 & Sim & 0,0475 & 0,1370 & Sim \\
& 0,7 & 0,0678 & 0,1370 & Sim & 0,0976 & 0,1370 & Sim \\
& 0,8 & 0,0704 & 0,1370 & Sim & 0,0818 & 0,1370 & Sim \\
\hline \multirow{4}{*}{ 15-Jun } & 0,2 & 0,0928 & 0,1370 & Sim & 0,0370 & 0,1370 & Sim \\
& 0,3 & 0,1193 & 0,1370 & Sim & 0,0960 & 0,1370 & Sim \\
& 0,5 & 0,0591 & 0,1370 & Sim & 0,0583 & 0,1370 & Sim \\
& 0,6 & 0,1017 & 0,1370 & Sim & 0,0809 & 0,1370 & Sim \\
& 0,4 & 0,0745 & 0,1370 & Sim & 0,0555 & 0,1370 & Sim \\
& 0,7 & 0,0814 & 0,1370 & Sim & 0,0525 & 0,1370 & Sim \\
& 0,8 & 0,1705 & 0,1370 & Não & 0,0582 & 0,1370 & Sim
\end{tabular}


Tabela 4A. Ajuste dos valores simulados de lâmina bruta de irrigação e produtividade de frutos de melancia à função de distribuição normal, pelo teste de Kolmogorov-Smirnov, em cada nivel de manejo (p) e época de semeadura no município de Teresina, Piauí.

\begin{tabular}{|c|c|c|c|c|c|c|c|}
\hline \multirow{2}{*}{$\begin{array}{l}\text { Época de } \\
\text { Semeadura }\end{array}$} & \multirow[t]{2}{*}{$\mathrm{p}$} & \multicolumn{3}{|c|}{ Lâmina bruta } & \multicolumn{3}{|c|}{ Produtividade } \\
\hline & & $D \max$ & Dtab & Ajuste & Dmax & Dtab & Ajuste \\
\hline \multirow{7}{*}{ 1-Jul } & 0,2 & 0,0665 & 0,1370 & Sim & 0,0392 & 0,1370 & Sim \\
\hline & 0,3 & 0,0522 & 0,1370 & Sim & 0,0599 & 0,1370 & Sim \\
\hline & 0,4 & 0,0839 & 0,1370 & Sim & 0,0439 & 0,1370 & Sim \\
\hline & 0,5 & 0,0612 & 0,1370 & Sim & 0,0656 & 0,1370 & Sim \\
\hline & 0,6 & 0,1032 & 0,1370 & Sim & 0,1002 & 0,1370 & Sim \\
\hline & 0,7 & 0,1294 & 0,1370 & Sim & 0,0606 & 0,1370 & Sim \\
\hline & 0,8 & 0,1499 & 0,1370 & Não & 0,0851 & 0,1370 & Sim \\
\hline \multirow{7}{*}{ 15-Jul } & 0,2 & 0,0576 & 0,1370 & Sim & 0,1058 & 0,1370 & Sim \\
\hline & 0,3 & 0,0699 & 0,1370 & Sim & 0,0790 & 0,1370 & Sim \\
\hline & 0,4 & 0,0827 & 0,1370 & Sim & 0,0634 & 0,1370 & Sim \\
\hline & 0,5 & 0,1022 & 0,1370 & Sim & 0,0716 & 0,1370 & Sim \\
\hline & 0,6 & 0,0972 & 0,1370 & Sim & 0,0512 & 0,1370 & Sim \\
\hline & 0,7 & 0,1422 & 0,1370 & Não & 0,1041 & 0,1370 & Sim \\
\hline & 0,8 & 0,2321 & 0,1370 & Não & 0,0646 & 0,1370 & Sim \\
\hline \multirow{7}{*}{ 1-Ago } & 0,2 & 0,0883 & 0,1370 & Sim & 0,0458 & 0,1370 & Sim \\
\hline & 0,3 & 0,1052 & 0,1370 & Sim & 0,0641 & 0,1370 & Sim \\
\hline & 0,4 & 0,0913 & 0,1370 & Sim & 0,0769 & 0,1370 & Sim \\
\hline & 0,5 & 0,0718 & 0,1370 & Sim & 0,0697 & 0,1370 & Sim \\
\hline & 0,6 & 0,1023 & 0,1370 & Sim & 0,0593 & 0,1370 & Sim \\
\hline & 0,7 & 0,1046 & 0,1370 & Sim & 0,0757 & 0,1370 & Sim \\
\hline & 0,8 & 0,1896 & 0,1370 & Não & 0,1512 & 0,1370 & Não \\
\hline \multirow{7}{*}{ 15-Ago } & 0,2 & 0,0540 & 0,1370 & Sim & 0,0502 & 0,1370 & Sim \\
\hline & 0,3 & 0,0448 & 0,1370 & Sim & 0,0714 & 0,1370 & Sim \\
\hline & 0,4 & 0,0540 & 0,1370 & Sim & 0,0477 & 0,1370 & Sim \\
\hline & 0,5 & 0,0861 & 0,1370 & Sim & 0,0588 & 0,1370 & Sim \\
\hline & 0,6 & 0,1031 & 0,1370 & Sim & 0,0851 & 0,1370 & Sim \\
\hline & 0,7 & 0,0710 & 0,1370 & Sim & 0,0587 & 0,1370 & Sim \\
\hline & 0,8 & 0,1561 & 0,1370 & Não & 0,0732 & 0,1370 & Sim \\
\hline
\end{tabular}


Tabela 4A. Ajuste dos valores simulados de lâmina bruta de irrigação e produtividade de frutos de melancia à função de distribuição normal, pelo teste de Kolmogorov-Smirnov, em cada nível de manejo (p) e época de semeadura no município de Teresina, Piauí.

\begin{tabular}{|c|c|c|c|c|c|c|c|}
\hline \multirow{2}{*}{$\begin{array}{l}\text { Época de } \\
\text { Semeadura }\end{array}$} & \multirow[t]{2}{*}{$\mathrm{p}$} & \multicolumn{3}{|c|}{ Lâmina bruta } & \multicolumn{3}{|c|}{ Produtividade } \\
\hline & & $D \max$ & Dtab & Ajuste & Dmax & Dtab & Ajuste \\
\hline \multirow{7}{*}{$1-$ Set } & 0,2 & 0,0935 & 0,1370 & $\operatorname{Sim}$ & 0,0781 & 0,1370 & Sim \\
\hline & 0,3 & 0,0679 & 0,1370 & Sim & 0,0806 & 0,1370 & Sim \\
\hline & 0,4 & 0,0526 & 0,1370 & Sim & 0,0540 & 0,1370 & Sim \\
\hline & 0,5 & 0,0832 & 0,1370 & Sim & 0,0480 & 0,1370 & Sim \\
\hline & 0,6 & 0,0732 & 0,1370 & Sim & 0,0675 & 0,1370 & Sim \\
\hline & 0,7 & 0,0732 & 0,1370 & Sim & 0,0449 & 0,1370 & Sim \\
\hline & 0,8 & 0,0789 & 0,1370 & Sim & 0,1005 & 0,1370 & Sim \\
\hline \multirow{7}{*}{$15-$ Set } & 0,2 & 0,0537 & 0,1370 & Sim & 0,0838 & 0,1370 & Sim \\
\hline & 0,3 & 0,0458 & 0,1370 & Sim & 0,0565 & 0,1370 & Sim \\
\hline & 0,4 & 0,0486 & 0,1370 & Sim & 0,0631 & 0,1370 & Sim \\
\hline & 0,5 & 0,0542 & 0,1370 & Sim & 0,0626 & 0,1370 & Sim \\
\hline & 0,6 & 0,0634 & 0,1370 & Sim & 0,0651 & 0,1370 & Sim \\
\hline & 0,7 & 0,0422 & 0,1370 & Sim & 0,0482 & 0,1370 & Sim \\
\hline & 0,8 & 0,1444 & 0,1370 & Não & 0,0648 & 0,1370 & Sim \\
\hline \multirow{7}{*}{ 1-Out } & 0,2 & 0,0581 & 0,1370 & Sim & 0,0497 & 0,1370 & Sim \\
\hline & 0,3 & 0,0537 & 0,1370 & Sim & 0,0461 & 0,1370 & Sim \\
\hline & 0,4 & 0,0554 & 0,1370 & Sim & 0,0786 & 0,1370 & Sim \\
\hline & 0,5 & 0,0740 & 0,1370 & Sim & 0,0722 & 0,1370 & Sim \\
\hline & 0,6 & 0,0542 & 0,1370 & Sim & 0,0758 & 0,1370 & Sim \\
\hline & 0,7 & 0,0663 & 0,1370 & Sim & 0,0374 & 0,1370 & Sim \\
\hline & 0,8 & 0,1084 & 0,1370 & Sim & 0,1159 & 0,1370 & Sim \\
\hline \multirow{7}{*}{ 15-Out } & 0,2 & 0,0705 & 0,1370 & Sim & 0,0468 & 0,1370 & Sim \\
\hline & 0,3 & 0,0414 & 0,1370 & Sim & 0,0418 & 0,1370 & Sim \\
\hline & 0,4 & 0,0917 & 0,1370 & Sim & 0,0541 & 0,1370 & Sim \\
\hline & 0,5 & 0,0316 & 0,1370 & Sim & 0,0553 & 0,1370 & Sim \\
\hline & 0,6 & 0,0778 & 0,1370 & Sim & 0,0856 & 0,1370 & Sim \\
\hline & 0,7 & 0,0539 & 0,1370 & Sim & 0,0682 & 0,1370 & Sim \\
\hline & 0,8 & 0,0662 & 0,1370 & Sim & 0,0628 & 0,1370 & Sim \\
\hline
\end{tabular}


Tabela 4A. Ajuste dos valores simulados de lâmina bruta de irrigação e produtividade de frutos de melancia à função de distribuição normal, pelo teste de Kolmogorov-Smirnov, em cada nível de manejo (p) e época de semeadura no município de Teresina, Piauí.

\begin{tabular}{|c|c|c|c|c|c|c|c|}
\hline \multirow{2}{*}{$\begin{array}{l}\text { Época de } \\
\text { Semeadura }\end{array}$} & \multirow[t]{2}{*}{$\mathrm{p}$} & \multicolumn{3}{|c|}{ Lâmina bruta } & \multicolumn{3}{|c|}{ Produtividade } \\
\hline & & Dmax & Dtab & Ajuste & $D \max$ & Dtab & Ajuste \\
\hline \multirow{7}{*}{ 1-Nov } & 0,2 & 0,0847 & 0,1370 & Sim & 0,0503 & 0,1370 & Sim \\
\hline & 0,3 & 0,1002 & 0,1370 & Sim & 0,0638 & 0,1370 & Sim \\
\hline & 0,4 & 0,0726 & 0,1370 & Sim & 0,0431 & 0,1370 & Sim \\
\hline & 0,5 & 0,0976 & 0,1370 & Sim & 0,0841 & 0,1370 & Sim \\
\hline & 0,6 & 0,0848 & 0,1370 & Sim & 0,0881 & 0,1370 & Sim \\
\hline & 0,7 & 0,0624 & 0,1370 & Sim & 0,0597 & 0,1370 & Sim \\
\hline & 0,8 & 0,1022 & 0,1370 & Sim & 0,1165 & 0,1370 & Sim \\
\hline \multirow{7}{*}{ 15-Nov } & 0,2 & 0,0275 & 0,1370 & Sim & 0,0512 & 0,1370 & Sim \\
\hline & 0,3 & 0,0586 & 0,1370 & Sim & 0,0325 & 0,1370 & Sim \\
\hline & 0,4 & 0,0579 & 0,1370 & Sim & 0,0594 & 0,1370 & Sim \\
\hline & 0,5 & 0,0560 & 0,1370 & Sim & 0,0618 & 0,1370 & Sim \\
\hline & 0,6 & 0,0341 & 0,1370 & Sim & 0,0591 & 0,1370 & Sim \\
\hline & 0,7 & 0,0532 & 0,1370 & Sim & 0,0983 & 0,1370 & Sim \\
\hline & 0,8 & 0,0748 & 0,1370 & Sim & 0,0726 & 0,1370 & Sim \\
\hline \multirow{7}{*}{ 1-Dez } & 0,2 & 0,0407 & 0,1370 & Sim & 0,0542 & 0,1370 & Sim \\
\hline & 0,3 & 0,0364 & 0,1370 & Sim & 0,0584 & 0,1370 & Sim \\
\hline & 0,4 & 0,0697 & 0,1370 & Sim & 0,0953 & 0,1370 & Sim \\
\hline & 0,5 & 0,0541 & 0,1370 & Sim & 0,0608 & 0,1370 & Sim \\
\hline & 0,6 & 0,0437 & 0,1370 & Sim & 0,0670 & 0,1370 & Sim \\
\hline & 0,7 & 0,0542 & 0,1370 & Sim & 0,0899 & 0,1370 & Sim \\
\hline & 0,8 & 0,0515 & 0,1370 & Sim & 0,0681 & 0,1370 & Sim \\
\hline \multirow{7}{*}{ 15-Dez } & 0,2 & 0,0615 & 0,1370 & Sim & 0,0724 & 0,1370 & Sim \\
\hline & 0,3 & 0,0457 & 0,1370 & Sim & 0,0520 & 0,1370 & Sim \\
\hline & 0,4 & 0,0577 & 0,1370 & Sim & 0,0487 & 0,1370 & Sim \\
\hline & 0,5 & 0,0599 & 0,1370 & Sim & 0,0775 & 0,1370 & Sim \\
\hline & 0,6 & 0,0742 & 0,1370 & Sim & 0,0352 & 0,1370 & Sim \\
\hline & 0,7 & 0,0559 & 0,1370 & Sim & 0,0592 & 0,1370 & Sim \\
\hline & 0,8 & 0,0598 & 0,1370 & Sim & 0,0698 & 0,1370 & Sim \\
\hline
\end{tabular}


Tabela 5A. Parâmetros da distribuição normal relativos aos valores simulados de lâmina bruta de irrigação e produtividade de grãos de feijão caupi, em cada nivel de manejo (p) e época de semeadura no município de Parnaiba, Piauí.

\begin{tabular}{|c|c|c|c|c|c|}
\hline \multirow{2}{*}{$\begin{array}{l}\text { Época de } \\
\text { Semeadura }\end{array}$} & \multirow[t]{2}{*}{$\mathrm{p}$} & \multicolumn{2}{|c|}{ Lâmina bruta (mm) } & \multicolumn{2}{|c|}{ Produtividade $\left(\mathrm{kg} \mathrm{ha}^{-1}\right)$} \\
\hline & & $\mu$ & $\sigma$ & $\mu$ & $\sigma$ \\
\hline \multirow{7}{*}{ 1-Jan } & 0,2 & 236,7 & 26,8 & 2287,1 & 25,5 \\
\hline & 0,3 & 224,2 & 30,2 & 2162,0 & 30,2 \\
\hline & 0,4 & 211,9 & 33,5 & 2057,2 & 47,9 \\
\hline & 0,5 & 200,5 & 35,2 & 1934,0 & 53,9 \\
\hline & 0,6 & 188,5 & 36,8 & 1840,2 & 65,7 \\
\hline & 0,7 & 178,4 & 39,5 & 1742,2 & 79,4 \\
\hline & 0,8 & 168,9 & 40,8 & 1662,9 & 86,7 \\
\hline \multirow{7}{*}{ 15-Jan } & 0,2 & 213,9 & 25,0 & 2309,6 & 25,1 \\
\hline & 0,3 & 200,0 & 28,6 & 2195,8 & 29,3 \\
\hline & 0,4 & 187,0 & 32,6 & 2078,9 & 44,7 \\
\hline & 0,5 & 173,4 & 35,6 & 1966,8 & 53,9 \\
\hline & 0,6 & 160,3 & 35,5 & 1868,5 & 72,7 \\
\hline & 0,7 & 149,8 & 40,6 & 1776,7 & 75,3 \\
\hline & 0,8 & 143,1 & 40,1 & 1707,1 & 87,0 \\
\hline \multirow{7}{*}{$1-\mathrm{Fev}$} & 0,2 & 193,1 & 27,0 & 2302,9 & 25,0 \\
\hline & 0,3 & 177,5 & 31,0 & 2196,1 & 28,9 \\
\hline & 0,4 & 161,4 & 34,6 & 2074,6 & 51,9 \\
\hline & 0,5 & 150,3 & 33,5 & 1978,5 & 56,2 \\
\hline & 0,6 & 138,9 & 37,2 & 1885,9 & 73,6 \\
\hline & 0,7 & 128,8 & 38,0 & 1806,1 & 85,8 \\
\hline & 0,8 & 116,8 & 38,7 & 1731,0 & 104,1 \\
\hline \multirow{7}{*}{$15-\mathrm{Fev}$} & 0,2 & 174,8 & 25,1 & 2293,8 & 26,0 \\
\hline & 0,3 & 161,5 & 27,3 & 2197,6 & 30,6 \\
\hline & 0,4 & 143,4 & 31,1 & 2068,8 & 53,9 \\
\hline & 0,5 & 130,3 & 32,4 & 1981,2 & 60,5 \\
\hline & 0,6 & 115,3 & 30,2 & 1891,0 & 81,9 \\
\hline & 0,7 & 108,6 & 33,0 & 1829,9 & 84,4 \\
\hline & 0,8 & 99,1 & 34,2 & 1749,8 & 101,0 \\
\hline
\end{tabular}


Tabela 5A. Parâmetros da distribuição normal relativos aos valores simulados de lâmina bruta de irrigação e produtividade de grãos de feijão caupi, em cada nível de manejo (p) e época de semeadura no município de Parnaíba, Piauí.

\begin{tabular}{|c|c|c|c|c|c|}
\hline \multirow{2}{*}{$\begin{array}{l}\text { Época de } \\
\text { Semeadura }\end{array}$} & \multirow[t]{2}{*}{$\mathrm{p}$} & \multicolumn{2}{|c|}{ Lâmina bruta (mm) } & \multicolumn{2}{|c|}{ Produtividade $\left(\mathrm{kg} \mathrm{ha}^{-\mathrm{i}}\right)$} \\
\hline & & $\mu$ & $\sigma$ & $\mu$ & $\sigma$ \\
\hline \multirow{7}{*}{ 1-Mar } & 0,2 & 167,6 & 26,6 & 2291,5 & 26,9 \\
\hline & 0,3 & 152,9 & 30,9 & 2199,1 & 34,1 \\
\hline & 0,4 & 136,9 & 33,3 & 2067,9 & 55,1 \\
\hline & 0,5 & 122,4 & 32,8 & 1987,6 & 68,9 \\
\hline & 0,6 & 111,2 & 35,9 & 1894,6 & 82,9 \\
\hline & 0,7 & 97,6 & 38,0 & 1824,0 & 98,9 \\
\hline & 0,8 & 85,1 & 39,8 & 1755,0 & 110,4 \\
\hline \multirow{7}{*}{ 15-Mar } & 0,2 & 175,8 & 25,8 & 2272,6 & 25,5 \\
\hline & 0,3 & 161,2 & 27,8 & 2182,8 & 33,8 \\
\hline & 0,4 & 145,6 & 30,6 & 2040,2 & 49,2 \\
\hline & 0,5 & 131,1 & 33,8 & 1952,2 & 58,2 \\
\hline & 0,6 & 120,2 & 36,9 & 1851,3 & 72,2 \\
\hline & 0,7 & 107,5 & 36,1 & 1778,0 & 85,1 \\
\hline & 0,8 & 96,2 & 36,6 & 1702,0 & 105,2 \\
\hline \multirow{7}{*}{$1-\mathrm{Abr}$} & 0,2 & 203,4 & 24,5 & 2273,3 & 23,1 \\
\hline & 0,3 & 191,3 & 26,9 & 2168,0 & 29,3 \\
\hline & 0,4 & 179,5 & 30,0 & 2019,0 & 47,0 \\
\hline & 0,5 & 167,5 & 30,0 & 1924,5 & 57,4 \\
\hline & 0,6 & 153,8 & 33,9 & 1803,6 & 70,8 \\
\hline & 0,7 & 145,6 & 36,4 & 1728,9 & 81,4 \\
\hline & 0,8 & 134,0 & 38,7 & 1640,7 & 93,8 \\
\hline \multirow{7}{*}{$15-\mathrm{Abr}$} & 0,2 & 228,4 & 22,8 & 2265,4 & 20,8 \\
\hline & 0,3 & 216,3 & 27,1 & 2151,7 & 26,1 \\
\hline & 0,4 & 205,9 & 27,2 & 1997,2 & 42,2 \\
\hline & 0,5 & 195,0 & 30,4 & 1888,9 & 53,4 \\
\hline & 0,6 & 183,3 & 34,7 & 1763,1 & 67,0 \\
\hline & 0,7 & 170,7 & 37,4 & 1676,1 & 71,4 \\
\hline & 0,8 & 166,5 & 40,3 & 1578,1 & 81,9 \\
\hline
\end{tabular}


Tabela 5A. Parâmetros da distribuição normal relativos aos valores simulados de lâmina bruta de irrigação e produtividade de grãos de feijão caupi, em cada nivel de manejo (p) e época de semeadura no município de Parnaiba, Piaui.

\begin{tabular}{|c|c|c|c|c|c|}
\hline \multirow{2}{*}{$\begin{array}{c}\text { Época de } \\
\text { Semeadura }\end{array}$} & \multirow[t]{2}{*}{$\mathrm{p}$} & \multicolumn{2}{|c|}{ Lâmina bruta (mm) } & \multicolumn{2}{|c|}{ Produtividade $\left(\mathrm{kg} \mathrm{ha}^{-1}\right)$} \\
\hline & & $\mu$ & $\sigma$ & $\mu$ & $\sigma$ \\
\hline \multirow{7}{*}{ 1-Mai } & 0,2 & 263,4 & 19,5 & 2261,6 & 20,4 \\
\hline & 0,3 & 254,9 & 20,8 & 2140,7 & 24,1 \\
\hline & 0,4 & 244,3 & 24,0 & 1977,7 & 37,7 \\
\hline & 0,5 & 238,7 & 26,1 & 1853,6 & 39,7 \\
\hline & 0,6 & 234,0 & 30,2 & 1732,0 & 46,7 \\
\hline & 0,7 & 222,4 & 35,1 & 1625,9 & 53,4 \\
\hline & 0,8 & 219,1 & 38,4 & 1517,6 & 52,6 \\
\hline \multirow{7}{*}{ 15-Mai } & 0,2 & 277,3 & 18,9 & 2268,2 & 22,5 \\
\hline & 0,3 & 269,6 & 22,3 & 2139,4 & 20,7 \\
\hline & 0,4 & 264,2 & 23,5 & 1989,4 & 41,1 \\
\hline & 0,5 & 256,2 & 26,4 & 1849,1 & 37,9 \\
\hline & 0,6 & 249,3 & 27,6 & 1728,7 & 44,7 \\
\hline & 0,7 & 246,7 & 30,5 & 1618,6 & 47,5 \\
\hline & 0,8 & 240,0 & 31,1 & 1510,2 & 48,5 \\
\hline \multirow{7}{*}{ 1-Jun } & 0,2 & 301,8 & 14,5 & 2283,3 & 21,5 \\
\hline & 0,3 & 296,6 & 15,5 & 2144,8 & 16,7 \\
\hline & 0,4 & 292,5 & 18,2 & 2005,7 & 37,8 \\
\hline & 0,5 & 286,7 & 19,9 & 1843,8 & 27,9 \\
\hline & 0,6 & 283,1 & 20,7 & 1742,4 & 44,6 \\
\hline & 0,7 & 276,8 & 23,0 & 1600,5 & 40,0 \\
\hline & 0,8 & 273,2 & 25,7 & 1510,6 & 48,6 \\
\hline \multirow{7}{*}{ 15-Jun } & 0,2 & 331,2 & 13,4 & 2309,4 & 22,1 \\
\hline & 0,3 & 327,3 & 14,0 & 2148,5 & 18,1 \\
\hline & 0,4 & 322,1 & 16,4 & 2036,2 & 33,0 \\
\hline & 0,5 & 319,1 & 15,8 & 1846,2 & 28,1 \\
\hline & 0,6 & 315,9 & 19,2 & 1762,2 & 34,1 \\
\hline & 0,7 & 311,2 & 20,9 & 1615,3 & 45,0 \\
\hline & 0,8 & 308,9 & 21,5 & 1520,7 & 40,6 \\
\hline
\end{tabular}


Tabela 5A. Parâmetros da distribuição normal relativos aos valores simulados de lâmina bruta de irrigação e produtividade de grãos de feijão caupi, em cada nível de manejo (p) e época de semeadura no município de Parnaíba, Piauí.

\begin{tabular}{|c|c|c|c|c|c|}
\hline \multirow{2}{*}{$\begin{array}{l}\text { Época de } \\
\text { Semeadura }\end{array}$} & \multirow[t]{2}{*}{$\mathrm{p}$} & \multicolumn{2}{|c|}{ Lâmina bruta (mm) } & \multicolumn{2}{|c|}{ Produtividade $\left(\mathrm{kg} \mathrm{ha}^{-1}\right)$} \\
\hline & & $\mu$ & $\sigma$ & $\mu$ & $\sigma$ \\
\hline \multirow{7}{*}{ 1-Jul } & 0,2 & 363,4 & 10,9 & 2335,3 & 20,8 \\
\hline & 0,3 & 358,8 & 12,5 & 2154,6 & 17,4 \\
\hline & 0,4 & 355,8 & 13,2 & 2059,1 & 29,3 \\
\hline & 0,5 & 353,4 & 16,9 & 1874,7 & 34,4 \\
\hline & 0,6 & 350,0 & 16,2 & 1763,1 & 25,7 \\
\hline & 0,7 & 346,5 & 18,0 & 1639,5 & 40,3 \\
\hline & 0,8 & 343,8 & 18,9 & 1522,5 & 35,0 \\
\hline \multirow{7}{*}{ 15-Jul } & 0,2 & 394,4 & 11,1 & 2361,9 & 20,4 \\
\hline & 0,3 & 390,3 & 11,1 & 2166,7 & 18,6 \\
\hline & 0,4 & 389,3 & 12,9 & 2076,4 & 20,5 \\
\hline & 0,5 & 387,2 & 14,0 & 1924,5 & 41,4 \\
\hline & 0,6 & 385,2 & 15,0 & 1767,4 & 25,2 \\
\hline & 0,7 & 382,9 & 15,1 & 1677,3 & 36,4 \\
\hline & 0,8 & 381,8 & 15,5 & 1529,0 & 40,7 \\
\hline \multirow{7}{*}{ 1-Ago } & 0,2 & 434,0 & 5,9 & 2391,8 & 17,9 \\
\hline & 0,3 & 430,7 & 7,1 & 2185,4 & 17,6 \\
\hline & 0,4 & 429,6 & 6,5 & 2088,7 & 18,2 \\
\hline & 0,5 & 428,1 & 8,4 & 1978,5 & 33,3 \\
\hline & 0,6 & 425,7 & 7,8 & 1775,1 & 25,3 \\
\hline & 0,7 & 424,4 & 7,1 & 1694,1 & 21,7 \\
\hline & 0,8 & 421,5 & 10,8 & 1577,5 & 43,5 \\
\hline \multirow{7}{*}{ 15-Ago } & 0,2 & 454,1 & 5,8 & 2411,5 & 17,1 \\
\hline & 0,3 & 451,9 & 7,2 & 2206,4 & 20,5 \\
\hline & 0,4 & 450,3 & 6,0 & 2098,0 & 17,8 \\
\hline & 0,5 & 446,6 & 7,3 & 2005,2 & 26,9 \\
\hline & 0,6 & 445,5 & 8,9 & 1800,5 & 32,7 \\
\hline & 0,7 & 441,3 & 11,9 & 1691,4 & 19,2 \\
\hline & 0,8 & 442,8 & 11,0 & 1613,2 & 35,1 \\
\hline
\end{tabular}


Tabela 5A. Parâmetros da distribuição normal relativos aos valores simulados de lâmina bruta de irrigação e produtividade de grãos de feijão caupi, em cada nível de manejo (p) e época de semeadura no município de Parnaíba, Piauí.

\begin{tabular}{|c|c|c|c|c|c|}
\hline \multirow{2}{*}{$\begin{array}{c}\text { Época de } \\
\text { Semeadura }\end{array}$} & \multirow[t]{2}{*}{$\mathrm{p}$} & \multicolumn{2}{|c|}{ Lâmina bruta $(\mathrm{mm})$} & \multicolumn{2}{|c|}{ Produtividade $\left(\mathrm{kg} \mathrm{ha}^{-1}\right)$} \\
\hline & & $\mu$ & $\sigma$ & $\mu$ & $\sigma$ \\
\hline \multirow{7}{*}{$1-$ Set } & 0,2 & 469,1 & 5,2 & 2420,8 & 15,3 \\
\hline & 0,3 & 467,1 & 6,3 & 2223,5 & 24,9 \\
\hline & 0,4 & 465,1 & 6,1 & 2098,9 & 16,9 \\
\hline & 0,5 & 462,1 & 7,1 & 2020,7 & 20,8 \\
\hline & 0,6 & 462,9 & 8,0 & 1826,5 & 42,1 \\
\hline & 0,7 & 457,7 & 11,2 & 1689,9 & 18,8 \\
\hline & 0,8 & 456,3 & 11,5 & 1642,9 & 20,5 \\
\hline \multirow{7}{*}{ 15-Set } & 0,2 & 465,2 & 7,1 & 2423,4 & 14,9 \\
\hline & 0,3 & 463,9 & 7,2 & 2219,6 & 22,8 \\
\hline & 0,4 & 461,3 & 7,3 & 2101,4 & 17,6 \\
\hline & 0,5 & 458,7 & 9,0 & 2023,0 & 23,0 \\
\hline & 0,6 & 459,5 & 9,1 & 1828,7 & 41,5 \\
\hline & 0,7 & 455,4 & 12,5 & 1697,9 & 23,4 \\
\hline & 0,8 & 452,1 & 11,0 & 1642,7 & 26,2 \\
\hline \multirow{7}{*}{ 1-Out } & 0,2 & 461,6 & 8,8 & 2417,6 & 17,7 \\
\hline & 0,3 & 459,6 & 10,2 & 2223,4 & 22,7 \\
\hline & 0,4 & 456,8 & 10,6 & 2101,2 & 17,5 \\
\hline & 0,5 & 454,1 & 11,8 & 2018,2 & 22,8 \\
\hline & 0,6 & 453,6 & 12,9 & 1821,2 & 38,9 \\
\hline & 0,7 & 451,4 & 12,9 & 1695,4 & 24,9 \\
\hline & 0,8 & 447,1 & 13,4 & 1641,5 & 23,9 \\
\hline \multirow{7}{*}{ 15-Out } & 0,2 & 450,1 & 10,2 & 2412,4 & 16,5 \\
\hline & 0,3 & 446,3 & 11,1 & 2206,6 & 21,2 \\
\hline & 0,4 & 446,1 & 10,7 & 2100,8 & 19,0 \\
\hline & 0,5 & 441,9 & 11,8 & 2013,5 & 24,4 \\
\hline & 0,6 & 440,5 & 13,5 & 1809,2 & 38,2 \\
\hline & 0,7 & 435,1 & 15,6 & 1699,7 & 24,3 \\
\hline & 0,8 & 435,5 & 15,3 & 1629,2 & 36,2 \\
\hline
\end{tabular}


Tabela 5A. Parâmetros da distribuição normal relativos aos valores simulados de lâmina bruta de irrigação e produtividade de grãos de feijão caupi, em cada nivel de manejo (p) e época de semeadura no municipio de Parnaiba, Piaui.

\begin{tabular}{|c|c|c|c|c|c|}
\hline \multirow{2}{*}{$\begin{array}{l}\text { Época de } \\
\text { Semeadura }\end{array}$} & \multirow[t]{2}{*}{$\mathrm{p}$} & \multicolumn{2}{|c|}{ Lâmina bruta (mm) } & \multicolumn{2}{|c|}{ Produtividade $\left(\mathrm{kg} \mathrm{ha}^{-1}\right)$} \\
\hline & & $\mu$ & $\sigma$ & $\mu$ & $\sigma$ \\
\hline \multirow{7}{*}{$1-\mathrm{Nov}$} & 0,2 & 403,8 & 17,3 & 2382,2 & 20,3 \\
\hline & 0,3 & 399,5 & 20,0 & 2196,2 & 20,0 \\
\hline & 0,4 & 394,1 & 20,7 & 2095,5 & 22,8 \\
\hline & 0,5 & 389,8 & 21,0 & 1967,4 & 36,7 \\
\hline & 0,6 & 387,5 & 24,3 & 1801,9 & 37,2 \\
\hline & 0,7 & 382,6 & 26,4 & 1706,4 & 36,1 \\
\hline & 0,8 & 378,6 & 28,3 & 1589,7 & 49,8 \\
\hline \multirow{7}{*}{ 15-Nov } & 0,2 & 357,6 & 20,5 & 2358,4 & 21,1 \\
\hline & 0,3 & 350,6 & 22,5 & 2188,5 & 25,5 \\
\hline & 0,4 & 345,5 & 24,9 & 2091,0 & 29,0 \\
\hline & 0,5 & 338,8 & 28,1 & 1948,5 & 47,0 \\
\hline & 0,6 & 331,8 & 29,0 & 1808,2 & 42,2 \\
\hline & 0,7 & 325,8 & 33,5 & 1717,3 & 48,1 \\
\hline & 0,8 & 319,4 & 35,2 & 1595,1 & 58,2 \\
\hline \multirow{7}{*}{ 1-Dez } & 0,2 & 325,4 & 20,6 & 2338,1 & 26,7 \\
\hline & 0,3 & 316,3 & 23,4 & 2180,7 & 24,3 \\
\hline & 0,4 & 310,1 & 24,7 & 2078,5 & 35,3 \\
\hline & 0,5 & 300,2 & 28,1 & 1929,9 & 46,0 \\
\hline & 0,6 & 295,0 & 27,0 & 1811,6 & 52,0 \\
\hline & 0,7 & 287,6 & 31,8 & 1708,2 & 57,3 \\
\hline & 0,8 & 283,2 & 33,7 & 1599,3 & 60,3 \\
\hline \multirow{7}{*}{ 15-Dez } & 0,2 & 278,8 & 26,1 & 2322,5 & 24,5 \\
\hline & 0,3 & 265,8 & 29,4 & 2176,4 & 26,0 \\
\hline & 0,4 & 256,8 & 32,2 & 2075,1 & 39,3 \\
\hline & 0,5 & 246,9 & 34,2 & 1928,4 & 54,1 \\
\hline & 0,6 & 239,7 & 35,4 & 1826,6 & 59,6 \\
\hline & 0,7 & 229,0 & 39,0 & 1716,1 & 67,9 \\
\hline & 0,8 & 222,4 & 42,2 & 1627,6 & 78,5 \\
\hline
\end{tabular}


Tabela 6A. Parâmetros da distribuição normal relativos aos valores simulados de lâmina bruta de irrigação e produtividade de frutos de melancia, em cada nivel de manejo (p) e época de semeadura no municipio de Parnaiba, Piaui.

\begin{tabular}{|c|c|c|c|c|c|}
\hline \multirow{2}{*}{$\begin{array}{l}\text { Época de } \\
\text { Semeadura }\end{array}$} & \multirow[t]{2}{*}{$\mathrm{p}$} & \multicolumn{2}{|c|}{ Lâmina bruta (mm) } & \multicolumn{2}{|c|}{ Produtividade $\left(\mathrm{kg} \mathrm{ha}^{-1}\right)$} \\
\hline & & $\mu$ & $\sigma$ & $\mu$ & $\sigma$ \\
\hline \multirow{7}{*}{ 1-Jan } & 0,2 & 233,6 & 26,0 & 43552,7 & 570,9 \\
\hline & 0,3 & 224,6 & 28,6 & 40743,4 & 790,6 \\
\hline & 0,4 & 211,2 & 31,4 & 37257,3 & 1007,0 \\
\hline & 0,5 & 202,1 & 34,2 & 34515,7 & 1222,4 \\
\hline & 0,6 & 188,6 & 35,3 & 31812,6 & 1465,7 \\
\hline & 0,7 & 178,3 & 38,2 & 29701,0 & 1781,7 \\
\hline & 0,8 & 165,4 & 41,7 & 27604,2 & 1781,6 \\
\hline \multirow{7}{*}{$15-J a n$} & 0,2 & 211,5 & 25,0 & 44329,4 & 578,5 \\
\hline & 0,3 & 198,7 & 28,7 & 41579,9 & 752,7 \\
\hline & 0,4 & 182,7 & 32,0 & 37886,8 & 1044,7 \\
\hline & 0,5 & 172,0 & 34,8 & 35407,5 & 1224,7 \\
\hline & 0,6 & 157,3 & 38,4 & 32773,1 & 1478,7 \\
\hline & 0,7 & 148,9 & 35,9 & 30958,0 & 1762,9 \\
\hline & 0,8 & 139,7 & 36,3 & 29087,7 & 1981,6 \\
\hline \multirow{7}{*}{$1-\mathrm{Fev}$} & 0,2 & 190,2 & 27,1 & 44203,8 & 544,2 \\
\hline & 0,3 & 176,3 & 29,6 & 41562,0 & 733,6 \\
\hline & 0,4 & 157,0 & 31,2 & 37977,0 & 1105,5 \\
\hline & 0,5 & 147,0 & 33,0 & 35778,8 & 1479,8 \\
\hline & 0,6 & 137,4 & 35,0 & 33420,2 & 1575,6 \\
\hline & 0,7 & 124,9 & 36,7 & 31472,3 & 1987,0 \\
\hline & 0,8 & 115,3 & 39,1 & 29683,5 & 2204,1 \\
\hline \multirow{7}{*}{$15-\mathrm{Fev}$} & 0,2 & 172,5 & 24,0 & 44061,5 & 558,6 \\
\hline & 0,3 & 158,1 & 25,1 & 41385,8 & 918,0 \\
\hline & 0,4 & 143,0 & 33,7 & 38140,9 & 1008,4 \\
\hline & 0,5 & 127,8 & 32,3 & 35674,9 & 1526,4 \\
\hline & 0,6 & 115,4 & 29,1 & 33719,1 & 1798,8 \\
\hline & 0,7 & 104,3 & 32,3 & 31784,2 & 1888,6 \\
\hline & 0,8 & 93,8 & 38,4 & 30174,4 & 1949,9 \\
\hline
\end{tabular}


Tabela 6A. Parâmetros da distribuição normal relativos aos valores simulados de lâmina bruta de irrigação e produtividade de frutos de melancia, em cada nível de manejo (p) e época de semeadura no município de Parnaiba, Piauí.

\begin{tabular}{|c|c|c|c|c|c|}
\hline \multirow{2}{*}{$\begin{array}{l}\text { Época de } \\
\text { Semeadura }\end{array}$} & \multirow[t]{2}{*}{$\mathrm{p}$} & \multicolumn{2}{|c|}{ Lâmina bruta $(\mathrm{mm})$} & \multicolumn{2}{|c|}{ Produtividade $\left(\mathrm{kg} \mathrm{ha}^{-1}\right)$} \\
\hline & & $\mu$ & $\sigma$ & $\mu$ & $\sigma$ \\
\hline \multirow{7}{*}{ 1-Mar } & 0,2 & 166,0 & 27,1 & 44108,6 & 613,7 \\
\hline & 0,3 & 150,3 & 29,5 & 41399,6 & 923,9 \\
\hline & 0,4 & 133,3 & 32,7 & 38124,5 & 1273,1 \\
\hline & 0,5 & 120,8 & 36,0 & 35784,5 & 1653,9 \\
\hline & 0,6 & 105,7 & 34,1 & 33652,7 & 1962,4 \\
\hline & 0,7 & 93,9 & 35,7 & 31787,0 & 2249,7 \\
\hline & 0,8 & 82,6 & 38,7 & 30395,1 & 2370,9 \\
\hline \multirow{7}{*}{ 15-Mar } & 0,2 & 174,3 & 25,3 & 43745,8 & 582,0 \\
\hline & 0,3 & 159,5 & 27,3 & 40897,4 & 895,4 \\
\hline & 0,4 & 142,4 & 30,0 & 37528,4 & 1088,0 \\
\hline & 0,5 & 131,4 & 31,9 & 35123,5 & 1341,9 \\
\hline & 0,6 & 116,7 & 34,2 & 32737,4 & 1637,1 \\
\hline & 0,7 & 105,9 & 39,3 & 30918,4 & 1959,2 \\
\hline & 0,8 & 89,4 & 38,6 & 29310,1 & 2373,3 \\
\hline \multirow{7}{*}{$1-\mathrm{Abr}$} & 0,2 & 202,1 & 24,0 & 43513,0 & 470,9 \\
\hline & 0,3 & 191,8 & 25,4 & 40633,5 & 778,2 \\
\hline & 0,4 & 176,2 & 28,7 & 36795,5 & 1128,1 \\
\hline & 0,5 & 164,7 & 30,6 & 33989,4 & 1312,1 \\
\hline & 0,6 & 154,8 & 34,9 & 31534,7 & 1570,4 \\
\hline & 0,7 & 141,1 & 36,5 & 29309,5 & 1783,2 \\
\hline & 0,8 & 133,9 & 40,2 & 27577,9 & 2102,5 \\
\hline \multirow{7}{*}{ 15-Abr } & 0,2 & 225,2 & 23,0 & 43262,9 & 426,0 \\
\hline & 0,3 & 215,9 & 26,7 & 40248,7 & 691,0 \\
\hline & 0,4 & 202,3 & 26,8 & 36174,0 & 970,9 \\
\hline & 0,5 & 193,3 & 30,9 & 33306,1 & 1160,0 \\
\hline & 0,6 & 180,2 & 34,2 & 30578,6 & 1407,9 \\
\hline & 0,7 & 170,1 & 37,4 & 28080,6 & 1509,9 \\
\hline & 0,8 & 162,2 & 40,2 & 26297,2 & 1646,5 \\
\hline
\end{tabular}


Tabela 6A. Parâmetros da distribuição normal relativos aos valores simulados de lâmina bruta de irrigação e produtividade de frutos de melancia, em cada nível de manejo (p) e época de semeadura no município de Parnaiba, Piauí.

\begin{tabular}{|c|c|c|c|c|c|}
\hline \multirow{2}{*}{$\begin{array}{l}\text { Época de } \\
\text { Semeadura }\end{array}$} & \multirow[t]{2}{*}{$\mathrm{p}$} & \multicolumn{2}{|c|}{ Lâmina bruta (mm) } & \multicolumn{2}{|c|}{ Produtividade $\left(\mathrm{kg} \mathrm{ha}^{-1}\right)$} \\
\hline & & $\mu$ & $\sigma$ & $\mu$ & $\sigma$ \\
\hline \multirow{7}{*}{ 1-Mai } & 0,2 & 261,2 & 18,5 & 43041,7 & 393,0 \\
\hline & 0,3 & 254,4 & 20,3 & 40050,6 & 649,8 \\
\hline & 0,4 & 243,1 & 23,8 & 35478,3 & 749,7 \\
\hline & 0,5 & 236,8 & 29,1 & 32442,5 & 918,6 \\
\hline & 0,6 & 228,5 & 32,8 & 29482,1 & 917,2 \\
\hline & 0,7 & 222,5 & 34,8 & 26873,8 & 1065,3 \\
\hline & 0,8 & 215,5 & 34,4 & 24741,9 & 1264,5 \\
\hline \multirow{7}{*}{ 15-Mai } & 0,2 & 273,8 & 18,8 & 43039,6 & 419,4 \\
\hline & 0,3 & 267,6 & 22,1 & 40120,3 & 523,9 \\
\hline & 0,4 & 260,5 & 23,2 & 35468,1 & 716,4 \\
\hline & 0,5 & 255,6 & 27,3 & 32526,2 & 873,1 \\
\hline & 0,6 & 247,8 & 29,2 & 29197,6 & 938,9 \\
\hline & 0,7 & 243,9 & 31,6 & 26870,5 & 1061,8 \\
\hline & 0,8 & 236,2 & 32,7 & 24445,6 & 1084,3 \\
\hline \multirow{7}{*}{ 1-Jun } & 0,2 & 299,9 & 13,9 & 43297,0 & 398,2 \\
\hline & 0,3 & 294,9 & 15,7 & 40375,4 & 513,2 \\
\hline & 0,4 & 290,3 & 18,3 & 35541,8 & 559,2 \\
\hline & 0,5 & 284,7 & 18,9 & 32661,0 & 680,5 \\
\hline & 0,6 & 278,4 & 23,2 & 28967,3 & 790,8 \\
\hline & 0,7 & 276,7 & 23,3 & 26795,2 & 809,0 \\
\hline & 0,8 & 272,0 & 25,1 & 24020,2 & 870,4 \\
\hline \multirow{7}{*}{ 15-Jun } & 0,2 & 328,3 & 13,4 & 43891,0 & 451,3 \\
\hline & 0,3 & 325,0 & 13,6 & 40720,6 & 424,0 \\
\hline & 0,4 & 319,1 & 16,2 & 36197,6 & 643,4 \\
\hline & 0,5 & 315,9 & 16,4 & 32907,4 & 517,4 \\
\hline & 0,6 & 311,8 & 20,2 & 29517,8 & 783,9 \\
\hline & 0,7 & 312,3 & 17,0 & 26888,7 & 762,7 \\
\hline & 0,8 & 305,9 & 21,4 & 24244,1 & 781,5 \\
\hline
\end{tabular}


Tabela 6A. Parâmetros da distribuição normal relativos aos valores simulados de lâmina bruta de irrigação e produtividade de frutos de melancia. em cada nível de manejo (p) e época de semeadura no município de Parnaiba, Piaui.

\begin{tabular}{|c|c|c|c|c|c|}
\hline \multirow{2}{*}{$\begin{array}{l}\text { Época de } \\
\text { Semeadura }\end{array}$} & \multirow[t]{2}{*}{$\mathrm{p}$} & \multicolumn{2}{|c|}{ Lâmina bruta (mm) } & \multicolumn{2}{|c|}{ Produtividade $\left(\mathrm{kg} \mathrm{ha}^{-1}\right)$} \\
\hline & & $\mu$ & $\sigma$ & $\mu$ & $\sigma$ \\
\hline \multirow{7}{*}{ 1-Jul } & 0.2 & 360,3 & 11,5 & 44668,3 & 520,4 \\
\hline & 0,3 & 356,3 & 11,9 & 40988,6 & 453,3 \\
\hline & 0,4 & 353,6 & 13,5 & 37154,9 & 700,8 \\
\hline & 0,5 & 349,9 & 15,2 & 33022,9 & 550,4 \\
\hline & 0,6 & 348,1 & 18,4 & 30100,4 & 748,2 \\
\hline & 0,7 & 344,0 & 18,6 & 26961,0 & 665,1 \\
\hline & 0,8 & 343,9 & 16,6 & 24684,3 & 853,9 \\
\hline \multirow{7}{*}{ 15-Jul } & 0,2 & 391,5 & 11,1 & 45546,1 & 521,6 \\
\hline & 0,3 & 388,1 & 11,3 & 41298,2 & 347,8 \\
\hline & 0,4 & 385,7 & 11,9 & 38118,3 & 581,3 \\
\hline & 0,5 & 384,7 & 12,9 & 33490,3 & 547,8 \\
\hline & 0,6 & 380,3 & 17,3 & 30876,8 & 674,1 \\
\hline & 0,7 & 379,5 & 16,1 & 27384,8 & 672,5 \\
\hline & 0,8 & 376,1 & 15,1 & 25029,8 & 579,6 \\
\hline \multirow{7}{*}{ 1-Ago } & 0,2 & 430,6 & 6,4 & 46923,8 & 491,4 \\
\hline & 0,3 & 428,3 & 6,6 & 41471,5 & 205,9 \\
\hline & 0,4 & 426,9 & 7,1 & 38868,6 & 481,2 \\
\hline & 0,5 & 424,8 & 8,2 & 34315,3 & 590,7 \\
\hline & 0,6 & 421,6 & 14,3 & 31030,0 & 528,6 \\
\hline & 0,7 & 420,5 & 9,3 & 28523,1 & 640,0 \\
\hline & 0,8 & 420,4 & 9,6 & 25205,2 & 476,5 \\
\hline \multirow{7}{*}{ 15-Ago } & 0,2 & 450,2 & 6,1 & 47644,4 & 425,6 \\
\hline & 0,3 & 448,8 & 6,2 & 41537,5 & 239,2 \\
\hline & 0,4 & 446,5 & 6,6 & 39354,6 & 399,9 \\
\hline & 0,5 & 445,0 & 7,8 & 35144,5 & 787,5 \\
\hline & 0,6 & 442,8 & 12,8 & 31290,4 & 407,3 \\
\hline & 0,7 & 439,9 & 9,2 & 29152,6 & 579,5 \\
\hline & 0,8 & 440,9 & 11,9 & 25396,6 & 499,0 \\
\hline
\end{tabular}


Tabela 6A. Parâmetros da distribuição normal relativos aos valores simulados de lâmina bruta de irrigação e produtividade de frutos de melancia, em cada nível de manejo (p) e época de semeadura no município de Parnaiba, Piauí.

\begin{tabular}{|c|c|c|c|c|c|}
\hline \multirow{2}{*}{$\begin{array}{l}\text { Época de } \\
\text { Semeadura }\end{array}$} & \multirow[t]{2}{*}{$\mathrm{p}$} & \multicolumn{2}{|c|}{ Lâmina bruta (mm) } & \multicolumn{2}{|c|}{ Produtividade $\left(\mathrm{kg} \mathrm{ha}^{-1}\right)$} \\
\hline & & $\mu$ & $\sigma$ & $\mu$ & $\sigma$ \\
\hline \multirow{7}{*}{$1-$ Set } & 0,2 & 464,8 & 4,8 & 48167,5 & 381,3 \\
\hline & 0,3 & 464,3 & 5,7 & 41506,9 & 212,8 \\
\hline & 0,4 & 461,3 & 6,3 & 39597,4 & 303,1 \\
\hline & 0,5 & 458,0 & 6,5 & 36089,0 & 711,4 \\
\hline & 0,6 & 457,5 & 14,8 & 31382,5 & 375,7 \\
\hline & 0,7 & 455,0 & 9,3 & 29614,6 & 603,6 \\
\hline & 0,8 & 453,9 & 11,1 & 25906,1 & 582,0 \\
\hline \multirow{7}{*}{ 15-Set } & 0,2 & 461,4 & 6,9 & 48172,6 & 377,3 \\
\hline & 0,3 & 460,4 & 7,6 & 41600,5 & 246,5 \\
\hline & 0,4 & 457,9 & 7,3 & 39619,4 & 416,1 \\
\hline & 0,5 & 455,0 & 8,1 & 36054,6 & 748,6 \\
\hline & 0,6 & 454,3 & 15,0 & 31582,7 & 422,9 \\
\hline & 0,7 & 451,5 & 11,4 & 29572,2 & 672,9 \\
\hline & 0,8 & 447,5 & 9,2 & 25989,7 & 575,6 \\
\hline \multirow{7}{*}{ 1-Out } & 0,2 & 458,2 & 8,5 & 48014,4 & 391,3 \\
\hline & 0,3 & 456,2 & 9,4 & 41577,2 & 221,5 \\
\hline & 0,4 & 453,6 & 10,7 & 39585,1 & 394,9 \\
\hline & 0,5 & 450,5 & 10,8 & 36034,9 & 677,5 \\
\hline & 0,6 & 448,7 & 16,6 & 31419,7 & 515,3 \\
\hline & 0,7 & 447,4 & 13,1 & 29570,2 & 607,2 \\
\hline & 0,8 & 445,1 & 15,9 & 25904,3 & 561,5 \\
\hline \multirow{7}{*}{ 15-Out } & 0,2 & 446,7 & 10,0 & 47687,7 & 447,8 \\
\hline & 0,3 & 444,3 & 10,6 & 41623,1 & 210,1 \\
\hline & 0,4 & 442,6 & 10,9 & 39445,9 & 454,1 \\
\hline & 0,5 & 438,9 & 11,3 & 35333,2 & 754,3 \\
\hline & 0,6 & 436,9 & 18,3 & 31419,0 & 460,1 \\
\hline & 0,7 & 432,9 & 14,4 & 29323,9 & 565,5 \\
\hline & 0,8 & 431,9 & 17,7 & 25667,3 & 537,7 \\
\hline
\end{tabular}


Tabela 6A. Parâmetros da distribuição normal relativos aos valores simulados de lâmina bruta de irrigação e produtividade de frutos de melancia, em cada nível de manejo (p) e época de semeadura no município de Parnaíba, Piauí.

\begin{tabular}{|c|c|c|c|c|c|}
\hline \multirow{2}{*}{$\begin{array}{l}\text { Época de } \\
\text { Semeadura }\end{array}$} & \multirow[t]{2}{*}{$\mathrm{p}$} & \multicolumn{2}{|c|}{ Lâmina bruta (mm) } & \multicolumn{2}{|c|}{ Produtividade $\left(\mathrm{kg} \mathrm{ha}^{-1}\right)$} \\
\hline & & $\mu$ & $\sigma$ & $\mu$ & $\sigma$ \\
\hline \multirow{7}{*}{$1-\mathrm{Nov}$} & 0,2 & 401,0 & 17,0 & 46332,0 & 591,6 \\
\hline & 0,3 & 397,2 & 19,2 & 41701,1 & 378,3 \\
\hline & 0,4 & 391,0 & 20,5 & 38761,8 & 673,8 \\
\hline & 0,5 & 388,7 & 22,0 & 34612,4 & 666,3 \\
\hline & 0,6 & 383,6 & 27,4 & 31501,7 & 726,8 \\
\hline & 0,7 & 379,7 & 25,3 & 28608,9 & 787,9 \\
\hline & 0,8 & 375,5 & 28,6 & 25834,6 & 811,5 \\
\hline \multirow{7}{*}{$15-\mathrm{Nov}$} & 0,2 & 354,9 & 20,1 & 45622,7 & 528,7 \\
\hline & 0,3 & 348,2 & 23,1 & 41580,7 & 480,5 \\
\hline & 0,4 & 343,0 & 24,1 & 38456,4 & 819,9 \\
\hline & 0,5 & 336,1 & 25,3 & 34363,6 & 840,0 \\
\hline & 0,6 & 326,9 & 29,3 & 31563,0 & 969,1 \\
\hline & 0,7 & 323,6 & 31,6 & 28638,6 & 1075,9 \\
\hline & 0,8 & 317,1 & 35,9 & 26166,3 & 1155,2 \\
\hline \multirow{7}{*}{ 1-Dez } & 0,2 & 322,6 & 20,0 & 45034,4 & 656,0 \\
\hline & 0,3 & 314,8 & 21,7 & 41440,0 & 526,0 \\
\hline & 0,4 & 308,8 & 25,6 & 37981,1 & 860,1 \\
\hline & 0,5 & 298,0 & 27,8 & 34227,6 & 915,4 \\
\hline & 0,6 & 291,1 & 30,9 & 31434,1 & 1129,3 \\
\hline & 0,7 & 284,1 & 31,2 & 28770,7 & 1118,0 \\
\hline & 0,8 & 279,2 & 34,4 & 26322,5 & 1336,5 \\
\hline \multirow{7}{*}{ 15-Dez } & 0,2 & 275,4 & 25,5 & 44518,3 & 558,9 \\
\hline & 0,3 & 264,7 & 28,0 & 41333,0 & 699,0 \\
\hline & 0,4 & 253,4 & 32,9 & 37650,9 & 882,3 \\
\hline & 0,5 & 244,5 & 34,9 & 34489,4 & 1182,2 \\
\hline & 0,6 & 235,9 & 35,9 & 31679,7 & 1388,6 \\
\hline & 0,7 & 226,1 & 40,6 & 29192,5 & 1370,7 \\
\hline & 0,8 & 218,4 & 39,9 & 27023,4 & 1578,0 \\
\hline
\end{tabular}


Tabela 7A. Parâmetros da distribuição normal relativos aos valores simulados de lâmina bruta de irrigação e produtividade de grãos de feijão caupi, em cada nivel de manejo (p) e época de semeadura no município de Teresina, Piauí.

\begin{tabular}{|c|c|c|c|c|c|}
\hline \multirow{2}{*}{$\begin{array}{l}\text { Época de } \\
\text { Semeadura }\end{array}$} & \multirow[t]{2}{*}{$\mathrm{p}$} & \multicolumn{2}{|c|}{ Lâmina bruta (mm) } & \multicolumn{2}{|c|}{ Produtividade $\left(\mathrm{kg} \mathrm{ha}^{-1}\right)$} \\
\hline & & $\mu$ & $\sigma$ & $\mu$ & $\sigma$ \\
\hline \multirow{7}{*}{ 1-Jan } & 0,2 & 148,7 & 25,2 & 2220,1 & 21,3 \\
\hline & 0,3 & 134,8 & 27,6 & 2120,8 & 42,1 \\
\hline & 0,4 & 118,6 & 32,3 & 2007,7 & 49,8 \\
\hline & 0,5 & 102,4 & 34,7 & 1900,3 & 67,2 \\
\hline & 0,6 & 86,9 & 34,9 & 1836,8 & 77,8 \\
\hline & 0,7 & 75,6 & 34,3 & 1766,0 & 99,6 \\
\hline & 0,8 & 68,1 & 37,1 & 1709,0 & 117,1 \\
\hline \multirow{7}{*}{ 15-Jan } & 0,2 & 133,4 & 25,6 & 2257,7 & 27,7 \\
\hline & 0,3 & 117,5 & 29,1 & 2160,8 & 41,9 \\
\hline & 0,4 & 101,5 & 30,2 & 2061,4 & 55,5 \\
\hline & 0,5 & 86,1 & 33,1 & 1970,7 & 67,3 \\
\hline & 0,6 & 73,0 & 37,2 & 1906,5 & 83,0 \\
\hline & 0,7 & 59,9 & 34,5 & 1844,2 & 101,2 \\
\hline & 0,8 & 52,6 & 34,0 & 1795,4 & 127,3 \\
\hline \multirow{7}{*}{$1-\mathrm{Fev}$} & 0,2 & 114,1 & 22,6 & 2276,1 & 28,0 \\
\hline & 0,3 & 95,1 & 26,2 & 2182,8 & 44,3 \\
\hline & 0,4 & 77,2 & 26,8 & 2095,8 & 58,0 \\
\hline & 0,5 & 63,0 & 26,2 & 2015,4 & 78,6 \\
\hline & 0,6 & 53,7 & 25,4 & 1971,3 & 95,8 \\
\hline & 0,7 & 41,3 & 28,0 & 1918,3 & 109,0 \\
\hline & 0,8 & 34,0 & 28,4 & 1881,3 & 123,0 \\
\hline \multirow{7}{*}{$15-\mathrm{Fev}$} & 0,2 & 106,6 & 29,4 & 2275,0 & 29,8 \\
\hline & 0,3 & 89,7 & 29,3 & 2181,2 & 48,7 \\
\hline & 0,4 & 73,5 & 32,8 & 2100,8 & 66,7 \\
\hline & 0,5 & 56,7 & 32,8 & 2024,1 & 82,9 \\
\hline & 0,6 & 48,0 & 34,1 & 1983,2 & 99,1 \\
\hline & 0,7 & 38,3 & 32,9 & 1939,5 & 123,7 \\
\hline & 0,8 & 31,5 & 30,5 & 1903,9 & 151,3 \\
\hline
\end{tabular}


Tabela 7A. Parâmetros da distribuição normal relativos aos valores simulados de lâmina bruta de irrigação e produtividade de grãos de feijão caupi, em cada nivel de manejo (p) e época de semeadura no município de Teresina, Piaui.

\begin{tabular}{|c|c|c|c|c|c|}
\hline \multirow{2}{*}{$\begin{array}{l}\text { Epoca de } \\
\text { Semeadura }\end{array}$} & \multirow[t]{2}{*}{$\mathrm{p}$} & \multicolumn{2}{|c|}{ Lâmina bruta (mm) } & \multicolumn{2}{|c|}{ Produtividade $\left(\mathrm{kg} \mathrm{ha}^{-1}\right)$} \\
\hline & & $\mu$ & $\sigma$ & $\mu$ & $\sigma$ \\
\hline \multirow{7}{*}{ 1-Mar } & 0,2 & 107,5 & 25,4 & 2270,2 & 28,6 \\
\hline & 0,3 & 89,6 & 28,9 & 2171,0 & 50,9 \\
\hline & 0,4 & 68,6 & 29,0 & 2088,5 & 62,2 \\
\hline & 0,5 & 58,5 & 30,0 & 2016,7 & 80,0 \\
\hline & 0,6 & 49,7 & 28,0 & 1966,8 & 100,7 \\
\hline & 0,7 & 38,7 & 27,9 & 1915,4 & 121,2 \\
\hline & 0,8 & 28,8 & 27,6 & 1875,0 & 144,2 \\
\hline \multirow{7}{*}{ 15-Mar } & 0,2 & 128,5 & 25,8 & 2251,5 & 26,7 \\
\hline & 0,3 & 109,7 & 30,3 & 2125,6 & 42,9 \\
\hline & 0,4 & 94,2 & 32,0 & 2046,8 & 56,4 \\
\hline & 0,5 & 80,6 & 33,1 & 1942,1 & 81,4 \\
\hline & 0,6 & 70,6 & 34,3 & 1872,7 & 98,6 \\
\hline & 0,7 & 56,8 & 32,6 & 1818,6 & 112,3 \\
\hline & 0,8 & 48,3 & 33,7 & 1763,0 & 133,1 \\
\hline \multirow{7}{*}{$1-A b r$} & 0,2 & 155,0 & 25,6 & 2228,8 & 28,3 \\
\hline & 0,3 & 141,1 & 26,9 & 2091,4 & 48,4 \\
\hline & 0,4 & 128,1 & 28,4 & 1999,8 & 57,8 \\
\hline & 0,5 & 115,7 & 33,4 & 1882,6 & 73,5 \\
\hline & 0,6 & 104,8 & 38,4 & 1798,8 & 90,4 \\
\hline & 0,7 & 95,5 & 38,1 & 1729,9 & 106,2 \\
\hline & 0,8 & 83,6 & 37,3 & 1661,9 & 126,5 \\
\hline \multirow{7}{*}{$15-\mathrm{Abr}$} & 0,2 & 188,1 & 22,1 & 2204,3 & 26,6 \\
\hline & 0,3 & 177,4 & 25,2 & 2048,0 & 39,8 \\
\hline & 0,4 & 163,6 & 29,4 & 1939,8 & 47,9 \\
\hline & 0,5 & 151,4 & 32,7 & 1808,9 & 62,7 \\
\hline & 0,6 & 144,5 & 33,9 & 1701,7 & 78,3 \\
\hline & 0,7 & 136,0 & 35,4 & 1614,3 & 92,8 \\
\hline & 0,8 & 126,9 & 37,1 & 1535,0 & 103,2 \\
\hline
\end{tabular}


Tabela 7A. Parâmetros da distribuição normal relativos aos valores simulados de lâmina bruta de irrigação e produtividade de grãos de feijão caupi, em cada nivel de manejo (p) e época de semeadura no município de Teresina, Piauí.

\begin{tabular}{|c|c|c|c|c|c|}
\hline \multirow{2}{*}{$\begin{array}{l}\text { Época de } \\
\text { Semeadura }\end{array}$} & \multirow[t]{2}{*}{$\mathrm{p}$} & \multicolumn{2}{|c|}{ Lâmina bruta (mm) } & \multicolumn{2}{|c|}{ Produtividade $\left(\mathrm{kg} \mathrm{ha}^{-1}\right)$} \\
\hline & & $\mu$ & $\sigma$ & $\mu$ & $\sigma$ \\
\hline \multirow{7}{*}{ 1-Mai } & 0,2 & 212,6 & 21,7 & 2187,2 & 20,8 \\
\hline & 0,3 & 202,0 & 24,6 & 2019,5 & 37,7 \\
\hline & 0,4 & 193,1 & 27,5 & 1905,0 & 43,9 \\
\hline & 0,5 & 185,2 & 32,7 & 1759,8 & 55,1 \\
\hline & 0,6 & 178,8 & 34,8 & 1647,0 & 64,8 \\
\hline & 0,7 & 172,5 & 34,8 & 1564,4 & 80,0 \\
\hline & 0,8 & 161,8 & 40,4 & 1455,8 & 84,9 \\
\hline \multirow{7}{*}{ 15-Mai } & 0,2 & 241,8 & 14,7 & 2177,7 & 18,1 \\
\hline & 0,3 & 235,0 & 16,6 & 2025,5 & 33,4 \\
\hline & 0,4 & 229,0 & 19,6 & 1881,5 & 30,1 \\
\hline & 0,5 & 223,6 & 22,1 & 1724,1 & 46,6 \\
\hline & 0,6 & 218,7 & 23,4 & 1621,2 & 52,6 \\
\hline & 0,7 & 211,0 & 25,6 & 1505,1 & 53,3 \\
\hline & 0,8 & 208,0 & 29,4 & 1407,5 & 68,6 \\
\hline \multirow{7}{*}{ 1-Jun } & 0,2 & 266,6 & 12,0 & 2180,3 & 15,4 \\
\hline & 0,3 & 261,5 & 14,3 & 2042,9 & 28,2 \\
\hline & 0,4 & 258,6 & 14,3 & 1874,2 & 26,8 \\
\hline & 0,5 & 255,2 & 16,4 & 1721,6 & 33,0 \\
\hline & 0,6 & 249,8 & 20,2 & 1618,9 & 39,5 \\
\hline & 0,7 & 248,5 & 19,2 & 1494,6 & 40,8 \\
\hline & 0,8 & 244,7 & 20,8 & 1386,8 & 46,3 \\
\hline \multirow{7}{*}{ 15-Jun } & 0,2 & 288,3 & 9,6 & 2190,8 & 14,7 \\
\hline & 0,3 & 284,2 & 11,8 & 2066,0 & 27,0 \\
\hline & 0,4 & 280,6 & 13,7 & 1875,1 & 22,3 \\
\hline & 0,5 & 276,9 & 14,4 & 1743,3 & 40,7 \\
\hline & 0,6 & 273,6 & 15,8 & 1612,4 & 33,4 \\
\hline & 0,7 & 271,3 & 16,9 & 1490,9 & 38,0 \\
\hline & 0,8 & 266,7 & 18,8 & 1394,5 & 35,5 \\
\hline
\end{tabular}


Tabela 7A. Parâmetros da distribuição normal relativos aos valores simulados de lâmina bruta de irrigação e produtividade de grãos de feijão caupi, em cada nivel de manejo (p) e época de semeadura no município de Teresina, Piauí.

\begin{tabular}{|c|c|c|c|c|c|}
\hline \multirow{2}{*}{$\begin{array}{c}\text { Época de } \\
\text { Semeadura }\end{array}$} & \multirow[t]{2}{*}{$\mathrm{p}$} & \multicolumn{2}{|c|}{ Lâmina bruta (mm) } & \multicolumn{2}{|c|}{ Produtividade $\left(\mathrm{kg} \mathrm{ha}^{-1}\right)$} \\
\hline & & $\mu$ & $\sigma$ & $\mu$ & $\sigma$ \\
\hline \multirow{7}{*}{ 1-Jul } & 0,2 & 314,7 & 8,0 & 2211,5 & 15,3 \\
\hline & 0,3 & 312,4 & 8,0 & 2091,2 & 23,2 \\
\hline & 0,4 & 310,0 & 9,6 & 1889,8 & 19,1 \\
\hline & 0,5 & 306,3 & 12,0 & 1777,5 & 30,4 \\
\hline & 0,6 & 305,0 & 13,5 & 1634,9 & 32,2 \\
\hline & 0,7 & 299,0 & 13,5 & 1523,5 & 43,0 \\
\hline & 0,8 & 300,6 & 16,8 & 1410,9 & 31,2 \\
\hline \multirow{7}{*}{ 15-Jul } & 0,2 & 337,2 & 8,5 & 2233,2 & 19,0 \\
\hline & 0,3 & 334,8 & 9,0 & 2110,9 & 19,4 \\
\hline & 0,4 & 332,0 & 9,4 & 1915,1 & 26,9 \\
\hline & 0,5 & 329,8 & 12,2 & 1804,4 & 20,3 \\
\hline & 0,6 & 328,8 & 12,8 & 1636,3 & 33,9 \\
\hline & 0,7 & 323,5 & 13,6 & 1543,1 & 28,3 \\
\hline & 0,8 & 321,0 & 15,5 & 1412,7 & 32,9 \\
\hline \multirow{7}{*}{ 1-Ago } & 0,2 & 351,5 & 8,4 & 2259,3 & 19,9 \\
\hline & 0,3 & 348,4 & 10,7 & 2128,3 & 15,9 \\
\hline & 0,4 & 347,1 & 10,9 & 1960,0 & 33,1 \\
\hline & 0,5 & 340,5 & 13,6 & 1813,0 & 21,4 \\
\hline & 0,6 & 338,3 & 16,0 & 1674,1 & 40,8 \\
\hline & 0,7 & 335,0 & 16,8 & 1556,1 & 29,8 \\
\hline & 0,8 & 334,3 & 16,1 & 1446,9 & 42,6 \\
\hline \multirow{7}{*}{ 15-Ago } & 0,2 & 360,8 & 9,7 & 2275,2 & 22,4 \\
\hline & 0,3 & 357,8 & 11,5 & 2136,2 & 14,6 \\
\hline & 0,4 & 356,0 & 13,0 & 1994,5 & 35,8 \\
\hline & 0,5 & 350,3 & 13,1 & 1820,3 & 25,3 \\
\hline & 0,6 & 349,4 & 14,8 & 1717,5 & 35,2 \\
\hline & 0,7 & 345,0 & 17,7 & 1576,7 & 32,6 \\
\hline & 0,8 & 341,3 & 18,9 & 1488,2 & 39,5 \\
\hline
\end{tabular}


Tabela 7A. Parâmetros da distribuição normal relativos aos valores simulados de lâmina bruta de irrigação e produtividade de grãos de feijão caupi, em cada nivel de manejo (p) e época de semeadura no município de Teresina, Piauí.

\begin{tabular}{|c|c|c|c|c|c|}
\hline \multirow{2}{*}{$\begin{array}{l}\text { Época de } \\
\text { Semeadura }\end{array}$} & \multirow[t]{2}{*}{$\mathrm{p}$} & \multicolumn{2}{|c|}{ Lâmina bruta (mm) } & \multicolumn{2}{|c|}{ Produtividade $\left(\mathrm{kg} \mathrm{ha}^{-1}\right)$} \\
\hline & & $\mu$ & $\sigma$ & $\mu$ & $\sigma$ \\
\hline \multirow{7}{*}{$1-$ Set } & 0,2 & 358,3 & 12,2 & 2280,6 & 21,8 \\
\hline & 0,3 & 353,7 & 13,0 & 2137,5 & 15,3 \\
\hline & 0,4 & 349,5 & 15,1 & 1999,5 & 38,9 \\
\hline & 0,5 & 344,1 & 18,2 & 1823,2 & 22,9 \\
\hline & 0,6 & 338,8 & 20,1 & 1717,6 & 38,8 \\
\hline & 0,7 & 337,1 & 21,3 & 1577,1 & 37,6 \\
\hline & 0,8 & 332,4 & 22,3 & 1500,9 & 40,5 \\
\hline \multirow{7}{*}{ 15-Set } & 0,2 & 349,3 & 13,7 & 2273,4 & 22,1 \\
\hline & 0,3 & 344,9 & 16,0 & 2135,2 & 16,8 \\
\hline & 0,4 & 338,7 & 18,7 & 1984,8 & 37,7 \\
\hline & 0,5 & 333,8 & 19,4 & 1825,0 & 30,2 \\
\hline & 0,6 & 331,4 & 21,1 & 1716,8 & 46,5 \\
\hline & 0,7 & $.325,4$ & 25,3 & 1583,1 & 39,4 \\
\hline & 0,8 & 323,7 & 24,8 & 1491,7 & 47,0 \\
\hline \multirow{7}{*}{ 1-Out } & 0,2 & 336,7 & 14,7 & 2257,6 & 20,2 \\
\hline & 0,3 & 332,9 & 15,8 & 2128,5 & 18,1 \\
\hline & 0,4 & 326,8 & 18,4 & 1967,3 & 32,8 \\
\hline & 0,5 & 321,5 & 21,6 & 1826,4 & 28,2 \\
\hline & 0,6 & 315,4 & 25,7 & 1698,7 & 40,3 \\
\hline & 0,7 & 311,1 & 25,1 & 1574,6 & 40,2 \\
\hline & 0,8 & 308,2 & 26,4 & 1472,1 & 46,2 \\
\hline \multirow{7}{*}{ 15-Out } & 0,2 & 317,3 & 16,5 & 2245,1 & 21,0 \\
\hline & 0,3 & 311,5 & 19,2 & 2127,7 & 17,9 \\
\hline & 0,4 & 304,3 & 21,4 & 1944,1 & 31,5 \\
\hline & 0,5 & 295,3 & 25,3 & 1827,7 & 31,5 \\
\hline & 0,6 & 291,7 & 27,4 & 1685,8 & 45,3 \\
\hline & 0,7 & 286,9 & 27,9 & 1583,2 & 43,1 \\
\hline & 0,8 & 282,1 & 28,5 & 1473,0 & 51,6 \\
\hline
\end{tabular}


Tabela 7A. Parâmetros da distribuição normal relativos aos valores simulados de lâmina bruta de irrigação e produtividade de grãos de feijão caupi, em cada nivel de manejo (p) e época de semeadura no município de Teresina, Piauí.

\begin{tabular}{|c|c|c|c|c|c|}
\hline \multirow{2}{*}{$\begin{array}{l}\text { Época de } \\
\text { Semeadura }\end{array}$} & \multirow[t]{2}{*}{$\mathrm{p}$} & \multicolumn{2}{|c|}{ Lâmina bruta (mm) } & \multicolumn{2}{|c|}{ Produtividade $\left(\mathrm{kg} \mathrm{ha}^{-1}\right)$} \\
\hline & & $\mu$ & $\sigma$ & $\mu$ & $\sigma$ \\
\hline \multirow{7}{*}{$1-\mathrm{Nov}$} & 0,2 & 273,2 & 21,1 & 2231,1 & 17,9 \\
\hline & 0,3 & 264,8 & 24,4 & 2116,2 & 29,3 \\
\hline & 0,4 & 253,6 & 29,1 & 1937,2 & 31,7 \\
\hline & 0,5 & 248,5 & 29,8 & 1830,6 & 44,1 \\
\hline & 0,6 & 239,9 & 32,8 & 1694,5 & 52,6 \\
\hline & 0,7 & 231,9 & 35,5 & 1599,2 & 57,4 \\
\hline & 0,8 & 223,6 & 38,9 & 1495,2 & 68,1 \\
\hline \multirow{7}{*}{ 15-Nov } & 0,2 & 236,4 & 23,9 & 2225,2 & 23,2 \\
\hline & 0,3 & 225,0 & 26,3 & 2109,2 & 33,4 \\
\hline & 0,4 & 210,5 & 29,2 & 1950,0 & 45,7 \\
\hline & 0,5 & 199,7 & 32,1 & 1842,0 & 62,3 \\
\hline & 0,6 & 189,8 & 37,2 & 1728,6 & 71,5 \\
\hline & 0,7 & 180,3 & 38,7 & 1627,9 & 81,7 \\
\hline & 0,8 & 172,9 & 39,4 & 1548,3 & 94,5 \\
\hline \multirow{7}{*}{ 1-Dez } & 0,2 & 208,1 & 22,4 & 2221,8 & 19,6 \\
\hline & 0,3 & 194,8 & 24,9 & 2106,0 & 34,5 \\
\hline & 0,4 & 180,7 & 29,3 & 1957,8 & 39,6 \\
\hline & 0,5 & 166,9 & 33,6 & 1841,6 & 54,6 \\
\hline & 0,6 & 161,2 & 33,2 & 1744,0 & 64,2 \\
\hline & 0,7 & 145,8 & 38,9 & 1645,3 & 69,7 \\
\hline & 0,8 & 133,7 & 42,6 & 1564,4 & 84,4 \\
\hline \multirow{7}{*}{ 15-Dez } & 0,2 & 178,8 & 24,8 & 2227,0 & 23,1 \\
\hline & 0,3 & 165,2 & 27,4 & 2112,3 & 39,7 \\
\hline & 0,4 & 148,7 & 29,5 & 1975,8 & 44,3 \\
\hline & 0,5 & 134,2 & 30,9 & 1864,6 & 66,2 \\
\hline & 0,6 & 122,6 & 35,0 & 1786,0 & 70,1 \\
\hline & 0,7 & 110,0 & 36,7 & 1697,1 & 89,5 \\
\hline & 0,8 & 97,4 & 37,2 & 1622,4 & 101,5 \\
\hline
\end{tabular}


Tabela 8A. Parâmetros da distribuição normal relativos aos valores simulados de lâmina bruta de irrigação e produtividade de frutos de melancia, em cada nivel de manejo (p) e época de semeadura no municipio de Teresina, Piaui.

\begin{tabular}{|c|c|c|c|c|c|}
\hline \multirow{2}{*}{$\begin{array}{c}\text { Época de } \\
\text { Semeadura }\end{array}$} & \multirow[t]{2}{*}{$\mathrm{p}$} & \multicolumn{2}{|c|}{ Lâmina bruta (mm) } & \multicolumn{2}{|c|}{ Produtividade $\left(\mathrm{kg} \mathrm{ha}^{-1}\right)$} \\
\hline & & $\mu$ & $\sigma$ & $\mu$ & $\sigma$ \\
\hline \multirow{7}{*}{ 1-Jan } & 0,2 & 149,3 & 24,5 & 42532,8 & 570,9 \\
\hline & 0,3 & 132,1 & 27,6 & 38892,6 & 965,0 \\
\hline & 0,4 & 115,2 & 30,7 & 36433,1 & 1320,9 \\
\hline & 0,5 & 97,9 & 32,2 & 33971,2 & 1579,8 \\
\hline & 0,6 & 83,9 & 35,0 & 32088,6 & 1867,4 \\
\hline & 0,7 & 73,8 & 34,7 & 30692,1 & 2274,2 \\
\hline & 0,8 & 65,7 & 36,9 & 29416,6 & 2569,3 \\
\hline \multirow{7}{*}{ 15-Jan } & 0,2 & 134,0 & 24,7 & 43583,8 & 645,9 \\
\hline & 0,3 & 112,4 & 29,0 & 40054,5 & 952,0 \\
\hline & 0,4 & 96,8 & 29,5 & 37802,7 & 1249,5 \\
\hline & 0,5 & 82,3 & 34,2 & 35707,9 & 1540,0 \\
\hline & 0,6 & 69,6 & 36,2 & 33985,0 & 1927,8 \\
\hline & 0,7 & 58,5 & 34,1 & 32622,0 & 2515,2 \\
\hline & 0,8 & 50,6 & 34,7 & 31569,4 & 2751,5 \\
\hline \multirow{7}{*}{$1-\mathrm{Fev}$} & 0,2 & 113,3 & 22,0 & 43947,5 & 739,0 \\
\hline & 0,3 & 91,4 & 26,0 & 40656,0 & 1016,2 \\
\hline & 0,4 & 76,2 & 25,9 & 38709,3 & 1486,0 \\
\hline & 0,5 & 60,9 & 26,2 & 36912,3 & 1765,0 \\
\hline & 0,6 & 50,3 & 27,0 & 35428,6 & 2179,0 \\
\hline & 0,7 & 36,7 & 26,1 & 34346,4 & 2463,7 \\
\hline & 0,8 & 31,8 & 25,4 & 33524,4 & 2682,9 \\
\hline \multirow{7}{*}{$15-\mathrm{Fev}$} & 0,2 & 107,6 & 28,8 & 44059,8 & 779,2 \\
\hline & 0,3 & 85,6 & 28,7 & 40900,6 & 1278,3 \\
\hline & 0,4 & 72,1 & 32,8 & 38908,0 & 1666,4 \\
\hline & 0,5 & 55,1 & 30,4 & 37154,7 & 2011,4 \\
\hline & 0,6 & 44,5 & 32,7 & 35865,2 & 2427,4 \\
\hline & 0,7 & 36,5 & 31,4 & 34941,0 & 2883,6 \\
\hline & 0,8 & 30,5 & 27,1 & 34271,8 & 3178,2 \\
\hline
\end{tabular}


Tabela 8A. Parâmetros da distribuição normal relativos aos valores simulados de lâmina bruta de irrigação e produtividade de frutos de melancia, em cada nível de manejo (p) e época de semeadura no município de Teresina, Piauí.

\begin{tabular}{|c|c|c|c|c|c|}
\hline \multirow{2}{*}{$\begin{array}{l}\text { Época de } \\
\text { Semeadura }\end{array}$} & \multirow[t]{2}{*}{$\mathrm{p}$} & \multicolumn{2}{|c|}{ Lâmina bruta (mm) } & \multicolumn{2}{|c|}{ Produtividade $\left(\mathrm{kg} \mathrm{ha}^{-1}\right)$} \\
\hline & & $\mu$ & $\sigma$ & $\mu$ & $\sigma$ \\
\hline \multirow{7}{*}{ 1-Mar } & 0,2 & 107,5 & 24,4 & 43848,5 & 780,6 \\
\hline & 0,3 & 85,9 & 26,0 & 40634,1 & 1278,2 \\
\hline & 0,4 & 66,3 & 26,8 & 38455,3 & 1593,6 \\
\hline & 0,5 & 55,8 & 28,6 & 36958,4 & 1881,2 \\
\hline & 0,6 & 45,6 & 28,3 & 35623,2 & 2348,7 \\
\hline & 0,7 & 34,2 & 26,7 & 34402,6 & 2896,7 \\
\hline & 0,8 & 24,3 & 25,2 & 33615,9 & 3249,8 \\
\hline \multirow{7}{*}{ 15-Mar } & 0,2 & 127,3 & 25,0 & 43303,1 & 702,2 \\
\hline & 0,3 & 106,6 & 29,1 & 39654,3 & 1020,3 \\
\hline & 0,4 & 91,4 & 33,3 & 37079,7 & 1448,8 \\
\hline & 0,5 & 80,0 & 31,3 & 35312,7 & 1835,9 \\
\hline & 0,6 & 65,6 & 32,3 & 33533,4 & 2245,5 \\
\hline & 0,7 & 54,3 & 31,7 & 32097,3 & 2635,1 \\
\hline & 0,8 & 45,6 & 33,6 & 30883,3 & 2943,9 \\
\hline \multirow{7}{*}{$1-\mathrm{Abr}$} & 0,2 & 154,5 & 24,3 & 42677,8 & 721,9 \\
\hline & 0,3 & 139,3 & 26,4 & 38585,8 & 1083,1 \\
\hline & 0,4 & 125,5 & 29,4 & 35694,1 & 1493,3 \\
\hline & 0,5 & 114,1 & 33,8 & 33421,2 & 1687,4 \\
\hline & 0,6 & 102,5 & 35,5 & 31280,1 & 1935,2 \\
\hline & 0,7 & 92,4 & 38,4 & 29482,4 & 2233,1 \\
\hline & 0,8 & 81,3 & 38,8 & 27999,6 & 2614,5 \\
\hline \multirow{7}{*}{ 15-Abr } & 0,2 & 187,5 & 21,7 & 42115,9 & 617,4 \\
\hline & 0,3 & 175,3 & 25,5 & 37479,5 & 925,8 \\
\hline & 0,4 & 159,8 & 28,8 & 34008,8 & 1202,5 \\
\hline & 0,5 & 150,8 & 32,3 & 31497,0 & 1466,5 \\
\hline & 0,6 & 140,4 & 31,9 & 29157,0 & 1804,0 \\
\hline & 0,7 & 134,0 & 33,9 & 26913,0 & 1992,9 \\
\hline & 0,8 & 125,6 & 36,7 & 24965,3 & 2157,4 \\
\hline
\end{tabular}


Tabela 8A. Parâmetros da distribuição normal relativos aos valores simulados de lâmina bruta de irrigação e produtividade de frutos de melancia, em cada nivel de manejo (p) e época de semeadura no município de Teresina, Piaui.

\begin{tabular}{|c|c|c|c|c|c|}
\hline \multirow{2}{*}{$\begin{array}{l}\text { Época de } \\
\text { Semeadura }\end{array}$} & \multirow[t]{2}{*}{$\mathrm{p}$} & \multicolumn{2}{|c|}{ Lâmina bruta (mm) } & \multicolumn{2}{|c|}{ Produtividade $\left(\mathrm{kg} \mathrm{ha}^{-1}\right)$} \\
\hline & & $\mu$ & $\sigma$ & $\mu$ & $\sigma$ \\
\hline \multirow{7}{*}{ 1-Mai } & 0,2 & 212,3 & 21,2 & 41613,6 & 513,0 \\
\hline & 0,3 & 199,8 & 24,4 & 36619,7 & 795,7 \\
\hline & 0,4 & 189,9 & 27,3 & 33037,6 & 1056,2 \\
\hline & 0,5 & 183,7 & 32,7 & 30385,9 & 1060,1 \\
\hline & 0,6 & 176,5 & 34,0 & 27644,0 & 1406,4 \\
\hline & 0,7 & 166,5 & 33,9 & 25204,5 & 1695,6 \\
\hline & 0,8 & 160,7 & 40,6 & 23094,6 & 1781,6 \\
\hline \multirow{7}{*}{ 15-Mai } & 0,2 & 240,3 & 14,0 & 41507,9 & 349,2 \\
\hline & 0,3 & 230,6 & 18,1 & 36182,4 & 548,7 \\
\hline & 0,4 & 227,8 & 19,9 & 32655,2 & 716,7 \\
\hline & 0,5 & 220,4 & 22,3 & 29531,7 & 794,7 \\
\hline & 0,6 & 214,6 & 22,5 & 26440,7 & 956,8 \\
\hline & 0,7 & 208,3 & 25,8 & 23954,7 & 1071,4 \\
\hline & 0,8 & 207,3 & 25,6 & 21929,5 & 1114,0 \\
\hline \multirow{7}{*}{ 1-Jun } & 0,2 & 264,2 & 12,5 & 41556,6 & 392,0 \\
\hline & 0,3 & 260,2 & 14,1 & 36562,9 & 552,9 \\
\hline & 0,4 & 256,4 & 14,7 & 33014,4 & 670,1 \\
\hline & 0,5 & 253,8 & 16,1 & 29415,3 & 609,0 \\
\hline & 0,6 & 247,8 & 19,2 & 26194,8 & 761,5 \\
\hline & 0,7 & 246,9 & 20,0 & 23815,9 & 851,9 \\
\hline & 0,8 & 242,7 & 21,6 & 21517,4 & 795,0 \\
\hline \multirow{7}{*}{ 15-Jun } & 0,2 & 286,6 & 9,6 & 41878,7 & 297,9 \\
\hline & 0,3 & 281,8 & 12,1 & 37175,5 & 523,9 \\
\hline & 0,4 & 277,6 & 12,4 & 33459,1 & 599,1 \\
\hline & 0,5 & 277,0 & 14,2 & 29552,3 & 561,2 \\
\hline & 0,6 & 270,7 & 16,4 & 26590,0 & 675,1 \\
\hline & 0,7 & 271,1 & 19,7 & 23939,9 & 563,3 \\
\hline & 0,8 & 266,4 & 17,6 & 21587,8 & 664,9 \\
\hline
\end{tabular}


Tabela 8A. Parâmetros da distribuição normal relativos aos valores simulados de lâmina bruta de irrigação e produtividade de frutos de melancia, em cada nivel de manejo (p) e época de semeadura no município de Teresina, Piaui.

\begin{tabular}{|c|c|c|c|c|c|}
\hline \multirow{2}{*}{$\begin{array}{c}\text { Época de } \\
\text { Semeadura }\end{array}$} & \multirow[t]{2}{*}{$\mathrm{p}$} & \multicolumn{2}{|c|}{ Lâmina bruta (mm) } & \multicolumn{2}{|c|}{ Produtividade $\left(\mathrm{kg} \mathrm{ha}^{-1}\right)$} \\
\hline & & $\mu$ & $\sigma$ & $\mu$ & $\sigma$ \\
\hline \multirow{7}{*}{ 1-Jul } & 0,2 & 313,1 & 7,5 & 42132,1 & 248,4 \\
\hline & 0,3 & 311,0 & 8,3 & 38244,1 & 550,1 \\
\hline & 0,4 & 306,6 & 9,8 & 33818,9 & 494,0 \\
\hline & 0,5 & 304,8 & 12,0 & 29878,4 & 518,4 \\
\hline & 0,6 & 302,3 & 12,4 & 27202,5 & 623,9 \\
\hline & 0,7 & 297,2 & 14,6 & 24121,2 & 577,2 \\
\hline & 0,8 & 296,9 & 13,6 & 21793,7 & 547,5 \\
\hline \multirow{7}{*}{ 15-Jul } & 0,2 & 335,3 & 6,9 & 42276,6 & 216,4 \\
\hline & 0,3 & 331,9 & 8,5 & 39070,9 & 553,5 \\
\hline & 0,4 & 330,7 & 9,3 & 34106,5 & 460,8 \\
\hline & 0,5 & 327,1 & 11,4 & 30740,5 & 614,6 \\
\hline & 0,6 & 324,4 & 11,6 & 27703,0 & 410,4 \\
\hline & 0,7 & 322,7 & 13,4 & 24497,1 & 605,3 \\
\hline & 0,8 & 323,4 & 16,4 & 22499,5 & 656,7 \\
\hline \multirow{7}{*}{ 1-Ago } & 0,2 & 348,9 & 9,3 & 42548,4 & 240,4 \\
\hline & 0,3 & 346,2 & 10,1 & 39813,0 & 405,2 \\
\hline & 0,4 & 343,9 & 11,3 & 34523,3 & 377,4 \\
\hline & 0,5 & 339,2 & 14,2 & 31650,4 & 537,6 \\
\hline & 0,6 & 337,2 & 17,2 & 27900,0 & 500,7 \\
\hline & 0,7 & 333,3 & 16,1 & 25419,1 & 635,4 \\
\hline & 0,8 & 330,8 & 12,9 & 22956,7 & 574,5 \\
\hline \multirow{7}{*}{ 15-Ago } & 0,2 & 357,9 & 9,5 & 42803,0 & 280,7 \\
\hline & 0,3 & 355,5 & 10,7 & 40180,0 & 367,6 \\
\hline & 0,4 & 352,0 & 11,9 & 34835,1 & 401,0 \\
\hline & 0,5 & 348,3 & 14,3 & 32186,0 & 506,8 \\
\hline & 0,6 & 346,9 & 14,9 & 28185,5 & 539,1 \\
\hline & 0,7 & 344,2 & 16,6 & 25962,0 & 697,1 \\
\hline & 0,8 & 337,9 & 15,1 & 22874,0 & 700,4 \\
\hline
\end{tabular}


Tabela 8A. Parâmetros da distribuição normal relativos aos valores simulados de lâmina bruta de irrigação e produtividade de frutos de melancia, em cada nível de manejo $(p)$ e época de semeadura no município de Teresina, Piauí.

\begin{tabular}{|c|c|c|c|c|c|}
\hline \multirow{2}{*}{$\begin{array}{c}\text { Época de } \\
\text { Semeadura }\end{array}$} & \multirow[t]{2}{*}{$\mathrm{p}$} & \multicolumn{2}{|c|}{ Lâmina bruta (mm) } & \multicolumn{2}{|c|}{ Produtividade $\left(\mathrm{kg} \mathrm{ha}^{-1}\right)$} \\
\hline & & $\mu$ & $\sigma$ & $\mu$ & $\sigma$ \\
\hline \multirow{7}{*}{ 1-Set } & 0,2 & 354,4 & 11,3 & 42956,5 & 318,4 \\
\hline & 0,3 & 350,3 & 13,0 & 40249,5 & 370,8 \\
\hline & 0,4 & 346,1 & 15,9 & 35037,9 & 444,4 \\
\hline & 0,5 & 341,4 & 17,4 & 32353,1 & 531,7 \\
\hline & 0,6 & 337,0 & 20,0 & 28453,0 & 546,2 \\
\hline & 0,7 & 333,8 & 20,5 & 26120,5 & 719,8 \\
\hline & 0,8 & 328,8 & 24,0 & 23244,6 & 717,2 \\
\hline \multirow{7}{*}{$15-$ Set } & 0,2 & 346,9 & 13,1 & 42878,6 & 318,8 \\
\hline & 0,3 & 341,8 & 15,3 & 40091,5 & 404,9 \\
\hline & 0,4 & 336,8 & 16,5 & 35012,8 & 511,0 \\
\hline & 0,5 & 332,3 & 18,9 & 32356,7 & 616,0 \\
\hline & 0,6 & 327,7 & 24,3 & 28512,2 & 604,6 \\
\hline & 0,7 & 325,8 & 22,7 & 26248,2 & 801,8 \\
\hline & 0,8 & 320,9 & 25,3 & 23375,4 & 784,8 \\
\hline \multirow{7}{*}{ 1-Out } & 0,2 & 334,6 & 13,7 & 42778,4 & 347,4 \\
\hline & 0,3 & 330,2 & 16,2 & 39892,6 & 474,2 \\
\hline & 0,4 & 323,7 & 19,6 & 34823,6 & 472,6 \\
\hline & 0,5 & 320,1 & 21,8 & 31983,0 & 670,9 \\
\hline & 0,6 & 315,3 & 24,1 & 28363,1 & 661,5 \\
\hline & 0,7 & 310,8 & 23,7 & 25876,8 & 711,7 \\
\hline & 0,8 & 305,4 & 27,3 & 23303,3 & 896,9 \\
\hline \multirow{7}{*}{ 15-Out } & 0,2 & 314,8 & 16,0 & 42706,2 & 347,9 \\
\hline & 0,3 & 309,0 & 17,8 & 39487,7 & 506,3 \\
\hline & 0,4 & 304,2 & 21,4 & 34798,1 & 658,2 \\
\hline & 0,5 & 296,0 & 22,7 & 31650,0 & 798,0 \\
\hline & 0,6 & 290,0 & 27,4 & 28452,2 & 800,1 \\
\hline & 0,7 & 281,7 & 31,1 & 25741,7 & 794,2 \\
\hline & 0,8 & 278,6 & 33,6 & 23633,8 & 881,6 \\
\hline
\end{tabular}


Tabela 8A. Parâmetros da distribuição normal relativos aos valores simulados de lâmina bruta de irrigação e produtividade de frutos de melancia, em cada nível de manejo (p) e época de semeadura no município de Teresina, Piauí.

\begin{tabular}{|c|c|c|c|c|c|}
\hline \multirow{2}{*}{$\begin{array}{l}\text { Época de } \\
\text { Semeadura }\end{array}$} & \multirow[t]{2}{*}{$\mathrm{p}$} & \multicolumn{2}{|c|}{ Lâmina bruta $(\mathrm{mm})$} & \multicolumn{2}{|c|}{ Produtividade $\left(\mathrm{kg} \mathrm{ha}^{-1}\right)$} \\
\hline & & $\mu$ & $\sigma$ & $\mu$ & $\sigma$ \\
\hline \multirow{7}{*}{$1-\mathrm{Nov}$} & 0,2 & 271,8 & 21,0 & 42568,9 & 381,8 \\
\hline & 0,3 & 263,4 & 23,3 & 38952,0 & 743,1 \\
\hline & 0,4 & 255,0 & 27,4 & 34902,3 & 735,9 \\
\hline & 0,5 & 244,6 & 30,9 & 31521,1 & 865,4 \\
\hline & 0,6 & 236,7 & 34,7 & 28697,0 & 1118,0 \\
\hline & 0,7 & 228,3 & 36,0 & 26138,6 & 1148,3 \\
\hline & 0,8 & 220,1 & 39,6 & 23977,4 & 1480,6 \\
\hline \multirow{7}{*}{ 15-Nov } & 0,2 & 235,5 & 23,9 & 42634,4 & 498,5 \\
\hline & 0,3 & 224,0 & 25,2 & 38697,3 & 863,4 \\
\hline & 0,4 & 209,8 & 28,0 & 35206,3 & 990,9 \\
\hline & 0,5 & 201,3 & 32,8 & 32031,2 & 1131,4 \\
\hline & 0,6 & 189,4 & 36,5 & 29367,8 & 1418,1 \\
\hline & 0,7 & 180,0 & 37,1 & 26992,3 & 1659,6 \\
\hline & 0,8 & 170,9 & 43,8 & 25121,7 & 1696,5 \\
\hline \multirow{7}{*}{ 1-Dez } & 0,2 & 207,5 & 21,7 & 42575,2 & 521,1 \\
\hline & 0,3 & 193,5 & 26,7 & 38515,1 & 755,1 \\
\hline & 0,4 & 177,7 & 27,5 & 35316,7 & 941,2 \\
\hline & 0,5 & 166,2 & 30,7 & 32273,0 & 1208,9 \\
\hline & 0,6 & 156,1 & 34,1 & 29750,4 & 1428,5 \\
\hline & 0,7 & 146,3 & 38,5 & 27761,7 & 1521,7 \\
\hline & 0,8 & 129,5 & 41,9 & 25681,4 & 1722,0 \\
\hline \multirow{7}{*}{ 15-Dez } & 0,2 & 179,3 & 24,1 & 42802,7 & 530,2 \\
\hline & 0,3 & 160,4 & 27,2 & 38619,7 & 952,1 \\
\hline & 0,4 & 149,0 & 29,4 & 35879,1 & 1194,0 \\
\hline & 0,5 & 132,9 & 30,5 & 33022,9 & 1404,0 \\
\hline & 0,6 & 117,8 & 34,0 & 30700,9 & 1852,9 \\
\hline & 0,7 & 107,3 & 33,8 & 28870,2 & 2065,1 \\
\hline & 0,8 & 96,2 & 39,7 & 27246,5 & 2257,6 \\
\hline
\end{tabular}


Tabela 9A. Parâmetros da distribuição normal relativos aos valores simulados de produtividade de grãos de feijão caupi $\left(\mathrm{kg} \mathrm{ha}^{-1}\right)$, em regime de sequeiro, em cada época de semeadura nos municípios de Parnaíba e Teresina, Piauí.

\begin{tabular}{lrrrr}
\hline Época de & \multicolumn{2}{c}{ Parnaiba } & \multicolumn{2}{c}{ Teresina } \\
\cline { 2 - 5 } Semeadura & \multicolumn{1}{c}{$\mu$} & \multicolumn{1}{c}{$\mu$} & $\sigma$ \\
\hline 1 - Jan & 921,3 & 375,5 & 1416,0 & 324,1 \\
15 - Jan & 1022,7 & 354,4 & 1549,3 & 330,0 \\
1 - Fev & 1162,0 & 383,6 & 1739,0 & 262,5 \\
15 - Fev & 1302,3 & 355,4 & 1774,4 & 297,1 \\
1 - Mar & 1339,3 & 347,4 & 1751,4 & 286,7 \\
15 - Mar & 1204,0 & 394,7 & 1522,6 & 316,3 \\
1 - Abr & 973,2 & 387,9 & 1251,1 & 385,4 \\
15 - Abr & 687,7 & 411,2 & 819,8 & 405,4 \\
1 - Mai & 349,6 & 261,5 & 535,0 & 382,2 \\
15 - Mai & 229,9 & 244,3 & 225,8 & 247,1 \\
1 - Jun & 90,8 & 124,6 & 48,8 & 88,7 \\
15 - Jun & 34,6 & 66,1 & 37,1 & 81,9 \\
1 - Jul & 26,2 & 66,8 & 17,4 & 52,6 \\
15 - Jul & 5,7 & 31,0 & 20,3 & 71,9 \\
1 - Ago & 0,0 & 0,0 & 18,5 & 67,3 \\
15 - Ago & 0,0 & 0,0 & 18,4 & 65,2 \\
1 - Set & 0,0 & 0,0 & 68,7 & 125,6 \\
15 - Set & 0,7 & 5,5 & 81,6 & 163,4 \\
1 - Out & 3,6 & 18,0 & 116,4 & 165,9 \\
15 - Out & 4,3 & 19,6 & 202,9 & 238,4 \\
1 - Nov & 84,9 & 145,0 & 431,2 & 344,7 \\
15 - Nov & 200,3 & 235,7 & 717,7 & 381,2 \\
1 - Dez & 324,5 & 265,7 & 852,3 & 383,0 \\
15 - Dez & 544,2 & 368,6 & 1154,8 & 359,8 \\
\hline
\end{tabular}


Tabela 10A. Parâmetros da distribuição normal relativos aos valores simulados de produtividade de frutos de melancia $\left(\mathrm{kg} \mathrm{ha}^{-1}\right)$, em regime de sequeiro, em cada época de semeadura nos municipios de Parnaiba e Teresina, Piauí.

\begin{tabular}{|c|c|c|c|c|}
\hline \multirow{2}{*}{$\begin{array}{l}\text { Época de } \\
\text { Semeadura }\end{array}$} & \multicolumn{2}{|c|}{ Parnaiba } & \multicolumn{2}{|c|}{ Teresina } \\
\hline & $\mu$ & $\sigma$ & $\mu$ & $\sigma$ \\
\hline $1-$ Jan & 13258,6 & 5430,0 & 24080,1 & 5842,2 \\
\hline 15 - Jan & 16026,5 & 5856,4 & 27086,4 & 5813,2 \\
\hline $1-\mathrm{Fev}$ & 18838,1 & 6255,2 & 30887,4 & 4724,3 \\
\hline $15-\mathrm{Fev}$ & 21524,8 & 6011,1 & 31669,1 & 5593,7 \\
\hline $1-\mathrm{Mar}$ & 22568,4 & 6262,5 & 31348,0 & 5447,0 \\
\hline $15-\mathrm{Mar}$ & 20029,8 & 6553,9 & 26663,3 & 5974,7 \\
\hline $1-\mathrm{Abr}$ & 14609,2 & 5860,1 & 19925,3 & 6533,9 \\
\hline $15-\mathrm{Abr}$ & 10464,4 & 5810,6 & 12223,0 & 5966,9 \\
\hline 1 - Mai & 4824,3 & 3189,0 & 7271,1 & 5151,2 \\
\hline 15 - Mai & 3177,0 & 2651,1 & 2858,8 & 2493,0 \\
\hline 1 - Jun & 1391,1 & 1164,0 & 889,7 & 905,4 \\
\hline 15 - Jun & 676,8 & 672,3 & 579,8 & 737,0 \\
\hline 1 - Jul & 448,2 & 609,2 & 304,4 & 479,2 \\
\hline $15-\mathrm{Jul}$ & 166,4 & 321,7 & 211,8 & 561,4 \\
\hline 1 - Ago & 2,7 & 0,3 & 260,4 & 523,5 \\
\hline 15 - Ago & 1,9 & 0,2 & 322,1 & 545,6 \\
\hline 1 - Set & 1,5 & 0,1 & 821,2 & 1158,0 \\
\hline $15-$ Set & 46,5 & 136,9 & 1067,5 & 1383,4 \\
\hline 1 - Out & 101,4 & 246,4 & 1441,0 & 1649,8 \\
\hline 15 - Out & 121,9 & 264,2 & 2398,7 & 2235,1 \\
\hline 1 - Nov & 1002,4 & 1188,2 & 5694,7 & 4367,3 \\
\hline $15-$ Nov & 2553,7 & 2228,7 & 9860,2 & 5031,2 \\
\hline $1-$ Dez & 4115,9 & 2831,1 & 13161,0 & 5808,5 \\
\hline $15-$ Dez & 7653,2 & 4847,1 & 18469,3 & 6065,4 \\
\hline
\end{tabular}


Tabela $11 \mathrm{~A}$. Estimativa da lâmina bruta de irrigação $(\mathrm{mm})$ necessária à cultura de feijão caupi, com diferentes probabilidades de ocorrência, em cada época de semeadura e nivel de manejo ( $p$ ) no município de Teresina, Piauí.

\begin{tabular}{|c|c|c|c|c|c|c|c|c|c|}
\hline \multirow{2}{*}{$\begin{array}{l}\text { Época de } \\
\text { Semeadura }\end{array}$} & \multirow[t]{2}{*}{$\mathrm{p}$} & \multicolumn{8}{|c|}{ Probabilidade de ocorrência (\%) } \\
\hline & & 95 & 90 & 85 & 80 & 75 & 70 & 65 & 60 \\
\hline \multirow{7}{*}{ 1-Jan } & 0,2 & 190,2 & 181,0 & 174,9 & 169,9 & 165,7 & 161,9 & 158,4 & 155,1 \\
\hline & 0,3 & 180,2 & 170,1 & 163,4 & 158,0 & 153,4 & 149,3 & 145,4 & 141,8 \\
\hline & 0,4 & 171,7 & 159,9 & 152,0 & 145,7 & 140,3 & 135,5 & 131,0 & 126,7 \\
\hline & 0,5 & 159,4 & 146,8 & 138,3 & 131,5 & 125,7 & 120,5 & 115,7 & 111,1 \\
\hline & 0,6 & 144,2 & 131,6 & 123,0 & 116,2 & 110,4 & 105,2 & 100,3 & 95,7 \\
\hline & 0,7 & 131,9 & 119,5 & 111,1 & 104,4 & 98,7 & 93,5 & 88,8 & 84,2 \\
\hline & 0,8 & 129,1 & 115,7 & 106,6 & 99,3 & 93,1 & 87,6 & 82,4 & 77,5 \\
\hline \multirow{7}{*}{ 15-Jan } & 0,2 & 175,5 & 166,2 & 160,0 & 155,0 & 150,7 & 146,9 & 143,3 & 139,9 \\
\hline & 0,3 & 165,3 & 154,7 & 147,6 & 141,9 & 137,1 & 132,7 & 128,7 & 124,8 \\
\hline & 0,4 & 151,1 & 140,2 & 132,7 & 126,9 & 121,8 & 117,3 & 113,1 & 109,1 \\
\hline & 0,5 & 140,6 & 128,5 & 120,4 & 114,0 & 108,4 & 103,4 & 98,8 & 94,5 \\
\hline & 0,6 & 134,3 & 120,7 & 111,6 & 104,4 & 98,1 & 92,6 & 87,4 & 82,5 \\
\hline & 0,7 & 116,6 & 104,1 & 95,6 & 88,9 & 83,1 & 78,0 & 73,2 & 68,6 \\
\hline & 0,8 & 102,9 & 102,9 & 102,9 & 65,5 & 65,5 & 65,5 & 65,5 & 65,5 \\
\hline \multirow{7}{*}{$1-\mathrm{Fev}$} & 0,2 & 151,3 & 143,1 & 137,6 & 133,1 & 129,4 & 126,0 & 122,8 & 119,8 \\
\hline & 0,3 & 138,3 & 128,7 & 122,3 & 117,2 & 112,8 & 108,9 & 105,2 & 101,8 \\
\hline & 0,4 & 121,3 & 111,6 & 105,0 & 99,8 & 95,3 & 91,3 & 87,5 & 84,0 \\
\hline & 0,5 & 106,1 & 96,6 & 90,2 & 85,1 & 80,7 & 76,8 & 73,1 & 69,7 \\
\hline & 0,6 & 95,4 & 86,1 & 79,9 & 75,0 & 70,8 & 67,0 & 63,4 & 60,1 \\
\hline & 0,7 & 94,4 & 79,9 & 65,3 & 65,3 & 50,8 & 50,8 & 50,8 & 36,3 \\
\hline & 0,8 & 75,4 & 75,4 & 58,6 & 58,6 & 41,9 & 41,9 & 41,9 & 41,9 \\
\hline \multirow{7}{*}{$15-\mathrm{Fev}$} & 0,2 & 154,9 & 144,2 & 137,0 & 131,3 & 126,4 & 122,0 & 117,9 & 114,0 \\
\hline & 0,3 & 137,9 & 127,3 & 120,1 & 114,4 & 109,5 & 105,1 & 101,0 & 97,1 \\
\hline & 0,4 & 127,5 & 115,6 & 107,5 & 101,1 & 95,7 & 90,7 & 86,2 & 81,8 \\
\hline & 0,5 & 110,7 & 98,8 & 90,7 & 84,3 & 78,8 & 73,9 & 69,3 & 65,0 \\
\hline & 0,6 & 104,1 & 91,7 & 83,3 & 76,7 & 71,0 & 65,9 & 61,1 & 56,6 \\
\hline & 0,7 & 83,1 & 83,1 & 64,6 & 64,6 & 64,6 & 46,2 & 46,2 & 27,7 \\
\hline & 0,8 & 75,1 & 75,1 & 58,4 & 58,4 & 41,7 & 41,7 & 41,7 & 41,7 \\
\hline
\end{tabular}


Tabela 11 A. Estimativa da lâmina bruta de irrigação (mm) necessária à cultura de feijão caupi, com diferentes probabilidades de ocorrência, em cada época de semeadura e nível de manejo (p) no município de Teresina, Piauí.

\begin{tabular}{|c|c|c|c|c|c|c|c|c|c|}
\hline \multirow{2}{*}{$\begin{array}{l}\text { Época de } \\
\text { Semeadura }\end{array}$} & \multirow[t]{2}{*}{$p$} & \multicolumn{8}{|c|}{ Probabilidade de ocorrência $(\%)$} \\
\hline & & 95 & 90 & 85 & 80 & 75 & 70 & 65 & 60 \\
\hline \multirow{7}{*}{ 1-Mar } & 0,2 & 149,3 & 140,0 & 133,8 & 128,9 & 124,6 & 120,8 & 117,3 & 113,9 \\
\hline & 0,3 & 137,1 & 126,6 & 119,5 & 113,9 & 109,1 & 104,7 & 100,7 & 96,9 \\
\hline & 0,4 & 116,3 & 105,7 & 98,6 & 93,0 & 88,1 & 83,8 & 79,8 & 75,9 \\
\hline & 0,5 & 107,9 & 97,0 & 89,6 & 83,8 & 78,8 & 74,3 & 70,1 & 66,1 \\
\hline & 0,6 & 95,8 & 85,6 & 78,8 & 73,3 & 68,6 & 64,4 & 60,5 & 56,8 \\
\hline & 0,7 & 84,6 & 74,5 & 67,6 & 62,2 & 57,5 & 53,3 & 49,5 & 45,8 \\
\hline & 0,8 & 70,6 & 70,6 & 57,8 & 44,9 & 32,1 & 32,1 & 32,1 & 32,1 \\
\hline \multirow{7}{*}{ 15-Mar } & 0,2 & 170,9 & 161,5 & 155,2 & 150,2 & 145,9 & 142,0 & 138,4 & 135,0 \\
\hline & 0,3 & 159,6 & 148,6 & 141,1 & 135,2 & 130,2 & 125,6 & 121,4 & 117,4 \\
\hline & 0,4 & 146,8 & 135,2 & 127,4 & 121,1 & 115,8 & 111,0 & 106,5 & 102,3 \\
\hline & 0,5 & 135,1 & 123,1 & 115,0 & 108,5 & 103,0 & 98,0 & 93,4 & 89,0 \\
\hline & 0,6 & 127,0 & 114,5 & 106,1 & 99,5 & 93,7 & 88,6 & 83,8 & 79,3 \\
\hline & 0,7 & 110,4 & 98,6 & 90,6 & 84,2 & 78,8 & 73,9 & 69,4 & 65,1 \\
\hline & 0,8 & 95,5 & 95,5 & 78,2 & 78,2 & 60,8 & 60,8 & 60,8 & 60,8 \\
\hline \multirow{7}{*}{$1-\mathrm{Abr}$} & 0,2 & 197,0 & 187,7 & 181,5 & 176,5 & 172,2 & 168,4 & 164,8 & 161,5 \\
\hline & 0,3 & 185,3 & 175,5 & 168,9 & 163,7 & 159,2 & 155,2 & 151,4 & 147,9 \\
\hline & 0,4 & 174,8 & 164,5 & 157,5 & 152,0 & 147,2 & 143,0 & 139,0 & 135,3 \\
\hline & 0,5 & 170,6 & 158,5 & 150,3 & 143,8 & 138,2 & 133,2 & 128,5 & 124,1 \\
\hline & 0,6 & 168,0 & 154,0 & 144,6 & 137,1 & 130,7 & 124,9 & 119,6 & 114,5 \\
\hline & 0,7 & 158,1 & 144,3 & 135,0 & 127,5 & 121,2 & 115,5 & 110,2 & 105,2 \\
\hline & 0,8 & 145,0 & 131,4 & 122,3 & 115,0 & 108,8 & 103,2 & 98,0 & 93,0 \\
\hline \multirow{7}{*}{$15-\mathrm{Abr}$} & 0,2 & 224,5 & 216,4 & 211,0 & 206,7 & 203,0 & 199,7 & 196,6 & 193,7 \\
\hline & 0,3 & 219,0 & 209,8 & 203,6 & 198,7 & 194,5 & 190,7 & 187,2 & 183,8 \\
\hline & 0,4 & 211,9 & 201,2 & 194,0 & 188,3 & 183,4 & 179,0 & 174,9 & 171,0 \\
\hline & 0,5 & 205,1 & 193,3 & 185,3 & 178,9 & 173,4 & 168,5 & 164,0 & 159,7 \\
\hline & 0,6 & 200,3 & 187,9 & 179,6 & 173,0 & 167,4 & 162,3 & 157,6 & 153,1 \\
\hline & 0,7 & 194,2 & 181,4 & 172,7 & 165,8 & 159,9 & 154,6 & 149,7 & 145,0 \\
\hline & 0,8 & 188,0 & 174,5 & 165,4 & 158,2 & 152,0 & 146,4 & 141,2 & 136,3 \\
\hline
\end{tabular}


Tabela 11A. Estimativa da lâmina bruta de irrigação $(\mathrm{mm})$ necessária à cultura de feijão caupi, com diferentes probabilidades de ocorrência, em cada época de semeadura e nível de manejo (p) no município de Teresina, Piaui.

\begin{tabular}{|c|c|c|c|c|c|c|c|c|c|}
\hline \multirow{2}{*}{$\begin{array}{l}\text { Época de } \\
\text { Semeadura }\end{array}$} & \multirow[t]{2}{*}{$\mathrm{p}$} & \multicolumn{8}{|c|}{ Probabilidade de ocorrência (\%) } \\
\hline & & 95 & 90 & 85 & 80 & 75 & 70 & 65 & 60 \\
\hline \multirow{7}{*}{ 1-Mai } & 0,2 & 248,4 & 240,5 & 235,1 & 230,9 & 227,3 & 224,0 & 221,0 & 218,1 \\
\hline & 0,3 & 242,5 & 233,5 & 227,5 & 222,7 & 218,6 & 214.9 & 211,5 & 208,2 \\
\hline & 0,4 & 238,3 & 228,3 & 221,6 & 216,2 & 211,6 & 207,5 & 203,7 & 200,0 \\
\hline & 0,5 & 239,0 & 227,1 & 219,1 & 212,7 & 207,3 & 202,4 & 197,8 & 193,5 \\
\hline & 0,6 & 236,0 & 223,4 & 214,9 & 208,1 & 202,3 & 197,1 & 192,2 & 187,6 \\
\hline & 0,7 & 229,7 & 217,0 & 208,5 & 201,7 & 195,9 & 190,7 & 185,9 & 181,3 \\
\hline & 0,8 & 228,3 & 213,6 & 203,7 & 195,9 & 189,1 & 183,0 & 177,4 & 172,1 \\
\hline \multirow{7}{*}{ 15-Mai } & 0,2 & 265,9 & 260,6 & 257,0 & 254,1 & 251,7 & 249,5 & 247,4 & 245,5 \\
\hline & 0,3 & 262,2 & 256,2 & 252,1 & 248,9 & 246,1 & 243,6 & 241,3 & 239,2 \\
\hline & 0,4 & 261,3 & 254,1 & 249,3 & 245,5 & 242,2 & 239,3 & 236,6 & 234,0 \\
\hline & 0,5 & 259,9 & 251,8 & 246,4 & 242,1 & 238,5 & 235,2 & 232,1 & 229,2 \\
\hline & 0,6 & 257,1 & 248,6 & 242,9 & 238,3 & 234,4 & 230,9 & 227,7 & 224,6 \\
\hline & 0,7 & 253,2 & 243,9 & 237,6 & 232,6 & 228,3 & 224,5 & 220,9 & 217,5 \\
\hline & 0,8 & 256,4 & 245,7 & 238,5 & 232,7 & 227,8 & 223,4 & 219,3 & 215,5 \\
\hline \multirow{7}{*}{ 1-Jun } & 0,2 & 286,3 & 281,9 & 279,0 & 276,6 & 274,6 & 272,8 & 271,2 & 269,6 \\
\hline & 0,3 & 285,0 & 279,8 & 276,3 & 273,5 & 271,1 & 269,0 & 267,0 & 265,1 \\
\hline & 0,4 & 282,1 & 276,9 & 273,4 & 270,6 & 268,2 & 266,1 & 264,1 & 262,2 \\
\hline & 0,5 & 282,2 & 276,2 & 272,2 & 269,0 & 266,2 & 263,8 & 261,5 & 259,3 \\
\hline & 0,6 & 283,0 & 275,6 & 270,7 & 266,8 & 263,4 & 260,3 & 257,5 & 254,9 \\
\hline & 0,7 & 280,0 & 273,1 & 268,4 & 264,6 & 261,4 & 258,5 & 255,9 & 253,3 \\
\hline & 0,8 & 280,7 & 267,2 & 253,6 & 253,6 & 253,6 & 253,6 & 253,6 & 253,6 \\
\hline \multirow{7}{*}{ 15-Jun } & 0,2 & 304,2 & 300,7 & 298,3 & 296,4 & 294,8 & 293,4 & 292,0 & 290,8 \\
\hline & 0,3 & 303,6 & 299,3 & 296,5 & 294,2 & 292,2 & 290,4 & 288,8 & 287,2 \\
\hline & 0,4 & 303,1 & 298,2 & 294,8 & 292,1 & 289,9 & 287,8 & 285,9 & 284,1 \\
\hline & 0,5 & 300,6 & 295,4 & 291,8 & 289,0 & 286,6 & 284,5 & 282,4 & 280,5 \\
\hline & 0,6 & 299,6 & 293,8 & 290,0 & 286,9 & 284,3 & 281,9 & 279,7 & 277,6 \\
\hline & 0,7 & 299,1 & 293,0 & 288,8 & 285,5 & 282,7 & 280,2 & 277,8 & 275,6 \\
\hline & 0,8 & 297,5 & 290,7 & 286,1 & 282,4 & 279,3 & 276,5 & 273,9 & 271,4 \\
\hline
\end{tabular}


Tabela $11 \mathrm{~A}$. Estimativa da lâmina bruta de irrigação $(\mathrm{mm})$ necessária à cultura de feijão caupi, com diferentes probabilidades de ocorrência, em cada época de semeadura e nível de manejo (p) no município de Teresina, Piaui.

\begin{tabular}{|c|c|c|c|c|c|c|c|c|c|}
\hline \multirow{2}{*}{$\begin{array}{l}\text { Época de } \\
\text { Semeadura }\end{array}$} & \multirow[t]{2}{*}{$\mathrm{p}$} & \multicolumn{8}{|c|}{ Probabilidade de ocorrência (\%) } \\
\hline & & 95 & 90 & 85 & 80 & 75 & 70 & 65 & 60 \\
\hline \multirow{7}{*}{ 1-Jul } & 0,2 & 327,8 & 324,9 & 323,0 & 321,4 & 320,1 & 318,9 & 317,8 & 316,7 \\
\hline & 0,3 & 325,5 & 322,6 & 320,7 & 319,1 & 317,8 & 316,6 & 315,5 & 314,4 \\
\hline & 0,4 & 325,8 & 322,3 & 320,0 & 318,1 & 316,5 & 315,0 & 313,7 & 312,4 \\
\hline & 0,5 & 326,2 & 321,8 & 318,8 & 316,5 & 314,5 & 312,7 & 311,0 & 309,4 \\
\hline & 0,6 & 320,2 & 320,2 & 320,2 & 310,7 & 310,7 & 310,7 & 310,7 & 310,7 \\
\hline & 0,7 & 321,3 & 316,3 & 313,0 & 310,4 & 308,1 & 306,1 & 304,2 & 302,5 \\
\hline & 0,8 & 328,3 & 322,2 & 318,0 & 314,8 & 312,0 & 309,4 & 307,1 & 304,9 \\
\hline \multirow{7}{*}{ [5-Jul } & 0,2 & 351,3 & 348,2 & 346,1 & 344,4 & 343,0 & 341,7 & 340,5 & 339,4 \\
\hline & 0,3 & 349,6 & 346,4 & 344,1 & 342,4 & 340,9 & 339,5 & 338,3 & 337,1 \\
\hline & 0,4 & 347,5 & 344,1 & 341,8 & 339,9 & 338,4 & 337,0 & 335,7 & 334,4 \\
\hline & 0,5 & 350,0 & 345,5 & 342,5 & 340,1 & 338,1 & 336,3 & 334,6 & 332,9 \\
\hline & 0,6 & 349,9 & 345,2 & 342,1 & 339,6 & 337,4 & 335,5 & 333,7 & 332,0 \\
\hline & 0,7 & 299,6 & 289,6 & 289,6 & 279,6 & 279,6 & 279,6 & 279,6 & 269,7 \\
\hline & 0,8 & 345,1 & 345,1 & 345,1 & 335,8 & 326,4 & 326,4 & 317,0 & 317,0 \\
\hline \multirow{7}{*}{ 1-Ago } & 0,2 & 365,4 & 362,3 & 360,3 & 358,6 & 357,2 & 356,0 & 354,8 & 353,7 \\
\hline & 0,3 & 365,9 & 362,1 & 359,4 & 357,4 & 355,6 & 354,0 & 352,5 & 351,1 \\
\hline & 0,4 & 365,0 & 361,1 & 358,4 & 356,3 & 354,5 & 352,8 & 351,3 & 349,9 \\
\hline & 0,5 & 356,3 & 356,3 & 356,3 & 356,3 & 356,3 & 356,3 & 356,3 & 346,7 \\
\hline & 0,6 & 350,6 & 350,6 & 350,6 & 350,6 & 350,6 & 339,9 & 339,9 & 339,9 \\
\hline & 0,7 & 362,7 & 356,6 & 352,5 & 349,2 & 346,4 & 343,9 & 341,5 & 339,3 \\
\hline & 0,8 & 360,8 & 354,9 & 351,0 & 347,9 & 345,2 & 342,7 & 340,5 & 338,4 \\
\hline \multirow{7}{*}{ 15-Ago } & 0,2 & 376,8 & 373,3 & 370,9 & 369,0 & 367,4 & 365,9 & 364,5 & 363,3 \\
\hline & 0,3 & 376,8 & 372,6 & 369,8 & 367,5 & 365,6 & 363,9 & 362,3 & 360,8 \\
\hline & 0,4 & 377,3 & 372,6 & 369,4 & 366,9 & 364,7 & 362,7 & 360,9 & 359,2 \\
\hline & 0,5 & 371,8 & 367,1 & 363,9 & 361,3 & 359,1 & 357,1 & 355,3 & 353,6 \\
\hline & 0,6 & 373,9 & 368,5 & 364,8 & 361,9 & 359,5 & 357,2 & 355,2 & 353,2 \\
\hline & 0,7 & 374,0 & 367,6 & 363,3 & 359,8 & 356,9 & 354,2 & 351,8 & 349,4 \\
\hline & 0,8 & 372,4 & 365,5 & 360,9 & 357,2 & 354,1 & 351,2 & 348,6 & 346,1 \\
\hline
\end{tabular}


Tabela 11 A. Estimativa da lâmina bruta de irrigação $(\mathrm{mm})$ necessária à cultura de feijão caupi, com diferentes probabilidades de ocorrência, em cada época de semeadura e nivel de manejo ( $p$ ) no municipio de Teresina, Piaui.

\begin{tabular}{|c|c|c|c|c|c|c|c|c|c|}
\hline \multirow{2}{*}{$\begin{array}{l}\text { Época de } \\
\text { Semeadura }\end{array}$} & \multirow[t]{2}{*}{$\mathrm{p}$} & \multicolumn{8}{|c|}{ Probabilidade de ocorrência (\%) } \\
\hline & & 95 & 90 & 85 & 80 & 75 & 70 & 65 & 60 \\
\hline \multirow{7}{*}{$1-$ Set } & 0,2 & 378,3 & 373,9 & 370,9 & 368,5 & 366,5 & 364,7 & 363,0 & 361,4 \\
\hline & 0,3 & 375,1 & 370,4 & 367,2 & 364,6 & 362,4 & 360,5 & 358,7 & 357,0 \\
\hline & 0,4 & 374,3 & 368,8 & 365,1 & 362,2 & 359,7 & 357,4 & 355,3 & 353,3 \\
\hline & 0,5 & 374,0 & 367,4 & 363,0 & 359,4 & 356,4 & 353,6 & 351,1 & 348,7 \\
\hline & 0,6 & 371,8 & 364,5 & 359,6 & 355,7 & 352,3 & 349,3 & 346,5 & 343,9 \\
\hline & 0,7 & 372,2 & 364,4 & 359,2 & 355,1 & 351,5 & 348,3 & 345,4 & 342,5 \\
\hline & 0,8 & 369,1 & 361,0 & 355,5 & 351,2 & 347,5 & 344,1 & 341,0 & 338,1 \\
\hline \multirow{7}{*}{$15-$ Set } & 0,2 & 371,8 & 366,8 & 363,5 & 360,8 & 358,5 & 356,5 & 354,6 & 352,8 \\
\hline & 0,3 & 371,2 & 365,4 & 361,5 & 358,4 & 355,7 & 353,3 & 351,1 & 349,0 \\
\hline & 0,4 & 369,6 & 362,7 & 358,1 & 354,5 & 351,4 & 348,6 & 345,9 & 343,5 \\
\hline & 0,5 & 365,6 & 358,6 & 353,9 & 350,1 & 346,9 & 344,0 & 341,3 & 338,7 \\
\hline & 0,6 & 366,1 & 358,5 & 353,3 & 349,2 & 345,7 & 342,5 & 339,5 & 336,8 \\
\hline & 0,7 & 367,0 & 357,8 & 351,6 & 346,7 & 342,5 & 338,7 & 335,2 & 331,8 \\
\hline & 0,8 & 364,6 & 355,6 & 349,5 & 344,6 & 340,5 & 336,8 & 333,3 & 330,0 \\
\hline \multirow{7}{*}{ 1-Out } & 0,2 & 360,8 & 355,5 & 351,9 & 349,0 & 346,6 & 344,4 & 342,4 & 340,4 \\
\hline & 0,3 & 358,9 & 353,2 & 349,3 & 346,2 & 343,6 & 341,2 & 339,0 & 336,9 \\
\hline & 0,4 & 357,0 & 350,3 & 345,8 & 342,2 & 339,2 & 336,4 & 333,9 & 331,4 \\
\hline & 0,5 & 357,1 & 349,3 & 344,0 & 339,7 & 336,1 & 332,9 & 329,9 & 327,0 \\
\hline & 0,6 & 357,7 & 348,4 & 342,1 & 337,1 & 332,8 & 328,9 & 325,3 & 321,9 \\
\hline & 0,7 & 352,4 & 343,2 & 337,1 & 332,2 & 328,0 & 324,3 & 320,8 & 317,5 \\
\hline & 0,8 & 351,6 & 342,0 & 335,5 & 330,4 & 326,0 & 322,0 & 318,3 & 314,9 \\
\hline \multirow{7}{*}{ 15-Out } & 0,2 & 344,4 & 338,4 & 334,4 & 331,2 & 328,4 & 325,9 & 323,6 & 321,4 \\
\hline & 0,3 & 343,0 & 336,1 & 331,4 & 327,6 & 324,4 & 321,5 & 318,9 & 316,3 \\
\hline & 0,4 & 339,6 & 331,8 & 326,5 & 322,4 & 318,8 & 315,6 & 312,6 & 309,8 \\
\hline & 0,5 & 336,9 & 327,7 & 321,5 & 316,6 & 312,4 & 308,6 & 305,0 & 301,7 \\
\hline & 0,6 & 336,7 & 326,7 & 320,0 & 314,7 & 310,1 & 306,0 & 302,2 & 298,6 \\
\hline & 0,7 & 332,7 & 322,6 & 315,8 & 310,3 & 305,7 & 301,5 & 297,6 & 293,9 \\
\hline & 0,8 & 329,1 & 318,7 & 311,7 & 306,2 & 301,4 & 297,1 & 293,1 & 289,4 \\
\hline
\end{tabular}


300

Tabela $11 \mathrm{~A}$. Estimativa da lâmina bruta de irrigação $(\mathrm{mm})$ necessária à cultura de feijão caupi, com diferentes probabilidades de ocorrência, em cada época de semeadura e nível de manejo (p) no município de Teresina, Piauí.

\begin{tabular}{|c|c|c|c|c|c|c|c|c|c|}
\hline \multirow{2}{*}{$\begin{array}{c}\text { Epoca de } \\
\text { Semeadura }\end{array}$} & \multirow[t]{2}{*}{$\mathrm{p}$} & \multicolumn{8}{|c|}{ Probabilidade de ocorrência (\%) } \\
\hline & & 95 & 90 & 85 & 80 & 75 & 70 & 65 & 60 \\
\hline \multirow{7}{*}{$1-$ Nov } & 0,2 & 307,8 & 300,2 & 295,0 & 290,9 & 287,4 & 284,2 & 281,3 & 278,5 \\
\hline & 0,3 & 304,9 & 296,0 & 290,1 & 285,3 & 281,2 & 277,6 & 274,2 & 271,0 \\
\hline & 0,4 & 301,5 & 290,9 & 283,7 & 278,1 & 273,2 & 268,8 & 264,8 & 260,9 \\
\hline & 0,5 & 297,6 & 286,8 & 279,5 & 273,6 & 268,7 & 264,2 & 260,0 & 256,1 \\
\hline & 0,6 & 293,8 & 281,9 & 273,9 & 267,5 & 262,0 & 257,1 & 252,5 & 248,2 \\
\hline & 0,7 & 290,3 & 277,4 & 268,7 & 261,8 & 255,9 & 250,5 & 245,6 & 240,9 \\
\hline & 0,8 & 287,6 & 273,5 & 263,9 & 256,3 & 249,8 & 244,0 & 238,6 & 233,5 \\
\hline \multirow{7}{*}{ 15-Nov } & 0,2 & 275,7 & 267,0 & 261,2 & 256,5 & 252,5 & 248,9 & 245,6 & 242,5 \\
\hline & 0,3 & 268,3 & 258,8 & 252,3 & 247,2 & 242,8 & 238,8 & 235,2 & 231,7 \\
\hline & 0,4 & 258,5 & 247,9 & 240,7 & 235,1 & 230,2 & 225,8 & 221,7 & 217,9 \\
\hline & 0,5 & 252,4 & 240,8 & 232,9 & 226,7 & 221,3 & 216,5 & 212,0 & 207,8 \\
\hline & 0,6 & 251,0 & 237,5 & 228,4 & 221,1 & 214,9 & 209,3 & 204,1 & 199,2 \\
\hline & 0,7 & 243,9 & 229,8 & 220,3 & 212,8 & 206,3 & 200,5 & 195,2 & 190,1 \\
\hline & 0,8 & 237,7 & 223,4 & 213,7 & 206,1 & 199,5 & 193,5 & 188,1 & 182,9 \\
\hline \multirow{7}{*}{ 1-Dez } & 0,2 & 244,9 & 236,8 & 231,3 & 226,9 & 223,2 & 219,8 & 216,7 & 213,7 \\
\hline & 0,3 & 235,8 & 226,7 & 220,6 & 215,8 & 211,6 & 207,9 & 204,4 & 201,1 \\
\hline & 0,4 & 228,9 & 218,2 & 211,1 & 205,3 & 200,4 & 196,0 & 192,0 & 188,1 \\
\hline & 0,5 & 222,2 & 210,0 & 201,8 & 195,2 & 189,6 & 184,5 & 179,9 & 175,4 \\
\hline & 0,6 & 215,8 & 203,7 & 195,6 & 189,1 & 183,6 & 178,6 & 174,0 & 169,6 \\
\hline & 0,7 & 209,9 & 195,7 & 186,2 & 178,6 & 172,1 & 166,2 & 160,8 & 155,7 \\
\hline & 0,8 & 203,8 & 188,3 & 177,9 & 169,6 & 162,4 & 156,1 & 150,1 & 144,5 \\
\hline \multirow{7}{*}{ 15-Dez } & 0,2 & 219,6 & 210,6 & 204,5 & 199,7 & 195,6 & 191,8 & 188,4 & 185,1 \\
\hline & 0,3 & 210,2 & 200,3 & 193,6 & 188,3 & 183,7 & 179,6 & 175,8 & 172,2 \\
\hline & 0,4 & 197,3 & 186,5 & 179,3 & 173,5 & 168,6 & 164,2 & 160,1 & 156,2 \\
\hline & 0,5 & 185,0 & 173,8 & 166,2 & 160,2 & 155,0 & 150,4 & 146,1 & 142,0 \\
\hline & 0,6 & 180,1 & 167,4 & 158,9 & 152,0 & 146,2 & 140,9 & 136,1 & 131,5 \\
\hline & 0,7 & 170,4 & 157,1 & 148,1 & 140,9 & 134,8 & 129,3 & 124,2 & 119,3 \\
\hline & 0,8 & 158,7 & 145,2 & 136,0 & 128,8 & 122,6 & 117,0 & 111,8 & 106,9 \\
\hline
\end{tabular}


Tabela 12A. Estimativa da lâmina bruta de irrigação $(\mathrm{mm})$ necessária à cultura de melancia, com diferentes probabilidades de ocorrência, em cada época de semeadura e nivel de manejo (p) no municipio de Parnaiba, Piaui.

\begin{tabular}{|c|c|c|c|c|c|c|c|c|c|}
\hline \multirow{2}{*}{$\begin{array}{l}\text { Época de } \\
\text { Semeadura }\end{array}$} & \multirow[t]{2}{*}{$\mathrm{p}$} & \multicolumn{8}{|c|}{ Probabilidade de ocorrência (\%) } \\
\hline & & 95 & 90 & 85 & 80 & 75 & 70 & 65 & 60 \\
\hline \multirow{7}{*}{ 1-Jan } & 0,2 & 276,4 & 266,9 & 260,6 & 255,5 & 251,2 & 247,3 & 243,6 & 240,2 \\
\hline & 0,3 & 271,6 & 261,3 & 254,2 & 248,7 & 243,9 & 239,6 & 235,6 & 231,9 \\
\hline & 0,4 & 262,8 & 251,4 & 243,7 & 237,6 & 232,4 & 227,6 & 223,3 & 219,1 \\
\hline & 0,5 & 258,4 & 246,0 & 237,6 & 230,9 & 225,2 & 220,1 & 215,3 & 210,8 \\
\hline & 0,6 & 246,6 & 233,8 & 225,1 & 218,3 & 212,4 & 207,1 & 202,2 & 197,5 \\
\hline & 0,7 & 241,1 & 227,2 & 217,9 & 210,4 & 204,1 & 198,3 & 193,0 & 188,0 \\
\hline & 0,8 & 234,0 & 218,8 & 208,6 & 200,5 & 193,5 & 187,2 & 181,4 & 175,9 \\
\hline \multirow{7}{*}{ 15-Jan } & 0,2 & 252,7 & 243,6 & 237,4 & 232,6 & 228,4 & 224,6 & 221,1 & 217,8 \\
\hline & 0,3 & 245,9 & 235,5 & 228,4 & 222,8 & 218,0 & 213,7 & 209,7 & 205,9 \\
\hline & 0,4 & 235,3 & 223,7 & 215,9 & 209,6 & 204,3 & 199,5 & 195,0 & 190,8 \\
\hline & 0,5 & 229,2 & 216,5 & 208,0 & 201,3 & 195,4 & 190,2 & 185,4 & 180,8 \\
\hline & 0,6 & 220,4 & 206,5 & 197,1 & 189,6 & 183,2 & 177,4 & 172,1 & 167,0 \\
\hline & 0,7 & 208,0 & 194,9 & 186,1 & 179,2 & 173,2 & 167,8 & 162,8 & 158,0 \\
\hline & 0,8 & $199 ; 4$ & 186,2 & 177,3 & 170,2 & 164,2 & 158,7 & 153,7 & 148,9 \\
\hline \multirow{7}{*}{$1-\mathrm{Fev}$} & 0,2 & 234,9 & 225,0 & 218,4 & 213,1 & 208,5 & 204,5 & 200,7 & 197,1 \\
\hline & 0,3 & 225,1 & 214,3 & 207,0 & 201,3 & 196,3 & 191,9 & 187,7 & 183,8 \\
\hline & 0,4 & 208,4 & 197,0 & 189,4 & 183,3 & 178,1 & 173,4 & 169,0 & 164,9 \\
\hline & 0,5 & 201,4 & 189,4 & 181,3 & 174,8 & 169,3 & 164,3 & 159,8 & 155,4 \\
\hline & 0,6 & 195,0 & 182,3 & 173,7 & 166,9 & 161,0 & 155,8 & 150,9 & 146,3 \\
\hline & 0,7 & 185,3 & 172,0 & 163,0 & 155,8 & 149,7 & 144,2 & 139,1 & 134,2 \\
\hline & 0,8 & 179,5 & 165,3 & 155,8 & 148,1 & 141,6 & 135,8 & 130,3 & 125,2 \\
\hline \multirow{7}{*}{$15-\mathrm{Fev}$} & 0,2 & 212,0 & 203,3 & 197,4 & 192,7 & 188,7 & 185,1 & 181,7 & 178,6 \\
\hline & 0,3 & 199,4 & 190,3 & 184,1 & 179,3 & 175,1 & 171,3 & 167,8 & 164,5 \\
\hline & 0,4 & 198,5 & 186,2 & 178,0 & 171,4 & 165,8 & 160,7 & 156,0 & 151,6 \\
\hline & 0,5 & 181,0 & 169,3 & 161,3 & 155,0 & 149,6 & 144,8 & 140,3 & 136,0 \\
\hline & 0,6 & 163,4 & 152,8 & 145,6 & 140,0 & 135,1 & 130,7 & 126,7 & 122,8 \\
\hline & 0,7 & 157,4 & 145,6 & 137,7 & 131,4 & 126,0 & 121,2 & 116,7 & 112,5 \\
\hline & 0,8 & 156,9 & 142,9 & 133,5 & 126,1 & 119,7 & 113,9 & 108,6 & 103,5 \\
\hline
\end{tabular}


Tabela 12A. Estimativa da lâmina bruta de irrigação $(\mathrm{mm})$ necessária à cultura de melancia, com diferentes probabilidades de ocorrência, em cada época de semeadura e nivel de manejo (p) no município de Parnaiba, Piauí.

\begin{tabular}{|c|c|c|c|c|c|c|c|c|c|}
\hline \multirow{2}{*}{$\begin{array}{l}\text { Epoca de } \\
\text { Semeadura }\end{array}$} & \multirow[t]{2}{*}{$\mathrm{p}$} & \multicolumn{8}{|c|}{ Probabilidade de ocorrência (\%) } \\
\hline & & 95 & 90 & 85 & 80 & 75 & 70 & 65 & 60 \\
\hline \multirow{7}{*}{ 1-Mar } & 0,2 & 210,6 & 200,8 & 194,1 & 188,8 & 184,3 & 180,2 & 176.4 & 172,9 \\
\hline & 0,3 & 198,7 & 188,0 & 180,8 & 175,1 & 170,1 & 165,7 & 161,6 & 157,7 \\
\hline & 0,4 & 187,1 & 175,3 & 167,2 & 160,9 & 155,4 & 150,5 & 145,9 & 141,6 \\
\hline & 0,5 & 180,1 & 167,0 & 158,2 & 151,2 & 145,1 & 139,7 & 134,7 & 130,0 \\
\hline & 0,6 & 161,8 & 149,4 & 141,0 & 134,4 & 128,7 & 123,6 & 118,8 & 114,3 \\
\hline & 0,7 & 152,7 & 139,8 & 131,0 & 124,0 & 118,1 & 112,7 & 107,7 & 103,0 \\
\hline & 0,8 & 146,3 & 132,2 & 122,7 & 115,2 & 108,7 & 102,9 & 97,5 & 92,4 \\
\hline \multirow{7}{*}{ 15-Mar } & 0,2 & 215,9 & 206,7 & 200,5 & 195,6 & 191,4 & 187,6 & 184,1 & 180,7 \\
\hline & 0,3 & 204,5 & 194,6 & 187,9 & 182,5 & 178,0 & 173,9 & 170,1 & 166,4 \\
\hline & 0,4 & 191,7 & 180,8 & 173,5 & 167,7 & 162,6 & 158,1 & 154,0 & 150,0 \\
\hline & 0,5 & 183,9 & 172,3 & 164,5 & 158,2 & 152,9 & 148,1 & 143,7 & 139,5 \\
\hline & 0,6 & 172,9 & 160,5 & 152,1 & 145,4 & 139,7 & 134,6 & 129,8 & 125,3 \\
\hline & 0,7 & 170,6 & 156,3 & 146,7 & 139,0 & 132,4 & 126,5 & 121,1 & 115,9 \\
\hline & 0,8 & 152,9 & 138,9 & 129,4 & 121,9 & 115,5 & 109,7 & 104,3 & 99,2 \\
\hline \multirow{7}{*}{$1-A b r$} & 0,2 & 241,6 & 232,8 & 227,0 & 222,3 & 218,3 & 214,7 & 211,3 & 208,1 \\
\hline & 0,3 & 233,6 & 224,4 & 218,2 & 213,2 & 209,0 & 205,1 & 201,6 & 198,3 \\
\hline & 0,4 & 223,4 & 213,0 & 206,0 & 200,4 & 195,6 & 191,3 & 187,3 & 183,5 \\
\hline & 0,5 & 215,0 & 203,9 & 196,4 & 190,4 & 185,3 & 180,7 & 176,5 & 172,5 \\
\hline & 0,6 & 212,3 & 199,6 & 191,0 & 184,2 & 178,4 & 173,1 & 168,3 & 163,7 \\
\hline & 0,7 & 201,1 & 187,9 & 178,9 & 171,8 & 165,7 & 160,2 & 155,2 & 150,3 \\
\hline & 0,8 & 200,0 & 185,4 & 175,5 & 167,7 & 161,0 & 155,0 & 149,4 & 144,1 \\
\hline \multirow{7}{*}{$15-\mathrm{Abr}$} & 0,2 & 263,0 & 254,7 & 249,0 & 244,5 & 240,7 & 237,2 & 234,1 & 231,0 \\
\hline & 0,3 & 259,8 & 250,1 & 243,6 & 238,4 & 233,9 & 229,9 & 226,2 & 222,6 \\
\hline & 0,4 & 246,4 & 236,7 & 230,1 & 224,8 & 220,4 & 216,3 & 212,6 & 209,1 \\
\hline & 0,5 & 244,1 & 232,9 & 225,3 & 219,3 & 214,1 & 209,5 & 205,2 & 201,1 \\
\hline & 0,6 & 236,4 & 224,0 & 215,6 & 209,0 & 203,3 & 198,1 & 193,4 & 188,9 \\
\hline & 0,7 & 231,6 & 218,0 & 208,9 & 201,6 & 195,3 & 189,7 & 184,5 & 179,6 \\
\hline & 0,8 & 228,3 & 213,7 & 203,9 & 196,0 & 189,3 & 183,3 & 177,7 & 172,4 \\
\hline
\end{tabular}


Tabela 12A. Estimativa da lâmina bruta de irrigação $(\mathrm{mm})$ necessária à cultura de melancia, com diferentes probabilidades de ocorrência, em cada época de semeadura e nível de manejo (p) no municipio de Parnaiba, Piauí.

\begin{tabular}{|c|c|c|c|c|c|c|c|c|c|}
\hline \multirow{2}{*}{$\begin{array}{l}\text { Época de } \\
\text { Semeadura }\end{array}$} & \multirow[t]{2}{*}{$\mathrm{p}$} & \multicolumn{8}{|c|}{ Probabilidade de ocorrência (\%) } \\
\hline & & 95 & 90 & 85 & 80 & 75 & 70 & 65 & 60 \\
\hline \multirow{7}{*}{ 1-Mai } & 0,2 & 291,7 & 285,0 & 280,4 & 276,8 & 273,7 & 270,9 & 268,3 & 265,9 \\
\hline & 0,3 & 287,8 & 280,5 & 275,5 & 271,5 & 268,1 & 265,1 & 262,3 & 259,6 \\
\hline & 0,4 & 282,1 & 273,5 & 267,7 & 263,1 & 259,1 & 255,5 & 252,2 & 249,1 \\
\hline & 0,5 & 284,7 & 274,1 & 267,0 & 261,3 & 256,5 & 252,1 & 248,0 & 244,2 \\
\hline & 0,6 & 282,4 & 270,5 & 262,5 & 256,1 & 250,6 & 245,7 & 241,1 & 236,8 \\
\hline & 0,7 & 279,8 & 267,1 & 258,6 & 251,8 & 246,0 & 240,8 & 235,9 & 231,3 \\
\hline & 0,8 & 272,1 & 259,6 & 251,2 & 244,5 & 238,7 & 233,6 & 228,8 & 224,2 \\
\hline \multirow{7}{*}{ 15-Mai } & 0,2 & 304,7 & 297,8 & 293,2 & 289,6 & 286,4 & 283,6 & 281,0 & 278,5 \\
\hline & 0,3 & 304,0 & 295,9 & 290,5 & 286,2 & 282,5 & 279,2 & 276,1 & 273,2 \\
\hline & 0,4 & 298,6 & 290,2 & 284,5 & 280,0 & 276,1 & 272,7 & 269,4 & 266,4 \\
\hline & 0,5 & 300,5 & 290,6 & 283,9 & 278,5 & 274,0 & 269,9 & 266,1 & 262,5 \\
\hline & 0,6 & 295,8 & 285,2 & 278,0 & 272,4 & 267,5 & 263,1 & 259,0 & 255,2 \\
\hline & 0,7 & 295,9 & 284,4 & 276,6 & 270,5 & 265,2 & 260,5 & 256,1 & 251,9 \\
\hline & 0,8 & 289,9 & 278,1 & 270,1 & 263,7 & 258,2 & 253,3 & 248,8 & 244,5 \\
\hline \multirow{7}{*}{ 1-Jun } & 0,2 & 322,8 & 317,8 & 314,3 & 311,6 & 309,3 & 307,2 & 305,3 & 303,5 \\
\hline & 0,3 & 320,8 & 315,1 & 311,2 & 308,1 & 305,5 & 303,2 & 301,0 & 298,9 \\
\hline & 0,4 & 320,4 & 313,7 & 309,2 & 305,7 & 302,6 & 299,9 & 297,3 & 294,9 \\
\hline & 0,5 & 315,9 & 309,0 & 304,4 & 300,7 & 297,5 & 294,7 & 292,0 & 289,5 \\
\hline & 0,6 & 316,5 & 308,0 & 302,4 & 297,8 & 294,0 & 290,5 & 287,3 & 284,2 \\
\hline & 0,7 & 315,0 & 306,5 & 300,8 & 296,3 & 292,4 & 288,9 & 285,7 & 282,6 \\
\hline & 0,8 & 313,3 & 304,2 & 298,0 & 293,1 & 288,9 & 285,2 & 281,7 & 278,3 \\
\hline \multirow{7}{*}{ 15-Jun } & 0,2 & 350,3 & 345,5 & 342,2 & 339,6 & 337,3 & 335,3 & 333,4 & 331,7 \\
\hline & 0,3 & 347,4 & 342,4 & 339,1 & 336,5 & 334,2 & 332,1 & 330,2 & 328,5 \\
\hline & 0,4 & 345,8 & 339,9 & 335,9 & 332,8 & 330,1 & 327,6 & 325,4 & 323,2 \\
\hline & 0,5 & 342,8 & 336,9 & 332,9 & 329,7 & 326,9 & 324,5 & 322,2 & 320,0 \\
\hline & 0,6 & 345,0 & 337,7 & 332,7 & 328,8 & 325,4 & 322,4 & 319,6 & 316,9 \\
\hline & 0,7 & 340,2 & 334,0 & 329,9 & 326,6 & 323,7 & 321,2 & 318,8 & 316,6 \\
\hline & 0,8 & 341,0 & 333,3 & 328,0 & 323,9 & 320,3 & 317,1 & 314,1 & 311,3 \\
\hline
\end{tabular}


304

Tabela 12A. Estimativa da lâmina bruta de irrigação $(\mathrm{mm})$ necessária à cultura de melancia, com diferentes probabilidades de ocorrência, em cada época de semeadura e nível de manejo (p) no município de Parnaiba, Piauí.

\begin{tabular}{|c|c|c|c|c|c|c|c|c|c|}
\hline \multirow{2}{*}{$\begin{array}{l}\text { Epoca de } \\
\text { Semeadura }\end{array}$} & \multirow[t]{2}{*}{$\mathrm{p}$} & \multicolumn{8}{|c|}{ Probabilidade de ocorrência ( $\%)$} \\
\hline & & 95 & 90 & 85 & 80 & 75 & 70 & 65 & 60 \\
\hline \multirow{7}{*}{ 1-Jul } & 0,2 & 379,2 & 375,1 & 372,2 & 370,0 & 368,1 & 366,4 & 364,8 & 363,2 \\
\hline & 0,3 & 375,9 & 371,5 & 368,6 & 366,3 & 364,3 & 362,5 & 360,9 & 359,3 \\
\hline & 0,4 & 375,7 & 370,8 & 367,5 & 364,9 & 362,7 & 360,6 & 358,8 & 357,0 \\
\hline & 0,5 & 374,8 & 369,3 & 365,6 & 362,6 & 360,1 & 357,8 & 355,7 & 353,7 \\
\hline & 0,6 & 378,3 & 371,6 & 367,1 & 363,5 & 360,5 & 357,7 & 355,2 & 352,7 \\
\hline & 0,7 & 374,5 & 367,8 & 363,2 & 359,6 & 356,5 & 353,7 & 351,1 & 348,7 \\
\hline & 0,8 & 371,3 & 365,2 & 361,1 & 357,9 & 355,1 & 352,6 & 350,3 & 348,1 \\
\hline \multirow{7}{*}{ 15-Jul } & 0,2 & 409,7 & 405,7 & 403,0 & 400,8 & 399,0 & 397,3 & 395,8 & 394,3 \\
\hline & 0,3 & 406,6 & 402,5 & 399,8 & 397,6 & 395,7 & 394,0 & 392,4 & 390,9 \\
\hline & 0,4 & 405,2 & 400,9 & 398,0 & 395,7 & 393,7 & 391,9 & 390,2 & 388,7 \\
\hline & 0,5 & 406,0 & 401,3 & 398,1 & 395,6 & 393,4 & 391,5 & 389,7 & 388,0 \\
\hline & 0,6 & 408,8 & 402,5 & 398,2 & 394,9 & 392,0 & 389,4 & 387,0 & 384,7 \\
\hline & 0,7 & 406,1 & 400,2 & 396,3 & 393,1 & 390,4 & 388,0 & 385,8 & 383,6 \\
\hline & 0,8 & 401,0 & 395,5 & 391,8 & 388,9 & 386,3 & 384,1 & 382,0 & 380,0 \\
\hline \multirow{7}{*}{ 1-Ago } & 0,2 & 441,2 & 438,9 & 437,3 & 436,0 & 435,0 & 434,0 & 433,1 & 432,2 \\
\hline & 0,3 & 439,2 & 436,7 & 435,1 & 433,8 & 432,7 & 431,7 & 430,8 & 429,9 \\
\hline & 0,4 & 438,5 & 435,9 & 434,2 & 432,8 & 431,6 & 430,6 & 429,6 & 428,6 \\
\hline & 0,5 & 438,3 & 435,3 & 433,3 & 431,7 & 430,3 & 429,1 & 428,0 & 426,9 \\
\hline & 0,6 & 445,0 & 439,8 & 436,3 & 433,6 & 431,2 & 429,0 & 427,1 & 425,2 \\
\hline & 0,7 & 435,8 & 432,4 & 430,2 & 428,3 & 426,8 & 425,4 & 424,1 & 422,9 \\
\hline & 0,8 & 436,1 & 432,7 & 430,3 & 428,5 & 426,9 & 425,4 & 424,1 & 422,8 \\
\hline \multirow{7}{*}{ 15-Ago } & 0,2 & 460,2 & 458,0 & 456,5 & 455,3 & 454,3 & 453,4 & 452,6 & 451,8 \\
\hline & 0,3 & 459,0 & 456,8 & 455,2 & 454,0 & 453,0 & 452,0 & 451,2 & 450,4 \\
\hline & 0,4 & 457,3 & 454,9 & 453,3 & 452,0 & 450,9 & 449,9 & 449,0 & 448,1 \\
\hline & 0,5 & 457,8 & 455,0 & 453,1 & 451,6 & 450,3 & 449,1 & 448,0 & 447,0 \\
\hline & 0,6 & 453,3 & 453,3 & 453,3 & 453,3 & 453,3 & 453,3 & 453,3 & 438,2 \\
\hline & 0,7 & 455,0 & 451,6 & 449,4 & 447,6 & 446,1 & 444,7 & 443,4 & 442,2 \\
\hline & 0,8 & 460,4 & 456,1 & 453,2 & 450,9 & 448,9 & 447,1 & 445,5 & 443,9 \\
\hline
\end{tabular}


Tabela 12A. Estimativa da lâmina bruta de irrigação $(\mathrm{mm})$ necessária à cultura de melancia, com diferentes probabilidades de ocorrência, em cada época de semeadura e nivel de manejo (p) no municipio de Parnaiba, Piaui.

\begin{tabular}{|c|c|c|c|c|c|c|c|c|c|}
\hline \multirow{2}{*}{$\begin{array}{c}\text { Época de } \\
\text { Semeadura }\end{array}$} & \multirow[t]{2}{*}{$\mathrm{p}$} & \multicolumn{8}{|c|}{ Probabilidade de ocorrência $(\%)$} \\
\hline & & 95 & 90 & 85 & 80 & 75 & 70 & 65 & 60 \\
\hline \multirow{7}{*}{$1-$ Set } & 0,2 & 472,7 & 470,9 & 469,7 & 468,8 & 468,0 & 467.3 & 466,6 & 466,0 \\
\hline & 0,3 & 473,6 & 471,6 & 470,2 & 469,1 & 468,1 & 467.2 & 466,5 & 465,7 \\
\hline & 0,4 & 471,6 & 469,4 & 467,8 & 466,6 & 465,5 & 464,6 & 463,7 & 462,9 \\
\hline & 0,5 & 468,7 & 466,3 & 464,7 & 463,5 & 462,4 & 461,4 & 460,5 & 459,7 \\
\hline & 0,6 & 469,8 & 469,8 & 469,8 & 469,8 & 469,8 & 469,8 & 469,8 & 452,4 \\
\hline & 0,7 & 470,3 & 466,9 & 464,7 & 462,8 & 461,3 & 459.9 & 458,6 & 457,4 \\
\hline & 0,8 & 472,1 & 468,0 & 465,3 & 463,2 & 461,3 & 459.7 & 458,1 & 456,7 \\
\hline \multirow{7}{*}{ 15-Set } & 0,2 & 472,7 & 470,2 & 468,5 & 467,2 & 466,0 & 465,0 & 464,0 & 463,1 \\
\hline & 0,3 & 473,0 & 470,2 & 468,3 & 466,8 & 465,6 & 464,4 & 463,3 & 462,3 \\
\hline & 0,4 & 469,9 & 467,3 & 465,5 & 464,1 & 462,8 & 461,7 & 460,7 & 459,8 \\
\hline & 0,5 & 468,3 & 465,3 & 463,3 & 461,8 & 460,4 & 459,2 & 458,1 & 457,0 \\
\hline & 0,6 & 479,0 & 473,5 & 469,8 & 466,9 & 464,4 & 462,2 & 460,1 & 458,1 \\
\hline & 0,7 & 470,3 & 466,2 & 463,4 & 461,1 & 459,2 & 457,5 & 455,9 & 454,4 \\
\hline & 0,8 & 462,6 & 459,3 & 457,0 & 455,3 & 453,7 & 452,4 & 451,1 & 449,9 \\
\hline \multirow{7}{*}{ 1-Out } & 0,2 & 472,2 & 469,1 & 467,0 & 465,3 & 463,9 & 462,6 & 461,5 & 460,3 \\
\hline & 0,3 & 471,8 & 468,3 & 466,0 & 464,2 & 462,6 & 461,2 & 459,9 & 458,6 \\
\hline & 0,4 & 471,3 & 467,4 & 464,7 & 462,6 & 460,8 & 459,2 & 457,7 & 456,3 \\
\hline & 0,5 & 468,4 & 464,4 & 461,8 & 459,7 & 457,9 & 456,2 & 454,7 & 453,3 \\
\hline & 0,6 & 463,0 & 463,0 & 463,0 & 463,0 & 463,0 & 463,0 & 463,0 & 448,0 \\
\hline & 0,7 & 469,0 & 464,3 & 461,0 & 458,5 & 456,3 & 454,3 & 452,5 & 450,7 \\
\hline & 0,8 & 471,2 & 465,4 & 461,5 & 458,4 & 455,8 & 453,4 & 451,2 & 449,1 \\
\hline \multirow{7}{*}{ 15-Out } & 0,2 & 463,1 & 459,5 & 457,0 & 455,1 & 453,4 & 451,9 & 450,5 & 449,2 \\
\hline & 0,3 & 461,9 & 458,0 & 455,4 & 453,3 & 451,5 & 449,9 & 448,4 & 447,0 \\
\hline & 0,4 & 460,5 & 456,6 & 453,9 & 451,8 & 450,0 & 448,3 & 446,8 & 445,4 \\
\hline & 0,5 & 457,5 & 453,4 & 450,6 & 448,4 & 446,5 & 444,8 & 443,3 & 441,8 \\
\hline & 0,6 & 466,9 & 460,3 & 455,8 & 452,3 & 449,2 & 446,5 & 443,9 & 441,5 \\
\hline & 0,7 & 456,5 & 451,3 & 447,7 & 445,0 & 442,6 & 440,4 & 438,4 & 436,5 \\
\hline & 0,8 & 461,0 & 454,5 & 450,2 & 446,7 & 443,8 & 441,1 & 438,7 & 436,3 \\
\hline
\end{tabular}


Tabela 12A. Estimativa da lâmina bruta de irrigação $(\mathrm{mm})$ necessária à cultura de melancia, com diferentes probabilidades de ocorrência, em cada época de semeadura e nivel de manejo (p) no municipio de Parnaiba, Piaui.

\begin{tabular}{|c|c|c|c|c|c|c|c|c|c|}
\hline \multirow{2}{*}{$\begin{array}{l}\text { Época de } \\
\text { Semeadura }\end{array}$} & \multirow[t]{2}{*}{$\mathrm{p}$} & \multicolumn{8}{|c|}{ Probabilidade de ocorrência (\%) } \\
\hline & & 95 & 90 & 85 & 80 & 75 & 70 & 65 & 60 \\
\hline \multirow{7}{*}{$1-\mathrm{Nov}$} & 0,2 & 428,9 & 422,7 & 418,6 & 415,3 & 412,4 & 409,9 & 407,5 & 405,3 \\
\hline & 0,3 & 428,8 & 421,8 & 417,1 & 413,4 & 410,2 & 407,3 & 404,6 & 402,1 \\
\hline & 0,4 & 424,7 & 417,2 & 412,2 & 408,2 & 404,8 & 401,7 & 398,9 & 396,2 \\
\hline & 0,5 & 425,0 & 417,0 & 411,6 & 407,3 & 403,6 & 400,3 & 397,2 & 394,3 \\
\hline & 0,6 & 428,6 & 418,7 & 412,0 & 406,6 & 402,1 & 397,9 & 394,1 & 390,5 \\
\hline & 0,7 & 421,2 & 412,0 & 405,9 & 400,9 & 396,7 & 392,9 & 389,4 & 386,1 \\
\hline & 0,8 & 422,6 & 412,2 & 405,2 & 399,6 & 394,8 & 390,6 & 386,6 & 382,8 \\
\hline \multirow{7}{*}{$15-\mathrm{Nov}$} & 0,2 & 388,0 & 380,7 & 375,7 & 371,8 & 368,5 & 365,5 & 362,7 & 360,0 \\
\hline & 0,3 & 386,3 & 377,9 & 372,2 & 367,7 & 363,8 & 360,4 & 357,1 & 354,1 \\
\hline & 0,4 & 382,5 & 373,8 & 367,9 & 363,2 & 359,2 & 355,6 & 352,2 & 349,1 \\
\hline & 0,5 & 377,7 & 368,5 & 362,3 & 357,4 & 353,1 & 349,3 & 345,8 & 342,5 \\
\hline & 0,6 & 375,1 & 364,4 & 357,2 & 351,5 & 346,6 & 342,2 & 338,2 & 334,3 \\
\hline & 0,7 & 375,6 & 364,2 & 356,4 & 350,2 & 345,0 & 340,2 & 335,8 & 331,7 \\
\hline & 0,8 & 376,1 & 363,0 & 354,3 & 347,3 & 341,3 & 335,9 & 330,9 & 326,2 \\
\hline \multirow{7}{*}{ 1-Dez } & 0,2 & 355,5 & 348,3 & 343,4 & 339,5 & 336,1 & 333,1 & 330,3 & 327,7 \\
\hline & 0,3 & 350,4 & 342,5 & 337,2 & 333,0 & 329,4 & 326,1 & 323,1 & 320,3 \\
\hline & 0,4 & 350,9 & 341,6 & 335,3 & 330,3 & 326,0 & 322,2 & 318,6 & 315,2 \\
\hline & 0,5 & 343,7 & 333,6 & 326,8 & 321,4 & 316,7 & 312,6 & 308,7 & 305,0 \\
\hline & 0,6 & 341,9 & 330,7 & 323,1 & 317,1 & 311,9 & 307,3 & 303,0 & 298,9 \\
\hline & 0,7 & 335,3 & 324,0 & 316,4 & 310,3 & 305,1 & 300,4 & 296,1 & 292,0 \\
\hline & 0,8 & 335,9 & 323,3 & 314,9 & 308,2 & 302,4 & 297,3 & 292,5 & 287,9 \\
\hline \multirow{7}{*}{ 15-Dez } & 0,2 & 317,3 & 308,1 & 301,8 & 296,9 & 292,6 & 288,8 & 285,2 & 281,9 \\
\hline & 0,3 & 310,7 & 300,5 & 293,7 & 288,2 & 283,5 & 279,3 & 275,5 & 271,8 \\
\hline & 0,4 & 307,5 & 295,6 & 287,5 & 281,1 & 275,6 & 270,7 & 266,1 & 261,8 \\
\hline & 0,5 & 302,0 & 289,3 & 280,7 & 273,9 & 268,1 & 262,8 & 258,0 & 253,4 \\
\hline & 0,6 & 295,0 & 281,9 & 273,1 & 266,1 & 260,1 & 254,7 & 249,7 & 245,0 \\
\hline & 0,7 & 292,9 & 278,1 & 268,2 & 260,3 & 253,5 & 247,4 & 241,7 & 236,4 \\
\hline & 0,8 & 284,1 & 269,6 & 259,8 & 252,0 & 245,3 & 239,3 & 233,8 & 228,5 \\
\hline
\end{tabular}


Tabela 13A. Estimativa da lâmina bruta de irrigação $(\mathrm{mm})$ necessária à cultura de melancia, com diferentes probabilidades de ocorrência, em cada época de semeadura e nivel de manejo (p) no município de Teresina, Piauí.

\begin{tabular}{lcrrrrrrrr}
\hline Época de & $\mathrm{p}$ & \multicolumn{7}{c}{ Probabilidade de ocorrência (\%) } \\
\cline { 2 - 10 } Semeadura & & \multicolumn{1}{c}{95} & \multicolumn{1}{c}{90} & \multicolumn{1}{c}{85} & \multicolumn{1}{c}{80} & \multicolumn{1}{c}{75} & \multicolumn{1}{c}{70} & \multicolumn{1}{c}{65} & \multicolumn{1}{c}{60} \\
\hline \multirow{6}{*}{ 1-Jan } & 0,2 & 189,7 & 180,8 & 174,8 & 170,0 & 165,9 & 162,2 & 158,8 & 155,6 \\
& 0,3 & 177,5 & 167,5 & 160,7 & 155,3 & 150,7 & 146,6 & 142,7 & 139,1 \\
& 0,4 & 165,7 & 154,5 & 147,0 & 141,0 & 135,9 & 131,3 & 127,0 & 123,0 \\
& 0,5 & 150,9 & 139,2 & 131,3 & 125,0 & 119,6 & 114,8 & 110,3 & 106,0 \\
& 0,6 & 141,5 & 128,8 & 120,2 & 113,4 & 107,5 & 102,3 & 97,4 & 92,8 \\
& 0,7 & 130,8 & 118,2 & 109,7 & 103,0 & 97,2 & 92,0 & 87,1 & 82,6 \\
& 0,8 & 126,4 & 113,0 & 103,9 & 96,8 & 90,6 & 85,1 & 79,9 & 75,1 \\
\hline \multirow{6}{*}{ 15-Jan } & 0,2 & 174,6 & 165,6 & 159,5 & 154,7 & 150,6 & 146,9 & 143,5 & 140,2 \\
& 0,3 & 160,2 & 149,6 & 142,5 & 136,8 & 132,0 & 127,6 & 123,6 & 119,8 \\
& 0,4 & 145,3 & 134,6 & 127,4 & 121,6 & 116,7 & 112,3 & 108,2 & 104,3 \\
& 0,5 & 138,6 & 126,2 & 117,8 & 111,1 & 105,4 & 100,3 & 95,5 & 91,0 \\
& 0,6 & 129,2 & 116,0 & 107,2 & 100,1 & 94,1 & 88,6 & 83,6 & 78,8 \\
& 0,7 & 114,5 & 102,2 & 93,8 & 87,2 & 81,5 & 76,4 & 71,6 & 67,2 \\
& 0,8 & 111,3 & 91,1 & 91,1 & 70,8 & 70,8 & 70,8 & 70,8 & 50,6 \\
\hline \multirow{6}{*}{ 15-Fev } & 0,2 & 149,5 & 141,5 & 136,1 & 131,8 & 128,2 & 124,9 & 121,8 & 118,9 \\
& 0,3 & 134,1 & 124,7 & 118,3 & 113,3 & 108,9 & 105,0 & 101,4 & 98,0 \\
& 0,5 & 105,0 & 94,0 & 86,5 & 80,6 & 75,5 & 71,0 & 66,8 & 62,8 \\
& 0,6 & 98,2 & 86,4 & 78,4 & 72,0 & 66,5 & 61,6 & 57,1 & 52,8 \\
& 0,4 & 118,7 & 109,4 & 103,0 & 98,0 & 93,7 & 89,8 & 86,2 & 82,8 \\
& 0,7 & 88,1 & 76,7 & 69,0 & 62,9 & 57,6 & 52,9 & 48,6 & 44,4 \\
& 0,8 & 104,0 & 94,5 & 88,1 & 83,0 & 78,6 & 74,7 & 71,0 & 67,6 \\
& 0,8 & 69,1 & 69,1 & 53,7 & 53,7 & 38,4 & 38,4 & 38,4 & 38,4 \\
& 0,6 & 94,7 & 84,9 & 78,3 & 73,0 & 68,5 & 64,5 & 60,7 & 57,1 \\
& 0,7 & 79,5 & 70,0 & 63,7 & 58,6 & 54,2 & 50,3 & 46,7 & 43,3 \\
& 0,8 & 80,2 & 67,8 & 67,8 & 55,5 & 43,2 & 43,2 & 30,8 & 30,8 \\
\hline \multirow{6}{*}{ 1-Fev } & 0,2 & 155,0 & 144,5 & 137,4 & 131,8 & 127,0 & 122,7 & 118,7 & 114,9 \\
& 0,3 & 132,8 & 122,4 & 115,4 & 109,8 & 105,0 & 100,7 & 96,7 & 92,9 \\
& 0,4 & 126,1 & 114,2 & 106,1 & 99,7 & 94,2 & 89,3 & 84,7 & 80,4 \\
& 0 & & & & & & & &
\end{tabular}


Tabela 13A. Estimativa da lâmina bruta de irrigação $(\mathrm{mm})$ necessária à cultura de melancia, com diferentes probabilidades de ocorrência, em cada época de semeadura e nível de manejo (p) no município de Teresina, Piauí.

\begin{tabular}{|c|c|c|c|c|c|c|c|c|c|}
\hline \multirow{2}{*}{$\begin{array}{l}\text { Época de } \\
\text { Semeadura }\end{array}$} & \multirow[t]{2}{*}{$\mathrm{p}$} & \multicolumn{8}{|c|}{ Probabilidade de ocorrência (\%) } \\
\hline & & 95 & 90 & 85 & 80 & 75 & 70 & 65 & 60 \\
\hline \multirow{7}{*}{ 1-Mar } & 0,2 & 147,7 & 138,8 & 132,8 & 128,1 & 124,0 & 120,3 & 116,9 & 113,7 \\
\hline & 0,3 & 128,7 & 119,3 & 112,9 & 107,8 & 103,5 & 99,6 & 95,9 & 92,5 \\
\hline & 0,4 & 110,4 & 100,7 & 94,1 & 88,9 & 84,4 & 80,4 & 76,6 & 73,1 \\
\hline & 0,5 & 102,8 & 92,4 & 85,4 & 79,8 & 75,0 & 70,8 & 66,8 & 63,0 \\
\hline & 0,6 & 92,1 & 81,9 & 74,9 & 69,4 & 64,7 & 60,4 & 56,5 & 52,8 \\
\hline & 0,7 & 78,1 & 68,4 & 61,9 & 56,7 & 52,2 & 48,2 & 44,5 & 41,0 \\
\hline & 0,8 & 72,4 & 59,2 & 32,9 & 32,9 & 32,9 & 32,9 & 32,9 & 32,9 \\
\hline \multirow{7}{*}{ 15-Mar } & 0,2 & 168,4 & 159,3 & 153,2 & 148,3 & 144,1 & 140,4 & 136,9 & 133,6 \\
\hline & 0,3 & 154,5 & 143,9 & 136,7 & 131,1 & 126,2 & 121,8 & 117,8 & 113,9 \\
\hline & 0,4 & 146,2 & 134,1 & 125,9 & 119,4 & 113,9 & 108,9 & 104,3 & 99,9 \\
\hline & 0,5 & 131,4 & 120,0 & 112,4 & 106,3 & 101,0 & 96,3 & 92,0 & 87,9 \\
\hline & 0,6 & 118,7 & 106,9 & 99,0 & 92,7 & 87,3 & 82,5 & 78,0 & 73,7 \\
\hline & 0,7 & 106,5 & 95,0 & 87,2 & 81,0 & 75,7 & 71,0 & 66,5 & 62,4 \\
\hline & 0,8 & 100,8 & 88,6 & 80,4 & 73,8 & 68,2 & 63,2 & 58,5 & 54,1 \\
\hline \multirow{7}{*}{$1-\mathrm{Abr}$} & 0,2 & 194,5 & 185,7 & 179,7 & 175,0 & 170,9 & 167,3 & 163,9 & 160,7 \\
\hline & 0,3 & 182,8 & 173,2 & 166,7 & 161,5 & 157,1 & 153,2 & 149,5 & 146,0 \\
\hline & 0,4 & 173,9 & 163,2 & 156,0 & 150,2 & 145,3 & 140,9 & 136,8 & 132,9 \\
\hline & 0,5 & 169,6 & 157,4 & 149,1 & 142,5 & 136,9 & 131,8 & 127,1 & 122,6 \\
\hline & 0,6 & 160,8 & 148,0 & 139,3 & 132,3 & 126,4 & 121,1 & 116,2 & 111,5 \\
\hline & 0,7 & 155,6 & 141,6 & 132,2 & 124,7 & 118,3 & 112,5 & 107,2 & 102,1 \\
\hline & 0,8 & 145,2 & 131,1 & 121,5 & 114,0 & 107,5 & 101,7 & 96,3 & 91,1 \\
\hline \multirow{7}{*}{$15-\mathrm{Abr}$} & 0,2 & 223,3 & 215,4 & 210,0 & 205,8 & 202,2 & 198,9 & 195,9 & 193,0 \\
\hline & 0,3 & 217,2 & 207,9 & 201,7 & 196,7 & 192,4 & 188,6 & 185,1 & 181,7 \\
\hline & 0,4 & 207,2 & 196,7 & 189,7 & 184,0 & 179,2 & 174,9 & 170,9 & 167,1 \\
\hline & 0,5 & 204,0 & 192,2 & 184,3 & 178,0 & 172,6 & 167,7 & 163,3 & 159,0 \\
\hline & 0,6 & 192,8 & 181,2 & 173,4 & 167,2 & 161,9 & 157,1 & 152,6 & 148,4 \\
\hline & 0,7 & 189,7 & 177,4 & 169,1 & 162,5 & 156,9 & 151,8 & 147,1 & 142,6 \\
\hline & 0,8 & 186,0 & 172,6 & 163,6 & 156,5 & 150,3 & 144,8 & 139,7 & 134,9 \\
\hline
\end{tabular}


Tabela 13A. Estimativa da lâmina bruta de irrigação $(\mathrm{mm})$ necessária à cultura de melancia, com diferentes probabilidades de ocorrência, em cada época de semeadura e nível de manejo (p) no município de Teresina, Piauí.

\begin{tabular}{|c|c|c|c|c|c|c|c|c|c|}
\hline \multirow{2}{*}{$\begin{array}{l}\text { Época de } \\
\text { Semeadura }\end{array}$} & \multirow[t]{2}{*}{$\mathrm{p}$} & \multicolumn{8}{|c|}{ Probabilidade de ocorrência (\%) } \\
\hline & & 95 & 90 & 85 & 80 & 75 & 70 & 65 & 60 \\
\hline \multirow{7}{*}{ 1-Mai } & 0,2 & 247,1 & 239,4 & 234,2 & 230,1 & 226,6 & 223,4 & 220,5 & 217,7 \\
\hline & 0,3 & 239,8 & 231,0 & 225,0 & 220,3 & 216,2 & 212,5 & 209,1 & 205,9 \\
\hline & 0,4 & 234,8 & 224,9 & 218,2 & 212,9 & 208,3 & 204,2 & 200,4 & 196,8 \\
\hline & 0,5 & 237,4 & 225,5 & 217,5 & 211,1 & 205,7 & 200,8 & 196,2 & 191,9 \\
\hline & 0,6 & 232,4 & 220,1 & 211,7 & 205,1 & 199,4 & 194,3 & 189,6 & 185,1 \\
\hline & 0,7 & 222,2 & 209,9 & 201,6 & 195,0 & 189,3 & 184,2 & 179,5 & 175,1 \\
\hline & 0,8 & 227,5 & 212,8 & 202,8 & 194,9 & 188,1 & 182,0 & 176,3 & 171,0 \\
\hline \multirow{7}{*}{ 15-Mai } & 0,2 & 263,3 & 258,2 & 254,8 & 252,1 & 249,7 & 247,6 & 245,7 & 243,9 \\
\hline & 0,3 & 260,3 & 253,7 & 249,3 & 245,8 & 242,7 & 240,0 & 237,5 & 235,1 \\
\hline & 0,4 & 260,5 & 253,3 & 248,4 & 244,5 & 241,2 & 238,2 & 235,5 & 232,8 \\
\hline & 0,5 & 257,2 & 249,0 & 243,6 & 239,2 & 235,5 & 232,1 & 229,0 & 226,1 \\
\hline & 0,6 & 251,5 & 243,3 & 237,8 & 233,5 & 229,7 & 226,3 & 223,2 & 220,2 \\
\hline & 0,7 & 250,7 & 241,3 & 235,0 & 230,0 & 225,7 & 221,8 & 218,2 & 214,8 \\
\hline & 0,8 & 249,4 & 240,1 & 233,9 & 228,9 & 224,6 & 220,8 & 217,2 & 213,8 \\
\hline \multirow{7}{*}{ 1-Jun } & 0,2 & 284,8 & 280,2 & 277,2 & 274,7 & 272,7 & 270,8 & 269,0 & 267,4 \\
\hline & 0,3 & 283,3 & 278,2 & 274,7 & 272,0 & 269,7 & 267,5 & 265,6 & 263,7 \\
\hline & 0,4 & 280,6 & 275,3 & 271,7 & 268,8 & 266,3 & 264,1 & 262,1 & 260,2 \\
\hline & 0,5 & 280,4 & 274,5 & 270,5 & 267,4 & 264,7 & 262,3 & 260,1 & 257,9 \\
\hline & 0,6 & 279,4 & 272,4 & 267,7 & 264,0 & 260,8 & 257,9 & 255,2 & 252,7 \\
\hline & 0,7 & 279,8 & 272,5 & 267,6 & 263,7 & 260,4 & 257,4 & 254,6 & 252,0 \\
\hline & 0,8 & 278,3 & 270,4 & 265,1 & 260,9 & 257,3 & 254,1 & 251,1 & 248,2 \\
\hline \multirow{7}{*}{ 15-Jun } & 0,2 & 302,4 & 298,9 & 296,5 & 294,7 & 293,1 & 291,6 & 290,3 & 289,0 \\
\hline & 0,3 & 301,7 & 297,3 & 294,4 & 292,0 & 290,0 & 288,2 & 286,5 & 284,9 \\
\hline & 0,4 & 297,9 & 293,4 & 290,4 & 288,0 & 285,9 & 284,0 & 282,3 & 280,7 \\
\hline & 0,5 & 300,4 & 295,2 & 291,7 & 289,0 & 286,6 & 284,5 & 282,5 & 280,6 \\
\hline & 0,6 & 297,6 & 291,7 & 287,7 & 284,5 & 281,8 & 279,3 & 277,0 & 274,9 \\
\hline & 0,7 & 303,5 & 296,3 & 291,5 & 287,7 & 284,4 & 281,4 & 278,7 & 276,1 \\
\hline & 0,8 & 301,2 & 277,8 & 277,8 & 277,8 & 277,8 & 277,8 & 277,8 & 266,0 \\
\hline
\end{tabular}


Tabela 13A. Estimativa da lâmina bruta de irrigação (mm) necessária à cultura de melancia, com diferentes probabilidades de ocorrência, em cada época de semeadura e nível de manejo (p) no município de Teresina, Piauí.

\begin{tabular}{|c|c|c|c|c|c|c|c|c|c|}
\hline \multirow{2}{*}{$\begin{array}{l}\text { Época de } \\
\text { Semeadura }\end{array}$} & \multirow[t]{2}{*}{$\mathrm{p}$} & \multicolumn{8}{|c|}{ Probabilidade de ocorrência (\%) } \\
\hline & & 95 & 90 & 85 & 80 & 75 & 70 & 65 & 60 \\
\hline \multirow{7}{*}{ 1-Jul } & 0,2 & 325,5 & 322,8 & 320,9 & 319,4 & 318,2 & 317,1 & 316,0 & 315,0 \\
\hline & 0,3 & 324,6 & 321,6 & 319,6 & 317,9 & 316,6 & 315,3 & 314,2 & 313,1 \\
\hline & 0,4 & 322,7 & 319,1 & 316,7 & 314,8 & 313,2 & 311,7 & 310,3 & 309,1 \\
\hline & 0,5 & 324,6 & 320,2 & 317,3 & 314,9 & 312,9 & 311,1 & 309,4 & 307,9 \\
\hline & 0,6 & 322,7 & 318,2 & 315,1 & 312,7 & 310,7 & 308,8 & 307,1 & 305,4 \\
\hline & 0,7 & 321,2 & 315,9 & 312,3 & 309,5 & 307,0 & 304,8 & 302,8 & 300,9 \\
\hline & 0,8 & 312,2 & 312,2 & 312,2 & 304,0 & 304,0 & 304,0 & 304,0 & 304,0 \\
\hline \multirow{7}{*}{ 15-Jul } & 0,2 & 346,7 & 344,2 & 342,5 & 341,1 & 340,0 & 338,9 & 337,9 & 337,0 \\
\hline & 0,3 & 345,8 & 342,7 & 340,6 & 339,0 & 337,6 & 336,3 & 335,1 & 334,0 \\
\hline & 0,4 & 346,0 & 342,6 & 340,3 & 338,5 & 337,0 & 335,6 & 334,3 & 333,0 \\
\hline & 0,5 & 345,9 & 341,8 & 339,0 & 336,7 & 334,8 & 333,1 & 331,5 & 330,0 \\
\hline & 0,6 & 343,5 & 339,3 & 336,4 & 334,2 & 332,2 & 330,5 & 328,9 & 327,3 \\
\hline & 0,7 & 342,3 & 331,8 & 331,8 & 331,8 & 331,8 & 331,8 & 331,8 & 321,3 \\
\hline & 0,8 & 350,4 & 344,4 & 340,4 & 337,2 & 334,5 & 332,0 & 329,7 & 327,6 \\
\hline \multirow{7}{*}{ 1-Ago } & 0,2 & 364,2 & 360,8 & 358,5 & 356,7 & 355,2 & 353,8 & 352,5 & 351,2 \\
\hline & 0,3 & 362,8 & 359,2 & 356,7 & 354,7 & 353,0 & 351,5 & 350,1 & 348,8 \\
\hline & 0,4 & 362,5 & 358,4 & 355,6 & 353,4 & 351,5 & 349,8 & 348,3 & 346,8 \\
\hline & 0,5 & 362,6 & 357,4 & 353,9 & 351,2 & 348,8 & 346,7 & 344,7 & 342,8 \\
\hline & 0,6 & 365,5 & 359,2 & 355,0 & 351,7 & 348,8 & 346,2 & 343,8 & 341,5 \\
\hline & 0,7 & 359,8 & 353,9 & 350,0 & 346,9 & 344,2 & 341,8 & 339,5 & 337,4 \\
\hline & 0,8 & 343,5 & 343,5 & 343,5 & 336,4 & 336,4 & 336,4 & 336,4 & 336,4 \\
\hline \multirow{7}{*}{ 15-Ago } & 0,2 & 373,5 & 370,0 & 367,7 & 365,8 & 364,3 & 362,8 & 361,5 & 360,3 \\
\hline & 0,3 & 373,1 & 369,2 & 366,6 & 364,5 & 362,7 & 361,1 & 359,6 & 358,2 \\
\hline & 0,4 & 371,6 & 367,2 & 364,3 & 362,0 & 360,0 & 358,2 & 356,6 & 355,0 \\
\hline & 0,5 & 371,8 & 366,6 & 363,1 & 360,3 & 357,9 & 355,8 & 353,8 & 351,9 \\
\hline & 0,6 & 371,4 & 366,0 & 362,4 & 359,4 & 356,9 & 354,7 & 352,6 & 350,7 \\
\hline & 0,7 & 371,5 & 365,5 & 361,4 & 358,2 & 355,4 & 352,9 & 350,6 & 348,4 \\
\hline & 0,8 & 361,2 & 351,6 & 341,9 & 341,9 & 341,9 & 341,9 & 341,9 & 341,9 \\
\hline
\end{tabular}


Tabela 13A. Estimativa da lâmina bruta de irrigação $(\mathrm{mm})$ necessária à cultura de melancia, com diferentes probabilidades de ocorrència, em cada época de semeadura e nível de manejo $(p)$ no municipio de Teresina, Piauí.

\begin{tabular}{|c|c|c|c|c|c|c|c|c|c|}
\hline \multirow{2}{*}{$\begin{array}{l}\text { Época de } \\
\text { Semeadura }\end{array}$} & \multirow[t]{2}{*}{$\mathrm{p}$} & \multicolumn{8}{|c|}{ Probabilidade de ocorrència $(\%)$} \\
\hline & & 95 & 90 & 85 & 80 & 75 & 70 & 65 & 60 \\
\hline \multirow{7}{*}{ 1-Set } & 0,2 & 372,9 & 368,8 & 366,0 & 363,9 & 362,0 & 360,3 & 358,7 & 357,2 \\
\hline & 0,3 & 371,6 & 366,9 & 363,7 & 361,2 & 359,0 & 357,1 & 355,3 & 353,6 \\
\hline & 0,4 & 372,3 & 366,5 & 362,6 & 359,5 & 356,9 & 354,5 & 352,3 & 350,2 \\
\hline & 0,5 & 370,0 & 363,7 & 359,4 & 356,0 & 353,1 & 350,5 & 348,1 & 345,8 \\
\hline & 0,6 & 369,9 & 362,7 & 357,8 & 353,9 & 350,5 & 347,5 & 344,7 & 342,1 \\
\hline & 0,7 & 367,6 & 360,2 & 355,1 & 351,1 & 347,7 & 344,6 & 341,8 & 339,0 \\
\hline & 0,8 & 368,3 & 359,6 & 353,7 & 349,0 & 345,0 & 341,4 & 338,0 & 334,9 \\
\hline \multirow{7}{*}{$15-$ Set } & 0,2 & 368,4 & 363,7 & 360,5 & 357,9 & 355,7 & 353,7 & 351,9 & 350,2 \\
\hline & 0,3 & 366,9 & 361,4 & 357,6 & 354,6 & 352,1 & 349,8 & 347,7 & 345,7 \\
\hline & 0,4 & 364,0 & 358,0 & 353,9 & 350,7 & 347,9 & 345,4 & 343,1 & 341,0 \\
\hline & 0,5 & 363,5 & 356,6 & 351,9 & 348,2 & 345,1 & 342,2 & 339,6 & 337,1 \\
\hline & 0,6 & 367,7 & 358,9 & 352,9 & 348,2 & 344,1 & 340,5 & 337,1 & 333,9 \\
\hline & 0,7 & 363,1 & 354,9 & 349,3 & 344,9 & 341,1 & 337,7 & 334,5 & 331,6 \\
\hline & 0,8 & 350,4 & 350,4 & 350,4 & 335,8 & 335,8 & 335,8 & 335,8 & 335,8 \\
\hline \multirow{7}{*}{ 1-Out } & 0,2 & 357,2 & 352,2 & 348,8 & 346,2 & 343,9 & 341,8 & 339,9 & 338,1 \\
\hline & 0,3 & 356,8 & 350,9 & 347,0 & 343,8 & 341,1 & 338,7 & 336,4 & 334,3 \\
\hline & 0,4 & 356,0 & 348,9 & 344,1 & 340,2 & 337,0 & 334,0 & 331,3 & 328,7 \\
\hline & 0,5 & 355,8 & 347,9 & 342,6 & 338,4 & 334,7 & 331,5 & 328,4 & 325,6 \\
\hline & 0,6 & 355,0 & 346,2 & 340,3 & 335,6 & 331,6 & 327,9 & 324,6 & 321,4 \\
\hline & 0,7 & 349,8 & 341,2 & 335,4 & 330,7 & 326,8 & 323,2 & 319,9 & 316,8 \\
\hline & 0,8 & 350,3 & 340,4 & 333,7 & 328,4 & 323,8 & 319,7 & 315,9 & 312,3 \\
\hline \multirow{7}{*}{ 15-Out } & 0,2 & 341,1 & 335,2 & 331,3 & 328,2 & 325,5 & 323,1 & 320,9 & 318,8 \\
\hline & 0,3 & 338,3 & 331,8 & 327,5 & 324,0 & 321,0 & 318,4 & 315,9 & 313,5 \\
\hline & 0,4 & 339,4 & 331,6 & 326,3 & 322,2 & 318,6 & 315,4 & 312,4 & 309,6 \\
\hline & 0,5 & 333,4 & 325,2 & 319,6 & 315,2 & 311,4 & 307,9 & 304,8 & 301,8 \\
\hline & 0,6 & 335,2 & 325,2 & 318,5 & 313,1 & 308,6 & 304,4 & 300,6 & 297,0 \\
\hline & 0,7 & 333,0 & 321,6 & 314,0 & 307,9 & 302,7 & 298,1 & 293,7 & 289,6 \\
\hline & 0,8 & 333,9 & 321,7 & 313,5 & 306,9 & 301,3 & 296,2 & 291,6 & 287,1 \\
\hline
\end{tabular}


Tabela 13A. Estimativa da lâmina bruta de irrigação $(\mathrm{mm})$ necessária à cultura de melancia, com diferentes probabilidades de ocorrència, em cada época de semeadura e nivel de manejo (p) no município de Teresina, Piauí.

\begin{tabular}{|c|c|c|c|c|c|c|c|c|c|}
\hline \multirow{2}{*}{$\begin{array}{l}\text { Época de } \\
\text { Semeadura }\end{array}$} & \multirow[t]{2}{*}{$p$} & \multicolumn{8}{|c|}{ Probabilidade de ocorrència ( $\%)$} \\
\hline & & 95 & 90 & 85 & 80 & 75 & 70 & 65 & 60 \\
\hline \multirow{7}{*}{$1-\mathrm{Nov}$} & 0,2 & 306,3 & 298,6 & 293,5 & 289,4 & 285,9 & 282,8 & 279,8 & 277,1 \\
\hline & 0,3 & 301,7 & 293,3 & 287,5 & 283,0 & 279,1 & 275,6 & 272,4 & 269,3 \\
\hline & 0,4 & 300,1 & 290,2 & 283,4 & 278,1 & 273,5 & 269,4 & 265,6 & 261,9 \\
\hline & 0,5 & 295,5 & 284,3 & 276,7 & 270,7 & 265,5 & 260,8 & 256,5 & 252,5 \\
\hline & 0,6 & 293,8 & 281,2 & 272,7 & 265,9 & 260,1 & 254,9 & 250,1 & 245,5 \\
\hline & 0,7 & 287,6 & 274,5 & 265,7 & 258,6 & 252,6 & 247,2 & 242,2 & 237,5 \\
\hline & 0,8 & 285,4 & 271,0 & 261,2 & 253,5 & 246,9 & 240,9 & 235,4 & 230,2 \\
\hline \multirow{7}{*}{ 15-Nov } & 0,2 & 274,8 & 266,1 & 260,3 & 255,6 & 251,6 & 248,1 & 244,7 & 241,6 \\
\hline & 0,3 & 265,5 & 256,3 & 250,1 & 245,2 & 241,0 & 237,2 & 233,7 & 230,4 \\
\hline & 0,4 & 255,9 & 245,7 & 238,9 & 233,4 & 228,7 & 224,5 & 220,6 & 216,9 \\
\hline & 0,5 & 255,3 & 243,4 & 235,3 & 228,9 & 223,4 & 218,5 & 214,0 & 209,6 \\
\hline & 0,6 & 249,5 & 236,2 & 227,3 & 220,2 & 214,1 & 208,6 & 203,5 & 198,7 \\
\hline & 0,7 & 241,0 & 227,5 & 218,4 & 211,2 & 205,0 & 199,4 & 194,3 & 189,4 \\
\hline & 0,8 & 242,9 & 227,0 & 216,2 & 207,7 & 200,4 & 193,8 & 187,7 & 182,0 \\
\hline \multirow{7}{*}{ 1-Dez } & 0,2 & 243,1 & 235,3 & 229,9 & 225,7 & 222,1 & 218,8 & 215,8 & 213,0 \\
\hline & 0,3 & 237,5 & 227,7 & 221,2 & 216,0 & 211,5 & 207,5 & 203,8 & 200,2 \\
\hline & 0,4 & 223,0 & 213,0 & 206,2 & 200,9 & 196,3 & 192,1 & 188,3 & 184,7 \\
\hline & 0,5 & 216,8 & 205,6 & 198,1 & 192,1 & 186,9 & 182,3 & 178,1 & 174,0 \\
\hline & 0,6 & 212,3 & 199,9 & 191,5 & 184,8 & 179,1 & 174,0 & 169,3 & 164,8 \\
\hline & 0,7 & 209,5 & 195,6 & 186,1 & 178,6 & 172,2 & 166,4 & 161,1 & 156,0 \\
\hline & 0,8 & 198,3 & 183,1 & 172,8 & 164,7 & 157,7 & 151,4 & 145,6 & 140,1 \\
\hline \multirow{7}{*}{ 15-Dez } & 0,2 & 219,0 & 210,2 & 204,3 & 199,6 & 195,6 & 192,0 & 188,6 & 185,4 \\
\hline & 0,3 & 205,1 & 195,2 & 188,5 & 183,2 & 178,7 & 174,6 & 170,8 & 167,3 \\
\hline & 0,4 & 197,3 & 186,6 & 179,4 & 173,7 & 168,8 & 164,4 & 160,3 & 156,4 \\
\hline & 0,5 & 183,1 & 172,0 & 164,5 & 158,6 & 153,5 & 148,9 & 144,7 & 140,7 \\
\hline & 0,6 & 173,8 & 161,4 & 153,1 & 146,5 & 140,8 & 135,7 & 130,9 & 126,4 \\
\hline & 0,7 & 162,9 & 150,7 & 142,4 & 135,8 & 130,1 & 125,1 & 120,4 & 115,9 \\
\hline & 0,8 & 161,5 & 147,1 & 137,4 & 129,6 & 123,0 & 117,0 & 111,5 & 106,2 \\
\hline
\end{tabular}


Tabela 14A. Estimativa da produtividade de grãos de feijão caupi $\left(\mathrm{kg} \mathrm{ha}^{-1}\right)$, com diferentes probabilidades de ocorrència, em cada época de semeadura e nivel de manejo (p) no municipio de Teresina, Piauí.

\begin{tabular}{|c|c|c|c|c|c|c|c|c|c|}
\hline \multirow{2}{*}{$\begin{array}{c}\text { Época de } \\
\text { Semeadura }\end{array}$} & \multirow[t]{2}{*}{$\mathrm{p}$} & \multicolumn{8}{|c|}{ Probabilidade de ocorrència $(\%)$} \\
\hline & & 5 & 10 & 15 & 20 & 25 & 30 & 35 & 40 \\
\hline \multirow{7}{*}{ 1-Jan } & 0,2 & 2185,0 & 2192,7 & 2198,0 & 2202,1 & 2205,7 & 2208.9 & 2211,9 & 2214,7 \\
\hline & 0,3 & 2051,6 & 2066,9 & 2077,2 & 2085,4 & 2092,4 & 2098.7 & 2104,6 & 2110,2 \\
\hline & 0,4 & 1925,8 & 1943,9 & 1956,1 & 1965,8 & 1974,1 & 1981.6 & 1988,5 & 1995,1 \\
\hline & 0,5 & 1789,7 & 1814,1 & 1830,6 & 1843,7 & 1854,9 & 1865.0 & 1874,4 & 1883,2 \\
\hline & 0,6 & 1708,8 & 1737,1 & 1756,2 & 1771,3 & 1784,3 & 1796.0 & 1806,8 & 1817,1 \\
\hline & 0,7 & 1602,2 & 1638,4 & 1662,8 & 1682,2 & 1698,8 & 1713.8 & 1727,6 & 1740,7 \\
\hline & 0,8 & 1516,4 & 1558,9 & 1587,6 & 1610,4 & 1630,0 & 1647,6 & 1663,9 & 1679,3 \\
\hline \multirow{7}{*}{ 15-Jan } & 0,2 & 2212,2 & 2222,3 & 2229,0 & 2234,4 & 2239,1 & 2243.2 & 2247,1 & 2250,7 \\
\hline & 0,3 & 2091,8 & 2107,1 & 2117,3 & 2125,5 & 2132,5 & 2138.8 & 2144,6 & 2150,2 \\
\hline & 0,4 & 1970,1 & 1990,3 & 2003,9 & 2014,7 & 2024,0 & 2032.3 & 2040,0 & 2047,4 \\
\hline & 0,5 & 1860,1 & 1884,5 & 1901,0 & 1914,1 & 1925,4 & 1935,5 & 1944,8 & 1953,7 \\
\hline & 0,6 & 1770,0 & 1800,2 & 1820,5 & 1836,7 & 1850,6 & 1863,0 & 1874,5 & 1885,5 \\
\hline & 0,7 & & & 1739,2 & 1759,0 & 1775,9 & 1791,1 & 1805,2 & 1818,5 \\
\hline & 0,8 & 1586,0 & 1632,2 & 1663,4 & 1688,2 & 1709,5 & 1728,6 & 1746,3 & 1763,1 \\
\hline \multirow{7}{*}{$1-\mathrm{Fev}$} & 0,2 & 2230,0 & 2240,2 & 2247,1 & 2252,6 & 2257,2 & 2261,4 & 2265,3 & 2269,0 \\
\hline & 0,3 & 2109,9 & 2126,0 & 2136,9 & 2145,5 & 2152,9 & 2159,6 & 2165,7 & 2171,6 \\
\hline & 0,4 & 2000,4 & 2021,5 & 2035,7 & 2047,0 & 2056,7 & 2065.4 & 2073,5 & 2081,1 \\
\hline & 0,5 & 1886,1 & 1914,6 & 1933,9 & 1949,2 & 1962,4 & 1974,1 & 1985,1 & 1995,4 \\
\hline & 0,6 & 1813,8 & 1848,6 & 1872,1 & 1890,7 & 1906,7 & 1921,1 & 1934,4 & 1947,1 \\
\hline & 0,7 & & & 1805,3 & 1826,6 & 1844,8 & 1861.1 & 1876,3 & 1890,7 \\
\hline & 0,8 & 1678,9 & 1723,6 & 1753,8 & 1777,7 & 1798,3 & 1816.8 & 1833,9 & 1850,1 \\
\hline \multirow{7}{*}{$15-\mathrm{Fev}$} & 0,2 & 2225,9 & 2236,8 & 2244,1 & 2249,9 & 2254,9 & 2259,4 & 2263,5 & 2267,4 \\
\hline & 0,3 & 2101,1 & 2118,8 & 2130,7 & 2140,2 & 2148,4 & 2155,7 & 2162,4 & 2168,9 \\
\hline & 0,4 & 1991,0 & 2015,3 & 2031,6 & 2044,6 & 2055,8 & 2065,8 & 2075,1 & 2083,9 \\
\hline & 0,5 & 1887,7 & 1917,9 & 1938,2 & 1954,3 & 1968,2 & 1980.6 & 1992,1 & 2003,1 \\
\hline & 0,6 & 1820,1 & 1856,1 & 1880,4 & 1899,7 & 1916,3 & 1931.2 & 1945,0 & 1958,0 \\
\hline & 0,7 & 1736,0 & 1780,9 & 1811,3 & 1835,4 & 1856,0 & 1874.6 & 1891,8 & 1908,1 \\
\hline & 0,8 & 1655,0 & 1710,0 & 1747,1 & 1776,6 & 1801,9 & 1824.6 & 1845,6 & 1865,6 \\
\hline
\end{tabular}


Tabela 14A. Estimativa da produtividade de grãos de feijão caupi $\left(\mathrm{kg} \mathrm{ha}^{-1}\right)$, com diferentes probabilidades de ocorrência, em cada época de semeadura e nível de manejo (p) no município de Teresina, Piauí.

\begin{tabular}{|c|c|c|c|c|c|c|c|c|c|}
\hline \multirow{2}{*}{$\begin{array}{l}\text { Época de } \\
\text { Semeadura }\end{array}$} & \multirow[t]{2}{*}{$\mathrm{p}$} & \multicolumn{8}{|c|}{ Probabilidade de ocorrência (\%) } \\
\hline & & 5 & 10 & 15 & 20 & 25 & 30 & 35 & 40 \\
\hline \multirow{7}{*}{ 1-Mar } & 0,2 & 2223,2 & 2233,5 & 2240,6 & 2246,1 & 2250,9 & 2255,2 & 2259,2 & 2263,0 \\
\hline & 0,3 & 2087,2 & 2105,7 & 2118,2 & 2128,1 & 2136,6 & 2144,3 & 2151,3 & 2158,1 \\
\hline & 0,4 & 1986,2 & 2008,8 & 2024,0 & 2036,1 & 2046,5 & 2055,9 & 2064,5 & 2072,7 \\
\hline & 0,5 & 1885,1 & 1914,2 & 1933,8 & 1949,4 & 1962,8 & 1974,8 & 1985,9 & 1996,5 \\
\hline & 0,6 & 1801,2 & 1837,8 & 1862,4 & 1882,1 & 1898,9 & 1914,0 & 1928,0 & 1941,3 \\
\hline & 0,7 & 1716,2 & 1760,2 & 1789,9 & 1813,5 & 1833,7 & 1851,9 & 1868,8 & 1884,7 \\
\hline & 0,8 & 1637,9 & 1690,2 & 1725,6 & 1753,7 & 1777,8 & 1799,4 & 1819,5 & 1838,5 \\
\hline \multirow{7}{*}{ 15-Mar } & 0,2 & 2207,6 & 2217,3 & 2223,9 & 2229,1 & 2233,5 & 2237,5 & 2241,2 & 2244,8 \\
\hline & 0,3 & 2055,0 & 2070,6 & 2081,1 & 2089,5 & 2096,7 & 2103,1 & 2109,1 & 2114,7 \\
\hline & 0,4 & 1954,0 & 1974,5 & 1988,3 & 1999,3 & 2008,8 & 2017,2 & 2025,1 & 2032,5 \\
\hline & 0,5 & 1808,2 & 1837,8 & 1857,7 & 1873,6 & 1887,2 & 1899,4 & 1910,7 & 1921,5 \\
\hline & 0,6 & 1710,5 & 1746,3 & 1770,5 & 1789,7 & 1806,2 & 1821,0 & 1834,7 & 1847,7 \\
\hline & 0,7 & 1634,0 & 1674,8 & 1702,3 & 1724,1 & 1742,9 & 1759,8 & 1775,4 & 1790,2 \\
\hline & 0,8 & 1544,1 & 1592,4 & 1625,1 & 1651,0 & 1673,2 & 1693,2 & 1711,7 & 1729,3 \\
\hline \multirow{7}{*}{$1-\mathrm{Abr}$} & 0,2 & 2182,3 & 2192,6 & 2199,5 & 2205,0 & 2209,7 & 2214,0 & 2217,9 & 2221,6 \\
\hline & 0,3 & 2011,9 & 2029,5 & 2041,3 & 2050,7 & 2058,8 & 2066,1 & 2072,8 & 2079,2 \\
\hline & 0,4 & 1904,8 & 1925,7 & 1939,9 & 1951,2 & 1960,8 & 1969,5 & 1977,5 & 1985,2 \\
\hline & 0,5 & 1761,7 & 1788,4 & 1806,5 & 1820,8 & 1833,0 & 1844,1 & 1854,3 & 1864,0 \\
\hline & 0,6 & 1650,2 & 1683,0 & 1705,2 & 1722,8 & 1737,9 & 1751,4 & 1764,0 & 1775,9 \\
\hline & 0,7 & 1555,3 & 1593,8 & 1619,8 & 1640,5 & 1658,3 & 1674,2 & 1689,0 & 1703,0 \\
\hline & 0,8 & 1453,9 & 1499,8 & 1530,8 & 1555,5 & 1576,6 & 1595,6 & 1613,2 & 1629,9 \\
\hline \multirow{7}{*}{$15-\mathrm{Abr}$} & 0,2 & 2160,5 & 2170,2 & 2176,7 & 2181,9 & 2186,4 & 2190,4 & 2194,1 & 2197,6 \\
\hline & 0,3 & 1982,5 & 1996,9 & 2006,7 & 2014,5 & 2021,1 & 2027,1 & 2032,7 & 2037,9 \\
\hline & 0,4 & 1861,0 & 1878,4 & 1890,2 & 1899,5 & 1907,5 & 1914,7 & 1921,4 & 1927,7 \\
\hline & 0,5 & 1705,7 & 1728,5 & 1743,9 & 1756,1 & 1766,6 & 1776,0 & 1784,8 & 1793,0 \\
\hline & 0,6 & 1572,8 & 1601,3 & 1620,5 & 1635,7 & 1648,8 & 1660,6 & 1671,5 & 1681,8 \\
\hline & 0,7 & 1461,8 & 1495,5 & 1518,2 & 1536,3 & 1551,8 & 1565,7 & 1578,6 & 1590,8 \\
\hline & 0,8 & 1365,3 & 1402,8 & 1428,1 & 1448,2 & 1465,4 & 1480,9 & 1495,2 & 1508,8 \\
\hline
\end{tabular}


Tabela 14A. Estimativa da produtividade de grãos de feijão caupi $\left(\mathrm{kg} \mathrm{ha}^{-1}\right)$, com diferentes probabilidades de ocorrência, em cada época de semeadura e nivel de manejo $(p)$ no município de Teresina, Piauí.

\begin{tabular}{|c|c|c|c|c|c|c|c|c|c|}
\hline \multirow{2}{*}{$\begin{array}{l}\text { Época de } \\
\text { Semeadura }\end{array}$} & \multirow[t]{2}{*}{$\mathrm{p}$} & \multicolumn{8}{|c|}{ Probabilidade de ocorrência (\%) } \\
\hline & & 5 & 10 & 15 & 20 & 25 & 30 & 35 & 40 \\
\hline \multirow{7}{*}{ 1-Mai } & 0,2 & 2153,0 & 2160,6 & 2165,7 & 2169,7 & 2173,2 & 2176,3 & 2179,2 & 2181,9 \\
\hline & 0,3 & 1957,5 & 1971,2 & 1980,4 & 1987,8 & 1994,1 & 1999,7 & 2005,0 & 2009,9 \\
\hline & 0,4 & 1832,9 & 1848,8 & 1859,6 & 1868,1 & 1875,4 & 1882,0 & 1888,1 & 1893,9 \\
\hline & 0,5 & 1669,1 & 1689,1 & 1702,7 & 1713,4 & 1722,6 & 1730,9 & 1738,5 & 1745,8 \\
\hline & 0,6 & 1540,4 & 1563,9 & 1579,8 & 1592,4 & 1603,3 & 1613,0 & 1622,0 & 1630,6 \\
\hline & 0,7 & 1432,8 & 1461,9 & 1481,5 & 1497,1 & 1510,5 & 1522,5 & 1533,6 & 1544,2 \\
\hline & 0,8 & 1316,1 & 1347,0 & 1367,8 & 1384,4 & 1398,6 & 1411,3 & 1423,1 & 1434,3 \\
\hline \multirow{7}{*}{ 15-Mai } & 0,2 & 2147,9 & 2154,5 & 2159,0 & 2162,5 & 2165,5 & 2168,2 & 2170,8 & 2173,2 \\
\hline & 0,3 & 1970,6 & 1982,7 & 1990,9 & 1997,4 & 2003,0 & 2008,0 & 2012,6 & 2017,0 \\
\hline & 0,4 & & 1842,9 & 1850,2 & 1856,1 & 1861,2 & 1865,7 & 1869,9 & 1873,8 \\
\hline & 0,5 & 1647,4 & 1664,4 & 1675,8 & 1684,9 & 1692,6 & 1699,6 & 1706,1 & 1712,3 \\
\hline & 0,6 & 1534,6 & 1553,7 & 1566,6 & 1576,9 & 1585,7 & 1593,6 & 1600,9 & 1607,8 \\
\hline & 0,7 & 1417,4 & 1436,8 & 1449,9 & 1460,3 & 1469,2 & 1477,2 & 1484,6 & 1491,6 \\
\hline & 0,8 & 1294,6 & 1319,5 & 1336,3 & 1349,7 & 1361,2 & 1371,5 & 1381,0 & 1390,1 \\
\hline \multirow{7}{*}{ 1-Jun } & 0,2 & 2155,0 & 2160,6 & 2164,3 & 2167,3 & 2169,9 & 2172,2 & 2174,4 & 2176,4 \\
\hline & 0,3 & 1996,5 & 2006,8 & 2013,7 & 2019,2 & 2023,9 & 2028,1 & 2032,0 & 2035,7 \\
\hline & 0,4 & 1830,2 & 1839,9 & 1846,5 & 1851,7 & 1856,1 & 1860,2 & 1863,9 & 1867,4 \\
\hline & 0,5 & 1667,2 & 1679,2 & 1687,3 & 1693,7 & 1699,3 & 1704,2 & 1708,8 & 1713,2 \\
\hline & 0,6 & 1553,9 & 1568,2 & 1577,9 & 1585,6 & 1592,2 & 1598,1 & 1603,6 & 1608,9 \\
\hline & 0,7 & 1427,5 & 1442,3 & 1452,3 & 1460,3 & 1467,1 & 1473,2 & 1478,9 & 1484,3 \\
\hline & 0,8 & 1310,6 & 1327,4 & 1338,8 & 1347,8 & 1355,5 & 1362,5 & 1368,9 & 1375,0 \\
\hline \multirow{7}{*}{ 15-Jun } & 0,2 & 2166,6 & 2172,0 & 2175,6 & 2178,4 & 2180,9 & 2183,1 & 2185,1 & 2187,1 \\
\hline & 0,3 & 2021,6 & 2031,4 & 2038,0 & 2043,3 & 2047,8 & 2051,8 & 2055,6 & 2059,2 \\
\hline & 0,4 & 1838,4 & 1846,5 & 1852,0 & 1856,3 & 1860,0 & 1863,4 & 1866,5 & 1869,5 \\
\hline & 0,5 & 1676,3 & 1691,1 & 1701,1 & 1709,0 & 1715,8 & 1721,9 & 1727,6 & 1733,0 \\
\hline & 0,6 & 1557,5 & 1569,6 & 1577,8 & 1584,3 & 1589,9 & 1594,9 & 1599,6 & 1604,0 \\
\hline & 0,7 & 1428,4 & 1442,2 & 1451,5 & 1458,9 & 1465,3 & 1471,0 & 1476,3 & 1481,3 \\
\hline & 0,8 & 1336,1 & 1349,0 & 1357,7 & 1364,6 & 1370,5 & 1375,9 & 1380,8 & 1385,5 \\
\hline
\end{tabular}


Tabela 14A. Estimativa da produtividade de grãos de feijão caupi $\left(\mathrm{kg} \mathrm{ha}^{-1}\right)$, com diferentes probabilidades de ocorrência, em cada época de semeadura e nível de manejo ( $p$ ) no município de Teresina, Piauí.

\begin{tabular}{|c|c|c|c|c|c|c|c|c|c|}
\hline \multirow{2}{*}{$\begin{array}{l}\text { Epoca de } \\
\text { Semeadura }\end{array}$} & \multirow[t]{2}{*}{$\mathrm{p}$} & \multicolumn{8}{|c|}{ Probabilidade de ocorrência (\%) } \\
\hline & & 5 & 10 & 15 & 20 & 25 & 30 & 35 & 40 \\
\hline \multirow{7}{*}{ 1-Jul } & 0,2 & 2186,3 & 2191,8 & 2195,6 & 2198,6 & 2201,2 & 2203,5 & 2205,6 & 2207,6 \\
\hline & 0,3 & 2053,0 & 2061,5 & 2067,2 & 2071,7 & 2075,6 & 2079,1 & 2082,3 & 2085,3 \\
\hline & 0,4 & 1858,4 & 1865,3 & 1870,0 & 1873,7 & 1876,9 & 1879,8 & 1882,4 & 1885,0 \\
\hline & 0,5 & 1727,5 & 1738,5 & 1746,0 & 1751,9 & 1757,0 & 1761,6 & 1765,8 & 1769,8 \\
\hline & 0,6 & 1581,9 & 1593,6 & 1601,5 & 1607,8 & 1613,2 & 1618,0 & 1622,5 & 1626,8 \\
\hline & 0,7 & 1452,8 & 1468,4 & 1479,0 & 1487,3 & 1494,5 & 1501,0 & 1507,0 & 1512,6 \\
\hline & 0,8 & 1359,6 & 1370,9 & 1378,6 & 1384,6 & 1389,9 & 1394,5 & 1398,9 & 1403,0 \\
\hline \multirow{7}{*}{ 15-Jul } & 0,2 & 2201,9 & 2208,8 & 2213,5 & 2217,2 & 2220,3 & 2223,2 & 2225,8 & 2228,3 \\
\hline & 0,3 & 2079,1 & 2086,1 & 2090,9 & 2094,6 & 2097,9 & 2100,8 & 2103,5 & 2106,0 \\
\hline & 0,4 & 1870,9 & 1880,7 & 1887,3 & 1892,5 & 1897,0 & 1901,0 & 1904,7 & 1908,3 \\
\hline & 0,5 & 1770,9 & 1778,3 & 1783,3 & 1787,3 & 1790,7 & 1793,7 & 1796,6 & 1799,2 \\
\hline & 0,6 & 1580,4 & 1592,8 & 1601,1 & 1607,7 & 1613,4 & 1618,5 & 1623,2 & 1627,7 \\
\hline & 0,7 & 1496,6 & 1506,9 & 1513,8 & 1519,3 & 1524,0 & 1528,3 & 1532,2 & 1536,0 \\
\hline & 0,8 & 1358,5 & 1370,5 & 1378,5 & 1385,0 & 1390,5 & 1395,4 & 1400,0 & 1404,3 \\
\hline \multirow{7}{*}{ 1-Ago } & 0,2 & 2226,6 & 2233,9 & 2238,7 & 2242,6 & 2245,9 & 2248,9 & 2251,7 & 2254,3 \\
\hline & 0,3 & 2102,2 & 2108,0 & 2111,8 & 2114,9 & 2117,6 & 2120,0 & 2122,2 & 2124,3 \\
\hline & 0,4 & 1905,6 & 1917,6 & 1925,7 & 1932,1 & 1937,7 & 1942,6 & 1947,2 & 1951,6 \\
\hline & 0,5 & 1777,8 & 1785,6 & 1790,8 & 1795,0 & 1798,6 & 1801,8 & 1804,7 & 1807,5 \\
\hline & 0,6 & 1607,1 & 1621,9 & 1631,9 & 1639,8 & 1646,6 & 1652,7 & 1658,4 & 1663,8 \\
\hline & 0,7 & 1507,1 & 1517,9 & 1525,2 & 1531,0 & 1536,0 & 1540,5 & 1544,6 & 1548,6 \\
\hline & 0,8 & 1376,9 & 1392,3 & 1402,8 & 1411,1 & 1418,2 & 1424,6 & 1430,5 & 1436,1 \\
\hline \multirow{7}{*}{ 15-Ago } & 0,2 & 2238,4 & 2246,6 & 2252,0 & 2256,4 & 2260,2 & 2263,5 & 2266,6 & 2269,6 \\
\hline & 0,3 & 2099,3 & 2099,3 & 2110,1 & 2110,1 & 2121,0 & 2121,0 & 2121,0 & 2121,0 \\
\hline & 0,4 & 1935,7 & 1948,7 & 1957,4 & 1964,4 & 1970,4 & 1975,8 & 1980,7 & 1985,5 \\
\hline & 0,5 & 1778,7 & 1787,9 & 1794,1 & 1799,0 & 1803,2 & 1807,0 & 1810,5 & 1813,8 \\
\hline & 0,6 & 1659,5 & 1672,3 & 1680,9 & 1687,8 & 1693,7 & 1699,0 & 1703,9 & 1708,5 \\
\hline & 0,7 & 1523,1 & 1534,9 & 1542,9 & 1549,2 & 1554,7 & 1559,6 & 1564,1 & 1568,4 \\
\hline & 0,8 & 1423,3 & 1437,6 & 1447,3 & 1455,0 & 1461,6 & 1467,5 & 1473,0 & 1478,2 \\
\hline
\end{tabular}


Tabela 14A. Estimativa da produtividade de grãos de feijão caupi $\left(\mathrm{kg} \mathrm{ha}^{-1}\right)$, com diferentes probabilidades de ocorrência, em cada época de semeadura e nivel de manejo (p) no município de Teresina, Piauí.

\begin{tabular}{|c|c|c|c|c|c|c|c|c|c|}
\hline \multirow{2}{*}{$\begin{array}{l}\text { Época de } \\
\text { Semeadura }\end{array}$} & \multirow[t]{2}{*}{$\mathrm{p}$} & \multicolumn{8}{|c|}{ Probabilidade de ocorrência $(\%)$} \\
\hline & & 5 & 10 & 15 & 20 & 25 & 30 & 35 & 40 \\
\hline \multirow{7}{*}{ 1-Set } & 0,2 & 2244,7 & 2252,6 & 2258,0 & 2262,2 & 2265,9 & 2269,2 & 2272,2 & 2275,1 \\
\hline & 0,3 & 2112,3 & 2117,9 & 2121,6 & 2124,6 & 2127,2 & 2129,5 & 2131,6 & 2133,6 \\
\hline & 0,4 & 1935,5 & 1949,6 & 1959,2 & 1966,7 & 1973,2 & 1979,1 & 1984,5 & 1989,6 \\
\hline & 0,5 & 1785,5 & 1793,8 & 1799,4 & 1803,9 & 1807,7 & 1811,2 & 1814,4 & 1817,4 \\
\hline & 0,6 & 1653,8 & 1667,9 & 1677,4 & 1685,0 & 1691,4 & 1697,3 & 1702,6 & 1707,8 \\
\hline & 0,7 & 1515,3 & 1528,9 & 1538,1 & 1545,5 & 1551,7 & 1557,4 & 1562,6 & 1567,6 \\
\hline & 0,8 & 1434,2 & 1448,9 & 1458,8 & 1466,7 & 1473,5 & 1479,6 & 1485,2 & 1490,6 \\
\hline \multirow{7}{*}{$15-$ Set } & 0,2 & 2237,0 & 2245,0 & 2250,4 & 2254,8 & 2258,5 & 2261,8 & 2264,9 & 2267,8 \\
\hline & 0,3 & 2107,5 & 2113,6 & 2117,8 & 2121,0 & 2123,9 & 2126,4 & 2128,7 & 2130,9 \\
\hline & 0,4 & 1922,7 & 1936,4 & 1945,7 & 1953,0 & 1959,3 & 1965,0 & 1970,2 & 1975,2 \\
\hline & 0,5 & 1775,4 & 1786,3 & 1793,7 & 1799,6 & 1804,6 & 1809,2 & 1813,4 & 1817,4 \\
\hline & 0,6 & 1640,3 & 1657,2 & 1668,6 & 1677,6 & 1685,4 & 1692,4 & 1698,8 & 1705,0 \\
\hline & 0,7 & 1518,3 & 1532,6 & 1542,3 & 1550,0 & 1556,5 & 1562,5 & 1567,9 & 1573,2 \\
\hline & 0,8 & 1414,4 & 1431,5 & 1443,0 & 1452,2 & 1460,0 & 1467,1 & 1473,6 & 1479,8 \\
\hline \multirow{7}{*}{ 1-Out } & 0,2 & 2224,3 & 2231,7 & 2236,6 & 2240,6 & 2243,9 & 2247,0 & 2249,8 & 2252,4 \\
\hline & 0,3 & 2098,8 & 2105,4 & 2109,8 & 2113,3 & 2116,3 & 2119,0 & 2121,5 & 2123,9 \\
\hline & 0,4 & 1913,3 & 1925,2 & 1933,2 & 1939,6 & 1945,1 & 1950,0 & 1954,6 & 1958,9 \\
\hline & 0,5 & 1780,0 & 1790,2 & 1797,2 & 1802,7 & 1807,4 & 1811,6 & 1815,6 & 1819,3 \\
\hline & 0,6 & 1632,4 & 1647,0 & 1656,9 & 1664,7 & 1671,5 & 1677,5 & 1683,1 & 1688,5 \\
\hline & 0,7 & 1508,5 & 1523,1 & 1533,0 & 1540,8 & 1547,5 & 1553,5 & 1559,1 & 1564,4 \\
\hline & 0,8 & 1396,1 & 1412,9 & 1424,2 & 1433,2 & 1441,0 & 1447,9 & 1454,3 & 1460,4 \\
\hline \multirow{7}{*}{ 15-Out } & 0,2 & 2210,5 & 2218,1 & 2223,3 & 2227,4 & 2230,9 & 2234,1 & 2237,0 & 2239,8 \\
\hline & 0,3 & 2098,3 & 2104,8 & 2109,2 & 2112,7 & 2115,7 & 2118,3 & 2120,8 & 2123,2 \\
\hline & 0,4 & 1892,3 & 1903,7 & 1911,4 & 1917,6 & 1922,8 & 1927,6 & 1931,9 & 1936,1 \\
\hline & 0,5 & 1775,8 & 1787,2 & 1795,0 & 1801,1 & 1806,4 & 1811,1 & 1815,5 & 1819,7 \\
\hline & 0,6 & 1611,3 & 1627,8 & 1638,9 & 1647,7 & 1655,3 & 1662,1 & 1668,4 & 1674,4 \\
\hline & 0,7 & 1512,3 & 1528,0 & 1538,5 & 1546,9 & 1554,1 & 1560,6 & 1566,6 & 1572,3 \\
\hline & 0,8 & 1388,2 & 1406,9 & 1419,5 & 1429,6 & 1438,2 & 1445,9 & 1453,1 & 1459,9 \\
\hline
\end{tabular}


Tabela 14A. Estimativa da produtividade de grãos de feijão caupi ( $\mathrm{kg} \mathrm{ha}^{-1}$ ), com diferentes probabilidades de ocorrência, em cada época de semeadura e nivel de manejo (p) no município de Teresina, Piauí.

\begin{tabular}{|c|c|c|c|c|c|c|c|c|c|}
\hline \multirow{2}{*}{$\begin{array}{l}\text { Epoca de } \\
\text { Semeadura }\end{array}$} & \multirow[t]{2}{*}{$\mathrm{p}$} & \multicolumn{8}{|c|}{ Probabilidade de ocorrência (\%) } \\
\hline & & 5 & 10 & 15 & 20 & 25 & 30 & 35 & 40 \\
\hline \multirow{7}{*}{$1-\mathrm{Nov}$} & 0,2 & 2201,6 & 2208,1 & 2212,5 & 2216,0 & 2219,0 & 2221,7 & 2224,2 & 2226,6 \\
\hline & 0,3 & 2068,0 & 2078,7 & 2085,9 & 2091,6 & 2096,5 & 2100,9 & 2104,9 & 2108,8 \\
\hline & 0,4 & 1885,0 & 1896,5 & 1904,3 & 1910,5 & 1915,8 & 1920,6 & 1925,0 & 1929,2 \\
\hline & 0,5 & 1758,1 & 1774,1 & 1784,9 & 1793,5 & 1800,9 & 1807,5 & 1813,6 & 1819,5 \\
\hline & 0,6 & 1607,9 & 1627,1 & 1640,0 & 1650,2 & 1659,0 & 1666,9 & 1674,2 & 1681,2 \\
\hline & 0,7 & 1504,7 & 1525,6 & 1539,6 & 1550,8 & 1560,4 & 1569,0 & 1577,0 & 1584,6 \\
\hline & 0,8 & 1383,1 & 1407,9 & 1424,6 & 1437,9 & 1449,2 & 1459,5 & 1468,9 & 1477,9 \\
\hline \multirow{7}{*}{$15-\mathrm{Nov}$} & 0,2 & 2187,0 & 2195,5 & 2201,2 & 2205,7 & 2209,6 & 2213,1 & 2216,3 & 2219,4 \\
\hline & 0,3 & 2054,2 & 2066,4 & 2074,6 & 2081,1 & 2086,6 & 2091,7 & 2096,3 & 2100,7 \\
\hline & 0,4 & 1874,9 & 1891,5 & 1902,7 & 1911,6 & 1919,2 & 1926,1 & 1932,4 & 1938,4 \\
\hline & 0,5 & 1739,5 & 1762,1 & 1777,4 & 1789,5 & 1800,0 & 1809,3 & 1818,0 & 1826,2 \\
\hline & 0,6 & 1611,0 & 1636,9 & 1654,5 & 1668,4 & 1680,4 & 1691,1 & 1701,0 & 1710,5 \\
\hline & 0,7 & 1493,4 & 1523,1 & 1543,2 & 1559,1 & 1572,7 & 1585,0 & 1596,4 & 1607,2 \\
\hline & 0,8 & 1392,9 & 1427,2 & 1450,4 & 1468,8 & 1484,6 & 1498,7 & 1511,9 & 1524,4 \\
\hline \multirow{7}{*}{ 1-Dez } & 0,2 & 2189,5 & 2196,6 & 2201,4 & 2205,2 & 2208,5 & 2211,5 & 2214,2 & 2216,8 \\
\hline & 0,3 & 2049,2 & 2061,8 & 2070,2 & 2077,0 & 2082,7 & 2087,9 & 2092,7 & 2097,3 \\
\hline & 0,4 & & 1907,1 & 1916,8 & 1924,5 & 1931,1 & 1937,0 & 1942,5 & 1947,8 \\
\hline & 0,5 & 1751,9 & 1771,7 & 1785,1 & 1795,7 & 1804,8 & 1813,0 & 1820,6 & 1827,8 \\
\hline & 0,6 & 1638,4 & 1661,7 & 1677,5 & 1690,0 & 1700,7 & 1710,3 & 1719,2 & 1727,7 \\
\hline & 0,7 & 1530,6 & 1556,0 & 1573,0 & 1586,6 & 1598,3 & 1608,7 & 1618,4 & 1627,6 \\
\hline & 0,8 & 1425,7 & 1456,3 & 1477,0 & 1493,4 & 1507,5 & 1520,2 & 1531,9 & 1543,1 \\
\hline \multirow{7}{*}{ 15-Dez } & 0,2 & 2188,9 & 2197,3 & 2203,0 & 2207,5 & 2211,3 & 2214,8 & 2218,0 & 2221,1 \\
\hline & 0,3 & 2047,1 & 2061,5 & 2071,2 & 2078,9 & 2085,5 & 2091,5 & 2097,0 & 2102,3 \\
\hline & 0,4 & 1902,8 & 1918,9 & 1929,8 & 1938,5 & 1945,9 & 1952,5 & 1958,7 & 1964,5 \\
\hline & 0,5 & 1755,7 & 1779,8 & 1796,0 & 1808,9 & 1820,0 & 1829,9 & 1839,1 & 1847,8 \\
\hline & 0,6 & 1670,7 & 1696,2 & 1713,4 & 1727,0 & 1738,7 & 1749,2 & 1759,0 & 1768,2 \\
\hline & 0,7 & 1549,8 & 1582,4 & 1604,3 & 1621,7 & 1636,7 & 1650,1 & 1662,6 & 1674,4 \\
\hline & 0,8 & 1455,5 & 1492,4 & 1517,3 & 1537,0 & 1554,0 & 1569,2 & 1583,3 & 1596,7 \\
\hline
\end{tabular}


Tabela 15A. Estimativa da produtividade de frutos de melancia $\left(\mathrm{kg} \mathrm{ha}^{-1}\right)$, com diferentes probabilidades de ocorrência, em cada época de semeadura e nível de manejo (p) no município de Parnaiba, Piaui.

\begin{tabular}{|c|c|c|c|c|c|c|c|c|c|}
\hline \multirow{2}{*}{$\begin{array}{l}\text { Época de } \\
\text { Semeadura }\end{array}$} & \multirow[t]{2}{*}{$\mathrm{p}$} & \multicolumn{8}{|c|}{ Probabilidade de ocorrência $(\%)$} \\
\hline & & 5 & 10 & 15 & 20 & 25 & 30 & 35 & 40 \\
\hline \multirow{7}{*}{ 1-Jan } & 0,2 & 42613,7 & 42821,1 & 42961,1 & 43072,3 & 43167,7 & 43253,4 & 43332,8 & 43408,1 \\
\hline & 0,3 & 39443,1 & 39730,3 & 39924,1 & 40078,1 & 40210,2 & 40328,9 & 40438,8 & 40543,1 \\
\hline & 0,4 & 35600,9 & 35966,8 & 36213,6 & 36409,8 & 36578,1 & 36729,2 & 36869,3 & 37002,2 \\
\hline & 0,5 & 32505,0 & 32949,1 & 33248,7 & 33486,9 & 33691,2 & 33874,6 & 34044,6 & 34206,0 \\
\hline & 0,6 & 29401,7 & 29934,2 & 30293,5 & 30579,0 & 30824,0 & 31044,0 & 31247,8 & 31441,3 \\
\hline & 0,7 & 26770,3 & 27417,6 & 27854,3 & 28201,4 & 28499,2 & 28766,6 & 29014,4 & 29249,6 \\
\hline & 0,8 & 24673,8 & 25321,1 & 25757,8 & 26104,8 & 26402,6 & 26670,0 & 26917,8 & 27152,9 \\
\hline \multirow{7}{*}{ 15-Jan } & 0,2 & 43377,9 & 43588,1 & 43729,9 & 43842,6 & 43939,3 & 44026,1 & 44106,5 & 44182,9 \\
\hline & 0,3 & 40341,8 & 40615,3 & 40799,8 & 40946,4 & 41072,2 & 41185,2 & 41289,8 & 41389,2 \\
\hline & 0,4 & 36168,5 & 36548,0 & 36804,1 & 37007,6 & 37182,2 & 37339,0 & 37484,2 & 37622,1 \\
\hline & 0,5 & 33392,9 & 33837,9 & 34138,1 & 34376,7 & 34581,4 & 34765,2 & 34935,5 & 35097,2 \\
\hline & 0,6 & 30340,9 & 30878,1 & 31240,5 & 31528,6 & 31775,8 & 31997,7 & 32203,4 & 32398,5 \\
\hline & 0,7 & 28058,3 & 28698,7 & 29130,9 & 29474,3 & 29768,9 & 30033,5 & 30278,7 & 30511,3 \\
\hline & 0,8 & 25828,3 & 26548,2 & 27033,9 & 27420,0 & 27751,1 & 28048,6 & 28324,2 & 28585,7 \\
\hline \multirow{7}{*}{$1-\mathrm{Fev}$} & & & & 43639,8 & 43745,8 & 43836,8 & 43918,5 & 43994,1 & \\
\hline & 0,3 & 40355,4 & 40621,9 & 40801,7 & 40944,6 & 41067,2 & 41177,3 & 41279,4 & 41376,2 \\
\hline & 0,4 & 36158,6 & 36560,2 & 36831,2 & 37046,6 & 37231,4 & 37397,3 & 37551,1 & 37697,0 \\
\hline & 0,5 & 33344,8 & 33882,4 & 34245,1 & 34533,4 & 34780,7 & 35002,8 & 35208,7 & 35403,9 \\
\hline & 0,6 & 30828,5 & 31400,9 & 31787,1 & 32094,1 & 32357,4 & 32593,9 & 32813,0 & 33021,0 \\
\hline & 0,7 & 28204,0 & 28925,9 & 29412,9 & 29800,0 & 30132,1 & 30430,3 & 30706,7 & 30968,9 \\
\hline & 0,8 & 26058,1 & 26858,9 & 27399,1 & 27828,5 & 28196,9 & 28527,7 & 28834,2 & 29125,1 \\
\hline \multirow{7}{*}{$15-\mathrm{Fev}$} & 0,2 & 43142,6 & 43345,5 & 43482,5 & 43591,3 & 43684,7 & 43768,5 & 43846,2 & 43919,9 \\
\hline & 0,3 & 39875,8 & 40209,3 & 40434,3 & 40613,2 & 40766,6 & 40904,4 & 41032,1 & 41153,2 \\
\hline & 0,4 & 36482,2 & 36848,6 & 37095,7 & 37292,2 & 37460,7 & 37612,1 & 37752,3 & 37885,4 \\
\hline & 0,5 & 33164,1 & 33718,7 & 34092,9 & 34390,2 & 34645,3 & 34874,4 & 35086,7 & 35288,2 \\
\hline & 0,6 & 30760,3 & 31413,8 & 31854,8 & 32205,2 & 32505,8 & 32775,8 & 33026,0 & 33263,4 \\
\hline & 0,7 & 28677,7 & 29363,9 & 29826,8 & 30194,7 & 30510,4 & 30793,8 & 31056,5 & 31305,7 \\
\hline & 0,8 & 26967,1 & 27675,5 & 28153,5 & 28533,4 & 28859,2 & 29151,9 & 29423,1 & 29680,4 \\
\hline
\end{tabular}


Tabela 15A. Estimativa da produtividade de frutos de melancia $\left(\mathrm{kg} \mathrm{ha}^{-1}\right)$, com diferentes probabilidades de ocorrência, em cada época de semeadura e nível de manejo (p) no município de Parnaíba, Piauí.

\begin{tabular}{|c|c|c|c|c|c|c|c|c|c|}
\hline \multirow{2}{*}{$\begin{array}{l}\text { Época de } \\
\text { Semeadura }\end{array}$} & \multirow[t]{2}{*}{$\mathrm{p}$} & \multicolumn{8}{|c|}{ Probabilidade de ocorrência (\%) } \\
\hline & & 5 & 10 & 15 & 20 & 25 & 30 & 35 & 40 \\
\hline \multirow{7}{*}{ 1-Mar } & 0,2 & 43099,2 & 43322,1 & 43472,6 & 43592,1 & 43694,7 & 43786,8 & 43872,1 & 43953,1 \\
\hline & 0,3 & 39879,9 & 40215,5 & 40442,0 & 40622,0 & 40776,4 & 40915,1 & 41043,6 & 41165,6 \\
\hline & 0,4 & 36030,3 & 36492,9 & 36805,0 & 37053,0 & 37265,8 & 37456,8 & 37633,9 & 37801,9 \\
\hline & 0,5 & 33064,0 & 33664,9 & 34070,3 & 34392,5 & 34669,0 & 34917,2 & 35147,2 & 35365,5 \\
\hline & 0,6 & 30424,9 & 31137,8 & 31618,8 & 32001,1 & 32329,1 & 32623,6 & 32896,5 & 33155,5 \\
\hline & 0,7 & 28086,6 & 28903,9 & 29455,3 & 29893,6 & 30269,6 & 30607,2 & 30920,1 & 31217,0 \\
\hline & 0,8 & 26495,3 & 27356,7 & 27937,8 & 28399,7 & 28795,9 & 29151,8 & 29481,5 & 29794,4 \\
\hline \multirow{7}{*}{ 15-Mar } & 0,2 & 42788,5 & 43000,0 & 43142,6 & 43256,0 & 43353,3 & 43440,6 & 43521,5 & 43598,4 \\
\hline & 0,3 & 39424,7 & 39749,9 & 39969,4 & 40143,8 & 40293,5 & 40427,9 & 40552,4 & 40670,6 \\
\hline & 0,4 & 35738,7 & 36134,0 & 36400,7 & 36612,7 & 36794,5 & 36957,8 & 37109,1 & 37252,7 \\
\hline & 0,5 & 32916,3 & 33403,8 & 33732,7 & 33994,1 & 34218,4 & 34419,8 & 34606,4 & 34783,5 \\
\hline & 0,6 & 30044,6 & 30639,4 & 31040,7 & 31359,6 & 31633,2 & 31878,9 & 32106,6 & 32322,6 \\
\hline & 0,7 & 27695,7 & 28407,5 & 28887,8 & 29269,5 & 29596,9 & 29891,0 & 30163,5 & 30422,1 \\
\hline & 0,8 & 25406,3 & 26268,6 & 26850,3 & 27312,6 & 27709,3 & 28065,5 & 28395,6 & 28708,8 \\
\hline \multirow{7}{*}{$1-\mathrm{Abr}$} & 0,2 & 42738,5 & 42909,6 & 43025,0 & 43116,7 & 43195,4 & 43266,1 & 43331,6 & 43393,7 \\
\hline & 0,3 & 39353,5 & 39636,2 & 39827,0 & 39978,6 & 40108,6 & 40225,4 & 40333,7 & 40436,4 \\
\hline & 0,4 & 34940,0 & 35349,8 & 35626,4 & 35846,1 & 36034,7 & 36204,0 & 36360,9 & 36509,8 \\
\hline & 0,5 & 31831,2 & 32307,9 & 32629,5 & 32885,1 & 33104,4 & 33301,3 & 33483,8 & 33657,0 \\
\hline & 0,6 & 28951,6 & 29522,1 & 29907,1 & 30213,0 & 30475,5 & 30711,2 & 30929,6 & 31136,8 \\
\hline & 0,7 & 26376,5 & 27024,3 & 27461,4 & 27808,8 & 28106,8 & 28374,4 & 28622,4 & 28857,7 \\
\hline & 0,8 & 24119,6 & 24883,5 & 25398,8 & 25808,4 & 26159,8 & 26475,4 & 26767,8 & 27045,3 \\
\hline \multirow{7}{*}{$15-\mathrm{Abr}$} & 0,2 & 42562,3 & 42717,0 & 42821,4 & 42904,4 & 42975,6 & 43039,5 & 43098,8 & 43155,0 \\
\hline & 0,3 & 39112,1 & 39363,1 & 39532,5 & 39667,1 & 39782,6 & 39886,3 & 39982,4 & 40073,6 \\
\hline & 0,4 & 34577,0 & 34929,7 & 35167,7 & 35356,8 & 35519,1 & 35664,8 & 35799,9 & 35928,0 \\
\hline & 0,5 & 31398,1 & 31819,5 & 32103,8 & 32329,8 & 32523,7 & 32697,8 & 32859,1 & 33012,2 \\
\hline & 0,6 & 28262,7 & 28774,3 & 29119,4 & 29393,6 & 29629,0 & 29840,3 & 30036,1 & 30221,9 \\
\hline & 0,7 & 25157,7 & 25708,7 & 25708,7 & 26259,7 & 26259,7 & 26810,6 & 26810,6 & 26810,6 \\
\hline & 0,8 & 23588,8 & 24187,0 & 24590,6 & 24911,4 & 25186,6 & 25433,7 & 25662,7 & 25880,0 \\
\hline
\end{tabular}


Tabela 15A. Estimativa da produtividade de frutos de melancia $\left(\mathrm{kg} \mathrm{ha}^{-1}\right)$, com diferentes probabilidades de ocorrência, em cada época de semeadura e nivel de manejo (p) no municipio de Parnaiba, Piauí.

\begin{tabular}{|c|c|c|c|c|c|c|c|c|c|}
\hline \multirow{2}{*}{$\begin{array}{l}\text { Época de } \\
\text { Semeadura }\end{array}$} & \multirow[t]{2}{*}{$\mathrm{p}$} & \multicolumn{8}{|c|}{ Probabilidade de ocorrência (\%) } \\
\hline & & 5 & 10 & 15 & 20 & 25 & 30 & 35 & 40 \\
\hline \multirow{7}{*}{ 1-Mai } & 0,2 & 42395,3 & 42538,1 & 42634,4 & 42711,0 & 42776,6 & 42835,6 & 42890,3 & 42942,2 \\
\hline & 0,3 & 38981,6 & 39217,7 & 39377,0 & 39503,6 & 39612,2 & 39709,8 & 39800,2 & 39885,9 \\
\hline & 0,4 & 34245,1 & 34517,5 & 34701,2 & 34847,3 & 34972,6 & 35085,1 & 35189,4 & 35288,3 \\
\hline & 0,5 & 30931,5 & 31265,2 & 31490,4 & 31669,4 & 31822,9 & 31960,8 & 32088,5 & 32209,8 \\
\hline & 0,6 & 27973,5 & 28306,7 & 28531,5 & 28710,2 & 28863,5 & 29001,1 & 29128,7 & 29249,8 \\
\hline & 0,7 & 25121,6 & 25508,6 & 25769,7 & 25977,3 & 26155,3 & 26315,2 & 26463,3 & 26603,9 \\
\hline & 0,8 & 22662,0 & 23121,4 & 23431,3 & 23677,7 & 23889,0 & 24078,8 & 24254,7 & 24421,5 \\
\hline \multirow{7}{*}{ 15-Mai } & 0,2 & 42349,8 & 42502,1 & 42604,9 & 42686,6 & 42756,7 & 42819,7 & 42878,0 & 42933,3 \\
\hline & 0,3 & 39258,5 & 39448,9 & 39577,3 & 39679,3 & 39766,9 & 39845,5 & 39918,4 & 39987,5 \\
\hline & 0,4 & 34289,7 & 34550,0 & 34725,6 & 34865,2 & 34984,9 & 35092,4 & 35192,1 & 35286,6 \\
\hline & 0,5 & 31090,1 & 31407,3 & 31621,3 & 31791,4 & 31937,3 & 32068,3 & 32189,8 & 32305,0 \\
\hline & 0,6 & 27653,3 & 27994,4 & 28224,5 & 28407,4 & 28564,4 & 28705,3 & 28835,8 & 28959,7 \\
\hline & 0,7 & 25124,0 & & 25770,0 & 25976,8 & 26154,3 & 26313,7 & 26461,3 & 26601,5 \\
\hline & 0,8 & 22662,1 & & 23321,8 & 23533,0 & 23714,2 & 23877,0 & 24027,8 & 24170,9 \\
\hline \multirow{7}{*}{ 1-Jun } & 0,2 & 42642,1 & 42786,8 & 42884,4 & 42961,9 & 43028,5 & 43088,2 & 43143,6 & 43196,2 \\
\hline & 0,3 & 39531,3 & 39717,7 & 39843,5 & 39943,5 & 40029,2 & 40106,3 & 40177,7 & 40245,4 \\
\hline & 0,4 & 34622,0 & 34825,1 & 34962,2 & 35071,1 & 35164,6 & 35248,5 & 35326,3 & 35400,1 \\
\hline & 0,5 & 31541,7 & 31788,9 & 31955,7 & 32088,3 & 32202,0 & 32304,2 & 32398,8 & 32488,6 \\
\hline & 0,6 & 27666,5 & 27953,8 & 28147,7 & 28301,7 & 28433,9 & 28552,6 & 28662,5 & 28766,9 \\
\hline & 0,7 & 25464,6 & 25758,5 & 25956,8 & 26114,4 & 26249,6 & 26371,0 & 26483,5 & 26590,3 \\
\hline & 0,8 & 22588,5 & 22904,8 & 23118,1 & 23287,7 & 23433,2 & 23563,8 & 23684,9 & 23799,7 \\
\hline \multirow{7}{*}{ 15-Jun } & 0,2 & 43148,7 & 43312,7 & 43423,3 & 43511,2 & 43586,6 & 43654,4 & 43717,1 & 43776,7 \\
\hline & 0,3 & 40023,2 & 40177,2 & 40281,1 & 40363,7 & 40434,6 & 40498,2 & 40557,2 & 40613,2 \\
\hline & 0,4 & 35139,3 & 35373,0 & 35530,8 & 35656,1 & 35763,6 & 35860,2 & 35949,7 & 36034,6 \\
\hline & 0,5 & 32056,4 & 32244,4 & 32371,2 & 32472,0 & 32558,5 & 32636,1 & 32708,1 & 32776,4 \\
\hline & 0,6 & 28228,4 & 28513,2 & 28705,3 & 28858,0 & 28989,1 & 29106,7 & 29215,7 & 29319,2 \\
\hline & 0,7 & 25634,1 & 25911,2 & 26098,2 & 26246,7 & 26374,2 & 26488,7 & 26594,8 & 26695,4 \\
\hline & 0,8 & 22958,6 & 23242,6 & 23434,1 & 23586,4 & 23717,0 & 23834,3 & 23943,0 & 24046,1 \\
\hline
\end{tabular}


Tabela 15A. Estimativa da produtividade de grãos de feijão caupi $\left(\mathrm{kg} \mathrm{ha}^{-1}\right)$, com diferentes probabilidades de ocorrência, em cada época de semeadura e nível de manejo $(p)$ no município de Teresina, Piauí.

\begin{tabular}{|c|c|c|c|c|c|c|c|c|c|}
\hline \multirow{2}{*}{$\begin{array}{l}\text { Época de } \\
\text { Semeadura }\end{array}$} & \multirow[t]{2}{*}{$\mathrm{p}$} & \multicolumn{8}{|c|}{ Probabilidade de ocorrência (\%) } \\
\hline & & 5 & 10 & 15 & 20 & 25 & 30 & 35 & 40 \\
\hline \multirow{7}{*}{ 1-Jul } & 0,2 & 43812,3 & 44001,4 & 44128,9 & 44230,3 & 44317,3 & 44395,4 & 44467,8 & 44536,5 \\
\hline & 0,3 & 40242,9 & 40407,6 & 40518,7 & 40607,0 & 40682,8 & 40750,8 & 40813,9 & 40873,7 \\
\hline & 0,4 & 36002,1 & 36256,7 & 36428,5 & 36565,1 & 36682,2 & 36787,4 & 36884,9 & 36977,4 \\
\hline & 0,5 & 32117,6 & 32317,6 & 32452,5 & 32559,7 & 32651,7 & 32734,3 & 32810,8 & 32883,5 \\
\hline & 0,6 & 28869,7 & 29141,6 & 29325,0 & 29470,7 & 29595,8 & 29708,1 & 29812,1 & 29910,9 \\
\hline & 0,7 & 25867,1 & 26108,7 & 26271,7 & 26401,3 & 26512,4 & 26612,3 & 26704,8 & 26792,5 \\
\hline & 0,8 & 23279,8 & 23590,0 & 23799,3 & 23965,6 & 24108,4 & 24236,5 & 24355,3 & 24468,0 \\
\hline \multirow{7}{*}{ 15-Jul } & & 44688,2 & 44877,7 & 45005,5 & 45107,1 & 45194,3 & 45272,6 & 45345,1 & 45414,0 \\
\hline & 0,3 & 40726,0 & 40852,4 & 40937,6 & 41005,4 & 41063,5 & 41115,8 & 41164,1 & 41210,0 \\
\hline & 0,4 & 37162,2 & 37373,4 & 37515,9 & 37629,1 & 37726,3 & 37813,5 & 37894,4 & 37971,1 \\
\hline & 0,5 & 32589,3 & 32788,3 & 32922,6 & 33029,3 & 33120,8 & 33203,0 & 33279,2 & 33351,5 \\
\hline & 0,6 & 29768,0 & 30012,9 & 30178,1 & 30309,5 & 30422,1 & 30523,3 & 30617,1 & 30706,0 \\
\hline & 0,7 & 26278,6 & 26522,9 & 26687,8 & 26818,8 & 26931,2 & 27032,1 & 27125,7 & 27214,4 \\
\hline & 0,8 & 24076,4 & 24287,0 & 24429,1 & 24542,0 & 24638,9 & 24725,8 & 24806,5 & 24882,9 \\
\hline \multirow{7}{*}{ 1-Ago } & 0,2 & 46115,4 & 46294,0 & 46414,4 & 46510,2 & 46592,3 & 46666,1 & 46734,4 & 46799,3 \\
\hline & 0,3 & 41132,8 & 41207,6 & 41258,1 & 41298,2 & 41332,6 & 41363,5 & 41392,1 & 41419,3 \\
\hline & 0,4 & 38077,2 & 38252,0 & 38369,9 & 38463,7 & 38544,1 & 38616,3 & 38683,2 & 38746,7 \\
\hline & 0,5 & 33343,7 & 33558,3 & 33703,1 & 33818,2 & 33916,9 & 34005,6 & 34087,7 & 34165,7 \\
\hline & 0,6 & 30160,6 & 30352,6 & 30482,2 & 30585,2 & 30673,5 & 30752,8 & 30826,4 & 30896,1 \\
\hline & 0,7 & 27470,4 & 27702,9 & 27859,8 & 27984,5 & 28091,4 & 28187,5 & 28276,5 & 28361,0 \\
\hline & 0,8 & 24421,3 & 24594,4 & 24711,3 & 24804,1 & 24883,7 & 24955,3 & 25021,5 & 25084,4 \\
\hline \multirow{7}{*}{ 15-Ago } & 0,2 & 46944,3 & 47098,9 & 47203,2 & 47286,2 & 47357,3 & 47421,2 & 47480,4 & 47536,5 \\
\hline & 0,3 & 41144,1 & 41231,0 & 41289,6 & 41336,2 & 41376,2 & 41412,1 & 41445,4 & 41476,9 \\
\hline & 0,4 & 38696,8 & 38842,1 & 38940,1 & 39018,0 & 39084,9 & 39144,9 & 39200,5 & 39253,3 \\
\hline & 0,5 & 33849,2 & 34135,3 & 34328,3 & 34481,8 & 34613,4 & 34731,6 & 34841,1 & 34945,0 \\
\hline & 0,6 & 30620,4 & 30768,4 & 30868,2 & 30947,6 & 31015,7 & 31076,8 & 31133,5 & 31187,2 \\
\hline & 0,7 & 28199,4 & 28410,0 & 28552,0 & 28664,9 & 28761,7 & 28848,7 & 28929,3 & 29005,8 \\
\hline & 0,8 & 24775,1 & 24775,1 & 24775,1 & 25100,2 & 25100,2 & 25100,2 & 25100,2 & 25100,2 \\
\hline
\end{tabular}


Tabela 15A. Estimativa da produtividade de frutos de melancia $\left(\mathrm{kg} \mathrm{ha}^{-1}\right)$, com diferentes probabilidades de ocorrência, em cada época de semeadura e nivel de manejo (p) no municipio de Parnaiba, Piaui.

\begin{tabular}{|c|c|c|c|c|c|c|c|c|c|}
\hline \multirow{2}{*}{$\begin{array}{l}\text { Época de } \\
\text { Semeadura }\end{array}$} & \multirow[t]{2}{*}{$\mathrm{p}$} & \multicolumn{8}{|c|}{ Probabilidade de ocomência $(\%)$} \\
\hline & & 5 & 10 & 15 & 20 & 25 & 30 & 35 & 40 \\
\hline \multirow{7}{*}{ 1-Set } & 0,2 & 47540,4 & 47678,9 & 47772,3 & 47846,6 & 47910,3 & 47967,6 & 48020,6 & 48070,9 \\
\hline & 0,3 & 41157,0 & 41234,3 & 41286,4 & 41327,8 & 41363,4 & 41395,3 & 41424,9 & 41453,0 \\
\hline & 0,4 & 39098,9 & 39209,0 & 39283,3 & 39342,3 & 39393,0 & 39438,5 & 39480,6 & 39520,6 \\
\hline & 0,5 & 34918,8 & 35177,3 & 35351,7 & 35490,3 & 35609,2 & 35715,9 & 35814,9 & 35908,8 \\
\hline & 0,6 & 30764,4 & 30900,9 & 30993,0 & 31066,2 & 31129,0 & 31185,4 & 31237,7 & 31287,3 \\
\hline & 0,7 & 28621,8 & 28841,1 & 28989,0 & 29106,6 & 29207,5 & 29298,1 & 29382,1 & 29461,7 \\
\hline & 0,8 & 24948,7 & 25160,2 & 25302,8 & 25416,2 & 25513,5 & 25600,9 & 25681,8 & 25758,6 \\
\hline \multirow{7}{*}{$15-$ Set } & 0,2 & 47551,9 & 47689,0 & 47781,5 & 47855,0 & 47918,1 & 47974,7 & 48027,2 & 48077,0 \\
\hline & 0,3 & 41195,0 & 41284,6 & 41345,0 & 41393,0 & 41434,2 & 41471,2 & 41505,5 & 41538,0 \\
\hline & 0,4 & 38934,9 & 39086,1 & 39188,1 & 39269,1 & 39338,7 & 39401,1 & 39459,0 & 39513,9 \\
\hline & 0,5 & 34823,2 & 35095,2 & 35278,7 & 35424,6 & 35549,7 & 35662,1 & 35766,2 & 35865,0 \\
\hline & 0,6 & 30887,1 & 31040,7 & 31144,4 & 31226,8 & 31297,4 & 31360,9 & 31419,7 & 31475,5 \\
\hline & 0,7 & 28465,4 & 28709,9 & 28874,8 & 29005,9 & 29118,4 & 29219,4 & 29312,9 & 29401,8 \\
\hline & 0,8 & 25042,9 & 25252,1 & 25393,1 & 25505,3 & 25601,5 & 25687,9 & 25767,9 & 25843,9 \\
\hline \multirow{7}{*}{ 1-Out } & 0,2 & 47370,8 & 47512,9 & 47608,8 & 47685,1 & 47750,5 & 47809,2 & 47863,6 & 47915,2 \\
\hline & 0,3 & 41212,8 & 41293,3 & 41347,6 & 41390,7 & 41427,8 & 41461,0 & 41491,8 & 41521,0 \\
\hline & 0,4 & 38935,6 & 39079,1 & 39175,9 & 39252,8 & 39318,8 & 39378,0 & 39433,0 & 39485,1 \\
\hline & 0,5 & 34920,6 & 35166,7 & 35332,7 & 35464,7 & 35577,9 & 35679,6 & 35773,8 & 35863,2 \\
\hline & 0,6 & 30572,1 & 30759,3 & 30885,6 & 30986,0 & 31072,2 & 31149,5 & 31221,2 & 31289,2 \\
\hline & 0,7 & 28571,4 & 28792,0 & 28940,9 & 29059,1 & 29160,6 & 29251,8 & 29336,2 & 29416,4 \\
\hline & 0,8 & 24980,8 & 25184,8 & 25322,4 & 25431,8 & 25525,6 & 25609,9 & 25688,0 & 25762,1 \\
\hline \multirow{7}{*}{ 15-Out } & 0,2 & 46951,1 & 47113,8 & 47223,6 & 47310,8 & 47385,6 & 47452,9 & 47515,1 & 47574,2 \\
\hline & 0,3 & 41277,5 & 41353,9 & 41405,4 & 41446,3 & 41481,4 & 41512,9 & 41542,2 & 41569,9 \\
\hline & 0,4 & 38698,9 & 38863,9 & 38975,2 & 39063,7 & 39139,6 & 39207,7 & 39270,9 & 39330,8 \\
\hline & 0,5 & 34092,5 & 34366,6 & 34551,4 & 34698,4 & 34824,4 & 34937,6 & 35042,5 & 35142,1 \\
\hline & 0,6 & 30662,3 & 30829,4 & 30942,2 & 31031,8 & 31108,7 & 31177,8 & 31241,8 & 31302,5 \\
\hline & 0,7 & 28393,7 & 28599,2 & 28737,8 & 28848,0 & 28942,5 & 29027,4 & 29106,0 & 29180,7 \\
\hline & 0,8 & 24782,8 & 24978,2 & 25110,0 & 25214,7 & 25304,6 & 25385,3 & 25460,1 & 25531,1 \\
\hline
\end{tabular}


Tabela 15A. Estimativa da produtividade de frutos de melancia $\left(\mathrm{kg} \mathrm{ha}^{-1}\right)$, com diferentes probabilidades de ocorrência, em cada época de semeadura e nível de manejo (p) no município de Parnaíba, Piauí.

\begin{tabular}{|c|c|c|c|c|c|c|c|c|c|}
\hline \multirow{2}{*}{$\begin{array}{l}\text { Época de } \\
\text { Semeadura }\end{array}$} & \multirow[t]{2}{*}{$\mathrm{p}$} & \multicolumn{8}{|c|}{ Probabilidade de ocorrência (\%) } \\
\hline & & 5 & 10 & 15 & 20 & 25 & 30 & 35 & 40 \\
\hline \multirow{7}{*}{$1-\mathrm{Nov}$} & 0,2 & 45358,9 & 45573,9 & 45718,9 & 45834,1 & 45933,0 & 46021,8 & 46104,1 & 46182,2 \\
\hline & 0,3 & 41078,9 & 41216,3 & 41309,0 & 41382,7 & 41445,9 & 41502,7 & 41555,3 & 41605,2 \\
\hline & 0,4 & 37653,5 & 37898,3 & 38063,4 & 38194,7 & 38307,3 & 38408,4 & 38502,1 & 38591,1 \\
\hline & 0,5 & 33516,4 & 33758,5 & 33921,8 & 34051,6 & 34163,0 & 34263,0 & 34355,6 & 34443,6 \\
\hline & 0,6 & 30306,2 & 30570,3 & 30748,4 & 30890,0 & 31011,5 & 31120,6 & 31221,7 & 31317,6 \\
\hline & 0,7 & 27313,0 & 27599,2 & 27792,4 & 27945,8 & 28077,5 & 28195,8 & 28305,4 & 28409,3 \\
\hline & 0,8 & 24499,8 & 24794,6 & 24993,5 & 25151,6 & 25287,2 & 25409,0 & 25521,9 & 25629,0 \\
\hline \multirow{7}{*}{ 15-Nov } & 0,2 & 44753,1 & 44945,2 & 45074,8 & 45177,8 & 45266,1 & 45345,5 & 45419,0 & 45488,8 \\
\hline & 0,3 & 40790,3 & 40964,9 & 41082,7 & 41176,3 & 41256,6 & 41328,7 & 41395,6 & 41459,0 \\
\hline & 0,4 & 37107,8 & 37405,7 & 37606,7 & 37766,4 & 37903,4 & 38026,5 & 38140,5 & 38248,7 \\
\hline & 0,5 & 32981,9 & 33287,1 & 33493,0 & 33656,6 & 33797,0 & 33923,1 & 34039,9 & 34150,8 \\
\hline & 0,6 & 29968,9 & 30321,0 & 30558,6 & 30747,4 & 30909,3 & 31054,8 & 31189,6 & 31317,5 \\
\hline & 0,7 & 26868,8 & 27259,7 & 27523,4 & 27733,0 & 27912,9 & 28074,3 & 28224,0 & 28366,0 \\
\hline & 0,8 & 24266,1 & 24685,8 & 24969,0 & 25194,1 & 25387,1 & 25560,5 & 25721,2 & 25873,7 \\
\hline \multirow{7}{*}{ 1-Dez } & 0,2 & 43955,3 & 44193,7 & 44354,5 & 44482,3 & 44591,9 & 44690,4 & 44781,6 & 44868,2 \\
\hline & 0,3 & 40574,8 & 40765,9 & 40894,9 & 40997,3 & 41085,2 & 41164,2 & 41237,3 & 41306,7 \\
\hline & 0,4 & 36566,4 & 36878,9 & 37089,7 & 37257,2 & 37401,0 & 37530,1 & 37649,7 & 37763,2 \\
\hline & 0,5 & 32722,0 & 33054,6 & 33278,9 & 33457,2 & 33610,2 & 33747,6 & 33874,9 & 33995,7 \\
\hline & 0,6 & 29576,5 & 29986,8 & 30263,6 & 30483,6 & 30672,4 & 30841,9 & 30999,0 & 31148,0 \\
\hline & 0,7 & 26931,9 & 27338,0 & 27612,0 & 27829,8 & 28016,7 & 28184,5 & 28339,9 & 28487,5 \\
\hline & 0,8 & 24124,2 & 24609,8 & 24937,4 & 25197,7 & 25421,1 & 25621,7 & 25807,5 & 25983,9 \\
\hline \multirow{7}{*}{ 15-Dez } & 0,2 & 43598,9 & 43802,0 & 43939,0 & 44047,9 & 44141,3 & 44225,2 & 44302,9 & 44376,7 \\
\hline & 0,3 & 40183,3 & 40437,2 & 40608,6 & 40744,7 & 40861,5 & 40966,4 & 41063,6 & 41155,9 \\
\hline & 0,4 & 36199,7 & 36520,2 & 36736,5 & 36908,3 & 37055,8 & 37188,2 & 37310,9 & 37427,4 \\
\hline & 0,5 & 32544,9 & 32974,4 & 33264,2 & 33494,5 & 33692,1 & 33869,5 & 34033,9 & 34189,9 \\
\hline & 0,6 & 29395,6 & 29900,1 & 30240,5 & 30511,0 & 30743,1 & 30951,5 & 31144,6 & 31327,9 \\
\hline & 0,7 & 26937,9 & 27435,9 & 27771,9 & 28038,9 & 28268,0 & 28473,7 & 28664,4 & 28845,3 \\
\hline & 0,8 & 24427,7 & 25001,0 & 25387,8 & 25695,3 & 25959,0 & 26195,8 & 26415,3 & 26623,6 \\
\hline
\end{tabular}


Tabela 16A. Estimativa da produtividade de frutos de melancia $\left(\mathrm{kg} \mathrm{ha}^{-1}\right)$, com diferentes probabilidades de ocorrência, em cada época de semeadura e nível de manejo (p) no municipio de Teresina, Piauí.

\begin{tabular}{|c|c|c|c|c|c|c|c|c|c|}
\hline \multirow{2}{*}{$\begin{array}{c}\text { Época de } \\
\text { Semeadura }\end{array}$} & \multirow[t]{2}{*}{$\mathrm{p}$} & \multicolumn{8}{|c|}{ Probabilidade de ocorrência (\%) } \\
\hline & & 5 & 10 & 15 & 20 & 25 & 30 & 35 & 40 \\
\hline \multirow{7}{*}{ 1-Jan } & 0,2 & 41593,8 & 41801,2 & 41941,1 & 42052,3 & 42147,7 & 42233,4 & 42312,8 & 42388,2 \\
\hline & 0,3 & 37305,3 & 37655,9 & 37892,4 & 38080,4 & 38241,7 & 38386,6 & 38520,8 & 38648,1 \\
\hline & 0,4 & 34260,4 & 34740,3 & 35064,1 & 35321,4 & 35542,2 & 35740,4 & 35924,1 & 36098,4 \\
\hline & 0,5 & 31372,6 & 31946,6 & 32333,8 & 32641,6 & 32905,6 & 33142,7 & 33362,5 & 33571,0 \\
\hline & 0,6 & 29017,0 & 29695,4 & 30153,2 & 30517,0 & 30829,1 & 31109,4 & 31369,1 & 31615,5 \\
\hline & 0,7 & 26951,4 & 27777,6 & 28335,0 & 28778,1 & 29158,2 & 29499,5 & 29815,8 & 30115,9 \\
\hline & 0,8 & 25190,6 & 26124,0 & 26753,8 & 27254,3 & 27683,7 & 28069,3 & 28426,7 & 28765,7 \\
\hline \multirow{7}{*}{ 15-Jan } & 0,2 & 42521,4 & 42756,0 & 42914,4 & 43040,2 & 43148,1 & 43245,1 & 43334,9 & 43420,2 \\
\hline & 0,3 & 38488,7 & 38834,5 & 39067,9 & 39253,3 & 39412,4 & 39555,3 & 39687,7 & 39813,3 \\
\hline & 0,4 & 35747,4 & 36201,4 & 36507,7 & 36751,1 & 36959,9 & 37147,4 & 37321,2 & 37486,1 \\
\hline & 0,5 & 33174,8 & 33734,3 & 34111,8 & 34411,8 & 34669,2 & 34900,3 & 35114,5 & 35317,8 \\
\hline & 0,6 & 30814,0 & 31514,4 & 31986,9 & 32362,5 & 32684,7 & 32974,0 & 33242,2 & 33496,6 \\
\hline & 0,7 & 28484,8 & 29398,6 & 30015,1 & 30505,1 & 30925,5 & 31303,0 & 31652,8 & 31984,7 \\
\hline & 0,8 & 27043,6 & 28043,2 & 28717,6 & 29253,6 & 29713,5 & 30126,5 & 30509,2 & 30872,3 \\
\hline \multirow{7}{*}{$1-\mathrm{Fev}$} & 0,2 & 42731,9 & 43000,4 & 43181,6 & 43325,5 & 43449,0 & 43560,0 & 43662,7 & 43760,3 \\
\hline & 0,3 & 38984,4 & 39353,6 & 39602,7 & 39800,7 & 39970,5 & 40123,1 & 40264,4 & 40398,5 \\
\hline & 0,4 & 36265,1 & 36804,9 & 37169,2 & 37458,7 & 37707,0 & 37930,1 & 38136,7 & 38332,8 \\
\hline & 0,5 & 34009,2 & 34650,4 & 35083,1 & 35426,9 & 35721,9 & 35986,8 & 36232,3 & 36465,2 \\
\hline & 0,6 & 31844,5 & 32636,1 & 33170,2 & 33594,7 & 33958,9 & 34285,9 & 34589,0 & 34876,6 \\
\hline & 0,7 & 30294,0 & 31189,1 & 31793,0 & 32272,9 & 32684,7 & 33054,4 & 33397,1 & 33722,2 \\
\hline & 0,8 & 29111,5 & 30086,2 & 30743,8 & 31266,4 & 31714,8 & 32117,5 & 32490,6 & 32844,7 \\
\hline \multirow{7}{*}{$15-\mathrm{Fev}$} & 0,2 & 42778,1 & 43061,2 & 43252,2 & 43404,0 & 43534,2 & 43651,2 & 43759,5 & 43862,4 \\
\hline & 0,3 & 38798,0 & 39262,4 & 39575,8 & 39824,8 & 40038,4 & 40230,3 & 40408,1 & 40576,8 \\
\hline & 0,4 & 36167,0 & 36772,4 & 37180,9 & 37505,5 & 37784,0 & 38034,1 & 38265,9 & 38485,8 \\
\hline & 0,5 & 33846,2 & 34577,0 & 35070,0 & 35461,9 & 35798,0 & 36099,9 & 36379,7 & 36645,1 \\
\hline & 0,6 & 31872,5 & 32754,4 & 33349,4 & 33822,3 & 34227,9 & 34592,3 & 34929,9 & 35250,2 \\
\hline & 0,7 & 30197,9 & 31245,6 & 31952,4 & 32514,1 & 32996,1 & 33428,9 & 33829,9 & 34210,5 \\
\hline & 0,8 & 29044,1 & 30198,7 & 30977,8 & 31596,9 & 32128,1 & 32605,1 & 33047,2 & 33466,6 \\
\hline
\end{tabular}


Tabela 16A. Estimativa da produtividade de frutos de melancia $\left(\mathrm{kg} \mathrm{ha}^{-1}\right)$, com diferentes probabilidades de ocorrência, em cada época de semeadura e nível de manejo (p) no município de Teresina. Piauí.

\begin{tabular}{|c|c|c|c|c|c|c|c|c|c|}
\hline \multirow{2}{*}{$\begin{array}{c}\text { Época de } \\
\text { Semeadura }\end{array}$} & \multirow[t]{2}{*}{$\mathrm{p}$} & \multicolumn{8}{|c|}{ Probabilidade de ocorrência $(\%)$} \\
\hline & & 5 & 10 & 15 & 20 & 25 & 30 & 35 & 40 \\
\hline \multirow{7}{*}{ 1-Mar } & 0,2 & 42564,6 & 42848,2 & 43039,5 & 43191,6 & 43322,1 & 43439,2 & 43547,8 & $+3650,8$ \\
\hline & 0,3 & 38531,7 & 38996,0 & 39309,3 & 39558,3 & 39772,0 & 39963,8 & 40141,6 & 40310,2 \\
\hline & 0,4 & 35834,0 & 36413,0 & 36803,6 & 37114,1 & 37380,4 & 37619,6 & 37841,2 & 38051,6 \\
\hline & 0,5 & 33864,1 & 34547,6 & 35008,7 & 35375,2 & 35689,6 & 35971,9 & 36233,6 & 36481,8 \\
\hline & 0,6 & 31759,8 & 32613,1 & 33188,8 & 33646,4 & 34039,0 & 34391,5 & 34718,1 & 35028,1 \\
\hline & 0,7 & 29637,9 & 30690,3 & 31400,4 & 31964,7 & 32448,8 & 32883,6 & 33286,4 & 33668,7 \\
\hline & 0,8 & 28270,4 & 29451,1 & 30247,7 & 30880,8 & 31423,9 & 31911,7 & 32363,7 & 32792,6 \\
\hline \multirow{7}{*}{ 15-Mar } & 0,2 & 42148,2 & 42403,3 & 42575,4 & 42712,2 & 42829,5 & 42934,9 & 43032,6 & 43125,2 \\
\hline & 0,3 & 37976,1 & 38346,8 & 38596,9 & 38795,6 & 38966,1 & 39119,3 & 39261,2 & 39395,8 \\
\hline & 0,4 & 34696,7 & 35223,0 & 35578,1 & 35860,4 & 36102,5 & 36319,9 & 36521,4 & 36712,6 \\
\hline & 0,5 & 32293,0 & 32959,9 & 33410,0 & 33767,6 & 34074,4 & 34350,0 & 34605,3 & 34847,6 \\
\hline & 0,6 & 29839,9 & 30655,7 & 31206,1 & 31643,5 & 32018,8 & 32355,9 & 32668,2 & 32964,5 \\
\hline & 0,7 & 27763,0 & 28720,3 & 29366,2 & 29879,6 & 30320,0 & 30715,5 & 31081,9 & 31429,7 \\
\hline & 0,8 & 26041,1 & 27110,6 & 27832,2 & 28405,7 & 28897,7 & 29339,5 & 29749,0 & 30137,5 \\
\hline \multirow{7}{*}{ 1-Abr } & 0,2 & 41490,4 & 41752,7 & 41929,6 & 42070,2 & 42190,9 & 42299,2 & 42399,7 & 42494,9 \\
\hline & 0,3 & 36804,3 & 37197,8 & 37463,3 & 37674,3 & 37855,3 & 38017,9 & 38168,5 & 38311,4 \\
\hline & 0,4 & 33237,9 & 33780,4 & 34146,5 & 34437,4 & 34686,9 & 34911,1 & 35118,7 & 35315,8 \\
\hline & 0,5 & 30645,7 & 31258,8 & 31672,4 & 32001,1 & 32283,1 & 32536,4 & 32771,0 & 32993,7 \\
\hline & 0,6 & 28097,0 & 28800,1 & 29274,4 & 29651,4 & 29974,8 & 30265,3 & 30534,4 & 30789,8 \\
\hline & 0,7 & 25809,2 & 26620,5 & 27167,9 & 27603,0 & 27976,2 & 28311,4 & 28621,9 & 28916,7 \\
\hline & 0,8 & 23699,0 & 24648,9 & 25289,8 & 25799,1 & 26236,1 & 26628,5 & 26992,1 & 27337,2 \\
\hline \multirow{7}{*}{$15-\mathrm{Abr}$} & 0,2 & 41100,4 & 41324,7 & 41476,0 & 41596,3 & 41699,5 & 41792,1 & 41878,0 & 41959,5 \\
\hline & 0,3 & 35956,7 & 36293,1 & 36520,0 & 36700,3 & 36855,1 & 36994,0 & 37122,8 & 37244,9 \\
\hline & 0,4 & 32030,9 & 32467,7 & 32762,5 & 32996,8 & 33197,7 & 33378,2 & 33545,5 & 33704,2 \\
\hline & 0,5 & 29084,7 & 29617,5 & 29977,0 & 30262,7 & 30507,8 & 30727,9 & 30931,9 & 31125,4 \\
\hline & 0,6 & 26189,6 & 26845,0 & 27287,2 & 27638,7 & 27940,2 & 28211,0 & 28461,9 & 28700,0 \\
\hline & 0,7 & 23634,9 & 24359,0 & 24847,4 & 25235,7 & 25568,8 & 25867,9 & 26145,1 & 26408,1 \\
\hline & 0,8 & 21416,8 & 22200,5 & 22729,4 & 23149,6 & 23510,2 & 23834,0 & 24134,1 & 24418,8 \\
\hline
\end{tabular}


Tabela 16A. Estimativa da produtividade de frutos de melancia $\left(\mathrm{kg} \mathrm{ha}^{-1}\right)$, com diferentes probabilidades de ocorrência, em cada época de semeadura e nivel de manejo (p) no município de Teresina, Piaui.

\begin{tabular}{|c|c|c|c|c|c|c|c|c|c|}
\hline \multirow{2}{*}{$\begin{array}{l}\text { Época de } \\
\text { Semeadura }\end{array}$} & \multirow[t]{2}{*}{$\mathrm{p}$} & \multicolumn{8}{|c|}{ Probabilidade de ocorrência (\%) } \\
\hline & & 5 & 10 & 15 & 20 & 25 & 30 & 35 & 40 \\
\hline \multirow{7}{*}{ 1-Mai } & 0,2 & 40769,8 & 40956,2 & 41081,9 & 41181,8 & 41267,6 & 41344,6 & 41415,9 & 41483,6 \\
\hline & 0,3 & 35311,0 & 35600,0 & 35795,1 & 35950,1 & 36083,0 & 36202,5 & 36313,1 & 36418,1 \\
\hline & 0,4 & 31300,4 & 31684,1 & 31943,0 & 32148,8 & 32325,3 & 32483,8 & 32630,7 & 32770,1 \\
\hline & 0,5 & 28642,1 & 29027,3 & 29287,1 & 29493,7 & 29670,8 & 29830,0 & 29977,4 & 30117,3 \\
\hline & 0,6 & 25330,8 & 25841,7 & 26186,4 & 26460,4 & 26695,5 & 26906,5 & 27102,1 & 27287,7 \\
\hline & 0,7 & 22415,5 & 23031,5 & 23447,1 & 23777,5 & 24060,9 & 24315,3 & 24551,2 & 24774,9 \\
\hline & 0,8 & 20164,2 & 20811,4 & 21248,1 & 21595,2 & 21893,0 & 22160,4 & 22408,1 & 22643,3 \\
\hline \multirow{7}{*}{ 15-Mai } & 0,2 & 40933,5 & 41060,3 & 41145,9 & 41214,0 & 41272,3 & 41324,7 & 41373,3 & 41419,4 \\
\hline & 0,3 & 35280,0 & 35479,3 & 35613,8 & 35720,6 & 35812,3 & 35894,7 & 35971,0 & 36043,4 \\
\hline & 0,4 & 31476,3 & 31736,7 & 31912,3 & 32052,0 & 32171,8 & 32279,3 & 32379,0 & 32473,6 \\
\hline & 0,5 & 28224,7 & 28513,4 & 28708,1 & 28862,9 & 28995,8 & 29115,0 & 29225,5 & 29330,4 \\
\hline & 0,6 & 24866,9 & 25214,5 & 25449,1 & 25635,5 & 25795,4 & 25939,0 & 26072,0 & 26198,3 \\
\hline & 0,7 & 22192,5 & 22581,7 & 22844,3 & 23053,0 & 23232,1 & 23392,9 & 23541,9 & 23683,3 \\
\hline & 0,8 & 20097,0 & 20501,8 & 20774,8 & 20991,9 & 21178,1 & 21345,3 & 21500,2 & 21647,2 \\
\hline \multirow{7}{*}{ 1-Jun } & 0,2 & 40911,8 & 41054,2 & 41150,3 & 41226,7 & 41292,2 & 41351,0 & 41405,6 & 41457,3 \\
\hline & 0,3 & 35653,4 & 35854,3 & 35989,8 & 36097,5 & 36189,9 & 36272,9 & 36349,8 & 36422,8 \\
\hline & 0,4 & 31912,2 & 32155,7 & 32319,9 & 32450,5 & 32562,5 & 32663,0 & 32756,2 & 32844,7 \\
\hline & 0,5 & 28413,6 & 28634,8 & 28784,1 & 28902,8 & 29004,5 & 29096,0 & 29180,7 & 29261,0 \\
\hline & 0,6 & 24942,3 & 25218,9 & 25405,6 & 25553,9 & 25681,2 & 25795,5 & 25901,4 & 26001,9 \\
\hline & 0,7 & 22414,7 & 22724,2 & 22933,0 & 23098,9 & 23241,3 & 23369,2 & 23487,7 & 23600,1 \\
\hline & 0,8 & 20209,7 & 20498,6 & 20693,5 & 20848,3 & 20981,2 & 21100,5 & 21211,1 & 21316,0 \\
\hline \multirow{7}{*}{ 15-Jun } & 0,2 & 41388,6 & 41496,9 & 41569,9 & 41627,9 & 41677,7 & 41722,4 & 41763,9 & 41803,2 \\
\hline & 0,3 & 36313,8 & 36504,1 & 36632,5 & 36734,6 & 36822,2 & 36900,8 & 36973,7 & 37042,8 \\
\hline & 0,4 & 32473,7 & 32691,3 & 32838,2 & 32954,9 & 33055,0 & 33144,9 & 33228,2 & 33307,3 \\
\hline & 0,5 & 28629,2 & 28833,1 & 28970,7 & 29080,0 & 29173,8 & 29258,0 & 29336,0 & 29410,1 \\
\hline & 0,6 & 25479,6 & 25724,8 & 25890,3 & 26021,8 & 26134,7 & 26236,0 & 26329,9 & 26419,0 \\
\hline & 0,7 & 23013,3 & 23218,0 & 23356,1 & 23465,8 & 23560,0 & 23644,5 & 23722,8 & 23797,2 \\
\hline & 0,8 & 20494,2 & 20735,7 & 20898,7 & 21028,2 & 21139,3 & 21239,1 & 21331,6 & 21419,4 \\
\hline
\end{tabular}


Tabela 16A. Estimativa da produtividade de frutos de melancia $\left(\mathrm{kg} \mathrm{ha}^{-1}\right)$, com diferentes probabilidades de ocorrência, em cada época de semeadura e nível de manejo (p) no município de Teresina, Piauí.

\begin{tabular}{|c|c|c|c|c|c|c|c|c|c|}
\hline \multirow{2}{*}{$\begin{array}{l}\text { Época de } \\
\text { Semeadura }\end{array}$} & \multirow[t]{2}{*}{$\mathrm{p}$} & \multicolumn{8}{|c|}{ Probabilidade de ocorrência (\%) } \\
\hline & & 5 & 10 & 15 & 20 & 25 & 30 & 35 & 40 \\
\hline \multirow{7}{*}{ 1-Jul } & 0,2 & 41723,6 & 41813,8 & 41874,7 & 41923,1 & 41964,6 & 42001,9 & 42036,4 & 42069,2 \\
\hline & 0,3 & 37339,3 & 37539,2 & 37674,0 & 37781,2 & 37873,1 & 37955,7 & 38032,2 & 38104,8 \\
\hline & 0,4 & 33006,3 & 33185,8 & 33306,9 & 33403,1 & 33485,7 & 33559,8 & 33628,6 & 33693,8 \\
\hline & 0,5 & 29025,8 & 29214,1 & 29341,2 & 29442,2 & 29528,8 & 29606,6 & 29678,7 & 29747,1 \\
\hline & 0,6 & 26176,2 & 26402,9 & 26555,8 & 26677,4 & 26781,7 & 26875,3 & 26962,1 & 27044,4 \\
\hline & 0,7 & 23171,9 & 23381,6 & 23523,0 & 23635,5 & 23731,9 & 23818,6 & 23898,8 & 23975,0 \\
\hline & 0,8 & 20893,2 & 21092,1 & 21226,3 & 21333,0 & 21424,5 & 21506,6 & 21582,8 & 21655,0 \\
\hline \multirow{7}{*}{ 15-Jul } & 0,2 & 41920,6 & 41999,3 & 42052,3 & 42094,5 & 42130,6 & 42163,1 & 42193,2 & 42221,8 \\
\hline & 0,3 & 38160,4 & 38361,5 & 38497,2 & 38605,0 & 38697,6 & 38780,6 & 38857,6 & 38930,7 \\
\hline & 0,4 & 33348,5 & 33515,9 & 33628,9 & 33718,7 & 33795,7 & 33864,8 & 33928,9 & 33989,8 \\
\hline & 0,5 & 29729,5 & 29952,8 & 30103,5 & 30223,2 & 30326,0 & 30418,2 & 30503,7 & 30584,8 \\
\hline & 0,6 & 27027,9 & 27177,0 & 27277,6 & 27357,5 & 27426,1 & 27487,7 & 27544,8 & 27599,0 \\
\hline & 0,7 & 23501,4 & 23721,3 & 23869,7 & 23987,6 & 24088,8 & 24179,7 & 24263,8 & 24343,7 \\
\hline & 0,8 & 21419,3 & 21657,9 & 21818,9 & 21946,8 & 22056,6 & 22155,1 & 22246,4 & 22333,1 \\
\hline \multirow{7}{*}{ 1-Ago } & 0,2 & 42153,0 & 42240,3 & 42299,2 & 42346,1 & 42386,3 & 42422,3 & 42455,8 & 42487,5 \\
\hline & 0,3 & 39146,5 & 39293,7 & 39393,0 & 39472,0 & 39539,7 & 39600,5 & 39656,9 & 39710,4 \\
\hline & 0,4 & 33902,5 & 34039,7 & 34132,2 & 34205,7 & 34268,8 & 34325,4 & 34377,9 & 34427,7 \\
\hline & 0,5 & 30766,1 & 30961,4 & 31093,2 & 31197,9 & 31287,8 & 31368,5 & 31443,2 & 31514,2 \\
\hline & 0,6 & 27076,3 & 27258,3 & 27381,0 & 27478,5 & 27562,2 & 27637,4 & 27707,0 & 27773,1 \\
\hline & 0,7 & 24374,1 & 24604,9 & 24760,6 & 24884,4 & 24990,6 & 25085,9 & 25174,3 & 25258,2 \\
\hline & 0,8 & 22031,6 & 22421,7 & 22421,7 & 22421,7 & 22421,7 & 22421,7 & 22811,7 & 22811,7 \\
\hline \multirow{7}{*}{ 15-Ago } & 0,2 & 42341,3 & 42443,2 & 42512,0 & 42566,7 & 42613,6 & 42655,8 & 42694,8 & 42731,8 \\
\hline & 0,3 & 39575,2 & 39708,8 & 39798,9 & 39870,5 & 39932,0 & 39987,2 & 40038,3 & 40086,8 \\
\hline & 0,4 & 34175,4 & 34321,1 & 34419,4 & 34497,6 & 34564,6 & 34624,8 & 34680,6 & 34733,5 \\
\hline & 0,5 & 31352,3 & 31536,5 & 31660,7 & 31759,4 & 31844,1 & 31920,2 & 31990,7 & 32057,6 \\
\hline & 0,6 & 27298,8 & 27494,6 & 27626,8 & 27731,8 & 27821,9 & 27902,8 & 27977,8 & 28048,9 \\
\hline & 0,7 & 24815,4 & 25068,6 & 25239,5 & 25375,3 & 25491,8 & 25596,4 & 25693,4 & 25785,4 \\
\hline & 0,8 & 21721,9 & 21976,4 & 22148,1 & 22284,5 & 22401,6 & 22506,7 & 22604,1 & 22696,6 \\
\hline
\end{tabular}


Tabela 16A. Estimativa da produtividade de frutos de melancia $\left(\mathrm{kg} \mathrm{ha}^{-1}\right)$, com diferentes probabilidades de ocorrência, em cada época de semeadura e nivel de manejo (p) no município de Teresina, Piaui.

\begin{tabular}{|c|c|c|c|c|c|c|c|c|c|}
\hline \multirow{2}{*}{$\begin{array}{c}\text { Época de } \\
\text { Semeadura }\end{array}$} & \multirow[t]{2}{*}{$\mathrm{p}$} & \multicolumn{8}{|c|}{ Probabilidade de ocorrència $(\%)$} \\
\hline & & 5 & 10 & 15 & 20 & 25 & 30 & 35 & 40 \\
\hline \multirow{7}{*}{ 1-Set } & 0,2 & 42432,7 & 42548,4 & 42626,5 & 42688,5 & 42741,7 & 42789,5 & 42833,8 & 42875,8 \\
\hline & 0,3 & 39639,5 & 39774,2 & 39865,1 & 39937,4 & 39999,4 & 40055,0 & 40106,6 & 40155,5 \\
\hline & 0,4 & 34306,8 & 34468,3 & 34577,2 & 34663,8 & 34738,1 & 34804,8 & 34866,6 & 34925,3 \\
\hline & 0,5 & 31478,6 & 31671,8 & 31802,1 & 31905,7 & 31994,5 & 32074,3 & 32148,3 & 32218,5 \\
\hline & 0,6 & 27554,6 & 27753,0 & 27886,9 & 27993,3 & 28084,6 & 28166,6 & 28242,5 & 28314,6 \\
\hline & 0,7 & 24936,6 & 25198,1 & 25374,5 & 25514,7 & 25635,0 & 25743,1 & 25843,2 & 25938,2 \\
\hline & 0,8 & 22065,0 & 22325,5 & 22501,3 & 22641,0 & 22760,9 & 22868,5 & 22968,3 & 23062,9 \\
\hline \multirow{7}{*}{$15-$ Set } & 0,2 & 42354,2 & 42470,1 & 42548,2 & 42610,3 & 42663,6 & 42711,4 & 42755,8 & 42797,8 \\
\hline & 0,3 & 39425,6 & 39572,7 & 39671,9 & 39750,8 & 39818,5 & 39879,2 & 39935,5 & 39989,0 \\
\hline & 0,4 & 34172,3 & 34357,9 & 34483,2 & 34582,7 & 34668,1 & 34744,8 & 34815,9 & 34883,4 \\
\hline & 0,5 & 31343,5 & 31567,3 & 31718,3 & 31838,3 & 31941,2 & 32033,7 & 32119,3 & 32200,6 \\
\hline & 0,6 & 27517,8 & 27737,4 & 27885,6 & 28003,4 & 28104,4 & 28195,2 & 28279,2 & 28359,0 \\
\hline & 0,7 & 24929,4 & 25220,7 & 25417,2 & 25573,4 & 25707,4 & 25827,8 & 25939,3 & 26045,1 \\
\hline & 0,8 & 22084,5 & 22369,6 & 22562,0 & 22714,9 & 22846,0 & 22963,8 & 23073,0 & 23176,5 \\
\hline \multirow{7}{*}{ 1-Out } & 0,2 & 42206,9 & 42333,1 & 42418,3 & 42485,9 & 42544,0 & 42596,2 & 42644,5 & 42690,3 \\
\hline & 0,3 & 39112,6 & 39284,9 & 39401,1 & 39493,5 & 39572,8 & 39643,9 & 39709,9 & 39772,5 \\
\hline & 0,4 & 34046,2 & 34217,9 & 34333,7 & 34425,8 & 34504,8 & 34575,7 & 34641,5 & 34703,9 \\
\hline & 0,5 & 30879,4 & 31123,2 & 31287,6 & 31418,3 & 31530,4 & 31631,1 & 31724,4 & 31813,0 \\
\hline & 0,6 & 27275,1 & 27515,4 & 27677,5 & 27806,4 & 27917,0 & 28016,2 & 28108,2 & 28195,5 \\
\hline & 0,7 & 24706,1 & 24964,7 & 25139,2 & 25277,8 & 25396,8 & 25503,6 & 25602,6 & 25696,5 \\
\hline & 0,8 & 21828,1 & 22153,9 & 22373,8 & 22548,5 & 22698,4 & 22833,0 & 22957,7 & 23076,1 \\
\hline \multirow{7}{*}{ 15-Out } & 0,2 & 42133,9 & 42260,3 & 42345,6 & 42413,4 & 42471,5 & 42523,7 & 42572,1 & 42618,0 \\
\hline & 0,3 & 38654,8 & 38838,8 & 38962,9 & 39061,6 & 39146,2 & 39222,2 & 39292,6 & 39359,4 \\
\hline & 0,4 & 33715,5 & 33954,6 & 34115,9 & 34244,1 & 34354,1 & 34452,9 & 34544,5 & 34631,3 \\
\hline & 0,5 & 30337,4 & 30627,3 & 30822,9 & 30978,4 & 31111,8 & 31231,5 & 31342,5 & 31447,9 \\
\hline & 0,6 & 27136,1 & 27426,8 & 27622,9 & 27778,8 & 27912,5 & 28032,6 & 28143,9 & 28249,5 \\
\hline & 0,7 & 24435,4 & 24724,0 & 24918,6 & 25073,3 & 25206,1 & 25325,3 & 25435,7 & 25540,5 \\
\hline & 0,8 & 22183,7 & 22504,0 & 22720,1 & 22891,8 & 23039,1 & 23171,5 & 23294,1 & 23410,4 \\
\hline
\end{tabular}


330

Tabela 16A. Estimativa da produtividade de frutos de melancia $\left(\mathrm{kg} \mathrm{ha}^{-1}\right)$, com diferentes probabilidades de ocorrência, em cada época de semeadura e nível de manejo (p) no município de Teresina, Piauí.

\begin{tabular}{|c|c|c|c|c|c|c|c|c|c|}
\hline \multirow{2}{*}{$\begin{array}{c}\text { Época de } \\
\text { Semeadura }\end{array}$} & \multirow[t]{2}{*}{$\mathrm{p}$} & \multicolumn{8}{|c|}{ Probabilidade de ocorrência ( $\%)$} \\
\hline & & 5 & 10 & 15 & 20 & 25 & 30 & 35 & 40 \\
\hline \multirow{7}{*}{$1-\mathrm{Nov}$} & 0,2 & 41940,9 & 42079,6 & 42173,2 & 42247,6 & 42311,4 & 42368,7 & 42421,8 & 42472,2 \\
\hline & 0,3 & 37729,7 & 37999,7 & 38181,8 & 38326,6 & 38450,8 & 38562,3 & 38665,7 & 38763,8 \\
\hline & 0,4 & 33692,0 & 33959,3 & 34139,7 & 34283,0 & 34406,0 & 34516,5 & 34618,8 & 34715,9 \\
\hline & 0,5 & 30097,7 & 30412,1 & 30624,2 & 30792,8 & 30937,4 & 31067,3 & 31187,7 & 31301,9 \\
\hline & 0,6 & 26858,0 & 27264,2 & 27538,3 & 27756,1 & 27942,9 & 28110,7 & 28266,2 & 28413,8 \\
\hline & 0,7 & 24249,7 & 24666,9 & 24948,4 & 25172,1 & 25364,0 & 25536,4 & 25696,1 & 25847,6 \\
\hline & 0,8 & 21542,1 & 22080,0 & 22442,9 & 22731,3 & 22978,8 & 23201,0 & 23406,9 & 23602,3 \\
\hline \multirow{7}{*}{ 15-Nov } & 0,2 & 41814,5 & 41995,6 & 42117,8 & 42214,9 & 42298,2 & 42373,0 & 42442,3 & 42508,1 \\
\hline & 0,3 & 37277,1 & 37590,8 & 37802,4 & 37970,6 & 38114,9 & 38244,5 & 38364,6 & 38478,6 \\
\hline & 0,4 & 33576,4 & 33936,4 & 34179,3 & 34372,3 & 34537,9 & 34686,6 & 34824,5 & 34955,2 \\
\hline & 0,5 & 30170,2 & 30581,2 & 30858,5 & 31079,0 & 31268,1 & 31437,9 & 31595,2 & 31744,6 \\
\hline & 0,6 & 27035,3 & 27550,5 & 27898,1 & 28174,4 & 28411,4 & 28624,2 & 28821,4 & 29008,6 \\
\hline & 0,7 & 24262,5 & 24865,4 & 25272,2 & 25595,5 & 25872,9 & 26122,0 & 26352,8 & 26571,8 \\
\hline & 0,8 & 22331,1 & 22947,5 & 23363,3 & 23693,8 & 23977,4 & 24232,0 & 24468,0 & 24691,9 \\
\hline \multirow{7}{*}{ 1-Dez } & 0,2 & 41718,1 & 41907,4 & 42035,1 & 42136,6 & 42223,7 & 42301,9 & 42374,4 & 42443,2 \\
\hline & 0,3 & 37273,1 & 37547,5 & 37732,5 & 37879,6 & 38005,8 & 38119,2 & 38224,2 & 38323,8 \\
\hline & 0,4 & 33768,6 & 34110,6 & 34341,3 & 34524,6 & 34681,9 & 34823,2 & 34954,1 & 35078,3 \\
\hline & 0,5 & 30284,6 & 30723,8 & 31020,1 & 31255,6 & 31457,7 & 31639,1 & 31807,2 & 31966,8 \\
\hline & 0,6 & 27400,7 & 27919,7 & 28269,8 & 28548,1 & 28786,9 & 29001,3 & 29200,0 & 29388,5 \\
\hline & 0,7 & 25258,7 & 25811,6 & 26184,6 & 26481,0 & 26735,3 & 26963,7 & 27175,4 & 27376,2 \\
\hline & 0,8 & 22849,1 & 23474,6 & 23896,7 & 24232,2 & 24520,0 & 24778,4 & 25017,9 & 25245,2 \\
\hline \multirow{7}{*}{ 15-Dez } & 0,2 & 41930,6 & 42123,2 & 42253,2 & 42356,4 & 42445,1 & 42524,6 & 42598,4 & 42668,3 \\
\hline & 0,3 & 37053,7 & 37399,6 & 37632,9 & 37818,4 & 37977,5 & 38120,4 & 38252,8 & 38378,5 \\
\hline & 0,4 & 33915,2 & 34348,9 & 34641,6 & 34874,2 & 35073,8 & 35253,0 & 35419,0 & 35576,6 \\
\hline & 0,5 & 30713,5 & 31223,6 & 31567,7 & 31841,3 & 32075,9 & 32286,6 & 32481,9 & 32667,2 \\
\hline & 0,6 & 27653,2 & 28326,4 & 28780,6 & 29141,5 & 29451,2 & 29729,3 & 29987,0 & 30231,5 \\
\hline & 0,7 & 25473,3 & 26223,6 & 26729,8 & 27132,1 & 27477,3 & 27787,2 & 28074,4 & 28347,0 \\
\hline & 0,8 & 23533,0 & 24353,2 & 24906,6 & 25346,4 & 25723,7 & 26062,6 & 26376,6 & 26674,5 \\
\hline
\end{tabular}


Tabela 17A. Estimativa da produtividade de grãos de feijão caupi ( $\mathrm{kg} \mathrm{ha}^{-1}$ ), em regime de sequeiro, com diferentes probabilidades de ocorrência, em cada época de semeadura no municipio de Parnaíba, Piaui.

\begin{tabular}{lrrrrrrrr}
\hline Época de & \multicolumn{7}{c}{ Probabilidade de ocorrência (\%) } \\
\cline { 2 - 9 } Semeadura & \multicolumn{1}{c}{5} & \multicolumn{1}{c}{10} & \multicolumn{1}{c}{15} & \multicolumn{1}{c}{20} & \multicolumn{1}{c}{25} & \multicolumn{1}{c}{ 品 } & \multicolumn{1}{c}{35} & \multicolumn{1}{c}{40} \\
\hline 1 - Jan & 303,7 & 440,1 & 532,1 & 605,3 & 668,0 & 724,4 & 776,6 & 826,2 \\
15 - Jan & 439,7 & 568,5 & 655,3 & 724,4 & 783,6 & 836,8 & 886,1 & 932,9 \\
1 - Fev & 531,1 & 670,4 & 764,4 & 839,1 & 903,3 & 960,8 & 1014,2 & 1064,8 \\
15 - Fev & 717,8 & 846,9 & 934,0 & 1003,3 & 1062,6 & 1116,0 & 1165,4 & 1212,3 \\
1 - Mar & 767,9 & 894,1 & 979,3 & 1046,9 & 1105,0 & 1157,1 & 1205,4 & 1251,3 \\
15 - Mar & 554,7 & 698,1 & 794,9 & 871,8 & 937,8 & 997,0 & 1051,9 & 1104,0 \\
1 - Abr & 335,2 & 476,2 & 571,2 & 646,8 & 711,6 & 769,8 & 823,8 & 875,0 \\
15 - Abr & 11,3 & 160,7 & 261,5 & 341,6 & 410,4 & 472,1 & 529,3 & 583,6 \\
1 - Mai & 0,0 & 14,5 & 78,6 & 129,6 & 173,3 & 212,5 & 248,9 & 283,4 \\
15 - Mai & 54,9 & 54,9 & 54,9 & 54,9 & 54,9 & 54,9 & 54,9 & 54,9 \\
1 - Jun & 28,2 & 28,2 & 28,2 & 28,2 & 28,2 & 28,2 & 28,2 & 28,2 \\
15 - Jun & 19,3 & 19,3 & 19,3 & 19,3 & 19,3 & 19,3 & 19,3 & 19,3 \\
1 - Jul & 21,6 & 21,6 & 21,6 & 21,6 & 21,6 & 21,6 & 21,6 & 21,6 \\
15 - Jul & 14,7 & 14,7 & 14,7 & 14,7 & 14,7 & 14,7 & 14,7 & 14,7 \\
1 - Ago & 0,0 & 0,0 & 0,0 & 0,0 & 0,0 & 0,0 & 0,0 & 0,0 \\
15 - Ago & 0,0 & 0,0 & 0,0 & 0,0 & 0,0 & 0,0 & 0,0 & 0,0 \\
1 - Set & 0,0 & 0,0 & 0,0 & 0,0 & 0,0 & 0,0 & 0,0 & 0,0 \\
15 - Set & 3,4 & 3,4 & 3,4 & 3,4 & 3,4 & 3,4 & 3,4 & 3,4 \\
1 - Out & 8,0 & 8,0 & 8,0 & 8,0 & 8,0 & 8,0 & 8,0 & 8,0 \\
15 - Out & 7,4 & 7,4 & 7,4 & 7,4 & 7,4 & 7,4 & 7,4 & 7,4 \\
1 - Nov & 42,1 & 42,1 & 42,1 & 42,1 & 42,1 & 42,1 & 42,1 & 42,1 \\
15 - Nov & 61,4 & 61,4 & 61,4 & 61,4 & 61,4 & 61,4 & 61,4 & 61,4 \\
1 - Dez & 0,0 & 0,0 & 49,1 & 100,9 & 145,3 & 185,2 & 222,1 & 257,2 \\
15 - Dez & 0,0 & 71,9 & 162,2 & 234,0 & 295,6 & 351,0 & 402,2 & 450,9 \\
\hline & & & & & & & &
\end{tabular}


Tabela 18A. Estimativa da produtividade de grãos de feijão caupi $\left(\mathrm{kg} \mathrm{ha}^{-1}\right)$, em regime de sequeiro, com diferentes probabilidades de ocorrência, em cada época de semeadura no município de Teresina, Piauí.

\begin{tabular}{lrrrrrrrr}
\hline Época de & \multicolumn{7}{c}{ Probabilidade de ocorrência (\%) } \\
\cline { 2 - 9 } Semeadura & \multicolumn{1}{c}{5} & \multicolumn{1}{c}{10} & \multicolumn{1}{c}{15} & \multicolumn{1}{c}{20} & \multicolumn{1}{c}{25} & \multicolumn{1}{c}{30} & \multicolumn{1}{c}{35} & \multicolumn{1}{c}{40} \\
\hline 1 - Jan & 882,9 & 1000,7 & 1080,1 & 1143,2 & 1197,4 & 1246,0 & 1291,1 & 1333,9 \\
15 - Jan & 1006,6 & 1126,4 & 1207,3 & 1271,6 & 1326,7 & 1376,3 & 1422,2 & 1465,7 \\
1 - Fev & 1307,2 & 1402,5 & 1466,9 & 1518,0 & 1561,9 & 1601,3 & 1637,8 & 1672,4 \\
15 - Fev & 1285,7 & 1393,6 & 1466,5 & 1524,4 & 1574,0 & 1618,6 & 1659,9 & 1699,1 \\
1 - Mar & 1279,8 & 1384,0 & 1454,3 & 1510,1 & 1558,1 & 1601,1 & 1641,0 & 1678,8 \\
15 - Mar & 1002,3 & 1117,2 & 1194,7 & 1256,4 & 1309,2 & 1356,7 & 1400,7 & 1442,4 \\
1 - Abr & 617,1 & 757,2 & 851,6 & 926,7 & 991,1 & 1049,0 & 1102,6 & 1153,4 \\
15 - Abr & 153,0 & 300,3 & 399,6 & 478,6 & 546,4 & 607,2 & 663,6 & 717,1 \\
1 - Mai & 0,0 & 45,2 & 138,9 & 213,3 & 277,2 & 334,6 & 387,8 & 438,2 \\
15 - Mai & 54,2 & 54,2 & 54,2 & 54,2 & 54,2 & 54,2 & 54,2 & 54,2 \\
1 - Jun & 28,9 & 28,9 & 28,9 & 28,9 & 28,9 & 28,9 & 28,9 & 28,9 \\
15 - Jun & 26,1 & 26,1 & 26,1 & 26,1 & 26,1 & 26,1 & 26,1 & 26,1 \\
1 - Jul & 15,0 & 15,0 & 15,0 & 15,0 & 15,0 & 15,0 & 15,0 & 15,0 \\
15 - Jul & 23,0 & 23,0 & 23,0 & 23,0 & 23,0 & 23,0 & 23,0 & 23,0 \\
1 - Ago & 27,1 & 27,1 & 27,1 & 27,1 & 27,1 & 27,1 & 27,1 & 27,1 \\
15 - Ago & 31,0 & 31,0 & 31,0 & 31,0 & 31,0 & 31,0 & 31,0 & 31,0 \\
1 - Set & 36,0 & 36,0 & 36,0 & 36,0 & 36,0 & 36,0 & 36,0 & 36,0 \\
15 - Set & 50,9 & 50,9 & 50,9 & 50,9 & 50,9 & 50,9 & 50,9 & 50,9 \\
1 - Out & 43,4 & 43,4 & 43,4 & 43,4 & 43,4 & 43,4 & 43,4 & 43,4 \\
15 - Out & 54,8 & 54,8 & 54,8 & 54,8 & 54,8 & 54,8 & 54,8 & 54,8 \\
1 - Nov & 0,0 & 0,0 & 73,9 & 141,1 & 198,7 & 250,4 & 298,3 & 343,8 \\
15 - Nov & 90,6 & 229,1 & 322,6 & 396,8 & 460,5 & 517,7 & 570,8 & 621,1 \\
1 - Dez & 222,3 & 361,4 & 455,3 & 529,9 & 593,9 & 651,4 & 704,7 & 755,2 \\
15 - Dez & 563,0 & 693,7 & 781,9 & 852,0 & 912,1 & 966,1 & 1016,2 & 1063,7 \\
\hline & & & & & & & &
\end{tabular}


Tabela 19A. Estimativa da produtividade de frutos de melancia $\left(\mathrm{kg} \mathrm{ha}^{-1}\right)$, em regime de sequeiro, com diferentes probabilidades de ocorrência, em cada época de semeadura no município de Parnaiba, Piauí.

\begin{tabular}{|c|c|c|c|c|c|c|c|c|}
\hline \multirow{2}{*}{$\begin{array}{l}\text { Época de } \\
\text { Semeadura }\end{array}$} & \multicolumn{8}{|c|}{ Probabilidade de ocorrência $(\%)$} \\
\hline & 5 & 10 & 15 & 20 & 25 & 30 & 35 & 40 \\
\hline $1-\operatorname{Jan}$ & 4327,0 & 6299,8 & 7630,8 & 8688,6 & 9596,1 & 10411,1 & 11166,3 & 11882,9 \\
\hline $15-J a n$ & 6393,6 & 8521,2 & 9956,7 & 11097,6 & 12076,4 & 12955,4 & 13769,9 & 14542,8 \\
\hline $1-\mathrm{Fev}$ & 8549,3 & 10821,8 & 12355,1 & 13573,6 & 14619,1 & 15557,9 & 16427,9 & 17253,4 \\
\hline $15-\mathrm{Fev}$ & 11637,4 & 13821,3 & 15294,7 & 16465,7 & 17470,4 & 18372,6 & 19208,6 & 20001,9 \\
\hline 1 - Mar & 12267,6 & 14542,8 & 16077,8 & 17297,8 & 18344,5 & 19284,4 & 20155,4 & 20981,9 \\
\hline $15-\mathrm{Mar}$ & 9249,6 & 11630,7 & 13237,1 & 14513,9 & 15609,3 & 16593,0 & 17504,5 & 18369,4 \\
\hline $1-\mathrm{Abr}$ & 4970,2 & 7099,2 & 8535,6 & 9677,2 & 10656,6 & 11536,2 & 12351,2 & 13124,6 \\
\hline $15-\mathrm{Abr}$ & 906,7 & 3017,8 & 4442,0 & 5574,0 & 6545,2 & 7417,3 & 8225,4 & 8992,3 \\
\hline 1-Mai & 0,0 & 737,5 & 1519,2 & 2140,4 & 2673,4 & 3152,0 & 3595,6 & 4016,4 \\
\hline 15 - Mai & 0,0 & 0,0 & 429,3 & 945,8 & 1388,9 & 1786,8 & 2155,5 & 2505,4 \\
\hline 1 - Jun & 313,3 & 313,3 & 313,3 & 313,3 & 313,3 & 908,3 & 908,3 & 908,3 \\
\hline 15 - Jun & 174,5 & 174,5 & 174,5 & 174,5 & 174,5 & 174,5 & 174,5 & 174,5 \\
\hline 1 - Jul & 176,9 & 176,9 & 176,9 & 176,9 & 176,9 & 176,9 & 176,9 & 176,9 \\
\hline $15-\mathrm{Jul}$ & 119,8 & 119,8 & 119,8 & 119,8 & 119,8 & 119,8 & 119,8 & 119,8 \\
\hline 1 - Ago & 2,2 & 2,3 & 2,3 & 2,4 & 2,5 & 2,5 & 2,5 & 2,6 \\
\hline 15 - Ago & 1,6 & 1,6 & 1,7 & 1,7 & 1,7 & 1,8 & 1,8 & 1,8 \\
\hline $1-$ Set & 1,2 & 1,3 & 1,3 & 1,4 & 1,4 & 1,4 & 1,4 & 1,4 \\
\hline 15 - Set & 49,0 & 49,0 & 49,0 & 49,0 & 49,0 & 49,0 & 49,0 & 49,0 \\
\hline 1 - Out & 78,3 & 78,3 & 78,3 & 78,3 & 78,3 & 78,3 & 78,3 & 78,3 \\
\hline 15 - Out & 75,5 & 75,5 & 75,5 & 75,5 & 75,5 & 75,5 & 75,5 & 75,5 \\
\hline 1 - Nov & 345,1 & 345,1 & 345,1 & 345,1 & 345,1 & 345,1 & 345,1 & 345,1 \\
\hline $15-$ Nov & 0,0 & 0,0 & 243,8 & 677,9 & 1050,4 & 1384,9 & 1694,9 & 1989,0 \\
\hline $1-\mathrm{Dez}$ & 0,0 & 487,7 & 1181,6 & 1733,2 & 2206,3 & 2631,2 & 3025,0 & 3398,6 \\
\hline $15-\mathrm{Dez}$ & 0,0 & 1441,3 & 2629,5 & 3573,7 & 4383,9 & 5111,4 & 5785,5 & 6425,2 \\
\hline
\end{tabular}


Tabela 20A. Estimativa da produtividade de frutos de melancia $\left(\mathrm{kg} \mathrm{ha}^{-1}\right)$, em regime de sequeiro, com diferentes probabilidades de ocorrência, em cada época de semeadura no município de Teresina, Piauí.

\begin{tabular}{lrrrrrrrr}
\hline Época de & \multicolumn{7}{c}{ Probabilidade de ocorrência (\%) } \\
\cline { 2 - 9 } Semeadura & \multicolumn{1}{c}{5} & \multicolumn{1}{c}{10} & \multicolumn{1}{c}{15} & \multicolumn{1}{c}{20} & \multicolumn{1}{c}{25} & \multicolumn{1}{c}{30} & \multicolumn{1}{c}{35} & \multicolumn{1}{c}{40} \\
\hline 1 - Jan & 14470,5 & 16593,0 & 18025,0 & 19163,1 & 20139,5 & 21016,4 & 21828.9 & 22599,9 \\
15 - Jan & 17524,4 & 19636,4 & 21061,3 & 22193,8 & 23165,4 & 24037,9 & 24846,4 & 25613,6 \\
1 - Fev & 23116,7 & 24833,0 & 25991,0 & 26911,4 & 27701,0 & 28410,0 & 29067,1 & 29690,5 \\
15 - Fev & 22468,3 & 24500,5 & 25871,6 & 26961,3 & 27896,2 & 28735,7 & 29513,7 & 30251.9 \\
1 - Mar & 22388,5 & 24367,4 & 25702,6 & 26763,7 & 27674,1 & 28491,6 & 29249,2 & 29968,1 \\
15 - Mar & 16835,7 & 19006,4 & 20470,9 & 21634,8 & 22633,4 & 23530,1 & 24361,1 & 25149,6 \\
1 - Abr & 9178,1 & 11551,8 & 13153,4 & 14426,3 & 15518,3 & 16499,0 & 17407,7 & 18270,0 \\
15 - Abr & 2408,3 & 4576,1 & 6038,7 & 7201,1 & 8198,4 & 9093,9 & 9923,8 & 10711,3 \\
1 - Mai & 0,0 & 669,6 & 1932,2 & 2935,8 & 3796,7 & 4569,8 & 5286,2 & 5966,0 \\
15 - Mai & 811,5 & 811,5 & 811,5 & 811,5 & 811,5 & 811,5 & 811,5 & 811,5 \\
1 - Jun & 376,0 & 376,0 & 376,0 & 376,0 & 376,0 & 376,0 & 376,0 & 376,0 \\
15 - Jun & 243,2 & 243,2 & 243,2 & 243,2 & 243,2 & 243,2 & 243,2 & 243,2 \\
1 - Jul & 148,1 & 148,1 & 148,1 & 148,1 & 148,1 & 148,1 & 148,1 & 148,1 \\
15 - Jul & 177,5 & 177,5 & 177,5 & 177,5 & 177,5 & 177,5 & 177,5 & 177,5 \\
1 - Ago & 192,4 & 192,4 & 192,4 & 192,4 & 192,4 & 192,4 & 192,4 & 192,4 \\
15 - Ago & 212,8 & 212,8 & 212,8 & 212,8 & 212,8 & 212,8 & 212,8 & 212,8 \\
1 - Set & 317,5 & 317,5 & 317,5 & 317,5 & 317,5 & 317,5 & 317,5 & 317,5 \\
15 - Set & 397,3 & 397,3 & 397,3 & 397,3 & 397,3 & 397,3 & 397,3 & 397,3 \\
1 - Out & 407,7 & 407,7 & 407,7 & 407,7 & 407,7 & 407,7 & 407,7 & 407,7 \\
15 - Out & 630,2 & 630,2 & 630,2 & 630,2 & 630,2 & 630,2 & 630,2 & 630,2 \\
1 - Nov & 0,0 & 97,8 & 1168,3 & 2019,1 & 2749,0 & 3404,5 & 4011,9 & 4588,3 \\
15 - Nov & 1584,7 & 3412,5 & 4645,8 & 5625,9 & 6466,8 & 7221,9 & 7921,6 & 8585,6 \\
1 - Dez & 3606,9 & 5717,1 & 7140,9 & 8272,5 & 9243,2 & 10115,0 & 10922,9 & 11689,4 \\
15 - Dez & 8492,6 & 10696,2 & 12182,9 & 13364,5 & 14378,2 & 15288,6 & 16132,2 & 16932,6 \\
\hline & & & & & & & &
\end{tabular}


Tabela 21 A. Ajuste dos preços mensais de venda dos produtos à função de distribuição triangular, pelo teste de Kolmogorov-Smirnov ${ }^{1}$.

\begin{tabular}{lcccccc}
\hline \multirow{2}{*}{ Meses } & \multicolumn{3}{c}{ Feijão caupi } & \multicolumn{3}{c}{ Melancia } \\
\cline { 2 - 7 } & Dmax $^{2}$ & Dtab & Ajuste & Dmax & Dtab & Ajuste \\
\hline Janeiro & 0,4919 & 0,6890 & Sim & 0,3755 & 0,6890 & Sim \\
Fevereiro & 0,4863 & 0,6890 & Sim & 0,6403 & 0,6890 & Sim \\
Março & 0,4623 & 0,6890 & Sim & 0,4179 & 0,6890 & Sim \\
Abril & 0,5974 & 0,6890 & Sim & 0,6032 & 0,6890 & Sim \\
Maio & 0,6987 & 0,6890 & Não & 0,4054 & 0,6890 & Sim \\
Junho & 0,6983 & 0,6890 & Não & 0,4985 & 0,6890 & Sim \\
Julho & 0,5494 & 0,5630 & Sim & 0,3054 & 0,5630 & Sim \\
Agosto & 0,5360 & 0,5630 & Sim & 0,5042 & 0,5630 & Sim \\
Setembro & 0,5350 & 0,5630 & Sim & 0,2274 & 0,5630 & Sim \\
Outubro & 0,4718 & 0,5630 & Sim & 0,4987 & 0,5630 & Sim \\
Novembro & 0,4947 & 0,5630 & Sim & 0,3205 & 0,5630 & Sim \\
Dezembro & 0,3057 & 0,5630 & Sim & 0,2000 & 0,5630 & Sim \\
\hline
\end{tabular}

${ }^{\mathrm{I}}$ Nível de $5 \%$ de probabilidade; ${ }^{2}$ Dmax - desvio máximo e Dtab - desvio tabelado. 
Tabela 22A. Ajuste dos preços mensais da tarifa de consumo de energia elétrica à função de distribuição triangular, pelo teste de Kolmogorov-Smirnov ${ }^{1}$.

\begin{tabular}{lccc}
\hline \multicolumn{1}{c}{ Meses } & Dmax $^{2}$ & Dtab & Ajuste \\
\hline Janeiro & 0,3041 & 0,4300 & Sim \\
Fevereiro & 0,2493 & 0,4300 & Sim \\
Março & 0,2037 & 0,4300 & Sim \\
Abril & 0,1342 & 0,4300 & Sim \\
Maio & 0,2022 & 0,4090 & Sim \\
Junho & 0,3483 & 0,4090 & Sim \\
Julho & 0,2149 & 0,4300 & Sim \\
Agosto & 0,2129 & 0,4300 & Sim \\
Setembro & 0,3490 & 0,4300 & Sim \\
Outubro & 0,3237 & 0,4300 & Sim \\
Novembro & 0,2583 & 0,4300 & Sim \\
Dezembro & 0,1767 & 0,4300 & Sim \\
\hline
\end{tabular}

${ }^{1}$ Nível de $5 \%$ de probabilidade; ${ }^{2}$ Dmax - desvio máximo e Dtab - desvio tabelado. 
Tabela 23 A. Parâmetros da distribuição triangular relativos aos preços mensais de venda dos produtos (US\$ $\mathrm{kg}^{-1}$ ).

\begin{tabular}{lcccccc}
\hline \multirow{2}{*}{ Meses } & \multicolumn{3}{c}{ Feijão caupi } & \multicolumn{3}{c}{ Melancia } \\
\cline { 2 - 7 } & Máximo & Mínimo & Moda & Máximo & Mínimo & Moda \\
\hline Janeiro & 0,89 & 0,35 & 0,55 & 0,12 & 0,09 & 0,10 \\
Fevereiro & 0,89 & 0,38 & 0,56 & 0,16 & 0,08 & 0,11 \\
Março & 0,88 & 0,34 & 0,54 & 0,13 & 0,10 & 0,11 \\
Abril & 0,88 & 0,33 & 0,52 & 0,13 & 0,11 & 0,11 \\
Maio & 0,91 & 0,35 & 0,52 & 0,14 & 0,10 & 0,12 \\
Junho & 0,91 & 0,35 & 0,52 & 0,14 & 0,10 & 0,12 \\
Julho & 0,90 & 0,21 & 0,45 & 0,11 & 0,08 & 0,09 \\
Agosto & 0,90 & 0,28 & 0,48 & 0,12 & 0,08 & 0,10 \\
Setembro & 0,85 & 0,29 & 0,48 & 0,09 & 0,07 & 0,09 \\
Outubro & 0,84 & 0,26 & 0,46 & 0,12 & 0,08 & 0,09 \\
Novembro & 0,84 & 0,26 & 0,47 & 0,10 & 0,08 & 0,09 \\
Dezembro & 0,79 & 0,26 & 0,49 & 0,11 & 0,07 & 0,09 \\
\hline
\end{tabular}


Tabela 24A. Parâmetros da distribuição triangular relativos aos preços mensais da tarifa de consumo de energia elétrica (US\$ $\mathrm{kWh}^{-1}$ ).

\begin{tabular}{lccc}
\hline \multicolumn{1}{c}{ Meses } & Máximo & Mínimo & Moda \\
\hline Janeiro & 0,067 & 0,048 & 0,059 \\
Fevereiro & 0,067 & 0,037 & 0,053 \\
Março & 0,076 & 0,034 & 0,055 \\
Abril & 0,079 & 0,023 & 0,054 \\
Maio & 0,073 & 0,016 & 0,052 \\
Junho & 0,067 & 0,011 & 0,052 \\
Julho & 0,066 & 0,042 & 0,056 \\
Agosto & 0,079 & 0,041 & 0,059 \\
Setembro & 0,065 & 0,042 & 0,057 \\
Outubro & 0,068 & 0,040 & 0,058 \\
Novembro & 0,068 & 0,041 & 0,059 \\
Dezembro & 0,070 & 0,043 & 0,059 \\
\hline
\end{tabular}


APÊNDICE 2 

Tabela 1B. Receitas brutas, composição de custos da irrigação, receitas líquidas e relação benefício/custo para o feijão caupi, em cada época de semeadura, nível de manejo da irrigação e risco de $5 \%$. Parnaiba, Piauí.

\begin{tabular}{|c|c|c|c|c|c|c|c|}
\hline $\begin{array}{l}\text { Época de } \\
\text { Semeadura }\end{array}$ & $\mathrm{p}$ & $\begin{array}{c}\mathrm{RB}^{1} \\
\left(\mathrm{US} \$ \mathrm{ha}^{-1}\right)\end{array}$ & $\begin{array}{c}E b \\
\left(\mathrm{kWh} \mathrm{ha}^{-1}\right)\end{array}$ & $\begin{array}{c}\mathrm{CE} \\
\left(\mathrm{US} \$ \mathrm{ha}^{-1}\right)\end{array}$ & $\begin{array}{c}\mathrm{CT} \\
\left(\mathrm{US} \$ \mathrm{ha}^{-1}\right)\end{array}$ & $\begin{array}{c}\mathrm{RL} \\
\left(\mathrm{US} \$ \mathrm{ha}^{-1}\right)\end{array}$ & $\mathrm{B} / \mathrm{C}$ \\
\hline \multirow{7}{*}{ 1-Jan } & 0,2 & 1041,74 & 705,87 & 45,94 & 763,52 & 278,22 & 1,36 \\
\hline & 0,3 & 980,14 & 688,54 & 44,81 & 762,39 & 217,75 & 1,29 \\
\hline & 0,4 & 917,96 & 671,45 & 43,70 & 761,28 & 156,68 & 1,21 \\
\hline & 0,5 & 856,24 & 649,57 & 42,27 & 759,86 & 96,38 & 1,13 \\
\hline & 0,6 & 803,76 & 626,08 & 40,74 & 758,33 & 45,44 & 1,06 \\
\hline & 0,7 & 747,73 & 612,22 & 39,84 & 757,43 & $-9,69$ & 0,99 \\
\hline & 0,8 & 705,46 & 593,45 & 38,62 & 756,20 & $-50,74$ & 0,93 \\
\hline \multirow{7}{*}{ 15-Jan } & 0,2 & 1052,48 & 641,42 & 41,74 & 759,33 & 293,15 & 1,39 \\
\hline & 0,3 & 996,49 & 621,30 & 40,43 & 758,02 & 238,48 & 1,31 \\
\hline & 0,4 & 930,51 & 605,23 & 39,39 & 756,97 & 173,54 & 1,23 \\
\hline & 0,5 & 871,43 & 583,19 & 37,95 & 755,54 & 115,89 & 1,15 \\
\hline & 0,6 & 811,52 & 550,13 & 35,80 & 753,39 & 58,14 & 1,08 \\
\hline & 0,7 & 766,91 & 544,45 & 35,43 & 753,02 & 13,89 & 1,02 \\
\hline & 0,8 & 725,73 & 525,62 & 34,21 & 751,79 & $-26,06$ & 0,97 \\
\hline \multirow{7}{*}{$1-\mathrm{Fev}$} & 0,2 & 1003,67 & 597,12 & 40,23 & 757,82 & 245,86 & 1,32 \\
\hline & 0,3 & 953,43 & 574,42 & 38,70 & 756,29 & 197,15 & 1,26 \\
\hline & 0,4 & 882,71 & 549,08 & 37,00 & 754,58 & 128,13 & 1,17 \\
\hline & 0,5 & 836,94 & 516,42 & 34,80 & 752,38 & 84,55 & 1,11 \\
\hline & 0,6 & 783,14 & 503,16 & 33,90 & 751,49 & 31,65 & 1,04 \\
\hline & 0,7 & 738,81 & 481,02 & 32,41 & 750,00 & $-11,19$ & 0,99 \\
\hline & 0,8 & 692,18 & 453,81 & 30,58 & 748,16 & $-55,98$ & 0,93 \\
\hline \multirow{7}{*}{ 15-Fev } & 0,2 & 998,91 & 543,30 & 36,61 & 754,19 & 244,72 & 1,32 \\
\hline & 0,3 & 952,84 & 518,91 & 34,96 & 752,55 & 200,29 & 1,27 \\
\hline & 0,4 & 878,64 & 489,04 & 32,95 & 750,54 & 128,11 & 1,17 \\
\hline & 0,5 & 835,01 & 461,52 & 31,10 & 748,68 & 86,33 & 1,12 \\
\hline & 0,6 & 779,33 & 415,00 & 27,96 & 745,55 & 33,79 & 1,05 \\
\hline & 0,7 & 750,43 & 409,39 & 27,58 & 745,17 & 5,26 & 1,01 \\
\hline & 0,8 & 702,75 & 390,68 & 26,32 & 743,91 & $-41,16$ & 0,94 \\
\hline
\end{tabular}


Tabela 1B. Receitas brutas, composição de custos da irrigação, receitas líquidas e relação benefício/custo para o feijão caupi, em cada época de semeadura, nível de manejo da irrigação e risco de $5 \%$. Parnaíba, Piauí

\begin{tabular}{|c|c|c|c|c|c|c|c|}
\hline $\begin{array}{l}\text { Época de } \\
\text { Semeadura }\end{array}$ & $\mathrm{p}$ & $\begin{array}{c}\mathrm{RB}^{1} \\
\left(\mathrm{US} \$ \mathrm{ha}^{-1}\right)\end{array}$ & $\begin{array}{c}E b \\
\left(\mathrm{kWh} \mathrm{ha}^{-1}\right)\end{array}$ & $\begin{array}{c}\text { CE } \\
\left(\text { US\$ ha }{ }^{-1}\right)\end{array}$ & $\begin{array}{c}\mathrm{CT} \\
\left(\mathrm{US} \$ \mathrm{ha}^{-1}\right)\end{array}$ & $\begin{array}{c}\mathrm{RL} \\
\left(\mathrm{US} \$ \mathrm{ha}^{-1}\right)\end{array}$ & $\mathrm{B} / \mathrm{C}$ \\
\hline \multirow{7}{*}{ 1-Mar } & 0,2 & 1022,46 & 531,17 & 35,46 & 753,04 & 269,42 & 1,36 \\
\hline & 0,3 & 975,04 & 512,38 & 34,21 & 751,79 & 223,25 & 1,30 \\
\hline & 0,4 & 899,61 & 481,99 & 32,18 & 749,76 & 149,85 & 1,20 \\
\hline & 0,5 & 852,82 & 443,30 & 29,59 & 747,18 & 105,64 & 1,14 \\
\hline & 0,6 & 800,03 & 428,22 & 28,59 & 746,17 & 53,86 & 1,07 \\
\hline & 0,7 & 755,92 & 402,51 & 26,87 & 744,46 & 11,47 & 1,02 \\
\hline & 0,8 & 715,94 & 378,70 & 25,28 & 742,87 & $-26,93$ & 0,96 \\
\hline \multirow{7}{*}{ 15-Mar } & 0,2 & 1014,88 & 548,56 & 36,62 & 754,21 & 260,68 & 1,35 \\
\hline & 0,3 & 967,86 & 520,11 & 34,72 & 752,31 & 215,56 & 1,29 \\
\hline & 0,4 & 891,46 & 492,51 & 32,88 & 750,46 & 141,00 & 1,19 \\
\hline & 0,5 & 844,69 & 469,37 & 31,33 & 748,92 & 95,77 & 1,13 \\
\hline & 0,6 & 788,27 & 454,80 & 30,36 & 747,95 & 40,32 & 1,05 \\
\hline & 0,7 & 745,28 & 419,79 & 28,02 & 745,61 & $-0,33$ & 1,00 \\
\hline & 0,8 & 695,65 & 393,22 & 26,25 & 743,84 & $-48,19$ & 0,94 \\
\hline \multirow{7}{*}{$1-A b r$} & 0,2 & 1009,51 & 612,63 & 38,52 & 756,10 & 253,41 & 1,34 \\
\hline & 0,3 & 957,32 & 592,31 & 37,24 & 754,83 & 202,50 & 1,27 \\
\hline & 0,4 & 876,85 & 575,31 & 36,17 & 753,76 & 123,09 & 1,16 \\
\hline & 0,5 & 826,48 & 545,25 & 34,28 & 751,87 & 74,61 & 1,10 \\
\hline & 0,6 & 761,87 & 526,81 & 33,12 & 750,71 & 11,16 & 1,01 \\
\hline & 0,7 & 720,32 & 516,89 & 32,50 & 750,08 & $-29,77$ & 0,96 \\
\hline & 0,8 & 671,25 & 497,08 & 31,25 & 748,84 & $-77,59$ & 0,90 \\
\hline \multirow{7}{*}{$15-\mathrm{Abr}$} & 0,2 & 1007,63 & 668,53 & 42,03 & 759,62 & 248,01 & 1,33 \\
\hline & 0,3 & 952,32 & 655,78 & 41,23 & 758,82 & 193,50 & 1,26 \\
\hline & 0,4 & 870,56 & 630,19 & 39,62 & 757,21 & 113,35 & 1,15 \\
\hline & 0,5 & 813,40 & 616,17 & 38,74 & 756,33 & 57,08 & 1,08 \\
\hline & 0,6 & 746,42 & 604,16 & 37,99 & 755,57 & $-9,15$ & 0,99 \\
\hline & 0,7 & 703,90 & 584,03 & 36,72 & 754,30 & $-50,40$ & 0,93 \\
\hline & 0,8 & 651,86 & 585,21 & 36,79 & 754,38 & $-102,52$ & 0,86 \\
\hline
\end{tabular}


Tabela 1B. Receitas brutas, composição de custos da irrigação, receitas líquidas e relação benefício/custo para o feijão caupi, em cada época de semeadura, nível de manejo da irrigação e risco de $5 \%$. Parnaíba, Piauí.

\begin{tabular}{|c|c|c|c|c|c|c|c|}
\hline $\begin{array}{l}\text { Época de } \\
\text { Semeadura }\end{array}$ & $\mathrm{p}$ & $\begin{array}{c}\mathrm{RB}^{1} \\
\left(\mathrm{US} \$ \mathrm{ha}^{-1}\right)\end{array}$ & $\begin{array}{c}\mathrm{Eb} \\
\left(\mathrm{kWh} \mathrm{ha} \mathrm{h}^{-1}\right)\end{array}$ & $\begin{array}{c}\text { CE } \\
\left(\mathrm{US} \$ \mathrm{ha}^{-1}\right)\end{array}$ & $\begin{array}{c}\text { CT } \\
\left(\mathrm{US} \$ \mathrm{ha}^{-1}\right)\end{array}$ & $\begin{array}{c}\mathrm{RL} \\
\left(\mathrm{US} \$ \mathrm{ha}^{-1}\right)\end{array}$ & $\mathrm{B} / \mathrm{C}$ \\
\hline \multirow{7}{*}{ 1-Mai } & 0,2 & 800,18 & 743,24 & 44,64 & 762,23 & 37,95 & 1,05 \\
\hline & 0,3 & 754,56 & 726,80 & 43,65 & 761,24 & $-6,68$ & 0,99 \\
\hline & 0,4 & 688,00 & 713,45 & 42,85 & 760,44 & $-72,44$ & 0,90 \\
\hline & 0,5 & 642,27 & 708,22 & 42,54 & 760,12 & $-117,85$ & 0,84 \\
\hline & 0,6 & 594,46 & 713,10 & 42,83 & 760,42 & $-165,95$ & 0,78 \\
\hline & 0,7 & 552,37 & 704,43 & 42,31 & 759,90 & $-207,52$ & 0,73 \\
\hline & 0,8 & 513,98 & 709,89 & 42,64 & 760,22 & $-246,24$ & 0,68 \\
\hline \multirow{7}{*}{ 15-Mai } & 0,2 & 801,30 & 775,47 & 46,58 & 764,16 & 37,14 & 1,05 \\
\hline & 0,3 & 756,11 & 770,07 & 46,25 & 763,84 & $-7,73$ & 0,99 \\
\hline & 0,4 & 690,21 & 761,44 & 45,73 & 763,32 & $-73,11$ & 0,90 \\
\hline & 0,5 & 641,70 & 753,41 & 45,25 & 762,84 & $-121,14$ & 0,84 \\
\hline & 0,6 & 594,45 & 741,27 & 44,52 & 762,11 & $-167,66$ & 0,78 \\
\hline & 0,7 & 553,27 & 746,50 & 44,84 & 762,42 & $-209,15$ & 0,73 \\
\hline & 0,8 & 513,74 & 732,19 & 43,98 & 761,56 & $-247,82$ & 0,67 \\
\hline \multirow{7}{*}{ 1-Jun } & 0,2 & 903,37 & 818,67 & 52,63 & 770,21 & 133,16 & 1,17 \\
\hline & 0,3 & 850,86 & 810,05 & 52,07 & 769,66 & 81,20 & 1,11 \\
\hline & 0,4 & 781,06 & 810,76 & 52,12 & 769,70 & 11,36 & 1,01 \\
\hline & 0,5 & 722,52 & 803,00 & 51,62 & 769,21 & $-46,69$ & 0,94 \\
\hline & 0,6 & 670,72 & 797,52 & 51,27 & 768,85 & $-98,14$ & 0,87 \\
\hline & 0,7 & 616,71 & 791,19 & 50,86 & 768,45 & $-151,73$ & 0,80 \\
\hline & 0,8 & 574,92 & 793,09 & 50,98 & 768,57 & $-193,65$ & 0,75 \\
\hline \multirow{7}{*}{ 15-Jun } & 0,2 & 913,40 & 888,07 & 57,09 & 774,67 & 138,73 & 1,18 \\
\hline & 0,3 & 851,46 & 880,96 & 56,63 & 774,22 & 77,25 & 1,10 \\
\hline & 0,4 & 796,45 & 877,69 & 56,42 & 774,01 & 22,44 & 1,03 \\
\hline & 0,5 & 723,34 & 867,60 & 55,77 & 773,36 & $-50,02$ & 0,94 \\
\hline & 0,6 & 685,61 & 873,66 & 56,16 & 773,75 & $-88,13$ & 0,89 \\
\hline & 0,7 & 619,39 & 869,21 & 55,88 & 773,46 & $-154,07$ & 0,80 \\
\hline & 0,8 & 584,30 & 865,51 & 55,64 & 773,22 & $-188,92$ & 0,76 \\
\hline
\end{tabular}


Tabela 1B. Receitas brutas, composição de custos da irrigação, receitas líquidas e relação beneficio/custo para o feijão caupi, em cada época de semeadura, nível de manejo da irrigação e risco de $5 \%$. Parnaiba, Piauí.

\begin{tabular}{|c|c|c|c|c|c|c|c|}
\hline $\begin{array}{l}\text { Época de } \\
\text { Semeadura }\end{array}$ & $\mathrm{p}$ & $\begin{array}{c}\mathrm{RB}^{1} \\
\left(\mathrm{US} \$ \mathrm{ha}^{-1}\right)\end{array}$ & $\begin{array}{c}\mathrm{Eb} \\
\left.(\mathrm{kWh} \mathrm{ha})^{-1}\right)\end{array}$ & $\begin{array}{c}\text { CE } \\
\left(\text { US\$ ha }{ }^{-1}\right)\end{array}$ & $\begin{array}{c}\mathrm{CT} \\
\left(\mathrm{US} \$ \mathrm{ha}^{-1}\right)\end{array}$ & $\begin{array}{c}\mathrm{RL} \\
\left(\mathrm{US} \$ \mathrm{ha}^{-1}\right)\end{array}$ & $\mathrm{B} / \mathrm{C}$ \\
\hline \multirow{7}{*}{ 1-Jul } & 0,2 & 934,76 & 959,15 & 62,58 & 780,17 & 154,59 & 1,20 \\
\hline & 0,3 & 863,63 & 953,76 & 62,23 & 779,82 & 83,81 & 1,11 \\
\hline & 0,4 & 816,87 & 949,16 & 61,93 & 779,52 & 37,35 & 1,05 \\
\hline & 0,5 & 738,55 & 958,58 & 62,55 & 780,13 & $-41,59$ & 0,95 \\
\hline & 0,6 & 699,01 & 946,92 & 61,79 & 779,37 & $-80,36$ & 0,90 \\
\hline & 0,7 & 639,08 & 945,94 & 61,72 & 779,31 & $-140,23$ & 0,82 \\
\hline & 0,8 & 595,08 & 942,76 & 61,52 & 779,10 & $-184,02$ & 0,76 \\
\hline \multirow{7}{*}{ 15-Jul } & 0,2 & 945,84 & 1037,84 & 67,72 & 785,30 & 160,53 & 1,20 \\
\hline & 0,3 & 867,76 & 1027,34 & 67,03 & 784,62 & 83,14 & 1,11 \\
\hline & 0,4 & 829,74 & 1032,25 & 67,35 & 784,94 & 44,80 & 1,06 \\
\hline & 0,5 & 754,15 & 1031,47 & 67,30 & 784,89 & $-30,74$ & 0,96 \\
\hline & 0,6 & 701,12 & 1030,58 & 67,25 & 784,83 & $-83,71$ & 0,89 \\
\hline & 0,7 & 657,00 & 1025,06 & 66,89 & 784,47 & $-127,47$ & 0,84 \\
\hline & 0,8 & 593,91 & 1024,32 & 66,84 & 784,42 & $-190,52$ & 0,76 \\
\hline \multirow{7}{*}{ 1-Ago } & 0,2 & 901,24 & 1115,63 & 72,57 & 790,15 & 111,09 & 1,14 \\
\hline & 0,3 & 822,70 & 1112,40 & 72,36 & 789,94 & 32,76 & 1,04 \\
\hline & 0,4 & 785,42 & 1107,17 & 72,02 & 789,60 & $-4,18$ & 0,99 \\
\hline & 0,5 & 733,88 & 1111,00 & 72,26 & 789,85 & $-55,97$ & 0,93 \\
\hline & 0,6 & 661,37 & 1102,48 & 71,71 & 789,29 & $-127,93$ & 0,84 \\
\hline & 0,7 & 632,68 & 1096,68 & 71,33 & 788,92 & $-156,23$ & 0,80 \\
\hline & 0,8 & 574,52 & 1104,70 & 71,85 & 789,44 & $-214,91$ & 0,73 \\
\hline \multirow{7}{*}{ 15-Ago } & 0,2 & 909,22 & 1165,53 & 75,81 & 793,40 & 115,83 & 1,15 \\
\hline & 0,3 & 828,91 & 1165,94 & 75,84 & 793,42 & 35,49 & 1,04 \\
\hline & 0,4 & 789,26 & 1157,22 & 75,27 & 792,86 & $-3,59$ & 1,00 \\
\hline & 0,5 & 748,14 & 1153,21 & 75,01 & 792,59 & $-44,45$ & 0,94 \\
\hline & 0,6 & 666,37 & 1157,17 & 75,27 & 792,85 & $-126,48$ & 0,84 \\
\hline & 0,7 & 633,26 & 1158,83 & 75,38 & 792,96 & $-159,70$ & 0,80 \\
\hline & 0,8 & 593,40 & 1158,94 & 75,38 & 792,97 & $-199,56$ & 0,75 \\
\hline
\end{tabular}


Tabela 1B. Receitas brutas, composição de custos da irrigação, receitas líquidas e relação beneficio/custo para o feijão caupi, em cada época de semeadura, nivel de manejo da irrigação e risco de $5 \%$. Parnaiba, Piaui.

\begin{tabular}{|c|c|c|c|c|c|c|c|}
\hline $\begin{array}{l}\text { Época de } \\
\text { Semeadura }\end{array}$ & $\mathrm{p}$ & $\begin{array}{c}\mathrm{RB}^{\mathrm{I}} \\
\left(\mathrm{US} \$ \mathrm{ha}^{-1}\right)\end{array}$ & $\begin{array}{c}\text { Eb } \\
\left(\mathrm{Kwh} \mathrm{ha}^{-1}\right)\end{array}$ & $\begin{array}{c}\text { CE } \\
\left(\mathrm{US} \$ \mathrm{ha}^{-1}\right)\end{array}$ & $\begin{array}{c}\text { CT } \\
\left(\mathrm{US} \$ \mathrm{ha}^{-1}\right)\end{array}$ & $\begin{array}{c}\mathrm{RL} \\
\left(\mathrm{US} \$ \mathrm{ha}^{-1}\right)\end{array}$ & $\mathrm{B} / \mathrm{C}$ \\
\hline \multirow{7}{*}{$1-$ Set } & 0,2 & 927,97 & 1201,09 & 73,77 & 791,35 & 136,62 & 1,17 \\
\hline & 0,3 & 845,42 & 1200,39 & 73,73 & 791,31 & 54,11 & 1,07 \\
\hline & 0,4 & 802,26 & 1194,84 & 73,38 & 790,97 & 11,29 & 1,01 \\
\hline & 0,5 & 769,43 & 1191,15 & 73,16 & 790,74 & $-21,31$ & 0,97 \\
\hline & 0,6 & 680,69 & 1196,78 & 73,50 & 791,09 & $-110,40$ & 0,86 \\
\hline & 0,7 & 642,59 & 1197,44 & 73,54 & 791,13 & $-148,54$ & 0,81 \\
\hline & 0,8 & 623,30 & 1194,99 & 73,39 & 790,98 & $-167,68$ & 0,79 \\
\hline \multirow{7}{*}{ 15-Set } & 0,2 & 929,23 & 1199,01 & 73,64 & 791,23 & 138,00 & 1,17 \\
\hline & 0,3 & 845,22 & 1196,28 & 73,47 & 791,06 & 54,16 & 1,07 \\
\hline & 0,4 & 803,21 & 1189,97 & 73,09 & 790,67 & 12,54 & 1,02 \\
\hline & 0,5 & 768,92 & 1190,73 & 73,13 & 790,72 & $-21,79$ & 0,97 \\
\hline & 0,6 & 681,91 & 1192,84 & 73,26 & 790,85 & $-108,94$ & 0,86 \\
\hline & 0,7 & 642,80 & 1196,84 & 73,51 & 791,09 & $-148,29$ & 0,81 \\
\hline & 0,8 & 619,61 & 1182,33 & 72,62 & 790,20 & $-170,59$ & 0,78 \\
\hline \multirow{7}{*}{ 1-Out } & 0,2 & 959,30 & 1196,96 & 75,75 & 793,33 & 165,97 & 1,21 \\
\hline & 0,3 & 878,52 & 1197,94 & 75,81 & 793,39 & 85,13 & 1,11 \\
\hline & 0,4 & 832,85 & 1192,68 & 75,47 & 793,06 & 39,79 & 1,05 \\
\hline & 0,5 & 796,00 & 1190,59 & 75,34 & 792,93 & 3,08 & 1,00 \\
\hline & 0,6 & 706,16 & 1193,90 & 75,55 & 793,14 & $-86,98$ & 0,89 \\
\hline & 0,7 & 664,84 & 1188,58 & 75,21 & 792,80 & $-127,96$ & 0,84 \\
\hline & 0,8 & 643,85 & 1179,70 & 74,65 & 792,24 & $-148,39$ & 0,81 \\
\hline \multirow{7}{*}{ 15-Out } & 0,2 & 958,56 & 1173,95 & 74,29 & 791,87 & 166,68 & 1,21 \\
\hline & 0,3 & 872,76 & 1168,23 & 73,93 & 791,51 & 81,25 & 1,10 \\
\hline & 0,4 & 831,68 & 1166,26 & 73,80 & 791,39 & 40,30 & 1,05 \\
\hline & 0,5 & 793,05 & 1160,16 & 73,42 & 791,00 & 2,05 & 1,00 \\
\hline & 0,6 & 701,78 & 1163,36 & 73,62 & 791,20 & $-89,42$ & 0,89 \\
\hline & 0,7 & 666,97 & 1158,72 & 73,33 & 790,91 & $-123,94$ & 0,84 \\
\hline & 0,8 & 630,81 & 1158,34 & 73,30 & 790,89 & $-160,07$ & 0,80 \\
\hline
\end{tabular}


Tabela 1B. Receitas brutas, composição de custos da irrigaçào, receitas líquidas e relação beneficio/custo para o feijão caupi, em cada época de semeadura, nível de manejo da irrigação e risco de $5 \%$. Parnaíba, Piauí.

\begin{tabular}{|c|c|c|c|c|c|c|c|}
\hline $\begin{array}{c}\text { Época de } \\
\text { Semeadura }\end{array}$ & $\mathrm{p}$ & $\begin{array}{c}\mathrm{RB}^{\mathrm{l}} \\
\left(\mathrm{US} \$ \mathrm{ha}^{-1}\right)\end{array}$ & $\begin{array}{c}\mathrm{Eb} \\
\left(\mathrm{kWh} \mathrm{ha}^{-1}\right)\end{array}$ & $\begin{array}{c}C E \\
\left(\mathrm{US} \$ \mathrm{ha}^{-1}\right)\end{array}$ & $\begin{array}{c}\text { CT } \\
(\text { US\$ ha-1 })\end{array}$ & $\begin{array}{c}\mathrm{RL} \\
\left(\mathrm{US} \$ \mathrm{ha}^{-1}\right)\end{array}$ & $\mathrm{B} / \mathrm{C}$ \\
\hline \multirow{7}{*}{ 1-Nov } & 0,2 & 1112,08 & 1086,94 & 69,56 & 787,15 & 324,94 & 1,41 \\
\hline & 0,3 & 1024,27 & 1087,13 & 69,57 & 787,16 & 237,11 & 1,30 \\
\hline & 0,4 & 974,38 & 1076,87 & 68,92 & 786,50 & 187,88 & 1,24 \\
\hline & 0,5 & 902,91 & 1066,91 & 68,28 & 785,86 & 117,05 & 1,15 \\
\hline & 0,6 & 824,21 & 1074,85 & 68,79 & 786,37 & 37,84 & 1,05 \\
\hline & 0,7 & 779,82 & 1071,05 & 68,54 & 786,13 & $-6,31$ & 0,99 \\
\hline & 0,8 & 713,91 & 1069,24 & 68,43 & 786,01 & $-72,10$ & 0,91 \\
\hline \multirow{7}{*}{ 15-Nov } & 0,2 & 1100,26 & 983,99 & 62,97 & 780,56 & 319,70 & 1,41 \\
\hline & 0,3 & 1016,34 & 974,43 & 62,36 & 779,94 & 236,39 & 1,30 \\
\hline & 0,4 & 967,50 & 971,55 & 62,18 & 779,76 & 187,74 & 1,24 \\
\hline & 0,5 & 886,01 & 968,33 & 61,97 & 779,55 & 106,45 & 1,14 \\
\hline & 0,6 & 823,28 & 954,42 & 61,08 & 778,66 & 44,62 & 1,06 \\
\hline & 0,7 & 775,70 & 957,67 & 61,29 & 778,87 & $-3,17$ & 1,00 \\
\hline & 0,8 & 709,95 & 948,65 & 60,71 & 778,29 & $-68,35$ & 0,91 \\
\hline \multirow{7}{*}{ 1-Dez } & 0,2 & 1127,67 & 903,19 & 57,82 & 775,41 & 352,26 & 1,45 \\
\hline & 0,3 & 1052,23 & 892,19 & 57,12 & 774,70 & 277,53 & 1,36 \\
\hline & 0,4 & 993,17 & 881,99 & 56,47 & 774,05 & 219,12 & 1,28 \\
\hline & 0,5 & 911,45 & 871,08 & 55,77 & 773,35 & 138,09 & 1,18 \\
\hline & 0,6 & 848,45 & 853,58 & 54,65 & 772,23 & 76,22 & 1,10 \\
\hline & 0,7 & 793,32 & 854,93 & 54,73 & 772,32 & 21,00 & 1,03 \\
\hline & 0,8 & 737,39 & 851,61 & 54,52 & 772,11 & $-34,72$ & 0,96 \\
\hline \multirow{7}{*}{ 15-Dez } & 0,2 & 1121,84 & 809,10 & 51,80 & 769,39 & 352,46 & 1,46 \\
\hline & 0,3 & 1048,79 & 789,72 & 50,56 & 768,14 & 280,64 & 1,37 \\
\hline & 0,4 & 988,23 & 778,95 & 49,87 & 767,45 & 220,78 & 1,29 \\
\hline & 0,5 & 904,20 & 762,43 & 48,81 & 766,40 & 137,81 & 1,18 \\
\hline & 0,6 & 849,64 & 749,14 & 47,96 & 765,55 & 84,10 & 1,11 \\
\hline & 0,7 & 788,68 & 737,15 & 47,19 & 764,78 & 23,90 & 1,03 \\
\hline & 0,8 & 736,57 & 733,90 & 46,99 & 764,57 & $-28,00$ & 0,96 \\
\hline
\end{tabular}

${ }^{1} \mathrm{RB}$ - receita bruta: $\mathrm{Eb}$ - energia requerida para o bombeamento: $\mathrm{CE}$ - custo de energia elétrica: $\mathrm{CT}$ - custo total de produção: RL - receita líquida e B/C - relação beneficio/custo. 
Tabela 2B. Receitas brutas, composição de custos da irrigação, receitas líquidas e relação benefício/custo para o feijão caupi, em cada época de semeadura, nível de manejo da irrigação e risco de $10 \%$. Parnaiba, Piauí.

\begin{tabular}{|c|c|c|c|c|c|c|c|}
\hline $\begin{array}{c}\text { Época de } \\
\text { Semeadura }\end{array}$ & $p$ & $\begin{array}{c}\mathrm{RB}^{1} \\
\left(\mathrm{US} \$ \mathrm{ha}^{-1}\right)\end{array}$ & $\begin{array}{c}\mathrm{Eb} \\
\left(\mathrm{kWh} \mathrm{ha}^{-1}\right)\end{array}$ & $\begin{array}{c}\text { CE } \\
\left(\mathrm{US} \$ \mathrm{ha}^{-1}\right) \\
\end{array}$ & $\begin{array}{c}\mathrm{CT} \\
\left(\mathrm{US} \$ \mathrm{ha}^{-1}\right)\end{array}$ & $\begin{array}{c}\mathrm{RL} \\
\left(\mathrm{US} \$ \mathrm{ha}^{-1}\right)\end{array}$ & $\mathrm{B} / \mathrm{C}$ \\
\hline \multirow{7}{*}{ 1-Jan } & 0,2 & 1071,18 & 681,42 & 43,04 & 760,63 & 310,56 & 1,41 \\
\hline & 0,3 & 1008,90 & 660,99 & 41,75 & 759,33 & 249,57 & 1,33 \\
\hline & 0,4 & 948,29 & 640,86 & 40,48 & 758,06 & 190,23 & 1,25 \\
\hline & 0,5 & 886,12 & 617,45 & 39,00 & 756,59 & 129,53 & 1,17 \\
\hline & 0,6 & 834,41 & 592,48 & 37,42 & 755,01 & 79,41 & 1,11 \\
\hline & 0,7 & 779,41 & 576,09 & 36,39 & 753,97 & 25,44 & 1,03 \\
\hline & 0,8 & 737,38 & 556,17 & 35,13 & 752,71 & $-15,34$ & 0,98 \\
\hline \multirow{7}{*}{ 15-Jan } & 0,2 & 1082,11 & 618,56 & 39,07 & 756,66 & 325,45 & 1,43 \\
\hline & 0,3 & 1025,50 & 595,15 & 37,59 & 755,18 & 270,33 & 1,36 \\
\hline & 0,4 & 960,59 & 575,41 & 36,34 & 753,93 & 206,66 & 1,27 \\
\hline & 0,5 & 901,68 & 550,67 & 34,78 & 752,37 & 149,31 & 1,20 \\
\hline & 0,6 & 843,57 & 517,66 & 32,70 & 750,28 & 93,28 & 1,12 \\
\hline & 0,7 & 798,33 & 507,37 & 32,05 & 749,63 & 48,70 & 1,06 \\
\hline & 0,8 & 758,18 & 488,98 & 30,89 & 748,47 & 9,71 & 1,01 \\
\hline \multirow{7}{*}{$1-F e v$} & 0,2 & 1033,91 & 572,48 & 37,04 & 754,62 & 279,29 & 1,37 \\
\hline & 0,3 & 983,01 & 546,12 & 35,33 & 752,92 & 230,09 & 1,31 \\
\hline & 0,4 & 914,26 & 517,43 & 33,48 & 751,06 & 163,20 & 1,22 \\
\hline & 0,5 & 867,99 & 485,85 & 31,43 & 749,02 & 118,97 & 1,16 \\
\hline & 0,6 & 815,68 & 469,18 & 30,35 & 747,94 & 67,74 & 1,09 \\
\hline & 0,7 & 772,22 & 446,29 & 28,87 & 746,46 & 25,76 & 1,03 \\
\hline & 0,8 & 727,39 & 418,46 & 27,07 & 744,66 & $-17,26$ & 0,98 \\
\hline \multirow{7}{*}{$15-\mathrm{Fev}$} & 0,2 & 1029,18 & 520,36 & 33,66 & 751,25 & 277,93 & 1,37 \\
\hline & 0,3 & 982,68 & 494,00 & 31,96 & 749,54 & 233,14 & 1,31 \\
\hline & 0,4 & 910,41 & 460,65 & 29,80 & 747,39 & 163,03 & 1,22 \\
\hline & 0,5 & 866,73 & 431,93 & 27,94 & 745,53 & 121,20 & 1,16 \\
\hline & 0,6 & 813,15 & 387,36 & 25,06 & 742,65 & 70,50 & 1,09 \\
\hline & 0,7 & 783,90 & 379,26 & 24,54 & 742,12 & 41,78 & 1,06 \\
\hline & 0,8 & 737,73 & 359,42 & 23,25 & 740,84 & $-3,10$ & 1,00 \\
\hline
\end{tabular}


Tabela 2B. Receitas brutas. composição de custos da irrigação, receitas líquidas e relação beneficio/custo para o feijão caupi, em cada época de semeadura, nível de manejo da irrigação e risco de $10 \%$. Parnaíba, Piauí.

\begin{tabular}{|c|c|c|c|c|c|c|c|}
\hline $\begin{array}{l}\text { Época de } \\
\text { Semeadura }\end{array}$ & $\mathrm{p}$ & $\begin{array}{c}\mathrm{RB}^{\mathrm{l}} \\
\left(\mathrm{US} \$ \mathrm{ha}^{-1}\right)\end{array}$ & $\begin{array}{c}E b \\
\left(k W h h^{-1}\right)\end{array}$ & $\begin{array}{c}\text { CE } \\
\left(\mathrm{US} \$ \mathrm{ha}^{-1}\right)\end{array}$ & $\begin{array}{c}\text { CT } \\
\left(\text { US\$ } \$ a^{-1}\right)\end{array}$ & $\begin{array}{c}\mathrm{RL} \\
\left(\mathrm{US} \$ \mathrm{ha}^{-1}\right)\end{array}$ & $\mathrm{B} / \mathrm{C}$ \\
\hline \multirow{7}{*}{ 1-Mar } & 0,2 & 1054,58 & 506,92 & 32,59 & 750,17 & 304,40 & 1,41 \\
\hline & 0,3 & 1007,10 & 484,14 & 31,13 & 748,71 & 258,39 & 1,35 \\
\hline & 0,4 & 933,20 & 451,56 & 29,03 & 746,62 & 186,59 & 1,25 \\
\hline & 0,5 & 887,48 & 413,35 & 26,57 & 744,16 & 143,32 & 1,19 \\
\hline & 0,6 & 835,65 & 395,41 & 25,42 & 743,01 & 92,65 & 1,12 \\
\hline & 0,7 & 793,07 & 367,84 & 23,65 & 741,23 & 51,84 & 1,07 \\
\hline & 0,8 & 753,96 & 342,31 & 22,01 & 739,59 & 14,37 & 1,02 \\
\hline \multirow{7}{*}{ 15-Mar } & 0,2 & 1046,56 & 525,02 & 33,75 & 751,34 & 295,22 & 1,39 \\
\hline & 0,3 & 999,67 & 494,75 & 31,81 & 749,39 & 250,28 & 1,33 \\
\hline & 0,4 & 923,83 & 464,60 & 29,87 & 747,45 & 176,38 & 1,24 \\
\hline & 0,5 & 877,32 & 438,52 & 28,19 & 745,78 & 131,55 & 1,18 \\
\hline & 0,6 & 821,77 & 421,09 & 27,07 & 744,66 & 77,11 & 1,10 \\
\hline & 0,7 & 779,81 & 386,78 & 24,87 & 742,45 & 37,35 & 1,05 \\
\hline & 0,8 & 732,24 & 359,80 & 23,13 & 740,72 & $-8,47$ & 0,99 \\
\hline \multirow{7}{*}{$1-\mathrm{Abr}$} & 0,2 & 1040,69 & 590,26 & 35,95 & 753,54 & 287,15 & 1,38 \\
\hline & 0,3 & 988,14 & 567,74 & 34,58 & 752,16 & 235,98 & 1,31 \\
\hline & 0,4 & 908,48 & 547,91 & 33,37 & 750,96 & 157,53 & 1,21 \\
\hline & 0,5 & 858,50 & 517,87 & 31,54 & 749,13 & 109,37 & 1,15 \\
\hline & 0,6 & 794,41 & 495,88 & 30,20 & 747,79 & 46,62 & 1,06 \\
\hline & 0,7 & 753,51 & 483,61 & 29,46 & 747,04 & 6,47 & 1,01 \\
\hline & 0,8 & 705,20 & 461,69 & 28,12 & 745,71 & $-40,50$ & 0,95 \\
\hline \multirow{7}{*}{ 15-Abr } & 0,2 & 1038,37 & 647,74 & 39,45 & 757,04 & 281,34 & 1,37 \\
\hline & 0,3 & 982,47 & 631,06 & 38,44 & 756,02 & 226,45 & 1,30 \\
\hline & 0,4 & 901,21 & 605,36 & 36,87 & 754,46 & 146,75 & 1,19 \\
\hline & 0,5 & 844,39 & 588,36 & 35,84 & 753,42 & 90,97 & 1,12 \\
\hline & 0,6 & 777,90 & 572,49 & 34,87 & 752,45 & 25,45 & 1,03 \\
\hline & 0,7 & 734,96 & 549,86 & 33,49 & 751,08 & $-16,11$ & 0,98 \\
\hline & 0,8 & 683,29 & 548,41 & 33,40 & 750,99 & $-67,70$ & 0,91 \\
\hline
\end{tabular}


Tabela 2B. Receitas brutas, composição de custos da irrigação, receitas líquidas e relação benefício/custo para o feijão caupi, em cada época de semeadura, nivel de manejo da irrigação e risco de $10 \%$. Parnaiba. Piaui.

\begin{tabular}{|c|c|c|c|c|c|c|c|}
\hline $\begin{array}{l}\text { Época de } \\
\text { Semeadura }\end{array}$ & $\mathrm{p}$ & $\begin{array}{c}\mathrm{RB}^{\mathrm{I}} \\
\left(\mathrm{US} \$ \mathrm{ha}^{-1}\right)\end{array}$ & $\begin{array}{c}\mathrm{Eb} \\
\left(\mathrm{kWh} \mathrm{ha} \mathrm{h}^{-1}\right)\end{array}$ & $\begin{array}{c}\text { CE } \\
\left(\mathrm{US} \$ \mathrm{ha}^{-1}\right)\end{array}$ & $\begin{array}{c}\mathrm{CT} \\
\left(\mathrm{US} \$ \mathrm{ha}^{-1}\right)\end{array}$ & $\begin{array}{c}\mathrm{RL} \\
\left(\mathrm{US} \$ \mathrm{ha}^{-1}\right)\end{array}$ & $\mathrm{B} / \mathrm{C}$ \\
\hline \multirow{7}{*}{ 1-Mai } & 0,2 & 835,32 & 725,39 & 42,63 & 760,22 & 75,10 & 1,10 \\
\hline & 0,3 & 788,36 & 707,85 & 41,60 & 759,19 & 29,18 & 1,04 \\
\hline & 0,4 & 720,95 & 691,57 & 40,65 & 758,23 & $-37,29$ & 0,95 \\
\hline & 0,5 & 673,64 & 684,38 & 40,22 & 757,81 & $-84,17$ & 0,89 \\
\hline & 0,6 & 624,85 & 685,53 & 40,29 & 757,88 & $-133,03$ & 0,82 \\
\hline & 0,7 & 581,97 & 672,37 & 39,52 & 757,10 & $-175,13$ & 0,77 \\
\hline & 0,8 & 541,91 & 674,80 & 39,66 & 757,25 & $-215,33$ & 0,72 \\
\hline \multirow{7}{*}{ 15-Mai } & 0,2 & 836,78 & 758,21 & 44,56 & 762,15 & 74,63 & 1,10 \\
\hline & 0,3 & 789,52 & 749,72 & 44,06 & 761,65 & 27,87 & 1,04 \\
\hline & 0,4 & 723,72 & 739,99 & 43,49 & 761,08 & $-37,36$ & 0,95 \\
\hline & 0,5 & 672,81 & 729,31 & 42,86 & 760,45 & $-87,64$ & 0,88 \\
\hline & 0,6 & 624,56 & 716,02 & 42,08 & 759,67 & $-135,10$ & 0,82 \\
\hline & 0,7 & 582,10 & 718,63 & 42,24 & 759,82 & $-177,72$ & 0,77 \\
\hline & 0,8 & 541,10 & 703,74 & 41,36 & 758,95 & $-217,84$ & 0,71 \\
\hline \multirow{7}{*}{ 1-Jun } & 0,2 & 936,25 & 805,47 & 50,36 & 767,95 & 168,30 & 1,22 \\
\hline & 0,3 & 881,29 & 795,86 & 49,76 & 767,35 & 113,94 & 1,15 \\
\hline & 0,4 & 812,38 & 794,11 & 49,65 & 767,24 & 45,14 & 1,06 \\
\hline & 0,5 & 750,42 & 784,85 & 49,08 & 766,66 & $-16,24$ & 0,98 \\
\hline & 0,6 & 699,45 & 778,61 & 48,68 & 766,27 & $-66,82$ & 0,91 \\
\hline & 0,7 & 642,98 & 770,19 & 48,16 & 765,74 & $-122,77$ & 0,84 \\
\hline & 0,8 & 601,11 & 769,65 & 48,12 & 765,71 & $-164,60$ & 0,79 \\
\hline \multirow{7}{*}{ 15-Jun } & 0,2 & 946,70 & 875,83 & 54,76 & 772,35 & 174,36 & 1,23 \\
\hline & 0,3 & 882,12 & 868,16 & 54,28 & 771,87 & 110,25 & 1,14 \\
\hline & 0,4 & 827,55 & 862,72 & 53,94 & 771,53 & 56,02 & 1,07 \\
\hline & 0,5 & 751,31 & 853,19 & 53,35 & 770,93 & $-19,63$ & 0,97 \\
\hline & 0,6 & 713,24 & 856,13 & 53,53 & 771,12 & $-57,87$ & 0,92 \\
\hline & 0,7 & 646,49 & 850,09 & 53,15 & 770,74 & $-124,25$ & 0,84 \\
\hline & 0,8 & 609,59 & 845,90 & 52,89 & 770,48 & $-160,89$ & 0,79 \\
\hline
\end{tabular}


Tabela 2B. Receitas brutas, composição de custos da irrigação, receitas líquidas e relação benefício/custo para o feijão caupi, em cada época de semeadura, nivel de manejo da irrigação e risco de $10 \%$. Parnaiba, Piaú.

\begin{tabular}{|c|c|c|c|c|c|c|c|}
\hline $\begin{array}{l}\text { Época de } \\
\text { Semeadura }\end{array}$ & $\mathrm{p}$ & $\begin{array}{c}\mathrm{RB}^{1} \\
\left(\mathrm{US} \$ \mathrm{ha}^{-1}\right)\end{array}$ & $\begin{array}{c}\mathrm{Eb} \\
\left(\mathrm{kWh} \mathrm{ha} \mathrm{h}^{-1}\right)\end{array}$ & $\begin{array}{c}\mathrm{CE} \\
\left(\mathrm{US} \$ \mathrm{ha}^{-1}\right)\end{array}$ & $\begin{array}{c}\text { CT } \\
\left(\mathrm{US} \$ \mathrm{ha}^{-1}\right)\end{array}$ & $\begin{array}{c}\mathrm{RL} \\
\left(\mathrm{US} \$ \mathrm{ha}^{-1}\right)\end{array}$ & $\mathrm{B} / \mathrm{C}$ \\
\hline \multirow{7}{*}{ 1-Jul } & 0,2 & 964,96 & 949,15 & 60,50 & 778,08 & 186,87 & 1,24 \\
\hline & 0,3 & 891,24 & 942,37 & 60,07 & 777,65 & 113,59 & 1,15 \\
\hline & 0,4 & 844,95 & 937,10 & 59,73 & 777,32 & 67,63 & 1,09 \\
\hline & 0,5 & 765,13 & 943,11 & 60,11 & 777,70 & $-12,56$ & 0,98 \\
\hline & 0,6 & 723,14 & 932,14 & 59,41 & 777,00 & $-53,86$ & 0,93 \\
\hline & 0,7 & 663,68 & 929,46 & 59,24 & 776,83 & $-113,15$ & 0,85 \\
\hline & 0,8 & 617,61 & 925,46 & 58,99 & 776,57 & $-158,96$ & 0,80 \\
\hline \multirow{7}{*}{ 15-Jul } & 0,2 & 976,29 & 1027,68 & 65,50 & 783,09 & 193,20 & 1,25 \\
\hline & 0,3 & 895,69 & 1017,21 & 64,84 & 782,42 & 113,26 & 1,14 \\
\hline & 0,4 & 856,86 & 1020,48 & 65,05 & 782,63 & 74,23 & 1,09 \\
\hline & 0,5 & 782,24 & 1018,69 & 64,93 & 782,52 & $-0,27$ & 1,00 \\
\hline & 0,6 & 725,23 & 1016,90 & 64,82 & 782,40 & $-57,17$ & 0,93 \\
\hline & 0,7 & 681,54 & 1011,29 & 64,46 & 782,04 & $-100,51$ & 0,87 \\
\hline & 0,8 & 617,26 & 1010,14 & 64,39 & 781,97 & $-164,71$ & 0,79 \\
\hline \multirow{7}{*}{ 1-Ago } & 0,2 & 932,78 & 1110,25 & 70,87 & 788,45 & 144,33 & 1,18 \\
\hline & 0,3 & 851,67 & 1105,91 & 70,59 & 788,18 & 63,50 & 1,08 \\
\hline & 0,4 & 813,28 & 1101,25 & 70,29 & 787,88 & 25,40 & 1,03 \\
\hline & 0,5 & 762,25 & 1103,35 & 70,43 & 788,01 & $-25,76$ & 0,97 \\
\hline & 0,6 & 686,25 & 1095,38 & 69,92 & 787,50 & $-101,25$ & 0,87 \\
\hline & 0,7 & 656,13 & 1090,16 & 69,59 & 787,17 & $-131,04$ & 0,83 \\
\hline & 0,8 & 599,22 & 1094,81 & 69,88 & 787,47 & $-188,24$ & 0,76 \\
\hline \multirow{7}{*}{ 15-Ago } & 0,2 & 940,92 & 1160,27 & 74,06 & 791,65 & 149,27 & 1,19 \\
\hline & 0,3 & 858,49 & 1159,38 & 74,00 & 791,59 & 66,90 & 1,08 \\
\hline & 0,4 & 817,18 & 1151,71 & 73,51 & 791,10 & 26,08 & 1,03 \\
\hline & 0,5 & 776,04 & 1146,51 & 73,18 & 790,77 & $-14,73$ & 0,98 \\
\hline & 0,6 & 692,48 & 1149,03 & 73,34 & 790,93 & $-98,45$ & 0,88 \\
\hline & 0,7 & 656,37 & 1147,99 & 73,28 & 790,86 & $-134,49$ & 0,83 \\
\hline & 0,8 & 617,51 & 1148,89 & 73,33 & 790,92 & $-173,41$ & 0,78 \\
\hline
\end{tabular}


Tabela 2B. Receitas brutas, composição de custos da irrigação, receitas líquidas e relação benefício/custo para o feijão caupi, em cada época de semeadura, nível de manejo da irrigação e risco de $10 \%$. Parnaiba, Piauí.

\begin{tabular}{|c|c|c|c|c|c|c|c|}
\hline $\begin{array}{l}\text { Época de } \\
\text { Semeadura }\end{array}$ & $p$ & $\begin{array}{c}\mathrm{RB}^{1} \\
\left(\mathrm{US} \$ \mathrm{ha}^{-1}\right)\end{array}$ & $\begin{array}{c}\text { Eb } \\
\left(\mathrm{kWh} \mathrm{ha}{ }^{-1}\right)\end{array}$ & $\begin{array}{c}\text { CE } \\
\left(\mathrm{US} \$ \mathrm{ha}^{-1}\right)\end{array}$ & $\begin{array}{c}\text { CT } \\
\left(\mathrm{US} \$ \mathrm{ha}^{-1}\right)\end{array}$ & $\begin{array}{c}R L \\
\left(U S \$ h a^{-1}\right)\end{array}$ & $\mathrm{B} / \mathrm{C}$ \\
\hline \multirow{7}{*}{ 1-Set } & 0,2 & 958,97 & 1196,33 & 72,83 & 790,41 & 168,56 & 1,21 \\
\hline & 0,3 & 875,25 & 1194,67 & 72,73 & 790,31 & 84,93 & 1,11 \\
\hline & 0,4 & 829,59 & 1189,25 & 72,40 & 789,98 & 39,61 & 1,05 \\
\hline & 0,5 & 796,32 & 1184,68 & 72,12 & 789,70 & 6,61 & 1,01 \\
\hline & 0,6 & 707,90 & 1189,50 & 72,41 & 790,00 & $-82,10$ & 0,90 \\
\hline & 0,7 & 665,25 & 1187,18 & 72,27 & 789,86 & $-124,61$ & 0,84 \\
\hline & 0,8 & 645,61 & 1184,49 & 72,11 & 789,69 & $-144,08$ & 0,82 \\
\hline \multirow{7}{*}{$15-$ Set } & 0,2 & 960,20 & 1192,53 & 72,60 & 790,18 & 170,02 & 1,22 \\
\hline & 0,3 & 874,74 & 1189,72 & 72,43 & 790,01 & 84,73 & 1,11 \\
\hline & 0,4 & 828,12 & 1183,32 & 72,04 & 789,62 & 38,50 & 1,05 \\
\hline & 0,5 & 796,11 & 1182,48 & 71,98 & 789,57 & 6,54 & 1,01 \\
\hline & 0,6 & 709,08 & 1184,56 & 72,11 & 789,70 & $-80,62$ & 0,90 \\
\hline & 0,7 & 666,12 & 1185,44 & 72,16 & 789,75 & $-123,63$ & 0,84 \\
\hline & 0,8 & 642,63 & 1172,25 & 71,36 & 788,95 & $-146,31$ & 0,81 \\
\hline \multirow{7}{*}{ 1-Out } & 0,2 & 987,16 & 1188,94 & 74,16 & 791,75 & 195,41 & 1,25 \\
\hline & 0,3 & 904,43 & 1188,62 & 74,14 & 791,73 & 112,70 & 1,14 \\
\hline & 0,4 & 856,81 & 1182,97 & 73,79 & 791,37 & 65,44 & 1,08 \\
\hline & 0,5 & 819,82 & 1179,83 & 73,59 & 791,18 & 28,64 & 1,04 \\
\hline & 0,6 & 730,09 & 1182,15 & 73,74 & 791,32 & $-61,23$ & 0,92 \\
\hline & 0,7 & 685,62 & 1176,77 & 73,40 & 790,99 & $-105,37$ & 0,87 \\
\hline & 0,8 & 663,93 & 1167,46 & 72,82 & 790,41 & $-126,47$ & 0,84 \\
\hline \multirow{7}{*}{ 15-Out } & 0,2 & 985,60 & 1164,65 & 72,65 & 790,23 & 195,37 & 1,25 \\
\hline & 0,3 & 898,31 & 1158,09 & 72,24 & 789,82 & 108,48 & 1,14 \\
\hline & 0,4 & 855,85 & 1156,44 & 72,14 & 789,72 & 66,13 & 1,08 \\
\hline & 0,5 & 817,03 & 1149,34 & 71,69 & 789,28 & 27,75 & 1,04 \\
\hline & 0,6 & 725,49 & 1151,06 & 71,80 & 789,38 & $-63,89$ & 0,92 \\
\hline & 0,7 & 687,71 & 1144,44 & 71,39 & 788,97 & $-101,26$ & 0,87 \\
\hline & 0,8 & 652,40 & 1144,38 & 71,38 & 788,97 & $-136,57$ & 0,83 \\
\hline
\end{tabular}


Tabela 2B. Receitas brutas, composição de custos da irrigação, receitas líquidas e relação benefício/custo para o feijão caupi, em cada época de semeadura, nível de manejo da irrigação e risco de $10 \%$. Parnaíba, Piauí.

\begin{tabular}{|c|c|c|c|c|c|c|c|}
\hline $\begin{array}{l}\text { Época de } \\
\text { Semeadura }\end{array}$ & $\mathrm{p}$ & $\begin{array}{c}\mathrm{RB}^{1} \\
\left(\mathrm{US} \$ \mathrm{ha}^{-1}\right)\end{array}$ & $\begin{array}{c}\mathrm{Eb} \\
\left(\mathrm{kWh} \mathrm{ha}^{-1}\right)\end{array}$ & $\begin{array}{c}\mathrm{CE} \\
\left(\mathrm{US} \$ \mathrm{ha}^{-1}\right)\end{array}$ & $\begin{array}{c}\text { CT } \\
\left(\mathrm{US} \$ \mathrm{ha}^{-1}\right)\end{array}$ & $\begin{array}{c}\mathrm{RL} \\
\left(\mathrm{US} \$ \mathrm{ha}^{-1}\right)\end{array}$ & $\mathrm{B} / \mathrm{C}$ \\
\hline \multirow{7}{*}{ 1-Nov } & 0,2 & 1141,93 & 1071,11 & 67,36 & 784,95 & 356,98 & 1,45 \\
\hline & 0,3 & 1051,99 & 1068,89 & 67,22 & 784,81 & 267,18 & 1,34 \\
\hline & 0,4 & 1001,42 & 1057,92 & 66,53 & 784,12 & 217,30 & 1,28 \\
\hline & 0,5 & 930,71 & 1047,74 & 65,89 & 783,48 & 147,23 & 1,19 \\
\hline & 0,6 & 850,22 & 1052,68 & 66,20 & 783,79 & 66,43 & 1,08 \\
\hline & 0,7 & 804,59 & 1046,96 & 65,84 & 783,43 & 21,17 & 1,03 \\
\hline & 0,8 & 739,54 & 1043,37 & 65,62 & 783,20 & $-43,66$ & 0,94 \\
\hline \multirow{7}{*}{ 15-Nov } & 0,2 & 1129,95 & 965,26 & 60,70 & 778,29 & 351,67 & 1,45 \\
\hline & 0,3 & 1044,84 & 953,90 & 59,99 & 777,57 & 267,26 & 1,34 \\
\hline & 0,4 & 995,45 & 948,83 & 59,67 & 777,26 & 218,19 & 1,28 \\
\hline & 0,5 & 915,20 & 942,64 & 59,28 & 776,87 & 138,33 & 1,18 \\
\hline & 0,6 & 850,15 & 927,91 & 58,36 & 775,94 & 74,21 & 1,10 \\
\hline & 0,7 & 802,48 & 927,08 & 58,30 & 775,89 & 26,59 & 1,03 \\
\hline & 0,8 & 736,96 & 916,53 & 57,64 & 775,22 & $-38,27$ & 0,95 \\
\hline \multirow{7}{*}{ 1-Dez } & 0,2 & 1156,75 & 884,40 & 55,27 & 772,85 & 383,90 & 1,50 \\
\hline & 0,3 & 1079,26 & 870,79 & 54,42 & 772,00 & 307,25 & 1,40 \\
\hline & 0,4 & 1020,93 & 859,39 & 53,71 & 771,29 & 249,64 & 1,32 \\
\hline & 0,5 & 939,40 & 845,43 & 52,83 & 770,42 & 168,98 & 1,22 \\
\hline & 0,6 & 876,15 & 828,90 & 51,80 & 769,39 & 106,76 & 1,14 \\
\hline & 0,7 & 820,81 & 825,85 & 51,61 & 769,20 & 51,62 & 1,07 \\
\hline & 0,8 & 764,21 & 820,82 & 51,30 & 768,88 & $-4,67$ & 0,99 \\
\hline \multirow{7}{*}{ 15-Dez } & 0,2 & 1150,39 & 785,26 & 49,07 & 766,66 & 383,73 & 1,50 \\
\hline & 0,3 & 1076,05 & 762,90 & 47,68 & 765,26 & 310,78 & 1,41 \\
\hline & 0,4 & 1016,61 & 749,55 & 46,84 & 764,43 & 252,19 & 1,33 \\
\hline & 0,5 & 933,48 & 731,17 & 45,69 & 763,28 & 170,20 & 1,22 \\
\hline & 0,6 & 878,76 & 716,83 & 44,80 & 762,38 & 116,38 & 1,15 \\
\hline & 0,7 & 817,99 & 701,54 & 43,84 & 761,43 & 56,56 & 1,07 \\
\hline & 0,8 & 766,70 & 695,31 & 43,45 & 761,04 & 5,67 & 1,01 \\
\hline
\end{tabular}

${ }^{1} \mathrm{RB}$ - receita bruta: $\mathrm{Eb}$ - energia requerida para o bombeamento: $\mathrm{CE}$ - custo de energia elétrica: $\mathrm{CT}$ - custo total de produção: $\mathrm{RL}$ - receita líquida e B/C - relação benefício/custo. 
Tabela 3B. Receitas brutas, composição de custos da irrigação, receitas líquidas e relação beneficio/custo para o feijão caupi, em cada época de semeadura, nivel de manejo da irrigação e risco de $15 \%$. Parnaíba, Piauí.

\begin{tabular}{|c|c|c|c|c|c|c|c|}
\hline $\begin{array}{l}\text { Época de } \\
\text { Semeadura }\end{array}$ & $\mathrm{p}$ & $\begin{array}{c}\mathrm{RB}^{\mathrm{l}} \\
\left(\mathrm{US} \$ \mathrm{ha}^{-1}\right)\end{array}$ & $\begin{array}{c}E b \\
\left(\mathrm{kWh} \mathrm{ha}{ }^{-1}\right)\end{array}$ & $\begin{array}{c}\text { CE } \\
\left(\mathrm{US} \$ \mathrm{ha}^{-1}\right)\end{array}$ & $\begin{array}{c}\text { CT } \\
\left(\text { US } \$ h^{-1}\right)^{-1}\end{array}$ & $\begin{array}{c}\mathrm{RL} \\
\left(\mathrm{US} \$ \mathrm{ha}^{-1}\right)\end{array}$ & $\mathrm{B} / \mathrm{C}$ \\
\hline \multirow{7}{*}{ 1-Jan } & 0,2 & 1100,07 & 664,93 & 41,02 & 758,61 & 341,47 & 1,45 \\
\hline & 0,3 & 1036,85 & 642,40 & 39,63 & 757,22 & 279,63 & 1,37 \\
\hline & 0,4 & 976,89 & 620,22 & 38,26 & 755,85 & 221,04 & 1,29 \\
\hline & 0,5 & 913,93 & 595,78 & 36,76 & 754,34 & 159,59 & 1,21 \\
\hline & 0,6 & 862,38 & 569,81 & 35,15 & 752,74 & 109,64 & 1,15 \\
\hline & 0,7 & 807,70 & 551,71 & 34,04 & 751,62 & 56,07 & 1,07 \\
\hline & 0,8 & 765,51 & 531,02 & 32,76 & 750,35 & 15,16 & 1,02 \\
\hline \multirow{7}{*}{ 15-Jan } & 0,2 & 1111,22 & 603,13 & 37,21 & 754,80 & 356,42 & 1,47 \\
\hline & 0,3 & 1053,74 & 577,51 & 35,63 & 753,21 & 300,53 & 1,40 \\
\hline & 0,4 & 989,10 & 555,29 & 34,26 & 751,84 & 237,25 & 1,32 \\
\hline & 0,5 & 929,86 & 528,72 & 32,62 & 750,20 & 179,66 & 1,24 \\
\hline & 0,6 & 872,59 & 495,75 & 30,59 & 748,17 & 124,41 & 1,17 \\
\hline & 0,7 & 826,58 & 482,35 & 29,76 & 747,34 & 79,24 & 1,11 \\
\hline & 0,8 & 786,85 & 464,26 & 28,64 & 746,23 & 40,62 & 1,05 \\
\hline \multirow{7}{*}{$1-\mathrm{Fev}$} & 0,2 & 1063,72 & 555,86 & 34,82 & 752,40 & 311,31 & 1,41 \\
\hline & 0,3 & 1011,94 & 527,02 & 33,01 & 750,60 & 261,34 & 1,35 \\
\hline & 0,4 & 944,03 & 496,08 & 31,07 & 748,66 & 195,37 & 1,26 \\
\hline & 0,5 & 897,04 & 465,22 & 29,14 & 746,72 & 150,32 & 1,20 \\
\hline & 0,6 & 845,37 & 446,26 & 27,95 & 745,54 & 99,84 & 1,13 \\
\hline & 0,7 & 802,17 & 422,86 & 26,49 & 744,07 & 58,10 & 1,08 \\
\hline & 0,8 & 758,27 & 394,61 & 24,72 & 742,30 & 15,96 & 1,02 \\
\hline \multirow{7}{*}{$15-\mathrm{Fev}$} & 0,2 & 1058,98 & 504,88 & 31,62 & 749,21 & 309,77 & 1,41 \\
\hline & 0,3 & 1011,80 & 477,19 & 29,89 & 747,47 & 264,32 & 1,35 \\
\hline & 0,4 & 940,32 & 441,50 & 27,65 & 745,24 & 195,08 & 1,26 \\
\hline & 0,5 & 896,25 & 411,96 & 25,80 & 743,39 & 152,86 & 1,21 \\
\hline & 0,6 & 843,72 & 368,72 & 23,10 & 740,68 & 103,04 & 1,14 \\
\hline & 0,7 & 814,00 & 358,93 & 22,48 & 740,07 & 73,93 & 1,10 \\
\hline & 0,8 & 768,53 & 338,32 & 21,19 & 738,78 & 29,75 & 1,04 \\
\hline
\end{tabular}


Tabela 3B. Receitas brutas, composição de custos da irrigação, receitas líquidas e relação beneficio/custo para o feijão caupi, em cada época de semeadura, nível de manejo da irrigação e risco de $15 \%$. Parnaíba, Piauí.

\begin{tabular}{|c|c|c|c|c|c|c|c|}
\hline $\begin{array}{l}\text { Época de } \\
\text { Semeadura }\end{array}$ & $\mathrm{p}$ & $\begin{array}{c}\mathrm{RB}^{\mathrm{l}} \\
\left(\mathrm{US} \$ \mathrm{ha}^{-1}\right)\end{array}$ & $\begin{array}{c}E b \\
\left(\mathrm{kWh} \mathrm{ha}^{-1}\right)\end{array}$ & $\begin{array}{c}\text { CE } \\
\left(\mathrm{US} \$ \mathrm{ha}^{-1}\right)\end{array}$ & $\begin{array}{c}\mathrm{CT} \\
\left(\mathrm{US} \$ \mathrm{ha}^{-1}\right)\end{array}$ & $\begin{array}{c}\mathrm{RL} \\
\left(\mathrm{US} \$ \mathrm{ha}^{-1}\right)\end{array}$ & $\mathrm{B} / \mathrm{C}$ \\
\hline \multirow{7}{*}{ 1-Mar } & 0,2 & 1086,19 & 490,55 & 30,56 & 748,14 & 338,04 & 1,45 \\
\hline & 0,3 & 1038,28 & 465,09 & 28,97 & 746,56 & 291,72 & 1,39 \\
\hline & 0,4 & 964,86 & 431,03 & 26,85 & 744,44 & 220,42 & 1,30 \\
\hline & 0,5 & 919,51 & 393,14 & 24,49 & 742,08 & 177,44 & 1,24 \\
\hline & 0,6 & 867,94 & 373,28 & 23,25 & 740,84 & 127,10 & 1,17 \\
\hline & 0,7 & 826,09 & 344,44 & 21,46 & 739,04 & 87,05 & 1,12 \\
\hline & 0,8 & 787,27 & 317,75 & 19,79 & 737,38 & 49,89 & 1,07 \\
\hline \multirow{7}{*}{ 15-Mar } & 0,2 & 1077,79 & 509,14 & 31,72 & 749,30 & 328,49 & 1,44 \\
\hline & 0,3 & 1030,61 & 477,64 & 29,76 & 747,34 & 283,27 & 1,38 \\
\hline & 0,4 & 954,53 & 445,76 & 27,77 & 745,35 & 209,18 & 1,28 \\
\hline & 0,5 & 907,83 & 417,71 & 26,02 & 743,61 & 164,23 & 1,22 \\
\hline & 0,6 & 852,43 & 398,34 & 24,82 & 742,40 & 110,03 & 1,15 \\
\hline & 0,7 & 810,85 & 364,51 & 22,71 & 740,29 & 70,56 & 1,10 \\
\hline & 0,8 & 764,37 & 337,25 & 21,01 & 738,59 & 25,77 & 1,03 \\
\hline \multirow{7}{*}{$1-A b r$} & 0,2 & 1071,55 & 575,16 & 34,04 & 751,63 & 319,93 & 1,43 \\
\hline & 0,3 & 1018,31 & 551,16 & 32,62 & 750,21 & 268,10 & 1,36 \\
\hline & 0,4 & 938,56 & 529,43 & 31,34 & 748,92 & 189,64 & 1,25 \\
\hline & 0,5 & 888,44 & 499,40 & 29,56 & 747,14 & 141,29 & 1,19 \\
\hline & 0,6 & 824,18 & 475,02 & 28,12 & 745,70 & 78,48 & 1,11 \\
\hline & 0,7 & 783,41 & 461,16 & 27,30 & 744,88 & 38,53 & 1,05 \\
\hline & 0,8 & 735,24 & 437,81 & 25,91 & 743,50 & $-8,26$ & 0,99 \\
\hline \multirow{7}{*}{$15-\mathrm{Abr}$} & 0,2 & 1068,91 & 633,71 & 37,51 & 755,09 & 313,81 & 1,42 \\
\hline & 0,3 & 1012,11 & 614,38 & 36,37 & 753,95 & 258,16 & 1,34 \\
\hline & 0,4 & 930,54 & 588,60 & 34,84 & 752,42 & 178,11 & 1,24 \\
\hline & 0,5 & 873,48 & 569,61 & 33,72 & 751,30 & 122,18 & 1,16 \\
\hline & 0,6 & 806,79 & 551,13 & 32,62 & 750,21 & 56,58 & 1,08 \\
\hline & 0,7 & 763,20 & 526,80 & 31,18 & 748,77 & 14,43 & 1,02 \\
\hline & 0,8 & 711,34 & 523,59 & 30,99 & 748,58 & $-37,23$ & 0,95 \\
\hline
\end{tabular}


Tabela 3B. Receitas brutas, composição de custos da irrigação, receitas líquidas e relação benefício/custo para o feijão caupi, em cada época de semeadura, nível de manejo da irrigação e risco de $15 \%$. Parnaíba, Piauí.

\begin{tabular}{|c|c|c|c|c|c|c|c|}
\hline $\begin{array}{l}\text { Época de } \\
\text { Semeadura }\end{array}$ & $\mathrm{p}$ & $\begin{array}{c}\mathrm{RB}^{\mathrm{l}} \\
\left(\mathrm{US} \$ \mathrm{ha}^{-1}\right)\end{array}$ & $\begin{array}{c}\mathrm{Eb} \\
\left(\mathrm{kWh} \mathrm{ha}^{-1}\right)\end{array}$ & $\begin{array}{c}C E \\
\left(\mathrm{US} \$ \mathrm{ha}^{-1}\right)\end{array}$ & $\begin{array}{c}\text { CT } \\
\left(\mathrm{US} \$ \mathrm{ha}^{-1}\right)\end{array}$ & $\begin{array}{c}\mathrm{RL} \\
\left(\mathrm{US} \$ \mathrm{ha}^{-1}\right)\end{array}$ & $\mathrm{B} / \mathrm{C}$ \\
\hline \multirow{7}{*}{ 1-Mai } & 0,2 & 870,66 & 713,34 & 41,07 & 758,66 & 112,01 & 1,15 \\
\hline & 0,3 & 822,18 & 695,06 & 40,02 & 757,60 & 64,57 & 1,09 \\
\hline & 0,4 & 753,36 & 676,81 & 38,97 & 756,55 & $-3,19$ & 1,00 \\
\hline & 0,5 & 704,35 & 668,30 & 38,48 & 756,06 & $-51,71$ & 0,93 \\
\hline & 0,6 & 654,28 & 666,93 & 38,40 & 755,98 & $-101,71$ & 0,87 \\
\hline & 0,7 & 610,33 & 650,74 & 37,47 & 755,05 & $-144,73$ & 0,81 \\
\hline & 0,8 & 568,59 & 651,12 & 37,49 & 755,07 & $-186,49$ & 0,75 \\
\hline \multirow{7}{*}{ 15-Mai } & 0,2 & 872,38 & 746,56 & 42,98 & 760,57 & 111,81 & 1,15 \\
\hline & 0,3 & 823,06 & 735,99 & 42,38 & 759,96 & 63,10 & 1,08 \\
\hline & 0,4 & 756,56 & 725,52 & 41,77 & 759,36 & $-2,79$ & 1,00 \\
\hline & 0,5 & 703,32 & 713,05 & 41,05 & 758,64 & $-55,32$ & 0,93 \\
\hline & 0,6 & 653,79 & 698,98 & 40,24 & 757,83 & $-104,04$ & 0,86 \\
\hline & 0,7 & 609,89 & 699,82 & 40,29 & 757,88 & $-147,98$ & 0,80 \\
\hline & 0,8 & 567,35 & 684,55 & 39,41 & 757,00 & $-189,64$ & 0,75 \\
\hline \multirow{7}{*}{ 1-Jun } & 0,2 & 969,08 & 796,56 & 48,65 & 766,23 & 202,85 & 1,26 \\
\hline & 0,3 & 911,83 & 786,28 & 48,02 & 765,61 & 146,22 & 1,19 \\
\hline & 0,4 & 842,87 & 782,88 & 47,81 & 765,40 & 77,47 & 1,10 \\
\hline & 0,5 & 777,85 & 772,60 & 47,19 & 764,77 & 13,08 & 1,02 \\
\hline & 0,6 & 726,97 & 765,85 & 46,77 & 764,36 & $-37,38$ & 0,95 \\
\hline & 0,7 & 668,18 & 756,03 & 46,17 & 763,76 & $-95,58$ & 0,87 \\
\hline & 0,8 & 625,84 & 753,84 & 46,04 & 763,62 & $-137,78$ & 0,82 \\
\hline \multirow{7}{*}{ 15-Jun } & 0,2 & 979,95 & 867,58 & 52,99 & 770,57 & 209,38 & 1,27 \\
\hline & 0,3 & 912,83 & 859,52 & 52,49 & 770,08 & 142,75 & 1,19 \\
\hline & 0,4 & 858,04 & 852,62 & 52,07 & 769,66 & 88,39 & 1,11 \\
\hline & 0,5 & 778,80 & 843,47 & 51,51 & 769,10 & 9,70 & 1,01 \\
\hline & 0,6 & 740,12 & 844,30 & 51,56 & 769,15 & $-29,03$ & 0,96 \\
\hline & 0,7 & 672,33 & 837,19 & 51,13 & 768,71 & $-96,38$ & 0,87 \\
\hline & 0,8 & 633,76 & 832,67 & 50,85 & 768,44 & $-134,68$ & 0,82 \\
\hline
\end{tabular}


Tabela 3B. Receitas brutas, composição de custos da irrigação, receitas líquidas e relação benefício/custo para o feijão caupi, em cada época de semeadura, nível de manejo da irrigação e risco de $15 \%$. Parnaiba, Piauí.

\begin{tabular}{|c|c|c|c|c|c|c|c|}
\hline $\begin{array}{l}\text { Época de } \\
\text { Semeadura }\end{array}$ & $\mathrm{p}$ & $\begin{array}{c}\mathrm{RB}^{\mathrm{l}} \\
\left(\mathrm{US} \$ \mathrm{ha}^{-1}\right)\end{array}$ & $\begin{array}{c}\mathrm{Eb} \\
\left(\mathrm{kWh} \mathrm{ha}^{-1}\right)\end{array}$ & $\begin{array}{c}\mathrm{CE} \\
\left(\mathrm{US} \$ \mathrm{ha}^{-1}\right)\end{array}$ & $\begin{array}{c}\mathrm{CT} \\
\left(\mathrm{US} \$ \mathrm{ha}^{-1}\right)\end{array}$ & $\begin{array}{c}\text { RL } \\
\left(\mathrm{US} \$ \mathrm{ha}^{-1}\right)\end{array}$ & $\mathrm{B} / \mathrm{C}$ \\
\hline \multirow{7}{*}{$1-\mathrm{Jul}$} & 0,2 & 995,04 & 942,40 & 58,94 & 776,52 & 218,52 & 1,28 \\
\hline & 0,3 & 918,84 & 934,69 & 58,45 & 776,04 & 142,80 & 1,18 \\
\hline & 0,4 & 872,46 & 928,97 & 58,10 & 775,68 & 96,78 & 1,12 \\
\hline & 0,5 & 790,88 & 932,68 & 58,33 & 775,91 & 14,97 & 1,02 \\
\hline & 0,6 & 746,76 & 922,16 & 57,67 & 775,26 & $-28,49$ & 0,96 \\
\hline & 0,7 & 687,12 & 918,35 & 57,43 & 775,02 & $-87,90$ & 0,89 \\
\hline & 0,8 & 639,15 & 913,78 & 57,15 & 774,73 & $-135,58$ & 0,82 \\
\hline \multirow{7}{*}{ 15-Jul } & 0,2 & 1006,66 & 1020,83 & 63,84 & 781,43 & 225,23 & 1,29 \\
\hline & 0,3 & 923,54 & 1010,38 & 63,19 & 780,77 & 142,76 & 1,18 \\
\hline & 0,4 & 883,79 & 1012,55 & 63,32 & 780,91 & 102,88 & 1,13 \\
\hline & 0,5 & 809,22 & 1010,07 & 63,17 & 780,75 & 28,46 & 1,04 \\
\hline & 0,6 & 748,85 & 1007,68 & 63,02 & 780,60 & $-31,75$ & 0,96 \\
\hline & 0,7 & 705,08 & 1002,00 & 62,66 & 780,25 & $-75,17$ & 0,90 \\
\hline & 0,8 & 639,40 & 1000,57 & 62,58 & 780,16 & $-140,76$ & 0,82 \\
\hline \multirow{7}{*}{ 1-Ago } & 0,2 & 964,44 & 1106,62 & 69,50 & 787,09 & 177,35 & 1,23 \\
\hline & 0,3 & 880,71 & 1101,54 & 69,18 & 786,77 & 93,94 & 1,12 \\
\hline & 0,4 & 841,14 & 1097,25 & 68,91 & 786,50 & 54,64 & 1,07 \\
\hline & 0,5 & 789,98 & 1098,19 & 68,97 & 786,56 & 3,43 & 1,00 \\
\hline & 0,6 & 710,75 & 1090,59 & 68,50 & 786,08 & $-75,33$ & 0,90 \\
\hline & 0,7 & 679,31 & 1085,77 & 68,19 & 785,78 & $-106,47$ & 0,86 \\
\hline & 0,8 & 622,75 & 1088,14 & 68,34 & 785,93 & $-163,18$ & 0,79 \\
\hline \multirow{7}{*}{ 15-Ago } & 0,2 & 972,76 & 1156,73 & 72,65 & 790,23 & 182,53 & 1,23 \\
\hline & 0,3 & 888,03 & 1154,96 & 72,54 & 790,12 & 97,91 & 1,12 \\
\hline & 0,4 & 845,13 & 1148,00 & 72,10 & 789,69 & 55,44 & 1,07 \\
\hline & 0,5 & 803,58 & 1141,99 & 71,72 & 789,31 & 14,27 & 1,02 \\
\hline & 0,6 & 717,92 & 1143,53 & 71,82 & 789,41 & $-71,49$ & 0,91 \\
\hline & 0,7 & 679,30 & 1140,68 & 71,64 & 789,23 & $-109,92$ & 0,86 \\
\hline & 0,8 & 640,79 & 1142,10 & 71,73 & 789,32 & $-148,52$ & 0,81 \\
\hline
\end{tabular}


Tabela 3B. Receitas brutas, composição de custos da irrigação, receitas líquidas e relação beneficio/custo para o feijão caupi, em cada época de semeadura, nível de manejo da irrigação e risco de $15 \%$. Parnaíba, Piauí.

\begin{tabular}{|c|c|c|c|c|c|c|c|}
\hline $\begin{array}{l}\text { Época de } \\
\text { Semeadura }\end{array}$ & $\mathrm{p}$ & $\begin{array}{c}\mathrm{RB}^{1} \\
\left(\mathrm{US} \$ \mathrm{ha}^{-1}\right)\end{array}$ & $\begin{array}{c}E b \\
\left(\mathrm{kWh} \mathrm{ha}^{-1}\right)\end{array}$ & $\begin{array}{c}C E \\
\left(\mathrm{US} \$ \mathrm{ha}^{-1}\right)\end{array}$ & $\begin{array}{c}\mathrm{CT} \\
\left(\mathrm{US} \$ \mathrm{ha}^{-1}\right)\end{array}$ & $\begin{array}{c}\text { RL } \\
\left(\mathrm{US} \$ \mathrm{ha}^{-1}\right)\end{array}$ & $\mathrm{B} / \mathrm{C}$ \\
\hline \multirow{7}{*}{ 1-Set } & 0,2 & 990,17 & 1193,11 & 71,97 & 789,55 & 200,62 & 1,25 \\
\hline & 0,3 & 904,82 & 1190,80 & 71,83 & 789,41 & 115,41 & 1,15 \\
\hline & 0,4 & 856,95 & 1185,47 & 71,51 & 789,09 & 67,86 & 1,09 \\
\hline & 0,5 & 823,05 & 1180,32 & 71,20 & 788,78 & 34,27 & 1,04 \\
\hline & 0,6 & 734,03 & 1184,60 & 71,45 & 789,04 & $-55,00$ & 0,93 \\
\hline & 0,7 & 687,72 & 1180,25 & 71,19 & 788,78 & $-101,06$ & 0,87 \\
\hline & 0,8 & 667,65 & 1177,42 & 71,02 & 788,61 & $-120,95$ & 0,85 \\
\hline \multirow{7}{*}{$15-$ Set } & 0,2 & 991,40 & 1188,15 & 71,67 & 789,25 & 202,15 & 1,26 \\
\hline & 0,3 & 904,09 & 1185,30 & 71,50 & 789,08 & 115,01 & 1,15 \\
\hline & 0,4 & 857,60 & 1178,83 & 71,11 & 788,69 & 68,91 & 1,09 \\
\hline & 0,5 & 823,06 & 1176,92 & 70,99 & 788,58 & 34,48 & 1,04 \\
\hline & 0,6 & 735,20 & 1178,97 & 71,11 & 788,70 & $-53,50$ & 0,93 \\
\hline & 0,7 & 689,08 & 1177,74 & 71,04 & 788,63 & $-99,54$ & 0,87 \\
\hline & 0,8 & 665,16 & 1165,45 & 70,30 & 787,88 & $-122,73$ & 0,84 \\
\hline \multirow{7}{*}{ 1-Out } & 0,2 & 1012,53 & 1183,53 & 72,89 & 790,47 & 222,05 & 1,28 \\
\hline & 0,3 & 930,02 & 1182,34 & 72,81 & 790,40 & 139,63 & 1,18 \\
\hline & 0,4 & 880,64 & 1176,42 & 72,45 & 790,03 & 90,61 & 1,11 \\
\hline & 0,5 & 843,25 & 1172,57 & 72,21 & 789,80 & 53,45 & 1,07 \\
\hline & 0,6 & 752,88 & 1174,23 & 72,31 & 789,90 & $-37,01$ & 0,95 \\
\hline & 0,7 & 705,82 & 1168,81 & 71,98 & 789,56 & $-83,75$ & 0,89 \\
\hline & 0,8 & 683,47 & 1159,20 & 71,39 & 788,97 & $-105,50$ & 0,87 \\
\hline \multirow{7}{*}{ 15-Out } & 0,2 & 1012,64 & 1158,38 & 71,34 & 788,92 & 223,72 & 1,28 \\
\hline & 0,3 & 923,59 & 1151,25 & 70,90 & 788,48 & 135,10 & 1,17 \\
\hline & 0,4 & 879,81 & 1149,82 & 70,81 & 788,40 & 91,41 & 1,12 \\
\hline & 0,5 & 840,55 & 1142,05 & 70,33 & 787,92 & 52,64 & 1,07 \\
\hline & 0,6 & 748,10 & 1142,76 & 70,38 & 787,96 & $-39,86$ & 0,95 \\
\hline & 0,7 & 707,90 & 1134,80 & 69,89 & 787,47 & $-79,57$ & 0,90 \\
\hline & 0,8 & 672,92 & 1134,96 & 69,90 & 787,48 & $-114,57$ & 0,85 \\
\hline
\end{tabular}


Tabela 3B. Receitas brutas, composição de custos da irrigação, receitas líquidas e relação beneficio/custo para o feijão caupi, em cada época de semeadura, nivel de manejo da irrigação e risco de $15 \%$. Parnaíba, Piauí.

\begin{tabular}{|c|c|c|c|c|c|c|c|}
\hline $\begin{array}{l}\text { Época de } \\
\text { Semeadura }\end{array}$ & $\mathrm{p}$ & $\begin{array}{c}\mathrm{RB}^{1} \\
\left(\mathrm{US} \$ \mathrm{ha}^{-1}\right)\end{array}$ & $\begin{array}{c}E b \\
\left(\mathrm{kWh} \mathrm{ha}{ }^{-1}\right)\end{array}$ & $\begin{array}{c}\text { CE } \\
\left(\mathrm{US} \$ \mathrm{ha}^{-1}\right)\end{array}$ & $\begin{array}{c}\text { CT } \\
\left(\mathrm{US} \$ \mathrm{ha}^{-1}\right)\end{array}$ & $\begin{array}{c}\mathrm{RL} \\
\left(\mathrm{US} \$ \mathrm{ha}^{-1}\right)\end{array}$ & $\mathrm{B} / \mathrm{C}$ \\
\hline \multirow{7}{*}{$1-\mathrm{Nov}$} & 0,2 & 1171,49 & 1060,43 & 65,74 & 783,32 & 388,17 & 1,50 \\
\hline & 0,3 & 1079,38 & 1056,58 & 65,50 & 783,08 & 296,30 & 1,38 \\
\hline & 0,4 & 1027,95 & 1045,14 & 64,79 & 782,37 & 245,58 & 1,31 \\
\hline & 0,5 & 957,26 & 1034,81 & 64,15 & 781,73 & 175,52 & 1,22 \\
\hline & 0,6 & 874,91 & 1037,72 & 64,33 & 781,91 & 93,00 & 1,12 \\
\hline & 0,7 & 828,07 & 1030,70 & 63,89 & 781,48 & 46,59 & 1,06 \\
\hline & 0,8 & 763,14 & 1025,92 & 63,60 & 781,18 & $-18,04$ & 0,98 \\
\hline \multirow{7}{*}{ 15-Nov } & 0,2 & 1159,32 & 952,63 & 59,05 & 776,64 & 382,68 & 1,49 \\
\hline & 0,3 & 1072,73 & 940,05 & 58,27 & 775,86 & 296,87 & 1,38 \\
\hline & 0,4 & 1022,59 & 933,50 & 57,87 & 775,45 & 247,13 & 1,32 \\
\hline & 0,5 & 942,62 & 925,31 & 57,36 & 774,95 & 167,68 & 1,22 \\
\hline & 0,6 & 875,45 & 910,02 & 56,41 & 774,00 & 101,46 & 1,13 \\
\hline & 0,7 & 827,37 & 906,44 & 56,19 & 773,78 & 53,59 & 1,07 \\
\hline & 0,8 & 761,52 & 894,86 & 55,47 & 773,06 & $-11,54$ & 0,99 \\
\hline \multirow{7}{*}{ 1-Dez } & 0,2 & 1185,11 & 871,73 & 53,46 & 771,04 & 414,07 & 1,54 \\
\hline & 0,3 & 1105,64 & 856,36 & 52,51 & 770,10 & 335,54 & 1,44 \\
\hline & 0,4 & 1047,42 & 844,15 & 51,76 & 769,35 & 278,07 & 1,36 \\
\hline & 0,5 & 965,48 & 828,13 & 50,78 & 768,37 & 197,12 & 1,26 \\
\hline & 0,6 & 901,61 & 812,25 & 49,81 & 767,39 & 134,22 & 1,17 \\
\hline & 0,7 & 845,76 & 806,24 & 49,44 & 767,02 & 78,73 & 1,10 \\
\hline & 0,8 & 788,30 & 800,04 & 49,06 & 766,64 & 21,66 & 1,03 \\
\hline \multirow{7}{*}{ 15-Dez } & 0,2 & 1178,32 & 769,18 & 47,17 & 764,75 & 413,57 & 1,54 \\
\hline & 0,3 & 1102,57 & 744,81 & 45,67 & 763,26 & 339,31 & 1,44 \\
\hline & 0,4 & 1043,52 & 729,72 & 44,75 & 762,33 & 281,19 & 1,37 \\
\hline & 0,5 & 960,45 & 710,08 & 43,54 & 761,13 & 199,32 & 1,26 \\
\hline & 0,6 & 905,24 & 695,02 & 42,62 & 760,20 & 145,04 & 1,19 \\
\hline & 0,7 & 844,20 & 677,51 & 41,55 & 759,13 & 85,07 & 1,11 \\
\hline & 0,8 & 793,14 & 669,27 & 41,04 & 758,62 & 34,51 & 1,05 \\
\hline
\end{tabular}

${ }_{\mathrm{RB}}$ - receita bruta: $\mathrm{Eb}$ - energia requerida para o bombeamento: CE - custo de energia elétrica: CT - custo total de produção; RL - receita liquida e B/C - relação benefício/custo. 
Tabela 4B. Receitas brutas, composição de custos da irrigação, receitas líquidas e relação benefício/custo para o feijão caupi, em cada época de semeadura, nivel de manejo da irrigação e risco de $25 \%$. Parnaíba, Piauí.

\begin{tabular}{|c|c|c|c|c|c|c|c|}
\hline $\begin{array}{l}\text { Época de } \\
\text { Semeadura }\end{array}$ & $p$ & $\begin{array}{c}\mathrm{RB}^{\mathrm{I}} \\
\left(\mathrm{US} \$ \mathrm{ha}^{-1}\right)\end{array}$ & $\begin{array}{c}E b \\
\left(\mathrm{kWh} \mathrm{ha} \mathrm{a}^{-1}\right)\end{array}$ & $\begin{array}{c}\text { CE } \\
\left(\mathrm{US} \$ \mathrm{ha}^{-1}\right)\end{array}$ & $\begin{array}{c}\text { CT } \\
\left(\mathrm{US} \$ \mathrm{ha}^{-1}\right)\end{array}$ & $\begin{array}{c}\mathrm{RL} \\
\left(\mathrm{US} \$ \mathrm{ha}^{-1}\right)\end{array}$ & $\mathrm{B} / \mathrm{C}$ \\
\hline \multirow{7}{*}{ 1-Jan } & 0,2 & 1159,02 & 640,57 & 38,03 & 755,61 & 403,41 & 1,53 \\
\hline & 0,3 & 1093,54 & 614,95 & 36,51 & 754,09 & 339,45 & 1,45 \\
\hline & 0,4 & 1033,91 & 589,74 & 35,01 & 752,60 & 281,32 & 1,37 \\
\hline & 0,5 & 968,94 & 563,78 & 33,47 & 751,05 & 217,89 & 1,29 \\
\hline & 0,6 & 917,03 & 536,33 & 31,84 & 749,43 & 167,60 & 1,22 \\
\hline & 0,7 & 862,20 & 515,72 & 30,62 & 748,20 & 113,99 & 1,15 \\
\hline & 0,8 & 819,26 & 493,88 & 29,32 & 746,91 & 72,35 & 1,10 \\
\hline \multirow{7}{*}{$15-J a n$} & 0,2 & 1170,64 & 580,35 & 34,45 & 752,04 & 418,60 & 1,56 \\
\hline & 0,3 & 1111,11 & 551,46 & 32,74 & 750,32 & 360,78 & 1,48 \\
\hline & 0,4 & 1046,12 & 525,59 & 31,20 & 748,79 & 297,33 & 1,40 \\
\hline & 0,5 & 985,67 & 496,32 & 29,47 & 747,05 & 238,62 & 1,32 \\
\hline & 0,6 & 929,03 & 463,41 & 27,51 & 745,10 & 183,93 & 1,25 \\
\hline & 0,7 & 881,25 & 445,41 & 26,44 & 744,03 & 137,22 & 1,18 \\
\hline & 0,8 & 841,71 & 427,76 & 25,39 & 742,98 & 98,73 & 1,13 \\
\hline \multirow{7}{*}{$1-\mathrm{Fev}$} & 0,2 & 1124,70 & 531,31 & 31,55 & 749,13 & 375,57 & 1,50 \\
\hline & 0,3 & 1070,86 & 498,81 & 29,62 & 747,20 & 323,66 & 1,43 \\
\hline & 0,4 & 1003,45 & 464,55 & 27,58 & 745,17 & 258,28 & 1,35 \\
\hline & 0,5 & 954,72 & 434,76 & 25,81 & 743,40 & 211,32 & 1,28 \\
\hline & 0,6 & 903,41 & 412,41 & 24,49 & 742,07 & 161,34 & 1,22 \\
\hline & 0,7 & 860,09 & 388,26 & 23,05 & 740,64 & 119,45 & 1,16 \\
\hline & 0,8 & 817,09 & 359,39 & 21,34 & 738,92 & 78,17 & 1,11 \\
\hline \multirow{7}{*}{$15-\mathrm{Fev}$} & 0,2 & 1119,88 & 482,02 & 28,62 & 746,20 & 373,68 & 1,50 \\
\hline & 0,3 & 1071,03 & 452,38 & 26,86 & 744,44 & 326,58 & 1,44 \\
\hline & 0,4 & 999,90 & 413,22 & 24,53 & 742,12 & 257,78 & 1,35 \\
\hline & 0,5 & 954,66 & 382,47 & 22,71 & 740,29 & 214,36 & 1,29 \\
\hline & 0,6 & 903,15 & 341,19 & 20,26 & 737,84 & 165,30 & 1,22 \\
\hline & 0,7 & 872,29 & 328,91 & 19,53 & 737,11 & 135,18 & 1,18 \\
\hline & 0,8 & 827,36 & 307,17 & 18,24 & 735,82 & 91,54 & 1,12 \\
\hline
\end{tabular}


Tabela 4B. Receitas brutas, composição de custos da irrigação, receitas líquidas e relação benefício/custo para o feijão caupi, em cada época de semeadura, nível de manejo da irrigação e risco de $25 \%$. Parnaíba, Piauí.

\begin{tabular}{|c|c|c|c|c|c|c|c|}
\hline $\begin{array}{l}\text { Época de } \\
\text { Semeadura }\end{array}$ & $\mathrm{p}$ & $\begin{array}{c}\mathrm{RB}^{1} \\
\left(\mathrm{US} \$ \mathrm{ha}^{-1}\right)\end{array}$ & $\begin{array}{c}E b \\
\left(\mathrm{kWh} \mathrm{ha}{ }^{-1}\right)\end{array}$ & $\begin{array}{c}\text { CE } \\
\left(\mathrm{US} \$ \mathrm{ha}^{-1}\right)\end{array}$ & $\begin{array}{c}\text { CT } \\
\left(\mathrm{US} \$ h \mathrm{~h}^{-1}\right)\end{array}$ & $\begin{array}{c}\mathrm{RL} \\
\left(\mathrm{US} \$ \mathrm{ha}^{-1}\right)\end{array}$ & $\mathrm{B} / \mathrm{C}$ \\
\hline \multirow{7}{*}{ 1-Mar } & 0,2 & 1150,81 & 466,38 & 27,48 & 745,07 & 405,74 & 1,54 \\
\hline & 0,3 & 1101,59 & 436,96 & 25,75 & 743,33 & 358,26 & 1,48 \\
\hline & 0,4 & 1027,98 & 400,71 & 23,61 & 741,20 & 286,78 & 1,39 \\
\hline & 0,5 & 982,66 & 363,30 & 21,41 & 738,99 & 243,67 & 1,33 \\
\hline & 0,6 & 930,82 & 340,60 & 20,07 & 737,66 & 193,16 & 1,26 \\
\hline & 0,7 & 889,61 & 309,89 & 18,26 & 735,85 & 153,76 & 1,21 \\
\hline & 0,8 & 850,76 & 281,49 & 16,59 & 734,17 & 116,58 & 1,16 \\
\hline \multirow{7}{*}{ 15-Mar } & 0,2 & 1141,70 & 485,69 & 28,62 & 746,21 & 395,49 & 1,53 \\
\hline & 0,3 & 1093,44 & 452,38 & 26,66 & 744,24 & 349,20 & 1,47 \\
\hline & 0,4 & 1016,00 & 417,95 & 24,63 & 742,21 & 273,79 & 1,37 \\
\hline & 0,5 & 968,39 & 386,98 & 22,80 & 740,39 & 228,00 & 1,31 \\
\hline & 0,6 & 912,50 & 364,75 & 21,49 & 739,08 & 173,43 & 1,23 \\
\hline & 0,7 & 871,01 & 331,63 & 19,54 & 737,13 & 133,88 & 1,18 \\
\hline & 0,8 & 825,65 & 303,95 & 17,91 & 735,50 & 90,15 & 1,12 \\
\hline \multirow{7}{*}{$1-\mathrm{Abr}$} & 0,2 & 1134,84 & 552,87 & 30,99 & 748,57 & 386,27 & 1,52 \\
\hline & 0,3 & 1079,79 & 526,68 & 29,52 & 747,11 & 332,68 & 1,45 \\
\hline & 0,4 & 998,88 & 502,14 & 28,15 & 745,73 & 253,15 & 1,34 \\
\hline & 0,5 & 947,87 & 472,13 & 26,46 & 744,05 & 203,82 & 1,27 \\
\hline & 0,6 & 882,52 & 444,20 & 24,90 & 742,48 & 140,04 & 1,19 \\
\hline & 0,7 & 841,42 & 428,01 & 23,99 & 741,57 & 99,85 & 1,13 \\
\hline & 0,8 & 792,85 & 402,55 & 22,56 & 740,15 & 52,70 & 1,07 \\
\hline \multirow{7}{*}{$15-\mathrm{Abr}$} & 0,2 & 1131,63 & 612,99 & 34,36 & 751,94 & 379,69 & 1,50 \\
\hline & 0,3 & 1072,68 & 589,75 & 33,06 & 750,64 & 322,04 & 1,43 \\
\hline & 0,4 & 989,54 & 563,86 & 31,60 & 749,19 & 240,35 & 1,32 \\
\hline & 0,5 & 931,36 & 541,91 & 30,37 & 747,96 & 183,40 & 1,25 \\
\hline & 0,6 & 863,48 & 519,59 & 29,12 & 746,71 & 116,77 & 1,16 \\
\hline & 0,7 & 818,28 & 492,76 & 27,62 & 745,20 & 73,07 & 1,10 \\
\hline & 0,8 & 765,47 & 486,93 & 27,29 & 744,88 & 20,59 & 1,03 \\
\hline
\end{tabular}


Tabela 4B. Receitas brutas, composição de custos da irrigação, receitas líquidas e relação benefício/custo para o feijão caupi, em cada época de semeadura, nível de manejo da irrigação e risco de $25 \%$. Parnaíba, Piauí.

\begin{tabular}{|c|c|c|c|c|c|c|c|}
\hline $\begin{array}{l}\text { Época de } \\
\text { Semeadura }\end{array}$ & $\mathrm{p}$ & $\begin{array}{c}\mathrm{RB}^{1} \\
\left(\mathrm{US} \$ \mathrm{ha}^{-1}\right)\end{array}$ & $\begin{array}{c}E b \\
\left(\mathrm{kWh} \mathrm{ha}^{-1}\right)\end{array}$ & $\begin{array}{c}C E \\
\left(\mathrm{US} \$ \mathrm{ha}^{-1}\right)\end{array}$ & $\begin{array}{c}\text { CT } \\
\left(\mathrm{US} \$ \mathrm{ha}^{-1}\right)\end{array}$ & $\begin{array}{c}\mathrm{RL} \\
\left(\mathrm{US} \$ \mathrm{ha}^{-1}\right)\end{array}$ & $\mathrm{B} / \mathrm{C}$ \\
\hline \multirow{7}{*}{ 1-Mai } & 0,2 & 943,80 & 695,55 & 38,43 & 756,02 & 187,78 & 1,25 \\
\hline & 0,3 & 891,98 & 676,17 & 37,36 & 754,95 & 137,03 & 1,18 \\
\hline & 0,4 & 819,69 & 655,01 & 36,19 & 753,78 & 65,91 & 1,09 \\
\hline & 0,5 & 767,04 & 644,56 & 35,62 & 753,20 & 13,84 & 1,02 \\
\hline & 0,6 & 714,00 & 639,47 & 35,34 & 752,92 & $-38,92$ & 0,95 \\
\hline & 0,7 & 667,54 & 618,81 & 34,19 & 751,78 & $-84,24$ & 0,89 \\
\hline & 0,8 & 622,31 & 616,16 & 34,05 & 751,63 & $-129,32$ & 0,83 \\
\hline \multirow{7}{*}{ 15-Mai } & 0,2 & 945,98 & 729,37 & 40,30 & 757,89 & 188,10 & 1,25 \\
\hline & 0,3 & 892,42 & 715,71 & 39,55 & 757,13 & 135,28 & 1,18 \\
\hline & 0,4 & 823,67 & 704,16 & 38,91 & 756,50 & 67,17 & 1,09 \\
\hline & 0,5 & 765,66 & 689,04 & 38,07 & 755,66 & 10,00 & 1,01 \\
\hline & 0,6 & 713,18 & 673,82 & 37,23 & 754,82 & $-41,64$ & 0,94 \\
\hline & 0,7 & 666,17 & 672,05 & 37,14 & 754,72 & $-88,55$ & 0,88 \\
\hline & 0,8 & 620,36 & 656,21 & 36,26 & 753,85 & $-133,49$ & 0,82 \\
\hline \multirow{7}{*}{ 1-Jun } & 0,2 & 1036,77 & 783,41 & 45,87 & 763,46 & 273,31 & 1,36 \\
\hline & 0,3 & 974,93 & 772,15 & 45,21 & 762,80 & 212,14 & 1,28 \\
\hline & 0,4 & 904,89 & 766,29 & 44,87 & 762,45 & 142,44 & 1,19 \\
\hline & 0,5 & 833,93 & 754,51 & 44,18 & 761,76 & 72,17 & 1,09 \\
\hline & 0,6 & 782,46 & 747,01 & 43,74 & 761,32 & 21,14 & 1,03 \\
\hline & 0,7 & 719,02 & 735,11 & 43,04 & 760,63 & $-41,61$ & 0,95 \\
\hline & 0,8 & 675,29 & 730,49 & 42,77 & 760,36 & $-85,07$ & 0,89 \\
\hline \multirow{7}{*}{ 15-Jun } & 0,2 & 1048,46 & 855,40 & 50,09 & 767,67 & 280,79 & 1,37 \\
\hline & 0,3 & 976,22 & 846,77 & 49,58 & 767,17 & 209,06 & 1,27 \\
\hline & 0,4 & 920,28 & 837,71 & 49,05 & 766,64 & 153,65 & 1,20 \\
\hline & 0,5 & 834,98 & 829,12 & 48,55 & 766,13 & 68,85 & 1,09 \\
\hline & 0,6 & 794,73 & 826,84 & 48,41 & 766,00 & 28,73 & $1,0 \dot{4}$ \\
\hline & 0,7 & 724,26 & 818,14 & 47,90 & 765,49 & $-41,23$ & 0,95 \\
\hline & 0,8 & 682,41 & 813,14 & 47,61 & 765,20 & $-82,79$ & 0,89 \\
\hline
\end{tabular}


Tabela 4B. Receitas brutas, composição de custos da irrigação, receitas líquidas e relação beneficio/custo para o feijão caupi, em cada época de semeadura, nível de manejo da irrigação e risco de $25 \%$. Parnaíba, Piauí.

\begin{tabular}{|c|c|c|c|c|c|c|c|}
\hline $\begin{array}{l}\text { Época de } \\
\text { Semeadura }\end{array}$ & $\mathrm{p}$ & $\begin{array}{c}\mathrm{RB}^{1} \\
\left(\mathrm{US} \$ \mathrm{ha}^{-1}\right)\end{array}$ & $\begin{array}{c}\mathrm{Eb} \\
\left(\mathrm{kWh} \mathrm{ha} \mathrm{h}^{-1}\right)\end{array}$ & $\begin{array}{c}\text { CE } \\
\left(\mathrm{US} \$ \mathrm{ha}^{-1}\right)\end{array}$ & $\begin{array}{c}\mathrm{CT} \\
\left(\mathrm{US} \$ \mathrm{ha}^{-1}\right)\end{array}$ & $\begin{array}{c}\text { RL } \\
\left(\mathrm{US} \$ \mathrm{ha}^{-1}\right)\end{array}$ & $\mathrm{B} / \mathrm{C}$ \\
\hline \multirow{7}{*}{ 1-Jul } & 0,2 & 1056,96 & 932,44 & 56,46 & 774,04 & 282,92 & 1,37 \\
\hline & 0,3 & 975,72 & 923,35 & 55,91 & 773,49 & 202,22 & 1,26 \\
\hline & 0,4 & 928,57 & 916,96 & 55,52 & 773,11 & 155,47 & 1,20 \\
\hline & 0,5 & 843,04 & 917,27 & 55,54 & 773,12 & 69,92 & 1,09 \\
\hline & 0,6 & 794,91 & 907,43 & 54,94 & 772,53 & 22,38 & 1,03 \\
\hline & 0,7 & 734,15 & 901,94 & 54,61 & 772,20 & $-38,04$ & 0,95 \\
\hline & 0,8 & 682,49 & 896,54 & 54,28 & 771,87 & $-89,38$ & 0,88 \\
\hline \multirow{7}{*}{ 15-Jul } & 0,2 & 1069,20 & 1010,71 & 61,20 & 778,78 & 290,42 & 1,37 \\
\hline & 0,3 & 980,89 & 1000,29 & 60,57 & 778,15 & 202,74 & 1,26 \\
\hline & 0,4 & 939,13 & 1000,83 & 60,60 & 778,18 & 160,95 & 1,21 \\
\hline & 0,5 & 863,60 & 997,33 & 60,39 & 777,97 & 85,63 & 1,11 \\
\hline & 0,6 & 797,03 & 994,05 & 60,19 & 777,77 & 19,26 & 1,02 \\
\hline & 0,7 & 752,53 & 988,28 & 59,84 & 777,42 & $-24,89$ & 0,97 \\
\hline & 0,8 & 683,69 & 986,45 & 59,73 & 777,31 & $-93,62$ & 0,88 \\
\hline \multirow{7}{*}{ 1-Ago } & 0,2 & 1029,88 & 1101,27 & 67,17 & 784,76 & 245,12 & 1,31 \\
\hline & 0,3 & 940,66 & 1095,07 & 66,80 & 784,38 & 156,28 & 1,20 \\
\hline & 0,4 & 898,62 & 1091,35 & 66,57 & 784,15 & 114,47 & 1,15 \\
\hline & 0,5 & 846,51 & 1090,57 & 66,52 & 784,11 & 62,40 & 1,08 \\
\hline & 0,6 & 760,86 & 1083,52 & 66,09 & 783,68 & $-22,81$ & 0,97 \\
\hline & 0,7 & 726,83 & 1079,29 & 65,83 & 783,42 & $-56,59$ & 0,93 \\
\hline & 0,8 & 670,01 & 1078,30 & 65,77 & 783,36 & $-113,35$ & 0,86 \\
\hline \multirow{7}{*}{ 15-Ago } & 0,2 & 1038,63 & 1151,49 & 70,24 & 787,82 & 250,81 & 1,32 \\
\hline & 0,3 & 948,91 & 1148,42 & 70,05 & 787,63 & 161,27 & 1,20 \\
\hline & 0,4 & 902,80 & 1142,50 & 69,69 & 787,27 & 115,53 & 1,15 \\
\hline & 0,5 & 859,98 & 1135,31 & 69,25 & 786,83 & 73,14 & 1,09 \\
\hline & 0,6 & 769,66 & 1135,42 & 69,26 & 786,84 & $-17,18$ & 0,98 \\
\hline & 0,7 & 726,42 & 1129,87 & 68,92 & 786,50 & $-60,08$ & 0,92 \\
\hline & 0,8 & 687,91 & 1132,08 & 69,05 & 786,64 & $-98,73$ & 0,87 \\
\hline
\end{tabular}


Tabela 4B. Receitas brutas, composição de custos da irrigação, receitas líquidas e relação benefício/custo para o feijão caupi, em cada época de semeadura, nivel de manejo da irrigação e risco de $25 \%$. Parnaiba, Piauí.

\begin{tabular}{|c|c|c|c|c|c|c|c|}
\hline $\begin{array}{c}\text { Época de } \\
\text { Semeadura }\end{array}$ & $\mathrm{p}$ & $\begin{array}{c}\mathrm{RB}^{\mathrm{I}} \\
\left(\mathrm{US} \$ \mathrm{ha}^{-1}\right)\end{array}$ & $\begin{array}{c}\mathrm{Eb} \\
\left(\mathrm{kWh} \mathrm{ha} \mathrm{a}^{-1}\right)\end{array}$ & $\begin{array}{c}\mathrm{CE} \\
\left(\mathrm{US} \$ \mathrm{ha}^{-1}\right)\end{array}$ & $\begin{array}{c}\text { CT } \\
\left(\mathrm{US} \$ \mathrm{ha}^{-1}\right)\end{array}$ & $\begin{array}{c}\mathrm{RL} \\
\left(\mathrm{US} \$ \mathrm{ha}^{-1}\right)\end{array}$ & $\mathrm{B} / \mathrm{C}$ \\
\hline \multirow{7}{*}{ 1-Set } & 0,2 & 1054,75 & 1188,37 & 70,30 & 787,88 & 266,87 & 1,34 \\
\hline & 0,3 & 965,56 & 1185,10 & 70,10 & 787,69 & 177,87 & 1,23 \\
\hline & 0,4 & 913,41 & 1179,90 & 69,79 & 787,38 & 126,03 & 1,16 \\
\hline & 0,5 & 878,01 & 1173,88 & 69,44 & 787,02 & 90,99 & 1,12 \\
\hline & 0,6 & 786,77 & 1177,36 & 69,64 & 787,23 & $-0,46$ & 1,00 \\
\hline & 0,7 & 733,87 & 1170,03 & 69,21 & 786,80 & $-52,92$ & 0,93 \\
\hline & 0,8 & 712,82 & 1166,96 & 69,03 & 786,61 & $-73,80$ & 0,91 \\
\hline \multirow{7}{*}{ 15-Set } & 0,2 & 1055,99 & 1181,69 & 69,90 & 787,49 & 268,50 & 1,34 \\
\hline & 0,3 & 964,46 & 1178,77 & 69,73 & 787,31 & 177,14 & 1,22 \\
\hline & 0,4 & 915,54 & 1172,21 & 69,34 & 786,92 & 128,62 & 1,16 \\
\hline & 0,5 & 878,37 & 1168,71 & 69,13 & 786,72 & 91,65 & 1,12 \\
\hline & 0,6 & 787,92 & 1170,72 & 69,25 & 786,84 & 1,09 & 1,00 \\
\hline & 0,7 & 736,04 & 1166,38 & 69,00 & 786,58 & $-50,54$ & 0,94 \\
\hline & 0,8 & 711,06 & 1155,41 & 68,35 & 785,93 & $-74,87$ & 0,90 \\
\hline \multirow{7}{*}{ 1-Out } & 0,2 & 1069,13 & 1175,54 & 70,69 & 788,27 & 280,86 & 1,36 \\
\hline & 0,3 & 982,43 & 1173,05 & 70,54 & 788,12 & 194,31 & 1,25 \\
\hline & 0,4 & 929,62 & 1166,75 & 70,16 & 787,74 & 141,88 & 1,18 \\
\hline & 0,5 & 891,13 & 1161,86 & 69,86 & 787,45 & 103,68 & 1,13 \\
\hline & 0,6 & 798,62 & 1162,52 & 69,90 & 787,49 & 11,13 & 1,01 \\
\hline & 0,7 & 746,84 & 1157,05 & 69,57 & 787,16 & $-40,32$ & 0,95 \\
\hline & 0,8 & 723,15 & 1147,00 & 68,97 & 786,55 & $-63,40$ & 0,92 \\
\hline \multirow{7}{*}{ 15-Out } & 0,2 & 1068,39 & 1149,11 & 69,10 & 786,68 & 281,71 & 1,36 \\
\hline & 0,3 & 975,42 & 1141,15 & 68,62 & 786,20 & 189,22 & 1,24 \\
\hline & 0,4 & 928,99 & 1140,04 & 68,55 & 786,14 & 142,86 & 1,18 \\
\hline & 0,5 & 888,55 & 1131,28 & 68,02 & 785,61 & 102,94 & 1,13 \\
\hline & 0,6 & 793,47 & 1130,50 & 67,98 & 785,56 & 7,91 & 1,01 \\
\hline & 0,7 & 748,93 & 1120,57 & 67,38 & 784,97 & $-36,03$ & 0,95 \\
\hline & 0,8 & 714,02 & 1121,06 & 67,41 & 784,99 & $-70,97$ & 0,91 \\
\hline
\end{tabular}


Tabela 4B. Receitas brutas, composição de custos da irrigação, receitas líquidas e relação beneficio/custo para o feijão caupi, em cada época de semeadura, nível de manejo da irrigação e risco de $25 \%$. Parnaíba, Piauí.

\begin{tabular}{|c|c|c|c|c|c|c|c|}
\hline $\begin{array}{l}\text { Época de } \\
\text { Semeadura }\end{array}$ & $p$ & $\begin{array}{c}\mathrm{RB}^{\mathrm{l}} \\
\left(\mathrm{US} \$ \mathrm{ha}^{-1}\right)\end{array}$ & $\begin{array}{c}E b \\
\left(\mathrm{kWh} \mathrm{ha} \mathrm{a}^{-1}\right)\end{array}$ & $\begin{array}{c}\text { CE } \\
\left(\mathrm{US} \$ h \mathrm{~h}^{-1}\right)\end{array}$ & $\begin{array}{c}\text { CT } \\
\left(\mathrm{US} \$ h \mathrm{~h}^{-1}\right)\end{array}$ & $\begin{array}{c}\mathrm{RL} \\
\left(\mathrm{US} \$ \mathrm{ha}^{-1}\right)\end{array}$ & $\mathrm{B} / \mathrm{C}$ \\
\hline \multirow{7}{*}{$1-\mathrm{Nov}$} & 0,2 & 1232,13 & 1044,65 & 63,17 & 780,76 & 451,37 & 1,58 \\
\hline & 0,3 & 1135,50 & 1038,41 & 62,79 & 780,38 & 355,12 & 1,46 \\
\hline & 0,4 & 1082,10 & 1026,26 & 62,06 & 779,64 & 302,46 & 1,39 \\
\hline & 0,5 & 1010,60 & 1015,71 & 61,42 & 779,01 & 231,59 & 1,30 \\
\hline & 0,6 & 924,33 & 1015,63 & 61,42 & 779,00 & 145,33 & 1,19 \\
\hline & 0,7 & 875,02 & 1006,69 & 60,88 & 778,46 & 96,56 & 1,12 \\
\hline & 0,8 & 809,52 & 1000,14 & 60,48 & 778,06 & 31,46 & 1,04 \\
\hline \multirow{7}{*}{$15-\mathrm{Nov}$} & 0,2 & 1219,50 & 933,98 & 56,48 & 774,06 & 445,44 & 1,58 \\
\hline & 0,3 & 1129,55 & 919,60 & 55,61 & 773,19 & 356,36 & 1,46 \\
\hline & 0,4 & 1077,63 & 910,87 & 55,08 & 772,67 & 304,96 & 1,39 \\
\hline & 0,5 & 997,18 & 899,72 & 54,41 & 771,99 & 225,19 & 1,29 \\
\hline & 0,6 & 925,85 & 883,61 & 53,43 & 771,02 & 154,83 & 1,20 \\
\hline & 0,7 & 876,54 & 875,95 & 52,97 & 770,55 & 105,98 & 1,14 \\
\hline & 0,8 & 809,40 & 862,86 & 52,18 & 769,76 & 39,63 & 1,05 \\
\hline \multirow{7}{*}{ 1-Dez } & 0,2 & 1242,74 & 853,01 & 50,72 & 768,31 & 474,44 & 1,62 \\
\hline & 0,3 & 1159,28 & 835,04 & 49,65 & 767,24 & 392,05 & 1,51 \\
\hline & 0,4 & 1100,62 & 821,64 & 48,86 & 766,44 & 334,17 & 1,44 \\
\hline & 0,5 & 1017,13 & 802,58 & 47,72 & 765,31 & 251,82 & 1,33 \\
\hline & 0,6 & 951,59 & 787,67 & 46,84 & 764,42 & 187,17 & 1,24 \\
\hline & 0,7 & 894,30 & 777,27 & 46,22 & 763,80 & 130,50 & 1,17 \\
\hline & 0,8 & 834,87 & 769,35 & 45,75 & 763,33 & 71,54 & 1,09 \\
\hline \multirow{7}{*}{ 15-Dez } & 0,2 & 1235,21 & 745,42 & 44,32 & 761,91 & 473,30 & 1,62 \\
\hline & 0,3 & 1156,40 & 718,09 & 42,70 & 760,28 & 396,12 & 1,52 \\
\hline & 0,4 & 1097,32 & 700,43 & 41,65 & 759,23 & 338,08 & 1,45 \\
\hline & 0,5 & 1013,43 & 678,94 & 40,37 & 757,96 & 255,48 & 1,34 \\
\hline & 0,6 & 956,87 & 662,83 & 39,41 & 757,00 & 199,87 & 1,26 \\
\hline & 0,7 & 894,72 & 642,04 & 38,18 & 755,76 & 138,96 & 1,18 \\
\hline & 0,8 & 843,46 & 630,81 & 37,51 & 755,09 & 88,37 & 1,12 \\
\hline
\end{tabular}

$\mathrm{RB}$ - receita bruta: $\mathrm{Eb}$ - energia requerida para o bombeamento: $\mathrm{CE}$ - custo de energia elétrica: $\mathrm{CT}$ - custo total de produção; $\mathrm{RL}$ - receita líquida e $\mathrm{B} / \mathrm{C}$ - relação benefício/custo. 
Tabela 5B. Receitas brutas, composição de custos da irrigação, receitas líquidas e relação benefício/custo para o feijão caupi, em cada época de semeadura, nivel de manejo da irrigação e risco de $30 \%$. Parnaiba, Piauí.

\begin{tabular}{|c|c|c|c|c|c|c|c|}
\hline $\begin{array}{l}\text { Época de } \\
\text { Semeadura }\end{array}$ & $\mathrm{p}$ & $\begin{array}{c}\mathrm{RB}^{1} \\
\left(\mathrm{US} \$ \mathrm{ha}^{-1}\right)\end{array}$ & $\begin{array}{c}E b \\
\left(\mathrm{kWh} \mathrm{ha}^{-1}\right)\end{array}$ & $\begin{array}{c}C E \\
\left(\mathrm{US} \$ \mathrm{ha}^{-1}\right)\end{array}$ & $\begin{array}{c}\mathrm{CT} \\
\left(\mathrm{US} \$ \mathrm{ha}^{-1}\right)\end{array}$ & $\begin{array}{c}\mathrm{RL} \\
\left(\mathrm{US} \$ \mathrm{ha}^{-1}\right)\end{array}$ & $\mathrm{B} / \mathrm{C}$ \\
\hline \multirow{7}{*}{ 1-Jan } & 0,2 & 1189,62 & 630,48 & 36,81 & 754,39 & 435,23 & 1,58 \\
\hline & 0,3 & 1122,89 & 603,56 & 35,24 & 752,82 & 370,06 & 1,49 \\
\hline & 0,4 & 1063,18 & 577,10 & 33,69 & 751,28 & 311,90 & 1,42 \\
\hline & 0,5 & 997,08 & 550,51 & 32,14 & 749,72 & 247,35 & 1,33 \\
\hline & 0,6 & 944,80 & 522,45 & 30,50 & 748,09 & 196,72 & 1,26 \\
\hline & 0,7 & 889,70 & 500,79 & 29,24 & 746,82 & 142,88 & 1,19 \\
\hline & 0,8 & 846,28 & 478,48 & 27,93 & 745,52 & 100,76 & 1,14 \\
\hline \multirow{7}{*}{ 15-Jan } & 0,2 & 1201,49 & 570,90 & 33,33 & 750,91 & 450,58 & 1,60 \\
\hline & 0,3 & 1140,82 & 540,66 & 31,56 & 749,15 & 391,67 & 1,52 \\
\hline & 0,4 & 1075,43 & 513,27 & 29,97 & 747,55 & 327,88 & 1,44 \\
\hline & 0,5 & 1014,22 & 482,89 & 28,19 & 745,78 & 268,44 & 1,36 \\
\hline & 0,6 & 957,65 & 450,00 & 26,27 & 743,86 & 213,80 & 1,29 \\
\hline & 0,7 & 908,90 & 430,09 & 25,11 & 742,69 & 166,20 & 1,22 \\
\hline & 0,8 & 869,31 & 412,62 & 24,09 & 741,67 & 127,63 & 1,17 \\
\hline \multirow{7}{*}{$1-\mathrm{Fev}$} & 0,2 & 1156,39 & 521,13 & 30,22 & 747,81 & 408,59 & 1,55 \\
\hline & 0,3 & 1101,43 & 487,12 & 28,25 & 745,83 & 355,59 & 1,48 \\
\hline & 0,4 & 1033,97 & 451,47 & 26,18 & 743,77 & 290,20 & 1,39 \\
\hline & 0,5 & 984,28 & 422,13 & 24,48 & 742,06 & 242,21 & 1,33 \\
\hline & 0,6 & 932,93 & 398,37 & 23,10 & 740,69 & 192,24 & 1,26 \\
\hline & 0,7 & 889,39 & 373,91 & 21,68 & 739,27 & 150,12 & 1,20 \\
\hline & 0,8 & 846,63 & 344,78 & 19,99 & 737,58 & 109,05 & 1,15 \\
\hline \multirow{7}{*}{ 15-Fev } & 0,2 & 1151,52 & 472,54 & 27,40 & 744,99 & 406,53 & 1,55 \\
\hline & 0,3 & 1101,73 & 442,09 & 25,64 & 743,22 & 358,51 & 1,48 \\
\hline & 0,4 & 1030,48 & 401,49 & 23,28 & 740,87 & 289,61 & 1,39 \\
\hline & 0,5 & 984,54 & 370,25 & 21,47 & 739,06 & 245,48 & 1,33 \\
\hline & 0,6 & 933,28 & 329,77 & 19,12 & 736,71 & 196,58 & 1,27 \\
\hline & 0,7 & 901,80 & 316,46 & 18,35 & 735,94 & 165,86 & 1,23 \\
\hline & 0,8 & 856,94 & 294,25 & 17,06 & 734,65 & 122,29 & 1,17 \\
\hline
\end{tabular}


Tabela 5B. Receitas brutas, composição de custos da irrigação, receitas líquidas e relação beneficio/custo para o feijão caupi, em cada época de semeadura, nível de manejo da irrigação e risco de 30 \%. Parnaíba, Piauí.

\begin{tabular}{|c|c|c|c|c|c|c|c|}
\hline $\begin{array}{l}\text { Época de } \\
\text { Semeadura }\end{array}$ & $\mathrm{p}$ & $\begin{array}{c}\mathrm{RB}^{1} \\
\left(\mathrm{US} \$ \mathrm{ha}^{-1}\right)\end{array}$ & $\begin{array}{c}E b \\
\left(\mathrm{kWh} \mathrm{ha} \mathrm{a}^{-1}\right)\end{array}$ & $\begin{array}{c}\text { CE } \\
\left(\mathrm{US} \$ \mathrm{ha}^{-1}\right)\end{array}$ & $\begin{array}{c}C T \\
\left(\mathrm{US} \$ \mathrm{ha}^{-1}\right)\end{array}$ & $\begin{array}{c}\mathrm{RL} \\
\left(\mathrm{US} \$ \mathrm{ha}^{-1}\right)\end{array}$ & $\mathrm{B} / \mathrm{C}$ \\
\hline \multirow{7}{*}{ 1-Mar } & 0,2 & 1184,39 & 456,36 & 26,20 & 743,79 & 440,60 & 1,59 \\
\hline & 0,3 & 1134,39 & 425,29 & 24,42 & 742,00 & 392,38 & 1,53 \\
\hline & 0,4 & 1060,40 & 388,14 & 22,29 & 739,87 & 320,53 & 1,43 \\
\hline & 0,5 & 1014,91 & 350,93 & 20,15 & 737,73 & 277,18 & 1,38 \\
\hline & 0,6 & 962,75 & 327,04 & 18,78 & 736,36 & 226,38 & 1,31 \\
\hline & 0,7 & 921,66 & 295,56 & 16,97 & 734,56 & 187,10 & 1,25 \\
\hline & 0,8 & 882,64 & 266,45 & 15,30 & 732,88 & 149,76 & 1,20 \\
\hline \multirow{7}{*}{ 15-Mar } & 0,2 & 1174,92 & 475,97 & 27,33 & 744,91 & 430,01 & 1,58 \\
\hline & 0,3 & 1125,99 & 441,91 & 25,37 & 742,96 & 383,03 & 1,52 \\
\hline & 0,4 & 1047,63 & 406,42 & 23,34 & 740,92 & 306,71 & 1,41 \\
\hline & 0,5 & 999,42 & 374,24 & 21,49 & 739,07 & 260,35 & 1,35 \\
\hline & 0,6 & 943,10 & 350,83 & 20,14 & 737,73 & 205,37 & 1,28 \\
\hline & 0,7 & 901,47 & 317,99 & 18,26 & 735,84 & 165,63 & 1,23 \\
\hline & 0,8 & 856,44 & 290,15 & 16,66 & 734,24 & 122,20 & 1,17 \\
\hline \multirow{7}{*}{ 1-Abr } & 0,2 & 1167,77 & 543,63 & 29,65 & 747,24 & 420,54 & 1,56 \\
\hline & 0,3 & 1111,69 & 516,53 & 28,17 & 745,76 & 365,93 & 1,49 \\
\hline & 0,4 & 1029,93 & 490,82 & 26,77 & 744,36 & 285,58 & 1,38 \\
\hline & 0,5 & 978,33 & 460,82 & 25,14 & 742,72 & 235,61 & 1,32 \\
\hline & 0,6 & 912,23 & 431,43 & 23,53 & 741,12 & 171,11 & 1,23 \\
\hline & 0,7 & 870,82 & 414,26 & 22,60 & 740,18 & 130,64 & 1,18 \\
\hline & 0,8 & 821,88 & 387,93 & 21,16 & 738,74 & 83,14 & 1,11 \\
\hline \multirow{7}{*}{$15-\mathrm{Abr}$} & 0,2 & 1164,29 & 604,40 & 32,97 & 750,55 & 413,74 & 1,55 \\
\hline & 0,3 & 1104,14 & 579,53 & 31,61 & 749,20 & 354,94 & 1,47 \\
\hline & 0,4 & 1019,96 & 553,60 & 30,20 & 747,78 & 272,18 & 1,36 \\
\hline & 0,5 & 961,05 & 530,42 & 28,93 & 746,52 & 214,53 & 1,29 \\
\hline & 0,6 & 892,37 & 506,51 & 27,63 & 745,21 & 147,15 & 1,20 \\
\hline & 0,7 & 846,26 & 478,64 & 26,11 & 743,69 & 102,57 & 1,14 \\
\hline & 0,8 & 792,82 & 471,73 & 25,73 & 743,32 & 49,51 & 1,07 \\
\hline
\end{tabular}


Tabela 5B. Receitas brutas, composição de custos da irrigação, receitas líquidas e relação benefício/custo para o feijão caupi, em cada época de semeadura, nível de manejo da irrigação e risco de $30 \%$. Parnaíba, Piauí.

\begin{tabular}{|c|c|c|c|c|c|c|c|}
\hline $\begin{array}{l}\text { Época de } \\
\text { Semeadura }\end{array}$ & $\mathrm{p}$ & $\begin{array}{c}\mathrm{RB}^{\mathrm{l}} \\
\left(\mathrm{US} \$ \mathrm{ha}^{-1}\right)\end{array}$ & $\begin{array}{c}\mathrm{Eb} \\
\left(\mathrm{kWh} \mathrm{ha} \mathrm{h}^{-1}\right)\end{array}$ & $\begin{array}{c}\mathrm{CE} \\
\left(\mathrm{US} \$ \mathrm{ha}^{-1}\right)\end{array}$ & $\begin{array}{c}\text { CT } \\
\left(\mathrm{US} \$ \mathrm{ha}^{-1}\right)\end{array}$ & $\begin{array}{c}\mathrm{RL} \\
\left(\mathrm{US} \$ \mathrm{ha}^{-1}\right)\end{array}$ & $\mathrm{B} / \mathrm{C}$ \\
\hline \multirow{7}{*}{ 1-Mai } & 0,2 & 982,03 & 688,17 & 37,23 & 754,82 & 227,21 & 1,30 \\
\hline & 0,3 & 928,42 & 668,34 & 36,16 & 753,74 & 174,68 & 1,23 \\
\hline & 0,4 & 854,20 & 645,97 & 34,95 & 752,53 & 101,67 & 1,14 \\
\hline & 0,5 & 799,62 & 634,71 & 34,34 & 751,92 & 47,70 & 1,06 \\
\hline & 0,6 & 744,96 & 628,08 & 33,98 & 751,56 & $-6,60$ & 0,99 \\
\hline & 0,7 & 697,13 & 605,56 & 32,76 & 750,35 & $-53,22$ & 0,93 \\
\hline & 0,8 & 650,08 & 601,66 & 32,55 & 750,14 & $-100,05$ & 0,87 \\
\hline \multirow{7}{*}{ 15-Mai } & 0,2 & 984,44 & 722,24 & 39,07 & 756,66 & 227,78 & 1,30 \\
\hline & 0,3 & 928,66 & 707,30 & 38,27 & 755,85 & 172,81 & 1,23 \\
\hline & 0,4 & 858,55 & 695,30 & 37,62 & 755,20 & 103,35 & 1,14 \\
\hline & 0,5 & 798,07 & 679,08 & 36,74 & 754,32 & 43,74 & 1,06 \\
\hline & 0,6 & 743,98 & 663,38 & 35,89 & 753,47 & $-9,49$ & 0,99 \\
\hline & 0,7 & 695,32 & 660,54 & 35,74 & 753,32 & $-58,00$ & 0,92 \\
\hline & 0,8 & 647,78 & 644,45 & 34,87 & 752,45 & $-104,67$ & 0,86 \\
\hline \multirow{7}{*}{ 1-Jun } & 0,2 & 1072,08 & 777,95 & 44,65 & 762,24 & 309,84 & 1,41 \\
\hline & 0,3 & 1007,89 & 766,28 & 43,98 & 761,57 & 246,32 & 1,32 \\
\hline & 0,4 & 937,06 & 759,41 & 43,59 & 761,17 & 175,88 & 1,23 \\
\hline & 0,5 & 863,08 & 747,01 & 42,88 & 760,46 & 102,62 & 1,13 \\
\hline & 0,6 & 811,12 & 739,19 & 42,43 & 760,01 & 51,11 & 1,07 \\
\hline & 0,7 & 745,28 & 726,44 & 41,69 & 759,28 & $-14,00$ & 0,98 \\
\hline & 0,8 & 700,74 & 720,81 & 41,37 & 758,96 & $-58,22$ & 0,92 \\
\hline \multirow{7}{*}{ 15-Jun } & 0,2 & 1084,19 & 850,34 & 48,81 & 766,39 & 317,80 & 1,41 \\
\hline & 0,3 & 1009,31 & 841,49 & 48,30 & 765,88 & 243,43 & 1,32 \\
\hline & 0,4 & 952,61 & 831,53 & 47,73 & 765,31 & 187,30 & 1,24 \\
\hline & 0,5 & 864,18 & 823,17 & 47,25 & 764,83 & 99,35 & 1,13 \\
\hline & 0,6 & 823,04 & 819,60 & 47,04 & 764,63 & 58,42 & 1,08 \\
\hline & 0,7 & 751,05 & 810,24 & 46,50 & 764,09 & $-13,04$ & 0,98 \\
\hline & 0,8 & 707,52 & 805,04 & 46,21 & 763,79 & $-56,27$ & 0,93 \\
\hline
\end{tabular}


Tabela 5B. Receitas brutas, composição de custos da irrigação, receitas líquidas e relação benefício/custo para o feijão caupi, em cada época de semeadura, nível de manejo da irrigação e risco de $30 \%$. Parnaíba, Piauí.

\begin{tabular}{|c|c|c|c|c|c|c|c|}
\hline $\begin{array}{c}\text { Época de } \\
\text { Semeadura }\end{array}$ & $\mathrm{p}$ & $\begin{array}{c}\mathrm{RB}^{\mathrm{l}} \\
\left(\mathrm{US} \$ \mathrm{ha}^{-1}\right) \\
\end{array}$ & $\begin{array}{c}\mathrm{Eb} \\
\left(\mathrm{kWh} \mathrm{ha} \mathrm{h}^{-1}\right)\end{array}$ & $\begin{array}{c}\mathrm{CE} \\
\left(\mathrm{US} \$ \mathrm{ha}^{-1}\right)\end{array}$ & $\begin{array}{c}\mathrm{CT} \\
\left(\mathrm{US} \$ \mathrm{ha}^{-1}\right)\end{array}$ & $\begin{array}{c}\mathrm{RL} \\
\left(\mathrm{US} \$ \mathrm{ha}^{-1}\right)\end{array}$ & $\mathrm{B} / \mathrm{C}$ \\
\hline \multirow{7}{*}{ 1-Jul } & 0,2 & 1089,24 & 928,31 & 55,39 & 772,98 & 316,26 & 1,41 \\
\hline & 0,3 & 1005,38 & 918,64 & 54,82 & 772,40 & 232,98 & 1,30 \\
\hline & 0,4 & 957,70 & 911,98 & 54,42 & 772,00 & 185,70 & 1,24 \\
\hline & 0,5 & 870,04 & 910,88 & 54,35 & 771,94 & 98,10 & 1,13 \\
\hline & 0,6 & 819,89 & 901,32 & 53,78 & 771,37 & 48,52 & 1,06 \\
\hline & 0,7 & 758,39 & 895,13 & 53,41 & 771,00 & $-12,61$ & 0,98 \\
\hline & 0,8 & 704,85 & 889,39 & 53,07 & 770,65 & $-65,80$ & 0,91 \\
\hline \multirow{7}{*}{ 15-Jul } & 0,2 & 1101,80 & 1006,51 & 60,06 & 777,64 & 324,16 & 1,42 \\
\hline & 0,3 & 1010,79 & 996,10 & 59,44 & 777,02 & 233,77 & 1,30 \\
\hline & 0,4 & 967,96 & 995,97 & 59,43 & 777,01 & 190,94 & 1,25 \\
\hline & 0,5 & 891,69 & 992,05 & 59,20 & 776,78 & 114,91 & 1,15 \\
\hline & 0,6 & 822,04 & 988,40 & 58,98 & 776,56 & 45,48 & 1,06 \\
\hline & 0,7 & 777,03 & 982,59 & 58,63 & 776,22 & 0,81 & 1,00 \\
\hline & 0,8 & 706,48 & 980,59 & 58,51 & 776,10 & $-69,61$ & 0,91 \\
\hline \multirow{7}{*}{ 1-Ago } & 0,2 & 1064,06 & 1099,05 & 66,11 & 783,69 & 280,36 & 1,36 \\
\hline & 0,3 & 971,96 & 1092,39 & 65,71 & 783,29 & 188,67 & 1,24 \\
\hline & 0,4 & 928,62 & 1088,90 & 65,50 & 783,08 & 145,53 & 1,19 \\
\hline & 0,5 & 875,85 & 1087,41 & 65,41 & 782,99 & 92,85 & 1,12 \\
\hline & 0,6 & 786,92 & 1080,59 & 65,00 & 782,58 & 4,34 & 1,01 \\
\hline & 0,7 & 751,56 & 1076,60 & 64,76 & 782,34 & $-30,79$ & 0,96 \\
\hline & 0,8 & 694,38 & 1074,21 & 64,62 & 782,20 & $-87,82$ & 0,89 \\
\hline \multirow{7}{*}{ 15-Ago } & 0,2 & 1073,03 & 1149,32 & 69,13 & 786,72 & 286,32 & 1,36 \\
\hline & 0,3 & 980,66 & 1145,71 & 68,92 & 786,50 & 194,16 & 1,25 \\
\hline & 0,4 & 932,90 & 1140,23 & 68,59 & 786,17 & 146,73 & 1,19 \\
\hline & 0,5 & 889,31 & 1132,55 & 68,12 & 785,71 & 103,60 & 1,13 \\
\hline & 0,6 & 796,50 & 1132,05 & 68,09 & 785,68 & 10,82 & 1,01 \\
\hline & 0,7 & 750,97 & 1125,39 & 67,69 & 785,28 & $-34,31$ & 0,96 \\
\hline & 0,8 & 712,29 & 1127,93 & 67,85 & 785,43 & $-73,14$ & 0,91 \\
\hline
\end{tabular}


Tabela 5B. Receitas brutas, composição de custos da irrigação, receitas liquidas e relação beneficio/custo para o feijão caupi, em cada época de semeadura, nivel de manejo da irrigação e risco de 30 \%. Parnaiba, Piauí.

\begin{tabular}{|c|c|c|c|c|c|c|c|}
\hline $\begin{array}{l}\text { Época de } \\
\text { Semeadura }\end{array}$ & $\mathrm{p}$ & $\begin{array}{c}\mathrm{RB}^{\mathrm{l}} \\
\left(\mathrm{US} \$ \mathrm{ha}^{-1}\right)\end{array}$ & $\begin{array}{c}E b \\
\left(k W h h^{-1}\right)\end{array}$ & $\begin{array}{c}C E \\
\left(\mathrm{US} \$ \mathrm{ha}^{-1}\right)\end{array}$ & $\begin{array}{c}\mathrm{CT} \\
\left(\mathrm{US} \$ \mathrm{ha}^{-1}\right)\end{array}$ & $\begin{array}{c}\mathrm{RL} \\
\left(\mathrm{US} \$ \mathrm{ha}^{-1}\right)\end{array}$ & $\mathrm{B} / \mathrm{C}$ \\
\hline \multirow{7}{*}{$1-$ Set } & 0,2 & 1088,49 & 1186,41 & 69,45 & 787,04 & 301,46 & 1,38 \\
\hline & 0,3 & 997,19 & 1182,73 & 69,24 & 786,82 & 210,36 & 1,27 \\
\hline & 0,4 & 942,88 & 1177,59 & 68,94 & 786,52 & 156,35 & 1,20 \\
\hline & 0,5 & 906,65 & 1171,21 & 68,56 & 786,15 & 120,50 & 1,15 \\
\hline & 0,6 & 814,02 & 1174,35 & 68,75 & 786,33 & 27,69 & 1,04 \\
\hline & 0,7 & 757,90 & 1165,79 & 68,25 & 785,83 & $-27,93$ & 0,96 \\
\hline & 0,8 & 736,31 & 1162,63 & 68,06 & 785,65 & $-49,34$ & 0,94 \\
\hline \multirow{7}{*}{$15-\mathrm{Set}$} & 0,2 & 1089,74 & 1179,01 & 69,02 & 786,61 & 303,14 & 1,39 \\
\hline & 0,3 & 995,91 & 1176,06 & 68,85 & 786,43 & 209,48 & 1,27 \\
\hline & 0,4 & 943,93 & 1169,46 & 68,46 & 786,05 & 157,89 & 1,20 \\
\hline & 0,5 & 907,17 & 1165,30 & 68,22 & 785,80 & 121,37 & 1,15 \\
\hline & 0,6 & 815,17 & 1167,30 & 68,34 & 785,92 & 29,25 & 1,04 \\
\hline & 0,7 & 760,44 & 1161,67 & 68,01 & 785,59 & $-25,15$ & 0,97 \\
\hline & 0,8 & 734,89 & 1151,25 & 67,40 & 784,98 & $-50,09$ & 0,94 \\
\hline \multirow{7}{*}{ 1-Out } & 0,2 & 1097,10 & 1172,23 & 69,67 & 787,25 & 309,84 & 1,39 \\
\hline & 0,3 & 1009,68 & 1169,20 & 69,49 & 787,07 & 222,61 & 1,28 \\
\hline & 0,4 & 955,13 & 1162,74 & 69,10 & 786,69 & 168,44 & 1,21 \\
\hline & 0,5 & 915,99 & 1157,41 & 68,79 & 786,37 & 129,62 & 1,16 \\
\hline & 0,6 & 822,18 & 1157,67 & 68,80 & 786,39 & 35,79 & 1,05 \\
\hline & 0,7 & 768,08 & 1152,17 & 68,48 & 786,06 & $-17,98$ & 0,98 \\
\hline & 0,8 & 743,71 & 1141,95 & 67,87 & 785,45 & $-41,75$ & 0,95 \\
\hline \multirow{7}{*}{ 15-Out } & 0,2 & 1097,46 & 1145,27 & 68,07 & 785,65 & 311,81 & 1,40 \\
\hline & 0,3 & 1002,39 & 1136,96 & 67,57 & 785,16 & 217,23 & 1,28 \\
\hline & 0,4 & 954,59 & 1135,98 & 67,51 & 785,10 & 169,49 & 1,22 \\
\hline & 0,5 & 913,46 & 1126,81 & 66,97 & 784,55 & 128,90 & 1,16 \\
\hline & 0,6 & 816,84 & 1125,42 & 66,89 & 784,47 & 32,37 & 1,04 \\
\hline & 0,7 & 770,19 & 1114,67 & 66,25 & 783,83 & $-13,65$ & 0,98 \\
\hline & 0,8 & 735,17 & 1115,29 & 66,28 & 783,87 & $-48,69$ & 0,94 \\
\hline
\end{tabular}


Tabela 5B. Receitas brutas, composição de custos da irrigação, receitas líquidas e relação beneficio/custo para o feijão caupi, em cada época de semeadura, nível de manejo da irrigação e risco de $30 \%$. Parnaíba, Piauí.

\begin{tabular}{|c|c|c|c|c|c|c|c|}
\hline $\begin{array}{c}\text { Época de } \\
\text { Semeadura }\end{array}$ & $\mathrm{p}$ & $\begin{array}{c}\mathrm{RB}^{1} \\
\left(\mathrm{US} \$ \mathrm{ha}^{-1}\right)\end{array}$ & $\begin{array}{c}E b \\
\left(\mathrm{kWh} \mathrm{ha}^{-1}\right)\end{array}$ & $\begin{array}{c}\text { CE } \\
\left(\mathrm{US} \$ \mathrm{ha}^{-1}\right)\end{array}$ & $\begin{array}{c}\mathrm{CT} \\
\left(\mathrm{US} \$ \mathrm{ha}^{-1}\right)\end{array}$ & $\begin{array}{c}\mathrm{RL} \\
\left(\mathrm{US} \$ \mathrm{ha}^{-1}\right)\end{array}$ & $\mathrm{B} / \mathrm{C}$ \\
\hline \multirow{7}{*}{$1-\mathrm{Nov}$} & 0,2 & 1263,68 & 1038,11 & 62,06 & 779,65 & 484,03 & 1,62 \\
\hline & 0,3 & 1164,68 & 1030,87 & 61,63 & 779,22 & 385,46 & 1,49 \\
\hline & 0,4 & 1110,20 & 1018,44 & 60,89 & 778,47 & 331,73 & 1,43 \\
\hline & 0,5 & 1038,08 & 1007,79 & 60,25 & 777,84 & 260,24 & 1,33 \\
\hline & 0,6 & 949,75 & 1006,47 & 60,17 & 777,76 & 171,99 & 1,22 \\
\hline & 0,7 & 899,16 & 996,74 & 59,59 & 777,18 & 121,98 & 1,16 \\
\hline & 0,8 & 833,16 & 989,46 & 59,16 & 776,74 & 56,42 & 1,07 \\
\hline \multirow{7}{*}{ 15-Nov } & 0,2 & 1250,80 & 926,24 & 55,38 & 772,96 & 477,84 & 1,62 \\
\hline & 0,3 & 1159,02 & 911,12 & 54,47 & 772,06 & 386,96 & 1,50 \\
\hline & 0,4 & 1106,11 & 901,49 & 53,90 & 771,48 & 334,63 & 1,43 \\
\hline & 0,5 & 1025,15 & 889,11 & 53,16 & 770,74 & 254,41 & 1,33 \\
\hline & 0,6 & 951,70 & 872,66 & 52,17 & 769,76 & 181,95 & 1,24 \\
\hline & 0,7 & 901,67 & 863,31 & 51,61 & 769,20 & 132,47 & 1,17 \\
\hline & 0,8 & 833,70 & 849,59 & 50,79 & 768,38 & 65,32 & 1,09 \\
\hline \multirow{7}{*}{ 1-Dez } & 0,2 & 1272,59 & 845,25 & 49,59 & 767,18 & 505,41 & 1,66 \\
\hline & 0,3 & 1187,08 & 826,20 & 48,48 & 766,06 & 421,02 & 1,55 \\
\hline & 0,4 & 1128,00 & 812,31 & 47,66 & 765,25 & 362,76 & 1,47 \\
\hline & 0,5 & 1043,54 & 791,99 & 46,47 & 764,05 & 279,49 & 1,37 \\
\hline & 0,6 & 977,03 & 777,48 & 45,62 & 763,20 & 213,83 & 1,28 \\
\hline & 0,7 & 918,92 & 765,26 & 44,90 & 762,49 & 156,43 & 1,21 \\
\hline & 0,8 & 858,40 & 756,63 & 44,39 & 761,98 & 96,42 & 1,13 \\
\hline \multirow{7}{*}{ 15-Dez } & 0,2 & 1264,70 & 735,58 & 43,16 & 760,74 & 503,96 & 1,66 \\
\hline & 0,3 & 1184,27 & 707,01 & 41,48 & 759,07 & 425,21 & 1,56 \\
\hline & 0,4 & 1124,96 & 688,28 & 40,38 & 757,97 & 366,99 & 1,48 \\
\hline & 0,5 & 1040,43 & 666,02 & 39,08 & 756,66 & 283,76 & 1,38 \\
\hline & 0,6 & 983,06 & 649,48 & 38,11 & 755,69 & 227,37 & 1,30 \\
\hline & 0,7 & 920,21 & 627,33 & 36,81 & 754,39 & 165,82 & 1,22 \\
\hline & 0,8 & 868,68 & 614,87 & 36,08 & 753,66 & 115,02 & 1,15 \\
\hline
\end{tabular}

${ }^{\mathrm{T}} \mathrm{RB}$ - receita bruta: $\mathrm{Eb}$ - energia requerida para o bombeamento: $\mathrm{CE}$ - custo de energia elétrica; $\mathrm{CT}$ - custo total de produção: $\mathrm{RL}$ - receita líquida e $\mathrm{B} / \mathrm{C}$ - relação benefício/custo. 
Tabela 6B. Receitas brutas, composição de custos da irrigação, receitas líquidas e relação beneficio/custo para o feijão caupi, em cada época de semeadura, nível de manejo da irrigação e risco de $35 \%$. Parnaiba, Piaui.

\begin{tabular}{|c|c|c|c|c|c|c|c|}
\hline $\begin{array}{l}\text { Época de } \\
\text { Semeadura }\end{array}$ & $\mathrm{p}$ & $\begin{array}{c}\mathrm{RB}^{1} \\
\left(\mathrm{US} \$ \mathrm{ha}^{-1}\right)\end{array}$ & $\begin{array}{c}E b \\
\left(\mathrm{kWh} \mathrm{ha-}{ }^{-1}\right)\end{array}$ & $\begin{array}{c}\text { CE } \\
\left(\mathrm{US} \$ \mathrm{ha}^{-1}\right)\end{array}$ & $\begin{array}{c}\text { CT } \\
\left(\text { US\$ ha }{ }^{-1}\right)\end{array}$ & $\begin{array}{c}\mathrm{RL} \\
\left(\mathrm{US} \$ \mathrm{ha}^{-1}\right)\end{array}$ & $\mathrm{B} / \mathrm{C}$ \\
\hline \multirow{7}{*}{ 1-Jan } & 0,2 & 1221,21 & 621,12 & 35,70 & 753,28 & 467,92 & 1,62 \\
\hline & 0,3 & 1153,15 & 593,01 & 34,08 & 751,67 & 401,49 & 1,53 \\
\hline & 0,4 & 1093,28 & 565,39 & 32,50 & 750,08 & 343,20 & 1,46 \\
\hline & 0,5 & 1025,97 & 538,22 & 30,93 & 748,52 & 277,46 & 1,37 \\
\hline & 0,6 & 973,27 & 509,59 & 29,29 & 746,87 & 226,40 & 1,30 \\
\hline & 0,7 & 917,82 & 486,96 & 27,99 & 745,57 & 172,25 & 1,23 \\
\hline & 0,8 & 873,85 & 464,21 & 26,68 & 744,27 & 129,59 & 1,17 \\
\hline \multirow{7}{*}{ 15-Jan } & 0,2 & 1233,35 & 562,15 & 32,31 & 749,89 & 483,45 & 1,64 \\
\hline & 0,3 & 1171,47 & 530,65 & 30,50 & 748,08 & 423,39 & 1,57 \\
\hline & 0,4 & 1105,60 & 501,85 & 28,84 & 746,43 & 359,17 & 1,48 \\
\hline & 0,5 & 1043,54 & 470,44 & 27,04 & 744,62 & 298,92 & 1,40 \\
\hline & 0,6 & 986,96 & 437,57 & 25,15 & 742,73 & 244,23 & 1,33 \\
\hline & 0,7 & 937,19 & 415,90 & 23,90 & 741,49 & 195,70 & 1,26 \\
\hline & 0,8 & 897,48 & 398,59 & 22,91 & 740,49 & 156,99 & 1,21 \\
\hline \multirow{7}{*}{$1-\mathrm{Fev}$} & 0,2 & 1189,13 & 511,70 & 29,02 & 746,61 & 442,52 & 1,59 \\
\hline & 0,3 & 1132,97 & 476,28 & 27,01 & 744,60 & 388,38 & 1,52 \\
\hline & 0,4 & 1065,37 & 439,36 & 24,92 & 742,50 & 322,87 & 1,43 \\
\hline & 0,5 & 1014,66 & 410,42 & 23,28 & 740,86 & 273,80 & 1,37 \\
\hline & 0,6 & 963,20 & 385,36 & 21,86 & 739,44 & 223,75 & 1,30 \\
\hline & 0,7 & 919,37 & 360,62 & 20,45 & 738,04 & 181,33 & 1,25 \\
\hline & 0,8 & 876,78 & 331,25 & 18,79 & 736,37 & 140,41 & 1,19 \\
\hline \multirow{7}{*}{$15-\mathrm{Fev}$} & 0,2 & 1184,20 & 463,76 & 26,30 & 743,89 & 440,31 & 1,59 \\
\hline & 0,3 & 1133,41 & 432,55 & 24,53 & 742,12 & 391,29 & 1,53 \\
\hline & 0,4 & 1061,94 & 390,62 & 22,16 & 739,74 & 322,20 & 1,44 \\
\hline & 0,5 & 1015,24 & 358,92 & 20,36 & 737,94 & 277,30 & 1,38 \\
\hline & 0,6 & 964,16 & 319,20 & 18,10 & 735,69 & 228,47 & 1,31 \\
\hline & 0,7 & 932,01 & 304,93 & 17,30 & 734,88 & 197,13 & 1,27 \\
\hline & 0,8 & 887,15 & 282,28 & 16,01 & 733,60 & 153,55 & 1,21 \\
\hline
\end{tabular}


Tabela 6B. Receitas brutas, composição de custos da irrigação, receitas líquidas e relação benefício/custo para o feijão caupi, em cada época de semeadura, nível de manejo da irrigação e risco de $35 \%$. Pamaíba, Piauí.

\begin{tabular}{|c|c|c|c|c|c|c|c|}
\hline $\begin{array}{c}\text { Época de } \\
\text { Semeadura }\end{array}$ & $p$ & $\begin{array}{c}\mathrm{RB}^{1} \\
\left(\mathrm{US} \$ \mathrm{ha}^{-1}\right)\end{array}$ & $\begin{array}{c}\text { Eb } \\
\left(\mathrm{kWh} \mathrm{ha}^{-1}\right)\end{array}$ & $\begin{array}{c}\text { CE } \\
\left(\text { US } \$ \mathrm{ha}^{-1}\right) \\
\end{array}$ & $\begin{array}{c}\text { CT } \\
\left(\text { US } \$ h^{-1}\right)^{-1} \\
\end{array}$ & $\begin{array}{c}\mathrm{RL} \\
\left(\mathrm{US} \$ \mathrm{ha}^{-\mathrm{I}}\right) \\
\end{array}$ & $\mathrm{B} / \mathrm{C}$ \\
\hline \multirow{7}{*}{ 1-Mar } & 0,2 & 1219,07 & 447,08 & 25,03 & 742,61 & 476,46 & 1,64 \\
\hline & 0,3 & 1168,22 & 414,48 & 23,20 & 740,79 & 427,44 & 1,58 \\
\hline & 0,4 & 1093,76 & 376,49 & 21,07 & 738,66 & 355,10 & 1,48 \\
\hline & 0,5 & 1048,04 & 339,46 & 19,00 & 736,59 & 311,45 & 1,42 \\
\hline & 0,6 & 995,47 & 314,48 & 17,60 & 735,19 & 260,28 & 1,35 \\
\hline & 0,7 & 954,44 & 282,29 & 15,80 & 733,39 & 221,05 & 1,30 \\
\hline & 0,8 & 915,20 & 252,51 & 14,13 & 731,72 & 183,48 & 1,25 \\
\hline \multirow{7}{*}{ 15-Mar } & 0,2 & 1209,24 & 466,96 & 26,14 & 743,72 & 465,51 & 1,63 \\
\hline & 0,3 & 1159,57 & 432,20 & 24,19 & 741,78 & 417,79 & 1,56 \\
\hline & 0,4 & 1080,19 & 395,73 & 22,15 & 739,74 & 340,46 & 1,46 \\
\hline & 0,5 & 1031,32 & 362,43 & 20,29 & 737,87 & 293,45 & 1,40 \\
\hline & 0,6 & 974,49 & 337,92 & 18,92 & 736,50 & 237,99 & 1,32 \\
\hline & 0,7 & 932,67 & 305,35 & 17,09 & 734,68 & 198,00 & 1,27 \\
\hline & 0,8 & 887,89 & 277,35 & 15,53 & 733,11 & 154,78 & 1,21 \\
\hline \multirow{7}{*}{$1-\mathrm{Abr}$} & 0,2 & 1201,80 & 535,06 & 28,39 & 745,97 & 455,83 & 1,61 \\
\hline & 0,3 & 1144,62 & 507,13 & 26,91 & 744,49 & 400,13 & 1,54 \\
\hline & 0,4 & 1061,91 & 480,33 & 25,48 & 743,07 & 318,84 & 1,43 \\
\hline & 0,5 & 1009,65 & 450,33 & 23,89 & 741,48 & 268,17 & 1,36 \\
\hline & 0,6 & 942,71 & 419,59 & 22,26 & 739,85 & 202,86 & 1,27 \\
\hline & 0,7 & 900,93 & 401,52 & 21,30 & 738,89 & 162,05 & 1,22 \\
\hline & 0,8 & 851,55 & 374,38 & 19,86 & 737,45 & 114,11 & 1,15 \\
\hline \multirow{7}{*}{$15-\mathrm{Abr}$} & 0,2 & 1198,05 & 596,44 & 31,65 & 749,23 & 448,82 & 1,60 \\
\hline & 0,3 & 1136,63 & 570,07 & 30,25 & 747,83 & 388,80 & 1,52 \\
\hline & 0,4 & 1051,31 & 544,10 & 28,87 & 746,45 & 304,86 & 1,41 \\
\hline & 0,5 & 991,59 & 519,78 & 27,58 & 745,16 & 246,43 & 1,33 \\
\hline & 0,6 & 922,02 & 494,39 & 26,23 & 743,82 & 178,20 & 1,24 \\
\hline & 0,7 & 874,96 & 465,56 & 24,70 & 742,29 & 132,67 & 1,18 \\
\hline & 0,8 & 820,81 & 457,64 & 24,28 & 741,87 & 78,95 & 1,11 \\
\hline
\end{tabular}


Tabela 6B. Receitas brutas, composição de custos da irrigação, receitas líquidas e relação beneficio/custo para o feijão caupi, em cada época de semeadura, nível de manejo da irrigação e risco de 35 \%. Parnaíba, Piauí.

\begin{tabular}{|c|c|c|c|c|c|c|c|}
\hline $\begin{array}{l}\text { Época de } \\
\text { Semeadura }\end{array}$ & $\mathrm{p}$ & $\begin{array}{c}\mathrm{RB}^{\mathrm{l}} \\
\left(\mathrm{US} \$ \mathrm{ha}^{-1}\right)\end{array}$ & $\begin{array}{c}E b \\
\left(\mathrm{kWh} \mathrm{ha}^{-1}\right)\end{array}$ & $\begin{array}{c}\text { CE } \\
\left(\mathrm{US} \$ \mathrm{ha}^{-1}\right)\end{array}$ & $\begin{array}{c}\mathrm{CT} \\
\left(\mathrm{US} \$ \mathrm{ha}^{-1}\right)\end{array}$ & $\begin{array}{c}\mathrm{RL} \\
\left(\mathrm{US} \$ \mathrm{ha}^{-1}\right)\end{array}$ & $\mathrm{B} / \mathrm{C}$ \\
\hline \multirow{7}{*}{ 1-Mai } & 0,2 & 1021,60 & 681,34 & 36,06 & 753,65 & 267,95 & 1,36 \\
\hline & 0,3 & 966,14 & 661,08 & 34,99 & 752,58 & 213,57 & 1,28 \\
\hline & 0,4 & 889,88 & 637,59 & 33,75 & 751,33 & 138,55 & 1,18 \\
\hline & 0,5 & 833,30 & 625,59 & 33,11 & 750,70 & 82,60 & 1,11 \\
\hline & 0,6 & 776,95 & 617,53 & 32,69 & 750,27 & 26,68 & 1,04 \\
\hline & 0,7 & 727,68 & 593,29 & 31,40 & 748,99 & $-21,31$ & 0,97 \\
\hline & 0,8 & 678,74 & 588,22 & 31,14 & 748,72 & $-69,98$ & 0,91 \\
\hline \multirow{7}{*}{ 15-Mai } & 0,2 & 1024,24 & 715,63 & 37,88 & 755,46 & 268,78 & 1,36 \\
\hline & 0,3 & 966,17 & 699,51 & 37,03 & 754,61 & 211,56 & 1,28 \\
\hline & 0,4 & 894,62 & 687,09 & 36,37 & 753,95 & 140,66 & 1,19 \\
\hline & 0,5 & 831,58 & 669,86 & 35,46 & 753,04 & 78,53 & 1,10 \\
\hline & 0,6 & 775,81 & 653,72 & 34,60 & 752,19 & 23,62 & 1,03 \\
\hline & 0,7 & 725,43 & 649,86 & 34,40 & 751,98 & $-26,56$ & 0,96 \\
\hline & 0,8 & 676,09 & 633,56 & 33,54 & 751,12 & $-75,03$ & 0,90 \\
\hline \multirow{7}{*}{ 1-Jun } & 0,2 & 1108,60 & 772,90 & 43,50 & 761,08 & 347,52 & 1,46 \\
\hline & 0,3 & 1041,99 & 760,85 & 42,82 & 760,40 & 281,58 & 1,37 \\
\hline & 0,4 & 970,26 & 753,04 & 42,38 & 759,96 & 210,30 & 1,28 \\
\hline & 0,5 & 893,20 & 740,06 & 41,65 & 759,23 & 133,97 & 1,18 \\
\hline & 0,6 & 840,67 & 731,95 & 41,19 & 758,78 & 81,89 & 1,11 \\
\hline & 0,7 & 772,37 & 718,40 & 40,43 & 758,01 & 14,35 & 1,02 \\
\hline & 0,8 & 726,95 & 711,84 & 40,06 & 757,65 & $-30,69$ & 0,96 \\
\hline \multirow{7}{*}{ 15-Jun } & 0,2 & 1121,16 & 845,66 & 47,59 & 765,18 & 355,98 & 1,47 \\
\hline & 0,3 & 1043,55 & 836,59 & 47,08 & 764,67 & 278,89 & 1,36 \\
\hline & 0,4 & 986,00 & 825,80 & 46,47 & 764,06 & 221,94 & 1,29 \\
\hline & 0,5 & 894,35 & 817,66 & 46,02 & 763,60 & 130,75 & 1,17 \\
\hline & 0,6 & 852,27 & 812,89 & 45,75 & 763,33 & 88,94 & 1,12 \\
\hline & 0,7 & 778,67 & 802,92 & 45,19 & 762,77 & 15,90 & 1,02 \\
\hline & 0,8 & 733,41 & 797,53 & 44,88 & 762,47 & $-29,06$ & 0,96 \\
\hline
\end{tabular}


Tabela 6B. Receitas brutas, composição de custos da irrigação, receitas líquidas e relação beneficio/custo para o feijão caupi, em cada época de semeadura, nível de manejo da irrigação e risco de $35 \%$. Parnaíba, Piauí.

\begin{tabular}{|c|c|c|c|c|c|c|c|}
\hline $\begin{array}{l}\text { Época de } \\
\text { Semeadura }\end{array}$ & $\mathrm{p}$ & $\begin{array}{c}\mathrm{RB}^{1} \\
\left(\mathrm{US} \$ \mathrm{ha}^{-1}\right)\end{array}$ & $\begin{array}{c}E b \\
\left(\mathrm{kWh} \mathrm{ha} a^{-1}\right)\end{array}$ & 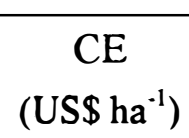 & $\begin{array}{c}C T \\
\left(\mathrm{US} \$ h \mathrm{~h}^{-1}\right)\end{array}$ & $\begin{array}{c}\mathrm{RL} \\
\left(\mathrm{US} \$ \mathrm{ha}^{-1}\right)\end{array}$ & $\mathrm{B} / \mathrm{C}$ \\
\hline \multirow{7}{*}{ 1-Jul } & 0,2 & 1122,61 & 924,48 & 54,40 & 771,98 & 350,63 & 1,45 \\
\hline & 0,3 & 1036,06 & 914,28 & 53,80 & 771,38 & 264,68 & 1,34 \\
\hline & 0,4 & 987,79 & 907,36 & 53,39 & 770,97 & 216,81 & 1,28 \\
\hline & 0,5 & 897,89 & 904,96 & 52,2 & 170,83 & 127,06 & 1,16 \\
\hline & 0,6 & 845,69 & 895,66 & 52,70 & 770,29 & 75,40 & 1,10 \\
\hline & 0,7 & 783,36 & 888,83 & 52,30 & 769,88 & 13,47 & 1,02 \\
\hline & 0,8 & 727,89 & 882,76 & 51,94 & 769,53 & $-41,64$ & 0,95 \\
\hline \multirow{7}{*}{ 15-Jul } & 0,2 & 1135,51 & 1002,62 & 58,99 & 776,58 & 358,93 & 1,46 \\
\hline & 0,3 & 1041,71 & 992,22 & 58,38 & 775,97 & 265,75 & 1,34 \\
\hline & 0,4 & 997,75 & 991,47 & 58,34 & 775,92 & 221,83 & 1,29 \\
\hline & 0,5 & 920,64 & 987,16 & 58,08 & 775,67 & 144,97 & 1,19 \\
\hline & 0,6 & 847,86 & 983,17 & 57,85 & 775,43 & 72,43 & 1,09 \\
\hline & 0,7 & 802,29 & 977,32 & 57,51 & 775,09 & 27,20 & 1,04 \\
\hline & 0,8 & 729,95 & 975,16 & 57,38 & 774,96 & $-45,01$ & 0,94 \\
\hline \multirow{7}{*}{ 1-Ago } & 0,2 & 1099,42 & 1096,99 & 65,08 & 782,67 & 316,76 & 1,40 \\
\hline & 0,3 & 1004,35 & 1089,91 & 64,66 & 782,25 & 222,10 & 1,28 \\
\hline & 0,4 & 959,65 & 1086,64 & 64,47 & 782,05 & 177,59 & 1,23 \\
\hline & 0,5 & 906,15 & 1084,49 & 64,34 & 781,93 & 124,22 & 1,16 \\
\hline & 0,6 & 813,85 & 1077,87 & 63,95 & 781,53 & 32,31 & 1,04 \\
\hline & 0,7 & 777,12 & 1074,10 & 63,72 & 781,31 & $-4,19$ & 0,99 \\
\hline & 0,8 & 719,50 & 1070,43 & 63,51 & 781,09 & $-61,59$ & 0,92 \\
\hline \multirow{7}{*}{ 15-Ago } & 0,2 & 1108,64 & 1147,31 & 68,07 & 785,65 & 322,99 & 1,41 \\
\hline & 0,3 & 1013,51 & 1143,20 & 67,82 & 785,41 & 228,10 & 1,29 \\
\hline & 0,4 & 964,04 & 1138,12 & 67,52 & 785,11 & 178,93 & 1,23 \\
\hline & 0,5 & 919,63 & 1129,98 & 67,04 & 784,62 & 135,01 & 1,17 \\
\hline & 0,6 & 824,21 & 1128,94 & 66,98 & 784,56 & 39,65 & 1,05 \\
\hline & 0,7 & 776,35 & 1121,24 & 66,52 & 784,11 & $-7,76$ & 0,99 \\
\hline & 0,8 & 737,45 & 1124,08 & 66,69 & 784,27 & $-46,82$ & 0,94 \\
\hline
\end{tabular}


Tabela 6B. Receitas brutas, composição de custos da irrigação, receitas líquidas e relação benefício/custo para o feijão caupi, em cada época de semeadura, nível de manejo da irrigação e risco de 35 \%. Parnaíba, Piauí.

\begin{tabular}{|c|c|c|c|c|c|c|c|}
\hline $\begin{array}{l}\text { Época de } \\
\text { Semeadura }\end{array}$ & $p$ & $\begin{array}{c}\mathrm{RB}^{1} \\
\left(\mathrm{US} \$ \mathrm{ha}^{-1}\right)\end{array}$ & $\begin{array}{c}E b \\
\left(k W h a^{-1}\right)\end{array}$ & $\begin{array}{c}\text { CE } \\
\left(\text { US } \$ \mathrm{ha}^{-1}\right)\end{array}$ & $\begin{array}{c}\text { CT } \\
\left(\text { US } \$ \mathrm{ha}^{-1}\right)\end{array}$ & $\begin{array}{c}\mathrm{RL} \\
\left(\mathrm{US} \$ \mathrm{ha}^{-1}\right)\end{array}$ & $\mathrm{B} / \mathrm{C}$ \\
\hline \multirow{7}{*}{$1-$ Set } & 0,2 & 1123,42 & 1184,58 & 68,60 & 786,18 & 337,24 & 1,43 \\
\hline & 0,3 & 1029,88 & 1180,54 & 68,36 & 785,95 & 243,94 & 1,31 \\
\hline & 0,4 & 973,36 & 1175,45 & 68,07 & 785,65 & 187,71 & 1,24 \\
\hline & 0,5 & 936,26 & 1168,73 & 67,68 & 785,26 & 151,00 & 1,19 \\
\hline & 0,6 & 842,11 & 1171,57 & 67,84 & 785,43 & 56,69 & 1,07 \\
\hline & 0,7 & 782,75 & 1161,86 & 67,28 & 784,86 & $-2,12$ & 1,00 \\
\hline & 0,8 & 760,59 & 1158,61 & 67,09 & 784,68 & $-24,08$ & 0,97 \\
\hline \multirow{7}{*}{ 15-Set } & 0,2 & 1124,68 & 1176,53 & 68,13 & 785,71 & 338,96 & 1,43 \\
\hline & 0,3 & 1028,43 & 1173,55 & 67,96 & 785,54 & 242,89 & 1,31 \\
\hline & 0,4 & 977,73 & 1166,92 & 67,57 & 785,16 & 192,57 & 1,25 \\
\hline & 0,5 & 936,94 & 1162,14 & 67,30 & 784,88 & 152,06 & 1,19 \\
\hline & 0,6 & 843,27 & 1164,13 & 67,41 & 785,00 & 58,27 & 1,07 \\
\hline & 0,7 & 785,66 & 1157,31 & 67,02 & 784,60 & 1,06 & 1,00 \\
\hline & 0,8 & 759,49 & 1147,39 & 66,44 & 784,03 & $-24,53$ & 0,97 \\
\hline \multirow{7}{*}{ 1-Out } & 0,2 & 1129,79 & 1169,16 & 68,68 & 786,26 & 343,53 & 1,44 \\
\hline & 0,3 & 1037,83 & 1165,63 & 68,47 & 786,05 & 251,77 & 1,32 \\
\hline & 0,4 & 981,50 & 1159,03 & 68,08 & 785,67 & 195,84 & 1,25 \\
\hline & 0,5 & 941,68 & 1153,29 & 67,74 & 785,33 & 156,35 & 1,20 \\
\hline & 0,6 & 846,43 & 1153,17 & 67,74 & 785,32 & 61,11 & 1,08 \\
\hline & 0,7 & 789,99 & 1147,65 & 67,41 & 785,00 & 5,00 & 1,01 \\
\hline & 0,8 & 764,91 & 1137,26 & 66,80 & 784,39 & $-19,48$ & 0,98 \\
\hline \multirow{7}{*}{ 15-Out } & 0,2 & 1127,53 & 1141,71 & 67,06 & 784,65 & 342,88 & 1,44 \\
\hline & 0,3 & 1030,25 & 1133,08 & 66,56 & 784,14 & 246,10 & 1,31 \\
\hline & 0,4 & 981,05 & 1132,22 & 66,51 & 784,09 & 196,95 & 1,25 \\
\hline & 0,5 & 939,18 & 1122,67 & 65,95 & 783,53 & 155,65 & 1,20 \\
\hline & 0,6 & 840,91 & 1120,71 & 65,83 & 783,42 & 57,50 & 1,07 \\
\hline & 0,7 & 792,12 & 1109,20 & 65,15 & 782,74 & 9,38 & 1,01 \\
\hline & 0,8 & 756,95 & 1109,95 & 65,20 & 782,78 & $-25,83$ & 0,97 \\
\hline
\end{tabular}


Tabela 6B. Receitas brutas, composição de custos da irrigação, receitas líquidas e relação benefício/custo para o feijão caupi, em cada época de semeadura, nível de manejo da irrigação e risco de $35 \%$. Parnaíba, Piauí.

\begin{tabular}{|c|c|c|c|c|c|c|c|}
\hline $\begin{array}{l}\text { Época de } \\
\text { Semeadura }\end{array}$ & $\mathrm{p}$ & $\begin{array}{c}\mathrm{RB}^{1} \\
\left(\mathrm{US} \$ \mathrm{ha}^{-1}\right)\end{array}$ & $\begin{array}{c}E b \\
\left(\mathrm{kWh} \mathrm{ha}^{-1}\right)\end{array}$ & $\begin{array}{c}\text { CE } \\
\left(\text { US\$ ha }{ }^{-1}\right)\end{array}$ & $\begin{array}{c}\text { CT } \\
\left(\mathrm{US} \$ \mathrm{ha}^{-1}\right)\end{array}$ & $\begin{array}{c}\mathrm{RL} \\
\left(\mathrm{US} \$ \mathrm{ha}^{-1}\right)\end{array}$ & $\mathrm{B} / \mathrm{C}$ \\
\hline \multirow{7}{*}{$1-\mathrm{Nov}$} & 0,2 & 1296,27 & 1032,05 & 61,03 & 778,61 & 517,66 & 1,66 \\
\hline & 0,3 & 1194,82 & 1023,89 & 60,54 & 778,13 & 416,69 & 1,54 \\
\hline & 0,4 & 1139,21 & 1011,18 & 59,79 & 777,38 & 361,84 & 1,47 \\
\hline & 0,5 & 1066,37 & 1000,46 & 59,16 & 776,74 & 289,63 & 1,37 \\
\hline & 0,6 & 975,91 & 997,98 & 59,01 & 776,60 & 199,31 & 1,26 \\
\hline & 0,7 & 923,99 & 987,52 & 58,39 & 775,98 & 148,02 & 1,19 \\
\hline & 0,8 & 857,41 & 979,55 & 57,92 & 775,51 & 81,90 & 1,11 \\
\hline \multirow{7}{*}{$15-\mathrm{Nov}$} & 0,2 & 1283,13 & 919,07 & 54,35 & 771,93 & 511,20 & 1,66 \\
\hline & 0,3 & 1189,44 & 903,26 & 53,41 & 771,00 & 418,44 & 1,54 \\
\hline & 0,4 & 1135,49 & 892,79 & 52,79 & 770,38 & 365,11 & 1,47 \\
\hline & 0,5 & 1053,90 & 879,28 & 51,99 & 769,58 & 284,32 & 1,37 \\
\hline & 0,6 & 978,29 & 862,51 & 51,00 & 768,59 & 209,71 & 1,27 \\
\hline & 0,7 & 927,47 & 851,60 & 50,36 & 767,94 & 159,53 & 1,21 \\
\hline & 0,8 & 858,60 & 837,29 & 49,51 & 767,10 & 91,51 & 1,12 \\
\hline \multirow{7}{*}{ 1-Dez } & 0,2 & 1303,38 & 838,05 & 48,57 & 766,15 & 537,23 & 1,70 \\
\hline & 0,3 & 1215,75 & 818,01 & 47,40 & 764,99 & 450,77 & 1,59 \\
\hline & 0,4 & 1156,20 & 803,66 & 46,57 & 764,16 & 392,04 & 1,51 \\
\hline & 0,5 & 1070,67 & 782,17 & 45,33 & 762,91 & 307,75 & 1,40 \\
\hline & 0,6 & 1003,12 & 768,03 & 44,51 & 762,09 & 241,03 & 1,32 \\
\hline & 0,7 & 944,11 & 754,13 & 43,70 & 761,29 & 182,83 & 1,24 \\
\hline & 0,8 & 882,46 & 744,84 & 43,16 & 760,75 & 121,71 & 1,16 \\
\hline \multirow{7}{*}{ 15-Dez } & 0,2 & 1295,14 & 726,45 & 42,10 & 759,68 & 535,45 & 1,70 \\
\hline & 0,3 & 1213,01 & 696,74 & 40,38 & 757,96 & 455,05 & 1,60 \\
\hline & 0,4 & 1153,40 & 677,03 & 39,23 & 756,82 & 396,58 & 1,52 \\
\hline & 0,5 & 1068,11 & 654,06 & 37,90 & 755,49 & 312,62 & 1,41 \\
\hline & 0,6 & 1009,88 & 637,11 & 36,92 & 754,51 & 255,37 & 1,34 \\
\hline & 0,7 & 946,26 & 613,69 & 35,56 & 753,15 & 193,11 & 1,26 \\
\hline & 0,8 & 894,39 & 600,09 & 34,78 & 752,36 & 142,03 & 1,19 \\
\hline
\end{tabular}

${ }^{T} \mathrm{RB}$ - receita bruta; $\mathrm{Eb}$ - energia requerida para o bombeamento; $\mathrm{CE}$ - custo de energia elétrica: CT - custo total de produção: RL - receita líquida e B/C - relação benefício/custo. 
Tabela 7B. Receitas brutas, composição de custos da irrigação, receitas líquidas e relação benefício/custo para o feijão caupi, em cada época de semeadura, nível de manejo da irrigação e risco de $40 \%$. Parnaiba, Piauí.

\begin{tabular}{|c|c|c|c|c|c|c|c|}
\hline $\begin{array}{l}\text { Época de } \\
\text { Semeadura }\end{array}$ & $\mathrm{p}$ & $\begin{array}{c}\mathrm{RB}^{1} \\
\left(\mathrm{US} \$ \mathrm{ha}^{-1}\right)\end{array}$ & $\begin{array}{c}E b \\
\left(\mathrm{kWh} \mathrm{ha}^{-1}\right)\end{array}$ & $\begin{array}{c}\text { CE } \\
\left(\mathrm{US} \$ \mathrm{ha}^{-1}\right)\end{array}$ & $\begin{array}{c}\text { CT } \\
\left(\mathrm{US} \$ \mathrm{ha}^{-1}\right)\end{array}$ & $\begin{array}{c}\mathrm{RL} \\
\left(\mathrm{US} \$ \mathrm{ha}^{-1}\right)\end{array}$ & $\mathrm{B} / \mathrm{C}$ \\
\hline \multirow{7}{*}{ 1-Jan } & 0,2 & 1253,95 & 612,24 & 34,67 & 752,26 & 501,70 & 1,67 \\
\hline & 0,3 & 1184,52 & 583,01 & 33,02 & 750,60 & 433,92 & 1,58 \\
\hline & 0,4 & 1124,42 & 554,28 & 31,39 & 748,97 & 375,45 & 1,50 \\
\hline & 0,5 & 1055,84 & 526,55 & 29,82 & 747,40 & 308,44 & 1,41 \\
\hline & 0,6 & 1002,66 & 497,38 & 28,17 & 745,75 & 256,91 & 1,34 \\
\hline & 0,7 & 946,81 & 473,84 & 26,83 & 744,42 & 202,39 & 1,27 \\
\hline & 0,8 & 902,25 & 450,67 & 25,52 & 743,11 & 159,14 & 1,21 \\
\hline \multirow{7}{*}{ 15-Jan } & 0,2 & 1266,37 & 553,85 & 31,36 & 748,95 & 517,42 & 1,69 \\
\hline & 0,3 & 1203,23 & 521,16 & 29,51 & 747,10 & 456,13 & 1,61 \\
\hline & 0,4 & 1136,81 & 491,02 & 27,81 & 745,39 & 391,42 & 1,53 \\
\hline & 0,5 & 1073,85 & 458,62 & 25,97 & 743,56 & 330,30 & 1,44 \\
\hline & 0,6 & 1017,21 & 425,78 & 24,11 & 741,70 & 275,51 & 1,37 \\
\hline & 0,7 & 966,37 & 402,43 & 22,79 & 740,37 & 225,99 & 1,31 \\
\hline & 0,8 & 926,50 & 385,28 & 21,82 & 739,40 & 187,09 & 1,25 \\
\hline \multirow{7}{*}{$1-\mathrm{Fev}$} & 0,2 & 1223,09 & 502,75 & 27,92 & 745,51 & 477,58 & 1,64 \\
\hline & 0,3 & 1165,68 & 466,00 & 25,88 & 743,46 & 422,22 & 1,57 \\
\hline & 0,4 & 1097,87 & 427,86 & 23,76 & 741,35 & 356,52 & 1,48 \\
\hline & 0,5 & 1046,08 & 399,31 & 22,18 & 739,76 & 306,32 & 1,41 \\
\hline & 0,6 & 994,45 & 373,02 & 20,72 & 738,30 & 256,15 & 1,35 \\
\hline & 0,7 & 950,30 & 348,00 & 19,33 & 736,91 & 213,39 & 1,29 \\
\hline & 0,8 & 907,84 & 318,41 & 17,68 & 735,27 & 172,57 & 1,23 \\
\hline \multirow{7}{*}{$15-\mathrm{Fev}$} & 0,2 & 1218,09 & 455,43 & 25,29 & 742,88 & 475,21 & 1,64 \\
\hline & 0,3 & 1166,25 & 423,50 & 23,52 & 741,10 & 425,15 & 1,57 \\
\hline & 0,4 & 1094,48 & 380,31 & 21,12 & 738,71 & 355,78 & 1,48 \\
\hline & 0,5 & 1046,98 & 348,16 & 19,34 & 736,92 & 310,06 & 1,42 \\
\hline & 0,6 & 996,02 & 309,16 & 17,17 & 734,75 & 261,27 & 1,36 \\
\hline & 0,7 & 963,18 & 293,98 & 16,33 & 733,91 & 229,27 & 1,31 \\
\hline & 0,8 & 918,27 & 270,93 & 15,05 & 732,63 & 185,64 & 1,25 \\
\hline
\end{tabular}


Tabela 7B. Receitas brutas, composição de custos da irrigação, receitas líquidas e relação beneficio/custo para o feijão caupi, em cada época de semeadura, nível de manejo da irrigação e risco de $40 \%$. Parnaíba, Piauí.

\begin{tabular}{|c|c|c|c|c|c|c|c|}
\hline $\begin{array}{l}\text { Época de } \\
\text { Semeadura }\end{array}$ & $\mathrm{p}$ & $\begin{array}{c}\mathrm{RB}^{1} \\
\left(\mathrm{US} \$ \mathrm{ha}^{-1}\right)\end{array}$ & $\begin{array}{c}\mathrm{Eb} \\
\left(\mathrm{kWh} \mathrm{ha} \mathrm{h}^{-1}\right)\end{array}$ & $\begin{array}{c}\text { CE } \\
\left(\mathrm{US} \$ \mathrm{ha}^{-1}\right)\end{array}$ & $\begin{array}{c}\mathrm{CT} \\
\left(\mathrm{US} \$ \mathrm{ha}^{-1}\right)\end{array}$ & $\begin{array}{c}\mathrm{RL} \\
\left(\mathrm{US} \$ \mathrm{ha}^{-1}\right)\end{array}$ & $\mathrm{B} / \mathrm{C}$ \\
\hline \multirow{7}{*}{ 1-Mar } & 0,2 & 1255,04 & 438,27 & 23,92 & 741,51 & 513,53 & 1,69 \\
\hline & 0,3 & 1203,30 & 404,22 & 22,06 & 739,65 & 463,65 & 1,63 \\
\hline & 0,4 & 1128,28 & 365,44 & 19,95 & 737,53 & 390,74 & 1,53 \\
\hline & 0,5 & 1082,27 & 328,58 & 17,94 & 735,52 & 346,75 & 1,47 \\
\hline & 0,6 & 1029,26 & 302,56 & 16,52 & 734,10 & 295,16 & 1,40 \\
\hline & 0,7 & 988,24 & 269,69 & 14,72 & 732,31 & 255,93 & 1,35 \\
\hline & 0,8 & 948,73 & 239,29 & 13,06 & 730,65 & 218,09 & 1,30 \\
\hline \multirow{7}{*}{ 15-Mar } & 0,2 & 1244,83 & 458,41 & 25,02 & 742,61 & 502,23 & 1,68 \\
\hline & 0,3 & 1194,38 & 422,99 & 23,09 & 740,67 & 453,70 & 1,61 \\
\hline & 0,4 & 1113,90 & 385,59 & 21,05 & 738,63 & 375,27 & 1,51 \\
\hline & 0,5 & 1064,32 & 351,23 & 19,17 & 736,76 & 327,57 & 1,44 \\
\hline & 0,6 & 1006,92 & 325,67 & 17,78 & 735,36 & 271,56 & 1,37 \\
\hline & 0,7 & 964,87 & 293,36 & 16,01 & 733,60 & 231,27 & 1,32 \\
\hline & 0,8 & 920,30 & 265,21 & 14,48 & 732,06 & 188,24 & 1,26 \\
\hline \multirow{7}{*}{$1-\mathrm{Abr}$} & 0,2 & 1237,10 & 526,94 & 27,17 & 744,76 & 492,34 & 1,66 \\
\hline & 0,3 & 1178,77 & 498,20 & 25,69 & 743,28 & 435,50 & 1,59 \\
\hline & 0,4 & 1095,03 & 470,38 & 24,26 & 741,84 & 353,18 & 1,48 \\
\hline & 0,5 & 1042,04 & 440,39 & 22,71 & 740,29 & 301,75 & 1,41 \\
\hline & 0,6 & 974,20 & 408,35 & 21,06 & 738,64 & 235,56 & 1,32 \\
\hline & 0,7 & 932,02 & 389,43 & 20,08 & 737,67 & 194,35 & 1,26 \\
\hline & 0,8 & 882,14 & 361,52 & 18,64 & 736,23 & 145,92 & 1,20 \\
\hline \multirow{7}{*}{$15-\mathrm{Abr}$} & 0,2 & 1233,08 & 588,89 & 30,37 & 747,95 & 485,13 & 1,65 \\
\hline & 0,3 & 1170,32 & 561,09 & 28,93 & 746,52 & 423,81 & 1,57 \\
\hline & 0,4 & 1083,78 & 535,08 & 27,59 & 745,18 & 338,60 & 1,45 \\
\hline & 0,5 & 1023,19 & 509,68 & 26,28 & 743,87 & 279,32 & 1,38 \\
\hline & 0,6 & 952,65 & 482,89 & 24,90 & 742,49 & 210,17 & 1,28 \\
\hline & 0,7 & 904,59 & 453,15 & 23,37 & 740,95 & 163,64 & 1,22 \\
\hline & 0,8 & 849,69 & 444,27 & 22,91 & 740,49 & 109,19 & 1,15 \\
\hline
\end{tabular}


Tabela 7B. Receitas brutas, composição de custos da irrigação, receitas liquidas e relação beneficio/custo para o feijão caupi, em cada época de semeadura, nivel de manejo da irrigação e risco de $40 \%$. Parnaiba, Piauí.

\begin{tabular}{|c|c|c|c|c|c|c|c|}
\hline $\begin{array}{l}\text { Época de } \\
\text { Semeadura }\end{array}$ & $p$ & $\begin{array}{c}\mathrm{RB}^{1} \\
\left(\mathrm{US} \$ \mathrm{ha}^{-1}\right)\end{array}$ & $\begin{array}{c}E b \\
\left(\mathrm{kWh} \mathrm{ha}^{-1}\right)\end{array}$ & $\begin{array}{c}\mathrm{CE} \\
\left(\mathrm{US} \$ \mathrm{ha}^{-1}\right)\end{array}$ & $\begin{array}{c}\mathrm{CT} \\
\left(\mathrm{US} \$ \mathrm{ha}^{-1}\right)\end{array}$ & $\begin{array}{c}\mathrm{RL} \\
\left(\mathrm{US} \$ \mathrm{ha}^{-1}\right)\end{array}$ & $\mathrm{B} / \mathrm{C}$ \\
\hline \multirow{7}{*}{ 1-Mai } & 0,2 & 1062,71 & 674,85 & 34,92 & 752,50 & 310,21 & 1,41 \\
\hline & 0,3 & 1005,32 & 654,19 & 33,85 & 751,43 & 253,89 & 1,34 \\
\hline & 0,4 & 926,93 & 629,65 & 32,58 & 750,16 & 176,76 & 1,24 \\
\hline & 0,5 & 868,26 & 616,93 & 31,92 & 749,51 & 118,76 & 1,16 \\
\hline & 0,6 & 810,15 & 607,51 & 31,43 & 749,02 & 61,13 & 1,08 \\
\hline & 0,7 & 759,38 & 581,65 & 30,10 & 747,68 & 11,70 & 1,02 \\
\hline & 0,8 & 708,48 & 575,48 & 29,78 & 747,36 & $-38,88$ & 0,95 \\
\hline \multirow{7}{*}{ 15-Mai } & 0,2 & 1065,59 & 709,36 & 36,70 & 754,29 & 311,30 & 1,41 \\
\hline & 0,3 & 1005,14 & 692,11 & 35,81 & 753,40 & 251,75 & 1,33 \\
\hline & 0,4 & 932,06 & 679,30 & 35,15 & 752,73 & 179,33 & 1,24 \\
\hline & 0,5 & 866,36 & 661,10 & 34,21 & 751,79 & 114,57 & 1,15 \\
\hline & 0,6 & 808,84 & 644,54 & 33,35 & 750,93 & 57,91 & 1,08 \\
\hline & 0,7 & 756,67 & 639,74 & 33,10 & 750,69 & 5,98 & 1,01 \\
\hline & 0,8 & 705,47 & 623,23 & 32,25 & 749,83 & $-44,36$ & 0,94 \\
\hline \multirow{7}{*}{ 1-Jun } & 0,2 & 1146,52 & 768,10 & 42,39 & 759,97 & 386,55 & 1,51 \\
\hline & 0,3 & 1077,40 & 755,70 & 41,70 & 759,29 & 318,11 & 1,42 \\
\hline & 0,4 & 1004,71 & 746,99 & 41,22 & 758,81 & 245,90 & 1,32 \\
\hline & 0,5 & 924,45 & 733,47 & 40,48 & 758,06 & 166,39 & 1,22 \\
\hline & 0,6 & 871,31 & 725,08 & 40,01 & 757,60 & 113,71 & 1,15 \\
\hline & 0,7 & 800,45 & 710,77 & 39,22 & 756,81 & 43,64 & 1,06 \\
\hline & 0,8 & 754,11 & 703,33 & 38,81 & 756,40 & $-2,29$ & 1,00 \\
\hline \multirow{7}{*}{ 15-Jun } & 0,2 & 1159,53 & 841,22 & 46,42 & 764,01 & 395,52 & 1,52 \\
\hline & 0,3 & 1079,10 & 831,94 & 45,91 & 763,50 & 315,61 & 1,41 \\
\hline & 0,4 & 1020,65 & 820,36 & 45,27 & 762,86 & 257,79 & 1,34 \\
\hline & 0,5 & 925,66 & 812,42 & 44,83 & 762,42 & 163,24 & 1,21 \\
\hline & 0,6 & 882,59 & 806,52 & 44,51 & 762,09 & 120,50 & 1,16 \\
\hline & 0,7 & 807,29 & 795,97 & 43,93 & 761,51 & 45,78 & 1,06 \\
\hline & 0,8 & 760,24 & 790,41 & 43,62 & 761,20 & $-0,96$ & 1,00 \\
\hline
\end{tabular}


Tabela 7B. Receitas brutas, composição de custos da irrigação, receitas líquidas e relação benefício/custo para o feijão caupi, em cada época de semeadura, nível de manejo da irrigação e risco de 40 \%. Parnaíba, Piauí.

\begin{tabular}{|c|c|c|c|c|c|c|c|}
\hline $\begin{array}{l}\text { Época de } \\
\text { Semeadura }\end{array}$ & $p$ & $\begin{array}{c}\mathrm{RB}^{\mathrm{l}} \\
\left(\mathrm{US} \$ \mathrm{ha}^{-1}\right)\end{array}$ & $\begin{array}{c}E b \\
\left(k W h h a^{-1}\right)\end{array}$ & $\begin{array}{c}C E \\
\left(U S \$ h^{-1}\right)\end{array}$ & $\begin{array}{c}C T \\
\left(\mathrm{US} \$ \mathrm{ha}^{-1}\right)\end{array}$ & $\begin{array}{c}\mathrm{RL} \\
\left(\mathrm{US} \$ \mathrm{ha}^{-1}\right)\end{array}$ & $\mathrm{B} / \mathrm{C}$ \\
\hline \multirow{7}{*}{ 1-Jul } & 0,2 & 1157,24 & 920,84 & 53,45 & 771,04 & 386,21 & 1,50 \\
\hline & 0,3 & 1067,91 & 910,15 & 52,83 & 770,42 & 297,49 & 1,39 \\
\hline & 0,4 & 1018,98 & 902,99 & 52,42 & 770,00 & 248,98 & 1,32 \\
\hline & 0,5 & 926,76 & 899,35 & 52,20 & 769,79 & 156,97 & 1,20 \\
\hline & 0,6 & 872,44 & 890,29 & 51,68 & 769,26 & 103,18 & 1,13 \\
\hline & 0,7 & 809,22 & 882,84 & 51,25 & 768,83 & 40,39 & 1,05 \\
\hline & 0,8 & 751,76 & 876,48 & 50,88 & 768,46 & $-16,70$ & 0,98 \\
\hline \multirow{7}{*}{ 15-Jul } & 0,2 & 1170,51 & 998,93 & 57,99 & 775,57 & 394,94 & 1,51 \\
\hline & 0,3 & 1073,81 & 988,54 & 57,38 & 774,97 & 298,84 & 1,39 \\
\hline & 0,4 & 1028,67 & 987,20 & 57,30 & 774,89 & 253,78 & 1,33 \\
\hline & 0,5 & 950,64 & 982,52 & 57,03 & 774,62 & 176,02 & 1,23 \\
\hline & 0,6 & 874,65 & 978,20 & 56,78 & 774,37 & 100,28 & 1,13 \\
\hline & 0,7 & 828,45 & 972,31 & 56,44 & 774,02 & 54,43 & 1,07 \\
\hline & 0,8 & 754,26 & 970,01 & 56,31 & 773,89 & $-19,64$ & 0,97 \\
\hline \multirow{7}{*}{ 1-Ago } & 0,2 & 1136,14 & 1095,04 & 64,08 & 781,66 & 354,48 & 1,45 \\
\hline & 0,3 & 1037,97 & 1087,55 & 63,64 & 781,22 & 256,75 & 1,33 \\
\hline & 0,4 & 991,86 & 1084,48 & 63,46 & 781,04 & 210,81 & 1,27 \\
\hline & 0,5 & 937,58 & 1081,71 & 63,30 & 780,88 & 156,70 & 1,20 \\
\hline & 0,6 & 841,78 & 1075,29 & 62,92 & 780,51 & 61,28 & 1,08 \\
\hline & 0,7 & 803,64 & 1071,74 & 62,71 & 780,30 & 23,34 & 1,03 \\
\hline & 0,8 & 745,53 & 1066,84 & 62,43 & 780,01 & $-34,49$ & 0,96 \\
\hline \multirow{7}{*}{ 15-Ago } & 0,2 & 1145,61 & 1145,40 & 67,02 & 784,61 & 361,00 & 1,46 \\
\hline & 0,3 & 1047,61 & 1140,82 & 66,76 & 784,34 & 263,27 & 1,34 \\
\hline & 0,4 & 996,36 & 1136,12 & 66,48 & 784,07 & 212,30 & 1,27 \\
\hline & 0,5 & 951,10 & 1127,55 & 65,98 & 783,56 & 167,53 & 1,21 \\
\hline & 0,6 & 852,95 & 1125,98 & 65,89 & 783,47 & 69,48 & 1,09 \\
\hline & 0,7 & 802,69 & 1117,30 & 65,38 & 782,97 & 19,72 & 1,03 \\
\hline & 0,8 & 763,53 & 1120,43 & 65,56 & 783,15 & $-19,61$ & 0,97 \\
\hline
\end{tabular}


Tabela 7B. Receitas brutas, composição de custos da irrigação, receitas líquidas e relação benefício/custo para o feijão caupi, em cada época de semeadura, nível de manejo da irrigação e risco de $40 \%$. Parnaiba, Piauí.

\begin{tabular}{|c|c|c|c|c|c|c|c|}
\hline $\begin{array}{c}\text { Época de } \\
\text { Semeadura }\end{array}$ & $\mathrm{p}$ & $\begin{array}{c}\mathrm{RB}^{1} \\
\left(\mathrm{US} \$ \mathrm{ha}^{-1}\right)\end{array}$ & $\begin{array}{c}E b \\
\left(\mathrm{kWh} \mathrm{ha}{ }^{-1}\right)\end{array}$ & $\begin{array}{c}\mathrm{CE} \\
\left(\mathrm{US} \$ \mathrm{ha}^{-1}\right)\end{array}$ & $\begin{array}{c}\text { CT } \\
\left(\mathrm{US} \$ \mathrm{ha}^{-1}\right)\end{array}$ & $\begin{array}{c}\mathrm{RL} \\
\left(\mathrm{US} \$ \mathrm{ha}^{-1}\right)\end{array}$ & $\mathrm{B} / \mathrm{C}$ \\
\hline \multirow{7}{*}{ 1-Set } & 0,2 & 1159,68 & 1182,85 & 67,72 & 785,30 & 374,38 & 1,48 \\
\hline & 0,3 & 1063,81 & 1178,46 & 67,46 & 785,05 & 278,77 & 1,36 \\
\hline & 0,4 & 1005,01 & 1173,42 & 67,18 & 784,76 & 220,25 & 1,28 \\
\hline & 0,5 & 967,00 & 1166,38 & 66,77 & 784,36 & 182,64 & 1,23 \\
\hline & 0,6 & 871,23 & 1168,93 & 66,92 & 784,50 & 86,73 & 1,11 \\
\hline & 0,7 & 808,53 & 1158,13 & 66,30 & 783,88 & 24,65 & 1,03 \\
\hline & 0,8 & 785,79 & 1154,80 & 66,11 & 783,69 & 2,10 & 1,00 \\
\hline \multirow{7}{*}{ 15-Set } & 0,2 & 1160,96 & 1174,18 & 67,22 & 784,80 & 376,15 & 1,48 \\
\hline & 0,3 & 1062,19 & 1171,17 & 67,05 & 784,63 & 277,56 & 1,35 \\
\hline & 0,4 & 1008,45 & 1164,50 & 66,66 & 784,25 & 224,20 & 1,29 \\
\hline & 0,5 & 967,83 & 1159,15 & 66,36 & 783,94 & 183,89 & 1,23 \\
\hline & 0,6 & 872,39 & 1161,13 & 66,47 & 784,06 & 88,33 & 1,11 \\
\hline & 0,7 & 811,82 & 1153,16 & 66,02 & 783,60 & 28,22 & 1,04 \\
\hline & 0,8 & 785,01 & 1143,73 & 65,48 & 783,06 & 1,95 & 1,00 \\
\hline \multirow{7}{*}{ 1-Out } & 0,2 & 1160,01 & 1166,24 & 67,70 & 785,28 & 374,72 & 1,48 \\
\hline & 0,3 & 1067,03 & 1162,25 & 67,47 & 785,05 & 281,97 & 1,36 \\
\hline & 0,4 & 1008,86 & 1155,50 & 67,07 & 784,66 & 224,20 & 1,29 \\
\hline & 0,5 & 968,31 & 1149,39 & 66,72 & 784,30 & 184,00 & 1,23 \\
\hline & 0,6 & 871,54 & 1148,90 & 66,69 & 784,28 & 87,26 & 1,11 \\
\hline & 0,7 & 812,71 & 1143,36 & 66,37 & 783,95 & 28,75 & 1,04 \\
\hline & 0,8 & 786,89 & 1132,81 & 65,76 & 783,34 & 3,54 & 1,00 \\
\hline \multirow{7}{*}{ 15-Out } & 0,2 & 1158,74 & 1138,33 & 66,08 & 783,66 & 375,07 & 1,48 \\
\hline & 0,3 & 1059,15 & 1129,39 & 65,56 & 783,14 & 276,00 & 1,35 \\
\hline & 0,4 & 1008,49 & 1128,66 & 65,52 & 783,10 & 225,39 & 1,29 \\
\hline & 0,5 & 965,84 & 1118,74 & 64,94 & 782,53 & 183,32 & 1,23 \\
\hline & 0,6 & 865,83 & 1116,24 & 64,80 & 782,38 & 83,45 & 1,11 \\
\hline & 0,7 & 814,85 & 1104,02 & 64,09 & 781,67 & 33,18 & 1,04 \\
\hline & 0,8 & 779,50 & 1104,88 & 64,14 & 781,72 & $-2,22$ & 1,00 \\
\hline
\end{tabular}


Tabela 7B. Receitas brutas, composição de custos da irrigação, receitas líquidas e relação beneficio/custo para o feijão caupi, em cada época de semeadura, nível de manejo da irrigação e risco de $40 \%$. Parnaíba, Piauí.

\begin{tabular}{|c|c|c|c|c|c|c|c|}
\hline $\begin{array}{l}\text { Época de } \\
\text { Semeadura }\end{array}$ & $\mathbf{P}$ & $\begin{array}{c}\mathrm{RB}^{1} \\
\left(\mathrm{US} \$ \mathrm{ha}^{-1}\right)\end{array}$ & $\begin{array}{c}E b \\
\left(k W h h^{-1}\right)\end{array}$ & $\begin{array}{c}\text { CE } \\
\left(\mathrm{US} \$ \mathrm{ha}^{-1}\right)\end{array}$ & $\begin{array}{c}\mathrm{CT} \\
\left(\mathrm{US} \$ \mathrm{ha}^{-1}\right)\end{array}$ & $\begin{array}{c}\mathrm{RL} \\
\left(\mathrm{US} \$ \mathrm{ha}^{-1}\right)\end{array}$ & $\mathrm{B} / \mathrm{C}$ \\
\hline \multirow{7}{*}{$1-\mathrm{Nov}$} & 0,2 & 1330,08 & 1026,30 & 60,04 & 777,62 & 552,45 & 1,71 \\
\hline & 0,3 & 1226,07 & 1017,26 & 59,51 & 777,09 & 448,98 & 1,58 \\
\hline & 0,4 & 1169,29 & 1004,30 & 58,75 & 776,34 & 392,96 & 1,51 \\
\hline & 0,5 & 1095,66 & 993,49 & 58,12 & 775,70 & 319,96 & 1,41 \\
\hline & 0,6 & 1002,98 & 989,93 & 57,91 & 775,49 & 227,48 & 1,29 \\
\hline & 0,7 & 949,69 & 978,76 & 57,26 & 774,84 & 174,85 & 1,23 \\
\hline & 0,8 & 882,46 & 970,16 & 56,75 & 774,34 & 108,12 & 1,14 \\
\hline \multirow{7}{*}{ 15-Nov } & 0,2 & 1316,67 & 912,27 & 53,37 & 770,95 & 545,72 & 1,71 \\
\hline & 0,3 & 1220,96 & 895,80 & 52,40 & 769,99 & 450,98 & 1,59 \\
\hline & 0,4 & 1165,93 & 884,54 & 51,75 & 769,33 & 396,60 & 1,52 \\
\hline & 0,5 & 1083,63 & 869,94 & 50,89 & 768,48 & 315,16 & 1,41 \\
\hline & 0,6 & 1005,79 & 852,88 & 49,89 & 767,48 & 238,31 & 1,31 \\
\hline & 0,7 & 954,14 & 840,49 & 49,17 & 766,75 & 187,38 & 1,24 \\
\hline & 0,8 & 884,30 & 825,63 & 48,30 & 765,88 & 118,41 & 1,15 \\
\hline \multirow{7}{*}{ 1-Dez } & 0,2 & 1335,29 & 831,23 & 47,61 & 765,19 & 570,09 & 1,75 \\
\hline & 0,3 & 1245,47 & 810,23 & 46,41 & 763,99 & 481,48 & 1,63 \\
\hline & 0,4 & 1185,37 & 795,45 & 45,56 & 763,14 & 422,23 & 1,55 \\
\hline & 0,5 & 1098,69 & 772,86 & 44,27 & 761,85 & 336,84 & 1,44 \\
\hline & 0,6 & 1030,05 & 759,07 & 43,48 & 761,06 & 268,99 & 1,35 \\
\hline & 0,7 & 970,09 & 743,57 & 42,59 & 760,17 & 209,92 & 1,28 \\
\hline & 0,8 & 907,25 & 733,65 & 42,02 & 759,61 & 147,65 & 1,19 \\
\hline \multirow{7}{*}{ 15-Dez } & 0,2 & 1326,68 & 717,79 & 41,11 & 758,70 & 567,98 & 1,75 \\
\hline & 0,3 & 1242,79 & 687,00 & 39,35 & 756,93 & 485,86 & 1,64 \\
\hline & 0,4 & 1182,82 & 666,35 & 38,17 & 755,75 & 427,07 & 1,57 \\
\hline & 0,5 & 1096,69 & 642,70 & 36,81 & 754,40 & 342,29 & 1,45 \\
\hline & 0,6 & 1037,54 & 625,37 & 35,82 & 753,40 & 284,14 & 1,38 \\
\hline & 0,7 & 973,08 & 600,76 & 34,41 & 751,99 & 221,09 & 1,29 \\
\hline & 0,8 & 920,83 & 586,07 & 33,57 & 751,15 & 169,68 & 1,23 \\
\hline
\end{tabular}

${ }^{1} \mathrm{RB}$ - receita bruta; $\mathrm{Eb}$ - energia requerida para o bombeamento; $\mathrm{CE}$ - custo de energia elétrica; CT - custo total de produção; RL - receita líquida e B/C - relação beneficio/custo. 
Tabela 8B. Receitas brutas, composição de custos da irrigação, receitas líquidas e relação benefício/custo para a melancia, em cada época de semeadura, nível de manejo da irrigação e risco de $5 \%$. Parnaíba, Piauí.

\begin{tabular}{|c|c|c|c|c|c|c|c|}
\hline $\begin{array}{l}\text { Época de } \\
\text { Semeadura }\end{array}$ & $\mathrm{p}$ & $\begin{array}{c}\mathrm{RB}^{1} \\
\left(\mathrm{US} \$ \mathrm{ha}^{-1}\right)\end{array}$ & $\begin{array}{c}E b \\
\left(\mathrm{kWh} \mathrm{ha}^{-1}\right)\end{array}$ & $\begin{array}{c}\text { CE } \\
\left(\text { US } \$ h^{-1}\right)\end{array}$ & $\begin{array}{c}\text { CT } \\
\left(\text { US } \$ \mathrm{ha}^{-1}\right)\end{array}$ & $\begin{array}{c}\mathrm{RL} \\
\left(\mathrm{US} \$ \mathrm{ha}^{-{ }^{-1}}\right)\end{array}$ & $\mathrm{B} / \mathrm{C}$ \\
\hline \multirow{7}{*}{ 1-Jan } & 0,2 & 4555,63 & 694,99 & 45,23 & 1112,33 & 3443,30 & 4,10 \\
\hline & 0,3 & 4216,67 & 683,02 & 44,45 & 1111,55 & 3105,12 & 3,79 \\
\hline & 0,4 & 3805,93 & 660,82 & 43,00 & 1110,11 & 2695,82 & 3,43 \\
\hline & 0,5 & 3474,96 & 649,85 & 42,29 & 1109,39 & 2365,56 & 3,13 \\
\hline & 0,6 & 3143,20 & 620,07 & 40,35 & 1107,46 & 2035,74 & 2,84 \\
\hline & 0,7 & 2861,89 & 606,23 & 39,45 & 1106,56 & 1755,33 & 2,59 \\
\hline & 0,8 & 2637,76 & 588,31 & 38,29 & 1105,39 & 1532,37 & 2,39 \\
\hline \multirow{7}{*}{ 15-Jan } & 0,2 & 4637,33 & 635,37 & 41,35 & 1108,45 & 3528,88 & 4,18 \\
\hline & 0,3 & 4312,75 & 618,29 & 40,24 & 1107,34 & 3205,41 & 3,89 \\
\hline & 0,4 & 3866,60 & 591,76 & 38,51 & 1105,61 & 2760,99 & 3,50 \\
\hline & 0,5 & 3569,88 & 576,27 & 37,50 & 1104,61 & 2465,28 & 3,23 \\
\hline & 0,6 & 3243,60 & 554,20 & 36,07 & 1103,17 & 2140,43 & 2,94 \\
\hline & 0,7 & 2999,58 & 523,00 & 34,04 & 1101,14 & 1898,44 & 2,72 \\
\hline & 0,8 & 2761,18 & 501,38 & 32,63 & 1099,73 & 1661,45 & 2,51 \\
\hline \multirow{7}{*}{$1-\mathrm{Fev}$} & 0,2 & 4883,40 & 590,61 & 39,79 & 1106,90 & 3776,50 & 4,41 \\
\hline & 0,3 & 4550,39 & 565,98 & 38,13 & 1105,24 & 3445,15 & 4,12 \\
\hline & 0,4 & 4077,16 & 523,99 & 35,31 & 1102,41 & 2974,75 & 3,70 \\
\hline & 0,5 & 3759,89 & 506,31 & 34,11 & 1101,22 & 2658,67 & 3,41 \\
\hline & 0,6 & 3476,15 & 490,30 & 33,04 & 1100,14 & 2376,01 & 3,16 \\
\hline & 0,7 & 3180,22 & 465,94 & 31,39 & 1098,50 & 2081,72 & 2,90 \\
\hline & 0,8 & 2938,26 & 451,42 & 30,42 & 1097,52 & 1840,74 & 2,68 \\
\hline \multirow{7}{*}{$15-\mathrm{Fev}$} & 0,2 & 4864,66 & 533,11 & 35,92 & 1103,02 & 3761,64 & 4,41 \\
\hline & 0,3 & 4496,31 & 501,42 & 33,78 & 1100,89 & 3395,42 & 4,08 \\
\hline & 0,4 & 4113,65 & 499,07 & 33,63 & 1100,73 & 3012,92 & 3,74 \\
\hline & 0,5 & 3739,52 & 455,19 & 30,67 & 1097,77 & 2641,74 & 3,41 \\
\hline & 0,6 & 3468,47 & 410,76 & 27,68 & 1094,78 & 2373,69 & 3,17 \\
\hline & 0,7 & 3233,64 & 395,68 & 26,66 & 1093,77 & 2139,87 & 2,96 \\
\hline & 0,8 & 3040,76 & 394,46 & 26,58 & 1093,68 & 1947,07 & 2,78 \\
\hline
\end{tabular}


Tabela 8B. Receitas brutas, composição de custos da irrigação, receitas líquidas e relação beneficio/custo para a melancia, em cada época de semeadura, nível de manejo da irrigação e risco de $5 \%$. Parnaíba, Piauí.

\begin{tabular}{|c|c|c|c|c|c|c|c|}
\hline $\begin{array}{l}\text { Época de } \\
\text { Semeadura }\end{array}$ & $\mathrm{p}$ & $\begin{array}{c}\mathrm{RB}^{\mathrm{l}} \\
\left(\mathrm{US} \$ \mathrm{ha}^{-1}\right)\end{array}$ & $\begin{array}{c}E b \\
\left(\mathrm{kWh} \mathrm{haa^{-1 }}\right)\end{array}$ & $\begin{array}{c}\text { CE } \\
\left(\mathrm{US} \$ \mathrm{ha}^{-1}\right)\end{array}$ & $\begin{array}{c}\text { CT } \\
\left.\left(\text { US } \$ h^{-1}\right)^{-1}\right)\end{array}$ & $\begin{array}{c}R L \\
(\text { US\$ ha } \\
\text { (-1) }\end{array}$ & $B / C$ \\
\hline \multirow{7}{*}{ 1-Mar } & 0,2 & 4825,50 & 529,61 & 35,36 & 1102,46 & 3723,04 & 4,38 \\
\hline & 0,3 & 4465,05 & 499,69 & 33,36 & 1100,46 & 3364,59 & 4,06 \\
\hline & 0,4 & 4034,05 & 470,58 & 31,42 & 1098,52 & 2935,53 & 3,67 \\
\hline & 0,5 & 3701,93 & 452,82 & 30,23 & 1097,33 & 2604,60 & 3,37 \\
\hline & 0,6 & 3406,45 & 406,82 & 27,16 & 1094,26 & 2312,18 & 3,11 \\
\hline & 0,7 & 3144,65 & 384,07 & 25,64 & 1092,74 & 2051,90 & 2,88 \\
\hline & 0,8 & 2966,49 & 367,87 & 24,56 & 1091,66 & 1874,82 & 2,72 \\
\hline \multirow{7}{*}{ 15-Mar } & 0,2 & 4790,71 & 542,79 & 36,24 & 1103,34 & 3687,37 & 4,34 \\
\hline & 0,3 & 4414,09 & 514,21 & 34,33 & 1101,43 & 3312,66 & 4,01 \\
\hline & 0,4 & 4001,40 & 482,09 & 32,18 & 1099,29 & 2902,11 & 3,64 \\
\hline & 0,5 & 3685,39 & 462,34 & 30,87 & 1097,97 & 2587,42 & 3,36 \\
\hline & 0,6 & 3363,88 & 434,81 & 29,03 & 1096,13 & 2267,74 & 3,07 \\
\hline & 0,7 & 3100,89 & 428,94 & 28,63 & 1095,74 & 2005,15 & 2,83 \\
\hline & 0,8 & 2844,56 & 384,59 & 25,67 & 1092,78 & 1751,78 & 2,60 \\
\hline \multirow{7}{*}{ 1-Abr } & 0,2 & 4667,80 & 607,43 & 38,19 & 1105,30 & 3562,51 & 4,22 \\
\hline & 0,3 & 4298,10 & 587,43 & 36,93 & 1104,04 & 3194,06 & 3,89 \\
\hline & 0,4 & 3816,06 & 561,78 & 35,32 & 1102,43 & 2713,64 & 3,46 \\
\hline & 0,5 & 3476,53 & 540,55 & 33,99 & 1101,09 & 2375,44 & 3,16 \\
\hline & 0,6 & 3162,03 & 533,72 & 33,56 & 1100,66 & 2061,36 & 2,87 \\
\hline & 0,7 & 2880,77 & 505,71 & 31,80 & 1098,90 & 1781,87 & 2,62 \\
\hline & 0,8 & 2634,29 & 502,87 & 31,62 & 1098,72 & 1535,57 & 2,40 \\
\hline \multirow{7}{*}{$15-\mathrm{Abr}$} & 0,2 & 4648,55 & 661,32 & 41,58 & 1108,68 & 3539,87 & 4,19 \\
\hline & 0,3 & 4271,73 & 653,34 & 41,08 & 1108,18 & 3163,54 & 3,85 \\
\hline & 0,4 & 3776,42 & 619,57 & 38,96 & 1106,06 & 2670,36 & 3,41 \\
\hline & 0,5 & 3429,22 & 613,81 & 38,59 & 1105,70 & 2323,52 & 3,10 \\
\hline & 0,6 & 3086,79 & 594,45 & 37,38 & 1104,48 & 1982,31 & 2,79 \\
\hline & 0,7 & 2747,67 & 582,45 & 36,62 & 1103,73 & 1643,94 & 2,49 \\
\hline & 0,8 & 2576,32 & 574,08 & 36,09 & 1103,20 & 1473,12 & 2,34 \\
\hline
\end{tabular}


Tabela 8B. Receitas brutas, composição de custos da irrigação, receitas liquidas e relação benefício/custo para a melancia, em cada época de semeadura, nivel de manejo da irrigação e risco de $5 \%$. Parnaiba, Piaui.

\begin{tabular}{|c|c|c|c|c|c|c|c|}
\hline $\begin{array}{l}\text { Época de } \\
\text { Semeadura }\end{array}$ & $\mathrm{p}$ & $\begin{array}{c}\mathrm{RB}^{\mathrm{I}} \\
\left(\mathrm{US} \$ \mathrm{ha}^{-1}\right)\end{array}$ & $\begin{array}{c}E b \\
(\mathrm{kWh} \mathrm{ha-1})\end{array}$ & $\begin{array}{c}C E \\
\left(\mathrm{US} \$ \mathrm{ha}^{-1}\right)\end{array}$ & $\begin{array}{c}\text { CT } \\
\left(\text { US\$ } \$ a^{-1}\right)\end{array}$ & $\begin{array}{c}\mathrm{RL} \\
\left(\mathrm{US} \$ \mathrm{ha} \mathrm{a}^{-1}\right)\end{array}$ & $\mathrm{B} / \mathrm{C}$ \\
\hline \multirow{7}{*}{ 1-Mai } & 0,2 & 3742,38 & 733,46 & 44,05 & 1111,16 & 2631,22 & 3,37 \\
\hline & 0,3 & 3441,05 & 723,78 & 43,47 & 1110,58 & 2330,47 & 3,10 \\
\hline & 0,4 & 3022,94 & 709,47 & 42,61 & 1109,72 & 1913,22 & 2,72 \\
\hline & 0,5 & 2730,43 & 715,98 & 43,00 & 1110,11 & 1620,33 & 2,46 \\
\hline & 0,6 & 2469,32 & 710,18 & 42,66 & 1109,76 & 1359,56 & 2,23 \\
\hline & 0,7 & 2217,58 & 703,51 & 42,26 & 1109,36 & 1108,22 & 2,00 \\
\hline & 0,8 & 2000,45 & 684,27 & 41,10 & 1108,20 & 892,25 & 1,81 \\
\hline \multirow{7}{*}{ 15-Mai } & 0,2 & 3738,37 & 766,08 & 46,01 & 1113,12 & 2625,25 & 3,36 \\
\hline & 0,3 & 3465,49 & 764,36 & 45,91 & 1113,01 & 2352,48 & 3,11 \\
\hline & 0,4 & 3026,88 & 750,86 & 45,10 & 1112,20 & 1914,68 & 2,72 \\
\hline & 0,5 & 2744,43 & 755,58 & 45,38 & 1112,49 & 1631,95 & 2,47 \\
\hline & 0,6 & 2441,06 & 743,83 & 44,68 & 1111,78 & 1329,28 & 2,20 \\
\hline & 0,7 & 2217,78 & 743,99 & 44,69 & 1111,79 & 1105,99 & 1,99 \\
\hline & 0,8 & 2000,46 & 729,02 & 43,79 & 1110,89 & 889,57 & 1,80 \\
\hline \multirow{7}{*}{ 1-Jun } & 0,2 & 3889,67 & 811,70 & 52,18 & 1119,28 & 2770,38 & 3,48 \\
\hline & 0,3 & 3605,91 & 806,56 & 51,85 & 1118,95 & 2486,95 & 3,22 \\
\hline & 0,4 & 3158,10 & 805,57 & 51,79 & 1118,89 & 2039,21 & 2,82 \\
\hline & 0,5 & 2877,13 & 794,30 & 51,06 & 1118,17 & 1758,96 & 2,57 \\
\hline & 0,6 & 2523,65 & 795,73 & 51,15 & 1118,26 & 1405,39 & 2,26 \\
\hline & 0,7 & 2322,79 & 792,04 & 50,92 & 1118,02 & 1204,77 & 2,08 \\
\hline & 0,8 & 2060,45 & 787,78 & 50,64 & 1117,75 & 942,70 & 1,84 \\
\hline \multirow{7}{*}{ 15-Jun } & 0,2 & 3935,88 & 880,95 & 56,63 & 1123,74 & 2812,14 & 3,50 \\
\hline & 0,3 & 3650,78 & 873,48 & 56,15 & 1123,26 & 2527,52 & 3,25 \\
\hline & 0,4 & 3205,29 & 869,56 & 55,90 & 1123,00 & 2082,28 & 2,85 \\
\hline & 0,5 & 2924,08 & 862,04 & 55,42 & 1122,52 & 1801,56 & 2,60 \\
\hline & 0,6 & 2574,90 & 867,56 & 55,77 & 1122,88 & 1452,02 & 2,29 \\
\hline & 0,7 & 2338,26 & 855,47 & 54,99 & 1122,10 & 1216,16 & 2,08 \\
\hline & 0,8 & 2094,21 & 857,53 & 55,13 & 1122,23 & 971,98 & 1,87 \\
\hline
\end{tabular}


Tabela 8B. Receitas brutas, composição de custos da irrigação, receitas líquidas e relação benefício/custo para a melancia, em cada época de semeadura, nivel de manejo da irrigação e risco de $5 \%$. Parnaiba, Piauí.

\begin{tabular}{|c|c|c|c|c|c|c|c|}
\hline $\begin{array}{l}\text { Época de } \\
\text { Semeadura }\end{array}$ & $p$ & $\begin{array}{c}\mathrm{RB}^{1} \\
\left(\mathrm{US} \$ \mathrm{ha}^{-1}\right)\end{array}$ & $\begin{array}{c}E b \\
\left(\mathrm{kWh} \mathrm{ha}{ }^{-1}\right)\end{array}$ & $\begin{array}{c}\text { CE } \\
\left(\mathrm{US} \$ h a^{-1}\right)\end{array}$ & $\begin{array}{c}\text { CT } \\
\left(\mathrm{US} \$ \mathrm{ha}^{-1}\right)\end{array}$ & $\begin{array}{c}\mathrm{RL} \\
\left(\mathrm{US} \$ \mathrm{ha}^{-1}\right)\end{array}$ & $\mathrm{B} / \mathrm{C}$ \\
\hline \multirow{7}{*}{ 1-Jul } & 0,2 & 3237,50 & 953,57 & 62,22 & 1129,33 & 2108,18 & 2,87 \\
\hline & 0,3 & 2973,74 & 945,12 & 61,67 & 1128,77 & 1844,97 & 2,63 \\
\hline & 0,4 & 2660,37 & 944,82 & 61,65 & 1128,75 & 1531,62 & 2,36 \\
\hline & 0,5 & 2373,33 & 942,42 & 61,49 & 1128,00 & 1244,73 & 2,10 \\
\hline & 0,6 & 2133,32 & 951,26 & 62,07 & 1129,18 & 1004,15 & 1,89 \\
\hline & 0,7 & 1911,44 & 941,74 & 61,45 & 1128,55 & 782,89 & 1,69 \\
\hline & 0,8 & 1720,25 & 933,55 & 60,91 & 1128,02 & 592,24 & 1,53 \\
\hline \multirow{7}{*}{ 15-Jul } & 0,2 & 3302,23 & 1030,30 & 67,23 & 1134,33 & 2167,89 & 2,91 \\
\hline & 0,3 & 3009,44 & 1022,45 & 66,72 & 1133,82 & 1875,62 & 2,65 \\
\hline & 0,4 & 2746,10 & 1018,87 & 66,48 & 1133,59 & 1612,51 & 2,42 \\
\hline & 0,5 & 2408,18 & 1020,85 & 66,61 & 1133,72 & 1274,47 & 2,12 \\
\hline & 0,6 & 2199,70 & 1027,88 & 67,07 & 1134,17 & 1065,53 & 1,94 \\
\hline & 0,7 & 1941,85 & 1021,07 & 66,63 & 1133,73 & 808,12 & 1,71 \\
\hline & 0,8 & 1779,12 & 1008,38 & 65,80 & 1132,90 & 646,22 & 1,57 \\
\hline \multirow{7}{*}{ 1-Ago } & 0,2 & 4118,89 & 1109,38 & 72,16 & 1139,26 & 2979,63 & 3,62 \\
\hline & 0,3 & 3673,85 & 1104,26 & 71,83 & 1138,93 & 2534,92 & 3,23 \\
\hline & 0,4 & 3400,94 & 1102,62 & 71,72 & 1138,82 & 2262,11 & 2,99 \\
\hline & 0,5 & 2978,16 & 1102,18 & 71,69 & 1138,80 & 1839,36 & 2,62 \\
\hline & 0,6 & 2693,85 & 1119,02 & 72,79 & 1139,89 & 1553,96 & 2,36 \\
\hline & 0,7 & 2453,57 & 1095,81 & 71,28 & 1138,38 & 1315,19 & 2,16 \\
\hline & 0,8 & 2181,24 & 1096,65 & 71,33 & 1138,44 & 1042,80 & 1,92 \\
\hline \multirow{7}{*}{ 15-Ago } & 0,2 & 4192,92 & 1157,23 & 75,27 & 1142,38 & 3050,54 & 3,67 \\
\hline & 0,3 & 3674,86 & 1154,24 & 75,08 & 1142,18 & 2532,68 & 3,22 \\
\hline & 0,4 & 3456,28 & 1149,85 & 74,79 & 1141,90 & 2314,38 & 3,03 \\
\hline & 0,5 & 3023,31 & 1151,18 & 74,88 & 1141,98 & 1881,33 & 2,65 \\
\hline & 0,6 & 2734,92 & 1139,81 & 74,14 & 1141,24 & 1593,68 & 2,40 \\
\hline & 0,7 & 2518,69 & 1144,03 & 74,41 & 1141,52 & 1377,17 & 2,21 \\
\hline & 0,8 & 2212,83 & 1157,79 & 75,31 & 1142,41 & 1070,42 & 1,94 \\
\hline
\end{tabular}


Tabela 8B. Receitas brutas, composição de custos da irrigação, receitas líquidas e relação benefício/custo para a melancia, em cada época de semeadura, nível de manejo da irrigação e risco de $5 \%$. Pamaíba, Piaui.

\begin{tabular}{|c|c|c|c|c|c|c|c|}
\hline $\begin{array}{l}\text { Época de } \\
\text { Semeadura }\end{array}$ & $\mathrm{p}$ & $\begin{array}{c}\mathrm{RB}^{1} \\
\left(\mathrm{US} \$ \mathrm{ha}^{-1}\right)\end{array}$ & $\begin{array}{c}E b \\
\left(\mathrm{kWh} \mathrm{ha}^{-1}\right)\end{array}$ & $\begin{array}{c}\mathrm{CE} \\
\left(\mathrm{US} \$ \mathrm{ha}^{-1}\right)\end{array}$ & $\begin{array}{c}\text { CT } \\
\left(\mathrm{US} \$ \mathrm{ha}^{-1}\right)\end{array}$ & $\begin{array}{c}\mathrm{RL} \\
\left(\mathrm{US} \$ \mathrm{ha}^{-1}\right)\end{array}$ & $\mathrm{B} / \mathrm{C}$ \\
\hline \multirow{7}{*}{$1-$ Set } & 0,2 & 4042,20 & 1188,49 & 72,99 & 1140,10 & 2902,10 & 3,55 \\
\hline & 0,3 & 3499,44 & 1190,96 & 73,15 & 1140,25 & 2359,19 & 3,07 \\
\hline & 0,4 & 3324,45 & 1185,95 & 72,84 & 1139,94 & 2184,50 & 2,92 \\
\hline & 0,5 & 2969,03 & 1178,49 & 72,38 & 1139,49 & 1829,55 & 2,61 \\
\hline & 0,6 & 2615,80 & 1181,27 & 72,55 & 1139,66 & 1476,14 & 2,30 \\
\hline & 0,7 & 2433,62 & 1182,63 & 72,63 & 1139,74 & 1293,88 & 2,14 \\
\hline & 0,8 & 2121,31 & 1186,99 & 72,90 & 1140,01 & 981,30 & 1,86 \\
\hline \multirow{7}{*}{$15-$ Set } & 0,2 & 4043,18 & 1188,65 & 73,00 & 1140,11 & 2903,07 & 3,55 \\
\hline & 0,3 & 3502,68 & 1189,31 & 73,04 & 1140,15 & 2362,53 & 3,07 \\
\hline & 0,4 & 3310,50 & 1181,70 & 72,58 & 1139,68 & 2170,82 & 2,90 \\
\hline & 0,5 & 2960,90 & 1177,46 & 72,32 & 1139,42 & 1821,48 & 2,60 \\
\hline & 0,6 & 2626,23 & 1204,44 & 73,97 & 1141,08 & 1485,15 & 2,30 \\
\hline & 0,7 & 2420,32 & 1182,63 & 72,63 & 1139,74 & 1280,58 & 2,12 \\
\hline & 0,8 & 2129,32 & 1163,30 & 71,45 & 1138,55 & 990,76 & 1,87 \\
\hline \multirow{7}{*}{ 1-Out } & 0,2 & 4127,21 & 1187,24 & 75,13 & 1142,23 & 2984,98 & 3,61 \\
\hline & 0,3 & 3590,69 & 1186,24 & 75,07 & 1142,17 & 2448,52 & 3,14 \\
\hline & 0,4 & 3392,29 & 1185,02 & 74,99 & 1142,09 & 2250,19 & 2,97 \\
\hline & 0,5 & 3042,48 & 1177,75 & 74,53 & 1141,63 & 1900,84 & 2,67 \\
\hline & 0,6 & 2663,62 & 1164,31 & 73,68 & 1140,78 & 1522,83 & 2,33 \\
\hline & 0,7 & 2489,30 & 1179,40 & 74,63 & 1141,74 & 1347,56 & 2,18 \\
\hline & 0,8 & 2176,47 & 1184,78 & 74,97 & 1142,08 & 1034,39 & 1,91 \\
\hline \multirow{7}{*}{ 15-Out } & 0,2 & 4090,64 & 1164,41 & 73,69 & 1140,79 & 2949,85 & 3,59 \\
\hline & 0,3 & 3596,33 & 1161,36 & 73,49 & 1140,60 & 2455,73 & 3,15 \\
\hline & 0,4 & 3371,67 & 1157,94 & 73,28 & 1140,38 & 2231,29 & 2,96 \\
\hline & 0,5 & 2970,33 & 1150,40 & 72,80 & 1139,90 & 1830,43 & 2,61 \\
\hline & 0,6 & 2671,47 & 1174,14 & 74,30 & 1141,41 & 1530,06 & 2,34 \\
\hline & 0,7 & 2473,82 & 1147,85 & 72,64 & 1139,74 & 1334,08 & 2,17 \\
\hline & 0,8 & 2159,22 & 1159,08 & 73,35 & 1140,45 & 1018,77 & 1,89 \\
\hline
\end{tabular}


Tabela 8B. Receitas brutas, composição de custos da irrigação, receitas líquidas e relação benefício/custo para a melancia, em cada época de semeadura, nível de manejo da irrigação e risco de $5 \%$. Parnaiba, Piauí.

\begin{tabular}{|c|c|c|c|c|c|c|c|}
\hline $\begin{array}{l}\text { Época de } \\
\text { Semeadura }\end{array}$ & $\mathrm{p}$ & $\begin{array}{c}\mathrm{RB}^{1} \\
\left(\mathrm{US} \$ \mathrm{ha}^{-1}\right)\end{array}$ & $\begin{array}{c}\mathrm{Eb} \\
\left(\mathrm{kWh} \mathrm{ha}^{-1}\right)\end{array}$ & $\begin{array}{c}\mathrm{CE} \\
\left(\mathrm{US} \$ \mathrm{ha}^{-1}\right)\end{array}$ & $\begin{array}{c}\text { CT } \\
\left(\mathrm{US} \$ \mathrm{ha}^{-1}\right)\end{array}$ & $\begin{array}{c}\mathrm{RL} \\
\left(\mathrm{US} \$ \mathrm{ha}^{-1}\right)\end{array}$ & $\mathrm{B} / \mathrm{C}$ \\
\hline \multirow{7}{*}{ 1-Nov } & 0,2 & 4390,11 & 1078,51 & 69,02 & 1136,13 & 3253,99 & 3,86 \\
\hline & 0,3 & 3975,86 & 1078,22 & 69,00 & 1136,11 & 2839,76 & 3,50 \\
\hline & 0,4 & 3644,33 & 1067,86 & 68,34 & 1135,44 & 2508,89 & 3,21 \\
\hline & 0,5 & 3243,92 & 1068,68 & 68,39 & 1135,50 & 2108,42 & 2,86 \\
\hline & 0,6 & 2933,22 & 1077,84 & 68,98 & 1136,08 & 1797,14 & 2,58 \\
\hline & 0,7 & 2643,52 & 1059,17 & 67,78 & 1134,89 & 1508,63 & 2,33 \\
\hline & 0,8 & 2371,24 & 1062,72 & 68,01 & 1135,11 & 1236,13 & 2,09 \\
\hline \multirow{7}{*}{ 15-Nov } & 0,2 & 4331,48 & 975,60 & 62,44 & 1129,54 & 3201,94 & 3,83 \\
\hline & 0,3 & 3947,94 & 971,27 & 62,16 & 1129,26 & 2818,68 & 3,50 \\
\hline & 0,4 & 3591,52 & 961,88 & 61,56 & 1128,66 & 2462,86 & 3,18 \\
\hline & 0,5 & 3192,19 & 949,62 & 60,77 & 1127,88 & 2064,31 & 2,83 \\
\hline & 0,6 & 2900,58 & 943,08 & 60,35 & 1127,46 & 1773,12 & 2,57 \\
\hline & 0,7 & 2600,53 & 944,54 & 60,45 & 1127,55 & 1472,98 & 2,31 \\
\hline & 0,8 & 2348,62 & 945,66 & 60,52 & 1127,62 & 1221,00 & 2,08 \\
\hline \multirow{7}{*}{ 1-Dez } & 0,2 & 4238,21 & 894,01 & 57,24 & 1124,34 & 3113,87 & 3,77 \\
\hline & 0,3 & 3912,27 & 881,11 & 56,41 & 1123,52 & 2788,75 & 3,48 \\
\hline & 0,4 & 3525,77 & 882,37 & 56,49 & 1123,60 & 2402,17 & 3,14 \\
\hline & 0,5 & 3155,09 & 864,32 & 55,34 & 1122,44 & 2032,65 & 2,81 \\
\hline & 0,6 & 2851,80 & 859,74 & 55,04 & 1122,15 & 1729,65 & 2,54 \\
\hline & 0,7 & 2596,80 & 843,16 & 53,98 & 1121,09 & 1475,71 & 2,32 \\
\hline & 0,8 & 2326,08 & 844,51 & 54,07 & 1121,17 & 1204,91 & 2,07 \\
\hline \multirow{7}{*}{ 15-Dez } & 0,2 & 4203,85 & 797,85 & 51,08 & 1118,19 & 3085,66 & 3,76 \\
\hline & 0,3 & 3874,51 & 781,23 & 50,02 & 1117,12 & 2757,39 & 3,47 \\
\hline & 0,4 & 3490,41 & 773,31 & 49,51 & 1116,61 & 2373,80 & 3,13 \\
\hline & 0,5 & 3138,01 & 759,28 & 48,61 & 1115,72 & 2022,30 & 2,81 \\
\hline & 0,6 & 2834,35 & 741,76 & 47,49 & 1114,59 & 1719,76 & 2,54 \\
\hline & 0,7 & 2597,38 & 736,40 & 47,15 & 1114,25 & 1483,12 & 2,33 \\
\hline & 0,8 & 2355,34 & 714,32 & 45,73 & 1112,84 & 1242,51 & 2,12 \\
\hline
\end{tabular}

${ }^{1} \mathrm{RB}$ - receita bruta: Eb - energia requerida para o bombeamento; $\mathrm{CE}$ - custo de energia elétrica: $\mathrm{CT}$ - custo total de produção: RL - receita liquida e B/C - relação beneficio/custo. 
Tabela 9B. Receitas brutas, composição de custos da irrigação, receitas líquidas e relação beneficio/custo para a melancia, em cada época de semeadura, nível de manejo da irrigação e risco de $10 \%$. Parnaíba, Piaui.

\begin{tabular}{|c|c|c|c|c|c|c|c|}
\hline $\begin{array}{l}\text { Época de } \\
\text { Semeadura }\end{array}$ & $\mathrm{p}$ & $\begin{array}{c}\mathrm{RB}^{1} \\
\left(\mathrm{US} \$ \mathrm{ha}^{-1}\right)\end{array}$ & $\begin{array}{c}E b \\
\left(\mathrm{kWh} \mathrm{ha}^{-1}\right)\end{array}$ & $\begin{array}{c}\mathrm{CE} \\
\left(\mathrm{US} \$ \mathrm{ha}^{-1}\right)\end{array}$ & $\begin{array}{c}\mathrm{CT} \\
\left(\mathrm{US} \$ \mathrm{ha}^{-1}\right)\end{array}$ & $\begin{array}{c}\mathrm{RL} \\
\left(\mathrm{US} \$ \mathrm{ha}^{-1}\right)\end{array}$ & $\mathrm{B} / \mathrm{C}$ \\
\hline \multirow{7}{*}{ 1-Jan } & 0,2 & 4609,53 & 671,24 & 42,40 & 1109,50 & 3500,02 & 4,15 \\
\hline & 0,3 & 4276,81 & 656,92 & 41,49 & 1108,60 & 3168,21 & 3,86 \\
\hline & 0,4 & 3871,68 & 632,16 & 39,93 & 1107,03 & 2764,65 & 3,50 \\
\hline & 0,5 & 3546,84 & 618,58 & 39,07 & 1106,18 & 2440,67 & 3,21 \\
\hline & 0,6 & 3222,30 & 587,84 & 37,13 & 1104,23 & 2118,07 & 2,92 \\
\hline & 0,7 & 2951,40 & 571,36 & 36,09 & 1103,19 & 1848,21 & 2,68 \\
\hline & 0,8 & 2725,72 & 550,20 & 34,75 & 1101,86 & 1623,86 & 2,47 \\
\hline \multirow{7}{*}{ 15-Jan } & 0,2 & 4692,09 & 612,50 & 38,69 & 1105,79 & 3586,29 & 4,24 \\
\hline & 0,3 & 4372,07 & 592,07 & 37,40 & 1104,50 & 3267,57 & 3,96 \\
\hline & 0,4 & 3934,25 & 562,51 & 35,53 & 1102,63 & 2831,62 & 3,57 \\
\hline & 0,5 & 3642,52 & 544,51 & 34,39 & 1101,50 & 2541,02 & 3,31 \\
\hline & 0,6 & 3323,91 & 519,15 & 32,79 & 1099,90 & 2224,01 & 3,02 \\
\hline & 0,7 & 3089,31 & 490,20 & 30,96 & 1098,07 & 1991,24 & 2,81 \\
\hline & 0,8 & 2857,81 & 468,23 & 29,58 & 1096,68 & 1761,13 & 2,61 \\
\hline \multirow{7}{*}{ 1-Fev } & 0,2 & 4921,38 & 565,82 & 36,61 & 1103,71 & 3817,67 & 4,46 \\
\hline & 0,3 & 4595,09 & 538,90 & 34,86 & 1101,97 & 3493,12 & 4,17 \\
\hline & 0,4 & 4135,63 & 495,45 & 32,05 & 1099,16 & 3036,48 & 3,76 \\
\hline & 0,5 & 3832,72 & 476,13 & 30,80 & 1097,91 & 2734,82 & 3,49 \\
\hline & 0,6 & 3552,02 & 458,31 & 29,65 & 1096,76 & 2455,26 & 3,24 \\
\hline & 0,7 & 3272,05 & 432,40 & 27,97 & 1095,08 & 2176,97 & 2,99 \\
\hline & 0,8 & 3038,23 & 415,74 & 26,90 & 1094,00 & 1944,23 & 2,78 \\
\hline \multirow{7}{*}{$15-\mathrm{Fev}$} & 0,2 & 4903,17 & 511,14 & 33,07 & 1100,17 & 3803,00 & 4,46 \\
\hline & 0,3 & 4548,41 & 478,50 & 30,96 & 1098,06 & 3450,35 & 4,14 \\
\hline & 0,4 & 4168,25 & 468,27 & 30,29 & 1097,40 & 3070,85 & 3,80 \\
\hline & 0,5 & 3814,20 & 425,64 & 27,54 & 1094,64 & 2719,56 & 3,48 \\
\hline & 0,6 & 3553,48 & 384,15 & 24,85 & 1091,96 & 2461,52 & 3,25 \\
\hline & 0,7 & 3321,59 & 366,20 & 23,69 & 1090,80 & 2230,80 & 3,05 \\
\hline & 0,8 & 3130,61 & 359,42 & 23,25 & 1090,36 & 2040,25 & 2,87 \\
\hline
\end{tabular}


Tabela 9B. Receitas brutas. composição de custos da irrigação, receitas líquidas e relação beneficio/custo para a melancia, em cada época de semeadura, nível de manejo da irrigação e risco de $10 \%$. Parnaiba, Piauí.

\begin{tabular}{|c|c|c|c|c|c|c|c|}
\hline $\begin{array}{c}\text { Época de } \\
\text { Semeadura }\end{array}$ & $\mathrm{p}$ & $\begin{array}{c}\mathrm{RB}^{1} \\
\left(\mathrm{US} \$ \mathrm{ha}^{-1}\right)\end{array}$ & $\begin{array}{c}\mathrm{Eb} \\
\left(\mathrm{kWh} \mathrm{ha}{ }^{-1}\right)\end{array}$ & $\begin{array}{c}\mathrm{CE} \\
\left(\mathrm{US} \$ \mathrm{ha}^{-1}\right)\end{array}$ & $\begin{array}{c}\text { CT } \\
\left(\mathrm{US} \$ \mathrm{ha}^{-1}\right)\end{array}$ & $\begin{array}{c}\mathrm{RL} \\
\left(\mathrm{US} \$ \mathrm{ha}^{-1}\right)\end{array}$ & $\mathrm{B} / \mathrm{C}$ \\
\hline \multirow{7}{*}{ 1-Mar } & 0,2 & 4883,65 & 504,81 & 32,46 & 1099,56 & 3784,09 & 4,44 \\
\hline & 0,3 & 4533,45 & 472,78 & 30,40 & 1097,50 & 3435,95 & 4,13 \\
\hline & 0,4 & 4113,80 & 440,69 & 28,33 & 1095,44 & 3018,36 & 3,76 \\
\hline & 0,5 & 3795,00 & 419,91 & 27,00 & 1094,10 & 2700,90 & 3,47 \\
\hline & 0,6 & 3510,13 & 375,65 & 24,15 & 1091,26 & 2418,87 & 3,22 \\
\hline & 0,7 & 3258,30 & 351,41 & 22,59 & 1089,70 & 2168,60 & 2,99 \\
\hline & 0,8 & 3083,88 & 332,50 & 21,38 & 1088,48 & 1995,40 & 2,83 \\
\hline \multirow{7}{*}{ 15-Mar } & 0,2 & 4847,33 & 519,72 & 33,41 & 1100,52 & 3746,81 & 4,40 \\
\hline & 0,3 & 4480,96 & 489,23 & 31,45 & 1098,56 & 3382,41 & 4,08 \\
\hline & 0,4 & 4073,34 & 454,71 & 29,23 & 1096,34 & 2977,00 & 3,72 \\
\hline & 0,5 & 3765,57 & 433,20 & 27,85 & 1094,96 & 2670,61 & 3,44 \\
\hline & 0,6 & 3453,94 & 403,57 & 25,95 & 1093,05 & 2360,89 & 3,16 \\
\hline & 0,7 & 3202,35 & 393,03 & 25,27 & 1092,37 & 2109,98 & 2,93 \\
\hline & 0,8 & 2961,22 & 349,29 & 22,46 & 1089,56 & 1871,66 & 2,72 \\
\hline \multirow{7}{*}{$1-A b r$} & 0,2 & 4721,54 & 585,49 & 35,66 & 1102,77 & 3618,77 & 4,28 \\
\hline & 0,3 & 4361,35 & 564,22 & 34,37 & 1101,47 & 3259,88 & 3,96 \\
\hline & 0,4 & 3889,70 & 535,56 & 32,62 & 1099,72 & 2789,98 & 3,54 \\
\hline & 0,5 & 3554,98 & 512,64 & 31,22 & 1098,33 & 2456,65 & 3,24 \\
\hline & 0,6 & 3248,46 & 501,82 & 30,56 & 1097,67 & 2150,79 & 2,96 \\
\hline & 0,7 & 2973,61 & 472,38 & 28,77 & 1095,88 & 1877,73 & 2,71 \\
\hline & 0,8 & 2738,04 & 466,17 & 28,39 & 1095,50 & 1642,54 & 2,50 \\
\hline \multirow{7}{*}{$15-\mathrm{Abr}$} & 0,2 & 4700,35 & 640,33 & 39,00 & 1106,11 & 3594,24 & 4,25 \\
\hline & 0,3 & 4331,30 & 628,92 & 38,31 & 1105,41 & 3225,89 & 3,92 \\
\hline & 0,4 & 3843,48 & 595,06 & 36,24 & 1103,35 & 2740,13 & 3,48 \\
\hline & 0,5 & 3501,24 & 585,60 & 35,67 & 1102,77 & 2398,47 & 3,17 \\
\hline & 0,6 & 3166,16 & 563,25 & 34,31 & 1101,41 & 2064,75 & 2,87 \\
\hline & 0,7 & 2828,85 & 548,26 & 33,39 & 1100,50 & 1728,35 & 2,57 \\
\hline & 0,8 & 2661,41 & 537,37 & 32,73 & 1099,84 & 1561,57 & 2,42 \\
\hline
\end{tabular}


Tabela 9B. Receitas brutas, composição de custos da irrigação, receitas liquidas e relação benefício/custo para a melancia, em cada época de semeadura, nivel de manejo da irrigação e risco de $10 \%$. Parnaiba, Piaui.

\begin{tabular}{|c|c|c|c|c|c|c|c|}
\hline $\begin{array}{l}\text { Época de } \\
\text { Semeadura }\end{array}$ & $p$ & $\begin{array}{c}\mathrm{RB}^{1} \\
\left(\mathrm{US} \$ \mathrm{ha}^{-1}\right)\end{array}$ & $\begin{array}{c}E b \\
\left(\mathrm{kWh} \mathrm{ha} a^{-1}\right)\end{array}$ & $\begin{array}{c}C E \\
\left(\mathrm{US} \$ \mathrm{ha}^{-1}\right)\end{array}$ & $\begin{array}{c}\mathrm{CT} \\
\left(\mathrm{US} \$ \mathrm{ha}^{-1}\right)\end{array}$ & $\begin{array}{c}\mathrm{RL} \\
\left(\mathrm{US} \$ \mathrm{ha} \mathrm{a}^{-1}\right)\end{array}$ & $\mathrm{B} / \mathrm{C}$ \\
\hline \multirow{7}{*}{ 1-Mai } & 0,2 & 3777,09 & 716,52 & 42,11 & 1109,22 & 2667,88 & 3,41 \\
\hline & 0,3 & 3482,27 & 705,23 & 41,45 & 1108,55 & 2373,72 & 3,14 \\
\hline & 0,4 & 3064,92 & 687,77 & 40,42 & 1107,53 & 1957,39 & 2,77 \\
\hline & 0,5 & 2776,14 & 689,35 & 40,52 & 1107,62 & 1668,52 & 2,51 \\
\hline & 0,6 & 2513,45 & 680,22 & 39,98 & 1107,08 & 1406,36 & 2,27 \\
\hline & 0,7 & 2265,00 & 671,71 & 39,48 & 1106,58 & 1158,41 & 2,05 \\
\hline & 0,8 & 2053,02 & 652,82 & 38,37 & 1105,47 & 947,55 & 1,86 \\
\hline \multirow{7}{*}{ 15-Mai } & 0,2 & 3773,91 & 748,93 & 44,02 & 1111,12 & 2662,78 & 3,40 \\
\hline & 0,3 & 3502,80 & 744,17 & 43,74 & 1110,84 & 2391,95 & 3,15 \\
\hline & 0,4 & 3067,81 & 729,70 & 42,89 & 1109,99 & 1957,82 & 2,76 \\
\hline & 0,5 & 2788,75 & 730,62 & 42,94 & 1110,05 & 1678,71 & 2,51 \\
\hline & 0,6 & 2485,72 & 717,15 & 42,15 & 1109,25 & 1376,46 & 2,24 \\
\hline & 0,7 & 2265,09 & 715,11 & 42,03 & 1109,13 & 1155,96 & 2,04 \\
\hline & 0,8 & 2047,22 & 699,18 & 41,09 & 1108,20 & 939,02 & 1,85 \\
\hline \multirow{7}{*}{ 1-Jun } & 0,2 & 3938,40 & 799,00 & 49,96 & 1117,06 & 2821,34 & 3,53 \\
\hline & 0,3 & 3655,90 & 792,21 & 49,54 & 1116,64 & 2539,26 & 3,27 \\
\hline & 0,4 & 3205,55 & 788,87 & 49,33 & 1116,43 & 2089,12 & 2,87 \\
\hline & 0,5 & 2926,08 & 777,00 & 48,58 & 1115,69 & 1810,39 & 2,62 \\
\hline & 0,6 & 2573,07 & 774,57 & 48,43 & 1115,54 & 1457,53 & 2,31 \\
\hline & 0,7 & 2370,99 & 770,77 & 48,19 & 1115,30 & 1255,70 & 2.13 \\
\hline & 0,8 & 2108,32 & 764,84 & 47,82 & 1114,93 & 993,39 & 1,89 \\
\hline \multirow{7}{*}{ 15-Jun } & 0,2 & 3986,81 & 868,68 & 54,32 & 1121,42 & 2865,39 & 3,56 \\
\hline & 0,3 & 3698,20 & 861,06 & 53,84 & 1120,94 & 2577,25 & 3,30 \\
\hline & 0,4 & 3255,99 & 854,74 & 53,45 & 1120,55 & 2135,44 & 2,91 \\
\hline & 0,5 & 2968,00 & 847,07 & 52,97 & 1120,07 & 1847,93 & 2,65 \\
\hline & 0,6 & 2624,56 & 849,13 & 53,09 & 1120,20 & 1504,36 & 2,34 \\
\hline & 0,7 & 2385,05 & 839,94 & 52,52 & 1119,62 & 1265,43 & 2,13 \\
\hline & 0,8 & 2139,41 & 838,00 & 52,40 & 1119,50 & 1019,91 & 1,91 \\
\hline
\end{tabular}


Tabela 9B. Receitas brutas, composição de custos da irrigação, receitas líquidas e relação benefício/custo para a melancia, em cada época de semeadura, nível de manejo da irrigação e risco de $10 \%$. Parnaíba, Piauí.

\begin{tabular}{|c|c|c|c|c|c|c|c|}
\hline $\begin{array}{l}\text { Época de } \\
\text { Semeadura }\end{array}$ & $\mathrm{p}$ & $\begin{array}{c}\mathrm{RB}^{1} \\
\left(\mathrm{US} \$ \mathrm{ha}^{-1}\right)\end{array}$ & $\begin{array}{c}E b \\
\left(k W h h^{-1}\right)\end{array}$ & $\begin{array}{c}\mathrm{CE} \\
\left(\mathrm{US} \$ \mathrm{ha}^{-1}\right)\end{array}$ & $\begin{array}{c}\text { CT } \\
\left(\mathrm{US} \$ \mathrm{ha}^{-1}\right)\end{array}$ & $\begin{array}{c}\text { RL } \\
\left(\mathrm{US} \$ \mathrm{ha}^{-1}\right)\end{array}$ & $\mathrm{B} / \mathrm{C}$ \\
\hline \multirow{7}{*}{ 1-Jul } & 0,2 & 3334,05 & 943,07 & 60,11 & 1127,22 & 2206,83 & 2,96 \\
\hline & 0,3 & 3061,75 & 934,26 & 59,55 & 1126,65 & 1935,09 & 2,72 \\
\hline & 0,4 & 2747,23 & 932,50 & 59,44 & 1126,54 & 1620,69 & 2,44 \\
\hline & 0,5 & 2448,75 & 928,58 & 59,19 & 1126,29 & 1322,46 & 2,17 \\
\hline & 0,6 & 2208,10 & 934,47 & 59,56 & 1126,67 & 1081,43 & 1,96 \\
\hline & 0,7 & 1978,30 & 924,77 & 58,95 & 1126,05 & 852,25 & 1,76 \\
\hline & 0,8 & 1787,45 & 918,34 & 58,54 & 1125,64 & 661,81 & 1,59 \\
\hline \multirow{7}{*}{ 15-Jul } & 0,2 & 3400,45 & 1020,18 & 65,03 & 1132,13 & 2268,32 & 3,00 \\
\hline & 0,3 & 3095,45 & 1012,15 & 64,52 & 1131,62 & 1963,83 & 2,74 \\
\hline & 0,4 & 2831,84 & 1008,02 & 64,25 & 1131,36 & 1700,48 & 2,50 \\
\hline & 0,5 & 2484,42 & 1009,04 & 64,32 & 1131,42 & 1353,00 & 2,20 \\
\hline & 0,6 & 2274,12 & 1012,07 & 64,51 & 1131,61 & 1142,51 & 2,01 \\
\hline & 0,7 & 2009,68 & 1006,34 & 64,14 & 1131,25 & 878,43 & 1,78 \\
\hline & 0,8 & 1840,26 & 994,55 & 63,39 & 1130,50 & 709,77 & 1,63 \\
\hline \multirow{7}{*}{ 1-Ago } & 0,2 & 4170,50 & 1103,51 & 70,44 & 1137,54 & 3032,96 & 3,67 \\
\hline & 0,3 & 3712,28 & 1098,21 & 70,10 & 1137,20 & 2575,08 & 3,26 \\
\hline & 0,4 & 3446,02 & 1096,15 & 69,97 & 1137,07 & 2308,95 & 3,03 \\
\hline & 0,5 & 3023,18 & 1094,66 & 69,87 & 1136,98 & 1886,20 & 2,66 \\
\hline & 0,6 & 2734,39 & 1106,00 & 70,60 & 1137,70 & 1596,69 & 2,40 \\
\hline & 0,7 & 2495,68 & 1087,34 & 69,41 & 1136,51 & 1359,17 & 2,20 \\
\hline & 0,8 & 2215,65 & 1087,92 & 69,44 & 1136,55 & 1079,10 & 1,95 \\
\hline \multirow{7}{*}{ 15-Ago } & 0,2 & 4243,02 & 1151,69 & 73,51 & 1140,62 & 3102,40 & 3,72 \\
\hline & 0,3 & 3714,39 & 1148,54 & 73,31 & 1140,42 & 2573,98 & 3,26 \\
\hline & 0,4 & 3499,18 & 1143,84 & 73,01 & 1140,12 & 2359,07 & 3,07 \\
\hline & 0,5 & 3075,16 & 1144,08 & 73,03 & 1140,13 & 1935,03 & 2,70 \\
\hline & 0,6 & 2771,84 & 1139,81 & 72,75 & 1139,86 & 1631,98 & 2,43 \\
\hline & 0,7 & 2559,38 & 1135,64 & 72,49 & 1139,59 & 1419,79 & 2,25 \\
\hline & 0,8 & 2231,92 & 1146,95 & 73,21 & 1140,31 & 1091,60 & 1,96 \\
\hline
\end{tabular}


Tabela 9B. Receitas brutas, composição de custos da irrigação, receitas líquidas e relação benefício/custo para a melancia, em cada época de semeadura, nível de manejo da irrigação e risco de 10 \%. Parnaíba, Piauí.

\begin{tabular}{|c|c|c|c|c|c|c|c|}
\hline $\begin{array}{l}\text { Época de } \\
\text { Semeadura }\end{array}$ & $\mathrm{p}$ & $\begin{array}{c}\mathrm{RB}^{1} \\
\left(\mathrm{US} \$ \mathrm{ha}^{-1}\right)\end{array}$ & $\begin{array}{c}E b \\
\left(\mathrm{kWh} \mathrm{ha}^{-1}\right)\end{array}$ & $\begin{array}{c}\text { CE } \\
\left(\mathrm{USS} \mathrm{ha}^{-1}\right)\end{array}$ & $\begin{array}{c}\mathrm{CT} \\
\left(\mathrm{US} \$ \mathrm{ha}^{-1}\right)\end{array}$ & $\begin{array}{c}\mathrm{RL} \\
\left(\mathrm{US} \$ \mathrm{ha}^{-1}\right)\end{array}$ & $\mathrm{B} / \mathrm{C}$ \\
\hline \multirow{7}{*}{ 1-Set } & 0,2 & 4077,89 & 1184,11 & 72,08 & 1139,19 & 2938,70 & 3,58 \\
\hline & 0,3 & 3526,69 & 1185,76 & 72,18 & 1139,29 & 2387,40 & 3,10 \\
\hline & 0,4 & 3353,48 & 1180,21 & 71,85 & 1138,95 & 2214,52 & 2,94 \\
\hline & 0,5 & 3008,65 & 1172,57 & 71,38 & 1138,49 & 1870,16 & 2,64 \\
\hline & 0,6 & 2642,90 & 1181,27 & 71,91 & 1139,02 & 1503,88 & 2,32 \\
\hline & 0,7 & 2466,73 & 1174,12 & 71,48 & 1138,58 & 1328,15 & 2,17 \\
\hline & 0,8 & 2151,90 & 1176,89 & 71,64 & 1138,75 & 1013,16 & 1,89 \\
\hline \multirow{7}{*}{$15-$ Set } & 0,2 & 4078,76 & 1182,36 & 71,98 & 1139,08 & 2939,67 & 3,58 \\
\hline & 0,3 & 3531,00 & 1182,32 & 71,98 & 1139,08 & 2391,92 & 3,10 \\
\hline & 0,4 & 3342,96 & 1175,01 & 71,53 & 1138,63 & 2204,33 & 2,94 \\
\hline & 0,5 & 3001,63 & 1170,08 & 71,23 & 1138,33 & 1863,30 & 2,64 \\
\hline & 0,6 & 2654,86 & 1190,71 & 72,49 & 1139,59 & 1515,27 & 2,33 \\
\hline & 0,7 & 2455,50 & 1172,18 & 71,36 & 1138,46 & 1317,04 & 2,16 \\
\hline & 0,8 & 2159,76 & 1154,92 & 70,31 & 1137,41 & 1022,35 & 1,90 \\
\hline \multirow{7}{*}{ 1-Out } & 0,2 & 4163,21 & 1179,48 & 73,57 & 1140,68 & 3022,53 & 3,65 \\
\hline & 0,3 & 3618,23 & 1177,62 & 73,46 & 1140,56 & 2477,66 & 3,17 \\
\hline & 0,4 & 3424,21 & 1175,20 & 73,31 & 1140,41 & 2283,80 & 3,00 \\
\hline & 0,5 & 3081,40 & 1167,84 & 72,85 & 1139,95 & 1941,44 & 2,70 \\
\hline & 0,6 & 2695,21 & 1164,31 & 72,63 & 1139,73 & 1555,48 & 2,36 \\
\hline & 0,7 & 2522,83 & 1167,39 & 72,82 & 1139,92 & 1382,91 & 2,21 \\
\hline & 0,8 & 2206,76 & 1170,27 & 73,00 & 1140,10 & 1066,65 & 1,94 \\
\hline \multirow{7}{*}{ 15-Out } & 0,2 & 4128,23 & 1155,30 & 72,06 & 1139,17 & 2989,06 & 3,62 \\
\hline & 0,3 & 3623,53 & 1151,63 & 71,84 & 1138,94 & 2484,59 & 3,18 \\
\hline & 0,4 & 3405,35 & 1148,02 & 71,61 & 1138,71 & 2266,64 & 2,99 \\
\hline & 0,5 & 3011,29 & 1140,08 & 71,11 & 1138,22 & 1873,07 & 2,65 \\
\hline & 0,6 & 2701,35 & 1157,44 & 72,20 & 1139,30 & 1562,05 & 2,37 \\
\hline & 0,7 & 2505,94 & 1134,73 & 70,78 & 1137,89 & 1368,05 & 2,20 \\
\hline & 0,8 & 2188,65 & 1142,92 & 71,29 & 1138,40 & 1050,26 & 1,92 \\
\hline
\end{tabular}


Tabela 9B. Receitas brutas, composição de custos da irrigação, receitas líquidas e relação beneficio/custo para a melancia, em cada época de semeadura, nível de manejo da irrigação e risco de $10 \%$. Parnaíba, Piauí.

\begin{tabular}{|c|c|c|c|c|c|c|c|}
\hline $\begin{array}{l}\text { Época de } \\
\text { Semeadura }\end{array}$ & $\mathrm{p}$ & $\begin{array}{c}\mathrm{RB}^{1} \\
\left(\mathrm{US} \$ \mathrm{ha}^{-1}\right)\end{array}$ & $\begin{array}{c}E b \\
\left(\mathrm{kWh} \mathrm{ha} \mathrm{a}^{-1}\right)\end{array}$ & $\begin{array}{c}\text { CE } \\
\left(\mathrm{US} \$ h \mathrm{a}^{-1}\right)\end{array}$ & $\begin{array}{c}C T \\
\left(\mathrm{US} \$ h \mathrm{~h}^{-1}\right)\end{array}$ & $\begin{array}{c}\mathrm{RL} \\
\left(\mathrm{US} \$ \mathrm{ha}^{-1}\right)\end{array}$ & $\mathrm{B} / \mathrm{C}$ \\
\hline \multirow{7}{*}{$1-\mathrm{Nov}$} & 0,2 & 4436,95 & 1063,01 & 66,85 & 1133,96 & 3302,99 & 3,91 \\
\hline & 0,3 & 4012,71 & 1060,70 & 66,71 & 1133,81 & 2878,90 & 3,54 \\
\hline & 0,4 & 3689,67 & 1049,15 & 65,98 & 1133,09 & 2556,59 & 3,26 \\
\hline & 0,5 & 3286,63 & 1048,54 & 65,94 & 1133,05 & 2153,59 & 2,90 \\
\hline & 0,6 & 2976,24 & 1052,80 & 66,21 & 1133,31 & 1842,93 & 2,63 \\
\hline & 0,7 & 2686,99 & 1036,09 & 65,16 & 1132,26 & 1554,72 & 2,37 \\
\hline & 0,8 & 2413,94 & 1036,56 & 65,19 & 1132,29 & 1281,64 & 2,13 \\
\hline \multirow{7}{*}{ 15-Nov } & 0,2 & 4375,74 & 957,23 & 60,20 & 1127,30 & 3248,44 & 3,88 \\
\hline & 0,3 & 3988,24 & 950,14 & 59,75 & 1126,86 & 2861,38 & 3,54 \\
\hline & 0,4 & 3641,72 & 939,90 & 59,11 & 1126,21 & 2515,50 & 3,23 \\
\hline & 0,5 & 3240,74 & 926,53 & 58,27 & 1125,37 & 2115,37 & 2,88 \\
\hline & 0,6 & 2951,97 & 916,33 & 57,63 & 1124,73 & 1827,24 & 2,62 \\
\hline & 0,7 & 2653,93 & 915,67 & 57,59 & 1124,69 & 1529,24 & 2,36 \\
\hline & 0,8 & 2403,35 & 912,89 & 57,41 & 1124,52 & 1278,83 & 2,14 \\
\hline \multirow{7}{*}{ 1-Dez } & 0,2 & 4336,98 & 875,73 & 54,73 & 1121,83 & 3215,15 & 3,87 \\
\hline & 0,3 & 4000,60 & 861,33 & 53,83 & 1120,93 & 2879,66 & 3,57 \\
\hline & 0,4 & 3619,13 & 858,96 & 53,68 & 1120,78 & 2498,35 & 3,23 \\
\hline & 0,5 & 3243,83 & 838,91 & 52,43 & 1119,53 & 2124,30 & 2,90 \\
\hline & 0,6 & 2942,78 & 831,50 & 51,96 & 1119,07 & 1823,71 & 2,63 \\
\hline & 0,7 & 2682,84 & 814,69 & 50,91 & 1118,02 & 1564,82 & 2,40 \\
\hline & 0,8 & 2415,10 & 813,06 & 50,81 & 1117,92 & 1297,18 & 2,16 \\
\hline \multirow{7}{*}{ 15-Dez } & 0,2 & 4298,54 & 774,60 & 48,41 & 1115,51 & 3183,03 & 3,85 \\
\hline & 0,3 & 3968,34 & 755,68 & 47,23 & 1114,33 & 2854,01 & 3,56 \\
\hline & 0,4 & 3583,94 & 743,25 & 46,45 & 1113,55 & 2470,39 & 3,22 \\
\hline & 0,5 & 3235,97 & 727,38 & 45,46 & 1112,56 & 2123,41 & 2,91 \\
\hline & 0,6 & 2934,27 & 708,95 & 44,31 & 1111,41 & 1822,86 & 2,64 \\
\hline & 0,7 & 2692,44 & 699,32 & 43,70 & 1110,81 & 1581,63 & 2,42 \\
\hline & 0,8 & 2453,50 & 677,84 & 42,36 & 1109,47 & 1344,03 & 2,21 \\
\hline
\end{tabular}

'RB - receita bruta: $\mathrm{Eb}$ - energia requerida para o bombeamento; CE - custo de energia elétrica: CT - custo total de produção: RL - receita líquida e B/C - relação benefício/custo. 
Tabela 10B. Receitas brutas, composição de custos da irrigação, receitas líquidas e relação benefício/custo para a melancia, em cada época de semeadura, nivel de manejo da irrigação e risco de $15 \%$. Parnaiba, Piauí.

\begin{tabular}{|c|c|c|c|c|c|c|c|}
\hline $\begin{array}{l}\text { Época de } \\
\text { Semeadura }\end{array}$ & $\mathrm{p}$ & $\begin{array}{c}\mathrm{RB}^{\mathrm{l}} \\
\left(\mathrm{US} \$ \mathrm{ha}^{-1}\right)\end{array}$ & $\begin{array}{c}E b \\
\left(\mathrm{kWh} \mathrm{ha}^{-1}\right)\end{array}$ & $\begin{array}{c}\mathrm{CE} \\
\left(\mathrm{US} \$ \mathrm{ha}^{-1}\right)\end{array}$ & $\begin{array}{c}\mathrm{CT} \\
\left(\mathrm{US} \$ \mathrm{ha}^{-1}\right)\end{array}$ & $\begin{array}{c}\mathrm{RL} \\
\left(\mathrm{US} \$ \mathrm{ha}^{-1}\right)\end{array}$ & $\mathrm{B} / \mathrm{C}$ \\
\hline \multirow{7}{*}{ 1-Jan } & 0,2 & 4657,31 & 655,21 & 40,42 & 1107,53 & 3549,78 & 4,21 \\
\hline & 0,3 & 4328,08 & 639,31 & 39,44 & 1106,55 & 3221,53 & 3,91 \\
\hline & 0,4 & 3925,84 & 612,82 & 37,81 & 1104,91 & 2820,92 & 3,55 \\
\hline & 0,5 & 3604,42 & 597,49 & 36,86 & 1103,97 & 2500,46 & 3,26 \\
\hline & 0,6 & 3284,05 & 566,10 & 34,93 & 1102,03 & 2182,02 & 2,98 \\
\hline & 0,7 & 3019,63 & 547,83 & 33,80 & 1100,90 & 1918,72 & 2,74 \\
\hline & 0,8 & 2792,34 & 524,50 & 32,36 & 1099,46 & 1692,88 & 2,54 \\
\hline \multirow{7}{*}{ 15-Jan } & 0,2 & 4740,66 & 597,07 & 36,84 & 1103,94 & 3636,72 & 4,29 \\
\hline & 0,3 & 4423,01 & 574,38 & 35,44 & 1102,54 & 3320,47 & 4,01 \\
\hline & 0,4 & 3989,85 & 542,77 & 33,49 & 1100,59 & 2889,26 & 3,63 \\
\hline & 0,5 & 3700,84 & 523,09 & 32,27 & 1099,38 & 2601,46 & 3,37 \\
\hline & 0,6 & 3386,72 & 495,50 & 30,57 & 1097,67 & 2289,04 & 3,09 \\
\hline & 0,7 & 3158,01 & 468,07 & 28,88 & 1095,98 & 2062,03 & 2,88 \\
\hline & 0,8 & 2930,69 & 445,87 & 27,51 & 1094,61 & 1836,08 & 2,68 \\
\hline \multirow{7}{*}{$1-\mathrm{Fev}$} & 0,2 & 4952,64 & 549,09 & 34,39 & 1101,50 & 3851,14 & 4,50 \\
\hline & 0,3 & 4630,55 & 520,63 & 32,61 & 1099,72 & 3530,84 & 4,21 \\
\hline & 0,4 & 4179,94 & 476,20 & 29,83 & 1096,93 & 3083,01 & 3,81 \\
\hline & 0,5 & 3886,45 & 455,78 & 28,55 & 1095,65 & 2790,80 & 3,55 \\
\hline & 0,6 & 3607,49 & 436,73 & 27,36 & 1094,46 & 2513,03 & 3,30 \\
\hline & 0,7 & 3338,05 & 409,78 & 25,67 & 1092,77 & 2245,27 & 3,05 \\
\hline & 0,8 & 3109,50 & 391,66 & 24,53 & 1091,64 & 2017,86 & 2,85 \\
\hline \multirow{7}{*}{ 15-Fev } & 0,2 & 4934,78 & 496,32 & 31,09 & 1098,19 & 3836,59 & 4,49 \\
\hline & 0,3 & 4588,85 & 463,04 & 29,00 & 1096,11 & 3492,75 & 4,19 \\
\hline & 0,4 & 4209,96 & 447,49 & 28,03 & 1095,13 & 3114,83 & 3,84 \\
\hline & 0,5 & 3869,17 & 405,70 & 25,41 & 1092,52 & 2776,65 & 3,54 \\
\hline & 0,6 & 3615,17 & 366,20 & 22,94 & 1090,04 & 2525,12 & 3,32 \\
\hline & 0,7 & 3385,02 & 346,31 & 21,69 & 1088,80 & 2296,22 & 3,11 \\
\hline & 0,8 & 3195,11 & 335,78 & 21,03 & 1088,14 & 2106,98 & 2,94 \\
\hline
\end{tabular}


Tabela 10B. Receitas brutas, composição de custos da irrigação, receitas líquidas e relação benefício/custo para a melancia, em cada época de semeadura, nivel de manejo da irrigação e risco de $15 \%$. Parnaíba, Piauí.

\begin{tabular}{|c|c|c|c|c|c|c|c|}
\hline $\begin{array}{l}\text { Época de } \\
\text { Semeadura }\end{array}$ & $\mathrm{p}$ & $\begin{array}{c}\mathrm{RB}^{1} \\
\left(\mathrm{US} \$ \mathrm{ha}^{-1}\right)\end{array}$ & $\begin{array}{c}\mathrm{Eb} \\
\left(\mathrm{kWh} \mathrm{ha}^{-1}\right)\end{array}$ & $\begin{array}{c}\mathrm{CE} \\
\left(\mathrm{US} \$ \mathrm{ha}^{-1}\right)\end{array}$ & $\begin{array}{c}\text { CT } \\
\left(\mathrm{US} \$ \mathrm{ha}^{-1}\right)\end{array}$ & $\begin{array}{c}\mathrm{RL} \\
\left(\mathrm{US} \$ \mathrm{ha}^{-1}\right)\end{array}$ & $\mathrm{B} / \mathrm{C}$ \\
\hline \multirow{7}{*}{ 1-Mar } & 0,2 & 4934,86 & 488,09 & 30,41 & 1097,51 & 3837,34 & 4,50 \\
\hline & 0,3 & 4590,84 & 454,63 & 28,32 & 1095,43 & 3495,41 & 4,19 \\
\hline & 0,4 & 4177,97 & 420,53 & 26,20 & 1093,30 & 3084,67 & 3,82 \\
\hline & 0,5 & 3867,55 & 397,71 & 24,78 & 1091,88 & 2775,67 & 3,54 \\
\hline & 0,6 & 3589,26 & 354,62 & 22,09 & 1089,20 & 2500,06 & 3,30 \\
\hline & 0,7 & 3343,67 & 329,38 & 20,52 & 1087,62 & 2256,04 & 3,07 \\
\hline & 0,8 & 3171,41 & 308,64 & 19,23 & 1086,33 & 2085,07 & 2,92 \\
\hline \multirow{7}{*}{ 15-Mar } & 0,2 & 4897,40 & 504,16 & 31,41 & 1098,51 & 3798,89 & 4,46 \\
\hline & 0,3 & 4537,19 & 472,37 & 29,43 & 1096,53 & 3440,66 & 4,14 \\
\hline & 0,4 & 4132,08 & 436,25 & 27,18 & 1094,28 & 3037,80 & 3,78 \\
\hline & 0,5 & 3829,22 & 413,54 & 25,76 & 1092,87 & 2736,36 & 3,50 \\
\hline & 0,6 & 3523,63 & 382,49 & 23,83 & 1090,93 & 2432,70 & 3,23 \\
\hline & 0,7 & 3279,24 & 368,80 & 22,97 & 1090,08 & 2189,16 & 3,01 \\
\hline & 0,8 & 3047,95 & 325,47 & 20,28 & 1087,38 & 1960,57 & 2,80 \\
\hline \multirow{7}{*}{$1-\mathrm{Abr}$} & 0,2 & 4770,38 & 570,68 & 33,78 & 1100,88 & 3669,49 & 4,33 \\
\hline & 0,3 & 4415,80 & 548,55 & 32,47 & 1099,57 & 3316,22 & 4,02 \\
\hline & 0,4 & 3950,05 & 517,87 & 30,65 & 1097,76 & 2852,30 & 3,60 \\
\hline & 0,5 & 3617,78 & 493,80 & 29,23 & 1096,33 & 2521,44 & 3,30 \\
\hline & 0,6 & 3315,93 & 480,30 & 28,43 & 1095,53 & 2220,40 & 3,03 \\
\hline & 0,7 & 3044,77 & 449,89 & 26,63 & 1093,73 & 1951,03 & 2,78 \\
\hline & 0,8 & 2816,08 & 441,40 & 26,13 & 1093,23 & 1722,85 & 2,58 \\
\hline \multirow{7}{*}{$15-\mathrm{Abr}$} & 0,2 & 4747,80 & 626,16 & 37,06 & 1104,17 & 3643,64 & 4,30 \\
\hline & 0,3 & 4383,14 & 612,44 & 36,25 & 1103,36 & 3279,79 & 3,97 \\
\hline & 0,4 & 3899,20 & 578,53 & 34,24 & 1101,35 & 2797,85 & 3,54 \\
\hline & 0,5 & 3559,49 & 566,57 & 33,54 & 1100,64 & 2458,85 & 3,23 \\
\hline & 0,6 & 3228,59 & 542,20 & 32,09 & 1099,20 & 2129,40 & 2,94 \\
\hline & 0,7 & 2850,44 & 525,19 & 31,09 & 1098,19 & 1752,25 & 2,60 \\
\hline & 0,8 & 2726,47 & 512,61 & 30,34 & 1097,45 & 1629,02 & 2,48 \\
\hline
\end{tabular}


Tabela 10B. Receitas brutas, composição de custos da irrigação, receitas líquidas e relação beneficio/custo para a melancia, em cada época de semeadura, nível de manejo da irrigação e risco de $15 \%$. Parnaíba, Piauí.

\begin{tabular}{|c|c|c|c|c|c|c|c|}
\hline $\begin{array}{l}\text { Época de } \\
\text { Semeadura }\end{array}$ & $\mathrm{p}$ & $\begin{array}{c}\mathrm{RB}^{\mathrm{I}} \\
\left(\mathrm{US} \$ \mathrm{ha}^{-1}\right)\end{array}$ & $\begin{array}{c}\text { Eb } \\
\left(\mathrm{kWh} h \mathrm{~h}^{-1}\right)\end{array}$ & $\begin{array}{c}\text { CE } \\
\left.\left(\text { US } \$ h^{-1}\right)^{-1}\right)\end{array}$ & $\begin{array}{c}\text { CT } \\
\left.\left(\text { US } \$ h^{-1}\right)^{-1}\right)\end{array}$ & $\begin{array}{c}\mathrm{RL} \\
\left(\mathrm{US} \$ \mathrm{ha}^{-1}\right)\end{array}$ & $\mathrm{B} / \mathrm{C}$ \\
\hline \multirow{7}{*}{ I-Mai } & 0,2 & 3808,43 & 705,09 & 40,60 & 1107,70 & 2700,73 & 3,44 \\
\hline & 0,3 & 3517,46 & 692,71 & 39,88 & 1106,99 & 2410,47 & 3,18 \\
\hline & 0,4 & 3099,78 & 673,12 & 38,76 & 1105,86 & 1993,92 & 2,80 \\
\hline & 0,5 & 2812,96 & 671,39 & 38,66 & 1105,76 & 1707,20 & 2,54 \\
\hline & 0,6 & 2548,65 & 660,00 & 38,00 & 1105,10 & 1443,55 & 2,31 \\
\hline & 0,7 & 2301,95 & 650,25 & 37,44 & 1104,54 & 1197,41 & 2,08 \\
\hline & 0,8 & 2093,06 & 631,61 & 36,37 & 1103,47 & 989,59 & 1,90 \\
\hline \multirow{7}{*}{ 15-Mai } & 0,2 & 3805,80 & 737,36 & 42,45 & 1109,56 & 2696,24 & 3,43 \\
\hline & 0,3 & 3535,35 & 730,54 & 42,06 & 1109,17 & 2426,18 & 3,19 \\
\hline & 0,4 & 3101,96 & 715,42 & 41,19 & 1108,30 & 1993,66 & 2,80 \\
\hline & 0,5 & 2824,65 & 713,79 & 41,10 & 1108,20 & 1716,45 & 2,55 \\
\hline & 0,6 & 2521,23 & 699,16 & 40,25 & 1107,36 & 1413,87 & 2,28 \\
\hline & 0,7 & 2301,97 & 695,63 & 40,05 & 1107,16 & 1194,82 & 2,08 \\
\hline & 0,8 & 2083,28 & 679,05 & 39,10 & 1106,20 & 977,08 & 1,88 \\
\hline \multirow{7}{*}{ 1-Jun } & 0,2 & 3984,01 & 790,44 & 48,27 & 1115,38 & 2868,63 & 3,57 \\
\hline & 0,3 & 3701,51 & 782,53 & 47,79 & 1114,90 & 2586,61 & 3,32 \\
\hline & 0,4 & 3248,03 & 777,60 & 47,49 & 1114,60 & 2133,43 & 2,91 \\
\hline & 0,5 & 2968,72 & 765,33 & 46,74 & 1113,85 & 1854,88 & 2,67 \\
\hline & 0,6 & 2614,95 & 760,29 & 46,43 & 1113,54 & 1501,41 & 2,35 \\
\hline & 0,7 & 2411,41 & 756,42 & 46,20 & 1113,30 & 1298,11 & 2,17 \\
\hline & 0,8 & 2147,70 & 749,36 & 45,77 & 1112,87 & 1034,83 & 1,93 \\
\hline \multirow{7}{*}{ 15-Jun } & 0,2 & 4034,08 & 860,40 & 52,55 & 1119,65 & 2914,42 & 3,60 \\
\hline & 0,3 & 3742,16 & 852,68 & 52,08 & 1119,18 & 2622,98 & 3,34 \\
\hline & 0,4 & 3300,85 & 844,74 & 51,59 & 1118,70 & 2182,15 & 2,95 \\
\hline & 0,5 & 3007,32 & 836,98 & 51,12 & 1118,22 & 1889,10 & 2,69 \\
\hline & 0,6 & 2666,76 & 836,69 & 51,10 & 1118,20 & 1548,55 & 2,38 \\
\hline & 0,7 & 2424,55 & 829,46 & 50,66 & 1117,76 & 1306,79 & 2,17 \\
\hline & 0,8 & 2177,06 & 824,83 & 50,38 & 1117,48 & 1059,58 & 1,95 \\
\hline
\end{tabular}


Tabela 10B. Receitas brutas, composição de custos da irrigação, receitas líquidas e relação benefício/custo para a melancia, em cada época de semeadura, nível de manejo da irrigação e risco de $15 \%$. Pamaiba, Piauí.

\begin{tabular}{|c|c|c|c|c|c|c|c|}
\hline $\begin{array}{c}\text { Época de } \\
\text { Semeadura }\end{array}$ & $\mathrm{p}$ & $\begin{array}{c}\mathrm{RB}^{1} \\
\left(\mathrm{US} \$ \mathrm{ha}^{-1}\right)\end{array}$ & $\begin{array}{c}E b \\
\left(\mathrm{kWh} h \mathrm{a}^{-1}\right)\end{array}$ & $\begin{array}{c}\text { CE } \\
\left(\mathrm{US} \$ \mathrm{ha}^{-1}\right)\end{array}$ & $\begin{array}{c}\text { CT } \\
\left.\left(\text { US } \$ h^{-1}\right)^{-1}\right)\end{array}$ & $\begin{array}{c}\mathrm{RL} \\
\left(\mathrm{US} \$ \mathrm{ha}^{-1}\right)\end{array}$ & $\mathrm{B} / \mathrm{C}$ \\
\hline & 0,2 & 3407,26 & 936,00 & 58,54 & 1125,64 & 2281,62 & 3,03 \\
\hline & 0,3 & 3128,51 & 926,92 & 57,97 & 1125,07 & 2003,44 & 2,78 \\
\hline & 0,4 & 2812,70 & 924,19 & 57,80 & 1124,90 & 1687,80 & 2,50 \\
\hline \multirow[t]{7}{*}{ 1-Jul } & 0,5 & 2505,71 & 919,24 & 57,49 & 1124,59 & 1381,11 & 2,23 \\
\hline & 0,6 & 2264,23 & 923,14 & 57,73 & 1124,84 & 1139,39 & 2,01 \\
\hline & 0,7 & 2028,48 & 913,32 & 57,12 & 1124,22 & 904,26 & 1,80 \\
\hline & 0,8 & 1837,58 & 908,08 & 56,79 & 1123,90 & 713,69 & 1,64 \\
\hline & 0,2 & 3474,95 & 1013,34 & 63,37 & 1130,48 & 2344,47 & 3,07 \\
\hline & 0,3 & 3160,86 & 1005,20 & 62,86 & 1129,97 & 2030,89 & 2,80 \\
\hline & 0,4 & 2896,66 & 1000,70 & 62,58 & 1129,69 & 1766,97 & 2,56 \\
\hline \multirow[t]{7}{*}{ 15-Jul } & 0,5 & 2542,00 & 1001,07 & 62,61 & 1129,71 & 1412,29 & 2,25 \\
\hline & 0,6 & 2330,10 & 1001,40 & 62,63 & 1129,73 & 1200,37 & 2,06 \\
\hline & 0,7 & 2060,60 & 996,40 & 62,31 & 1129,42 & 931,19 & 1,82 \\
\hline & 0,8 & 1886,21 & 985,22 & 61,61 & 1128,72 & 757,49 & 1,67 \\
\hline & 0,2 & 4218,12 & 1099,55 & 69,06 & 1136,16 & 3081,96 & 3,71 \\
\hline & 0,3 & 3749,51 & 1094,13 & 68,72 & 1135,82 & 2613,69 & 3,30 \\
\hline & 0,4 & 3487,04 & 1091,79 & 68,57 & 1135,68 & 2351,37 & 3,07 \\
\hline \multirow[t]{7}{*}{ 1-Ago } & 0,5 & 3062,92 & 1089,58 & 68,43 & 1135,54 & 1927,38 & 2,70 \\
\hline & 0,6 & 2770,21 & 1097,21 & 68,91 & 1136,02 & 1634,19 & 2,44 \\
\hline & 0,7 & 2531,89 & 1081,63 & 67,93 & 1135,04 & 1396,85 & 2,23 \\
\hline & 0,8 & 2245,75 & 1082,04 & 67,96 & 1135,06 & 1110,68 & 1,98 \\
\hline & 0,2 & 4289,81 & 1147,94 & 72,10 & 1139,20 & 3150,61 & 3,77 \\
\hline & 0,3 & 3752,38 & 1144,70 & 71,89 & 1139,00 & 2613,38 & 3,29 \\
\hline & 0,4 & 3538,86 & 1139,79 & 71,59 & 1138,69 & 2400,17 & 3,11 \\
\hline \multirow[t]{4}{*}{ 15-Ago } & 0,5 & 3119,74 & 1139,30 & 71,55 & 1138,66 & 1981,08 & 2,74 \\
\hline & 0,6 & 2805,29 & 1139,81 & 71,59 & 1138,69 & 1666,60 & 2,46 \\
\hline & 0,7 & 2594,79 & 1129,97 & 70,97 & 1138,07 & 1456,72 & 2,28 \\
\hline & 0,8 & 2251,55 & 1139,63 & 71,58 & 1138,68 & 1112,87 & 1,98 \\
\hline
\end{tabular}


Tabela 10B. Receitas brutas, composição de custos da irrigação, receitas líquidas e relação benefício/custo para a melancia, em cada época de semeadura, nível de manejo da irrigação e risco de $15 \%$. Parnaiba, Piauí.

\begin{tabular}{|c|c|c|c|c|c|c|c|}
\hline $\begin{array}{c}\text { Época de } \\
\text { Semeadura }\end{array}$ & $\mathrm{p}$ & $\begin{array}{c}\mathrm{RB}^{1} \\
\left(\mathrm{US} \$ \mathrm{ha}^{-1}\right)\end{array}$ & $\begin{array}{c}\mathrm{Eb} \\
\left(\mathrm{kWh} \mathrm{ha}^{-1}\right)\end{array}$ & $\begin{array}{c}C E \\
\left(U S \$ h^{-1}\right)\end{array}$ & $\begin{array}{c}\mathrm{CT} \\
\left(\mathrm{US} \$ \mathrm{ha}^{-1}\right)\end{array}$ & $\begin{array}{c}\mathrm{RL} \\
\left(\mathrm{US} \$ \mathrm{ha}^{-1}\right)\end{array}$ & $\mathrm{B} / \mathrm{C}$ \\
\hline \multirow{7}{*}{$1-$ Set } & 0,2 & 4110,52 & 1181,15 & 71,25 & 1138,35 & 2972,17 & 3,61 \\
\hline & 0,3 & 3552,44 & 1182,24 & 71,31 & 1138,42 & 2414,03 & 3,12 \\
\hline & 0,4 & 3380,09 & 1176,33 & 70,95 & 1138,06 & 2242,03 & 2,97 \\
\hline & 0,5 & 3041,79 & 1168,58 & 70,49 & 1137,59 & 1904,20 & 2,67 \\
\hline & 0,6 & 2666,76 & 1181,27 & 71,25 & 1138,36 & 1528,40 & 2,34 \\
\hline & 0,7 & 2494,33 & 1168,38 & 70,48 & 1137,58 & 1356,75 & 2,19 \\
\hline & 0,8 & 2177,16 & 1170,08 & 70,58 & 1137,68 & 1039,47 & 1,91 \\
\hline \multirow{7}{*}{$15-$ Set } & 0,2 & 4111,31 & 1178,11 & 71,06 & 1138,17 & 2973,14 & 3,61 \\
\hline & 0,3 & 3557,48 & 1177,61 & 71,03 & 1138,14 & 2419,35 & 3,13 \\
\hline & 0,4 & 3371,89 & 1170,50 & 70,60 & 1137,71 & 2234,19 & 2,96 \\
\hline & 0,5 & 3035,52 & 1165,10 & 70,28 & 1137,38 & 1898,14 & 2,67 \\
\hline & 0,6 & 2679,78 & 1181,45 & 71,26 & 1138,37 & 1541,41 & 2,35 \\
\hline & 0,7 & 2484,50 & 1165,13 & 70,28 & 1137,38 & 1347,12 & 2,18 \\
\hline & 0,8 & 2184,92 & 1149,26 & 69,32 & 1136,43 & 1048,50 & 1,92 \\
\hline \multirow{7}{*}{ 1-Out } & 0,2 & 4195,94 & 1174,24 & 72,31 & 1139,42 & 3056,52 & 3,68 \\
\hline & 0,3 & 3644,11 & 1171,81 & 72,17 & 1139,27 & 2504,84 & 3,20 \\
\hline & 0,4 & 3452,71 & 1168,57 & 71,97 & 1139,07 & 2313,64 & 3,03 \\
\hline & 0,5 & 3114,00 & 1161,16 & 71,51 & 1138,61 & 1975,39 & 2,73 \\
\hline & 0,6 & 2722,06 & 1164,31 & 71,70 & 1138,81 & 1583,25 & 2,39 \\
\hline & 0,7 & 2550,66 & 1159,29 & 71,39 & 1138,50 & 1412,16 & 2,24 \\
\hline & 0,8 & 2231,75 & 1160,49 & 71,47 & 1138,57 & 1093,18 & 1,96 \\
\hline \multirow{7}{*}{ 15-Out } & 0,2 & 4161,98 & 1149,16 & 70,77 & 1137,87 & 3024,10 & 3,66 \\
\hline & 0,3 & 3649,20 & 1145,07 & 70,52 & 1137,62 & 2511,58 & 3,21 \\
\hline & 0,4 & 3435,02 & 1141,33 & 70,29 & 1137,39 & 2297,63 & 3,02 \\
\hline & 0,5 & 3045,14 & 1133,12 & 69,78 & 1136,89 & 1908,25 & 2,68 \\
\hline & 0,6 & 2727,05 & 1146,16 & 70,59 & 1137,69 & 1589,36 & 2,40 \\
\hline & 0,7 & 2532,77 & 1125,88 & 69,34 & 1136,44 & 1396,32 & 2,23 \\
\hline & 0,8 & 2213,03 & 1132,01 & 69,71 & 1136,82 & 1076,21 & 1,95 \\
\hline
\end{tabular}


Tabela 10B. Receitas brutas, composição de custos da irrigação, receitas liquidas e relação benefício/custo para a melancia, em cada época de semeadura, nível de manejo da irrigação e risco de $15 \%$. Pamaiba, Piauí.

\begin{tabular}{|c|c|c|c|c|c|c|c|}
\hline $\begin{array}{l}\text { Época de } \\
\text { Semeadura }\end{array}$ & $\mathrm{p}$ & $\begin{array}{c}\mathrm{RB}^{1} \\
\left(\mathrm{US} \$ \mathrm{ha}^{-1}\right)\end{array}$ & $\begin{array}{c}\mathrm{Eb} \\
\left(\mathrm{kWh} \mathrm{ha}^{-1}\right)\end{array}$ & $\begin{array}{c}\text { CE } \\
\left(\mathrm{US} \$ \mathrm{ha}^{-1}\right)\end{array}$ & $\begin{array}{c}\text { CT } \\
\left(\mathrm{US} \$ \mathrm{ha}^{-1}\right)\end{array}$ & $\begin{array}{c}\mathrm{RL} \\
\left(\mathrm{US} \$ \mathrm{ha}^{-1}\right)\end{array}$ & $\mathrm{B} / \mathrm{C}$ \\
\hline \multirow{7}{*}{ 1-Nov } & 0,2 & 4477,92 & 1052,56 & 65,25 & 1132,35 & 3345,57 & 3,95 \\
\hline & 0,3 & 4046,00 & 1048,87 & 65,02 & 1132,13 & 2913,87 & 3,57 \\
\hline & 0,4 & 3728,11 & 1036,53 & 64,26 & 1131,36 & 2596,75 & 3,30 \\
\hline & 0,5 & 3322,46 & 1034,95 & 64,16 & 1131,26 & 2191,20 & 2,94 \\
\hline & 0,6 & 3011,65 & 1035,91 & 64,22 & 1131,32 & 1880,32 & 2,66 \\
\hline & 0,7 & 2722,11 & 1020,53 & 63,26 & 1130,37 & 1591,74 & 2,41 \\
\hline & 0,8 & 2447,98 & 1018,92 & 63,16 & 1130,27 & 1317,71 & 2,17 \\
\hline \multirow{7}{*}{ 15-Nov } & 0,2 & 4414,83 & 944,83 & 58,57 & 1125,68 & 3289,16 & 3,92 \\
\hline & 0,3 & 4023,83 & 935,89 & 58,02 & 1125,12 & 2898,71 & 3,58 \\
\hline & 0,4 & 3683,37 & 925,07 & 57,35 & 1124,45 & 2558,92 & 3,28 \\
\hline & 0,5 & 3280,46 & 910,95 & 56,47 & 1123,58 & 2156,88 & 2,92 \\
\hline & 0,6 & 2993,05 & 898,29 & 55,69 & 1122,79 & 1870,26 & 2,67 \\
\hline & 0,7 & 2695,77 & 896,19 & 55,56 & 1122,66 & 1573,11 & 2,40 \\
\hline & 0,8 & 2445,58 & 890,77 & 55,22 & 1122,32 & 1323,26 & 2,18 \\
\hline \multirow{7}{*}{ 1-Dez } & 0,2 & 4430,96 & 863,40 & 52,94 & 1120,05 & 3310,91 & 3,96 \\
\hline & 0,3 & 4085,35 & 847,98 & 52,00 & 1119,10 & 2966,25 & 3,65 \\
\hline & 0,4 & 3705,22 & 843,16 & 51,70 & 1118,81 & 2586,41 & 3,31 \\
\hline & 0,5 & 3324,53 & 821,77 & 50,39 & 1117,50 & 2207,03 & 2,97 \\
\hline & 0,6 & 3023,30 & 812,44 & 49,82 & 1116,92 & 1906,38 & 2,71 \\
\hline & 0,7 & 2758,41 & 795,48 & 48,78 & 1115,88 & 1642,53 & 2,47 \\
\hline & 0,8 & 2491,21 & 791,84 & 48,56 & 1115,66 & 1375,55 & 2,23 \\
\hline \multirow{7}{*}{ 15-Dez } & 0,2 & 4389,46 & 758,91 & 46,54 & 1113,64 & 3275,81 & 3,94 \\
\hline & 0,3 & 4056,75 & 738,44 & 45,28 & 1112,39 & 2944,36 & 3,65 \\
\hline & 0,4 & 3669,93 & 722,97 & 44,33 & 1111,44 & 2558,49 & 3,30 \\
\hline & 0,5 & 3323,06 & 705,87 & 43,28 & 1110,39 & 2212,67 & 2,99 \\
\hline & 0,6 & 3020,99 & 686,81 & 42,12 & 1109,22 & 1911,77 & 2,72 \\
\hline & 0,7 & 2774,38 & 674,31 & 41,35 & 1108,45 & 1665,92 & 2,50 \\
\hline & 0,8 & 2536,22 & 653,24 & 40,06 & 1107,16 & 1429,05 & 2,29 \\
\hline
\end{tabular}

${ }^{1} \mathrm{RB}$ - receita bruta: $\mathrm{Eb}$ - energia requerida para o bombeamento; $\mathrm{CE}$ - custo de energia elétrica: $\mathrm{CT}$ - custo total de produção; $\mathrm{RL}$ - receita líquida e $\mathrm{B} / \mathrm{C}$ - relação benefício/custo. 
Tabela 11B. Receitas brutas, composição de custos da irrigação, receitas líquidas e relação beneficio/custo para a melancia, em cada época de semeadura, nivel de manejo da irrigação e risco de $20 \%$. Parnaiba, Piauí.

\begin{tabular}{|c|c|c|c|c|c|c|c|}
\hline $\begin{array}{l}\text { Época de } \\
\text { Semeadura }\end{array}$ & $\mathrm{p}$ & $\begin{array}{c}R B \\
\left(U S \$ h a^{-1}\right)\end{array}$ & $\begin{array}{c}E b \\
\left(\mathrm{kWh} \mathrm{ha}^{-1}\right)\end{array}$ & $\begin{array}{c}\text { CE } \\
\left(\text { US } \$ h a^{-1}\right)\end{array}$ & $\begin{array}{c}\text { CT } \\
\left(\text { US } \$ h a^{-1}\right)\end{array}$ & $\begin{array}{c}\mathrm{RL} \\
\left(\mathrm{US} \$ \mathrm{ha}^{-1}\right)\end{array}$ & $B / C$ \\
\hline \multirow{7}{*}{ 1-Jan } & 0,2 & 4703,16 & 642,47 & 38,84 & 1105,95 & 3597,21 & 4,25 \\
\hline & 0,3 & 4376,21 & 625,32 & 37,81 & 1104,91 & 3271,30 & 3,96 \\
\hline & 0,4 & 3975,66 & 597,45 & 36,12 & 1103,23 & 2872,44 & 3,60 \\
\hline & 0,5 & 3656,51 & 580,72 & 35,11 & 1102,21 & 2554,29 & 3,32 \\
\hline & 0,6 & 3338,99 & 548,82 & 33,18 & 1100,28 & 2238,71 & 3,03 \\
\hline & 0,7 & 3079,38 & 529,14 & 31,99 & 1099,10 & 1980,28 & 2,80 \\
\hline & 0,8 & 2850,44 & 504,07 & 30,47 & 1097,58 & 1752,87 & 2,60 \\
\hline \multirow{7}{*}{ 15-Jan } & 0,2 & 4787,27 & 584,81 & 35,36 & 1102,46 & 3684,81 & 4,34 \\
\hline & 0,3 & 4471,03 & 560,32 & 33,88 & 1100,98 & 3370,05 & 4,06 \\
\hline & 0,4 & 4040,94 & 527,08 & 31,87 & 1098,97 & 2941,97 & 3,68 \\
\hline & 0,5 & 3753,67 & 506,06 & 30,60 & 1097,70 & 2655,97 & 3,42 \\
\hline & 0,6 & 3442,68 & 476,70 & 28,82 & 1095,93 & 2346,75 & 3,14 \\
\hline & 0,7 & 3218,36 & 450,48 & 27,24 & 1094,34 & 2124,02 & 2,94 \\
\hline & 0,8 & 2994,05 & 428,09 & 25,88 & 1092,99 & 1901,06 & 2,74 \\
\hline \multirow{7}{*}{ 1-Fev } & 0,2 & 4981,37 & 535,80 & 32,63 & 1099,74 & 3881,64 & 4,53 \\
\hline & 0,3 & 4662,40 & 506,11 & 30,82 & 1097,93 & 3564,47 & 4,25 \\
\hline & 0,4 & 4218,53 & 460,89 & 28,07 & 1095,17 & 3123,35 & 3,85 \\
\hline & 0,5 & 3932,35 & 439,60 & 26,77 & 1093,88 & 2838,47 & 3,59 \\
\hline & 0,6 & 3654,58 & 419,58 & 25,55 & 1092,66 & 2561,92 & 3,34 \\
\hline & 0,7 & 3393,35 & 391,79 & 23,86 & 1090,97 & 2302,39 & 3,11 \\
\hline & 0,8 & 3168,85 & 372,52 & 22,69 & 1089,79 & 2079,06 & 2,91 \\
\hline \multirow{7}{*}{$15-\mathrm{Fev}$} & 0,2 & 4963,78 & 484,54 & 29,51 & 1096,61 & 3867,16 & 4,53 \\
\hline & 0,3 & 4624,66 & 450,75 & 27,45 & 1094,56 & 3530,10 & 4,23 \\
\hline & 0,4 & 4246,49 & 430,97 & 26,25 & 1093,35 & 3153,14 & 3,88 \\
\hline & 0,5 & 3916,04 & 389,85 & 23,74 & 1090,85 & 2825,20 & 3,59 \\
\hline & 0,6 & 3667,23 & 351,93 & 21,43 & 1088,54 & 2578,69 & 3,37 \\
\hline & 0,7 & 3438,30 & 330,51 & 20,13 & 1087,23 & 2351,07 & 3,16 \\
\hline & 0,8 & 3249,12 & 316,99 & 19,31 & 1086,41 & 2162,71 & 2,99 \\
\hline
\end{tabular}


Tabela 11B. Receitas brutas, composição de custos da irrigação, receitas líquidas e relação benefício/custo para a melancia, em cada época de semeadura, nível de manejo da irrigação e risco de $20 \%$. Parnaíba, Piauí

\begin{tabular}{|c|c|c|c|c|c|c|c|}
\hline $\begin{array}{c}\text { Epoca de } \\
\text { Semeadura }\end{array}$ & $\mathrm{p}$ & $\begin{array}{c}\mathrm{RB} \\
\left(\mathrm{US} \$ \mathrm{ha}^{-1}\right)\end{array}$ & $\begin{array}{c}E b \\
\left(\mathrm{kWh} \mathrm{ha}^{-1}\right)\end{array}$ & $\begin{array}{c}\text { CE } \\
\left(\mathrm{US} \$ \mathrm{ha}^{-1}\right)\end{array}$ & $\begin{array}{c}\mathrm{CT} \\
\left(\mathrm{US} \$ \mathrm{ha}^{-1}\right)\end{array}$ & $\begin{array}{c}\mathrm{RL} \\
\left(\mathrm{US} \$ \mathrm{ha}^{-1}\right)\end{array}$ & $\mathrm{B} / \mathrm{C}$ \\
\hline \multirow{7}{*}{ 1-Mar } & 0,2 & 4983,79 & 474,79 & 28,74 & 1095,85 & 3887,94 & 4,55 \\
\hline & 0,3 & 4644,23 & 440,20 & 26,65 & 1093,75 & 3550,48 & 4,25 \\
\hline & 0,4 & 4236,19 & 404,50 & 24,49 & 1091,59 & 3144,60 & 3,88 \\
\hline & 0,5 & 3932,02 & 380,07 & 23,01 & 1090,11 & 2841,91 & 3,61 \\
\hline & 0,6 & 3658,62 & 337,91 & 20,46 & 1087,56 & 2571,06 & 3,36 \\
\hline & 0,7 & 3417,67 & 311,88 & 18,88 & 1085,99 & 2331,69 & 3,15 \\
\hline & 0,8 & 3246,88 & 289,68 & 17,54 & 1084,64 & 2162,23 & 2,99 \\
\hline \multirow{7}{*}{ 15-Mar } & 0,2 & 4945,37 & 491,79 & 29,77 & 1096,88 & 3848,49 & 4,51 \\
\hline & 0,3 & 4589,56 & 458,98 & 27,79 & 1094,89 & 3494,67 & 4,19 \\
\hline & 0,4 & 4185,85 & 421,57 & 25,52 & 1092,63 & 3093,22 & 3,83 \\
\hline & 0,5 & 3886,48 & 397,91 & 24,09 & 1091,19 & 2795,28 & 3,56 \\
\hline & 0,6 & 3585,28 & 365,73 & 22,14 & 1089,25 & 2496,03 & 3,29 \\
\hline & 0,7 & 3346,32 & 349,54 & 21,16 & 1088,27 & 2258,05 & 3,07 \\
\hline & 0,8 & 3122,60 & 306,54 & 18,56 & 1085,66 & 2036,93 & 2,88 \\
\hline \multirow{7}{*}{$1-\mathrm{Abr}$} & 0,2 & 4817,84 & 558,91 & 32,19 & 1099,29 & 3718,55 & 4,38 \\
\hline & 0,3 & 4467,19 & 536,10 & 30,87 & 1097,98 & 3369,21 & 4,07 \\
\hline & 0,4 & 4005,43 & 503,81 & 29,01 & 1096,12 & 2909,31 & 3,65 \\
\hline & 0,5 & 3674,56 & 478,84 & 27,58 & 1094,68 & 2579,88 & 3,36 \\
\hline & 0,6 & 3375,99 & 463,19 & 26,67 & 1093,78 & 2282,21 & 3,09 \\
\hline & 0,7 & 3107,34 & 432,02 & 24,88 & 1091,98 & 2015,35 & 2,85 \\
\hline & 0,8 & 2883,82 & 421,72 & 24,29 & 1091,39 & 1792,43 & 2,64 \\
\hline \multirow{7}{*}{$15-\mathrm{Abr}$} & 0,2 & 4794,12 & 614,90 & 35,41 & 1102,52 & 3691,60 & 4,35 \\
\hline & 0,3 & 4432,38 & 599,35 & 34,52 & 1101,62 & 3330,76 & 4,02 \\
\hline & 0,4 & 3950,76 & 565,38 & 32,56 & 1099,66 & 2851,09 & 3,59 \\
\hline & 0,5 & 3612,52 & 551,44 & 31,76 & 1098,86 & 2513,65 & 3,29 \\
\hline & 0,6 & 3284,43 & 525,47 & 30,26 & 1097,37 & 2187,06 & 2,99 \\
\hline & 0,7 & 2934,24 & 506,86 & 29,19 & 1096,29 & 1837,95 & 2,68 \\
\hline & 0,8 & 2783,59 & 492,93 & 28,39 & 1095,49 & 1688,09 & 2,54 \\
\hline
\end{tabular}


Tabela 11B. Receitas brutas, composição de custos da irrigação, receitas líquidas e relação benefício/custo para a melancia, em cada época de semeadura, nivel de manejo da irrigação e risco de $20 \%$. Parnaíba, Piauí.

\begin{tabular}{|c|c|c|c|c|c|c|c|}
\hline $\begin{array}{l}\text { Época de } \\
\text { Semeadura }\end{array}$ & $\mathrm{p}$ & $\begin{array}{c}\text { RB } \\
\left(\mathrm{US} \$ \mathrm{ha}^{-1}\right)\end{array}$ & $\begin{array}{c}\mathrm{Eb} \\
\left(\mathrm{kWh} \mathrm{ha} \mathrm{h}^{-1}\right)\end{array}$ & $\begin{array}{c}\mathrm{CE} \\
\left(\mathrm{US} \$ \mathrm{ha}^{-1}\right)\end{array}$ & $\begin{array}{c}\text { CT } \\
\left(\mathrm{US} \$ \mathrm{ha}^{-1}\right)\end{array}$ & $\begin{array}{c}\mathrm{RL} \\
\left(\mathrm{US} \$ \mathrm{ha}^{-1}\right)\end{array}$ & $\mathrm{B} / \mathrm{C}$ \\
\hline \multirow{7}{*}{ 1-Mai } & 0,2 & 3838,77 & 696,00 & 39,26 & 1106,37 & 2732,41 & 3,47 \\
\hline & 0,3 & 3550,51 & 682,76 & 38,52 & 1105,62 & 2444,88 & 3,21 \\
\hline & 0,4 & 3132,00 & 661,48 & 37,32 & 1104,42 & 2027,58 & 2,84 \\
\hline & 0,5 & 2846,38 & 657,11 & 37,07 & 1104,17 & 1742,20 & 2,58 \\
\hline & 0,6 & 2580,41 & 643,93 & 36,33 & 1103,43 & 1476,98 & 2,34 \\
\hline & 0,7 & 2334,78 & 633,20 & 35,72 & 1102,82 & 1231,96 & 2,12 \\
\hline & 0,8 & 2128,10 & 614,75 & 34,68 & 1101,78 & 1026,32 & 1,93 \\
\hline \multirow{7}{*}{ 15-Mai } & 0,2 & 3836,59 & 728,16 & 41,08 & 1108,18 & 2728,41 & 3,46 \\
\hline & 0,3 & 3566,30 & 719,71 & 40,60 & 1107,70 & 2458,59 & 3,22 \\
\hline & 0,4 & 3133,61 & 704,07 & 39,72 & 1106,82 & 2026,79 & 2,83 \\
\hline & 0,5 & 2857,34 & 700,41 & 39,51 & 1106,62 & 1750,73 & 2,58 \\
\hline & 0,6 & 2553,20 & 684,85 & 38,63 & 1105,74 & 1447,46 & 2,31 \\
\hline & 0,7 & 2334,75 & 680,14 & 38,37 & 1105,47 & 1229,27 & 2,11 \\
\hline & 0,8 & 2115,10 & 663,05 & 37,40 & 1104,51 & 1010,59 & 1,91 \\
\hline \multirow{7}{*}{ 1-Jun } & 0,2 & 4029,00 & 783,63 & 46,84 & 1113,94 & 2915,06 & 3,62 \\
\hline & 0,3 & 3745,93 & 774,84 & 46,31 & 1113,42 & 2632,51 & 3,36 \\
\hline & 0,4 & 3288,99 & 768,64 & 45,94 & 1113,05 & 2175,95 & 2,95 \\
\hline & 0,5 & 3009,26 & 756,05 & 45,19 & 1112,29 & 1896,97 & 2,71 \\
\hline & 0,6 & 2654,15 & 748,95 & 44,76 & 1111,87 & 1542,29 & 2,39 \\
\hline & 0,7 & 2449,02 & 745,01 & 44,53 & 1111,63 & 1337,39 & 2,20 \\
\hline & 0,8 & 2183,93 & 737,05 & 44,05 & 1111,16 & 1072,78 & 1,97 \\
\hline \multirow{7}{*}{ 15-Jun } & 0,2 & 4080,51 & 853,82 & 51,03 & 1118,14 & 2962,38 & 3,65 \\
\hline & 0,3 & 3785,34 & 846,02 & 50,57 & 1117,67 & 2667,67 & 3,39 \\
\hline & 0,4 & 3343,85 & 836,80 & 50,01 & 1117,12 & 2226,73 & 2,99 \\
\hline & 0,5 & 3045,25 & 828,95 & 49,55 & 1116,65 & 1928,60 & 2,73 \\
\hline & 0,6 & 2706,33 & 826,81 & 49,42 & 1116,52 & 1589,81 & 2,42 \\
\hline & 0,7 & 2461,44 & 821,14 & 49,08 & 1116,18 & 1345,26 & 2,21 \\
\hline & 0,8 & 2211,95 & 814,36 & 48,67 & 1115,78 & 1096,17 & 1,98 \\
\hline
\end{tabular}


Tabela 11B. Receitas brutas, composição de custos da irrigação, receitas líquidas e relação beneficio/custo para a melancia, em cada época de semeadura, nível de manejo da irrigação e risco de $20 \%$. Parnaíba, Piauí.

\begin{tabular}{|c|c|c|c|c|c|c|c|}
\hline $\begin{array}{l}\text { Época de } \\
\text { Semeadura }\end{array}$ & $\mathrm{p}$ & $\begin{array}{c}\text { RB } \\
\left(\mathrm{US} \$ \mathrm{ha}^{-1}\right)\end{array}$ & $\begin{array}{c}\mathrm{Eb} \\
\left(\mathrm{kWh} \mathrm{ha}^{-1}\right)\end{array}$ & $\begin{array}{c}\text { CE } \\
\left(\mathrm{US} \$ \mathrm{ha}^{-1}\right)\end{array}$ & $\begin{array}{c}\mathrm{CT} \\
\left(\mathrm{US} \$ \mathrm{ha}^{-1}\right)\end{array}$ & $\begin{array}{c}\text { RL } \\
\left(\mathrm{US} \$ \mathrm{ha}^{-1}\right)\end{array}$ & $\mathrm{B} / \mathrm{C}$ \\
\hline \multirow{7}{*}{ 1-Jul } & 0,2 & 3468,79 & 930,37 & 57,21 & 1124,32 & 2344,47 & 3,09 \\
\hline & 0,3 & 3184,63 & 921,09 & 56,64 & 1123,75 & 2060,88 & 2,83 \\
\hline & 0,4 & 2867,64 & 917,58 & 56,43 & 1123,53 & 1744,10 & 2,55 \\
\hline & 0,5 & 2553,51 & 911,82 & 56,07 & 1123,18 & 1430,33 & 2,27 \\
\hline & 0,6 & 2311,26 & 914,14 & 56,21 & 1123,32 & 1187,94 & 2,06 \\
\hline & 0,7 & 2070,54 & 904,22 & 55,61 & 1122,71 & 947,83 & 1,84 \\
\hline & 0,8 & 1879,52 & 899,93 & 55,34 & 1122,45 & 757,07 & 1,67 \\
\hline \multirow{7}{*}{ 15-Jul } & 0,2 & 3537,55 & 1007,92 & 61,98 & 1129,09 & 2408,46 & 3,13 \\
\hline & 0,3 & 3215,87 & 999,68 & 61,47 & 1128,58 & 2087,29 & 2,85 \\
\hline & 0,4 & 2951,08 & 994,88 & 61,18 & 1128,28 & 1822,80 & 2,62 \\
\hline & 0,5 & 2590,34 & 994,74 & 61,17 & 1128,28 & 1462,06 & 2,30 \\
\hline & 0,6 & 2377,04 & 992,92 & 61,06 & 1128,16 & 1248,87 & 2,11 \\
\hline & 0,7 & 2103,28 & 988,51 & 60,79 & 1127,89 & 975,39 & 1,86 \\
\hline & 0,8 & 1924,72 & 977,80 & 60,13 & 1127,23 & 797,48 & 1,71 \\
\hline \multirow{7}{*}{ 1-Ago } & 0,2 & 4264,77 & 1096,40 & 67,84 & 1134,94 & 3129,82 & 3,76 \\
\hline & 0,3 & 3786,85 & 1090,89 & 67,50 & 1134,60 & 2652,25 & 3,34 \\
\hline & 0,4 & 3526,94 & 1088,32 & 67,34 & 1134,44 & 2392,50 & 3,11 \\
\hline & 0,5 & 3100,97 & 1085,55 & 67,17 & 1134,27 & 1966,70 & 2,73 \\
\hline & 0,6 & 2804,52 & 1090,23 & 67,46 & 1134,56 & 1669,96 & 2,47 \\
\hline & 0,7 & 2566,05 & 1077,08 & 66,64 & 1133,75 & 1432,30 & 2,26 \\
\hline & 0,8 & 2274,42 & 1077,36 & 66,66 & 1133,76 & 1140,65 & 2,01 \\
\hline \multirow{7}{*}{ 15-Ago } & 0,2 & 4335,92 & 1144,97 & 70,84 & 1137,95 & 3197,97 & 3,81 \\
\hline & 0,3 & 3790,34 & 1141,65 & 70,64 & 1137,74 & 2652,60 & 3,33 \\
\hline & 0,4 & 3577,77 & 1136,57 & 70,32 & 1137,43 & 2440,34 & 3,15 \\
\hline & 0,5 & 3161,82 & 1135,49 & 70,26 & 1137,36 & 2024,45 & 2,78 \\
\hline & 0,6 & 2837,75 & 1139,81 & 70,52 & 1137,63 & 1700,12 & 2,49 \\
\hline & 0,7 & 2628,44 & 1125,47 & 69,64 & 1136,74 & 1491,70 & 2,31 \\
\hline & 0,8 & 2301,57 & 1133,82 & 70,15 & 1137,26 & 1164,32 & 2,02 \\
\hline
\end{tabular}


Tabela 11B. Receitas brutas, composição de custos da irrigação, receitas líquidas e relação benefício/custo para a melancia, em cada época de semeadura, nível de manejo da irrigação e risco de $20 \%$. Parnaiba, Piauí.

\begin{tabular}{|c|c|c|c|c|c|c|c|}
\hline $\begin{array}{l}\text { Época de } \\
\text { Semeadura }\end{array}$ & $\mathrm{p}$ & $\begin{array}{c}\mathrm{RB} \\
\left(\mathrm{US} \$ \mathrm{ha}^{-1}\right)\end{array}$ & $\begin{array}{c}E b \\
\left(\mathrm{kWh} \mathrm{ha}^{-1}\right)\end{array}$ & $\begin{array}{c}\text { CE } \\
\left(\mathrm{US} \$ \mathrm{ha}^{-1}\right)\end{array}$ & $\begin{array}{c}\mathrm{CT} \\
\left(\mathrm{US} \$ \mathrm{ha}^{-1}\right)\end{array}$ & $\begin{array}{c}\mathrm{RL} \\
\left(\mathrm{US} \$ \mathrm{ha}^{-1}\right)\end{array}$ & $\mathrm{B} / \mathrm{C}$ \\
\hline \multirow{7}{*}{$1-$ Set } & 0,2 & 4142,32 & 1178,79 & 70,43 & 1137,53 & 3004,79 & 3,64 \\
\hline & 0,3 & 3577,96 & 1179,45 & 70,47 & 1137,57 & 2440,39 & 3,15 \\
\hline & 0,4 & 3406,06 & 1173,25 & 70,10 & 1137,20 & 2268,86 & 3,00 \\
\hline & 0,5 & 3072,57 & 1165,40 & 69,63 & 1136,73 & 1935,84 & 2,70 \\
\hline & 0,6 & 2689,56 & 1181,27 & 70,58 & 1137,68 & 1551,88 & 2,36 \\
\hline & 0,7 & 2519,91 & 1163,82 & 69,53 & 1136,64 & 1383,27 & 2,22 \\
\hline & 0,8 & 2200,41 & 1164,66 & 69,58 & 1136,69 & 1063,72 & 1,94 \\
\hline \multirow{7}{*}{$15-$ Set } & 0,2 & 4143,05 & 1174,73 & 70,18 & 1137,29 & 3005,76 & 3,64 \\
\hline & 0,3 & 3583,60 & 1173,86 & 70,13 & 1137,24 & 2446,36 & 3,15 \\
\hline & 0,4 & 3399,72 & 1166,91 & 69,72 & 1136,82 & 2262,90 & 2,99 \\
\hline & 0,5 & 3066,88 & 1161,15 & 69,37 & 1136,48 & 1930,40 & 2,70 \\
\hline & 0,6 & 2703,46 & 1174,09 & 70,15 & 1137,25 & 1566,20 & 2,38 \\
\hline & 0,7 & 2511,18 & 1159,52 & 69,28 & 1136,38 & 1374,80 & 2,21 \\
\hline & 0,8 & 2208,12 & 1144,77 & 68,39 & 1135,50 & 1072,62 & 1,94 \\
\hline \multirow{7}{*}{ 1-Out } & 0,2 & 4227,75 & 1170,08 & 71,19 & 1138,30 & 3089,45 & 3,71 \\
\hline & 0,3 & 3669,69 & 1167,19 & 71,02 & 1138,12 & 2531,57 & 3,22 \\
\hline & 0,4 & 3480,14 & 1163,31 & 70,78 & 1137,88 & 2342,26 & 3,06 \\
\hline & 0,5 & 3144,29 & 1155,85 & 70,33 & 1137,43 & 2006,86 & 2,76 \\
\hline & 0,6 & 2747,21 & 1164,31 & 70,84 & 1137,95 & 1609,27 & 2,41 \\
\hline & 0,7 & 2576,38 & 1152,85 & 70,14 & 1137,25 & 1439,13 & 2,27 \\
\hline & 0,8 & 2254,78 & 1152,71 & 70,13 & 1137,24 & 1117,54 & 1,98 \\
\hline \multirow{7}{*}{ 15-Out } & 0,2 & 4194,56 & 1144,28 & 69,62 & 1136,73 & 3057,84 & 3,69 \\
\hline & 0,3 & 3674,62 & 1139,85 & 69,35 & 1136,46 & 2538,16 & 3,23 \\
\hline & 0,4 & 3463,38 & 1136,01 & 69,12 & 1136,22 & 2327,15 & 3,05 \\
\hline & 0,5 & 3076,35 & 1127,58 & 68,61 & 1135,71 & 1940,64 & 2,71 \\
\hline & 0,6 & 2751,27 & 1137,21 & 69,19 & 1136,30 & 1614,98 & 2,42 \\
\hline & 0,7 & 2557,66 & 1118,84 & 68,07 & 1135,18 & 1422,48 & 2,25 \\
\hline & 0,8 & 2235,53 & 1123,35 & 68,35 & 1135,45 & 1100,08 & 1,97 \\
\hline
\end{tabular}


Tabela 11B. Receitas brutas, composição de custos da irrigação, receitas líquidas e relação benefício/custo para a melancia, em cada época de semeadura, nivel de manejo da irrigação e risco de $20 \%$. Parnaiba, Piauí.

\begin{tabular}{|c|c|c|c|c|c|c|c|}
\hline $\begin{array}{l}\text { Época de } \\
\text { Semeadura }\end{array}$ & $p$ & $\begin{array}{c}\mathrm{RB} \\
\left(\mathrm{US} \$ \mathrm{ha}^{-1}\right)\end{array}$ & $\begin{array}{c}E b \\
\left(\mathrm{kWh} \mathrm{ha}^{-1}\right)\end{array}$ & $\begin{array}{c}\text { CE } \\
\left(\mathrm{US} \$ \mathrm{ha}^{-1}\right)\end{array}$ & $\begin{array}{c}\text { CT } \\
\left(\text { US } \$ \mathrm{ha}^{-1}\right)\end{array}$ & $\begin{array}{c}\mathrm{RL} \\
\left(\mathrm{US} \$ \mathrm{ha}^{-1}\right)\end{array}$ & $\mathrm{B} / \mathrm{C}$ \\
\hline \multirow{7}{*}{$1-\mathrm{Nov}$} & 0,2 & 4516,93 & 1044,24 & 63,91 & 1131,01 & 3385,92 & 3,99 \\
\hline & 0,3 & 4078,25 & 1039,47 & 63,61 & 1130,72 & 2947,53 & 3,61 \\
\hline & 0,4 & 3764,07 & 1026,50 & 62,82 & 1129,93 & 2634,14 & 3,33 \\
\hline & 0,5 & 3355,77 & 1024,15 & 62,68 & 1129,78 & 2225,99 & 2,97 \\
\hline & 0,6 & 3044,20 & 1022,49 & 62,57 & 1129,68 & 1914,52 & 2,69 \\
\hline & 0,7 & 2754,05 & 1008,15 & 61,70 & 1128,80 & 1625,25 & 2,44 \\
\hline & 0,8 & 2478,68 & 1004,89 & 61,50 & 1128,60 & 1350,08 & 2,20 \\
\hline \multirow{7}{*}{$15-\mathrm{Nov}$} & 0,2 & 4452,25 & 934,98 & 57,22 & 1124,32 & 3327,92 & 3,96 \\
\hline & 0,3 & 4057,91 & 924,57 & 56,58 & 1123,69 & 2934,22 & 3,61 \\
\hline & 0,4 & 3721,86 & 913,28 & 55,89 & 1123,00 & 2598,86 & 3,31 \\
\hline & 0,5 & 3316,84 & 898,57 & 54,99 & 1122,10 & 2194,75 & 2,96 \\
\hline & 0,6 & 3030,14 & 883,95 & 54,10 & 1121,20 & 1908,94 & 2,70 \\
\hline & 0,7 & 2733,08 & 880,71 & 53,90 & 1121,00 & 1612,08 & 2,44 \\
\hline & 0,8 & 2482,86 & 873,20 & 53,44 & 1120,54 & 1362,32 & 2,22 \\
\hline \multirow{7}{*}{ 1-Dez } & 0,2 & 4524,50 & 853,60 & 51,50 & 1118,60 & 3405,90 & 4,04 \\
\hline & 0,3 & 4170,03 & 837,37 & 50,52 & 1117,63 & 3052,40 & 3,73 \\
\hline & 0,4 & 3789,61 & 830,61 & 50,11 & 1117,22 & 2672,39 & 3,39 \\
\hline & 0,5 & 3403,09 & 808,15 & 48,76 & 1115,86 & 2287,23 & 3,05 \\
\hline & 0,6 & 3100,63 & 797,30 & 48,10 & 1115,21 & 1985,43 & 2,78 \\
\hline & 0,7 & 2830,70 & 780,21 & 47,07 & 1114,18 & 1716,52 & 2,54 \\
\hline & 0,8 & 2562,98 & 774,98 & 46,76 & 1113,86 & 1449,12 & 2,30 \\
\hline \multirow{7}{*}{ 15-Dez } & 0,2 & 4480,32 & 746,45 & 45,04 & 1112,14 & 3368,18 & 4,03 \\
\hline & 0,3 & 4144,34 & 724,73 & 43,73 & 1110,83 & 3033,51 & 3,73 \\
\hline & 0,4 & 3754,12 & 706,85 & 42,65 & 1109,75 & 2644,37 & 3,38 \\
\hline & 0,5 & 3406,88 & 688,76 & 41,55 & 1108,66 & 2298,22 & 3,07 \\
\hline & 0,6 & 3103,41 & 669,22 & 40,38 & 1107,48 & 1995,93 & 2,80 \\
\hline & 0,7 & 2851,97 & 654,43 & 39,48 & 1106,59 & 1745,38 & 2,58 \\
\hline & 0,8 & 2613,59 & 633,68 & 38,23 & 1105,34 & 1508,25 & 2,36 \\
\hline
\end{tabular}


Tabela 12B. Receitas brutas, composição de custos da irrigação, receitas liquidas e relação benefício/custo para a melancia, em cada época de semeadura, nível de manejo da irrigação e risco de $25 \%$. Parnaiba, Piaui.

\begin{tabular}{|c|c|c|c|c|c|c|c|}
\hline $\begin{array}{l}\text { Época de } \\
\text { Semeadura }\end{array}$ & $\mathrm{p}$ & $\begin{array}{c}\mathrm{RB}^{\mathrm{l}} \\
\left(\mathrm{US} \$ \mathrm{ha}^{-1}\right)\end{array}$ & $\begin{array}{c}\mathrm{Eb} \\
\left(\mathrm{kWh} \mathrm{ha}^{-1}\right)\end{array}$ & $\begin{array}{c}\mathrm{CE} \\
\left(\mathrm{US} \$ \mathrm{ha}^{-1}\right)\end{array}$ & $\begin{array}{c}\text { CT } \\
\left(\mathrm{US} \$ \mathrm{ha}^{-1}\right)\end{array}$ & $\begin{array}{c}\mathrm{RL} \\
\left(\mathrm{US} \$ \mathrm{ha}^{-1}\right)\end{array}$ & $\mathrm{B} / \mathrm{C}$ \\
\hline \multirow{7}{*}{ 1-Jan } & 0,2 & 4748,51 & 631,54 & 37,49 & 1104,60 & 3643,92 & 4,30 \\
\hline & 0,3 & 4423,18 & 613,31 & 36,41 & 1103,52 & 3319,67 & 4,01 \\
\hline & 0,4 & 4023,65 & 584,27 & 34,69 & 1101,79 & 2921,85 & 3,65 \\
\hline & 0,5 & 3706,08 & 566,34 & 33,62 & 1100,73 & 2605,36 & 3,37 \\
\hline & 0,6 & 3390,69 & 533,99 & 31,70 & 1098,81 & 2291,88 & 3,09 \\
\hline & 0,7 & 3134,96 & 513,09 & 30,46 & 1097,57 & 2037,39 & 2,86 \\
\hline & 0,8 & 2904,33 & 486,54 & 28,88 & 1095,99 & 1808,34 & 2,65 \\
\hline \multirow{7}{*}{ 15-Jan } & 0,2 & 4833,39 & 574,29 & 34,09 & 1101,20 & 3732,19 & 4,39 \\
\hline & 0,3 & 4518,00 & 548,26 & 32,55 & 1099,65 & 3418,35 & 4,11 \\
\hline & 0,4 & 4090,10 & 513,62 & 30,49 & 1097,60 & 2992,50 & 3,73 \\
\hline & 0,5 & 3804,01 & 491,46 & 29,18 & 1096,28 & 2707,73 & 3,47 \\
\hline & 0,6 & 3495,38 & 460,58 & 27,34 & 1094,45 & 2400,93 & 3,19 \\
\hline & 0,7 & 3274,63 & 435,40 & 25,85 & 1092,95 & 2181,67 & 3,00 \\
\hline & 0,8 & 3052,67 & 412,84 & 24,51 & 1091,61 & 1961,06 & 2,80 \\
\hline \multirow{7}{*}{$1-F e v$} & 0,2 & 5009,00 & 524,39 & 31,13 & 1098,24 & 3910,76 & 4,56 \\
\hline & 0,3 & 4692,54 & 493,65 & 29,31 & 1096,41 & 3596,12 & 4,28 \\
\hline & 0,4 & 4254,23 & 447,77 & 26,58 & 1093,69 & 3160,54 & 3,89 \\
\hline & 0,5 & 3974,21 & 425,71 & 25,28 & 1092,38 & 2881,83 & 3,64 \\
\hline & 0,6 & 3697,31 & 404,86 & 24,04 & 1091,14 & 2606,17 & 3,39 \\
\hline & 0,7 & 3443,04 & 376,37 & 22,35 & 1089,45 & 2353,59 & 3,16 \\
\hline & 0,8 & 3221,91 & 356,10 & 21,14 & 1088,25 & 2133,66 & 2,96 \\
\hline \multirow{7}{*}{ 15-Fev } & 0,2 & 4991,62 & 474,44 & 28,17 & 1095,27 & 3896,34 & 4,56 \\
\hline & 0,3 & 4658,18 & 440,20 & 26,14 & 1093,24 & 3564,94 & 4,26 \\
\hline & 0,4 & 4280,44 & 416,80 & 24,75 & 1091,85 & 3188,59 & 3,92 \\
\hline & 0,5 & 3958,74 & 376,26 & 22,34 & 1089,44 & 2869,30 & 3,63 \\
\hline & 0,6 & 3714,27 & 339,69 & 20,17 & 1087,27 & 2626,99 & 3,42 \\
\hline & 0,7 & 3486,26 & 316,95 & 18,82 & 1085,92 & 2400,34 & 3,21 \\
\hline & 0,8 & 3297,59 & 300,88 & 17,86 & 1084,97 & 2212,62 & 3,04 \\
\hline
\end{tabular}


408

Tabela 12B. Receitas brutas, composição de custos da irrigação, receitas líquidas e relação beneficio/custo para a melancia, em cada época de semeadura, nível de manejo da irrigação e risco de $25 \%$. Pamaíba, Piauí.

\begin{tabular}{|c|c|c|c|c|c|c|c|}
\hline $\begin{array}{c}\text { Época de } \\
\text { Semeadura }\end{array}$ & $\mathrm{p}$ & $\begin{array}{c}\mathrm{RB}^{1} \\
\left(\mathrm{US} \$ \mathrm{ha}^{-1}\right)\end{array}$ & $\begin{array}{c}\mathrm{Eb} \\
\left(\mathrm{kWh} \mathrm{ha}^{-1}\right)\end{array}$ & $\begin{array}{c}\text { CE } \\
\left(\mathrm{US} \$ \mathrm{ha}^{-1}\right)\end{array}$ & $\begin{array}{c}\mathrm{CT} \\
\left(\mathrm{US} \$ \mathrm{ha}^{-1}\right)\end{array}$ & $\begin{array}{c}\mathrm{RL} \\
\left(\mathrm{US} \$ \mathrm{ha}^{-1}\right)\end{array}$ & $\mathrm{B} / \mathrm{C}$ \\
\hline \multirow{7}{*}{ 1-Mar } & 0,2 & 5032,09 & 463,39 & 27,31 & 1094,41 & 3937,68 & 4,60 \\
\hline & 0,3 & 4696,02 & 427,82 & 25,21 & 1092,32 & 3603,70 & 4,30 \\
\hline & 0,4 & 4291,71 & 390,75 & 23,03 & 1090,13 & 3201,58 & 3,94 \\
\hline & 0,5 & 3992,65 & 364,93 & 21,51 & 1088,61 & 2904,04 & 3,67 \\
\hline & 0,6 & 3723,18 & 323,57 & 19,07 & 1086,17 & 2637,00 & 3,43 \\
\hline & 0,7 & 3486,00 & 296,85 & 17,49 & 1084,60 & 2401,40 & 3,21 \\
\hline & 0,8 & 3316,28 & 273,40 & 16,11 & 1083,22 & 2233,07 & 3,06 \\
\hline \multirow{7}{*}{ 15-Mar } & 0,2 & 4992,78 & 481,18 & 28,36 & 1095,46 & 3897,32 & 4,56 \\
\hline & 0,3 & 4640,40 & 447,49 & 26,37 & 1093,47 & 3546,92 & 4,24 \\
\hline & 0,4 & 4237,44 & 408,97 & 24,10 & 1091,21 & 3146,23 & 3,88 \\
\hline & 0,5 & 3940,76 & 384,50 & 22,66 & 1089,76 & 2851,00 & 3,62 \\
\hline & 0,6 & 3643,04 & 351,36 & 20,71 & 1087,81 & 2555,23 & 3,35 \\
\hline & 0,7 & 3408,53 & 333,02 & 19,62 & 1086,73 & 2321,80 & 3,14 \\
\hline & 0,8 & 3191,14 & 290,30 & 17,11 & 1084,21 & 2106,93 & 2,94 \\
\hline \multirow{7}{*}{$1-A b r$} & 0,2 & 4865,19 & 548,82 & 30,76 & 1097,87 & 3767,32 & 4,43 \\
\hline & 0,3 & 4517,52 & 525,42 & 29,45 & 1096,55 & 3420,96 & 4,12 \\
\hline & 0,4 & 4058,66 & 491,74 & 27,56 & 1094,67 & 2963,99 & 3,71 \\
\hline & 0,5 & 3728,61 & 466,00 & 26,12 & 1093,22 & 2635,39 & 3,41 \\
\hline & 0,6 & 3432,51 & 448,52 & 25,14 & 1092,24 & 2340,27 & 3,14 \\
\hline & 0,7 & 3165,72 & 416,68 & 23,36 & 1090,46 & 2075,26 & 2,90 \\
\hline & 0,8 & 2946,43 & 404,83 & 22,69 & 1089,80 & 1856,64 & 2,70 \\
\hline \multirow{7}{*}{$15-\mathrm{Abr}$} & 0,2 & 4840,43 & 605,24 & 33,92 & 1101,03 & 3739,40 & 4,40 \\
\hline & 0,3 & 4480,79 & 588,11 & 32,96 & 1100,07 & 3380,73 & 4,07 \\
\hline & 0,4 & 4000,59 & 554,11 & 31,06 & 1098,16 & 2902,43 & 3,64 \\
\hline & 0,5 & 3663,21 & 538,46 & 30,18 & 1097,29 & 2565,92 & 3,34 \\
\hline & 0,6 & 3337,17 & 511,12 & 28,65 & 1095,75 & 2241,42 & 3,05 \\
\hline & 0,7 & 2957,68 & 491,13 & 27,53 & 1094,63 & 1863,05 & 2,70 \\
\hline & 0,8 & 2836,81 & 476,05 & 26,68 & 1093,79 & 1743,03 & 2,59 \\
\hline
\end{tabular}


Tabela 12B. Receitas brutas, composição de custos da irrigação, receitas liquidas e relação benefício/custo para a melancia, em cada época de semeadura, nivel de manejo da irrigação e risco de $25 \%$. Parnaiba, Piauí.

\begin{tabular}{|c|c|c|c|c|c|c|c|}
\hline $\begin{array}{l}\text { Época de } \\
\text { Semeadura }\end{array}$ & $\mathrm{p}$ & $\begin{array}{c}\mathrm{RB}^{\mathrm{I}} \\
\left(\mathrm{US} \$ \mathrm{ha}^{-1}\right)\end{array}$ & $\begin{array}{c}\mathrm{Eb} \\
\left(\mathrm{kWh} \mathrm{ha}^{-1}\right)\end{array}$ & $\begin{array}{c}\text { CE } \\
\left(\mathrm{US} \$ \mathrm{ha}^{-1}\right)\end{array}$ & $\begin{array}{c}\mathrm{CT} \\
\left(\mathrm{US} \$ \mathrm{ha}^{-1}\right)\end{array}$ & $\begin{array}{c}\mathrm{RL} \\
\left(\mathrm{US} \$ \mathrm{ha}^{-1}\right)\end{array}$ & $\mathrm{B} / \mathrm{C}$ \\
\hline \multirow{7}{*}{ 1-Mai } & 0,2 & 3868,96 & 688,21 & 38,03 & 1105,13 & 2763,83 & 3,50 \\
\hline & 0,3 & 3582,76 & 674,23 & 37,26 & 1104,36 & 2478,40 & 3,24 \\
\hline & 0,4 & 3163,12 & 651,50 & 36,00 & 1103,11 & 2060,02 & 2,87 \\
\hline & 0,5 & 2878,24 & 644,86 & 35,63 & 1102,74 & 1775,51 & 2,61 \\
\hline & 0,6 & 2610,58 & 630,15 & 34,82 & 1101,93 & 1508,65 & 2,37 \\
\hline & 0,7 & 2365,64 & 618,57 & 34,18 & 1101,29 & 1264,35 & 2,15 \\
\hline & 0,8 & 2160,66 & 600,28 & 33,17 & 1100,28 & 1060,38 & 1,96 \\
\hline \multirow{7}{*}{ 15-Mai } & 0,2 & 3867,16 & 720,27 & 39,80 & 1106,91 & 2760,26 & 3,49 \\
\hline & 0,3 & 3596,75 & 710,42 & 39,26 & 1106,36 & 2490,39 & 3,25 \\
\hline & 0,4 & 3164,23 & 694,34 & 38,37 & 1105,47 & 2058,76 & 2,86 \\
\hline & 0,5 & 2888,59 & 688,93 & 38,07 & 1105,17 & 1783,42 & 2,61 \\
\hline & 0,6 & 2583,52 & 672,58 & 37,17 & 1104,27 & 1479,25 & 2,34 \\
\hline & 0,7 & 2365,55 & 666,85 & 36,85 & 1103,95 & 1261,59 & 2,14 \\
\hline & 0,8 & 2144,85 & 649,33 & 35,88 & 1102,99 & 1041,87 & 1,94 \\
\hline \multirow{7}{*}{ 1-Jun } & 0,2 & 4074,29 & 777,79 & 45,54 & 1112,65 & 2961,64 & 3,66 \\
\hline & 0,3 & 3790,29 & 768,24 & 44,98 & 1112,09 & 2678,21 & 3,41 \\
\hline & 0,4 & 3329,67 & 760,96 & 44,56 & 1111,66 & 2218,01 & 3,00 \\
\hline & 0,5 & 3049,15 & 748,09 & 43,80 & 1110,91 & 1938,24 & 2,74 \\
\hline & 0,6 & 2692,35 & 739,21 & 43,28 & 1110,39 & 1581,96 & 2,42 \\
\hline & 0,7 & 2485,52 & 735,23 & 43,05 & 1110,15 & 1375,37 & 2,24 \\
\hline & 0,8 & 2218,84 & 726,50 & 42,54 & 1109,64 & 1109,20 & 2,00 \\
\hline \multirow{7}{*}{ 15-Jun } & 0,2 & 4127,14 & 848,18 & 49,66 & 1116,77 & 3010,37 & 3,70 \\
\hline & 0,3 & 3828,68 & 840,30 & 49,20 & 1116,31 & 2712,37 & 3,43 \\
\hline & 0,4 & 3386,39 & 829,98 & 48,60 & 1115,70 & 2270,69 & 3,04 \\
\hline & 0,5 & 3082,90 & 822,07 & 48,13 & 1115,24 & 1967,66 & 2,76 \\
\hline & 0,6 & 2744,92 & 818,33 & 47,92 & 1115,02 & 1629,90 & 2,46 \\
\hline & 0,7 & 2497,33 & 813,99 & 47,66 & 1114,77 & 1382,56 & 2,24 \\
\hline & 0,8 & 2245,72 & 805,38 & 47,16 & 1114,26 & 1131,46 & 2,02 \\
\hline
\end{tabular}


410

Tabela 12B. Receitas brutas, composição de custos da irrigação, receitas líquidas e relação benefício/custo para a melancia, em cada época de semeadura, nível de manejo da irrigação e risco de $25 \%$. Parnaíba, Piauí.

\begin{tabular}{|c|c|c|c|c|c|c|c|}
\hline $\begin{array}{c}\text { Epoca de } \\
\text { Semeadura }\end{array}$ & $\mathrm{p}$ & $\begin{array}{c}\mathrm{RB}^{1} \\
\left(\mathrm{US} \$ \mathrm{ha}^{-1}\right)\end{array}$ & $\begin{array}{c}E b \\
\left(\mathrm{kWh} \mathrm{ha}^{-1}\right)\end{array}$ & $\begin{array}{c}\mathrm{CE} \\
\left(\mathrm{US} \$ \mathrm{ha}^{-1}\right)\end{array}$ & $\begin{array}{c}\mathrm{CT} \\
\left(\mathrm{US} \$ \mathrm{ha}^{-1}\right)\end{array}$ & $\begin{array}{c}\mathrm{RL} \\
\left(\mathrm{US} \$ \mathrm{ha}^{-1}\right)\end{array}$ & $\mathrm{B} / \mathrm{C}$ \\
\hline \multirow{7}{*}{ 1-Jul } & 0,2 & 3523,01 & 925,54 & 56,04 & 1123,14 & 2399,86 & 3,14 \\
\hline & 0,3 & 3234,08 & 916,10 & 55,47 & 1122,57 & 2111,51 & 2,88 \\
\hline & 0,4 & 2916,05 & 911,91 & 55,22 & 1122,32 & 1793,74 & 2,60 \\
\hline & 0,5 & 2595,65 & 905,45 & 54,82 & 1121,93 & 1473,72 & 2,31 \\
\hline & 0,6 & 2352,72 & 906,41 & 54,88 & 1121,99 & 1230,73 & 2,10 \\
\hline & 0,7 & 2107,61 & 896,42 & 54,28 & 1121,38 & 986,23 & 1,88 \\
\hline & 0,8 & 1916,50 & 892,93 & 54,07 & 1121,17 & 795,33 & 1,71 \\
\hline \multirow{7}{*}{ 15-Jul } & 0,2 & 3592,73 & 1003,26 & 60,75 & 1127,85 & 2464,87 & 3,19 \\
\hline & 0,3 & 3264,35 & 994,94 & 60,24 & 1127,35 & 2137,00 & 2,90 \\
\hline & 0,4 & 2999,05 & 989,88 & 59,94 & 1127,04 & 1872,01 & 2,66 \\
\hline & 0,5 & 2632,94 & 989,31 & 59,90 & 1127,01 & 1505,94 & 2,34 \\
\hline & 0,6 & 2418,41 & 985,65 & 59,68 & 1126,78 & 1291,63 & 2,15 \\
\hline & 0,7 & 2140,90 & 981,73 & 59,44 & 1126,55 & 1014,35 & 1,90 \\
\hline & 0,8 & 1958,67 & 971,44 & 58,82 & 1125,92 & 832,74 & 1,74 \\
\hline \multirow{7}{*}{ 1-Ago } & 0,2 & 4311,52 & 1093,70 & 66,71 & 1133,82 & 3177,70 & 3,80 \\
\hline & 0,3 & 3824,80 & 1088,11 & 66,37 & 1133,47 & 2691,32 & 3,37 \\
\hline & 0,4 & 3566,76 & 1085,35 & 66,20 & 1133,31 & 2433,45 & 3,15 \\
\hline & 0,5 & 3138,57 & 1082,09 & 66,00 & 1133,11 & 2005,46 & 2,77 \\
\hline & 0,6 & 2838,44 & 1084,23 & 66,13 & 1133,24 & 1705,20 & 2,50 \\
\hline & 0,7 & 2599,50 & 1073,19 & 65,46 & 1132,56 & 1466,93 & 2,30 \\
\hline & 0,8 & 2302,67 & 1073,34 & 65,47 & 1132,57 & 1170,09 & 2,03 \\
\hline \multirow{7}{*}{ 15-Ago } & 0,2 & 4382,31 & 1142,42 & 69,68 & 1136,79 & 3245,52 & 3,85 \\
\hline & 0,3 & 3828,83 & 1139,03 & 69,48 & 1136,58 & 2692,25 & 3,37 \\
\hline & 0,4 & 3616,80 & 1133,80 & 69,16 & 1136,26 & 2480,54 & 3,18 \\
\hline & 0,5 & 3203,02 & 1132,23 & 69,06 & 1136,17 & 2066,86 & 2,82 \\
\hline & 0,6 & 2870,10 & 1139,81 & 69,52 & 1136,63 & 1733,47 & 2,53 \\
\hline & 0,7 & 2661,53 & 1121,61 & 68,41 & 1135,52 & 1526,01 & 2,34 \\
\hline & 0,8 & 2322,70 & 1128,83 & 68,85 & 1135,96 & 1186,74 & 2,04 \\
\hline
\end{tabular}


Tabela 12B. Receitas brutas, composição de custos da irrigação, receitas líquidas e relação benefício/custo para a melancia, em cada época de semeadura, nível de manejo da irrigação e risco de $25 \%$. Parnaiba, Piauí.

\begin{tabular}{|c|c|c|c|c|c|c|c|}
\hline $\begin{array}{c}\text { Época de } \\
\text { Semeadura }\end{array}$ & $\mathrm{p}$ & $\begin{array}{c}\mathrm{RB}^{\mathrm{l}} \\
\left(\mathrm{US} \$ \mathrm{ha}^{-1}\right)\end{array}$ & $\begin{array}{c}\mathrm{Eb} \\
\left(\mathrm{kWh} \mathrm{ha}^{-1}\right)\end{array}$ & $\begin{array}{c}\text { CE } \\
\left(\mathrm{US} \$ \mathrm{ha}^{-1}\right)\end{array}$ & $\begin{array}{c}\mathrm{CT} \\
\left(\mathrm{US} \$ \mathrm{ha}^{-1}\right)\end{array}$ & $\begin{array}{c}\mathrm{RL} \\
\left(\mathrm{US} \$ \mathrm{ha}^{-1}\right)\end{array}$ & $\mathrm{B} / \mathrm{C}$ \\
\hline \multirow{7}{*}{ 1-Set } & 0,2 & 4174,09 & 1176,78 & 69,61 & 1136,71 & 3037,37 & 3,67 \\
\hline & 0,3 & 3603,70 & 1177,06 & 69,63 & 1136,73 & 2466,97 & 3,17 \\
\hline & 0,4 & 3432,03 & 1170,60 & 69,24 & 1136,35 & 2295,68 & 3,02 \\
\hline & 0,5 & 3102,37 & 1162,68 & 68,78 & 1135,88 & 1966,49 & 2,73 \\
\hline & 0,6 & 2712,05 & 1181,27 & 69,88 & 1136,98 & 1575,07 & 2,39 \\
\hline & 0,7 & 2544,64 & 1159,91 & 68,61 & 1135,72 & 1408,93 & 2,24 \\
\hline & 0,8 & 2222,81 & 1160,02 & 68,62 & 1135,72 & 1087,09 & 1,96 \\
\hline \multirow{7}{*}{$15-$ Set } & 0,2 & 4174,76 & 1171,84 & 69,32 & 1136,42 & 3038,34 & 3,67 \\
\hline & 0,3 & 3609,87 & 1170,64 & 69,25 & 1136,35 & 2473,52 & 3,18 \\
\hline & 0,4 & 3427,30 & 1163,84 & 68,84 & 1135,95 & 2291,35 & 3,02 \\
\hline & 0,5 & 3097,19 & 1157,75 & 68,48 & 1135,59 & 1961,60 & 2,73 \\
\hline & 0,6 & 2726,72 & 1167,77 & 69,08 & 1136,18 & 1590,54 & 2,40 \\
\hline & 0,7 & 2536,88 & 1154,71 & 68,30 & 1135,41 & 1401,47 & 2,23 \\
\hline & 0,8 & 2230,48 & 1140,91 & 67,49 & 1134,59 & 1095,88 & 1,97 \\
\hline \multirow{7}{*}{ 1-Out } & 0,2 & 4259,47 & 1166,51 & 70,14 & 1137,25 & 3122,22 & 3,75 \\
\hline & 0,3 & 3695,47 & 1163,23 & 69,95 & 1137,05 & 2558,42 & 3,25 \\
\hline & 0,4 & 3507,34 & 1158,79 & 69,68 & 1136,78 & 2370,56 & 3,09 \\
\hline & 0,5 & 3173,65 & 1151,29 & 69,23 & 1136,33 & 2037,32 & 2,79 \\
\hline & 0,6 & 2771,72 & 1164,31 & 70,01 & 1137,12 & 1634,61 & 2,44 \\
\hline & 0,7 & 2601,21 & 1147,32 & 68,99 & 1136,09 & 1465,11 & 2,29 \\
\hline & 0,8 & 2276,96 & 1146,04 & 68,91 & 1136,02 & 1140,94 & 2,00 \\
\hline \multirow{7}{*}{ 15-Out } & 0,2 & 4226,93 & 1140,10 & 68,55 & 1135,66 & 3091,27 & 3,72 \\
\hline & 0,3 & 3700,25 & 1135,38 & 68,27 & 1135,38 & 2564,88 & 3,26 \\
\hline & 0,4 & 3491,35 & 1131,45 & 68,03 & 1135,14 & 2356,22 & 3,08 \\
\hline & 0,5 & 3106,43 & 1122,84 & 67,52 & 1134,62 & 1971,81 & 2,74 \\
\hline & 0,6 & 2774,98 & 1129,52 & 67,92 & 1135,02 & 1639,96 & 2,44 \\
\hline & 0,7 & 2581,75 & 1112,81 & 66,91 & 1134,02 & 1447,73 & 2,28 \\
\hline & 0,8 & 2257,24 & 1115,91 & 67,10 & 1134,20 & 1123,04 & 1,99 \\
\hline
\end{tabular}


Tabela 12B. Receitas brutas, composição de custos da irrigação, receitas líquidas e relação benefício/custo para a melancia, em cada época de semeadura, nível de manejo da irrigação e risco de $25 \%$. Parnaíba, Piauí.

\begin{tabular}{|c|c|c|c|c|c|c|c|}
\hline $\begin{array}{c}\text { Época de } \\
\text { Semeadura }\end{array}$ & $\mathrm{p}$ & $\begin{array}{c}\mathrm{RB}^{1} \\
\left(\mathrm{US} \$ \mathrm{ha}^{-1}\right)\end{array}$ & $\begin{array}{c}E b \\
\left(\mathrm{kWh} \mathrm{ha}^{-1}\right)\end{array}$ & $\begin{array}{c}\text { CE } \\
\left(\text { US } \$ \mathrm{ha}^{-1}\right)\end{array}$ & $\begin{array}{c}\text { CT } \\
\left.\left(\text { US\$ } h^{-1}\right)^{-1}\right)\end{array}$ & $\begin{array}{c}\mathrm{RL} \\
\left(\mathrm{US} \$ \mathrm{ha}^{-1}\right)\end{array}$ & $\mathrm{B} / \mathrm{C}$ \\
\hline \multirow{7}{*}{ 1-Nov } & 0,2 & 4555,34 & 1037,12 & 62,71 & 1129,82 & 3425,52 & 4,03 \\
\hline & 0,3 & 4110,34 & 1031,41 & 62,37 & 1129,47 & 2980,87 & 3,64 \\
\hline & 0,4 & 3799,07 & 1017,90 & 61,55 & 1128,66 & 2670,42 & 3,37 \\
\hline & 0,5 & 3388,06 & 1014,89 & 61,37 & 1128,48 & 2259,59 & 3,00 \\
\hline & 0,6 & 3075,52 & 1010,98 & 61,13 & 1128,24 & 1947,28 & 2,73 \\
\hline & 0,7 & 2784,55 & 997,54 & 60,32 & 1127,43 & 1657,12 & 2,47 \\
\hline & 0,8 & 2507,83 & 992,86 & 60,04 & 1127,14 & 1380,68 & 2,22 \\
\hline \multirow{7}{*}{$15-\mathrm{Nov}$} & 0,2 & 4489,21 & 926,53 & 56,03 & 1123,13 & 3366,07 & 4,00 \\
\hline & 0,3 & 4091,57 & 914,85 & 55,32 & 1122,43 & 2969,14 & 3,65 \\
\hline & 0,4 & 3759,02 & 903,17 & 54,62 & 1121,72 & 2637,30 & 3,35 \\
\hline & 0,5 & 3351,77 & 887,94 & 53,69 & 1120,80 & 2230,97 & 2,99 \\
\hline & 0,6 & 3065,39 & 871,64 & 52,71 & 1119,81 & 1945,58 & 2,74 \\
\hline & 0,7 & 2768,22 & 867,42 & 52,45 & 1119,56 & 1648,66 & 2,47 \\
\hline & 0,8 & 2517,73 & 858,12 & 51,89 & 1119,00 & 1398,74 & 2,25 \\
\hline \multirow{7}{*}{ 1-Dez } & 0,2 & 4619,19 & 845,19 & 50,26 & 1117,36 & 3501,83 & 4,13 \\
\hline & 0,3 & 4255,94 & 828,27 & 49,25 & 1116,35 & 3139,59 & 3,81 \\
\hline & 0,4 & 3874,30 & 819,84 & 48,75 & 1115,85 & 2758,45 & 3,47 \\
\hline & 0,5 & 3481,62 & 796,46 & 47,36 & 1114,46 & 2367,16 & 3,12 \\
\hline & 0,6 & 3177,30 & 784,31 & 46,64 & 1113,74 & 2063,56 & 2,85 \\
\hline & 0,7 & 2902,20 & 767,12 & 45,61 & 1112,72 & 1789,48 & 2,61 \\
\hline & 0,8 & 2633,32 & 760,51 & 45,22 & 1112,33 & 1521,00 & 2,37 \\
\hline \multirow{7}{*}{ 15-Dez } & 0,2 & 4572,52 & 735,75 & 43,75 & 1110,85 & 3461,66 & 4,12 \\
\hline & 0,3 & 4232,77 & 712,98 & 42,39 & 1109,50 & 3123,27 & 3,82 \\
\hline & 0,4 & 3838,54 & 693,02 & 41,21 & 1108,31 & 2730,23 & 3,46 \\
\hline & 0,5 & 3490,10 & 674,09 & 40,08 & 1107,19 & 2382,91 & 3,15 \\
\hline & 0,6 & 3184,62 & 654,12 & 38,90 & 1106,00 & 2078,62 & 2,88 \\
\hline & 0,7 & 2928,23 & 637,37 & 37,90 & 1105,00 & 1823,22 & 2,65 \\
\hline & 0,8 & 2689,05 & 616,90 & 36,68 & 1103,79 & 1585,26 & 2,44 \\
\hline
\end{tabular}

${ }^{T} \mathrm{RB}$ - receita bruta; $\mathrm{Eb}$ - energia requerida para o bombeamento; $\mathrm{CE}$ - custo de energia elétrica; $\mathrm{CT}$ - custo total de produção; RL - receita líquida e B/C - relação benefício/custo. 
Tabela 13B. Receitas brutas, composição de custos da irrigação, receitas liquidas e relação benefício/custo para a melancia, em cada época de semeadura, nível de manejo da irrigação e risco de $30 \%$. Parnaíba, Piauí.

\begin{tabular}{|c|c|c|c|c|c|c|c|}
\hline $\begin{array}{l}\text { Época de } \\
\text { Semeadura }\end{array}$ & $\mathrm{p}$ & $\begin{array}{c}\mathrm{RB}^{\mathrm{l}} \\
\left(\mathrm{US} \$ \mathrm{ha}^{-1}\right)\end{array}$ & $\begin{array}{c}\mathrm{Eb} \\
\left(\mathrm{kWh} \mathrm{ha}^{-1}\right)\end{array}$ & $\begin{array}{c}\mathrm{CE} \\
\left(\mathrm{US} \$ \mathrm{ha}^{-1}\right)\end{array}$ & $\begin{array}{c}\mathrm{CT} \\
\left(\mathrm{US} \$ \mathrm{ha}^{-1}\right)\end{array}$ & $\begin{array}{c}\mathrm{RL} \\
\left(\mathrm{US} \$ \mathrm{ha}^{-1}\right)\end{array}$ & $\mathrm{B} / \mathrm{C}$ \\
\hline \multirow{7}{*}{ 1-Jan } & 0,2 & 4794,13 & 621,73 & 36,30 & 1103,40 & 3690,73 & 4,34 \\
\hline & 0,3 & 4469,98 & 602,53 & 35,18 & 1102,28 & 3367,70 & 4,06 \\
\hline & 0,4 & 4071,01 & 572,42 & 33,42 & 1100,52 & 2970,48 & 3,70 \\
\hline & 0,5 & 3754,61 & 553,42 & 32,31 & 1099,41 & 2655,20 & 3,42 \\
\hline & 0,6 & 3440,86 & 520,68 & 30,40 & 1097,50 & 2343,36 & 3,14 \\
\hline & 0,7 & 3188,45 & 498,69 & 29,11 & 1096,22 & 2092,23 & 2,91 \\
\hline & 0,8 & 2956,06 & 470,80 & 27,49 & 1094,59 & 1861,47 & 2,70 \\
\hline \multirow{7}{*}{ 15-Jan } & 0,2 & 4879,78 & 564,84 & 32,98 & 1100,08 & 3779,70 & 4,44 \\
\hline & 0,3 & 4564,90 & 537,43 & 31,38 & 1098,48 & 3466,42 & 4,16 \\
\hline & 0,4 & 4138,59 & 501,54 & 29,28 & 1096,39 & 3042,20 & 3,77 \\
\hline & 0,5 & 3853,32 & 478,34 & 27,93 & 1095,03 & 2758,29 & 3,52 \\
\hline & 0,6 & 3546,57 & 446,10 & 26,04 & 1093,15 & 2453,42 & 3,24 \\
\hline & 0,7 & 3328,87 & 421,85 & 24,63 & 1091,73 & 2237,13 & 3,05 \\
\hline & 0,8 & 3108,86 & 399,15 & 23,30 & 1090,41 & 2018,45 & 2,85 \\
\hline \multirow{7}{*}{$1-\mathrm{Fev}$} & 0,2 & 5036,22 & 514,15 & 29,82 & 1096,92 & 3939,30 & 4,59 \\
\hline & 0,3 & 4721,89 & 482,47 & 27,98 & 1095,08 & 3626,81 & 4,31 \\
\hline & 0,4 & 4288,42 & 435,98 & 25,28 & 1092,39 & 3196,04 & 3,93 \\
\hline & 0,5 & 4013,85 & 413,25 & 23,96 & 1091,07 & 2922,78 & 3,68 \\
\hline & 0,6 & 3737,61 & 391,64 & 22,71 & 1089,82 & 2647,79 & 3,43 \\
\hline & 0,7 & 3489,51 & 362,51 & 21,02 & 1088,13 & 2401,38 & 3,21 \\
\hline & 0,8 & 3271,32 & 341,36 & 19,80 & 1086,90 & 2184,42 & 3,01 \\
\hline \multirow{7}{*}{$15-\mathrm{Fev}$} & 0,2 & 5019,02 & 465,36 & 26,99 & 1094,09 & 3924,93 & 4,59 \\
\hline & 0,3 & 4690,59 & 430,73 & 24,98 & 1092,08 & 3598,50 & 4,30 \\
\hline & 0,4 & 4313,05 & 404,08 & 23,43 & 1090,54 & 3222,52 & 3,95 \\
\hline & 0,5 & 3999,12 & 364,05 & 21,11 & 1088,22 & 2910,91 & 3,67 \\
\hline & 0,6 & 3758,46 & 328,69 & 19,06 & 1086,17 & 2672,30 & 3,46 \\
\hline & 0,7 & 3531,19 & 304,77 & 17,67 & 1084,78 & 2446,41 & 3,26 \\
\hline & 0,8 & 3342,91 & 286,40 & 16,61 & 1083,71 & 2259,19 & 3,08 \\
\hline
\end{tabular}


414

Tabela 13B. Receitas brutas, composição de custos da irrigação, receitas líquidas e relação benefício/custo para a melancia, em cada época de semeadura, nivel de manejo da irrigação e risco de $30 \%$. Parnaíba, Piauí.

\begin{tabular}{|c|c|c|c|c|c|c|c|}
\hline $\begin{array}{l}\text { Época de } \\
\text { Semeadura }\end{array}$ & $\mathrm{p}$ & $\begin{array}{c}\mathrm{RB}^{1} \\
\left(\mathrm{US} \$ \mathrm{ha}^{-1}\right)\end{array}$ & $\begin{array}{c}E b \\
\left(\mathrm{kWh} \mathrm{ha}^{-1}\right)\end{array}$ & $\begin{array}{c}\text { CE } \\
\left(\mathrm{US} \$ \mathrm{ha}^{-1}\right)\end{array}$ & $\begin{array}{c}\text { CT } \\
\left(\mathrm{US} \$ \mathrm{ha}^{-1}\right)\end{array}$ & $\begin{array}{c}\mathrm{RL} \\
\left(\mathrm{US} \$ \mathrm{ha}^{-1}\right)\end{array}$ & $\mathrm{B} / \mathrm{C}$ \\
\hline \multirow{7}{*}{ 1-Mar } & 0,2 & 5080,60 & 453,15 & 26,02 & 1093,12 & 3987,48 & 4,65 \\
\hline & 0,3 & 4747,40 & 416,71 & 23,93 & 1091,03 & 3656,37 & 4,35 \\
\hline & 0,4 & 4346,13 & 378,40 & 21,73 & 1088,83 & 3257,30 & 3,99 \\
\hline & 0,5 & 4051,46 & 351,34 & 20,17 & 1087,28 & 2964,18 & 3,73 \\
\hline & 0,6 & 3785,33 & 310,70 & 17,84 & 1084,94 & 2700,39 & 3,49 \\
\hline & 0,7 & 3551,37 & 283,36 & 16,27 & 1083,37 & 2468,00 & 3,28 \\
\hline & 0,8 & 3382,49 & 258,79 & 14,86 & 1081,96 & 2300,53 & 3,13 \\
\hline \multirow{7}{*}{ 15-Mar } & 0,2 & 5040,43 & 471,65 & 27,08 & 1094,19 & 3946,25 & 4,61 \\
\hline & 0,3 & 4690,86 & 437,17 & 25,10 & 1092,21 & 3598,66 & 4,29 \\
\hline & 0,4 & 4288,23 & 397,67 & 22,83 & 1089,94 & 3198,29 & 3,93 \\
\hline & 0,5 & 3993,75 & 372,46 & 21,39 & 1088,49 & 2905,26 & 3,67 \\
\hline & 0,6 & 3698,92 & 338,45 & 19,43 & 1086,54 & 2612,39 & 3,40 \\
\hline & 0,7 & 3468,26 & 318,19 & 18,27 & 1085,37 & 2382,89 & 3,20 \\
\hline & 0,8 & 3256,45 & 275,72 & 15,83 & 1082,94 & 2173,52 & 3,01 \\
\hline \multirow{7}{*}{$1-A b r$} & 0,2 & 4913,07 & 539,75 & 29,44 & 1096,55 & 3816,53 & 4,48 \\
\hline & 0,3 & 4567,79 & 515,83 & 28,14 & 1095,24 & 3472,55 & 4,17 \\
\hline & 0,4 & 4111,13 & 480,91 & 26,23 & 1093,34 & 3017,80 & 3,76 \\
\hline & 0,5 & 3781,52 & 454,46 & 24,79 & 1091,89 & 2689,63 & 3,46 \\
\hline & 0,6 & 3487,40 & 435,34 & 23,75 & 1090,85 & 2396,55 & 3,20 \\
\hline & 0,7 & 3222,05 & 402,91 & 21,98 & 1089,08 & 2132,97 & 2,96 \\
\hline & 0,8 & 3006,40 & 389,67 & 21,25 & 1088,36 & 1918,04 & 2,76 \\
\hline \multirow{7}{*}{ 15-Abr } & 0,2 & 4887,34 & 596,57 & 32,54 & 1099,64 & 3787,70 & 4,44 \\
\hline & 0,3 & 4529,28 & 578,02 & 31,53 & 1098,63 & 3430,65 & 4,12 \\
\hline & 0,4 & 4049,91 & 543,98 & 29,67 & 1096,78 & 2953,14 & 3,69 \\
\hline & 0,5 & 3712,99 & 526,81 & 28,74 & 1095,84 & 2617,15 & 3,39 \\
\hline & 0,6 & 3388,51 & 498,23 & 27,18 & 1094,28 & 2294,22 & 3,10 \\
\hline & 0,7 & 3044,48 & 477,01 & 26,02 & 1093,12 & 1951,35 & 2,79 \\
\hline & 0,8 & 2888,12 & 460,88 & 25,14 & 1092,24 & 1795,87 & 2,64 \\
\hline
\end{tabular}


Tabela 13B. Receitas brutas, composição de custos da irrigação, receitas liquidas e relação benefício/custo para a melancia, em cada época de semeadura, nível de manejo da irrigação e risco de $30 \%$. Parnaíba, Piauí.

\begin{tabular}{|c|c|c|c|c|c|c|c|}
\hline $\begin{array}{l}\text { Época de } \\
\text { Semeadura }\end{array}$ & $\mathrm{p}$ & $\begin{array}{c}\mathrm{RB}^{1} \\
\left(\mathrm{US} \$ \mathrm{ha}^{-1}\right)\end{array}$ & $\begin{array}{c}E b \\
\left(\mathrm{kWh} \mathrm{ha} a^{-1}\right)\end{array}$ & $\begin{array}{c}C E \\
\left(U S \$ h a^{-1}\right)\end{array}$ & $\begin{array}{c}\text { CT } \\
\left(\text { US } \$ h^{-1}\right)^{-1}\end{array}$ & $\begin{array}{c}\mathrm{RL} \\
\left(\mathrm{US} \$ \mathrm{ha}^{-1}\right)\end{array}$ & $\mathrm{B} / \mathrm{C}$ \\
\hline \multirow{7}{*}{ 1-Mai } & 0,2 & 3899,45 & 681,21 & 36,85 & 1103,96 & 2795,49 & 3,53 \\
\hline & 0,3 & 3614,89 & 666,56 & 36,06 & 1103,17 & 2511,72 & 3,28 \\
\hline & 0,4 & 3193,90 & 642,53 & 34,76 & 1101,87 & 2092,03 & 2,90 \\
\hline & 0,5 & 2909,48 & 633,86 & 34,29 & 1101,40 & 1808,08 & 2,64 \\
\hline & 0,6 & 2640,06 & 617,77 & 33,42 & 1100,53 & 1539,53 & 2,40 \\
\hline & 0,7 & 2395,54 & 605,43 & 32,75 & 1099,86 & 1295,69 & 2,18 \\
\hline & 0,8 & 2191,96 & 587,29 & 31,77 & 1098,88 & 1093,08 & 1,99 \\
\hline \multirow{7}{*}{ 15-Mai } & 0,2 & 3897,99 & 713,18 & 38,58 & 1105,69 & 2792,30 & 3,53 \\
\hline & 0,3 & 3627,25 & 702,08 & 37,98 & 1105,09 & 2522,16 & 3,28 \\
\hline & 0,4 & 3194,56 & 685,60 & 37,09 & 1104,20 & 2090,36 & 2,89 \\
\hline & 0,5 & 2919,27 & 678,62 & 36,71 & 1103,82 & 1815,45 & 2,64 \\
\hline & 0,6 & 2613,12 & 661,56 & 35,79 & 1102,90 & 1510,22 & 2,37 \\
\hline & 0,7 & 2395,41 & 654,92 & 35,43 & 1102,54 & 1292,87 & 2,17 \\
\hline & 0,8 & 2173,59 & 637,00 & 34,46 & 1101,57 & 1072,02 & 1,97 \\
\hline \multirow{7}{*}{ 1-Jun } & 0,2 & 4120,37 & 772,54 & 44,34 & 1111,45 & 3008,93 & 3,71 \\
\hline & 0,3 & 3835,22 & 762,32 & 43,75 & 1110,86 & 2724,36 & 3,45 \\
\hline & 0,4 & 3370,69 & 754,06 & 43,28 & 1110,38 & 2260,30 & 3,04 \\
\hline & 0,5 & 3089,13 & 740,94 & 42,53 & 1109,63 & 1979,50 & 2,78 \\
\hline & 0,6 & 2730,38 & 730,47 & 41,93 & 1109,03 & 1621,35 & 2,46 \\
\hline & 0,7 & 2521,76 & 726,44 & 41,69 & 1108,80 & 1412,96 & 2,27 \\
\hline & 0,8 & 2253,32 & 717,02 & 41,15 & 1108,26 & 1145,06 & 2,03 \\
\hline \multirow{7}{*}{ 15-Jun } & 0,2 & 4174,51 & 843,11 & 48,39 & 1115,50 & 3059,01 & $\overline{3,74}$ \\
\hline & 0,3 & 3872,70 & 835,17 & 47,94 & 1115,04 & 2757,66 & 3,47 \\
\hline & 0,4 & 3429,18 & 823,86 & 47,29 & 1114,39 & 2314,79 & 3,08 \\
\hline & 0,5 & 3120,87 & 815,89 & 46,83 & 1113,93 & 2006,94 & 2,80 \\
\hline & 0,6 & 2783,37 & 810,71 & 46,53 & 1113,64 & 1669,73 & 2,50 \\
\hline & 0,7 & 2533,02 & 807,58 & 46,35 & 1113,46 & 1419,56 & 2,27 \\
\hline & 0,8 & 2279,19 & 797,31 & 45,76 & 1112,87 & 1166,32 & 2,05 \\
\hline
\end{tabular}


Tabela 13B. Receitas brutas, composição de custos da irrigação, receitas líquidas e relação benefício/custo para a melancia, em cada época de semeadura, nível de manejo da irrigação e risco de $30 \%$. Parnaíba, Piauí.

\begin{tabular}{|c|c|c|c|c|c|c|c|}
\hline $\begin{array}{c}\text { Época de } \\
\text { Semeadura }\end{array}$ & $\mathrm{p}$ & $\begin{array}{c}\mathrm{RB}^{\mathrm{l}} \\
\left(\mathrm{US} \$ \mathrm{ha}^{-1}\right)\end{array}$ & $\begin{array}{c}\mathrm{Eb} \\
\left(\mathrm{kWh} \mathrm{ha} \mathrm{h}^{-1}\right)\end{array}$ & $\begin{array}{c}\text { CE } \\
\left(\mathrm{US} \$ \mathrm{ha}^{-1}\right)\end{array}$ & $\begin{array}{c}\mathrm{CT} \\
\left(\mathrm{US} \$ \mathrm{ha}^{-1}\right)\end{array}$ & $\begin{array}{c}\mathrm{RL} \\
\left(\mathrm{US} \$ \mathrm{ha}^{-1}\right)\end{array}$ & $\mathrm{B} / \mathrm{C}$ \\
\hline \multirow{7}{*}{ 1-Jul } & 0,2 & 3572,14 & 921,21 & 54,97 & 1122,07 & 2450,07 & 3,18 \\
\hline & 0,3 & 3278,90 & 911,61 & 54,40 & 1121,50 & 2157,40 & 2,92 \\
\hline & 0,4 & 2959,99 & 906,83 & 54,11 & 1121,21 & 1838,77 & 2,64 \\
\hline & 0,5 & 2633,87 & 899,73 & 53,69 & 1120,79 & 1513,08 & 2,35 \\
\hline & 0,6 & 2390,37 & 899,47 & 53,67 & 1120,78 & 1269,60 & 2,13 \\
\hline & 0,7 & 2141,28 & 889,41 & 53,07 & 1120,18 & 1021,10 & 1,91 \\
\hline & 0,8 & 1950,12 & 886,65 & 52,91 & 1120,01 & 830,11 & 1,74 \\
\hline \multirow{7}{*}{ 15-Jul } & 0,2 & 3642,72 & 999,07 & 59,61 & 1126,72 & 2516,01 & 3,23 \\
\hline & 0,3 & 3308,26 & 990,68 & 59,11 & 1126,22 & 2182,04 & 2,94 \\
\hline & 0,4 & 3042,55 & 985,40 & 58,80 & 1125,90 & 1916,65 & 2,70 \\
\hline & 0,5 & 2671,59 & 984,43 & 58,74 & 1125,85 & 1545,74 & 2,37 \\
\hline & 0,6 & 2455,97 & 979,11 & 58,42 & 1125,53 & 1330,44 & 2,18 \\
\hline & 0,7 & 2175,06 & 975,65 & 58,22 & 1125,32 & 1049,74 & 1,93 \\
\hline & 0,8 & 1989,49 & 965,73 & 57,62 & 1124,73 & 864,76 & 1,77 \\
\hline \multirow{7}{*}{ 1-Ago } & 0,2 & 4358,95 & 1091,28 & 65,64 & 1132,75 & 3226,21 & 3,85 \\
\hline & 0,3 & 3863,66 & 1085,61 & 65,30 & 1132,41 & 2731,25 & 3,41 \\
\hline & 0,4 & 3607,05 & 1082,67 & 65,12 & 1132,23 & 2474,82 & 3,19 \\
\hline & 0,5 & 3176,37 & 1078,98 & 64,90 & 1132,01 & 2044,36 & 2,81 \\
\hline & 0,6 & 2872,54 & 1078,85 & 64,89 & 1132,00 & 1740,54 & 2,54 \\
\hline & 0,7 & 2632,92 & 1069,69 & 64,34 & 1131,45 & 1501,47 & 2,33 \\
\hline & 0,8 & 2331,01 & 1069,74 & 64,35 & 1131,45 & 1199,55 & 2,06 \\
\hline \multirow{7}{*}{ 15-Ago } & 0,2 & 4429,49 & 1140,13 & 68,58 & 1135,69 & 3293,80 & 3,90 \\
\hline & 0,3 & 3868,20 & 1136,67 & 68,37 & 1135,48 & 2732,72 & 3,41 \\
\hline & 0,4 & 3656,42 & 1131,32 & 68,05 & 1135,16 & 2521,27 & 3,22 \\
\hline & 0,5 & 3244,19 & 1129,30 & 67,93 & 1135,03 & 2109,15 & 2,86 \\
\hline & 0,6 & 2902,80 & 1139,81 & 68,56 & 1135,67 & 1767,14 & 2,56 \\
\hline & 0,7 & 2694,68 & 1118,14 & 67,26 & 1134,36 & 1560,32 & 2,38 \\
\hline & 0,8 & 2344,55 & 1124,35 & 67,63 & 1134,74 & 1209,81 & 2,07 \\
\hline
\end{tabular}


Tabela 13B. Receitas brutas, composição de custos da irrigação, receitas líquidas e relação benefício/custo para a melancia, em cada época de semeadura, nivel de manejo da irrigação e risco de $30 \%$. Parnaiba. Piauí.

\begin{tabular}{|c|c|c|c|c|c|c|c|}
\hline $\begin{array}{l}\text { Época de } \\
\text { Semeadura }\end{array}$ & $\mathrm{p}$ & $\begin{array}{c}\mathrm{RB}^{1} \\
\left(\mathrm{US} \$ \mathrm{ha}^{-1}\right)\end{array}$ & $\begin{array}{c}E b \\
\left(\mathrm{kWh} \mathrm{ha} a^{-1}\right)\end{array}$ & $\begin{array}{c}\text { CE } \\
\left(\mathrm{US} \$ \mathrm{ha}^{-1}\right)\end{array}$ & $\begin{array}{c}\mathrm{CT} \\
\left(\mathrm{US} \$ \mathrm{ha}^{-1}\right)\end{array}$ & $\begin{array}{c}\mathrm{RL} \\
\left(\mathrm{US} \$ \mathrm{ha}^{-1}\right)\end{array}$ & $\mathrm{B} / \mathrm{C}$ \\
\hline \multirow{7}{*}{ 1-Set } & 0,2 & 4206,25 & 1174,96 & 68,78 & 1135,89 & 3070,36 & 3,70 \\
\hline & 0,3 & 3629,94 & 1174,90 & 68,78 & 1135,88 & 2494,05 & 3,20 \\
\hline & 0,4 & 3458,34 & 1168,23 & 68,39 & 1135,49 & 2322,85 & 3,05 \\
\hline & 0,5 & 3131,91 & 1160,23 & 67,92 & 1135,03 & 1996,89 & 2,76 \\
\hline & 0,6 & 2734,63 & 1181,27 & 69,15 & 1136,26 & 1598,38 & 2,41 \\
\hline & 0,7 & 2569,14 & 1156,40 & 67,70 & 1134,80 & 1434,34 & 2,26 \\
\hline & 0,8 & 2244,93 & 1155,84 & 67,66 & 1134,77 & 1110,16 & 1,98 \\
\hline \multirow{7}{*}{15 -Set } & 0,2 & 4206,88 & 1169,24 & 68,45 & 1135,55 & 3071,33 & 3,70 \\
\hline & 0,3 & 3636,59 & 1167,76 & 68,36 & 1135,47 & 2501,12 & 3,20 \\
\hline & 0,4 & 3455,07 & 1161,08 & 67,97 & 1135,08 & 2319,99 & 3,04 \\
\hline & 0,5 & 3127,19 & 1154,70 & 67,60 & 1134,70 & 1992,49 & 2,76 \\
\hline & 0,6 & 2750,02 & 1162,10 & 68,03 & 1135,14 & 1614,89 & 2,42 \\
\hline & 0,7 & 2562,23 & 1150,40 & 67,35 & 1134,45 & 1427,78 & 2,26 \\
\hline & 0,8 & 2252,56 & 1137,45 & 66,59 & 1133,69 & 1118,86 & 1,99 \\
\hline \multirow{7}{*}{ 1-Out } & 0,2 & 4291,55 & 1163,31 & 69,14 & 1136,24 & 3155,31 & 3,78 \\
\hline & 0,3 & 3721,71 & 1159,67 & 68,92 & 1136,03 & 2585,68 & 3,28 \\
\hline & 0,4 & 3534,73 & 1154,74 & 68,63 & 1135,73 & 2399,00 & 3,11 \\
\hline & 0,5 & 3202,75 & 1147,20 & 68,18 & 1135,29 & 2067,46 & 2,82 \\
\hline & 0,6 & 2796,11 & 1164,31 & 69,20 & 1136,30 & 1659,80 & 2,46 \\
\hline & 0,7 & 2625,76 & 1142,36 & 67,89 & 1135,00 & 1490,76 & 2,31 \\
\hline & 0,8 & 2298,85 & 1140,05 & 67,76 & 1134,86 & 1163,99 & 2,03 \\
\hline \multirow{7}{*}{ 15-Out } & 0,2 & 4259,56 & 1136,33 & 67,53 & 1134,64 & 3124,92 & 3,75 \\
\hline & 0,3 & 3726,37 & 1131,36 & 67,24 & 1134,34 & 2592,03 & 3,29 \\
\hline & 0,4 & 3519,44 & 1127,35 & 67,00 & 1134,11 & 2385,34 & 3,10 \\
\hline & 0,5 & 3136,14 & 1118,57 & 66,48 & 1133,58 & 2002,56 & 2,77 \\
\hline & 0,6 & 2798,64 & 1122,62 & 66,72 & 1133,82 & $166 \dot{4}, 82$ & 2,47 \\
\hline & 0,7 & 2605,62 & 1107,39 & 65,81 & 1132,92 & 1472,70 & 2,30 \\
\hline & 0,8 & 2278,69 & 1109,23 & 65,92 & 1133,03 & 1145,66 & 2,01 \\
\hline
\end{tabular}


Tabela 13B. Receitas brutas, composição de custos da imigação, receitas líquidas e relação benefício/custo para a melancia, em cada época de semeadura, nível de manejo da irrigação e risco de $30 \%$. Parnaiba, Piauí.

\begin{tabular}{|c|c|c|c|c|c|c|c|}
\hline $\begin{array}{c}\text { Época de } \\
\text { Semeadura }\end{array}$ & $\mathrm{p}$ & $\begin{array}{c}\mathrm{RB}^{\mathrm{I}} \\
\left(\mathrm{US} \$ \mathrm{ha}^{-1}\right)\end{array}$ & $\begin{array}{c}\mathrm{Eb} \\
\left(\mathrm{kWh} \mathrm{ha}^{-1}\right)\end{array}$ & $\begin{array}{c}\text { CE } \\
\left(\mathrm{US} \$ \mathrm{ha}^{-1}\right)\end{array}$ & $\begin{array}{c}\text { CT } \\
\left(\mathrm{US} \$ \mathrm{ha}^{-1}\right)\end{array}$ & $\begin{array}{c}\mathrm{RL} \\
\left(\mathrm{US} \$ \mathrm{ha}^{-1}\right)\end{array}$ & $\mathrm{B} / \mathrm{C}$ \\
\hline \multirow{7}{*}{$1-\mathrm{Nov}$} & 0,2 & 4593,84 & 1030,71 & 61,62 & 1128,73 & 3465,12 & 4,07 \\
\hline & 0,3 & 4142,75 & 1024,17 & 61,23 & 1128,34 & 3014,42 & 3,67 \\
\hline & 0,4 & 3833,89 & 1010,17 & 60,39 & 1127,50 & 2706,39 & 3,40 \\
\hline & 0,5 & 3420,09 & 1006,57 & 60,18 & 1127,28 & 2292,81 & 3,03 \\
\hline & 0,6 & 3106,42 & 1000,63 & 59,82 & 1126,93 & 1979,49 & 2,76 \\
\hline & 0,7 & 2814,47 & 988,00 & 59,07 & 1126,17 & 1688,30 & 2,50 \\
\hline & 0,8 & 2536,30 & 982,05 & 58,71 & 1125,82 & 1410,48 & 2,25 \\
\hline \multirow{7}{*}{$15-N o v$} & 0,2 & 4526,34 & 918,94 & 54,94 & 1122,04 & 3404,29 & 4,03 \\
\hline & 0,3 & 4125,39 & 906,12 & 54,17 & 1121,28 & 3004,11 & 3,68 \\
\hline & 0,4 & 3795,76 & 894,09 & 53,45 & 1120,56 & 2675,20 & 3,39 \\
\hline & 0,5 & 3386,16 & 878,40 & 52,52 & 1119,62 & 2266,54 & 3,02 \\
\hline & 0,6 & 3099,86 & 860,60 & 51,45 & 1118,56 & 1981,30 & 2,77 \\
\hline & 0,7 & 2802,35 & 855,50 & 51,15 & 1118,25 & 1684,10 & 2,51 \\
\hline & 0,8 & 2551,42 & 844,58 & 50,49 & 1117,60 & 1433,82 & 2,28 \\
\hline \multirow{7}{*}{ 1-Dez } & 0,2 & 4715,96 & 837,64 & 49,15 & 1116,25 & 3599,71 & 4,22 \\
\hline & 0,3 & 4343,86 & 820,09 & 48,12 & 1115,22 & 3228,64 & 3,90 \\
\hline & 0,4 & 3960,37 & 810,17 & 47,54 & 1114,64 & 2845,73 & 3,55 \\
\hline & 0,5 & 3561,23 & 785,96 & 46,12 & 1113,22 & 2448,00 & 3,20 \\
\hline & 0,6 & 3254,60 & 772,65 & 45,33 & 1112,44 & 2142,16 & 2,93 \\
\hline & 0,7 & 2974,17 & 755,36 & 44,32 & 1111,42 & 1862,75 & 2,68 \\
\hline & 0,8 & 2703,73 & 747,52 & 43,86 & 1110,96 & 1592,77 & 2,43 \\
\hline \multirow{7}{*}{ 15-Dez } & 0,2 & 4666,87 & 726,14 & 42,61 & 1109,71 & 3557,16 & 4,21 \\
\hline & 0,3 & 4322,99 & 702,42 & 41,21 & 1108,32 & 3214,67 & 3,90 \\
\hline & 0,4 & 3924,29 & 680,61 & 39,93 & 1107,04 & 2817,26 & 3,54 \\
\hline & 0,5 & 3574,09 & 660,92 & 38,78 & 1105,88 & 2468,20 & 3,23 \\
\hline & 0,6 & 3266,16 & 640,56 & 37,58 & 1104,69 & 2161,47 & 2,96 \\
\hline & 0,7 & 3004,69 & 622,06 & 36,50 & 1103,60 & 1901,09 & 2,72 \\
\hline & 0,8 & 2764,32 & 601,83 & 35,31 & 1102,42 & 1661,91 & 2,51 \\
\hline
\end{tabular}

${ }^{1} \mathrm{RB}$ - receita bruta; $\mathrm{Eb}$ - energia requerida para o bombeamento; $\mathrm{CE}$ - custo de energia elétrica: $\mathrm{CT}$ - custo total de produção; $\mathrm{RL}$ - receita líquida e $\mathrm{B} / \mathrm{C}$ - relação benefício/custo. 
Tabela 14B. Receitas brutas, composição de custos da irrigação, receitas líquidas e relação benefício/custo para a melancia, em cada época de semeadura, nível de manejo da irrigação e risco de 35 \%. Parnaíba, Piauí.

\begin{tabular}{|c|c|c|c|c|c|c|c|}
\hline $\begin{array}{l}\text { Época de } \\
\text { Semeadura }\end{array}$ & $\mathrm{p}$ & $\begin{array}{c}\mathrm{RB}^{\mathrm{I}} \\
\left(\mathrm{USS} \mathrm{ha}^{-1}\right)\end{array}$ & $\begin{array}{c}E b \\
\left(\mathrm{kWh} \mathrm{ha}^{-1}\right)\end{array}$ & $\begin{array}{c}\text { CE } \\
\left(\text { US } \$ \mathrm{ha}^{-1}\right)\end{array}$ & $\begin{array}{c}\text { CT } \\
\left.\left(\text { US } \$ h^{-1}\right)^{-1}\right)\end{array}$ & $\begin{array}{c}\mathrm{RL} \\
\left(\mathrm{US} \$ \mathrm{ha}^{-1}\right)\end{array}$ & $\mathrm{B} / \mathrm{C}$ \\
\hline \multirow{7}{*}{ 1-Jan } & 0,2 & 4840,51 & 612,64 & 35,21 & 1102,32 & 3738,20 & 4,39 \\
\hline & 0,3 & 4517,24 & 592,54 & 34,06 & 1101,16 & 3416,08 & 4,10 \\
\hline & 0,4 & 4118,50 & 561,45 & 32,27 & 1099,37 & 3019,13 & 3,75 \\
\hline & 0,5 & 3802,98 & 541,45 & 31,12 & 1098,22 & 2704,75 & 3,46 \\
\hline & 0,6 & 3490,56 & 508,34 & 29,22 & 1096,32 & 2394,24 & 3,18 \\
\hline & 0,7 & 3241,08 & 485,34 & 27,89 & 1095,00 & 2146,08 & 2,96 \\
\hline & 0,8 & 3006,87 & 456,21 & 26,22 & 1093,33 & 1913,54 & 2,75 \\
\hline \multirow{7}{*}{ 15-Jan } & 0,2 & 4926,95 & 556,08 & 31,96 & 1099,07 & 3827,88 & 4,48 \\
\hline & 0,3 & 4612,31 & 527,39 & 30,31 & 1097,42 & 3514,89 & 4,20 \\
\hline & 0,4 & 4187,20 & 490,34 & 28,18 & 1095,29 & 3091,91 & 3,82 \\
\hline & 0,5 & 3902,50 & 466,18 & 26,79 & 1093,90 & 2808,60 & 3,57 \\
\hline & 0,6 & 3597,30 & 432,68 & 24,87 & 1091,97 & 2505,32 & 3,29 \\
\hline & 0,7 & 3382,30 & 409,29 & 23,52 & 1090,63 & 2291,67 & 3,10 \\
\hline & 0,8 & 3163,97 & 386,46 & 22,21 & 1089,32 & 2074,65 & 2,90 \\
\hline \multirow{7}{*}{$1-\mathrm{Fev}$} & 0,2 & 5063,46 & 504,66 & 28,62 & 1095,73 & 3967,74 & 4,62 \\
\hline & 0,3 & 4751,01 & 472,10 & 26,78 & 1093,88 & 3657,13 & 4,34 \\
\hline & 0,4 & 4321,90 & 425,05 & 24,11 & 1091,21 & 3230,69 & 3,96 \\
\hline & 0,5 & 4052,31 & 401,70 & 22,78 & 1089,89 & 2962,42 & 3,72 \\
\hline & 0,6 & 3776,59 & 379,40 & 21,52 & 1088,62 & 2687,96 & 3,47 \\
\hline & 0,7 & 3534,16 & 349,68 & 19,83 & 1086,94 & 2447,22 & 3,25 \\
\hline & 0,8 & 3318,65 & 327,70 & 18,59 & 1085,69 & 2232,95 & 3,06 \\
\hline \multirow{7}{*}{$15-\mathrm{Fev}$} & 0,2 & 5046,44 & 456,95 & 25,92 & 1093,02 & 3953,41 & 4,62 \\
\hline & 0,3 & 4722,55 & 421,96 & 23,93 & 1091,04 & 3631,51 & 4,33 \\
\hline & 0,4 & 4345,07 & 392,28 & 22,25 & 1089,35 & 3255,72 & 3,99 \\
\hline & 0,5 & 4038,28 & 352,74 & 20,01 & 1087,11 & 2951,16 & 3,71 \\
\hline & 0,6 & 3801,09 & 318,51 & 18,07 & 1085,17 & 2715,92 & 3,50 \\
\hline & 0,7 & 3574,42 & 293,48 & 16,65 & 1083,75 & 2490,67 & 3,30 \\
\hline & 0,8 & 3386,42 & 272,99 & 15,48 & 1082,59 & 2303,83 & 3,13 \\
\hline
\end{tabular}


Tabela 14B. Receitas brutas, composição de custos da irrigação, receitas líquidas e relação beneficio/custo para a melancia, em cada época de semeadura, nível de manejo da irrigação e risco de 35 \%. Parnaíba, Piauí.

\begin{tabular}{|c|c|c|c|c|c|c|c|}
\hline $\begin{array}{l}\text { Época de } \\
\text { Semeadura }\end{array}$ & $\mathrm{p}$ & $\begin{array}{c}\mathrm{RB}^{1} \\
\left(\mathrm{US} \$ \mathrm{ha}^{-1}\right)\end{array}$ & $\begin{array}{c}E b \\
\left(\mathrm{kWh} \mathrm{ha} \mathrm{a}^{-1}\right)\end{array}$ & 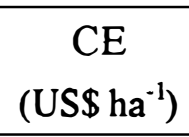 & $\begin{array}{c}\text { CT } \\
\left(\text { US\$ ha }{ }^{-1}\right)\end{array}$ & $\begin{array}{c}\mathrm{RL} \\
\left(\mathrm{US} \$ \mathrm{ha}^{-1}\right)\end{array}$ & $\mathrm{B} / \mathrm{C}$ \\
\hline \multirow{7}{*}{ 1-Mar } & 0,2 & 5129,85 & 443,66 & 24,83 & 1091,94 & 4037,92 & 4,70 \\
\hline & 0,3 & 4799,12 & 406,41 & 22,75 & 1089,85 & 3709,27 & 4,40 \\
\hline & 0,4 & 4400,44 & 366,96 & 20,54 & 1087,65 & 3312,79 & 4,05 \\
\hline & 0,5 & 4109,68 & 338,75 & 18,96 & 1086,07 & 3023,61 & 3,78 \\
\hline & 0,6 & 3846,51 & 298,77 & 16,72 & 1083,83 & 2762,68 & 3,55 \\
\hline & 0,7 & 3615,41 & 270,86 & 15,16 & 1082,27 & 2533,14 & 3,34 \\
\hline & 0,8 & 3447,20 & 245,25 & 13,73 & 1080,83 & 2366,37 & 3,19 \\
\hline \multirow{7}{*}{ 15-Mar } & 0,2 & 5088,86 & 462,82 & 25,91 & 1093,01 & 3995,85 & 4,66 \\
\hline & 0,3 & 4741,69 & 427,60 & 23,94 & 1091,04 & 3650,65 & 4,35 \\
\hline & 0,4 & 4339,08 & 387,19 & 21,67 & 1088,78 & 3250,30 & 3,99 \\
\hline & 0,5 & 4046,44 & 361,30 & 20,22 & 1087,33 & 2959,11 & 3,72 \\
\hline & 0,6 & 3754,14 & 326,49 & 18,28 & 1085,38 & 2668,76 & 3,46 \\
\hline & 0,7 & 3526,94 & 304,44 & 17,04 & 1084,15 & 2442,79 & 3,25 \\
\hline & 0,8 & 3320,22 & 262,21 & 14,68 & 1081,78 & 2238,44 & 3,07 \\
\hline \multirow{7}{*}{$1-\mathrm{Abr}$} & 0,2 & 4961,95 & 531,35 & 28,19 & 1095,30 & 3866,65 & 4,53 \\
\hline & 0,3 & 4618,65 & 506,94 & 26,90 & 1094,00 & 3524,65 & 4,22 \\
\hline & 0,4 & 4163,73 & 470,87 & 24,98 & 1092,09 & 3071,64 & 3,81 \\
\hline & 0,5 & 3834,27 & 443,78 & 23,55 & 1090,65 & 2743,62 & 3,52 \\
\hline & 0,6 & 3541,78 & 423,13 & 22,45 & 1089,55 & 2452,23 & 3,25 \\
\hline & 0,7 & 3277,58 & 390,15 & 20,70 & 1087,80 & 2189,78 & 3,01 \\
\hline & 0,8 & 3065,21 & 375,62 & 19,93 & 1087,03 & 1978,18 & 2,82 \\
\hline \multirow{7}{*}{$15-\mathrm{Abr}$} & 0,2 & 4935,29 & 588,53 & 31,23 & 1098,33 & 3836,96 & 4,49 \\
\hline & 0,3 & 4578,43 & 568,68 & 30,17 & 1097,28 & 3481,16 & 4,17 \\
\hline & 0,4 & 4099,48 & 534,60 & 28,36 & 1095,47 & 3004,02 & 3,74 \\
\hline & 0,5 & 3762,74 & 516,01 & 27,38 & 1094,48 & 2668,25 & 3,44 \\
\hline & 0,6 & 3439,47 & 486,28 & 25,80 & 1092,90 & 2346,56 & 3,15 \\
\hline & 0,7 & 3070,12 & 463,92 & 24,61 & 1091,72 & 1978,40 & 2,81 \\
\hline & 0,8 & 2938,67 & 446,83 & 23,71 & 1090,81 & 1847,85 & 2,69 \\
\hline
\end{tabular}


Tabela 14B. Receitas brutas, composição de custos da irrigação, receitas líquidas e relação beneficio/custo para a melancia, em cada época de semeadura, nível de manejo da irrigação e risco de $35 \%$. Parnaíba, Piauí.

\begin{tabular}{|c|c|c|c|c|c|c|c|}
\hline $\begin{array}{l}\text { Época de } \\
\text { Semeadura }\end{array}$ & $\mathrm{p}$ & $\begin{array}{c}\mathrm{RB}^{1} \\
\left(\mathrm{US} \$ \mathrm{ha}^{-1}\right)\end{array}$ & $\begin{array}{c}E b \\
\left(\mathrm{kWh} \mathrm{ha} \mathrm{a}^{-1}\right)\end{array}$ & $\begin{array}{c}C E \\
\left(\mathrm{US} \$ \mathrm{ha}^{-1}\right)\end{array}$ & $\begin{array}{c}\text { CT } \\
\left(\mathrm{US} \$ \mathrm{ha}^{-1}\right)\end{array}$ & $\begin{array}{c}\mathrm{RL} \\
\left(\mathrm{US} \$ \mathrm{ha}^{-1}\right)\end{array}$ & $\mathrm{B} / \mathrm{C}$ \\
\hline \multirow{7}{*}{ 1-Mai } & 0,2 & 3930,52 & 674,72 & 35,71 & 1102,82 & 2827,70 & 3,56 \\
\hline & 0,3 & 3647,33 & 659,46 & 34,91 & 1102,01 & 2545,32 & 3,31 \\
\hline & 0,4 & 3224,80 & 634,22 & 33,57 & 1100,68 & 2124,12 & 2,93 \\
\hline & 0,5 & 2940,63 & 623,67 & 33,01 & 1100,12 & 1840,51 & 2,67 \\
\hline & 0,6 & 2669,39 & 606,30 & 32,09 & 1099,20 & 1570,19 & 2,43 \\
\hline & 0,7 & 2425,13 & 593,25 & 31,40 & 1098,51 & 1326,63 & 2,21 \\
\hline & 0,8 & 2222,73 & 575,26 & 30,45 & 1097,55 & 1125,17 & 2,03 \\
\hline \multirow{7}{*}{ 15-Mai } & 0,2 & 3929,39 & 706,62 & 37,40 & 1104,51 & 2824,88 & 3,56 \\
\hline & 0,3 & 3658,17 & 694,35 & 36,75 & 1103,86 & 2554,31 & 3,31 \\
\hline & 0,4 & 3225,04 & 677,50 & 35,86 & 1102,97 & 2122,08 & 2,92 \\
\hline & 0,5 & 2949,91 & 669,06 & 35,42 & 1102,52 & 1847,39 & 2,68 \\
\hline & 0,6 & 2642,55 & 651,35 & 34,48 & 1101,58 & 1540,97 & 2,40 \\
\hline & 0,7 & 2424,95 & 643,87 & 34,08 & 1101,19 & 1323,76 & 2,20 \\
\hline & 0,8 & 2201,93 & 625,58 & 33,11 & 1100,22 & 1101,72 & 2,00 \\
\hline \multirow{7}{*}{ 1-Jun } & 0,2 & 4167,62 & 767,68 & 43,20 & 1110,31 & 3057,31 & 3,75 \\
\hline & 0,3 & 3881,11 & 756,82 & 42,59 & 1109,70 & 2771,41 & 3,50 \\
\hline & 0,4 & 3412,48 & 747,67 & 42,08 & 1109,18 & 2303,30 & 3,08 \\
\hline & 0,5 & 3129,68 & 734,32 & 41,33 & 1108,43 & 2021,25 & 2,82 \\
\hline & 0,6 & 2768,77 & 722,37 & 40,65 & 1107,76 & 1661,01 & 2,50 \\
\hline & 0,7 & 2558,28 & 718,30 & 40,42 & 1107,53 & 1450,75 & 2,31 \\
\hline & 0,8 & 2287,93 & 708,24 & 39,86 & 1106,96 & 1180,96 & 2,07 \\
\hline \multirow{7}{*}{ 15-Jun } & 0,2 & 4223,02 & 838,41 & 47,18 & 1114,29 & 3108,73 & 3,79 \\
\hline & 0,3 & 3917,78 & 830,42 & 46,73 & 1113,84 & 2803,94 & 3,52 \\
\hline & 0,4 & 3472,69 & 818,18 & 46,05 & 1113,15 & 2359,54 & 3,12 \\
\hline & 0,5 & 3159,56 & 810,16 & 45,59 & 1112,70 & 2046,86 & 2,84 \\
\hline & 0,6 & 2822,20 & 803,66 & 45,23 & 1112,33 & 1709,87 & 2,54 \\
\hline & 0,7 & 2569,02 & 801,63 & 45,11 & 1112,22 & 1456,80 & 2,31 \\
\hline & 0,8 & 2312,86 & 789,84 & 44,45 & 1111,56 & 1201,31 & 2,08 \\
\hline
\end{tabular}


Tabela 14B. Receitas brutas, composição de custos da irrigação, receitas líquidas e relação benefício/custo para a melancia, em cada época de semeadura, nível de manejo da irrigação e risco de $35 \%$. Parnaíba, Piauí.

\begin{tabular}{|c|c|c|c|c|c|c|c|}
\hline $\begin{array}{l}\text { Época de } \\
\text { Semeadura }\end{array}$ & $\mathrm{p}$ & $\begin{array}{c}\mathrm{RB}^{1} \\
\left(\mathrm{US} \$ \mathrm{ha}^{-1}\right)\end{array}$ & 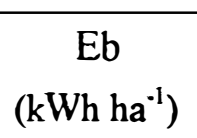 & $\begin{array}{c}\text { CE } \\
\left(\mathrm{US} \$ \mathrm{ha}^{-1}\right)\end{array}$ & $\begin{array}{c}\text { CT } \\
\left(\text { US } \$ h^{-1}{ }^{-1}\right)\end{array}$ & $\begin{array}{c}\mathrm{RL} \\
\left(\mathrm{US} \$ \mathrm{ha}^{-1}\right)\end{array}$ & $\mathrm{B} / \mathrm{C}$ \\
\hline \multirow{7}{*}{$1-\mathrm{Jul}$} & 0,2 & 3617,51 & 917,19 & 53,97 & 1121,07 & 2496,44 & 3,23 \\
\hline & 0,3 & 3320,26 & 907,44 & 53,39 & 1120,50 & 2199,76 & 2,96 \\
\hline & 0,4 & 3000,63 & 902,11 & 53,08 & 1120,19 & 1880,44 & 2,68 \\
\hline & 0,5 & 2669,20 & 894,44 & 52,63 & 1119,73 & 1549,47 & 2,38 \\
\hline & 0,6 & 2425,25 & 893,05 & 52,55 & 1119,65 & 1305,60 & 2,17 \\
\hline & 0,7 & 2172,47 & 882,91 & 51,95 & 1119,06 & 1053,41 & 1,94 \\
\hline & 0,8 & 1981,33 & 880,82 & 51,83 & 1118,93 & 862,40 & 1,77 \\
\hline \multirow{7}{*}{ 15-Jul } & 0,2 & 3688,88 & 995,20 & 58,56 & 1125,66 & 2563,22 & 3,28 \\
\hline & 0,3 & 3348,75 & 986,74 & 58,06 & 1125,16 & 2223,59 & 2,98 \\
\hline & 0,4 & 3082,75 & 981,24 & 57,74 & 1124,84 & 1957,91 & 2,74 \\
\hline & 0,5 & 2707,31 & 979,91 & 57,66 & 1124,76 & 1582,54 & 2,41 \\
\hline & 0,6 & 2490,74 & 973,06 & 57,25 & 1124,36 & 1366,38 & 2,22 \\
\hline & 0,7 & 2206,71 & 970,01 & 57,08 & 1124,18 & 1082,53 & 1,96 \\
\hline & 0,8 & 2018,04 & 960,44 & 56,51 & 1123,62 & 894,42 & 1,80 \\
\hline \multirow{7}{*}{ 1-Ago } & 0,2 & 4407,49 & 1089,03 & 64,61 & 1131,71 & 3275,78 & 3,89 \\
\hline & 0,3 & 3903,67 & 1083,30 & 64,27 & 1131,37 & 2772,29 & 3,45 \\
\hline & 0,4 & 3648,19 & 1080,20 & 64,09 & 1131,19 & 2517,00 & 3,23 \\
\hline & 0,5 & 3214,79 & 1076,10 & 63,84 & 1130,95 & 2083,84 & 2,84 \\
\hline & $0 ; 6$ & 2907,21 & 1073,87 & 63,71 & 1130,82 & 1776,40 & 2,57 \\
\hline & 0,7 & 2666,74 & 1066,45 & 63,27 & 1130,37 & 1536,36 & 2,36 \\
\hline & $0 ; 8$ & 2359,76 & 1066,40 & 63,27 & 1130,37 & 1229,39 & 2,09 \\
\hline \multirow{7}{*}{ 15-Ago } & 0,2 & 4477,84 & 1138,01 & 67,52 & 1134,62 & 3343,22 & 3,95 \\
\hline & 0,3 & 3908,69 & 1134,49 & 67,31 & 1134,41 & 2774,27 & 3,45 \\
\hline & 0,4 & 3696,98 & 1129,02 & 66,98 & 1134,09 & 2562,89 & 3,26 \\
\hline & 0,5 & 3285,84 & 1126,59 & 66,84 & 1133,94 & 2151,90 & 2,90 \\
\hline & 0,6 & 2936,18 & 1139,81 & 67,62 & 1134,73 & 1801,45 & 2,59 \\
\hline & 0,7 & 2728,31 & 1114,93 & 66,15 & 1133,25 & 1595,05 & 2,41 \\
\hline & 0,8 & 2367,19 & 1120,20 & 66,46 & 1133,56 & 1233,62 & 2,09 \\
\hline
\end{tabular}


Tabela 14B. Receitas brutas, composição de custos da irrigação, receitas líquidas e relação beneficio/custo para a melancia, em cada época de semeadura, nivel de manejo da irrigação e risco de $35 \%$. Parnaiba, Piauí.

\begin{tabular}{|c|c|c|c|c|c|c|c|}
\hline $\begin{array}{l}\text { Época de } \\
\text { Semeadura }\end{array}$ & $\mathrm{p}$ & $\begin{array}{c}\mathrm{RB}^{\mathrm{l}} \\
\left(\mathrm{US} \$ \mathrm{ha}^{-1}\right)\end{array}$ & $\begin{array}{c}E b \\
\left(\mathrm{kWh} \mathrm{ha}{ }^{-1}\right)\end{array}$ & $\begin{array}{c}\mathrm{CE} \\
\left(\mathrm{US} \$ \mathrm{ha}^{-1}\right)\end{array}$ & $\begin{array}{c}\text { CT } \\
\left(\mathrm{US} \$ \mathrm{ha}^{-1}\right)\end{array}$ & $\begin{array}{c}\mathrm{RL} \\
\left(\mathrm{US} \$ \mathrm{ha}^{-1}\right)\end{array}$ & $\mathrm{B} / \mathrm{C}$ \\
\hline \multirow{7}{*}{ 1-Set } & 0,2 & 4239,10 & 1173,28 & 67,94 & 1135,05 & 3104,05 & 3,73 \\
\hline & 0,3 & 3656,85 & 1172,91 & 67,92 & 1135,02 & 2521,83 & 3,22 \\
\hline & 0,4 & 3485,22 & 1166,03 & 67,52 & 1134,63 & 2350,59 & 3,07 \\
\hline & 0,5 & 3161,62 & 1157,97 & 67,05 & 1134,16 & 2027,46 & 2,79 \\
\hline & 0,6 & 2757,56 & 1181,27 & 68,40 & 1135,51 & 1622,05 & 2,43 \\
\hline & 0,7 & 2593,75 & 1153,14 & 66,77 & 1133,88 & 1459,87 & 2,29 \\
\hline & 0,8 & 2267,11 & 1151,98 & 66,71 & 1133,81 & 1133,29 & 2,00 \\
\hline \multirow{7}{*}{ 15-Set } & 0,2 & 4239,68 & 1166,83 & 67,57 & 1134,67 & 3105,01 & 3,74 \\
\hline & 0,3 & 3663,97 & 1165,08 & 67,47 & 1134,57 & 2529,40 & 3,23 \\
\hline & 0,4 & 3483,31 & 1158,52 & 67,09 & 1134,19 & 2349,12 & 3,07 \\
\hline & 0,5 & 3157,32 & 1151,88 & 66,70 & 1133,81 & 2023,51 & 2,78 \\
\hline & 0,6 & 2773,63 & 1156,84 & 66,99 & 1134,09 & 1639,53 & 2,45 \\
\hline & 0,7 & 2587,65 & 1146,39 & 66,38 & 1133,49 & 1454,16 & 2,28 \\
\hline & 0,8 & 2274,71 & 1134,24 & 65,68 & 1132,78 & 1141,92 & 2,01 \\
\hline \multirow{7}{*}{ 1-Out } & 0,2 & 4324,28 & 1160,34 & 68,16 & 1135,26 & 3189,02 & 3,81 \\
\hline & 0,3 & 3748,61 & 1156,37 & 67,93 & 1135,03 & 2613,58 & 3,30 \\
\hline & 0,4 & 3562,60 & 1150,98 & 67,61 & 1134,71 & 2427,89 & 3,14 \\
\hline & 0,5 & 3232,02 & 1143,41 & 67,16 & 1134,27 & 2097,75 & 2,85 \\
\hline & 0,6 & 2820,70 & 1164,31 & 68,39 & 1135,50 & 1685,21 & 2,48 \\
\hline & 0,7 & 2650,41 & 1137,76 & 66,83 & 1133,94 & 1516,47 & 2,34 \\
\hline & 0,8 & 2320,80 & 1134,49 & 66,64 & 1133,74 & 1187,06 & 2,05 \\
\hline \multirow{7}{*}{ 15-Out } & 0,2 & 4292,80 & 1132,85 & 66,54 & 1133,65 & 3159,15 & 3,79 \\
\hline & 0,3 & 3753,16 & 1127,63 & 66,24 & 1133,34 & 2619,82 & 3,31 \\
\hline & 0,4 & 3547,96 & 1123,55 & 66,00 & 1133,10 & 2414,86 & 3,13 \\
\hline & 0,5 & 3165,95 & 1114,62 & 65,47 & 1132,58 & 2033,37 & 2,80 \\
\hline & 0,6 & 2822,56 & 1116,22 & 65,57 & 1132,67 & 1689,89 & 2,49 \\
\hline & 0,7 & 2629,61 & 1102,37 & 64,75 & 1131,86 & 1497,75 & 2,32 \\
\hline & 0,8 & 2300,22 & 1103,05 & 64,79 & 1131,90 & 1168,32 & 2,03 \\
\hline
\end{tabular}


Tabela 14B. Receitas brutas, composição de custos da irrigação, receitas líquidas e relação benefício/custo para a melancia, em cada época de semeadura, nível de manejo da irrigação e risco de $35 \%$. Parnaíba, Piauí.

\begin{tabular}{|c|c|c|c|c|c|c|c|}
\hline $\begin{array}{c}\text { Época de } \\
\text { Semeadura }\end{array}$ & $\mathrm{p}$ & $\begin{array}{c}\mathrm{RB}^{1} \\
\left(\mathrm{US} \$ \mathrm{ha}^{-1}\right)\end{array}$ & $\begin{array}{c}E b \\
\left(\mathrm{kWh} \mathrm{ha}^{-1}\right)\end{array}$ & $\begin{array}{c}\text { CE } \\
\left(\text { US } \$ \mathrm{ha}^{-1}\right)\end{array}$ & $\begin{array}{c}\text { CT } \\
\left(\mathrm{US} \$ \mathrm{ha}^{-1}\right)\end{array}$ & $\begin{array}{c}\mathrm{RL} \\
\left(\mathrm{US} \$ \mathrm{ha}^{-1}\right)\end{array}$ & $\mathrm{B} / \mathrm{C}$ \\
\hline \multirow{7}{*}{ 1-Nov } & 0,2 & 4632,89 & 1024,78 & 60,60 & 1127,70 & 3505,19 & 4,11 \\
\hline & 0,3 & 4175,80 & 1017,46 & 60,16 & 1127,27 & 3048,53 & 3,70 \\
\hline & 0,4 & 3868,99 & 1003,01 & 59,31 & 1126,41 & 2742,57 & 3,43 \\
\hline & 0,5 & 3452,32 & 998,86 & 59,06 & 1126,17 & 2326,15 & 3,07 \\
\hline & 0,6 & 3137,39 & 991,05 & 58,60 & 1125,71 & 2011,68 & 2,79 \\
\hline & 0,7 & 2844,34 & 979,17 & 57,90 & 1125,00 & 1719,33 & 2,53 \\
\hline & 0,8 & 2564,63 & 972,04 & 57,48 & 1124,58 & 1440,05 & 2,28 \\
\hline \multirow{7}{*}{$15-\mathrm{Nov}$} & 0,2 & 4564,05 & 911,90 & 53,92 & 1121,03 & 3443,02 & 4,07 \\
\hline & 0,3 & 4159,74 & 898,03 & 53,10 & 1120,21 & 3039,54 & 3,71 \\
\hline & 0,4 & 3832,65 & 885,68 & 52,37 & 1119,48 & 2713,17 & 3,42 \\
\hline & 0,5 & 3420,59 & 869,56 & 51,42 & 1118,52 & 2302,07 & 3,06 \\
\hline & 0,6 & 3134,17 & 850,36 & 50,28 & 1117,39 & 2016,78 & 2,80 \\
\hline & 0,7 & 2836,16 & 844,44 & 49,93 & 1117,04 & 1719,12 & 2,54 \\
\hline & 0,8 & 2584,66 & 832,04 & 49,20 & 1116,30 & 1468,36 & 2,32 \\
\hline \multirow{7}{*}{ 1-Dez } & 0,2 & 4815,49 & 830,64 & 48,14 & 1115,24 & 3700,25 & 4,32 \\
\hline & 0,3 & 4434,36 & 812,52 & 47,09 & 1114,19 & 3320,17 & 3,98 \\
\hline & 0,4 & 4048,58 & 801,20 & 46,43 & 1113,53 & 2935,04 & 3,64 \\
\hline & 0,5 & 3642,67 & 776,24 & 44,98 & 1112,09 & 2530,58 & 3,28 \\
\hline & 0,6 & 3333,40 & 761,84 & 44,15 & 1111,25 & 2222,15 & 3,00 \\
\hline & 0,7 & 3047,47 & 744,46 & 43,14 & 1110,25 & 1937,23 & 2,74 \\
\hline & 0,8 & 2775,16 & 735,48 & 42,62 & 1109,73 & 1665,43 & 2,50 \\
\hline \multirow{7}{*}{ 15-Dez } & 0,2 & 4764,02 & 717,24 & 41,56 & 1108,67 & 3655,35 & 4,30 \\
\hline & 0,3 & 4415,69 & 692,64 & 40,14 & 1107,24 & 3308,44 & 3,99 \\
\hline & 0,4 & 4012,15 & 669,10 & 38,77 & 1105,88 & 2906,27 & 3,63 \\
\hline & 0,5 & 3659,76 & 648,71 & 37,59 & 1104,70 & 2555,06 & 3,31 \\
\hline & 0,6 & 3349,06 & 628,00 & 36,39 & 1103,50 & 2245,57 & 3,03 \\
\hline & 0,7 & 3082,36 & 607,86 & 35,23 & 1102,33 & 1980,03 & 2,80 \\
\hline & 0,8 & 2840,51 & 587,87 & 34,07 & 1101,17 & 1739,34 & 2,58 \\
\hline
\end{tabular}

${ }^{T} \mathrm{RB}$ - receita bruta; $\mathrm{Eb}$ - energia requerida para o bombeamento; $\mathrm{CE}$ - custo de energia elétrica; $\mathrm{CT}$ - custo total de produção; RL - receita líquida e B/C - relação benefício/custo. 
Tabela 15B. Receitas brutas, composição de custos da irrigação. receitas liquidas e relação beneficio/custo para a melancia, em cada época de semeadura, nível de manejo da irrigação e risco de $40 \%$. Parnaíba, Piauí.

\begin{tabular}{|c|c|c|c|c|c|c|c|}
\hline $\begin{array}{c}\text { Época de } \\
\text { Semeadura }\end{array}$ & $\mathrm{p}$ & $\begin{array}{c}\mathrm{RB}^{\mathrm{I}} \\
\left(\mathrm{US} \$ \mathrm{ha}^{-1}\right)\end{array}$ & $\begin{array}{c}\mathrm{Eb} \\
\left(\mathrm{kWh} \mathrm{ha}{ }^{-1}\right)\end{array}$ & $\begin{array}{c}\text { CE } \\
\left(\mathrm{US} \$ \mathrm{ha}^{-1}\right)\end{array}$ & $\begin{array}{c}\mathrm{CT} \\
\left(\mathrm{US} \$ \mathrm{ha}^{-1}\right)\end{array}$ & $\begin{array}{c}\mathrm{RL} \\
\left(\mathrm{US} \$ \mathrm{ha}^{-1}\right)\end{array}$ & $\mathrm{B} / \mathrm{C}$ \\
\hline \multirow{7}{*}{ 1-Jan } & 0,2 & 4888,05 & 604,01 & 34,21 & 1101,31 & 3786,74 & 4,44 \\
\hline & 0,3 & 4565,44 & 583,06 & 33,02 & 1100,12 & 3465,32 & 4,15 \\
\hline & 0,4 & 4166,70 & 551,04 & 31,21 & 1098,31 & 3068,39 & 3,79 \\
\hline & 0,5 & 3851,83 & 530,09 & 30,02 & 1097,12 & 2754,71 & 3,51 \\
\hline & 0,6 & 3540,50 & 496,63 & 28,12 & 1095,23 & 2445,28 & 3,23 \\
\hline & 0,7 & 3293,71 & 472,67 & 26,77 & 1093,87 & 2199,83 & 3,01 \\
\hline & 0,8 & 3057,60 & 442,37 & 25,05 & 1092,16 & 1965,45 & 2,80 \\
\hline \multirow{7}{*}{ 15-Jan } & 0,2 & 4975,30 & 547,77 & 31,02 & 1098,13 & 3877,17 & 4,53 \\
\hline & 0,3 & 4660,71 & 517,86 & 29,33 & 1096,43 & 3564,28 & 4,25 \\
\hline & 0,4 & 4236,51 & 479,71 & 27,17 & 1094,27 & 3142,24 & 3,87 \\
\hline & 0,5 & 3952,19 & 454,65 & 25,75 & 1092,85 & 2859,33 & 3,62 \\
\hline & 0,6 & 3648,30 & 419,95 & 23,78 & 1090,89 & 2557,41 & 3,34 \\
\hline & 0,7 & 3435,79 & 397,38 & 22,50 & 1089,61 & 2346,18 & 3,15 \\
\hline & 0,8 & 3218,94 & 374,41 & 21,20 & 1088,31 & 2130,64 & 2,96 \\
\hline \multirow{7}{*}{$1-\mathrm{Fev}$} & 0,2 & 5091,06 & 495,65 & 27,53 & 1094,63 & 3996,43 & 4,65 \\
\hline & 0,3 & 4780,30 & 462,26 & 25,67 & 1092,78 & 3687,53 & 4,37 \\
\hline & 0,4 & 4355,23 & 414,68 & 23,03 & 1090,13 & 3265,10 & 4,00 \\
\hline & 0,5 & 4090,31 & 390,74 & 21,70 & 1088,80 & 3001,51 & 3,76 \\
\hline & 0,6 & 3815,00 & 367,78 & 20,42 & 1087,53 & 2727,47 & 3,51 \\
\hline & 0,7 & 3577,93 & 337,49 & 18,74 & 1085,85 & 2492,08 & 3,30 \\
\hline & 0,8 & 3364,90 & 314,74 & 17,48 & 1084,58 & 2280,32 & 3,10 \\
\hline \multirow{7}{*}{$15-\mathrm{Fev}$} & 0,2 & 5074,19 & 448,97 & 24,93 & 1092,04 & 3982,15 & 4,65 \\
\hline & 0,3 & 4754,54 & 413,63 & 22,97 & 1090,08 & 3664,47 & 4,36 \\
\hline & 0,4 & 4377,01 & 381,09 & 21,16 & 1088,27 & 3288,74 & 4,02 \\
\hline & 0,5 & 4076,94 & 342,01 & 18,99 & 1086,10 & 2990,84 & 3,75 \\
\hline & 0,6 & 3843,01 & 308,84 & 17,15 & 1084,26 & 2758,75 & 3,54 \\
\hline & 0,7 & 3616,84 & 282,77 & 15,70 & 1082,81 & 2534,03 & 3,34 \\
\hline & 0,8 & 3429,06 & 260,26 & 14,45 & 1081,56 & 2347,50 & 3,17 \\
\hline
\end{tabular}


Tabela 15B. Receitas brutas, composição de custos da irrigação, receitas líquidas e relação benefício/custo para a melancia, em cada época de semeadura, nível de manejo da irrigação e risco de $40 \%$. Parnaíba, Piauí.

\begin{tabular}{|c|c|c|c|c|c|c|c|}
\hline $\begin{array}{l}\text { Época de } \\
\text { Semeadura }\end{array}$ & $\mathrm{p}$ & $\begin{array}{c}\mathrm{RB}^{\mathrm{l}} \\
\left(\mathrm{US} \$ \mathrm{ha}^{-1}\right)\end{array}$ & $\begin{array}{c}\mathrm{Eb} \\
\left(\mathrm{kWh} \mathrm{ha}^{-1}\right)\end{array}$ & $\begin{array}{c}\text { CE } \\
\left(\mathrm{US} \$ \mathrm{ha}^{-1}\right)\end{array}$ & $\begin{array}{c}\mathrm{CT} \\
\left(\mathrm{US} \$ \mathrm{ha}^{-1}\right)\end{array}$ & $\begin{array}{c}\text { RL } \\
\left(\mathrm{US} \$ \mathrm{ha}^{-1}\right)\end{array}$ & $\mathrm{B} / \mathrm{C}$ \\
\hline \multirow{7}{*}{ 1-Mar } & 0,2 & 5180,30 & 434,65 & 23,73 & 1090,83 & 4089,47 & 4,75 \\
\hline & 0,3 & 4851,76 & 396,63 & 21,65 & 1088,75 & 3763,00 & 4,46 \\
\hline & 0,4 & 4455,32 & 356,10 & 19,44 & 1086,54 & 3368,78 & 4,10 \\
\hline & 0,5 & 4168,17 & 326,79 & 17,84 & 1084,94 & 3083,22 & 3,84 \\
\hline & 0,6 & 3907,70 & 287,44 & 15,69 & 1082,79 & 2824,90 & 3,61 \\
\hline & 0,7 & 3679,23 & 259,00 & 14,14 & 1081,24 & 2597,98 & 3,40 \\
\hline & 0,8 & 3511,56 & 232,40 & 12,69 & 1079,79 & 2431,77 & 3,25 \\
\hline \multirow{7}{*}{ 15-Mar } & 0,2 & 5138,49 & 454,44 & 24,81 & 1091,91 & 4046,58 & 4,71 \\
\hline & 0,3 & 4793,42 & 418,53 & 22,85 & 1089,95 & 3703,47 & 4,40 \\
\hline & 0,4 & 4390,59 & 377,24 & 20,59 & 1087,70 & 3302,90 & 4,04 \\
\hline & 0,5 & 4099,57 & 350,72 & 19,14 & 1086,25 & 3013,33 & 3,77 \\
\hline & 0,6 & 3809,54 & 315,14 & 17,20 & 1084,31 & 2725,23 & 3,51 \\
\hline & 0,7 & 3585,53 & 291,40 & 15,91 & 1083,01 & 2502,52 & 3,31 \\
\hline & 0,8 & 3383,61 & 249,38 & 13,61 & 1080,72 & 2302,89 & 3,13 \\
\hline \multirow{7}{*}{$1-A b r$} & 0,2 & 5012,20 & 523,38 & 26,99 & 1094,09 & 3918,10 & 4,58 \\
\hline & 0,3 & 4670,61 & 498,51 & 25,71 & 1092,81 & 3577,79 & 4,27 \\
\hline & 0,4 & 4217,06 & 461,35 & 23,79 & 1090,90 & 3126,17 & 3,87 \\
\hline & 0,5 & 3887,55 & 433,64 & 22,36 & 1089,47 & 2798,08 & 3,57 \\
\hline & 0,6 & 3596,46 & 411,54 & 21,22 & 1088,33 & 2508,14 & 3,30 \\
\hline & 0,7 & 3333,22 & 378,05 & 19,50 & 1086,60 & 2246,62 & 3,07 \\
\hline & 0,8 & 3123,86 & 362,29 & 18,68 & 1085,79 & 2038,08 & 2,88 \\
\hline \multirow{7}{*}{$15-\mathrm{Abr}$} & 0,2 & 4984,62 & 580,90 & 29,96 & 1097,06 & 3887,56 & 4,54 \\
\hline & 0,3 & 4628,71 & 559,80 & 28,87 & 1095,97 & 3532,73 & 4,22 \\
\hline & 0,4 & 4149,87 & 525,69 & 27,11 & 1094,21 & 3055,65 & 3,79 \\
\hline & 0,5 & 3813,08 & 505,76 & 26,08 & 1093,19 & 2719,89 & 3,49 \\
\hline & 0,6 & 3490,78 & 474,95 & 24,49 & 1091,60 & 2399,19 & 3,20 \\
\hline & 0,7 & 3096,77 & 451,50 & 23,28 & 1090,39 & 2006,38 & 2,84 \\
\hline & 0,8 & 2989,27 & 433,50 & 22,35 & 1089,46 & 1899,81 & 2,74 \\
\hline
\end{tabular}


Tabela 15B. Receitas brutas, composição de custos da irrigação, receitas liquidas e relação benefício/custo para a melancia, em cada época de semeadura, nivel de manejo da irrigação e risco de $40 \%$. Parnaiba, Piauí.

\begin{tabular}{|c|c|c|c|c|c|c|c|}
\hline $\begin{array}{l}\text { Época de } \\
\text { Semeadura }\end{array}$ & $\mathrm{p}$ & $\begin{array}{c}\mathrm{RB}^{1} \\
\left(\mathrm{US} \$ \mathrm{ha}^{-1}\right)\end{array}$ & $\begin{array}{c}E b \\
\left(\mathrm{kWh} \mathrm{ha}^{-1}\right)\end{array}$ & $\begin{array}{c}\text { CE } \\
\left(\text { US } \$ h a^{-1}\right)\end{array}$ & $\begin{array}{c}\mathrm{CT} \\
\left(\mathrm{US} \$ \mathrm{ha}^{-1}\right)\end{array}$ & $\begin{array}{c}\mathrm{RL} \\
\left(\mathrm{US} \$ \mathrm{ha}^{-1}\right)\end{array}$ & $\mathrm{B} / \mathrm{C}$ \\
\hline \multirow{7}{*}{ 1-Mai } & 0,2 & 3962,42 & 668,56 & 34,59 & 1101,70 & 2860,73 & 3,60 \\
\hline & 0,3 & 3680,41 & 652,72 & 33,77 & 1100,88 & 2579,54 & 3,34 \\
\hline & 0,4 & 3256,18 & 626,33 & 32,41 & 1099,51 & 2156,67 & 2,96 \\
\hline & 0,5 & 2972,11 & 614,00 & 31,77 & 1098,87 & 1873,23 & 2,70 \\
\hline & 0,6 & 2698,98 & 595,41 & 30,81 & 1097,91 & 1601,06 & 2,46 \\
\hline & 0,7 & 2454,84 & 581,70 & 30,10 & 1097,20 & 1357,63 & 2,24 \\
\hline & 0,8 & 2253,46 & 563,83 & 29,17 & 1096,28 & 1157,18 & 2,06 \\
\hline \multirow{7}{*}{ 15-Mai } & 0,2 & 3961,61 & 700,39 & 36,24 & 1103,34 & 2858,26 & 3,59 \\
\hline & 0,3 & 3689,79 & 687,01 & 35,55 & 1102,65 & 2587,14 & 3,35 \\
\hline & 0,4 & 3256,02 & 669,81 & 34,66 & 1101,76 & 2154,26 & 2,96 \\
\hline & 0,5 & 2980,89 & 660,00 & 34,15 & 1101,25 & 1879,64 & 2,71 \\
\hline & 0,6 & 2672,22 & 641,66 & 33,20 & 1100,31 & 1571,91 & 2,43 \\
\hline & 0,7 & 2454,61 & 633,37 & 32,77 & 1099,88 & 1354,73 & 2,23 \\
\hline & 0,8 & 2230,33 & 614,74 & 31,81 & 1098,91 & 1131,42 & 2,03 \\
\hline \multirow{7}{*}{ 1-Jun } & 0,2 & 4216,35 & 763,07 & 42,11 & 1109,22 & 3107,13 & 3,80 \\
\hline & 0,3 & 3928,33 & 751,61 & 41,48 & 1108,58 & 2819,74 & 3,54 \\
\hline & 0,4 & 3455,38 & 741,60 & 40,93 & 1108,03 & 2347,35 & 3,12 \\
\hline & 0,5 & 3171,19 & 728,04 & 40,18 & 1107,28 & 2063,91 & 2,86 \\
\hline & 0,6 & 2807,92 & 714,68 & 39,44 & 1106,54 & 1701,37 & 2,54 \\
\hline & 0,7 & 2595,46 & 710,57 & 39,21 & 1106,32 & 1489,14 & 2,35 \\
\hline & 0,8 & 2323,08 & 699,90 & 38,62 & 1105,73 & 1217,35 & 2,10 \\
\hline \multirow{7}{*}{ 15-Jun } & 0,2 & 4273,01 & 833,95 & 46,02 & 1113,13 & 3159,89 & 3,84 \\
\hline & 0,3 & 3964,22 & 825,91 & 45,58 & 1112,68 & 2851,54 & 3,56 \\
\hline & 0,4 & 3517,31 & 812,80 & 44,85 & 1111,96 & 2405,35 & 3,16 \\
\hline & 0,5 & 3199,28 & 804,72 & 44,41 & 1111,51 & 2087,76 & 2,88 \\
\hline & 0,6 & 2861,83 & 796,96 & 43,98 & 1111,09 & 1750,74 & 2,58 \\
\hline & 0,7 & 2605,72 & 795,99 & 43,93 & 1111,03 & 1494,69 & 2,35 \\
\hline & 0,8 & 2347,13 & 782,75 & 43,20 & 1110,30 & 1236,83 & 2,11 \\
\hline
\end{tabular}


428

Tabela 15B. Receitas brutas, composição de custos da irrigação, receitas líquidas e relação benefício/custo para a melancia, em cada época de semeadura, nível de manejo da irrigação e risco de $40 \%$. Parnaíba, Piauí.

\begin{tabular}{|c|c|c|c|c|c|c|c|}
\hline $\begin{array}{l}\text { Época de } \\
\text { Semeadura }\end{array}$ & $\mathrm{p}$ & $\begin{array}{c}\mathrm{RB}^{1} \\
\left(\mathrm{US} \$ \mathrm{ha}^{-1}\right)\end{array}$ & $\begin{array}{c}\mathrm{Eb} \\
\left(\mathrm{kWh} \mathrm{ha}^{-1}\right)\end{array}$ & $\begin{array}{c}\text { CE } \\
\left(\mathrm{US} \$ \mathrm{ha}^{-1}\right)\end{array}$ & $\begin{array}{c}\text { CT } \\
\left(\mathrm{US} \$ \mathrm{ha}^{-1}\right)\end{array}$ & $\begin{array}{c}\mathrm{RL} \\
\left(\mathrm{US} \$ \mathrm{ha}^{-1}\right)\end{array}$ & $\mathrm{B} / \mathrm{C}$ \\
\hline \multirow{7}{*}{ 1-Jul } & 0,2 & 3659,96 & 913,38 & 53,02 & 1120,12 & 2539,83 & 3,27 \\
\hline & 0,3 & 3358,96 & 903,50 & 52,45 & 1119,55 & 2239,41 & 3,00 \\
\hline & 0,4 & 3038,76 & 897,63 & 52,11 & 1119,21 & 1919,55 & 2,72 \\
\hline & 0,5 & 2702,33 & 889,41 & 51,63 & 1118,73 & 1583,60 & 2,42 \\
\hline & 0,6 & 2458,04 & 886,95 & 51,48 & 1118,59 & 1339,45 & 2,20 \\
\hline & 0,7 & 2201,78 & 876,75 & 50,89 & 1118,00 & 1083,78 & 1,97 \\
\hline & 0,8 & 2010,75 & 875,30 & 50,81 & 1117,91 & 892,84 & 1,80 \\
\hline \multirow{7}{*}{ 15-Jul } & 0,2 & 3732,07 & 991,52 & 57,55 & 1124,66 & 2607,41 & 3,32 \\
\hline & 0,3 & 3386,60 & 983,00 & 57,06 & 1124,17 & 2262,43 & 3,01 \\
\hline & 0,4 & 3120,42 & 977,30 & 56,73 & 1123,83 & 1996,59 & 2,78 \\
\hline & 0,5 & 2740,79 & 975,62 & 56,63 & 1123,74 & 1617,05 & 2,44 \\
\hline & 0,6 & 2523,39 & 967,31 & 56,15 & 1123,25 & 1400,13 & 2,25 \\
\hline & 0,7 & 2236,45 & 964,66 & 56,00 & 1123,10 & 1113,35 & 1,99 \\
\hline & 0,8 & 2044,85 & 955,41 & 55,46 & 1122,56 & 922,29 & 1,82 \\
\hline \multirow{7}{*}{ 1-Ago } & 0,2 & 4457,48 & 1086,90 & 63,60 & 1130,71 & 3326,77 & 3,94 \\
\hline & 0,3 & 3945,05 & 1081,10 & 63,26 & 1130,37 & 2814,69 & 3,49 \\
\hline & 0,4 & 3690,50 & 1077,85 & 63,07 & 1130,18 & 2560,32 & 3,27 \\
\hline & 0,5 & 3254,17 & 1073,37 & 62,81 & 1129,91 & 2124,25 & 2,88 \\
\hline & 0,6 & 2942,75 & 1069,14 & 62,56 & 1129,67 & 1813,09 & 2,60 \\
\hline & 0,7 & 2701,29 & 1063,37 & 62,22 & 1129,33 & 1571,96 & 2,39 \\
\hline & 0,8 & 2389,21 & 1063,23 & 62,22 & 1129,32 & 1259,89 & 2,12 \\
\hline \multirow{7}{*}{ 15-Ago } & 0,2 & 4527,70 & 1135,99 & 66,47 & 1133,58 & 3394,12 & 3,99 \\
\hline & 0,3 & 3950,54 & 1132,42 & 66,27 & 1133,37 & 2817,17 & 3,49 \\
\hline & 0,4 & 3738,75 & 1126,84 & 65,94 & 1133,04 & 2605,71 & 3,30 \\
\hline & 0,5 & 3328,40 & 1124,01 & 65,77 & 1132,88 & 2195,52 & 2,94 \\
\hline & 0,6 & 2970,48 & 1101,94 & 64,48 & 1131,59 & 1838,89 & 2,63 \\
\hline & 0,7 & 2762,71 & 1111,88 & 65,06 & 1132,17 & 1630,54 & 2,44 \\
\hline & 0,8 & 2390,72 & 1116,26 & 65,32 & 1132,42 & 1258,29 & 2,11 \\
\hline
\end{tabular}


Tabela 15B. Receitas brutas, composição de custos da irrigação, receitas líquidas e relação benefício/custo para a melancia, em cada época de semeadura, nível de manejo da irrigação e risco de $40 \%$. Parnaiba, Piauí.

\begin{tabular}{|c|c|c|c|c|c|c|c|}
\hline $\begin{array}{l}\text { Época de } \\
\text { Semeadura }\end{array}$ & $\mathrm{p}$ & $\begin{array}{c}\mathrm{RB}^{\mathrm{I}} \\
\left(\mathrm{US} \$ \mathrm{ha}^{-1}\right)\end{array}$ & 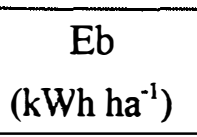 & $\begin{array}{c}C E \\
\left.\left(\text { US } \$ h^{-1}\right)^{-1}\right)\end{array}$ & $\begin{array}{c}\text { CT } \\
\left(\mathrm{US} \$ \mathrm{ha}^{-1}\right) \\
\end{array}$ & $\begin{array}{c}\mathrm{RL} \\
\left(\mathrm{US} \$ \mathrm{ha}^{-1}\right) \\
\end{array}$ & $\mathrm{B} / \mathrm{C}$ \\
\hline \multirow{7}{*}{$1-$ Set } & 0,2 & 4272,87 & 1171,69 & 67,08 & 1134,18 & 3138,69 & 3,77 \\
\hline & 0,3 & 3684,63 & 1171,02 & 67,04 & 1134,14 & 2550,49 & 3,25 \\
\hline & 0,4 & 3512,87 & 1163,94 & 66,63 & 1133,74 & 2379,13 & 3,10 \\
\hline & 0,5 & 3191,82 & 1155,82 & 66,17 & 1133,27 & 2058,55 & 2,82 \\
\hline & 0,6 & 2781,03 & 1137,54 & 65,12 & 1132,23 & 1648,80 & 2,46 \\
\hline & 0,7 & 2618,76 & 1150,05 & 65,84 & 1132,94 & 1485,82 & 2,31 \\
\hline & 0,8 & 2289,61 & 1148,31 & 65,74 & 1132,84 & 1156,76 & 2,02 \\
\hline \multirow{7}{*}{ 15-Set } & 0,2 & 4273,41 & 1164,54 & 66,67 & 1133,77 & 3139,64 & 3,77 \\
\hline & 0,3 & 3692,19 & 1162,54 & 66,55 & 1133,66 & 2558,53 & 3,26 \\
\hline & 0,4 & 3512,27 & 1156,09 & 66,18 & 1133,29 & 2378,98 & 3,10 \\
\hline & 0,5 & 3187,93 & 1149,20 & 65,79 & 1132,89 & 2055,03 & 2,81 \\
\hline & 0,6 & 2797,76 & 1151,85 & 65,94 & 1133,05 & 1664,72 & 2,47 \\
\hline & 0,7 & 2613,43 & 1142,60 & 65,41 & 1132,52 & 1480,92 & 2,31 \\
\hline & 0,8 & 2297,18 & 1131,20 & 64,76 & 1131,86 & 1165,32 & 2,03 \\
\hline \multirow{7}{*}{ 1-Out } & 0,2 & 4357,92 & 1157,52 & 67,19 & 1134,30 & 3223,62 & 3,84 \\
\hline & 0,3 & 3776,36 & 1153,25 & 66,94 & 1134,05 & 2642,31 & 3,33 \\
\hline & 0,4 & 3591,19 & 1147,41 & 66,60 & 1133,71 & 2457,48 & 3,17 \\
\hline & 0,5 & 3261,78 & 1139,81 & 66,16 & 1133,27 & 2128,51 & 2,88 \\
\hline & 0,6 & 2845,77 & 1126,54 & 65,39 & 1132,50 & 1713,27 & 2,51 \\
\hline & 0,7 & 2675,43 & 1133,40 & 65,79 & 1132,90 & 1542,54 & 2,36 \\
\hline & 0,8 & 2343,07 & 1129,22 & 65,55 & 1132,65 & 1210,42 & 2,07 \\
\hline \multirow{7}{*}{ 15-Out } & 0,2 & 4326,90 & 1129,54 & 65,57 & 1132,67 & 3194,23 & 3,82 \\
\hline & 0,3 & 3780,80 & 1124,10 & 65,25 & 1132,36 & 2648,44 & 3,34 \\
\hline & 0,4 & 3577,16 & 1119,95 & 65,01 & 1132,12 & 2445,04 & 3,16 \\
\hline & 0,5 & 3196,19 & 1110,87 & 64,48 & 1131,59 & 2064,60 & 2,82 \\
\hline & 0,6 & 2846,98 & 1110,15 & 64,44 & 1131,55 & 1715,43 & 2,52 \\
\hline & 0,7 & 2654,00 & 1097,60 & 63,71 & 1130,82 & 1523,18 & 2,35 \\
\hline & 0,8 & 2322,07 & 1097,18 & 63,69 & 1130,79 & 1191,27 & 2,05 \\
\hline
\end{tabular}


Tabela 15B. Receitas brutas, composição de custos da irrigação, receitas líquidas e relação benefício/custo para a melancia, em cada época de semeadura, nível de manejo da irrigação e risco de $40 \%$. Parnaiba, Piauí.

\begin{tabular}{|c|c|c|c|c|c|c|c|}
\hline $\begin{array}{c}\text { Época de } \\
\text { Semeadura }\end{array}$ & $\mathrm{p}$ & $\begin{array}{c}\mathrm{RB}^{1} \\
\left(\mathrm{US} \$ \mathrm{ha}^{-1}\right)\end{array}$ & $\begin{array}{c}\text { Eb } \\
\left(\mathrm{kWh} h \mathrm{a}^{-1}\right)\end{array}$ & $\begin{array}{c}\text { CE } \\
\left.\left(\text { US } \$ h^{-1}\right)^{-1}\right)\end{array}$ & $\begin{array}{c}C T \\
\left(\mathrm{US} \$ \mathrm{ha}^{-1}\right) \\
\end{array}$ & $\begin{array}{c}\mathrm{RL} \\
\left(\mathrm{US} \$ \mathrm{ha}^{-1}\right)\end{array}$ & $\mathrm{B} / \mathrm{C}$ \\
\hline \multirow{7}{*}{$1-\mathrm{Nov}$} & 0,2 & 4672,83 & 1019,15 & 59,62 & 1126,72 & 3546,11 & 4,15 \\
\hline & 0,3 & 4209,73 & 1011,09 & 59,15 & 1126,25 & 3083,48 & 3,74 \\
\hline & 0,4 & 3904,75 & 996,22 & 58,28 & 1125,38 & 2779,36 & 3,47 \\
\hline & 0,5 & 3485,09 & 991,54 & 58,00 & 1125,11 & 2359,98 & 3,10 \\
\hline & 0,6 & 3168,80 & 981,96 & 57,44 & 1124,55 & 2044,25 & 2,82 \\
\hline & 0,7 & 2874,53 & 970,79 & 56,79 & 1123,90 & 1750,64 & 2,56 \\
\hline & 0,8 & 2593,21 & 962,54 & 56,31 & 1123,41 & 1469,79 & 2,31 \\
\hline \multirow{7}{*}{ 15-Nov } & 0,2 & 4602,68 & 905,23 & 52,96 & 1120,06 & 3482,62 & 4,11 \\
\hline & 0,3 & 4194,93 & 890,36 & 52,09 & 1119,19 & 3075,74 & 3,75 \\
\hline & 0,4 & 3870,11 & 877,70 & 51,34 & 1118,45 & 2751,66 & 3,46 \\
\hline & 0,5 & 3455,46 & 861,18 & 50,38 & 1117,48 & 2337,98 & 3,09 \\
\hline & 0,6 & 3168,79 & 840,64 & 49,18 & 1116,28 & 2052,50 & 2,84 \\
\hline & 0,7 & 2870,15 & 833,96 & 48,79 & 1115,89 & 1754,25 & 2,57 \\
\hline & 0,8 & 2617,96 & 820,13 & 47,98 & 1115,08 & 1502,88 & 2,35 \\
\hline \multirow{7}{*}{ 1-Dez } & 0,2 & 4918,41 & 824,00 & 47,20 & 1114,30 & 3804,11 & 4,41 \\
\hline & 0,3 & 4528,01 & 805,33 & 46,13 & 1113,23 & 3414,78 & 4,07 \\
\hline & 0,4 & 4139,57 & 792,70 & 45,40 & 1112,51 & 3027,06 & 3,72 \\
\hline & 0,5 & 3726,58 & 767,01 & 43,93 & 1111,04 & 2615,55 & 3,35 \\
\hline & 0,6 & 3414,42 & 751,58 & 43,05 & 1110,15 & 2304,26 & 3,08 \\
\hline & 0,7 & 3122,77 & 734,12 & 42,05 & 1109,15 & 2013,62 & 2,82 \\
\hline & 0,8 & 2848,34 & 724,05 & 41,47 & 1108,58 & 1739,76 & 2,57 \\
\hline \multirow{7}{*}{ 15-Dez } & 0,2 & 4864,53 & 708,80 & 40,60 & 1107,70 & 3756,83 & 4,39 \\
\hline & 0,3 & 4511,47 & 683,36 & 39,14 & 1106,24 & 3405,23 & 4,08 \\
\hline & 0,4 & 4102,75 & 658,18 & 37,70 & 1104,80 & 2997,95 & 3,71 \\
\hline & 0,5 & 3747,87 & 637,12 & 36,49 & 1103,60 & 2644,27 & 3,40 \\
\hline & 0,6 & 3434,13 & 616,08 & 35,29 & 1102,39 & 2331,74 & 3,12 \\
\hline & 0,7 & 3161,99 & 594,39 & 34,04 & 1101,15 & 2060,84 & 2,87 \\
\hline & 0,8 & 2918,45 & 574,62 & 32,91 & 1100,02 & 1818,44 & 2,65 \\
\hline
\end{tabular}

${ }^{T} \mathrm{RB}$ - receita bruta; $\mathrm{Eb}$ - energia requerida para o bombeamento; $\mathrm{CE}$ - custo de energia elétrica: $\mathrm{CT}$ - custo total de produção; RL - receita líquida e B/C - relação benefício/custo. 
Tabela 16B. Receitas brutas, composição de custos da irrigação, receitas líquidas e relação benefício/custo para o feijão caupi, em cada época de semeadura, nível de manejo da irrigação e risco de $5 \%$. Teresina, Piaú.

\begin{tabular}{|c|c|c|c|c|c|c|c|}
\hline $\begin{array}{l}\text { Época de } \\
\text { Semeadura }\end{array}$ & $p$ & $\begin{array}{c}\mathrm{RB}^{\mathrm{I}} \\
\left(\mathrm{US} \$ \mathrm{ha}^{-1}\right)\end{array}$ & $\begin{array}{c}E b \\
\left(\mathrm{kWh} h \mathrm{a}^{-1}\right)\end{array}$ & $\begin{array}{c}\text { CE } \\
\left(\mathrm{US} \$ \mathrm{ha}^{-1}\right)\end{array}$ & $\begin{array}{c}\text { CT } \\
\left(\mathrm{US} \$ \mathrm{ha}^{-1}\right)\end{array}$ & $\begin{array}{c}\mathrm{RL} \\
\left(\mathrm{US} \$ \mathrm{ha}^{-1}\right)\end{array}$ & $\mathrm{B} / \mathrm{C}$ \\
\hline \multirow{7}{*}{ 1-Jan } & 0,2 & 1013,83 & 478,27 & 31,12 & 748,71 & 265,12 & 1,35 \\
\hline & 0,3 & 951,94 & 452,99 & 29,48 & 747,06 & 204,87 & 1,27 \\
\hline & 0,4 & 893,56 & 431,68 & 28,09 & 745,68 & 147,89 & 1,20 \\
\hline & 0,5 & 830,42 & 400,73 & 26,08 & 743,66 & 86,76 & 1,12 \\
\hline & 0,6 & 792,90 & 362,69 & 23,60 & 741,19 & 51,71 & 1,07 \\
\hline & 0,7 & 743,42 & 331,69 & 21,59 & 739,17 & 4,25 & 1,01 \\
\hline & 0,8 & 703,60 & 324,69 & 21,13 & 738,71 & $-35,12$ & 0,95 \\
\hline \multirow{7}{*}{ 15-Jan } & 0,2 & 1026,46 & 441,41 & 28,73 & 746,31 & 280,15 & 1,38 \\
\hline & 0,3 & 970,60 & 415,63 & 27,05 & 744,63 & 225,97 & 1,30 \\
\hline & 0,4 & 914,12 & 380,00 & 24,73 & 742,31 & 171,81 & 1,23 \\
\hline & 0,5 & 863,09 & 353,44 & 23,00 & 740,59 & 122,50 & 1,17 \\
\hline & 0,6 & 821,29 & 337,64 & 21,97 & 739,56 & 81,74 & 1,11 \\
\hline & 0,7 & 778,42 & 293,25 & 19,08 & 736,67 & 41,75 & 1,06 \\
\hline & 0,8 & 735,88 & 258,73 & 16,84 & 734,42 & 1,46 & 1,00 \\
\hline \multirow{7}{*}{$1-\mathrm{Fev}$} & 0,2 & 989,58 & 380,47 & 25,64 & 743,22 & 246,36 & 1,33 \\
\hline & 0,3 & 936,26 & 347,70 & 23,43 & 741,01 & 195,25 & 1,26 \\
\hline & 0,4 & 887,69 & 305,00 & 20,55 & 738,14 & 149,56 & 1,20 \\
\hline & 0,5 & 836,95 & 266,85 & 17,98 & 735,56 & 101,38 & 1,14 \\
\hline & 0,6 & 804,87 & 239,78 & 16,16 & 733,74 & 71,13 & 1,10 \\
\hline & 0,7 & 771,69 & 237,29 & 15,99 & 733,57 & 38,11 & 1,05 \\
\hline & 0,8 & 745,02 & 189,52 & 12,77 & 730,35 & 14,66 & 1,02 \\
\hline \multirow{7}{*}{$15-\mathrm{Fev}$} & 0,2 & 987,75 & 389,38 & 26,24 & 743,82 & 243,93 & 1,33 \\
\hline & 0,3 & 932,36 & 346,77 & 23,36 & 740,95 & 191,41 & 1,26 \\
\hline & 0,4 & 883,52 & 320,61 & 21,60 & 739,19 & 144,33 & 1,20 \\
\hline & 0,5 & 837,68 & 278,31 & 18,75 & 736,34 & 101,34 & 1,14 \\
\hline & 0,6 & 807,66 & 261,75 & 17,64 & 735,22 & 72,44 & 1,10 \\
\hline & 0,7 & 770,34 & 208,89 & 14,07 & 731,66 & 38,68 & 1,05 \\
\hline & 0,8 & 734,41 & 188,92 & 12,73 & 730,31 & 4,10 & 1,01 \\
\hline
\end{tabular}


Tabela 16B. Receitas brutas, composição de custos da irrigação, receitas líquidas e relação benefício/custo para o feijão caupi, em cada época de semeadura, nível de manejo da irrigação e risco de $5 \%$. Teresina, Piauí

\begin{tabular}{|c|c|c|c|c|c|c|c|}
\hline $\begin{array}{l}\text { Época de } \\
\text { Semeadura }\end{array}$ & $\mathrm{p}$ & $\begin{array}{c}\mathrm{RB}^{1} \\
\left(\mathrm{US} \$ \mathrm{ha}^{-1}\right)\end{array}$ & $\begin{array}{c}E b \\
\left(\mathrm{kWh} \mathrm{ha}^{-1}\right)\end{array}$ & $\begin{array}{c}\mathrm{CE} \\
\left(\mathrm{US} \$ \mathrm{ha}^{-1}\right)\end{array}$ & $\begin{array}{c}\text { CT } \\
\left(\mathrm{US} \$ \mathrm{ha}^{-1}\right)\end{array}$ & $\begin{array}{c}\mathrm{RL} \\
\left(\mathrm{US} \$ \mathrm{ha}^{-1}\right)\end{array}$ & $\mathrm{B} / \mathrm{C}$ \\
\hline \multirow{7}{*}{ 1-Mar } & 0,2 & 1011,52 & 375,33 & 25,06 & 742,64 & 268,87 & 1,36 \\
\hline & 0,3 & 949,65 & 344,73 & 23,01 & 740,60 & 209,05 & 1,28 \\
\hline & 0,4 & 903,70 & 292,37 & 19,52 & 737,10 & 166,60 & 1,23 \\
\hline & 0,5 & 857,73 & 271,23 & 18,11 & 735,69 & 122,03 & 1,17 \\
\hline & 0,6 & 819,53 & 240,94 & 16,08 & 733,67 & 85,86 & 1,12 \\
\hline & 0,7 & 780,84 & 212,76 & 14,20 & 731,79 & 49,05 & 1,07 \\
\hline & 0,8 & 745,21 & 177,60 & 11,86 & 729,44 & 15,77 & 1,02 \\
\hline \multirow{7}{*}{ 15-Mar } & 0,2 & 1004,44 & 429,66 & 28,68 & 746,27 & 258,17 & 1,35 \\
\hline & 0,3 & 935,00 & 401,28 & 26,79 & 744,37 & 190,63 & 1,26 \\
\hline & 0,4 & 889,05 & 369,17 & 24,64 & 742,23 & 146,82 & 1,20 \\
\hline & 0,5 & 822,71 & 339,83 & 22,69 & 740,27 & 82,44 & 1,11 \\
\hline & 0,6 & 778,26 & 319,33 & 21,32 & 738,90 & 39,36 & 1,05 \\
\hline & 0,7 & 743,45 & 277,59 & 18,53 & 736,12 & 7,33 & 1,01 \\
\hline & 0,8 & 702,54 & 240,24 & 16,04 & 733,62 & $-31,08$ & 0,96 \\
\hline \multirow{7}{*}{$1-\mathrm{Abr}$} & 0,2 & 985,54 & 495,42 & 31,15 & 748,73 & 236,81 & 1,32 \\
\hline & 0,3 & 908,57 & 465,89 & 29,29 & 746,88 & 161,69 & 1,22 \\
\hline & 0,4 & 860,19 & 439,49 & 27,63 & 745,22 & 114,97 & 1,15 \\
\hline & 0,5 & 795,60 & 428,98 & 26,97 & 744,56 & 51,05 & 1,07 \\
\hline & 0,6 & 745,23 & 422,38 & 26,56 & 744,14 & 1,08 & 1,00 \\
\hline & 0,7 & 702,36 & 397,61 & 25,00 & 742,58 & $-40,23$ & 0,95 \\
\hline & 0,8 & 656,58 & 364,54 & 22,92 & 740,50 & $-83,92$ & 0,89 \\
\hline \multirow{7}{*}{$15-\mathrm{Abr}$} & 0,2 & 975,71 & 564,48 & 35,49 & 753,08 & 222,63 & 1,30 \\
\hline & 0,3 & 895,29 & 550,56 & 34,62 & 752,20 & 143,09 & 1,19 \\
\hline & 0,4 & 840,43 & 532,72 & 33,49 & 751,08 & 89,35 & 1,12 \\
\hline & 0,5 & 770,32 & 515,81 & 32,43 & 750,02 & 20,30 & 1,03 \\
\hline & 0,6 & 710,28 & 503,55 & 31,66 & 749,24 & $-38,97$ & 0,95 \\
\hline & 0,7 & 660,13 & 488,36 & 30,71 & 748,29 & $-88,16$ & 0,88 \\
\hline & 0,8 & 616,57 & 472,70 & 29,72 & 747,31 & $-130,74$ & 0,83 \\
\hline
\end{tabular}


Tabela 16B. Receitas brutas, composição de custos da irrigação, receitas líquidas e relação benefício/custo para o feijão caupi, em cada época de semeadura, nível de manejo da irrigação e risco de $5 \%$. Teresina, Piauí.

\begin{tabular}{|c|c|c|c|c|c|c|c|}
\hline $\begin{array}{l}\text { Época de } \\
\text { Semeadura }\end{array}$ & $\mathrm{p}$ & $\begin{array}{c}\mathrm{RB}^{1} \\
\left(\mathrm{US} \$ \mathrm{ha}^{-1}\right)\end{array}$ & $\begin{array}{c}E b \\
\left(\mathrm{kWh} \mathrm{ha}^{-1}\right)\end{array}$ & $\begin{array}{c}\text { CE } \\
\left(\mathrm{US} \$ \mathrm{ha}^{-1}\right)\end{array}$ & $\begin{array}{c}\text { CT } \\
\left(\mathrm{US} \$ \mathrm{ha}^{-1}\right) \\
\end{array}$ & $\begin{array}{c}\mathrm{RL} \\
\left(\mathrm{US} \$ \mathrm{ha}^{-1}\right)\end{array}$ & $\mathrm{B} / \mathrm{C}$ \\
\hline \multirow{7}{*}{ 1-Mai } & 0,2 & 773,25 & 624,54 & 37,51 & 755,10 & 18,15 & 1,02 \\
\hline & 0,3 & 703,01 & 609,70 & 36,62 & 754,21 & $-51,20$ & 0,93 \\
\hline & 0,4 & 658,27 & 599,31 & 36,00 & 753,58 & $-95,31$ & 0,87 \\
\hline & 0,5 & 599,45 & 601,01 & 36,10 & 753,68 & $-154,23$ & 0,80 \\
\hline & 0,6 & 553,20 & 593,45 & 35,64 & 753,23 & $-200,03$ & 0,73 \\
\hline & 0,7 & 514,57 & 577,52 & 34,69 & 752,27 & $-237,70$ & 0,68 \\
\hline & 0,8 & 472,68 & 574,12 & 34,48 & 752,07 & $-279,39$ & 0,63 \\
\hline \multirow{7}{*}{ 15-Mai } & 0,2 & 771,41 & 668,71 & 40,17 & 757,75 & 13,66 & 1,02 \\
\hline & 0,3 & 707,72 & 659,36 & 39,60 & 757,19 & $-49,47$ & 0,93 \\
\hline & 0,4 & 657,92 & 657,00 & 39,46 & 757,05 & $-99,13$ & 0,87 \\
\hline & 0,5 & 591,66 & 653,43 & 39,25 & 756,83 & $-165,17$ & 0,78 \\
\hline & 0,6 & 551,14 & 646,46 & 38,83 & 756,41 & $-205,27$ & 0,73 \\
\hline & 0,7 & 509,07 & 636,59 & 38,24 & 755,82 & $-246,76$ & 0,67 \\
\hline & 0,8 & 464,94 & 644,61 & 38,72 & 756,30 & $-291,36$ & 0,61 \\
\hline \multirow{7}{*}{ 1-Jun } & 0,2 & 866,00 & 719,80 & 46,27 & 763,86 & 102,14 & 1,13 \\
\hline & 0,3 & 802,32 & 716,53 & 46,06 & 763,65 & 38,67 & 1,05 \\
\hline & 0,4 & 735,47 & 709,46 & 45,61 & 763,19 & $-27,72$ & 0,96 \\
\hline & 0,5 & 669,98 & 709,61 & 45,62 & 763,20 & $-93,22$ & 0,88 \\
\hline & 0,6 & 624,44 & 711,55 & 45,74 & 763,33 & $-138,88$ & 0,82 \\
\hline & 0,7 & 573,65 & 704,12 & 45,26 & 762,85 & $-189,20$ & 0,75 \\
\hline & 0,8 & 526,69 & 705,86 & 45,38 & 762,96 & $-236,27$ & 0,69 \\
\hline \multirow{7}{*}{ 15-Jun } & 0,2 & 870,68 & 764,80 & 49,16 & 766,75 & 103,93 & 1,14 \\
\hline & 0,3 & 812,40 & 763,45 & 49,08 & 766,66 & 45,74 & 1,06 \\
\hline & 0,4 & 738,77 & 762,19 & 49,00 & 766,58 & $-27,81$ & 0,96 \\
\hline & 0,5 & 673,63 & 755,93 & 48,59 & 766,18 & $-92,55$ & 0,88 \\
\hline & 0,6 & 625,90 & 753,29 & 48,42 & 766,01 & $-140,11$ & 0,82 \\
\hline & 0,7 & 574,02 & 752,18 & 48,35 & 765,94 & $-191,91$ & 0,75 \\
\hline & 0,8 & 536,94 & 748,08 & 48,09 & 765,67 & $-228,74$ & 0,70 \\
\hline
\end{tabular}


Tabela 16B. Receitas brutas, composição de custos da irrigação, receitas líquidas e relação beneficio/custo para o feijão caupi, em cada época de semeadura, nivel de manejo da irrigação e risco de $5 \%$. Teresina, Piauí.

\begin{tabular}{|c|c|c|c|c|c|c|c|}
\hline $\begin{array}{l}\text { Época de } \\
\text { Semeadura }\end{array}$ & $\mathrm{p}$ & $\begin{array}{c}\mathrm{RB}^{\mathrm{l}} \\
\left(\mathrm{US} \$ \mathrm{ha}^{-1}\right)\end{array}$ & $\begin{array}{c}E b \\
\left(\mathrm{kWh} \mathrm{ha}^{-1}\right)\end{array}$ & $\begin{array}{c}\text { CE } \\
\left(\text { US } \$ \mathrm{ha}^{-1}\right)\end{array}$ & $\begin{array}{c}\text { CT } \\
\left(\mathrm{US} \$ \mathrm{ha}^{-1}\right)\end{array}$ & $\begin{array}{c}\mathrm{RL} \\
\left(\mathrm{US} \$ \mathrm{ha}^{-1}\right)\end{array}$ & $\mathrm{B} / \mathrm{C}$ \\
\hline \multirow{7}{*}{ 1-Jul } & 0,2 & 888,10 & 824,31 & 53,79 & 771,37 & 116,73 & 1,15 \\
\hline & 0,3 & 833,98 & 818,59 & 53,41 & 771,00 & 62,98 & 1,08 \\
\hline & 0,4 & 754,92 & 819,29 & 53,46 & 771,04 & $-16,12$ & 0,98 \\
\hline & 0,5 & 701,73 & 820,14 & 53,51 & 771,10 & $-69,37$ & 0,91 \\
\hline & 0,6 & 642,61 & 805,24 & 52,54 & 770,13 & $-127,52$ & 0,83 \\
\hline & 0,7 & 590,14 & 807,80 & 52,71 & 770,29 & $-180,15$ & 0,77 \\
\hline & 0,8 & 552,28 & 825,44 & 53,86 & 771,45 & $-219,16$ & 0,72 \\
\hline \multirow{7}{*}{$15-\mathrm{Jul}$} & 0,2 & 894,45 & 883,26 & 57,63 & 775,22 & 119,23 & 1,15 \\
\hline & 0,3 & 844,56 & 879,12 & 57,36 & 774,95 & 69,62 & 1,09 \\
\hline & 0,4 & 760,00 & 873,78 & 57,01 & 774,60 & $-14,60$ & 0,98 \\
\hline & 0,5 & 719,38 & 879,96 & 57,42 & 775,00 & $-55,62$ & 0,93 \\
\hline & 0,6 & 641,99 & 879,74 & 57,40 & 774,99 & $-132,99$ & 0,83 \\
\hline & 0,7 & 607,94 & 753,29 & 49,15 & 766,74 & $-158,80$ & 0,79 \\
\hline & 0,8 & 551,85 & 867,88 & 56,63 & 774,21 & $-222,36$ & 0,71 \\
\hline \multirow{7}{*}{ 1-Ago } & 0,2 & 849,47 & 918,81 & 59,76 & 777,35 & 72,12 & 1,09 \\
\hline & 0,3 & 802,00 & 920,18 & 59,85 & 777,44 & 24,56 & 1,03 \\
\hline & 0,4 & 726,99 & 917,81 & 59,70 & 777,28 & $-50,30$ & 0,94 \\
\hline & 0,5 & 678,25 & 895,97 & 58,28 & 775,86 & $-97,61$ & 0,87 \\
\hline & 0,6 & 613,10 & 881,49 & 57,34 & 774,92 & $-161,82$ & 0,79 \\
\hline & 0,7 & 574,96 & 912,06 & 59,32 & 776,91 & $-201,95$ & 0,74 \\
\hline & 0,8 & 525,28 & 907,21 & 59,01 & 776,59 & $-251,31$ & 0,68 \\
\hline \multirow{7}{*}{ 15-Ago } & 0,2 & 853,97 & 947,51 & 61,63 & 779,21 & 74,75 & 1,10 \\
\hline & 0,3 & 800,88 & 947,37 & 61,62 & 779,21 & 21,68 & 1,03 \\
\hline & 0,4 & 738,46 & 948,65 & 61,70 & 779,29 & $-40,83$ & 0,95 \\
\hline & 0,5 & 678,57 & 934,99 & 60,82 & 778,40 & $-99,83$ & 0,87 \\
\hline & 0,6 & 633,10 & 940,08 & 61,15 & 778,73 & $-145,63$ & 0,81 \\
\hline & 0,7 & 581,05 & 940,43 & 61,17 & 778,75 & $-197,70$ & 0,75 \\
\hline & 0,8 & 542,97 & 936,37 & 60,91 & 778,49 & $-235,52$ & 0,70 \\
\hline
\end{tabular}


Tabela 16B. Receitas brutas, composição de custos da irrigação, receitas líquidas e relação benefício/custo para o feijão caupi, em cada época de semeadura, nivel de manejo da irrigação e risco de $5 \%$. Teresina, Piauí.

\begin{tabular}{|c|c|c|c|c|c|c|c|}
\hline $\begin{array}{c}\text { Época de } \\
\text { Semeadura }\end{array}$ & $\mathrm{p}$ & $\begin{array}{c}\mathrm{RB}^{\mathrm{l}} \\
\left(\mathrm{US} \$ \mathrm{ha}^{-1}\right)\end{array}$ & $\begin{array}{c}\mathrm{Eb} \\
\left(\mathrm{kWh} \mathrm{ha}^{-1}\right)\end{array}$ & $\begin{array}{c}\text { CE } \\
\left(\mathrm{US} \$ \mathrm{ha}^{-1}\right)\end{array}$ & $\begin{array}{c}\mathrm{CT} \\
\left(\mathrm{US} \$ \mathrm{ha}^{-1}\right)\end{array}$ & $\begin{array}{c}\mathrm{RL} \\
\left(\mathrm{US} \$ \mathrm{ha}^{-1}\right)\end{array}$ & $\mathrm{B} / \mathrm{C}$ \\
\hline \multirow{7}{*}{$1-$ Set } & 0,2 & 869,49 & 951,34 & 58,43 & 776,01 & 93,48 & 1,12 \\
\hline & 0,3 & 818,22 & 943,21 & 57,93 & 775,51 & 42,70 & 1,06 \\
\hline & 0,4 & 749,72 & 941,22 & 57,81 & 775,39 & $-25,67$ & 0,97 \\
\hline & 0,5 & 691,61 & 940,50 & 57,76 & 775,35 & $-83,74$ & 0,89 \\
\hline & 0,6 & 640,62 & 934,92 & 57,42 & 775,01 & $-134,39$ & 0,83 \\
\hline & 0,7 & 586,96 & 935,86 & 57,48 & 775,06 & $-188,11$ & 0,76 \\
\hline & 0,8 & 555,54 & 928,02 & 57,00 & 774,58 & $-219,04$ & 0,72 \\
\hline \multirow{7}{*}{ 15-Set } & 0,2 & 866,50 & 934,87 & 57,42 & 775,00 & 91,50 & 1,12 \\
\hline & 0,3 & 816,35 & 933,46 & 57,33 & 774,92 & 41,44 & 1,05 \\
\hline & 0,4 & 744,77 & 929,26 & 57,07 & 774,66 & $-29,89$ & 0,96 \\
\hline & 0,5 & 687,70 & 919,42 & 56,47 & 774,05 & $-86,35$ & 0,89 \\
\hline & 0,6 & 635,38 & 920,68 & 56,55 & 774,13 & $-138,75$ & 0,82 \\
\hline & 0,7 & 588,12 & 922,84 & 56,68 & 774,26 & $-186,15$ & 0,76 \\
\hline & 0,8 & 547,88 & 916,79 & 56,31 & 773,89 & $-226,01$ & 0,71 \\
\hline \multirow{7}{*}{ 1-Out } & 0,2 & 893,88 & 907,30 & 57,41 & 775,00 & 118,88 & 1,15 \\
\hline & 0,3 & 843,43 & 902,45 & 57,11 & 774,69 & 68,74 & 1,09 \\
\hline & 0,4 & 768,87 & 897,62 & 56,80 & 774,39 & $-5,52$ & 0,99 \\
\hline & 0,5 & 715,32 & 897,97 & 56,82 & 774,41 & $-59,09$ & 0,92 \\
\hline & 0,6 & 655,99 & 899,53 & 56,92 & 774,51 & $-118,51$ & 0,85 \\
\hline & 0,7 & 606,23 & 886,00 & 56,07 & 773,65 & $-167,42$ & 0,78 \\
\hline & 0,8 & 561,05 & 884,07 & 55,94 & 773,53 & $-212,48$ & 0,73 \\
\hline \multirow{7}{*}{ 15-Out } & 0,2 & 888,32 & 866,03 & 54,80 & 772,39 & 115,94 & 1,15 \\
\hline & 0,3 & 843,23 & 862,55 & 54,58 & 772,17 & 71,06 & 1,09 \\
\hline & 0,4 & 760,44 & 853,86 & 54,03 & 771,62 & $-11,18$ & 0,99 \\
\hline & 0,5 & 713,62 & 847,13 & 53,61 & 771,19 & $-57,57$ & 0,93 \\
\hline & 0,6 & 647,54 & 846,58 & 53,57 & 771,16 & $-123,62$ & 0,84 \\
\hline & 0,7 & 607,74 & 836,64 & 52,94 & 770,53 & $-162,79$ & 0,79 \\
\hline & 0,8 & 557,85 & 827,43 & 52,36 & 769,95 & $-212,09$ & 0,72 \\
\hline
\end{tabular}


Tabela 16B. Receitas brutas, composição de custos da irrigação, receitas líquidas e relação benefício/custo para o feijão caupi, em cada época de semeadura, nível de manejo da irrigação e risco de $5 \%$. Teresina, Piaú.

\begin{tabular}{|c|c|c|c|c|c|c|c|}
\hline $\begin{array}{c}\text { Época de } \\
\text { Semeadura }\end{array}$ & $\mathrm{p}$ & $\begin{array}{c}\mathrm{RB}^{1} \\
\left(\mathrm{US} \$ \mathrm{ha}^{-1}\right)\end{array}$ & $\begin{array}{c}E b \\
\left(\mathrm{kWh} \mathrm{ha} \mathrm{a}^{-1}\right)\end{array}$ & $\begin{array}{c}\text { CE } \\
\left(\text { US\$ ha }{ }^{-1}\right)\end{array}$ & $\begin{array}{c}\text { CT } \\
\left(\text { US } \$ h a^{-1}\right)\end{array}$ & $\begin{array}{c}\text { RL } \\
\left(\text { US\$ ha }{ }^{-1}\right)\end{array}$ & $\mathrm{B} / \mathrm{C}$ \\
\hline \multirow{7}{*}{$1-\mathrm{Nov}$} & 0,2 & 1042,43 & 774,02 & 49,53 & 767,12 & 275,31 & 1,36 \\
\hline & 0,3 & 979,17 & 766,65 & 49,06 & 766,65 & 212,52 & 1,28 \\
\hline & 0,4 & 892,51 & 758,04 & 48,51 & 766,10 & 126,42 & 1,17 \\
\hline & 0,5 & 832,43 & 748,37 & 47,89 & 765,48 & 66,96 & 1,09 \\
\hline & 0,6 & 761,33 & 738,81 & 47,28 & 764,87 & $-3,54$ & 1,00 \\
\hline & 0,7 & 712,44 & 729,94 & 46,71 & 764,30 & $-51,85$ & 0,93 \\
\hline & 0,8 & 654,89 & 723,13 & 46,28 & 763,86 & $-108,98$ & 0,86 \\
\hline \multirow{7}{*}{$15-\mathrm{Nov}$} & 0,2 & 1035,52 & 693,21 & 44,36 & 761,95 & 273,57 & 1,36 \\
\hline & 0,3 & 972,64 & 674,70 & 43,18 & 760,76 & 211,87 & 1,28 \\
\hline & 0,4 & 887,72 & 650,08 & 41,60 & 759,19 & 128,53 & 1,17 \\
\hline & 0,5 & 823,61 & 634,73 & 40,62 & 758,20 & 65,41 & 1,09 \\
\hline & 0,6 & 762,76 & 631,23 & 40,40 & 757,98 & 4,78 & 1,01 \\
\hline & 0,7 & 707,12 & 613,25 & 39,25 & 756,83 & $-49,71$ & 0,93 \\
\hline & 0,8 & 659,49 & 597,82 & 38,26 & 755,84 & $-96,35$ & 0,87 \\
\hline \multirow{7}{*}{ 1-Dez } & 0,2 & 1076,24 & 615,84 & 39,43 & 757,01 & 319,23 & 1,42 \\
\hline & 0,3 & 1007,30 & 592,87 & 37,96 & 755,54 & 251,76 & 1,33 \\
\hline & 0,4 & 930,34 & 575,57 & 36,85 & 754,43 & 175,91 & 1,23 \\
\hline & 0,5 & 861,13 & 558,81 & 35,78 & 753,36 & 107,77 & 1,14 \\
\hline & 0,6 & 805,35 & 542,57 & 34,74 & 752,32 & 53,03 & 1,07 \\
\hline & 0,7 & 752,38 & 527,68 & 33,78 & 751,37 & 1,01 & 1,00 \\
\hline & 0,8 & 700,79 & 512,45 & 32,81 & 750,39 & $-49,60$ & 0,93 \\
\hline \multirow{7}{*}{ 15-Dez } & 0,2 & 1075,95 & 552,28 & 35,36 & 752,94 & 323,00 & 1,43 \\
\hline & 0,3 & 1006,23 & 528,62 & 33,84 & 751,43 & 254,80 & 1,34 \\
\hline & 0,4 & 935,34 & 496,00 & 31,75 & 749,34 & 186,00 & 1,25 \\
\hline & 0,5 & 863,02 & 465,17 & 29,78 & 747,37 & 115,65 & 1,15 \\
\hline & 0,6 & 821,24 & 452,98 & 29,00 & 746,59 & 74,66 & 1,10 \\
\hline & 0,7 & 761,82 & 428,48 & 27,43 & 745,02 & 16,80 & 1,02 \\
\hline & 0,8 & 715,46 & 399,01 & 25,55 & 743,13 & $-27,67$ & 0,96 \\
\hline
\end{tabular}

TRB - receita bruta; $E b$ - energia requerida para o bombeamento; $C E$ - custo de energia elétrica: $C T$ - custo total de produção; RL - receita líquida e B/C - relação benefício/custo. 
Tabela 17B. Receitas brutas, composição de custos da irrigação, receitas líquidas e relação benefício/custo para o feijão caupi, em cada época de semeadura, nivel de manejo da irrigação e risco de $10 \%$. Teresina, Piauí.

\begin{tabular}{|c|c|c|c|c|c|c|c|}
\hline $\begin{array}{l}\text { Época de } \\
\text { Semeadura }\end{array}$ & $\mathrm{p}$ & $\begin{array}{c}\mathrm{RB}^{\mathrm{l}} \\
\left(\mathrm{US} \$ \mathrm{ha}^{-1}\right)\end{array}$ & $\begin{array}{c}E b \\
\left(\mathrm{kWh} \mathrm{ha} \mathrm{a}^{-1}\right)\end{array}$ & $\begin{array}{c}\text { CE } \\
\left(\mathrm{US} \$ \mathrm{ha}^{-1}\right)\end{array}$ & $\begin{array}{c}\mathrm{CT} \\
\left(\mathrm{US} \$ \mathrm{ha}^{-1}\right)\end{array}$ & $\begin{array}{c}\mathrm{RL} \\
\left(\mathrm{US} \$ \mathrm{ha} \mathrm{a}^{-1}\right)\end{array}$ & $B / C$ \\
\hline & 0,2 & 1041,88 & 455,22 & 28,75 & 746,34 & 295,54 & 1,40 \\
\hline & 0,3 & 982,08 & 427,80 & 27,02 & 744,61 & 237,47 & 1,32 \\
\hline & 0,4 & 923,63 & 402,18 & 25,40 & 742,99 & 180,65 & 1,24 \\
\hline \multirow[t]{7}{*}{ 1-Jan } & 0,5 & 861,98 & 369,07 & 23,31 & 740,90 & 121,08 & 1,16 \\
\hline & 0,6 & 825,38 & 330,85 & 20,90 & 738,48 & 86,90 & 1,12 \\
\hline & 0,7 & 778,48 & 300,39 & 18,97 & 736,56 & 41,92 & 1,06 \\
\hline & 0,8 & 740,72 & 290,81 & 18,37 & 735,95 & 4,77 & 1,01 \\
\hline & 0,2 & 1055,90 & 418,03 & 26,40 & 743,99 & 311,91 & 1,42 \\
\hline & 0,3 & 1001,16 & 389,06 & 24,57 & 742,16 & 259,00 & 1,35 \\
\hline & 0,4 & 945,67 & 352,41 & 22,26 & 739,84 & 205,83 & 1,28 \\
\hline \multirow[t]{7}{*}{ 15-Jan } & 0,5 & 895,44 & 323,18 & 20,41 & 738,00 & 157,44 & 1,21 \\
\hline & 0,6 & 855,36 & 303,63 & 19,18 & 736,76 & 118,59 & 1,16 \\
\hline & 0,7 & 814,60 & 261,73 & 16,53 & 734,12 & 80,49 & 1,11 \\
\hline & 0,8 & 775,55 & 258,73 & 16,34 & 733,93 & 41,62 & 1,06 \\
\hline & 0,2 & 1019,95 & 359,81 & 23,28 & 740,86 & 279,08 & 1,38 \\
\hline & 0,3 & 967,94 & 323,73 & 20,94 & 738,53 & 229,41 & 1,31 \\
\hline & 0,4 & 920,36 & 280,52 & 18,15 & 735,73 & 184,63 & 1,25 \\
\hline \multirow[t]{7}{*}{$1-\mathrm{Fev}$} & 0,5 & 871,71 & 242,91 & 15,72 & 733,30 & 138,41 & 1,19 \\
\hline & 0,6 & 841,65 & 216,62 & 14,01 & 731,60 & 110,05 & 1,15 \\
\hline & 0,7 & 809,78 & 200,79 & 12,99 & 730,57 & 79,21 & 1,11 \\
\hline & 0,8 & 784,74 & 189,52 & 12,26 & 729,85 & 54,90 & 1,08 \\
\hline & 0,2 & 1018,38 & 362,56 & 23,46 & 741,04 & 277,34 & 1,37 \\
\hline & 0,3 & 964,66 & 319,98 & 20,70 & 738,29 & 226,38 & 1,31 \\
\hline & 0,4 & 917,53 & 290,63 & 18,80 & 736,39 & 181,14 & 1,25 \\
\hline \multirow[t]{4}{*}{$15-\mathrm{Fev}$} & 0,5 & 873,17 & 248,33 & 16,07 & 733,65 & 139,52 & 1,19 \\
\hline & 0,6 & 845,06 & 230,57 & 14,92 & 732,50 & 112,56 & 1,15 \\
\hline & 0,7 & 810,84 & 208,89 & 13,51 & 731,10 & 79,74 & 1,11 \\
\hline & 0,8 & 778,54 & 188,92 & 12,22 & 729,81 & 48,73 & 1,07 \\
\hline
\end{tabular}


Tabela 17B. Receitas brutas, composição de custos da irrigação, receitas líquidas e relação beneficio/custo para o feijão caupi, em cada época de semeadura, nível de manejo da irrigação e risco de $10 \%$. Teresina, Piauí.

\begin{tabular}{|c|c|c|c|c|c|c|c|}
\hline $\begin{array}{c}\text { Época de } \\
\text { Semeadura }\end{array}$ & $\mathrm{p}$ & $\begin{array}{c}\mathrm{RB}^{\mathrm{l}} \\
\left(\mathrm{US} \$ \mathrm{ha}^{-1}\right)\end{array}$ & $\begin{array}{c}\mathrm{Eb} \\
\left(\mathrm{kWh} \mathrm{ha}^{-1}\right)\end{array}$ & $\begin{array}{c}\text { CE } \\
\left(\mathrm{US} \$ \mathrm{ha}^{-1}\right)\end{array}$ & $\begin{array}{c}\mathrm{CT} \\
\left(\mathrm{US} \$ \mathrm{ha}^{-1}\right)\end{array}$ & $\begin{array}{c}\mathrm{RL} \\
\left(\mathrm{US} \$ \mathrm{ha}^{-1}\right)\end{array}$ & $\mathrm{B} / \mathrm{C}$ \\
\hline \multirow{7}{*}{ 1-Mar } & 0,2 & 1043,62 & 352,14 & 22,64 & 740,22 & 303,40 & 1,41 \\
\hline & 0,3 & 983,88 & 318,33 & 20,47 & 738,05 & 245,83 & 1,33 \\
\hline & 0,4 & 938,60 & 265,88 & 17,09 & 734,68 & 203,93 & 1,28 \\
\hline & 0,5 & 894,41 & 243,83 & 15,68 & 733,26 & 161,15 & 1,22 \\
\hline & 0,6 & 858,70 & 215,32 & 13,84 & 731,43 & 127,27 & 1,17 \\
\hline & 0,7 & 822,44 & 187,27 & 12,04 & 729,62 & 92,82 & 1,13 \\
\hline & 0,8 & 789,76 & 177,60 & 11,42 & 729,00 & 60,76 & 1,08 \\
\hline \multirow{7}{*}{ 15-Mar } & 0,2 & 1036,03 & 406,11 & 26,11 & 743,69 & 292,34 & 1,39 \\
\hline & 0,3 & 967,48 & 373,58 & 24,02 & 741,60 & 225,88 & 1,30 \\
\hline & 0,4 & 922,58 & 339,95 & 21,86 & 739,44 & 183,14 & 1,25 \\
\hline & 0,5 & 858,69 & 309,55 & 19,90 & 737,49 & 121,21 & 1,16 \\
\hline & 0,6 & 815,97 & 288,03 & 18,52 & 736,10 & 79,87 & 1,11 \\
\hline & 0,7 & 782,53 & 247,85 & 15,93 & 733,52 & 49,01 & 1,07 \\
\hline & 0,8 & 744,06 & 240,24 & 15,45 & 733,03 & 11,03 & 1,02 \\
\hline \multirow{7}{*}{$1-\mathrm{Abr}$} & 0,2 & 1016,95 & 472,06 & 28,75 & 746,34 & 270,61 & 1,36 \\
\hline & 0,3 & 941,29 & 441,34 & 26,88 & 744,47 & 196,82 & 1,26 \\
\hline & 0,4 & 893,19 & 413,56 & 25,19 & 742,77 & 150,41 & 1,20 \\
\hline & 0,5 & 829,50 & 398,47 & 24,27 & 741,85 & 87,64 & 1,12 \\
\hline & 0,6 & 780,60 & 387,30 & 23,59 & 741,17 & 39,43 & 1,05 \\
\hline & 0,7 & 739,23 & 362,83 & 22,10 & 739,68 & $-0,45$ & 1,00 \\
\hline & 0,8 & 695,65 & 330,45 & 20,13 & 737,71 & $-42,07$ & 0,94 \\
\hline \multirow{7}{*}{$15-\mathrm{Abr}$} & 0,2 & 1006,57 & 544,27 & 33,15 & 750,74 & 255,84 & 1,34 \\
\hline & 0,3 & 926,21 & 527,50 & 32,13 & 749,71 & 176,50 & 1,24 \\
\hline & 0,4 & 871,23 & 505,90 & 30,81 & 748,40 & 122,83 & 1,16 \\
\hline & 0,5 & 801,72 & 485,97 & 29,60 & 747,18 & 54,53 & 1,07 \\
\hline & 0,6 & 742,68 & 472,58 & 28,78 & 746,37 & $-3,69$ & 1,00 \\
\hline & 0,7 & 693,61 & 456,04 & 27,78 & 745,36 & $-51,75$ & 0,93 \\
\hline & 0,8 & 650,62 & 438,78 & 26,73 & 744,31 & $-93,69$ & 0,87 \\
\hline
\end{tabular}


Tabela 17B. Receitas brutas, composição de custos da irrigação, receitas líquidas e relação benefício/custo para o feijão caupi, em cada época de semeadura, nivel de manejo da irrigação e risco de $10 \%$. Teresina, Piauí.

\begin{tabular}{|c|c|c|c|c|c|c|c|}
\hline $\begin{array}{l}\text { Época de } \\
\text { Semeadura }\end{array}$ & $\mathrm{p}$ & $\begin{array}{c}\mathrm{RB}^{\mathrm{I}} \\
\left(\mathrm{US} \$ \mathrm{ha}^{-1}\right)\end{array}$ & $\begin{array}{c}\mathrm{Eb} \\
\left(\mathrm{kWh} \mathrm{ha} \mathrm{h}^{-1}\right)\end{array}$ & $\begin{array}{c}C E \\
\left(\mathrm{US} \$ \mathrm{ha}^{-1}\right)\end{array}$ & $\begin{array}{c}\mathrm{CT} \\
\left(\mathrm{US} \$ \mathrm{ha}^{-1}\right)\end{array}$ & $\begin{array}{c}\mathrm{RL} \\
\left(\mathrm{US} \$ \mathrm{ha}^{-1}\right)\end{array}$ & $\mathrm{B} / \mathrm{C}$ \\
\hline \multirow{7}{*}{ 1-Mai } & 0,2 & 807,35 & 604,68 & 35,54 & 753,12 & 54,23 & 1,07 \\
\hline & 0,3 & 736,57 & 587,23 & 34,51 & 752,10 & $-15,53$ & 0,98 \\
\hline & 0,4 & 690,85 & 574,17 & 33,75 & 751,33 & $-60,48$ & 0,92 \\
\hline & 0,5 & 631,19 & 571,13 & 33,57 & 751,15 & $-119,97$ & 0,84 \\
\hline & 0,6 & 584,39 & 561,69 & 33,01 & 750,60 & $-166,21$ & 0,78 \\
\hline & 0,7 & 546,25 & 545,75 & 32,08 & 749,66 & $-203,41$ & 0,73 \\
\hline & 0,8 & 503,34 & 537,19 & 31,57 & 749,16 & $-245,82$ & 0,67 \\
\hline \multirow{7}{*}{ 15-Mai } & 0,2 & 805,08 & 655,28 & 38,51 & 756,10 & 48,99 & 1,06 \\
\hline & 0,3 & 740,88 & 644,22 & 37,86 & 755,45 & $-14,57$ & 0,98 \\
\hline & 0,4 & 688,63 & 639,06 & 37,56 & 755,15 & $-66,52$ & 0,91 \\
\hline & 0,5 & 621,92 & 633,28 & 37,22 & 754,81 & $-132,88$ & 0,82 \\
\hline & 0,6 & 580,58 & 625,12 & 36,74 & 754,33 & $-173,74$ & 0,77 \\
\hline & 0,7 & 536,90 & 613,19 & 36,04 & 753,62 & $-216,73$ & 0,71 \\
\hline & 0,8 & 493,07 & 617,75 & 36,31 & 753,89 & $-260,82$ & 0,65 \\
\hline \multirow{7}{*}{ 1-Jun } & 0,2 & 896,73 & 708,87 & 44,32 & 761,91 & 134,82 & 1,18 \\
\hline & 0,3 & 832,89 & 703,49 & 43,99 & 761,57 & 71,31 & 1,09 \\
\hline & 0,4 & 763,63 & 696,36 & 43,54 & 761,13 & 2,51 & 1,00 \\
\hline & 0,5 & 696,94 & 694,59 & 43,43 & 761,02 & $-64,07$ & 0,92 \\
\hline & 0,6 & 650,88 & 693,10 & 43,34 & 760,92 & $-110,04$ & 0,86 \\
\hline & 0,7 & 598,62 & 686,61 & 42,93 & 760,52 & $-161,90$ & 0,79 \\
\hline & 0,8 & 550,95 & 671,76 & 42,00 & 759,59 & $-208,64$ & 0,73 \\
\hline \multirow{7}{*}{ 15-Jun } & 0,2 & 901,46 & 756,00 & 47,27 & 764,86 & 136,60 & 1,18 \\
\hline & 0,3 & 843,12 & 752,69 & 47,06 & 764,65 & 78,47 & 1,10 \\
\hline & 0,4 & 766,37 & 749,71 & 46,88 & 764,46 & 1,91 & 1,00 \\
\hline & 0,5 & 701,87 & 742,74 & 46,44 & 764,03 & $-62,15$ & 0,92 \\
\hline & 0,6 & 651,46 & 738,89 & 46,20 & 763,79 & $-112,32$ & 0,85 \\
\hline & 0,7 & 598,59 & 736,71 & 46,06 & 763,65 & $-165,06$ & 0,78 \\
\hline & 0,8 & 559,90 & 730,95 & 45,70 & 763,29 & $-203,39$ & 0,73 \\
\hline
\end{tabular}


Tabela 17B. Receitas brutas, composição de custos da irrigação, receitas líquidas e relação beneficio/custo para o feijão caupi, em cada época de semeadura, nível de manejo da irrigação e risco de $10 \%$. Teresina, Piauí.

\begin{tabular}{|c|c|c|c|c|c|c|c|}
\hline $\begin{array}{l}\text { Época de } \\
\text { Semeadura }\end{array}$ & $p$ & $\begin{array}{c}\mathrm{RB}^{1} \\
\left(\mathrm{US} \$ \mathrm{ha}^{-1}\right)\end{array}$ & $\begin{array}{c}\text { Eb } \\
\left(\mathrm{kWh} \mathrm{ha} a^{-1}\right)\end{array}$ & $\begin{array}{c}\text { CE } \\
\left(\mathrm{US} \$ \mathrm{ha}^{-1}\right)\end{array}$ & $\begin{array}{c}\mathrm{CT} \\
\left(\mathrm{US} \$ \mathrm{ha}^{-1}\right)\end{array}$ & $\begin{array}{c}\mathrm{RL} \\
\left(\mathrm{US} \$ \mathrm{ha}^{-1}\right)\end{array}$ & $B / C$ \\
\hline \multirow{7}{*}{ 1-Jul } & 0,2 & 916,12 & 817,03 & 52,08 & 769,66 & 146,46 & 1,19 \\
\hline & 0,3 & 861,63 & 811,28 & 51,71 & 769,30 & 92,34 & 1,12 \\
\hline & 0,4 & 779,66 & 810,50 & 51,66 & 769,25 & 10,41 & 1,01 \\
\hline & 0,5 & 726,65 & 809,13 & 51,57 & 769,16 & $-42,51$ & 0,94 \\
\hline & 0,6 & 666,09 & 805,24 & 51,33 & 768,91 & $-102,82$ & 0,87 \\
\hline & 0,7 & 613,75 & 795,45 & 50,70 & 768,29 & $-154,54$ & 0,80 \\
\hline & 0,8 & 573,00 & 810,10 & 51,64 & 769,22 & $-196,22$ & 0,74 \\
\hline \multirow{7}{*}{ 15-Jul } & 0,2 & 923,21 & 875,47 & 55,80 & 773,39 & 149,82 & 1,19 \\
\hline & 0,3 & 871,93 & 870,91 & 55,51 & 773,10 & 98,84 & 1,13 \\
\hline & 0,4 & 786,06 & 865,19 & 55,15 & 772,73 & 13,33 & 1,02 \\
\hline & 0,5 & 743,28 & 868,79 & 55,38 & 772,96 & $-29,68$ & 0,96 \\
\hline & 0,6 & 665,72 & 868,04 & 55,33 & 772,91 & $-107,19$ & 0,86 \\
\hline & 0,7 & 629,82 & 728,21 & 46,42 & 764,00 & $-134,18$ & 0,82 \\
\hline & 0,8 & 572,82 & 867,88 & 55,32 & 772,90 & $-200,09$ & 0,74 \\
\hline \multirow{7}{*}{ 1-Ago } & 0,2 & 879,63 & 911,10 & 58,16 & 775,74 & 103,89 & 1,13 \\
\hline & 0,3 & 830,05 & 910,41 & 58,11 & 775,70 & 54,36 & 1,07 \\
\hline & 0,4 & 755,09 & 907,89 & 57,95 & 775,54 & $-20,44$ & 0,97 \\
\hline & 0,5 & 703,12 & 895,97 & 57,19 & 774,77 & $-71,66$ & 0,91 \\
\hline & 0,6 & 638,65 & 881,49 & 56,27 & 773,85 & $-135,20$ & 0,83 \\
\hline & 0,7 & 597,72 & 896,69 & 57,24 & 774,82 & $-177,11$ & 0,77 \\
\hline & 0,8 & 548,26 & 892,50 & 56,97 & 774,55 & $-226,29$ & 0,71 \\
\hline \multirow{7}{*}{ 15-Ago } & 0,2 & 884,63 & 938,60 & 59,91 & 777,50 & 107,13 & 1,14 \\
\hline & 0,3 & 826,64 & 936,86 & 59,80 & 777,39 & 49,25 & 1,06 \\
\hline & 0,4 & 767,33 & 936,81 & 59,80 & 777,38 & $-10,06$ & 0,99 \\
\hline & 0,5 & 704,01 & 923,01 & 58,92 & 776,50 & $-72,50$ & 0,91 \\
\hline & 0,6 & 658,50 & 926,51 & 59,14 & 776,72 & $-118,23$ & 0,85 \\
\hline & 0,7 & 604,40 & 924,30 & 59,00 & 776,58 & $-172,18$ & 0,78 \\
\hline & 0,8 & 566,09 & 919,11 & 58,67 & 776,25 & $-210,16$ & 0,73 \\
\hline
\end{tabular}


Tabela 17B. Receitas brutas, composição de custos da irrigação, receitas liquidas e relação benefício/custo para o feijão caupi, em cada época de semeadura, nível de manejo da irrigação e risco de $10 \%$. Teresina, Piauí.

\begin{tabular}{|c|c|c|c|c|c|c|c|}
\hline $\begin{array}{l}\text { Época de } \\
\text { Semeadura }\end{array}$ & $p$ & $\begin{array}{c}\mathrm{RB}^{\mathrm{l}} \\
\left(\mathrm{US} \$ \mathrm{ha}^{-1}\right)\end{array}$ & $\begin{array}{c}\mathrm{Eb} \\
\left(\mathrm{kWh} \mathrm{ha}^{-1}\right)\end{array}$ & $\begin{array}{c}\text { CE } \\
\left(\mathrm{US} \$ \mathrm{ha}^{-1}\right)\end{array}$ & $\begin{array}{c}\mathrm{CT} \\
\left(\mathrm{US} \$ \mathrm{ha}^{-1}\right)\end{array}$ & $\begin{array}{c}\mathrm{RL} \\
\left(\mathrm{US} \$ \mathrm{ha}^{-1}\right)\end{array}$ & $\mathrm{B} / \mathrm{C}$ \\
\hline \multirow{7}{*}{$1-$ Set } & 0,2 & 899,62 & 940,21 & 57,24 & 774,82 & 124,80 & 1,16 \\
\hline & 0,3 & 845,81 & 931,29 & 56,69 & 774,28 & 71,54 & 1,09 \\
\hline & 0,4 & 778,62 & 927,43 & 56,46 & 774,04 & 4,57 & 1,01 \\
\hline & 0,5 & 716,39 & 923,89 & 56,24 & 773,83 & $-57,44$ & 0,93 \\
\hline & 0,6 & 666,11 & 916,58 & 55,80 & 773,38 & $-107,27$ & 0,86 \\
\hline & 0,7 & 610,61 & 916,40 & 55,79 & 773,37 & $-162,76$ & 0,79 \\
\hline & 0,8 & 578,65 & 907,67 & 55,26 & 772,84 & $-194,19$ & 0,75 \\
\hline \multirow{7}{*}{$15-$ Set } & 0,2 & 896,58 & 922,38 & 56,15 & 773,74 & 122,85 & 1,16 \\
\hline & 0,3 & 844,11 & 918,84 & 55,94 & 773,52 & 70,59 & 1,09 \\
\hline & 0,4 & 773,34 & 912,13 & 55,53 & 773,11 & 0,23 & 1,00 \\
\hline & 0,5 & 713,40 & 901,74 & 54,89 & 772,48 & $-59,08$ & 0,92 \\
\hline & 0,6 & 661,83 & 901,39 & 54,87 & 772,46 & $-110,63$ & 0,86 \\
\hline & 0,7 & 612,07 & 899,74 & 54,77 & 772,36 & $-160,28$ & 0,79 \\
\hline & 0,8 & 571,69 & 894,09 & 54,43 & 772,01 & $-200,32$ & 0,74 \\
\hline \multirow{7}{*}{ 1-Out } & 0,2 & 919,82 & 893,90 & 55,76 & 773,34 & 146,48 & 1,19 \\
\hline & 0,3 & 867,76 & 888,01 & 55,39 & 772,98 & 94,78 & 1,12 \\
\hline & 0,4 & 793,50 & 880,85 & 54,94 & 772,53 & 20,97 & 1,03 \\
\hline & 0,5 & 737,88 & 878,22 & 54,78 & 772,37 & $-34,48$ & 0,96 \\
\hline & 0,6 & 678,85 & 876,02 & 54,64 & 772,23 & $-93,38$ & 0,88 \\
\hline & 0,7 & 627,78 & 863,11 & 53,84 & 771,42 & $-143,64$ & 0,81 \\
\hline & 0,8 & 582,36 & 859,96 & 53,64 & 771,23 & $-188,87$ & 0,76 \\
\hline \multirow{7}{*}{ 15-Out } & 0,2 & 914,25 & 850,95 & 53,08 & 770,66 & 143,58 & 1,19 \\
\hline & 0,3 & 867,53 & 845,03 & 52,71 & 770,30 & 97,23 & 1,13 \\
\hline & 0,4 & 784,65 & 834,29 & 52,04 & 769,63 & 15,03 & 1,02 \\
\hline & 0,5 & 736,64 & 824,03 & 51,40 & 768,98 & $-32,34$ & 0,96 \\
\hline & 0,6 & 670,92 & 821,58 & 51,25 & 768,83 & $-97,91$ & 0,87 \\
\hline & 0,7 & 629,78 & 811,17 & 50,60 & 768,18 & $-138,41$ & 0,82 \\
\hline & 0,8 & 579,88 & 801,38 & 49,99 & 767,57 & $-187,70$ & 0,76 \\
\hline
\end{tabular}


Tabela 17B. Receitas brutas, composição de custos da irrigação, receitas líquidas e relação benefício/custo para o feijão caupi, em cada época de semeadura, nível de manejo da irrigação e risco de $10 \%$. Teresina, Piauí.

\begin{tabular}{|c|c|c|c|c|c|c|c|}
\hline $\begin{array}{c}\text { Época de } \\
\text { Semeadura }\end{array}$ & $\mathrm{p}$ & $\begin{array}{c}\mathrm{RB}^{1} \\
\left(\mathrm{US} \$ \mathrm{ha}^{-1}\right)\end{array}$ & $\begin{array}{c}E b \\
\left(\mathrm{kWh} \mathrm{ha} \mathrm{h}^{-1}\right)\end{array}$ & $\begin{array}{c}\text { CE } \\
\left(\mathrm{US} \$ \mathrm{ha}^{-1}\right)\end{array}$ & $\begin{array}{c}\text { CT } \\
\left(\mathrm{US} \$ \mathrm{ha}^{-1}\right)\end{array}$ & $\begin{array}{c}\mathrm{RL} \\
\left(\mathrm{US} \$ \mathrm{ha}^{-\mathrm{l}}\right)\end{array}$ & $\mathrm{B} / \mathrm{C}$ \\
\hline \multirow{7}{*}{$1-$ Nov } & 0,2 & 1070,21 & 754,77 & 47,47 & 765,05 & 305,15 & 1,40 \\
\hline & 0,3 & 1007,46 & 744,38 & 46,81 & 764,40 & 243,06 & 1,32 \\
\hline & 0,4 & 919,18 & 731,43 & 46,00 & 763,58 & 155,60 & 1,20 \\
\hline & 0,5 & 859,86 & 721,10 & 45,35 & 762,93 & 96,92 & 1,13 \\
\hline & 0,6 & 788,58 & 708,84 & 44,58 & 762,16 & 26,41 & 1,03 \\
\hline & 0,7 & 739,38 & 697,52 & 43,87 & 761,45 & $-22,07$ & 0,97 \\
\hline & 0,8 & 682,35 & 687,61 & 43,24 & 760,83 & $-78,48$ & 0,90 \\
\hline \multirow{7}{*}{ 15-Nov } & 0,2 & 1064,07 & 671,41 & 42,22 & 759,81 & 304,26 & 1,40 \\
\hline & 0,3 & 1001,49 & 650,65 & 40,92 & 758,50 & 242,99 & 1,32 \\
\hline & 0,4 & 916,73 & 623,38 & 39,20 & 756,79 & 159,94 & 1,21 \\
\hline & 0,5 & 854,04 & 605,42 & 38,07 & 755,66 & 98,38 & 1,13 \\
\hline & 0,6 & 793,37 & 597,21 & 37,56 & 755,14 & 38,23 & 1,05 \\
\hline & 0,7 & 738,21 & 577,91 & 36,34 & 753,93 & $-15,72$ & 0,98 \\
\hline & 0,8 & 691,71 & 561,79 & 35,33 & 752,92 & $-61,21$ & 0,92 \\
\hline \multirow{7}{*}{ 1-Dez } & 0,2 & 1102,93 & 595,37 & 37,21 & 754,79 & 348,13 & 1,46 \\
\hline & 0,3 & 1035,22 & 570,13 & 35,63 & 753,21 & 282,00 & 1,37 \\
\hline & 0,4 & 957,54 & 548,78 & 34,30 & 751,88 & 205,66 & 1,27 \\
\hline & 0,5 & 889,57 & 528,08 & 33,00 & 750,59 & 138,98 & 1,19 \\
\hline & 0,6 & 834,35 & 512,28 & 32,01 & 749,60 & 84,75 & 1,11 \\
\hline & 0,7 & 781,25 & 492,12 & 30,75 & 748,34 & 32,91 & 1,04 \\
\hline & 0,8 & 731,23 & 473,53 & 29,59 & 747,18 & $-15,95$ & 0,98 \\
\hline \multirow{7}{*}{ 15-Dez } & 0,2 & 1103,27 & 529,61 & 33,10 & 750,68 & 352,58 & 1,47 \\
\hline & 0,3 & 1035,07 & 503,63 & 31,47 & 749,06 & 286,01 & 1,38 \\
\hline & 0,4 & 963,51 & 469,02 & 29,31 & 746,90 & 216,61 & 1,29 \\
\hline & 0,5 & 893,62 & 436,97 & 27,31 & 744,89 & 148,73 & 1,20 \\
\hline & 0,6 & 851,66 & 421,02 & 26,31 & 743,90 & 107,76 & 1,14 \\
\hline & 0,7 & 794,50 & 394,96 & 24,68 & 742,27 & 52,24 & 1,07 \\
\hline & 0,8 & 749,33 & 365,00 & 22,81 & 740,40 & 8,94 & 1,01 \\
\hline
\end{tabular}

${ }^{1} \mathrm{RB}$ - receita bruta; $\mathrm{Eb}$ - energia requerida para o bombeamento; $\mathrm{CE}$ - custo de energia elétrica: $\mathrm{CT}$ - custo total de produção; RL - receita líquida e B/C - relação beneficio/custo. 
Tabela 18B. Receitas brutas, composição de custos da irrigação, receitas líquidas e relação beneficio/custo para o feijão caupi, em cada época de semeadura, nível de manejo da irrigação e risco de $15 \%$. Teresina, Piauí.

\begin{tabular}{|c|c|c|c|c|c|c|c|}
\hline $\begin{array}{c}\text { Época de } \\
\text { Semeadura }\end{array}$ & $\mathrm{p}$ & $\begin{array}{c}\mathrm{RB}^{1} \\
\left(\mathrm{US} \$ \mathrm{ha}^{-1}\right)\end{array}$ & $\begin{array}{c}\mathrm{Eb} \\
\left(\mathrm{kWh} \mathrm{ha}^{-1}\right)\end{array}$ & $\begin{array}{c}\mathrm{CE} \\
\left(\mathrm{US} \$ \mathrm{ha}^{-1}\right)\end{array}$ & $\begin{array}{c}\text { CT } \\
\left(\mathrm{US} \$ \mathrm{ha}^{-1}\right)\end{array}$ & $\begin{array}{c}\mathrm{RL} \\
\left(\mathrm{US} \$ \mathrm{ha}^{-1}\right)\end{array}$ & $\mathrm{B} / \mathrm{C}$ \\
\hline \multirow{7}{*}{ 1-Jan } & 0,2 & 1069,56 & 439,68 & 27,13 & 744,71 & 324,85 & 1,44 \\
\hline & 0,3 & 1010,80 & 410,80 & 25,34 & 742,93 & 267,87 & 1,36 \\
\hline & 0,4 & 951,86 & 382,27 & 23,58 & 741,17 & 210,69 & 1,28 \\
\hline & 0,5 & 890,79 & 347,70 & 21,45 & 739,04 & 151,76 & 1,21 \\
\hline & 0,6 & 854,57 & 309,37 & 19,09 & 736,67 & 117,90 & 1,16 \\
\hline & 0,7 & 809,13 & 279,27 & 17,23 & 734,81 & 74,32 & 1,10 \\
\hline & 0,8 & 772,56 & 267,96 & 16,53 & 734,12 & 38,45 & 1,05 \\
\hline \multirow{7}{*}{ 15-Jan } & 0,2 & 1084,68 & 402,25 & 24,82 & 742,40 & 342,28 & 1,46 \\
\hline & 0,3 & 1030,32 & 371,14 & 22,90 & 740,48 & 289,84 & 1,39 \\
\hline & 0,4 & 975,12 & 333,80 & 20,59 & 738,18 & 236,94 & 1,32 \\
\hline & 0,5 & 925,07 & 302,76 & 18,68 & 736,26 & 188,81 & 1,26 \\
\hline & 0,6 & 885,89 & 280,68 & 17,32 & 734,90 & 150,99 & 1,21 \\
\hline & 0,7 & 846,34 & 240,47 & 14,84 & 732,42 & 113,92 & 1,16 \\
\hline & 0,8 & 809,45 & 258,73 & 15,96 & 733,55 & 75,90 & 1,10 \\
\hline \multirow{7}{*}{$1-\mathrm{Fev}$} & 0,2 & 1049,74 & 345,87 & 21,66 & 739,25 & 310,49 & 1,42 \\
\hline & 0,3 & 998,24 & 307,56 & 19,26 & 736,85 & 261,40 & 1,35 \\
\hline & 0,4 & 950,99 & 264,00 & 16,54 & 734,12 & 216,87 & 1,30 \\
\hline & 0,5 & 903,43 & 226,76 & 14,20 & 731,79 & 171,64 & 1,23 \\
\hline & 0,6 & 874,54 & 200,99 & 12,59 & 730,17 & 144,37 & 1,20 \\
\hline & 0,7 & 843,37 & 164,28 & 10,29 & 727,87 & 115,49 & 1,16 \\
\hline & 0,8 & 819,28 & 147,40 & 9,23 & 726,82 & 92,46 & 1,13 \\
\hline \multirow{7}{*}{ 15-Fev } & 0,2 & 1048,33 & 344,46 & 21,58 & 739,16 & 309,17 & 1,42 \\
\hline & 0,3 & 995,38 & 301,91 & 18,91 & 736,50 & 258,88 & 1,35 \\
\hline & 0,4 & 949,08 & 270,39 & 16,94 & 734,52 & 214,56 & 1,29 \\
\hline & 0,5 & 905,42 & 228,10 & 14,29 & 731,87 & 173,55 & 1,24 \\
\hline & 0,6 & 878,44 & 209,53 & 13,12 & 730,71 & 147,73 & 1,20 \\
\hline & 0,7 & 846,14 & 162,47 & 10,18 & 727,76 & 118,37 & 1,16 \\
\hline & 0,8 & 816,16 & 146,94 & 9,20 & 726,79 & 89,37 & 1,12 \\
\hline
\end{tabular}


Tabela 18B. Receitas brutas, composição de custos da irrigação, receitas líquidas e relação beneficio/custo para o feijão caupi, em cada época de semeadura, nível de manejo da irrigação e risco de $15 \%$. Teresina, Piauí.

\begin{tabular}{|c|c|c|c|c|c|c|c|}
\hline $\begin{array}{l}\text { Época de } \\
\text { Semeadura }\end{array}$ & $\mathrm{p}$ & $\begin{array}{c}\mathrm{RB}^{1} \\
\left(\mathrm{US} \$ \mathrm{ha}^{-1}\right)\end{array}$ & $\begin{array}{c}E b \\
\left(\mathrm{kWh} \mathrm{ha} a^{-1}\right)\end{array}$ & $\begin{array}{c}\text { CE } \\
\left(\mathrm{US} \$ h \mathrm{~h}^{-1}\right)\end{array}$ & $\begin{array}{c}\text { CT } \\
\left(\text { US } \$ h^{-1}\right) \\
\end{array}$ & $\begin{array}{c}\mathrm{RL} \\
\left(\mathrm{US} \$ \mathrm{ha}^{-1}\right)\end{array}$ & $\mathrm{B} / \mathrm{C}$ \\
\hline \multirow{7}{*}{ 1-Mar } & 0,2 & 1075,14 & 336,49 & 20,96 & 738,55 & 336,59 & 1,46 \\
\hline & 0,3 & 1016,41 & 300,51 & 18,72 & 736,31 & 280,10 & 1,38 \\
\hline & 0,4 & 971,24 & 248,01 & 15,45 & 733,03 & 238,20 & 1,32 \\
\hline & 0,5 & 927,94 & 225,34 & 14,04 & 731,62 & 196,32 & 1,27 \\
\hline & 0,6 & 893,70 & 198,03 & 12,34 & 729,92 & 163,78 & 1,22 \\
\hline & 0,7 & 858,87 & 170,07 & 10,59 & 728,18 & 130,69 & 1,18 \\
\hline & 0,8 & 828,03 & 145,31 & 9,05 & 726,64 & 101,39 & 1,14 \\
\hline \multirow{7}{*}{ 15-Mar } & 0,2 & 1067,12 & 390,22 & 24,31 & 741,89 & 325,23 & 1,44 \\
\hline & 0,3 & 998,62 & 354,88 & 22,11 & 739,69 & 258,93 & 1,35 \\
\hline & 0,4 & 954,10 & 320,23 & 19,95 & 737,53 & 216,57 & 1,29 \\
\hline & 0,5 & 891,43 & 289,13 & 18,01 & 735,60 & 155,83 & 1,21 \\
\hline & 0,6 & 849,58 & 266,91 & 16,63 & 734,21 & 115,37 & 1,16 \\
\hline & 0,7 & 816,84 & 227,78 & 14,19 & 731,77 & 85,07 & 1,12 \\
\hline & 0,8 & 779,78 & 196,56 & 12,24 & 729,83 & 49,95 & 1,07 \\
\hline \multirow{7}{*}{$1-\mathrm{Abr}$} & 0,2 & 1047,78 & 456,31 & 27,01 & 744,59 & 303,18 & 1,41 \\
\hline & 0,3 & 972,41 & 424,77 & 25,14 & 742,73 & 229,68 & 1,31 \\
\hline & 0,4 & 924,11 & 396,06 & 23,44 & 741,03 & 183,08 & 1,25 \\
\hline & 0,5 & 860,53 & 377,89 & 22,37 & 739,95 & 120,58 & 1,16 \\
\hline & 0,6 & 812,28 & 363,63 & 21,52 & 739,11 & 73,18 & 1,10 \\
\hline & 0,7 & 771,64 & 339,37 & 20,09 & 737,67 & 33,97 & 1,05 \\
\hline & 0,8 & 729,24 & 307,45 & 18,20 & 735,78 & $-6,54$ & 0,99 \\
\hline \multirow{7}{*}{$15-\mathrm{Abr}$} & 0,2 & 1036,93 & 530,63 & 31,41 & 748,99 & 287,94 & 1,38 \\
\hline & 0,3 & 955,93 & 511,95 & 30,30 & 747,89 & 208,05 & 1,28 \\
\hline & 0,4 & 900,41 & 487,81 & 28,87 & 746,46 & 153,95 & 1,21 \\
\hline & 0,5 & 830,74 & 465,84 & 27,57 & 745,16 & 85,58 & 1,11 \\
\hline & 0,6 & 771,93 & 451,69 & 26,74 & 744,32 & 27,61 & 1,04 \\
\hline & 0,7 & 723,22 & 434,23 & 25,70 & 743,29 & $-20,07$ & 0,97 \\
\hline & 0,8 & 680,28 & 415,89 & 24,62 & 742,20 & $-61,92$ & 0,92 \\
\hline
\end{tabular}


Tabela 18B. Receitas brutas, composição de custos da irrigação, receitas líquidas e relação benefício/custo para o feijão caupi, em cada época de semeadura, nível de manejo da irrigação e risco de $15 \%$. Teresina, Piauí.

\begin{tabular}{|c|c|c|c|c|c|c|c|}
\hline $\begin{array}{l}\text { Época de } \\
\text { Semeadura }\end{array}$ & $\mathrm{p}$ & $\begin{array}{c}\mathrm{RB}^{\mathrm{I}} \\
\left(\mathrm{US} \$ \mathrm{ha}^{-1}\right)\end{array}$ & $\begin{array}{c}\mathrm{Eb} \\
\left(\mathrm{kWh} \mathrm{ha}^{-1}\right)\end{array}$ & $\begin{array}{c}\text { CE } \\
\left(\mathrm{US} \$ \mathrm{ha}^{-1}\right)\end{array}$ & $\begin{array}{c}\text { CT } \\
\left(\mathrm{US} \$ \mathrm{ha}^{-1}\right)\end{array}$ & $\begin{array}{c}\mathrm{RL} \\
\left(\mathrm{US} \$ \mathrm{ha}^{-1}\right)\end{array}$ & $\mathrm{B} / \mathrm{C}$ \\
\hline \multirow{7}{*}{ 1-Mai } & 0,2 & 841,61 & 591,28 & 34,04 & 751,63 & 89,98 & 1,12 \\
\hline & 0,3 & 769,61 & 572,07 & 32,94 & 750,52 & 19,09 & 1,03 \\
\hline & 0,4 & 722,65 & 557,20 & 32,08 & 749,67 & $-27,01$ & 0,96 \\
\hline & 0,5 & 661,67 & 550,97 & 31,72 & 749,31 & $-87,64$ & 0,88 \\
\hline & 0,6 & 613,93 & 540,26 & 31,11 & 748,69 & $-134,76$ & 0,82 \\
\hline & 0,7 & 575,72 & 524,32 & 30,19 & 747,77 & $-172,05$ & 0,77 \\
\hline & 0,8 & 531,55 & 512,28 & 29,49 & 747,08 & $-215,53$ & 0,71 \\
\hline \multirow{7}{*}{ 15-Mai } & 0,2 & 839,00 & 646,22 & 37,21 & 754,79 & 84,21 & 1,11 \\
\hline & 0,3 & 773,68 & 634,00 & 36,50 & 754,09 & 19,59 & 1,03 \\
\hline & 0,4 & 719,03 & 626,96 & 36,10 & 753,68 & $-34,65$ & 0,95 \\
\hline & 0,5 & 651,23 & 619,69 & 35,68 & 753,26 & $-102,04$ & 0,86 \\
\hline & 0,6 & 608,81 & 610,72 & 35,16 & 752,75 & $-143,94$ & 0,81 \\
\hline & 0,7 & 563,44 & 597,40 & 34,40 & 751,98 & $-188,54$ & 0,75 \\
\hline & 0,8 & 519,32 & 599,64 & 34,52 & 752,11 & $-232,79$ & 0,69 \\
\hline \multirow{7}{*}{ 1-Jun } & 0,2 & 927,63 & 701,49 & 42,84 & 760,43 & 167,20 & 1,22 \\
\hline & 0,3 & 863,05 & 694,69 & 42,43 & 760,01 & 103,04 & 1,14 \\
\hline & 0,4 & 791,39 & 687,52 & 41,99 & 759,57 & 31,81 & 1,04 \\
\hline & 0,5 & 723,17 & 684,45 & 41,80 & 759,39 & $-36,21$ & 0,95 \\
\hline & 0,6 & 676,29 & 680,65 & 41,57 & 759,15 & $-82,86$ & 0,89 \\
\hline & 0,7 & 622,45 & 674,80 & 41,21 & 758,80 & $-136,34$ & 0,82 \\
\hline & 0,8 & 573,80 & 637,67 & 38,94 & 756,53 & $-182,73$ & 0,76 \\
\hline \multirow{7}{*}{ 15-Jun } & 0,2 & 932,44 & 750,07 & 45,81 & 763,39 & 169,05 & 1,22 \\
\hline & 0,3 & 873,49 & 745,43 & 45,53 & 763,11 & 110,38 & 1,14 \\
\hline & 0,4 & 793,75 & 741,29 & 45,27 & 762,86 & 30,89 & 1,04 \\
\hline & 0,5 & 729,08 & 733,85 & 44,82 & 762,40 & $-33,33$ & 0,96 \\
\hline & 0,6 & 676,25 & 729,17 & 44,53 & 762,12 & $-85,87$ & 0,89 \\
\hline & 0,7 & 622,13 & 726,27 & 44,36 & 761,94 & $-139,81$ & 0,82 \\
\hline & 0,8 & 581,91 & 719,39 & 43,94 & 761,52 & $-179,61$ & 0,76 \\
\hline
\end{tabular}


Tabela 18B. Receitas brutas, composição de custos da irrigação, receitas líquidas e relação benefício/custo para o feijão caupi, em cada época de semeadura, nível de manejo da irrigação e risco de $15 \%$. Teresina, Piauí.

\begin{tabular}{|c|c|c|c|c|c|c|c|}
\hline $\begin{array}{c}\text { Época de } \\
\text { Semeadura }\end{array}$ & $\mathrm{p}$ & $\begin{array}{c}\mathrm{RB}^{\mathrm{l}} \\
\left(\mathrm{US} \$ \mathrm{ha}^{-1}\right)\end{array}$ & $\begin{array}{c}\mathrm{Eb} \\
\left(\mathrm{kWh} \mathrm{ha} \mathrm{a}^{-1}\right)\end{array}$ & $\begin{array}{c}\mathrm{CE} \\
\left(\mathrm{US} \$ \mathrm{ha}^{-1}\right)\end{array}$ & $\begin{array}{c}\mathrm{CT} \\
\left(\mathrm{US} \$ \mathrm{ha}^{-1}\right)\end{array}$ & $\begin{array}{c}\mathrm{RL} \\
\left(\mathrm{US} \$ \mathrm{ha}^{-1}\right)\end{array}$ & $\mathrm{B} / \mathrm{C}$ \\
\hline \multirow{7}{*}{ 1-Jul } & 0,2 & 944,22 & 812,12 & 50,79 & 768,37 & 175,85 & 1,23 \\
\hline & 0,3 & 888,99 & 806,35 & 50,43 & 768,01 & 120,97 & 1,16 \\
\hline & 0,4 & 804,20 & 804,56 & 50,32 & 767,90 & 36,30 & 1,05 \\
\hline & 0,5 & 750,86 & 801,70 & 50,14 & 767,72 & $-16,86$ & 0,98 \\
\hline & 0,6 & 688,74 & 805,24 & 50,36 & 767,94 & $-79,20$ & 0,90 \\
\hline & 0,7 & 636,02 & 787,13 & 49,23 & 766,81 & $-130,79$ & 0,83 \\
\hline & 0,8 & 592,85 & 799,74 & 50,02 & 767,60 & $-174,75$ & 0,77 \\
\hline \multirow{7}{*}{ 15-Jul } & 0,2 & 951,90 & 870,21 & 54,42 & 772,01 & 179,90 & 1,23 \\
\hline & 0,3 & 899,18 & 865,37 & 54,12 & 771,70 & 127,48 & 1,17 \\
\hline & 0,4 & 811,62 & 859,40 & 53,75 & 771,33 & 40,28 & 1,05 \\
\hline & 0,5 & 766,91 & 861,26 & 53,86 & 771,45 & $-4,53$ & 0,99 \\
\hline & 0,6 & 688,54 & 860,15 & 53,79 & 771,38 & $-82,83$ & 0,89 \\
\hline & 0,7 & 651,01 & 728,21 & 45,54 & 763,13 & $-112,12$ & 0,85 \\
\hline & 0,8 & 592,85 & 867,88 & 54,28 & 771,86 & $-179,02$ & 0,77 \\
\hline \multirow{7}{*}{ 1-Ago } & 0,2 & 909,79 & 905,91 & 56,90 & 774,48 & 135,30 & 1,17 \\
\hline & 0,3 & 858,22 & 903,83 & 56,77 & 774,35 & 83,87 & 1,11 \\
\hline & 0,4 & 782,58 & 901,20 & 56,60 & 774,19 & 8,39 & 1,01 \\
\hline & 0,5 & 727,76 & 895,97 & 56,27 & 773,86 & $-46,09$ & 0,94 \\
\hline & 0,6 & 663,17 & 881,49 & 55,36 & 772,95 & $-109,78$ & 0,86 \\
\hline & 0,7 & 619,83 & 886,32 & 55,67 & 773,25 & $-153,42$ & 0,80 \\
\hline & 0,8 & 570,07 & 882,57 & 55,43 & 773,02 & $-202,95$ & 0,74 \\
\hline \multirow{7}{*}{ 15-Ago } & 0,2 & 915,20 & 932,60 & 58,57 & 776,16 & 139,04 & 1,18 \\
\hline & 0,3 & 857,53 & 929,78 & 58,40 & 775,98 & 81,55 & 1,11 \\
\hline & 0,4 & 795,47 & 928,82 & 58,34 & 775,92 & 19,55 & 1,03 \\
\hline & 0,5 & 729,08 & 914,93 & 57,46 & 775,05 & $-45,97$ & 0,94 \\
\hline & 0,6 & 683,10 & 917,37 & 57,62 & 775,20 & $-92,10$ & 0,88 \\
\hline & 0,7 & 627,01 & 913,42 & 57,37 & 774,95 & $-147,94$ & 0,81 \\
\hline & 0,8 & 588,16 & 907,47 & 56,99 & 774,58 & $-186,42$ & 0,76 \\
\hline
\end{tabular}


Tabela 18B. Receitas brutas, composição de custos da irrigação, receitas líquidas e relação benefício/custo para o feijão caupi, em cada época de semeadura, nivel de manejo da irrigação e risco de $15 \%$. Teresina, Piauí.

\begin{tabular}{|c|c|c|c|c|c|c|c|}
\hline $\begin{array}{l}\text { Época de } \\
\text { Semeadura }\end{array}$ & $\mathrm{p}$ & $\begin{array}{c}\mathrm{RB}^{1} \\
\left(\mathrm{US} \$ \mathrm{ha}^{-1}\right)\end{array}$ & $\begin{array}{c}E b \\
\left(\mathrm{kWh} \mathrm{ha}^{-1}\right)\end{array}$ & $\begin{array}{c}\text { CE } \\
\left(\text { US } \$ \mathrm{ha}^{-1}\right)\end{array}$ & $\begin{array}{c}\text { CT } \\
\left(\mathrm{US} \$ \mathrm{ha}^{-1}\right)\end{array}$ & $\begin{array}{c}\mathrm{RL} \\
\left(\mathrm{US} \$ \mathrm{ha}^{-1}\right)\end{array}$ & $\mathrm{B} / \mathrm{C}$ \\
\hline \multirow{7}{*}{ 1-Set } & 0,2 & 929,65 & 932,70 & 56,26 & 773,84 & 155,81 & 1,20 \\
\hline & 0,3 & 873,52 & 923,25 & 55,69 & 773,27 & 100,24 & 1,13 \\
\hline & 0,4 & 806,62 & 918,13 & 55,38 & 772,97 & 33,66 & 1,04 \\
\hline & 0,5 & 740,86 & 912,67 & 55,05 & 772,64 & $-31,78$ & 0,96 \\
\hline & 0,6 & 690,62 & 904,20 & 54,54 & 772,13 & $-81,51$ & 0,89 \\
\hline & 0,7 & 633,28 & 903,27 & 54,48 & 772,07 & $-138,79$ & 0,82 \\
\hline & 0,8 & 600,63 & 893,95 & 53,92 & 771,51 & $-170,87$ & 0,78 \\
\hline \multirow{7}{*}{$15-$ Set } & 0,2 & 926,55 & 913,96 & 55,13 & 772,71 & 153,83 & 1,20 \\
\hline & 0,3 & 871,92 & 908,97 & 54,83 & 772,41 & 99,51 & 1,13 \\
\hline & 0,4 & 801,07 & 900,58 & 54,32 & 771,91 & 29,16 & 1,04 \\
\hline & 0,5 & 738,51 & 889,82 & 53,67 & 771,26 & $-32,75$ & 0,96 \\
\hline & 0,6 & 686,99 & 888,37 & 53,59 & 771,17 & $-84,18$ & 0,89 \\
\hline & 0,7 & 634,98 & 884,16 & 53,33 & 770,92 & $-135,93$ & 0,82 \\
\hline & 0,8 & 594,11 & 878,77 & 53,01 & 770,59 & $-176,48$ & 0,77 \\
\hline \multirow{7}{*}{ 1-Out } & 0,2 & 945,56 & 884,86 & 54,49 & 772,08 & 173,48 & 1,22 \\
\hline & 0,3 & 891,93 & 878,27 & 54,09 & 771,67 & 120,26 & 1,16 \\
\hline & 0,4 & 817,29 & 869,54 & 53,55 & 771,13 & 46,16 & 1,06 \\
\hline & 0,5 & 759,77 & 864,89 & 53,26 & 770,85 & $-11,08$ & 0,99 \\
\hline & 0,6 & 700,47 & 860,16 & 52,97 & 770,56 & $-70,09$ & 0,91 \\
\hline & 0,7 & 648,08 & 847,67 & 52,20 & 769,79 & $-121,71$ & 0,84 \\
\hline & 0,8 & 602,11 & 843,69 & 51,96 & 769,54 & $-167,43$ & 0,78 \\
\hline \multirow{7}{*}{ 15-Out } & 0,2 & 939,92 & 840,78 & 51,78 & 769,36 & 170,56 & 1,22 \\
\hline & 0,3 & 891,68 & 833,21 & 51,31 & 768,90 & 122,78 & 1,16 \\
\hline & 0,4 & 808,08 & 821,10 & 50,57 & 768,15 & 39,93 & 1,05 \\
\hline & 0,5 & 758,84 & 808,44 & 49,79 & 767,37 & $-8,53$ & 0,99 \\
\hline & 0,6 & 692,86 & 804,71 & 49,56 & 767,14 & $-74,29$ & 0,90 \\
\hline & 0,7 & 650,43 & 793,99 & 48,90 & 766,48 & $-116,05$ & 0,85 \\
\hline & 0,8 & 600,12 & 783,80 & 48,27 & 765,85 & $-165,73$ & 0,78 \\
\hline
\end{tabular}


Tabela 18B. Receitas brutas, composição de custos da irrigação, receitas líquidas e relação benefício/custo para o feijão caupi, em cada época de semeadura, nivel de manejo da irrigação e risco de $15 \%$. Teresina, Piauí.

\begin{tabular}{|c|c|c|c|c|c|c|c|}
\hline $\begin{array}{l}\text { Época de } \\
\text { Semeadura }\end{array}$ & $\mathrm{p}$ & $\begin{array}{c}\mathrm{RB}^{1} \\
\left(\mathrm{US} \$ \mathrm{ha}^{-1}\right)\end{array}$ & $\begin{array}{c}E b \\
\left(\mathrm{kWh} \mathrm{ha} \mathrm{a}^{-1}\right)\end{array}$ & $\begin{array}{c}\text { CE } \\
\left(\text { US } \$ h^{-1}{ }^{-1}\right)\end{array}$ & $\begin{array}{c}\text { CT } \\
\left(\text { US } \$ h^{-1}\right)^{-1}\end{array}$ & $\begin{array}{c}\mathrm{RL} \\
\left(\mathrm{US} \$ \mathrm{ha}^{-1}\right)\end{array}$ & $\mathrm{B} / \mathrm{C}$ \\
\hline \multirow{7}{*}{$1-\mathrm{Nov}$} & 0,2 & 1097,77 & 741,79 & 45,98 & 763,57 & 334,21 & 1,44 \\
\hline & 0,3 & 1034,93 & 729,35 & 45,21 & 762,80 & 272,13 & 1,36 \\
\hline & 0,4 & 944,85 & 713,48 & 44,23 & 761,81 & 183,03 & 1,24 \\
\hline & 0,5 & 885,62 & 702,71 & 43,56 & 761,15 & 124,47 & 1,16 \\
\hline & 0,6 & 813,68 & 688,62 & 42,69 & 760,27 & 53,41 & 1,07 \\
\hline & 0,7 & 763,91 & 675,65 & 41,88 & 759,47 & 4,44 & 1,01 \\
\hline & 0,8 & 706,83 & 663,64 & 41,14 & 758,72 & $-51,90$ & 0,93 \\
\hline \multirow{7}{*}{ 15-Nov } & 0,2 & 1092,14 & 656,70 & 40,71 & 758,29 & 333,84 & 1,44 \\
\hline & 0,3 & 1029,32 & 634,42 & 39,33 & 756,91 & 272,40 & 1,36 \\
\hline & 0,4 & 944,04 & 605,37 & 37,53 & 755,11 & 188,92 & 1,25 \\
\hline & 0,5 & 881,88 & 585,65 & 36,31 & 753,89 & 127,99 & 1,17 \\
\hline & 0,6 & 820,89 & 574,25 & 35,60 & 753,18 & 67,71 & 1,09 \\
\hline & 0,7 & 765,66 & 554,07 & 34,35 & 751,93 & 13,73 & 1,02 \\
\hline & 0,8 & 719,61 & 537,47 & 33,32 & 750,90 & $-31,29$ & 0,96 \\
\hline \multirow{7}{*}{ 1-Dez } & 0,2 & 1129,22 & 581,56 & 35,66 & 753,25 & 375,98 & 1,50 \\
\hline & 0,3 & 1061,93 & 554,79 & 34,02 & 751,61 & 310,32 & 1,41 \\
\hline & 0,4 & 983,20 & 530,70 & 32,54 & 750,13 & 233,08 & 1,31 \\
\hline & 0,5 & 915,65 & 507,35 & 31,11 & 748,70 & 166,95 & 1,22 \\
\hline & 0,6 & 860,45 & 491,85 & 30,16 & 747,75 & 112,70 & 1,15 \\
\hline & 0,7 & 806,89 & 468,13 & 28,71 & 746,29 & 60,60 & 1,08 \\
\hline & 0,8 & 757,63 & 447,26 & 27,43 & 745,01 & 12,62 & 1,02 \\
\hline \multirow{7}{*}{ 15-Dez } & 0,2 & 1130,01 & 514,31 & 31,54 & 749,12 & 380,89 & 1,51 \\
\hline & 0,3 & 1062,42 & 486,77 & 29,85 & 747,43 & 314,98 & 1,42 \\
\hline & 0,4 & 989,90 & 450,83 & 27,65 & 745,23 & 244,67 & 1,33 \\
\hline & 0,5 & 921,26 & 417,94 & 25,63 & 743,21 & 178,04 & 1,24 \\
\hline & 0,6 & 878,87 & 399,45 & 24,49 & 742,08 & 136,79 & 1,18 \\
\hline & 0,7 & 822,93 & 372,34 & 22,83 & 740,42 & 82,51 & 1,11 \\
\hline & 0,8 & 778,28 & 342,06 & 20,98 & 738,56 & 39,72 & 1,05 \\
\hline
\end{tabular}

${ }^{\mathrm{T}} \mathrm{RB}$ - receita bruta; $\mathrm{Eb}$ - energia requerida para o bombeamento; $\mathrm{CE}$ - custo de energia elétrica; $\mathrm{CT}$ - custo total de produção; $R L$ - receita líquida e $B / C$ - relação benefício/custo. 
Tabela 19B. Receitas brutas, composição de custos da irrigação, receitas líquidas e relação benefício/custo para o feijão caupi, em cada época de semeadura, nível de manejo da irrigação e risco de $20 \%$. Teresina, Piauí.

\begin{tabular}{|c|c|c|c|c|c|c|c|}
\hline $\begin{array}{l}\text { Época de } \\
\text { Semeadura }\end{array}$ & $\mathrm{p}$ & $\begin{array}{c}\mathrm{RB} \\
\left(\mathrm{US} \$ \mathrm{ha}^{-1}\right)\end{array}$ & $\begin{array}{c}E b \\
\left(\mathrm{kWh} \mathrm{ha}{ }^{-1}\right)\end{array}$ & $\begin{array}{c}C E \\
\left(U S \$ h a^{-1}\right)\end{array}$ & $\begin{array}{c}\text { CT } \\
\left(\mathrm{US} \$ \mathrm{ha}^{-1}\right)\end{array}$ & $\begin{array}{c}\mathrm{RL} \\
\left(\mathrm{US} \$ \mathrm{ha}^{-1}\right)\end{array}$ & $\mathrm{B} / \mathrm{C}$ \\
\hline \multirow{7}{*}{ 1-Jan } & 0,2 & 1097,59 & 427,32 & 25,83 & 743,42 & 354,17 & 1,48 \\
\hline & 0,3 & 1039,41 & 397,30 & 24,02 & 741,60 & 297,80 & 1,40 \\
\hline & 0,4 & 979,79 & 366,46 & 22,16 & 739,74 & 240,05 & 1,32 \\
\hline & 0,5 & 918,93 & 330,72 & 19,99 & 737,58 & 181,35 & 1,25 \\
\hline & 0,6 & 882,86 & 292,29 & 17,67 & 735,26 & 147,61 & 1,20 \\
\hline & 0,7 & 838,43 & 262,49 & 15,87 & 733,45 & 104,98 & 1,14 \\
\hline & 0,8 & 802,68 & 249,79 & 15,10 & 732,69 & 69,99 & 1,10 \\
\hline \multirow{7}{*}{ 15-Jan } & 0,2 & 1113,69 & 389,71 & 23,56 & 741,15 & 372,54 & 1,50 \\
\hline & 0,3 & 1059,40 & 356,90 & 21,58 & 739,16 & 320,23 & 1,43 \\
\hline & 0,4 & 1004,17 & 319,01 & 19,29 & 736,87 & 267,30 & 1,36 \\
\hline & 0,5 & 954,05 & 286,53 & 17,32 & 734,91 & 219,14 & 1,30 \\
\hline & 0,6 & 915,44 & 262,45 & 15,87 & 733,45 & 181,99 & 1,25 \\
\hline & 0,7 & 876,70 & 223,56 & 13,52 & 731,10 & 145,60 & 1,20 \\
\hline & 0,8 & 841,45 & 164,65 & 9,95 & 727,54 & 113,91 & 1,16 \\
\hline \multirow{7}{*}{$1-\mathrm{Fev}$} & 0,2 & 1079,81 & 334,80 & 20,39 & 737,97 & 341,84 & 1,46 \\
\hline & 0,3 & 1028,50 & 294,70 & 17,95 & 735,53 & 292,96 & 1,40 \\
\hline & 0,4 & 981,28 & 250,88 & 15,28 & 732,86 & 248,41 & 1,34 \\
\hline & 0,5 & 934,40 & 213,93 & 13,03 & 730,61 & 203,79 & 1,28 \\
\hline & 0,6 & 906,36 & 188,58 & 11,48 & 729,07 & 177,29 & 1,24 \\
\hline & 0,7 & 875,61 & 164,28 & 10,00 & 727,59 & 148,02 & 1,20 \\
\hline & 0,8 & 852,20 & 147,40 & 8,98 & 726,56 & 125,64 & 1,17 \\
\hline \multirow{7}{*}{$15-\mathrm{Fev}$} & 0,2 & 1078,54 & 330,07 & 20,10 & 737,69 & 340,85 & 1,46 \\
\hline & 0,3 & 1025,96 & 287,55 & 17,51 & 735,10 & 290,86 & 1,40 \\
\hline & 0,4 & 980,14 & 254,31 & 15,49 & 733,07 & 247,07 & 1,34 \\
\hline & 0,5 & 936,85 & 212,03 & 12,91 & 730,50 & 206,35 & 1,28 \\
\hline & 0,6 & 910,67 & 192,81 & 11,74 & 729,33 & 181,35 & 1,25 \\
\hline & 0,7 & 879,82 & 162,47 & 9,89 & 727,48 & 152,34 & 1,21 \\
\hline & 0,8 & 851,64 & 146,94 & 8,95 & 726,53 & 125,10 & 1,17 \\
\hline
\end{tabular}


Tabela 19B. Receitas brutas, composição de custos da irrigação, receitas líquidas e relação benefício/custo para o feijão caupi, em cada época de semeadura. nível de manejo da irrigação e risco de $20 \%$. Teresina, Piauí

\begin{tabular}{|c|c|c|c|c|c|c|c|}
\hline $\begin{array}{l}\text { Época de } \\
\text { Semeadura }\end{array}$ & $\mathrm{p}$ & $\begin{array}{c}\text { RB } \\
\left(\mathrm{US} \$ \mathrm{ha}^{-1}\right)\end{array}$ & $\begin{array}{c}E b \\
\left(\mathrm{kWh} \mathrm{ha}^{-1}\right)\end{array}$ & $\begin{array}{c}\mathrm{CE} \\
\left(\mathrm{US} \$ \mathrm{ha}^{-1}\right)\end{array}$ & $\begin{array}{c}\mathrm{CT} \\
\left(\mathrm{US} \$ \mathrm{ha}^{-1}\right)\end{array}$ & $\begin{array}{c}\mathrm{RL} \\
\left(\mathrm{US} \$ \mathrm{ha}^{-1}\right)\end{array}$ & $\mathrm{B} / \mathrm{C}$ \\
\hline \multirow{7}{*}{ 1-Mar } & 0,2 & 1106,97 & 324,05 & 19,62 & 737,20 & 369,77 & 1,50 \\
\hline & 0,3 & 1048,79 & 286,36 & 17,34 & 734,92 & 313,87 & 1,43 \\
\hline & 0,4 & 1003,48 & 233,80 & 14,15 & 731,74 & 271,74 & 1,37 \\
\hline & 0,5 & 960,72 & 210,64 & 12,75 & 730,34 & 230,39 & 1,32 \\
\hline & 0,6 & 927,54 & 184,29 & 11,16 & 728,74 & 198,79 & 1,27 \\
\hline & 0,7 & 893,74 & 156,41 & 9,47 & 727,05 & 166,68 & 1,23 \\
\hline & 0,8 & 864,27 & 113,02 & 6,84 & 724,43 & 139,84 & 1,19 \\
\hline \multirow{7}{*}{ 15-Mar } & 0,2 & 1098,55 & 377,59 & 22,86 & 740,44 & 358,10 & 1,48 \\
\hline & 0,3 & 1029,76 & 340,03 & 20,58 & 738,17 & 291,59 & 1,40 \\
\hline & 0,4 & 985,33 & 304,57 & 18,44 & 736,02 & 249,30 & 1,34 \\
\hline & 0,5 & 923,36 & 272,89 & 16,52 & 734,11 & 189,25 & 1,26 \\
\hline & 0,6 & 882,03 & 250,12 & 15,14 & 732,73 & 149,30 & 1,20 \\
\hline & 0,7 & 849,71 & 211,84 & 12,82 & 730,41 & 119,30 & 1,16 \\
\hline & 0,8 & 813,65 & 196,56 & 11,90 & 729,48 & 84,17 & 1,12 \\
\hline \multirow{7}{*}{$1-A b r$} & 0,2 & 1078,91 & 443,79 & 25,56 & 743,14 & 335,76 & 1,45 \\
\hline & 0,3 & 1003,41 & 411,61 & 23,70 & 741,29 & 262,12 & 1,35 \\
\hline & 0,4 & 954,70 & 382,16 & 22,01 & 739,59 & 215,11 & 1,29 \\
\hline & 0,5 & 890,89 & 361,53 & 20,82 & 738,40 & 152,49 & 1,21 \\
\hline & 0,6 & 842,95 & 344,82 & 19,86 & 737,44 & 105,50 & 1,14 \\
\hline & 0,7 & 802,70 & 320,72 & 18,47 & 736,05 & 66,65 & 1,09 \\
\hline & 0,8 & 761,09 & 289,17 & 16,65 & 734,24 & 26,85 & 1,04 \\
\hline \multirow{7}{*}{ 15-Abr } & 0,2 & 1067,61 & 519,79 & 29,93 & 747,52 & 320,09 & 1,43 \\
\hline & 0,3 & 985,68 & 499,59 & 28,77 & 746,36 & 239,32 & 1,32 \\
\hline & 0,4 & 929,41 & 473,43 & 27,26 & 744,85 & 184,56 & 1,25 \\
\hline & 0,5 & 859,27 & 449,84 & 25,91 & 743,49 & 115,78 & 1,16 \\
\hline & 0,6 & 800,35 & 435,09 & 25,06 & 742,64 & 57,71 & 1,08 \\
\hline & 0,7 & 751,69 & 416,90 & 24,01 & 741,59 & 10,10 & 1,01 \\
\hline & 0,8 & 708,58 & 397,70 & 22,90 & 740,49 & $-31,91$ & 0,96 \\
\hline
\end{tabular}


Tabela 19B. Receitas brutas, composição de custos da irrigação, receitas líquidas e relação benefício/custo para o feijão caupi, em cada época de semeadura, nível de manejo da irrigação e risco de $20 \%$. Teresina, Piauí.

\begin{tabular}{|c|c|c|c|c|c|c|c|}
\hline $\begin{array}{l}\text { Época de } \\
\text { Semeadura }\end{array}$ & $p$ & $\begin{array}{c}\mathrm{RB} \\
\left(\mathrm{US} \$ \mathrm{ha}^{-1}\right)\end{array}$ & $\begin{array}{c}E b \\
\left(\mathrm{kWh} \mathrm{ha}{ }^{-1}\right)\end{array}$ & $\begin{array}{c}\text { CE } \\
\left(\mathrm{US} \$ \mathrm{ha}^{-1}\right)\end{array}$ & $\begin{array}{c}\mathrm{CT} \\
\left(\mathrm{US} \$ \mathrm{ha} \mathrm{a}^{-1}\right)\end{array}$ & $\begin{array}{c}\mathrm{RL} \\
\left(\mathrm{US} \$ \mathrm{ha}^{-1}\right)\end{array}$ & $B / C$ \\
\hline \multirow{7}{*}{ 1-Mai } & 0,2 & 876,56 & 580,62 & 32,75 & 750,34 & 126,22 & 1,17 \\
\hline & 0,3 & 803,05 & 560,02 & 31,59 & 749,18 & 53,87 & 1,07 \\
\hline & 0,4 & 754,71 & 543,72 & 30,67 & 748,26 & 6,46 & 1,01 \\
\hline & 0,5 & 692,21 & 534,95 & 30,18 & 747,76 & $-55,56$ & 0,93 \\
\hline & 0,6 & 643,34 & 523,23 & 29,52 & 747,10 & $-103,76$ & 0,86 \\
\hline & 0,7 & 604,81 & 507,28 & 28,62 & 746,20 & $-141,39$ & 0,81 \\
\hline & 0,8 & 559,28 & 492,47 & 27,78 & 745,37 & $-186,09$ & 0,75 \\
\hline \multirow{7}{*}{ 15-Mai } & 0,2 & 873,64 & 639,02 & 36,05 & 753,63 & 120,01 & 1,16 \\
\hline & 0,3 & 806,94 & 625,88 & 35,31 & 752,89 & 54,04 & 1,07 \\
\hline & 0,4 & 749,87 & 617,35 & 34,83 & 752,41 & $-2,54$ & 1,00 \\
\hline & 0,5 & 680,68 & 608,89 & 34,35 & 751,93 & $-71,26$ & 0,91 \\
\hline & 0,6 & 637,06 & 599,28 & 33,81 & 751,39 & $-114,34$ & 0,85 \\
\hline & 0,7 & 589,94 & 584,85 & 32,99 & 750,58 & $-160,64$ & 0,79 \\
\hline & 0,8 & 545,28 & 585,24 & 33,01 & 750,60 & $-205,32$ & 0,73 \\
\hline \multirow{7}{*}{ 1-Jun } & 0,2 & 959,17 & 695,63 & 41,58 & 759,16 & 200,01 & 1,26 \\
\hline & 0,3 & 893,59 & 687,69 & 41,10 & 758,69 & 134,90 & 1,18 \\
\hline & 0,4 & 819,47 & 680,50 & 40,67 & 758,26 & 61,21 & 1,08 \\
\hline & 0,5 & 749,58 & 676,40 & 40,43 & 758,01 & $-8,44$ & 0,99 \\
\hline & 0,6 & 701,72 & 670,76 & 40,09 & 757,67 & $-55,95$ & 0,93 \\
\hline & 0,7 & 646,24 & 665,41 & 39,77 & 757,36 & $-111,11$ & 0,85 \\
\hline & 0,8 & 596,48 & 637,67 & 38,11 & 755,70 & $-159,21$ & 0,79 \\
\hline \multirow{7}{*}{ 15-Jun } & 0,2 & 964,08 & 745,35 & 44,55 & 762,13 & 201,94 & 1,26 \\
\hline & 0,3 & 904,27 & 739,66 & 44,21 & 761,79 & 142,47 & 1,19 \\
\hline & 0,4 & 821,52 & 734,59 & 43,91 & 761,49 & 60,03 & 1,08 \\
\hline & 0,5 & 756,33 & 726,78 & 43,44 & 761,02 & $-4,69$ & 0,99 \\
\hline & 0,6 & 701,15 & 721,45 & 43,12 & 760,70 & $-59,55$ & 0,92 \\
\hline & 0,7 & 645,67 & 717,97 & 42,91 & 760,50 & $-114,83$ & 0,85 \\
\hline & 0,8 & 603,92 & 710,20 & 42,45 & 760,03 & $-156,11$ & 0,79 \\
\hline
\end{tabular}


Tabela 19B. Receitas brutas, composição de custos da irrigação, receitas líquidas e relação benefício/custo para o feijão caupi, em cada época de semeadura, nível de manejo da irrigação e risco de $20 \%$. Teresina, Piauí.

\begin{tabular}{|c|c|c|c|c|c|c|c|}
\hline $\begin{array}{l}\text { Época de } \\
\text { Semeadura }\end{array}$ & $\mathrm{p}$ & $\begin{array}{c}\mathrm{RB} \\
\left(\mathrm{US} \$ \mathrm{ha}^{-1}\right)\end{array}$ & $\begin{array}{c}E b \\
\left(\mathrm{kWh} \mathrm{ha} a^{-1}\right)\end{array}$ & $\begin{array}{c}C E \\
\left(\mathrm{US} \$ \mathrm{ha}^{-\mathrm{I}}\right)\end{array}$ & $\begin{array}{c}\text { CT } \\
\left(\text { US\$ ha }{ }^{-1}\right)\end{array}$ & $\begin{array}{c}\mathrm{RL} \\
\left(\mathrm{US} \$ \mathrm{ha}^{-1}\right)\end{array}$ & $\mathrm{B} / \mathrm{C}$ \\
\hline \multirow{7}{*}{ 1-Jul } & 0,2 & 972,87 & 808,21 & 49,70 & 767,29 & 205,58 & 1,27 \\
\hline & 0,3 & 916,71 & 802,43 & 49,35 & 766,93 & 149,78 & 1,20 \\
\hline & 0,4 & 829,12 & 799,85 & 49,19 & 766,77 & 62,35 & 1,08 \\
\hline & 0,5 & 775,21 & 795,80 & 48,94 & 766,52 & 8,69 & 1,01 \\
\hline & 0,6 & 711,45 & 781,33 & 48,05 & 765,63 & $-54,19$ & 0,93 \\
\hline & 0,7 & 658,14 & 780,51 & 48,00 & 765,58 & $-107,44$ & 0,86 \\
\hline & 0,8 & 612,69 & 791,52 & 48,67 & 766,26 & $-153,56$ & 0,80 \\
\hline \multirow{7}{*}{ 15-Jul } & 0,2 & 981,08 & 866,03 & 53,26 & 770,84 & 210,24 & 1,27 \\
\hline & 0,3 & 926,87 & 860,97 & 52,95 & 770,53 & 156,34 & 1,20 \\
\hline & 0,4 & 837,41 & 854,80 & 52,57 & 770,15 & 67,26 & 1,09 \\
\hline & 0,5 & 790,86 & 855,27 & 52,59 & 770,18 & 20,68 & 1,03 \\
\hline & 0,6 & 711,39 & 853,87 & 52,51 & 770,09 & $-58,70$ & 0,92 \\
\hline & 0,7 & 672,29 & 703,14 & 43,24 & 760,82 & $-88,54$ & 0,88 \\
\hline & 0,8 & 612,84 & 844,33 & 51,92 & 769,51 & $-156,67$ & 0,80 \\
\hline \multirow{7}{*}{ 1-Ago } & 0,2 & 940,49 & 901,77 & 55,80 & 773,38 & 167,11 & 1,22 \\
\hline & 0,3 & 886,95 & 898,59 & 55,60 & 773,18 & 113,77 & 1,15 \\
\hline & 0,4 & 810,29 & 895,87 & 55,43 & 773,02 & 37,28 & 1,05 \\
\hline & 0,5 & 752,77 & 895,97 & 55,44 & 773,02 & $-20,25$ & 0,97 \\
\hline & 0,6 & 687,70 & 881,49 & 54,54 & 772,13 & $-84,43$ & 0,89 \\
\hline & 0,7 & 642,08 & 878,07 & 54,33 & 771,91 & $-129,84$ & 0,83 \\
\hline & 0,8 & 591,77 & 874,68 & 54,12 & 771,70 & $-179,94$ & 0,77 \\
\hline \multirow{7}{*}{ 15-Ago } & 0,2 & 946,28 & 927,82 & 57,41 & 774,99 & 171,29 & 1,22 \\
\hline & 0,3 & 884,94 & 924,14 & 57,18 & 774,77 & 110,17 & 1,14 \\
\hline & 0,4 & 823,83 & 922,48 & 57,08 & 774,66 & 49,16 & 1,06 \\
\hline & 0,5 & 754,45 & 908,51 & 56,21 & 773,80 & $-19,35$ & 0,97 \\
\hline & 0,6 & 707,82 & 910,09 & 56,31 & 773,90 & $-66,08$ & 0,91 \\
\hline & 0,7 & 649,71 & 904,77 & 55,98 & 773,57 & $-123,85$ & 0,84 \\
\hline & 0,8 & 610,18 & 898,21 & 55,58 & 773,16 & $-162,98$ & 0,79 \\
\hline
\end{tabular}


Tabela 19B. Receitas brutas, composição de custos da irrigação, receitas líquidas e relação benefício/custo para o feijão caupi, em cada época de semeadura, nível de manejo da irrigação e risco de $20 \%$. Teresina, Piauí.

\begin{tabular}{|c|c|c|c|c|c|c|c|}
\hline $\begin{array}{l}\text { Época de } \\
\text { Semeadura }\end{array}$ & $\mathrm{p}$ & $\begin{array}{c}\mathrm{RB} \\
\left(\mathrm{US} \$ \mathrm{ha}^{-1}\right)\end{array}$ & $\begin{array}{c}E b \\
\left(\mathrm{kWh} \mathrm{ha}^{-1}\right)\end{array}$ & $\begin{array}{c}\text { CE } \\
\left(\text { US } \$ h^{-1}\right)\end{array}$ & $\begin{array}{c}\mathrm{CT} \\
\left(\mathrm{US} \$ \mathrm{ha}^{-1}\right)\end{array}$ & $\begin{array}{c}\mathrm{RL} \\
\left(\mathrm{US} \$ \mathrm{ha}^{-1}\right)\end{array}$ & $\mathrm{B} / \mathrm{C}$ \\
\hline \multirow{7}{*}{1 -Set } & 0,2 & 960,18 & 926,73 & 55,37 & 772,95 & 187,22 & 1,24 \\
\hline & 0,3 & 901,77 & 916,87 & 54,78 & 772,36 & 129,41 & 1,17 \\
\hline & 0,4 & 834,76 & 910,73 & 54,41 & 772,00 & 62,76 & 1,08 \\
\hline & 0,5 & 765,65 & 903,76 & 54,00 & 771,58 & $-5,93$ & 0,99 \\
\hline & 0,6 & 715,16 & 894,37 & 53,43 & 771,02 & $-55,86$ & 0,93 \\
\hline & 0,7 & 655,95 & 892,84 & 53,34 & 770,93 & $-114,97$ & 0,85 \\
\hline & 0,8 & 622,54 & 883,04 & 52,76 & 770,34 & $-147,80$ & 0,81 \\
\hline \multirow{7}{*}{ 15-Set } & 0,2 & 957,00 & 907,26 & 54,20 & 771,79 & 185,21 & 1,24 \\
\hline & 0,3 & 900,25 & 901,13 & 53,84 & 771,42 & 128,82 & 1,17 \\
\hline & 0,4 & 828,94 & 891,39 & 53,26 & 770,84 & 58,09 & 1,08 \\
\hline & 0,5 & 763,82 & 880,34 & 52,60 & 770,18 & $-6,36$ & 0,99 \\
\hline & 0,6 & 712,05 & 878,03 & 52,46 & 770,04 & $-57,99$ & 0,92 \\
\hline & 0,7 & 657,86 & 871,77 & 52,08 & 769,67 & $-111,81$ & 0,85 \\
\hline & 0,8 & 616,35 & 866,60 & 51,78 & 769,36 & $-153,01$ & 0,80 \\
\hline \multirow{7}{*}{ 1-Out } & 0,2 & 971,66 & 877,68 & 53,40 & 770,99 & 200,68 & 1,26 \\
\hline & 0,3 & 916,47 & 870,53 & 52,97 & 770,55 & 145,92 & 1,19 \\
\hline & 0,4 & 841,15 & 860,54 & 52,36 & 769,94 & 71,21 & 1,09 \\
\hline & 0,5 & 781,76 & 854,30 & 51,98 & 769,56 & 12,20 & 1,02 \\
\hline & 0,6 & 721,95 & 847,55 & 51,57 & 769,15 & $-47,21$ & 0,94 \\
\hline & 0,7 & 668,20 & 835,40 & 50,83 & 768,41 & $-100,22$ & 0,87 \\
\hline & 0,8 & 621,55 & 830,76 & 50,55 & 768,13 & $-146,58$ & 0,81 \\
\hline \multirow{7}{*}{ 15-Out } & 0,2 & 965,95 & 832,70 & 50,66 & 768,25 & 197,70 & 1,26 \\
\hline & 0,3 & 916,20 & 823,82 & 50,12 & 767,71 & 148,49 & 1,19 \\
\hline & 0,4 & 831,59 & 810,61 & 49,32 & 766,90 & 64,69 & 1,08 \\
\hline & 0,5 & 781,09 & 796,05 & 48,43 & 766,02 & 15,07 & 1,02 \\
\hline & 0,6 & 714,56 & 791,31 & 48,15 & 765,73 & $-51,17$ & 0,93 \\
\hline & 0,7 & 670,85 & 780,33 & 47,48 & 765,06 & $-94,21$ & 0,88 \\
\hline & 0,8 & 619,96 & 769,83 & 46,84 & 764,42 & $-144,46$ & 0,81 \\
\hline
\end{tabular}


Tabela 19B. Receitas brutas, composição de custos da irrigação, receitas líquidas e relação beneficio/custo para o feijão caupi, em cada época de semeadura, nível de manejo da irrigação e risco de $20 \%$. Teresina, Piauí.

\begin{tabular}{|c|c|c|c|c|c|c|c|}
\hline $\begin{array}{c}\text { Época de } \\
\text { Semeadura }\end{array}$ & $\mathrm{p}$ & $\begin{array}{c}R B \\
\left(U S \$ h^{-1}\right) \\
\end{array}$ & $\begin{array}{c}E b \\
\left(\mathrm{kWh} \mathrm{ha}{ }^{-1}\right)\end{array}$ & $\begin{array}{c}\text { CE } \\
\left(\mathrm{US} \$ \mathrm{ha}^{-1}\right)\end{array}$ & $\begin{array}{c}\text { CT } \\
\left(\text { US } \$ \text { ha }^{-1}\right)\end{array}$ & $\begin{array}{c}\mathrm{RL} \\
\left(\mathrm{US} \$ \mathrm{ha}^{-1}\right)\end{array}$ & $\mathrm{B} / \mathrm{C}$ \\
\hline \multirow{7}{*}{$1-\mathrm{Nov}$} & 0,2 & 1125,75 & 731,47 & 44,77 & 762,35 & 363,40 & 1,48 \\
\hline & 0,3 & 1062,53 & 717,41 & 43,90 & 761,49 & 301,04 & 1,40 \\
\hline & 0,4 & 970,54 & 699,21 & 42,79 & 760,38 & 210,16 & 1,28 \\
\hline & 0,5 & 911,12 & 688,09 & 42,11 & 759,69 & 151,42 & 1,20 \\
\hline & 0,6 & 838,31 & 672,55 & 41,16 & 758,74 & 79,57 & 1,10 \\
\hline & 0,7 & 787,82 & 658,27 & 40,29 & 757,87 & 29,95 & 1,04 \\
\hline & 0,8 & 730,44 & 644,59 & 39,45 & 757,03 & $-26,59$ & 0,96 \\
\hline \multirow{7}{*}{ 15-Nov } & 0,2 & 1120,50 & 645,01 & 39,47 & 757,06 & 363,44 & 1,48 \\
\hline & 0,3 & 1057,19 & 621,53 & 38,04 & 755,62 & 301,57 & 1,40 \\
\hline & 0,4 & 971,09 & 591,06 & 36,17 & 753,76 & 217,33 & 1,29 \\
\hline & 0,5 & 909,10 & 569,94 & 34,88 & 752,46 & 156,63 & 1,21 \\
\hline & 0,6 & 847,56 & 556,01 & 34,03 & 751,61 & 95,95 & 1,13 \\
\hline & 0,7 & 792,02 & 535,12 & 32,75 & 750,33 & 41,69 & 1,06 \\
\hline & 0,8 & 746,14 & 518,15 & 31,71 & 749,29 & $-3,16$ & 1,00 \\
\hline \multirow{7}{*}{ 1-Dez } & 0,2 & 1155,82 & 570,59 & 34,43 & 752,01 & 403,81 & 1,54 \\
\hline & 0,3 & 1088,58 & 542,60 & 32,74 & 750,32 & 338,26 & 1,45 \\
\hline & 0,4 & 1008,66 & 516,33 & 31,15 & 748,74 & 259,93 & 1,35 \\
\hline & 0,5 & 941,16 & 490,87 & 29,62 & 747,20 & 193,96 & 1,26 \\
\hline & 0,6 & 885,75 & 475,61 & 28,69 & 746,28 & 139,47 & 1,19 \\
\hline & 0,7 & 831,59 & 449,07 & 27,09 & 744,68 & 86,91 & 1,12 \\
\hline & 0,8 & 782,75 & 426,39 & 25,73 & 743,31 & 39,44 & 1,05 \\
\hline \multirow{7}{*}{ 15-Dez } & 0,2 & 1156,99 & 502,16 & 30,30 & 747,88 & 409,11 & 1,55 \\
\hline & 0,3 & 1089,61 & 473,37 & 28,56 & 746,14 & 343,47 & 1,46 \\
\hline & 0,4 & 1015,99 & 436,36 & 26,33 & 743,91 & 272,08 & 1,37 \\
\hline & 0,5 & 948,08 & 402,82 & 24,30 & 741,89 & 206,20 & 1,28 \\
\hline & 0,6 & 905,17 & 382,31 & 23,07 & 740,65 & 164,52 & 1,22 \\
\hline & 0,7 & 849,99 & 354,36 & 21,38 & 738,96 & 111,03 & 1,15 \\
\hline & 0,8 & 805,59 & 323,82 & 19,54 & 737,12 & 68,47 & 1,09 \\
\hline
\end{tabular}


Tabela 20B. Receitas brutas, composição de custos da irrigação, receitas líquidas e relação benefício/custo para o feijão caupi, em cada época de semeadura, nível de manejo da irrigação e risco de $25 \%$. Teresina, Piauí.

\begin{tabular}{|c|c|c|c|c|c|c|c|}
\hline $\begin{array}{c}\text { Época de } \\
\text { Semeadura }\end{array}$ & $\mathrm{p}$ & $\begin{array}{c}\mathrm{RB}^{1} \\
\left(\mathrm{US} \$ \mathrm{ha}^{-1}\right)\end{array}$ & $\begin{array}{c}E b \\
\left(\mathrm{kWh} \mathrm{ha}^{-1}\right)\end{array}$ & $\begin{array}{c}C E \\
\left(\mathrm{US} \$ \mathrm{ha}^{-1}\right)\end{array}$ & $\begin{array}{c}\text { CT } \\
\left(\mathrm{US} \$ \mathrm{ha}^{-1}\right)\end{array}$ & $\begin{array}{c}\mathrm{RL} \\
\left(\mathrm{US} \$ \mathrm{ha}^{-1}\right)\end{array}$ & $\mathrm{B} / \mathrm{C}$ \\
\hline \multirow{7}{*}{ 1-Jan } & 0,2 & 1126,24 & 416,72 & 24,74 & 742,32 & 383,91 & 1,52 \\
\hline & 0,3 & 1068,40 & 385,71 & 22,90 & 740,48 & 327,92 & 1,44 \\
\hline & 0,4 & 1007,99 & 352,89 & 20,95 & 738,53 & 269,46 & 1,36 \\
\hline & 0,5 & 947,13 & 316,15 & 18,77 & 736,35 & 210,78 & 1,29 \\
\hline & 0,6 & 911,08 & 277,64 & 16,48 & 734,07 & 177,01 & 1,24 \\
\hline & 0,7 & 867,42 & 248,09 & 14,73 & 732,31 & 135,11 & 1,18 \\
\hline & 0,8 & 832,29 & 234,20 & 13,90 & 731,49 & 100,80 & 1,14 \\
\hline \multirow{7}{*}{ 15-Jan } & 0,2 & 1143,27 & 378,96 & 22,50 & 740,08 & 403,19 & 1,54 \\
\hline & 0,3 & 1088,87 & 344,67 & 20,46 & 738,05 & 350,82 & 1,48 \\
\hline & 0,4 & 1033,45 & 306,32 & 18,19 & 735,77 & 297,68 & 1,40 \\
\hline & 0,5 & 983,11 & 272,61 & 16,18 & 733,77 & 249,34 & 1,34 \\
\hline & 0,6 & 944,90 & 246,80 & 14,65 & 732,24 & 212,66 & 1,29 \\
\hline & 0,7 & 906,77 & 209,06 & 12,41 & 730,00 & 176,77 & 1,24 \\
\hline & 0,8 & 872,88 & 164,65 & 9,77 & 727,36 & 145,52 & 1,20 \\
\hline \multirow{7}{*}{$1-\mathrm{Fev}$} & 0,2 & 1110,52 & 325,29 & 19,31 & 736,90 & 373,62 & 1,51 \\
\hline & 0,3 & 1059,19 & 283,68 & 16,84 & 734,43 & 324,77 & 1,44 \\
\hline & 0,4 & 1011,85 & 239,62 & 14,23 & 731,81 & 280,04 & 1,38 \\
\hline & 0,5 & 965,44 & 202,92 & 12,05 & 729,63 & 235,81 & 1,32 \\
\hline & 0,6 & 938,07 & 177,92 & 10,56 & 728,15 & 209,93 & 1,29 \\
\hline & 0,7 & 907,60 & 127,77 & 7,59 & 725,17 & 182,43 & 1,25 \\
\hline & 0,8 & 884,73 & 105,29 & 6,25 & 723,84 & 160,89 & 1,22 \\
\hline \multirow{7}{*}{ 15-Fev } & 0,2 & 1109,36 & 317,73 & 18,86 & 736,45 & 372,91 & 1,51 \\
\hline & 0,3 & 1056,95 & 275,23 & 16,34 & 733,93 & 323,02 & 1,44 \\
\hline & 0,4 & 1011,41 & 240,52 & 14,28 & 731,86 & 279,54 & 1,38 \\
\hline & 0,5 & 968,30 & 198,23 & 11,77 & 729,35 & 238,95 & 1,33 \\
\hline & 0,6 & 942,78 & 178,47 & 10,60 & 728,18 & 214,59 & 1,29 \\
\hline & 0,7 & 913,13 & 162,47 & 9,65 & 727,23 & 185,90 & 1,26 \\
\hline & 0,8 & 886,48 & 104,96 & 6,23 & 723,82 & 162,66 & 1,22 \\
\hline
\end{tabular}


Tabela 20B. Receitas brutas, composição de custos da irrigação, receitas líquidas e relação benefício/custo para o feijão caupi, em cada época de semeadura, nível de manejo da irrigação e risco de $25 \%$. Teresina, Piauí.

\begin{tabular}{|c|c|c|c|c|c|c|c|}
\hline $\begin{array}{l}\text { Época de } \\
\text { Semeadura }\end{array}$ & $p$ & $\begin{array}{c}\mathrm{RB}^{1} \\
\left(\mathrm{US} \$ \mathrm{ha}^{-1}\right)\end{array}$ & $\begin{array}{c}E b \\
\left(\mathrm{kWh} \mathrm{ha}^{-1}\right)\end{array}$ & $\begin{array}{c}C E \\
\left(\mathrm{US} \$ \mathrm{ha}^{-1}\right)\end{array}$ & $\begin{array}{c}\mathrm{CT} \\
\left(\mathrm{US} \$ \mathrm{ha}^{-1}\right)\end{array}$ & $\begin{array}{c}\mathrm{RL} \\
\left(\mathrm{US} \$ \mathrm{ha}^{-1}\right)\end{array}$ & $\mathrm{B} / \mathrm{C}$ \\
\hline \multirow{7}{*}{ 1-Mar } & 0,2 & 1139,47 & 313,38 & 18,47 & 736,05 & 403,42 & 1,55 \\
\hline & 0,3 & 1081,60 & 274,21 & 16,16 & 733,74 & 347,85 & 1,47 \\
\hline & 0,4 & 1036,00 & 221,62 & 13,06 & 730,64 & 305,36 & 1,42 \\
\hline & 0,5 & 993,60 & 198,03 & 11,67 & 729,25 & 264,34 & 1,36 \\
\hline & 0,6 & 961,26 & 172,50 & 10,17 & 727,75 & 233,51 & 1,32 \\
\hline & 0,7 & 928,27 & 144,68 & 8,53 & 726,11 & 202,16 & 1,28 \\
\hline & 0,8 & 899,95 & 80,73 & 4,76 & 722,34 & 177,61 & 1,25 \\
\hline \multirow{7}{*}{ 15-Mar } & 0,2 & 1130,66 & 366,75 & 21,61 & 739,20 & 391,46 & 1,53 \\
\hline & 0,3 & 1061,37 & 327,28 & 19,29 & 736,87 & 324,50 & 1,44 \\
\hline & 0,4 & 1016,88 & 291,13 & 17,16 & 734,74 & 282,14 & 1,38 \\
\hline & 0,5 & 955,33 & 258,97 & 15,26 & 732,85 & 222,49 & 1,30 \\
\hline & 0,6 & 914,34 & 235,72 & 13,89 & 731,48 & 182,86 & 1,25 \\
\hline & 0,7 & 882,30 & 198,16 & 11,68 & 729,26 & 153,04 & 1,21 \\
\hline & 0,8 & 847,02 & 152,88 & 9,01 & 726,59 & 120,43 & 1,17 \\
\hline \multirow{7}{*}{$1-\mathrm{Abr}$} & 0,2 & 1110,70 & 433,04 & 24,27 & 741,86 & 368,84 & 1,50 \\
\hline & 0,3 & 1034,83 & 400,31 & 22,44 & 740,02 & 294,81 & 1,40 \\
\hline & 0,4 & 985,58 & 370,23 & 20,75 & 738,34 & 247,25 & 1,33 \\
\hline & 0,5 & 921,36 & 347,49 & 19,48 & 737,06 & 184,30 & 1,25 \\
\hline & 0,6 & 873,52 & 328,68 & 18,42 & 736,01 & 137,51 & 1,19 \\
\hline & 0,7 & 833,50 & 304,72 & 17,08 & 734,66 & 98,84 & 1,13 \\
\hline & 0,8 & 792,46 & 273,49 & 15,33 & 732,91 & 59,55 & 1,08 \\
\hline \multirow{7}{*}{$15-\mathrm{Abr}$} & 0,2 & 1098,95 & 510,49 & 28,61 & 746,20 & 352,76 & 1,47 \\
\hline & 0,3 & 1015,90 & 488,98 & 27,41 & 744,99 & 270,91 & 1,36 \\
\hline & 0,4 & 958,78 & 461,09 & 25,84 & 743,43 & 215,35 & 1,29 \\
\hline & 0,5 & 887,97 & 436,11 & 24,44 & 742,03 & 145,94 & 1,20 \\
\hline & 0,6 & 828,75 & 420,84 & 23,59 & 741,17 & 87,58 & 1,12 \\
\hline & 0,7 & 779,98 & 402,03 & 22,53 & 740,12 & 39,86 & 1,05 \\
\hline & 0,8 & 736,56 & 382,10 & 21,42 & 739,00 & $-2,44$ & 1,00 \\
\hline
\end{tabular}


Tabela 20B. Receitas brutas, composição de custos da irrigação, receitas líquidas e relação benefício/custo para o feijão caupi, em cada época de semeadura, nível de manejo da irrigação e risco de $25 \%$. Teresina, Piauí.

\begin{tabular}{|c|c|c|c|c|c|c|c|}
\hline $\begin{array}{c}\text { Época de } \\
\text { Semeadura }\end{array}$ & $\mathrm{p}$ & $\begin{array}{c}\mathrm{RB}^{\mathrm{l}} \\
\left(\mathrm{US} \$ \mathrm{ha}^{-1}\right)\end{array}$ & $\begin{array}{c}\mathrm{Eb} \\
\left(\mathrm{kWh} \mathrm{ha}^{-1}\right)\end{array}$ & $\begin{array}{c}\mathrm{CE} \\
\left(\mathrm{US} \$ \mathrm{ha}^{-1}\right)\end{array}$ & $\begin{array}{c}\text { CT } \\
\left(\mathrm{US} \$ \mathrm{ha}^{-1}\right)\end{array}$ & $\begin{array}{c}\mathrm{RL} \\
\left(\mathrm{US} \$ \mathrm{ha}^{-1}\right)\end{array}$ & $\mathrm{B} / \mathrm{C}$ \\
\hline \multirow{7}{*}{ 1-Mai } & 0,2 & 912,46 & 571,48 & 31,58 & 749,16 & 163,30 & 1,22 \\
\hline & 0,3 & 837,25 & 549,69 & 30,37 & 747,96 & 89,29 & 1,12 \\
\hline & 0,4 & 787,45 & 532,16 & 29,41 & 746,99 & 40,46 & 1,05 \\
\hline & 0,5 & 723,27 & 521,20 & 28,80 & 746,39 & $-23,11$ & 0,97 \\
\hline & 0,6 & 673,17 & 508,62 & 28,11 & 745,69 & $-72,52$ & 0,90 \\
\hline & 0,7 & 634,20 & 492,66 & 27,22 & 744,81 & $-110,61$ & 0,85 \\
\hline & 0,8 & 587,22 & 475,48 & 26,27 & 743,86 & $-156,64$ & 0,79 \\
\hline \multirow{7}{*}{ 15-Mai } & 0,2 & 909,24 & 632,84 & 34,97 & 752,55 & 156,69 & 1,21 \\
\hline & 0,3 & 840,98 & 618,92 & 34,20 & 751,78 & 89,20 & 1,12 \\
\hline & 0,4 & 781,45 & 609,10 & 33,66 & 751,24 & 30,20 & 1,04 \\
\hline & 0,5 & 710,69 & 599,62 & 33,13 & 750,72 & $-40,02$ & 0,95 \\
\hline & 0,6 & 665,78 & 589,47 & 32,57 & 750,16 & $-84,38$ & 0,89 \\
\hline & 0,7 & 616,86 & 574,08 & 31,72 & 749,31 & $-132,45$ & 0,82 \\
\hline & 0,8 & 571,52 & 572,88 & 31,66 & 749,24 & $-177,72$ & 0,76 \\
\hline \multirow{7}{*}{ 1-Jun } & 0,2 & 991,56 & 690,60 & 40,44 & 758,02 & 233,54 & 1,31 \\
\hline & 0,3 & 924,83 & 681,69 & 39,92 & 757,50 & 167,33 & 1,22 \\
\hline & 0,4 & 848,18 & 674,47 & 39,49 & 757,08 & 91,10 & 1,12 \\
\hline & 0,5 & 776,49 & 669,49 & 39,20 & 756,79 & 19,71 & 1,03 \\
\hline & 0,6 & 727,58 & 662,27 & 38,78 & 756,36 & $-28,78$ & 0,96 \\
\hline & 0,7 & 670,39 & 657,35 & 38,49 & 756,07 & $-85,68$ & 0,89 \\
\hline & 0,8 & 619,43 & 637,67 & 37,34 & 754,92 & $-135,49$ & 0,82 \\
\hline \multirow{7}{*}{ 15-Jun } & 0,2 & 996,57 & 741,30 & 43,41 & 760,99 & 235,58 & 1,31 \\
\hline & 0,3 & 935,76 & 734,71 & 43,02 & 760,60 & 175,15 & 1,23 \\
\hline & 0,4 & 849,97 & 728,85 & 42,68 & 760,26 & 89,71 & 1,12 \\
\hline & 0,5 & 784,06 & 720,71 & 42,20 & 759,78 & 24,28 & 1,03 \\
\hline & 0,6 & 726,52 & 714,82 & 41,86 & 759,44 & $-32,92$ & 0,96 \\
\hline & 0,7 & 669,58 & 710,86 & 41,62 & 759,21 & $-89,63$ & 0,88 \\
\hline & 0,8 & 626,28 & 702,31 & 41,12 & 758,71 & $-132,42$ & 0,83 \\
\hline
\end{tabular}


Tabela 20B. Receitas brutas, composição de custos da irrigação, receitas líquidas e relação benefício/custo para o feijão caupi, em cada época de semeadura, nível de manejo da irrigação e risco de $25 \%$. Teresina, Piauí.

\begin{tabular}{|c|c|c|c|c|c|c|c|}
\hline $\begin{array}{l}\text { Época de } \\
\text { Semeadura }\end{array}$ & $\mathrm{p}$ & $\begin{array}{c}\mathrm{RB}^{1} \\
\left(\mathrm{US} \$ \mathrm{ha}^{-1}\right)\end{array}$ & $\begin{array}{c}\mathrm{Eb} \\
\left(\mathrm{kWh} \mathrm{ha} \mathrm{h}^{-1}\right)\end{array}$ & $\begin{array}{c}C E \\
\left(\mathrm{US} \$ \mathrm{ha}^{-1}\right)\end{array}$ & $\begin{array}{c}\mathrm{CT} \\
\left(\mathrm{US} \$ \mathrm{ha}^{-1}\right)\end{array}$ & $\begin{array}{c}\mathrm{RL} \\
\left(\mathrm{US} \$ \mathrm{ha}^{-1}\right)\end{array}$ & $\mathrm{B} / \mathrm{C}$ \\
\hline \multirow{7}{*}{ 1-Jul } & 0,2 & 1002,26 & 804,86 & 48,73 & 766,32 & 235,94 & 1,31 \\
\hline & 0,3 & 945,08 & 799,07 & 48,38 & 765,97 & 179,11 & 1,23 \\
\hline & 0,4 & 854,63 & 795,80 & 48,18 & 765,77 & 88,86 & 1,12 \\
\hline & 0,5 & 800,02 & 790,74 & 47,88 & 765,46 & 34,56 & 1,05 \\
\hline & 0,6 & 734,54 & 781,33 & 47,31 & 764,89 & $-30,35$ & 0,96 \\
\hline & 0,7 & 680,51 & 774,83 & 46,92 & 764,50 & $-83,99$ & 0,89 \\
\hline & 0,8 & 632,85 & 784,46 & 47,50 & 765,08 & $-132,24$ & 0,83 \\
\hline \multirow{7}{*}{ 15-Jul } & 0,2 & 1011,00 & 862,45 & 52,22 & 769,80 & 241,19 & 1,31 \\
\hline & 0,3 & 955,23 & 857,19 & 51,90 & 769,49 & 185,75 & 1,24 \\
\hline & 0,4 & 863,75 & 850,85 & 51,52 & 769,10 & 94,65 & 1,12 \\
\hline & 0,5 & 815,35 & 850,13 & 51,47 & 769,06 & 46,29 & 1,06 \\
\hline & 0,6 & 734,62 & 848,49 & 51,37 & 768,96 & $-34,34$ & 0,96 \\
\hline & 0,7 & 693,95 & 703,14 & 42,57 & 760,16 & $-66,21$ & 0,91 \\
\hline & 0,8 & 633,12 & 820,77 & 49,70 & 767,28 & $-134,16$ & 0,83 \\
\hline \multirow{7}{*}{ 1-Ago } & 0,2 & 971,99 & 898,23 & 54,79 & 772,37 & 199,62 & 1,26 \\
\hline & 0,3 & 916,45 & 894,10 & 54,54 & 772,12 & 144,33 & 1,19 \\
\hline & 0,4 & 838,58 & 891,31 & 54,37 & 771,95 & 66,63 & 1,09 \\
\hline & 0,5 & 778,38 & 895,97 & 54,65 & 772,24 & 6,14 & 1,01 \\
\hline & 0,6 & 712,62 & 881,49 & 53,77 & 771,35 & $-58,73$ & 0,92 \\
\hline & 0,7 & 664,76 & 871,00 & 53,13 & 770,71 & $-105,96$ & 0,86 \\
\hline & 0,8 & 613,76 & 867,91 & 52,94 & 770,52 & $-156,76$ & 0,80 \\
\hline \multirow{7}{*}{ 15-Ago } & 0,2 & 978,14 & 923,73 & 56,34 & 773,93 & 204,22 & 1,26 \\
\hline & 0,3 & 917,91 & 919,31 & 56,07 & 773,66 & 144,26 & 1,19 \\
\hline & 0,4 & 852,74 & 917,03 & 55,94 & 773,52 & 79,22 & 1,10 \\
\hline & 0,5 & 780,39 & 903,00 & 55,08 & 772,66 & 7,72 & 1,01 \\
\hline & 0,6 & 732,99 & 903,86 & 55,13 & 772,72 & $-39,73$ & 0,95 \\
\hline & 0,7 & 672,84 & 897,35 & 54,73 & 772,32 & $-99,48$ & 0,87 \\
\hline & 0,8 & 632,54 & 890,28 & 54,30 & 771,89 & $-139,34$ & 0,82 \\
\hline
\end{tabular}


Tabela 20B. Receitas brutas, composição de custos da irrigação, receitas líquidas e relação benefício/custo para o feijão caupi, em cada época de semeadura, nível de manejo da irrigação e risco de $25 \%$. Teresina, Piauí.

\begin{tabular}{|c|c|c|c|c|c|c|c|}
\hline $\begin{array}{l}\text { Época de } \\
\text { Semeadura }\end{array}$ & $\mathrm{p}$ & $\begin{array}{c}\mathrm{RB}^{\mathrm{l}} \\
\left(\mathrm{US} \$ \mathrm{ha}^{-1}\right)\end{array}$ & $\begin{array}{c}E b \\
\left(k W h h^{-1}\right)\end{array}$ & $\begin{array}{c}\text { CE } \\
\left(\mathrm{US} \$ \mathrm{ha}^{-1}\right)\end{array}$ & $\begin{array}{c}\mathrm{CT} \\
\left(\mathrm{US} \$ \mathrm{ha}^{-1}\right)\end{array}$ & $\begin{array}{c}\mathrm{RL} \\
\left(\mathrm{US} \$ \mathrm{ha}^{-1}\right)\end{array}$ & $\mathrm{B} / \mathrm{C}$ \\
\hline \multirow{7}{*}{ 1-Set } & 0,2 & 991,46 & 921,61 & 54,52 & 772,10 & 219,36 & 1,28 \\
\hline & 0,3 & 930,77 & 911,38 & 53,91 & 771,50 & 159,28 & 1,21 \\
\hline & 0,4 & 863,41 & 904,39 & 53,50 & 771,08 & 92,33 & 1,12 \\
\hline & 0,5 & 791,00 & 896,12 & 53,01 & 770,59 & 20,40 & 1,03 \\
\hline & 0,6 & 740,11 & 885,93 & 52,41 & 769,99 & $-29,88$ & 0,96 \\
\hline & 0,7 & 678,98 & 883,89 & 52,28 & 769,87 & $-90,89$ & 0,88 \\
\hline & 0,8 & 644,75 & 873,68 & 51,68 & 769,27 & $-124,51$ & 0,84 \\
\hline \multirow{7}{*}{ 15-Set } & 0,2 & 988,21 & 901,52 & 53,33 & 770,91 & 217,30 & 1,28 \\
\hline & 0,3 & 929,32 & 894,40 & 52,91 & 770,49 & 158,82 & 1,21 \\
\hline & 0,4 & 857,33 & 883,52 & 52,26 & 769,85 & 87,48 & 1,11 \\
\hline & 0,5 & 789,64 & 872,21 & 51,59 & 769,18 & 20,47 & 1,03 \\
\hline & 0,6 & 737,47 & 869,15 & 51,41 & 769,00 & $-31,53$ & 0,96 \\
\hline & 0,7 & 681,08 & 861,15 & 50,94 & 768,52 & $-87,44$ & 0,89 \\
\hline & 0,8 & 638,85 & 856,16 & 50,64 & 768,23 & $-129,38$ & 0,83 \\
\hline \multirow{7}{*}{ 1-Out } & 0,2 & 998,38 & 871,52 & 52,40 & 769,99 & 228,39 & 1,30 \\
\hline & 0,3 & 941,60 & 863,89 & 51,95 & 769,53 & 172,07 & 1,22 \\
\hline & 0,4 & 865,43 & 852,83 & 51,28 & 768,87 & 96,56 & 1,13 \\
\hline & 0,5 & 804,15 & 845,21 & 50,82 & 768,41 & 35,75 & 1,05 \\
\hline & 0,6 & 743,68 & 836,74 & 50,31 & 767,90 & $-24,22$ & 0,97 \\
\hline & 0,7 & 688,53 & 824,87 & 49,60 & 767,18 & $-78,66$ & 0,90 \\
\hline & 0,8 & 641,12 & 819,67 & 49,29 & 766,87 & $-125,75$ & 0,84 \\
\hline \multirow{7}{*}{ 15-Out } & 0,2 & 992,59 & 825,76 & 49,65 & 767,24 & 225,35 & 1,29 \\
\hline & 0,3 & 941,31 & 815,76 & 49,05 & 766,64 & 174,67 & 1,23 \\
\hline & 0,4 & 855,52 & 801,61 & 48,20 & 765,79 & 89,73 & 1,12 \\
\hline & 0,5 & 803,71 & 785,43 & 47,23 & 764,81 & 38,90 & 1,05 \\
\hline & 0,6 & 736,48 & 779,81 & 46,89 & 764,47 & $-28,00$ & 0,96 \\
\hline & 0,7 & 691,47 & 768,61 & 46,22 & 763,80 & $-72,33$ & 0,91 \\
\hline & 0,8 & 639,89 & 757,84 & 45,57 & 763,15 & $-123,27$ & 0,84 \\
\hline
\end{tabular}


Tabela 20B. Receitas brutas, composição de custos da irrigação, receitas liquidas e relação beneficio/custo para o feijão caupi, em cada época de semeadura, nível de manejo da irrigação e risco de $25 \%$. Teresina, Piauí.

\begin{tabular}{|c|c|c|c|c|c|c|c|}
\hline $\begin{array}{l}\text { Época de } \\
\text { Semeadura }\end{array}$ & $\mathrm{p}$ & $\begin{array}{c}\mathrm{RB}^{1} \\
\left(\mathrm{US} \$ \mathrm{ha}^{-1}\right)\end{array}$ & $\begin{array}{c}E b \\
\left(\mathrm{kWh} \mathrm{ha}^{-1}\right)\end{array}$ & $\begin{array}{c}\text { CE } \\
\left(\mathrm{US} \$ \mathrm{ha}^{-1}\right)\end{array}$ & $\begin{array}{c}\text { CT } \\
\left(\mathrm{US} \$ \mathrm{ha}^{-1}\right)\end{array}$ & $\begin{array}{c}\mathrm{RL} \\
\left(\mathrm{US} \$ \mathrm{ha}^{-1}\right)\end{array}$ & $\mathrm{B} / \mathrm{C}$ \\
\hline \multirow{7}{*}{$1-\mathrm{Nov}$} & 0,2 & 1154,38 & 722,62 & 43,70 & 761,28 & 393,10 & 1,52 \\
\hline & 0,3 & 1090,63 & 707,17 & 42,76 & 760,35 & 330,28 & 1,43 \\
\hline & 0,4 & 996,64 & 686,97 & 41,54 & 759,13 & 237,51 & 1,31 \\
\hline & 0,5 & 936,86 & 675,55 & 40,85 & 758,44 & 178,43 & 1,24 \\
\hline & 0,6 & 863,05 & 658,76 & 39,84 & 757,42 & 105,63 & 1,14 \\
\hline & 0,7 & 811,77 & 643,36 & 38,90 & 756,49 & 55,28 & 1,07 \\
\hline & 0,8 & 753,93 & 628,24 & 37,99 & 755,57 & $-1,64$ & 1,00 \\
\hline \multirow{7}{*}{ 15-Nov } & 0,2 & 1149,47 & 634,98 & 38,40 & 755,98 & 393,49 & 1,52 \\
\hline & 0,3 & 1085,52 & 610,46 & 36,92 & 754,50 & 331,02 & 1,44 \\
\hline & 0,4 & 998,42 & 578,78 & 35,00 & 752,58 & 245,83 & 1,33 \\
\hline & 0,5 & 936,38 & 556,46 & 33,65 & 751,23 & 185,15 & 1,25 \\
\hline & 0,6 & 874,16 & 540,35 & 32,68 & 750,26 & 123,90 & 1,17 \\
\hline & 0,7 & 818,18 & 518,86 & 31,38 & 748,96 & 69,22 & 1,09 \\
\hline & 0,8 & 772,30 & 501,57 & 30,33 & 747,92 & 24,39 & 1,03 \\
\hline \multirow{7}{*}{ 1-Dez } & 0,2 & 1183,00 & 561,18 & 33,37 & 750,95 & 432,05 & 1,58 \\
\hline & 0,3 & 1115,62 & 532,14 & 31,64 & 749,23 & 366,39 & 1,49 \\
\hline & 0,4 & 1034,39 & 504,00 & 29,97 & 747,55 & 286,84 & 1,38 \\
\hline & 0,5 & 966,75 & 476,74 & 28,35 & 745,93 & 220,81 & 1,30 \\
\hline & 0,6 & 910,97 & 461,67 & 27,45 & 745,04 & 165,94 & 1,22 \\
\hline & 0,7 & 856,12 & 432,71 & 25,73 & 743,31 & 112,80 & 1,15 \\
\hline & 0,8 & 807,52 & 408,48 & 24,29 & 741,87 & 65,64 & 1,09 \\
\hline \multirow{7}{*}{ 15-Dez } & 0,2 & 1184,51 & 491,72 & 29,24 & 746,82 & 437,69 & 1,59 \\
\hline & 0,3 & 1117,13 & 461,87 & 27,46 & 745,05 & 372,08 & 1,50 \\
\hline & 0,4 & 1042,31 & 423,96 & 25,21 & 742,79 & 299,51 & 1,40 \\
\hline & 0,5 & 974,86 & 389,84 & 23,18 & 740,77 & 234,10 & 1,32 \\
\hline & 0,6 & 931,35 & 367,61 & 21,86 & 739,44 & 191,91 & 1,26 \\
\hline & 0,7 & 876,70 & 338,94 & 20,15 & 737,74 & 138,97 & 1,19 \\
\hline & 0,8 & 832,39 & 308,17 & 18,32 & 735,91 & 96,48 & 1,13 \\
\hline
\end{tabular}

${ }^{\top} \mathrm{RB}$ - receita bruta: $\mathrm{Eb}$ - energia requerida para o bombeamento; $\mathrm{CE}$ - custo de energia elétrica; $\mathrm{CT}$ - custo total de produção; RL - receita líquida e B/C - relação benefício/custo. 
Tabela 21B. Receitas brutas, composição de custos da irrigação, receitas liquidas e relação benefício/custo para o feijão caupi, em cada época de semeadura, nível de manejo da irrigação e risco de $30 \%$. Teresina, Piauí.

\begin{tabular}{|c|c|c|c|c|c|c|c|}
\hline $\begin{array}{c}\text { Época de } \\
\text { Semeadura }\end{array}$ & $p$ & $\begin{array}{c}\mathrm{RB}^{1} \\
\left(\mathrm{US} \$ \mathrm{ha}^{-1}\right)\end{array}$ & $\begin{array}{c}E b \\
\left(\mathrm{kWh} \mathrm{ha}^{-1}\right)\end{array}$ & $\begin{array}{c}C E \\
\left(U S \$ \mathrm{ha}^{-1}\right)\end{array}$ & $\begin{array}{c}\text { CT } \\
\left(\mathrm{US} \$ \mathrm{ha}^{-1}\right)\end{array}$ & $\begin{array}{c}\mathrm{RL} \\
\left(\mathrm{US} \$ \mathrm{ha}^{-1}\right)\end{array}$ & $\mathrm{B} / \mathrm{C}$ \\
\hline \multirow{7}{*}{ 1-Jan } & 0,2 & 1155,70 & 407,20 & 23,77 & 741,36 & 414,34 & 1,56 \\
\hline & 0,3 & 1098,07 & 375,30 & 21,91 & 739,50 & 358,57 & 1,48 \\
\hline & 0,4 & 1036,77 & 340,70 & 19,89 & 737,48 & 299,29 & 1,41 \\
\hline & 0,5 & 975,77 & 303,07 & 17,69 & 735,28 & 240,49 & 1,33 \\
\hline & 0,6 & 939,66 & 264,49 & 15,44 & 733,03 & 206,63 & 1,28 \\
\hline & 0,7 & 896,64 & 235,16 & 13,73 & 731,31 & 165,32 & 1,23 \\
\hline & 0,8 & 862,02 & 220,21 & 12,86 & 730,44 & 131,58 & 1,18 \\
\hline \multirow{7}{*}{ 15-Jan } & 0,2 & 1173,65 & 369,30 & 21,56 & 739,14 & 434,50 & 1,59 \\
\hline & 0,3 & 1119,02 & 333,70 & 19,48 & 737,07 & 381,96 & 1,52 \\
\hline & 0,4 & 1063,30 & 294,92 & 17,22 & 734,80 & 328,50 & 1,45 \\
\hline & 0,5 & 1012,64 & 260,11 & 15,19 & 732,77 & 279,87 & 1,38 \\
\hline & 0,6 & 974,73 & 232,75 & 13,59 & 731,17 & 243,55 & 1,33 \\
\hline & 0,7 & 937,09 & 196,04 & 11,45 & 729,03 & 208,06 & 1,29 \\
\hline & 0,8 & 904,41 & 164,65 & 9,61 & 727,20 & 177,22 & 1,24 \\
\hline \multirow{7}{*}{$1-\mathrm{Fev}$} & 0,2 & 1142,06 & 316,76 & 18,37 & 735,95 & 406,11 & 1,55 \\
\hline & 0,3 & 1090,62 & 273,77 & 15,88 & 733,46 & 357,16 & 1,49 \\
\hline & 0,4 & 1043,06 & 229,50 & 13,31 & 730,89 & 312,16 & 1,43 \\
\hline & 0,5 & 996,98 & 193,03 & 11,19 & 728,78 & 268,20 & 1,37 \\
\hline & 0,6 & 970,19 & 168,35 & 9,76 & 727,35 & 242,84 & 1,33 \\
\hline & 0,7 & 939,91 & 127,77 & 7,41 & 724,99 & 214,92 & 1,30 \\
\hline & 0,8 & 917,50 & 105,29 & 6,11 & 723,69 & 193,81 & 1,27 \\
\hline \multirow{7}{*}{$15-\mathrm{Fev}$} & 0,2 & 1141,02 & 306,65 & 17,78 & 735,37 & 405,65 & 1,55 \\
\hline & 0,3 & 1088,64 & 264,16 & 15,32 & 732,90 & 355,74 & 1,49 \\
\hline & 0,4 & 1043,26 & 228,13 & 13,23 & 730,81 & 312,45 & 1,43 \\
\hline & 0,5 & 1000,24 & 185,85 & 10,78 & 728,36 & 271,88 & 1,37 \\
\hline & 0,6 & 975,27 & 165,58 & 9,60 & 727,19 & 248,08 & 1,34 \\
\hline & 0,7 & 946,70 & 116,05 & 6,73 & 724,31 & 222,39 & 1,31 \\
\hline & 0,8 & 921,43 & 104,96 & 6,09 & 723,67 & 197,76 & 1,27 \\
\hline
\end{tabular}


Tabela 21B. Receitas brutas, composição de custos da irrigação, receitas líquidas e relação benefício/custo para o feijão caupi, em cada época de semeadura, nível de manejo da irrigação e risco de $30 \%$. Teresina, Piauí.

\begin{tabular}{|c|c|c|c|c|c|c|c|}
\hline $\begin{array}{l}\text { Época de } \\
\text { Semeadura }\end{array}$ & $\mathrm{p}$ & $\begin{array}{c}\mathrm{RB}^{\mathrm{l}} \\
\left(\mathrm{US} \$ \mathrm{ha}^{-1}\right)\end{array}$ & $\begin{array}{c}E b \\
\left(\mathrm{kWh} \mathrm{ha}{ }^{-1}\right)\end{array}$ & $\begin{array}{c}\text { CE } \\
\left(\mathrm{US} \$ \mathrm{ha}^{-1}\right)\end{array}$ & $\begin{array}{c}C T \\
\left(\text { US } \$ h^{-1}\right)^{-1}\end{array}$ & $\begin{array}{c}\mathrm{RL} \\
\left(\mathrm{US} \$ \mathrm{ha}^{-1}\right)\end{array}$ & $\mathrm{B} / \mathrm{C}$ \\
\hline \multirow{7}{*}{ 1-Mar } & 0,2 & 1172,87 & 303,80 & 17,44 & 735,03 & 437,84 & 1,60 \\
\hline & 0,3 & 1115,16 & 263,30 & 15,12 & 732,70 & 382,45 & 1,52 \\
\hline & 0,4 & 1069,20 & 210,68 & 12,10 & 729,68 & 339,51 & 1,47 \\
\hline & 0,5 & 1027,02 & 186,71 & 10,72 & 728,31 & 298,71 & 1,41 \\
\hline & 0,6 & 995,41 & 161,91 & 9,30 & 726,88 & 268,52 & 1,37 \\
\hline & 0,7 & 963,12 & 134,15 & 7,70 & 725,29 & 237,83 & 1,33 \\
\hline & 0,8 & 935,82 & 80,73 & 4,64 & 722,22 & 213,60 & 1,30 \\
\hline \multirow{7}{*}{ 15-Mar } & 0,2 & 1163,67 & 357,02 & 20,50 & 738,08 & 425,58 & 1,58 \\
\hline & 0,3 & 1093,76 & 315,83 & 18,13 & 735,72 & 358,04 & 1,49 \\
\hline & 0,4 & 1049,10 & 279,06 & 16,02 & 733,61 & 315,49 & 1,43 \\
\hline & 0,5 & 987,82 & 246,46 & 14,15 & 731,74 & 256,08 & 1,35 \\
\hline & 0,6 & 947,05 & 222,79 & 12,79 & 730,38 & 216,67 & 1,30 \\
\hline & 0,7 & 915,19 & 185,87 & 10,67 & 728,26 & 186,94 & 1,26 \\
\hline & 0,8 & 880,58 & 152,88 & 8,78 & 726,36 & 154,21 & 1,21 \\
\hline \multirow{7}{*}{$1-\mathrm{Abr}$} & 0,2 & 1143,36 & 423,40 & 23,09 & 740,68 & 402,69 & 1,54 \\
\hline & 0,3 & 1066,98 & 390,17 & 21,28 & 738,87 & 328,11 & 1,44 \\
\hline & 0,4 & 1017,11 & 359,51 & 19,61 & 737,19 & 279,91 & 1,38 \\
\hline & 0,5 & 952,34 & 334,89 & 18,27 & 735,85 & 216,48 & 1,29 \\
\hline & 0,6 & 904,49 & 314,18 & 17,14 & 734,72 & 169,77 & 1,23 \\
\hline & 0,7 & $864,60^{\circ}$ & 290,35 & 15,84 & 733,42 & 131,18 & 1,18 \\
\hline & 0,8 & 824,01 & 259,40 & 14,15 & 731,73 & 92,28 & 1,13 \\
\hline \multirow{7}{*}{ 15-Abr } & 0,2 & 1131,17 & 502,14 & 27,39 & 744,97 & 386,20 & 1,52 \\
\hline & 0,3 & 1046,86 & 479,46 & 26,15 & 743,74 & 303,13 & 1,41 \\
\hline & 0,4 & 988,81 & 450,02 & 24,55 & 742,13 & 246,67 & 1,33 \\
\hline & 0,5 & 917,20 & 423,79 & 23,12 & 740,70 & 176,50 & 1,24 \\
\hline & 0,6 & 857,57 & 408,05 & 22,26 & 739,84 & 117,73 & 1,16 \\
\hline & 0,7 & 808,57 & 388,68 & 21,20 & 738,79 & 69,79 & 1,09 \\
\hline & 0,8 & 764,77 & 368,08 & 20,08 & 737,66 & 27,11 & 1,04 \\
\hline
\end{tabular}


Tabela 21B. Receitas brutas, composição de custos da irrigação, receitas líquidas e relação benefício/custo para o feijão caupi, em cada época de semeadura, nível de manejo da irrigação e risco de $30 \%$. Teresina, Piauí.

\begin{tabular}{|c|c|c|c|c|c|c|c|}
\hline $\begin{array}{l}\text { Época de } \\
\text { Semeadura }\end{array}$ & $\mathrm{p}$ & $\begin{array}{c}\mathrm{RB}^{\mathrm{I}} \\
\left(\mathrm{US} \$ \mathrm{ha}^{-1}\right)\end{array}$ & $\begin{array}{c}E b \\
\left(\mathrm{kWh} \mathrm{ha}{ }^{-1}\right)\end{array}$ & $\begin{array}{c}\text { CE } \\
\left(\mathrm{US} \$ \mathrm{ha}^{-1}\right)\end{array}$ & $\begin{array}{c}\text { CT } \\
\left(\text { US } \$ \mathrm{ha}^{-1}\right)\end{array}$ & $\begin{array}{c}\mathrm{RL} \\
\left(\mathrm{US} \$ \mathrm{ha}^{-1}\right)\end{array}$ & $\mathrm{B} / \mathrm{C}$ \\
\hline \multirow{7}{*}{ 1-Mai } & 0,2 & 949,49 & 563,28 & 30,47 & 748,06 & 201,43 & 1,27 \\
\hline & 0,3 & 872,45 & 540,41 & 29,24 & 746,82 & 125,62 & 1,17 \\
\hline & 0,4 & 821,10 & 521,77 & 28,23 & 745,81 & 75,29 & 1,10 \\
\hline & 0,5 & 755,16 & 508,86 & 27,53 & 745,11 & 10,04 & 1,01 \\
\hline & 0,6 & 703,73 & 495,50 & 26,81 & 744,39 & $-40,66$ & 0,95 \\
\hline & 0,7 & 664,23 & 479,54 & 25,94 & 743,53 & $-79,30$ & 0,89 \\
\hline & 0,8 & 615,73 & 460,23 & 24,90 & 742,48 & $-126,75$ & 0,83 \\
\hline \multirow{7}{*}{ 15-Mai } & 0,2 & 945,97 & 627,29 & 33,94 & 751,52 & 194,45 & 1,26 \\
\hline & 0,3 & 876,04 & 612,66 & 33,15 & 750,73 & 125,31 & 1,17 \\
\hline & 0,4 & 813,97 & 601,69 & 32,55 & 750,14 & 63,83 & 1,09 \\
\hline & 0,5 & 741,53 & 591,30 & 31,99 & 749,57 & $-8,05$ & 0,99 \\
\hline & 0,6 & 695,25 & 580,65 & 31,41 & 749,00 & $-53,74$ & 0,93 \\
\hline & 0,7 & 644,46 & 564,41 & 30,54 & 748,12 & $-103,66$ & 0,86 \\
\hline & 0,8 & 598,36 & 561,79 & 30,39 & 747,98 & $-149,62$ & 0,80 \\
\hline \multirow{7}{*}{ 1-Jun } & 0,2 & 1024,96 & 686,09 & 39,38 & 756,96 & 268,00 & 1,35 \\
\hline & 0,3 & 956,96 & 676,30 & 38,82 & 756,40 & 200,56 & 1,27 \\
\hline & 0,4 & 877,72 & 669,06 & 38,40 & 755,99 & 121,73 & 1,16 \\
\hline & 0,5 & 804,14 & 663,28 & 38,07 & 755,65 & 48,48 & 1,06 \\
\hline & 0,6 & 754,09 & 654,64 & 37,57 & 755,16 & $-1,07$ & 1,00 \\
\hline & 0,7 & 695,13 & 650,12 & 37,31 & 754,90 & $-59,77$ & 0,92 \\
\hline & 0,8 & 642,89 & 637,67 & 36,60 & 754,18 & $-111,29$ & 0,85 \\
\hline \multirow{7}{*}{ 15-Jun } & 0,2 & 1030,09 & 737,67 & 42,34 & 759,92 & 270,17 & 1,36 \\
\hline & 0,3 & 968,16 & 730,26 & 41,91 & 759,50 & 208,66 & 1,27 \\
\hline & 0,4 & 879,25 & 723,69 & 41,54 & 759,12 & 120,12 & 1,16 \\
\hline & 0,5 & 812,50 & 715,26 & 41,05 & 758,64 & 53,86 & 1,07 \\
\hline & 0,6 & 752,56 & 708,87 & 40,69 & 758,27 & $-5,71$ & 0,99 \\
\hline & 0,7 & 694,09 & 704,47 & 40,43 & 758,02 & $-63,93$ & 0,92 \\
\hline & 0,8 & 649,21 & 695,24 & 39,90 & 757,49 & $-108,28$ & 0,86 \\
\hline
\end{tabular}


Tabela 21B. Receitas brutas, composição de custos da irrigação, receitas líquidas e relação benefício/custo para o feijão caupi, em cada época de semeadura, nível de manejo da irrigação e risco de $30 \%$. Teresina, Piauí.

\begin{tabular}{|c|c|c|c|c|c|c|c|}
\hline $\begin{array}{l}\text { Época de } \\
\text { Semeadura }\end{array}$ & $p$ & $\begin{array}{c}\mathrm{RB}^{1} \\
\left(\mathrm{US} \$ \mathrm{ha}^{-1}\right)\end{array}$ & $\begin{array}{c}E b \\
\left(\mathrm{kWh} \mathrm{ha}{ }^{-1}\right)\end{array}$ & $\begin{array}{c}\text { CE } \\
\left(\mathrm{US} \$ \mathrm{ha}^{-1}\right)\end{array}$ & $\begin{array}{c}\mathrm{CT} \\
\left(\mathrm{US} \$ \mathrm{ha}^{-1}\right)\end{array}$ & $\begin{array}{c}\mathrm{RL} \\
\left(\mathrm{US} \$ \mathrm{ha} \mathrm{a}^{-1}\right)\end{array}$ & $\mathrm{B} / \mathrm{C}$ \\
\hline \multirow{7}{*}{$1-J u l$} & 0,2 & 1032,56 & 801,85 & 47,85 & 765,43 & 267,13 & 1,35 \\
\hline & 0,3 & 974,26 & 796,05 & 47,50 & 765,08 & 209,18 & 1,27 \\
\hline & 0,4 & 880,88 & 792,17 & 47,27 & 764,85 & 116,03 & 1,15 \\
\hline & 0,5 & 825,48 & 786,19 & 46,91 & 764,50 & 60,99 & 1,08 \\
\hline & 0,6 & 758,22 & 781,33 & 46,62 & 764,21 & $-5,99$ & 0,99 \\
\hline & 0,7 & 703,37 & 769,73 & 45,93 & 763,51 & $-60,14$ & 0,92 \\
\hline & 0,8 & 653,49 & 778,12 & 46,43 & 764,01 & $-110,53$ & 0,86 \\
\hline \multirow{7}{*}{ 15-Jul } & 0,2 & 1041,81 & 859,23 & 51,27 & 768,85 & 272,95 & 1,36 \\
\hline & 0,3 & 984,44 & 853,80 & 50,95 & 768,53 & 215,91 & 1,28 \\
\hline & 0,4 & 890,82 & 847,30 & 50,56 & 768,14 & 122,68 & 1,16 \\
\hline & 0,5 & 840,55 & 845,52 & 50,45 & 768,04 & 72,52 & 1,09 \\
\hline & 0,6 & 758,42 & 843,66 & 50,34 & 767,93 & $-9,51$ & 0,99 \\
\hline & 0,7 & 716,17 & 703,14 & 41,96 & 759,54 & $-43,37$ & 0,94 \\
\hline & 0,8 & 653,90 & 820,77 & 48,98 & 766,56 & $-112,66$ & 0,85 \\
\hline \multirow{7}{*}{ 1-Ago } & 0,2 & 1004,44 & 895,05 & 53,84 & 771,42 & 233,02 & 1,30 \\
\hline & 0,3 & 946,85 & 890,06 & 53,54 & 771,12 & 175,73 & 1,23 \\
\hline & 0,4 & 867,65 & 887,21 & 53,37 & 770,95 & 96,70 & 1,13 \\
\hline & 0,5 & 804,73 & 895,97 & 53,89 & 771,48 & 33,25 & 1,04 \\
\hline & 0,6 & 738,18 & 854,62 & 51,41 & 768,99 & $-30,81$ & 0,96 \\
\hline & 0,7 & 688,04 & 864,65 & 52,01 & 769,59 & $-81,56$ & 0,89 \\
\hline & 0,8 & 636,27 & 861,83 & 51,84 & 769,43 & $-133,16$ & 0,83 \\
\hline \multirow{7}{*}{ 15-Ago } & 0,2 & 1010,97 & 920,05 & 55,34 & 772,93 & 238,04 & 1,31 \\
\hline & 0,3 & 947,31 & 914,97 & 55,04 & 772,62 & 174,69 & 1,23 \\
\hline & 0,4 & 882,45 & 912,14 & 54,87 & 772,45 & 110,00 & 1,14 \\
\hline & 0,5 & 807,07 & 898,05 & 54,02 & 771,60 & 35,47 & 1,05 \\
\hline & 0,6 & 758,82 & 898,25 & 54,03 & 771,62 & $-12,79$ & 0,98 \\
\hline & 0,7 & 696,57 & 890,69 & 53,58 & 771,16 & $-74,59$ & 0,90 \\
\hline & 0,8 & 655,45 & 883,15 & 53,12 & 770,71 & $-115,26$ & 0,85 \\
\hline
\end{tabular}


Tabela 21B. Receitas brutas, composição de custos da irrigação, receitas líquidas e relação benefício/custo para o feijão caupi, em cada época de semeadura, nível de manejo da irrigação e risco de $30 \%$. Teresina, Piauí.

\begin{tabular}{|c|c|c|c|c|c|c|c|}
\hline $\begin{array}{l}\text { Época de } \\
\text { Semeadura }\end{array}$ & $\mathrm{p}$ & $\begin{array}{c}\mathrm{RB}^{\mathrm{l}} \\
\left(\mathrm{US} \$ \mathrm{ha}^{-1}\right)\end{array}$ & $\begin{array}{c}\mathrm{Eb} \\
\left(\mathrm{kWh} \mathrm{ha} \mathrm{a}^{-1}\right)\end{array}$ & $\begin{array}{c}\mathrm{CE} \\
\left(\mathrm{US} \$ \mathrm{ha}^{-1}\right)\end{array}$ & $\begin{array}{c}\mathrm{CT} \\
\left(\mathrm{US} \$ \mathrm{ha}^{-1}\right)\end{array}$ & $\begin{array}{c}\text { RL } \\
\left(\mathrm{US} \$ \mathrm{ha}^{-1}\right)\end{array}$ & $\mathrm{B} / \mathrm{C}$ \\
\hline \multirow{7}{*}{$1-$ Set } & 0,2 & 1023,69 & 917,01 & 53,68 & 771,27 & 252,42 & 1,33 \\
\hline & 0,3 & 960,67 & 906,46 & 53,07 & 770,65 & 190,02 & 1,25 \\
\hline & 0,4 & 892,82 & 898,70 & 52,61 & 770,20 & 122,63 & 1,16 \\
\hline & 0,5 & 817,08 & 889,25 & 52,06 & 769,64 & 47,44 & 1,06 \\
\hline & 0,6 & 765,68 & 878,35 & 51,42 & 769,00 & $-3,32$ & 1,00 \\
\hline & 0,7 & 702,58 & 875,85 & 51,27 & 768,86 & $-66,28$ & 0,91 \\
\hline & 0,8 & 667,49 & 865,28 & 50,65 & 768,24 & $-100,75$ & 0,87 \\
\hline \multirow{7}{*}{$15-$ Set } & 0,2 & 1020,36 & 896,36 & 52,47 & 770,06 & 250,30 & 1,33 \\
\hline & 0,3 & 959,27 & 888,36 & 52,01 & 769,59 & 189,68 & 1,25 \\
\hline & 0,4 & 886,47 & 876,44 & 51,31 & 768,89 & 117,58 & 1,15 \\
\hline & 0,5 & 816,17 & 864,90 & 50,63 & 768,22 & 47,96 & 1,06 \\
\hline & 0,6 & 763,49 & 861,18 & 50,41 & 768,00 & $-4,51$ & 0,99 \\
\hline & 0,7 & 704,88 & 851,60 & 49,85 & 767,44 & $-62,56$ & 0,92 \\
\hline & 0,8 & 661,84 & 846,78 & 49,57 & 767,16 & $-105,31$ & 0,86 \\
\hline \multirow{7}{*}{ 1-Out } & 0,2 & 1025,88 & 865,98 & 51,47 & 769,05 & 256,83 & 1,33 \\
\hline & 0,3 & 967,47 & 857,93 & 50,99 & 768,57 & 198,89 & 1,26 \\
\hline & 0,4 & 890,31 & 845,90 & 50,27 & 767,86 & 122,45 & 1,16 \\
\hline & 0,5 & 827,12 & 837,05 & 49,75 & 767,33 & 59,79 & 1,08 \\
\hline & 0,6 & 765,89 & 827,03 & 49,15 & 766,74 & $-0,84$ & 1,00 \\
\hline & 0,7 & 709,29 & 815,42 & 48,46 & 766,05 & $-56,76$ & 0,93 \\
\hline & 0,8 & 661,06 & 809,71 & 48,12 & 765,71 & $-104,65$ & 0,86 \\
\hline \multirow{7}{*}{ 15-Out } & 0,2 & 1019,99 & 819,54 & 48,71 & 766,29 & 253,70 & 1,33 \\
\hline & 0,3 & 967,16 & 808,52 & 48,05 & 765,64 & 201,52 & 1,26 \\
\hline & 0,4 & 880,05 & 793,52 & 47,16 & 764,75 & 115,31 & 1,15 \\
\hline & 0,5 & 826,89 & 775,88 & 46,11 & 763,70 & 63,19 & 1,08 \\
\hline & 0,6 & 758,84 & 769,48 & 45,73 & 763,32 & $-4,47$ & 0,99 \\
\hline & 0,7 & 712,51 & 758,09 & 45,05 & 762,64 & $-50,13$ & 0,93 \\
\hline & 0,8 & 660,16 & 747,08 & 44,40 & 761,98 & $-101,83$ & 0,87 \\
\hline
\end{tabular}


Tabela 21B. Receitas brutas, composição de custos da irrigação, receitas liquidas e relação beneficio/custo para o feijão caupi, em cada época de semeadura, nível de manejo da irrigação e risco de $30 \%$. Teresina, Piauí.

\begin{tabular}{|c|c|c|c|c|c|c|c|}
\hline $\begin{array}{l}\text { Época de } \\
\text { Semeadura }\end{array}$ & $p$ & $\begin{array}{c}\mathrm{RB}^{1} \\
\left(\mathrm{US} \$ \mathrm{ha}^{-1}\right)\end{array}$ & $\begin{array}{c}E b \\
\left(\mathrm{kWh} \mathrm{ha}{ }^{-1}\right)\end{array}$ & $\begin{array}{c}C E \\
\left(\mathrm{US} \$ h \mathrm{~h}^{-1}\right)\end{array}$ & $\begin{array}{c}C T \\
\left(\text { US } \$ h^{-1}\right)^{-1}\end{array}$ & $\begin{array}{c}\mathrm{RL} \\
\left(\mathrm{US} \$ \mathrm{ha}^{-1}\right)\end{array}$ & $\mathrm{B} / \mathrm{C}$ \\
\hline \multirow{7}{*}{$1-$ Nov } & 0,2 & 1183,85 & 714,67 & 42,73 & 760,31 & 423,53 & 1,56 \\
\hline & 0,3 & 1119,46 & 697,97 & 41,73 & 759,31 & 360,15 & 1,47 \\
\hline & 0,4 & 1023,38 & 675,98 & 40,41 & 758,00 & 265,38 & 1,35 \\
\hline & 0,5 & 963,14 & 664,28 & 39,71 & 757,30 & 205,84 & 1,27 \\
\hline & 0,6 & 888,21 & 646,38 & 38,64 & 756,23 & 131,98 & 1,17 \\
\hline & 0,7 & 836,07 & 629,97 & 37,66 & 755,25 & 80,82 & 1,11 \\
\hline & 0,8 & 777,69 & 613,56 & 36,68 & 754,27 & 23,42 & 1,03 \\
\hline \multirow{7}{*}{$15-\mathrm{Nov}$} & 0,2 & 1179,24 & 625,98 & 37,42 & 755,01 & 424,23 & 1,56 \\
\hline & 0,3 & 1114,55 & 600,53 & 35,90 & 753,49 & 361,07 & 1,48 \\
\hline & 0,4 & 1026,32 & 567,75 & 33,94 & 751,53 & 274,79 & 1,37 \\
\hline & 0,5 & 964,10 & 544,35 & 32,54 & 750,13 & 213,97 & 1,29 \\
\hline & 0,6 & 901,11 & 526,30 & 31,47 & 749,05 & 152,06 & 1,20 \\
\hline & 0,7 & 844,58 & 504,26 & 30,15 & 747,73 & 96,85 & 1,13 \\
\hline & 0,8 & 798,61 & 486,69 & 29,10 & 746,68 & 51,93 & 1,07 \\
\hline \multirow{7}{*}{ 1-Dez } & 0,2 & 1210,93 & 552,72 & 32,43 & 750,02 & 460,92 & 1,61 \\
\hline & 0,3 & 1143,28 & 522,74 & 30,67 & 748,26 & 395,02 & 1,53 \\
\hline & 0,4 & 1060,66 & 492,93 & 28,92 & 746,51 & 314,16 & 1,42 \\
\hline & 0,5 & 992,74 & 464,04 & 27,23 & 744,81 & 247,93 & 1,33 \\
\hline & 0,6 & 936,52 & 449,16 & 26,35 & 743,94 & 192,58 & 1,26 \\
\hline & 0,7 & 880,90 & 418,02 & 24,53 & 742,11 & 138,79 & 1,19 \\
\hline & 0,8 & 832,42 & 392,40 & 23,02 & 740,61 & 91,81 & 1,12 \\
\hline \multirow{7}{*}{ 15-Dez } & 0,2 & 1212,77 & 482,36 & 28,30 & 745,89 & 466,88 & 1,63 \\
\hline & 0,3 & 1145,24 & 451,55 & 26,49 & 744,08 & 401,17 & 1,54 \\
\hline & 0,4 & 1069,14 & 412,81 & 24,22 & 741,81 & 327,34 & 1,44 \\
\hline & 0,5 & 1002,00 & 378,19 & 22,19 & 739,77 & 262,22 & 1,35 \\
\hline & 0,6 & 957,84 & 354,40 & 20,79 & 738,38 & 219,46 & 1,30 \\
\hline & 0,7 & 903,57 & 325,08 & 19,07 & 736,66 & 166,91 & 1,23 \\
\hline & 0,8 & 859,25 & 294,12 & 17,26 & 734,84 & 124,41 & 1,17 \\
\hline
\end{tabular}

${ }^{1} \mathrm{RB}$ - receita bruta; $\mathrm{Eb}$ - energia requerida para o bombeamento; $\mathrm{CE}$ - custo de energia elétrica; $\mathrm{CT}$ - custo total de produção; RL - receita líquida e B/C - relação benefício/custo. 
Tabela 22B. Receitas brutas, composição de custos da irrigação, receitas líquidas e relação beneficio/custo para o feijão caupi, em cada época de semeadura, nível de manejo da irrigação e risco de $35 \%$. Teresina, Piauí.

\begin{tabular}{|c|c|c|c|c|c|c|c|}
\hline $\begin{array}{l}\text { Época de } \\
\text { Semeadura }\end{array}$ & $\mathrm{p}$ & $\begin{array}{c}\mathrm{RB}^{\mathrm{I}} \\
\left(\mathrm{US} \$ \mathrm{ha}^{-1}\right)\end{array}$ & $\begin{array}{c}\mathrm{Eb} \\
\left(\mathrm{kWh} \mathrm{ha}^{-1}\right)\end{array}$ & $\begin{array}{c}\mathrm{CE} \\
\left(\mathrm{US} \$ \mathrm{ha}^{-1}\right)\end{array}$ & $\begin{array}{c}\text { CT } \\
\left(\text { US\$ ha }^{-1}\right)\end{array}$ & $\begin{array}{c}\mathrm{RL} \\
\left(\mathrm{US} \$ \mathrm{ha}^{-1}\right)\end{array}$ & $\mathrm{B} / \mathrm{C}$ \\
\hline \multirow{7}{*}{ 1-Jan } & 0,2 & 1186,12 & 398,37 & 22,90 & 740,48 & 445,64 & 1,60 \\
\hline & 0,3 & 1128,60 & 365,65 & 21,02 & 738,60 & 390,00 & 1,53 \\
\hline & 0,4 & 1066,35 & 329,41 & 18,93 & 736,52 & 329,84 & 1,45 \\
\hline & 0,5 & 1005,13 & 290,95 & 16,72 & 734,31 & 270,83 & 1,37 \\
\hline & 0,6 & 968,91 & 252,30 & 14,50 & 732,09 & 236,82 & 1,32 \\
\hline & 0,7 & 926,43 & 223,18 & 12,83 & 730,41 & 196,02 & 1,27 \\
\hline & 0,8 & 892,26 & 207,24 & 11,91 & 729,50 & 162,77 & 1,22 \\
\hline \multirow{7}{*}{ 15-Jan } & 0,2 & 1205,00 & 360,35 & 20,71 & 738,30 & 466,70 & 1,63 \\
\hline & 0,3 & 1150,07 & 323,53 & 18,59 & 736,18 & 413,89 & 1,56 \\
\hline & 0,4 & 1093,97 & 284,36 & 16,34 & 733,93 & 360,05 & 1,49 \\
\hline & 0,5 & 1042,92 & 248,52 & 14,28 & 731,87 & 311,05 & 1,43 \\
\hline & 0,6 & 1005,23 & 219,73 & 12,63 & 730,21 & 275,02 & 1,38 \\
\hline & 0,7 & 968,02 & 183,97 & 10,57 & 728,16 & 239,86 & 1,33 \\
\hline & 0,8 & 936,47 & 164,65 & 9,46 & 727,05 & 209,43 & 1,29 \\
\hline \multirow{7}{*}{$1-\mathrm{Fev}$} & 0,2 & 1174,64 & 308,85 & 17,52 & 735,10 & 439,54 & 1,60 \\
\hline & 0,3 & 1122,99 & 264,60 & 15,01 & 732,59 & 390,40 & 1,53 \\
\hline & 0,4 & 1075,14 & 220,13 & 12,49 & 730,07 & 345,07 & 1,47 \\
\hline & 0,5 & 1029,32 & 183,87 & 10,43 & 728,01 & 301,30 & 1,41 \\
\hline & 0,6 & 1003,05 & 159,49 & 9,05 & 726,63 & 276,42 & 1,38 \\
\hline & 0,7 & 972,92 & 127,77 & 7,25 & 724,83 & 248,09 & 1,34 \\
\hline & 0,8 & 950,92 & 105,29 & 5,97 & 723,56 & 227,36 & 1,31 \\
\hline \multirow{7}{*}{$15-\mathrm{Fev}$} & 0,2 & 1173,69 & 296,38 & 16,81 & 734,39 & 439,30 & 1,60 \\
\hline & 0,3 & 1121,28 & 253,91 & 14,40 & 731,99 & 389,29 & 1,53 \\
\hline & 0,4 & 1075,98 & 216,65 & 12,29 & 729,87 & 346,11 & 1,47 \\
\hline & 0,5 & 1032,98 & 174,37 & 9,89 & 727,47 & 305,50 & 1,42 \\
\hline & 0,6 & 1008,51 & 153,65 & 8,71 & 726,30 & 282,21 & 1,39 \\
\hline & 0,7 & 980,95 & 116,05 & 6,58 & 724,17 & 256,78 & 1,35 \\
\hline & 0,8 & 957,00 & 104,96 & 5,95 & 723,54 & 233,46 & 1,32 \\
\hline
\end{tabular}


Tabela 22B. Receitas brutas, composição de custos da irrigação, receitas líquidas e relação beneficio/custo para o feijão caupi, em cada época de semeadura, nível de manejo da irrigação e risco de $35 \%$. Teresina, Piauí.

\begin{tabular}{|c|c|c|c|c|c|c|c|}
\hline $\begin{array}{c}\text { Época de } \\
\text { Semeadura }\end{array}$ & $\mathrm{p}$ & $\begin{array}{c}\mathrm{RB}^{1} \\
\left(\mathrm{US} \$ \mathrm{ha}^{-1}\right)\end{array}$ & $\begin{array}{c}E b \\
\left(\mathrm{kWh} \mathrm{ha}^{-1}\right)\end{array}$ & $\begin{array}{c}\mathrm{CE} \\
\left(\mathrm{US} \$ \mathrm{ha}^{-1}\right)\end{array}$ & $\begin{array}{c}\text { CT } \\
\left(\mathrm{US} \$ \mathrm{ha}^{-1}\right)\end{array}$ & $\begin{array}{c}\mathrm{RL} \\
\left(\mathrm{US} \$ \mathrm{ha}^{-1}\right)\end{array}$ & $\mathrm{B} / \mathrm{C}$ \\
\hline \multirow{7}{*}{ 1-Mar } & 0,2 & 1207,36 & 294,92 & 16,51 & 734,09 & 473,27 & 1,64 \\
\hline & 0,3 & 1149,71 & 253,20 & 14,17 & 731,76 & 417,95 & 1,57 \\
\hline & 0,4 & 1103,32 & 200,54 & 11,23 & 728,81 & 374,51 & 1,51 \\
\hline & 0,5 & 1061,30 & 176,22 & 9,86 & 727,45 & 333,85 & 1,46 \\
\hline & 0,6 & 1030,35 & 152,11 & 8,51 & 726,10 & 304,25 & 1,42 \\
\hline & 0,7 & 998,70 & 124,39 & 6,96 & 724,55 & 274,15 & 1,38 \\
\hline & 0,8 & 972,36 & 80,73 & 4,52 & 722,10 & 250,26 & 1,35 \\
\hline \multirow{7}{*}{ 15-Mar } & 0,2 & 1197,76 & 348,00 & 19,48 & 737,06 & 460,70 & 1,63 \\
\hline & 0,3 & 1127,13 & 305,23 & 17,09 & 734,67 & 392,46 & 1,53 \\
\hline & 0,4 & 1082,24 & 267,87 & 14,99 & 732,58 & 349,66 & 1,48 \\
\hline & 0,5 & 1021,12 & 234,87 & 13,15 & 730,73 & 290,39 & 1,40 \\
\hline & 0,6 & 980,51 & 210,81 & 11,80 & 729,38 & 251,12 & 1,34 \\
\hline & 0,7 & 948,79 & 174,48 & 9,77 & 727,35 & 221,44 & 1,30 \\
\hline & 0,8 & 914,77 & 152,88 & 8,56 & 726,14 & 188,62 & 1,26 \\
\hline \multirow{7}{*}{$1-\mathrm{Abr}$} & 0,2 & 1177,10 & 414,46 & 21,99 & 739,57 & 437,52 & 1,59 \\
\hline & 0,3 & 1100,08 & 380,77 & 20,20 & 737,79 & 362,30 & 1,49 \\
\hline & 0,4 & 1049,53 & 349,59 & 18,55 & 736,13 & 313,39 & 1,43 \\
\hline & 0,5 & 984,12 & 323,21 & 17,15 & 734,73 & 249,39 & 1,34 \\
\hline & 0,6 & 936,20 & 300,75 & 15,96 & 733,54 & 202,66 & 1,28 \\
\hline & 0,7 & 896,37 & 277,04 & 14,70 & 732,28 & 164,09 & 1,22 \\
\hline & 0,8 & 856,16 & 246,36 & 13,07 & 730,66 & 125,50 & 1,17 \\
\hline \multirow{7}{*}{ 15-Abr } & 0,2 & 1164,45 & 494,40 & 26,23 & 743,82 & 420,63 & 1,57 \\
\hline & 0,3 & 1078,78 & 470,64 & 24,97 & 742,55 & 336,23 & 1,45 \\
\hline & 0,4 & 1019,71 & 439,75 & 23,33 & 740,92 & 278,80 & 1,38 \\
\hline & 0,5 & 947,22 & 412,36 & 21,88 & 739,46 & 207,75 & 1,28 \\
\hline & 0,6 & 887,09 & 396,19 & 21,02 & 738,61 & 148,48 & 1,20 \\
\hline & 0,7 & 837,80 & 376,30 & 19,97 & 737,55 & 100,25 & 1,14 \\
\hline & 0,8 & 793,56 & 355,10 & 18,84 & 736,42 & 57,13 & 1,08 \\
\hline
\end{tabular}


Tabela 22B. Receitas brutas, composição de custos da irrigação, receitas líquidas e relação benefício/custo para o feijão caupi, em cada época de semeadura, nível de manejo da irrigação e risco de $35 \%$. Teresina, Piauí.

\begin{tabular}{|c|c|c|c|c|c|c|c|}
\hline $\begin{array}{l}\text { Época de } \\
\text { Semeadura }\end{array}$ & $\mathrm{p}$ & $\begin{array}{c}\mathrm{RB}^{1} \\
\left(\mathrm{US} \$ \mathrm{ha}^{-1}\right)\end{array}$ & $\begin{array}{c}\mathrm{Eb} \\
\left(\mathrm{kWh} \mathrm{ha}{ }^{-1}\right)\end{array}$ & $\begin{array}{c}\text { CE } \\
\left(\mathrm{US} \$ \mathrm{ha}^{-1}\right)\end{array}$ & $\begin{array}{c}\text { CT } \\
\left(\mathrm{US} \$ \mathrm{ha}^{-1}\right)\end{array}$ & $\begin{array}{c}\mathrm{RL} \\
\left(\mathrm{US} \$ \mathrm{ha}^{-1}\right)\end{array}$ & $\mathrm{B} / \mathrm{C}$ \\
\hline \multirow{7}{*}{ 1-Mai } & 0,2 & 987,82 & 555,67 & 29,41 & 747,00 & 240,82 & 1,32 \\
\hline & 0,3 & 908,84 & 531,81 & 28,15 & 745,73 & 163,11 & 1,22 \\
\hline & 0,4 & 855,88 & 512,14 & 27,11 & 744,69 & 111,19 & 1,15 \\
\hline & 0,5 & 788,07 & 497,42 & 26,33 & 743,91 & 44,16 & 1,06 \\
\hline & 0,6 & 735,26 & 483,34 & 25,58 & 743,17 & $-7,91$ & 0,99 \\
\hline & 0,7 & 695,17 & 467,38 & 24,74 & 742,32 & $-47,15$ & 0,94 \\
\hline & 0,8 & 645,09 & 446,09 & 23,61 & 741,20 & $-96,10$ & 0,87 \\
\hline \multirow{7}{*}{ 15-Mai } & 0,2 & 984,00 & 622,15 & 32,93 & 750,52 & 233,48 & 1,31 \\
\hline & 0,3 & 912,31 & 606,87 & 32,12 & 749,71 & 162,60 & 1,22 \\
\hline & 0,4 & 847,60 & 594,82 & 31,49 & 749,07 & 98,53 & 1,13 \\
\hline & 0,5 & 773,38 & 583,58 & 30,89 & 748,48 & 24,90 & 1,03 \\
\hline & 0,6 & 725,68 & 572,48 & 30,30 & 747,89 & $-22,21$ & 0,97 \\
\hline & 0,7 & 672,95 & 555,46 & 29,40 & 746,99 & $-74,03$ & 0,90 \\
\hline & 0,8 & 626,02 & 551,51 & 29,19 & 746,78 & $-120,76$ & 0,84 \\
\hline \multirow{7}{*}{ 1-Jun } & 0,2 & 1059,53 & 681,90 & 38,38 & 755,96 & 303,57 & 1,40 \\
\hline & 0,3 & 990,17 & 671,31 & 37,78 & 755,36 & 234,81 & 1,31 \\
\hline & 0,4 & 908,24 & 664,04 & 37,37 & 754,96 & 153,28 & 1,20 \\
\hline & 0,5 & 832,68 & 657,53 & 37,00 & 754,59 & 78,09 & 1,10 \\
\hline & 0,6 & 781,43 & 647,58 & 36,44 & 754,03 & 27,40 & 1,04 \\
\hline & 0,7 & 720,63 & 643,42 & 36,21 & 753,79 & $-33,16$ & 0,96 \\
\hline & 0,8 & 667,06 & 637,67 & 35,89 & 753,47 & $-86,41$ & 0,89 \\
\hline \multirow{7}{*}{ 15-Jun } & 0,2 & 1064,78 & 734,30 & 41,33 & 758,91 & 305,87 & 1,40 \\
\hline & 0,3 & 1001,66 & 726,14 & 40,87 & 758,45 & 243,21 & 1,32 \\
\hline & 0,4 & 909,52 & 718,91 & 40,46 & 758,04 & 151,47 & 1,20 \\
\hline & 0,5 & 841,83 & 710,21 & 39,97 & 757,55 & 84,28 & 1,11 \\
\hline & 0,6 & 779,44 & 703,36 & 39,58 & 757,17 & 22,27 & 1,03 \\
\hline & 0,7 & 719,37 & 698,54 & 39,31 & 756,90 & $-37,53$ & 0,95 \\
\hline & 0,8 & 672,84 & 688,68 & 38,76 & 756,34 & $-83,50$ & 0,89 \\
\hline
\end{tabular}


Tabela 22B. Receitas brutas, composição de custos da irrigação, receitas líquidas e relação benefício/custo para o feijão caupi, em cada época de semeadura, nível de manejo da irrigação e risco de $35 \%$. Teresina, Piauí.

\begin{tabular}{|c|c|c|c|c|c|c|c|}
\hline $\begin{array}{c}\text { Época de } \\
\text { Semeadura }\end{array}$ & $\mathrm{p}$ & $\begin{array}{c}\mathrm{RB}^{1} \\
\left(\mathrm{US} \$ \mathrm{ha}^{-1}\right)\end{array}$ & $\begin{array}{c}E b \\
\left(\mathrm{kWh} \mathrm{ha}^{-1}\right)\end{array}$ & $\begin{array}{c}\text { CE } \\
\left(\mathrm{US} \$ \mathrm{ha}^{-1}\right)\end{array}$ & $\begin{array}{c}\text { CT } \\
\left(\mathrm{US} \$ \mathrm{ha}^{-1}\right)\end{array}$ & $\begin{array}{c}\mathrm{RL} \\
\left(\mathrm{US} \$ \mathrm{ha}^{-1}\right)\end{array}$ & $\mathrm{B} / \mathrm{C}$ \\
\hline \multirow{7}{*}{ 1-Jul } & 0,2 & 1063,90 & 799,07 & 47,02 & 764,60 & 299,30 & 1,39 \\
\hline & 0,3 & 1004,42 & 793,25 & 46,68 & 764,26 & 240,16 & 1,31 \\
\hline & 0,4 & 908,02 & 788,80 & 46,41 & 764,00 & 144,02 & 1,19 \\
\hline & 0,5 & 851,76 & 781,98 & 46,01 & 763,60 & 88,16 & 1,12 \\
\hline & 0,6 & 782,64 & 781,33 & 45,97 & 763,56 & 19,08 & 1,02 \\
\hline & 0,7 & 726,91 & 765,01 & 45,01 & 762,60 & $-35,69$ & 0,95 \\
\hline & 0,8 & 674,77 & 772,25 & 45,44 & 763,02 & $-88,26$ & 0,88 \\
\hline \multirow{7}{*}{$15-J u l$} & 0,2 & 1073,67 & 856,25 & 50,38 & 767,97 & 305,70 & 1,40 \\
\hline & 0,3 & 1014,64 & 850,66 & 50,05 & 767,64 & 247,00 & 1,32 \\
\hline & 0,4 & 918,78 & 844,02 & 49,66 & 767,25 & 151,53 & 1,20 \\
\hline & 0,5 & 866,59 & 841,24 & 49,50 & 767,08 & 99,51 & 1,13 \\
\hline & 0,6 & 782,96 & 839,18 & 49,38 & 766,96 & 16,00 & 1,02 \\
\hline & 0,7 & 739,09 & 703,14 & 41,37 & 758,96 & $-19,87$ & 0,97 \\
\hline & 0,8 & 675,30 & 797,22 & 46,91 & 764,49 & $-89,19$ & 0,88 \\
\hline \multirow{7}{*}{ 1-Ago } & 0,2 & 1038,02 & 892,10 & 52,93 & 770,51 & 267,51 & 1,35 \\
\hline & 0,3 & 978,32 & 886,33 & 52,58 & 770,17 & 208,15 & 1,27 \\
\hline & 0,4 & 897,67 & 883,41 & 52,41 & 770,00 & 127,67 & 1,17 \\
\hline & 0,5 & 831,98 & 895,97 & 53,16 & 770,74 & 61,24 & 1,08 \\
\hline & 0,6 & 764,53 & 854,62 & 50,70 & 768,29 & $-3,76$ & 1,00 \\
\hline & 0,7 & 712,08 & 858,77 & 50,95 & 768,53 & $-56,46$ & 0,93 \\
\hline & 0,8 & 659,46 & 856,20 & 50,80 & 768,38 & $-108,93$ & 0,86 \\
\hline \multirow{7}{*}{ 15-Ago } & 0,2 & 1044,91 & 916,64 & 54,38 & 771,97 & 272,94 & 1,35 \\
\hline & 0,3 & 977,77 & 910,95 & 54,05 & 771,63 & 206,14 & 1,27 \\
\hline & 0,4 & 913,12 & 907,61 & 53,85 & 771,43 & 141,69 & 1,18 \\
\hline & 0,5 & 834,64 & 893,47 & 53,01 & 770,59 & 64,05 & 1,08 \\
\hline & 0,6 & 785,48 & 893,06 & 52,98 & 770,57 & 14,92 & 1,02 \\
\hline & 0,7 & 721,05 & 884,51 & 52,48 & 770,06 & $-49,01$ & 0,94 \\
\hline & 0,8 & 679,06 & 876,54 & 52,00 & 769,59 & $-90,53$ & 0,88 \\
\hline
\end{tabular}


Tabela 22B. Receitas brutas, composição de custos da irrigação, receitas líquidas e relação benefício/custo para o feijão caupi, em cada época de semeadura, nivel de manejo da irrigação e risco de $35 \%$. Teresina, Piauí.

\begin{tabular}{|c|c|c|c|c|c|c|c|}
\hline $\begin{array}{c}\text { Época de } \\
\text { Semeadura }\end{array}$ & $\mathrm{p}$ & $\begin{array}{c}\mathrm{RB}^{\mathrm{I}} \\
\left(\mathrm{US} \$ \mathrm{ha}^{-1}\right)\end{array}$ & $\begin{array}{c}\mathrm{Eb} \\
\left(\mathrm{kWh} \mathrm{ha}^{-1}\right)\end{array}$ & $\begin{array}{c}\text { CE } \\
\left(\mathrm{US} \$ \mathrm{ha}^{-1}\right)\end{array}$ & $\begin{array}{c}\text { CT } \\
\left(\mathrm{US} \$ \mathrm{ha}^{-1}\right)\end{array}$ & $\begin{array}{c}\text { RL } \\
\left(\mathrm{US} \$ \mathrm{ha}^{-1}\right)\end{array}$ & $\mathrm{B} / \mathrm{C}$ \\
\hline \multirow{7}{*}{$1-$ Set } & 0,2 & 1057,01 & 912,74 & 52,85 & 770,44 & 286,57 & 1,37 \\
\hline & 0,3 & 991,61 & 901,90 & 52,23 & 769,81 & 221,80 & 1,29 \\
\hline & 0,4 & 923,17 & 893,42 & 51,73 & 769,32 & 153,85 & 1,20 \\
\hline & 0,5 & 844,04 & 882,89 & 51,13 & 768,71 & 75,33 & 1,10 \\
\hline & 0,6 & 792,06 & 871,33 & 50,46 & 768,04 & 24,02 & 1,03 \\
\hline & 0,7 & 726,91 & 868,40 & 50,29 & 767,87 & $-40,96$ & 0,95 \\
\hline & 0,8 & 690,92 & 857,49 & 49,65 & 767,24 & $-76,32$ & 0,90 \\
\hline \multirow{7}{*}{$15-$ Set } & 0,2 & 1053,59 & 891,58 & 51,63 & 769,21 & 284,38 & 1,37 \\
\hline & 0,3 & 990,27 & 882,76 & 51,12 & 768,70 & 221,56 & 1,29 \\
\hline & 0,4 & 916,54 & 869,88 & 50,37 & 767,96 & 148,59 & 1,19 \\
\hline & 0,5 & 843,57 & 858,13 & 49,69 & 767,28 & 76,29 & 1,10 \\
\hline & 0,6 & 790,29 & 853,80 & 49,44 & 767,03 & 23,27 & 1,03 \\
\hline & 0,7 & 729,40 & 842,76 & 48,80 & 766,39 & $-36,99$ & 0,95 \\
\hline & 0,8 & 685,52 & 838,09 & 48,53 & 766,12 & $-80,60$ & 0,89 \\
\hline \multirow{7}{*}{ 1-Out } & 0,2 & 1054,30 & 860,86 & 50,57 & 768,15 & 286,14 & 1,37 \\
\hline & 0,3 & 994,20 & 852,40 & 50,07 & 767,65 & 226,55 & 1,30 \\
\hline & 0,4 & 915,97 & 839,48 & 49,31 & 766,90 & 149,08 & 1,19 \\
\hline & 0,5 & 850,81 & 829,49 & 48,72 & 766,31 & 84,50 & 1,11 \\
\hline & 0,6 & 788,75 & 818,03 & 48,05 & 765,64 & 23,12 & 1,03 \\
\hline & 0,7 & 730,64 & 806,65 & 47,38 & 764,97 & $-34,32$ & 0,96 \\
\hline & 0,8 & 681,53 & 800,48 & 47,02 & 764,60 & $-83,07$ & 0,89 \\
\hline \multirow{7}{*}{ 15-Out } & 0,2 & 1048,31 & 813,77 & 47,80 & 765,39 & 282,92 & 1,37 \\
\hline & 0,3 & 993,87 & 801,82 & 47,10 & 764,68 & 229,19 & 1,30 \\
\hline & 0,4 & 905,35 & 786,04 & 46,17 & 763,76 & 141,60 & 1,19 \\
\hline & 0,5 & 850,79 & 767,04 & 45,06 & 762,64 & 88,15 & 1,12 \\
\hline & 0,6 & 781,84 & 759,91 & 44,64 & 762,22 & 19,62 & 1,03 \\
\hline & 0,7 & 734,14 & 748,34 & 43,96 & 761,54 & $-27,40$ & 0,96 \\
\hline & 0,8 & 680,96 & 737,10 & 43,30 & 760,88 & $-79,92$ & 0,89 \\
\hline
\end{tabular}


Tabela 22B. Receitas brutas, composição de custos da irrigação, receitas líquidas e relação beneficio/custo para o feijão caupi, em cada época de semeadura, nível de manejo da irrigação e risco de $35 \%$. Teresina, Piauí.

\begin{tabular}{|c|c|c|c|c|c|c|c|}
\hline $\begin{array}{l}\text { Época de } \\
\text { Semeadura }\end{array}$ & $\mathrm{p}$ & $\begin{array}{c}\mathrm{RB}^{1} \\
\left(\mathrm{US} \$ \mathrm{ha}^{-1}\right)\end{array}$ & $\begin{array}{c}E b \\
\left(\mathrm{kWh} \mathrm{ha}{ }^{-1}\right)\end{array}$ & $\begin{array}{c}\text { CE } \\
\left(\text { US } \$ \mathrm{ha}^{-1}\right)\end{array}$ & $\begin{array}{c}\text { CT } \\
\left(\text { US } \$ \mathrm{ha}^{-1}\right) \\
\end{array}$ & $\begin{array}{c}\mathrm{RL} \\
\left(\mathrm{US} \$ \mathrm{ha}^{-1}\right)\end{array}$ & $\mathrm{B} / \mathrm{C}$ \\
\hline \multirow{7}{*}{ 1-Nov } & 0,2 & 1214,29 & 707,31 & 41,82 & 759,41 & 454,88 & 1,60 \\
\hline & 0,3 & 1149,19 & 689,44 & 40,77 & 758,35 & 390,84 & 1,52 \\
\hline & 0,4 & 1050,93 & 665,79 & 39,37 & 756,95 & 293,98 & 1,39 \\
\hline & 0,5 & 990,15 & 653,85 & 38,66 & 756,25 & 233,91 & 1,31 \\
\hline & 0,6 & 914,03 & 634,90 & 37,54 & 755,13 & 158,91 & 1,21 \\
\hline & 0,7 & 860,97 & 617,56 & 36,52 & 754,10 & 106,87 & 1,14 \\
\hline & 0,8 & 801,97 & 599,96 & 35,48 & 753,06 & 48,91 & 1,06 \\
\hline \multirow{7}{*}{$15-\mathrm{Nov}$} & 0,2 & 1209,98 & 617,63 & 36,52 & 754,11 & 455,87 & 1,60 \\
\hline & 0,3 & 1144,48 & 591,32 & 34,97 & 752,55 & 391,93 & 1,52 \\
\hline & 0,4 & 1055,00 & 557,53 & 32,97 & 750,55 & 304,45 & 1,41 \\
\hline & 0,5 & 992,52 & 533,13 & 31,53 & 749,11 & 243,41 & 1,32 \\
\hline & 0,6 & 928,68 & 513,27 & 30,35 & 747,94 & 180,75 & 1,24 \\
\hline & 0,7 & 871,54 & 490,73 & 29,02 & 746,60 & 124,94 & 1,17 \\
\hline & 0,8 & 825,41 & 472,89 & 27,96 & 745,55 & 79,86 & 1,11 \\
\hline \multirow{7}{*}{ 1-Dez } & 0,2 & 1239,78 & 544,89 & 31,58 & 749,16 & 490,62 & 1,65 \\
\hline & 0,3 & 1171,76 & 514,04 & 29,79 & 747,37 & 424,38 & 1,57 \\
\hline & 0,4 & 1087,67 & 482,68 & 27,97 & 745,56 & 342,12 & 1,46 \\
\hline & 0,5 & 1019,38 & 452,28 & 26,21 & 743,79 & 275,59 & 1,37 \\
\hline & 0,6 & 962,65 & 437,56 & 25,36 & 742,94 & 219,70 & 1,30 \\
\hline & 0,7 & 906,20 & 404,41 & 23,44 & 741,02 & 165,18 & 1,22 \\
\hline & 0,8 & 857,77 & 377,49 & 21,88 & 739,46 & 118,31 & 1,16 \\
\hline \multirow{7}{*}{ 15-Dez } & 0,2 & 1241,93 & 473,68 & 27,45 & 745,03 & 496,90 & 1,67 \\
\hline & 0,3 & 1174,17 & 441,98 & 25,61 & 743,20 & 430,97 & 1,58 \\
\hline & 0,4 & 1096,71 & 402,49 & 23,32 & 740,91 & 355,81 & 1,48 \\
\hline & 0,5 & 1029,76 & 367,40 & 21,29 & 738,88 & 290,88 & 1,39 \\
\hline & 0,6 & 984,90 & 342,16 & 19,83 & 737,41 & 247,49 & 1,34 \\
\hline & 0,7 & 930,93 & 312,25 & 18,09 & 735,68 & 195,25 & 1,27 \\
\hline & 0,8 & 886,54 & 281,10 & 16,29 & 733,87 & 152,66 & 1,21 \\
\hline
\end{tabular}

$\mathrm{RB}$ - receita bruta; $\mathrm{Eb}$ - energia requerida para o bombeamento; $\mathrm{CE}$ - custo de energia elétrica; $\mathrm{CT}$ - custo total de produção; $R L$ - receita líquida e B/C - relação benefício/custo. 
Tabela 23B. Receitas brutas, composição de custos da irrigação, receitas líquidas e relação benefício/custo para o feijão caupi, em cada época de semeadura, nível de manejo da irrigação e risco de $40 \%$. Teresina, Piauí.

\begin{tabular}{|c|c|c|c|c|c|c|c|}
\hline $\begin{array}{l}\text { Época de } \\
\text { Semeadura }\end{array}$ & $\mathrm{p}$ & $\begin{array}{c}\mathrm{RB}^{1} \\
\left(\mathrm{US} \$ \mathrm{ha}^{-1}\right)\end{array}$ & $\begin{array}{c}E b \\
\left(\mathrm{kWh} \mathrm{ha}{ }^{-1}\right)\end{array}$ & $\begin{array}{c}\text { CE } \\
\left(\text { US\$ ha }{ }^{-1}\right)\end{array}$ & $\begin{array}{c}\mathrm{CT} \\
\left(\mathrm{US} \$ \mathrm{ha}^{-1}\right)\end{array}$ & $\begin{array}{c}\mathrm{RL} \\
\left(\mathrm{US} \$ \mathrm{ha} \mathrm{a}^{-1}\right)\end{array}$ & $\mathrm{B} / \mathrm{C}$ \\
\hline \multirow{7}{*}{ 1-Jan } & 0,2 & 1217,68 & 390,00 & 22,09 & 739,67 & 478,01 & 1,65 \\
\hline & 0,3 & 1160,21 & 356,50 & 20,19 & 737,77 & 422,43 & 1,57 \\
\hline & 0,4 & 1096,94 & 318,69 & 18,05 & 735,63 & 361,31 & 1,49 \\
\hline & 0,5 & 1035,44 & 279,45 & 15,83 & 733,41 & 302,03 & 1,41 \\
\hline & 0,6 & 999,06 & 240,73 & 13,63 & 731,22 & 267,85 & 1,37 \\
\hline & 0,7 & 957,10 & 211,81 & 11,99 & 729,58 & 227,52 & 1,31 \\
\hline & 0,8 & 923,33 & 194,93 & 11,04 & 728,62 & 194,71 & 1,27 \\
\hline \multirow{7}{*}{ 15-Jan } & 0,2 & 1237,49 & 351,85 & 19,93 & 737,51 & 499,98 & 1,68 \\
\hline & 0,3 & 1182,21 & 313,88 & 17,78 & 735,36 & 446,85 & 1,61 \\
\hline & 0,4 & 1125,68 & 274,34 & 15,54 & 733,12 & 392,56 & 1,54 \\
\hline & 0,5 & 1074,19 & 237,53 & 13,45 & 731,04 & 343,15 & 1,47 \\
\hline & 0,6 & 1036,69 & 207,38 & 11,74 & 729,33 & 307,36 & 1,42 \\
\hline & 0,7 & 999,86 & 172,52 & 9,77 & 727,35 & 272,50 & 1,37 \\
\hline & 0,8 & 969,41 & 164,65 & 9,32 & 726,91 & 242,50 & 1,33 \\
\hline \multirow{7}{*}{$1-\mathrm{Fev}$} & 0,2 & 1208,41 & 301,35 & 16,74 & 734,32 & 474,09 & 1,65 \\
\hline & 0,3 & 1156,52 & 255,89 & 14,21 & 731,80 & 424,72 & 1,58 \\
\hline & 0,4 & 1108,33 & 211,24 & 11,73 & 729,32 & 379,01 & 1,52 \\
\hline & 0,5 & 1062,71 & 175,17 & 9,73 & 727,31 & 335,40 & 1,46 \\
\hline & 0,6 & 1036,94 & 151,07 & 8,39 & 725,97 & 310,96 & 1,43 \\
\hline & 0,7 & 1006,92 & 91,27 & 5,07 & 722,65 & 284,27 & 1,39 \\
\hline & 0,8 & 985,31 & 105,29 & 5,85 & 723,43 & 261,88 & 1,36 \\
\hline \multirow{7}{*}{$15-\mathrm{Fev}$} & 0,2 & 1207,57 & 286,63 & 15,92 & 733,50 & 474,07 & 1,65 \\
\hline & 0,3 & 1155,06 & 244,18 & 13,56 & 731,15 & 423,92 & 1,58 \\
\hline & 0,4 & 1109,81 & 205,76 & 11,43 & 729,01 & 380,80 & 1,52 \\
\hline & 0,5 & 1066,77 & 163,48 & 9,08 & 726,66 & 340,11 & 1,47 \\
\hline & 0,6 & 1042,79 & 142,32 & 7,90 & 725,49 & 317,30 & 1,44 \\
\hline & 0,7 & 1016,21 & 69,63 & 3,87 & 721,45 & 294,76 & 1,41 \\
\hline & 0,8 & 993,54 & 104,96 & 5,83 & 723,41 & 270,13 & 1,37 \\
\hline
\end{tabular}


Tabela 23B. Receitas brutas, composição de custos da irrigação, receitas líquidas e relação benefício/custo para o feijão caupi, em cada época de semeadura, nível de manejo da irrigação e risco de $40 \%$. Teresina, Piauí.

\begin{tabular}{|c|c|c|c|c|c|c|c|}
\hline $\begin{array}{l}\text { Época de } \\
\text { Semeadura }\end{array}$ & $\mathrm{p}$ & $\begin{array}{c}\mathrm{RB}^{\mathrm{l}} \\
\left(\mathrm{US} \$ \mathrm{ha}^{-1}\right)\end{array}$ & $\begin{array}{c}\mathrm{Eb} \\
\left(\mathrm{kWh} \mathrm{ha} \mathrm{h}^{-1}\right)\end{array}$ & $\begin{array}{c}\mathrm{CE} \\
\left(\mathrm{US} \$ \mathrm{ha}^{-1}\right)\end{array}$ & $\begin{array}{c}\mathrm{CT} \\
\left(\mathrm{US} \$ \mathrm{ha}^{-1}\right)\end{array}$ & $\begin{array}{c}\mathrm{RL} \\
\left(\mathrm{US} \$ \mathrm{ha}^{-1}\right)\end{array}$ & $\mathrm{B} / \mathrm{C}$ \\
\hline \multirow{7}{*}{ 1-Mar } & 0,2 & 1243,13 & 286,50 & 15,64 & 733,22 & 509,90 & 1,70 \\
\hline & 0,3 & 1185,49 & 243,60 & 13,30 & 730,88 & 454,61 & 1,62 \\
\hline & 0,4 & 1138,62 & 190,91 & 10,42 & 728,01 & 410,61 & 1,56 \\
\hline & 0,5 & 1096,71 & 166,27 & 9,08 & 726,66 & 370,05 & 1,51 \\
\hline & 0,6 & 1066,40 & 142,80 & 7,79 & 725,38 & 341,02 & 1,47 \\
\hline & 0,7 & 1035,35 & 115,13 & 6,28 & 723,87 & 311,48 & 1,43 \\
\hline & 0,8 & 1009,95 & 80,73 & 4,41 & 721,99 & 287,96 & 1,40 \\
\hline \multirow{7}{*}{ 15-Mar } & 0,2 & 1233,12 & 339,45 & 18,53 & 736,11 & 497,01 & 1,68 \\
\hline & 0,3 & 1161,69 & 295,16 & 16,11 & 733,70 & 428,00 & 1,58 \\
\hline & 0,4 & 1116,53 & 257,26 & 14,04 & 731,63 & 384,90 & 1,53 \\
\hline & 0,5 & 1055,52 & 223,87 & 12,22 & 729,80 & 325,72 & 1,45 \\
\hline & 0,6 & 1015,02 & 199,44 & 10,89 & 728,47 & 286,55 & 1,39 \\
\hline & 0,7 & 983,40 & 163,68 & 8,93 & 726,52 & 256,88 & 1,35 \\
\hline & 0,8 & 949,94 & 152,88 & 8,34 & 725,93 & 224,01 & 1,31 \\
\hline \multirow{7}{*}{$1-A b r$} & 0,2 & 1212,08 & 405,97 & 20,94 & 738,52 & 473,56 & 1,64 \\
\hline & 0,3 & 1134,36 & 371,85 & 19,18 & 736,76 & 397,60 & 1,54 \\
\hline & 0,4 & 1083,07 & 340,16 & 17,54 & 735,13 & 347,94 & 1,47 \\
\hline & 0,5 & 1016,96 & 312,13 & 16,10 & 733,68 & 283,28 & 1,39 \\
\hline & 0,6 & 968,91 & 288,01 & 14,85 & 732,44 & 236,48 & 1,32 \\
\hline & 0,7 & 929,11 & 264,40 & 13,63 & 731,22 & 197,89 & 1,27 \\
\hline & 0,8 & 889,23 & 233,97 & 12,07 & 729,65 & 159,58 & 1,22 \\
\hline \multirow{7}{*}{$15-\mathrm{Abr}$} & 0,2 & 1198,96 & 487,06 & 25,12 & 742,70 & 456,26 & 1,61 \\
\hline & 0,3 & 1111,85 & 462,26 & 23,84 & 741,42 & 370,43 & 1,50 \\
\hline & 0,4 & 1051,71 & 430,01 & 22,17 & 739,76 & 311,95 & 1,42 \\
\hline & 0,5 & 978,25 & 401,52 & 20,71 & 738,29 & 239,96 & 1,33 \\
\hline & 0,6 & 917,56 & 384,95 & 19,85 & 737,44 & 180,12 & 1,24 \\
\hline & 0,7 & 867,93 & 364,56 & 18,80 & 736,38 & 131,55 & 1,18 \\
\hline & 0,8 & 823,20 & 342,77 & 17,68 & 735,26 & 87,94 & 1,12 \\
\hline
\end{tabular}


Tabela 23B. Receitas brutas, composição de custos da irrigação, receitas líquidas e relação beneficio/custo para o feijão caupi, em cada época de semeadura, nível de manejo da irrigação e risco de $40 \%$. Teresina, Piauí.

\begin{tabular}{|c|c|c|c|c|c|c|c|}
\hline $\begin{array}{l}\text { Época de } \\
\text { Semeadura }\end{array}$ & $\mathrm{p}$ & $\begin{array}{c}\mathrm{RB}^{\mathrm{I}} \\
\left(\mathrm{US} \$ \mathrm{ha}^{-1}\right)\end{array}$ & $\begin{array}{c}E b \\
\left(\mathrm{kWh} \mathrm{ha}^{-1}\right)\end{array}$ & $\begin{array}{c}\text { CE } \\
\left(\mathrm{US} \$ \mathrm{ha}^{-1}\right)\end{array}$ & $\begin{array}{c}\mathrm{CT} \\
\left(\mathrm{US} \$ \mathrm{ha}^{-1}\right)\end{array}$ & $\begin{array}{c}\text { RL } \\
\left(\mathrm{US} \$ \mathrm{ha}^{-1}\right)\end{array}$ & $\mathrm{B} / \mathrm{C}$ \\
\hline \multirow{7}{*}{ 1-Mai } & 0,2 & 1027,63 & 548,46 & 28,38 & 745,96 & 281,67 & 1,38 \\
\hline & 0,3 & 946,63 & 523,65 & 27,09 & 744,68 & 201,95 & 1,27 \\
\hline & 0,4 & 891,99 & 503,01 & 26,03 & 743,61 & 148,38 & 1,20 \\
\hline & 0,5 & 822,24 & 486,57 & 25,18 & 742,76 & 79,47 & 1,11 \\
\hline & 0,6 & 767,97 & 471,81 & 24,41 & 742,00 & 25,97 & 1,03 \\
\hline & 0,7 & 727,26 & 455,84 & 23,59 & 741,17 & $-13,91$ & 0,98 \\
\hline & 0,8 & 675,53 & 432,67 & 22,39 & 739,97 & $-64,44$ & 0,91 \\
\hline \multirow{7}{*}{ 15-Mai } & 0,2 & 1023,50 & 617,27 & 31,94 & 749,52 & 273,98 & 1,37 \\
\hline & 0,3 & 949,96 & 601,36 & 31,12 & 748,70 & 201,26 & 1,27 \\
\hline & 0,4 & 882,53 & 588,31 & 30,44 & 748,03 & 134,50 & 1,18 \\
\hline & 0,5 & 806,44 & 576,27 & 29,82 & 747,40 & 59,03 & 1,08 \\
\hline & 0,6 & 757,25 & 564,73 & 29,22 & 746,81 & 10,45 & 1,01 \\
\hline & 0,7 & 702,51 & 546,95 & 28,30 & 745,89 & $-43,38$ & 0,94 \\
\hline & 0,8 & 654,70 & 541,76 & 28,03 & 745,62 & $-90,92$ & 0,88 \\
\hline \multirow{7}{*}{ 1-Jun } & 0,2 & 1095,43 & 677,93 & 37,41 & 755,00 & 340,43 & 1,45 \\
\hline & 0,3 & 1024,64 & 666,57 & 36,78 & 754,37 & 270,27 & 1,36 \\
\hline & 0,4 & 939,91 & 659,28 & 36,38 & 753,97 & 185,95 & 1,25 \\
\hline & 0,5 & 862,28 & 652,07 & 35,99 & 753,57 & 108,71 & 1,14 \\
\hline & 0,6 & 809,78 & 640,88 & 35,37 & 752,95 & 56,83 & 1,08 \\
\hline & 0,7 & 747,06 & 637,05 & 35,16 & 752,74 & $-5,68$ & 0,99 \\
\hline & 0,8 & 692,09 & 637,67 & 35,19 & 752,77 & $-60,68$ & 0,92 \\
\hline \multirow{7}{*}{ 15-Jun } & 0,2 & 1100,80 & 731,11 & 40,35 & 757,93 & 342,87 & 1,45 \\
\hline & 0,3 & 1036,42 & 722,23 & 39,86 & 757,44 & 278,98 & 1,37 \\
\hline & 0,4 & 940,94 & 714,38 & 39,42 & 757,01 & 183,93 & 1,24 \\
\hline & 0,5 & 872,25 & 705,42 & 38,93 & 756,51 & 115,73 & 1,15 \\
\hline & 0,6 & 807,31 & 698,13 & 38,53 & 756,11 & 51,20 & 1,07 \\
\hline & 0,7 & 745,58 & 692,92 & 38,24 & 755,82 & $-10,25$ & 0,99 \\
\hline & 0,8 & 697,35 & 682,45 & 37,66 & 755,25 & $-57,90$ & 0,92 \\
\hline
\end{tabular}


Tabela 23B. Receitas brutas, composição de custos da irrigação, receitas líquidas e relação beneficio/custo para o feijão caupi, em cada época de semeadura, nível de manejo da irrigação e risco de $40 \%$. Teresina, Piauí.

\begin{tabular}{|c|c|c|c|c|c|c|c|}
\hline $\begin{array}{l}\text { Época de } \\
\text { Semeadura }\end{array}$ & $\mathrm{p}$ & $\begin{array}{c}\mathrm{RB}^{1} \\
\left(\mathrm{US} \$ \mathrm{ha}^{-1}\right)\end{array}$ & $\begin{array}{c}E b \\
\left(\mathrm{kWh} \mathrm{ha}^{-1}\right)\end{array}$ & $\begin{array}{c}\text { CE } \\
\left(\mathrm{US} \$ \mathrm{ha}^{-1}\right)\end{array}$ & $\begin{array}{c}\mathrm{CT} \\
\left(\mathrm{US} \$ \mathrm{ha}^{-1}\right)\end{array}$ & $\begin{array}{c}\mathrm{RL} \\
\left(\mathrm{US} \$ \mathrm{ha}^{-1}\right)\end{array}$ & $\mathrm{B} / \mathrm{C}$ \\
\hline \multirow{7}{*}{ 1-Jul } & 0,2 & 1096,44 & 796,42 & 46,23 & 763,81 & 332,63 & 1,44 \\
\hline & 0,3 & 1035,71 & 790,60 & 45,89 & 763,48 & 272,24 & 1,36 \\
\hline & 0,4 & 936,19 & 785,60 & 45,60 & 763,19 & 173,00 & 1,23 \\
\hline & 0,5 & 879,00 & 777,98 & 45,16 & 762,74 & 116,26 & 1,15 \\
\hline & 0,6 & 807,95 & 781,33 & 45,35 & 762,94 & 45,01 & 1,06 \\
\hline & 0,7 & 751,28 & 760,53 & 44,15 & 761,73 & $-10,46$ & 0,99 \\
\hline & 0,8 & 696,81 & 766,67 & 44,50 & 762,09 & $-65,27$ & 0,91 \\
\hline \multirow{7}{*}{ 15-Jul } & 0,2 & 1106,74 & 853,42 & 49,54 & 767,12 & 339,61 & 1,44 \\
\hline & 0,3 & 1045,99 & 847,68 & 49,21 & 766,79 & 279,20 & 1,36 \\
\hline & 0,4 & 947,77 & 840,90 & 48,81 & 766,40 & 181,37 & 1,24 \\
\hline & 0,5 & 893,61 & 837,19 & 48,60 & 766,18 & 127,43 & 1,17 \\
\hline & 0,6 & 808,40 & 834,93 & 48,47 & 766,05 & 42,35 & 1,06 \\
\hline & 0,7 & 762,85 & 678,07 & 39,36 & 756,94 & 5,91 & 1,01 \\
\hline & 0,8 & 697,48 & 797,22 & 46,28 & 763,86 & $-66,38$ & 0,91 \\
\hline \multirow{7}{*}{ 1-Ago } & 0,2 & 1072,88 & 889,30 & 52,04 & 769,62 & 303,25 & 1,39 \\
\hline & 0,3 & 1010,99 & 882,78 & 51,66 & 769,24 & 241,75 & 1,31 \\
\hline & 0,4 & 928,81 & 879,81 & 51,48 & 769,07 & 159,74 & 1,21 \\
\hline & 0,5 & 860,26 & 871,90 & 51,02 & 768,61 & 91,65 & 1,12 \\
\hline & 0,6 & 791,84 & 854,62 & 50,01 & 767,59 & 24,25 & 1,03 \\
\hline & 0,7 & 737,00 & 853,19 & 49,93 & 767,51 & $-30,51$ & 0,96 \\
\hline & 0,8 & 683,48 & 850,85 & 49,79 & 767,37 & $-83,89$ & 0,89 \\
\hline \multirow{7}{*}{ 15-Ago } & 0,2 & 1080,15 & 913,40 & 53,45 & 771,03 & 309,11 & 1,40 \\
\hline & 0,3 & 1009,43 & 907,14 & 53,08 & 770,67 & 238,76 & 1,31 \\
\hline & 0,4 & 944,94 & 903,31 & 52,86 & 770,44 & 174,49 & 1,23 \\
\hline & 0,5 & 863,25 & 889,12 & 52,03 & 769,61 & 93,64 & 1,12 \\
\hline & 0,6 & 813,13 & 888,14 & 51,97 & 769,56 & 43,58 & 1,06 \\
\hline & 0,7 & 746,45 & 878,65 & 51,42 & 769,00 & $-22,55$ & 0,97 \\
\hline & 0,8 & 703,52 & 870,27 & 50,93 & 768,51 & $-64,99$ & 0,92 \\
\hline
\end{tabular}


Tabela 23B. Receitas brutas, composição de custos da irrigação, receitas líquidas e relação beneficio/custo para o feijão caupi, em cada época de semeadura, nível de manejo da irrigação e risco de $40 \%$. Teresina, Piauí.

\begin{tabular}{|c|c|c|c|c|c|c|c|}
\hline $\begin{array}{c}\text { Época de } \\
\text { Semeadura }\end{array}$ & $\mathrm{p}$ & $\begin{array}{c}\mathrm{RB}^{\mathrm{l}} \\
\left(\mathrm{US} \$ \mathrm{ha}^{-1}\right)\end{array}$ & $\begin{array}{c}\mathrm{Eb} \\
\left(\mathrm{kWh} \mathrm{ha} \mathrm{h}^{-1}\right)\end{array}$ & $\begin{array}{c}\mathrm{CE} \\
\left(\mathrm{US} \$ \mathrm{ha}^{-1}\right)\end{array}$ & $\begin{array}{c}\mathrm{CT} \\
\left(\mathrm{US} \$ \mathrm{ha}^{-1}\right)\end{array}$ & $\begin{array}{c}\mathrm{RL} \\
\left(\mathrm{US} \$ \mathrm{ha}^{-1}\right)\end{array}$ & $\mathrm{B} / \mathrm{C}$ \\
\hline \multirow{7}{*}{ 1-Set } & 0,2 & 1091,60 & 908,70 & 52,02 & 769,61 & 322,00 & 1,42 \\
\hline & 0,3 & 1023,74 & 897,57 & 51,38 & 768,97 & 254,77 & 1,33 \\
\hline & 0,4 & 954,64 & 888,41 & 50,86 & 768,44 & 186,19 & 1,24 \\
\hline & 0,5 & 872,01 & 876,85 & 50,20 & 767,78 & 104,22 & 1,14 \\
\hline & 0,6 & 819,40 & 864,67 & 49,50 & 767,08 & 52,32 & 1,07 \\
\hline & 0,7 & 752,13 & 861,33 & 49,31 & 766,89 & $-14,76$ & 0,98 \\
\hline & 0,8 & 715,19 & 850,10 & 48,67 & 766,25 & $-51,06$ & 0,93 \\
\hline \multirow{7}{*}{15 -Set } & 0,2 & 1088,10 & 887,05 & 50,78 & 768,37 & 319,73 & 1,42 \\
\hline & 0,3 & 1022,44 & 877,45 & 50,23 & 767,82 & 254,63 & 1,33 \\
\hline & 0,4 & 947,73 & 863,66 & 49,44 & 767,03 & 180,70 & 1,24 \\
\hline & 0,5 & 871,98 & 851,71 & 48,76 & 766,34 & 105,64 & 1,14 \\
\hline & 0,6 & 818,06 & 846,79 & 48,48 & 766,06 & 52,00 & 1,07 \\
\hline & 0,7 & 754,81 & 834,37 & 47,77 & 765,35 & $-10,54$ & 0,99 \\
\hline & 0,8 & 710,03 & 829,84 & 47,51 & 765,09 & $-55,06$ & 0,93 \\
\hline \multirow{7}{*}{ 1-Out } & 0,2 & 1083,78 & 855,99 & 49,69 & 767,27 & 316,51 & 1,41 \\
\hline & 0,3 & 1021,94 & 847,16 & 49,18 & 766,76 & 255,18 & 1,33 \\
\hline & 0,4 & 942,56 & 833,39 & 48,38 & 765,96 & 176,60 & 1,23 \\
\hline & 0,5 & 875,36 & 822,31 & 47,73 & 765,32 & 110,04 & 1,14 \\
\hline & 0,6 & 812,41 & 809,49 & 46,99 & 764,57 & 47,84 & 1,06 \\
\hline & 0,7 & 752,74 & 798,34 & 46,34 & 763,93 & $-11,19$ & 0,99 \\
\hline & 0,8 & 702,69 & 791,72 & 45,96 & 763,54 & $-60,85$ & 0,92 \\
\hline \multirow{7}{*}{ 15-Out } & 0,2 & 1077,68 & 808,29 & 46,92 & 764,50 & 313,18 & 1,41 \\
\hline & 0,3 & 1021,59 & 795,45 & 46,17 & 763,76 & 257,83 & 1,34 \\
\hline & 0,4 & 931,57 & 778,93 & 45,22 & 762,80 & 168,77 & 1,22 \\
\hline & 0,5 & 875,55 & 758,65 & 44,04 & 761,62 & 113,93 & 1,15 \\
\hline & 0,6 & 805,63 & 750,83 & 43,58 & 761,17 & 44,46 & 1,06 \\
\hline & 0,7 & 756,51 & 739,09 & 42,90 & 760,49 & $-3,97$ & 0,99 \\
\hline & 0,8 & 702,45 & 727,64 & 42,24 & 759,82 & $-57,38$ & 0,92 \\
\hline
\end{tabular}


Tabela 23B. Receitas brutas, composição de custos da irrigação, receitas líquidas e relação beneficio/custo para o feijão caupi, em cada época de semeadura, nível de manejo da irrigação e risco de $40 \%$. Teresina, Piauí.

\begin{tabular}{|c|c|c|c|c|c|c|c|}
\hline $\begin{array}{l}\text { Época de } \\
\text { Semeadura }\end{array}$ & $\mathrm{p}$ & $\begin{array}{c}\mathrm{RB}^{1} \\
\left(\mathrm{US} \$ \mathrm{ha}^{-1}\right)\end{array}$ & $\begin{array}{c}E b \\
\left(\mathrm{kWh} \mathrm{ha}{ }^{-1}\right)\end{array}$ & $\begin{array}{c}\text { CE } \\
\left(\mathrm{US} \$ \mathrm{ha}^{-1}\right)\end{array}$ & $\begin{array}{c}C T \\
\left(\text { US } \$ h^{-1}{ }^{-1}\right)\end{array}$ & $\begin{array}{c}\mathrm{RL} \\
\left(\mathrm{US} \$ \mathrm{ha}^{-1}\right)\end{array}$ & $\mathrm{B} / \mathrm{C}$ \\
\hline \multirow{7}{*}{ 1-Nov } & 0,2 & 1245,88 & 700,32 & 40,97 & 758,55 & 487,33 & 1,64 \\
\hline & 0,3 & 1180,00 & 681,35 & 39,86 & 757,44 & 422,55 & 1,56 \\
\hline & 0,4 & 1079,47 & 656,12 & 38,38 & 755,97 & 323,50 & 1,43 \\
\hline & 0,5 & 1018,09 & 643,94 & 37,67 & 755,25 & 262,83 & 1,35 \\
\hline & 0,6 & 940,70 & 624,01 & 36,50 & 754,09 & 186,61 & 1,25 \\
\hline & 0,7 & 886,67 & 605,78 & 35,44 & 753,02 & 133,65 & 1,18 \\
\hline & 0,8 & 826,99 & 587,06 & 34,34 & 751,93 & 75,06 & 1,10 \\
\hline \multirow{7}{*}{$15-\mathrm{Nov}$} & 0,2 & 1241,85 & 609,71 & 35,67 & 753,25 & 488,60 & 1,65 \\
\hline & 0,3 & 1175,47 & 582,59 & 34,08 & 751,67 & 423,80 & 1,56 \\
\hline & 0,4 & 1084,67 & 547,83 & 32,05 & 749,63 & 335,04 & 1,45 \\
\hline & 0,5 & 1021,86 & 522,49 & 30,57 & 748,15 & 273,71 & 1,37 \\
\hline & 0,6 & 957,11 & 500,91 & 29,30 & 746,89 & 210,22 & 1,28 \\
\hline & 0,7 & 899,30 & 477,89 & 27,96 & 745,54 & 153,75 & 1,21 \\
\hline & 0,8 & 852,96 & 459,80 & 26,90 & 744,48 & 108,48 & 1,15 \\
\hline \multirow{7}{*}{ 1-Dez } & 0,2 & 1269,69 & 537,45 & 30,78 & 748,37 & 521,32 & 1,70 \\
\hline & 0,3 & 1201,23 & 505,78 & 28,97 & 746,55 & 454,68 & 1,61 \\
\hline & 0,4 & 1115,61 & 472,94 & 27,09 & 744,67 & 370,93 & 1,50 \\
\hline & 0,5 & 1046,88 & 441,12 & 25,27 & 742,85 & 304,03 & 1,41 \\
\hline & 0,6 & 989,57 & 426,56 & 24,43 & 742,02 & 247,55 & 1,33 \\
\hline & 0,7 & 932,25 & 391,49 & 22,42 & 740,01 & 192,24 & 1,26 \\
\hline & 0,8 & 883,81 & 363,35 & 20,81 & 738,40 & 145,42 & 1,20 \\
\hline \multirow{7}{*}{ 15-Dez } & 0,2 & 1272,15 & 465,44 & 26,66 & 744,24 & 527,91 & 1,71 \\
\hline & 0,3 & 1204,09 & 432,91 & 24,80 & 742,38 & 461,71 & 1,62 \\
\hline & 0,4 & 1125,21 & 392,69 & 22,49 & 740,08 & 385,14 & 1,52 \\
\hline & 0,5 & 1058,37 & 357,15 & 20,46 & 738,04 & 320,33 & 1,43 \\
\hline & 0,6 & 1012,78 & 330,55 & 18,93 & 736,52 & 276,27 & 1,38 \\
\hline & 0,7 & 959,04 & 300,07 & 17,19 & 734,77 & 224,27 & 1,31 \\
\hline & 0,8 & 914,53 & 268,75 & 15,39 & 732,98 & 181,56 & 1,25 \\
\hline
\end{tabular}

${ }^{\top} \mathrm{RB}$ - receita bruta: $\mathrm{Eb}$ - energia requerida para 0 bombeamento; $\mathrm{CE}$ - custo de energia elétrica; CT - custo total de produção; RL - receita líquida e B/C - relação benefício/custo. 
Tabela 24B. Receitas brutas, composição de custos da irrigação, receitas líquidas e relação benefício/custo para a melancia, em cada época de semeadura, nivel de manejo da irrigação e risco de $5 \%$. Teresina, Piauí.

\begin{tabular}{|c|c|c|c|c|c|c|c|}
\hline $\begin{array}{l}\text { Época de } \\
\text { Semeadura }\end{array}$ & $\mathrm{p}$ & $\begin{array}{c}\mathrm{RB}^{\mathrm{l}} \\
\left(\mathrm{US} \$ \mathrm{ha}^{-1}\right)\end{array}$ & $\begin{array}{c}\mathrm{Eb} \\
\left(\mathrm{kWh} \mathrm{ha} \mathrm{a}^{-1}\right)\end{array}$ & $\begin{array}{c}\text { CE } \\
\left(\mathrm{US} \$ \mathrm{ha}^{-1}\right)\end{array}$ & $\begin{array}{c}\mathrm{CT} \\
\left(\mathrm{US} \$ \mathrm{ha}^{-1}\right)\end{array}$ & $\begin{array}{c}\mathrm{RL} \\
\left(\mathrm{US} \$ \mathrm{ha}^{-1}\right)\end{array}$ & $\mathrm{B} / \mathrm{C}$ \\
\hline \multirow{7}{*}{ 1-Jan } & 0,2 & 4446,59 & 476,95 & 31,04 & 1098,14 & 3348,45 & 4,05 \\
\hline & 0,3 & 3988,14 & 446,27 & 29,04 & 1096,15 & 2891,99 & 3,64 \\
\hline & 0,4 & 3662,62 & 416,60 & 27,11 & 1094,22 & 2568,41 & 3,35 \\
\hline & 0,5 & 3353,90 & 379,47 & 24,69 & 1091,80 & 2262,10 & 3,07 \\
\hline & 0,6 & 3102,07 & 355,71 & 23,15 & 1090,25 & 2011,82 & 2,85 \\
\hline & 0,7 & 2881,24 & 328,94 & 21,41 & 1088,51 & 1792,73 & 2,65 \\
\hline & 0,8 & 2693,01 & 317,76 & 20,68 & 1087,78 & 1605,22 & 2,48 \\
\hline \multirow{7}{*}{ 15-Jan } & 0,2 & 4545,76 & 438,92 & 28,56 & 1095,67 & 3450,09 & 4,15 \\
\hline & 0,3 & 4114,65 & 402,71 & 26,21 & 1093,31 & 3021,33 & 3,76 \\
\hline & 0,4 & 3821,59 & 365,41 & 23,78 & 1090,88 & 2730,71 & 3,50 \\
\hline & 0,5 & 3546,56 & 348,56 & 22,68 & 1089,79 & 2456,77 & 3,25 \\
\hline & 0,6 & 3294,18 & 324,87 & 21,14 & 1088,25 & 2205,93 & 3,03 \\
\hline & 0,7 & 3045,18 & 288,01 & 18,74 & 1085,85 & 1959,33 & 2,80 \\
\hline & 0,8 & 2891,10 & 279,90 & 18,22 & 1085,32 & 1805,78 & 2,66 \\
\hline \multirow{7}{*}{$1-\mathrm{Fev}$} & 0,2 & 4818,36 & 375,86 & 25,32 & 1092,43 & 3725,93 & 4,41 \\
\hline & 0,3 & 4395,80 & 337,26 & 22,72 & 1089,83 & 3305,97 & 4,03 \\
\hline & 0,4 & 4089,17 & 298,59 & 20,12 & 1087,22 & 3001,95 & 3,76 \\
\hline & 0,5 & 3834,81 & 261,60 & 17,63 & 1084,73 & 2750,08 & 3,54 \\
\hline & 0,6 & 3590,72 & 238,14 & 16,05 & 1083,15 & 2507,57 & 3,32 \\
\hline & 0,7 & 3415,89 & 199,95 & 13,47 & 1080,58 & 2335,31 & 3,16 \\
\hline & 0,8 & 3282,55 & 201,63 & 13,59 & 1080,69 & 2201,86 & 3,04 \\
\hline \multirow{7}{*}{$15-\mathrm{Fev}$} & 0,2 & 4823,57 & 389,67 & 26,26 & 1093,36 & 3730,21 & 4,41 \\
\hline & 0,3 & 4374,78 & 333,93 & 22,50 & 1089,60 & 3285,17 & 4,02 \\
\hline & 0,4 & 4078,11 & 317,07 & 21,36 & 1088,47 & 2989,64 & 3,75 \\
\hline & 0,5 & 3816,43 & 264,01 & 17,79 & 1084,89 & 2731,54 & 3,52 \\
\hline & 0,6 & 3593,88 & 247,04 & 16,65 & 1083,75 & 2510,13 & 3,32 \\
\hline & 0,7 & 3405,05 & 221,46 & 14,92 & 1082,03 & 2323,03 & 3,15 \\
\hline & 0,8 & 3274,95 & 173,71 & 11,70 & 1078,81 & 2196,14 & 3,04 \\
\hline
\end{tabular}


Tabela 24B. Receitas brutas, composição de custos da irrigação, receitas líquidas e relação benefício/custo para a melancia, em cada época de semeadura, nível de manejo da irrigação e risco de $5 \%$. Teresina, Piauí.

\begin{tabular}{|c|c|c|c|c|c|c|c|}
\hline $\begin{array}{l}\text { Época de } \\
\text { Semeadura }\end{array}$ & $p$ & $\begin{array}{c}\mathrm{RB}^{\mathrm{l}} \\
\left(\mathrm{US} \$ \mathrm{ha}^{-1}\right)\end{array}$ & $\begin{array}{c}E b \\
\left(\mathrm{kWh} \mathrm{ha}{ }^{-1}\right)\end{array}$ & $\begin{array}{c}\text { CE } \\
\left(\mathrm{US} \$ \mathrm{ha}^{-1}\right)\end{array}$ & $\begin{array}{c}\mathrm{CT} \\
\left(\mathrm{US} \$ \mathrm{ha}^{-1}\right)\end{array}$ & $\begin{array}{c}\mathrm{RL} \\
\left(\mathrm{US} \$ \mathrm{ha}^{-1}\right)\end{array}$ & $\mathrm{B} / \mathrm{C}$ \\
\hline \multirow{7}{*}{ 1-Mar } & 0,2 & 4765,64 & 371,31 & 24,79 & 1091,89 & 3673,75 & 4,36 \\
\hline & 0,3 & 4314,11 & 323,71 & 21,61 & 1088,72 & 3225,39 & 3,96 \\
\hline & 0,4 & 4012,07 & 277,57 & 18,53 & 1085,63 & 2926,44 & 3,70 \\
\hline & 0,5 & 3791,52 & 258,38 & 17,25 & 1084,35 & 2707,16 & 3,50 \\
\hline & 0,6 & 3555,91 & 231,69 & 15,47 & 1082,57 & 2473,34 & 3,28 \\
\hline & 0,7 & 3318,34 & 196,37 & 13,11 & 1080,21 & 2238,13 & 3,07 \\
\hline & 0,8 & 3165,23 & 182,09 & 12,16 & 1079,26 & 2085,97 & 2,93 \\
\hline \multirow{7}{*}{ 15-Mar } & 0,2 & 4719,02 & 423,41 & 28,27 & 1095,37 & 3623,65 & 4,31 \\
\hline & 0,3 & 4251,90 & 388,40 & 25,93 & 1093,03 & 3158,87 & 3,89 \\
\hline & 0,4 & 3884,73 & 367,52 & 24,53 & 1091,64 & 2793,09 & 3,56 \\
\hline & 0,5 & 3615,60 & 330,33 & 22,05 & 1089,16 & 2526,45 & 3,32 \\
\hline & 0,6 & 3340,95 & 298,39 & 19,92 & 1087,02 & 2253,92 & 3,07 \\
\hline & 0,7 & 3108,42 & 267,84 & 17,88 & 1084,99 & 2023,43 & 2,86 \\
\hline & 0,8 & 2915,63 & 253,41 & 16,92 & 1084,02 & 1831,61 & 2,69 \\
\hline \multirow{7}{*}{$1-A b r$} & 0,2 & 4531,48 & 489,14 & 30,75 & 1097,86 & 3433,62 & 4,13 \\
\hline & 0,3 & 4019,68 & 459,60 & 28,90 & 1096,00 & 2923,68 & 3,67 \\
\hline & 0,4 & 3630,17 & 437,25 & 27,49 & 1094,60 & 2535,57 & 3,32 \\
\hline & 0,5 & 3347,06 & 426,56 & 26,82 & 1093,92 & 2253,13 & 3,06 \\
\hline & 0,6 & 3068,69 & 404,44 & 25,43 & 1092,53 & 1976,16 & 2,81 \\
\hline & 0,7 & 2818,82 & 391,20 & 24,60 & 1091,70 & 1727,12 & 2,58 \\
\hline & 0,8 & 2588,35 & 365,02 & 22,95 & 1090,06 & 1498,30 & 2,37 \\
\hline \multirow{7}{*}{ 15-Abr } & 0,2 & 4488,88 & 561,38 & 35,30 & 1102,40 & 3386,48 & 4,07 \\
\hline & 0,3 & 3927,11 & 546,04 & 34,33 & 1101,44 & 2825,67 & 3,57 \\
\hline & 0,4 & 3498,33 & 520,91 & 32,75 & 1099,86 & 2398,48 & 3,18 \\
\hline & 0,5 & 3176,56 & 512,92 & 32,25 & 1099,35 & 2077,21 & 2,89 \\
\hline & 0,6 & 2860,37 & 484,79 & 30,48 & 1097,59 & 1762,78 & 2,61 \\
\hline & 0,7 & 2581,35 & 477,11 & 30,00 & 1097,10 & 1484,25 & 2,35 \\
\hline & 0,8 & 2339,09 & 467,66 & 29,40 & 1096,51 & 1242,58 & 2,13 \\
\hline
\end{tabular}


Tabela 24B. Receitas brutas, composição de custos da irrigação, receitas líquidas e relação benefício/custo para a melancia, em cada época de semeadura, nível de manejo da irrigação e risco de $5 \%$. Teresina, Piauí.

\begin{tabular}{|c|c|c|c|c|c|c|c|}
\hline $\begin{array}{l}\text { Época de } \\
\text { Semeadura }\end{array}$ & $\mathrm{p}$ & $\begin{array}{c}\mathrm{RB}^{\mathrm{l}} \\
\left(\mathrm{US} \$ \mathrm{ha}^{-1}\right)\end{array}$ & $\begin{array}{c}\mathrm{Eb} \\
\left(\mathrm{kWh} \mathrm{ha} \mathrm{h}^{-1}\right)\end{array}$ & $\begin{array}{c}C E \\
\left(\text { US\$ ha }{ }^{-1}\right)\end{array}$ & $\begin{array}{c}\mathrm{CT} \\
\left(\mathrm{US} \$ \mathrm{ha}^{-1}\right)\end{array}$ & $\begin{array}{c}\mathrm{RL} \\
\left(\mathrm{US} \$ \mathrm{ha}^{-1}\right)\end{array}$ & $\mathrm{B} / \mathrm{C}$ \\
\hline \multirow{7}{*}{ 1-Mai } & 0,2 & 3598,90 & 621,36 & 37,32 & 1104,43 & 2494,47 & 3,26 \\
\hline & 0,3 & 3117,03 & 603,08 & 36,22 & 1103,33 & 2013,70 & 2,83 \\
\hline & 0,4 & 2763,00 & 590,49 & 35,47 & 1102,57 & 1660,43 & 2,51 \\
\hline & 0,5 & 2528,34 & 596,90 & 35,85 & 1102,96 & 1425,39 & 2,29 \\
\hline & 0,6 & 2236,04 & 584,42 & 35,10 & 1102,21 & 1133,83 & 2,03 \\
\hline & 0,7 & 1978,70 & 558,83 & 33,57 & 1100,67 & 878,03 & 1,80 \\
\hline & 0,8 & 1779,97 & 572,14 & 34,37 & 1101,47 & 678,50 & 1,62 \\
\hline \multirow{7}{*}{ 15-Mai } & 0,2 & 3613,35 & 662,05 & 39,77 & 1106,87 & 2506,48 & 3,26 \\
\hline & 0,3 & 3114,29 & 654,46 & 39,31 & 1106,41 & 2007,87 & 2,81 \\
\hline & 0,4 & 2778,52 & 655,10 & 39,35 & 1106,45 & 1672,07 & 2,51 \\
\hline & 0,5 & 2491,49 & 646,61 & 38,84 & 1105,94 & 1385,55 & 2,25 \\
\hline & 0,6 & 2195,09 & 632,37 & 37,98 & 1105,09 & 1090,01 & 1,99 \\
\hline & 0,7 & 1959,01 & 630,39 & 37,86 & 1104,97 & 854,04 & 1,77 \\
\hline & 0,8 & 1774,04 & 627,16 & 37,67 & 1104,77 & 669,26 & 1,61 \\
\hline \multirow{7}{*}{ 1-Jun } & 0,2 & 3731,83 & 716,11 & 46,03 & 1113,14 & 2618,69 & 3,35 \\
\hline & 0,3 & 3252,18 & 712,37 & 45,79 & 1112,90 & 2139,29 & 2,92 \\
\hline & 0,4 & 2910,92 & 705,60 & 45,36 & 1112,46 & 1798,46 & 2,62 \\
\hline & 0,5 & 2591,79 & 704,96 & 45,32 & 1112,42 & 1479,37 & 2,33 \\
\hline & 0,6 & 2275,15 & 702,65 & 45,17 & 1112,27 & 1162,87 & 2,05 \\
\hline & 0,7 & 2044,59 & 703,50 & 45,22 & 1112,33 & 932,26 & 1,84 \\
\hline & 0,8 & 1843,46 & 699,79 & 44,99 & 1112,09 & 731,37 & 1,66 \\
\hline \multirow{7}{*}{ 15-Jun } & 0,2 & 3775,33 & 760,33 & 48,88 & 1115,98 & 2659,35 & 3,38 \\
\hline & 0,3 & 3312,42 & 758,68 & 48,77 & 1115,88 & 2196,54 & 2,97 \\
\hline & 0,4 & 2962,14 & 749,01 & 48,15 & 1115,25 & 1846,88 & 2,66 \\
\hline & 0,5 & 2611,46 & 755,36 & 48,56 & 1115,66 & 1495,80 & 2,34 \\
\hline & 0,6 & 2324,16 & 748,43 & 48,11 & 1115,22 & 1208,94 & 2,08 \\
\hline & 0,7 & 2099,20 & 763,05 & 49,05 & 1116,16 & 983,04 & 1,88 \\
\hline & 0,8 & 1869,41 & 757,49 & 48,69 & 1115,80 & 753,61 & 1,68 \\
\hline
\end{tabular}


Tabela 24B. Receitas brutas, composição de custos da irrigação, receitas liquidas e relação benefício/custo para a melancia, em cada época de semeadura, nível de manejo da irrigação e risco de $5 \%$. Teresina, Piauí.

\begin{tabular}{|c|c|c|c|c|c|c|c|}
\hline $\begin{array}{l}\text { Época de } \\
\text { Semeadura }\end{array}$ & $\mathrm{p}$ & $\begin{array}{c}\mathrm{RB}^{1} \\
\left(\mathrm{US} \$ \mathrm{ha}^{-1}\right)\end{array}$ & $\begin{array}{c}\mathrm{Eb} \\
\left(\mathrm{kWh} \mathrm{ha}^{-1}\right)\end{array}$ & $\begin{array}{c}\mathrm{CE} \\
\left(\mathrm{US} \$ \mathrm{ha}^{-1}\right)\end{array}$ & $\begin{array}{c}\mathrm{CT} \\
\left(\mathrm{US} \$ \mathrm{ha}^{-1}\right)\end{array}$ & $\begin{array}{c}\mathrm{RL} \\
\left(\mathrm{US} \$ \mathrm{ha}^{-1}\right)\end{array}$ & $\mathrm{B} / \mathrm{C}$ \\
\hline \multirow{7}{*}{ 1-Jul } & 0,2 & 3083,16 & 818,43 & 53,40 & 1120,51 & 1962,65 & 2,75 \\
\hline & 0,3 & 2759,18 & 816,15 & 53,25 & 1120,36 & 1638,82 & 2,46 \\
\hline & 0,4 & 2439,00 & 811,45 & 52,95 & 1120,05 & 1318,94 & 2,18 \\
\hline & 0,5 & 2144,86 & 816,14 & 53,25 & 1120,36 & 1024,50 & 1,91 \\
\hline & 0,6 & 1934,29 & 811,36 & 52,94 & 1120,05 & 814,24 & 1,73 \\
\hline & 0,7 & 1712,28 & 807,56 & 52,69 & 1119,80 & 592,49 & 1,53 \\
\hline & 0,8 & 1543,90 & 785,15 & 51,23 & 1118,34 & 425,57 & 1,38 \\
\hline \multirow{7}{*}{ 15-Jul } & 0,2 & 3097,72 & 871,73 & 56,88 & 1123,99 & 1973,73 & 2,76 \\
\hline & 0,3 & 2819,86 & 869,51 & 56,74 & 1123,84 & 1696,02 & 2,51 \\
\hline & 0,4 & 2464,28 & 869,91 & 56,76 & 1123,87 & 1340,42 & 2,19 \\
\hline & 0,5 & 2196,86 & 869,80 & 56,76 & 1123,86 & 1073,00 & 1,95 \\
\hline & 0,6 & 1997,22 & 863,79 & 56,36 & 1123,47 & 873,75 & 1,78 \\
\hline & 0,7 & 1736,63 & 860,73 & 56,16 & 1123,27 & 613,37 & 1,55 \\
\hline & 0,8 & 1582,78 & 881,05 & 57,49 & 1124,59 & 458,18 & 1,41 \\
\hline \multirow{7}{*}{ 1-Ago } & 0,2 & 3764,97 & 915,81 & 59,57 & 1126,67 & 2638,30 & 3,34 \\
\hline & 0,3 & 3496,44 & 912,36 & 59,34 & 1126,45 & 2369,99 & 3,10 \\
\hline & 0,4 & 3028,07 & 911,41 & 59,28 & 1126,39 & 1901,68 & 2,69 \\
\hline & 0,5 & 2747,93 & 911,74 & 59,30 & 1126,41 & 1621,53 & 2,44 \\
\hline & 0,6 & 2418,38 & 919,07 & 59,78 & 1126,89 & 1291,49 & 2,15 \\
\hline & 0,7 & 2177,02 & 904,63 & 58,84 & 1125,95 & 1051,07 & 1,93 \\
\hline & 0,8 & 1967,80 & 863,62 & 56,17 & 1123,28 & 844,52 & 1,75 \\
\hline \multirow{7}{*}{ 15-Ago } & 0,2 & 3781,79 & 939,06 & 61,08 & 1128,19 & 2653,61 & 3,35 \\
\hline & 0,3 & 3534,74 & 938,05 & 61,01 & 1128,12 & 2406,62 & 3,13 \\
\hline & 0,4 & 3052,44 & 934,32 & 60,77 & 1127,88 & 1924,57 & 2,71 \\
\hline & 0,5 & 2800,29 & 934,84 & 60,81 & 1127,91 & 1672,38 & 2,48 \\
\hline & 0,6 & 2438,24 & 934,00 & 60,75 & 1127,86 & 1310,39 & 2,16 \\
\hline & 0,7 & 2216,43 & 934,21 & 60,77 & 1127,87 & 1088,56 & 1,97 \\
\hline & 0,8 & 1940,13 & 908,30 & 59,08 & 1126,18 & 813,95 & 1,72 \\
\hline
\end{tabular}


Tabela 24B. Receitas brutas, composição de custos da irrigação, receitas líquidas e relação benefício/custo para a melancia, em cada época de semeadura, nível de manejo da irrigação e risco de $5 \%$. Teresina, Piauí.

\begin{tabular}{|c|c|c|c|c|c|c|c|}
\hline $\begin{array}{l}\text { Época de } \\
\text { Semeadura }\end{array}$ & $\mathrm{p}$ & $\begin{array}{c}\mathrm{RB}^{\mathrm{I}} \\
\left(\mathrm{US} \$ \mathrm{ha}^{-1}\right)\end{array}$ & $\begin{array}{c}E b \\
\left(k W h h^{-1}\right)\end{array}$ & $\begin{array}{c}\text { CE } \\
\left(\mathrm{US} \$ \mathrm{ha}^{-1}\right)\end{array}$ & $\begin{array}{c}\text { CT } \\
\left(\mathrm{US} \$ \mathrm{ha}^{-1}\right)\end{array}$ & $\begin{array}{c}\mathrm{RL} \\
\left(\mathrm{US} \$ \mathrm{ha}^{-1}\right)\end{array}$ & $\mathrm{B} / \mathrm{C}$ \\
\hline \multirow{7}{*}{ 1-Set } & 0,2 & 3607,91 & 937,66 & 57,59 & 1124,69 & 2483,22 & 3,21 \\
\hline & 0,3 & 3370,42 & 934,40 & 57,39 & 1124,49 & 2245,92 & 3,00 \\
\hline & 0,4 & 2917,00 & 936,19 & 57,50 & 1124,60 & 1792,39 & 2,59 \\
\hline & 0,5 & 2676,52 & 930,39 & 57,14 & 1124,25 & 1552,28 & 2,38 \\
\hline & 0,6 & 2342,88 & 930,17 & 57,13 & 1124,23 & 1218,64 & 2,08 \\
\hline & 0,7 & 2120,28 & 924,36 & 56,77 & 1123,88 & 996,40 & 1,89 \\
\hline & 0,8 & 1876,11 & 926,09 & 56,88 & 1123,98 & 752,13 & 1,67 \\
\hline \multirow{7}{*}{$15-$ Set } & 0,2 & 3601,24 & 926,45 & 56,90 & 1124,01 & 2477,23 & 3,20 \\
\hline & 0,3 & 3352,22 & 922,63 & 56,67 & 1123,77 & 2228,45 & 2,98 \\
\hline & 0,4 & 2905,55 & 915,25 & 56,21 & 1123,32 & 1782,24 & 2,59 \\
\hline & 0,5 & 2665,03 & 913,95 & 56,13 & 1123,24 & 1541,79 & 2,37 \\
\hline & 0,6 & 2339,74 & 924,62 & 56,79 & 1123,89 & 1215,85 & 2,08 \\
\hline & 0,7 & 2119,66 & 913,13 & 56,08 & 1123,19 & 996,47 & 1,89 \\
\hline & 0,8 & 1877,77 & 881,06 & 54,11 & 1121,22 & 756,55 & 1,67 \\
\hline \multirow{7}{*}{ 1-Out } & 0,2 & 3677,30 & 898,18 & 56,84 & 1123,94 & 2553,36 & 3,27 \\
\hline & 0,3 & 3407,71 & 897,19 & 56,78 & 1123,88 & 2283,83 & 3,03 \\
\hline & 0,4 & 2966,29 & 895,17 & 56,65 & 1123,75 & 1842,54 & 2,64 \\
\hline & 0,5 & 2690,39 & 894,75 & 56,62 & 1123,73 & 1566,66 & 2,39 \\
\hline & 0,6 & 2376,36 & 892,62 & 56,49 & 1123,59 & 1252,77 & 2,11 \\
\hline & 0,7 & 2152,54 & 879,56 & 55,66 & 1122,76 & 1029,77 & 1,92 \\
\hline & 0,8 & 1901,79 & 880,78 & 55,74 & 1122,84 & 778,95 & 1,69 \\
\hline \multirow{7}{*}{ 15-Out } & 0,2 & 3670,94 & 857,58 & 54,27 & 1121,37 & 2549,57 & 3,27 \\
\hline & 0,3 & 3367,83 & 850,59 & 53,83 & 1120,93 & 2246,90 & 3,00 \\
\hline & 0,4 & 2937,48 & 853,32 & 54,00 & 1121,10 & 1816,38 & 2,62 \\
\hline & 0,5 & 2643,17 & 838,39 & 53,05 & 1120,16 & 1523,01 & 2,36 \\
\hline & 0,6 & 2364,25 & 842,85 & 53,34 & 1120,44 & 1243,81 & 2,11 \\
\hline & 0,7 & 2128,95 & 837,24 & 52,98 & 1120,09 & 1008,87 & 1,90 \\
\hline & 0,8 & 1932,77 & 839,65 & 53,13 & 1120,24 & 812,53 & 1,73 \\
\hline
\end{tabular}


Tabela 24B. Receitas brutas, composição de custos da irrigação, receitas líquidas e relação benefício/custo para a melancia, em cada época de semeadura, nível de manejo da irrigação e risco de $5 \%$. Teresina, Piauí.

\begin{tabular}{|c|c|c|c|c|c|c|c|}
\hline $\begin{array}{l}\text { Época de } \\
\text { Semeadura }\end{array}$ & $\mathrm{p}$ & $\begin{array}{c}\mathrm{RB}^{\mathrm{l}} \\
\left(\mathrm{US} \$ \mathrm{ha}^{-1}\right)\end{array}$ & $\begin{array}{c}E b \\
\left(k W h h a^{-1}\right)\end{array}$ & $\begin{array}{c}\text { CE } \\
\left(\text { US } \$ \mathrm{ha}^{-1}\right)\end{array}$ & $\begin{array}{c}\text { CT } \\
\left(\mathrm{US} \$ \mathrm{ha}^{-1}\right)\end{array}$ & $\begin{array}{c}\mathrm{RL} \\
\left(\mathrm{US} \$ \mathrm{ha}^{-1}\right)\end{array}$ & $\mathrm{B} / \mathrm{C}$ \\
\hline \multirow{7}{*}{ 1-Nov } & 0,2 & 4059,30 & 770,10 & 49,28 & 1116,39 & 2942,91 & 3,64 \\
\hline & 0,3 & 3651,71 & 758,66 & 48,55 & 1115,66 & 2536,06 & 3,27 \\
\hline & 0,4 & 3260,91 & 754,69 & 48,30 & 1115,40 & 2145,51 & 2,92 \\
\hline & 0,5 & 2913,04 & 743,06 & 47,55 & 1114,66 & 1798,38 & 2,61 \\
\hline & 0,6 & 2599,48 & 738,84 & 47,28 & 1114,39 & 1485,10 & 2,33 \\
\hline & 0,7 & 2347,04 & 723,10 & 46,28 & 1113,38 & 1233,66 & 2,11 \\
\hline & 0,8 & 2084,97 & 717,56 & 45,92 & 1113,03 & 971,95 & 1,87 \\
\hline \multirow{7}{*}{$15-\mathrm{Nov}$} & 0,2 & 4047,06 & 691,02 & 44,22 & 1111,33 & 2935,73 & 3,64 \\
\hline & 0,3 & 3607,90 & 667,51 & 42,72 & 1109,82 & 2498,08 & 3,25 \\
\hline & 0,4 & 3249,73 & 643,52 & 41,18 & 1108,29 & 2141,44 & 2,93 \\
\hline & 0,5 & 2920,05 & 641,88 & 41,08 & 1108,18 & 1811,87 & 2,63 \\
\hline & 0,6 & 2616,64 & 627,39 & 40,15 & 1107,26 & 1509,39 & 2,36 \\
\hline & 0,7 & 2348,27 & 605,96 & 38,78 & 1105,88 & 1242,39 & 2,12 \\
\hline & 0,8 & 2161,34 & 610,75 & 39,09 & 1106,19 & 1055,15 & 1,95 \\
\hline \multirow{7}{*}{ 1-Dez } & 0,2 & 4022,50 & 611,37 & 39,14 & 1106,25 & 2916,25 & 3,64 \\
\hline & 0,3 & 3593,91 & 597,09 & 38,23 & 1105,33 & 2488,58 & 3,25 \\
\hline & 0,4 & 3256,00 & 560,67 & 35,90 & 1103,00 & 2153,00 & 2,95 \\
\hline & 0,5 & 2920,07 & 545,08 & 34,90 & 1102,00 & 1818,07 & 2,65 \\
\hline & 0,6 & 2642,00 & 533,71 & 34,17 & 1101,27 & 1540,73 & 2,40 \\
\hline & 0,7 & 2435,47 & 526,88 & 33,73 & 1100,84 & 1334,63 & 2,21 \\
\hline & 0,8 & 2203,13 & 498,64 & 31,92 & 1099,03 & 1104,10 & 2,00 \\
\hline \multirow{7}{*}{ 15-Dez } & 0,2 & 4042,99 & 550,66 & 35,25 & 1102,36 & 2940,63 & 3,67 \\
\hline & 0,3 & 3572,75 & 515,61 & 33,01 & 1100,12 & 2472,64 & 3,25 \\
\hline & 0,4 & 3270,13 & 496,09 & 31,76 & 1098,87 & 2171,27 & 2,98 \\
\hline & 0,5 & 2961,43 & 460,43 & 29,48 & 1096,58 & 1864,85 & 2,70 \\
\hline & 0,6 & 2666,35 & 436,99 & 27,98 & 1095,08 & 1571,27 & 2,43 \\
\hline & 0,7 & 2456,16 & 409,72 & 26,23 & 1093,34 & 1362,83 & 2,25 \\
\hline & 0,8 & 2269,08 & 406,21 & 26,01 & 1093,11 & 1175,96 & 2,08 \\
\hline
\end{tabular}

$\mathrm{RB}$ - receita bruta: $\mathrm{Eb}$ - energia requerida para o bombeamento: $\mathrm{CE}$ - custo de energia elétrica; $\mathrm{CT}$ - custo total de produção; RL - receita líquida e B/C - relação benefício/custo. 
Tabela 25B. Receitas brutas, composição de custos da irrigação, receitas líquidas e relação benefício/custo para a melancia, em cada época de semeadura, nível de manejo da irrigação e risco de $10 \%$. Teresina, Piauí.

\begin{tabular}{|c|c|c|c|c|c|c|c|}
\hline $\begin{array}{l}\text { Época de } \\
\text { Semeadura }\end{array}$ & $\mathrm{p}$ & $\begin{array}{c}\mathrm{RB}^{1} \\
\left(\mathrm{US} \$ \mathrm{ha}^{-1}\right)\end{array}$ & $\begin{array}{c}E b \\
\left(\mathrm{kWh} h \mathrm{ha}^{-1}\right)\end{array}$ & $\begin{array}{c}\text { CE } \\
\left(\mathrm{US} \$ \mathrm{ha}^{-1}\right)\end{array}$ & 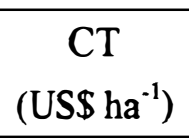 & $\begin{array}{c}\mathrm{RL} \\
\left(\mathrm{US} \$ \mathrm{ha}^{-1}\right)\end{array}$ & $\mathrm{B} / \mathrm{C}$ \\
\hline \multirow{7}{*}{ 1-Jan } & 0,2 & 4499,73 & 454,55 & 28,71 & 1095,82 & 3403,92 & 4,11 \\
\hline & 0,3 & 4053,51 & 421,08 & 26,60 & 1093,70 & 2959,81 & 3,71 \\
\hline & 0,4 & 3739,66 & 388,58 & 24,54 & 1091,65 & 2648,01 & 3,43 \\
\hline & 0,5 & 3438,92 & 350,01 & 22,11 & 1089,21 & 2349,71 & 3,16 \\
\hline & 0,6 & 3196,60 & 323,75 & 20,45 & 1087,55 & 2109,04 & 2,94 \\
\hline & 0,7 & 2990,15 & 297,26 & 18,78 & 1085,88 & 1904,27 & 2,75 \\
\hline & 0,8 & 2812,15 & 284,08 & 17,94 & 1085,05 & 1727,10 & 2,59 \\
\hline \multirow{7}{*}{ 15-Jan } & 0,2 & 4602,52 & 416,37 & 26,30 & 1093,40 & 3509,12 & 4,21 \\
\hline & 0,3 & 4180,39 & 376,19 & 23,76 & 1090,87 & 3089,52 & 3,83 \\
\hline & 0,4 & 3896,94 & 338,48 & 21,38 & 1088,48 & 2808,45 & 3,58 \\
\hline & 0,5 & 3631,36 & 317,28 & 20,04 & 1087,15 & 2544,22 & 3,34 \\
\hline & 0,6 & 3392,40 & 291,79 & 18,43 & 1085,54 & 2306,86 & 3,13 \\
\hline & 0,7 & 3164,64 & 256,91 & 16,23 & 1083,33 & 2081,31 & 2,92 \\
\hline & 0,8 & 3018,74 & 229,01 & 14,47 & 1081,57 & 1937,17 & 2,79 \\
\hline \multirow{7}{*}{$1-\mathrm{Fev}$} & 0,2 & 4864,14 & 355,79 & 23,02 & 1090,12 & 3774,01 & 4,46 \\
\hline & 0,3 & 4451,62 & 313,55 & 20,29 & 1087,39 & 3364,23 & 4,09 \\
\hline & 0,4 & 4163,31 & 274,97 & 17,79 & 1084,89 & 3078,42 & 3,84 \\
\hline & 0,5 & 3919,60 & 237,65 & 15,37 & 1082,48 & 2837,12 & 3,62 \\
\hline & 0,6 & 3691,75 & 213,48 & 13,81 & 1080,92 & 2610,83 & 3,42 \\
\hline & 0,7 & 3528,06 & 176,14 & 11,40 & 1078,50 & 2449,56 & 3,27 \\
\hline & 0,8 & 3403,30 & 170,61 & 11,04 & 1078,14 & 2325,16 & 3,16 \\
\hline \multirow{7}{*}{$15-\mathrm{Fev}$} & 0,2 & 4871,01 & 363,34 & 23,51 & 1090,61 & 3780,40 & 4,47 \\
\hline & 0,3 & 4441,30 & 307,73 & 19,91 & 1087,01 & 3354,29 & 4,09 \\
\hline & 0,4 & 4159,63 & 287,07 & 18,57 & 1085,68 & 3073,96 & 3,83 \\
\hline & 0,5 & 3911,29 & 236,28 & 15,29 & 1082,39 & 2828,90 & 3,61 \\
\hline & 0,6 & 3705,12 & 217,17 & 14,05 & 1081,15 & 2623,97 & 3,43 \\
\hline & 0,7 & 3534,45 & 192,79 & 12,47 & 1079,58 & 2454,87 & 3,27 \\
\hline & 0,8 & 3416,03 & 173,71 & 11,24 & 1078,34 & 2337,69 & 3,17 \\
\hline
\end{tabular}


Tabela 25B. Receitas brutas, composição de custos da irrigação, receitas líquidas e relação benefício/custo para a melancia, em cada época de semeadura, nível de manejo da irrigação e risco de $10 \%$. Teresina, Piauí.

\begin{tabular}{|c|c|c|c|c|c|c|c|}
\hline $\begin{array}{l}\text { Época de } \\
\text { Semeadura }\end{array}$ & $\mathrm{p}$ & $\begin{array}{c}\mathrm{RB}^{1} \\
\left(\mathrm{US} \$ \mathrm{ha}^{-1}\right)\end{array}$ & $\begin{array}{c}E b \\
\left(\mathrm{kWh} \mathrm{ha} \mathrm{a}^{-1}\right)\end{array}$ & $\begin{array}{c}\text { CE } \\
\left(\mathrm{US} \$ \mathrm{ha}^{-1}\right)\end{array}$ & $\begin{array}{c}\text { CT } \\
\left(\mathrm{US} \$ \mathrm{ha}^{-1}\right)\end{array}$ & $\begin{array}{c}\mathrm{RL} \\
\left(\mathrm{US} \$ \mathrm{ha}^{-1}\right)\end{array}$ & $\mathrm{B} / \mathrm{C}$ \\
\hline \multirow{7}{*}{ 1-Mar } & 0,2 & 4830,22 & 349,03 & 22,44 & 1089,54 & 3740,68 & 4,43 \\
\hline & 0,3 & 4395,98 & 299,93 & 19,28 & 1086,39 & 3309,59 & 4,05 \\
\hline & 0,4 & 4104,79 & 253,10 & 16,27 & 1083,38 & 3021,42 & 3,79 \\
\hline & 0,5 & 3894,51 & 232,29 & 14,93 & 1082,04 & 2812,47 & 3,60 \\
\hline & 0,6 & 3676,44 & 205,83 & 13,23 & 1080,34 & 2596,10 & 3,40 \\
\hline & 0,7 & 3459,68 & 171,99 & 11,06 & 1078,16 & 2381,52 & 3,21 \\
\hline & 0,8 & 3319,98 & 148,98 & 9,58 & 1076,68 & 2243,30 & 3,08 \\
\hline \multirow{7}{*}{ 15-Mar } & 0,2 & 4780,07 & 400,58 & 25,75 & 1092,86 & 3687,21 & 4,37 \\
\hline & 0,3 & 4322,78 & 361,80 & 23,26 & 1090,37 & 3232,42 & 3,96 \\
\hline & 0,4 & 3970,65 & 337,12 & 21,67 & 1088,78 & 2881,87 & 3,65 \\
\hline & 0,5 & 3715,53 & 301,78 & 19,40 & 1086,51 & 2629,03 & 3,42 \\
\hline & 0,6 & 3455,78 & 268,90 & 17,29 & 1084,39 & 2371,38 & 3,19 \\
\hline & 0,7 & 3237,61 & 238,85 & 15,36 & 1082,46 & 2155,15 & 2,99 \\
\hline & 0,8 & 3056,15 & 222,75 & 14,32 & 1081,43 & 1974,72 & 2,83 \\
\hline \multirow{7}{*}{$1-\mathrm{Abr}$} & 0,2 & 4594,23 & 466,92 & 28,44 & 1095,54 & 3498,69 & 4,19 \\
\hline & 0,3 & 4093,05 & 435,45 & 26,52 & 1093,63 & 2999,42 & 3,74 \\
\hline & 0,4 & 3717,01 & 410,35 & 24,99 & 1092,10 & 2624,92 & 3,40 \\
\hline & 0,5 & 3439,54 & 395,69 & 24,10 & 1091,21 & 2348,34 & 3,15 \\
\hline & 0,6 & 3169,00 & 372,03 & 22,66 & 1089,76 & 2079,24 & 2,91 \\
\hline & 0,7 & 2929,18 & 356,10 & 21,69 & 1088,79 & 1840,38 & 2,69 \\
\hline & 0,8 & 2712,23 & 329,55 & 20,07 & 1087,18 & 1625,05 & 2,49 \\
\hline \multirow{7}{*}{$15-\mathrm{Abr}$} & 0,2 & 4547,14 & 541,52 & 32,98 & 1100,09 & 3447,05 & 4,13 \\
\hline & 0,3 & 3993,49 & 522,77 & 31,84 & 1098,95 & 2894,54 & 3,63 \\
\hline & 0,4 & 3572,57 & 494,63 & 30,13 & 1097,23 & 2475,34 & 3,26 \\
\hline & 0,5 & 3258,95 & 483,37 & 29,44 & 1096,55 & 2162,40 & 2,97 \\
\hline & 0,6 & 2953,88 & 455,67 & 27,75 & 1094,86 & 1859,02 & 2,70 \\
\hline & 0,7 & 2680,33 & 446,16 & 27,17 & 1094,28 & 1586,05 & 2,45 \\
\hline & 0,8 & 2442,83 & 434,11 & 26,44 & 1093,55 & 1349,28 & 2,23 \\
\hline
\end{tabular}


Tabela 25B. Receitas brutas, composição de custos da irrigação, receitas líquidas e relação beneficio/custo para a melancia, em cada época de semeadura, nível de manejo da irrigação e risco de $10 \%$. Teresina, Piauí.

\begin{tabular}{|c|c|c|c|c|c|c|c|}
\hline $\begin{array}{l}\text { Época de } \\
\text { Semeadura }\end{array}$ & $\mathrm{p}$ & $\begin{array}{c}\mathrm{RB}^{1} \\
\left(\mathrm{US} \$ \mathrm{ha}^{-1}\right)\end{array}$ & $\begin{array}{c}E b \\
(\mathrm{kWh} \mathrm{ha-1})\end{array}$ & $\begin{array}{c}\mathrm{CE} \\
\left(\mathrm{US} \$ \mathrm{ha}^{-1}\right)\end{array}$ & $\begin{array}{c}\mathrm{CT} \\
\left(\mathrm{US} \$ \mathrm{ha}^{-1}\right)\end{array}$ & $\begin{array}{c}\mathrm{RL} \\
\left(\mathrm{US} \$ \mathrm{ha}^{-1}\right)\end{array}$ & $\mathrm{B} / \mathrm{C}$ \\
\hline \multirow{7}{*}{ 1-Mai } & 0,2 & 3636,63 & 602,03 & 35,38 & 1102,49 & 2534,14 & 3,30 \\
\hline & 0,3 & 3161,04 & 580,82 & 34,14 & 1101,24 & 2059,80 & 2,87 \\
\hline & 0,4 & 2813,34 & 565,52 & 33,24 & 1100,34 & 1713,00 & 2,56 \\
\hline & 0,5 & 2577,43 & 567,06 & 33,33 & 1100,43 & 1476,99 & 2,34 \\
\hline & 0,6 & 2294,57 & 553,36 & 32,52 & 1099,63 & 1194,94 & 2,09 \\
\hline & 0,7 & 2045,05 & 527,85 & 31,02 & 1098,13 & 946,92 & 1,86 \\
\hline & 0,8 & 1847,92 & 535,02 & 31,45 & 1098,55 & 749,37 & 1,68 \\
\hline \multirow{7}{*}{ 15-Mai } & 0,2 & 3645,88 & 649,29 & 38,16 & 1105,27 & 2540,62 & 3,30 \\
\hline & 0,3 & 3150,32 & 637,96 & 37,50 & 1104,60 & 2045,72 & 2,85 \\
\hline & 0,4 & 2818,00 & 636,92 & 37,43 & 1104,54 & 1713,46 & 2,55 \\
\hline & 0,5 & 2531,79 & 626,22 & 36,81 & 1103,91 & 1427,88 & 2,29 \\
\hline & 0,6 & 2238,88 & 611,86 & 35,96 & 1103,07 & 1135,82 & 2,03 \\
\hline & 0,7 & 2005,11 & 606,84 & 35,67 & 1102,77 & 902,33 & 1,82 \\
\hline & 0,8 & 1820,42 & 603,79 & 35,49 & 1102,59 & 717,83 & 1,65 \\
\hline \multirow{7}{*}{ 1-Jun } & 0,2 & 3778,92 & 704,69 & 44,06 & 1111,17 & 2667,76 & 3,40 \\
\hline & 0,3 & 3300,29 & 699,52 & 43,74 & 1110,84 & 2189,44 & 2,97 \\
\hline & 0,4 & 2959,84 & 692,17 & 43,28 & 1110,38 & 1849,45 & 2,67 \\
\hline & 0,5 & 2635,76 & 690,23 & 43,16 & 1110,26 & 1525,49 & 2,37 \\
\hline & 0,6 & 2321,33 & 685,08 & 42,84 & 1109,94 & 1211,39 & 2,09 \\
\hline & 0,7 & 2091,70 & 685,27 & 42,85 & 1109,95 & 981,74 & 1,88 \\
\hline & 0,8 & 1886,84 & 680,03 & 42,52 & 1109,63 & 777,21 & 1,70 \\
\hline \multirow{7}{*}{ 15-Jun } & 0,2 & 3819,67 & 751,56 & 46,99 & 1114,10 & 2705,57 & 3,43 \\
\hline & 0,3 & 3360,10 & 747,64 & 46,75 & 1113,85 & 2246,25 & 3,02 \\
\hline & 0,4 & 3009,14 & 737,72 & 46,13 & 1113,23 & 1895,91 & 2,70 \\
\hline & 0,5 & 2654,01 & 742,37 & 46,42 & 1113,52 & 1540,48 & 2,38 \\
\hline & 0,6 & 2367,90 & 733,47 & 45,86 & 1112,97 & 1254,93 & 2,13 \\
\hline & 0,7 & 2137,15 & 745,08 & 46,59 & 1113,69 & 1023,46 & 1,92 \\
\hline & 0,8 & 1908,67 & 698,48 & 43,67 & 1110,78 & 797,89 & 1,72 \\
\hline
\end{tabular}


Tabela 25B. Receitas brutas, composição de custos da irrigação, receitas líquidas e relação benefício/custo para a melancia, em cada época de semeadura, nível de manejo da irrigação e risco de $10 \%$. Teresina, Piaú.

\begin{tabular}{|c|c|c|c|c|c|c|c|}
\hline $\begin{array}{l}\text { Época de } \\
\text { Semeadura }\end{array}$ & $\mathrm{p}$ & $\begin{array}{c}\mathrm{RB}^{1} \\
\left(\mathrm{US} \$ \mathrm{ha}^{-1}\right)\end{array}$ & $\begin{array}{c}\text { Eb } \\
\left(\mathrm{kWh} h \mathrm{a}^{-1}\right)\end{array}$ & $\begin{array}{c}\text { CE } \\
\left(\mathrm{US} \$ \mathrm{ha}^{-1}\right)\end{array}$ & $\begin{array}{c}\mathrm{CT} \\
\left(\mathrm{US} \$ \mathrm{ha} \mathrm{a}^{-1}\right)\end{array}$ & $\begin{array}{c}\mathrm{RL} \\
\left(\mathrm{US} \$ \mathrm{ha}^{-1}\right)\end{array}$ & $\mathrm{B} / \mathrm{C}$ \\
\hline \multirow{7}{*}{$1-\mathrm{Jul}$} & 0,2 & 3168,30 & 811,57 & 51,73 & 1118,83 & 2049,46 & 2,83 \\
\hline & 0,3 & 2844,40 & 808,61 & 51,54 & 1118,65 & 1725,75 & 2,54 \\
\hline & 0,4 & 2514,54 & 802,49 & 51,15 & 1118,26 & 1396,28 & 2,25 \\
\hline & 0,5 & 2213,60 & 805,16 & 51,32 & 1118,43 & 1095,17 & 1,98 \\
\hline & 0,6 & 2000,59 & 800,06 & 51,00 & 1118,10 & 882,49 & 1,79 \\
\hline & 0,7 & 1771,66 & 794,24 & 50,63 & 1117,73 & 653,93 & 1,59 \\
\hline & 0,8 & 1598,18 & 785,15 & 50,05 & 1117,15 & 481,03 & 1,43 \\
\hline \multirow{7}{*}{ 15-Jul } & 0,2 & 3182,35 & 865,40 & 55,16 & 1122,27 & 2060,08 & 2,84 \\
\hline & 0,3 & 2906,71 & 861,77 & 54,93 & 1122,03 & 1784,68 & 2,59 \\
\hline & 0,4 & 2539,55 & 861,44 & 54,91 & 1122,01 & 1417,54 & 2,26 \\
\hline & 0,5 & 2269,57 & 859,37 & 54,78 & 1121,88 & 1147,69 & 2,02 \\
\hline & 0,6 & 2059,24 & 853,16 & 54,38 & 1121,49 & 937,76 & 1,84 \\
\hline & 0,7 & 1797,40 & 834,33 & 53,18 & 1120,29 & 677,12 & 1,60 \\
\hline & 0,8 & 1641,05 & 866,07 & 55,20 & 1122,31 & 518,74 & 1,46 \\
\hline \multirow{7}{*}{ 1-Ago } & 0,2 & 3805,32 & 907,30 & 57,91 & 1125,02 & 2680,30 & 3,38 \\
\hline & 0,3 & 3539,87 & 903,13 & 57,65 & 1124,75 & 2415,11 & 3,15 \\
\hline & 0,4 & 3066,54 & 901,10 & 57,52 & 1124,62 & 1941,92 & 2,73 \\
\hline & 0,5 & 2789,23 & 898,75 & 57,37 & 1124,47 & 1664,76 & 2,48 \\
\hline & 0,6 & 2455,63 & 903,33 & 57,66 & 1124,76 & 1330,86 & 2,18 \\
\hline & 0,7 & 2216,59 & 889,95 & 56,81 & 1123,91 & 1092,68 & 1,97 \\
\hline & 0,8 & 2019,91 & 863,62 & 55,12 & 1122,23 & 897,68 & 1,80 \\
\hline \multirow{7}{*}{ 15-Ago } & 0,2 & 3823,60 & 930,41 & 59,39 & 1126,49 & 2697,11 & 3,39 \\
\hline & 0,3 & 3577,26 & 928,30 & 59,25 & 1126,36 & 2450,90 & 3,18 \\
\hline & 0,4 & 3091,90 & 923,43 & 58,94 & 1126,05 & 1965,85 & 2,75 \\
\hline & 0,5 & 2841,04 & 921,78 & 58,84 & 1125,94 & 1715,09 & 2,52 \\
\hline & 0,6 & 2476,92 & 920,35 & 58,75 & 1125,85 & 1351,07 & 2,20 \\
\hline & 0,7 & 2258,37 & 919,04 & 58,66 & 1125,77 & 1132,60 & 2,01 \\
\hline & 0,8 & 1979,79 & 884,00 & 56,43 & 1123,53 & 856,26 & 1,76 \\
\hline
\end{tabular}


Tabela 25B. Receitas brutas, composição de custos da irrigação, receitas líquidas e relação beneficio/custo para a melancia, em cada época de semeadura, nível de manejo da irrigação e risco de $10 \%$. Teresina, Piauí.

\begin{tabular}{|c|c|c|c|c|c|c|c|}
\hline $\begin{array}{l}\text { Época de } \\
\text { Semeadura }\end{array}$ & $\mathrm{p}$ & $\begin{array}{c}\mathrm{RB}^{\mathrm{I}} \\
\left(\mathrm{US} \$ \mathrm{ha}^{-1}\right)\end{array}$ & 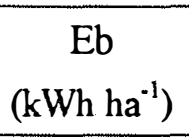 & $\begin{array}{c}\mathrm{CE} \\
\left(\mathrm{US} \$ \mathrm{ha}^{-1}\right)\end{array}$ & $\begin{array}{c}\text { CT } \\
\left(\mathrm{US} \$ \mathrm{ha}^{-1}\right)\end{array}$ & $\begin{array}{c}\mathrm{RL} \\
\left(\mathrm{US} \$ \mathrm{ha}^{-1}\right)\end{array}$ & $\mathrm{B} / \mathrm{C}$ \\
\hline \multirow{7}{*}{ 1-Set } & 0,2 & 3639,09 & 927,37 & 56,45 & 1123,56 & 2515,53 & 3,24 \\
\hline & 0,3 & 3401,82 & 922,57 & 56,16 & 1123,27 & 2278,55 & 3,03 \\
\hline & 0,4 & 2948,01 & 921,64 & 56,11 & 1123,21 & 1824,80 & 2,62 \\
\hline & 0,5 & 2708,83 & 914,49 & 55,67 & 1122,78 & 1586,06 & 2,41 \\
\hline & 0,6 & 2373,67 & 911,91 & 55,51 & 1122,62 & 1251,05 & 2,11 \\
\hline & 0,7 & 2155,15 & 905,61 & 55,13 & 1122,23 & 1032,91 & 1,92 \\
\hline & 0,8 & 1909,46 & 904,15 & 55,04 & 1122,15 & 787,31 & 1,70 \\
\hline \multirow{7}{*}{ 15-Set } & 0,2 & 3632,39 & 914,46 & 55,67 & 1122,77 & 2509,61 & 3,24 \\
\hline & 0,3 & 3384,58 & 908,67 & 55,32 & 1122,42 & 2262,16 & 3,02 \\
\hline & 0,4 & 2938,57 & 900,13 & 54,80 & 1121,90 & 1816,67 & 2,62 \\
\hline & 0,5 & 2699,89 & 896,64 & 54,58 & 1121,69 & 1578,20 & 2,41 \\
\hline & 0,6 & 2372,33 & 902,41 & 54,94 & 1122,04 & 1250,29 & 2,11 \\
\hline & 0,7 & 2157,08 & 892,39 & 54,33 & 1121,43 & 1035,65 & 1,92 \\
\hline & 0,8 & 1913,23 & 881,06 & 53,64 & 1120,74 & 792,49 & 1,71 \\
\hline \multirow{7}{*}{ 1-Out } & 0,2 & 3709,34 & 885,62 & 55,24 & 1122,35 & 2586,99 & 3,30 \\
\hline & 0,3 & 3442,24 & 882,43 & 55,04 & 1122,15 & 2320,10 & 3,07 \\
\hline & 0,4 & 2998,26 & 877,25 & 54,72 & 1121,82 & 1876,43 & 2,67 \\
\hline & 0,5 & 2727,09 & 874,88 & 54,57 & 1121,68 & 1605,41 & 2,43 \\
\hline & 0,6 & 2410,97 & 870,57 & 54,30 & 1121,41 & 1289,56 & 2,15 \\
\hline & 0,7 & 2187,47 & 857,88 & 53,51 & 1120,62 & 1066,86 & 1,95 \\
\hline & 0,8 & 1941,18 & 855,85 & 53,38 & 1120,49 & 820,70 & 1,73 \\
\hline \multirow{7}{*}{ 15-Out } & 0,2 & 3702,96 & 842,98 & 52,58 & 1119,69 & 2583,27 & 3,31 \\
\hline & 0,3 & 3403,16 & 834,36 & 52,04 & 1119,15 & 2284,01 & 3,04 \\
\hline & 0,4 & 2975,19 & 833,79 & 52,01 & 1119,11 & 1856,08 & 2,66 \\
\hline & 0,5 & 2683,65 & 817,62 & 51,00 & 1118,10 & 1565,54 & 2,40 \\
\hline & 0,6 & 2403,21 & 817,77 & 51,01 & 1118,11 & 1285,09 & 2,15 \\
\hline & 0,7 & 2166,38 & 808,79 & 50,45 & 1117,55 & 1048,82 & 1,94 \\
\hline & 0,8 & 1971,86 & 808,93 & 50,46 & 1117,56 & 854,29 & 1,76 \\
\hline
\end{tabular}


Tabela 25B. Receitas brutas, composição de custos da irrigação, receitas líquidas e relação benefício/custo para a melancia, em cada época de semeadura, nível de manejo da irrigação e risco de $10 \%$. Teresina, Piauí.

\begin{tabular}{|c|c|c|c|c|c|c|c|}
\hline $\begin{array}{l}\text { Época de } \\
\text { Semeadura }\end{array}$ & $\mathrm{p}$ & $\begin{array}{c}\mathrm{RB}^{\mathrm{l}} \\
\left(\mathrm{US} \$ \mathrm{ha}^{-1}\right)\end{array}$ & $\begin{array}{c}\mathrm{Eb} \\
\left(\mathrm{kWh} \mathrm{ha}^{-1}\right)\end{array}$ & $\begin{array}{c}\text { CE } \\
\left(\mathrm{US} \$ \mathrm{ha}^{-1}\right)\end{array}$ & $\begin{array}{c}\text { CT } \\
\left(\mathrm{US} \$ \mathrm{ha}^{-1}\right)\end{array}$ & $\begin{array}{c}\mathrm{RL} \\
\left(\mathrm{US} \$ \mathrm{ha}^{-1}\right)\end{array}$ & $\mathrm{B} / \mathrm{C}$ \\
\hline \multirow{7}{*}{$1-$ Nov } & 0,2 & 4096,76 & 750,93 & 47,23 & 1114,33 & 2982,43 & 3,68 \\
\hline & 0,3 & 3699,55 & 737,38 & 46,37 & 1113,48 & 2586,07 & 3,32 \\
\hline & 0,4 & 3306,19 & 729,63 & 45,89 & 1112,99 & 2193,20 & 2,97 \\
\hline & 0,5 & 2960,84 & 714,80 & 44,95 & 1112,06 & 1848,78 & 2,66 \\
\hline & 0,6 & 2654,37 & 707,12 & 44,47 & 1111,57 & 1542,80 & 2,39 \\
\hline & 0,7 & 2401,51 & 690,20 & 43,41 & 1110,51 & 1291,00 & 2,16 \\
\hline & 0,8 & 2149,65 & 681,34 & 42,85 & 1109,95 & 1039,69 & 1,94 \\
\hline \multirow{7}{*}{ 15-Nov } & 0,2 & 4088,58 & 669,21 & 42,09 & 1109,19 & 2979,39 & 3,69 \\
\hline & 0,3 & 3659,74 & 644,51 & 40,53 & 1107,64 & 2552,10 & 3,30 \\
\hline & 0,4 & 3303,96 & 617,91 & 38,86 & 1105,96 & 2197,99 & 2,99 \\
\hline & 0,5 & 2977,30 & 611,92 & 38,48 & 1105,59 & 1871,72 & 2,69 \\
\hline & 0,6 & 2682,24 & 594,02 & 37,36 & 1104,46 & 1577,78 & 2,43 \\
\hline & 0,7 & 2420,83 & 572,09 & 35,98 & 1103,08 & 1317,75 & 2,19 \\
\hline & 0,8 & 2234,10 & 570,75 & 35,89 & 1103,00 & 1131,11 & 2,03 \\
\hline \multirow{7}{*}{ 1-Dez } & 0,2 & 4112,62 & 591,57 & 36,97 & 1104,07 & 3008,54 & 3,72 \\
\hline & 0,3 & 3684,75 & 572,66 & 35,79 & 1102,89 & 2581,86 & 3,34 \\
\hline & 0,4 & 3347,47 & 535,54 & 33,47 & 1100,57 & 2246,89 & 3,04 \\
\hline & 0,5 & 3015,10 & 517,00 & 32,31 & 1099,41 & 1915,69 & 2,74 \\
\hline & 0,6 & 2739,92 & 502,54 & 31,41 & 1098,51 & 1641,41 & 2,49 \\
\hline & 0,7 & 2533,04 & 491,74 & 30,73 & 1097,84 & 1435,20 & 2,31 \\
\hline & 0,8 & 2303,70 & 460,41 & 28,77 & 1095,88 & 1207,82 & 2,10 \\
\hline \multirow{7}{*}{ 15-Dez } & 0,2 & 4133,79 & 528,62 & 33,04 & 1100,14 & 3033,65 & 3,76 \\
\hline & 0,3 & 3670,23 & 490,80 & 30,67 & 1097,78 & 2572,46 & 3,34 \\
\hline & 0,4 & 3370,86 & 469,25 & 29,33 & 1096,43 & 2274,43 & 3,07 \\
\hline & 0,5 & 3064,15 & 432,56 & 27,03 & 1094,14 & 1970,01 & 2,80 \\
\hline & 0,6 & 2779,83 & 405,90 & 25,37 & 1092,47 & 1687,36 & 2,54 \\
\hline & 0,7 & 2573,47 & 378,85 & 23,68 & 1090,78 & 1482,69 & 2,36 \\
\hline & 0,8 & 2389,92 & 369,90 & 23,12 & 1090,22 & 1299,70 & 2,19 \\
\hline
\end{tabular}

${ }^{1} \mathrm{RB}$ - receita bruta; $\mathrm{Eb}$ - energia requerida para o bombeamento; $\mathrm{CE}$ - custo de energia elétrica; $\mathrm{CT}$ - custo total de produção; RL - receita líquida e B/C - relação benefício/custo. 
Tabela 26B. Receitas brutas, composição de custos da irrigação, receitas líquidas e relação benefício/custo para a melancia, em cada época de semeadura, nível de manejo da irrigação e risco de $15 \%$. Teresina, Piauí.

\begin{tabular}{|c|c|c|c|c|c|c|c|}
\hline $\begin{array}{l}\text { Época de } \\
\text { Semeadura }\end{array}$ & $p$ & $\begin{array}{c}\mathrm{RB}^{\mathrm{l}} \\
\left(\mathrm{US} \$ \mathrm{ha}^{-1}\right)\end{array}$ & 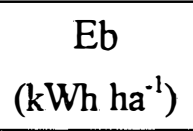 & $\begin{array}{c}\text { CE } \\
\left(\mathrm{US} \$ \mathrm{ha}^{-1}\right)\end{array}$ & $\begin{array}{c}\text { CT } \\
\left(\mathrm{US} \$ \mathrm{ha}^{-1}\right)\end{array}$ & $\begin{array}{c}\mathrm{RL} \\
\left(\mathrm{US} \$ \mathrm{ha}^{-1}\right)\end{array}$ & $\mathrm{B} / \mathrm{C}$ \\
\hline \multirow{7}{*}{ 1-Jan } & 0,2 & 4546,74 & 439,44 & 27,11 & 1094,22 & 3452,53 & 4,16 \\
\hline & 0,3 & 4107,84 & 404,07 & 24,93 & 1092,03 & 3015,80 & 3,76 \\
\hline & 0,4 & 3801,22 & 369,67 & 22,81 & 1089,91 & 2711,31 & 3,49 \\
\hline & 0,5 & 3505,24 & 330,14 & 20,37 & 1087,47 & 2417,76 & 3,22 \\
\hline & 0,6 & 3268,84 & 302,18 & 18,64 & 1085,75 & 2183,09 & 3,01 \\
\hline & 0,7 & 3071,74 & 275,88 & 17,02 & 1084,13 & 1987,61 & 2,83 \\
\hline & 0,8 & 2900,32 & 261,36 & 16,12 & 1083,23 & 1817,09 & 2,68 \\
\hline \multirow{7}{*}{ 15-Jan } & 0,2 & 4652,25 & 401,16 & 24,75 & 1091,85 & 3560,40 & 4,26 \\
\hline & 0,3 & 4235,26 & 358,31 & 22,11 & 1089,21 & 3146,05 & 3,89 \\
\hline & 0,4 & 3957,71 & 320,30 & 19,76 & 1086,87 & 2870,85 & 3,64 \\
\hline & 0,5 & 3697,98 & 296,18 & 18,27 & 1085,38 & 2612,60 & 3,41 \\
\hline & 0,6 & 3467,63 & 269,48 & 16,63 & 1083,73 & 2383,90 & 3,20 \\
\hline & 0,7 & 3253,87 & 235,92 & 14,55 & 1081,66 & 2172,21 & 3,01 \\
\hline & 0,8 & 3113,21 & 229,01 & 14,13 & 1081,23 & 2031,98 & 2,88 \\
\hline \multirow{7}{*}{ 1-Fev } & 0,2 & 4900,63 & 342,24 & 21,44 & 1088,54 & 3812,09 & 4,50 \\
\hline & 0,3 & 4494,48 & 297,56 & 18,64 & 1085,74 & 3408,73 & 4,14 \\
\hline & 0,4 & 4218,29 & 259,03 & 16,22 & 1083,33 & 3134,97 & 3,89 \\
\hline & 0,5 & 3981,54 & 221,49 & 13,87 & 1080,98 & 2900,57 & 3,68 \\
\hline & 0,6 & 3764,46 & 196,85 & 12,33 & 1079,43 & 2685,03 & 3,49 \\
\hline & 0,7 & 3608,15 & 160,08 & 10,03 & 1077,13 & 2531,02 & 3,35 \\
\hline & 0,8 & 3489,08 & 170,61 & 10,69 & 1077,79 & 2411,29 & 3,24 \\
\hline \multirow{7}{*}{$15-\mathrm{Fev}$} & 0,2 & 4908,65 & 345,58 & 21,65 & 1088,75 & 3819,90 & 4,51 \\
\hline & 0,3 & 4491,42 & 290,06 & 18,17 & 1085,27 & 3406,14 & 4,14 \\
\hline & 0,4 & 4219,62 & 266,83 & 16,71 & 1083,82 & 3135,80 & 3,89 \\
\hline & 0,5 & 3980,06 & 217,57 & 13,63 & 1080,73 & 2899,33 & 3,68 \\
\hline & 0,6 & 3784,79 & 197,02 & 12,34 & 1079,45 & 2705,34 & 3,51 \\
\hline & 0,7 & 3626,25 & 173,45 & 10,86 & 1077,97 & 2548,28 & 3,36 \\
\hline & 0,8 & 3515,64 & 135,11 & 8,46 & 1075,57 & 2440,07 & 3,27 \\
\hline
\end{tabular}


Tabela 26B. Receitas brutas, composição de custos da irrigação, receitas líquidas e relação benefício/custo para a melancia, em cada época de semeadura, nível de manejo da irrigação e risco de $15 \%$. Teresina, Piauí.

\begin{tabular}{|c|c|c|c|c|c|c|c|}
\hline $\begin{array}{l}\text { Época de } \\
\text { Semeadura }\end{array}$ & $\mathrm{p}$ & $\begin{array}{c}\mathrm{RB}^{1} \\
\left(\mathrm{US} \$ \mathrm{ha}^{-1}\right)\end{array}$ & $\begin{array}{c}E b \\
\left(\mathrm{kWh} \mathrm{ha}^{-1}\right)\end{array}$ & $\begin{array}{c}\text { CE } \\
\left(\mathrm{US} \$ \mathrm{ha}^{-1}\right)\end{array}$ & $\begin{array}{c}\mathrm{CT} \\
\left(\mathrm{US} \$ \mathrm{ha}^{-1}\right)\end{array}$ & $\begin{array}{c}\mathrm{RL} \\
\left(\mathrm{US} \$ \mathrm{ha}^{-1}\right)\end{array}$ & $\mathrm{B} / \mathrm{C}$ \\
\hline \multirow{7}{*}{ 1-Mar } & 0,2 & 4885,70 & 333,99 & 20,81 & 1087,91 & 3797,79 & 4,49 \\
\hline & 0,3 & 4462,26 & 283,87 & 17,68 & 1084,79 & 3377,47 & 4,11 \\
\hline & 0,4 & 4177,82 & 236,59 & 14,74 & 1081,84 & 3095,98 & 3,86 \\
\hline & 0,5 & 3974,07 & 214,68 & 13,37 & 1080,48 & 2893,59 & 3,68 \\
\hline & 0,6 & 3767,48 & 188,39 & 11,74 & 1078,84 & 2688,64 & 3,49 \\
\hline & 0,7 & 3564,46 & 155,54 & 9,69 & 1076,79 & 2487,67 & 3,31 \\
\hline & 0,8 & 3433,61 & 82,77 & 5,16 & 1072,26 & 2361,35 & 3,20 \\
\hline \multirow{7}{*}{ 15-Mar } & 0,2 & 4833,01 & 385,17 & 23,99 & 1091,10 & 3741,91 & 4,43 \\
\hline & 0,3 & 4381,38 & 343,85 & 21,42 & 1088,53 & 3292,86 & 4,03 \\
\hline & 0,4 & 4038,71 & 316,62 & 19,72 & 1086,83 & 2951,88 & 3,72 \\
\hline & 0,5 & 3792,58 & 282,51 & 17,60 & 1084,70 & 2707,88 & 3,50 \\
\hline & 0,6 & 3542,41 & 249,00 & 15,51 & 1082,62 & 2459,79 & 3,27 \\
\hline & 0,7 & 3333,55 & 219,29 & 13,66 & 1080,77 & 2252,79 & 3,08 \\
\hline & 0,8 & 3159,42 & 202,07 & 12,59 & 1079,69 & 2079,72 & 2,93 \\
\hline \multirow{7}{*}{$1-\mathrm{Abr}$} & 0,2 & 4648,92 & 451,93 & 26,75 & 1093,85 & 3555,07 & 4,25 \\
\hline & 0,3 & 4153,72 & 419,16 & 24,81 & 1091,92 & 3061,81 & 3,80 \\
\hline & 0,4 & 3785,97 & 392,20 & 23,21 & 1090,32 & 2695,65 & 3,47 \\
\hline & 0,5 & 3511,66 & 374,87 & 22,19 & 1089,29 & 2422,36 & 3,22 \\
\hline & 0,6 & 3245,79 & 350,17 & 20,73 & 1087,83 & 2157,95 & 2,98 \\
\hline & 0,7 & 3012,23 & 332,42 & 19,68 & 1086,78 & 1925,45 & 2,77 \\
\hline & 0,8 & 2803,99 & 305,61 & 18,09 & 1085,19 & 1718,80 & 2,58 \\
\hline \multirow{7}{*}{$15-\mathrm{Abr}$} & 0,2 & 4598,63 & 528,12 & 31,26 & 1098,36 & 3500,27 & 4,19 \\
\hline & 0,3 & 4049,13 & 507,07 & 30,01 & 1097,12 & 2952,01 & 3,69 \\
\hline & 0,4 & 3632,52 & 476,89 & 28,23 & 1095,33 & 2537,19 & 3,32 \\
\hline & 0,5 & 3323,68 & 463,44 & 27,43 & 1094,54 & 2229,15 & 3,04 \\
\hline & 0,6 & 3025,46 & 436,02 & 25,81 & 1092,91 & 1932,54 & 2,77 \\
\hline & 0,7 & 2754,95 & 425,27 & 25,17 & 1092,28 & 1662,67 & 2,52 \\
\hline & 0,8 & 2520,11 & 411,47 & 24,36 & 1091,46 & 1428,65 & 2,31 \\
\hline
\end{tabular}


Tabela 26B. Receitas brutas, composição de custos da irrigação, receitas líquidas e relação benefício/custo para a melancia, em cada época de semeadura, nível de manejo da irrigação e risco de $15 \%$. Teresina, Piauí.

\begin{tabular}{|c|c|c|c|c|c|c|c|}
\hline $\begin{array}{l}\text { Época de } \\
\text { Semeadura }\end{array}$ & $\mathrm{p}$ & $\begin{array}{c}\mathrm{RB}^{\mathrm{l}} \\
\left(\mathrm{US} \$ \mathrm{ha}^{-1}\right)\end{array}$ & $\begin{array}{c}E b \\
\left(\mathrm{kWh} \mathrm{ha}^{-1}\right)\end{array}$ & $\begin{array}{c}C E \\
\left(U S \$ h^{-1}\right)\end{array}$ & $\begin{array}{c}\text { CT } \\
\left(\mathrm{US} \$ \mathrm{ha}^{-1}\right)\end{array}$ & $\begin{array}{c}\mathrm{RL} \\
\left(\mathrm{US} \$ \mathrm{ha}^{-1}\right)\end{array}$ & $\mathrm{B} / \mathrm{C}$ \\
\hline \multirow{7}{*}{ 1-Mai } & 0,2 & 3669,75 & 588,99 & 33,91 & 1101,02 & 2568,73 & 3,33 \\
\hline & 0,3 & 3197,49 & 565,80 & 32,58 & 1099,68 & 2097,81 & 2,91 \\
\hline & 0,4 & 2853,39 & 548,67 & 31,59 & 1098,69 & 1754,70 & 2,60 \\
\hline & 0,5 & 2616,15 & 546,94 & 31,49 & 1098,59 & 1517,56 & 2,38 \\
\hline & 0,6 & 2339,17 & 532,40 & 30,65 & 1097,76 & 1241,41 & 2,13 \\
\hline & 0,7 & 2094,48 & 506,95 & 29,19 & 1096,29 & 998,19 & 1,91 \\
\hline & 0,8 & 1898,05 & 509,97 & 29,36 & 1096,47 & 801,58 & 1,73 \\
\hline \multirow{7}{*}{ 15-Mai } & 0,2 & 3675,47 & 640,68 & 36,89 & 1103,99 & 2571,48 & 3,33 \\
\hline & 0,3 & 3181,29 & 626,82 & 36,09 & 1103,19 & 2078,10 & 2,88 \\
\hline & 0,4 & 2850,65 & 624,65 & 35,96 & 1103,07 & 1747,58 & 2,58 \\
\hline & 0,5 & 2564,43 & 612,46 & 35,26 & 1102,37 & 1462,06 & 2,33 \\
\hline & 0,6 & 2273,31 & 598,02 & 34,43 & 1101,54 & 1171,77 & 2,06 \\
\hline & 0,7 & 2040,63 & 590,95 & 34,02 & 1101,13 & 939,50 & 1,85 \\
\hline & 0,8 & 1855,77 & $588 ; 02$ & 33,86 & 1100,96 & 754,81 & 1,69 \\
\hline \multirow{7}{*}{ 1-Jun } & 0,2 & 3822,91 & 696,98 & 42,57 & 1109,67 & 2713,24 & 3,45 \\
\hline & 0,3 & 3343,50 & 690,85 & 42,19 & 1109,30 & 2234,20 & 3,01 \\
\hline & 0,4 & $3002 ; 56$ & 683,11 & 41,72 & 1108,82 & 1893,73 & 2,71 \\
\hline & 0,5 & 2674,08 & 680,30 & 41,55 & 1108,65 & 1565,43 & 2,41 \\
\hline & 0,6 & 2360,21 & 673,23 & 41,12 & 1108,22 & 1251,99 & 2,13 \\
\hline & 0,7 & 2130,50 & 672,97 & 41,10 & 1108,20 & 1022,30 & 1,92 \\
\hline & 0,8 & 1922,45 & 666,69 & 40,72 & 1107,82 & 814,62 & 1,74 \\
\hline \multirow{7}{*}{ 15-Jun } & 0,2 & 3861,89 & 745,65 & 45,54 & 1112,64 & 2749,25 & 3,47 \\
\hline & 0,3 & 3403,21 & 740,19 & 45,21 & 1112,31 & 2290,90 & 3,06 \\
\hline & 0,4 & 3050,70 & 730,11 & 44,59 & 1111,70 & 1939,01 & 2,74 \\
\hline & 0,5 & 2691,41 & 733,60 & 44,80 & 1111,91 & 1579,50 & 2,42 \\
\hline & 0,6 & 2405,24 & 723,38 & 44,18 & 1111,28 & 1293,96 & 2,16 \\
\hline & 0,7 & 2169,81 & 732,94 & 44,76 & 1111,87 & 1057,94 & 1,95 \\
\hline & 0,8 & $1941,5+-$ & 698,48 & 42,66 & 1109,76 & 831,75 & 1,75 \\
\hline
\end{tabular}


Tabela 26B. Receitas brutas, composição de custos da irrigação, receitas líquidas e relação benefício/custo para a melancia, em cada época de semeadura, nível de manejo da irrigação-e risco de $15 \%$. Teresina, Piauí.

\begin{tabular}{|c|c|c|c|c|c|c|c|}
\hline $\begin{array}{l}\text { Epoca de } \\
\text { Semeadura }\end{array}$ & $\mathrm{p}$ & $\begin{array}{c}\mathrm{RB}^{\mathrm{l}} \\
\left(\mathrm{US} \$ \mathrm{ha}^{-1}\right)\end{array}$ & $\begin{array}{c}E b \\
\left(\mathrm{kWh} h \mathrm{a}^{-1}\right)\end{array}$ & $\begin{array}{c}\text { CE } \\
\left(\mathrm{US} \$ h \mathrm{a}^{-1}\right)\end{array}$ & $\begin{array}{c}\text { CT } \\
\left(\mathrm{US} \$ \mathrm{ha}^{-1}\right)\end{array}$ & $\begin{array}{c}\mathrm{RL} \\
\left(\mathrm{US} \$ \mathrm{ha}^{-1}\right)\end{array}$ & $\mathrm{B} / \mathrm{C}$ \\
\hline \multirow{7}{*}{ 1-Jul } & 0,2 & 3233,21 & 806,93 & 50,46 & 1117,57 & 2115,64 & 2,89 \\
\hline & 0,3 & 2908,87 & 803,52 & 50,25 & 1117,36 & 1791,51 & 2,60 \\
\hline & 0,4 & 2571,68 & $796 ; 44$ & 49,81 & 1116,91 & 1454,76 & 2,30 \\
\hline & 0,5 & 2265,48 & 797,76 & 49,89 & 1117,00 & 1148,48 & 2,03 \\
\hline & 0,6 & $20-50,42$ & 792,43 & 49,56 & 1116,66 & 933,75 & 1,84 \\
\hline & 0,7 & 1816,25 & 785,26 & 49,11 & 1116,21 & 700,04 & 1,63 \\
\hline & 0,8 & 1638,92 & 785,15 & 49,10 & 1116,21 & 522,71 & 1,47 \\
\hline \multirow{7}{*}{ 15-Jul } & 0,2 & 3246,92 & 861,13 & $53,85^{\circ}$ & 1120,96 & 2125,96 & 2,90 \\
\hline & 0,3 & 2972,43 & 856,54 & 53,57 & 1120,67 & 1851,76 & 2,65 \\
\hline & 0,4 & 2596,54 & 855,72 & 53,52 & 1120,62 & 1475,92 & 2,32 \\
\hline & 0,5 & 2324,34 & 852,33 & 53,30 & 1120,41 & 1203,93 & 2,07 \\
\hline & 0,6 & 2106,14 & 845,99 & 52,91 . & 1120,01 & 986,13 & 1,88 \\
\hline & 0,7 & 1843,02 & 834,33 & 52,18 & 1119,28 & 723,73 & 1,65 \\
\hline & 0,8 & 1684,67 & 855,97 & 53,53 & 1120,64 & 564,03 & 1,50 \\
\hline \multirow{7}{*}{ 1-Ago } & 0,2 & 3844,14 & 901,56 & 56,62 & 1123,73 & 2720,41 & 3,42 \\
\hline & 0,3 & 3580,02 & 896,90 & 56,33 & 1123,44 & 2456,58 & 3,19 \\
\hline & 0,4 & 3101,92 & 894,15 & 56,16 & 1123,26 & 1978,65 & 2,76 \\
\hline & 0,5 & 2825,73 & 889,99 & 55,90 & 1123,00 & 1702,73 & 2,52 \\
\hline & 0,6 & 2488,37 & 892,71 & 56,07 & $1123 ; 17$ & 1365,20 & 2,22 \\
\hline & 0,7 & 2250,23 & 880,04 & 55,27 & 1122,38 & 1127,86 & 2,00 \\
\hline & 0,8 & 2037,67 & $863 ; 62$ & 54,24 & 1121,34 & 916,33 & 1,82 \\
\hline \multirow{7}{*}{ 15-Ago } & 0,2 & 3863,47 & 924,57 & 58,07 & 1125,17 & 2738,30 & 3,43 \\
\hline & 0,3 & 3616,91 & 921,73 & 57,89 & 1124,99 & 2491,91 & 3,22 \\
\hline & 0,4 & 3128,02 & 916,09 & 57,54 & 1124,64 & 2003,38 & 2,78 \\
\hline & 0,5 & 2877,31 & 912,97 & 57,34 & 1124,44 & 1752,86 & 2,56 \\
\hline & 0,6 & 2510,71 & 911,14 & 57,23 & 1124,33 & 1386,38 & 2,23 \\
\hline & 0,7 & 2293,75 & 908,81 & 57,08 & 1124,18 & 1169,57 & 2,04 \\
\hline & 0,8 & 2012,81 & 859,70 & 53,99 & 1121,10 & 891,71 & 1,80 \\
\hline
\end{tabular}


Tabela 26B. Receitas brutas, composição de custos da irrigação, receitas líquidas e relação benefício/custo para a melancia, em cada época de semeadura, nível de manejo da irrigação e risco de $15 \%$. Teresina, Piauí.

\begin{tabular}{|c|c|c|c|c|c|c|c|}
\hline $\begin{array}{l}\text { Época de } \\
\text { Semeadura }\end{array}$ & $\mathrm{p}$ & $\begin{array}{c}\mathrm{RB}^{1} \\
\left(\mathrm{US} \$ \mathrm{ha}^{-1}\right)\end{array}$ & $\begin{array}{c}E b \\
\left(\mathrm{kWh} \mathrm{ha}^{-1}\right)\end{array}$ & $\begin{array}{c}\text { CE } \\
\left(\mathrm{US} \$ \mathrm{ha}^{-1}\right)\end{array}$ & $\begin{array}{c}\text { CT } \\
\left(\mathrm{US} \$ \mathrm{ha}^{-1}\right)\end{array}$ & $\begin{array}{c}\mathrm{RL} \\
\left(\mathrm{US} \$ \mathrm{ha}^{-1}\right)\end{array}$ & $B / C$ \\
\hline \multirow{7}{*}{$1-$ Set } & 0,2 & 3667,75 & 920,43 & 55,52 & 1122,62 & 2545,12 & 3,27 \\
\hline & 0,3 & 3430,15 & 914,59 & 55,17 & 1122,27 & 2307,88 & 3,06 \\
\hline & 0,4 & 2975,16 & 911,83 & 55,00 & 1122,11 & 1853,06 & 2,65 \\
\hline & 0,5 & 2736,38 & 903,77 & 54,51 & 1121,62 & 1614,76 & 2,44 \\
\hline & 0,6 & 2399,50 & 899,59 & 54,26 & 1121,37 & 1278,13 & 2,14 \\
\hline & 0,7 & 2183,32 & 892,96 & 53,86 & 1120,97 & 1062,36 & 1,95 \\
\hline & 0,8 & 1936,10 & 889,35 & 53,64 & 1120,75 & 815,35 & 1,73 \\
\hline \multirow{7}{*}{$15-$ Set } & 0,2 & 3661,01 & 906,37 & 54,67 & 1121,78 & 2539,24 & 3,26 \\
\hline & 0,3 & 3413,52 & 899,25 & 54,24 & 1121,35 & 2292,18 & 3,04 \\
\hline & 0,4 & 2967,07 & 889,94 & 53,68 & 1120,78 & 1846,28 & 2,65 \\
\hline & 0,5 & 2729,16 & 884,96 & 53,38 & 1120,48 & 1608,68 & 2,44 \\
\hline & 0,6 & 2399,39 & 887,43 & 53,53 & 1120,63 & 1278,75 & 2,14 \\
\hline & 0,7 & 2186,99 & 878,40 & 52,98 & 1120,09 & 1066,91 & 1,95 \\
\hline & 0,8 & 1941,32 & 881,06 & 53,14 & 1120,25 & 821,07 & 1,73 \\
\hline \multirow{7}{*}{ 1-Out } & 0,2 & 3738,47 & 877,16 & 54,02 & 1121,12 & 2617,35 & 3,33 \\
\hline & 0,3 & 3472,56 & 872,47 & 53,73 & 1120,83 & 2351,73 & 3,10 \\
\hline & 0,4 & 3025,95 & 865,16 & 53,28 & 1120,38 & 1905,57 & 2,70 \\
\hline & 0,5 & 2757,49 & 861,48 & 53,05 & 1120,16 & 1637,33 & 2,46 \\
\hline & 0,6 & 2439,32 & 855,70 & 52,70 & 1119,80 & 1319,52 & 2,18 \\
\hline & 0,7 & 2215,60 & 843,25 & 51,93 & 1119,04 & 1096,57 & 1,98 \\
\hline & 0,8 & 1971,88 & 839,03 & 51,67 & 1118,78 & 853,10 & 1,76 \\
\hline \multirow{7}{*}{ 15-Out } & 0,2 & 3732,07 & 833,12 & 51,31 & 1118,41 & 2613,65 & 3,34 \\
\hline & 0,3 & 3433,94 & 823,41 & 50,71 & 1117,81 & 2316,13 & 3,07 \\
\hline & 0,4 & 3006,76 & 820,61 & 50,54 & 1117,64 & 1889,12 & 2,69 \\
\hline & 0,5 & 2716,54 & 803,60 & 49,49 & 1116,59 & 1599,94 & 2,43 \\
\hline & 0,6 & 2434,51 & 800,85 & 49,32 & 1116,42 & 1318,08 & 2,18 \\
\hline & 0,7 & 2196,17 & 789,59 & 48,63 & 1115,73 & 1080,44 & 1,97 \\
\hline & 0,8 & 2002,40 & 788,20 & 48,54 & 1115,65 & 886,76 & 1,79 \\
\hline
\end{tabular}


Tabela 26B. Receitas brutas, composição- de etstos da irrigação, receitas líquidas e relação beneficio/custo para a melancia, em cada época de semeadura, nívet de manejo da ifrigação e risco de $15 \%$. Teresina, Piauí.

\begin{tabular}{|c|c|c|c|c|c|c|c|}
\hline $\begin{array}{c}\text { Época de } \\
\text { Semeadura }\end{array}$ & $\mathrm{p}$ & $\begin{array}{c}\mathrm{RB}^{\mathrm{l}} \\
\left(\mathrm{US} \$ \mathrm{ha}^{-1}\right)\end{array}$ & $\begin{array}{c}\mathrm{Eb} \\
\left(\mathrm{kWh} h \mathrm{a}^{-1}\right)\end{array}$ & $\begin{array}{c}\text { CE } \\
\left(\text { US\$ ha }{ }^{-1}\right)\end{array}$ & $\begin{array}{c}\text { CT } \\
\left(\mathrm{US} \$ \mathrm{ha}^{-1}\right)\end{array}$ & $\begin{array}{c}\mathrm{RL} \\
\left(\mathrm{US} \$ \mathrm{ha}^{-1}\right)\end{array}$ & $\mathrm{B} / \mathrm{C}$ \\
\hline \multirow{7}{*}{$1-\mathrm{Nov}$} & 0,2 & 4130,64 & 738,00 & 45,75 & 1112,85 & 3017,78 & 3,71 \\
\hline & 0,3 & 3739,71 & 723,03 & 44,82 & 1111,93 & 2627,78 & 3,36 \\
\hline & $0 ; 4$ & 3343,80 & 712,71 & 44,18 & 1111,29 & 2232,51 & 3,01 \\
\hline & 0,5 & 2999,48 & 695,73 & 43.13 & 1110,23 & 1889,24 & 2,70 \\
\hline & $\theta ; 6$ & 2697,23 & 685,71 & $42,5 i$ & 1109,61 & 1587,61 & 2,43 \\
\hline & 0,7 & 2443,56 & 668,01 & 41,41 & 1108,52 & 1335,05 & 2,20 \\
\hline & $0 ; 8$ & 2198,16 & 656,90 & $40 ; 72$ & 1107,83 & 1090,34 & 1,98 \\
\hline \multirow{7}{*}{ 15-Nov } & 0,2 & 4125,21 & 654,50 & 40,57 & 1107,68 & 3017,53 & 3,72 \\
\hline & 0,3 & 3702,54 & 628,98 & 38,99 & 1106,10 & 2596,45 & 3,35 \\
\hline & 0,4 & $3: 347,68$ & $600 ; 62$ & 37,23 & 1104,34 & 2243,34 & 3,03 \\
\hline & 0,5 & 3022,43 & 591,70 & 36,68 & 1103,79 & 1918,64 & 2,74 \\
\hline & 0,6 & 2732,47 & 571,50 & 35,43 & 1102,53 & 1629,94 & 2,48 \\
\hline & 0,7 & 2475,28 & 549,23 & 34,05 & 1101,15 & 1374,13 & 2,25 \\
\hline & 0,8 & 2288,31 & 543,76 & $33 ; 71$ & 1100,81 & 1187,50 & 2,08 \\
\hline \multirow{7}{*}{ 1-Dez } & 0,2 & 4199,26 & $578,2 \theta$ & 35,46 & $ł ¥ \theta 2,56$ & 3096,70 & 3,81 \\
\hline & 0,3 & 3769,44 & 556,18 & 34,11 & 1101,21 & 2668,23 & 3,42 \\
\hline & $0 ; 4$ & 3430,65 & 518,58 & 31,80 & 1098,90 & 2331,75 & 3,12 \\
\hline & 0,5 & 3098,88 & 498,05 & 30,54 & 1097,65 & 2001,23 & 2,82 \\
\hline & $0 ; 6$ & 2824,13 & 481,50 & 29,53 & 1096,63 & 1727,50 & 2,58 \\
\hline & 0,7 & 2615,81 & 468,03 & 28,70 & 1095,80 & 1520,00 & 2,39 \\
\hline & $\theta, 8$ & 2387,26 & 434,61 & 26,65 & 1093,76 & 1293,50 & 2,18 \\
\hline \multirow{7}{*}{ 15-Dez } & 0,2 & 4221,04 & 513,75 & 31,50 & 1098,61 & 3122,43 & 3,84 \\
\hline & 0,3 & 3759,49 & 474,06 & 29,07 & 1096,17 & 2663,31 & 3,43 \\
\hline & 0,4 & 3460,66 & 451,14 & 27,66 & 1094,77 & 2365,89 & 3,16 \\
\hline & 0,5 & 3153,58 & 413,76 & 25,37 & 1092,48 & 2061,11 & 2,89 \\
\hline & 0,6 & 2875,15 & 384,93 & 23,60 & 1090,71 & 1784,44 & 2,64 \\
\hline & 0,7 & 2670,28 & 358,01 & 21,95 & 1089,06 & 1581,22 & 2,45 \\
\hline & 0,8 & 2488,14 & 345,41 & 21,18 & 1088,29 & 1399,86 & 2,29 \\
\hline
\end{tabular}

'RB - receita bruta; $E b$ - energia requerida pard $\sigma$ bombeantento, CE - custo de energia elétrica; CT - custo total de produção; RL - receita líquida e B/C - relação benefício/custo. 
Tabela 27B. Receitas brutas, composição de custos da irrigação, receitas líquidas e relação benefício/custo para a melancia, em cada época de semeadura, nível de manejo da irrigação e risco de $20 \%$. Teresina, Piauí.

\begin{tabular}{|c|c|c|c|c|c|c|c|}
\hline $\begin{array}{l}\text { Época de } \\
\text { Semeadura }\end{array}$ & $\mathrm{p}$ & $\begin{array}{c}\mathrm{RB} \\
\left(\mathrm{US} \$ \mathrm{ha}^{-1}\right)\end{array}$ & $\begin{array}{c}E b \\
\left(k W h h^{-1}\right)\end{array}$ & $\begin{array}{c}\text { CE } \\
\left(\mathrm{US} \$ \mathrm{ha}^{-1}\right)\end{array}$ & $\begin{array}{c}\text { CT } \\
\left(\mathrm{US} \$ \mathrm{ha}^{-1}\right)\end{array}$ & $\begin{array}{c}\mathrm{RL} \\
\left(\mathrm{US} \$ \mathrm{ha}^{-1}\right)\end{array}$ & $\mathrm{B} / \mathrm{C}$ \\
\hline \multirow{7}{*}{ 1-Jan } & 0,2 & 4591,79 & 427,43 & 25,84 & 1092,95 & 3498,84 & 4,20 \\
\hline & 0,3 & 4158,09 & 390,56 & 23,61 & 1090,72 & 3067,37 & 3,81 \\
\hline & 0,4 & 3856,82 & 354,64 & 21,44 & 1088,55 & 2768,28 & 3,54 \\
\hline & 0,5 & 3564,21 & 314,34 & 19,00 & 1086,11 & 2478,10 & 3,28 \\
\hline & 0,6 & 3332,22 & 285,05 & 17,23 & 1084,34 & 2247,88 & 3,07 \\
\hline & 0,7 & 3142,34 & 258,89 & 15,65 & 1082,76 & 2059,58 & 2,90 \\
\hline & 0,8 & 2975,96 & 243,30 & 14,71 & 1081,81 & 1894,14 & 2,75 \\
\hline \multirow{7}{*}{ 15-Jan } & 0,2 & 4699,65 & 389,07 & 23,52 & 1090,63 & 3609,03 & 4,31 \\
\hline & 0,3 & 4286,16 & 344,09 & 20,80 & 1087,91 & 3198,25 & 3,94 \\
\hline & 0,4 & 4012,93 & 305,86 & 18,49 & 1085,60 & 2927,33 & 3,70 \\
\hline & 0,5 & 3757,50 & 279,41 & 16,89 & 1084,00 & 2673,50 & 3,47 \\
\hline & 0,6 & 3533,73 & 251,75 & 15,22 & 1082,32 & 2451,41 & 3,26 \\
\hline & 0,7 & 3330,92 & 219,24 & 13,25 & 1080,36 & 2250,56 & 3,08 \\
\hline & 0,8 & 3194,27 & 178,12 & 10,77 & 1077,87 & 2116,40 & 2,96 \\
\hline \multirow{7}{*}{$1-\mathrm{Fev}$} & 0,2 & 4933,51 & 331,48 & 20,19 & 1087,29 & 3846,22 & 4,54 \\
\hline & 0,3 & 4532,14 & 284,84 & 17,35 & 1084,45 & 3447,69 & 4,18 \\
\hline & 0,4 & 4265,45 & 246,36 & 15,00 & 1082,11 & 3183,34 & 3,94 \\
\hline & 0,5 & 4034,09 & 208,65 & 12,71 & 1079,81 & 2954,28 & 3,74 \\
\hline & 0,6 & 3825,46 & 183,63 & 11,18 & 1078,29 & 2747,17 & 3,55 \\
\hline & 0,7 & 3674,94 & 147,31 & 8,97 & 1076,08 & 2598,87 & 3,42 \\
\hline & 0,8 & 3560,34 & 139,59 & 8,50 & 1075,61 & 2484,73 & 3,31 \\
\hline \multirow{7}{*}{$15-\mathrm{Fev}$} & 0,2 & 4942,45 & 331,47 & 20,19 & 1087,29 & 3855,16 & 4,55 \\
\hline & 0,3 & 4534,88 & 276,01 & 16,81 & 1083,91 & 3450,97 & 4,18 \\
\hline & 0,4 & 4270,78 & 250,74 & 15,27 & 1082,38 & 3188,41 & 3,95 \\
\hline & 0,5 & 4038,07 & 202,70 & 12,34 & 1079,45 & 2958,62 & 3,74 \\
\hline & 0,6 & 3851,37 & 181,01 & 11,02 & 1078,13 & 2773,24 & 3,57 \\
\hline & 0,7 & 3702,41 & 158,08 & 9,63 & 1076,73 & 2625,68 & 3,44 \\
\hline & 0,8 & 3597,97 & 135,11 & 8,23 & 1075,33 & 2522,64 & 3,35 \\
\hline
\end{tabular}


Tabela 27B. Receitas brutas, composição de custos da irrigação, receitas líquidas e relação benefício/custo para a melancia, em cada época de semeadura, nível de manejo da irrigação e risco de $20 \%$. Teresina, Piauí

\begin{tabular}{|c|c|c|c|c|c|c|c|}
\hline $\begin{array}{l}\text { Época de } \\
\text { Semeadura }\end{array}$ & $p$ & $\begin{array}{c}R B \\
\left(\text { US } \$ h^{-1}{ }^{-1}\right)\end{array}$ & $\begin{array}{c}E b \\
\left(\mathrm{kWh} h \mathrm{~h}^{-1}\right)\end{array}$ & $\begin{array}{c}\text { CE } \\
\left(\mathrm{US} \$ h a^{-1}\right)\end{array}$ & $\begin{array}{c}\text { CT } \\
\left(\text { US } \$ \mathrm{ha}^{-1}\right) \\
\end{array}$ & $\begin{array}{c}\mathrm{RL} \\
\left(\mathrm{US} \$ \mathrm{ha}^{-1}\right) \\
\end{array}$ & $\mathrm{B} / \mathrm{C}$ \\
\hline \multirow{7}{*}{ 1-Mar } & 0,2 & 4938,00 & 322,04 & 19,50 & 1086,60 & 3851,40 & 4,54 \\
\hline & 0,3 & 4522,62 & 271,12 & 16,41 & 1083,52 & 3439,10 & 4,17 \\
\hline & 0,4 & 4243,17 & 223,47 & 13,53 & 1080,63 & 3162,54 & 3,93 \\
\hline & 0,5 & 4044,37 & 200,69 & 12,15 & 1079,25 & 2965,11 & 3,75 \\
\hline & 0,6 & 3846,72 & 174,52 & 10,57 & 1077,67 & 2769,05 & 3,57 \\
\hline & 0,7 & 3654,45 & 142,46 & 8,62 & 1075,73 & 2578,72 & 3,40 \\
\hline & 0,8 & 3530,53 & 82,77 & $5 ; 01$ & 1072,12 & 2458,42 & 3,29 \\
\hline \multirow{7}{*}{ 15-Mar } & 0,2 & 4883,19 & 372,93 & 22,58 & 1089,68 & 3793,51 & 4,48 \\
\hline & 0,3 & 4435,42 & 329,59 & 19,95 & 1087,06 & 3348,36 & 4,08 \\
\hline & 0,4 & 4099,84 & 300,32 & 18,18 & 1085,29 & 3014,55 & 3,78 \\
\hline & 0,5 & 3860,58 & 267,20 & 16,18 & 1083,28 & 2777,30 & 3,56 \\
\hline & 0,6 & 3617,74 & 233,19 & 14,12 & 1081,22 & 2536,52 & 3,35 \\
\hline & 0,7 & 3416,07 & 203,74 & 12,33 & 1079,44 & 2336,63 & 3,16 \\
\hline & 0,8 & 3247,56 & 185,63 & 11,24 & 1078,34 & 2169,22 & 3,01 \\
\hline \multirow{7}{*}{$1-\mathrm{Abr}$} & 0,2 & 4700,91 & $440,0 \mathrm{I}$ & 25,34 & 1092,44 & 3608,46 & 4,30 \\
\hline & 0,3 & 4209,71 & 406,21 & 23,39 & 1090,50 & 3119,21 & 3,86 \\
\hline & 0,4 & 3848,01 & 377,77 & 21,76 & 1088,86 & 2759,15 & 3,53 \\
\hline & 0,5 & 3575,79 & 358,32 & 20,64 & 1087,74 & 2488,04 & 3,29 \\
\hline & 0,6 & 3313,23 & 332,79 & 19,17 & 1086,27 & 2226,96 & 3,05 \\
\hline & 0,7 & 3084,34 & 313,60 & 18,06 & 1085,17 & 1999,18 & 2,84 \\
\hline & 0,8 & 2882,78 & 286,59 & 16,50 & 1083,61 & 1799,17 & 2,66 \\
\hline \multirow{7}{*}{ 15-Abr } & 0,2 & 4647,95 & 517,47 & 29,80 & 1096,91 & 3551,04 & 4,24 \\
\hline & 0,3 & 4100,88 & 494,60 & 28,48 & 1095,59 & 3005,29 & 3,74 \\
\hline & 0,4 & 3687,04 & 462,80 & 26,65 & 1093,76 & 2593,28 & 3,37 \\
\hline & 0,5 & 3381,54 & 447,60 & 25,78 & 1092,88 & 2288,66 & 3,09 \\
\hline & 0,6 & 3088,33 & 420,40 & 24,21 & 1091,32 & 1997,02 & 2,83 \\
\hline & 0,7 & 2819,82 & 408,68 & 23,54 & 1090,64 & 1729,18 & 2,59 \\
\hline & 0,8 & 2586,73 & 393,47 & 22,66 & 1089,76 & 1496,96 & 2,37 \\
\hline
\end{tabular}


Tabela 27B. Receitas brutas, composição de custos da irrigação, receitas líquidas e relação benefício/custo para a melancia, em cada época de semeadura, nível de manejo da irrigação e risco de $20 \%$. Teresina, Piauí.

\begin{tabular}{|c|c|c|c|c|c|c|c|}
\hline $\begin{array}{l}\text { Época de } \\
\text { Semeadura }\end{array}$ & $\mathrm{p}$ & $\begin{array}{c}\mathrm{RB} \\
\left(\mathrm{US} \$ \mathrm{ha}^{-1}\right)\end{array}$ & $\begin{array}{c}E b \\
\left(\mathrm{kWh} \mathrm{ha}{ }^{-1}\right)\end{array}$ & $\begin{array}{c}\text { CE } \\
\left(\mathrm{US} \$ h a^{-1}\right)\end{array}$ & $\begin{array}{c}\text { CT } \\
\left(\mathrm{US} \$ \mathrm{ha}^{-1}\right) \\
\end{array}$ & $\begin{array}{c}\mathrm{RL} \\
\left(\mathrm{US} \$ \mathrm{ha}^{-1}\right)\end{array}$ & $\mathrm{B} / \mathrm{C}$ \\
\hline & 0,2 & 3701,34 & 578,63 & 32,64 & 1099,75 & 2601,59 & 3,37 \\
\hline & 0,3 & 3231,12 & 553,86 & 31,24 & 1098,35 & 2132,77 & 2,94 \\
\hline & 0,4 & 2889,46 & 535,28 & 30,20 & 1097,30 & 1792,16 & 2,63 \\
\hline \multirow[t]{7}{*}{ 1-Mai } & 0,5 & 2650,83 & 530,94 & 29,95 & 1097,06 & 1553,77 & 2,42 \\
\hline & 0,6 & 2378,21 & 515,74 & 29,09 & 1096,20 & 1282,01 & 2,17 \\
\hline & 0,7 & 2137,07 & 490,34 & 27,66 & 1094,77 & 1042,30 & 1,95 \\
\hline & 0,8 & 1940,93 & 490,06 & 27,65 & 1094,75 & 846,18 & 1,77 \\
\hline & 0,2 & 3704,23 & 633,84 & 35,76 & 1102,86 & 2601,37 & 3,36 \\
\hline & 0,3 & 3210,50 & 617,97 & 34,86 & 1101,97 & 2108,53 & 2,91 \\
\hline & 0,4 & 2880,77 & 614,91 & 34,69 & 1101,79 & 1778,97 & 2,61 \\
\hline \multirow[t]{7}{*}{ 15-Mai } & 0,5 & 2594,14 & 601,53 & 33,93 & 1101,04 & 1493,10 & 2,36 \\
\hline & 0,6 & 2304,06 & 587,02 & 33,11 & 1100,22 & 1203,84 & 2,09 \\
\hline & 0,7 & 2071,96 & 578,31 & 32,62 & 1099,73 & 972,23 & 1,88 \\
\hline & 0,8 & 1886,71 & 575,49 & 32,46 & 1099,57 & 787,14 & 1,72 \\
\hline & 0,2 & 3866,27 & 690,86 & 41,29 & 1108,40 & 2757,87 & 3,49 \\
\hline & 0,3 & 3385,25 & 683,95 & 40,88 & 1107,98 & 2277,27 & 3,06 \\
\hline & 0,4 & 3043,23 & 675,91 & 40,40 & 1107,50 & 1935,72 & 2,75 \\
\hline \multirow[t]{7}{*}{ 1-Jun } & 0,5 & 2710,52 & 672,40 & 40,19 & 1107,29 & 1603,23 & 2,45 \\
\hline & 0,6 & 2396,46 & 663,80 & 39,67 & 1106,78 & 1289,68 & 2,17 \\
\hline & 0,7 & 2166,23 & 663,19 & 39,64 & 1106,74 & 1059,49 & 1,96 \\
\hline & 0,8 & 1955,17 & 656,10 & 39,21 & 1106,32 & 848,85 & 1,77 \\
\hline & 0,2 & 3903,89 & 740,94 & 44,29 & 1111,39 & 2792,51 & 3,51 \\
\hline & 0,3 & 3445,00 & 734,26 & 43,89 & 1110,99 & 2334,01 & 3,10 \\
\hline & 0,4 & 3090,53 & 724,06 & 43,28 & 1110,38 & 1980,15 & 2,78 \\
\hline \multirow[t]{4}{*}{ 15-Jun } & 0,5 & 2727,14 & 726,64 & 43,43 & 1110,53 & 1616,61 & 2,46 \\
\hline & 0,6 & 2440,35 & 715,36 & 42,76 & 1109,86 & 1330,49 & 2,20 \\
\hline & 0,7 & 2200,64 & 723,30 & 43,23 & 1110,34 & 1090,30 & 1,98 \\
\hline & 0,8 & 1972,04 & 698,48 & 41,75 & 1108,85 & 863,19 & 1,78 \\
\hline
\end{tabular}


Tabela 27B. Receitas brutas, composição de custos da irrigação, receitas líquidas e relação benefício/custo para a melancia, em cada época de semeadura, nível de manejo da irrigação e risco de $20 \%$. Teresina, Piauí.

\begin{tabular}{|c|c|c|c|c|c|c|c|}
\hline $\begin{array}{l}\text { Época de } \\
\text { Semeadura }\end{array}$ & $p$ & $\begin{array}{c}\mathrm{RB} \\
\left(\mathrm{US} \$ \mathrm{ha}^{-1}\right)\end{array}$ & $\begin{array}{c}E b \\
\left(\mathrm{kWh} \mathrm{ha}{ }^{-1}\right)\end{array}$ & $\begin{array}{c}\text { CE } \\
\left(\text { US } \$ \mathrm{ha}^{-1}\right)\end{array}$ & $\begin{array}{c}\mathrm{CT} \\
\left(\mathrm{US} \$ \mathrm{ha}^{-1}\right)\end{array}$ & $\begin{array}{c}\mathrm{RL} \\
\left(\mathrm{US} \$ \mathrm{ha}^{-1}\right)\end{array}$ & $\mathrm{B} / \mathrm{C}$ \\
\hline \multirow{7}{*}{ 1-Jul } & 0,2 & 3287,84 & 803,25 & 49,40 & 1116,50 & 2171,34 & 2,94 \\
\hline & 0,3 & 2963,01 & 799,48 & 49,16 & 1116,27 & 1846,74 & 2,65 \\
\hline & 0,4 & 2619,66 & 791,63 & 48,68 & 1115,79 & 1503,87 & 2,35 \\
\hline & 0,5 & 2309,02 & 791,87 & 48,70 & 1115,80 & 1193,22 & 2,07 \\
\hline & 0,6 & 2092,19 & 786,36 & 48,36 & 1115,46 & 976,73 & 1,88 \\
\hline & 0,7 & 1853,63 & 778,12 & 47,85 & 1114,96 & 738,67 & 1,66 \\
\hline & $\theta, 8$ & 1673,05 & 764,47 & 47,01 & 1114,12 & 558,93 & 1,50 \\
\hline \multirow{7}{*}{ 15-Jul } & 0,2 & 3301,28 & 857,73 & 52,75 & 1119,85 & 2181,43 & 2,95 \\
\hline & 0,3 & 3027,62 & 852,39 & 52,42 & 1119,52 & 1908,10 & 2,70 \\
\hline & 0,4 & $2644 ; 40$ & 851,17 & 52,34 & 1119,45 & 1524,96 & 2,36 \\
\hline & 0,5 & 2370,27 & 846,74 & 52,07 & 1119,17 & 1251,10 & 2,12 \\
\hline & 0,6 & 2145,53 & 840,30 & 51,67 & 1118,78 & 1026,75 & 1,92 \\
\hline & 0,7 & 1881,24 & 834,33 & 51,31 & 1118,41 & 762,83 & 1,68 \\
\hline & 0,8 & 1721,19 & 847,94 & 52,14 & 1119,25 & 601,94 & 1,54 \\
\hline \multirow{7}{*}{ 1-Ago } & 0,2 & 3882,94 & 896,99 & 55,50 & 1122,61 & 2760,33 & 3,46 \\
\hline & 0,3 & 3619,40 & 891,95 & 55,19 & 1122,29 & 2497,10 & 3,22 \\
\hline & 0,4 & 3136,50 & 888,63 & 54,98 & 1122,09 & 2014,42 & 2,80 \\
\hline & 0,5 & 2860,70 & 883,02 & 54,64 & 1121,74 & 1738,96 & 2,55 \\
\hline & 0,6 & 2519,66 & 884,26 & 54,71 & 1121,82 & 1397,84 & 2,25 \\
\hline & 0,7 & 2281,78 & 872,17 & 53,96 & 1121,07 & 1160,71 & 2,04 \\
\hline & 0,8 & 2055,96 & 846,01 & 52,35 & 1119,45 & 936,51 & 1,84 \\
\hline \multirow{7}{*}{ 15-Ago } & 0,2 & 3903,17 & 919,93 & 56,92 & 1124,02 & 2779,15 & 3,47 \\
\hline & 0,3 & 3655,94 & 916,50 & 56,71 & 1123,81 & 2532,13 & 3,25 \\
\hline & 0,4 & 3163,27 & 910,25 & 56,32 & 1123,43 & 2039,84 & 2,82 \\
\hline & 0,5 & 2912,19 & 905,97 & 56,06 & 1123,16 & 1789,03 & 2,59 \\
\hline & 0,6 & 2542,88 & 903,82 & 55,92 & 1123,03 & 1419,85 & 2,26 \\
\hline & 0,7 & 2326,80 & 900,68 & 55,73 & 1122,83 & 1203,96 & 2,07 \\
\hline & 0,8 & 2043,39 & 859,70 & 53,19 & 1120,30 & 923,09 & 1,82 \\
\hline
\end{tabular}


Tabela 27B. Receitas brutas, composição de custos da irrigação, receitas líquidas e relação benefício/custo para a melancia, em cada época de semeadura, nível de manejo da irrigação e risco de $20 \%$. Teresina, Piauí.

\begin{tabular}{|c|c|c|c|c|c|c|c|}
\hline $\begin{array}{c}\text { Época de } \\
\text { Semeadura }\end{array}$ & $\mathrm{p}$ & $\begin{array}{c}\mathrm{RB} \\
\left(\mathrm{US} \$ \mathrm{ha}^{-1}\right)\end{array}$ & $\begin{array}{c}E b \\
\left(\mathrm{kWh} \mathrm{ha}^{-1}\right)\end{array}$ & $\begin{array}{c}\text { CE } \\
\left(\mathrm{US} \$ \mathrm{ha}^{-1}\right) \\
\end{array}$ & $\begin{array}{c}\text { CT } \\
\left(\mathrm{US} \$ \mathrm{ha}^{-1}\right) \\
\end{array}$ & $\begin{array}{c}\text { RL } \\
\left(\mathrm{US} \$ h \mathrm{~h}^{-1}\right)\end{array}$ & $\mathrm{B} / \mathrm{C}$ \\
\hline \multirow{7}{*}{ 1-Set } & 0,2 & 3695,76 & 914,91 & 54,66 & 1121,77 & 2573,99 & 3,29 \\
\hline & 0,3 & 3457,58 & 908,24 & 54,26 & 1121,37 & 2336,21 & 3,08 \\
\hline & 0,4 & 3001,02 & 904,03 & 54,01 & 1121,12 & 1879,90 & 2,68 \\
\hline & 0,5 & 2762,23 & 895,24 & 53,49 & 1120,59 & 1641,64 & 2,46 \\
\hline & 0,6 & 2423,52 & 889,80 & 53,16 & 1120,27 & 1303,25 & 2,16 \\
\hline & 0,7 & 2208,94 & 882,91 & 52,75 & 1119,85 & 1089,08 & 1,97 \\
\hline & 0,8 & 1960,14 & 877,58 & 52,43 & 1119,54 & 840,61 & 1,75 \\
\hline \multirow{7}{*}{ 15-Set } & 0,2 & 3688,99 & 899,95 & 53,77 & 1120,87 & 2568,11 & 3,29 \\
\hline & 0,3 & 3441,42 & 891,76 & 53,28 & 1120,38 & 2321,04 & 3,07 \\
\hline & 0,4 & 2994,00 & 881,83 & 52,69 & 1119,79 & 1874,21 & 2,67 \\
\hline & 0,5 & 2756,40 & 875,68 & 52,32 & 1119,42 & 1636,98 & 2,46 \\
\hline & 0,6 & 2424,39 & 875,52 & 52,31 & 1119,41 & 1304,98 & 2,17 \\
\hline & 0,7 & 2214,02 & 867,28 & 51,82 & 1118,92 & 1095,10 & 1,98 \\
\hline & 0,8 & 1966,54 & 844,36 & 50,45 & 1117,55 & 848,99 & 1,76 \\
\hline \multirow{7}{*}{ 1-Out } & 0,2 & 3766,79 & 870,42 & 52,96 & 1120,06 & 2646,73 & 3,36 \\
\hline & 0,3 & 3501,48 & 864,55 & 52,60 & 1119,71 & 2381,78 & 3,13 \\
\hline & 0,4 & 3052,18 & 855,55 & 52,05 & 1119,16 & 1933,03 & 2,73 \\
\hline & 0,5 & 2785,54 & 850,82 & 51,77 & 1118,87 & 1666,67 & 2,49 \\
\hline & 0,6 & 2465,31 & 843,88 & 51,34 & 1118,45 & 1346,86 & 2,20 \\
\hline & 0,7 & 2241,13 & 831,63 & 50,60 & 1117,70 & 1123,42 & 2,01 \\
\hline & 0,8 & 1999,14 & 825,66 & 50,24 & 1117,34 & 881,80 & 1,79 \\
\hline \multirow{7}{*}{ 15-Out } & 0,2 & 3760,36 & 825,29 & 50,21 & 1117,32 & 2643,04 & 3,37 \\
\hline & 0,3 & 3463,19 & 814,71 & 49,57 & 1116,67 & 2346,51 & 3,10 \\
\hline & 0,4 & 3036,08 & 810,14 & 49,29 & 1116,40 & 1919,68 & 2,72 \\
\hline & 0,5 & 2746,54 & 792,46 & 48,22 & 1115,32 & 1631,22 & 2,46 \\
\hline & 0,6 & 2462,86 & 787,41 & 47,91 & 1115,01 & 1347,85 & 2,21 \\
\hline & 0,7 & 2223,00 & 774,33 & 47,11 & 1114,22 & 1108,78 & 2,00 \\
\hline & 0,8 & 2029,58 & 771,72 & 46,95 & 1114,06 & 915,52 & 1,82 \\
\hline
\end{tabular}


Tabela 27B. Receitas brutas, composição de custos da irrigação, receitas líquidas e relação benefício/custo para a melancia, em cada época de semeadura, nível de manejo da irrigação e risco de $20 \%$. Teresina, Piauí.

\begin{tabular}{|c|c|c|c|c|c|c|c|}
\hline $\begin{array}{l}\text { Época de } \\
\text { Semeadura }\end{array}$ & $\mathrm{p}$ & $\begin{array}{c}\mathrm{RB} \\
\left(\mathrm{US} \$ \mathrm{ha}^{-1} \text { ) }\right.\end{array}$ & $\begin{array}{c}E b \\
\left(\mathrm{kWh} \mathrm{ha}^{-1}\right)\end{array}$ & $\begin{array}{c}\text { CE } \\
\left(\mathrm{US} \$ \mathrm{ha}^{-1}\right)\end{array}$ & $\begin{array}{c}C T \\
\left(U S \$ h^{-1}\right)\end{array}$ & $\begin{array}{c}\mathrm{RL} \\
\left(\mathrm{US} \$ \mathrm{ha}^{-1}\right)\end{array}$ & $\mathrm{B} / \mathrm{C}$ \\
\hline \multirow{7}{*}{ 1-Nov } & 0,2 & 4163,48 & 727,73 & 44,54 & 1111,64 & 3051,84 & 3,75 \\
\hline & 0,3 & 3777,07 & 711,62 & 43,55 & 1110,65 & 2666,41 & 3,40 \\
\hline & 0,4 & 3378,58 & 699,27 & 42,79 & 1109,90 & 2268,68 & 3,04 \\
\hline & 0,5 & 3034,62 & 680,58 & 41,65 & 1108,75 & 1925,86 & 2,74 \\
\hline & 0,6 & 2735,35 & 668,70 & 40,92 & 1108,03 & 1627,32 & 2,47 \\
\hline & 0,7 & 2480,70 & 650,36 & 39,80 & 1106,91 & 1373,79 & 2,24 \\
\hline & 0,8 & 2240,16 & 637,48 & 39,01 & 1106,12 & 1134,04 & 2,03 \\
\hline \multirow{7}{*}{ 15-Nov } & 0,2 & 4160,26 & 642,80 & 39,34 & 1106,44 & 3053,81 & 3,76 \\
\hline & 0,3 & 3741,99 & 616,64 & 37,74 & 1104,84 & 2637,14 & 3,39 \\
\hline & 0,4 & 3387,37 & 586,89 & 35,92 & 1103,02 & 2284,35 & 3,07 \\
\hline & 0,5 & 3062,82 & 575,64 & 35,23 & 1102,33 & 1960,48 & 2,78 \\
\hline & 0,6 & 2776,57 & 553,61 & 33,88 & 1100,98 & 1675,59 & 2,52 \\
\hline & 0,7 & 2522,43 & 531,07 & 32,50 & 1099,61 & 1422,82 & 2,29 \\
\hline & 0,8 & 2335,02 & 522,31 & 31,96 & 1099,07 & 1235,95 & 2,12 \\
\hline \multirow{7}{*}{ 1-Dez } & 0,2 & 4285,92 & 567,58 & 34,24 & 1101,35 & 3184,57 & 3,89 \\
\hline & 0,3 & 3852,92 & 543,08 & 32,77 & 1099,87 & 2753,05 & 3,50 \\
\hline & 0,4 & 3511,66 & 505,10 & 30,47 & 1097,58 & 2414,08 & 3,20 \\
\hline & 0,5 & 3179,16 & 482,99 & 29,14 & 1096,24 & 2082,91 & 2,90 \\
\hline & 0,6 & 2903,77 & 464,79 & 28,04 & 1095,15 & 1808,62 & 2,65 \\
\hline & 0,7 & 2693,51 & 449,18 & 27,10 & 1094,21 & 1599,30 & 2,46 \\
\hline & 0,8 & 2464,77 & 414,11 & 24,98 & 1092,09 & 1372,68 & 2,26 \\
\hline \multirow{7}{*}{ 15-Dez } & 0,2 & 4308,27 & 501,93 & 30,28 & 1097,39 & 3210,88 & 3,93 \\
\hline & 0,3 & 3846,69 & 460,76 & 27,80 & 1094,90 & $275 \mathrm{l}, 78$ & 3,51 \\
\hline & 0,4 & 3547,22 & 436,75 & 26,35 & 1093,46 & 2453,76 & 3,24 \\
\hline & 0,5 & 3238,72 & 398,82 & 24,06 & $1091,1, \ldots$ & 2147,56 & 2,97 \\
\hline & 0,6 & 2964,12 & 368,26 & 22,22 & $1089,32 \ldots$ & 1874,80 & 2,72 \\
\hline & 0,7 & 2759,73 & $341 ; 46$ & 20,60 & $1087,71 \ldots$ & 1672,03 & 2,54 \\
\hline & 0,8 & 2578,10 & 325,94 & 19,66 & 1086,77 & 1491,33 & 2,37 \\
\hline
\end{tabular}


Tabela 28B. Receitas brutas, composição de custos da irrigação, receitas líquidas e relação benefício/custo para a melancia, em cada época de semeadura, nível de manejo da irrigação e risco de $25 \%$. Teresina, Piaui.

\begin{tabular}{|c|c|c|c|c|c|c|c|}
\hline $\begin{array}{l}\text { Época de } \\
\text { Semeadura }\end{array}$ & $\mathrm{p}$ & $\begin{array}{c}\mathrm{RB}^{\mathrm{l}} \\
\left(\mathrm{US} \$ \mathrm{ha}^{-1}\right)\end{array}$ & $\begin{array}{c}\mathrm{Eb} \\
\left(\mathrm{kWh} \mathrm{ha}^{-1}\right)\end{array}$ & $\begin{array}{c}\text { CE } \\
\left(\mathrm{US} \$ \mathrm{ha}^{-1}\right)\end{array}$ & $\begin{array}{c}\mathrm{CT} \\
\left(\mathrm{US} \$ \mathrm{ha}^{-1}\right)\end{array}$ & $\begin{array}{c}\mathrm{RL} \\
\left(\mathrm{US} \$ \mathrm{ha}^{-1}\right)\end{array}$ & $\mathrm{B} / \mathrm{C}$ \\
\hline \multirow{7}{*}{ 1-Jan } & 0,2 & 4636,32 & 417,13 & 24,76 & 1091,87 & 3544,45 & 4,25 \\
\hline & 0,3 & 4206,65 & 378,97 & 22,50 & 1089,60 & 3117,05 & 3,86 \\
\hline & 0,4 & 3909,69 & 341,75 & 20,29 & 1087,39 & 2822,30 & 3,60 \\
\hline & 0,5 & 3619,67 & 300,79 & 17,86 & 1084,96 & 2534,71 & 3,34 \\
\hline & 0,6 & 3391,25 & 270,34 & 16,05 & 1083,15 & 2308,09 & 3,13 \\
\hline & 0,7 & 3207,44 & 244,32 & 14,50 & 1081,61 & 2125,83 & 2,97 \\
\hline & 0,8 & 3045,25 & 227,80 & 13,52 & 1080,63 & 1964,62 & 2,82 \\
\hline \multirow{7}{*}{ 15-Jan } & 0,2 & 4746,36 & 378,70 & 22,48 & 1089,59 & 3656,78 & 4,36 \\
\hline & 0,3 & 4335,43 & 331,89 & 19,70 & 1086,81 & 3248,62 & 3,99 \\
\hline & 0,4 & 4065,65 & 293,47 & 17,42 & 1084,53 & 2981,12 & 3,75 \\
\hline & 0,5 & 3813,66 & 265,02 & 15,73 & 1082,84 & 2730,83 & 3,52 \\
\hline & 0,6 & 3595,37 & 236,53 & 14,04 & 1081,15 & 2514,22 & 3,33 \\
\hline & 0,7 & 3401,85 & 204,92 & 12,17 & 1079,27 & 2322,58 & 3,15 \\
\hline & 0,8 & 3268,53 & 178,12 & 10,57 & 1077,68 & 2190,85 & 3,03 \\
\hline \multirow{7}{*}{$1-\mathrm{Fev}$} & 0,2 & 4964,69 & 322,24 & 19,13 & 1086,24 & 3878,46 & 4,57 \\
\hline & 0,3 & 4567,22 & 273,94 & 16,26 & 1083,37 & 3483,85 & 4,22 \\
\hline & 0,4 & 4308,58 & 235,50 & 13,98 & 1081,09 & 3227,50 & 3,99 \\
\hline & 0,5 & 4081,75 & 197,63 & 11,73 & 1078,84 & 3002,91 & 3,78 \\
\hline & 0,6 & 3880,30 & 172,28 & 10,23 & 1077,33 & 2802,97 & 3,60 \\
\hline & 0,7 & 3734,71 & 136,36 & 8,10 & 1075,20 & 2659,51 & 3,47 \\
\hline & 0,8 & 3623,89 & 108,57 & 6,45 & 1073,55 & 2550,34 & 3,38 \\
\hline \multirow{7}{*}{ 15-Fev } & 0,2 & 4974,43 & 319,36 & 18,96 & 1086,07 & 3888,36 & 4,58 \\
\hline & 0,3 & 4574,98 & 263,96 & 15,67 & 1082,78 & 3492,20 & 4,23 \\
\hline & 0,4 & 4317,38 & 236,94 & 14,07 & 1081,17 & 3236,21 & 3,99 \\
\hline & 0,5 & 4090,45 & 189,94 & 11,28 & 1078,38 & 3012,07 & 3,79 \\
\hline & 0,6 & 3911,05 & 167,27 & 9,93 & 1077,04 & 2834,01 & 3,63 \\
\hline & 0,7 & 3770,29 & 144,90 & 8,60 & 1075,71 & 2694,58 & 3,50 \\
\hline & 0,8 & 3671,11 & 96,51 & 5,73 & 1072,83 & 2598,28 & 3,42 \\
\hline
\end{tabular}


Tabela 28B. Receitas brutas, composição de custos da irrigação, receitas líquidas e relação benefício/custo para a melancia, em cada época de semeadura, nivel de manejo da irrigação e risco de $25 \%$. Teresina, Piauí.

\begin{tabular}{|c|c|c|c|c|c|c|c|}
\hline $\begin{array}{l}\text { Época de } \\
\text { Semeadura }\end{array}$ & $\mathrm{p}$ & $\begin{array}{c}\mathrm{RB}^{1} \\
\left(\mathrm{US} \$ \mathrm{ha}^{-1}\right)\end{array}$ & $\begin{array}{c}E b \\
\left(\mathrm{kWh} h \mathrm{a}^{-1}\right)\end{array}$ & $\begin{array}{c}\text { CE } \\
\left(\mathrm{US} \$ \mathrm{ha}^{-1}\right)\end{array}$ & $\begin{array}{c}C T \\
\left(\mathrm{US} \$ h a^{-1}\right)\end{array}$ & $\begin{array}{c}\mathrm{RL} \\
\left(\mathrm{US} \$ \mathrm{ha}^{-1}\right)\end{array}$ & $\mathrm{B} / \mathrm{C}$ \\
\hline \multirow{7}{*}{ 1-Mar } & 0,2 & 4989,18 & 311,79 & 18,37 & 1085,48 & 3903,70 & 4,60 \\
\hline & 0,3 & 4580,34 & 260,17 & 15,33 & 1082,44 & 3497,90 & 4,23 \\
\hline & 0,4 & 4304,91 & 212,21 & 12,51 & 1079,61 & 3225,30 & 3,99 \\
\hline & 0,5 & 4110,19 & 188,69 & 11,12 & 1078,22 & 3031,97 & 3,81 \\
\hline & 0,6 & 3920,09 & 162,62 & 9,58 & 1076,69 & 2843,41 & 3,64 \\
\hline & 0,7 & 3736,96 & 131,25 & 7,73 & 1074,84 & 2662,13 & 3,48 \\
\hline & 0,8 & $3618 ; 93$ & 82,77 & 4,88 & 1071,98 & 2546,95 & 3,38 \\
\hline \multirow{7}{*}{ 15-Mar } & 0,2 & 4932,46 & 362,43 & 21,36 & 1088,46 & 3844,00 & 4,53 \\
\hline & 0,3 & 4487,53 & 317,35 & 18,70 & 1085,81 & 3401,73 & 4,13 \\
\hline & 0,4 & 4157,74 & 286,34 & 16,87 & 1083,98 & 3073,76 & 3,84 \\
\hline & 0,5 & 3924,18 & 254,07 & 14,97 & 1082,08 & 2842,11 & 3,63 \\
\hline & 0,6 & 3687,45 & 219,62 & 12,94 & 1080,05 & 2607,40 & 3,41 \\
\hline & 0,7 & 3491,80 & 190,40 & 11,22 & 1078,32 & 2413,47 & 3,24 \\
\hline & 0,8 & 3328,00 & 171,52 & 10,11 & 1077,21 & 2250,79 & 3,09 \\
\hline \multirow{7}{*}{$1-\mathrm{Abr}$} & 0,2 & 4752,05 & 429,79 & 24,09 & 1091,19 & 3660,85 & 4,35 \\
\hline & 0,3 & 4263,72 & 395,10 & 22,15 & 1089,25 & 3174,47 & 3,91 \\
\hline & 0,4 & 3906,86 & 365,39 & 20,48 & 1087,59 & 2819,27 & 3,59 \\
\hline & 0,5 & 3636,11 & 344,12 & 19,29 & 1086,39 & 2549,72 & 3,35 \\
\hline & 0,6 & 3376,13 & 317,88 & 17,82 & 1084,92 & 2291,20 & 3,11 \\
\hline & 0,7 & 3151,01 & 297,46 & 16,67 & 1083,78 & 2067,24 & 2,91 \\
\hline & 0,8 & 2955,02 & 270,27 & 15,15 & 1082,25 & 1872,77 & 2,73 \\
\hline \multirow{7}{*}{$15-\mathrm{Abr}$} & 0,2 & 4696,69 & 508,33 & 28,49 & 1095,60 & 3601,10 & 4,29 \\
\hline & 0,3 & 4151,06 & 483,89 & 27,12 & 1094,23 & 3056,83 & 3,79 \\
\hline & 0,4 & 3739,13 & 450,70 & 25,26 & 1092,37 & 2646,76 & 3,42 \\
\hline & 0,5 & 3436,16 & 434,01 & 24,33 & 1091,43 & 2344,72 & 3,15 \\
\hline & 0,6 & 3146,96 & 407,01 & 22,81 & 1089,92 & 2057,04 & 2,89 \\
\hline & 0,7 & 2879,86 & 394,44 & 22,11 & 1089,21 & 1790,65 & 2,64 \\
\hline & 0,8 & 2648,00 & 378,04 & 21,19 & 1088,29 & 1559,71 & 2,43 \\
\hline
\end{tabular}


Tabela 28B. Receitas brutas, composição de custos da irrigação, receitas líquidas e relação benefício/custo para a melancia, em cada época de semeadura, nível de manejo da irrigação e risco de $25 \%$. Teresina, Piauí.

\begin{tabular}{|c|c|c|c|c|c|c|c|}
\hline $\begin{array}{l}\text { Época de } \\
\text { Semeadura }\end{array}$ & $\mathrm{p}$ & $\begin{array}{c}\mathrm{RB}^{1} \\
\left(\mathrm{US} \$ \mathrm{ha}^{-1}\right)\end{array}$ & $\begin{array}{c}\mathrm{Eb} \\
\left(\mathrm{kWh} \mathrm{ha}^{-1}\right)\end{array}$ & $\begin{array}{c}\mathrm{CE} \\
\left(\mathrm{US} \$ \mathrm{ha}^{-1}\right)\end{array}$ & $\begin{array}{c}\text { CT } \\
\left(\mathrm{US} \$ \mathrm{ha}^{-1}\right)\end{array}$ & $\begin{array}{c}\mathrm{RL} \\
\left(\mathrm{US} \$ \mathrm{ha}^{-1}\right)\end{array}$ & $\mathrm{B} / \mathrm{C}$ \\
\hline \multirow{7}{*}{ 1-Mai } & 0,2 & 3732,48 & 569,74 & 31,48 & 1098,59 & 2633,89 & 3,40 \\
\hline & 0,3 & 3263,56 & 543,62 & 30,04 & 1097,14 & 2166,41 & 2,97 \\
\hline & 0,4 & 2923,68 & 523,79 & 28,94 & 1096,05 & 1827,63 & 2,67 \\
\hline & 0,5 & 2683,60 & 517,21 & 28,58 & 1095,68 & 1587,92 & 2,45 \\
\hline & 0,6 & 2414,49 & 501,45 & 27,71 & 1094,81 & 1319,68 & 2,21 \\
\hline & 0,7 & 2176,20 & 476,09 & 26,31 & 1093,41 & 1082,79 & 1,99 \\
\hline & 0,8 & 1980,13 & 472,98 & 26,14 & 1093,24 & 886,88 & 1,81 \\
\hline \multirow{7}{*}{ 15-Mai } & 0,2 & 3732,91 & 627,97 & 34,70 & 1101,81 & 2631,10 & 3,39 \\
\hline & 0,3 & 3239,07 & 610,38 & 33,73 & 1100,83 & 2138,24 & 2,94 \\
\hline & 0,4 & 2909,80 & 606,54 & 33,52 & 1100,62 & 1809,18 & 2,64 \\
\hline & 0,5 & 2622,54 & 592,15 & 32,72 & 1099,83 & 1522,72 & 2,38 \\
\hline & 0,6 & 2333,08 & 577,58 & 31,92 & 1099,02 & 1234,06 & 2,12 \\
\hline & 0,7 & 2101,24 & 567,48 & 31,36 & 1098,46 & 1002,78 & 1,91 \\
\hline & 0,8 & 1915,47 & 564,74 & 31,21 & 1098,31 & 817,15 & 1,74 \\
\hline \multirow{7}{*}{ 1-Jun } & 0,2 & 3909,88 & 685,61 & 40,14 & 1107,25 & 2802,63 & 3,53 \\
\hline & 0,3 & 3426,76 & 678,04 & 39,70 & 1106,81 & 2319,95 & 3,10 \\
\hline & 0,4 & 3083,28 & $669 ; 73$ & $39-21$ & 1106,32 & $1976 ; 96$ & 2,79 \\
\hline & 0,5 & 2746,39 & 665,63 & 38,97 & 1106,08 & 1640,31 & 2,48 \\
\hline & $\theta ; 6$ & 2431,70 & 655,72 & 38,39 & 1105,50 & $13-26,20$ & 2,20 \\
\hline & 0,7 & 2200,68 & 654,80 & 38,34 & 1105,45 & 1095,23 & 1,99 \\
\hline & 0,8 & $1986 ; 67$ & 647,01 & 37,88 & 1104,99 & 881,68 & 1,80 \\
\hline \multirow{7}{*}{ 15-Jun } & 0,2 & 3946,39 & 736,91 & 43,15 & 1110,25 & 2836,13 & 3,55 \\
\hline & 0,3 & 3486,62 & 729,18 & 42,70 & 1109,80 & 2376,82 & 3,14 \\
\hline & 0,4 & 3129,92 & 718,87 & 42,09 & 1109,20 & 2020,72 & 2,82 \\
\hline & 0,5 & 2762,41 & 720,66 & 42,20 & 1109,30 & 1653,11 & 2,49 \\
\hline & 0,6 & 2474,64 & 708,48 & 41,48 & 1108,59 & 1366,06 & 2,23 \\
\hline & 0,7 & 2230,85 & 715,03 & 41,87 & 1108,97 & 1121,88 & 2,01 \\
\hline & 0,8 & 2001,65 & 698,48 & 40,90 & 1108,00 & 893,64 & 1,81 \\
\hline
\end{tabular}


506

Tabela 28B. Receitas brutas, composição de custos da irrigação, receitas líquidas e relação beneficio/custo para a melancia, em cada época de semeadura, nível de manejo da irrigação e risco de $25 \%$. Teresina, Piauí.

\begin{tabular}{|c|c|c|c|c|c|c|c|}
\hline $\begin{array}{l}\text { Época de } \\
\text { Semeadura }\end{array}$ & $p$ & $\begin{array}{c}\mathrm{RB}^{1} \\
\left(\mathrm{US} \$ \mathrm{ha}^{-1}\right)\end{array}$ & $\begin{array}{c}E b \\
\left(\mathrm{kWh} h \mathrm{~h}^{-1}\right)\end{array}$ & $\begin{array}{c}\mathrm{CE} \\
\left(\mathrm{US} \$ \mathrm{ha}^{-1}\right)\end{array}$ & $\begin{array}{c}\mathrm{CT} \\
\left(\mathrm{US} \$ \mathrm{ha}^{-1}\right)\end{array}$ & $\begin{array}{c}\mathrm{RL} \\
\left(\mathrm{US} \$ \mathrm{ha}^{-1}\right)\end{array}$ & $\mathrm{B} / \mathrm{C}$ \\
\hline \multirow{7}{*}{ 1-Jul } & 0,2 & 3335,98 & 800,09 & 48,44 & 1115,55 & 2220,43 & 2,99 \\
\hline & 0,3 & 3010,73 & 796,01 & 48,20 & 1115,30 & 1895,42 & 2,70 \\
\hline & 0,4 & 2661,95 & 787,51 & 47,68 & 1114,79 & 1547,16 & 2,39 \\
\hline & 0,5 & 2347,40 & 786,82 & 47,64 & 1114,75 & 1232,65 & 2,11 \\
\hline & 0,6 & 2129,01 & 781,16 & 47,30 & 1114,40 & 1014,61 & 1,91 \\
\hline & 0,7 & 1886,57 & 772,00 & 46,74 & 1113,85 & 772,73 & 1,69 \\
\hline & 0,8 & 1703,14 & 764,47 & 46,29 & 1113,39 & 589,75 & 1,53 \\
\hline \multirow{7}{*}{ 15-Jul } & 0,2 & 3349,18 & 854,82 & 51,76 & 1118,86 & 2230,31 & 2,99 \\
\hline & 0,3 & 3076,27 & 848,83 & 51,40 & 1118,50 & 1957,77 & 2,75 \\
\hline & 0,4 & 2686,59 & 847,27 & 51,30 & 1118,41 & 1568,19 & 2,40 \\
\hline & 0,5 & 2410,77 & 841,94 & 50,98 & 1118,08 & 1292,68 & 2,16 \\
\hline & 0,6 & 2180,24 & 835,41 & 50,58 & 1117,69 & 1062,56 & 1,95 \\
\hline & 0,7 & 1914,94 & 834,33 & 50,52 & 1117,62 & 797,32 & 1,71 \\
\hline & 0,8 & 1753,39 & 841,05 & 50,92 & 1118,03 & 635,36 & 1,57 \\
\hline \multirow{7}{*}{ 1-Ago } & 0,2 & 3922,30 & 893,08 & 54,47 & I 121,58 & 2800,72 & 3,50 \\
\hline & 0,3 & 3658,89 & 887,71 & 54,15 & 1121,25 & 2537,64 & 3,26 \\
\hline & 0,4 & 3171,13 & 883,89 & 53,91 & 1121,02 & 2050,11 & 2,83 \\
\hline & 0,5 & 2895,28 & 877,05 & 53,50 & 1120,60 & 1774,68 & 2,58 \\
\hline & 0,6 & 2550,53 & 877,02 & 53,49 & 1120,60 & 1429,93 & 2,28 \\
\hline & 0,7 & 2312,56 & 865,42 & 52,79 & 1119,89 & 1192,66 & 2,06 \\
\hline & 0,8 & 2074,84 & 846,01 & 51,60 & 1118,71 & 956,13 & 1,85 \\
\hline \multirow{7}{*}{ 15-Ago } & 0,2 & 3943,34 & 915,95 & 55,87 & 1122,97 & 2820,37 & 3,51 \\
\hline & 0,3 & 3695,19 & 912,02 & 55,63 & 1122,73 & 2572,46 & 3,29 \\
\hline & 0,4 & 3198,51 & 905,24 & 55,22 & 1122,32 & 2076,19 & 2,85 \\
\hline & 0,5 & 2946,76 & 899,96 & 54,89 & 1122,00 & 1824,76 & 2,63 \\
\hline & 0,6 & 2574,56 & 897,54 & 54,75 & 1121,85 & 1452,70 & 2,29 \\
\hline & 0,7 & 2358,94 & 893,70 & 54,51 & 1121,62 & 1237,32 & 2,10 \\
\hline & 0,8 & 2072,98 & 859,70 & 52,44 & 1119,54 & 953,43 & 1,85 \\
\hline
\end{tabular}


Tabela 28B. Receitas brutas, composição de custos da irrigação, receitas líquidas e relação benefício/custo para a melancia, em cada época de semeadura, nível de manejo da irrigação e risco de $25 \%$. Teresina, Piauí.

\begin{tabular}{|c|c|c|c|c|c|c|c|}
\hline $\begin{array}{l}\text { Época de } \\
\text { Semeadura }\end{array}$ & $\mathrm{p}$ & $\begin{array}{c}\mathrm{RB}^{\mathrm{l}} \\
\left(\mathrm{US} \$ \mathrm{ha}^{-1}\right)\end{array}$ & $\begin{array}{c}\mathrm{Eb} \\
\left(\mathrm{kWh} \mathrm{ha} \mathrm{a}^{-1}\right)\end{array}$ & $\begin{array}{c}\text { CE } \\
\left(\mathrm{US} \$ \mathrm{ha}^{-1}\right)\end{array}$ & $\begin{array}{c}\text { CT } \\
\left(\mathrm{US} \$ \mathrm{ha}^{-1}\right)\end{array}$ & $\begin{array}{c}\mathrm{RL} \\
\left(\mathrm{US} \$ \mathrm{ha}^{-1}\right)\end{array}$ & $\mathrm{B} / \mathrm{C}$ \\
\hline \multirow{7}{*}{ 1-Set } & 0,2 & 3723,78 & 910,18 & 53,84 & 1120,94 & 2602,84 & 3,32 \\
\hline & 0,3 & 3484,86 & 902,80 & 53,40 & 1120,51 & 2364,35 & 3,11 \\
\hline & 0,4 & 3026,49 & 897,34 & 53,08 & 1120,18 & 1906,30 & 2,70 \\
\hline & 0,5 & 2787,46 & 887,93 & 52,52 & 1119,63 & 1667,83 & 2,49 \\
\hline & 0,6 & 2446,81 & 881,39 & 52,14 & 1119,24 & 1327,57 & 2,19 \\
\hline & 0,7 & 2233,40 & 874,28 & 51,72 & 1118,82 & 1114,58 & 2,00 \\
\hline & 0,8 & 1982,99 & 867,49 & 51,31 & 1118,42 & 864,57 & 1,77 \\
\hline \multirow{7}{*}{ 15-Set } & 0,2 & 3716,98 & 894,43 & 52,91 & 1120,01 & 2596,96 & 3,32 \\
\hline & 0,3 & 3469,10 & 885,34 & 52,37 & 1119,48 & 2349,62 & 3,10 \\
\hline & 0,4 & 3020,39 & 874,88 & 51,75 & 1118,86 & 1901,53 & 2,70 \\
\hline & 0,5 & 2782,81 & 867,71 & 51,33 & 1118,43 & 1664,38 & 2,49 \\
\hline & 0,6 & 2448,54 & 865,30 & 51,19 & 1118,29 & 1330,25 & 2,19 \\
\hline & 0,7 & 2239,71 & 857,74 & 50,74 & 1117,84 & 1121,86 & 2,00 \\
\hline & 0,8 & 1990,41 & 844,36 & 49,95 & 1117,05 & 873,36 & 1,78 \\
\hline \multirow{7}{*}{ 1-Out } & 0,2 & 3795,04 & 864,65 & 51,99 & 1119,10 & 2675,95 & 3,39 \\
\hline & 0,3 & 3530,00 & 857,76 & 51,58 & 1118,68 & 2411,31 & 3,16 \\
\hline & 0,4 & 3077,92 & 847,31 & 50,95 & 1118,05 & 1959,87 & 2,75 \\
\hline & 0,5 & 2812,60 & 841,68 & 50,61 & 1117,72 & 1694,89 & 2,52 \\
\hline & 0,6 & 2490,27 & 833,74 & 50,13 & 1117,24 & 1373,03 & 2,23 \\
\hline & 0,7 & 2265,46 & 821,65 & 49,41 & 1116,51 & 1148,95 & 2,03 \\
\hline & 0,8 & 2024,76 & 814,19 & 48,96 & 1116,06 & 908,70 & 1,81 \\
\hline \multirow{7}{*}{ 15-Out } & 0,2 & 3788,57 & 818,58 & 49,22 & 1116,33 & 2672,25 & 3,39 \\
\hline & 0,3 & 3491,94 & 807,24 & 48,54 & 1115,64 & 2376,30 & 3,13 \\
\hline & 0,4 & 3064,48 & 801,16 & 48,17 & 1115,28 & 1949,20 & 2,75 \\
\hline & 0,5 & 2775,25 & 782,91 & 47,08 & 1114,18 & 1661,07 & 2,49 \\
\hline & 0,6 & 2489,87 & 775,87 & 46,65 & 1113,76 & 1376,12 & 2,24 \\
\hline & 0,7 & 2248,45 & 761,24 & 45,77 & 1112,88 & 1135,57 & 2,02 \\
\hline & 0,8 & 2055,15 & 757,59 & 45,55 & 1112,66 & 942,50 & 1,85 \\
\hline
\end{tabular}


Tabela 28B. Receitas brutas, composição de custos da irrigação, receitas líquidas e relação benefício/custo para a melancia, em cada época de semeadura, nível de manejo da irrigação e risco de $25 \%$. Teresina, Piauí.

\begin{tabular}{|c|c|c|c|c|c|c|c|}
\hline $\begin{array}{l}\text { Época de } \\
\text { Semeadura }\end{array}$ & $p$ & $\begin{array}{c}\mathrm{RB}^{1} \\
\left(\mathrm{US} \$ \mathrm{ha}^{-1}\right)\end{array}$ & $\begin{array}{c}E b \\
\left(\mathrm{kWh} \mathrm{ha}^{-1}\right)\end{array}$ & $\begin{array}{c}\mathrm{CE} \\
\left(\mathrm{US} \$ \mathrm{ha}^{-1}\right)\end{array}$ & $\begin{array}{c}\mathrm{CT} \\
\left(\mathrm{US} \$ \mathrm{ha}^{-1}\right)\end{array}$ & $\begin{array}{c}\mathrm{RL} \\
\left(\mathrm{US} \$ \mathrm{ha}^{-1}\right)\end{array}$ & $\mathrm{B} / \mathrm{C}$ \\
\hline \multirow{7}{*}{$1-\mathrm{Nov}$} & 0,2 & 4196,17 & 718,91 & 43,47 & 1110,58 & 3085,59 & 3,78 \\
\hline & 0,3 & 3813,31 & 701,84 & 42,44 & 1109,55 & 2703,76 & 3,44 \\
\hline & 0,4 & 3412,17 & 687,74 & 41,59 & 1108,69 & 2303,48 & 3,08 \\
\hline & 0,5 & 3068,18 & 667,57 & 40,37 & 1107,47 & 1960,70 & 2,77 \\
\hline & 0,6 & 2771,20 & 654,11 & 39,55 & 1106,66 & 1664,54 & 2,50 \\
\hline & 0,7 & 2515,44 & 635,23 & 38,41 & 1105,52 & 1409,93 & 2,28 \\
\hline & 0,8 & 2278,89 & 620,81 & 37,54 & 1104,65 & 1174,24 & 2,06 \\
\hline \multirow{7}{*}{ 15-Nov } & 0,2 & 4194,86 & 632,77 & 38,26 & 1105,37 & 3089,50 & 3,79 \\
\hline & 0,3 & 3779,99 & 606,06 & 36,65 & 1103,75 & 2676,24 & 3,42 \\
\hline & 0,4 & 3425,25 & 575,10 & 34,78 & 1101,88 & 2323,37 & 3,11 \\
\hline & 0,5 & 3100,97 & 561,85 & 33,98 & 1101,08 & 1999,89 & 2,82 \\
\hline & 0,6 & 2817,66 & 538,26 & 32,55 & 1099,65 & 1718,00 & 2,56 \\
\hline & 0,7 & 2565,91 & 515,49 & 31,17 & 1098,28 & 1467,63 & 2,34 \\
\hline & 0,8 & 2377,92 & 503,90 & 30,47 & 1097,58 & 1280,35 & 2,17 \\
\hline \multirow{7}{*}{ 1-Dez } & 0,2 & 4373,88 & 558,47 & $33 ; 21$ & 1100,31 & 3273,57 & 3,98 \\
\hline & 0,3 & 3936,95 & 531,84 & 31,62 & 1098,73 & 2838,23 & 3,58 \\
\hline & 0,4 & 3592,64 & 493,54 & 29,35 & 1096,45 & 2496,19 & 3,28 \\
\hline & 0,5 & 3258,64 & 470,07 & 27,95 & 1095,06 & 2163,59 & 2,98 \\
\hline & 0,6 & 2981,98 & 450,44 & 26,78 & 1093,89 & 1888,09 & 2,73 \\
\hline & 0,7 & 2769,47 & 433,01 & 25,75 & 1092,85 & 1676,61 & 2,53 \\
\hline & 0,8 & 2539,98 & $396 ; 52$ & $23 ; 58$ & 1090,68 & 1449,30 & 2,33 \\
\hline \multirow{7}{*}{ 15-Dez } & 0,2 & 4396,81 & 491,80 & 29,24 & 1096,35 & 3300,46 & 4,01 \\
\hline & 0,3 & 3934,02 & 449,35 & 26,72 & 1093,82 & 2840,20 & 3,60 \\
\hline & 0,4 & 3633,23 & 424,40 & 25,24 & 1092,34 & 2540,89 & 3,33 \\
\hline & 0,5 & 3322,68 & 386,00 & 22,95 & 1090,06 & 2232,63 & 3,05 \\
\hline & 0,6 & 3050,80 & 353,96 & 21,05 & 1088,15 & 1962,64 & 2,80 \\
\hline & 0,7 & 2846,32 & 327,25 & 19,46 & 1086,56 & 1759,76 & 2,62 \\
\hline & 0,8 & 2664,68 & 309,24 & 18,39 & 1085,49 & 1579,18 & 2,45 \\
\hline
\end{tabular}

RB - receita bruta; $E b$ - energia requerida para o bombeamento; $C E$ - custo de energia elétrica; $C T$ - custo total de produção; $\mathrm{RL}$ - receita líquida e $\mathrm{B} / \mathrm{C}$ - relação beneficio/custo. 
Tabela 29B. Receitas brutas, composição de custos da irrigação, receitas líquidas e relação beneficio/custo para a melancia, em cada época de semeadura, nível de manejo da irrigação e risco de $30 \%$. Teresina, Piauí.

\begin{tabular}{|c|c|c|c|c|c|c|c|}
\hline $\begin{array}{c}\text { Época de } \\
\text { Semeadura }\end{array}$ & $\mathrm{p}$ & $\begin{array}{c}\mathrm{RB}^{\mathrm{l}} \\
\left(\mathrm{US} \$ \mathrm{ha}^{-1}\right)\end{array}$ & $\begin{array}{c}\mathrm{Eb} \\
\left(\mathrm{kWh} \mathrm{ha} \mathrm{a}^{-1}\right)\end{array}$ & $\begin{array}{c}\text { CE } \\
\left(\mathrm{US} \$ \mathrm{ha}^{-1}\right)\end{array}$ & $\begin{array}{c}\text { CT } \\
\left(\mathrm{US} \$ \mathrm{ha}^{-1}\right)\end{array}$ & $\begin{array}{c}\text { RL } \\
\left(\mathrm{US} \$ \mathrm{ha}^{-1}\right)\end{array}$ & $\mathrm{B} / \mathrm{C}$ \\
\hline \multirow{7}{*}{ 1-Jan } & 0,2 & 4681,08 & 407,87 & 23,81 & 1090,92 & 3590,17 & 4,29 \\
\hline & 0,3 & 4254,70 & 368,56 & 21,52 & 1088,62 & 3166,08 & 3,91 \\
\hline & 0,4 & 3961,41 & 330,17 & 19,28 & 1086,38 & 2875,03 & 3,65 \\
\hline & 0,5 & 3673,49 & 288,62 & 16,85 & 1083,95 & 2589,53 & 3,39 \\
\hline & 0,6 & 3448,11 & 257,14 & 15,01 & 1082,12 & 2365,99 & 3,19 \\
\hline & 0,7 & 3269,68 & 231,23 & 13,50 & 1080,60 & 2189,07 & 3,03 \\
\hline & 0,8 & 3111,16 & 213,89 & 12,49 & 1079,59 & 2031,57 & 2,88 \\
\hline \multirow{7}{*}{ 15-Jan } & 0,2 & 4793,21 & 369,38 & 21,57 & 1088,67 & 3704,54 & 4,40 \\
\hline & 0,3 & 4384,25 & 320,94 & 18,74 & 1085,84 & 3298,40 & 4,04 \\
\hline & 0,4 & 4117,36 & 282,34 & 16,48 & 1083,59 & 3033,77 & 3,80 \\
\hline & 0,5 & 3868,29 & 252,09 & 14,72 & 1081,82 & 2786,47 & 3,58 \\
\hline & 0,6 & 3654,79 & 222,87 & 13,01 & 1080,12 & 2574,67 & 3,38 \\
\hline & 0,7 & 3469,57 & 192,07 & 11,21 & 1078,32 & 2391,25 & 3,22 \\
\hline & 0,8 & 3339,17 & 178,12 & 10,40 & 1077,50 & 2261,67 & 3,10 \\
\hline \multirow{7}{*}{$1-F e v$} & 0,2 & 4995,11 & 313,95 & 18,21 & 1085,31 & 3909,80 & 4,60 \\
\hline & 0,3 & 4600,99 & 264,14 & 15,32 & 1082,42 & 3518,57 & 4,25 \\
\hline & 0,4 & 4349,52 & 225,74 & 13,09 & 1080,20 & 3269,32 & 4,03 \\
\hline & 0,5 & 4126,68 & 187,73 & 10,89 & 1077,99 & 3048,69 & 3,83 \\
\hline & 0,6 & 3931,64 & 162,10 & 9,40 & 1076,50 & 2855,13 & 3,65 \\
\hline & 0,7 & 3790,42 & 126,52 & 7,34 & 1074,44 & 2715,98 & 3,53 \\
\hline & 0,8 & 3682,98 & 108,57 & 6,30 & 1073,40 & 2609,58 & 3,43 \\
\hline \multirow{7}{*}{ 15-Fev } & 0,2 & 5005,57 & 308,48 & 17,89 & 1084,99 & 3920,57 & 4,61 \\
\hline & 0,3 & 4613,29 & 253,14 & 14,68 & 1081,78 & 3531,50 & 4,26 \\
\hline & 0,4 & 4361,45 & 224,55 & 13,02 & 1080,13 & 3281,32 & 4,04 \\
\hline & 0,5 & 4139,65 & 178,48 & 10,35 & 1077,45 & 3062,20 & 3,84 \\
\hline & 0,6 & 3966,76 & 154,93 & 8,98 & 1076,09 & 2890,67 & 3,69 \\
\hline & 0,7 & 3833,36 & 133,05 & 7,72 & 1074,82 & 2758,54 & 3,57 \\
\hline & 0,8 & 3738,90 & 96,51 & 5,60 & 1072,70 & 2666,20 & 3,49 \\
\hline
\end{tabular}


Tabela 29B. Receitas brutas, composição de custos da irrigação, receitas líquidas e relação benefício/custo para a melancia, em cada época de semeadura, nível de manejo da irrigação e risco de $30 \%$. Teresina, Piauí.

\begin{tabular}{|c|c|c|c|c|c|c|c|}
\hline $\begin{array}{l}\text { Época de } \\
\text { Semeadura }\end{array}$ & $\mathrm{p}$ & $\begin{array}{c}\mathrm{RB}^{1} \\
\left(\mathrm{US} \$ \mathrm{ha}^{-1}\right)\end{array}$ & $\begin{array}{c}E b \\
\left(\mathrm{kWh} \mathrm{ha}^{-1}\right)\end{array}$ & $\begin{array}{c}\mathrm{CE} \\
\left(\mathrm{US} \$ \mathrm{ha}^{-1}\right)\end{array}$ & $\begin{array}{c}\mathrm{CT} \\
\left(\mathrm{US} \$ \mathrm{ha}^{-1}\right)\end{array}$ & $\begin{array}{c}\mathrm{RL} \\
\left(\mathrm{US} \$ \mathrm{ha}^{-1}\right)\end{array}$ & $\mathrm{B} / \mathrm{C}$ \\
\hline \multirow{7}{*}{ 1-Mar } & 0,2 & 5040,27 & 302,58 & 17,37 & 1084,48 & 3955,79 & 4,65 \\
\hline & 0,3 & 4637,02 & 250,35 & 14,37 & 1081,48 & 3555,54 & 4,29 \\
\hline & 0,4 & $4365 ; 02$ & 202,10 & 11,60 & 1078,71 & 3286,31 & 4,05 \\
\hline & 0,5 & 4173,84 & 177,91 & 10,22 & 1077,32 & 3096,52 & 3,87 \\
\hline & $0 ; 6$ & 3990,46 & 151,94 & 8,72 & 1075,83 & 2914,63 & 3,71 \\
\hline & 0,7 & 3815,49 & 121,17 & 6,96 & 1074,06 & 2741,43 & 3,55 \\
\hline & 0,8 & 3702,73 & 82,77 & 4,75 & 1071,86 & 2630,87 & 3,45 \\
\hline \multirow{7}{*}{ 15-Mar } & 0,2 & 4981,76 & 353,00 & 20,27 & 1087,37 & 3894,38 & 4,58 \\
\hline & 0,3 & 4539,03 & 306,36 & 17,59 & 1084,70 & 3454,33 & 4,18 \\
\hline & 0,4 & 4214,22 & 273,78 & 15,72 & 1082,82 & 3131,39 & 3,89 \\
\hline & 0,5 & 3985,64 & 242,27 & 13,91 & 1081,02 & 2904,63 & 3,69 \\
\hline & 0,6 & 3754,27 & 207,44 & 11,91 & 1079,02 & 2675,25 & 3,48 \\
\hline & 0,7 & 3563,93 & 178,43 & 10,24 & 1077,35 & 2486,58 & 3,31 \\
\hline & 0,8 & 3404,28 & 158,86 & 9,12 & 1076,23 & 2328,05 & 3,16 \\
\hline \multirow{7}{*}{$1-\mathrm{Abr}$} & 0,2 & 4803,28 & $420,6 \mathrm{I}$ & 22,94 & 1090,05 & 3713,23 & 4,41 \\
\hline & 0,3 & 4317,11 & 385,13 & 21,01 & 1088,11 & 3229,00 & 3,97 \\
\hline & 0,4 & 3964,32 & 354,28 & 19,32 & $1086 ; 43$ & 2877,89 & 3,65 \\
\hline & 0,5 & 3694,66 & 331,37 & 18,08 & 1085,18 & 2609,48 & 3,40 \\
\hline & 0,6 & $3436 ; 77$ & 304,49 & 16,61 & 1083,71 & 2353,06 & 3,17 \\
\hline & 0,7 & 3214,89 & 282,96 & 15,43 & 1082,54 & 2132,35 & 2,97 \\
\hline & $\theta, 8$ & 3023,79 & $255 ; 62$ & 13,94 & 1081,05 & 1942,75 & 2,80 \\
\hline \multirow{7}{*}{ 15-Abr } & 0,2 & 4745,70 & 500,12 & 27,28 & 1094,38 & 3651,31 & 4,34 \\
\hline & 0,3 & 4200,85 & 474,28 & 25,87 & 1092,97 & 3107,87 & 3,84 \\
\hline & 0,4 & 3790,26 & 439,84 & 23,99 & 1091,10 & 2699,16 & 3,47 \\
\hline & 0,5 & 3489,30 & 421,81 & 23,01 & 1090,11 & 2399,19 & 3,20 \\
\hline & 0,6 & 3203,49 & 394,98 & 21,54 & 1088,65 & 2114,84 & 2,94 \\
\hline & 0,7 & 2937,42 & 381,65 & 20,82 & 1087,92 & 1849,50 & 2,70 \\
\hline & 0,8 & 2706,47 & 364,17 & 19,86 & 1086,97 & 1619,50 & 2,49 \\
\hline
\end{tabular}


Tabela 29B. Receitas brutas, composição de custos da irrigação, receitas líquidas e relação benefício/custo para a melancia, em cada época de semeadura, nível de manejo da irrigação e risco de $30 \%$. Teresina, Piauí.

\begin{tabular}{|c|c|c|c|c|c|c|c|}
\hline $\begin{array}{l}\text { Época de } \\
\text { Semeadura }\end{array}$ & $\mathrm{p}$ & $\begin{array}{c}\mathrm{RB}^{\mathrm{l}} \\
\left(\mathrm{US} \$ \mathrm{ha}^{-1}\right)\end{array}$ & $\begin{array}{c}E b \\
\left(\mathrm{kWh} h a^{-1}\right)\end{array}$ & $\begin{array}{c}C E \\
\left(U S \$ h a^{-1}\right)\end{array}$ & $\begin{array}{c}\mathrm{CT} \\
\left(\mathrm{US} \$ \mathrm{ha}^{-1}\right)\end{array}$ & $\begin{array}{c}\mathrm{RL} \\
\left(\mathrm{US} \$ \mathrm{ha}^{-1}\right)\end{array}$ & $\mathrm{B} / \mathrm{C}$ \\
\hline \multirow{7}{*}{ 1-Mai } & 0,2 & 3763,71 & 561,76 & 30,39 & 1097,50 & 2666,21 & 3,43 \\
\hline & 0,3 & 3295,61 & 534,43 & 28,91 & 1096,02 & 2199,59 & 3,01 \\
\hline & 0,4 & 2957,09 & 513,48 & 27,78 & 1094,88 & 1862,20 & 2,70 \\
\hline & 0,5 & 2715,50 & 504,89 & 27,32 & 1094,42 & 1621,08 & 2,48 \\
\hline & 0,6 & 2449,38 & 488,62 & 26,44 & 1093,54 & 1355,84 & 2,24 \\
\hline & 0,7 & 2213,49 & 463,29 & 25,06 & 1092,17 & 1121,32 & 2,03 \\
\hline & 0,8 & 2017,32 & 457,64 & 24,76 & 1091,86 & 925,46 & 1,85 \\
\hline \multirow{7}{*}{ 15-Mai } & 0,2 & 3761,91 & 622,70 & 33,69 & 1100,79 & 2661,11 & 3,42 \\
\hline & 0,3 & 3267,59 & 603,56 & 32,65 & 1099,76 & 2167,84 & 2,97 \\
\hline & 0,4 & 2938,48 & 599,03 & 32,41 & 1099,51 & 1838,96 & 2,67 \\
\hline & 0,5 & 2650,42 & 583,73 & 31,58 & 1098,69 & 1551,74 & 2,41 \\
\hline & 0,6 & 2361,30 & 569,11 & 30,79 & 1097,89 & 1263,40 & 2,15 \\
\hline & 0,7 & 2129,52 & 557,75 & 30,18 & 1097,28 & 1032,24 & 1,94 \\
\hline & 0,8 & 1943,12 & 555,08 & 30,03 & 1097,14 & 845,98 & 1,77 \\
\hline \multirow{7}{*}{ 1-Jun } & 0,2 & 3954,25 & 680,89 & 39,08 & 1106,19 & 2848,06 & 3,57 \\
\hline & 0,3 & 3468,65 & 672,73 & 38,61 & 1105,72 & 2362,93 & 3,14 \\
\hline & 0,4 & 3123,45 & 664,18 & 38,12 & 1105,23 & 2018,22 & 2,83 \\
\hline & 0,5 & 2782,34 & 659,54 & 37,86 & 1104,96 & 1677,38 & 2,52 \\
\hline & 0,6 & 2466,73 & 648,46 & 37,22 & 1104,32 & 1362,40 & 2,23 \\
\hline & 0,7 & 2234,71 & 647,27 & 37,15 & 1104,26 & 1130,46 & 2,02 \\
\hline & 0,8 & 2017,77 & 638,84 & 36,67 & 1103,77 & 914,00 & 1,83 \\
\hline \multirow{7}{*}{ 15-Jun } & 0,2 & 3989,76 & 733,29 & 42,09 & 1109,19 & 2880,57 & 3,60 \\
\hline & 0,3 & 3528,69 & 724,62 & 41,59 & 1108,69 & 2419,99 & 3,18 \\
\hline & 0,4 & 3169,53 & 714,21 & 40,99 & 1108,10 & 2061,43 & 2,86 \\
\hline & 0,5 & 2797,84 & 715,29 & 41,06 & 1108,16 & 1689,68 & 2,52 \\
\hline & 0,6 & 2508,85 & 702,30 & 40,31 & 1107,41 & 1401,44 & 2,27 \\
\hline & 0,7 & 2261,04 & 707,60 & 40,61 & 1107,72 & 1153,32 & 2,04 \\
\hline & 0,8 & 2031,02 & 698,48 & 40,09 & 1107,19 & 923,83 & 1,83 \\
\hline
\end{tabular}


Tabela 29B. Receitas brutas; composição de custos da irrigação, receitas líquidas e relação benefício/custo para a melancia, em cada época de semeadura, nivel de manejo da irrigação e risco de $30 \%$. Teresina, Piauí.

\begin{tabular}{|c|c|c|c|c|c|c|c|}
\hline $\begin{array}{l}\text { Época de } \\
\text { Semeadura }\end{array}$ & $\mathrm{p}$ & $\begin{array}{c}\mathrm{RB}^{\mathrm{l}} \\
\left(\mathrm{US} \$ \mathrm{ha}^{-1}\right)\end{array}$ & $\begin{array}{c}E b \\
\left(\mathrm{kWh} h \mathrm{~h}^{-1}\right)\end{array}$ & $\begin{array}{c}C E \\
\left(\mathrm{US} \$ \mathrm{ha}^{-1}\right)\end{array}$ & $\begin{array}{c}\text { CT } \\
\left(\mathrm{US} \$ \mathrm{ha}^{-1}\right)\end{array}$ & $\begin{array}{c}\mathrm{RL} \\
\left(\mathrm{US} \$ \mathrm{ha} \mathrm{a}^{-1}\right)\end{array}$ & $\mathrm{B} / \mathrm{C}$ \\
\hline \multirow{7}{*}{ 1-Jul } & 0,2 & 3379,56 & 797,26 & $47,5 T$ & III 4,68 & 2264,88 & 3,03 \\
\hline & 0,3 & 3053,99 & 792,90 & 47,31 & 1114,42 & 1939,57 & 2,74 \\
\hline & 0,4 & $2700 ; 29-$ & $783 ; 80$ & $46 ; 77$ & 1113,87 & 1586,42 & 2,42 \\
\hline & 0,5 & 2382,21 & 782,29 & 46,68 & 1113,78 & 1268,43 & 2,14 \\
\hline & 0,6 & 2162,44 & 776,49 & 46,33 & 1113,44 & 1049,00 & 1,94 \\
\hline & 0,7 & 1916,49 & 766,50 & 45,74 & 1112,84 & 803,65 & 1,72 \\
\hline & 0,8 & 1730,47 & 764,47 & 45,62 & $1112 ; 72$ & 617,75 & 1,56 \\
\hline \multirow{7}{*}{ 15-Jul } & $\theta, 2$ & 3392,53 & 852,21 & 50,85 & 1117,96 & 2274,57 & 3,03 \\
\hline & 0,3 & 3120,37 & 845,63 & 50,46 & 1117,56 & 2002,81 & 2,79 \\
\hline & 0,4 & 2724,84 & 843,77 & $50 ; 35$ & 1117,45 & 1607,38 & 2,44 \\
\hline & 0,5 & 2447,51 & 837,63 & 49,98 & 1117,09 & 1330,43 & 2,19 \\
\hline & $0 ; 6$ & 2211,72 & 831,02 & $49 ; 59$ & 1116,69 & 1095,03 & 1,98 \\
\hline & 0,7 & 1945,54 & 834,33 & 49,78 & 1116,89 & 828,66 & 1,74 \\
\hline & $\theta ; 8$ & 1782,65 & 834,86 & $49 ; 82$ & 1116,92 & 665,73 & 1,60 \\
\hline \multirow{7}{*}{ 1-Ago } & 0,2 & 3962,56 & 889,56 & 53,51 & II 20,61 & 2841,95 & 3,54 \\
\hline & 0,3 & 3698,98 & 883,89 & 53,17 & 1120,27 & 2578,71 & 3,30 \\
\hline & 0,4 & 3206,25 & 879,63 & 52,91 . & 1120,02 & 2086,23 & 2,86 \\
\hline & 0,5 & 2930,05 & 871,68 & 52,43 & 1119,54 & 1810,51 & 2,62 \\
\hline & 0,6 & 2581,54 & 870,52 & 52,36 & 1119,47 & 1462,07 & 2,31 \\
\hline & 0,7 & 2343,21 & 859,35 & 51,69 & 1118,80 & 1224,42 & 2,09 \\
\hline & 0,8 & 2094,35 & 846,01 & 50,89 & 1117,99 & 976,36 & 1,87 \\
\hline \multirow{7}{*}{ 15-Ago } & 0,2 & 3984,36 & 912,38 & 54,88 & 1121,99 & 2862,38 & 3,55 \\
\hline & 0,3 & 3735,10 & 907,99 & 54,62 & 1121,72 & 2613,38 & 3,33 \\
\hline & 0,4 & 3234,21 & 900,75 & 54,18 & 1121,29 & 2112,92 & 2,88 \\
\hline & 0,5 & 2981,58 & 894,56 & 53,81 & 1120,91 & 1860,67 & 2,66 \\
\hline & 0,6 & 2606,33 & 891,91 & 53,65 & 1120,75 & 1485,57 & 2,33 \\
\hline & 0,7 & 2390,90 & 887,43 & 53,38 & 1120,49 & 1270,41 & 2,13 \\
\hline & 0,8 & 2102,29 & 859,70 & 51,71 & 1118,82 & 983,48 & 1,88 \\
\hline
\end{tabular}


Tabela 29B. Receitas brutas, composição de custos da irrigação, receitas líquidas e relação beneficio/custo para a melancia, em cada época de semeadura, nível de manejo da irrigação e risco de $30 \%$. Teresina, Piauí.

\begin{tabular}{|c|c|c|c|c|c|c|c|}
\hline $\begin{array}{l}\text { Época de } \\
\text { Semeadura }\end{array}$ & $\mathrm{p}$ & $\begin{array}{c}\mathrm{RB}^{1} \\
\left(\mathrm{US} \$ \mathrm{ha}^{-1}\right)\end{array}$ & $\begin{array}{c}E b \\
\left(\mathrm{kWh} \mathrm{ha}^{-1}\right)\end{array}$ & $\begin{array}{c}\mathrm{CE} \\
\left(\mathrm{US} \$ \mathrm{ha}^{-1}\right)\end{array}$ & $\begin{array}{c}\mathrm{CT} \\
\left(\mathrm{US} \$ \mathrm{ha}^{-1}\right)\end{array}$ & $\begin{array}{c}\mathrm{RL} \\
\left(\mathrm{US} \$ \mathrm{ha}^{-1}\right)\end{array}$ & $\mathrm{B} / \mathrm{C}$ \\
\hline \multirow{7}{*}{$1-$ Set } & 0,2 & 3752,19 & 905,93 & 53,03 & 1120,14 & 2632,05 & 3,35 \\
\hline & 0,3 & 3512,40 & 897,91 & 52,56 & 1119,67 & 2392,73 & 3,14 \\
\hline & 0,4 & 3052,02 & 891,33 & 52,18 & 1119,28 & 1932,73 & 2,73 \\
\hline & 0,5 & 2812,58 & 881,36 & 51,60 & 1118,70 & 1693,88 & 2,51 \\
\hline & 0,6 & 2469,91 & 873,85 & 51,16 & 1118,26 & 1351,65 & 2,21 \\
\hline & 0,7 & 2257,40 & 866,53 & 50,73 & 1117,83 & 1139,56 & 2,02 \\
\hline & 0,8 & 2005,33 & 858,42 & 50,25 & 1117,36 & 887,97 & 1,79 \\
\hline \multirow{7}{*}{ 15-Set } & 0,2 & 3745,34 & 889,48 & 52,07 & 1119,18 & 2626,17 & 3,35 \\
\hline & 0,3 & 3496,99 & 879,57 & 51,49 & 1118,60 & 2378,39 & 3,13 \\
\hline & 0,4 & 3046,76 & 868,64 & 50,85 & 1117,96 & 1928,80 & 2,73 \\
\hline & 0,5 & 2809,02 & 860,56 & 50,38 & 1117,48 & 1691,53 & 2,51 \\
\hline & 0,6 & 2472,42 & 856,13 & 50,12 & 1117,22 & 1355,20 & 2,21 \\
\hline & 0,7 & 2264,82 & 849,17 & 49,71 & 1116,82 & 1148,01 & 2,03 \\
\hline & 0,8 & 2013,69 & 844,36 & 49,43 & 1116,53 & 897,15 & 1,80 \\
\hline \multirow{7}{*}{ 1-Out } & 0,2 & 3823,61 & 859,46 & 51,08 & 1118,18 & 2705,42 & 3,42 \\
\hline & 0,3 & 3558,60 & 851,66 & 50,62 & 1117,72 & 2440,88 & 3,18 \\
\hline & 0,4 & 3103,66 & 839,91 & 49,92 & 1117,02 & 1986,64 & 2,78 \\
\hline & 0,5 & 2839,34 & 833,47 & 49,53 & 1116,64 & 1722,70 & 2,54 \\
\hline & 0,6 & 2514,85 & 824,63 & 49,01 & 1116,11 & 1398,74 & 2,25 \\
\hline & 0,7 & 2289,31 & 812,70 & 48,30 & 1115,40 & 1173,90 & 2,05 \\
\hline & 0,8 & 2049,58 & 803,89 & 47,78 & 1114,88 & 934,70 & 1,84 \\
\hline \multirow{7}{*}{ 15-Out } & 0,2 & 3817,10 & 812,54 & 48,29 & 1115,40 & 2701,71 & 3,42 \\
\hline & 0,3 & 3520,74 & 800,54 & 47,58 & 1114,68 & 2406,06 & 3,16 \\
\hline & 0,4 & 3092,63 & 793,09 & 47,14 & 1114,24 & 1978,40 & 2,78 \\
\hline & 0,5 & 2803,47 & 774,33 & 46,02 & 1113,12 & 1690,35 & 2,52 \\
\hline & 0,6 & 2516,32 & 765,51 & 45,50 & 1112,60 & 1403,72 & 2,26 \\
\hline & 0,7 & 2273,30 & 749,48 & 44,54 & 1111,65 & 1161,65 & 2,04 \\
\hline & 0,8 & 2079,96 & 744,90 & 44,27 & 1111,38 & 968,59 & 1,87 \\
\hline
\end{tabular}


Tabela 29B. Receitas brutas, composição de custos da irrigação, receitas líquidas e relação beneficio/custo para a melancia, em cada época de semeadura, nível de manejo da irrigação e risco de $30 \%$. Teresina, Piauí.

\begin{tabular}{|c|c|c|c|c|c|c|c|}
\hline $\begin{array}{l}\text { Época de } \\
\text { Semeadura }\end{array}$ & $\mathrm{p}$ & $\begin{array}{c}\mathrm{RB}^{\mathrm{l}} \\
\left(\mathrm{US} \$ \mathrm{ha}^{-1}\right)\end{array}$ & $\begin{array}{c}E b \\
\left(\mathrm{kWh} h \mathrm{a}^{-1}\right)\end{array}$ & $\begin{array}{c}C E \\
\left(\mathrm{US} \$ h a^{-1}\right)\end{array}$ & $\begin{array}{c}\text { CT } \\
\left(\mathrm{US} \$ h \mathrm{a}^{-1}\right)\end{array}$ & $\begin{array}{c}\mathrm{RL} \\
\left(\mathrm{US} \$ \mathrm{ha} \mathrm{a}^{-1}\right)\end{array}$ & $\mathrm{B} / \mathrm{C}$ \\
\hline \multirow{7}{*}{ 1-Nov } & 0,2 & 4229,19 & 711,00 & $42,5 \mathrm{I}$ & I 109,61 & 3119,58 & 3,81 \\
\hline & 0,3 & 3849,25 & 693,05 & 41,43 & 1108,54 & 2740,71 & 3,47 \\
\hline & 0,4 & 3445,39 & 677,38 & $40 ; 50$ & 1107,60 & 2337,79 & 3,11 \\
\hline & 0,5 & 3101,11 & 655,90 & 39,21 & 1106,32 & 1994,79 & 2,80 \\
\hline & $0 ; 6$ & 2805,98 & $64 \mathrm{r}, 0 \mathrm{H}$ & $38 ; 32$ & 1105,43 & 1700,55 & 2,54 \\
\hline & 0,7 & 2549,01 & 621,64 & 37,17 & 1104,27 & 1444,74 & 2,31 \\
\hline & $0 ; 8$ & 2315,90 & $605 ; 85$ & $36 ; 22$ & 1103,33 & 1212,57 & 2,10 \\
\hline \multirow{7}{*}{$15-\mathrm{Nov}$} & 0,2 & 4229,63 & 623,76 & 37,29 & 1104,40 & 3125,23 & 3,83 \\
\hline & 0,3 & 3817,52 & 596,56 & 35,67 & 1102,77 & 2714,75 & 3,46 \\
\hline & 0,4 & 3462,38 & 564,52 & 33,75 & 1100,85 & 2361,53 & 3,15 \\
\hline & 0,5 & 3138,09 & 549,47 & 32,85 & 1099,96 & 2038,14 & 2,85 \\
\hline & 0,6 & 2857,24 & 524,47 & 31,36 & 1098,46 & 1758,78 & 2,60 \\
\hline & 0,7 & 2607,47 & 501,49 & 29,98 & 1097,09 & 1510,38 & 2,38 \\
\hline & 0,8 & 2418,81 & 487,38 & 29,14 & 1096,24 & 1322,57 & 2,21 \\
\hline \multirow{7}{*}{ 1-Dez } & 0,2 & 4463,92 & 550,29 & 32,29 & 1099,39 & 3364,53 & 4,06 \\
\hline & 0,3 & 4022,53 & 521,75 & 30,61 & 1097,72 & 2924,81 & 3,66 \\
\hline & 0,4 & 3674,72 & $483 ; 16$ & $28 ; 35$ & 1095,45 & 2579,27 & 3,35 \\
\hline & 0,5 & 3338,72 & 458,47 & 26,90 & 1094,00 & 2244,72 & 3,05 \\
\hline & $\theta, 6$ & 3060,37 & 437,57 & $25 ; 67$ & 1092,78 & 1967,59 & 2,80 \\
\hline & 0,7 & 2845,35 & 418,49 & 24,55 & 1091,66 & 1753,69 & 2,61 \\
\hline & 0,8 & 2614,75 & 380,72 & $22 ; 34$ & 1089,44 & 1525,31 & 2,40 \\
\hline \multirow{7}{*}{ 15-Dez } & 0,2 & 4487,42 & 482,69 & 28,32 & 1095,43 & 3391,99 & 4,10 \\
\hline & 0,3 & 4022,66 & 439,10 & 25,76 & 1092,87 & 2929,80 & 3,68 \\
\hline & 0,4 & 3720,08 & 413,32 & 24,25 & 1091,36 & 2628,72 & 3,41 \\
\hline & 0,5 & 3407,05 & 374,49 & 21,97 & 1089,08 & 2317,97 & 3,13 \\
\hline & 0,6 & 3137,19 & 341,12 & 20,01 & 1087,12 & 2050,07 & 2,89 \\
\hline & 0,7 & 2932,25 & 314,49 & 18,45 & 1085,56 & 1846,69 & 2,70 \\
\hline & 0,8 & 2750,26 & 294,24 & 17,26 & 1084,37 & 1665,89 & 2,54 \\
\hline
\end{tabular}

${ }^{1} \mathrm{RB}$ - receita bruta; $\mathrm{Eb}$ - energia requerida para o bombeamento; $\mathrm{CE}$ - custo de energia elétrica; $\mathrm{CT}$ - custo total de produção; RL - receita líquida e B/C - relação benefício/custo. 
Tabela 30B. Receitas brutas, composição de custos da irrigação, receitas liquidas e relação beneficio/custo para a melancia, em cada época de semeadura, nível de manejo da irrigação e risco de $35 \%$. Teresina, Piauí.

\begin{tabular}{|c|c|c|c|c|c|c|c|}
\hline $\begin{array}{l}\text { Época de } \\
\text { Semeadura }\end{array}$ & $\mathrm{p}$ & $\begin{array}{c}\mathrm{RB}^{1} \\
\left(\mathrm{US} \$ \mathrm{ha}^{-1}\right)\end{array}$ & $\begin{array}{c}\mathrm{Eb} \\
\left(\mathrm{kWh} \mathrm{ha}^{-1}\right)\end{array}$ & $\begin{array}{c}C E \\
\left(\mathrm{US} \$ \mathrm{ha}^{-1}\right)\end{array}$ & $\begin{array}{c}\mathrm{CT} \\
\left(\mathrm{US} \$ \mathrm{ha}^{-1}\right)\end{array}$ & $\begin{array}{c}\mathrm{RL} \\
\left(\mathrm{US} \$ \mathrm{ha}^{-1}\right)\end{array}$ & $\mathrm{B} / \mathrm{C}$ \\
\hline \multirow{7}{*}{ 1-Jan } & 0,2 & 4726,58 & 399,30 & 22,95 & 1090,05 & 3636,53 & 4,34 \\
\hline & 0,3 & 4302,99 & 358,92 & 20,63 & 1087,73 & 3215,25 & 3,96 \\
\hline & 0,4 & 4012,93 & 319,44 & 18,36 & 1085,46 & 2927,46 & 3,70 \\
\hline & 0,5 & 3726,78 & 277,34 & 15,94 & 1083,04 & 2643,73 & 3,44 \\
\hline & 0,6 & 3504,10 & 244,91 & 14,08 & 1081,18 & 2422,92 & 3,24 \\
\hline & 0,7 & 3330,59 & 219,10 & 12,59 & 1079,70 & 2250,89 & 3,08 \\
\hline & 0,8 & 3175,42 & 200,99 & 11,55 & 1078,66 & 2096,76 & 2,94 \\
\hline \multirow{7}{*}{ 15-Jan } & 0,2 & 4840,75 & 360,75 & 20,73 & 1087,84 & 3752,92 & 4,45 \\
\hline & 0,3 & 4433,34 & 310,79 & 17,86 & 1084,97 & 3348,37 & 4,09 \\
\hline & 0,4 & 4168,99 & 272,03 & 15,63 & 1082,74 & 3086,25 & 3,85 \\
\hline & 0,5 & 3922,49 & 240,12 & 13,80 & 1080,91 & 2841,58 & 3,63 \\
\hline & 0,6 & 3713,34 & 210,21 & 12,08 & 1079,19 & 2634,15 & 3,44 \\
\hline & 0,7 & 3535,79 & 180,16 & 10,35 & 1077,46 & 2458,34 & 3,28 \\
\hline & 0,8 & 3408,04 & 178,12 & 10,24 & 1077,34 & 2330,70 & 3,16 \\
\hline \multirow{7}{*}{$1-F e v$} & 0,2 & 5025,32 & 306,26 & 17,37 & 1084,48 & 3940,85 & 4,63 \\
\hline & 0,3 & 4634,20 & 255,07 & 14,47 & 1081,57 & 3552,62 & 4,28 \\
\hline & 0,4 & 4389,31 & 216,70 & 12,29 & 1079,40 & 3309,92 & 4,07 \\
\hline & 0,5 & 4170,12 & 178,57 & 10,13 & 1077,23 & 3092,89 & 3,87 \\
\hline & 0,6 & 3980,99 & 152,66 & 8,66 & 1075,76 & 2905,22 & 3,70 \\
\hline & 0,7 & 3843,81 & 117,41 & 6,66 & 1073,76 & 2770,04 & 3,58 \\
\hline & 0,8 & 3739,48 & 77,55 & 4,40 & 1071,50 & 2667,98 & 3,49 \\
\hline \multirow{7}{*}{ 15-Fev } & 0,2 & 5036,46 & 298,40 & 16,93 & 1084,03 & 3952,43 & 4,65 \\
\hline & 0,3 & 4650,73 & 243,11 & 13,79 & 1080,89 & 3569,84 & 4,30 \\
\hline & 0,4 & 4404,18 & 213,06 & 12,08 & 1079,19 & 3324,99 & 4,08 \\
\hline & 0,5 & 4187,08 & 167,87 & 9,52 & 1076,63 & 3110,46 & 3,89 \\
\hline & 0,6 & 4020,22 & 143,50 & 8,14 & 1075,24 & 2944,98 & 3,74 \\
\hline & 0,7 & 3893,62 & 122,08 & 6,92 & 1074,03 & 2819,60 & 3,63 \\
\hline & 0,8 & 3803,53 & 96,51 & 5,47 & 1072,58 & 2730,95 & 3,55 \\
\hline
\end{tabular}


Tabela 30B: Receitas brutas, composição de custos da irrigação, receitas líquidas e relação benefício/custo para a melancia, em cada época de semeadura, nível de manejo da irrigação-e risco de 35\%. Teresina, Piauí.

\begin{tabular}{|c|c|c|c|c|c|c|c|}
\hline $\begin{array}{l}\text { Época de } \\
\text { Semeadura }\end{array}$ & $p$ & $\begin{array}{c}\mathrm{RB}^{1} \\
\left(\mathrm{US} \$ \mathrm{ha}^{-1}\right)\end{array}$ & $\begin{array}{c}E b \\
\left(\mathrm{kWh} h \mathrm{ha}^{-1}\right)\end{array}$ & $\begin{array}{c}C E \\
\left(\mathrm{US} \$ h \mathrm{a}^{-1}\right)\end{array}$ & $\begin{array}{c}\text { CT } \\
\left(\mathrm{US} \$ h \mathrm{a}^{-1}\right)\end{array}$ & $\begin{array}{c}\mathrm{RL} \\
\left(\mathrm{US} \$ \mathrm{ha}^{-1}\right)\end{array}$ & $\mathrm{B} / \mathrm{C}$ \\
\hline \multirow{7}{*}{ 1-Mar } & 0,2 & 5091,93 & 294,05 & 16,46 & 1083,56 & 4008,37 & 4,70 \\
\hline & 0,3 & 4693,65 & 241,24 & 13,50 & 1080,61 & 3613,04 & 4,34 \\
\hline & $0 ; 4$ & 4424,68 & $19 z, 74$ & $10 ; 79$ & 1077,89 & 3346,79 & 4,10 \\
\hline & 0,5 & 4236,70 & 167,92 & 9,40 & 1076,50 & 3160,19 & 3,94 \\
\hline & $\theta ; 6$ & 4059,50 & 142,04 & 7,95 & 1075,06 & 2984,45 & 3,78 \\
\hline & 0,7 & 3892,10 & 111,84 & 6,26 & 1073,37 & 2818,73 & 3,63 \\
\hline & $0 ; 8$ & 3784,20 . & 82,77 & 4,63 & 1071,74 & 2712,46 & 3,53 \\
\hline \multirow{7}{*}{ 15-Mar } & 0,2 & 5031,69 & 344,26 & 19,27 & 1086,37 & 3945,31 & 4,63 \\
\hline & 0,3 & 4590,71 & 296,18 & 16,58 & 1083,68 & 3507,03 & 4,24 \\
\hline & 0,4 & 4270,36 & 262,14 & 14,67 & 1081,78 & 3188,58 & 3,95 \\
\hline & 0,5 & 4046,31 & 231,34 & 12,95 & 1080,05 & 2966,26 & 3,75 \\
\hline & 0,6 & 3819,81 & 196,15 & 10,98 & 1078,08 & 2741,72 & 3,54 \\
\hline & 0,7 & 3634,33 & 167,33 & 9,37 & 1076,47 & 2557,86 & 3,38 \\
\hline & 0,8 & 3478,47 & 147,12 & 8,24 & 1075,34 & 2403,13 & 3,23 \\
\hline \multirow{7}{*}{$1-\mathrm{Abr}$} & 0,2 & 4855,23 & 412,10 & $2 \mathrm{~T}, 86^{-}$ & 1088,97 & 3766,26 & 4,46 \\
\hline & 0,3 & 4370,72 & 375,88 & 19,94 & 1087,05 & 3283,67 & 4,02 \\
\hline & 0,4 & 4021,49 & 343,98 & 18,25 & 1085,35 & 2936,13 & 3,71 \\
\hline & 0,5 & 3752,65 & 319,56 & 16,95 & 1084,06 & 2668,59 & 3,46 \\
\hline & $\theta ; 6$ & $3496 ; 53$ & 292,08 & $15 ; 50$ & 1082,60 & 2413,93 & 3,23 \\
\hline & 0,7 & 3277,53 & 269,52 & 14,30 & 1081,40 & 2196,13 & 3,03 \\
\hline & 0,8 & 3090,90 & 242,03 & 12,84 & 1079,95 & 2010,95 & 2,86 \\
\hline \multirow{7}{*}{ 15-Abr } & 0,2 & 4795,50 & 492,52 & 26,13 & 1093,24 & 3702,26 & 4,39 \\
\hline & 0,3 & 4250,97 & 465,37 & 24,69 & 1091,80 & 3159,18 & 3,89 \\
\hline & 0,4 & 3841,33 & 429,78 & 22,80 & 1089,91 & 2751,42 & 3,52 \\
\hline & 0,5 & 3542,05 & 410,50 & 21,78 & 1088,88 & 2453,16 & 3,25 \\
\hline & 0,6 & 3259,20 & 383,83 & 20,36 & 1087,47 & 2171,73 & 3,00 \\
\hline & 0,7 & 2993,90 & 369,80 & 19,62 & 1086,72 & 1907,18 & 2,75 \\
\hline & 0,8 & 2763,62 & 351,33 & 18,64 & 1085,74 & 1677,87 & 2,55 \\
\hline
\end{tabular}


Tabela 30B. Receitas brutas, composição de custos da irrigação, receitas líquidas e relação benefício/custo para a melancia, em cada época de semeadura, nível de manejo da irrigação e risco de $35 \%$. Teresina, Piauí.

\begin{tabular}{|c|c|c|c|c|c|c|c|}
\hline $\begin{array}{c}\text { Época de } \\
\text { Semeadura }\end{array}$ & $\mathrm{p}$ & $\begin{array}{c}\mathrm{RB}^{\mathrm{l}} \\
\left(\mathrm{US} \$ \mathrm{ha}^{-1}\right)\end{array}$ & $\begin{array}{c}\mathrm{Eb} \\
\left(\mathrm{kWh} \mathrm{ha}^{-1}\right)\end{array}$ & $\begin{array}{c}\text { CE } \\
\left(\mathrm{US} \$ \mathrm{ha}^{-1}\right)\end{array}$ & $\begin{array}{c}\text { CT } \\
\left(\mathrm{US} \$ \mathrm{ha}^{-1}\right)\end{array}$ & $\begin{array}{c}\mathrm{RL} \\
\left(\mathrm{US} \$ \mathrm{ha}^{-1}\right)\end{array}$ & $\mathrm{B} / \mathrm{C}$ \\
\hline \multirow{7}{*}{ 1-Mai } & 0,2 & 3795,40 & 554,36 & 29,34 & 1096,45 & 2698,95 & 3,46 \\
\hline & 0,3 & 3327,78 & 525,90 & 27,84 & 1094,94 & 2232,84 & 3,04 \\
\hline & 0,4 & 2990,31 & 503,92 & 26,67 & 1093,78 & 1896,54 & 2,73 \\
\hline & 0,5 & 2747,16 & 493,47 & 26,12 & 1093,23 & 1653,94 & 2,51 \\
\hline & 0,6 & 2483,67 & 476,73 & 25,23 & 1092,34 & 1391,33 & 2,27 \\
\hline & 0,7 & 2249,90 & 451,43 & 23,90 & 1091,00 & 1158,90 & 2,06 \\
\hline & 0,8 & 2053,51 & 443,43 & 23,47 & 1090,58 & 962,93 & 1,88 \\
\hline \multirow{7}{*}{ 15-Mai } & 0,2 & 3791,50 & 617,82 & 32,70 & 1099,81 & 2691,69 & 3,45 \\
\hline & 0,3 & 3296,43 & 597,24 & 31,61 & 1098,72 & 2197,71 & 3,00 \\
\hline & 0,4 & 2967,25 & 592,07 & 31,34 & 1098,44 & 1868,81 & 2,70 \\
\hline & 0,5 & 2678,26 & 575,92 & 30,48 & 1097,59 & 1580,67 & 2,44 \\
\hline & 0,6 & 2389,27 & 561,26 & 29,71 & 1096,81 & 1292,46 & 2,18 \\
\hline & 0,7 & 2157,41 & 548,73 & 29,05 & 1096,15 & 1061,26 & 1,97 \\
\hline & 0,8 & 1970,31 & 546,14 & 28,91 & 1096,01 & 874,29 & 1,80 \\
\hline \multirow{7}{*}{ 1-Jun } & 0,2 & 3999,73 & 676,52 & 38,07 & 1105,18 & 2894,55 & 3,62 \\
\hline & 0,3 & 3511,35 & 667,82 & 37,58 & 1104,69 & 2406,66 & 3,18 \\
\hline & 0,4 & 3164,21 & 659,04 & 37,09 & 1104,19 & 2060,02 & 2,87 \\
\hline & 0,5 & 2818,82 & 653,90 & 36,80 & 1103,91 & 1714,91 & 2,55 \\
\hline & 0,6 & 2502,04 & 641,73 & 36,12 & 1103,22 & 1398,82 & 2,27 \\
\hline & 0,7 & 2268,88 & 640,28 & 36,03 & 1103,14 & 1165,74 & 2,06 \\
\hline & 0,8 & 2048,97 & 631,28 & 35,53 & 1102,63 & 946,33 & 1,86 \\
\hline \multirow{7}{*}{ 15-Jun } & 0,2 & 4034,34 & 729,93 & 41,08 & 1108,18 & 2926,15 & 3,64 \\
\hline & 0,3 & 3571,61 & 720,39 & 40,54 & 1107,65 & 2463,96 & 3,22 \\
\hline & 0,4 & 3209,81 & 709,89 & 39,95 & 1107,06 & 2102,75 & 2,90 \\
\hline & 0,5 & 2833,82 & 710,32 & 39,98 & 1107,08 & 1726,74 & 2,56 \\
\hline & 0,6 & 2543,44 & 696,58 & 39,20 & 1106,31 & 1437,13 & 2,30 \\
\hline & 0,7 & 2291,60 & 700,72 & 39,44 & 1106,54 & 1185,06 & 2,07 \\
\hline & 0,8 & 2060,61 & 698,48 & 39,31 & 1106,41 & 954,19 & 1,86 \\
\hline
\end{tabular}


Tabela 30B. Receitas brutas; composição- de custos da irrigação, receitas líquidas e relação benefício/custo para a melancia, em cada época de semeadura, nível de manejo da irrigação e risco de $35 \%$ : Teresina, Piauí.

\begin{tabular}{|c|c|c|c|c|c|c|c|}
\hline $\begin{array}{l}\text { Época de } \\
\text { Semeadura }\end{array}$ & $\mathrm{p}$ & $\begin{array}{c}\mathrm{RB}^{\mathrm{l}} \\
\left(\mathrm{US} \$ \mathrm{ha}^{-1}\right)\end{array}$ & $\begin{array}{c}\mathrm{Eb} \\
\left(\mathrm{kWh} \mathrm{ha} \mathrm{a}^{-1}\right)\end{array}$ & $\begin{array}{c}C E \\
\left(\mathrm{US} \$ \mathrm{ha}^{-1}\right)\end{array}$ & $\begin{array}{c}\text { CT } \\
\left(\mathrm{US} \$ \mathrm{ha}^{-1}\right)\end{array}$ & $\begin{array}{c}\mathrm{RL} \\
\left(\mathrm{US} \$ \mathrm{ha}^{-1}\right)\end{array}$ & $\mathrm{B} / \mathrm{C}$ \\
\hline \multirow{7}{*}{ 1-Jul } & 0,2 & 3419,72 & 794,63 & 46,76 & 1113,86 & 2305,85 & 3,07 \\
\hline & 0,3 & 3093,97 & 790,01 & 46,48 & 1113,59 & 1980,38 & 2,78 \\
\hline & $\theta, 4$ & 2735,73 & $780 ; 37$ & $45 ; 92$ & 1113,02 & 1622,70 & 2,46 \\
\hline & 0,5 & 2414,40 & 778,08 & 45,78 & 1112,89 & 1301,51 & 2,17 \\
\hline & 0,6 & 2193,40 & 772,16 & 45,43 & 1112,54 & 1080,86 & 1,97 \\
\hline & 0,7 & 1944,20 & 761,41 & 44,80 & 1111,91 & 832,29 & 1,75 \\
\hline & 0,8 & 1755,79 & 764,47 & 44,98 & 1112,09 & 643,70 & 1,58 \\
\hline \multirow{7}{*}{$15-J u l$} & $\theta, 2$ & 3432,47 & 849,78 & 50,00 & $1 \mathrm{f} 17,11$ & 2315,36 & 3,07 \\
\hline & 0,3 & 3161,12 & 842,67 & 49,58 & 1116,69 & 2044,43 & 2,83 \\
\hline & $0 ; 4$ & $2760 ; 16$ & 840,53 & $49 ; 46$ & $1116 ; 56$ & 1643,60 & 2,47 \\
\hline & 0,5 & 2481,51 & 833,63 & 49,05 & 1116,16 & 1365,36 & 2,22 \\
\hline & $\theta, 6$ & 2240,80 & $826 ; 95$ & 48,66 & 1115,76 & 1125,04 & 2,01 \\
\hline & 0,7 & 1973,89 & 834,33 & 49,09 & 1116,20 & 857,70 & 1,77 \\
\hline & $0 ; 8$ & 1809,78 & 829,13 & $48 ; 79$ & 1115,89 & 693,89 & 1,62 \\
\hline \multirow{7}{*}{ 1-Ago } & 0,2 & 4003,98 & 886,31 & 52,58 & III9,69 & 2884,29 & 3,58 \\
\hline & 0,3 & 3740,01 & 880,36 & 52,23 & 1119,33 & 2620,68 & 3,34 \\
\hline & 0,4 & 3242,16 & 875,69 & 51,95 & 1119,06 & 2123,10 & 2,90 \\
\hline & 0,5 & 2965,39 & 866,71 & 51,42 & 1118,52 & 1846,87 & 2,65 \\
\hline & 0,6 & 2613,03 & $864 ; 49$ & 51,29 & $1118 ; 39$ & 1494,64 & 2,34 \\
\hline & 0,7 & 2374,17 & 853,73 & 50,65 & 1117,75 & 1256,42 & 2,12 \\
\hline & 0,8 & 2151,36 & 846,01 & 50,19 & 1117,30 & 1034,06 & 1,93 \\
\hline \multirow{7}{*}{ 15-Ago } & 0,2 & 4026,52 & $909,0 \tau$ & 53,93 & IT21,04 & 2905,48 & 3,59 \\
\hline & 0,3 & 3775,99 & 904,26 & 53,65 & 1120,75 & 2655,23 & 3,37 \\
\hline & 0,4 & 3270,70 & 896,58 & $53 ; 19$ & 1120,30 & 2150,40 & 2,92 \\
\hline & 0,5 & 3017,02 & 889,57 & 52,78 & 1119,88 & 1897,14 & 2,69 \\
\hline & 0,6 & 2638,57 & $886 ; 68$ & 52,61 & 1119,71 & 1518,86 & 2,36 \\
\hline & 0,7 & 2423,13 & 881,63 & 52,31 & 1119,41 & 1303,72 & 2,16 \\
\hline & 0,8 & 2131,78 & $859 ; 70$ & 51,00 & 1118,11 & 1013,67 & 1,91 \\
\hline
\end{tabular}


Tabela 30B. Receitas brutas, composição de custos da irrigação, receitas líquidas e relação benefício/custo para a melancia, em cada época de semeadura, nível de manejo da irrigação e risco de $35 \%$. Teresina, Piauí.

\begin{tabular}{|c|c|c|c|c|c|c|c|}
\hline $\begin{array}{l}\text { Época de } \\
\text { Semeadura }\end{array}$ & $\mathrm{p}$ & $\begin{array}{c}\mathrm{RB}^{\mathrm{l}} \\
\left(\mathrm{US} \$ \mathrm{ha}^{-1}\right)\end{array}$ & $\begin{array}{c}\mathrm{Eb} \\
\left(\mathrm{kWh} \mathrm{ha}^{-1}\right)\end{array}$ & $\begin{array}{c}\text { CE } \\
\left(\mathrm{US} \$ \mathrm{ha}^{-1}\right)\end{array}$ & $\begin{array}{c}\mathrm{CT} \\
\left(\mathrm{US} \$ \mathrm{ha}^{-1}\right)\end{array}$ & $\begin{array}{c}\text { RL } \\
\left(\mathrm{US} \$ \mathrm{ha}^{-1}\right)\end{array}$ & $\mathrm{B} / \mathrm{C}$ \\
\hline \multirow{7}{*}{ 1-Set } & 0,2 & 3781,22 & 901,99 & 52,23 & 1119,34 & 2661,89 & 3,38 \\
\hline & 0,3 & 3540,48 & 893,38 & 51,73 & 1118,84 & 2421,64 & 3,16 \\
\hline & 0,4 & 3077,91 & 885,76 & 51,29 & 1118,40 & 1959,51 & 2,75 \\
\hline & 0,5 & 2837,94 & 875,27 & 50,68 & 1117,79 & 1720,15 & 2,54 \\
\hline & 0,6 & 2493,16 & 866,86 & 50,20 & 1117,30 & 1375,85 & 2,23 \\
\hline & 0,7 & 2281,35 & 859,36 & 49,76 & 1116,87 & 1164,48 & 2,04 \\
\hline & 0,8 & 2027,56 & 850,02 & 49,22 & 1116,33 & 911,23 & 1,82 \\
\hline \multirow{7}{*}{$15-$ Set } & 0,2 & 3774,34 & 884,89 & 51,24 & 1118,35 & 2655,99 & 3,37 \\
\hline & 0,3 & 3525,38 & 874,23 & 50,62 & 1117,73 & 2407,65 & 3,15 \\
\hline & 0,4 & 3073,43 & 862,85 & 49,96 & 1117,07 & 1956,36 & 2,75 \\
\hline & 0,5 & 2835,39 & 853,94 & 49,45 & 1116,55 & 1718,84 & 2,54 \\
\hline & 0,6 & 2496,40 & 847,63 & 49,08 & 1116,19 & 1380,21 & 2,24 \\
\hline & 0,7 & 2289,83 & 841,23 & 48,71 & 1115,82 & 1174,02 & 2,05 \\
\hline & 0,8 & 2036,81 & 844,36 & 48,89 & 1116,00 & 920,81 & 1,83 \\
\hline \multirow{7}{*}{ 1-Out } & 0,2 & 3852,75 & 854,66 & 50,20 & 1117,31 & 2735,45 & 3,45 \\
\hline & 0,3 & 3587,62 & 846,01 & 49,69 & 1116,80 & 2470,82 & 3,21 \\
\hline & 0,4 & 3129,71 & 833,05 & 48,93 & 1116,04 & 2013,68 & 2,80 \\
\hline & 0,5 & 2866,17 & 825,86 & 48,51 & 1115,62 & 1750,56 & 2,57 \\
\hline & 0,6 & 2539,46 & 816,19 & 47,94 & 1115,05 & 1424,42 & 2,28 \\
\hline & 0,7 & 2313,09 & 804,40 & 47,25 & 1114,35 & 1198,73 & 2,08 \\
\hline & 0,8 & 2074,14 & 794,34 & 46,66 & 1113,76 & 960,37 & 1,86 \\
\hline \multirow{7}{*}{ 15-Out } & 0,2 & 3846,21 & 806,95 & 47,40 & 1114,51 & 2731,71 & 3,45 \\
\hline & 0,3 & 3549,92 & 794,32 & 46,66 & 1113,76 & 2436,16 & 3,19 \\
\hline & 0,4 & 3120,95 & 785,62 & 46,15 & 1113,25 & 2007,70 & 2,80 \\
\hline & 0,5 & 2831,67 & 766,38 & 45,02 & 1112,12 & 1719,55 & 2,55 \\
\hline & 0,6 & 2542,69 & 755,91 & 44,40 & 1111,51 & 1431,18 & 2,29 \\
\hline & 0,7 & 2298,01 & 738,59 & 43,38 & 1110,49 & 1187,52 & 2,07 \\
\hline & 0,8 & 2104,52 & 733,14 & 43,06 & 1110,17 & 994,35 & 1,90 \\
\hline
\end{tabular}


Tabela 30B. Receitas brutas; composição de custos da irrigação, receitas líquidas e relação benefício/custo para a melancia, em cada época de semeadura, nível de manejo da irrigação e risco de $35 \%$. Teresina, Piauí.

\begin{tabular}{|c|c|c|c|c|c|c|c|}
\hline $\begin{array}{c}\text { Época de } \\
\text { Semeadura }\end{array}$ & $\mathrm{p}$ & $\begin{array}{c}\mathrm{RB}^{\mathrm{l}} \\
\left(\mathrm{US} \$ \mathrm{ha}^{-1}\right)\end{array}$ & $\begin{array}{c}\mathrm{Eb} \\
\left(\mathrm{kWh} \mathrm{ha} \mathrm{a}^{-1}\right)\end{array}$ & $\begin{array}{c}\text { CE } \\
\left(\mathrm{US} \$ \mathrm{ha}^{-1}\right)\end{array}$ & $\begin{array}{c}\text { CT } \\
\left(\text { USS ha }{ }^{-1}\right)\end{array}$ & $\begin{array}{c}\mathrm{RL} \\
\left(\mathrm{US} \$ \mathrm{ha}^{-1}\right)\end{array}$ & $\mathrm{B} / \mathrm{C}$ \\
\hline \multirow{7}{*}{$1-\mathrm{Nov}$} & 0,2 & 4262,86 & 703,66 & $4 \mathrm{I}, 6 \mathrm{I}$ & 1108,71 & 3154,15 & 3,84 \\
\hline & 0,3 & 3885,42 & 684,90 & 40,50 & 1107,60 & 2777,82 & 3,51 \\
\hline & $\theta ; 4$ & 3478,76 & 667,78 & 39,49 & 1106,59 & 2372,17 & 3,14 \\
\hline & 0,5 & 3133,98 & 645,08 & 38,14 & 1105,25 & 2028,73 & 2,84 \\
\hline & $\theta ; 6$ & 2840,41 & $628 ; 86$ & 37,19 & 1104,29 & 1736,12 & 2,57 \\
\hline & 0,7 & 2582,14 & 609,04 & 36,01 & 1103,12 & 1479,02 & 2,34 \\
\hline & 0,8 & $2352 ; 1\}$ & 591,99 & $35 ; 01$ & 1102,11 & 1250,00 & 2,13 \\
\hline \multirow{7}{*}{$15-\mathrm{Nov}$} & 0,2 & 4264,93 & $615,4 \mathrm{I}$ & 36,39 & 1103,49 & 3161,43 & 3,86 \\
\hline & 0,3 & 3855,17 & 587,75 & 34,75 & 1101,86 & 2753,31 & 3,50 \\
\hline & 0,4 & 3499,43 & 554,71 & 32,80 & 1099,91 & 2399,52 & 3,18 \\
\hline & 0,5 & 3174,93 & 538,00 & 31,81 & 1098,92 & 2076,01 & 2,89 \\
\hline & 0,6 & 2896,20 & 511,69 & 30,26 & 1097,36 & 1798,83 & 2,64 \\
\hline & 0,7 & 2648,13 & 488,52 & 28,89 & 1095,99 & 1552,14 & 2,42 \\
\hline & 0,8 & 2458,73 & 472,06 & 27,91 & 1095,02 & 1363,71 & 2,25 \\
\hline \multirow{7}{*}{ 1-Dez } & 0,2 & 4556,64 & 542,71 & 31,45 & 1098,55 & 3458,08 & 4,15 \\
\hline & 0,3 & 4110,35 & 512,40 & 29,69 & 1096,80 & 3013,55 & 3,75 \\
\hline & $0 ; 4$ & 3758,71 & $473 ; 53$ & 27,44 & 1094,55 & 2664,16 & 3,43 \\
\hline & 0,5 & 3420,32 & 447,71 & 25,95 & 1093,05 & 2327,27 & 3,13 \\
\hline & 0,6 & 3139,95 & 425,63 & 24,67 & 1091,77 & 2048,18 & 2,88 \\
\hline & 0,7 & 2922,24 & 405,04 & 23,47 & 1090,58 & 1831,67 & 2,68 \\
\hline & 0,8 & $2690 ; 25$ & 366,08 & 21,21 & 1088,32 & 1601,93 & 2,47 \\
\hline \multirow{7}{*}{ 15-Dez } & 0,2 & 4580,72 & 474,26 & 27,48 & 1094,59 & 3486,13 & 4,18 \\
\hline & 0,3 & 4113,43 & 429,60 & 24,90 & 1092,00 & 3021,43 & 3,77 \\
\hline & 0,4 & 3808,71 & 403,04 & 23,36 & 1090,46 & 2718,25 & 3,49 \\
\hline & 0,5 & 3492,87 & 363,83 & 21,08 & 1088,19 & 2404,68 & 3,21 \\
\hline & 0,6 & 3224,58 & 329,22 & 19,08 & 1086,18 & 2138,40 & 2,97 \\
\hline & 0,7 & 3018,92 & 302,67 & 17,54 & 1084,64 & 1934,28 & 2,78 \\
\hline & 0,8 & 2836,35 & 280,34 & 16,25 & 1083,35 & 1753,00 & 2,62 \\
\hline
\end{tabular}

TRB - receita bruta; $\mathrm{Eb}$ - energia requerida para o bombeamento: $\mathrm{CE}$ - custo de energia elétrica; $\mathrm{CT}$ - custo total de produção; $\mathrm{RL}$ - receita líquida e $\mathrm{B} / \mathrm{C}$ - relação beneficio/custo. 
Tabela 31B. Receitas brutas, composição de custos da irrigação, receitas líquidas e relação benefício/custo para a melancia, em cada época de semeadura, nível de manejo da irrigação e risco de $40 \%$. Teresina, Piauí.

\begin{tabular}{|c|c|c|c|c|c|c|c|}
\hline $\begin{array}{l}\text { Época de } \\
\text { Semeadura }\end{array}$ & $\mathrm{p}$ & $\begin{array}{c}\mathrm{RB}^{1} \\
\left(\mathrm{US} \$ \mathrm{ha}^{-1}\right)\end{array}$ & $\begin{array}{c}E b \\
\left(\mathrm{kWh} \mathrm{ha}^{-1}\right)\end{array}$ & $\begin{array}{c}\text { CE } \\
\left(\mathrm{US} \$ \mathrm{ha}^{-1}\right)\end{array}$ & $\begin{array}{c}\text { CT } \\
\left(\mathrm{US} \$ \mathrm{ha}^{-1}\right)\end{array}$ & $\begin{array}{c}\mathrm{RL} \\
\left(\mathrm{US} \$ \mathrm{ha}^{-1}\right)\end{array}$ & $\mathrm{B} / \mathrm{C}$ \\
\hline \multirow{7}{*}{ 1-Jan } & 0,2 & 4773,20 & 391,16 & 22,15 & 1089,26 & 3683,95 & 4,38 \\
\hline & 0,3 & 4352,05 & 349,76 & 19,81 & 1086,91 & 3265,14 & 4,00 \\
\hline & 0,4 & 4064,93 & 309,26 & 17,51 & 1084,62 & 2980,32 & 3,75 \\
\hline & 0,5 & 3780,32 & 266,64 & 15,10 & 1082,20 & 2698,12 & 3,49 \\
\hline & 0,6 & 3560,13 & 233,30 & 13,21 & 1080,32 & 2479,81 & 3,30 \\
\hline & 0,7 & 3391,26 & 207,59 & 11,76 & 1078,86 & 2312,40 & 3,14 \\
\hline & 0,8 & 3239,22 & 188,76 & 10,69 & 1077,79 & 2161,43 & 3,01 \\
\hline \multirow{7}{*}{ 15-Jan } & 0,2 & 4889,41 & 352,56 & 19,97 & 1087,07 & 3802,34 & 4,50 \\
\hline & 0,3 & 4483,26 & 301,16 & 17,05 & 1084,16 & 3399,10 & 4,14 \\
\hline & 0,4 & 4221,20 & 262,25 & 14,85 & 1081,96 & 3139,24 & 3,90 \\
\hline & 0,5 & 3977,02 & 228,76 & 12,95 & 1080,06 & 2896,96 & 3,68 \\
\hline & 0,6 & 3771,95 & 198,19 & 11,22 & 1078,33 & 2693,62 & 3,50 \\
\hline & 0,7 & 3601,70 & 168,86 & 9,56 & 1076,67 & 2525,04 & 3,35 \\
\hline & 0,8 & 3476,43 & 127,23 & 7,21 & 1074,31 & 2402,12 & 3,24 \\
\hline \multirow{7}{*}{$1-\mathrm{Fev}$} & 0,2 & 5055,74 & 298,97 & 16,60 & 1083,71 & 3972,04 & 4,67 \\
\hline & 0,3 & 4667,35 & 246,46 & 13,69 & 1080,79 & 3586,56 & 4,32 \\
\hline & 0,4 & 4428,70 & 208,11 & 11,56 & 1078,66 & 3350,04 & 4,11 \\
\hline & 0,5 & 4212,92 & 169,87 & 9,43 & 1076,54 & 3136,38 & 3,91 \\
\hline & 0,6 & 4029,38 & 143,70 & 7,98 & 1075,09 & 2954,30 & 3,75 \\
\hline & 0,7 & 3896,02 & 108,76 & 6,04 & 1073,14 & 2822,88 & 3,63 \\
\hline & 0,8 & 3794,64 & 77,55 & 4,31 & 1071,41 & 2723,23 & 3,54 \\
\hline \multirow{7}{*}{$15-\mathrm{Fev}$} & 0,2 & 5067,54 & 288,84 & 16,04 & 1083,15 & 3984,39 & 4,68 \\
\hline & 0,3 & 4687,95 & 233,59 & 12,97 & 1080,08 & 3607,87 & 4,34 \\
\hline & 0,4 & 4446,37 & 202,16 & 11,23 & 1078,33 & 3368,04 & 4,12 \\
\hline & 0,5 & 4233,71 & 157,80 & 8,76 & 1075,87 & 3157,84 & 3,94 \\
\hline & 0,6 & 4072,55 & 132,65 & 7,37 & 1074,47 & 2998,08 & 3,79 \\
\hline & 0,7 & 3952,43 & 111,67 & 6,20 & 1073,31 & 2879,13 & 3,68 \\
\hline & 0,8 & 3866,49 & 96,51 & 5,36 & 1072,46 & 2794,03 & 3,61 \\
\hline
\end{tabular}


Tabela 31B. Receitas brutas, composição de eustos da irrigação, receitas líquidas e relação benefício/custo para a melancia, em cada época de semeadura, nível de manejo-da irrigação e risco de $40 \%$. Teresina, Piauí.

\begin{tabular}{|c|c|c|c|c|c|c|c|}
\hline $\begin{array}{c}\text { Época de } \\
\text { Semeadura }\end{array}$ & $\mathrm{p}$ & $\begin{array}{c}\mathrm{RB}^{1} \\
\left(\mathrm{US} \$ \mathrm{ha}^{-1}\right)\end{array}$ & $\begin{array}{c}\mathrm{Eb} \\
\left(\mathrm{kWl}+\mathrm{ha}^{-1}\right)-\end{array}$ & $\begin{array}{c}\mathrm{CE} \\
\left(\mathrm{US} \$ \mathrm{ha}^{-1}\right)\end{array}$ & $\begin{array}{c}\mathrm{CT} \\
\left(\mathrm{US} \$ \mathrm{ha}^{-1}\right)\end{array}$ & $\begin{array}{c}\mathrm{RL} \\
\left(\mathrm{US} \$ \mathrm{ha}^{-1}\right)\end{array}$ & $\mathrm{B} / \mathrm{C}$ \\
\hline \multirow{7}{*}{ 1-Mar } & 0,2 & $5144,6 T$ & 285,95 & 15,61 & 1082,71 & 4061,95 & 4,75 \\
\hline & 0,3 & 4750,95 & 232,60 & 12,70 & 1079,80 & 3671,15 & 4,40 \\
\hline & 0,4 & 4484,74 & 183,85 & 10,04 & 1077,14 & 3407,60 & 4,16 \\
\hline & 0,5 & 4299,74 & 158,44 & 8,65 & 1075,75 & 3223,98 & 4,00 \\
\hline & 0,6 & $4128 ; 40$ & 132,65 & 7,24 & 1074,35 & 3054,06 & 3,84 \\
\hline & 0,7 & 3968,18 & 102,98 & 5,62 & 1072,73 & 2895,46 & 3,70 \\
\hline & 0,8 & 3864,92 & 82,77 & 4,52 & 1071,62 & 2793,30 & 3,61 \\
\hline \multirow{7}{*}{ 15-Mar } & 0,2 & 5082,72 & 335,96 & 18,34 & 1085,44 & 3997,28 & 4,68 \\
\hline & 0,3 & 4643,18 & 286,51 & 15,64 & 1082,74 & 3560,44 & 4,29 \\
\hline & 0,4 & 4326,94 & 251,10 & 13,71 & 1080,81 & 3246,13 & 4,00 \\
\hline & 0,5 & 4107,13 & 220,97 & 12,06 & 1079,17 & 3027,96 & 3,81 \\
\hline & 0,6 & 3885,19 & 185,43 & 10,12 & 1077,23 & 2807,96 & 3,61 \\
\hline & 0,7 & 3704,29 & 156,80 & 8,56 & 1075,66 & 2628,63 & 3,44 \\
\hline & 0,8 & 3551,99 & 135,98 & 7,42 & 1074,53 & 2477,47 & 3,31 \\
\hline \multirow{7}{*}{$1-\mathrm{Abr}$} & 0,2 & 4908,38 & 404,03 & $20,8.4$ & 1087,94 & 3820,44 & 4,51 \\
\hline & 0,3 & 4425,17 & 367,11 & 18,93 & 1086,04 & 3339,13 & 4,07 \\
\hline & 0,4 & 4079,16 & 334,21 & 17,23 & 1084,34 & 2994,82 & 3,76 \\
\hline & 0,5 & 3810,94 & 308,35 & 15,90 & 1083,01 & 2727,94 & 3,52 \\
\hline & 0,6 & $3556 ; 38$ & 280,31 & 14,46 & 1081,56 & 2474,82 & 3,29 \\
\hline & 0,7 & 3340,02 & 256,77 & 13,24 & 1080,35 & 2259,67 & 3,09 \\
\hline & 0,8 & 3157,58 & $229 ; 15$ & 11,82 & 1078,92 & 2078,66 & 2,93 \\
\hline \multirow{7}{*}{$15-\mathrm{Abr}$} & 0,2 & 4846,53 & 485,31 & $25 ; 03$ & 1092,13 & 3754,40 & 4,44 \\
\hline & 0,3 & 4301,98 & 456,92 & 23,56 & 1090,67 & 3211,31 & 3,94 \\
\hline & 0,4 & 3893,00 & 420,23 & 21,67 & 1088,78 & 2804,23 & 3,58 \\
\hline & 0,5 & 3595,15 & 399,77 & 20,62 & 1087,72 & 2507,43 & 3,31 \\
\hline & 0,6 & 3314,99 & 373,25 & 19,25 & 1086,35 & 2228,64 & 3,05 \\
\hline & 0,7 & 3050,27 & 358,56 & 18,49 & 1085,59 & 1964,67 & 2,81 \\
\hline & 0,8 & 2820,49 & 339,14 & 17,49 & 1084,59 & 1735,90 & 2,60 \\
\hline
\end{tabular}


Tabela 31B. Receitas brutas, composição de custos da irrigação, receitas líquidas e relação benefício/custo para a melancia, em cada época de semeadura, nível de manejo da irrigação e risco de $40 \%$. Teresina, Piauí.

\begin{tabular}{|c|c|c|c|c|c|c|c|}
\hline $\begin{array}{c}\text { Época de } \\
\text { Semeadura }\end{array}$ & $\mathrm{p}$ & $\begin{array}{c}\mathrm{RB}^{1} \\
\left(\mathrm{US} \$ \mathrm{ha}^{-1}\right)\end{array}$ & $\begin{array}{c}E b \\
\left(k W h h^{-1}\right)\end{array}$ & 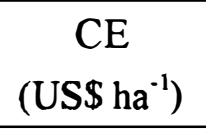 & $\begin{array}{c}\text { CT } \\
\left({\left.\text { US } \$ h^{-1}\right)}^{-1}\right)\end{array}$ & $\begin{array}{c}\text { RL } \\
\left(\text { US } \$ h^{-1}\right)\end{array}$ & $B / C$ \\
\hline & 0,2 & 3827,84 & 547,34 & 28,32 & 1095,43 & 2732,41 & 3,49 \\
\hline & 0,3 & 3360,43 & 517,82 & 26,79 & 1093,90 & 2266,53 & 3,07 \\
\hline & 0,4 & 3023,81 & 494,85 & 25,60 & 1092,71 & 1931,10 & 2,77 \\
\hline \multirow[t]{7}{*}{ 1-Mai } & 0,5 & 2779,03 & 482,63 & 24,97 & 1092,08 & 1686,95 & 2,54 \\
\hline & 0,6 & 2517,93 & 465,44 & 24,08 & 1091,19 & 1426,75 & 2,31 \\
\hline & 0,7 & 2286,07 & 440,18 & 22,78 & 1089,88 & 1196,19 & 2,10 \\
\hline & 0,8 & 2089,37 & 429,95 & 22,25 & 1089,35 & 1000,02 & 1,92 \\
\hline & 0,2 & 3821,91 & 613,19 & 31,73 & 1098,83 & 2723,08 & 3,48 \\
\hline & 0,3 & 3325,85 & 591,24 & 30,59 & 1097,70 & 2228,15 & 3,03 \\
\hline & 0,4 & 2996,45 & 585,47 & 30,29 & 1097,40 & 1899,05 & 2,73 \\
\hline \multirow[t]{7}{*}{ 15-Mai } & 0,5 & 2706,42 & 568,51 & 29,42 & 1096,52 & 1609,90 & 2,47 \\
\hline & 0,6 & 2417,41 & 553,81 & 28,66 & 1095,76 & 1321,65 & 2,21 \\
\hline & 0,7 & 2185,34 & 540,17 & 27,95 & 1095,05 & 1090,29 & 2,00 \\
\hline & 0,8 & 1997,47 & 537,64 & 27,82 & 1094,92 & 902,54 & 1,82 \\
\hline & 0,2 & 4046,62 & 672,37 & 37,11 & 1104,21 & 2942,41 & 3,66 \\
\hline & 0,3 & 3555,20 & 663,15 & 36,60 & 1103,70 & 2451,50 & 3,22 \\
\hline & 0,4 & 3205,95 & 654,16 & 36,10 & 1103,20 & 2102,74 & 2,91 \\
\hline \multirow[t]{7}{*}{ 1-Jun } & 0,5 & 2856,15 & 648,55 & 35,79 & 1102,90 & 1753,25 & 2,59 \\
\hline & 0,6 & 2538,03 & 635,35 & 35,06 & 1102,17 & 1435,86 & 2,30 \\
\hline & 0,7 & 2303,59 & 633,66 & 34,97 & 1102,07 & 1201,52 & 2,09 \\
\hline & 0,8 & 2080,64 & 624,10 & 34,44 & 1101,55 & 979,10 & 1,89 \\
\hline & 0,2 & 4080,38 & 726,75 & 40,11 & 1107,21 & 2973,17 & 3,69 \\
\hline & 0,3 & 3615,72 & 716,37 & 39,53 & 1106,64 & 2509,09 & 3,27 \\
\hline & 0,4 & 3251,10 & 705,79 & 38,95 & 1106,05 & 2145,05 & 2,94 \\
\hline \multirow[t]{4}{*}{ 15-Jun } & 0,5 & 2870,70 & 705,60 & 38,94 & 1106,04 & 1764,66 & 2,60 \\
\hline & 0,6 & 2578,74 & 691,15 & 38,14 & 1105,25 & 1473,50 & 2,33 \\
\hline & 0,7 & 2322,83 & 694,19 & 38,31 & 1105,41 & 1217,41 & 2,10 \\
\hline & 0,8 & 2090,73 & 668,98 & 36,92 & 1104,02 & 986,71 & 1,89 \\
\hline
\end{tabular}


Tabela 31B. Receitas brutas, composição de custos da irrigação, receitas líquidas e relação benefício/custo para a melancia, em cada época de semeadura, nível de manejo da ifrigação e risco de $40 \%$ : Teresina, Piauí.

\begin{tabular}{|c|c|c|c|c|c|c|c|}
\hline $\begin{array}{l}\text { Época de } \\
\text { Semeadura }\end{array}$ & $\mathrm{p}$ & $\begin{array}{c}\mathrm{RB}^{1} \\
\left(\mathrm{US \$} \mathrm{ha}^{-1}\right)\end{array}$ & $\begin{array}{c}E b \\
\left(\mathrm{kWh}-\mathrm{ha} a^{-1}\right)\end{array}$ & $\begin{array}{c}\text { CE } \\
\left(\mathrm{US} \$ \mathrm{ha}^{-1}\right)\end{array}$ & $\begin{array}{c}\text { CT } \\
\left(\text { US\$ } \$ \mathrm{ha}^{-1}\right)\end{array}$ & $\begin{array}{c}\mathrm{RL} \\
\left(\mathrm{US} \$ \mathrm{ha}^{-1}\right)\end{array}$ & $\mathrm{B} / \mathrm{C}$ \\
\hline \multirow{7}{*}{ 1-Jul } & 0,2 & 3457,20 & 792,14 & 45,98 & 1113,09 & 2344,11 & 3,11 \\
\hline & 0,3 & 3131,41 & 787,27 & 45,70 & 1112,80 & 2018,61 & 2,81 \\
\hline & 0,4 & 2768,92 & 777,12 & 45,11 & 1112,21 & 1656,70 & 2,49 \\
\hline & 0,5 & 2444,59 & 774,10 & 44,93 & 1112,04 & 1332,55 & 2,20 \\
\hline & 0,6 & 2222,48 & 768,05 & 44,58 & $11 \cdot 11,69$ & 1110,79 & 2,00 \\
\hline & 0,7 & 1970,24 & 756,57 & 43,92 & 1111,02 & 859,22 & 1,77 \\
\hline & $0 ; 8$ & 1779,59 & 764,47 & 44,38 & 1111,48 & 668,11 & 1,60 \\
\hline \multirow{7}{*}{ 15-Jul } & 0,2 & 3469,74 & 847,48 & 49,19 & 1116,30 & 2353,44 & 3,11 \\
\hline & 0,3 & 3199,28 & 839,85 & 48,75 & 1115,86 & 2083,42 & 2,87 \\
\hline & $\theta, 4$ & $2793 ; 24$ & 837,45 & $48 ; 61$ & $1115 ; 72$ & 1677,52 & 2,50 \\
\hline & 0,5 & 2513,43 & 829,84 & 48,17 & 1115,27 & 1398,15 & 2,25 \\
\hline & 0,6 & 2268,05 & $823 ; 09$ & 47,78 & 1114,88 & 1153,17 & 2,03 \\
\hline & 0,7 & 2000,54 & 807,93 & 46,90 & 1114,00 & 886,54 & 1,80 \\
\hline & $\theta ; 8$ & $1835 ; 31$ & $823 ; 69$ & 47,81 & 1114,92 & 720,39 & 1,65 \\
\hline \multirow{7}{*}{ 1-Ago } & 0,2 & 4046,80 & 885,21 & 51,68 & โI18,79 & 2928,01 & 3,62 \\
\hline & 0,3 & 3782,28 & 877,01 & 51,32 & 1118,42 & 2663,86 & 3,38 \\
\hline & 0,4 & 3279,13 & 871,95 & 51,02 & 1118,13 & 2161,00 & 2,93 \\
\hline & 0,5 & 3001,62 & 861,99 & 50,44 & 1117,55 & 1884,08 & 2,69 \\
\hline & 0,6 & $2645 ; 30$ & 858,77 & 50,25 & 1117,36 & 1527,94 & 2,37 \\
\hline & 0,7 & 2405,76 & 848,40 & 49,65 & 1116,75 & 1289,01 & 2,15 \\
\hline & 0,8 & 2172,74 & 846,01 & 49,51 & 1116,61 & 1056,13 & 1,95 \\
\hline \multirow{7}{*}{ 15-Ago } & 0,2 & 4070,07 & 905,92 & 53,01 & 1120,12 & 2949,95 & 3,63 \\
\hline & 0,3 & 3818,14 & 900,72 & 52,71 & 1119,81 & 2698,33 & 3,41 \\
\hline & 0,4 & 3308,25 & 892,62 & 52,23 & 1119,34 & 2188,91 & 2,96 \\
\hline & 0,5 & 3053,38 & 884,82 & 51,78 & 1118,88 & 1934,50 & 2,73 \\
\hline & 0,6 & 2671,57 & 881,72 & 51,60 & 1118,70 & 1552,87 & 2,39 \\
\hline & 0,7 & 2455,98 & 876,12 & 51,27 & 1118,37 & 1337,60 & 2,20 \\
\hline & 0,8 & 2161,77 & 859,70 & 50,31 & 1117,41 & 1044,36 & 1,93 \\
\hline
\end{tabular}


Tabela 31B. Receitas brutas, composição de custos da irrigação, receitas líquidas e relação beneficio/custo para a melancia, em cada época de semeadura, nível de manejo da irrigação e risco de $40 \%$. Teresina, Piauí.

\begin{tabular}{|c|c|c|c|c|c|c|c|}
\hline $\begin{array}{c}\text { Época de } \\
\text { Semeadura }\end{array}$ & $\mathrm{p}$ & $\begin{array}{c}\mathrm{RB}^{\mathrm{l}} \\
\left(\mathrm{US} \$ \mathrm{ha}^{-1}\right)\end{array}$ & $\begin{array}{c}E b \\
\left(\mathrm{kWh} \mathrm{ha}{ }^{-1}\right)\end{array}$ & $\begin{array}{c}\text { CE } \\
\left({\left.\text { US } \$ h a^{-1}\right)}^{2}\right.\end{array}$ & $\begin{array}{c}\text { CT } \\
\left({\left.\text { US } \$ \mathrm{ha}^{-1}\right)}^{2}\right.\end{array}$ & $\begin{array}{c}\mathrm{RL} \\
\left(\mathrm{US} \$ \mathrm{ha}^{-1}\right)\end{array}$ & $\mathrm{B} / \mathrm{C}$ \\
\hline \multirow{7}{*}{ 1-Set } & 0,2 & 3811,10 & 898,26 & 51,42 & 1118,53 & 2692,57 & 3,41 \\
\hline & 0,3 & 3569,30 & 889,08 & 50,90 & 1118,00 & 2451,30 & 3,19 \\
\hline & 0,4 & 3104,40 & 880,47 & 50,40 & 1117,51 & 1986,89 & 2,78 \\
\hline & 0,5 & 2863,80 & 869,50 & 49,78 & 1116,88 & 1746,92 & 2,56 \\
\hline & 0,6 & 2516,80 & 860,22 & 49,25 & 1116,35 & 1400,45 & 2,25 \\
\hline & 0,7 & 2305,56 & 852,55 & 48,81 & 1115,91 & 1189,65 & 2,07 \\
\hline & 0,8 & 2049,99 & 842,05 & 48,21 & 1115,31 & 934,68 & 1,84 \\
\hline \multirow{7}{*}{$15-$ Set } & 0,2 & 3804,17 & 880,54 & 50,41 & 1117,51 & 2686,65 & 3,40 \\
\hline & 0,3 & 3554,49 & 869,16 & 49,76 & 1116,86 & 2437,63 & 3,18 \\
\hline & 0,4 & 3100,67 & 857,36 & 49,08 & 1116,19 & 1984,49 & 2,78 \\
\hline & 0,5 & 2862,21 & 847,65 & 48,53 & 1115,63 & 1746,58 & 2,57 \\
\hline & 0,6 & 2520,75 & 839,56 & 48,06 & 1115,17 & 1405,58 & 2,26 \\
\hline & 0,7 & 2315,07 & 833,70 & 47,73 & 1114,83 & 1200,24 & 2,08 \\
\hline & 0,8 & 2060,09 & 844,36 & 48,34 & 1115,44 & 944,65 & 1,85 \\
\hline \multirow{7}{*}{ 1-Out } & 0,2 & 3882,71 & 850,10 & 49,35 & 1116,45 & 2766,26 & 3,48 \\
\hline & 0,3 & 3617,32 & 840,64 & 48,80 & 1115,90 & 2501,42 & 3,24 \\
\hline & 0,4 & 3156,33 & 826,54 & 47,98 & 1115,08 & 2041,25 & 2,83 \\
\hline & 0,5 & 2893,41 & 818,65 & 47,52 & 1114,63 & 1778,78 & 2,60 \\
\hline & 0,6 & 2564,40 & 808,18 & 46,91 & 1114,02 & 1450,38 & 2,30 \\
\hline & 0,7 & 2337,11 & 796,52 & 46,24 & 1113,34 & 1223,77 & 2,10 \\
\hline & 0,8 & 2098,78 & 785,29 & 45,58 & 1112,69 & 986,09 & 1,89 \\
\hline \multirow{7}{*}{ 15-Out } & 0,2 & 3876,13 & 801,65 & 46,53 & 1113,64 & 2762,49 & 3,48 \\
\hline & 0,3 & 3579,76 & 788,43 & 45,77 & 1112,87 & 2466,89 & 3,22 \\
\hline & 0,4 & 3149,74 & 778,52 & 45,19 & 1112,30 & 2037,44 & 2,83 \\
\hline & 0,5 & 2860,20 & 758,83 & 44,05 & 1111,15 & 1749,04 & 2,57 \\
\hline & 0,6 & 2569,31 & 746,80 & 43,35 & 1110,46 & 1458,85 & 2,31 \\
\hline & 0,7 & 2322,92 & 728,25 & 42,27 & 1109,38 & 1213,55 & 2,09 \\
\hline & 0,8 & 2129,19 & 721,98 & 41,91 & 1109,01 & 1020,17 & 1,92 \\
\hline
\end{tabular}


Tabela 31B. Receitas brutas, composição de custos da irrigação, receitas líquidas e relação benefício/custo para a melancia, em cada época de semeadura, nivel de manejo da irrigação e risco de $40 \%$. Teresina, Piauí.

\begin{tabular}{|c|c|c|c|c|c|c|c|}
\hline $\begin{array}{l}\text { Época de } \\
\text { Semeadura }\end{array}$ & $\mathrm{p}$ & $\begin{array}{c}\mathrm{RB}^{1} \\
\left(\mathrm{US} \$ \mathrm{ha}^{-1}\right)\end{array}$ & $\begin{array}{c}\mathrm{Eb} \\
\left(\mathrm{kWh} \mathrm{ha} \mathrm{h}^{-1}\right)\end{array}$ & $\begin{array}{c}\text { CE } \\
\left(\mathrm{US} \$ \mathrm{ha}^{-1}\right)\end{array}$ & $\begin{array}{c}\text { CT } \\
\left(\mathrm{US} \$ \mathrm{ha}^{-1}\right)\end{array}$ & $\begin{array}{c}\mathrm{RL} \\
\left(\mathrm{US} \$ \mathrm{ha}^{-1}\right)\end{array}$ & $\mathrm{B} / \mathrm{C}$ \\
\hline \multirow{7}{*}{ 1-Nov } & 0,2 & 4297,45 & 696,70 & 40,76 & 1107,86 & 3189,58 & 3,88 \\
\hline & 0,3 & 3922,22 & 677,17 & 39,61 & 1106,72 & 2815,50 & 3,54 \\
\hline & 0,4 & 3512,65 & 658,68 & 38,53 & 1105,64 & 2407,01 & 3,18 \\
\hline & 0,5 & 3167,21 & 634,81 & 37,14 & 1104,24 & 2062,97 & 2,87 \\
\hline & 0,6 & 2874,98 & 617,34 & 36,11 & 1103,22 & 1771,76 & 2,61 \\
\hline & 0,7 & 2615,33 & 597,09 & 34,93 & 1102,03 & 1513,30 & 2,37 \\
\hline & 0,8 & 2388,14 & 578,83 & 33,86 & 1100,97 & 1287,18 & 2,17 \\
\hline \multirow{7}{*}{ 15-Nov } & 0,2 & 4301,08 & 607,48 & 35,54 & 1102,64 & 3198,44 & 3,90 \\
\hline & 0,3 & 3893,36 & 579,39 & 33,89 & 1101,00 & 2792,36 & 3,54 \\
\hline & 0,4 & 3536,86 & 545,40 & 31,91 & 1099,01 & 2437,85 & 3,22 \\
\hline & 0,5 & 3212,00 & 527,12 & 30,84 & 1097,94 & 2114,06 & 2,93 \\
\hline & 0,6 & 2935,16 & 499,57 & 29,22 & 1096,33 & 1838,83 & 2,68 \\
\hline & 0,7 & 2688,61 & 476,22 & 27,86 & 1094,96 & 1593,64 & 2,46 \\
\hline & 0,8 & 2498,39 & 457,53 & 26,77 & 1093,87 & 1404,52 & 2,28 \\
\hline \multirow{7}{*}{ 1-Dez } & 0,2 & 4652,59 & 535,51 & 30,67 & 1097,78 & 3554,81 & 4,24 \\
\hline & 0,3 & 4201,02 & 503,53 & 28,84 & 1095,94 & 3105,08 & 3,83 \\
\hline & 0,4 & 3845,25 & 464,40 & 26,60 & 1093,70 & 2751,55 & 3,52 \\
\hline & 0,5 & 3504,17 & 437,51 & 25,06 & 1092,16 & 2412,01 & 3,21 \\
\hline & 0,6 & 3221,54 & 414,31 & 23,73 & 1090,83 & 2130,71 & 2,95 \\
\hline & 0,7 & 3000,96 & 392,27 & 22,47 & 1089,57 & 1911,38 & 2,75 \\
\hline & 0,8 & 2767,35 & 352,19 & 20,17 & 1087,28 & 1680,08 & 2,55 \\
\hline \multirow{7}{*}{ 15-Dez } & 0,2 & 4677,27 & 466,25 & 26,70 & 1093,81 & 3583,46 & 4,28 \\
\hline & 0,3 & 4207,01 & 420,59 & 24,09 & 1091,19 & 3115,82 & 3,86 \\
\hline & 0,4 & 3899,88 & 393,29 & 22,53 & 1089,63 & 2810,25 & 3,58 \\
\hline & 0,5 & 3580,95 & 353,70 & 20,26 & 1087,36 & 2493,58 & 3,29 \\
\hline & 0,6 & 3313,95 & 317,93 & 18,21 & 1085,31 & 2228,64 & 3,05 \\
\hline & 0,7 & 3107,37 & 291,46 & 16,69 & 1083,80 & 2023,57 & 2,87 \\
\hline & 0,8 & 2924,04 & 267,15 & 15,30 & 1082,41 & 1841,63 & 2,70 \\
\hline
\end{tabular}

${ }^{\mathrm{I}} \mathrm{RB}$ - receita bruta; $\mathrm{Eb}$ - energia requerida para o bombeamento; CE - custo de energia elérrica: CT - custo total de produção; $\mathrm{RL}$ - receita liquida e $\mathrm{B} / \mathrm{C}$ - relação benefício/custo. 
Tabela 32B. Receitas líquidas para o feijão caupi (US $\$ \mathrm{ha}^{-1}$ ), em cada época de semeadura, nível de manejo da irrigação e nivel de risco. Parnaiba, Piauí.

\begin{tabular}{|c|c|c|c|c|c|c|c|c|c|}
\hline \multirow{2}{*}{$\begin{array}{l}\text { Época de } \\
\text { Semeadura }\end{array}$} & \multirow[t]{2}{*}{$\mathrm{p}$} & \multicolumn{8}{|c|}{ Nível de risco (\%) } \\
\hline & & 5 & 10 & 15 & 20 & 25 & 30 & 35 & 40 \\
\hline \multirow{7}{*}{ 1-Jan } & 0,2 & 278,22 & 310,56 & 341,47 & 372,25 & 403,41 & 435,23 & 467,92 & 501,70 \\
\hline & 0,3 & 217,75 & 249,57 & 279,63 & 309,41 & 339,45 & 370,06 & 401,49 & 433,92 \\
\hline & 0,4 & 156,68 & 190,23 & 221,04 & 251,16 & 281,32 & 311,90 & 343,20 & 375,45 \\
\hline & 0,5 & 96,38 & 129,53 & 159,59 & 188,77 & 217,89 & 247,35 & 277,46 & 308,44 \\
\hline & 0,6 & 45,44 & 79,41 & 109,64 & 138,73 & 167,60 & 196,72 & 226,40 & 256,91 \\
\hline & 0,7 & $-9,69$ & 25,44 & 56,07 & 85,24 & 113,99 & 142,88 & 172,25 & 202,39 \\
\hline & 0,8 & $-50,74$ & $-15,34$ & 15,16 & 44,01 & 72,35 & 100,76 & 129,59 & 159,14 \\
\hline \multirow{7}{*}{ 15-Jan } & 0,2 & 293,15 & 325,45 & 356,42 & 387,31 & 418,60 & 450,58 & 483,45 & 517,42 \\
\hline & 0,3 & 238,48 & 270,33 & 300,53 & 330,50 & 360,78 & 391,67 & 423,39 & 456,13 \\
\hline & 0,4 & 173,54 & 206,66 & 237,25 & 267,25 & 297,33 & 327,88 & 359,17 & 391,42 \\
\hline & 0,5 & 115,89 & 149,31 & 179,66 & 209,16 & 238,62 & 268,44 & 298,92 & 330,30 \\
\hline & 0,6 & 58,14 & 93,28 & 124,41 & 154,31 & 183,93 & 213,80 & 244,23 & 275,51 \\
\hline & 0,7 & 13,89 & 48,70 & 79,24 & 108,40 & 137,22 & 166,20 & 195,70 & 225,99 \\
\hline & 0,8 & $-26,06$ & 9,71 & 40,62 & 69,92 & 98,73 & 127,63 & 156,99 & 187,09 \\
\hline \multirow{7}{*}{$1-\mathrm{Fev}$} & 0,2 & 245,86 & 279,29 & 311,31 & 343,24 & 375,57 & 408,59 & 442,52 & 477,58 \\
\hline & 0,3 & 197,15 & 230,09 & 261,34 & 292,35 & 323,66 & 355,59 & 388,38 & 422,22 \\
\hline & 0,4 & 128,13 & 163,20 & 195,37 & 226,81 & 258,28 & 290,20 & 322,87 & 356,52 \\
\hline & 0,5 & 84,55 & 118,97 & 150,32 & 180,84 & 211,32 & 242,21 & 273,80 & 306,32 \\
\hline & 0,6 & 31,65 & 67,74 & 99,84 & 130,71 & 161,34 & 192,24 & 223,75 & 256,15 \\
\hline & 0,7 & $-11,19$ & 25,76 & 58,10 & 88,97 & 119,45 & 150,12 & 181,33 & 213,39 \\
\hline & 0,8 & $-55,98$ & $-17,26$ & 15,96 & 47,35 & 78,17 & 109,05 & 140,41 & 172,57 \\
\hline \multirow{7}{*}{$15-\mathrm{Fev}$} & 0,2 & 244,72 & 277,93 & 309,77 & 341,52 & 373,68 & 406,53 & 440,31 & 475,21 \\
\hline & 0,3 & 200,29 & 233,14 & 264,32 & 295,29 & 326,58 & 358,51 & 391,29 & 425,15 \\
\hline & 0,4 & 128,11 & 163,03 & 195,08 & 226,41 & 257,78 & 289,61 & 322,20 & 355,78 \\
\hline & 0,5 & 86,33 & 121,20 & 152,86 & 183,64 & 214,36 & 245,48 & 277,30 & 310,06 \\
\hline & 0,6 & 33,79 & 70,50 & 103,04 & 134,30 & 165,30 & 196,58 & 228,47 & 261,27 \\
\hline & 0,7 & 5,26 & 41,78 & 73,93 & 104,71 & 135,18 & 165,86 & 197,13 & 229,27 \\
\hline & 0,8 & $-41,16$ & $-3,10$ & 29,75 & 60,90 & 91,54 & 122,29 & 153,55 & 185,64 \\
\hline
\end{tabular}


Tabela 32B. Receitas líquidas para o feijão caupi (US\$ ha ${ }^{-1}$ ), em cada época de semeadura, nível de manejo da irrigação e nível de risco. Pamaíba, Piauí.

\begin{tabular}{|c|c|c|c|c|c|c|c|c|c|}
\hline \multirow{2}{*}{$\begin{array}{l}\text { Época de } \\
\text { Semeadura }\end{array}$} & \multirow[t]{2}{*}{$\mathrm{p}$} & \multicolumn{8}{|c|}{ Nivel dè risco (\%) } \\
\hline & & 5 & 10 & 15 & 20 & 25 & 30 & 35 & 40 \\
\hline \multirow{7}{*}{ 1-Mar } & 0,2 & 269,42 & 304,40 & 338,04 & 371,66 & 405,74 & 440,60 & 476,46 & 513,53 \\
\hline & 0,3 & 223,25 & 258,39 & 291,72 & 324,81 & 358,26 & 392,38 & 427,44 & 463,65 \\
\hline & 0,4 & 149,85 & 186,59 & 220,42 & 253,56 & 286,78 & 320,53 & 355,10 & 390,74 \\
\hline & 0,5 & 105,64 & 143,32 & 177,44 & 210,58 & 243,67 & 277,18 & 311,45 & 346,75 \\
\hline & 0,6 & 53,86 & 92,65 & 127,10 & 160,25 & 193,16 & 226,38 & 260,28 & 295,16 \\
\hline & 0,7 & 11,47 & 51,84 & 87,05 & 120,62 & 153,76 & 187,10 & 221,05 & 255,93 \\
\hline & 0,8 & $-26,93$ & $14,37$. & 49,89 & 83,52 & 116,58 & 149,76 & 183,48 & 218,09 \\
\hline \multirow{7}{*}{ 15-Mar } & $0, \mathcal{Z}$ & 260,68 & 295,22 & 328,49 & $36 \mathrm{I}, 75$ & 395,49 & 430,01 & 465,51 & 502,23 \\
\hline & 0,3 & 215,56 & 250,28 & 283,27 & 316,06 & 349,20 & 383,03 & 417,79 & 453,70 \\
\hline & $0 ; 4$ & 141,00 & 176,38 & 209,18 & 241,41 & 273,79 & 306,71 & 340,46 & 375,27 \\
\hline & 0,5 & 95,77 & 131,55 & 164,23 & 196,11 & 228,00 & 260,35 & 293,45 & 327,57 \\
\hline & 0,6 & 40,32 & 77,11 & 110,03 & 141,81 & 173,43 & 205,37 & 237,99 & 271,56 \\
\hline & 0,7 & $-0,33$ & 37,35 & 70,56 & 102,37 & 133,88 & 165,63 & 198,00 & 231,27 \\
\hline & $0 ; 8$ & $-48 ; 19$ & $-8,47$ & $25 ; 77$ & 58,23 & 90,15 & 122,20 & 154,78 & 188,24 \\
\hline \multirow{7}{*}{$1-\mathrm{Abr}$} & 0,2 & 253,41 & 287,15 & 319,93 & 352,82 & 386,27 & 420,54 & 455,83 & 492,34 \\
\hline & 0,3 & 202,50 & 235,98 & 268,10 & 300,17 & 332,68 & 365,93 & 400,13 & 435,50 \\
\hline & 0,4 & 123,09 & 157,53 & 189,64 & 221,29 & 253,15 & 285,58 & 318,84 & 353,18 \\
\hline & 0,5 & 74,61 & 109,37 & 141,29 & 172,52 & 203,82 & 235,61 & 268,17 & 301,75 \\
\hline & 0,6 . & 11,16 & 46,62 & 78,48 & 109,32 & 140,04 & 171,11 & 202,86 & 235,56 \\
\hline & 0,7 & $-29,77$ & 6,47 & 38,53 & 69,32 & 99,85 & 130,64 & 162,05 & 194,35 \\
\hline & 0,8 . & $-77,59$ & $-40,50$ & $-8,26$ & 22,43 & 52,70 & 83,14 & 114,11 & 145,92 \\
\hline \multirow{7}{*}{$15-\mathrm{Abr}$} & 0,2 & 248,01 & $28 \mathrm{I} ; 34$ & 313,81 & $346 ; 46$ & 379,69 & 413,74 & 448,82 & 485,13 \\
\hline & 0,3 & 193,50 & 226,45 & 258,16 & 289,87 & 322,04 & 354,94 & 388,80 & 423,81 \\
\hline & $0 ; 4$ & $113 ; 35$ & $146 ; 75$ & 178,11 & $209 ; 10$ & $240 ; 35$ & 272,18 & 304,86 & 338,60 \\
\hline & 0,5 & 57,08 & 90,97 & 122,18 & 152,74 & 183,40 & 214,53 & 246,43 & 279,32 \\
\hline & 0,6 & $-9,15$ & 25,45 & 56,58 & 86,73 & 116,77 & 147,15 & 178,20 & 210,17 \\
\hline & 0,7 & $-50,40$ & $-16,11$ & 14,43 & 43,85 & 73,07 & 102,57 & 132,67 & 163,64 \\
\hline & $\theta, 8$ & $-102,52$ & $-67,70$ & $-37,23$ & $-8,14$ & $20 ; 59$ & 49,51 & 78,95 & 109,19 \\
\hline
\end{tabular}


Tabela 32B. Receitas líquidas para o feijão caupi (US\$ ha ${ }^{-1}$ ), em cada época de semeadura, nível de manejo da irrigação e nível de risco. Parnaíba, Piauí.

\begin{tabular}{|c|c|c|c|c|c|c|c|c|c|}
\hline \multirow{2}{*}{$\begin{array}{l}\text { Época de } \\
\text { Semeadura }\end{array}$} & \multirow[t]{2}{*}{$\mathrm{p}$} & \multicolumn{8}{|c|}{ Nível de risco (\%) } \\
\hline & & 5 & 10 & 15 & 20 & 25 & 30 & 35 & 40 \\
\hline \multirow{7}{*}{ 1-Mai } & 0,2 & 37,95 & 75,10 & 112,01 & 149,45 & 187,78 & 227,21 & 267,95 & 310,21 \\
\hline & 0,3 & $-6,68$ & 29,18 & 64,57 & 100,41 & 137,03 & 174,68 & 213,57 & 253,89 \\
\hline & 0,4 & $-72,44$ & $-37,29$ & $-3,19$ & 31,05 & 65,91 & 101,67 & 138,55 & 176,76 \\
\hline & 0,5 & $-117,85$ & $-84,17$ & $-51,71$ & $-19,20$ & 13,84 & 47,70 & 82,60 & 118,76 \\
\hline & 0,6 & $-165,95$ & $-133,03$ & $-101,71$ & $-70,52$ & $-38,92$ & $-6,60$ & 26,68 & 61,13 \\
\hline & 0,7 & $-207,52$ & $-175,13$ & $-144,73$ & $-114,63$ & $-84,24$ & $-53,22$ & $-21,31$ & 11,70 \\
\hline & 0,8 & $-246,24$ & $-215,33$ & $-186,49$ & $-158,02$ & $-129,32$ & $-100,05$ & $-69,98$ & $-38,88$ \\
\hline \multirow{7}{*}{ 15-Mai } & 0,2 & 37,14 & 74,63 & 111,81 & 149,52 & 188,10 & 227,78 & 268,78 & 311,30 \\
\hline & 0,3 & $-7,73$ & 27,87 & 63,10 & 98,79 & 135,28 & 172,81 & 211,56 & 251,75 \\
\hline & 0,4 & $-73,11$ & $-37,36$ & $-2,79$ & 31,89 & 67,17 & 103,35 & 140,66 & 179,33 \\
\hline & 0,5 & $-121,14$ & $-87,64$ & $-55,32$ & $-22,93$ & 10,00 & 43,74 & 78,53 & 114,57 \\
\hline & 0,6 & $-167,66$ & $-135,10$ & $-104,04$ & $-73,06$ & $-41,64$ & $-9,49$ & 23,62 & 57,91 \\
\hline & 0,7 & $-209,15$ & $-177,72$ & $-147,98$ & $-118,44$ & $-88,55$ & $-58,00$ & $-26,56$ & 5,98 \\
\hline & 0,8 & $-247,82$ & $-217,84$ & $-189,64$ & $-161,71$ & $-133,49$ & $-104,67$ & $-75,03$ & $-44,36$ \\
\hline \multirow{7}{*}{ 1-Jun } & 0,2 & 133,16 & 168,30 & 202,85 & 237,73 & 273,31 & 309,84 & 347,52 & 386,55 \\
\hline & 0,3 & 81,20 & 113,94 & 146,22 & 178,84 & 212,14 & 246,32 & 281,58 & 318,11 \\
\hline & 0,4 & 11,36 & 45,14 & 77,47 & 109,74 & 142,44 & 175,88 & 210,30 & 245,90 \\
\hline & 0,5 & $-46,69$ & $-16,24$ & 13,08 & 42,41 & 72,17 & 102,62 & 133,97 & 166,39 \\
\hline & 0,6 & $-98,14$ & $-66,82$ & $-37,38$ & $-8,25$ & 21,14 & 51,11 & 81,89 & 113,71 \\
\hline & 0,7 & $-151,73$ & $-122,77$ & $-95,58$ & $-68,71$ & $-41,61$ & $-14,00$ & 14,35 & 43,64 \\
\hline & 0,8 & $-193,65$ & $-164,60$ & $-137,78$ & $-111,47$ & $-85,07$ & $-58,22$ & $-30,69$ & $-2,29$ \\
\hline \multirow{7}{*}{ 15-Jun } & 0,2 & 138,73 & 174,36 & 209,38 & 244,73 & 280,79 & 317,80 & 355,98 & 395,52 \\
\hline & 0,3 & 77,25 & 110,25 & 142,75 & 175,57 & 209,06 & 243,43 & 278,89 & 315,61 \\
\hline & 0,4 & 22,44 & 56,02 & 88,39 & 120,77 & 153,65 & 187,30 & 221,94 & 257,79 \\
\hline & 0,5 & $-50,02$ & $-19,63$ & 9,70 & 39,05 & 68,85 & 99,35 & 130,75 & 163,24 \\
\hline & 0,6 & $-88,13$ & $-57,87$ & $-29,03$ & $-0,32$ & 28,73 & 58,42 & 88,94 & 120,50 \\
\hline & 0,7 & $-154,07$ & $-124,25$ & $-96,38$ & $-68,90$ & $-41,23$ & $-13,04$ & 15,90 & 45,78 \\
\hline & 0,8 & $-188,92$ & $-160,89$ & $-134,68$ & $-108,83$ & $-82,79$ & $-56,27$ & $-29,06$ & $-0,96$ \\
\hline
\end{tabular}


Tabela 32B. Receitas líquidas para o feijão caupi (US\$ $\mathrm{ha}^{-1}$ ), em cada época de semeadura, nível de manejo da irrigação e nível-de risco. Parnaiba, Piauí.

\begin{tabular}{|c|c|c|c|c|c|c|c|c|c|}
\hline \multirow{2}{*}{$\begin{array}{l}\text { Época de } \\
\text { Semeadura }\end{array}$} & \multirow[t]{2}{*}{$\mathrm{p}$} & \multicolumn{8}{|c|}{ Nivel de risco (\%) } \\
\hline & & 5 & 10 & 15 & 20 & 25 & 30 & 35 & 40 \\
\hline \multirow{7}{*}{ 1-Jul } & 0,2 & 154,59 & $186,8 T$ & 218,52 & 250,41 & 282,92 & 316,26 & 350,63 & 386,21 \\
\hline & 0,3 & 83,81 & 113,59 & 142,80 & 172,23 & 202,22 & 232,98 & 264,68 & 297,49 \\
\hline & 0,4 & 37,35 & 67,63 & 96,78 & 125,91 & 155,47 & 185,70 & 216,81 & 248,98 \\
\hline & 0,5 & $-41,59$ & $-12,56$ & 14,97 & 42,30 & 69,92 & 98,10 & 127,06 & 156,97 \\
\hline & 0,6 & $-80,36$ & $-53,86$ & $-28,49$ & $-3,22$ & 22,38 & 48,52 & 75,40 & 103,18 \\
\hline & 0,7 & $-140,23$ & $-113,15$ & $-87,90$ & $-63,04$ & $-38,04$ & $-12,61$ & 13,47 & 40,39 \\
\hline & 0,8 & $-184,02$ & $-158,96$ & $-135,58$ & $-112,55$ & $-89,38$ & $-65,80$ & $-41,64$ & $-16,70$ \\
\hline \multirow{7}{*}{ 15-Jul } & 0,2 & 160,53 & 193,20 & 225,23 & 257,52 & 290,42 & 324,16 & 358,93 & 394,94 \\
\hline & 0,3 & 83,14 & 113,26 & 142,76 & 172,48 & 202,74 & 233,77 & 265,75 & 298,84 \\
\hline & 0,4 & 44,80 & 74,23 & 102,88 & 131,67 & 160,95 & 190,94 & 221,83 & 253,78 \\
\hline & 0,5 & $-30,74$ & $-0,27$ & 28,46 & 56,92 & 85,63 & 114,91 & 144,97 & 176,02 \\
\hline & 0,6 & $-83,71$ & $-57,17$ & $-31,75$ & $-6 ; 41$ & $19 ; 26$ & 45,48 & 72,43 & 100,28 \\
\hline & 0,7 & $-127,47$ & $-100,51$ & $-75,17$ & $-50,13$ & $-24,89$ & 0,81 & 27,20 & 54,43 \\
\hline & 0,8 & $-190 ; 52$ & $-164,7-1$ & $-140,76$ & $-117,24$ & $-93,6 z$ & $-69,61$ & $-45,01$ & $-19,64$ \\
\hline \multirow{7}{*}{ 1-Ago } & 0,2 & 111,09 & 144,33 & 177,35 & 210,85 & 245,12 & 280,36 & 316,76 & 354,48 \\
\hline & 0,3 & 32,76 & 63,50 & 93,94 & 124,77 & 156,28 & 188,67 & 222,10 & 256,75 \\
\hline & 0,4 & $-4,18$ & 25,40 & 54,64 & 84,24 & 114,47 & 145,53 & 177,59 & 210,81 \\
\hline & 0,5 & $-55,97$ & $-25,76$ & 3,43 & 32,68 & 62,40 & 92,85 & 124,22 & 156,70 \\
\hline & 0,6 & $-127,93$ & $-101,25$ & $-75,33$ & $-49,30$ & $-22,81$ & 4,34 & 32,31 & 61,28 \\
\hline & 0,7 & $-156,23$ & $-131,04$ & $-106,47$ & $-81,75$ & $-56,59$ & $-30,79$ & $-4,19$ & 23,34 \\
\hline & 0,8 & $-214,91$ & $-188,24$ & $-163,18$ & $-138,37$ & $-113,35$ & $-87,82$ & $-61,59$ & $-34,49$ \\
\hline \multirow{7}{*}{ 15-Ago } & $\theta, 2$ & If 5,83 & 149,27 & 182,53 & $216 ; 28$ & 250,81 & 286,32 & 322,99 & 361,00 \\
\hline & 0,3 & 35,49 & 66,90 & 97,91 & 129,26 & 161,27 & 194,16 & 228,10 & 263,27 \\
\hline & $\theta, 4$ & $-3,59$ & $26 ; 08$ & 55,44 & 85,16 & 115,53 & 146,73 & 178,93 & 212,30 \\
\hline & 0,5 & $-44,45$ & $-14,73$ & 14,27 & 43,44 & 73,14 & 103,60 & 135,01 & 167,53 \\
\hline & 0,6 & $-126,48$ & $-98,45$ & $-71,49$ & $-44,53$ & $-17,18$ & 10,82 & 39,65 & 69,48 \\
\hline & 0,7 & $-159,70$ & $-134,49$ & $-109,92$ & $-85,22$ & $-60,08$ & $-34,31$ & $-7,76$ & 19,72 \\
\hline & $0 ; 8$ & $-199,56$ & $-173 ; 4-1$ & $-148,52$ & $-123 ; 77$ & $-98,73$ & $-73,14$ & $-46,82$ & $-19,61$ \\
\hline
\end{tabular}


Tabela 32B. Receitas líquidas para o feijão caupi (US $\$ \mathrm{ha}^{-1}$ ), em cada época de semeadura, nível de manejo da irrigação e nível de risco. Parnaíba, Piauí.

\begin{tabular}{|c|c|c|c|c|c|c|c|c|c|}
\hline \multirow{2}{*}{$\begin{array}{l}\text { Época de } \\
\text { Semeadura }\end{array}$} & \multirow[t]{2}{*}{$\mathrm{p}$} & \multicolumn{8}{|c|}{ Nível de risco (\%) } \\
\hline & & 5 & 10 & 15 & 20 & 25 & 30 & 35 & 40 \\
\hline \multirow{7}{*}{ 1-Set } & 0,2 & 136,62 & 168,56 & 200,62 & 233,31 & 266,87 & 301,46 & 337,24 & 374,38 \\
\hline & 0,3 & 54,11 & 84,93 & 115,41 & 146,29 & 177,87 & 210,36 & 243,94 & 278,77 \\
\hline & 0,4 & 11,29 & 39,61 & 67,86 & 96,58 & 126,03 & 156,35 & 187,71 & 220,25 \\
\hline & 0,5 & $-21,31$ & 6,61 & 34,27 & 62,30 & 90,99 & 120,50 & 151,00 & 182,64 \\
\hline & 0,6 & $-110,40$ & $-82,10$ & $-55,00$ & $-27,94$ & $-0,46$ & 27,69 & 56,69 & 86,73 \\
\hline & 0,7 & $-148,54$ & $-124,61$ & $-101,06$ & $-77,25$ & $-52,92$ & $-27,93$ & $-2,12$ & 24,65 \\
\hline & 0,8 & $-167,68$ & $-144,08$ & $-120,95$ & $-97,62$ & $-73,80$ & $-49,34$ & $-24,08$ & 2,10 \\
\hline \multirow{7}{*}{ 15-Set } & 0,2 & 138,00 & 170,02 & 202,15 & 234,90 & 268,50 & 303,14 & 338,96 & 376,15 \\
\hline & 0,3 & 54,16 & 84,73 & 115,01 & 145,72 & 177,14 & 209,48 & 242,89 & 277,56 \\
\hline & 0,4 & 12,54 & 38,50 & 68,91 & 96,29 & 128,62 & 157,89 & 192,57 & 224,20 \\
\hline & 0,5 & $-21,79$ & 6,54 & 34,48 & 62,75 & 91,65 & 121,37 & 152,06 & 183,89 \\
\hline & 0,6 & $-108,94$ & $-80,62$ & $-53,50$ & $-26,41$ & 1,09 & 29,25 & 58,27 & 88,33 \\
\hline & 0,7 & $-148,29$ & $-123,63$ & $-99,54$ & $-75,28$ & $-50,54$ & $-25,15$ & 1,06 & 28,22 \\
\hline & 0,8 & $-170,59$ & $-146,31$ & $-122,73$ & $-99,02$ & $-74,87$ & $-50,09$ & $-24,53$ & 1,95 \\
\hline \multirow{7}{*}{ 1-Out } & 0,2 & 165,97 & 195,41 & 222,05 & 249,32 & 280,86 & 309,84 & 343,53 & 374,72 \\
\hline & 0,3 & 85,13 & 112,70 & 139,63 & 166,72 & 194,31 & 222,61 & 251,77 & 281,97 \\
\hline & 0,4 & 39,79 & 65,44 & 90,61 & 115,99 & 141,88 & 168,44 & 195,84 & 224,20 \\
\hline & 0,5 & 3,08 & 28,64 & 53,45 & 78,35 & 103,68 & 129,62 & 156,35 & 184,00 \\
\hline & 0,6 & $-86,98$ & $-61,23$ & $-37,01$ & $-13,05$ & 11,13 & 35,79 & 61,11 & 87,26 \\
\hline & 0,7 & $-127,96$ & $-105,37$ & $-83,75$ & $-62,18$ & $-40,32$ & $-17,98$ & 5,00 & 28,75 \\
\hline & 0,8 & $-148,39$ & $-126,47$ & $-105,50$ & $-84,59$ & $-63,40$ & $-41,75$ & $-19,48$ & 3,54 \\
\hline \multirow{7}{*}{ 15-Out } & 0,2 & 166,68 & 195,37 & 223,72 & 252,40 & 281,71 & 311,81 & 342,88 & 375,07 \\
\hline & 0,3 & 81,25 & 108,48 & 135,10 & 161,91 & 189,22 & 217,23 & 246,10 & 276,00 \\
\hline & 0,4 & 40,30 & 66,13 & 91,41 & 116,89 & 142,86 & 169,49 & 196,95 & 225,39 \\
\hline & 0,5 & 2,05 & 27,75 & 52,64 & 77,58 & 102,94 & 128,90 & 155,65 & 183,32 \\
\hline & 0,6 & $-89,42$ & $-63,89$ & $-39,86$ & $-16,08$ & 7,91 & 32,37 & 57,50 & 83,45 \\
\hline & 0,7 & $-123,94$ & $-101,26$ & $-79,57$ & $-57,94$ & $-36,03$ & $-13,65$ & 9,38 & 33,18 \\
\hline & 0,8 & $-160,07$ & $-136,57$ & $-114,57$ & $-92,85$ & $-70,97$ & $-48,69$ & $-25,83$ & $-2,22$ \\
\hline
\end{tabular}


Tabela 32B. Receitas líquidas para o feijão caupi (US\$ ha ${ }^{-1}$ ), em cada época de semeadura, nível de manejo da irrigação e nível de risco. Pamaíba, Piauí.

\begin{tabular}{|c|c|c|c|c|c|c|c|c|c|}
\hline \multirow{2}{*}{$\begin{array}{l}\text { Época de } \\
\text { Semeadura }\end{array}$} & \multirow[t]{2}{*}{$\mathrm{p}$} & \multicolumn{8}{|c|}{ Nivel de risco (\%) } \\
\hline & & 5 & 10 & 15 & 20 & 25 & 30 & 35 & 40 \\
\hline \multirow{7}{*}{ 1-Nov } & 0,2 & 324,94 & 356,98 & 388,17 & 419,50 & 451,37 & 484,03 & 517,66 & 552,45 \\
\hline & 0,3 & 237,11 & 267,18 & 296,30 & 325,48 & 355,12 & 385,46 & 416,69 & 448,98 \\
\hline & 0,4 & 187,88 & 217,30 & 245,58 & 273,82 & 302,46 & 331,73 & 361,84 & 392,96 \\
\hline & 0,5 & 117,05 & 147,23 & 175,52 & 203,46 & 231,59 & 260,24 & 289,63 & 319,96 \\
\hline & 0,6 & 37,84 & 66,43 & 93,00 & 119,10 & 145,33 & 171,99 & 199,31 & 227,48 \\
\hline & 0,7 & $-6,31$ & 21,17 & 46,59 & 71,54 & 96,56 & 121,98 & 148,02 & 174,85 \\
\hline & 0,8 & $-72,10$ & $-43,66$ & $-18,04$ & 6,76 & 31,46 & 56,42 & 81,90 & 108,12 \\
\hline \multirow{7}{*}{$15-\mathrm{Nov}$} & 0,2 & 319,70 & 351,67 & 382,68 & $4 \mathrm{~T} 3,8 \mathrm{~T}$ & 445,44 & 477,84 & 511,20 & 545,72 \\
\hline & 0,3 & 236,39 & 267,26 & 296,87 & 326,42 & 356,36 & 386,96 & 418,44 & 450,98 \\
\hline & 0,4 & 187,74 & 218,19 & 247,13 & $275 ; 89$ & 304,96 & 334,63 & 365,11 & 396,60 \\
\hline & 0,5 & 106,45 & 138,33 & 167,68 & 196,40 & 225,19 & 254,41 & 284,32 & 315,16 \\
\hline & 0,6 & 44,62 & 74,21 & $10 \mathrm{r}, 46$ & 128,12 & 154,83 & 181,95 & 209,71 & 238,31 \\
\hline & 0,7 & $-3,17$ & 26,59 & 53,59 & 79,82 & 105,98 & 132,47 & 159,53 & 187,38 \\
\hline & 0,8 & $-68,35$ & $-38,27$ & $-11 ; 54$ & 14,15 & 39,63 & 65,32 & 91,51 & 118,41 \\
\hline \multirow{7}{*}{ 1-Dez } & 0,2 & 352,26 & 383,90 & 414,07 & 444,08 & 474,44 & 505,41 & 537,23 & 570,09 \\
\hline & 0,3 & 277,53 & 307,25 & 335,54 & 363,64 & 392,05 & 421,02 & 450,77 & 481,48 \\
\hline & 0,4 & 219,12 & 249,64 & $278,0.7$ & 306,06 & 334,17 & 362,76 & 392,04 & 422,23 \\
\hline & 0,5 & 138,09 & 168,98 & 197,12 & 224,49 & 251,82 & 279,49 & 307,75 & 336,84 \\
\hline & 0,6 & 76,22 & 106,76 & 134,22 & 160,77 & 187,17 & 213,83 & 241,03 & 268,99 \\
\hline & 0,7 & 21,00 & 51,62 & 78,73 & 104,75 & 130,50 & 156,43 & 182,83 & 209,92 \\
\hline & 0,8 & $-34,72$ & $-4,67$ & 21,66 & 46,77 & 71,54 & 96,42 & 121,71 & 147,65 \\
\hline \multirow{7}{*}{ 15-Dez } & $0 ; 2$ & 352,46 & 383,73 & $4 \mathrm{I} 3,57$ & 443,26 & $473 ; 30$ & 503,96 & 535,45 & 567,98 \\
\hline & 0,3 & 280,64 & 310,78 & 339,31 & 367,58 & 396,12 & 425,21 & 455,05 & 485,86 \\
\hline & 0,4 & 220,78 & 252,19 & $28 \cdot 1,19$ & $309 ; 60$ & $338 ; 08$ & 366,99 & 396,58 & 427,07 \\
\hline & 0,5 & 137,81 & 170,20 & 199,32 & 227,47 & 255,48 & 283,76 & 312,62 & 342,29 \\
\hline & 0,6 & 84,10 & $116 ; 38$ & $145 ; 04$ & 172,58 & 199,87 & 227,37 & 255,37 & 284,14 \\
\hline & 0,7 & 23,90 & 56,56 & 85,07 & 112,21 & 138,96 & 165,82 & 193,11 & 221,09 \\
\hline & 0,8 & $-28,00$ & 5,67 & $34,5 \cdot 1$ & 61,72 & 88,37 & 115,02 & 142,03 & 169,68 \\
\hline
\end{tabular}


Tabela 33B. Receitas líquidas para o feijão caupi (US\$ ha ${ }^{-1}$ ), em cada época de semeadura, nível de manejo da irrigação e nível de risco. Teresina, Piauí.

\begin{tabular}{|c|c|c|c|c|c|c|c|c|c|}
\hline \multirow{2}{*}{$\begin{array}{c}\text { Época de } \\
\text { Semeadura }\end{array}$} & \multirow[t]{2}{*}{$\mathrm{p}$} & \multicolumn{8}{|c|}{ Nível de risco (\%) } \\
\hline & & 5 & 10 & 15 & 20 & 25 & 30 & 35 & 40 \\
\hline \multirow{7}{*}{ 1-Jan } & 0,2 & 265,12 & 295,54 & 324,85 & 354,17 & 383,91 & 414,34 & 445,64 & 478,01 \\
\hline & 0,3 & 204,87 & 237,47 & 267,87 & 297,80 & 327,92 & 358,57 & 390,00 & 422,43 \\
\hline & 0,4 & 147,89 & 180,65 & 210,69 & 240,05 & 269,46 & 299,29 & 329,84 & 361,31 \\
\hline & 0,5 & 86,76 & 121,08 & 151,76 & 181,35 & 210,78 & 240,49 & 270,83 & 302,03 \\
\hline & 0,6 & 51,71 & 86,90 & 117,90 & 147,61 & 177,01 & 206,63 & 236,82 & 267,85 \\
\hline & 0,7 & 4,25 & 41,92 & 74,32 & 104,98 & 135,11 & 165,32 & 196,02 & 227,52 \\
\hline & 0,8 & $-35,12$ & 4,77 & 38,45 & 69,99 & 100,80 & 131,58 & 162,77 & 194,71 \\
\hline \multirow{7}{*}{ 15-Jan } & 0,2 & 280,15 & 311,91 & 342,28 & 372,54 & 403,19 & 434,50 & 466,70 & 499,98 \\
\hline & 0,3 & 225,97 & 259,00 & 289,84 & 320,23 & 350,82 & 381,96 & 413,89 & 446,85 \\
\hline & 0,4 & 171,81 & 205,83 & 236,94 & 267,30 & 297,68 & 328,50 & 360,05 & 392,56 \\
\hline & 0,5 & 122,50 & 157,44 & 188,81 & 219,14 & 249,34 & 279,87 & 311,05 & 343,15 \\
\hline & 0,6 & 81,74 & 118,59 & 150,99 & 181,99 & 212,66 & 243,55 & 275,02 & 307,36 \\
\hline & 0,7 & 41,75 & 80,49 & 113,92 & 145,60 & 176,77 & 208,06 & 239,86 & 272,50 \\
\hline & 0,8 & 1,46 & 41,62 & 75,90 & 113,91 & 145,52 & 177,22 & 209,43 & 242,50 \\
\hline \multirow{7}{*}{$1-\mathrm{Fev}$} & 0,2 & 246,36 & 279,08 & 310,49 & 341,84 & 373,62 & 406,11 & 439,54 & 474,09 \\
\hline & 0,3 & 195,25 & 229,41 & 261,40 & 292,96 & 324,77 & 357,16 & 390,40 & 424,72 \\
\hline & 0,4 & 149,56 & 184,63 & 216,87 & 248,41 & 280,04 & 312,16 & 345,07 & 379,01 \\
\hline & 0,5 & 101,38 & 138,41 & 171,64 & 203,79 & 235,81 & 268,20 & 301,30 & 335,40 \\
\hline & 0,6 & 71,13 & 110,05 & 144,37 & 177,29 & 209,93 & 242,84 & 276,42 & 310,96 \\
\hline & 0,7 & 38,11 & 79,21 & 115,49 & 148,02 & 182,43 & 214,92 & 248,09 & 284,27 \\
\hline & 0,8 & 14,66 & 54,90 & 92,46 & 125,64 & 160,89 & 193,81 & 227,36 & 261,88 \\
\hline \multirow{7}{*}{$15-\mathrm{Fev}$} & 0,2 & 243,93 & 277,34 & 309,17 & 340,85 & 372,91 & 405,65 & 439,30 & 474,07 \\
\hline & 0,3 & 191,41 & 226,38 & 258,88 & 290,86 & 323,02 & 355,74 & 389,29 & 423,92 \\
\hline & 0,4 & 144,33 & 181,14 & 214,56 & 247,07 & 279,54 & 312,45 & 346,11 & 380,80 \\
\hline & 0,5 & 101,34 & 139,52 & 173,55 & 206,35 & 238,95 & 271,88 & 305,50 & 340,11 \\
\hline & 0,6 & 72,44 & 112,56 & 147,73 & 181,35 & 214,59 & 248,08 & 282,21 & 317,30 \\
\hline & 0,7 & 38,68 & 79,74 & 118,37 & 152,34 & 185,90 & 222,39 & 256,78 & 294,76 \\
\hline & 0,8 & 4,10 & 48,73 & 89,37 & 125,10 & 162,66 & 197,76 & 233,46 & 270,13 \\
\hline
\end{tabular}


Tabela 33B. Receitas líquidas para o feijão caupi (US\$ ha ${ }^{-1}$ ), em cada época de semeadura, nível de manejo-da irrigação e nível de risco. Teresina, Piauí.

\begin{tabular}{|c|c|c|c|c|c|c|c|c|c|}
\hline \multirow{2}{*}{$\begin{array}{l}\text { Época de } \\
\text { Semeadura }\end{array}$} & \multirow[t]{2}{*}{$\mathrm{p}$} & \multicolumn{8}{|c|}{ Nivel de risco (\%) } \\
\hline & & 5 & 10 & 15 & 20 & 25 & 30 & 35 & 40 \\
\hline \multirow{7}{*}{ 1-Mar } & 0,2 & 268,87 & 303,40 & 336,59 & 369,77 & 403,42 & 437,84 & 473,27 & 509,90 \\
\hline & 0,3 & 209,05 & 245,83 & 280,10 & 313,87 & 347,85 & 382,45 & 417,95 & 454,61 \\
\hline & 0,4 & $166 ; 60$ & 203,93 & 238,20 & 271,74 & 305,36 & 339,51 & 374,51 & 410,61 \\
\hline & 0,5 & 122,03 & 161,15 & 196,32 & 230,39 & 264,34 & 298,71 & 333,85 & 370,05 \\
\hline & $\theta ; 6$ & $85 ; 86$ & 127,27 & 163,78 & $198 ; 79$ & 23,$3 ; 51$ & 268,52 & 304,25 & 341,02 \\
\hline & 0,7 & 49,05 & 92,82 & 130,69 & 166,68 & 202,16 & 237,83 & 274,15 & 311,48 \\
\hline & 0,8 & 15,77 & 60,76 & 101,39 & 139,84 & 177,61 & 213,60 & 250,26 & 287,96 \\
\hline \multirow{7}{*}{ 15-Mar } & 0,2 & 258,17 & 292,34 & 32523 & 358,10 & 391,46 & 425,58 & 460,70 & 497,01 \\
\hline & 0,3 & 190,63 & 225,88 & 258,93 & 291,59 & 324,50 & 358,04 & 392,46 & 428,00 \\
\hline & 0,4 & 146,82 & 183,14 & 216,57 & 249,30 & 282,14 & 315,49 & 349,66 & 384,90 \\
\hline & 0,5 & 82,44 & 121,21 & 155,83 & 189,25 & 222,49 & 256,08 & 290,39 & 325,72 \\
\hline & 0,6 & 39,36 & $79 ; 87$ & $115 ; 37$ & $149 ; 30$ & 182,86 & 216,67 & 251,12 & 286,55 \\
\hline & 0,7 & 7,33 & 49,01 & 85,07 & 119,30 & 153,04 & 186,94 & 221,44 & 256,88 \\
\hline & 0,8 & $-31,08$ & 11,03 & 49,95 & 84,17 & 120,43 & 154,21 & 188,62 & 224,01 \\
\hline \multirow{7}{*}{$1-\mathrm{Abr}$} & 0,2 & 236,81 & 270,61 & 303,18 & 335,76 & $368 ; 84$ & 402,69 & 437,52 & 473,56 \\
\hline & 0,3 & 161,69 & 196,82 & 229,68 & 262,12 & 294,81 & 328,11 & 362,30 & 397,60 \\
\hline & 0,4 & 114,97 & 150,41 & 183,08 & $215,1-1$ & 247,25 & 279,91 & 313,39 & 347,94 \\
\hline & 0,5 & 51,05 & 87,64 & 120,58 & 152,49 & 184,30 & 216,48 & 249,39 & 283,28 \\
\hline & 0,6 & 1,08 & $39 ; 43$ & 73,18 & $105 ; 50$ & 137,51 & 169,77 & 202,66 & 236,48 \\
\hline & 0,7 & $-40,23$ & $-0,45$ & 33,97 & 66,65 & 98,84 & 131,18 & 164,09 & 197,89 \\
\hline & 0,8 & $-83,92$ & $-42,07$ & $-6,54$ & $26 ; 85$ & 59,55 & 92,28 & 125,50 & 159,58 \\
\hline \multirow{7}{*}{$15-\mathrm{Abr}$} & 0,2 & 222,63 & 255,84 & 287,94 & 320,09 & 352,76 & 386,20 & 420,63 & 456,26 \\
\hline & 0,3 & 143,09 & 176,50 & 208,05 & 239,32 & 270,91 & 303,13 & 336,23 & 370,43 \\
\hline & 0,4 & 89,35 & 122,83 & 153,95 & 184,56 & 215,35 & 246,67 & 278,80 & 311,95 \\
\hline & 0,5 & 20,30 & 54,53 & 85,58 & 115,78 & 145,94 & 176,50 & 207,75 & 239,96 \\
\hline & 0,6 & $-38,97$ & $-3,69$ & 27,61 & 57,71 & 87,58 & 117,73 & 148,48 & 180,12 \\
\hline & 0,7 & $-88,16$ & $-51,75$ & $-20,07$ & 10,10 & 39,86 & 69,79 & 100,25 & 131,55 \\
\hline & 0,8 & $-130,74$ & $-93,69$ & $-61,92$ & $-31 ; 91$ & $-2,44$ & 27,11 & 57,13 & 87,94 \\
\hline
\end{tabular}


Tabela 33B. Receitas líquidas para o feijão caupi (US\$ ha ${ }^{-1}$ ), em cada época de semeadura, nível de manejo da irrigação e nível de risco. Teresina, Piauí.

\begin{tabular}{|c|c|c|c|c|c|c|c|c|c|}
\hline \multirow{2}{*}{$\begin{array}{l}\text { Época de } \\
\text { Semeadura }\end{array}$} & \multirow[t]{2}{*}{$\mathrm{p}$} & \multicolumn{8}{|c|}{ Nível de risco (\%) } \\
\hline & & 5 & 10 & 15 & 20 & 25 & 30 & 35 & 40 \\
\hline \multirow{7}{*}{ 1-Mai } & 0,2 & 18,15 & 54,23 & 89,98 & 126,22 & 163,30 & 201,43 & 240,82 & 281,67 \\
\hline & 0,3 & $-51,20$ & $-15,53$ & 19,09 & 53,87 & 89,29 & 125,62 & 163,11 & 201,95 \\
\hline & 0,4 & $-95,31$ & $-60,48$ & $-27,01$ & 6,46 & 40,46 & 75,29 & 111,19 & 148,38 \\
\hline & 0,5 & $-154,23$ & $-119,97$ & $-87,64$ & $-55,56$ & $-23,11$ & 10,04 & 44,16 & 79,47 \\
\hline & 0,6 & $-200,03$ & $-166,21$ & $-134,76$ & $-103,76$ & $-72,52$ & $-40,66$ & $-7,91$ & 25,97 \\
\hline & 0,7 & $-237,70$ & $-203,41$ & $-172,05$ & $-141,39$ & $-110,61$ & $-79,30$ & $-47,15$ & $-13,91$ \\
\hline & 0,8 & $-279,39$ & $-245,82$ & $-215,53$ & $-186,09$ & $-156,64$ & $-126,75$ & $-96,10$ & $-64,44$ \\
\hline \multirow{7}{*}{ 15-Mai } & 0,2 & 13,66 & 48,99 & 84,21 & 120,01 & 156,69 & 194,45 & 233,48 & 273,98 \\
\hline & 0,3 & $-49,47$ & $-14,57$ & 19,59 & 54,04 & 89,20 & 125,31 & 162,60 & 201,26 \\
\hline & 0,4 & $-99,13$ & $-66,52$ & $-34,65$ & $-2,54$ & 30,20 & 63,83 & 98,53 & 134,50 \\
\hline & 0,5 & $-165,17$ & $-132,88$ & $-102,04$ & $-71,26$ & $-40,02$ & $-8,05$ & 24,90 & 59,03 \\
\hline & 0,6 & $-205,27$ & $-173,74$ & $-143,94$ & $-114,34$ & $-84,38$ & $-53,74$ & $-22,21$ & 10,45 \\
\hline & 0,7 & $-246,76$ & $-216,73$ & $-188,54$ & $-160,64$ & $-132,45$ & $-103,66$ & $-74,03$ & $-43,38$ \\
\hline & 0,8 & $-291,36$ & $-260,82$ & $-232,79$ & $-205,32$ & $-177,72$ & $-149,62$ & $-120,76$ & $-90,92$ \\
\hline \multirow{7}{*}{ 1-Jun } & 0,2 & 102,14 & 134,82 & 167,20 & 200,01 & 233,54 & 268,00 & 303,57 & 340,43 \\
\hline & 0,3 & 38,67 & 71,31 & 103,04 & 134,90 & 167,33 & 200,56 & 234,81 & 270,27 \\
\hline & 0,4 & $-27,72$ & 2,51 & 31,81 & 61,21 & 91,10 & 121,73 & 153,28 & 185,95 \\
\hline & 0,5 & $-93,22$ & $-64,07$ & $-36,21$ & $-8,44$ & 19,71 & 48,48 & 78,09 & 108,71 \\
\hline & 0,6 & $-138,88$ & $-110,04$ & $-82,86$ & $-55,95$ & $-28,78$ & $-1,07$ & 27,40 & 56,83 \\
\hline & 0,7 & $-189,20$ & $-161,90$ & $-136,34$ & $-111,11$ & $-85,68$ & $-59,77$ & $-33,16$ & $-5,68$ \\
\hline & 0,8 & $-236,27$ & $-208,64$ & $-182,73$ & $-159,21$ & $-135,49$ & $-111,29$ & $-86,41$ & $-60,68$ \\
\hline \multirow{7}{*}{ 15-Jun } & 0,2 & 103,93 & 136,60 & 169,05 & 201,94 & 235,58 & 270,17 & 305,87 & 342,87 \\
\hline & 0,3 & 45,74 & 78,47 & 110,38 & 142,47 & 175,15 & 208,66 & 243,21 & 278,98 \\
\hline & 0,4 & $-27,81$ & 1,91 & 30,89 & 60,03 & 89,71 & 120,12 & 151,47 & 183,93 \\
\hline & 0,5 & $-92,55$ & $-62,15$ & $-33,33$ & $-4,69$ & 24,28 & 53,86 & 84,28 & 115,73 \\
\hline & 0,6 & $-140,11$ & $-112,32$ & $-85,87$ & $-59,55$ & $-32,92$ & $-5,71$ & 22,27 & 51,20 \\
\hline & 0,7 & $-191,91$ & $-165,06$ & $-139,81$ & $-114,83$ & $-89,63$ & $-63,93$ & $-37,53$ & $-10,25$ \\
\hline & 0,8 & $-228,74$ & $-203,39$ & $-179,61$ & $-156,11$ & $-132,42$ & $-108,28$ & $-83,50$ & $-57,90$ \\
\hline
\end{tabular}


Tabela 33B. Receitas líquidas para o feijão caupi (US\$ ha ${ }^{-1}$ ), em cada época de semeadura, nível-de manejo da irrigação e nível de risco. Teresina, Piauí.

\begin{tabular}{|c|c|c|c|c|c|c|c|c|c|}
\hline \multirow{2}{*}{$\begin{array}{l}\text { Época de } \\
\text { Semeadura }\end{array}$} & \multirow[t]{2}{*}{$\mathrm{p}$} & \multicolumn{8}{|c|}{ Nível de risco (\%) } \\
\hline & & 5 & 10 & 15 & 20 & 25 & 30 & 35 & 40 \\
\hline \multirow{7}{*}{ 1-Jul } & 0,2 & 116,73 & 146,46 & 175,85 & 205,58 & 235,94 & 267,13 & 299,30 & 332,63 \\
\hline & 0,3 & 62,98 & 92,34 & 120,97 & 149,78 & 179,11 & 209,18 & 240,16 & 272,24 \\
\hline & 0,4 & $-16,12$ & $10 ; 41$ & $36 ; 30$ & 62,35 & $88 ; 86$ & 116,03 & 144,02 & 173,00 \\
\hline & 0,5 & $-69,37$ & $-42,51$ & $-16,86$ & 8,69 & 34,56 & 60,99 & 88,16 & 116,26 \\
\hline & $\theta ; 6$ & $-127,52$ & $-10 z, 8 z$ & $-79,20$ & $-54,19$ & $-30,35$ & $-5,99$ & 19,08 & 45,01 \\
\hline & 0,7 & $-180,15$ & $-154,54$ & $-130,79$ & $-107,44$ & $-83,99$ & $-60,14$ & $-35,69$ & $-10,46$ \\
\hline & $\theta ; 8$ & $-219,16$ & $-196 ; 22$ & $-174,75$ & $-153,56$ & $-132,24$ & $-110,53$ & $-88,26$ & $-65,27$ \\
\hline \multirow{7}{*}{$15-J u l$} & 0,2 & IT9,23 & 149,82 & 179,90 & 210,24 & 241,19 & 272,95 & 305,70 & 339,61 \\
\hline & 0,3 & 69,62 & 98,84 & 127,48 & 156,34 & 185,75 & 215,91 & 247,00 & 279,20 \\
\hline & 0,4 & $-14,60$ & 13,33 & 40,28 & 67,26 & 94,65 & 122,68 & 151,53 & 181,37 \\
\hline & 0,5 & $-55,62$ & $-29,68$ & $-4,53$ & 20,68 & 46,29 & 72,52 & 99,51 & 127,43 \\
\hline & 0,6 & $-132,99$ & $-107,19$ & $-82,83$ & $-58,70$ & $-34,34$ & $-9,51$ & 16,00 & 42,35 \\
\hline & 0,7 & $-158,80$ & $-134,18$ & $-112,12$ & $-88,54$ & $-66,21$ & $-43,37$ & $-19,87$ & 5,91 \\
\hline & 0,8 & $-222,36$ & $-200,09$ & $-179,02$ & $-156,67$ & $-134,16$ & $-112,66$ & $-89,19$ & $-66,38$ \\
\hline \multirow{7}{*}{ 1-Ago } & $\sigma, 2$ & 72,12 & 103,89 & 135,30 & 167,11 & 199,62 & 233,02 & 267,51 & 303,25 \\
\hline & 0,3 & 24,56 & 54,36 & 83,87 & 113,77 & 144,33 & 175,73 & 208,15 & 241,75 \\
\hline & 0,4 & $-50,30$ & $-20,44$ & 8,39 & 37,28 & 66,63 & 96,70 & 127,67 & 159,74 \\
\hline & 0,5 & $-97,61$ & $-71,66$ & $-46,09$ & $-20,25$ & 6,14 & 33,25 & 61,24 & 91,65 \\
\hline & 0,6 & $-161 ; 82$ & $-135,20$ & $-109,78$ & $-84 ; 43$ & $-58,73$ & $-30,81$ & $-3,76$ & 24,25 \\
\hline & 0,7 & $-201,95$ & $-177,11$ & $-153,42$ & $-129,84$ & $-105,96$ & $-81,56$ & $-56,46$ & $-30,51$ \\
\hline & 0,8 & $-251,31$ & $-226,29$ & $-202,95$ & $-179,94$ & $-156,76$ & $-133,16$ & $-108,93$ & $-83,89$ \\
\hline \multirow{7}{*}{ 15-Ago } & 0,2 & 74,75 & 107,13 & 139,04 & 171,29 & 204,22 & 238,04 & 272,94 & 309,11 \\
\hline & 0,3 & 21,68 & 49,25 & 81,55 & 110,17 & 144,26 & 174,69 & 206,14 & 238,76 \\
\hline & 0,4 . & $-40,83$ & $-10,06$ & 19,55 & 49,16 & 79,22 & 110,00 & 141,69 & 174,49 \\
\hline & 0,5 & $-99,83$ & $-72,50$ & $-45,97$ & $-19,35$ & 7,72 & 35,47 & 64,05 & 93,64 \\
\hline & 0,6 & $-145,63$ & $-118,23$ & $-92,10$ & $-66,08$ & $-39,73$ & $-12,79$ & 14,92 & 43,58 \\
\hline & 0,7 & $-197,70$ & $-172,18$ & $-147,94$ & $-123,85$ & $-99,48$ & $-74,59$ & $-49,01$ & $-22,55$ \\
\hline & $\theta, 8$ & $-235,52$ & $-210,16$ & $-186 ; 42$ & $-162,98$ & $-139,34$ & $-115,26$ & $-90,53$ & $-64,99$ \\
\hline
\end{tabular}


Tabela 33B. Receitas líquidas para o feijão caupi (US $\$ \mathrm{ha}^{-1}$ ), em cada época de semeadura, nível de manejo da irrigação e nível de risco. Teresina, Piauí.

\begin{tabular}{|c|c|c|c|c|c|c|c|c|c|}
\hline \multirow{2}{*}{$\begin{array}{l}\text { Época de } \\
\text { Semeadura }\end{array}$} & \multirow[t]{2}{*}{$\mathrm{p}$} & \multicolumn{8}{|c|}{ Nível de risco (\%) } \\
\hline & & 5 & 10 & 15 & 20 & 25 & 30 & 35 & 40 \\
\hline \multirow{7}{*}{ 1-Set } & 0,2 & 93,48 & 124,80 & 155,81 & 187,22 & 219,36 & 252,42 & 286,57 & 322,00 \\
\hline & 0,3 & 42,70 & 71,54 & 100,24 & 129,41 & 159,28 & 190,02 & 221,80 & 254,77 \\
\hline & 0,4 & $-25,67$ & 4,57 & 33,66 & 62,76 & 92,33 & 122,63 & 153,85 & 186,19 \\
\hline & 0,5 & $-83,74$ & $-57,44$ & $-31,78$ & $-5,93$ & 20,40 & 47,44 & 75,33 & 104,22 \\
\hline & 0,6 & $-134,39$ & $-107,27$ & $-81,51$ & $-55,86$ & $-29,88$ & $-3,32$ & 24,02 & 52,32 \\
\hline & 0,7 & $-188,11$ & $-162,76$ & $-138,79$ & $-114,97$ & $-90,89$ & $-66,28$ & $-40,96$ & $-14,76$ \\
\hline & 0,8 & $-219,04$ & $-194,19$ & $-170,87$ & $-147,80$ & $-124,51$ & $-100,75$ & $-76,32$ & $-51,06$ \\
\hline \multirow{7}{*}{ 15-Set } & 0,2 & 91,50 & 122,85 & 153,83 & 185,21 & 217,30 & 250,30 & 284,38 & 319,73 \\
\hline & 0,3 & 41,44 & 70,59 & 99,51 & 128,82 & 158,82 & 189,68 & 221,56 & 254,63 \\
\hline & 0,4 & $-29,89$ & 0,23 & 29,16 & 58,09 & 87,48 & 117,58 & 148,59 & 180,70 \\
\hline & 0,5 & $-86,35$ & $-59,08$ & $-32,75$ & $-6,36$ & 20,47 & 47,96 & 76,29 & 105,64 \\
\hline & 0,6 & $-138,75$ & $-110,63$ & $-84,18$ & $-57,99$ & $-31,53$ & $-4,51$ & 23,27 & 52,00 \\
\hline & 0,7 & $-186,15$ & $-160,28$ & $-135,93$ & $-111,81$ & $-87,44$ & $-62,56$ & $-36,99$ & $-10,54$ \\
\hline & 0,8 & $-226,01$ & $-200,32$ & $-176,48$ & $-153,01$ & $-129,38$ & $-105,31$ & $-80,60$ & $-55,06$ \\
\hline \multirow{7}{*}{ 1-Out } & 0,2 & 118,88 & 146,48 & 173,48 & 200,68 & 228,39 & 256,83 & 286,14 & 316,51 \\
\hline & 0,3 & 68,74 & 94,78 & 120,26 & 145,92 & 172,07 & 198,89 & 226,55 & 255,18 \\
\hline & 0,4 & $-5,52$ & 20,97 & 46,16 & 71,21 & 96,56 & 122,45 & 149,08 & 176,60 \\
\hline & 0,5 & $-59,09$ & $-34,48$ & $-11,08$ & 12,20 & 35,75 & 59,79 & 84,50 & 110,04 \\
\hline & 0,6 & $-118,51$ & $-93,38$ & $-70,09$ & $-47,21$ & $-24,22$ & $-0,84$ & 23,12 & 47,84 \\
\hline & 0,7 & $-167,42$ & $-143,64$ & $-121,71$ & $-100,22$ & $-78,66$ & $-56,76$ & $-34,32$ & $-11,19$ \\
\hline & 0,8 & $-212,48$ & $-188,87$ & $-167,43$ & $-146,58$ & $-125,75$ & $-104,65$ & $-83,07$ & $-60,85$ \\
\hline \multirow{7}{*}{ 15-Out } & 0,2 & 115,94 & 143,58 & 170,56 & 197,70 & 225,35 & 253,70 & 282,92 & 313,18 \\
\hline & 0,3 & 71,06 & 97,23 & 122,78 & 148,49 & 174,67 & 201,52 & 229,19 & 257,83 \\
\hline & 0,4 & $-11,18$ & 15,03 & 39,93 & 64,69 & 89,73 & 115,31 & 141,60 & 168,77 \\
\hline & 0,5 & $-57,57$ & $-32,34$ & $-8,53$ & 15,07 & 38,90 & 63,19 & 88,15 & 113,93 \\
\hline & 0,6 & $-123,62$ & $-97,91$ & $-74,29$ & $-51,17$ & $-28,00$ & $-4,47$ & 19,62 & 44,46 \\
\hline & 0,7 & $-162,79$ & $-138,41$ & $-116,05$ & $-94,21$ & $-72,33$ & $-50,13$ & $-27,40$ & $-3,97$ \\
\hline & 0,8 & $-212,09$ & $-187,70$ & $-165,73$ & $-144,46$ & $-123,27$ & $-101,83$ & $-79,92$ & $-57,38$ \\
\hline
\end{tabular}


Tabela 33B. Receitas líquidas para o feijão caupi (US\$ ha ${ }^{-1}$ ), em cada época de semeadura, nível de manejo da irrigação e nível de risco. Teresina, Piauí.

\begin{tabular}{|c|c|c|c|c|c|c|c|c|c|}
\hline \multirow{2}{*}{$\begin{array}{l}\text { Época de } \\
\text { Semeadura }\end{array}$} & \multirow[t]{2}{*}{$\mathrm{p}$} & \multicolumn{8}{|c|}{ Nivel de risco (\%) } \\
\hline & & 5 & 10 & 15 & 20 & 25 & 30 & 35 & 40 \\
\hline \multirow{7}{*}{$1-\mathrm{Nov}$} & 0,2 & 275,31 & 305,15 & 334,21 & 363,40 & 393,10 & 423,53 & 454,88 & 487,33 \\
\hline & 0,3 & 212,52 & 243,06 & 272,13 & 301,04 & 330,28 & 360,15 & 390,84 & 422,55 \\
\hline & 0,4 & $126 ; 42$ & $155 ; 60$ & $183 ; 03$ & 210,16 & 237,51 & 265,38 & 293,98 & 323,50 \\
\hline & 0,5 & 66,96 & 96,92 & 124,47 & 151,42 & 178,43 & 205,84 & 233,91 & 262,83 \\
\hline & 0,6 & $-3 ; 54$ & 26,41 & $5: 3 ; 41$ & 79,57 & 105,63 & 131,98 & 158,91 & 186,61 \\
\hline & 0,7 & $-51,85$ & $-22,07$ & 4,44 & 29,95 & 55,28 & 80,82 & 106,87 & 133,65 \\
\hline & 0,8 & $-108 ; 98$ & $-78,48$ & $-5-1,90$ & $-26 ; 59$ & $-1,64$ & 23,42 & 48,91 & 75,06 \\
\hline \multirow{7}{*}{$15-\mathrm{Nov}$} & 0,2 & 273,57 & 304,26 & 333,84 & 363,44 & 393,49 & 424,23 & 455,87 & 488,60 \\
\hline & 0,3 & 211,87 & 242,99 & 272,40 & 301,57 & 331,02 & 361,07 & 391,93 & 423,80 \\
\hline & 0,4 & 128,53 & 159,94 & 188,92 & 217,33 & 245,83 & 274,79 & 304,45 & 335,04 \\
\hline & 0,5 & 65,41 & 98,38 & 127,99 & 156,63 & 185,15 & 213,97 & 243,41 & 273,71 \\
\hline & $\theta, 6$ & 4,78 & $38 ; 23$ & 67,71 & 95,95 & $123 ; 90$ & 152,06 & 180,75 & 210,22 \\
\hline & 0,7 & $-49,71$ & $-15,72$ & 13,73 & 41,69 & 69,22 & 96,85 & 124,94 & 153,75 \\
\hline & 0,8 & $-96,35$ & $-61,21$ & $-31,29$ & $-3,16$ & 24,39 & 51,93 & 79,86 & 108,48 \\
\hline \multirow{7}{*}{ 1-Dez } & $\sigma, 2$ & 319,23 & 348,13 & 375,98 & 403,81 & 432,05 & 460,92 & 490,62 & 521,32 \\
\hline & 0,3 & 251,76 & 282,00 & 310,32 & 338,26 & 366,39 & 395,02 & 424,38 & 454,68 \\
\hline & 0,4 & 175,91 & 205,66 & 233,08 & $259 ; 93$ & 286,84 & 314,16 & 342,12 & 370,93 \\
\hline & 0,5 & 107,77 & 138,98 & 166,95 & 193,96 & 220,81 & 247,93 & 275,59 & 304,03 \\
\hline & 0,6 & 53,03 & $84,7-5$ & 112,70 & 139,47 & 165,94 & 192,58 & 219,70 & 247,55 \\
\hline & 0,7 & 1,01 & 32,91 & 60,60 & 86,91 & 112,80 & 138,79 & 165,18 & 192,24 \\
\hline & $0 ; 8$. & $-49 ; 60$ & $-15,95$ & $12 ; 62$ & 39,44 & $65 ; 64$ & 91,81 & 118,31 & 145,42 \\
\hline \multirow{7}{*}{ 15-Dez } & 0,2 & 323,00 & 352,58 & 380,89 & $409, \Pi$ & 437,69 & 466,88 & 496,90 & 527,91 \\
\hline & 0,3 & 254,80 & 286,01 & 314,98 & 343,47 & 372,08 & 401,17 & 430,97 & 461,71 \\
\hline & 0,4 & 186,00 & $216 ; 61$ & 244,67 & 272,08 & 299,51 & 327,34 & 355,81 & 385,14 \\
\hline & 0,5 & 115,65 & 148,73 & 178,04 & 206,20 & 234,10 & 262,22 & 290,88 & 320,33 \\
\hline & 0,6 & 74,66 & 107,76 & 136,79 & 164,52 & 191,91 & 219,46 & 247,49 & 276,27 \\
\hline & 0,7 & 16,80 & 52,24 & 82,51 & 111,03 & 138,97 & 166,91 & 195,25 & 224,27 \\
\hline & 0,8 & $-27,67$ & $8 ; 94$ & 39,72 & 68,47 & 96,48 & 124,41 & 152,66 & 181,56 \\
\hline
\end{tabular}


Tabela 34B. Receitas líquidas para a melancia $\left(\mathrm{US} \$ \mathrm{ha}^{-1}\right.$ ), em cada época de semeadura, nível de manejo da irrigação e nível de risco. Parnaíba, Piauí.

\begin{tabular}{|c|c|c|c|c|c|c|c|c|c|}
\hline \multirow{2}{*}{$\begin{array}{l}\text { Época de } \\
\text { Semeadura }\end{array}$} & \multirow[t]{2}{*}{$\mathrm{p}$} & \multicolumn{8}{|c|}{ Nível de risco (\%) } \\
\hline & & 5 & 10 & 15 & 20 & 25 & 30 & 35 & 40 \\
\hline \multirow{7}{*}{ 1-Jan } & 0,2 & 3443,30 & 3500,02 & 3549,78 & 3597,21 & 3643,92 & 3690,73 & 3738,20 & 3786,74 \\
\hline & 0,3 & 3105,12 & 3168,21 & 3221,53 & 3271,30 & 3319,67 & 3367,70 & 3416,08 & 3465,32 \\
\hline & 0,4 & 2695,82 & 2764,65 & 2820,92 & 2872,44 & 2921,85 & 2970,48 & 3019,13 & 3068,39 \\
\hline & 0,5 & 2365,56 & 2440,67 & 2500,46 & 2554,29 & 2605,36 & 2655,20 & 2704,75 & 2754,71 \\
\hline & 0,6 & 2035,74 & 2118,07 & 2182,02 & 2238,71 & 2291,88 & 2343,36 & 2394,24 & 2445,28 \\
\hline & 0,7 & 1755,33 & 1848,21 & 1918,72 & 1980,28 & 2037,39 & 2092,23 & 2146,08 & 2199,83 \\
\hline & 0,8 & 1532,37 & 1623,86 & 1692,88 & 1752,87 & 1808,34 & 1861,47 & 1913,54 & 1965,45 \\
\hline \multirow{7}{*}{ 15-Jan } & 0,2 & 3528,88 & 3586,29 & 3636,72 & 3684,81 & 3732,19 & 3779,70 & 3827,88 & 3877,17 \\
\hline & 0,3 & 3205,41 & 3267,57 & 3320,47 & 3370,05 & 3418,35 & 3466,42 & 3514,89 & 3564,28 \\
\hline & 0,4 & 2760,99 & 2831,62 & 2889,26 & 2941,97 & 2992,50 & 3042,20 & 3091,91 & 3142,24 \\
\hline & 0,5 & 2465,28 & 2541,02 & 2601,46 & 2655,97 & 2707,73 & 2758,29 & 2808,60 & 2859,33 \\
\hline & 0,6 & 2140,43 & 2224,01 & 2289,04 & 2346,75 & 2400,93 & 2453,42 & 2505,32 & 2557,41 \\
\hline & 0,7 & 1898,44 & 1991,24 & 2062,03 & 2124,02 & 2181,67 & 2237,13 & 2291,67 & 2346,18 \\
\hline & 0,8 & 1661,45 & 1761,13 & 1836,08 & 1901,06 & 1961,06 & 2018,45 & 2074,65 & 2130,64 \\
\hline \multirow{7}{*}{$1-\mathrm{Fev}$} & 0,2 & 3776,50 & 3817,67 & 3851,14 & 3881,64 & 3910,76 & 3939,30 & 3967,74 & 3996,43 \\
\hline & 0,3 & 3445,15 & 3493,12 & 3530,84 & 3564,47 & 3596,12 & 3626,81 & 3657,13 & 3687,53 \\
\hline & 0,4 & 2974,75 & 3036,48 & 3083,01 & 3123,35 & 3160,54 & 3196,04 & 3230,69 & 3265,10 \\
\hline & 0,5 & 2658,67 & 2734,82 & 2790,80 & 2838,47 & 2881,83 & 2922,78 & 2962,42 & 3001,51 \\
\hline & 0,6 & 2376,01 & 2455,26 & 2513,03 & 2561,92 & 2606,17 & 2647,79 & 2687,96 & 2727,47 \\
\hline & 0,7 & 2081,72 & 2176,97 & 2245,27 & 2302,39 & 2353,59 & 2401,38 & 2447,22 & 2492,08 \\
\hline & 0,8 & 1840,74 & 1944,23 & 2017,86 & 2079,06 & 2133,66 & 2184,42 & 2232,95 & 2280,32 \\
\hline \multirow{7}{*}{$15-\mathrm{Fev}$} & 0,2 & 3761,64 & 3803,00 & 3836,59 & 3867,16 & 3896,34 & 3924,93 & 3953,41 & 3982,15 \\
\hline & 0,3 & 3395,42 & 3450,35 & 3492,75 & 3530,10 & 3564,94 & 3598,50 & 3631,51 & 3664,47 \\
\hline & 0,4 & 3012,92 & 3070,85 & 3114,83 & 3153,14 & 3188,59 & 3222,52 & 3255,72 & 3288,74 \\
\hline & 0,5 & 2641,74 & 2719,56 & 2776,65 & 2825,20 & 2869,30 & 2910,91 & 2951,16 & 2990,84 \\
\hline & 0,6 & 2373,69 & 2461,52 & 2525,12 & 2578,69 & 2626,99 & 2672,30 & 2715,92 & 2758,75 \\
\hline & 0,7 & 2139,87 & 2230,80 & 2296,22 & 2351,07 & 2400,34 & 2446,41 & 2490,67 & 2534,03 \\
\hline & 0,8 & 1947,07 & 2040,25 & 2106,98 & 2162,71 & 2212,62 & 2259,19 & 2303,83 & 2347,50 \\
\hline
\end{tabular}


540

Tabela 34B. Receitas líquidas para a melancia (US\$ ha ${ }^{-1}$ ), em cada época de semeadura, nível de manejo da irfigação e nível de risco. Parnaíba, Piauí.

\begin{tabular}{|c|c|c|c|c|c|c|c|c|c|}
\hline \multirow{2}{*}{$\begin{array}{l}\text { Época de } \\
\text { Semeadura }\end{array}$} & \multirow[t]{2}{*}{$p$} & \multicolumn{8}{|c|}{ Nivel de risco (\%) } \\
\hline & & 5 & 10 & 15 & 20 & 25 & 30 & 35 & 40 \\
\hline \multirow{7}{*}{ 1-Mar } & 0,2 & 3723,04 & 3784,09 & 3837,34 & 3887,94 & 3937,68 & 3987,48 & 4037,92 & 4089,47 \\
\hline & 0,3 & 3364,59 & 3435,95 & 3495,41 & 3550,48 & 3603,70 & 3656,37 & 3709,27 & 3763,00 \\
\hline & 0,4 & 2935,53 & 3018,36 & 3084,67 & 3144,60 & 3201,58 & 3257,30 & 3312,79 & 3368,78 \\
\hline & 0,5 & 2604,60 & 2700,90 & 2775,67 & 2841,91 & 2904,04 & 2964,18 & 3023,61 & 3083,22 \\
\hline & 0,6 & 2312,18 & 2418,87 & 2500,06 & 2571,06 & 2637,00 & 2700,39 & 2762,68 & 2824,90 \\
\hline & 0,7 & 2051,90 & 2168,60 & 2256,04 & 2331,69 & 2401,40 & 2468,00 & 2533,14 & 2597,98 \\
\hline & 0,8 & 1874,82 & 1995,40 & 2085,07 & 2162,23 & 2233,07 & 2300,53 & 2366,37 & 2431,77 \\
\hline \multirow{7}{*}{ 15-Mar } & 0,2 & 3687,37 & $3746 ; 81$ & 3798,89 & 3848,49 & 3897,32 & 3946,25 & 3995,85 & 4046,58 \\
\hline & 0,3 & 3312,66 & 3382,41 & 3440,66 & 3494,67 & 3546,92 & 3598,66 & 3650,65 & 3703,47 \\
\hline & $\theta, 4$ & 2902,11 & 2977,00 & $3037 ; 80$ & 3093,22 & 3146,23 & 3198,29 & 3250,30 & 3302,90 \\
\hline & 0,5 & 2587,42 & 2670,61 & 2736,36 & 2795,28 & 2851,00 & 2905,26 & 2959,11 & 3013,33 \\
\hline & 0,6 & 2267,74 & $2360 ; 89$ & 2432,70 & $2496 ; 03$ & 2555,23 & 2612,39 & 2668,76 & 2725,23 \\
\hline & 0,7 & 2005,15 & 2109,98 & 2189,16 & 2258,05 & 2321,80 & 2382,89 & 2442,79 & 2502,52 \\
\hline & $\theta, 8$ & 1751,78 & 1871,66 & 1960,57 & $2036 ; 93$ & 2106,93 & 2173,52 & 2238,44 & 2302,89 \\
\hline \multirow{7}{*}{$1-\mathrm{Abr}$} & 0,2 & 3562,51 & 3618,77 & 3669,49 & 3718,55 & 3767,32 & 3816,53 & 3866,65 & 3918,10 \\
\hline & 0,3 & 3194,06 & 3259,88 & 3316,22 & 3369,21 & 3420,96 & 3472,55 & 3524,65 & 3577,79 \\
\hline & 0,4 & 2713,64 & 2789,98 & 2852,30 & 2909,31 & 2963,99 & 3017,80 & 3071,64 & 3126,17 \\
\hline & 0,5 & 2375,44 & 2456,65 & 2521,44 & 2579,88 & 2635,39 & 2689,63 & 2743,62 & 2798,08 \\
\hline & 0,6 & 2061,36 & 2150,79 & 2220,40 & 2282,21 & 2340,27 & 2396,55 & 2452,23 & 2508,14 \\
\hline & 0,7 & 1781,87 & 1877,73 & 1951,03 & 2015,35 & 2075,26 & 2132,97 & 2189,78 & 2246,62 \\
\hline & 0,8 & 1535,57 & 1642,54 & 1722,85 & 1792,43 & 1856,64 & 1918,04 & 1978,18 & 2038,08 \\
\hline \multirow{7}{*}{$15-\mathrm{Abr}$} & 0,2 & 3539,87 & 3594,24 & 3643,64 & 3691,60 & 3739,40 & 3787,70 & 3836,96 & 3887,56 \\
\hline & 0,3 & 3163,54 & 3225,89 & 3279,79 & 3330,76 & 3380,73 & 3430,65 & 3481,16 & 3532,73 \\
\hline & 0,4 & 2670,36 & 2740,13 & 2797,85 & 2851,09 & 2902,43 & 2953,14 & 3004,02 & 3055,65 \\
\hline & 0,5 & 2323,52 & 2398,47 & 2458,85 & 2513,65 & 2565,92 & 2617,15 & 2668,25 & 2719,89 \\
\hline & 0,6 & 1982,31 & 2064,75 & 2129,40 & 2187,06 & 2241,42 & 2294,22 & 2346,56 & 2399,19 \\
\hline & 0,7 & 1643,94 & 1728,35 & 1752,25 & 1837,95 & 1863,05 & 1951,35 & 1978,40 & 2006,38 \\
\hline & 0,8 & $1473 ; 12$ & 1561,57 & 1629,02 & $1688 ; 09$ & 1743,03 & 1795,87 & 1847,85 & 1899,81 \\
\hline
\end{tabular}


Tabela 34B. Receitas líquidas para a melancia (US\$ ha ${ }^{-1}$ ), em cada época de semeadura, nível de manejo da irrigação e nível de risco. Parnaíba, Piauí.

\begin{tabular}{|c|c|c|c|c|c|c|c|c|c|}
\hline \multirow{2}{*}{$\begin{array}{l}\text { Época de } \\
\text { Semeadura }\end{array}$} & \multirow[t]{2}{*}{$\mathrm{p}$} & \multicolumn{8}{|c|}{ Nível de risco (\%) } \\
\hline & & 5 & 10 & 15 & 20 & 25 & 30 & 35 & 40 \\
\hline \multirow{7}{*}{ 1-Mai } & 0,2 & 2631,22 & 2667,88 & 2700,73 & 2732,41 & 2763,83 & 2795,49 & 2827,70 & 2860,73 \\
\hline & 0,3 & 2330,47 & 2373,72 & 2410,47 & 2444,88 & 2478,40 & 2511,72 & 2545,32 & 2579,54 \\
\hline & 0,4 & 1913,22 & 1957,39 & 1993,92 & 2027,58 & 2060,02 & 2092,03 & 2124,12 & 2156,67 \\
\hline & 0,5 & 1620,33 & 1668,52 & 1707,20 & 1742,20 & 1775,51 & 1808,08 & 1840,51 & 1873,23 \\
\hline & 0,6 & 1359,56 & 1406,36 & 1443,55 & 1476,98 & 1508,65 & 1539,53 & 1570,19 & 1601,06 \\
\hline & 0,7 & 1108,22 & 1158,41 & 1197,41 & 1231,96 & 1264,35 & 1295,69 & 1326,63 & 1357,63 \\
\hline & 0,8 & 892,25 & 947,55 & 989,59 & 1026,32 & 1060,38 & 1093,08 & 1125,17 & 1157,18 \\
\hline \multirow{7}{*}{ 15-Mai } & 0,2 & 2625,25 & 2662,78 & 2696,24 & 2728,41 & 2760,26 & 2792,30 & 2824,88 & 2858,26 \\
\hline & 0,3 & 2352,48 & 2391,95 & 2426,18 & 2458,59 & 2490,39 & 2522,16 & 2554,31 & 2587,14 \\
\hline & 0,4 & 1914,68 & 1957,82 & 1993,66 & 2026,79 & 2058,76 & 2090,36 & 2122,08 & 2154,26 \\
\hline & 0,5 & 1631,95 & 1678,71 & 1716,45 & 1750,73 & 1783,42 & 1815,45 & 1847,39 & 1879,64 \\
\hline & 0,6 & 1329,28 & 1376,46 & 1413,87 & 1447,46 & 1479,25 & 1510,22 & 1540,97 & 1571,91 \\
\hline & 0,7 & 1105,99 & 1155,96 & 1194,82 & 1229,27 & 1261,59 & 1292,87 & 1323,76 & 1354,73 \\
\hline & 0,8 & 889,57 & 939,02 & 977,08 & 1010,59 & 1041,87 & 1072,02 & 1101,72 & 1131,42 \\
\hline \multirow{7}{*}{ 1-Jun } & 0,2 & 2770,38 & 2821,34 & 2868,63 & 2915,06 & 2961,64 & 3008,93 & 3057,31 & 3107,13 \\
\hline & 0,3 & 2486,95 & 2539,26 & 2586,61 & 2632,51 & 2678,21 & 2724,36 & 2771,41 & 2819,74 \\
\hline & 0,4 & 2039,21 & 2089,12 & 2133,43 & 2175,95 & 2218,01 & 2260,30 & 2303,30 & 2347,35 \\
\hline & 0,5 & 1758,96 & 1810,39 & 1854,88 & 1896,97 & 1938,24 & 1979,50 & 2021,25 & 2063,91 \\
\hline & 0,6 & 1405,39 & 1457,53 & 1501,41 & 1542,29 & 1581,96 & 1621,35 & 1661,01 & 1701,37 \\
\hline & 0,7 & 1204,77 & 1255,70 & 1298,11 & 1337,39 & 1375,37 & 1412,96 & 1450,75 & 1489,14 \\
\hline & 0,8 & 942,70 & 993,39 & 1034,83 & 1072,78 & 1109,20 & 1145,06 & 1180,96 & 1217,35 \\
\hline \multirow{7}{*}{ 15-Jun } & 0,2 & 2812,14 & 2865,39 & 2914,42 & 2962,38 & 3010,37 & 3059,01 & 3108,73 & 3159,89 \\
\hline & 0,3 & 2527,52 & 2577,25 & 2622,98 & 2667,67 & 2712,37 & 2757,66 & 2803,94 & 2851,54 \\
\hline & 0,4 & 2082,28 & 2135,44 & 2182,15 & 2226,73 & 2270,69 & 2314,79 & 2359,54 & 2405,35 \\
\hline & 0,5 & 1801,56 & 1847,93 & 1889,10 & 1928,60 & 1967,66 & 2006,94 & 2046,86 & 2087,76 \\
\hline & 0,6 & 1452,02 & 1504,36 & 1548,55 & 1589,81 & 1629,90 & 1669,73 & 1709,87 & 1750,74 \\
\hline & 0,7 & 1216,16 & 1265,43 & 1306,79 & 1345,26 & 1382,56 & 1419,56 & 1456,80 & 1494,69 \\
\hline & 0,8 & 971,98 & 1019,91 & 1059,58 & 1096,17 & 1131,46 & 1166,32 & 1201,31 & 1236,83 \\
\hline
\end{tabular}


Tabela 34B. Receitas líquidas para a melancia (US\$ ha ${ }^{-1}$ ), em cada época de semeadura, nível de manejo da irrigação e nível de risco. Parnaíba, Piauí.

\begin{tabular}{|c|c|c|c|c|c|c|c|c|c|}
\hline \multirow{2}{*}{$\begin{array}{l}\text { Época de } \\
\text { Semeadura }\end{array}$} & \multirow[t]{2}{*}{$\mathrm{p}$} & \multicolumn{8}{|c|}{ Nivel de risco (\%) } \\
\hline & & 5 & 10 & 15 & 20 & 25 & 30 & 35 & 40 \\
\hline \multirow{7}{*}{ 1-Jul } & 0,2 & 2108,18 & 2206,83 & 2281,62 & 2344,47 & 2399,86 & 2450,07 & 2496,44 & 2539,83 \\
\hline & 0,3 & 1844,97 & 1935,09 & 2003,44 & 2060,88 & 2111,51 & 2157,40 & 2199,76 & 2239,41 \\
\hline & 0,4 & 1531,62 & 1620,69 & 1687,80 & 1744,10 & 1793,74 & 1838,77 & 1880,44 & 1919,55 \\
\hline & 0,5 & 1244,73 & 1322,46 & 1381,11 & 1430,33 & 1473,72 & 1513,08 & 1549,47 & 1583,60 \\
\hline & 0,6 & 1004,15 & 1081,43 & $1139,3.9$ & 1187,94 & 1230,73 & 1269,60 & 1305,60 & 1339,45 \\
\hline & 0,7 & 782,89 & 852,25 & 904,26 & 947,83 & 986,23 & 1021,10 & 1053,41 & 1083,78 \\
\hline & 0,8 & 592,24 & 661,81 & 713,69 & 757,07 & 795,33 & 830,11 & 862,40 & 892,84 \\
\hline \multirow{7}{*}{ 15-Jul } & $\theta, 2$ & 2167,89 & 2268,32 & 2344,47 & 2408,46 & 2464,87 & 2516,01 & 2563,22 & 2607,41 \\
\hline & 0,3 & 1875,62 & 1963,83 & 2030,89 & 2087,29 & 2137,00 & 2182,04 & 2223,59 & 2262,43 \\
\hline & $\theta ; 4$ & & & & 1822,80 & & & 1957,91 & \\
\hline & 0,5 & 1274,47 & 1353,00 & 1412,29 & 1462,06 & 1505,94 & 1545,74 & 1582,54 & 1617,05 \\
\hline & 0,6 & 1065,53 & $1142,5 \mathrm{r}$ & $1200 ; 37$ & 1248,87 & 1291,63 & 1330,44 & 1366,38 & 1400,13 \\
\hline & 0,7 & 808,12 & 878,43 & 931,19 & 975,39 & 1014,35 & 1049,74 & 1082,53 & 1113,35 \\
\hline & $\theta, 8$ & 646,22 & $709 ; 77$ & 757,49 & 797,48 & 832,74 & 864,76 & 894,42 & 922,29 \\
\hline \multirow{7}{*}{ 1-Ago } & & & 3032,96 & & & & 3226,21 & & \\
\hline & 0,3 & 2534,92 & 2575,08 & 2613,69 & 2652,25 & 2691,32 & 2731,25 & 2772,29 & 2814,69 \\
\hline & 0,4 & 2262,11 & 2308,95 & 2351,37 & 2392,50 & 2433,45 & 2474,82 & 2517,00 & 2560,32 \\
\hline & 0,5 & 1839,36 & 1886,20 & 1927,38 & 1966,70 & 2005,46 & 2044,36 & 2083,84 & 2124,25 \\
\hline & 0,6 & 1553,96 & 1596,69 & 1634,19 & 1669,96 & 1705,20 & 1740,54 & 1776,40 & 1813,09 \\
\hline & 0,7 & 1315,19 & 1359,17 & 1396,85 & 1432,30 & 1466,93 & 1501,47 & 1536,36 & 1571,96 \\
\hline & 0,8 & 1042,80 & 1079,10 & 1110,68 & 1140,65 & 1170,09 & 1199,55 & 1229,39 & 1259,89 \\
\hline \multirow{7}{*}{ 15-Ago } & 0,2 & 3050,54 & 3102,40 & 3150,61 & 3197,97 & 3245,52 & 3293,80 & 3343,22 & 3394,12 \\
\hline & 0,3 & 2532,68 & 2573,98 & 2613,38 & 2652,60 & 2692,25 & 2732,72 & 2774,27 & 2817,17 \\
\hline & 0,4 & 2314,38 & 2359,07 & 2400,17 & 2440,34 & 2480,54 & 2521,27 & 2562,89 & 2605,71 \\
\hline & 0,5 & 1881,33 & 1935,03 & 1981,08 & 2024,45 & 2066,86 & 2109,15 & 2151,90 & 2195,52 \\
\hline & 0,6 & 1593,68 & 1631,98 & $1666 ; 60$ & 1700,12 & 1733,47 & 1767,14 & 1801,45 & 1838,89 \\
\hline & 0,7 & 1377,17 & 1419,79 & 1456,72 & 1491,70 & 1526,01 & 1560,32 & 1595,05 & 1630,54 \\
\hline & 0,8 & 1070,42 & $109+, 60$ & 1112,87 & 1164,32 & 1186,74 & 1209,81 & 1233,62 & 1258,29 \\
\hline
\end{tabular}


Tabela 34B. Receitas líquidas para a melancia (US\$ ha ${ }^{-1}$ ), em cada época de semeadura, nível de manejo da irrigação e nível de risco. Parnaiba, Piauí.

\begin{tabular}{|c|c|c|c|c|c|c|c|c|c|}
\hline \multirow{2}{*}{$\begin{array}{l}\text { Época de } \\
\text { Semeadura }\end{array}$} & \multirow[t]{2}{*}{$p$} & \multicolumn{8}{|c|}{ Nivel de risco (\%) } \\
\hline & & 5 & 10 & 15 & 20 & 25 & 30 & 35 & 40 \\
\hline \multirow{7}{*}{$1-$ Set } & 0,2 & 2902,10 & 2938,70 & 2972,17 & 3004,79 & 3037,37 & 3070,36 & 3104,05 & 3138,69 \\
\hline & 0,3 & 2359,19 & 2387,40 & 2414,03 & 2440,39 & 2466,97 & 2494,05 & 2521,83 & 2550,49 \\
\hline & 0,4 & 2184,50 & 2214,52 & 2242,03 & 2268,86 & 2295,68 & 2322,85 & 2350,59 & 2379,13 \\
\hline & 0,5 & 1829,55 & 1870,16 & 1904,20 & 1935,84 & 1966,49 & 1996,89 & 2027,46 & 2058,55 \\
\hline & 0,6 & 1476,14 & 1503,88 & 1528,40 & 1551,88 & 1575,07 & 1598,38 & 1622,05 & 1648,80 \\
\hline & 0,7 & 1293,88 & 1328,15 & 1356,75 & 1383,27 & 1408,93 & 1434,34 & 1459,87 & 1485,82 \\
\hline & 0,8 & 981,30 & 1013,16 & 1039,47 & 1063,72 & 1087,09 & 1110,16 & 1133,29 & 1156,76 \\
\hline \multirow{7}{*}{15 -Set } & 0,2 & 2903,07 & 2939,67 & 2973,14 & 3005,76 & 3038,34 & 3071,33 & 3105,01 & 3139,64 \\
\hline & 0,3 & 2362,53 & 2391,92 & 2419,35 & 2446,36 & 2473,52 & 2501,12 & 2529,40 & 2558,53 \\
\hline & 0,4 & 2170,82 & 2204,33 & 2234,19 & 2262,90 & 2291,35 & 2319,99 & 2349,12 & 2378,98 \\
\hline & 0,5 & 1821,48 & 1863,30 & 1898,14 & 1930,40 & 1961,60 & 1992,49 & 2023,51 & 2055,03 \\
\hline & 0,6 & 1485,15 & 1515,27 & 1541,41 & 1566,20 & 1590,54 & 1614,89 & 1639,53 & 1664,72 \\
\hline & 0,7 & 1280,58 & 1317,04 & 1347,12 & 1374,80 & 1401,47 & 1427,78 & 1454,16 & 1480,92 \\
\hline & 0,8 & 990,76 & 1022,35 & 1048,50 & 1072,62 & 1095,88 & 1118,86 & 1141,92 & 1165,32 \\
\hline \multirow{7}{*}{ 1-Out } & 0,2 & 2984,98 & 3022,53 & 3056,52 & 3089,45 & 3122,22 & 3155,31 & 3189,02 & 3223,62 \\
\hline & 0,3 & 2448,52 & 2477,66 & 2504,84 & 2531,57 & 2558,42 & 2585,68 & 2613,58 & 2642,31 \\
\hline & 0,4 & 2250,19 & 2283,80 & 2313,64 & 2342,26 & 2370,56 & 2399,00 & 2427,89 & 2457,48 \\
\hline & 0,5 & 1900,84 & 1941,44 & 1975,39 & 2006,86 & 2037,32 & 2067,46 & 2097,75 & 2128,51 \\
\hline & 0,6 & 1522,83 & 1555,48 & 1583,25 & 1609,27 & 1634,61 & 1659,80 & 1685,21 & 1713,27 \\
\hline & 0,7 & 1347,56 & 1382,91 & 1412,16 & 1439,13 & 1465,11 & 1490,76 & 1516,47 & 1542,54 \\
\hline & 0,8 & 1034,39 & 1066,65 & 1093,18 & 1117,54 & 1140,94 & 1163,99 & 1187,06 & 1210,42 \\
\hline \multirow{7}{*}{ 15-Out } & 0,2 & 2949,85 & 2989,06 & 3024,10 & 3057,84 & 3091,27 & 3124,92 & 3159,15 & 3194,23 \\
\hline & 0,3 & 2455,73 & 2484,59 & 2511,58 & 2538,16 & 2564,88 & 2592,03 & 2619,82 & 2648,44 \\
\hline & 0,4 & 2231,29 & 2266,64 & 2297,63 & 2327,15 & 2356,22 & 2385,34 & 2414,86 & 2445,04 \\
\hline & 0,5 & 1830,43 & 1873,07 & 1908,25 & 1940,64 & 1971,81 & 2002,56 & 2033,37 & 2064,60 \\
\hline & 0,6 & 1530,06 & 1562,05 & 1589,36 & 1614,98 & 1639,96 & 1664,82 & 1689,89 & 1715,43 \\
\hline & 0,7 & 1334,08 & 1368,05 & 1396,32 & 1422,48 & 1447,73 & 1472,70 & 1497,75 & 1523,18 \\
\hline & 0,8 & 1018,77 & 1050,26 & 1076,21 & 1100,08 & 1123,04 & 1145,66 & 1168,32 & 1191,27 \\
\hline
\end{tabular}


Tabela 34B. Receitas líquidas para a melancia $\left(\mathrm{US} \$ \mathrm{ha}^{-1}\right.$ ), em cada época de semeadura, nivel de manejo da irrigação e nível de risco. Parnaiba, Piauí.

\begin{tabular}{|c|c|c|c|c|c|c|c|c|c|}
\hline \multirow{2}{*}{$\begin{array}{l}\text { Época de } \\
\text { Semeadura }\end{array}$} & \multirow[t]{2}{*}{$\mathrm{p}$} & \multicolumn{8}{|c|}{ Nivel de risco (\%) } \\
\hline & & 5 & 10 & 15 & 20 & 25 & 30 & 35 & 40 \\
\hline \multirow{7}{*}{$1-\mathrm{Nov}$} & 0,2 & 3253,99 & 3302,99 & 3345,57 & 3385,92 & 3425,52 & 3465,12 & 3505,19 & 3546,11 \\
\hline & 0,3 & 2839,76 & 2878,90 & 2913,87 & 2947,53 & 2980,87 & 3014,42 & 3048,53 & 3083,48 \\
\hline & 0,4 & 2508,89 & 2556,59 & 2596,75 & 2634,14 & 2670,42 & 2706,39 & 2742,57 & 2779,36 \\
\hline & 0,5 & 2108,42 & 2153,59 & 2191,20 & 2225,99 & 2259,59 & 2292,81 & 2326,15 & 2359,98 \\
\hline & 0,6 & 1797,14 & 1842,93 & 1880,32 & 1914,52 & 1947,28 & 1979,49 & 2011,68 & 2044,25 \\
\hline & 0,7 & 1508,63 & 1554,72 & 1591,74 & 1625,25 & 1657,12 & 1688,30 & 1719,33 & 1750,64 \\
\hline & 0,8 & 1236,13 & 1281,64 & 1317,71 & 1350,08 & 1380,68 & 1410,48 & 1440,05 & 1469,79 \\
\hline \multirow{7}{*}{$15-\mathrm{Nov}$} & $\theta, 2$ & 3201,94 & $3248 ; 44$ & 3289,16 & 3327,92 & 3366,07 & 3404,29 & 3443,02 & 3482,62 \\
\hline & 0,3 & 2818,68 & 2861,38 & 2898,71 & 2934,22 & 2969,14 & 3004,11 & 3039,54 & 3075,74 \\
\hline & 0,4 & 2462,86 & $2515 ; 50$ & 2558,92 & 2598,86 & 2637,30 & 2675,20 & 2713,17 & 2751,66 \\
\hline & 0,5 & 2064,31 & 2115,37 & 2156,88 & 2194,75 & 2230,97 & 2266,54 & 2302,07 & 2337,98 \\
\hline & 0,6 & 1773,12 & 1827,24 & 1870,26 & 1908,94 & 1945,58 & 1981,30 & 2016,78 & 2052,50 \\
\hline & 0,7 & 1472,98 & 1529,24 & 1573,11 & 1612,08 & 1648,66 & 1684,10 & 1719,12 & 1754,25 \\
\hline & $0 ; 8$ & 1221,00 & 1278,83 & 1323,26 & 1362,32 & 1398,74 & 1433,82 & 1468,36 & 1502,88 \\
\hline \multirow{7}{*}{ 1-Dez } & 0,2 & 3113,87 & 3215,15 & 3310,91 & 3405,90 & 3501,83 & 3599,71 & 3700,25 & 3804,11 \\
\hline & 0,3 & 2788,75 & 2879,66 & 2966,25 & 3052,40 & 3139,59 & 3228,64 & 3320,17 & 3414,78 \\
\hline & 0,4 & 2402,17 & 2498,35 & 2586,41 & 2672,39 & 2758,45 & 2845,73 & 2935,04 & 3027,06 \\
\hline & 0,5 & 2032,65 & 2124,30 & 2207,03 & 2287,23 & 2367,16 & 2448,00 & 2530,58 & 2615,55 \\
\hline & 0,6 . & 1729,65 & 1823,71 & 1906,38 & 1985,43 & 2063,56 & 2142,16 & 2222,15 & 2304,26 \\
\hline & 0,7 & 1475,71 & 1564,82 & 1642,53 & 1716,52 & 1789,48 & 1862,75 & 1937,23 & 2013,62 \\
\hline & 0,8 & 1204,91 & 1297,18 & 1375,55 & 1449,12 & 1521,00 & 1592,77 & 1665,43 & 1739,76 \\
\hline \multirow{7}{*}{ 15-Dez } & 0,2 & 3085,66 & 3183,03 & $3275,8 \mathrm{I}$ & 3368,18 & 3461,66 & 3557,16 & 3655,35 & 3756,83 \\
\hline & 0,3 & 2757,39 & 2854,01 & 2944,36 & 3033,51 & 3123,27 & 3214,67 & 3308,44 & 3405,23 \\
\hline & $0 ; 4$ & 2373,80 & 2470,39 & 2558,49 & 2644,37 & 2730,23 & 2817,26 & 2906,27 & 2997,95 \\
\hline & 0,5 & 2022,30 & 2123,41 & 2212,67 & 2298,22 & 2382,91 & 2468,20 & 2555,06 & 2644,27 \\
\hline & 0,6 & 1719,76 & 1822,86 & 1911,77 & 1995,93 & 2078,62 & 2161,47 & 2245,57 & 2331,74 \\
\hline & 0,7 & 1483,12 & 1581,63 & 1665,92 & 1745,38 & 1823,22 & 1901,09 & 1980,03 & 2060,84 \\
\hline & 0,8 & 1242,51 & 1344,03 & 1429,05 & 1508,25 & $1585 ; 26$ & 1661,91 & 1739,34 & 1818,44 \\
\hline
\end{tabular}


Tabela 35B. Relação beneficio/custo para o feijão caupi, em cada época de semeadura, nivel de manejo da irrigação e nível de risco. Teresina, Piauí.

\begin{tabular}{|c|c|c|c|c|c|c|c|c|c|}
\hline \multirow{2}{*}{$\begin{array}{l}\text { Época de } \\
\text { Semeadura }\end{array}$} & \multirow[t]{2}{*}{$\mathrm{p}$} & \multicolumn{8}{|c|}{ Nivel de risco (\%) } \\
\hline & & 5 & 10 & 15 & 20 & 25 & 30 & 35 & 40 \\
\hline \multirow{7}{*}{ 1-Jan } & 0,2 & 1,35 & 1,40 & 1,44 & 1,48 & 1,52 & 1,56 & 1,60 & 1,65 \\
\hline & 0,3 & 1,27 & 1,32 & 1,36 & 1,40 & 1,44 & 1,48 & 1,53 & 1,57 \\
\hline & 0,4 & 1,20 & 1,24 & 1,28 & 1,32 & 1,36 & 1,41 & 1,45 & 1,49 \\
\hline & 0,5 & 1,12 & 1,16 & 1,21 & 1,25 & 1,29 & 1,33 & 1,37 & 1,41 \\
\hline & 0,6 & 1,07 & 1,12 & 1,16 & 1,20 & 1,24 & 1,28 & 1,32 & 1,37 \\
\hline & 0,7 & 1,01 & 1,06 & 1,10 & 1,14 & 1,18 & 1,23 & 1,27 & 1,31 \\
\hline & 0,8 & 0,95 & 1,01 & 1,05 & 1,10 & 1,14 & 1,18 & 1,22 & 1,27 \\
\hline \multirow{7}{*}{ 15-Jan } & 0,2 & 1,38 & 1,42 & 1,46 & 1,50 & 1,54 & 1,59 & 1,63 & 1,68 \\
\hline & 0,3 & 1,30 & 1,35 & 1,39 & 1,43 & 1,48 & 1,52 & 1,56 & 1,61 \\
\hline & 0,4 & 1,23 & 1,28 & 1,32 & 1,36 & 1,40 & 1,45 & 1,49 & 1,54 \\
\hline & 0,5 & 1,17 & 1,21 & 1,26 & 1,30 & 1,34 & 1,38 & 1,43 & 1,47 \\
\hline & 0,6 & 1,11 & 1,16 & 1,21 & 1,25 & 1,29 & 1,33 & 1,38 & 1,42 \\
\hline & 0,7 & 1,06 & 1,11 & 1,16 & 1,20 & 1,24 & 1,29 & 1,33 & 1,37 \\
\hline & 0,8 & 1,00 & 1,06 & 1,10 & 1,16 & 1,20 & 1,24 & 1,29 & 1,33 \\
\hline \multirow{7}{*}{$1-\mathrm{Fev}$} & 0,2 & 1,33 & 1,38 & 1,42 & 1,46 & 1,51 & 1,55 & 1,60 & 1,65 \\
\hline & 0,3 & 1,26 & 1,31 & 1,35 & 1,40 & 1,44 & 1,49 & 1,53 & 1,58 \\
\hline & 0,4 & 1,20 & 1,25 & 1,30 & 1,34 & 1,38 & 1,43 & 1,47 & 1,52 \\
\hline & 0,5 & 1,14 & 1,19 & 1,23 & 1,28 & 1,32 & 1,37 & 1,41 & 1,46 \\
\hline & 0,6 & 1,10 & 1,15 & 1,20 & 1,24 & 1,29 & 1,33 & 1,38 & 1,43 \\
\hline & 0,7 & 1,05 & 1,11 & 1,16 & 1,20 & 1,25 & 1,30 & 1,34 & 1,39 \\
\hline & 0,8 & 1,02 & 1,08 & 1,13 & 1,17 & 1,22 & 1,27 & 1,31 & 1,36 \\
\hline \multirow{7}{*}{$15-\mathrm{Fev}$} & 0,2 & 1,33 & 1,37 & 1,42 & 1,46 & 1,51 & 1,55 & 1,60 & 1,65 \\
\hline & 0,3 & 1,26 & 1,31 & 1,35 & 1,40 & 1,44 & 1,49 & 1,53 & 1,58 \\
\hline & 0,4 & 1,20 & 1,25 & 1,29 & 1,34 & 1,38 & 1,43 & 1,47 & 1,52 \\
\hline & 0,5 & 1,14 & 1,19 & 1,24 & 1,28 & 1,33 & 1,37 & 1,42 & 1,47 \\
\hline & 0,6 & 1,10 & 1,15 & 1,20 & 1,25 & 1,29 & 1,34 & 1,39 & 1,44 \\
\hline & 0,7 & 1,05 & 1,11 & 1,16 & 1,21 & 1,26 & 1,31 & 1,35 & 1,41 \\
\hline & 0,8 & 1,01 & 1,07 & 1,12 & 1,17 & 1,22 & 1,27 & 1,32 & 1,37 \\
\hline
\end{tabular}


546

Tabela 35B. Relação benefício/custo para $\Theta$ feijão caupi, em cada época de semeadura, nível de manejo da irrigação e nível de risco. Teresina, Piauí.

\begin{tabular}{|c|c|c|c|c|c|c|c|c|c|}
\hline \multirow{2}{*}{$\begin{array}{l}\text { Época de } \\
\text { Semeadura }\end{array}$} & \multirow[t]{2}{*}{$\mathrm{p}$} & \multicolumn{8}{|c|}{ Nível de risco (\%) } \\
\hline & & 5 & 10 & 15 & 20 & 25 & 30 & 35 & 40 \\
\hline \multirow{7}{*}{ 1-Mar } & 0,2 & 1,36 & $1,4 \mathrm{I}$ & 1,46 & 1,50 & 1,55 & 1,60 & 1,64 & 1,70 \\
\hline & 0,3 & 1,28 & 1,33 & 1,38 & 1,43 & 1,47 & 1,52 & 1,57 & 1,62 \\
\hline & 0,4 & 1,23 & 1,28 & 1,32 & 1,37 & 1,42 & 1,47 & 1,51 & 1,56 \\
\hline & 0,5 & 1,17 & 1,22 & 1,27 & 1,32 & 1,36 & 1,41 & 1,46 & 1,51 \\
\hline & $\theta, 6$ & 1,12 & 1,17 & 1,22 & 1,27 & 1,32 & 1,37 & 1,42 & 1,47 \\
\hline & 0,7 & 1,07 & 1,13 & 1,18 & 1,23 & 1,28 & 1,33 & 1,38 & 1,43 \\
\hline & 0,8 & 1,02 & 1,08 & 1,14 & 1,19 & 1,25 & 1,30 & 1,35 & 1,40 \\
\hline \multirow{7}{*}{ 15-Mar } & 0,2 & 1,35 & 1,39 & 1,44 & 1,48 & 1,53 & 1,58 & 1,63 & 1,68 \\
\hline & 0,3 & 1,26 & 1,30 & 1,35 & 1,40 & 1,44 & 1,49 & 1,53 & 1,58 \\
\hline & 0,4 & 1,20 & 1,25 & 1,29 & 1,34 & 1,38 & 1,43 & 1,48 & 1,53 \\
\hline & 0,5 & 1,11 & 1,16 & 1,21 & 1,26 & 1,30 & 1,35 & 1,40 & 1,45 \\
\hline & $0 ; 6$ & 1,05 & $1, \mathrm{HH}$ & 1,16 & 1,20 & 1,25 & 1,30 & 1,34 & 1,39 \\
\hline & 0,7 & 1,01 & 1,07 & 1,12 & 1,16 & 1,21 & 1,26 & 1,30 & 1,35 \\
\hline & 0,8 & 0,96 & 1,02 & 1,07 & 1,12 & 1,17 & 1,21 & 1,26 & 1,31 \\
\hline \multirow{7}{*}{$1-\mathrm{Abr}$} & 0,2 & 1,32 & 1,36 & $\mathrm{I}, 4 \mathrm{I}$ & 1,45 & 1,50 & 1,54 & 1,59 & 1,64 \\
\hline & 0,3 & 1,22 & 1,26 & 1,31 & 1,35 & 1,40 & 1,44 & 1,49 & 1,54 \\
\hline & 0,4 & 1,15 & 1,20 & 1,25 & 1,29 & 1,33 & 1,38 & 1,43 & 1,47 \\
\hline & 0,5 & 1,07 & 1,12 & 1,16 & 1,21 & 1,25 & 1,29 & 1,34 & 1,39 \\
\hline & 0,6 & 1,00 & 1,05 & 1,10 & 1,14 & 1,19 & 1,23 & 1,28 & 1,32 \\
\hline & 0,7 & 0,95 & 1,00 & 1,05 & 1,09 & 1,13 & 1,18 & 1,22 & 1,27 \\
\hline & $0 ; 8$ & 0,89 & $\theta, 94$ & $\theta, 99$ & 1,04 & 1,08 & 1,13 & 1,17 & 1,22 \\
\hline \multirow{7}{*}{ 15-Abr } & 0,2 & 1,30 & 1,34 & 1,38 & 1,43 & $\mathrm{I}, 47$ & 1,52 & 1,57 & 1,61 \\
\hline & 0,3 & 1,19 & 1,24 & 1,28 & 1,32 & 1,36 & 1,41 & 1,45 & 1,50 \\
\hline & 0,4 & 1,12 & 1,16 & 1,21 & $1 ; 25$ & 1,29 & 1,33 & 1,38 & 1,42 \\
\hline & 0,5 & 1,03 & 1,07 & 1,11 & 1,16 & 1,20 & 1,24 & 1,28 & 1,33 \\
\hline & 0,6 & 0,95 & 1,00 & 1,04 & 1,08 & 1,12 & 1,16 & 1,20 & 1,24 \\
\hline & 0,7 & 0,88 & 0,93 & 0,97 & 1,01 & 1,05 & 1,09 & 1,14 & 1,18 \\
\hline & 0,8 & 0,83 & 0,87 & $0 ; 92$ & 0,96 & 1,00 & 1,04 & 1,08 & 1,12 \\
\hline
\end{tabular}


Tabela 35B. Relação beneficio/custo para o feijão caupi, em cada época de semeadura, nível de manejo da irrigação e nível de risco. Teresina, Piauí.

\begin{tabular}{|c|c|c|c|c|c|c|c|c|c|}
\hline \multirow{2}{*}{$\begin{array}{l}\text { Época de } \\
\text { Semeadura }\end{array}$} & \multirow[t]{2}{*}{$\mathrm{p}$} & \multicolumn{8}{|c|}{ Nível de risco (\%) } \\
\hline & & 5 & 10 & 15 & 20 & 25 & 30 & 35 & 40 \\
\hline \multirow{7}{*}{ 1-Mai } & 0,2 & 1,02 & 1,07 & 1,12 & 1,17 & 1,22 & 1,27 & 1,32 & 1,38 \\
\hline & 0,3 & 0,93 & 0,98 & 1,03 & 1,07 & 1,12 & 1,17 & 1,22 & 1,27 \\
\hline & 0,4 & 0,87 & 0,92 & 0,96 & 1,01 & 1,05 & 1,10 & 1,15 & 1,20 \\
\hline & 0,5 & 0,80 & 0,84 & 0,88 & 0,93 & 0,97 & 1,01 & 1,06 & 1,11 \\
\hline & 0,6 & 0,73 & 0,78 & 0,82 & 0,86 & 0,90 & 0,95 & 0,99 & 1,03 \\
\hline & 0,7 & 0,68 & 0,73 & 0,77 & 0,81 & 0,85 & 0,89 & 0,94 & 0,98 \\
\hline & 0,8 & 0,63 & 0,67 & 0,71 & 0,75 & 0,79 & 0,83 & 0,87 & 0,91 \\
\hline \multirow{7}{*}{ 15-Mai } & 0,2 & 1,02 & 1,06 & 1,11 & 1,16 & 1,21 & 1,26 & 1,31 & 1,37 \\
\hline & 0,3 & 0,93 & 0,98 & 1,03 & 1,07 & 1,12 & 1,17 & 1,22 & 1,27 \\
\hline & 0,4 & 0,87 & 0,91 & 0,95 & 1,00 & 1,04 & 1,09 & 1,13 & 1,18 \\
\hline & 0,5 & 0,78 & 0,82 & 0,86 & 0,91 & 0,95 & 0,99 & 1,03 & 1,08 \\
\hline & 0,6 & 0,73 & 0,77 & 0,81 & 0,85 & 0,89 & 0,93 & 0,97 & 1,01 \\
\hline & 0,7 & 0,67 & 0,71 & 0,75 & 0,79 & 0,82 & 0,86 & 0,90 & 0,94 \\
\hline & 0,8 & 0,61 & 0,65 & 0,69 & 0,73 & 0,76 & 0,80 & 0,84 & 0,88 \\
\hline \multirow{7}{*}{ 1-Jun } & 0,2 & 1,13 & 1,18 & 1,22 & 1,26 & 1,31 & 1,35 & 1,40 & 1,45 \\
\hline & 0,3 & 1,05 & 1,09 & 1,14 & 1,18 & 1,22 & 1,27 & 1,31 & 1,36 \\
\hline & 0,4 & 0,96 & 1,00 & 1,04 & 1,08 & 1,12 & 1,16 & 1,20 & 1,25 \\
\hline & 0,5 & 0,88 & 0,92 & 0,95 & 0,99 & 1,03 & 1,06 & 1,10 & 1,14 \\
\hline & 0,6 & 0,82 & 0,86 & 0,89 & 0,93 & 0,96 & 1,00 & 1,04 & 1,08 \\
\hline & 0,7 & 0,75 & 0,79 & 0,82 & 0,85 & 0,89 & 0,92 & 0,96 & 0,99 \\
\hline & 0,8 & 0,69 & 0,73 & 0,76 & 0,79 & 0,82 & 0,85 & 0,89 & 0,92 \\
\hline \multirow{7}{*}{ 15-Jun } & 0,2 & 1,14 & 1,18 & 1,22 & 1,26 & 1,31 & 1,36 & 1,40 & 1,45 \\
\hline & 0,3 & 1,06 & 1,10 & 1,14 & 1,19 & 1,23 & 1,27 & 1,32 & 1,37 \\
\hline & 0,4 & 0,96 & 1,00 & 1,04 & 1,08 & 1,12 & 1,16 & 1,20 & 1,24 \\
\hline & 0,5 & 0,88 & 0,92 & 0,96 & 0,99 & 1,03 & 1,07 & 1,11 & 1,15 \\
\hline & 0,6 & 0,82 & 0,85 & 0,89 & 0,92 & 0,96 & 0,99 & 1,03 & 1,07 \\
\hline & 0,7 & 0,75 & 0,78 & 0,82 & 0,85 & 0,88 & 0,92 & 0,95 & 0,99 \\
\hline & 0,8 & 0,70 & 0,73 & 0,76 & 0,79 & 0,83 & 0,86 & 0,89 & 0,92 \\
\hline
\end{tabular}


Tabela 35B. Relação beneficio/custo para o feijão caupi, em cada época de semeadura, nível de manejo da irrigação e nível de risco. Teresina, Piauí.

\begin{tabular}{|c|c|c|c|c|c|c|c|c|c|}
\hline \multirow{2}{*}{$\begin{array}{l}\text { Época de } \\
\text { Semeadura }\end{array}$} & \multirow[t]{2}{*}{$\mathrm{p}$} & \multicolumn{8}{|c|}{ Nivel de risco (\%) } \\
\hline & & 5 & 10 & 15 & 20 & 25 & 30 & 35 & 40 \\
\hline \multirow{7}{*}{ 1-Jul } & $\theta, 2$ & $1, \mathrm{I} 5$ & 1,19 & 1,23 & 1,27 & $1,3 \mathrm{I}$ & 1,35 & 1,39 & 1,44 \\
\hline & 0,3 & 1,08 & 1,12 & 1,16 & 1,20 & 1,23 & 1,27 & 1,31 & 1,36 \\
\hline & $0 ; 4$ & $0 ; 98$ & 1,01 & 1,05 & 1,08 & 1,12 & 1,15 & 1,19 & 1,23 \\
\hline & 0,5 & 0,91 & 0,94 & 0,98 & 1,01 & 1,05 & 1,08 & 1,12 & 1,15 \\
\hline & 0,6 & 0,83 & $0 ; 87$ & 0,90 & 0,93 & 0,96 & 0,99 & 1,02 & 1,06 \\
\hline & 0,7 & 0,77 & 0,80 & 0,83 & 0,86 & 0,89 & 0,92 & 0,95 & 0,99 \\
\hline & 0,8 & 0,72 & 0,74 & 0,77 & $0 ; 80$ & 0,83 & 0,86 & 0,88 & 0,91 \\
\hline \multirow{7}{*}{$15-J u l$} & 0,2 & 1,15 & 1,19 & 1,23 & 1,27 & 1,31 & 1,36 & 1,40 & 1,44 \\
\hline & 0,3 & 1,09 & 1,13 & 1,17 & 1,20 & 1,24 & 1,28 & 1,32 & 1,36 \\
\hline & 0,4 & 0,98 & 1,02 & 1,05 & 1,09 & 1,12 & 1,16 & 1,20 & 1,24 \\
\hline & 0,5 & 0,93 & 0,96 & 0,99 & 1,03 & 1,06 & 1,09 & 1,13 & 1,17 \\
\hline & 0,6 & 0,83 & 0,86 & 0,89 & 0,92 & 0,96 & 0,99 & 1,02 & 1,06 \\
\hline & 0,7 & 0,79 & 0,82 & 0,85 & 0,88 & 0,91 & 0,94 & 0,97 & 1,01 \\
\hline & 0,8 & 0,71 & 0,74 & 0,77 & 0,80 & 0,83 & 0,85 & 0,88 & 0,91 \\
\hline \multirow{7}{*}{ 1-Ago } & 0,2 & $\mathrm{I}, 09$ & 1,13 & 1,17 & 1,22 & 1,26 & 1,30 & 1,35 & 1,39 \\
\hline & 0,3 & 1,03 & 1,07 & 1,11 & 1,15 & 1,19 & 1,23 & 1,27 & 1,31 \\
\hline & 0,4 & 0,94 & 0,97 & 1,01 & 1,05 & 1,09 & 1,13 & 1,17 & 1,21 \\
\hline & 0,5 & 0,87 & 0,91 & 0,94 & 0,97 & 1,01 & 1,04 & 1,08 & 1,12 \\
\hline & 0,6 & 0,79 & 0,83 & 0,86 & 0,89 . & 0,92 & 0,96 & 1,00 & 1,03 \\
\hline & 0,7 & 0,74 & 0,77 & 0,80 & 0,83 & 0,86 & 0,89 & 0,93 & 0,96 \\
\hline & $\theta ; 8$ & 0,68 & $0 ; 71$ & 0,74 & 0,77 & 0,80 & 0,83 & 0,86 & 0,89 \\
\hline \multirow{7}{*}{ 15-Ago } & 0,2 & 1,10 & 1,14 & 1,18 & 1,22 & 1,26 & 1,31 & 1,35 & 1,40 \\
\hline & 0,3 & 1,03 & 1,06 & 1,11 & 1,14 & 1,19 & 1,23 & 1,27 & 1,31 \\
\hline & 0,4 & 0,95 & 0,99 & 1,03 & 1,06 & 1,10 & 1,14 & 1,18 & 1,23 \\
\hline & 0,5 & 0,87 & 0,91 & 0,94 & 0,97 & 1,01 & 1,05 & 1,08 & 1,12 \\
\hline & 0,6 & 0,81 & 0,85 & 0,88 & 0,91 & 0,95 & 0,98 & 1,02 & 1,06 \\
\hline & 0,7 & 0,75 & 0,78 & 0,81 & 0,84 & 0,87 & 0,90 & 0,94 & 0,97 \\
\hline & 0,8 & 0,70 & 0,73 & 0,76 & 0,79 & 0,82 & 0,85 & 0,88 & 0,92 \\
\hline
\end{tabular}


Tabela 35B. Relação benefício/custo para o feijão caupi, em cada época de semeadura, nível de manejo da irrigação e nível de risco. Parnaíba, Piauí.

\begin{tabular}{|c|c|c|c|c|c|c|c|c|c|}
\hline \multirow{2}{*}{$\begin{array}{l}\text { Época de } \\
\text { Semeadura }\end{array}$} & \multirow[t]{2}{*}{$\mathrm{p}$} & \multicolumn{8}{|c|}{ Nível de risco (\%) } \\
\hline & & 5 & 10 & 15 & 20 & 25 & 30 & 35 & 40 \\
\hline \multirow{7}{*}{ 1-Set } & 0,2 & 1,12 & 1,16 & 1,20 & 1,24 & 1,28 & 1,33 & 1,37 & 1,42 \\
\hline & 0,3 & 1,06 & 1,09 & 1,13 & 1,17 & 1,21 & 1,25 & 1,29 & 1,33 \\
\hline & 0,4 & 0,97 & 1,01 & 1,04 & 1,08 & 1,12 & 1,16 & 1,20 & 1,24 \\
\hline & 0,5 & 0,89 & 0,93 & 0,96 & 0,99 & 1,03 & 1,06 & 1,10 & 1,14 \\
\hline & 0,6 & 0,83 & 0,86 & 0,89 & 0,93 & 0,96 & 1,00 & 1,03 & 1,07 \\
\hline & 0,7 & 0,76 & 0,79 & 0,82 & 0,85 & 0,88 & 0,91 & 0,95 & 0,98 \\
\hline & 0,8 & 0,72 & 0,75 & 0,78 & 0,81 & 0,84 & 0,87 & 0,90 & 0,93 \\
\hline \multirow{7}{*}{15 -Set } & 0,2 & 1,12 & 1,16 & 1,20 & 1,24 & 1,28 & 1,33 & 1,37 & 1,42 \\
\hline & 0,3 & 1,05 & 1,09 & 1,13 & 1,17 & 1,21 & 1,25 & 1,29 & 1,33 \\
\hline & 0,4 & 0,96 & 1,00 & 1,04 & 1,08 & 1,11 & 1,15 & 1,19 & 1,24 \\
\hline & 0,5 & 0,89 & 0,92 & 0,96 & 0,99 & 1,03 & 1,06 & 1,10 & 1,14 \\
\hline & 0,6 & 0,82 & 0,86 & 0,89 & 0,92 & 0,96 & 0,99 & 1,03 & 1,07 \\
\hline & 0,7 & 0,76 & 0,79 & 0,82 & 0,85 & 0,89 & 0,92 & 0,95 & 0,99 \\
\hline & 0,8 & 0,71 & 0,74 & 0,77 & 0,80 & 0,83 & 0,86 & 0,89 & 0,93 \\
\hline \multirow{7}{*}{ 1-Out } & 0,2 & 1,15 & 1,19 & 1,22 & 1,26 & 1,30 & 1,33 & 1,37 & 1,41 \\
\hline & 0,3 & 1,09 & 1,12 & 1,16 & 1,19 & 1,22 & 1,26 & 1,30 & 1,33 \\
\hline & 0,4 & 0,99 & 1,03 & 1,06 & 1,09 & 1,13 & 1,16 & 1,19 & 1,23 \\
\hline & 0,5 & 0,92 & 0,96 & 0,99 & 1,02 & 1,05 & 1,08 & 1,11 & 1,14 \\
\hline & 0,6 & 0,85 & 0,88 & 0,91 & 0,94 & 0,97 & 1,00 & 1,03 & 1,06 \\
\hline & 0,7 & 0,78 & 0,81 & 0,84 & 0,87 & 0,90 & 0,93 & 0,96 & 0,99 \\
\hline & 0,8 & 0,73 & 0,76 & 0,78 & 0,81 & 0,84 & 0,86 & 0,89 & 0,92 \\
\hline \multirow{7}{*}{ 15-Out } & 0,2 & 1,15 & 1,19 & 1,22 & 1,26 & 1,29 & 1,33 & 1,37 & 1,41 \\
\hline & 0,3 & 1,09 & 1,13 & 1,16 & 1,19 & 1,23 & 1,26 & 1,30 & 1,34 \\
\hline & 0,4 & 0,99 & 1,02 & 1,05 & 1,08 & 1,12 & 1,15 & 1,19 & 1,22 \\
\hline & 0,5 & 0,93 & 0,96 & 0,99 & 1,02 & 1,05 & 1,08 & 1,12 & 1,15 \\
\hline & 0,6 & 0,84 & 0,87 & 0,90 & 0,93 & 0,96 & 0,99 & 1,03 & 1,06 \\
\hline & 0,7 & 0,79 & 0,82 & 0,85 & 0,88 & 0,91 & 0,93 & 0,96 & 0,99 \\
\hline & 0,8 & 0,72 & 0,76 & 0,78 & 0,81 & 0,84 & 0,87 & 0,89 & 0,92 \\
\hline
\end{tabular}


550

Tabela 35B. Relação beneficio/custo para o feijão caupi, em cada época de semeadura, nivel de manejo da irrigação e nível de risco. Teresina, Piauí.

\begin{tabular}{|c|c|c|c|c|c|c|c|c|c|}
\hline \multirow{2}{*}{$\begin{array}{l}\text { Época de } \\
\text { Semeadura }\end{array}$} & \multirow[t]{2}{*}{$\mathrm{p}$} & \multicolumn{8}{|c|}{ Nivel de risco (\%) } \\
\hline & & 5 & 10 & 15 & 20 & 25 & 30 & 35 & 40 \\
\hline \multirow{7}{*}{$1-\mathrm{Nov}$} & 0,2 & $\mathrm{I}, 36$ & 1,40 & 1,44 & 1,48 & 1,52 & 1,56 & 1,60 & 1,64 \\
\hline & 0,3 & 1,28 & 1,32 & 1,36 & 1,40 & 1,43 & 1,47 & 1,52 & 1,56 \\
\hline & 0,4 & 1,17 & 1,20 & 1,24 & 1,28 & 1,31 & 1,35 & 1,39 & 1,43 \\
\hline & 0,5 & 1,09 & 1,13 & 1,16 & 1,20 & 1,24 & 1,27 & 1,31 & 1,35 \\
\hline & 0,6 & 1,00 & 1,03 & 1,07 & 1,10 & 1,14 & 1,17 & 1,21 & 1,25 \\
\hline & 0,7 & 0,93 & 0,97 & 1,01 & 1,04 & 1,07 & 1,11 & 1,14 & 1,18 \\
\hline & 0,8 & 0,86 & 0,90 & 0,93 & 0,96 & 1,00 & 1,03 & 1,06 & 1,10 \\
\hline \multirow{7}{*}{ 15-Nov } & 0,2 & 1,36 & 1,40 & 1,44 & 1,48 & 1,52 & 1,56 & 1,60 & 1,65 \\
\hline & 0,3 & 1,28 & 1,32 & 1,36 & 1,40 & 1,44 & 1,48 & 1,52 & 1,56 \\
\hline & $\theta ; 4$ & 1,17 & 1,21 & 1,25 & 1,29 & 1,33 & 1,37 & 1,41 & 1,45 \\
\hline & 0,5 & 1,09 & 1,13 & 1,17 & 1,21 & 1,25 & 1,29 & 1,32 & 1,37 \\
\hline & 0,6 & $1 ; 0 \cdot 1$ & 1,05 & 1,09 & 1,13 & 1,17 & 1,20 & 1,24 & 1,28 \\
\hline & 0,7 & 0,93 & 0,98 & 1,02 & 1,06 & 1,09 & 1,13 & 1,17 & 1,21 \\
\hline & $\theta, 8$ & 0,87 & 0,92 & $\theta, 96$ & 1,00 & 1,03 & 1,07 & 1,11 & 1,15 \\
\hline \multirow{7}{*}{ 1-Dez } & 0,2 & 1,42 & 1,46 & 1,50 & 1,54 & 1,58 & 1,61 & 1,65 & 1,70 \\
\hline & 0,3 & 1,33 & 1,37 & 1,41 & 1,45 & 1,49 & 1,53 & 1,57 & 1,61 \\
\hline & 0,4 & 1,23 & 1,27 & 1,31 & 1,35 & 1,38 & 1,42 & 1,46 & 1,50 \\
\hline & 0,5 & 1,14 & 1,19 & 1,22 & 1,26 & 1,30 & 1,33 & 1,37 & 1,41 \\
\hline & 0,6 & 1,07 & 1,11 & 1,15 & 1,19 & 1,22 & 1,26 & 1,30 & 1,33 \\
\hline & 0,7 & 1,00 & 1,04 & 1,08 & 1,12 & 1,15 & 1,19 & 1,22 & 1,26 \\
\hline & 0,8 & 0,93 & 0,98 & 1,02 & 1,05 & 1,09 & 1,12 & 1,16 & 1,20 \\
\hline \multirow{7}{*}{ 15-Dez } & 0,2 & 1,43 & 1,47 & 1,51 & 1,55 & 1,59 & 1,63 & 1,67 & 1,71 \\
\hline & 0,3 & 1,34 & 1,38 & 1,42 & 1,46 & 1,50 & 1,54 & 1,58 & 1,62 \\
\hline & 0,4 & 1,25 & 1,29 & 1,33 & 1,37 & 1,40 & 1,44 & 1,48 & 1,52 \\
\hline & 0,5 & 1,15 & 1,20 & 1,24 & 1,28 & 1,32 & 1,35 & 1,39 & 1,43 \\
\hline & 0,6 & 1,10 & 1,14 & 1,18 & 1,22 & 1,26 & 1,30 & 1,34 & 1,38 \\
\hline & 0,7 & 1,02 & 1,07 & 1,11 & 1,15 & 1,19 & 1,23 & 1,27 & 1,31 \\
\hline & 0,8 & 0,96 & 1,01 & 1,05 & 1,09 & 1,13 & 1,17 & 1,21 & 1,25 \\
\hline
\end{tabular}


Tabela 36B. Relação benefício/custo para a melancia, em cada época de semeadura, nível de manejo da irrigação e nível de risco. Parnaíba, Piauí.

\begin{tabular}{|c|c|c|c|c|c|c|c|c|c|}
\hline \multirow{2}{*}{$\begin{array}{l}\text { Época de } \\
\text { Semeadura }\end{array}$} & \multirow[t]{2}{*}{$\mathrm{p}$} & \multicolumn{8}{|c|}{ Nível de risco (\%) } \\
\hline & & 5 & 10 & 15 & 20 & 25 & 30 & 35 & 40 \\
\hline \multirow{7}{*}{ 1-Jan } & 0,2 & 4,10 & 4,15 & 4,21 & 4,25 & 4,30 & 4,34 & 4,39 & 4,44 \\
\hline & 0,3 & 3,79 & 3,86 & 3,91 & 3,96 & 4,01 & 4,06 & 4,10 & 4,15 \\
\hline & 0,4 & 3,43 & 3,50 & 3,55 & 3,60 & 3,65 & 3,70 & 3,75 & 3,79 \\
\hline & 0,5 & 3,13 & 3,21 & 3,26 & 3,32 & 3,37 & 3,42 & 3,46 & 3,51 \\
\hline & 0,6 & 2,84 & 2,92 & 2,98 & 3,03 & 3,09 & 3,14 & 3,18 & 3,23 \\
\hline & 0,7 & 2,59 & 2,68 & 2,74 & 2,80 & 2,86 & 2,91 & 2,96 & 3,01 \\
\hline & 0,8 & 2,39 & 2,47 & 2,54 & 2,60 & 2,65 & 2,70 & 2,75 & 2,80 \\
\hline \multirow{7}{*}{ 15-Jan } & 0,2 & 4,18 & 4,24 & 4,29 & 4,34 & 4,39 & 4,44 & 4,48 & 4,53 \\
\hline & 0,3 & 3,89 & 3,96 & 4,01 & 4,06 & 4,11 & 4,16 & 4,20 & 4,25 \\
\hline & 0,4 & 3,50 & 3,57 & 3,63 & 3,68 & 3,73 & 3,77 & 3,82 & 3,87 \\
\hline & 0,5 & 3,23 & 3,31 & 3,37 & 3,42 & 3,47 & 3,52 & 3,57 & 3,62 \\
\hline & 0,6 & 2,94 & 3,02 & 3,09 & 3,14 & 3,19 & 3,24 & 3,29 & 3,34 \\
\hline & 0,7 & 2,72 & 2,81 & 2,88 & 2,94 & 3,00 & 3,05 & 3,10 & 3,15 \\
\hline & 0,8 & 2,51 & 2,61 & 2,68 & 2,74 & 2,80 & 2,85 & 2,90 & 2,96 \\
\hline \multirow{7}{*}{$1-\mathrm{Fev}$} & 0,2 & 4,41 & 4,46 & 4,50 & 4,53 & 4,56 & 4,59 & 4,62 & 4,65 \\
\hline & 0,3 & 4,12 & 4,17 & 4,21 & 4,25 & 4,28 & 4,31 & 4,34 & 4,37 \\
\hline & 0,4 & 3,70 & 3,76 & 3,81 & 3,85 & 3,89 & 3,93 & 3,96 & 4,00 \\
\hline & 0,5 & 3,41 & 3,49 & 3,55 & 3,59 & 3,64 & 3,68 & 3,72 & 3,76 \\
\hline & 0,6 & 3,16 & 3,24 & 3,30 & 3,34 & 3,39 & 3,43 & 3,47 & 3,51 \\
\hline & 0,7 & 2,90 & 2,99 & 3,05 & 3,11 & 3,16 & 3,21 & 3,25 & 3,30 \\
\hline & 0,8 & 2,68 & 2,78 & 2,85 & 2,91 & 2,96 & 3,01 & 3,06 & 3,10 \\
\hline \multirow{7}{*}{$15-\mathrm{Fev}$} & 0,2 & 4,41 & 4,46 & 4,49 & 4,53 & 4,56 & 4,59 & 4,62 & 4,65 \\
\hline & 0,3 & 4,08 & 4,14 & 4,19 & 4,23 & 4,26 & 4,30 & 4,33 & 4,36 \\
\hline & 0,4 & 3,74 & 3,80 & 3,84 & 3,88 & 3,92 & 3,95 & 3,99 & 4,02 \\
\hline & 0,5 & 3,41 & 3,48 & 3,54 & 3,59 & 3,63 & 3,67 & 3,71 & 3,75 \\
\hline & 0,6 & 3,17 & 3,25 & 3,32 & 3,37 & 3,42 & 3,46 & 3,50 & 3,54 \\
\hline & 0,7 & 2,96 & 3,05 & 3,11 & 3,16 & 3,21 & 3,26 & 3,30 & 3,34 \\
\hline & 0,8 & 2,78 & 2,87 & 2,94 & 2,99 & 3,04 & 3,08 & 3,13 & 3,17 \\
\hline
\end{tabular}


Tabela 36B. Relą̧ão beneficio/custo para a melancia, em cada época de semeadura, nível de manejo da irrigação e nivel de risco. Parnaiba, Piauí.

\begin{tabular}{|c|c|c|c|c|c|c|c|c|c|}
\hline \multirow{2}{*}{$\begin{array}{l}\text { Época de } \\
\text { Semeadura }\end{array}$} & \multirow[t]{2}{*}{$\mathrm{p}$} & \multicolumn{8}{|c|}{ Nível de risco (\%) } \\
\hline & & 5 & 10 & 15 & 20 & 25 & 30 & 35 & 40 \\
\hline \multirow{7}{*}{ 1-Mar } & 0,2 & 4,38 & 4,44 & 4,50 & 4,55 & 4,60 & 4,65 & 4,70 & 4,75 \\
\hline & 0,3 & 4,06 & 4,13 & 4,19 & 4,25 & 4,30 & 4,35 & 4,40 & 4,46 \\
\hline & 0,4 & 3,67 & 3,76 & 3,82 & 3,88 & 3,94 & 3,99 & 4,05 & 4,10 \\
\hline & 0,5 & 3,37 & 3,47 & 3,54 & 3,61 & 3,67 & 3,73 & 3,78 & 3,84 \\
\hline & $\theta ; 6$ & 3,11 & 3,22 & 3,30 & $3 ; 36$ & 3,43 & 3,49 & 3,55 & 3,61 \\
\hline & 0,7 & 2,88 & 2,99 & 3,07 & 3,15 & 3,21 & 3,28 & 3,34 & 3,40 \\
\hline & 0,8 & 2,72 & $2,83$. & 2,92 & 2,99 & 3,06 & 3,13 & 3,19 & 3,25 \\
\hline \multirow{7}{*}{ 15-Mar } & 0,2 & 4,34 & 4,40 & 4,46 & 4,51 & 4,56 & 4,61 & 4,66 & 4,71 \\
\hline & 0,3 & 4,01 & 4,08 & 4,14 & 4,19 & 4,24 & 4,29 & 4,35 & 4,40 \\
\hline & $0 ; 4$ & $3 ; 64$ & 3,72 & $3 ; 78$ & 3,83 & 3,88 & 3,93 & 3,99 & 4,04 \\
\hline & 0,5 & 3,36 & 3,44 & 3,50 & 3,56 & 3,62 & 3,67 & 3,72 & 3,77 \\
\hline & 0,6 & 3,07 & $3 ; 16$ & 3,23 & 3,29 & 3,35 & 3,40 & 3,46 & 3,51 \\
\hline & 0,7 & 2,83 & 2,93 & 3,01 & 3,07 & 3,14 & 3,20 & 3,25 & 3,31 \\
\hline & 0,8 & 2,60 & 2,72 & $2,8 \theta$ & 2,88 & 2,94 & 3,01 & 3,07 & 3,13 \\
\hline \multirow{7}{*}{$1-\mathrm{Abr}$} & 0,2 & 4,22 & 4,28 & 4,33 & 4,38 & 4,43 & 4,48 & 4,53 & 4,58 \\
\hline & 0,3 & 3,89 & 3,96 & 4,02 & 4,07 & 4,12 & 4,17 & 4,22 & 4,27 \\
\hline & 0,4 & 3,46 & 3,54 & 3,60 & 3,65 & 3,71 & 3,76 & 3,81 & 3,87 \\
\hline & 0,5 & 3,16 & 3,24 & 3,30 & 3,36 & 3,41 & 3,46 & 3,52 & 3,57 \\
\hline & 0,6 & 2,87 & 2,96 & 3,03 & 3,09 & 3,14 & 3,20 & 3,25 & 3,30 \\
\hline & 0,7 & 2,62 & 2,71 & 2,78 & 2,85 & 2,90 & 2,96 & 3,01 & 3,07 \\
\hline & 0,8 & 2,40 & 2,50 & 2,58 & 2,64 & 2,70 & 2,76 & 2,82 & 2,88 \\
\hline \multirow[t]{2}{*}{ 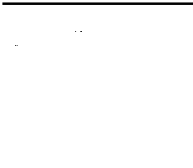 } & 0,2 & 4,19 & 4,25 & 4,30 & 4,35 & 4,40 & 4,44 & 4,49 & 4,54 \\
\hline & 0,3 & 3,85 & 3,92 & 3,97 & 4,02 & 4,07 & 4,12 & 4,17 & 4,22 \\
\hline \multirow{5}{*}{$15-\mathrm{Abr}$} & 0,4 & 3,41 & 3,48 & $3 ; 54$ & 3,59 & 3,64 & 3,69 & 3,74 & 3,79 \\
\hline & 0,5 & 3,10 & 3,17 & 3,23 & 3,29 & 3,34 & 3,39 & 3,44 & 3,49 \\
\hline & $\theta, 6$ & 2,79 & 2,87 & 2,94 & 2,99 & 3,05 & 3,10 & 3,15 & 3,20 \\
\hline & 0,7 & 2,49 & 2,57 & 2,60 & 2,68 & 2,70 & 2,79 & 2,81 & 2,84 \\
\hline & 0,8 & 2,34 & 2,42 & 2,48 & 2,54 & 2,59 & 2,64 & 2,69 & 2,74 \\
\hline
\end{tabular}


Tabela 36B. Relação benefício/custo para a melancia, em cada época de semeadura, nível de manejo da irrigação e nível de risco. Parnaíba, Piauí.

\begin{tabular}{|c|c|c|c|c|c|c|c|c|c|}
\hline \multirow{2}{*}{$\begin{array}{l}\text { Época de } \\
\text { Semeadura }\end{array}$} & \multirow[t]{2}{*}{$p$} & \multicolumn{8}{|c|}{ Nível de risco (\%) } \\
\hline & & 5 & 10 & 15 & 20 & 25 & 30 & 35 & 40 \\
\hline \multirow{7}{*}{ 1-Mai } & 0,2 & 3,37 & 3,41 & 3,44 & 3,47 & 3,50 & 3,53 & 3,56 & 3,60 \\
\hline & 0,3 & 3,10 & 3,14 & 3,18 & 3,21 & 3,24 & 3,28 & 3,31 & 3,34 \\
\hline & 0,4 & 2,72 & 2,77 & 2,80 & 2,84 & 2,87 & 2,90 & 2,93 & 2,96 \\
\hline & 0,5 & 2,46 & 2,51 & 2,54 & 2,58 & 2,61 & 2,64 & 2,67 & 2,70 \\
\hline & 0,6 & 2,23 & 2,27 & 2,31 & 2,34 & 2,37 & 2,40 & 2,43 & 2,46 \\
\hline & 0,7 & 2,00 & 2,05 & 2,08 & 2,12 & 2,15 & 2,18 & 2,21 & 2,24 \\
\hline & 0,8 & 1,81 & 1,86 & 1,90 & 1,93 & 1,96 & 1,99 & 2,03 & 2,06 \\
\hline \multirow{7}{*}{ 15-Mai } & 0,2 & 3,36 & 3,40 & 3,43 & 3,46 & 3,49 & 3,53 & 3,56 & 3,59 \\
\hline & 0,3 & 3,11 & 3,15 & 3,19 & 3,22 & 3,25 & 3,28 & 3,31 & 3,35 \\
\hline & 0,4 & 2,72 & 2,76 & 2,80 & 2,83 & 2,86 & 2,89 & 2,92 & 2,96 \\
\hline & 0,5 & 2,47 & 2,51 & 2,55 & 2,58 & 2,61 & 2,64 & 2,68 & 2,71 \\
\hline & 0,6 & 2,20 & 2,24 & 2,28 & 2,31 & 2,34 & 2,37 & 2,40 & 2,43 \\
\hline & 0,7 & 1,99 & 2,04 & 2,08 & 2,11 & 2,14 & 2,17 & 2,20 & 2,23 \\
\hline & 0,8 & 1,80 & 1,85 & 1,88 & 1,91 & 1,94 & 1,97 & 2,00 & 2,03 \\
\hline \multirow{7}{*}{ 1-Jun } & 0,2 & 3,48 & 3,53 & 3,57 & 3,62 & 3,66 & 3,71 & 3,75 & 3,80 \\
\hline & 0,3 & 3,22 & 3,27 & 3,32 & 3,36 & 3,41 & 3,45 & 3,50 & 3,54 \\
\hline & 0,4 & 2,82 & 2,87 & 2,91 & 2,95 & 3,00 & 3,04 & 3,08 & 3,12 \\
\hline & 0,5 & 2,57 & 2,62 & 2,67 & 2,71 & 2,74 & 2,78 & 2,82 & 2,86 \\
\hline & 0,6 & 2,26 & 2,31 & 2,35 & 2,39 & 2,42 & 2,46 & 2,50 & 2,54 \\
\hline & 0,7 & 2,08 & 2,13 & 2,17 & 2,20 & 2,24 & 2,27 & 2,31 & 2,35 \\
\hline & 0,8 & 1,84 & 1,89 & 1,93 & 1,97 & 2,00 & 2,03 & 2,07 & 2,10 \\
\hline \multirow{7}{*}{ 15-Jun } & 0,2 & 3,50 & 3,56 & 3,60 & 3,65 & 3,70 & 3,74 & 3,79 & 3,84 \\
\hline & 0,3 & 3,25 & 3,30 & 3,34 & 3,39 & 3,43 & 3,47 & 3,52 & 3,56 \\
\hline & 0,4 & 2,85 & 2,91 & 2,95 & 2,99 & 3,04 & 3,08 & 3,12 & 3,16 \\
\hline & 0,5 & 2,60 & 2,65 & 2,69 & 2,73 & 2,76 & 2,80 & 2,84 & 2,88 \\
\hline & 0,6 & 2,29 & 2,34 & 2,38 & 2,42 & 2,46 & 2,50 & 2,54 & 2,58 \\
\hline & 0,7 & 2,08 & 2,13 & 2,17 & 2,21 & 2,24 & 2,27 & 2,31 & 2,35 \\
\hline & 0,8 & 1,87 & 1,91 & 1,95 & 1,98 & 2,02 & 2,05 & 2,08 & 2,11 \\
\hline
\end{tabular}


Tabela 36B. Relação beneficio/custo para-a melancia, em cada época de semeadura, nível de manejo da irrigação e nível de risco. Parnaiba, Piauí.

\begin{tabular}{|c|c|c|c|c|c|c|c|c|c|}
\hline \multirow{2}{*}{$\begin{array}{l}\text { Época de } \\
\text { Semeadura }\end{array}$} & \multirow[t]{2}{*}{$\mathrm{p}$} & \multicolumn{8}{|c|}{ Nivel de risco (\%) } \\
\hline & & 5 & 10 & 15 & 20 & 25 & 30 & 35 & 40 \\
\hline \multirow{7}{*}{ 1-Jul } & 0,2 & 2,87 & 2,96 & 3,03 & 3,09 & 3,14 & 3,18 & 3,23 & 3,27 \\
\hline & 0,3 & 2,63 & 2,72 & 2,78 & 2,83 & 2,88 & 2,92 & 2,96 & 3,00 \\
\hline & 0,4 & 2,36 & 2,44 & 2,50 & 2,55 & 2,60 & 2,64 & 2,68 & 2,72 \\
\hline & 0,5 & 2,10 & 2,17 & 2,23 & 2,27 & 2,31 & 2,35 & 2,38 & 2,42 \\
\hline & 0,6 & 1,89 & 1,96 & $2 ; 01$ & 2,06 & 2,10 & 2,13 & 2,17 & 2,20 \\
\hline & 0,7 & 1,69 & 1,76 & 1,80 & 1,84 & 1,88 & 1,91 & 1,94 & 1,97 \\
\hline & $0 ; 8$ & 1,53 & 1,59 & 1,64 & 1,67 & 1,71 & 1,74 & 1,77 & 1,80 \\
\hline \multirow{7}{*}{ 15-Jul } & 0,2 & $2,9.1$ & 3,00 & $3,07$. & 3,13 & 3,19 & 3,23 & 3,28 & 3,32 \\
\hline & 0,3 & 2,65 & 2,74 & 2,80 & 2,85 & 2,90 & 2,94 & 2,98 & 3,01 \\
\hline & 0,4 & 2,42 & 2,50 & 2,56 & 2,62 & 2,66 & 2,70 & 2,74 & 2,78 \\
\hline & 0,5 & 2,12 & 2,20 & 2,25 & 2,30 & 2,34 & 2,37 & 2,41 & 2,44 \\
\hline & 0,6 & 1,94 & 2,01 & 2,06 & 2,11 & 2,15 & 2,18 & 2,22 & 2,25 \\
\hline & 0,7 & 1,71 & 1,78 & 1,82 & 1,86 & 1,90 & 1,93 & 1,96 & 1,99 \\
\hline & 0,8 & 1,57 & 1,63 & 1,67 & 1,71 & 1,74 & 1,77 & 1,80 & 1,82 \\
\hline \multirow{7}{*}{ 1-Ago } & 0,2 & 3,62 & 3,67 & $3,71^{-}$ & 3,76 & 3,80 & 3,85 & 3,89 & 3,94 \\
\hline & 0,3 & 3,23 & 3,26 & 3,30 & 3,34 & 3,37 & 3,41 & 3,45 & 3,49 \\
\hline & 0,4 & 2,99 & $3 ; 03$ & 3,07 & 3,11 & 3,15 & 3,19 & 3,23 & 3,27 \\
\hline & 0,5 & 2,62 & 2,66 & 2,70 & 2,73 & 2,77 & 2,81 & 2,84 & 2,88 \\
\hline & 0,6 & 2,36 & 2,40 & 2,44 & 2,47 & 2,50 & 2,54 & 2,57 & 2,60 \\
\hline & 0,7 & 2,16 & 2,20 & 2,23 & 2,26 & 2,30 & 2,33 & 2,36 & 2,39 \\
\hline & 0,8 & 1,92 & 1,95 & 1,98 & 2,01 & 2,03 & 2,06 & 2,09 & 2,12 \\
\hline \multirow{7}{*}{ 15-Ago } & 0,2 & 3,67 & 3,72 & 3,77 & 3,81 & 3,85 & 3,90 & 3,95 & 3,99 \\
\hline & 0,3 & 3,22 & 3,26 & 3,29 & 3,33 & 3,37 & 3,41 & 3,45 & 3,49 \\
\hline & 0,4 & 3,03 & 3,07 & 3,11 & 3,15 & 3,18 & 3,22 & 3,26 & 3,30 \\
\hline & 0,5 & 2,65 & 2,70 & 2,74 & 2,78 & 2,82 & 2,86 & 2,90 & 2,94 \\
\hline & 0,6 & 2,40 & 2,43 & 2,46 & 2,49 & 2,53 & 2,56 & 2,59 & 2,63 \\
\hline & 0,7 & 2,21 & 2,25 & 2,28 & 2,31 & 2,34 & 2,38 & 2,41 & 2,44 \\
\hline & 0,8 & 1,94 & 1,96 & 1,98 & 2,02 & 2,04 & 2,07 & 2,09 & 2,11 \\
\hline
\end{tabular}


Tabela 36B. Relação beneficio/custo para a melancia, em cada época de semeadura, nível de manejo da irrigação e nível de risco. Parnaíba, Piauí.

\begin{tabular}{|c|c|c|c|c|c|c|c|c|c|}
\hline \multirow{2}{*}{$\begin{array}{c}\text { Época de } \\
\text { Semeadura }\end{array}$} & \multirow[t]{2}{*}{$\mathrm{p}$} & \multicolumn{8}{|c|}{ Nível de risco (\%) } \\
\hline & & 5 & 10 & 15 & 20 & 25 & 30 & 35 & 40 \\
\hline \multirow{7}{*}{$1-$ Set } & 0,2 & 3,55 & 3,58 & 3,61 & 3,64 & 3,67 & 3,70 & 3,73 & 3,77 \\
\hline & 0,3 & 3,07 & 3,10 & 3,12 & 3,15 & 3,17 & 3,20 & 3,22 & 3,25 \\
\hline & 0,4 & 2,92 & 2,94 & 2,97 & 3,00 & 3,02 & 3,05 & 3,07 & 3,10 \\
\hline & 0,5 & 2,61 & 2,64 & 2,67 & 2,70 & 2,73 & 2,76 & 2,79 & 2,82 \\
\hline & 0,6 & 2,30 & 2,32 & 2,34 & 2,36 & 2,39 & 2,41 & 2,43 & 2,46 \\
\hline & 0,7 & 2,14 & 2,17 & 2,19 & 2,22 & 2,24 & 2,26 & 2,29 & 2,31 \\
\hline & 0,8 & 1,86 & 1,89 & 1,91 & 1,94 & 1,96 & 1,98 & 2,00 & 2,02 \\
\hline \multirow{7}{*}{$15-$ Set } & 0,2 & 3,55 & 3,58 & 3,61 & 3,64 & 3,67 & 3,70 & 3,74 & 3,77 \\
\hline & 0,3 & 3,07 & 3,10 & 3,13 & 3,15 & 3,18 & 3,20 & 3,23 & 3,26 \\
\hline & 0,4 & 2,90 & 2,94 & 2,96 & 2,99 & 3,02 & 3,04 & 3,07 & 3,10 \\
\hline & 0,5 & 2,60 & 2,64 & 2,67 & 2,70 & 2,73 & 2,76 & 2,78 & 2,81 \\
\hline & 0,6 & 2,30 & 2,33 & 2,35 & 2,38 & 2,40 & 2,42 & 2,45 & 2,47 \\
\hline & 0,7 & 2,12 & 2,16 & 2,18 & 2,21 & 2,23 & 2,26 & 2,28 & 2,31 \\
\hline & 0,8 & 1,87 & 1,90 & 1,92 & 1,94 & 1,97 & 1,99 & 2,01 & 2,03 \\
\hline \multirow{7}{*}{ 1-Out } & 0,2 & 3,61 & 3,65 & 3,68 & 3,71 & 3,75 & 3,78 & 3,81 & 3,84 \\
\hline & 0,3 & 3,14 & 3,17 & 3,20 & 3,22 & 3,25 & 3,28 & 3,30 & 3,33 \\
\hline & 0,4 & 2,97 & 3,00 & 3,03 & 3,06 & 3,09 & 3,11 & 3,14 & 3,17 \\
\hline & 0,5 & 2,67 & 2,70 & 2,73 & 2,76 & 2,79 & 2,82 & 2,85 & 2,88 \\
\hline & 0,6 & 2,33 & 2,36 & 2,39 & 2,41 & 2,44 & 2,46 & 2,48 & 2,51 \\
\hline & 0,7 & 2,18 & 2,21 & 2,24 & 2,27 & 2,29 & 2,31 & 2,34 & 2,36 \\
\hline & 0,8 & 1,91 & 1,94 & 1,96 & 1,98 & 2,00 & 2,03 & 2,05 & 2,07 \\
\hline \multirow{7}{*}{ 15-Out } & 0,2 & 3,59 & 3,62 & 3,66 & 3,69 & 3,72 & 3,75 & 3,79 & 3,82 \\
\hline & 0,3 & 3,15 & 3,18 & 3,21 & 3,23 & 3,26 & 3,29 & 3,31 & 3,34 \\
\hline & 0,4 & 2,96 & 2,99 & 3,02 & 3,05 & 3,08 & 3,10 & 3,13 & 3,16 \\
\hline & 0,5 & 2,61 & 2,65 & 2,68 & 2,71 & 2,74 & 2,77 & 2,80 & 2,82 \\
\hline & 0,6 & 2,34 & 2,37 & 2,40 & 2,42 & 2,44 & 2,47 & 2,49 & 2,52 \\
\hline & 0,7 & 2,17 & 2,20 & 2,23 & 2,25 & 2,28 & 2,30 & 2,32 & 2,35 \\
\hline & 0,8 & 1,89 & 1,92 & 1,95 & 1,97 & 1,99 & 2,01 & 2,03 & 2,05 \\
\hline
\end{tabular}


556

Tabela 36B. Relação beneficio/custo para a melancia, em cada época de semeadura, nível de manejo da irrigação e nível de risco. Parnaíba, Piauí.

\begin{tabular}{|c|c|c|c|c|c|c|c|c|c|}
\hline \multirow{2}{*}{$\begin{array}{l}\text { Época de } \\
\text { Semeadura }\end{array}$} & \multirow[t]{2}{*}{$\mathrm{p}$} & \multicolumn{8}{|c|}{ Nivel de risco (\%) } \\
\hline & & 5 & 10 & 15 & 20 & 25 & 30 & 35 & 40 \\
\hline \multirow{7}{*}{ 1-Nov } & 0,2 & 3,86 & 3,91 & 3,95 & 3,99 & 4,03 & 4,07 & 4,11 & 4,15 \\
\hline & 0,3 & 3,50 & 3,54 & 3,57 & 3,61 & 3,64 & 3,67 & 3,70 & 3,74 \\
\hline & 0,4 & 3,21 & 3,26 & 3,30 . & 3,33 & 3,37 & 3,40 & 3,43 & 3,47 \\
\hline & 0,5 & 2,86 & 2,90 & 2,94 & 2,97 & 3,00 & 3,03 & 3,07 & 3,10 \\
\hline & 0,6 & 2,58 & 2,63 & 2,66 & 2,69 & 2,73 & 2,76 & 2,79 & 2,82 \\
\hline & 0,7 & 2,33 & 2,37 & 2,41 & 2,44 & 2,47 & 2,50 & 2,53 & 2,56 \\
\hline & 0,8 & 2,09 & 2,13 & 2,17 & 2,20 & 2,22 & 2,25 & 2,28 & 2,31 \\
\hline \multirow{7}{*}{ 15-Nov } & 0,2 & 3,83 & 3,88 & 3,92 & 3,96 & 4,00 & 4,03 & 4,07 & 4,11 \\
\hline & 0,3 & 3,50 & 3,54 & 3,58 & 3,61 & 3,65 & 3,68 & 3,71 & 3,75 \\
\hline & 0,4 & 3,18 & 3,23 & $3 ; 28$ & 3,31 & 3,35 & 3,39 & 3,42 & 3,46 \\
\hline & 0,5 & 2,83 & 2,88 & 2,92 & 2,96 & 2,99 & 3,02 & 3,06 & 3,09 \\
\hline & 0,6 & 2,57 & 2,62 & 2,67 & 2,70 & 2,74 & 2,77 & 2,80 & 2,84 \\
\hline & 0,7 & 2,31 & 2,36 & 2,40 & 2,44 & 2,47 & 2,51 & 2,54 & 2,57 \\
\hline & $0 ; 8$ & 2,08 & 2,14 & 2,18 & 2,22 & 2,25 & 2,28 & 2,32 & 2,35 \\
\hline \multirow{7}{*}{ 1-Dez } & 0,2 & 3,77 & $3 ; 87$ & 3,96 & 4,04 & 4,13 & 4,22 & 4,32 & 4,41 \\
\hline & 0,3 & 3,48 & 3,57 & 3,65 & 3,73 & 3,81 & 3,90 & 3,98 & 4,07 \\
\hline & 0,4 & 3,14 . & 3,23 & $3,3.1$ & 3,39 & $3,47$. & 3,55 & 3,64 & 3,72 \\
\hline & 0,5 & 2,81 & 2,90 & 2,97 & 3,05 & 3,12 & 3,20 & 3,28 & 3,35 \\
\hline & 0,6 & 2,54 & 2,63 & 2,71 & 2,78 & 2,85 & 2,93 & 3,00 & 3,08 \\
\hline & 0,7 & 2,32 & 2,40 & 2,47 & 2,54 & 2,61 & 2,68 & 2,74 & 2,82 \\
\hline & 0,8 & 2,07 & 2,16 & 2,23 & 2,30 & 2,37 & 2,43 & 2,50 & 2,57 \\
\hline \multirow{7}{*}{ 15-Dez } & 0,2 & 3,76 & 3,85 & 3,94 & 4,03 & 4,12 & 4,21 & 4,30 & 4,39 \\
\hline & 0,3 & 3,47 & 3,56 & 3,65 & 3,73 & 3,82 & 3,90 & 3,99 & 4,08 \\
\hline & 0,4 & 3,13 & 3,22 & 3,30 & 3,38 & 3,46 & 3,54 & 3,63 & 3,71 \\
\hline & 0,5 & 2,81 & 2,91 & 2,99 & 3,07 & 3,15 & 3,23 & 3,31 & 3,40 \\
\hline & 0,6 & 2,54 & 2,64 & 2,72 & 2,80 & 2,88 & 2,96 & 3,03 & 3,12 \\
\hline & 0,7 & 2,33 & 2,42 & 2,50 & 2,58 & 2,65 & 2,72 & 2,80 & 2,87 \\
\hline & 0,8 & 2,12 & 2,21 & 2,29 & 2,36 & 2,44 & 2,51 & 2,58 & 2,65 \\
\hline
\end{tabular}


Tabela 37B. Relação benefício/custo para a melancia, em cada época de semeadura, nível de manejo da irrigação e nível de risco. Teresina, Piauí.

\begin{tabular}{|c|c|c|c|c|c|c|c|c|c|}
\hline \multirow{2}{*}{$\begin{array}{c}\text { Época de } \\
\text { Semeadura }\end{array}$} & \multirow[t]{2}{*}{$\mathrm{p}$} & \multicolumn{8}{|c|}{ Nível de risco (\%) } \\
\hline & & 5 & 10 & 15 & 20 & 25 & 30 & 35 & 40 \\
\hline \multirow{7}{*}{ 1-Jan } & 0,2 & 4,05 & 4,11 & 4,16 & 4,20 & 4,25 & 4,29 & 4,34 & 4,38 \\
\hline & 0,3 & 3,64 & 3,71 & 3,76 & 3,81 & 3,86 & 3,91 & 3,96 & 4,00 \\
\hline & 0,4 & 3,35 & 3,43 & 3,49 & 3,54 & 3,60 & 3,65 & 3,70 & 3,75 \\
\hline & 0,5 & 3,07 & 3,16 & 3,22 & 3,28 & 3,34 & 3,39 & 3,44 & 3,49 \\
\hline & 0,6 & 2,85 & 2,94 & 3,01 & 3,07 & 3,13 & 3,19 & 3,24 & 3,30 \\
\hline & 0,7 & 2,65 & 2,75 & 2,83 & 2,90 & 2,97 & 3,03 & 3,08 & 3,14 \\
\hline & 0,8 & 2,48 & 2,59 & 2,68 & 2,75 & 2,82 & 2,88 & 2,94 & 3,01 \\
\hline \multirow{7}{*}{ 15-Jan } & 0,2 & 4,15 & 4,21 & 4,26 & 4,31 & 4,36 & 4,40 & 4,45 & 4,50 \\
\hline & 0,3 & 3,76 & 3,83 & 3,89 & 3,94 & 3,99 & 4,04 & 4,09 & 4,14 \\
\hline & 0,4 & 3,50 & 3,58 & 3,64 & 3,70 & 3,75 & 3,80 & 3,85 & 3,90 \\
\hline & 0,5 & 3,25 & 3,34 & 3,41 & 3,47 & 3,52 & 3,58 & 3,63 & 3,68 \\
\hline & 0,6 & 3,03 & 3,13 & 3,20 & 3,26 & 3,33 & 3,38 & 3,44 & 3,50 \\
\hline & 0,7 & 2,80 & 2,92 & 3,01 & 3,08 & 3,15 & 3,22 & 3,28 & 3,35 \\
\hline & 0,8 & 2,66 & 2,79 & 2,88 & 2,96 & 3,03 & 3,10 & 3,16 & 3,24 \\
\hline \multirow{7}{*}{ 1-Fev } & 0,2 & 4,41 & 4,46 & 4,50 & 4,54 & 4,57 & 4,60 & 4,63 & 4,67 \\
\hline & 0,3 & 4,03 & 4,09 & 4,14 & 4,18 & 4,22 & 4,25 & 4,28 & 4,32 \\
\hline & 0,4 & 3,76 & 3,84 & 3,89 & 3,94 & 3,99 & 4,03 & 4,07 & 4,11 \\
\hline & 0,5 & 3,54 & 3,62 & 3,68 & 3,74 & 3,78 & 3,83 & 3,87 & 3,91 \\
\hline & 0,6 & 3,32 & 3,42 & 3,49 & 3,55 & 3,60 & 3,65 & 3,70 & 3,75 \\
\hline & 0,7 & 3,16 & 3,27 & 3,35 & 3,42 & 3,47 & 3,53 & 3,58 & 3,63 \\
\hline & 0,8 & 3,04 & 3,16 & 3,24 & 3,31 & 3,38 & 3,43 & 3,49 & 3,54 \\
\hline \multirow{7}{*}{$15-\mathrm{Fev}$} & 0,2 & 4,41 & 4,47 & 4,51 & 4,55 & 4,58 & 4,61 & 4,65 & 4,68 \\
\hline & 0,3 & 4,02 & 4,09 & 4,14 & 4,18 & 4,23 & 4,26 & 4,30 & 4,34 \\
\hline & 0,4 & 3,75 & 3,83 & 3,89 & 3,95 & 3,99 & 4,04 & 4,08 & 4,12 \\
\hline & 0,5 & 3,52 & 3,61 & 3,68 & 3,74 & 3,79 & 3,84 & 3,89 & 3,94 \\
\hline & 0,6 & 3,32 & 3,43 & 3,51 & 3,57 & 3,63 & 3,69 & 3,74 & 3,79 \\
\hline & 0,7 & 3,15 & 3,27 & 3,36 & 3,44 & 3,50 & 3,57 & 3,63 & 3,68 \\
\hline & 0,8 & 3,04 & 3,17 & 3,27 & 3,35 & 3,42 & 3,49 & 3,55 & 3,61 \\
\hline
\end{tabular}


Tabela 37B. Relação beneficio/custo para a melancia, em cada época de semeadura, nível de manejo da irrigação e nível de risco. Teresina, Piauí.

\begin{tabular}{|c|c|c|c|c|c|c|c|c|c|}
\hline \multirow{2}{*}{$\begin{array}{l}\text { Época de } \\
\text { Semeadura }\end{array}$} & \multirow[t]{2}{*}{$\mathrm{p}$} & \multicolumn{8}{|c|}{ Nível de risco (\%) } \\
\hline & & 5 & 10 & 15 & 20 & 25 & 30 & 35 & 40 \\
\hline \multirow{7}{*}{ 1-Mar } & 0,2 & 4,36 & 4,43 & 4,49 & $4,54^{-}$ & 4,60 & 4,65 & 4,70 & 4,75 \\
\hline & 0,3 & 3,96 & 4,05 & 4,11 & 4,17 & 4,23 & 4,29 & 4,34 & 4,40 \\
\hline & 0,4 & 3,70 & 3,79 & 3,86 & 3,93 & 3,99 & 4,05 & 4,10 & 4,16 \\
\hline & 0,5 & 3,50 & 3,60 & 3,68 & 3,75 & 3,81 & 3,87 & 3,94 & 4,00 \\
\hline & 0,6 & 3,28 & 3,40 & 319 & 3,57 & 3,64 & 3,71 & 3,78 & 3,84 \\
\hline & 0,7 & 3,07 & 3,21 & 3,31 & 240 & 3,48 & 3,55 & 3,63 & 3,70 \\
\hline & 0,8 & 2,93 & 3,08 & 3,20 & 3,29 & 3,38 & 3,45 & 3,53 & 3,61 \\
\hline \multirow{7}{*}{ 15-Mar } & 0,2 & 4,31 & 4,37 & 4,43 & $4,48^{\circ}$ & 4,53 & 4,58 & 4,63 & 4,68 \\
\hline & 0,3 & 3,89 & 3,96 & 4,03 & 4,08 & 4,13 & 4,18 & 4,24 & 4,29 \\
\hline & 0,4 & 3,56 & 3,65 & 3,72 & 3,78 & 3,84 & 3,89 & 3,95 & 4,00 \\
\hline & 0,5 & 3,32 & 3,42 & 3,50 & 3,56 & 3,63 & 3,69 & 3,75 & 3,81 \\
\hline & 0,6 & 3,07 & 3,19 & $3 ; 27$ & 3,35 & 3,41 & 3,48 & 3,54 & 3,61 \\
\hline & 0,7 & 2,86 & 2,99 & 3,08 & 3,16 & 3,24 & 3,31 & 3,38 & 3,44 \\
\hline & 0,8 & 2,69 & 2,83 & 2,93 & 3,01 & 3,09 & 3,16 & 3,23 & 3,31 \\
\hline \multirow{7}{*}{$1-\mathrm{Abr}$} & 0,2 & 4,13 & $4,19^{-}$ & 4,25 & 4,30 & 4,35 & 4,41 & 4,46 & 4,51 \\
\hline & 0,3 & 3,67 & 3,74 & 3,80 & 3,86 & 3,91 & 3,97 & 4,02 & 4,07 \\
\hline & 0,4 & 3,32 & 3,40 & 3,47 & 3,53 & 3,59 & 3,65 & 3,71 & 3,76 \\
\hline & 0,5 & 3,06 & 3,15 & 3,22 & 3,29 & 3,35 & 3,40 & 3,46 & 3,52 \\
\hline & 0,6 & 2,81 & 2,91 & 2,98 & 3,05 & 3,11 & 3,17 & 3,23 & 3,29 \\
\hline & 0,7 & 2,58 & 2,69 & 2,77 & 2,84 & 2,91 & 2,97 & 3,03 & 3,09 \\
\hline & 0,8 & 2,37 & 2,49 & 2,58 & 2,66 & 2,73 & 2,80 & 2,86 & 2,93 \\
\hline \multirow{7}{*}{$15-\mathrm{Abr}$} & 0,2 & 4,07 & $4 ; \mathrm{13}$ & 4,19 & 4,24 & 4,29 & 4,34 & 4,39 & 4,44 \\
\hline & 0,3 & 3,57 & 3,63 & 3,69 & 3,74 & 3,79 & 3,84 & 3,89 & 3,94 \\
\hline & 0,4 & $3 ; 18$ & 3,26 & 3,32 & 3,37 & 3,42 & 3,47 & 3,52 & 3,58 \\
\hline & 0,5 & 2,89 & 2,97 & 3,04 & 3,09 & 3,15 & 3,20 & 3,25 & 3,31 \\
\hline & 0,6 & 2,61 & 2.70 & 2,77 & 2,83 & 2,89 & 2,94 & 3,00 & 3,05 \\
\hline & 0,7 & 2,35 & 2,45 & 2,52 & 2,59 & 2,64 & 2,70 & 2,75 & 2,81 \\
\hline & 0,8 & 2,13 & 2,23 & 2,31 & 2,37 & 2,43 & 2,49 & 2,55 & 2,60 \\
\hline
\end{tabular}


Tabela 37B. Relação benefício/custo para a melancia, em cada época de semeadura, nível de manejo da irrigação e nível de risco. Teresina, Piauí.

\begin{tabular}{|c|c|c|c|c|c|c|c|c|c|}
\hline \multirow{2}{*}{$\begin{array}{l}\text { Época de } \\
\text { Semeadura }\end{array}$} & \multirow[t]{2}{*}{$\mathrm{p}$} & \multicolumn{8}{|c|}{ Nível de risco (\%) } \\
\hline & & 5 & 10 & 15 & 20 & 25 & 30 & 35 & 40 \\
\hline \multirow{7}{*}{ 1-Mai } & 0,2 & 3,26 & 3,30 & 3,33 & 3,37 & 3,40 & 3,43 & 3,46 & 3,49 \\
\hline & 0,3 & 2,83 & 2,87 & 2,91 & 2,94 & 2,97 & 3,01 & 3,04 & 3,07 \\
\hline & 0,4 & 2,51 & 2,56 & 2,60 & 2,63 & 2,67 & 2,70 & 2,73 & 2,77 \\
\hline & 0,5 & 2,29 & 2,34 & 2,38 & 2,42 & 2,45 & 2,48 & 2,51 & 2,54 \\
\hline & 0,6 & 2,03 & 2,09 & 2,13 & 2,17 & 2,21 & 2,24 & 2,27 & 2,31 \\
\hline & 0,7 & 1,80 & 1,86 & 1,91 & 1,95 & 1,99 & 2,03 & 2,06 & 2,10 \\
\hline & 0,8 & 1,62 & 1,68 & 1,73 & 1,77 & 1,81 & 1,85 & 1,88 & 1,92 \\
\hline \multirow{7}{*}{ 15-Mai } & 0,2 & 3,26 & 3,30 & 3,33 & 3,36 & 3,39 & 3,42 & 3,45 & 3,48 \\
\hline & 0,3 & 2,81 & 2,85 & 2,88 & 2,91 & 2,94 & 2,97 & 3,00 & 3,03 \\
\hline & 0,4 & 2,51 & 2,55 & 2,58 & 2,61 & 2,64 & 2,67 & 2,70 & 2,73 \\
\hline & 0,5 & 2,25 & 2,29 & 2,33 & 2,36 & 2,38 & 2,41 & 2,44 & 2,47 \\
\hline & 0,6 & 1,99 & 2,03 & 2,06 & 2,09 & 2,12 & 2,15 & 2,18 & 2,21 \\
\hline & 0,7 & 1,77 & 1,82 & 1,85 & 1,88 & 1,91 & 1,94 & 1,97 & 2,00 \\
\hline & 0,8 & 1,61 & 1,65 & 1,69 & 1,72 & 1,74 & 1,77 & 1,80 & 1,82 \\
\hline \multirow{7}{*}{ 1-Jun } & 0,2 & 3,35 & 3,40 & 3,45 & 3,49 & 3,53 & 3,57 & 3,62 & 3,66 \\
\hline & 0,3 & 2,92 & 2,97 & 3,01 & 3,06 & 3,10 & 3,14 & 3,18 & 3,22 \\
\hline & 0,4 & 2,62 & 2,67 & 2,71 & 2,75 & 2,79 & 2,83 & 2,87 & 2,91 \\
\hline & 0,5 & 2,33 & 2,37 & 2,41 & 2,45 & 2,48 & 2,52 & 2,55 & 2,59 \\
\hline & 0,6 & 2,05 & 2,09 & 2,13 & 2,17 & 2,20 & 2,23 & 2,27 & 2,30 \\
\hline & 0,7 & 1,84 & 1,88 & 1,92 & 1,96 & 1,99 & 2,02 & 2,06 & 2,09 \\
\hline & 0,8 & 1,66 & 1,70 & 1,74 & 1,77 & 1,80 & 1,83 & 1,86 & 1,89 \\
\hline \multirow{7}{*}{ 15-Jun } & 0,2 & 3,38 & 3,43 & 3,47 & 3,51 & 3,55 & 3,60 & 3,64 & 3,69 \\
\hline & 0,3 & 2,97 & 3,02 & 3,06 & 3,10 & 3,14 & 3,18 & 3,22 & 3,27 \\
\hline & 0,4 & 2,66 & 2,70 & 2,74 & 2,78 & 2,82 & 2,86 & 2,90 & 2,94 \\
\hline & 0,5 & 2,34 & 2,38 & 2,42 & 2,46 & 2,49 & 2,52 & 2,56 & 2,60 \\
\hline & 0,6 & 2,08 & 2,13 & 2,16 & 2,20 & 2,23 & 2,27 & 2,30 & 2,33 \\
\hline & 0,7 & 1,88 & 1,92 & 1,95 & 1,98 & 2,01 & 2,04 & 2,07 & 2,10 \\
\hline & 0,8 & 1,68 & 1,72 & 1,75 & 1,78 & 1,81 & 1,83 & 1,86 & 1,89 \\
\hline
\end{tabular}


Tabela 37B: Relação beneficio/custo para a melancia, em cada época de semeadura, nível de manejo da irrigação e nível de risco. Teresina, Piauí.

\begin{tabular}{|c|c|c|c|c|c|c|c|c|c|}
\hline \multirow{2}{*}{$\begin{array}{l}\text { Época de } \\
\text { Semeadura }\end{array}$} & \multirow[t]{2}{*}{$\mathrm{p}$} & \multicolumn{8}{|c|}{ Nivel de risco (\%) } \\
\hline & & 5 & 10 & 15 & 20 & 25 & 30 & 35 & 40 \\
\hline \multirow{7}{*}{ 1-Jul } & $\theta, 2$ & 2,75 & 2,83 & 2,89 & 2,94 & 2,99 & 3,03 & 3,07 & 3,11 \\
\hline & 0,3 & 2,46 & 2,54 & 2,60 & 2,65 & 2,70 & 2,74 & 2,78 & 2,81 \\
\hline & 0,4 & 2,18 & 2,25 & 2,30 & 2,35 & 2,39 & 2,42 & 2,46 & 2,49 \\
\hline & 0,5 & 1,91 & 1,98 & 2,03 & 2,07 & 2,11 & 2,14 & 2,17 & 2,20 \\
\hline & 0,6 & 1,73 & 1,79 & 1,84 & 1,88 & 1,91 & 1,94 & 1,97 & 2,00 \\
\hline & 0,7 & 1,53 & 1,59 & 1,63 & 1,66 & 1,69 & 1,72 & 1,75 & 1,77 \\
\hline & 0,8 & 1,38 & 1,43 & 1,47 & 1,50 & 1,53 & 1,56 & 1,58 & 1,60 \\
\hline \multirow{7}{*}{ 15-Jul } & 0,2 & 2,76 & 2,84 & 2,90 & 2,95 & 2,99 & 3,03 & 3,07 & 3,11 \\
\hline & 0,3 & 2,51 & 2,59 & 2,65 & 2,70 & 2,75 & 2,79 & 2,83 & 2,87 \\
\hline & 0,4 & 2,19 & 2,26 & 2,32 & 2,36 & 2,40 & 2,44 & 2,47 & 2,50 \\
\hline & 0,5 & 1,95 & 2,02 & 2,07 & 2,12 & 2,16 & 2,19 & 2,22 & 2,25 \\
\hline & 0,6 & 1,78 & 1,84 & 1,88 & 1,92 & 1,95 & 1,98 & 2,01 & 2,03 \\
\hline & 0,7 & 1,55 & 1,60 & 1,65 & 1,68 & 1,71 & 1,74 & 1,77 & 1,80 \\
\hline & 0,8 & $1,41$. & 1,46 & 1,50 & $1,54$. & 1,57 & 1,60 & 1,62 & 1,65 \\
\hline \multirow{7}{*}{ 1-Ago } & 0,2 & 3,34 & 3,38 & 3,42 & 3,46 & 3,50 & 3,54 & 3,58 & 3,62 \\
\hline & 0,3 & 3,10 & 3,15 & 3,19 & 3,22 & 3,26 & 3,30 & 3,34 & 3,38 \\
\hline & 0,4 & 2,69 & 2,73 & 2,76 & 2,80 & 2,83 & 2,86 & 2,90 & 2,93 \\
\hline & 0,5 & 2,44 & 2,48 & 2,52 & 2,55 & 2,58 & 2,62 & 2,65 & 2,69 \\
\hline & $\theta, 6$ & 2,15 & 2,18 & 2,22 & 2,25 & 2,28 & 2,31 & 2,34 & 2,37 \\
\hline & 0,7 & 1,93 & 1,97 & 2,00 & 2,04 & 2,06 & 2,09 & 2,12 & 2,15 \\
\hline & 0,8 & 1,75 & 1,80 & 1,82 & 1,84 & 1,85 & 1,87 & 1,93 & 1,95 \\
\hline \multirow{7}{*}{ 15-Ago } & 0,2 & 3,35 & 3,39 & 3,43 & 3,47 & 3,51 & 3,55 & 3,59 & 3,63 \\
\hline & 0,3 & 3,13 & 3,18 & 3,22 & 3,25 & 3,29 & 3,33 & $3,3.7$ & 3,41 \\
\hline & 0,4 & 2,71 & 2,75 & 2,78 & 2,82 & 2,85 & 2,88 & 2,92 & 2,96 \\
\hline & 0,5 & 2,48 & 2,52 & 2,56 & 2,59 & 2,63 & 2,66 & 2,69 & 2,73 \\
\hline & 0,6 & 2,16 & 2,20 & 2,23 & 2,26 & 2,29 & 2,33 & 2,36 & 2,39 \\
\hline & 0,7 & 1,97 & 2,01 & 2,04 & 2,07 & 2,10 & 2,13 & 2,16 & 2,20 \\
\hline & 0,8 & 1,72 & 1,76 & 1,80 & 1,82 & 1,85 & 1,88 & 1,91 & 1,93 \\
\hline
\end{tabular}


Tabela 37B. Relação benefício/custo para a melancia, em cada época de semeadura, nível de manejo da irrigação e nível de risco. Teresina, Piauí.

\begin{tabular}{|c|c|c|c|c|c|c|c|c|c|}
\hline \multirow{2}{*}{$\begin{array}{l}\text { Época de } \\
\text { Semeadura }\end{array}$} & \multirow[t]{2}{*}{$\mathrm{p}$} & \multicolumn{8}{|c|}{ Nivel de risco (\%) } \\
\hline & & 5 & 10 & 15 & 20 & 25 & 30 & 35 & 40 \\
\hline \multirow{7}{*}{$1-$ Set } & 0,2 & 3,21 & 3,24 & 3,27 & 3,29 & 3,32 & 3,35 & 3,38 & 3,41 \\
\hline & 0,3 & 3,00 & 3,03 & 3,06 & 3,08 & 3,11 & 3,14 & 3,16 & 3,19 \\
\hline & 0,4 & 2,59 & 2,62 & 2,65 & 2,68 & 2,70 & 2,73 & 2,75 & 2,78 \\
\hline & 0,5 & 2,38 & 2,41 & 2,44 & 2,46 & 2,49 & 2,51 & 2,54 & 2,56 \\
\hline & 0,6 & 2,08 & 2,11 & 2,14 & 2,16 & 2,19 & 2,21 & 2,23 & 2,25 \\
\hline & 0,7 & 1,89 & 1,92 & 1,95 & 1,97 & 2,00 & 2,02 & 2,04 & 2,07 \\
\hline & 0,8 & 1,67 & 1,70 & 1,73 & 1,75 & 1,77 & 1,79 & 1,82 & 1,84 \\
\hline \multirow{7}{*}{15 -Set } & 0,2 & 3,20 & 3,24 & 3,26 & 3,29 & 3,32 & 3,35 & 3,37 & 3,40 \\
\hline & 0,3 & 2,98 & 3,02 & 3,04 & 3,07 & 3,10 & 3,13 & 3,15 & 3,18 \\
\hline & 0,4 & 2,59 & 2,62 & 2,65 & 2,67 & 2,70 & 2,73 & 2,75 & 2,78 \\
\hline & 0,5 & 2,37 & 2,41 & 2,44 & 2,46 & 2,49 & 2,51 & 2,54 & 2,57 \\
\hline & 0,6 & 2,08 & 2,11 & 2,14 & 2,17 & 2,19 & 2,21 & 2,24 & 2,26 \\
\hline & 0,7 & 1,89 & 1,92 & 1,95 & 1,98 & 2,00 & 2,03 & 2,05 & 2,08 \\
\hline & 0,8 & 1,67 & 1,71 & 1,73 & 1,76 & 1,78 & 1,80 & 1,83 & 1,85 \\
\hline \multirow{7}{*}{ 1-Out } & 0,2 & 3,27 & 3,30 & 3,33 & 3,36 & 3,39 & 3,42 & 3,45 & 3,48 \\
\hline & 0,3 & 3,03 & 3,07 & 3,10 & 3,13 & 3,16 & 3,18 & 3,21 & 3,24 \\
\hline & 0,4 & 2,64 & 2,67 & 2,70 & 2,73 & 2,75 & 2,78 & 2,80 & 2,83 \\
\hline & 0,5 & 2,39 & 2,43 & 2,46 & 2,49 & 2,52 & 2,54 & 2,57 & 2,60 \\
\hline & 0,6 & 2,11 & 2,15 & 2,18 & 2,20 & 2,23 & 2,25 & 2,28 & 2,30 \\
\hline & $0 ; 7$ & 1,92 & 1,95 & 1,98 & 2,01 & 2,03 & 2,05 & 2,08 & 2,10 \\
\hline & $0 ; 8$ & 1,69 & 1,73 & 1,76 & 1,79 & 1,81 & 1,84 & 1,86 & 1,89 \\
\hline \multirow{7}{*}{ 15-Out } & $0 ; 2$ & 3,27 & 3,31 & 3,34 & 3,37 & 3,39 & 3,42 & 3,45 & 3,48 \\
\hline & 0,3 & 3,00 & 3,04 & 3,07 & 3,10 & 3,13 & 3,16 & 3,19 & 3,22 \\
\hline & 0,4 & 2,62 & 2,66 & 2,69 & 2,72 & 2,75 & 2,78 & 2,80 & 2,83 \\
\hline & 0,5 & 2,36 & 2,40 & 2,43 & 2,46 & 2,49 & 2,52 & 2,55 & 2,57 \\
\hline & 0,6 & 2,11 & 2,15 & 2,18 & 2,21 & 2,24 & 2,26 & 2,29 & 2,31 \\
\hline & 0,7 & 1,90 & 1,94 & 1,97 & 2,00 & 2,02 & 2,04 & 2,07 & 2,09 \\
\hline & 0,8 & 1,73 & 1,76 & 1,79 & 1,82 & 1,85 & 1,87 & 1,90 & 1,92 \\
\hline
\end{tabular}


Tabela 37B. Relação beneficio/custo para a melancia, em cada época de semeadura, nível de manejo da irrigação e nível de risco. Teresina, Piauí.

\begin{tabular}{|c|c|c|c|c|c|c|c|c|c|}
\hline \multirow{2}{*}{$\begin{array}{l}\text { Época de } \\
\text { Semeadura }\end{array}$} & \multirow[t]{2}{*}{$\mathrm{p}$} & \multicolumn{8}{|c|}{ Nível de risco (\%) } \\
\hline & & 5 & 10 & 15 & 20 & 25 & 30 & 35 & 40 \\
\hline \multirow{7}{*}{$1-\mathrm{Nov}$} & 0,2 & 3,64 & 3,68 & $3, \pi$ & 3,75 & 3,78 & 3,81 & 3,84 & 3,88 \\
\hline & 0,3 & 3,27 & 3,32 & 3,36 & 3,40 & 3,44 & 3,47 & 3,51 & 3,54 \\
\hline & 0,4 & 2,92 & 2,97 & 3,01 & 3,04 & 3,08 & 3,11 & 3,14 & 3,18 \\
\hline & 0,5 & 2,61 & 2,66 & 2,70 & 2,74 & 2,77 & 2,80 & 2,84 & 2,87 \\
\hline & 0,6 & 2,33 & 2,39 & 2,43 & 2,47 & 2,50 & 2,54 & 2,57 & 2,61 \\
\hline & 0,7 & 2,11 & 2,16 & 2,20 & 2,24 & 2,28 & 2,31 & 2,34 & 2,37 \\
\hline & 0,8 & 1,87 & 1,94 & 1,98 & 2,03 & 2,06 & 2,10 & 2,13 & 2,17 \\
\hline \multirow{7}{*}{ 15-Nov } & $\theta, 2$ & 3,64 & 3,69 & 3,72 & 3,76 & 3,79 & 3,83 & 3,86 & 3,90 \\
\hline & 0,3 & 3,25 & 3,30 & 3,35 & 3,39 & 3,42 & 3,46 & 3,50 & 3,54 \\
\hline & 0,4 & 2,93 & 2,99 & $3 ; 03$ & 3,07 & $3 ; 11$ & 3,15 & 3,18 & 3,22 \\
\hline & 0,5 & 2,63 & 2,69 & 2,74 & 2,78 & 2,82 & 2,85 & 2,89 & 2,93 \\
\hline & $\theta, 6$ & 2,36 & 2,43 & 2,48 & 2,52 & 2,56 & 2,60 & 2,64 & 2,68 \\
\hline & 0,7 & 2,12 & 2,19 & 2,25 & 2,29 & 2,34 & 2,38 & 2,42 & 2,46 \\
\hline & 0,8 & 1,95 & 2,03 & 2,08 . & 2,12 & 2,17 & 2,21 & 2,25 & 2,28 \\
\hline \multirow{7}{*}{ 1-Dez } & 0,2 & 3,64 & 3,72 & 3,81 & $3,89$. & 3,98 & 4,06 & 4,15 & 4,24 \\
\hline & 0,3 & 3,25 & 3,34 & 3,42 & 3,50 & 3,58 & 3,66 & 3,75 & 3,83 \\
\hline & 0,4 & 2,95 & 3,04 & 3,12 & 3,20 & 3,28 & 3,35 & 3,43 & 3,52 \\
\hline & 0,5 & 2,65 & 2,74 & 2,82 & 2,90 & 2,98 & 3,05 & 3,13 & 3,21 \\
\hline & 0,6 & 2,40 & 2,49 & 2,58 & 2,65 & 2,73 & 2,80 & 2,88 & 2,95 \\
\hline & 0,7 & 2,21 & 2,31 & 2,39 & 2,46 & 2,53 & 2,61 & 2,68 & 2,75 \\
\hline & 0,8 & 2,00 & 2,10 & 2,18 & 2,26 . & 2,33 & 2,40 & 2,47 & 2,55 \\
\hline \multirow{7}{*}{ 15-Dez } & 0,2 & 3,67 & 3,76 & 3,84 & 3,93 & 4,01 & 4,10 & 4,18 & 4,28 \\
\hline & 0,3 & 3,25 & 3,34 & 3,43 & 3,51 & 3,60 & 3,68 & 3,77 & 3,86 \\
\hline & 0,4 & 2,98 & 3,07 & 3,16 & 3,24 & 3,33 & 3,41 & 3,49 & 3,58 \\
\hline & 0,5 & 2,70 & 2,80 & 2,89 & 2,97 & 3,05 & 3,13 & 3,21 & 3,29 \\
\hline & 0,6 & 2,43 & 2,54 & 2,64 & 2,72 & 2,80 & 2,89 & 2,97 & 3,05 \\
\hline & 0,7 & 2,25 & 2,36 & 2,45 & 2,54 & 2,62 & 2,70 & 2,78 & 2,87 \\
\hline & 0,8 & 2,08 & 2,19 & 2,29 . & 2,37 & 2,45 & 2,54 & 2,62 & 2,70 \\
\hline
\end{tabular}


Tabela 38B. Relação benefício/custo para o feijão caupi, em regime de sequeiro, em cada época de semeadura e nível de risco. Parnaiba, Piauí.

\begin{tabular}{|c|c|c|c|c|c|c|c|c|}
\hline \multirow{2}{*}{$\begin{array}{l}\text { Época de } \\
\text { Semeadura }\end{array}$} & \multicolumn{8}{|c|}{ Nível de risco $(\%)$} \\
\hline & 5 & 10 & 15 & 20 & 25 & 30 & 35 & 40 \\
\hline 1-Jan & 0,44 & 0,65 & 0,80 & 0,93 & 1,06 & 1,17 & 1,29 & 1,41 \\
\hline 15-Jan & 0,63 & 0,84 & 0,99 & 1,12 & 1,24 & 1,36 & 1,47 & 1,59 \\
\hline $1-F e v$ & 0,73 & 0,95 & 1,11 & 1,25 & 1,38 & 1,50 & 1,63 & 1,76 \\
\hline $15-\mathrm{Fev}$ & 0,99 & 1,19 & 1,35 & 1,49 & 1,62 & 1,75 & 1,87 & 2,00 \\
\hline 1-Mar & 1,08 & 1,29 & 1,46 & 1,60 & 1,73 & 1,86 & 1,99 & 2,13 \\
\hline 15-Mar & 0,78 & 1,01 & 1,18 & 1,33 & 1,47 & 1,61 & 1,74 & 1,88 \\
\hline $1-\mathrm{Abr}$ & 0,47 & 0,68 & 0,84 & 0,98 & 1,11 & 1,23 & 1,35 & 1,48 \\
\hline $15-\mathrm{Abr}$ & 0,02 & 0,23 & 0,39 & 0,52 & 0,64 & 0,76 & 0,87 & 0,99 \\
\hline 1-Mai & 0,00 & 0,02 & 0,09 & 0,16 & 0,23 & 0,29 & 0,35 & 0,41 \\
\hline 15-Mai & 0,06 & 0,06 & 0,07 & 0,07 & 0,07 & 0,07 & 0,08 & 0,08 \\
\hline 1-Jun & 0,04 & 0,04 & 0,04 & 0,04 & 0,04 & 0,04 & 0,04 & 0,04 \\
\hline 15-Jun & 0,02 & 0,02 & 0,03 & 0,03 & 0,03 & 0,03 & 0,03 & 0,03 \\
\hline 1-Jul & 0,03 & 0,03 & 0,03 & 0,03 & 0,03 & 0,03 & 0,03 & 0,03 \\
\hline 15-Jul & 0,02 & 0,02 & 0,02 & 0,02 & 0,02 & 0,02 & 0,02 & 0,02 \\
\hline 1-Ago & 0,00 & 0,00 & 0,00 & 0,00 & 0,00 & 0,00 & 0,00 & 0,00 \\
\hline 15-Ago & 0,00 & 0,00 & 0,00 & 0,00 & 0,00 & 0,00 & 0,00 & 0,00 \\
\hline 1-Set & 0,00 & 0,00 & 0,00 & 0,00 & 0,00 & 0,00 & 0,00 & 0,00 \\
\hline $15-$ Set & 0,00 & 0,00 & 0,00 & 0,00 & 0,00 & 0,00 & 0,00 & 0,01 \\
\hline 1-Out & 0,01 & 0,01 & 0,01 & 0,01 & 0,01 & 0,01 & 0,01 & 0,01 \\
\hline 15-Out & 0,01 & 0,01 & 0,01 & 0,01 & 0,01 & 0,01 & 0,01 & 0,01 \\
\hline $1-$ Nov & 0,06 & 0,06 & 0,06 & 0,07 & 0,07 & 0,07 & 0,07 & 0,07 \\
\hline 15-Nov & 0,09 & 0,09 & 0,09 & 0,10 & 0,10 & 0,10 & 0,10 & 0,11 \\
\hline 1-Dez & 0,00 & 0,00 & 0,08 & 0,16 & 0,24 & 0,31 & 0,39 & 0,46 \\
\hline 15-Dez & 0,00 & 0,11 & 0,26 & 0,38 & 0,49 & 0,60 & 0,70 & 0,80 \\
\hline
\end{tabular}


Tabela 39B. Relação beneficio/custo para o feijão caupi, em regime de sequeiro, em cada época de semeadura e nível de risco. Teresina, Piauí.

\begin{tabular}{lcccccccc}
\hline Época de & \multicolumn{7}{c}{ Nivel de risco (\%) } \\
\cline { 2 - 8 } Semeadura & 5 & 10 & 15 & 20 & 25 & 30 & 35 & 40 \\
\hline 1-Jan & 1,27 & 1,47 & 1,63 & 1,76 & 1,89 & 2,02 & 2,14 & 2,27 \\
15-Jan & 1,45 & 1,66 & 1,82 & 1,96 & 2,10 & 2,23 & 2,36 & 2,50 \\
1-Fev & 1,80 & 1,98 & 2,12 & 2,25 & 2,38 & 2,50 & 2,63 & 2,76 \\
15-Fev & 1,77 & 1,96 & 2,12 & 2,26 & 2,40 & 2,53 & 2,67 & 2,80 \\
1-Mar & 1,80 & 2,00 & 2,16 & 2,30 & 2,44 & 2,58 & 2,72 & 2,86 \\
15-Mar & 1,41 & 1,62 & 1,78 & 1,92 & 2,05 & 2,19 & 2,32 & 2,45 \\
1-Abr & 0,86 & 1,09 & 1,26 & 1,40 & 1,54 & 1,68 & 1,81 & 1,95 \\
15-Abr & 0,21 & 0,43 & 0,59 & 0,73 & 0,85 & 0,97 & 1,09 & 1,21 \\
1-Mai & 0,00 & 0,05 & 0,17 & 0,27 & 0,36 & 0,45 & 0,54 & 0,64 \\
15-Mai & 0,06 & 0,06 & 0,07 & 0,07 & 0,07 & 0,07 & 0,08 & 0,08 \\
1-Jun & 0,04 & 0,04 & 0,04 & 0,04 & 0,04 & 0,04 & 0,04 & 0,05 \\
15-Jun & 0,03 & 0,03 & 0,03 & 0,04 & 0,04 & 0,04 & 0,04 & 0,04 \\
1-Juf & 0,02 & 0,02 & 0,02 & 0,02 & 0,02 & 0,02 & 0,02 & 0,02 \\
15-Jui & 0,03 & 0,03 & 0,03 & 0,03 & 0,03 & 0,03 & 0,03 & 0,04 \\
1-Ago & 0,03 & 0,03 & 0,03 & 0,04 & 0,04 & 0,04 & 0,04 & 0,04 \\
15-Ago & 0,04 & 0,04 & 0,04 & 0,04 & 0,04 & 0,04 & 0,04 & 0,05 \\
1-Set & 0,04 & 0,04 & 0,05 & 0,05 & 0,05 & 0,05 & 0,05 & 0,05 \\
15-Set & 0,06 & 0,06 & 0,06 & 0,07 & 0,07 & 0,07 & 0,07 & 0,08 \\
1-Out & 0,05 & 0,06 & 0,06 & 0,06 & 0,06 & 0,06 & 0,06 & 0,06 \\
15-Out & 0,07 & 0,07 & 0,07 & 0,07 & 0,08 & 0,08 & 0,08 & 0,08 \\
1-Nov & 0,00 & 0,00 & 0,11 & 0,22 & 0,32 & 0,41 & 0,50 & 0,60 \\
15-Nov & 0,13 & 0,34 & 0,50 & 0,62 & 0,74 & 0,85 & 0,96 & 1,08 \\
1-Dez & 0,34 & 0,56 & 0,72 & 0,86 & 0,99 & 1,10 & 1,22 & 1,34 \\
15-Dez & 0,86 & 1,08 & 1,24 & 1,38 & 1,51 & 1,64 & 1,76 & 1,89 \\
\hline
\end{tabular}


Tabela 40B. Relação benefício/custo para a melancia, em regime de sequeiro, em cada época de semeadura e-nível de risco. Parnaíba, Piauí.

\begin{tabular}{|c|c|c|c|c|c|c|c|c|}
\hline \multirow{2}{*}{$\begin{array}{l}\text { Época de } \\
\text { Semeadura }\end{array}$} & \multicolumn{8}{|c|}{ Nível de risco (\%) } \\
\hline & 5 & 10 & 15 & 20 & 25 & 30 & 35 & 40 \\
\hline $1-J a n$ & 0,69 & 1,01 & 1,23 & 1,41 & 1,57 & 1,72 & 1,85 & 1,99 \\
\hline 15-Jan & 1,02 & 1,36 & 1,61 & 1,80 & 1,98 & 2,14 & 2,29 & 2,44 \\
\hline l-Fev & 1,43 & 1,82 & 2,09 & 2,30 & 2,48 & 2,65 & 2,81 & 2,96 \\
\hline $15-\mathrm{Fev}$ & 1,95 & 2,33 & 2,58 & 2,79 & 2,97 & 3,13 & 3,29 & 3,44 \\
\hline 1-Mar & 2,04 & 2,44 & 2,71 & $2 ; 94$ & 3,14 & 3,33 & 3,50 & 3,68 \\
\hline 15-Mar & 1,54 & 1,95 & 2,23 & 2,47 & 2,67 & 2,86 & 3,04 & 3,22 \\
\hline $1-A b r$ & $0 ; 81$ & 1,16 & 1,41 & 1,61 & 1,78 & 1,95 & 2,10 & 2,25 \\
\hline $15-\mathrm{Abr}$ & 0,15 & 0,49 & 0,73 & 0,93 & 1,10 & 1,25 & 1,40 & 1,54 \\
\hline I-Maí & $0 ; 00$ & $\theta, 10$ & 0,20 & 0,29 & 0,36 & 0,43 & 0,49 & 0,55 \\
\hline 15-Mai & 0,00 & 0,00 & 0,06 & 0,13 & 0,19 & 0,24 & 0,29 & 0,34 \\
\hline l-Jum & 0,04 & $\theta, 04$ & $\theta, 04$ & 0,04 & 0,04 & 0,13 & 0,13 & 0,13 \\
\hline 15-Jun & 0,02 & 0,02 & 0,02 & 0,02 & 0,02 & 0,02 & 0,03 & 0,03 \\
\hline $1-J a l$ & 0,02 & $\theta, 02$ & $\theta, \theta 2$ & $0 ; 02$ & 0,02 & 0,02 & 0,02 & 0,02 \\
\hline 15-Jul & 0,01 & 0,01 & 0,01 & 0,01 & 0,01 & 0,01 & 0,01 & 0,01 \\
\hline F-Ago & 0,00 & $\theta, \theta \theta$ & $\theta, 00$ & $\theta, \theta \theta$ & $\theta, 00$ & 0,00 & $\theta, 00$ & 0,00 \\
\hline 15-Ago & 0,00 & 0,00 & 0,00 & 0,00 & 0,00 & 0,00 & 0,00 & 0,00 \\
\hline 1-Set & $\theta, 0 \theta$ & $\theta, \theta \theta$ & 0,00 & $0 ; 00$ & $\theta, 00$ & 0,00 & 0,00 & 0,00 \\
\hline 15-Set & 0,01 & 0,01 & 0,01 & 0,01 & 0,01 & 0,01 & 0,01 & 0,01 \\
\hline 1-Out & $\theta, 01$ & $\theta, 01$ & 0,01 & $\theta, \theta \mathrm{H}$ & $\theta ; \theta \mathrm{I}$ & 0,01 & 0,01 & 0,01 \\
\hline $15-0 x t$ & 0,01 & 0,01 & 0,01 & 0,01 & 0,01 & 0,01 & 0,01 & 0,01 \\
\hline $1-N_{0}$ & 0,05 & 0,05 & $0 ; 05$ & $0 ; 05$ & 0,05 & 0,05 & 0,05 & 0,05 \\
\hline 15-Noy & 0,00 & 0,00 & 0,04 & 0,10 & 0,15 & 0,21 & 0,25 & 0,30 \\
\hline 1-Dez & 0,00 & $\theta, 07$ & $0 ; 18$ & 0,26 & 0,34 & 0,41 & 0,48 & 0,55 \\
\hline 15-Dez & 0,00 & 0,21 & 0,39 & 0,54 & 0,68 & 0,80 & 0,93 & 1,05 \\
\hline
\end{tabular}


Tabela 4lB. Relação beneficio/custo para a melancia, em regime de sequeiro, em cada época de semeadura e nível de risco. Teresina, Piauí.

\begin{tabular}{lcccccccc}
\hline Época de & \multicolumn{7}{c}{ Nivel de risco (\%) } \\
\cline { 2 - 9 } Semeadura & 5 & 10 & 15 & 20 & 25 & 30 & 35 & 40 \\
\hline 1-Jan & 2,30 & 2,66 & $2 ; 91$ & 3,11 & 3,29 & 3,46 & 3,63 & 3,78 \\
15-Jan & 2,79 & 3,14 & 3,40 & 3,60 & 3,79 & 3,96 & 4,13 & 4,29 \\
1-Fev & 3,88 & 4,18 & 4,39 & 4,56 & 4,71 & 4,84 & 4,98 & 5,10 \\
15-Fev & 3,77 & 4,12 & 4,37 & 4,57 & 4,74 & 4,90 & 5,05 & 5,20 \\
1-Mar & 3,73 & 4,09 & 4,34 & 4,55 & 4,74 & 4,92 & 5,09 & 5,25 \\
15-Mar & 2,80 & 3,19 & 3,46 & 3,68 & 3,88 & 4,06 & 4,24 & 4,41 \\
1-Abr & $1,49-$ & 1,89 & 2,17 & 2,40 & 2,60 & 2,79 & 2,96 & 3,14 \\
15-Abr & 0,39 & 0,75 & 1,00 & 1,20 & 1,37 & 1,54 & 1,69 & 1,84 \\
1-Mai & $0,00$. & 0,09 & 0,26 & 0,39 & 0,51 & 0,62 & 0,72 & 0,82 \\
15-Mai & 0,11 & 0,11 & 0,11 & 0,11 & 0,11 & 0,11 & 0,11 & 0,11 \\
1-Jun & 0,05 & 0,05 & 0,05 & 0,05 & 0,05 & 0,05 & 0,05 & 0,05 \\
15-Jun & 0,03 & 0,03 & 0,03 & 0,03 & 0,03 & 0,03 & 0,03 & 0,04 \\
1-Jul & 0,02 & 0,02 & 0,02 & 0,02 & 0,02 & 0,02 & 0,02 & 0,02 \\
15-Jul & 0,02 & 0,02 & 0,02 & 0,02 & 0,02 & 0,02 & 0,02 & 0,02 \\
1-Ago & 0,03 & 0,03 & 0,03 & 0,03 & 0,03 & 0,03 & 0,03 & 0,03 \\
15-Ago & 0,03 & 0,03 & 0,03 & 0,03 & 0,03 & 0,03 & 0,03 & 0,03 \\
1-Set & 0,04 & 0,04 & 0,04 & 0,04 & 0,04 & 0,04 & 0,04 & 0,04 \\
15-Set & 0,05 & 0,05 & 0,05 & 0,05 & 0,05 & 0,05 & 0,05 & 0,05 \\
1-Out & 0,05 & 0,05 & 0,05 & 0,05 & 0,05 & 0,05 & 0,05 & 0,06 \\
15-Out & 0,08 & 0,08 & 0,08 & 0,08 & 0,08 & 0,08 & 0,08 & 0,09 \\
1-Nov & 0,00 & 0,01 & 0,17 & 0,30 & 0,41 & 0,51 & 0,60 & 0,69 \\
15-Nov & 0,23 & 0,49 & 0,68 & 0,82 & 0,95 & 1,07 & 1,18 & 1,29 \\
1-Dez & 0,52 & 0,83 & 1,06 & 1,25 & 1,42 & 1,59 & 1,75 & 1,91 \\
15-Dez & 1,22 & 1,56 & 1,81 & 2,02 & 2,21 & 2,40 & 2,58 & 2,76 \\
\hline & & & & & & & &
\end{tabular}

